PLANTAE WILSONIANAE 


\title{
PLANTAE WILSONIANAE
}

AN ENUMERATION OF THE WOODY PLANTS COLLECTED IN WESTERN CHINA FOR THE ARNOLD ARBORETUM OF HARVARD UNIVERSITY DURING THE YEARS 1907,1908 , AND 1910 BY E. H. WILSON

\author{
EDITED BY \\ CHARLES SPRAGUE SARGENT \\ VoLUMe II
}

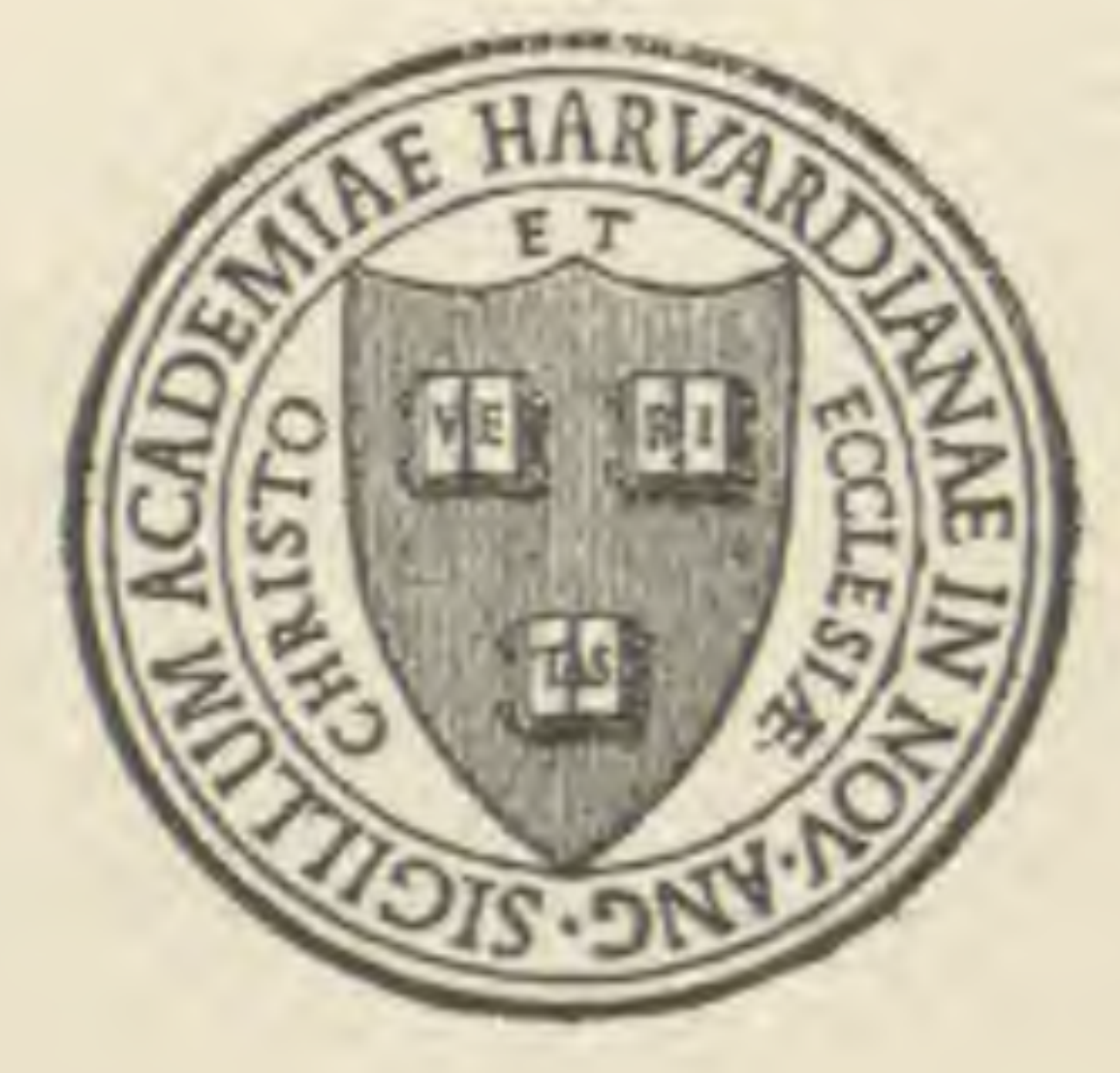

CAMBRIDGE

THE UNIVERSITY PRESS 
Part I. (pp. 1-262) issued March 24, 1914.

Part II. (pp. 263-422) issued December 28, 1915.

Part III. (pp. 423-659) issued March 30, 1916. 


\section{TABLE OF CONTENTS}

PAGE

Ginkgoaceat: Ginkgo ............... . . 1

Taxaceae: Cephalotaxus, Torreya, Taxus, Podocarpus . . . . 3

Pinaceae: Pinus, Larix, Pseudolarix, Picea, Tsuga, Keteleeria,

Abies, Cunninghamia, Cryptomeria, Thuja, Cupressus,

Juniperus . . . . . . . . . . . . . . . . . 10

Gramineae: Arundinaria, Phyllostachys, Bambusa . . . . . 63

Lauraceae: Cinnamomum, Alseodaphne, Phoebe, Machilus,

Sassafras, Actinodaphne, Litsea, Neolitsea, Lindera . . . .

Leguminosae: Albizzia, Cercis, Bauhinia, Cassia, Gleditsia,

Gymnocladus, Pterolobium, Caesalpinia, Mezoneurum,

Ormosia, Sophora, Cladrastis, Maackia, Piptanthus, Indigofera, Millettia, Wisteria, Caragana, Desmodium, Uraria, Lespedeza, Campylotropis, Dalbergia, Dumasia, Erythrina, Apios, Mucuna, Stizolobium, Pueraria, Rhynchosia, Flemingia . . . . . . . . . . . 87

Zygophyllaceat: Nitraria ............. 120

Rutaceae: Zanthoxylum, Evodia, Orixa, Phellodendron, Tod-

dalia, Skimmia, Clausena, Citrus, Poncirus . . . . . 121

Simarubaceae: Picrasma, Ailanthus . . . . . . . . 152

Burseraceat: Canarium ............. 155

Meliaceat: Cedrela, Melia, Cipadessa . . . . . . . . 156

Polygalaceae: Polygala . . . . . . . . . . . . 160

Buxaceat: Sarcocea, Pachysandra, Buxus ....... 163

Cortariaceae: Coriaria. . . . . . . . . . . 170

Anacardiaceae: Spondias, Pistacia, Cotinus, Rhus . . . 172

Staphyleaceat: Staphylea, Turpinia, Euscaphis, Tapiscia . . 185

ICACINACEAE: Mappia, Hosiea . . . . . . . . . . . 190

SAPINDACEAE: Sapindus, Koelreuteria, Euphoria . . . . . . 191

Sabiaceat: Sabia, Meliosma ........... 195

Rhamnaceat: Paliurus, Zizyphus, Berchemia, Chaydaia, Rham-

nella, Sageretia, Rhamnus, Hovenia, Ventilago, Gouania . 209

Nyssaceae: Nyssa, Camptotheca, Davidia . . . . . . . . 254

Olisaceae: Fraxinus . . . . . . . . . . . . 258 
Rosaceat: Pyrus, Sorbus, Malus, Docynia, Chaenomeles, Rhodotypus, Kerria, Potentilla, Rosa, Pygeum, Dichotomanthes, Prinsepia .

Celastraceae: Celastrus, Gymnosporia, Perrottetia . . . 346 ElafocarPaceat: Elaeocarpus, Sloanea . . . . . . . 360

Trlitaceat: Tilia, Grewia . . . . . . . . . . . 363

Malvaceat: Abutilon, Urena, Hibiscus. . . . . . . . 373

Stercultaceae: Reevesia, Sterculia, Firmiana. . . . . . 376

Dilleniaceae: Actinidia, Clematoclethra . . . . . . . 378

Theaceae: Thea, Gordonia, Stewartia, Ternstroemia, Eurya . 390

Guttiferae: Hypericum . . . . . . . . . . . . 402

Tamaricaceae: Tamarix, Myricaria ......... 406

Passifloraceat: Passiflora . . . . . . . . . . . . 408

Elateagnaceae: Hippophae, Elaeagnus . . . . . . . . . 409

LYTHRACEAE: Lagerstroemia . . . . . . . . . . . . . . 418

Punicaceaf: Punica . . . . . . . . . . . . . 419

Mrrtaceae: Eugenia. ............... . 420

Melastomataceae: Melastoma, Osbeckia. . . . . . . 421

Betulaceae: Ostryopsis, Ostrya, Carpinus, Corylus, Betula,

Alnus. . . . . . . . . . . . . 423

LEgUMINOSAE: Wistaria . . . . . . . . . . . . 509

Euphorbiaceat: Andrachne, Sauropus, Glochidion, Phyllanthus,

Securinega, Fluggea, Bischofia, Daphniphyllum, Anti-

desma, Croton, Acalypha, Alchornea, Mallotus, Sapium,

Excoecaria, Aleurites .

516

Thymelafaceae: Wikstroemia, Daphne, Eriosolena, Edge-

worthia, Stellera . . . . . . . . . . . 530

AlangIaceae: Alangium ............ 552

Araliaceae: Schefflera, Hedera, Brassaiopsis, Nothopanax,

Acanthopanax, Kalopanax, Pentapanax, Aralia

555

Cornaceae: Torricellia, Helwingia, Aucuba, Cornus . . . . 569

Mrrsinaceae: Myrsine, Ardisia, Maesa . . . . . . . . 580

Plumbaginaceat: Ceratostigma . . . . . . . . . . . 586

Ebenaceae: Diospyros . . . . . . . . . . . . 587

Symplocaceat: Symplocos ............. 593

Oleaceae: Ligustrum, Osmanthus, Chionanthus, Jasminum . . 600

Caprifoliaceat: Heptacodium . . . . . . . . . 617

Corrections

INDEX. 


\section{GINKGOACEAE.}

Determined by AlFred ReHDer and E. H. Wilson.

\section{GINKGO L.}

Ginkgo biloba Linnaeus, Mant. alt. 313 (1771).- Thunberg, Fl. Jap. 358 (1784). - Lamarck, Encycl. Méth. II. 712 (1786). - Parlatore in De Candolle, Prodr. XVI. pt. II. 507 (1868). - Miquel in Siebold \& Zuccarini, Fl. Jap. II. 73, t. 136 (1870). - Franchet \& Savatier, Enum. Pl. Jap. I. 474 (1875). - Debeaux in Act. Soc. Linn. Bordeaux, XXX. 110 (Fl. Shangh. 58) (1875). - Masters in Jour. Linn. Soc. XVIII. 500 (1881); XXVI. 546 (1902). - Sargent in Garden \& Forest, VI. 473 (1893); Forest Fl. Jap. 75 (1894). - Pritzel in Bot. Jahrb. XXIX. 213 (1900). - Shirasawa, Icon. Ess. For. Jap. I. 10, t. 8, fig. 1-14 (1900). - Pampanini in Nuov. Giorn. Bot. Ital. n. ser. XVIII. 15 (1911).

Ginkgo Kaempfer, Amoen. 811, t. (1712).

Salisburia adiantifolia Smith in Trans. Linn. Soc. III. 330 (1797). - Bunge in Mém. Acad. Sav. Êtr. St. Pétersbourg, II. 136 (Enum. Pl. Chin. Bor. 62) (1833). - Siebold \& Zuccarini in Abh. Akad. Münch. IV. pt. III. 233 (Fl. Jap. Fam. Nat. II. 109) (1846).

Pierophyllus Salisburiensis Nelson, Pinaceae, 163 (1866).

Kiangsi: Kuling, Temple of Wang Lung, planted, July 1907 (No. r743; tree $26 \mathrm{~m}$. tall, $6 \mathrm{~m}$. girth). Western Hupeh: Ichang, planted around temples and houses, alt. 30-1000 m., May and October 1907 (No. 2109; tree 20-30 m. tall, girth 3-6 m.).

The Ginkgo is common as a cultivated tree in central and western China up to an altitude of $1500 \mathrm{~m}$. We never met with a spontaneous specimen and in our opinion the tree no longer exists in a wild state. Masters (in Jour. Linn. Soc. XXVI. 547 [1902]) states that Mrs. Bishop met with the Ginkgo in the forests which surround the sourees of the Great Gold River and the smaller Min, in western China; and also in the forests of central Hokkaido, Japan. This is an error. We have traversed the regions in western China cited by Mrs. Bishop and no Ginkgo grows there. Cercidiphyllum japonicum, var. sinense Rehder \& Wilson is common in that region and is colloquially known as the Peh-k'o tree, the name which is generally applied all over China to the Ginkgo. We suspect Mrs. Bishop was misled or confused and that the tree she saw and mistook for the Ginkgo was the Cercidiphyllum. It is now known that the tree in the forests of Japan, Mrs. Bishop took for the Ginkgo was Cercidiphyllum japonicum Siebold \& Zuccarini. 
The Chinese name "Peh-k'o" signifies white nut. The seeds after roasting are eaten by the Chinese and much esteemed. In the late autumn the leaves of the Ginkgo assume a beautiful yellow color and the trees are in consequence most conspicuous objects at this season. Occasionally in old specimens large, ovoid protuberances, covered with thick bark and a foot or more long, grow out and downwards from the larger branches. This phenomenon is, however, rare as far as our observations go.

Pictures of this tree will be found under Nos. 51, 260, 335, 387, 388, 439 of the collection of Wilson's photographs and also in his Vegetation of Western China, Nos. 229, 230, 231, 232. 


\section{TAXACEAE.}

Determined by ALFred REHDER and E. H. WILSON.

\section{CEPHALOTAXUS Sieb. \& Zucc.}

Cephalotaxus drupacea Siebold \& Zuccarini in Abh. Akad. Münch. IV. pt. III. 232 (Fl. Jap. Fam. Nat. II. 108) (1846). - Endlicher, Syn. Conif. 239 (1847). - Miquel in Ann. Mus. Lugd.-Bat. III. 169 (1867); Prol. Fl. Jap. 333 (1867); in Siebold \& Zuccarini, Fl. Jap. II. 66, t. 130, 131 (1870). - Franchet \& Savatier, Enum. Pl. Jap. I. 473 (1875).- - Masters in Jour. Linn. Soc. XVIII. 499 (1881); XXVI. 544 (1902); XXXVII. 413 (1906); in Gard. Chron. ser. 3, XXXIII. 228, fig. 94 (1903); in Jour. Bot. XLI. 269 (1903). - Sargent in Garden \& Forest, VI. 473 (1893); Forest Fl. Jap. 75 (1894). - Pritzel in Bot. Jahrb. XXIX. 214 (1900).- Shirasawa, Icon. Ess. For. Jap. I. 31, t. 14 (1900), - Palibin in Act. Hort. Petrop. XIX. 136 (Consp. Fl. Kor.) (1901). - Pilger in Engler, Pflanzenr. IV.-5, 100, fig. 20 (Taxaceae) (1903). - Matsumura \& Hayata in Jour. Coll. Sci. Tokyo, XXII. 400 (Enum. Pl. Formos.) (1906), - Hemsley in Bot. Mag. CXXXV. t. 8285 (1909). - Patschke in Bot. Jahrb. XLVIII. 629 (1913).

Taxus baccata Thunberg, $F l$. Jap. 275 (non Linnaeus) (1784).

Taxus coriacea Hort. ex Knight \& Perry, Syn. Conif. 51 (quasi synon.) (1850?).

Cephalotaxus coriacea Hort. ex Knight \& Perry, Syn. Conif. 51 (quasi synon.) (1850?).

Podocarpus coriacea Hort. ex Knight \& Perry, Syn. Conif. 51 (quasi synon.) (1850?).

Cephalotaxus Fortunei foemina Hort. ex Carrière, Traité Conif. 509 (quasi synon.) (1855).

Cephalotaxus foemina Hort. ex Carrière, Traité Conif. 720 (quasi synon.) (1867)

Western Hupeh: without locality, A. Henry (Nos. 5030, 7831.) Korea : without locality, W. R. Carles (No. 202).

Henry's specimens are male and apparently typical and are the only ones we have seen from central China referable to the type species.

Cephalotaxus drupacea, var. sinensis Rehder \& Wilson, n. var.

Differt a typo praecipue foliis lineari-lanceolatis apicem versus plus minusve sensim attenuatis. - Frutex 2-4-metralis, ramosissimus. 
Folia lineari-lanceolata, acuminata v. acuta, basi subito contracta, subsessila, supra obscure viridia, subtus glauca v. glaucescentia.

Western Szech'uan: Mupin, woodlands, alt. 1000-1300 m., September 1908 (No. III5, \&, type); Chiu-ting-shan, thickets, alt. 2000 m., May 23, 1908 (No. III5, ठ , type). Western Hupeh: Hsing-shan Hsien, woodlands, alt. 600-1300 m., May and September 1907 (No. I67, $\delta$ and $\$$ ); same locality, alt. 1000-1300 m., May and August 1907 (Nos. 267, §̊, $167^{\mathrm{a}}$,, , in part); Fang Hsien, woodlands, alt. 1000-1300 m., August and September 1907 (Nos. 167,, in part, $267, \delta$ ); without locality, May 1901 (Veitch Exped. No. 2114, $\delta$ and §). Shensi: "Huo-kio-zaez," July 1897, G. Giraldi.

This is a common shrub in thickets and woodlands in western Hupeh and in Szech'uan, more especially in rough, steep, limestone regions. The very narrowly lanceolate leaves tapering to a sharp, acuminate point distinguish this variety from the type in which the leaves are linear and abruptly contracted to a mucronate apex. Cephalotaxus. Fortunei Hooker differs from this new variety in its much longer leaves $(5-9 \mathrm{~cm}$.) very distinctly narrowed towards the base.

We have seen specimens from central China belonging to this new variety identified as C. Fortunei, C. Griffthii and C.pedunculata, and Franchet, Pritzel and Masters have recorded the latter species from Shensi and Hupeh. It is highly probable that all these specimens are referable to this new variety. Of C. pedunculata Siebold \& Zuecarini, the correct name for which is C. Harringtonia K. Koch, we have seen only male, eultivated specimens. These are obviously distinct from C. drupacea Siebold \& Zuccarini and until more is known concerning the female plant and the habitat of $C$. Harringtonia we prefer to keep it as a distinet species.

Cephalotaxus drupacea, var. sinensis, f. globosa Rehder \& Wilson n. forma.

A typo varietatis fructu globoso v. subgloboso recedit.

Western Hupeh: Hsing-shan Hsien, woods, alt. 1000 m., August 1907 (No. I63, 9 ; bush $3 \mathrm{~m}$. tall).

It is possible that this plant may prove identical with the $C$. pedunculata var. sphaeralis Masters (in Gard. Chron. n. ser. XXI. 113, fig. 113, 1884). It is in cultivation and we have separated it more in the hope of elucidating the origin of Masters' plant than on account of the shape of its fruit. It is exceedingly doubtful if the shape or size of the fruit in Cephalotaxus is of taxonomie value.

Cephalotaxus Fortunei Hooker in Bot. Mag. LXXVI. t. 4499 (1850). - Parlatore in De Candolle, Prodr. XVI. pt. II. 503 (1868). Franchet in Nouv. Arch. Mus. Paris, sér. 2, VII. 102 (Pl. David. I. 292) (1884); in Jour. de Bot. XIII. 265 (1899). - Kanitz in Növén. Gyüjït. Szèchenyi, II. 848 (Pl. Enum. 63) (1891); in Wiss. Ergeb. Reise Szèchenyi, II. 738 (1898). - Beissner in Nuov. Giorn. Bot. Ital. n. ser. IV. 186 (1897); in Bull. Soc. Bot. Ital. 1901, 358. - Pritzel in Bot. 
Jahrb. XXIX. 213 (1900). - Masters in Jour. Linn. Soc. XXVI. 545 (1902); XXXVII. 413 (1906); in Jour. Bot. XLI. 269 (1903). Pilger in Engler, Pflanzenr. IV.-5, 103 (Taxaceae) (1903). - Diels in Wiss. Ergeb. Exped. Filchner China Tibet, X. 247 (1908). - Dunn \& Tutcher in Kew Bull. Misc. Inform. Add. ser. X. 256 (Fl. Kwangtung \& Hongkong) (1912). - Patschke in Bot. Jahrb. XLVIII. 629 (1913).

Cephalotaxus filiformis Knight \& Perry ex Gordon, Pinetum, 46 (quasi synon.) (1858).

Cephalotaxus drupacea K. Koch, Dendr. II. pt. II. 104 (non Siebold \& Zuccarini) (1873), quoad synon. C. Fortunei.

Cephalotaxus Griffithii Beissner in Bull. Soc. Bot. Ital. 1901, 358 (non Hooker f.). - Masters in Jour. Bot. XLI. 269 (1903); in Jour. Linn. Soc. XXXVII. 414 (1906).

Cephalotaxus Mannii Masters in Jour. Linn. Soc. XXVI. 545 (non Hooker f.) (1902).

Kiangsi: Kuling, thickets, alt. 1300 m., August 1, 1907 (No. I74I ${ }^{\mathrm{a}}$, $)$. Western Hupeh : north and south of Ichang, woodlands, alt, 600-1300 m., May and September 1907 (No. $1386, \delta$ and, , in part; bush or tree 5-8 m. tall); Fang Hsien, woods, alt. 1300 m., August 1907 (No. $1386, \delta$ and $\&$, in part; tree $6 \mathrm{~m}$. tall); Hsing-shan Hsien, ravine, alt. $300 \mathrm{~m}$., rare, May 1907 (No. 2110, ?; bush $2 \mathrm{~m}$. tall); without locality, April 1900 (Veitch Exped. No. 100, $q$ and $\delta$ ); without locality A. Henry (No. 7186); "Monte Tien-pong-scian," alt. 1990 m., September 1907, C. Silvestri (No.94, \&). Eastern Szech'uan: Wushan Hsien, A. Henry (No. 7018, \&). Western Szech'uan: Wa-shan, roadside, alt. 1300 m., September 1908 (No. I386, \&, in part; tree 12 m. tall, girth $1.5 \mathrm{~m}$., fruit purple); west and near Wên-ch'uan Hsien, alt. 1300-1600 m., October 1901 (No. 4054, $\$$; small tree 5-8 m. tall); Tachien-lu, Prince Henri d'Orléans. Yunnan: mountains north of Mengtze, alt. 2300 m., A. Henry (No. 9100, ठ). Chekiang: near Ningpo, June 1907, F. N. Meyer (No. 432, ९). Shensi: Tai-pei-shan, 1910, W. Purdom.

This handsome species is rather common as a small tree, $5-10 \mathrm{~m}$. tall, in the woods and thickets of western Hupeh and in Szech'uan, more especially in precipitous limestone regions. The trunk always divides a few feet above the ground into 2-5 ascending stems. The lateral branches are very numerous, slender, spreading and often somewhat pendulous at the extremities. The leaves in both sexes are equally long, dark green above, glaucous below; the fruit varies somewhat in size and shape and when ripe is purple on the surface.

This tree is the Lo-han-shu of the Chinese and is frequently associated with wayside shrines, tombs and temples. The specimens identified as $C$. Griffithii by Masters (in Jour. Bot. XLI. 269 [1903]) probably belong here. 
A picture of this tree will be found under No. 369 of the collection of Wilson's photographs and also in his Vegetation of Western China, No. 162.

Cephalotaxus Fortunei, var. concolor Franchet in Jour. de Bot. XIII. 265 (1899). - Pampanini in Nuov. Giorn, Bot. Ital. n. ser. XVII. 231 (1910).

Kiangsi: Kuling, thickets alt. 1300 m., common, July 28, 1907 (No. I74I, \&; bush 1-2.5 m.). Eastern Szech'uan: Cheng-kou Ting, $P$. Farges (type).

Cephalotaxus Oliveri Masters in Bull. Herb. Boissier, VI. 270 (1898); in Jour. Linn. Soc. XXVI. 545 (1902); XXXVII. 413 (1906); in Gard. Chron. ser. 3, XXXIII. 227, fig. 93 (1903); in Jour. Bot. XLI. 269 (1903). - Pritzel in Bot. Jahrb. XXIX. 214 (1900). - Pilger in Engler, Pflanzenr. IV.-5. 104 (Taxaceae) (1903). - Patschke in Bot. Jahrb. XLVIII. 629 (1913).

Cephalotaxus Griffithii Oliver in Hooker's Icon. XX. t. 1933 (non Hooker f.), (1890), excludendis speciminibus a Griffith et Watt collectis.

Western Hupeh: vicinity of Ichang, ravines and glens, alt. 30$600 \mathrm{~m}$., April and Oetober 1907 (No. 4I8, $\delta$ and $\$$; bush 2-3 m. tall); Changyang Hsien, ravine, alt. 300 m., April 1900 (Veitch Exped. No. 72, ९); without locality, A. Henry, (Nos. 7479, $९, 7832^{\text {a }}, \delta$ ).

This very distinct species is well distinguished by the peetinate arrangement of the leaves which are closely set on the branches; the leaf-base is truncate and the apex abruptly acute.

This shrub is common in western Hupeh and in Szech'uan up to an altitude of $600 \mathrm{~m}$., selecting rocky places.

Cephalotaxus argotaenia Pilger in Engler, Pflanzenr. IV.-5, 104 (Taxaceae) (1903). - Patschke in Bot. Jahrb. XLVIII. 629 (1913).

Podocarpus argotaenia Hance in Jour. Bot. XXI. 357 (1883). - Masters in Jour. Linn. Soc. XXVI. 547 (1902); XXXVIII. 414 (1906); in Jour. Bot. XLI. 269 (1903). - Dunn \& Tutcher in Kew Bull. Misc. Inform. Add. ser. X. 256 (Fl. Kwangtung \& Hongkong) (1912).

Podocarpus insignis Hemsley in Jour. Bot. XXIII. 287, 312 (1885).

Western Hupeh: Hsing-shan Hsien, cliffs of ravines, alt. $300 \mathrm{~m}$., very rare, May 7, 1907 (No. 2ro7; bush $2 \mathrm{~m}$. tall). Western Szech'uan: without precise locality, ravines, alt. 1100 m., rare, July 1903 (Veitch Exped. No. 3005, ㅇ).

This is a rare plant of which the ripe fruit is unknown to us. 


\section{TORREYA Arn.}

Torreya grandis Fortune in Gard. Chron. 1857, 788; 1860, 170. Gordon, Pinetum, 326 (1858).- - Parlatore in De Candolle, Prodr. XVI. pt. II. 505 (1868). - Franchet in Nouv. Arch. Mus. Paris, sér. 2, VII. 102 (Pl. David. I. 292) (1884). - Masters in Jour. Linn. Soc. XXVI. 546 (1902). - Henry in Elwes \& Henry, Trees of Great Britain and Ireland, VI. 1464 (1912).

Caryotaxus grandis Henkel \& Hochstetter, Syn. Nadelh. 367 (1865).

Tumion grande Greene in Pittonia II. 194 (1891).

Torreya Fargesii Franchet in Jour. de Bot. XIII. 264 (1899). - Pritzel in Bot. Jahrb. XXIX. 214 (1900), - Pilger in Engler, Pflanzenr. IV.-5, 108 (Taxaceae) (1903). - Pampanini in Nuov. Giorn. Bot. Ital. n. ser. XVII. 231 (1910). - Patschke in Bot. Jahrb. XLVIII. 630 (1913).

Torreya nucifera Pritzel in Bot. Jahrb. XXIX. 214 (non Siebold \& Zuccarini) (1900). - Masters in Jour. Linn. Soc. XXVI. 546 (1902); XXXVII. 414 (1906); in Jour. Bot. XLI. 269 (1903).

Torreya nucifera, var. grandis Pilger in Engler, Pflanzenr. IV.-5. 107 (Taxaceae) (1903).

Western Hupeh: Hsing-shan Hsien, woodlands, alt. 1000-1600 m., rare, June and July 1907 (No. 2108, $\delta$ and $९$, in part; tree 5-12 m. tall, girth 0.6-1.5 m.); Fang Hsien, woodlands, alt. $1300 \mathrm{~m}$., August 1907 (No. 2108, \&, in part); same locality, ravine, alt. 1300 m. June 1910 (No. 465o, \&; bush $4 \mathrm{~m}$. tall, fruit globose); without locality, $A$. Henry (Nos. 6346, 6478, ᄋ). Eastern Szech'uan: Wushan Hsien, A. Henry (No. 7096); Cheng-kou Ting, P. Farges (No. 128, \&, ¿", type of T. Fargesii Franchet).

This is a rather rare tree in western Hupeh and still more rare in western Szech'uan but is not uncommon in either region in bush form. The globose or subglobose seeds, the scarcely foetid leaves and the gray, yellowish green bark on shoots two years old and upwards distinguish this plant from the Japanese $T$. nucifera Siebold \& Zuccarini, which has an ellipsoid seed, more foetid leaves and reddish brown bark on shoots two years old and upwards. The difference in color of the bark is constant and affords an easy means of distinguishing these two species. In this connection it is worthy of note that the eastern American $T$. taxifolia Arnott agrees with $T$. grandis Fortune, in having gray, yellowish green bark, and that the western American T. californica Torrey agrees with $T$. nucifera Siebold \& Zuccarini, in having reddish brown bark on shoots two years old and upwards.

Torreya grandis Fortune, is occasionally met with in gardens under the erroneous name of $T$. taxifolia. It is extremely doubtful if the true $T$. taxifolia Arnott, which is a rare and local plant known only in a few stations in western Florida, is now in cultivation. A picture of $T$. grandis Fortune, will be found under No. 280 of the collection of Wilson's photographs and also in his Vegetation of Western China, No. 488. 


\section{TAXUS L.}

Taxus cuspidata Siebold \& Zuccarini in Abh. Akad. Münch. IV. pt. III. 232 (Fl. Jap. Fam. Nat. II. 108) (1846). - Endlicher, Syn. Conif. 243 (1847). - Miquel in Ann. Mus. Lugd.-Bat. III. 169 (1867); Prol. Fl. Jap. 333 (1867); in Siebold, Fl. Jap.II. 61, t. 128 (1870). - Parlatore in De Candolle, Prodr. XVI. pt. II. 502 (1868). - Franchet \& Savatier, Enum. Pl. Jap. I. 472 (1875), - Masters in Jour. Linn. Soc. XVIII. 499 (1881). - Sargent in Garden \& Forest, VI. 473 (1893); Forest Fl. Jap. 76 (1894). - Shirasawa, Icon. Ess. For. Jap. I. 33, t. 15, fig. 1-18 (1900). - Komarov in Act. Hort. Petrop. XX. 210 (Fl. Mandsh.) (1901).

Cephalotaxus umbraculifera Siebold apud Endlicher, Syn. Conif. 239 (1847).Franchet \& Savatier, Enum. Pl. Jap. 1. 473 (1875).

Taxus baccata, subsp. 2. cuspidata Pilger in Engler, Pflanzenr. IV.-5, 112 (Taxaceae) (1903), - Patschke in Bot. Jahrb. XLVIIl. 630 (1913).

Japan.

\section{Taxus cuspidata, var. chinensis Rehder \& Wilson, n. comb.}

Taxus baccata Franchet in Nouv. Arch. Mus. Paris, sér. 2, VII. 103. (Pl. David. I. 293) (non Linnaeus) (1884); in Jour. de Bot. XIII. 264 (1899). - Pritzel in Bot. Jahrb. XXIX. 214 (1900). - Masters in Jour. Linn. Soc. XXVI. 546 (1902); in Jour. Bot. XLI. 269 (1903); in Jour. Linn. Soc. XXXVII. 414 (1906).

Taxus baccata, subsp. 2. cuspidata, var. b. chinensis Pilger in Engler, Pflanzenr. IV.-5, 112 (Taxaceae) (1903). - Patschke in Bot. Jahrb. XLVIII, 630 (1913).

Western Hupeh: north and south of Ichang, woodlands, alt. 600-1300 m., not common, June 1907 (No. 1265, in part; tree 5-12 m. tall, 1-3 m. girth); without locality, A. Henry (No. 6913). Eastern Szech'uan: Wushan Hsien, ravine, May 1900 (Veitch Exped. No. 624); Wushan Hsien, A. Henry (Nos. 7097, 7155, type of Pilger's var. b.chinensis). Western Szech'uan : near Mt. Omei, alt. $600 \mathrm{~m}$., September 1908 (No. 1265, in part; tree 16 m. tall, 5 m. girth); near Yachou Fu, woodlands, alt. 600 m., October 1908 (No. I265, in part; tree 10-16 m. tall, 2.5-5 m. girth); west and near Wen-ch'uan Hsien, alt. 2100 m., October 1910 (No. 4053, in part; tree $13 \mathrm{~m}$. tall, girth $4 \mathrm{~m}$.); west of Kuan Hsien, Pan-lan-shan, woods, alt. 1600$2000 \mathrm{~m}$., October 1910 (No. 4053, in part; tree 8-10 m. tall, girth 1.5-2 m.). Shensi : Tai-pei-shan, 1910, W. Purdom. Chekiang: near Ningpo, June 1907, F. N. Meyer (No. 433). 
This variety is distinguished from the type by its broadly ovoid, smoother, slightly compressed seeds which are slightly 2 -angled (never 3 or 4 -angled), and more prominently apiculate at the summit, by its smaller winter-buds composed of rounded scales without a keel on the back, and by its more falcate leaves, convex above with the middrib very slightly raised. The specimens from Szech'uan differ from the Hupeh plant which represents the type, in their brighter green, more falcate and somewhat larger leaves, generally $2-3 \mathrm{~cm}$. long and $2.5-4 \mathrm{~mm}$. wide. The description of the seeds refers to the Szech'uan plant which is in cultivation.

Taxus baccata Linnaeus is well distinguished from T. cuspidata Siebold \& Zucearini and its var. chinensis by its longer $(6-7 \mathrm{~mm}$.), ellipsoid seed. Both T. cuspidata and the var. chinensis fruit much more freely than $T$. baccata; branches frequently producing fruit from every leaf-axil.

The Chinese Yew occurs scattered through western Hupeh and Szech'uan up to $2000 \mathrm{~m}$. al itude and more especially in regions where hard carboniferous limestone prevails. It is nowhere common but here and there very fine specimens occur, trees $15 \mathrm{~m}$. and more tall with trunks more than $1 \mathrm{~m}$. in diameter and massive, wide-spreading branches. The bark on old trees is red-brown and the leaves are always very dark green. When dry the leaves assume a rich brown color on the nnderside and the same is true of the type, T. cuspidata Siebold \& Zuccarini. A Chinese name for this tree is "Hung-tao-sha" (Red Bean Fir).

Pictures of this tree will be found under Nos. 374, 375, 376 of the collection of Wilson's photographs and also in his Vegetation of Western China, No. 483.

To complete the enumeration of the Taxaceae of central and western China, a note on Podocarpus neriifolius which was not collected during the Arnold Arboretum Expeditions may be added here.

\section{PODOCARPUS L'Hérit.}

Podocarpus neriifolius D. Don in Lambert, Descr. Pinus, II. 21 (pro parte) (1824); ed. minor 142 (1832). - Hooker in Bot. Mag. XXXVIII. t. 4655 (1852). Masters in Jour. Linn. Soc. XXVI. 548 (1902); LXXVII. 414 (1906). - Pilger in Engler, Pflanzenr.1V.-5, 112 (Taxaceae) (1903). - Patschke in Bot.Jahrb. XLVIII. 629 (1913).

Podocarpus macrophylla Wallich, Tent. Fl. Nepal. 56, t. 43 (non D. Don) (1824), excludendis synon.; Cat. No. 6052 (1830). - Franchet in Jour. de Bot. XIII. 265 (1899). - Pritzel in Bot. Jahrb. XXIX. 213 (1900). Masters in Jour. Linn. Soc. XXVI. 548 (1902), - Patschke in Bot. Jahrb. XLVIII. 629 (pro parte) (1913).

Podocarpus macrophylla, var. acuminatissima Pritzel in Bot. Jahrb. XXIX. 213 (1900).

Western Szech'uan: Mt. Omei, alt. 1000 m., planted, October 1903 (Veitch Exped. No. 3007 ; tree $16 \mathrm{~m}$. tall.)

This handsome tree is occasionally planted around temples in the warmer part of Szech'uan and more especially on Mount Omei. 


\title{
PINACEAE.
}

\author{
Determined by Aufred ReHder and E. H. WiLson.1
}

\author{
Subfam. ABIETEAE Spach.
}

\section{PINUS L.}

Determined by George Russell Shaw, with notes by E. H. Wilson.

On the first pages of the first volume of this publication the specimens of Pinus, collected by Mr. Wilson, are treated according to the conception of Franchet, Beissner and Masters, but Pinus Thunbergii Parlatore and Pinus koraiensis Siebold \& Zuccarini, which are eredited to China by these authors, were not found by Mr. Wilson, and it is now my belief that Pinus densiflora Siebold \& Zuccarini also has not yet been collected in a wild state within the limits of China proper.

The acquisition of more material from Kansu, Shansi and Chili, especially from the neighborhood of Peking, the possession of authentic specimens of $P$. funebris Komarov and of $P$. leucosperma Maximowicz together with a longer acquaintance with Mr. Wilson's admirable collections, have led me to believe that there are, in the eighteen provinces of China, but two species of Hard Pine - one confined to the subtropical levels of central southern and south-eastern China and the other, a mountain species of the western ranges and of the colder northern latitudes. The subtropical species has long been known under the name of $P$. Massoniana Lambert, while the mountain species has appeared under various names, some of them based on characters which appear distinct, but which prove, in the Wilson collection, to be the ultimate developments of variations that are more or less obvious in all the localities.

In all the mountain specimens from Yunnan to northern Chili the leaves have the same leaf-section, in which the resin-ducts are commonly external, but, in every locality, leaves with both external and medial ducts are not infrequent. The branchlet is yellow and slightly pruinose. The staminate flowers are in short, capitate clusters. The conelet always has the same form and the same mucronate scales. The cone is tenaciously persistent, subsymmetrical to oblique and undergoes a change in color, for at first a rather pale yellow, it slowly changes to a nut brown, quite different from the original color. This change takes place not only on the tree but in the herbarium. It is a character new to me and I do not wish to give it undue importance, but taken with other characters common to these specimens, it seems to establish the proof of specific identity. Moreover their variations, whether of dimensions or of form, are so associated and lead by such easy gradations into one another, that the establishment of specific limits among them appears, to me at least, impossible.

Pinus funebris Komarov represents the most northern form of this Pine, with

1 Pinus determined by G. R. Shaw. 
short leaves and small cones. Pinus leucosperma Maximowicz is founded on specimens with white seeds which appear also in other localities and represent merely a variation in color not confined to Kansu, where the specimens on which Maximowicz founded his species were collected, but is, in Kansu as elsewhere, an occasional variation. Pinus tabulaeformis Carrière is apparently founded on Fortune's manuscript name tabuliformis, for the Pine planted near Peking. Pinus yunnanensis Franchet is the south-western form bearing the longest leaves and the largest cones, presenting, however, great dimensional variations of fruit and foliage in the localities where it is common. Mr. Wilson collected in Mupin the typical P. yunnanensis on lower slopes, while above, on rocky ledges, he found a tree (No. 1472) which, he admits, must be the same species but which has the smallest cones and the shortest leaves of the collection. It is also noteworthy that the leaves of the specimen (No. 1464) from the lower altitudes are more prevalently in fascicles of 3 , while in the specimen from the upper altitudes fascicles of 2 predominate. That is to say, the difference between these two trees is in perfect correlation with their exposure. Pinus densata Masters and $P$. prominens Masters, present the extreme form of the oblique cone but, among these trees, the subsymmetrical cone is also found and, with some numbers (Nos. 4073, 4074, for instance) this character is intermediate. Pinus Henryi Masters and P. Wilsonii Shaw represent the form corresponding with Lambert's $P$. sinensis, which is the proper name, it seems to me, for the Chinese mountain Pine.

This species differs from P. Massoniana in its usually shorter, always stouter, leaves, more often in fascicles of $3-$ a rare condition in P. Massoniana; in its always shortly ovate cone, yellow at maturity, for the cone of $P$. Massoniana is usually long-ovate and always brotwn when ripe; in its conspicuously mucronate conelet - that of $P$. Massoniana is partly mutic, partly tuberculate or minutely mucronate; and in its short-capitate staminate inflorescence which never attains the long dense clusters common to both $P$. Massoniana and $P$. densiflora. These distinctions partly appear in the plates of $P$. Massoniana and $P$. sinensis, in the quarto edition of Lambert's Genus Pinus of 1832. Here the staminate inflorescence of both species are illustrated and clearly distinguished, while the cone of $P$. sinensis corresponds with the usual shortly ovate form characteristic of the mountain Pine. Moreover, Lambert's statement that $P$. sinensis resembles $P$. laricio can apply only to the mountain Pine with its yellow cone and stout leaves and not at all to $P$. Massoniana with its cone always brown and its leaf always very slender. In employing the name sinensis which, after Massoniana, is the oldest name for a Chinese Pine, there should be no chance for confusion.

Confusion of $P$. sinensis with $P$. Thunbergii Parlatore, is not possible, for the white bud and the characteristic leaf-section of the Japanese Black Pine are not found in China. Confusion with P. densiflora Siebold \& Zucearini is natural, for the leaf-sections and the leaf-dimensions of the two are often similar. But the cone of $P$. sinensis is tenaciously persistent, while that of $P$. densiflora is deciduous or, when persistent, it has a weak hold on the branch. The color of the $P$. densiflora cone is a dull testaceous yellow and remains so until changed to the gray tones common to all long-exposed eones. The cone of $P$. sinensis changes from a more or less lustrous yellow to a nut-brown before the ultimate change to grey.

Pinus Massoniana resembles $P$. densiflora in its long male inflorescence and in its leaf-section, but differs in the brown color of its cone. The best distinction, however, is found in the form and armature of the conelet. In P. Massoniana the scales of the conelet are mutic toward its base, and tuberculate or minutely mucronate toward its apex, the tubercle or mucro lying against the scale below. In $P$. densiflora the scales toward the apex of the conelet are conspicuously mucronate, the mucro dorsal and patulous, and not touching an adjacent scale. 
Pinus Armandi Franchet is remarkable for the variation in the position of the resin-ducts of the leaves. The duct in the ventral angle of the leaf is medial but the dorsal ducts may be external only, medial only or both external and medial, and this variation may be seen in leaves growing on the same branchlet. Masters's $P$. scipioniformis is founded on an immature cone of $P$. Armandi and a leaf with external ducts. Therefore he classifies it with the section Strobus. Patschke, on the other hand (Bot. Jahrb. XLVIII. 664), finds that the dorsal duets are medial and therefore classifies it with the section Cembra. This system of classification breaks down with this species for no account is taken of dorsal ducts in both positions in the same leaf and this character is frequent, in the Wilson collection, among the leaves that I have examined. Masters's P. mandschurica and Patschke's $P$. excelsa, both from the same locality in Yunnan, are certainly this species. $P$. Armandi and $P$. koraiensis need not be confused. The cone of $P$. koraiensis shrinks, and exposes its seeds to view, but is inert under hygrometric changes, while the cone of $P$. Armandi opens at maturity and closes when immersed in water. The seed of $P$. koraiensis is unique among Pines, the nut being entirely covered, except the black umbilical scar, with a brown membranous spermoderm, while the spermoderm of $P$. Armandi is reduced to a marginal border produced into a rudimentary wing, exactly as in $P$. flexilis James. The branchlet of $P$. koraiensis is tomentose, that of $P$. Armandi glabrous.

In accordance with these considerations the Chinese specimens are rearranged below. The four species collected by Mr. Wilson represent, so far as I can determine, all the Pines that have been found within the limits of the eighteen provinces of China proper.

Pinus Armandi Franchet in Nouv. Arch. Mus. Paris, sér. 2, VII. 95, t. 12 (Pl. David.I. 285) (1884); in Jour. de Bot. XIII. 254 (1899).Masters in Jour. Linn. Soc. XXVI. 549 (1902); XXXVII. 415 (1906). - Beissner in Nuov. Giorn. Bot. Ital. n. ser. IV. 184 (1897). Clinton-Baker, Ill. Conif. I. t. 6 (1909). - Stapf in Bot. Mag. CXXXVI. t. 8347 (1910). - Mottet in Rev. Hort. 1910, 423, f. 177180. - Patschke in Bot. Jahrb. XLVIII. 657 (1912).

Pinus koraiensis Beissner in Nuov. Giorn. Bot. Ital. n. ser., IV. 184 (non Siebold \& Zuccarini) (1897). - Masters in Jour. Linn. Soc. XXVI. 550 (1902); XXXVII. 415 (1906); in Gard. Chron. ser. 3, XXXIII. 34, f. 18, 19 (1903). - Patschke in Bot. Jahrb. XLVIII. 657 (1912).

Pinus scipioniformis Masters in Bull. Herb. Boissier, VI. 270 (1898); in Jour. Linn. Soc. XXVI. 552 (1902); XXXVII. 415 (1906), - Patschke in Bot. Jahrb. XLVIII. 657 (1912).

Pinus mandschurica Masters in Jour. Linn. Soc. XXVI. 551 (non Ruprecht) (1902); XXXVII. 416 (1906).

Pinus Mastersiana Hayata in Gard. Chron. ser. 3, XLIII. 194 (1908).

Pinus Armandi, var. Mastersiana Hayata in Jour. Coll. Sci. Tokyo, XXV. art. XIX. 215, f. 8 (Fl. Mont. Formosae) (1908).

Pinus levis Lemée \& Léveillé in Fedde, Rep. Sp. Nov. VIII. 60 (1910).

Pinus excelsa, var. chinensis Patschke in Bot. Jahrb. XLVIII. 657 (1912).

Western Hupeh: Hsing-shan Hsien, around hamlet of Sze-koutze, alt. 1500-2000 m., abundant on cliffs, December 1907 (No. 2505; tree $15-20 \mathrm{~m}$. tall, girth $0.6-1.5 \mathrm{~m}$., bark smooth, pale gray); same 
locality, October 1900 (Veitch Exped. No. 662); north-west of Hsingshan Hsien, alt. 2000 m., July and September 1907 (No. 2506, 25Ir; tree $15-20 \mathrm{~m}$. tall); Patung Hsien, around hamlet of Ta-wan, alt. $1500 \mathrm{~m}$., June and July 1907 (No. 2509; tree 15-20 m. tall, cones very large). Western Szech'uan: west and near Wên-ch'uan Hsien, alt. 1500-2500 m., July and November 1908, October 1910 (Nos. Ir 5I, II $\mathrm{II}^{\mathrm{a}}, 25 \mathrm{IO}$; tree 8-20 m. tall, girth $0.6-1.3 \mathrm{~m}$., cones often small); Chingchi Hsien, Fei-yüeh-ling, alt. 2500-2800 m., August and October 1908 (No. I387; tree $12.20 \mathrm{~m}$. tall, cones of huge size); north of Tachien-lu, alt. 3000-3300 m., November 1908 (No. 1470, in part; tree 6-15 m. tall); west of Kuan Hsien, Pan-lan-shan, cliffs, alt. 2500-2600 m., June 21, 1908 (No. 1470, in part; tree 15-25 m. tall; girth 0.6-2 m.); Lungan Fu, cliffs, alt. 2000-3000 m., August 1910 (No. II 5 I ${ }^{\mathrm{b}}$; tree $10-20 \mathrm{~m}$. tall); without precise locality, October 1904 (Veitch Exped. No. 3017). Yunnan: Mengtze, alt. 2300 m., $A$. Henry (No. 10519); Milê district, A. Henry (No. 9868). Shensi : without locality, G. Giraldi.

This is the White Pine of China and the only member of this group known from the eighteen provinces of China. It is widely distributed in the temperate regions of that country and presents much variation in size of cone. It is everywhere a tree of medium size, shapely in habit with smooth, pale gray bark, and cones borne on the ends of the branches which, normally, are straight and horizontally wide-spreading. The wood is resinous, close grained, soft but durable. It is esteemed for general building purposes and is commonly used tor torches. The tree delights in a rocky country where precipitation is relatively great.

Colloquially this Pine is frequently called the "Peh Sung" (literally White Pine) but this name more correctly belongs to $P$. Bungeana Zuccarini.

Pictures of this tree will be found under Nos. 116, 266, 084, 093, 0283 of the collection of my photographs and in my Vegetation of Western China, Nos. 357, 358.

E. H. W.

Pinus Bungeana Zuccarini in Endlicher, Syn. Conif. 166 (1847). Fortune, Yedo and Peling, 377, 378, fig. (1863). - Naudin in Rev. Hort. (1863) 372. - Hance in Jour. Linn. Soc. XIII. 87 (1873). Masters in Gard. Chron, ser. 2, XVIII. 8, fig. 1, 2 (1882); in Gartenzeit. II. 399, fig. 79 (1883); in Jour. Linn. Soc. XXVI. 549 (1902); XXXVII. 415 (1906). - Beissner in Nuov. Giorn. Bot. Ital. n. ser. IV. 185 (1897). - Clinton-Baker, Ill. Conif. I. t. 11 (1909). - Patschke in Bot. Jahrb. XLVIII. 657 (1912).

Western Hupeh: Patung Hsien, on mud and sandstone shales, alt. 1000-1250 m., indigenous but rare (No. 25r2; tree 15-25 m. tall, girth 1-2.5 m., wood brittle, bark milk white exfoliating in thin sheets of irregular shape). Chili: Peking, temple grounds near Summer 
Palace, September 17, 1903, C. S. Sargent; near Peking, October 7, 1905, J. G. Jack; same locality, December 1905, F. N. Meyer (No. 327).

This Pine though frequently met with as a planted tree in temple grounds and courtyards in north-eastern China is very rare in a wild state. It is only known to me from two districts in western Hupeh where it occurs on escarpments of mud-shales. It grows from 5 to $20 \mathrm{~m}$. tall and commonly the trunk divides a few feet above the ground into several stems. The habit is pyramidal, often somewhat irregular and in old trees occasionally round-headed. On old trees the bark on the trunk, on the main branches and exposed main roots is milk-white and exfoliates in flakes of irregular contour. The wood is brittle and of no value except as fuel. With its white bark, massive trunk, stout, deep green leaves this tree is highly ornamental and is so esteemed by the Chinese whose name for it is "Peh Sung" (White Pine).

Pictures of this tree will be found in my collection of photographs under Nos. $15,522,526,527,683$ and in my Vegetation of Western China, Nos. 359, 360, 361, 362,363 .

E. H. W.

Pinus Massoniana Lambert, Descr. Pinus, I. 17, t. 12 (1803); ed. 2, I. 16, t. 8 (1828); ed. minor 20, t. 8 (1832). - Debeaux in Act. Soc. Linn. Bordeaux, XXX. 109 (Fl. Shangh. 57) (1875). - Beissner in Nuov. Giorn. Bot. Ital. n. ser. IV. 185 (1897). - Masters in Jour. Linn. Soc. XXVI. 551 (1902); XXXVII. 416 (1906), - Patschke in Bot. Jahrb. XLVIII. 658 (1912).

Pinus canaliculata Miquel in Jour. Bot. N6erland. I. 86 (1861).

Pinus sinensis Bentham, Fl. Hongk. 337 (non Lambert) (1861).

Kiangsi : Kiukiang foot-hills, alt. 300 m., August 1907 (No. I744; tree 5-15 m. tall, bark reddish). Western Hupeh: Ichang and vicinity, alt. 30-1300 m., abundant, April and December 1907 (Nos. I48o, I48I, 2503; tree 10-25 m. tall, girth $0.6-3 \mathrm{~m}$., often planted as a source of fuel); Hsing-shan Hsien, alt. 1300-1500 m., July 1907 and January 1909 (No. I469; tree 15-20 m. tall, girth 1-3 m.); Changyang Hsien, alt. $1500 \mathrm{~m}$., November 1907 (No. I482; tree 15-20 m. tall); "Kao-kien-scian," alt. 800 m., June 1907, C. Silvestri (No. 100). Western Szech'uan: near Wa-shan, alt. 1100-1500 m., September and November 1908 (Nos. 1378, 1476; tree 13-20 m. tall); Kiating Fu and westward to Mupin, alt. 300-1000 m., May and November 1908 (No. I468; tree 10-25 m. tall, girth 1-3 m., abundant on red-sandstone). Hongkong: Happy Valley, woods, alt. sea-level to $600 \mathrm{~m}$., April 1909 (No. 1483; tree 15-25 m. tall, girth 1-3 m.); same locality, November 4, 1903, C.S. Sargent. Fokien: Fuchou, 1886, H. Mayr.

In all but the cold parts of China this is the common low-level Pine. Throughout the Yangtsze Valley it is abundant and extends from the sea-coast to the 
western limits of the Red Basin of Szech'uan, a distance of some eighteen hundred miles; its altitudinal limit in this region is about $1300 \mathrm{~m}$. In this region it is everywhere abundant, but is not partial to limestone; it is commonly planted as a source of fuel. As ordinarily met with it is a tree of no great beauty, but when allowed to develop fully, it is one of the handsomest members of the genus. At its best it is a tree from 25 to $30 \mathrm{~m}$. tall with a clean trunk for twothirds of its height and a rounded oval or flattened head. In the upper, windswept parts of the tree the bark is red and peels off in thin strips but near the base of the trunk the bark is dark grey, persistent and fissured into thick, irregular oblong massies. At low levels the wood is loose-grained, brittle and useless except for fuel; at $800 \mathrm{~m}$. altitude and upwards the wood is close-grained and durable, and is esteemed for general building purposes. At these altitudes the trunks of the standing trees are often deeply gashed and after a lapse of time felled and the wood used for torches.

This Pine and the other Hard Pines of China are known by the general name of "Sung Shu" (literally Pine tree).

Pictures of this tree will be found under Nos. 284, 303, 304, 383, 475, 476, 477, $478,503,587,595,638,663,664,021,0178$ in the collection of my photographs and also in my Vegetation of Western China, Nos. 366-380.

E. H. W.

Pinus sinensis Lambert, Descr. Pinus, ed. minor, I. 47, t. 29 (1832); ed. 1, III. f. [2], t. (1837). - Loudon, Arb. Brit. IV. 2264, fig. 2169 (1838); Encycl. Trees and Shrubs, 999, fig. 1874 (1842). - Forbes, Pinetum Woburn. 39, fig. 12 (1839). - Antoine, Conif. 1, t. 1, fig. 1 (1840). - Mayr, Fremdl. Wald- \& Parkb. 349, fig. 113 (1906), excludendo synonymo.

Pinus tabulaeformis Carrière, Traité Conif. ed. 2, 510 (1867).

Pinus leucosperma Maximowicz in Bull. Acad. Sci. St. Pétersbourg, XVI. 558 (1881); in Mél. Biol. XI. 347 (1881).

Pinus Thunbergii Franchet in Nouv. Arch. Mus. Paris, sér. 2, VII. 95 (Pl. David. I. 285) (non Parlatore) (1884); in Jour. de Bot. XIII. 253 (1899). Beissner in Nuov. Giorn. Bot. Ital. n. ser. IV. 185 (1897). - Masters in Jour. Linn. Soc. XXVI. 552 (1902); XXXVII. 417 (1906). - Patschke in Bot. Jahrb. XLVIII. 658 (1912).

Pinus densiflora Franchet in Jour. de Bot. XIII. 253 (non Siebold \& Zucearini) (1899). - Masters in Jour. Linn. Soc. XXVI. 549 (1902); XXXVII. 416 (1906). - Shaw in Sargent, Pl. Wilson. I. 2 (1911). - Patschke in Bot. Jahrb. XLVIII. 658 (1912).

Pinus funebris Komarov in Act. Hort. Petrop. XX. 177 (1901). Pinus densiflora, var. tabuliformis Masters in Jour. Linn. Soc. XXVI. 549
(1902).

Pinus Henryi Masters in Jour. Linn. Soc. XXVI. 550 (1902); XXXVII. 416 (1906). - Patschke in Bot. Jahrb. XLVIII. 568 (1912).

Pinus Argyi Lemée \& Léveillé, $P$. nana Faurie \& Lemée et $P$. Cavaleriei Lemée \& Léveillé in Fedde Rep. Sp. Nov. VIII. 60 (1910), verisimiliter
huc ducenda.

Pinus Wilsonii Shaw in Sargent, Pl. Wilson. I. 3. (1911).

Kiangsi : Kuling, alt. 1400-1500 m., July and August 1907 (Nos. I745, I747; tree 6-10 m. tall, sometimes scrub 1-1.5 m, tall). Western 
Hupeh: Hsing-shan Hsien, alt. 1200-2600 m., May, July and December 1907, January 1908 and 1909, abundant (Nos. 1484, I490, I495, I497, I498, I499, I496, I485, I486, I487, I492; tree 10-20 m. tall, girth 0.6-2.5 m.); Fang Hsien, cliffs, alt. 1600-2500 m., May 1907 (Nos. I488, I494, 4430; small tree 12-15 m. tall); samelocality, alt. 2300 m., A. Henry (No. 6909); Patung Hsien, near hamlet of Ta-wan, alt. $2200 \mathrm{~m}$., May, July and December 1907 (No. r489; tree 15-20 m. tall, girth 1-2 m.). Western Szech'uan: Mupin and vicinity, alt. 1500-2300 m., November 1908 (Nos. ro97, I472, r390; tree 6-25 m. tall, girth 1-2.5 m.); Yungtsen, 12 kilometers from Mupin, alt. $1300 \mathrm{~m}$., November 1908 (No. I376; tree $10 \mathrm{~m}$. tall, bark reddish); near Tachienlu, alt. 2300 m., August 1908 (No. 250r; tree 20-25 m. tall, girth 2$2.5 \mathrm{~m}$.) ; north-east of Tachien-lu, forests of Ta-p'ao-shan, alt. $3500 \mathrm{~m}$., forming forests, July 1908 (No. I49r; tree 20-25 m. tall, girth 1-3 m.); Wa-shan, alt. 1600-2000 m., common, September 1908 (Nos. I47I, I477; tree 20-25m., girth 2-3 m.); west of Kuan Hsien, Niu-tou-shan, alt. $2300 \mathrm{~m}$., abundant, June 21, 1908 (No. 2500; tree 15-25 m. tall); west of Kuan Hsien; ascent of Pan-lan-shan valley, abundant on cliffs; October 1910 (Nos. 4073, 4074; tree 10-25 m. tall, girth 1-2.5 m.); west and near Wên-ch'uan Hsien, alt. 1600-2300 m., common, May, July and November 1908 (Nos. I475, 1369, 1370; tree 15-25 m. tall, girth 1-3 m.); near Mao-chou, alt. 1600-2300 m., forming forests, October 1910 (No. 4056; tree 12-25 m. tall, girth 1-3 m.); same locality, September 1903 (Veitch Exped. No. 3001); near Mao-chou, alt. 1900 m. May 1908 (No. I493, type of P. Wilsonii Shaw). Kansu: Tow River valley, 1910, W. Purdom (No. 814). Shansi: Wutai-shan, 1909, W. Purdom (No. 813); same locality, F. N. Meyer (Nos. 22,680, 22,673). Chili: Peking, grounds of Temple of Heaven, May 16, 1910, (No. 2513; tree 8-10 m. tall, flat-topped); Peking Plain, September 17, 1903, C. S. Sargent, vicinity of Peking, 1906, Butler; Ming tombs, October 1905, J. G. Jack; Tung-ling, November 1908, F. N. Meyer (No. 23913); Wei-chang, 1909, W. Purdom (No. 812).

As here understood this is the only hard Pine found in a wild state in northern China and is also the common Pine on the mountains of central and western China. In Szech'uan its western limit is about long. $104^{\circ} \mathrm{E}$., but in the province of Kansu it extends westward beyond this parallel. In habit and degree of persistence of the cones it presents much variation. On the wind-swept plains of northern China it is a low flat-headed tree with gnarled branches and stout leaves. On the mountains of central China it is a shapely tree of medium size, rather thin leaves, and cones variable in size, and persisting on the tree for four or five years. In western Szech'uan it is a handsome tree $25 \mathrm{~m}$. tall with stout leaves and cones persisting for seven years or more. The bark is usually dark grey, fissured and 
persistent, but occasionally on the exposed upper parts of the tree the bark is red and peels off in thin sheets as in P. Massoniana Lambert. The wood is elosegrained and resinous, very durable and is esteemed for general building purposes.

Pictures of this tree will be found under Nos. 81 (type tree of $P$. Wilsonii Shaw), 114, 117, 168, 058, 059, 0123, 0141, 0330 of the collection of my photographs and also in my Vegetation of Western China, Nos. 352-356.

E. H. W.

\section{Pinus sinensis, var. yunnanensis Shaw, n. var.}

Pinus yunnanensis Franchet in Jour. de Bot. XIII. 253 (1899), - Masters in Jour. Linn. Soc. XXVI. 553 (1902); XXXVII. 415 (1906). - Shaw in Sargent, Pl. Wilson. I. 2 (1911). - Patschke in Bot. Jahrb. XLVIII. 657 (1912).

This variety has the longest leaves and largest cones of the species.

Western Szech'uan: Mupin, alt. 1300-2000 m., November 1908 (Nos. I395, I399, I464; tree 6-20 m. tall, girth 1-2 m.); Chingchi Hsien, Nitou, alt. 1500-1600 m., November 1908 (No. I393; tree 3-20 m. tall, girth 0.6-3 m.); valley of Tung River, alt. 1300-1600 m., November 1908 (No. I396; tree 6-15 m. tall, girth 1-2.5 m.); west of Wa-shan, Malie, alt. 1600 m., November 1908 (No. I394; tree 16 m. tall, girth 3 m.); same locality, July 1903 (Veitch Exped. No. 3000).

This is the low-level Pine in the river-valleys of south-west Szech'uan and west of the limits of the Red Basin. It extends southward into western Yunnan. It is a tree of medium size usually with long, drooping, slender leaves in fascicles of three on all the main shoots and relatively large, long persistent cones. On the upper part of the trunk and main branches the bark is usually red and exfoliates in thin sheets. On the lower part of the trunk the bark is persistent and deeply fissured into irregular, oblong masses. The branches are rather short and the habit usually pyramidal, though old trees are frequently flat-headed. The wood is moderately close-grained and is used for fuel and also for general construction purposes.

Pictures of this tree will be found under Nos. 273, 274, 275, 276 of the collection of my photographs and also in my Vegetation of Western China, Nos. 381, 382, 383.

E. H. W.

Pinus sinensis, var. densata Shaw, n, var.

Pinus densata Masters in Jour. Linn. Soc. XXXVII. 416 (1906). - Shaw in Sargent, Pl. Wilson. I. 2 (1911). - Patschke in Bot. Jahrb. XLVIII. 658 (1912).

Pinus prominens Masters in Jour. Linn. Soc. XXXVII. 417 (1906), - Patschke in Bot. Jahrb. XLVIII. 658 (1912).

This variety differs chiefly in its oblique cones with their posterior apophyses tumid and prominent.

Western Szech'uan: west of Tachien-lu, descent to valley of Yalung River, around hamlet of Orang-che, alt. 3000-4000 m., October 1908 (Nos. I465, I466, I467, 1478, I479; tree 20-30 m. tall, girth 1-4 m.); same locality, June 1904 (Veitch Exped. No. 3015, type of 
$P$. densata Masters); valley of Tung River, around village of Moshimien, alt. 1100 m., October 1908 (Nos. I398, 2504; tree 10-15 m. tall, girth 1-2 m.); 20 kilometers north of Tachien-lu, alt. 2800-3300 m., October 1908 (No. 1397, 2502; tree 6-20 m. tall); 16 kilometres west of Tachien-lu, around hamlet of Cheto, alt. 3300 m., July 1908 (No. 905; tree 8-25 m. tall, girth 0.6-2 m.); same locality, June 1904 (Veitch Exped. No. 3016, type of P. prominens Masters); west of Kuan Hsien, near Monkong Ting, valley of Hsao-chin Ho, alt. 23002600 m., June 1908 (No. I500; tree 15-25 m. tall); west and near Wênch'uan Hsien, alt. 1600-2300 m., November 1908 (No. I368; tree 1220 m. tall); near Sung-pan Ting, alt. 2600-3000 m., August 1910 (No. 4055 ; tree $15-20 \mathrm{~m}$. tall, girth 1-2.5 m.).

This is the common Pine on the mountains of western Szech'uan west of the Red Basin and its altitudinal range is higher than that of any other Chinese Pine. The form on which Masters based his $P$. prominens has dark grey persistent bark and short branches and is always a tree of medium size with a close pyramidal habit. Pictures of this form will be found under No. 231 of the collection of my photographs and in my Vegetation of Western China, No. 364.

The form on which $P$. densata Masters is founded very strongly resembles $P$. sylvestris Linnaeus in habit and general appearance, having a clean trunk, massive branches forming a rounded or flattened head and pale red bark on the.branches and upper part of the trunk, which peels off in thin flakes. West of Fuchien-lu at altitudes of from $3000-3500 \mathrm{~m}$. in the descent to the Yalung River this tree forms extensive forests.

In the two varieties the cones are long persistent, and the wood is close-grained, very resinous and durable and is highly esteemed for general building purposes, it is also used for torches.

E. H. W.

\section{LARIX Mill.}

Larix Potaninii Batalin in Act. Hort. Petrop. XIII. 385 (1893). Masters in Jour. Linn. Soc. XXVI. 558 (1902); XXXVII. 424. (1906); in Gard. Chron. ser. 3, XXXIX. 178, fig. 68 (1906). - Bean in Kew Bull. Misc. Inform. XXIII. 173, t. (1910). - Patschke in Bot. Jahrb. XLVIII. 651, (1913).

Larix chinensis Beissner in Mitt. Deutsch. Dendr. Ges. V. 68 (1896); in Nuov. Giorn. Bot. Ital. n. ser. IV. 183, t. 5, fig. 1 (1897). - Pritzel in Bot. Jahrb. XXIX. 216 (1900), - Masters in Jour. Linn. Soc. XXVI. 558 (1902); XXXVII. 424 (1906), - Patschke in Bot. Jahrb. XLVIII. 651 (1913).

Larix thibetica Franchet in Jour. de Bot. XIII. 262 (1899). - Pritzel in Bot. Jahrb. XXIX. 216 (1900). - Masters in Jour. Linn. Soc. XXVI. 558 (1902); XXXVII. 424 (1906).

Larix Griffithii Masters in Jour. Linn. Soc. XXVI. 558 (non Hooker f. \& Thomson) (1902); XXXVII. 424 (1906).

Pinus sinensis Voss in Putlitz \& Meyer, Landlexicon, IV. 769 (non Lambert) (1913). 
Western Szech'uan: Tachien-lu, forests to west and southwest, alt. 3300-4000 m., July 20, 1908 (No. 9ro; tree 6-25 m. tall, 0.6-3 m. girth); same locality, alt. 2500-3800 m., June and September 1904 (Veitch Exped. No. 3009); north-east of Tachien-lu, Ta-p'aoshan, forests, alt. 3300-4800 m., abundant, July 7, 1908 (No. 903; tree 6-30 m. tall, 1-4 m. girth); vicinity of Tachien-lu, Prince Henri d'Orléans, type of $L$. thibetica Franchet; west and near Wên-ch'uan Hsien, alt. 2300-3000 m., July 1908 (No. 906a ; tree 10-16 m. tall, 1-2 m. girth); west of Kuan Hsien, Pan-lan-shan, forests, alt. 2600-3500 m., October 1910 (No. 407x; tree 13-25 m. tall, 1-2.5 m. girth); Mupin, forests, alt. 3000-3600 m., September 1910 (No. 4362; tree 6$16 \mathrm{~m}$. tall, 0.5-2 m. girth); northeast of Sungpan, Hsueh-pao-ting, forests, alt. 2500-3600 m., common, August 1910, (No. 4729; tree 8$25 \mathrm{~m}$. tall, 1-3 m. girth). Kansu: Lotani, road to Siku Ting, alt. 3000-3300 m., 1911, W. Purdom (No. 760); Peling-shan, 1911, W. Purdom (No. 817). Shensi: Tsinling range, Tai-pei-shan, alt. 3000-3300 m., 1910, W. Purdom (No. 404; tree 6-10 m. tall).

This is the common Larch of western Szech'uan where it is found from $2500 \mathrm{~m}$. altitude to the limits of arborescent vegetation. At its lowest altitude it occurs sparingly in moist woods and more especially by the sides of streams, in company with other conifers and broad-leaved trees. As the altitude increases it becomes more and more abundant until finally in the high alpine regions it forms forests. In moist, rich woodlands this Larch grows from $25-30 \mathrm{~m}$. tall; the trunk is mastlike and covered with grey and grey-brown bark which is rough and fissured. The branches are slender, relatively short and horizontally spreading; the branchlets are pendulous, shining orange-brown or purplish brown becoming grey in the second or third year. The symmetrical cones are very freely produced and vary in length from 3-4.5 $\mathrm{cm}$. and in color from reddish when young to violet-purple at maturity, afterwards changing to grey-brown or grey. The bracts although varying considerably in size and shape are always exserted, erect, and usually long-acuminate. The seeds ripen the end of June or early in July. With its symmetrical habit, weeping branchlets and pale, often greyish, green foliage this Larch is a decidedly handsome and striking tree. Colloquially it is known as the "Hung-sha" (Red Fir), and the wood is esteemed the most valuable of all timber in western Szech'uan for general construction work.

Purdom's No. 404, from the type locality of $L$. chinensis Beissner, removes all doubt of the identity of that species with $L$. Potaninii. The species of Larch collected in southern Shensi by David (Franchet in Nouv. Arch. Mus. Paris, sér, 2, VII. 97 (Pl. David. 1. 287) (1884), must also be referred to $L$. Potaninii.

Pictures of this tree will be found under Nos. 177, 193, 195, 229, 232 of the collection of Wilson's photographs and also in his Vegetation of Western China, Nos. 279-285.

Larix Mastersiana Rehder \& Wilson, n. sp.

Arbor 10-20-metralis, trunco 0.3-0.75 m. diam., cortice einereobrunneo, irregulariter fisso; rami primarii satis longi, horizontaliter 
patentes; ramuli penduli, annotini obscure pallide flavo-brunnei, glabri, hornotini initio sparse pubescentes; gemmae brachyblasticae ovatae, obtusae, avellaneae, nitidulae, basi pilis pallidis circumdatae. Folia fasciculata, 25-40 v. plura, laete viridia, linearia, supra medium paulo latiora, basim versus sensim angustata, apice acuta $\mathrm{v}$. acutiuscula leviter incrassata, margine leviter recurva, 1.2-3.5, plerumque 2-3 cm. longa, circiter quater latiora quam crassa, utrinque carinata, subtus fasciebus 2 stomatiferis leviter glaucescentibus, epidermide leviter papillosa, hypodermide supra contigua, subtus tantum sub carina et marginem versus evoluta, endodermide ovali, fasciculo vasculari cellulis sclerenchymaticis instructo. Strobili numerosi, breviter pedunculati, erecti, maturitate brunnei, 3-4 cm. longi; bracteae persistentes, triangulari-ovatae, squamis longiores, reflexae, sensim in cuspidem attenuatae, rarius leviter contractae, 10-14 $\mathrm{mm}$. longi, 6-7 mm. lati; squamae numerosae, reniformi-orbiculares, rotundatae v. leviter truncatae, integrae, 6-9 $\mathrm{mm}$. longae et 9-12 $\mathrm{mm}$. latae; semina obovoidea, $2-2.5 \mathrm{~mm}$. longa, alis obovatis rotundatis v. obtusiusculis $6-8 \mathrm{~mm}$. longis nitidulis brunneis.

Western Szech'uan: west of Kuan Hsien, on the Niu-tou-shan, alt. 2600-3300 m., June 21, 1908, seeds ripe (No. 9o6, in part, type); west of Kuan Hsien, lower slopes of the Pan-lan-shan, sides of streams, alt. 2000-3300 m., common, June and July 1908 (No. 906, in part); west and near Wên-ch'uan Hsien, woodlands, alt. 2500-3500 m., October 1910 (No. 4730).

This new Larch is closely related to L. Griffithii Hooker f. \& Thomson, which is distinguished chiefly by its very much larger cones $5-8 \mathrm{~cm}$. long, with larger bracts abruptly cuspidate at the apex, and by the leaves which have a smooth, not papillose epidermis and a continuous hypoderm.

Larix Potaninii Batalin, the only other and much more common Larch found in western Szech'uan can be distinguished at once by its shining orange-brown or purple-brown branchlets and by the violet-purple color of its ripe cones with shorter, erect bracts. The habit is also less spreading and more pendulous than that of $L$. Mastersiana and in this respect $L$. Potaninii more closely resembles $L$. Griffithii. These three species of Larch with the north-west American species $L$. occidentalis Nuttall, and L. Lyallii Parlatore, form a well-marked section of the genus, distinguished by the relatively large cones with exserted bracts. In $L$. Potanini, $L$. occidentalis and $L$. Lyallii, the exserted part of the bract is erect; in L. Griffithii and L. Mastersiana it is strongly recurved.

Larix Mastersiana is apparently a very local species and is known to us only from the petty tribal state of Wassu, situated immediately west of the Min river north of Kuan Hsien. In this small territory this Larch is abundant, but in 1908 and 1910 it was being rapidly cut in the more accessible districts. The timber is esteemed for house building and general construction work and commands a high price at Kuan Hsien. Fortunately the region is extremely precipitous and difficult of access and there is very little possibility of this interesting tree being ex- 
terminated. It is now in cultivation at the Arnold Arboretum and is in other collections.

A picture of this tree will be found under No. 126 in Wilson's collection of photographs and in his Vegetation of Western China, No. 281.

Here may be added a note on a variety of $L$. dahurica Turczaninow collected in Shansi by W. Purdom and by F. N. Meyer.

Larix dahurica Turezaninow, var. Principis Rupprechtii Rehder \& Wilson, n. var.

Larix Principis Rupprechtii Mayr, Fremdl. Wald- $u$. Parkb. 309, fig. 94 (1906). - Masters in Jour. Linn. Soc. XXXVII. 424, (1906).

Shansi: Wutai village, around temples, 1909, W. Purdom (Nos. 161, 161 ${ }^{\mathrm{a}}$, $\left.161^{b}\right)$; Wutaishan, over the pass, alt. 2600-3000 m., 1909, W. Purdom; without precise locality, alt. 2000 m., 1910, W. Purdom; Wutai-shan, "Tshai-ling-tse" temple, February 25, 1908, F. N. Meyer (No, 22674). Chili: Weichang, 1909, W. Purdom (No. 21; tree 20-25 m. tall, girth $2 \mathrm{~m}$.), Weichang north and west, 1909, W. Purdom (Nos. 204, 246).

The typical form of L. Principis Rupprechtii Mayr as represented by the specimens from Wutai-shan looks quite distinct from typical $L$.dahurica, but the specimens from Weichang, together with others from Manchuria, Amurland and Korea form a series which gradually merge into typical $L$. dahurica. With $L$. sibirica Ledebour with which it has been compared, it agrees only in the size of its cones, but differs in their perfectly glabrous, more spreading and thinner scales not incurved on the margin, truncate or (particularly in the Weichang specimens) even emarginate at the apex, and in the more conspicuous bracts which are often, particularly in the lower part of the cone, more than half as long as the scales; in all these characters $L$. Principis Rupprechtii agrees with $L$. dahurica and it seems therefore best to consider it a variety of this species, distinguished by the more numerous scales. Purdom and also Meyer speak of this Larch as forming forests on the northern slopes of Wutai-shan and in its neighbourhood where, according to Meyer, the snow does not melt until well into May. In the Weichang region Purdom remarks that this tree is now becoming very scarce.

We are not able to distinguish from typical $L$. dahurica the $L$. Cajanderi Mayr (Fremdl. Wald-u. Parkb. 297, fig. 88 (1906)).

\section{PSEUDOLARIX Gord.}

Pseudolarix Kaempferi Gordon, Pinetum, 292 (1858), excludendo synonymo Pinus Kaempferi. - Masters in Gard. Chron. n. ser., XXI. 584, figs. 112, 113 (1884); in Jour. Linn. Soc. XXII. 208, fig. 32, t. 9, 10 (pro parte) (1887). - Patschke in Bot. Jahrb. XLVIII. 655 (1913).

Abies Kaempferi Lindley in Gard. Chron. 1854, 255, 455, fig., excludendo synonymo, non Lindley in Penny Cycl. I. 34 (1833); in Gard. Chron. 1855, 644, fig. - Fortune in Gard. Chron. 1855, 242; 1860, 170; Residence among Chinese, 274, fig. (1857).- Murray in Proc. Hort. Soc. Lond. II. 643, fig. 172-182 (1862); Pines and Firs Jap. 97, fig. (1863).

Larix Kaempferi Carrière in Fl. des Serr. XI. 97 (1856). - Franchet \& Savatier, Enum. Pl. Jap. I. 466 (1875), quoad plantam chinensem. Franchet in Nouv. Arch. Mus. Paris, sér. 2, VII. 96 (Pl. David. I. 286) (1884).

Larix amabilis Nelson, Pinac. 84 (1866). 
Pinus Kaempferi Parlatore in De Candolle, Prodr. XVI, pt. 2, 412 (non Lambert) (1868).

Pseudolarix Fortunei Mayr, Monog. Abiet. Jap. 99 (1890), - Masters in Jour. Linn. Soc. XXVI. 557 (1902); XXXVII. 424 (1906), - Wilson in Gard. Chron. ser. 3, XLII, 344 (1907), - Hemsley in Bot. Mag. CXXXIV. t. 8176 (1908).

Laricopsis Kaempferi Kent in Veitch's Man. Conif. 404, figs. 105, 106 (1900).

Kiangsi: Kuling, alt. 1300 m., not common, August 1, 1907 (No. I742; tree 4-12 m. tall).

This remarkable tree reaches the western limits of its distribution on the Lushan range in the Kiangsi province where it is rare and no large trees remain. From this point it extends eastward to the neighbourhood of Ningpo where Fortune discovered it. The first mention of the tree in western writings is found in Barrow's Travels in China, 536 (1804) where, speaking of the country south of the Poyang lake (Kiangsi province), he says "the mountains between which the river was hemmed in were covered with forests of the larch fir." No true larch is known from this region and Barrow's tree cannot be any other than the Pseudolarix.

The Chinese name for this tree is "Kin-ye-sung" (Golden-leaved Pine) and refers to the autumn color of the leaves. It is perfectly clear that Lindley, in describing this tree from Fortune's material as Abies Kaempferi, thought he was dealing with the "Larix conifera" etc., of Kaempfer (Amoen. 883), a plant which Endlicher (Synop. Conif. 130) in 1847 referred to Abies leptolepis Siebold \& Zuccarini. This mistake, however, cannot invalidate Gordon's specific name for Fortune's tree, since there is no older name to replace it,

\section{PICEA Link.}

\section{Sect. I. EUPICEA Willk.}

Picea asperata Masters in Jour. Linn. Soc. XXXVII. 419 (1906).Beissner, Handb. Nadelholzk. 256 (1909). - Patschke in Bot. Jahrb. XLVIII. 633 (1913).

Western Szech'uan: west and near Wên-ch'uan Hsien, forests, alt. 2000-3300 m., June 1908 and Oetober 1910 (Nos. 2080, 4046, 4047; tree 15-25 m. tall, girth 1-3 m.); west of Kuan Hsien, Pan-lanshan, forests, alt. 2600-3800 m., October 1910 (No. 4066; tree 15$35 \mathrm{~m}$. tall, girth 1.5-3 m.); Sungpan Ting, forests, alt. 2500-3500 m., abundant, August and October 1910 (Nos. 473I, 406r; tree 10-35 m. tall, girth 1-3 m.); same locality, August 1903 (Veitch Exped. No. 3025 , type).

This is the common quadrangular-leaved spruce of northwestern Szech'uan, and is more especially abundant in the department of Sungpan Ting where extensive forests of this species occur. In general appearance it closely resembles the 
Picea Abies Karsten. In mature trees the horizontally spreading branches are slightly decurved but upturned at the ends. Old trees are very spire-like in appearance. The bark is greyish-chestnut and rough, and peels off in thin irregularly shaped flakes. The young shoots are pale yellowish-grey, often slightly pruinose, and change to brown and finally to grey. The degree of pubescence on the shoots varies considerably and the peg-like petioles may be ascending-spreading, spreading or recurved. The cones vary from 8-12 $\mathrm{cm}$. in length, are fawn-grey when ripe changing to shining chestnut-brown with age, and are retained on the tree for six months or so after they are mature. The cone-scales exhibit considerable variation in shape, being either rounded, or even slightly truncate, to rhombic at the summit. The winter buds are the same in all the specimens, being conical, and often much swollen at base. The bud-scales are thin, loosely imbricated, free, inclined to be recurved at the summit. Although the variation in different characters is considerable, yet with abundant material before us we cannot distinguish more than one species among the numbers eited. The timber resembles that of the Picea Abies and is esteemed for general building purposes in the region where the tree grows. Some of the trees are very glaucous in appearance, hence the colloquial name "Yün sha" (Cloudy Fir). Pictures of this tree will be found under Nos. 0289, 0303, 0308, 0314, 0318, 0327 of the collection of Wilson's photographs.

\section{Picea asperata, var. notabilis Rehder \& Wilson, n. var.}

A typo recedit foliis majoribus $12-20 \mathrm{~mm}$. longis, strobilis 9-12 $\mathrm{cm}$. longis, squamis praesertim inferioribus rhombico-ovatis, apicem versus attenuatis et paullo productis apice interdum leviter emarginatis.

Western Szech'uan: west of Kuan Hsien, Pan-lan-shan, forests, alt. 2600-3800 m., June 1908 and October 1910 (Nos. 2068, type; 4067; tree 15-35 m. tall, girth 1.5-3 m.); Chiu-ting-shan, east of Mao-chou, open country, alt. 2000-2500 m., May and October 1908 (No. 973; tree 10-20 m. tall, girth 1-2.5 m.).

This variety differs from the type chiefly in the shape of the scales which are more or less rhombic-ovate in outline and gradually narrowed toward the apex, or sometimes abruptly contracted at the apex, not rounded, except the upper scales which are sometimes rounded. The scales resemble in shape somewhat those of P. montigena Masters, but differ in color and texture. In No. 973 the scales are less elongated and the cones somewhat larger.

A picture of this tree will be found under No. 142 of the collection of Wilson's photographs and in his Vegetation of Western China, No. 340.

Picea asperata, var. ponderosa Rehder \& Wilson, n. var.

A typo recedit cortice crassiore brunneo-cinereo, ramulis glabris v. fere glabris luteis, pulvinis tumidioribus apice supra petiolum producto acuto, strobilis majoribus $12-14 \mathrm{~cm}$. longis.

Western Szech'uan: west of Kuan Hsien, Pan-lan-shan, forests, alt. 3000-3300 m., October 1910 (No, 4068; tree 25-35 m. tall).

This handsome variety is remarkable for its large cones which in size rival those of $P$. morinda Link. 


\section{Picea heterolepis Rehder \& Wilson, n. sp.}

Arbor 6-25-metralis, trunco 0.3-0.6 m. diam.; rami horizontaliter patentes; ramuli juniores fulvi v. fusco-brunnei, nitiduli, glabri, vetustiores cinerascentes; pulvini rhombici v. lineares, apice saltem in ramis robustioribus supra petiolum producti, obtusi et turgidi, petiolis patentibus $\mathrm{v}$. in ramis robustioribus reflexis $1-1.5 \mathrm{~mm}$. longis, cicatricibus quadrangularibus; gemmae elongato-ovatae, flavo-brunneae, resinosae, perulis laxe adpressis apice obtusis revolutis persistentibus. Folia undique subaequaliter patentia, linearia, quadrangularia, crassa, leviter falcata, saepe glaucescentia, subito spinosoacuminulata, 1-2 cm. longa, fasciebus stomatiferis 4 e seriebus stomatum 3-5 compositis. Strobili oblongo-cylindrici, pallide fulvo-brunnei, vix nitentes, 9-14 cm. longi et 3-4 cm. diam., decidui 6-8 menses post maturitatem; bracteae oblongo-obovatae et apice triangulariacutae v. lineari-lanceolatae, $5-6 \mathrm{~mm}$. longae; squamae rigidae, cuneato-obovatae v. rhombico-obovatae, apicem versus sensim angustatae et apice ipso profunde emarginata v. bifidae, tantum squamae summae rotundatae et integrae, leviter striatae, sub maturitate erectopatentes; semina alis anguste oblongo-obovatis $\mathrm{v}$. oblongo-obovatis, circiter $15 \mathrm{~mm}$. longis et $4.5-7 \mathrm{~mm}$. latis apice rotundatis quam squamae triente brevioribus pallide fulvo-brunneis, testa atrobrunnea sparse puberula.

Western Szech'uan: Mao-chou, woodlands and open country, alt. 1600-2500 m., October 1910 (No. 4064).

This new Spruce is characterized by its bright orange brown, glabrous shoots, elongated buds with loosely imbricated reflexed bud-scales and by the bilobed nearly rhombic-obovate cone-scales. It is most closely related to P.asperata Masters, which grows in the same region and has pubescent, duller colored shoots, conical winter-buds with much less loosely imbricated and scarcely reflexed bud-scales and entire, rounded, obovate cone-scales. The bilobed cone-scales are very remarkable and a constant character in the numerous specimens before us which were collected from different trees.

A picture of this tree will be found under No. 0336 in the collection of Wilson's photographs.

\section{Picea gemmata Rehder \& Wilson, n. sp.}

Arbor 20-40-metralis, trunco 0.5-1 m. diam., cortice griseo v. griseobrunneo fisso et in lamellas satis tenues irregulares soluto; rami horizontaliter patentes; ramuli pallide fulvi, dense hirtello-villosi, tomento per plures annos persistente, vetustiores einereo-brunnei v. grisei, ad bases innovationum incrassati; pulvini tumidi, rhombici v. oblongi, in ramis robustioribus apice supra petiolum erecto-patentem circiter 
$1 \mathrm{~mm}$. longum hirtellum producti et acuti, cicatricibus quadrangularibus; gemmae conicae, crassae, acutiusculae, pallide flavo-brunneae, resinosae, perulis interioribus ovatis acutis $\mathrm{v}$. obtusiusculis apice laxe adpressis, infimis foliaceis crassis rigidis acuminatis dorso hirtellis. Folia linearia, quadrangularia, erecto-patentia, 6-18, plerumque 8-15 mm. longa, 1-2 mm. lata, recta v. curvata, subito acuminata, pungentia, ea ramulorum robustiorum fere lanceolata, subadpressa, ad basim gemmorum sensim in perulas dorso hirtellas mutata, fasciebus stomatiferis 4 e seriebus stomatum 4-6 compositis. Strobili oblongocylindrici, apice attenuata, 8-12 cm. longi et $3.5 \mathrm{~cm}$. diam., fulvo brunnei, nitidi; bracteae ovato-lanceolatae, acutae v. obtusae, denticulatae, 4-5 mm. longae; squamae adpressae, maturitate erecto-patentes, firmae, coriaceae, rotundato-obovatae, apice rotundatae, obsolete erosae, basi late cuneatae, circiter $1.8 \mathrm{~cm}$. longae et latae; semina alis oblongo-obovatis, $10-15 \mathrm{~mm}$. longis pallide brunneis, testa atrobrunnea puberula.

Western Szech'uan: northeast of Tachien-lu, Ta-p'ao-shan, forests, alt. 3300-3600 m., October 1908 (No. 2067).

This new Spruce is distinguished by its densely hairy shoots, relatively short, very pungent leaves, and smooth, shining cones with broad, rounded scales. The leaves subtending the winter-buds show a complete transition into budscales and are remarkable in being distinctly hairy on the outer surface. This new species is most closely related to $P$. asperata Masters, which differs chiefly in its pale yellow-grey, often pruinose, much less hairy and often glabrescent shoots, in its fawn-grey to chestnut-brown cones with less broad, usually rhombic scales, and to a lesser degree in its bark which is greyish chestnut and peels off in thin flakes. The scales of the winter-buds are also more loosely appressed and often somewhat recurved at the apex of the bud.

Picea retroflexa Masters in Jour. Linn. Soc. XXXVII. 420 (1906). - Patschke in Bot. Jahrb. XLVIII. 632 (1913).

Descriptioni originali adde: Arbor 10-45-metralis, cortice tenui cinereo in lamellas tenues satis magnas soluto et corticem interiorem pallide fulvum v. roseo-fulvum detegente; gemmae conicae, acutiusculae, perulis membranaceis laxe adpressis persistentibus. Folia spiraliter disposita, patentia, linearia, quadrangularia, $1-2.5 \mathrm{~cm}$. longa, circiter $1 \mathrm{~mm}$. diam., subito acuminata, pungentia, fasciebus stomatiferis 4 e seriebus stomatum 5-7 compositis. Strobili bracteae lanceolatae, acutae, $6 \mathrm{~mm}$. longae; semina alis $1.5 \mathrm{~cm}$. longis oblique oblongo-obovatis pallide brunneis nitentibus, testa atrobrunnea minute puberula.

Western Szech'uan: northeast of Tachien-lu, Ta-p'ao-shan, 
forests, alt. 3000-4000 m., June and July 1908 (Nos. 2074, 2065; tree 10-45 m. tall, girth 1-4 m.); west and southwest of Tachien-lu, woods and forests, alt. 3000-3500 m., October 1910 (No. 4083; tree 20-30 m. tall, girth 1.5-2.5 m.); same locality, June 1904 (Veitch Exped. No. $\left.3029^{\mathrm{a}}\right)$.

This is a very common Spruce in the neighborhood of Tachien-lu and one of the principal eonstituents of the upland forests in that region. In general appearance it resembles the Picea Abies Karsten, but it is often very glaucous. The bark of adult trees is grey and peels off in thin plates of irregular size and shape and exposes a dun-coloured layer below. The shoots are glabrous or very rarely slightly hairy, usually golden yellow, very seldom "fusco-aurantiaci" as described by Masters, and change to grey the third or fourth year. The cone is symmetrical, pale, shining brown becoming darker with age and is retained on the tree for nearly a year after the seeds have dispersed. The cone-scales are rounded or rhombic erect-spreading and always striated. It is unfortunate that Masters founded this species mainly on cones which, as he himself suspected, were malformed through an infestation of a common fungus, Pleosporopsis strobilorum. Masters cites No. $3030^{3}$, but in the herbarium of the Arnold Arboretum the number referable to his $P$. reflexa is No, $3029^{a}$.

Pictures of this tree will be found under Nos. 169, 170, 171 of the collection of Wilson's photographs in his Vegetation of Western China, Nos. 342, 343.

Picea aurantiaca Masters in Jour. Linn. Soc. XXXVII.420 (1906).Beissner, Handb. Nadelholzk. ed. 2, 257 (1909). - Patschke in Bot. Jahrb. XLVIII. 632 (1913).

Western Szech'uan: neighborhood of Tachien-lu, Cheto-shan, forests and open country, alt. 2600-3800 m., July and October 1908, October 1910 (Nos. 2058, 2069, 408I ; tree 10-25 m. tall, girth 1-2 m.); same locality, ait. 3000-4000 m. July 1903 (Veitch Exped. No. 3029, type).

This is a rather local species so far known only from the regions to the west and southwest of Tachien-lu. Adult trees are very spire-like in appearance and but sparingly branched. The bark is very distinct being pale grey, almost white, in color, rough and exfoliating in relatively thin, irregularly oblong plates. The young shoots vary from deep orange to dull orange, and are often slightly pruinose; they became greyish the fourth or fifth year. The ripe cones are from 11-12 cm. long, very symmetrical, dull cinnamon-brown passing to shining chestnut-brown with broad, rounded, sub-coriaceous slightly erose scales, and fall from the tree a month or so after they have shed the seeds.

A picture of this tree will be found under No. 230 of the collection of Wilson's photographs and also in his Vegetation of Western China, No. 348.

Picea Neoveitchii Masters in Gard. Chron. ser. 3, XXXIII. 116, fig. 50, 51 (1903); in Jour. Bot. XLI. 270 (1903); in Jour. Linn. Soc. XXXVII. 421 (1906). - Beissner in Mitt. Deutsch. Dendr. Ges. XII. 68 (1903); Handb. Nadelholzk. ed. 2, 249 (1909). - Mayr, Fremdl. 
Wald- u. Parkb. 332 (1906), - Patschke in Bot. Jahrb. XLVIII. 633 (1913).

Western Hupeh: Hsing-shan Hsien, cliffs, alt. 1800 m., very rare, June 1907 (No. 2054; tree 8-15 m. tall, 1-1.5 m. girth).

This very rare tree is only known to us from a few specimens of medium size growing on steep cliffs in the northeastern part of the district of Hsing-shan. The habit is pyramidal, the branches being rather short and ascending-spreading and densely elothed with dark green pungent leaves. The dark grey bark is rather rough and exfoliates in small, thin, irregular-shaped flakes.

Picea Watsoniana Masters in Jour. Linn. Soc. XXXVII. 419 (1906). - Beissner, Handb. Nadelholzk. ed. 2, 256 (1909). - Patschke in Bot. Jahrb. XLVIII. 632 (1913).

Picea Maximowiczii Masters in Jour. Linn. Soc. XXVI. 554 (1902), quoad specimen chinense, non Regel.

Western Hupeh: Hsing-shan Hsien, woods, alt. 1600-2300 m., May and June 1907 (No. 205I; tree 10-20 m. tall); Fang Hsien, mountains, July 1901 (Veitch Exped. No. 2411, seed No. 1309); same locality, A. Henry (Nos. 6763, 6823). Western Szech'uan: Sungpan Ting, woods, alt. 2200-3300 m., August 1903 (Veitch Exped. No. 3023, type). Shensi: Tai-pei-shan, south side, alt. $2600 \mathrm{~m}$, rare, W. Purdom (No. 673).

This tree is fairly common on the mountains of northwestern Hupeh between 1600 and $2500 \mathrm{~m}$. altitude and also in northwestern Szech'uan. It is a shapely and rather small tree with slender horizontally disposed branches of more or less equal length from the base to the top of the tree and densely clothed with very narrow, pungent, dark green leaves. The cones are small and fall from the tree soon after they are ripe. It is most closely related to $P$. Wilsonii Masters, which grows in the same region in Hupeh but this species is an altogether much larger tree, with stouter, shorter, more decidedly 4 -angled leaves marked by broader more conspicuous stomatiferous bands, and larger cones which are abundantly produced and persist on the tree for a year after they are ripe.

A pieture of $P$. Watsoniana Masters, will be found under Nos. 080, 0134 of the collection of Wilson's photographs.

Picea Wilsonii Masters in Gard. Chron. ser. 3, XXXIII. 133, fig. 55, 56 (1903); in Jour. Bot. XLI. 270 (1903); in Jour. Linn. Soc. XXXVII. 421 (1906), - Beissner in Mitt. Deutsch. Dend. Ges. XII. 69 (1903); in Handb. Nadelholzk. ed. 2, 248 (1909). - Mayr, Fremdl. Wald.- u. Parkb. 339 (1906). - Patschke in Bot. Jahrb. XLVIII. 632 (1913).

Picea Mastersii Mayr, Fremdl.Wald.- u. Parkb. 328, fig. 105, 106, 107 (1906). Masters in Jour. Linn. Soc. XXXVII, 421 (1906). 
Western Hupeh: Fang Hsien, forests and open country, alt. 2000-2600 m., May, June and July 1907 (Nos. 2053, 2087; tree 6$25 \mathrm{~m}$. tall, 1-2 m. girth); Hsing-shan Hsien, woods, 2000-2500 m., June 1910 (No. 38r7; tree 10-20 m. tall, 1-1.5 m. girth). Fang Hsien, woodlands and steep country, alt. 2300-2600 m., May and July 1901 (Veitch Exped. Nos. 1897, 1897 ${ }^{\mathrm{a}}$ ). Shansi: Wutai-shan, "Pei-santse " temple, alt. 2000-2300 m., 1907, F. N. Meyer (No. 22671); same locality 1909, W. Purdom (No. 145).

This Spruce is fairly common on the higher ranges of northwestern Hupeh. It forms a shapely pyramidal tree with short, dense horizontally spreading branches. The shoots are very pale, quite glabrous and shining, becoming pale grey or almost white the second year. The winter-buds are ovoid with polished dark brown scales. The cones are very freely produced and remain on the tree for a year or more after they are ripe. The specimens from Wutai-shan have slightly stouter leaves than the type, but otherwise are identical. Judging from Mayr's remarks it is probable that he had loose cones of P. Meyeri Rehder \& Wilson as well as shoots with cones attached of $P$. Wilsonii Masters when establishing his $P$. Mastersii.

Pictures of this tree will be found under No. 097 of the collection of Wilson's photographs.

Here may be added two Chinese species of this section, not collected during the Arnold Arboretum expeditions.

Picea Meyeri Rehder \& Wilson, n. sp.

Arbor mediocris (ex Meyer); ramuli juniores fulvi v. cinnamomei, hirtello-villosi, saepius dense, tomento per plures annos persistente, rarius glabrescentes, vetustiores cinerei; pulvini trapezoidei v. lineares, tumidi, apice obtusi, vix supra petiolum producti, petiolis hirtellis patentibus v. erecto-patentibus, 1-2 mm. longis; gemmae ovoideae v. conicae, acutiusculae, resinosae, perulis avellaneis adpressis nitidulis, infimis gemmarium robustiorum acutis et dorso breviter hirtellis. Folia quadrangularia, leviter compressa, in ramis lateralibus basi torta et manifeste sursum curvata, subobtusa, $8-20 \mathrm{~mm}$. longa, glauco-viridia, faseiebus stomatiferis 4 e seriebus stomatum 5-8 compositis. Strobili oblongo-cylindrici, acutiusculi, brunnei, nitidi, $6-7 \mathrm{~cm}$. longi, post maturitatem diu persistentes; bracteae spatulatae, apice triangulares et obtusae v. rotundatae, $5-6 \mathrm{~mm}$. longae; squamae sub maturitate patentes, obovato-cuneatae, $12-15 \mathrm{~mm}$. longae et latae, apice rotundatae $\mathrm{v}$. truncatae; semina alis obovato-oblongis apice rotundatis, 10-11 $\mathrm{mm}$. longis, testa atrobrunnea puberula.

Shansi: Wutai-shan, temple of "Tchai-ling-tse," Feb. 25, 1908, F. N. Meyer (No. 22672, type); Wutai-shan, alt. 3000 m., 1910, W. Purdom (No. 144). Kansu: Tao-chan Ting, 1911, W. Purdom (No. 790); Choni, 1911, W. Purdom (No. 813).

This quadrangular-leaved Spruce is characterized by its hairy shoots, curved non-pungent leaves, and medium-sized symmetrical cones with rounded or truncate scales. It is most closely related to P.gemmata Rehder \& Wilson, which has similarly hairy shoots, more densely hairy buds, very pungent leaves and larger cones with much broader scales. It is also related to $P$. asperata Masters, which has paler, more yellow, less pubescent shoots, slightly pungent leaves, larger cones with 
rhombic scales paler in color and winter-buds with more loosely appressed and more recurved scales. The shoots in P. Meyeri show great variation in degree of pubescence, and this is not constant from year to year on the same branch. One year a shoot may be densely pubescent and the next year the new shoot on the same branch almost glabrous.

Picea Schrenkiana Fischer \& Meyer in Bull. Acad. Sci. St. Pétersbourg, X. 253 (1842). - Regel in Act. Hort. Petrop. VI. pt. 2, 485 (1880). - Clinton-Baker, Ill. Conif. II. 48, t. (1909). — Patschke in Bot. Jahrb. XLVIII. 766 (1913).

Picea orientalis, $\beta$. longifolia Lebebour, Fl. Ross. III. 671 (1846-1851).

Pinus Schrenkiana Antoine, Conif. 97 (1847).

Abies Schrenkiana Lindley \& Gordon in Jour. Hort. Soc. Lond. V. 212 (1850), - Maximowicz in Bull. Soc. Nat. Mosc. LIV. 58 (1879). Kanitz in Noven. Gyüjit. Szèchenyi, II. 848 (Pl. Enum. 64) (1891).

Picea obovata Schrenkiana Carrière, Traité Conif. ed. 2, 338 (1867). - Masters in Jour. Linn. Soc. XVIII. 506 (1881); XXVI. 554 (1902). - Pritzel in Bot. Jahrb. XXIX. 217 (1900).

Pinus obovata, $\beta$. Schrenkiana Parlatore in De Candolle, Prodr. XVI. pt. 2, 415 (1868).

Abies Smithiana Herder in Bull. Soc. Nat. Mosc. XLI. pt. 1. 423 (Enum. $\mathrm{Pl}$. Semenov.) (non Forbes) (1868).

Picea tianschanica Ruprecht in Mém. Acad. Sci. St. Pétersbourg, sér. 7, XIV. No. IV. 72 (Sert. Tianschan.) (1869).

Pinus abies, f. schrenkiana Voss in Mitt. Deutsch. Dendr. Ges. XVI. 93 (1907).

Northern Chili: Weichang west, south \& northeast, alt. $1300 \mathrm{~m}$., W. Purdom (Nos. 202, 203, 100); south of Jehol, 1909, W. Purdom (No. 205). Kansu: Choni, 1911, W. Purdom (No. 813); "Lotani," 1911, W. Purdom (No. 806); Tow River, 1911, W. Purdom (No. 790).

Apparently common in these regions.

\section{Sect. II. Casicta Mayr.}

Picea purpurea Masters in Jour. Linn. Soc. XXXVII. 418 (1906); in Fedde, Rep. Sp. Nov. IV. 109 (1907). - Beissner, Handb. Nadelholzk. ed. 2, 288 (1909), - Patschke in Bot. Jahrb. XLVIII. 632 (1913).

Western Szech'uan: Sungpan Ting, forests, alt. 3000-3600 m., August and October 1910. (Nos. 4062, 4059, 4063); same locality August 1903 (Veitch Exped. No. 3026, type). Kansu: Taochau Ting, 1911, W. Purdom (No. 815).

This handsome and remarkable Spruce is abundant in the forests round Sungpan. Young trees are pyramidal in outline, but old trees have wide-spreading, thick, horizontally disposed branches and massive trunks. The small violetpurple cones are very distinct with cone-seales abruptly contracted above the middle and acute or merely rhombic, truncate or erose. The bark is dark grey and fissured into rather thin, scaly flakes. The timber is brownish, close-grained, resinous and much-esteemed for building purposes.

Pietures of this tree and of the cones will be found under Nos. 0294, 0301, 0315, 0316, 0323 of the collection of Wilson's photographs. 
Picea Balfouriana Rehder \& Wilson, n. sp.

Arbor 15-40-metralis, trunco 0.3-1 m. diam. procero, cortice cinereo, subtus pallide fulvo, profunde in lamellas crassas irregulares fisso; rami satis breves, horizontaliter patentes; ramuli dense villosi tomento ad tertium annum persistente, juniores flavidi v. pallide flavo-cinerei, vetustiores cinerei; pulvini leviter turgidi, oblongi, apice obtusi, petiolis plus minusve villosis circiter $1 \mathrm{~mm}$. longis patentibus v. erecto-patentibus, cicatricibus transverse rhombicis v. fere triangularibus; gemmae late ovatae v. conicae, obtusae, leviter resinosae, perulis arcte adpressis castaneis $\mathrm{v}$. avellaneis nitidulis persistentibus. Folia spiraliter disposita, linearia, quadrangularia, compressa, recta $\mathrm{v}$. leviter curvata, utrinque carinata, subacuta $\mathrm{v}$. obtusa, rarissime pungentia, 8-15 $\mathrm{mm}$. longa et $1.5 \mathrm{~mm}$. lata, supra utrinsecus stomatum seriebus 4-7, dorso utrinsecus stomatum seriebus 1-4. Strobili ovato- v. ovali-oblongi, violaceo-purpurei, squamis extus ad apicem brunnescentibus, 5-9, plerumque 6-8 cm. longi, decidui 6-8 menses post maturitatem, squamis infimis cum redunculo in ramo remanentibus; bracteae ovatae, acutae, circiter 2.5 $\mathrm{mm}$. longae; squamae flexiles striatae, erecto-patentes, rhombicoovatae, $2-2.5 \mathrm{~cm}$. longae et $1.3-1.5 \mathrm{~cm}$. latae, infra medium latissimae, saepe infra apicem contractae et productae, supra medium erosae et plerumque plus minus laciniatae et undulatae, basi late cuneatae v. subito contractae et interdum leviter auriculatae; semina alis obovatis circiter $1 \mathrm{~cm}$. longis vix dimidiam squamam aequantibus nitidis brunneis purpureo-punctulatis, testa cinereo-brunnea minute puberula.

Western Szech'uan: west of Tachien-lu, Orangche, forests, alt. 3600-4000 m., October 1910 (No. 408o, type); northeast of Tachien-lu, Ta-p'ao-shan, forests, alt. 3300-4000 m., July 1908 (No. 2055, 2059); west of Kuan Hsien, Pan-lan-shan, forests, alt. 33003600 m., October 1910 (No. 4065).

This new Spruce is one of the tallest of the Chinese species. The trunk is mastlike with short, spreading branches giving a spire-like appearance to the tree. The species is characterized by its thick, deeply furrowed bark, densely villose shoots, compressed leaves obscurely stomatiferous on the dorsal surface, violetpurple cones with membranous, flexible cone-scales rhombic-ovate in shape, elongated in the upper half where they are undulate, laciniate or erose, and ascending-spreading in the open cone.

It is most closely related to $P$. purpurea Masters, which has a thicker and more massive trunk, stouter more wide-spreading branches and becomes flat-headed in old individuals; it has more flattened, shorter and straight leaves, and much smaller cones with scales often abruptly elongated above the middle and acute. 
No. 2059 has abnormal looking cones probably due to having been frozen before they were ripe. In No. 4065 the cones are rather small and the leaves longer than usual and somewhat pungent. In general appearance this number suggests $P$. purpurea Masters.

Picea Balfouriana has a very extensive altitudinal range and west of Tachien-lu is the most alpine of all the species. The wood is resinous close-grained, easily worked and the timber is highly valued for general construction purposes.

Pictures of this tree will be found under No. 201 of the collection of Wilson's photographs and also in his Vegetation of Western China, No. 346.

This species is named for Mr. F. R. S. Balfour a lover and enthusiastic planter of trees on his estate at Dawyck, Scotland, as a slight return for his substantial assistance to the Arboretum in its second Wilson Expedition to China.

Picea likiangensis Pritzel in Bot. Jahrb. XXIX. 217 (1900). Mastersin Jour. Linn. Soc. XXVI. 554 (1902);XXXVII.418 (1906). Beissner, Handb. Nadelholzk. ed. 2, 249 (1909). - Patschke in Bot. Jahrb. XLVIII. 632, fig. 1, 6 (1913).

Abies likiangensis Franchet in Jour. de Bot. XIII. 257 (1899).

Picea Alcockiana Masters in Jour. Linn. Soc. XXXVII. 418 (non Carrière) (1906).

Western Szech'uan: west of Tachien-lu, Cheto-shan, woodlands and open country, alt. 3600-4000 m., July and October 1908 (Nos. 206I, 2063; tree 8-25 m. tall, girth 0.6-3 m.); same locality, alt. 3300-4600 m., June and October 1904 (Veitch Exped. No. 3028, seed Nos. 1834, 1836). Yunnan: Likiang, alt. 2500., July 1884, J. M. Delavay (No. 1031, type).

This Spruce is a common species west of Tachien-lu and is usually a mediumsized tree, from 15 to $20 \mathrm{~m}$. tall. In favorable localities it grows to $35 \mathrm{~m}$. tall with a rather slender mast-like trunk. The branches are long, relatively slender and spreading with the ends of the shoots ascending. The species is characterized by its pale yellow-grey sparsely hairy young shoots, prominently keeled, somewhat compressed leaves, and by its cones with soft, flexible scales, somewhat undulate and denticulate above the middle and horizontally spreading in the ripe cone.

A picture of this tree will be found under No. 224 of the collection of Wilson's photographs and also in his Vegetation of Western China, No. 347.

Picea likiangensis, var. rubescens Rehder \& Wilson, n. var.

A typo differt ramulis fulvescentibus v. rubescentibus foliis brevioribus et crassioribus strobili squamis tenuioribus magis purpurascentibus, paullo longioribus et angustioribus.

Western Szech'uan: Tachien-lu and the neighborhood, forests and open country, alt. 3000-4100 m., June and October 1908 (Nos. 2057, type, 2064); northeast of Tachien-lu, forests, alt. 3300-4000 m., July 1908 (No. 2066). 
This variety differs from the type in the shorter, stouter leaves, more elongate and more purple cone-scales and in the somewhat darker more fulvous or pinkish branchlets. In the texture and shape of the cone-scales it approaches somewhat $P$. Balfouriana Rehder \& Wilson, which has narrower scales, contracted above the middle, wavy incised, and more purple in color; the leaves also are longer and more slender. Picea montigena Masters, differs in its cinnamon colored cones with very minutely erose or sometimes almost entire scales.

This variety is a common tree round Tachien-lu and in general appearance and habit resemble the type. Pictures of this tree will be found under Nos. 187 188, 191 of the collection of Wilson's photographs and also in his Vegetation of Western China, Nos. 344, 345 .

Picea hirtella Rehder \& Wilson, n. sp.

Arbor 8-16-metralis, trunco $0.3-0.6 \mathrm{~m}$. diam.; rami elongati, horizontaliter patentes; ramuli graciles, annotini pallide flavi, dense tomento hirtulo ad tertium annum persistente vestiti, vetustiores cinerei; pulvini lineares, apice acuti, petiolis infra apicem divergentibus erecto-patentibus v. patenti-ascendentibus rufescentibus, cicatricibus quadrangularibus $\mathrm{v}$. fere orbicularibus; perulae gemmarum basin innovationum eingentibus arcte adpressis. Folia spiraliter disposita, patentia, linearia, fere recta v. basi leviter curvata, compressa, utrinque carinata, 1-2 $\mathrm{cm}$. longa et 1-2 $\mathrm{mm}$. lata, dorso obscure viridia utrinsecus seriebus stomatum indistinctis et paucis notata, ventre fasciebus 2 glaucescentibus stomatiferis ornatae e seriebus stomatum 4-6 compositis. Strobili ovato-oblongi v. ovoideocylindrici, $5.5-8 \mathrm{~cm}$. longi, pallide flavo-brunnei, nitiduli, decidui squamis basalibus in ramo remanentibus, squamis patenti-ascendentibus; bracteae lanceolatae, $3-4 \mathrm{~mm}$. longae; squamae flexiles, late ovatae v. rhombico-ovatae, 12-20 $\mathrm{mm}$. longae et 10-15 latae, extus striatae, intus purpurascentes, apicem obtusum v. rotundatum versus sensim angustatae et minute eroso-denticulatae et leviter undulatae, basi late cuneatae; semina alis dimidiam squamam vix superantibus.

Western Szech'uan: west of Kuan Hsien, Pan-lan-shan, forests, alt. 3600-4100 m., June 1908 (No. 2084, type); north-east of Tachienlu, Ta-p'ao-shan, forests, alt. 3000-3300 m., July 1908 (No. 2082).

This new species is most closely related to P. likiangensis Pritzel, from which it is distinguished by its densely villose shoots, much less prominent petioles, more compressed, longer and pungent leaves, rather different cones and larger, lanceolate bracts.

Picea hirtella is a rather rare tree with a relatively slender trunk, and short thin branches forming a pyramidal head. The leaves are comparatively long and the shining yellow-brown cones are particularly striking. In No. 2082 the conescales are rather more attenuate at the summit than those of the type. 
The cone figured by Masters as that of his P. montigena appears to belong here.

A picture of this tree will be found under No. 167 of the collection of Wilson's photographs and also in his Vegetation of Western China, No. 341.

Picea montigena Masters in Gard. Chron. ser. 3, XXXIX. 146, fig. 56 (1906), descriptione et figura strobili maturi excludendis. Patschke in Bot. Jahrb. XLVIII. 632 (1913).

Descriptio strobili maturi addenda: Strobili cylindrici, 7-10 $\mathrm{em}$. longi, 3-4 cm. diam., cinnamomei, nitiduli; squamae coriaceae, flexiles, erectae, rhombico-ovatae, apice rotundatae, margine leviter erosae, circiter $2 \mathrm{~cm}$. longae et $1.5-1.7 \mathrm{~cm}$. latae; semina alis squamam dimidiam aequantibus.

Western Szech'uan: west and south-west of Tachien-lu, alt. 3600-4000 m., rare, July and October 1908 (Nos. 2056, 206o, 2062, 4084; tree $16-30 \mathrm{~m}$. tall, girth 2-4 m.); same locality, alt. $3300 \mathrm{~m}$., June 1904 (Veitch Exped. No. 3027, type).

This fine Spruce is common in the neighbourhood of Tachien-lu. It has relatively long, horizontally spreading branches upturned at the ends. Both primary and lateral shoots are more or less setose, pale brown, becoming grey in their second year. The winter-buds are ovoid, acutish and very resinous. The short, stout leaves are scarcely if at all pungent, shining green and more or less glaucescent. The medium-sized, handsome, cinnamon-brown cones are very freely produced and persist on the tree for fully a year after they are ripe.

A picture of this Spruce will be found under No. 233 of the collection of Wilson's photographs and also in his Vegetation of Western China, No. 349.

Owing to some confusion the mature cone figured by Masters (1. c.) does not belong here, but apparently to $P$. hirtella Rehder \& Wilson.

\section{Sect. III. OMorica Mayr.}

Picea brachytyla Pritzel in Bot. Jahrb. XXIX. 216 (1900). Masters in Jour. Linn. Soc, XXVI. 553 (1902), - Beissner, Handb. Nadelholzk. ed. 2, 249 (1909). - Patschke in Bot. Jahrb. XLVIII. 630 (1913).

Abies brachytyla Franchet in Jour. de Bot. XIII. 258 (1899), excludendo specimine Delavayano.

Picea ajanensis Masters in Jour. Linn. Soc. XXVI. 553 (non Fischer) (1902); XXXVII. 418 (1906); in Jour. Bot. XLI. 269 (1903).

Picea Alcockiana Masters in Jour. Bot. XLI. 269 (non Carrière) (1903).

Picea pachyclada Patschke in Bot. Jahrb. XLVIII. 630 (1913).

Western Hupeh: Hsing-shan Hsien, woodlands, alt. 1600-2300 m., rare, May 1907, January 1909 (No. 2052; tree 12-20 m. tall, 2-3 m. girth); same locality, June 1900, October 1901 (Veitch Exped. 
No. 1896, seed No. 1282); without locality, A. Henry (No. 6908). Eastern Szech'uan: Wushan Hsien, A. Henry (Nos. 7074ª 7157); Cheng-kou Ting, P. Farges (No. 806, type).

Formerly this handsome, flat-leaved Spruce was very common in north-western Hupeh between altitudes of 1600 and $2500 \mathrm{~m}$., but it has been felled for lumber and is now quite rare. It forms a medium-sized, open branched tree from 10 to $25 \mathrm{~m}$. tall, the principal branches are relatively long, horizontally spreading, but ascending at the extremities; the branchlets are pendulous. The bark is grey-brown, becoming dark grey with age, rough and deeply fissured into thick, irregularly oblong plates. The pale dull brown colored cones are retained rarely a year after the seeds are ripe. The species with which Masters confused this Spruce have differently shaped cones with much thinner scales and do not occur in central or western China. The specimen from Yunnan (Delavay No. 4129), referred by Franchet to this species, probably belongs to P. complanata Masters.

A picture of this tree will be found under Nos. $608,609,701$ of the collection of Wilson's photographs and also in his Vegetation of Western China, Nos. 338, 351.

\section{Picea ascendens Patschke in Bot. Jahrb. XLVIII. 632 (1913).}

Western Szech'uan: in temple grounds, city of Wên-chuan Hsien, alt. 1300 m., May 1908 (No. 2073; tree 13 m. tall, girth 2 m.); same locality, and from same tree as the preceding number, August 21, 1903 (Veitch Exped. No. 3024, ${ }^{1}$ type); Pan-lan-shan, west of Kuan Hsien, forests, alt. 2700-3200, June 1908 (Nos. 2071, 2072; trees 12$26 \mathrm{~m}$. tall, girth 1.20-4 m.); same locality, alt. 2500-3200 m., October 1910 (No. 4048 ; tree $18-25 \mathrm{~m}$. tall); west and near Wên-ch'uan Hsien, alt. 2500 m., October 1910 (No. 405o; tree 18-23 m. tall); Tu-ti-liang-shan, forests, alt. 2500-3000 m., October 1910 (No. 4050; tree 10-30 m. tall, girth 1-3.25 m; colloquially "Mê-tiao-sha").

Picea ascendens is closely related to $P$. brachytyla Pritzel, but differs in its more slender, sometimes hairy branchlets with less prominent pulvini, in its narrower and longer leaves, and in the more slender cones with appressed scales slightly undulate at the apex; from $P$. complanata Masters it is easily distinguished by its rhombic cone-scales, truncate and usually emarginate at the apex.

In $P$. ascendens, the cone-scales are rhombic, rather pointed and erose. The degree of pubescence on the shoots varies considerably in the material before us, some of the specimens being almost glabrous, while others are densely setose. This character is very inconstant but the stronger shoots are invariably the less hairy. The ovoid, ehestnut-brown winter-buds are very numerous and prominent in this species, as they are in $P$. complanata Masters.

Picea ascendens is abundant on the mountains in the west of the Lungan prefecture, and is the only member of the Omorika group found in that region. The tree is pyramidal in habit with a mast-like trunk, horizontally-spreading branches upturned at the ends, and clothed with long, whip-like, lateral pendant branchlets which give it a distinct appearance. The wood is close-grained, almost white and

1 Patschke quotes No. 3034 (Herb. Kew) as the type of his species, but in the Arnold Arboretum Herbarium the number reads 3024. 
is esteemed for general building purposes and planking. The ripe cone is larger than it is described by Patschke, being commonly from 10 to $15 \mathrm{~cm}$. long.

A picture of this tree will be found under Nos. 119, 0302 of the collection of Wilson's photographs and also in his Vegetation of Western China, No. 339.

Picea complanata Masters in Gard. Chron. ser. 3, XXXIX. 146, fig. 57 (1906). - Beissner, Handb. Nadelholzk. ed. 2, 288 (1909). Bean in Kew Bull. Misc. Inform. 1910, 174. - Patschke in Bot. Jahrb. XLVIII. 632 (1913).

Western Szech'uan: west and near Wên-ch'uan Hsien, forests, alt. 2300-3000 m., July and November 1908 (Nos. 2083, 2075; tree 20-26 m. tall, girth 2.5-3 m.); Mupin, forests, alt. $2000-2600 \mathrm{~m}$., August and September 1908 (Nos. 2086, 2079; tree 10-20 m. tall, girth 1-2.5 m.); near Wa-shan, woodlands and open country, alt. 2300 m., rare, September 1908 (No. 208r; tree 20 m. tall, girth 2 m.); same locality, June 1903 (Veitch Exped. No. 3030, type in part, 3031); south-east of Tachien-lu, open country and woodland, alt. 1600$2300 \mathrm{~m}$., July and October 1908 (Nos. 2077, 2076; tree 6-20 m. tall, girth 1-2.5 m.); same locality, July and October 1903 (Veitch Exped. No. 3032, type in part, seed No. 1530).

This is everywhere a rare species as far as our knowledge goes, although it oceurs scattered over a large area. The timber is highly valued and in consequence the tree has been ruthlessly cut. In woods this Spruce is pyramidal and shapely in habit, but in open country it is commonly round-headed. The weak, lateral shoots are flagellate and pendent, but are comparatively short. As in $P$. ascendens Patschke, and $P$. Sargentiana Rehder \& Wilson, the shoots vary considerably in the amount of their pubescence, and the stouter ones are frequently nearly or quite glabrous. The cone-scales are broad and truncate or rounded at the summit and this character best distinguishes this species from P. ascendens Patschke, which has rhombic, subacute cone-scales. The bark of $P$. complanata is pale grey, firm and comparatively smooth except on old trees on which it becomes dark grey and breaks up into irregular patches which remain firmly attached to the trunk.

Like other Chinese species of the Omorika group this Spruce is colloquially known as the "Mê-tiao-sha." A picture of this tree will be found under Nos. 352, 353 of the collection of Wilson's photographs and also in his Vegetation of Western China, No. 350 .

The specimen from Yunnan ("Ona-pen-Késu sur le Ma-eul-chan, $2500 \mathrm{~m} . "$ ) collected by J. M. Delavay (No. 4129) on August 7, 1889, referred by Franchet (Jour. de Bot. XIII. 258 (1899)) to his Abies brachytyla (Picea brachybyla Pritzel) of which we have seen a fragment, in all probability belongs to $P$. complanata.

\section{Picea Sargentiana Rehder \& Wilson, n. sp.}

Arbor 10-25-metralis, trunco 0.4-1 m. diam., cortice fusco-cinereo, in lamellas tenues irregulares fisso; rami horizontaliter patentes, leviter dependentes; ramuli hornotini brunneo-flavescentes, plus minusve glandulis brevibus stipitatis vestiti praesertim in ramulis 
tenuioribus, leviter pruinosi, annotini aurantiaci v. straminei; pulvini leviter tumidi, rhombici, apice obtusi, infra apicem obtusum in petiolum brevem leviter recurvum producti; gemmae conspicuae, ovatae v. ovato-conicae, acutiusculae, brunneae, perulis imbricatis persistentibus basin ramulorum cingentibus. Folia spiraliter disposita, sursum curvata, linearia, complanata, subacuta v. obtusa, 10-15 mm. longa et 1.5-2 mm. lata, utrinque carinata, supra fasciebus 2 glaucis latis stomatiferis, dorso nitida viridia. Strobili oblongo-cylindrici, 6-12 cm., plerumque $10 \mathrm{~cm}$. longi, saepe parce resinosi et leviter pruinosi, obscure cinnamomei, saepe persistentes per totum annum post maturitatem; bracteae minutae, spathulatae apice rotundatae, $3 \mathrm{~mm}$. longae; squamae lignosae, sub maturitate patentes, late cuneatoobovatae, $2-2.3 \mathrm{~cm}$. longae et $1.8-2 \mathrm{~cm}$. latae, apice rotundatae v. truncatae, rarissime medio paullo productae; semina alis obovatis apice rotundatis $1.5-1.8 \mathrm{~cm}$. longis nitidis pallide brunneis, testa brunnea puberula.

Western Szech'uan: west and near Wên-ch'uan Hsien, woodlands, alt. 2000-2500 m., October 1910, July 1908 (Nos. 4048, type, 2085); west of Kuan Hsien, Niu-tou-shan, forests, alt. 2600-3500 m., June 1908 (No. 2070); Mupin, forests, alt. 2600-3600 m., October 1908 (No. 2078).

The relatively short, broad leaves readily distinguish this Spruce from all other Chinese speeies belonging to the Omorika group. It is most closely related to $P$. complanata Masters, which has leaves up to $3 \mathrm{~cm}$. long and $1 \mathrm{~mm}$. wide, acute and often pungent at the apex, rather longer petioles, long-acuminate bracts and a more close, less fissured bark.

This new Spruce is locally quite common and, like its allied species, is colloquially known as "Mê-tiao-sha." The wood is valued for planking and for general construction purposes.

\section{TSUGA Carr.}

Tsuga yunnanensis Masters in Jour. Linn. Soc. XXVI. 556 (1902).Beissner, Handb. Nadelholzk. ed. 2, 83 (1909). - Patschke in Bot. Jahrb. XLVIII. 639 (1913).

Abies dumosa, var. chinensis Franchet in Jour. de Bot. XIII. 258 (1899) quoad specimina Delavayana.

Abies yunnanensis Franchet in Jour. de Bot. XIII. 258 (1899). - Bois in Bull. Soc. Hort. France, sér. 4, I. 231 (1900).

Western Szech'uan: west and near Wên-ch'uan Hsien, forests, alt. 3000-3300 m., July 1908 (No. 2098, in part; tree 20-33 m. tall, 
girth 2-6 m.); west of Kuan Hsien, cliffs, alt. 2600-3600 m., June 1908 (No. 2098, in part; tree 12-25 m. tall, girth 2-4 m.); south-east of Tachien-lu, forests, alt. 2600-3300 m., common, July 1908 (No. 2098, in part; tree 20-50 m. tall, girth 2-4 m.); Wa-shan, forests, alt. 2600-3600 m., common, June and October 1908 (No. 2099; tree 10$40 \mathrm{~m}$. tall, girth 2-6 m.). Yunnan: near Mo-so-yu in woods at Koutoni, January $1890, J . M$. Delavay (No. 4618, type); in woods at Peetsao-lo, alt. 2800, April 1886, J. M. Delavay.

This species is only known to us from Yunnan and western Szech'uan and is much less widely distributed than $T$. chinensis Pritzel from which it is readily distinguished by its rufous-grey, more setulose shoots, narrower leaves rounded, not emarginate at the apex and always very white on the underside, and by its smaller, dull colored cones composed of fewer and thinner scales which are slightly recurved at the apex. The two species are very distinct. Tsuga yunnanensis is closely related to the Himalayan $T$. dumosa Eichler, which has rather larger, more pointed leaves, and slightly longer and more pointed cones.

Tsuga yunnanensis occurs on Mount Omei and is fairly common on Wa-shan and south-east of Tachien-lu. It has usually more massive branches than T. chinensis but is otherwise very similar. It bears the same colloquial name (Tieh-sha) and the timber is used for the same purposes as that of $T$. chinensis.

A picture of $T$. yunnanensis will be found under No. 332 of the collection of Wilson's photographs.

Tsuga chinensis Pritzel in Bot. Jahrb. XXIX. 217 (1900). Masters in Jour. Linn. Soc. XXVI. 556 (1902); XXXVII. 421 (1906).Beissner, Handb. Nadelholzk. ed. 2, 82 (1909). - Patschke in Bot. Jahrb. XLVIII. 639 (1913).

Abies thié-sha David, Jour. de Trois. Voy. I. 343 (nomen nudum) (1875).

Abies Tsuga Franchet in Nouv. Arch. Mus. Paris, sér. 2. VII. 97 (Pl. David. I. 287) (non Siebold \& Zuccarini) (1884).

Abies dumosa, var. chinensis Franchet in Jour. de Bot. XIII. 258 (1899), quoad specimen Fargesianum.

Abies chinensis Franchet in Jour. de Bot. XIII. 259 (1899). - Bois in Bull. Soc. Hort. France, sér. 4, I. 230 (1900).

Tsuga dumosa, var. chinensis Pritzel in Bot. Jahrb. XXIX. 217 (1900).

Tsuga Sieboldi Pritzel in Bot. Jahrb. XXIX. 217 (non Carrière) (1900). Masters in Jour. Linn. Soc. XXVI. 556 (1902); XXXVII. 421 (1906); in Jour. Bot. XLI. 270 (1903).

Tsuga yunnanensis Masters in Gard. Chron. ser. 3, XXXIX. 236, fig. 93 (pro parte) (1906), non Masters in Jour. Linn.Soc. XXVI. 556 (1902) ${ }^{1}$; XXXVII. 421 (1906). - Bean in Kew Bull. Misc. Inform. 1910, 176.

1 The short description agrees fairly well with $T$. yunnanensis, but the specimens quoted belong at least partly to $T$. chinensis; the cones figured apparently represent those of the latter species, while the leaves probably are those of $T$. yunnanensis. 
Western Hupeh: Fang Hsien; Sheng-neng-chia, forests, alt. 2600-3000 m., May 1907 (No. 2096, in part; tree 12-33 m. tall, girth 2-4 m.); Hsing-shan Hsien, woods, alt. 2000-3000 m., July 1907 (No. 2096 , in part; tree $15-20 \mathrm{~m}$. tall, girth $2 \mathrm{~m}$.) ; same locality, May and October 1901 (Veitch Exped. Nos. 572, 1898, seed No. 952); Changyang Hsien, on cliffs, alt. 2000-2300 m., November 1907 (No. 2096, in part; tree 8-20 m. tall, girth 1-2 m.); without locality, $A$. Henry (No. 6907). Eastern Szech'uan: Taning Hsien, woodlands June and October 1910 (No. 4453; tree 16-25 m. tall, girth 1.5-4 m.); Cheng-kou Ting, alt. 2500 m., P. Farges (Nos. 808, type, 29). Western Szech'uan: Ching-chi Hsien, near summit of Feiyüeh-ling, forests, alt. 2800 m., August 1908 (No. 2097; tree 12-33 m. tall, girth 2-4 m.); north-east of Tachien-lu, Ta-p'ao-shan, forests, alt. 2300-3000 m., July 1908 (No. 210o, in part; tree 10-40 m. tall, girth 1-5 m.); Wên-ch'uan Hsien, temple grounds, alt. 1300 m., May 1908 (No. 2100, in part; tree $13 \mathrm{~m}$. tall, girth $2 \mathrm{~m}$.); west of Kuan Hsien; ascent of Pan-lan-shan, forests, alt. 2600-3800 m., common, June 1908 (No. 2100, in part; tree 10-20 m. tall, girth 1-3 m.); same locality, October 1901 (No. 4072; tree 20-40 m. tall, girth 2-6 m.). Shensi: southern slopes of the Tai-pai-shan, alt. 2300 m. 1910,W. Purdom (No. 668; tree 5 m. tall).

This Hemlock which is very widely dispersed in central and western China is everywhere partial to steep cliffs. In Hupeh it is usually met with in the form of a rather small, densely pyramidal tree, large specimens being rare. In the extensively forested regions of western Szech'uan it is fairly abundant and trees of very large size are common, and in these the habit is loose and open. The species is characterized by its pubescent yellow-grey shoots, relatively long and broad, and always rounded and emarginate leaves which at maturity are nearly always green on both surfaces, and by its polished cones with cone-scales usually slightly inflexed at the summit. It is very closely related to $T$. diversifolia Maximowicz, which is ehiefly distinguished by its shorter leaves, more hairy shoots, and by its slightly different cone.

The young leaves of $T$. chinensis often have two white, longitudinal bands on the underside and are occasionally furnished with a few remote bristle-like teeth which disappear with age. On the specimens before us the leaves vary from 10 to $28 \mathrm{~mm}$. in length and from 1.5 to $3 \mathrm{~mm}$. in width; and the cones from 15 to 30 $\mathrm{mm}$. in length. The degree of pubescence on the shoots varies considerably but on none can it be described as dense. The cones are pendulous as in all other species, not erect as described by Franchet, and in appearance vary according to age, but are usually shining.

This Hemlock is called the Tieh-sha (Iron Fir) by the Chinese and the timber though soft is considered very durable. It is used in general construction work and is largely made into shingles and used for roofing purposes.

Tsuga formosana Hayata (in Gard. Chron. ser. 3, XLIII. 194 (1908) very probably belongs here.

Pictures of Tsuga chinensis will be found under Nos. 175, 176 of the collection of Wilson's photographs and also in his Vegetation of Western China, No. 489. 


\section{KETELEERIA Carr.}

Keteleeria Davidiana Beissner, Handb. Nadelholzk. 424, fig. 117 (1891). - Van Tieghem in Bull. Soc. Bot. France, XXXVIII. 412 (1891). - Pritzel in Bot. Jahrb. XXIX. 217 (1900). - Masters in Jour. Linn. Soc. XXVI. 554 (1902); XXXVII. 421 (1906); in Gard. Chron. ser. 3, XXXIII. 84, fig. 37, 38 (1903); in Jour. Bot. XLI. 270 (1903).Mottet in Rev. Hort. 1904, 130, fig. 53. - Patschke in Bot. Jahrb. XLVIII. 649 (1913).

Pseudotsuga Davidiana Bertrand apud Carrière in Rev. Hort. 1873, 37, fig. 3, 4, 5. - Bertrand in Ann. Sci. Nat. sér. 5, XX. 86 (1874).

Abies sacra David, Jour. de Trois. Voy. II. 29 (nomen nudum) (1875). Franchet in Nouv. Arch. Mus. Paris, sér. 2, VII. 100, t. 14 (Pl. David. I. 290 , t. 14) (1884).

Pinus (Pseudotsuga) Davidiana McNab in Proc. Roy. Irish Acad. ser. 2, II. 702 (1877).

Abies Davidiana Franchet in Nouv. Arch. Mus. Paris, sér. 2, VII. 98 t. 13 (Pl. David. I. 288, t. 13) (1884); in Jour. de Bot. XIII. 260 (1899).-Masters in Gard. Chron. ser. 3, I. 481 (1887).

Keteleeria sacra Beissner, Handb. Nadelholzk. 426 (1891). - Van Tieghem in Bull. Soc. Bot. France, XXXVIII. 412 (1891). - Mottet in Rev. Hort. 1904, 130. - Patschke in Bot. Jahrb. XLVIII. 649 (1913).

Keteleeria Delavayi Van Tieghem in Bull. Soc. Bot. France, XXXVIII. 412 (nomen seminudum) (1891).

Podocarpus sutchuenensis Franchet in Jour. de Bot. XIII. 265 (1899). Pritzel in Bot. Jahrb. XXIX. 213 (1900). - Masters in Jour. Linn. Soc. XXVI. 548 (1902); XXXVII. 414 (1906).

Pinus sacra Voss in Mitt. Deutsch. Dendr. Ges. XVI. 94 (1907).

Western Hupeh: north and south of Ichang, alt. 600-1300 m., August and November 1907 (Nos. 797 ${ }^{\circ}, 797$, in part; tree 12-33 m. tall, girth 1.5-6 m.); Changyang Hsien, mountain slopes, alt. 10001300 m., April, May and November 1907 (No. 797, in part; tree 13-33 m. tall, girth 2-6 m., bark rough, dark grey); Patung Hsien, woodlands, alt. 500-1000 m., April 1907 (No. 797, in part; tree 6$25 \mathrm{~m}$. tall, girth 1-5 m.); Hsing-shan Hsien, alt. $1000 \mathrm{~m}$., November 1907 (No. 797, in part; tree 13-33 m. tall, girth 2-6 m.); without locality, May 1900 (Veitch Exped. No. 420); without locality, A. Henry (Nos. 3878, 7576). Eastern Szech'uan: Wushan Hsien, A. Henry No. 7098); Cheng-kou Ting, P. Farges (No. 1292, type of Podocarpus sutchuenensis Franchet). Yunnan: Mengtze, mountains, alt. 1600 m., A. Henry (No. 11355); Szemao, mountains, alt. 1600 m., A. Henry (Nos. 12734, 12855).

This handsome tree is widely distributed in central, western and south-western China between 300 and $1500 \mathrm{~m}$. altitude and is more especially abundant in regions 
where a relatively dry, hot climate obtains. Most commonly it is met with in small groups, or as a solitary individual, shading tombs and wayside shrines, but sometimes it forms extensive woods, usually with scrub oak as an undergrowth. Young trees in habit and appearance closely resemble the Silver Firs, but with age this resemblance disappears and the old trees with their massive branches and irregularly shaped heads from a distance scarcely suggest a coniferous tree. This Keteleeria grows from 25 to $40 \mathrm{~m}$. tall and forms a trunk from 2 to $2.5 \mathrm{~m}$. in diameter, with large buttress-like roots spreading from the base of the bole. The bark is rough, irregularly fissured and dark grey; the wood is resinous, closegrained, easily worked and esteemed for building purposes and planking. The branchlets are grey, glabrous or puberulous and are sometimes clothed with short, ferruginous, villose tomentum. The leaves vary in length from 2 to $5 \mathrm{~cm}$. and may be rounded, emarginate, obtuse or acute at the apex. On young trees and on adventitious branches of old trees, the leaves are usually sharply acute and spinescent. Usually the leaves are shining dark green on both surfaces but occasionally they are slightly glaucescent on the underside. The cones are quite erect, terminal on short, lateral, spur-like, leafy branchlets from 1.5 to $3 \mathrm{~cm}$. long, which serve as stout peduncles. In length the cones vary from 5 to $20 \mathrm{~cm}$., their average length being from 10 to $15 \mathrm{~cm}$. When quite young the cones are reddish but soon become green and when ripe they are pale chestnut-brown. The bracts vary in shape somewhat according to age and size, and at maturity are usually more or less laciniated at the apex, which may be erect or recurved. The cone-seales are persistent and when the cone falls away the lower part with a few scales remains on the tree. In dried specimens the leaves remain attached to the branches and in this respect, and in the erect cones, Keteleeria resembles Abies, but in the persistent character of the cone-scales it resembles Picea.

The variation in the leaves and cones of this tree has produced some confusion. The figure of Abies sacra Franchet represents an old cone from which the seeds have fallen. In the figure of $A$. Davidiana Franchet the cone is practically ripe and full of seeds. Podocarpus sutchuenensis Franchet is founded on a branch with male flowers and is typical $K$. Davidiana. It is doubtful if $K$. Evelyniana Masters (in Gard. Chron. ser. 3, XXXIII. 194, fig. 82 [1903]), K, formosana Hayata (in Gard. Chron. ser. 3, XLIII. 194 [1908], K. Davidiana, var. formosana Hayata in Jour. Coll. Sci. Tokyo, XXV. art. XIX. 221 (Fl. Mont. Formosae) [1908]) and K. Esquirolii Léveillé (in Fedde, Rep. Sp. Nov. VIII. 60 [1910]) are really distinct from $K$. Davidiana.

Pictures of this tree will be found under Nos. 502, 525, 528, 529, 530, 541, 554, $704,035,0144$ in the collection of Wilson's photographs and also in his Vegetation of Western China, Nos. 270-276.

Here may be added a note on K. Fortunei.

Keteleeria Fortunei Carrière in Rev. Hort. 1866, 449; 1887, 207, fig. 42-45; 1. c. 246; Traité Conif. ed. 2, 260 (1867). - Pirotta in Bull. Soc. Tosc. Ort. XII. 269 (1887).- - Masters in Gard. Chron. ser. 3, II. 440 (1887); in Jour. Linn. Soc. XXVI. 555 (1902). - Beissner, Handb. Nadelholzk. 421, fig. 116 (1891).

Abies Jezoënsis Lindley in Lindley \& Paxton, Fl. Gard, I. 42, fig. 26 (non Siebold \& Zuecarini) (1850); in Gard. Chron. 1850, 311, fig. - Planchon in Fl. des Serres, IX. 7. x. (1853).

Pinus jezoensis Lemaire in Jard. Fleur. IV. Misc. 28, fig. (non Antoine) (1854).

Abies (Picea) Fortuni Murray in Proc. Hort. Soc. Lond. 1862, 421, fig. 82-97; Pines \& Firs of Japan, 49, fig. 82-97.

Pinus Fortunei Parlatore in De Candolle, Prodr. XVI. pt. 2, 430 (1868). 
Pseudotsuga jezoensis Bertrand in Ann. Sci. Nat. sér. 5, XX. 86. (1874). Abies Fortunei Masters in Gard. Chron. ser. 2, XXI. 348, fig. 64-67 (1884); in XXV. 428, fig. 82-83 (1886).

Abietia Fortunei Kent, Veitch's Man. Conif. ed. 2, 485, fig. 123 (1900).

Keteleeria sp. Masters in Jour. Linn. Soc. XXVI. 556 (1902); XXXVII. 421 (1906).

Hongkong: St. John's Cathedral compound, cultivated, March 15, 1887, C. Ford (No. 386, type of Masters's Keteleeria sp.): from same tree, $\delta$ flower, March 15, 1887; immature cone, August 5, 1893 (ex Herb. Bot. Gard. Hongkong, No. 10210). Fokien: Fuchou, April 2, 1904, W. Mackenzie (No. 165); same locality, 1886, H. Mayr.

Through the courtesy of the Director of the Royal Gardens, Kew, we have seen the type of Masters's Keteleeria sp.; the Superintendent of the Botanic Gardens, Hongkong, has favoured us with more material from the same tree and we are able to identify this obscure plant as $K$. Fortunei Carrière.

\section{ABIES Juss.}

Abies Delavayi Franchet in Jour. de Bot. XIII. 255 (1899). - Masters in Jour. Linn. Soc. XXVI. 557 (1902); in Gard. Chron. ser. 3, XXXIX. 212, fig. 82 (1906); in Jour. Linn. Soc. XXXVII. 422 (1906).- - Beissner, Handb. Nadelholzk. ed, 2, 194 (1909). - Patschke in Bot. Jahrb. XLVIII. 642, fig. 3, 2 (1913).

Keteleeria Fabri Masters in Jour. Linn. Soc. XXVI. 555 (1902); in Gard. Chron. ser. 3, XXXIII. 194 (1903); in Jour. Linn. Soc. XXXVII. 421 (1906). - Mottet in Rev. Hort. 1904, 130. - Beissner, Handb. Nadelholzk, ed. 2, 203 (1909). - Patschke in Bot. Jahrb. XLVIII. 649 (1913).

Abies Fargesii Masters in Gard. Chron. ser. 3, XXXIX. 213, fig. 83 (non Franchet) (1906); in Jour. Linn. Soc. XXXVII. 422 (1906).

Pinus Fabri Voss in Putlitz \& Meyer, Landlexikon, IV. 773 (1913).

Western Szech'uan: south-east of Tachien-lu, forests, alt. 3000-4000 m., abundant, October 1910 (No. 4078; tree 25-40 m. tall, girth 2-6 m.); west of Tachien-lu, Cheto-shan, alt. 3600-4000 m., October 1910 (No. 4082; tree 25-40 m. tall, girth 2-6 m.); Mt. Omei, alt. 2000-3600 m., common, October 1910 (No. 4086; tree 15-35 m. tall, girth 1-5 m.); Mupin, forming forests, alt. 2000-4000 m., June 1908 (No. 2093; tree 20-40 m. tall, girth 2.5-6 m.); Hungya Hsien, Wa-wu-shan, on summit, alt. 3000 m., abundant, September 1908 (No. 2089, in part; tree $25-40 \mathrm{~m}$. tall); Wa-shan, on summit, alt. 3000-3600 m., July and October 1908 (No. 2089; tree 20-40 m. tall, girth 2.5-5 m.); same locality, July 1903 (Veitch Exped. Nos. 3021, 3022 , seed No. 1515); west and near Wên-ch'uan Hsien, forests, alt. 2600-3500 m., October 1910 (No. 4049; tree 20-35 m. tall, girth 2-4 m.). Yunnan: near Tali Fu, "Tsang-chan," alt. 3500-4000 m., June 1884, J. M. Delavay (No. 1210, type). 
This is the common Silver Fir of western and especially of south-western Szech'uan and has a greater altitudinal and latitudinal range than any other Chinese Fir-tree. One of the handsomest of the family, it grows to a large size and the old trees have massive branches. It is characterized by its red-brown, usually glabrous and shining shoots, its dark violet-black, oblong-ovoid to oblong-cylindric cones which are larger than in any other Chinese species, and by its rather slender leaves revolute on the margins with lateral sub-epidermal resin-ducts. In cross-section the leaves are acute at the margins, where is found several layers of sclerotic cells; the hypoderm consists of a single uniform layer of cells. In ripe cones the apex of the bract is usually slightly exserted, and the caudate cuspis varies from 3 to 6 $\mathrm{mm}$. in length and may be erect or recurved.

The cone is scarcely if at all resinous, very symmetrical, always slightly widest at the base and but very little narrowed upwards, from 7 to $11 \mathrm{~cm}$. long, and from 3.5 to $5.5 \mathrm{~cm}$. wide, the average being 8 or $9 \mathrm{~cm}$. long and $4 \mathrm{~cm}$. wide.

Our specimens agree very well with Franchet's description except that the cones on the average are larger and the cuspis to the bract rather shorter. In No. 4082 , the weak lateral shoots are sparsely villose; in No. 4049 the cones are relatively small $(7 \mathrm{~cm}$. long, $3.5 \mathrm{~cm}$. wide) and the weak lateral shoots sparsely villose. In all the leaves we have examined the resin-ducts are lateral and subepidermal and occasionally we find that they are wanting.

The cones figured by Masters under the names of $A$. Delavayi and A. Fargesii are drawn as if they were widest above the middle, which is never the case. The other slight difference shown in these figures can usually be found in any one cone or branch.

Through the courtesy of the Director of the Royal Gardens, Kew, we are in possession of a fragment of the type specimen of Keteleeria Fabri Masters, and are able to identify it as Abies Delavayi. The channelled upper surface of the leaf at once removes it from the genus Keteleeria in which the leaves of all the species have the midrib slightly raised on the upper surface, never depressed. The revolute margins and other details of the leaf, and Master's original description of young cones agree exactly with $A$. Delavayi.

This Silver Fir is abundant on Mount Omei, the type locality of Keteleeria Fabri Masters. We have searched this mountain in vain for a species of Keteleeria other than $K$. Davidiana Beissner, which occurs sparingly in one or two places on the lower slopes and the fragment of the type shows that we were justified in doubting that any other Keteleeria existed in that region.

Abies Delavayi forms very extensive forests in the more inaccessible parts of south-western Szech'uan. Colloquially it is known as the Lien-sha, this name meaning Cold Fir, in allusion to the fact that the tree grows in cold regions. The timber though soft and not very durable is valued on account of the large size of the logs which it yields. These logs are rafted down the Ya River to Kiating Fu in quantity every year. The wood is white and is used as planking and for beams, etc., in house-building and general indoor work.

Pictures of this tree and of the cones will be found under Nos. 206, 207, 328, $329,331,333,334,0346$, of the colleetion of Wilson's photographs and also in his Vegetation of Western China, Nos, 94-100.

Abies Faxoniana Rehder \& Wilson, n. sp.

Arbor 20-40-metralis, trunco $0.6-1.5 \mathrm{~m}$. diam.; cortex arborum vetustiorum obscure griseus, subtus fuscus, fissus; rami horizontales; ramuli laterales annotini plerumque satis dense et breviter ferrugineohirto-villosi, terminales minus villosi, rarius glabrescentes; pulvini 
lineares, cicatrice orbiculari leviter impressa albida; gemmae ovoideae, obtusae v. acutae, fusco-purpureae, valde resinosae et inter folia abscondita, perulis late ovatis obtusis persistentibus et bases ramulorum arcte cingentibus. Folia congesta, spiraliter disposita, torta et irregulariter in unam planitiem disposita, ea faciei inferioris ramulorum assurgentia, lineari-ligulata, margine leviter revoluta, subito acuta, obtusa $\mathrm{v}$. emarginata, basi leviter constricta, 10-25 $\mathrm{mm}$. longa et $1.5-2.5 \mathrm{~mm}$. lata, supra nitida atroviridia, canaliculata, subtus carinata et duobus fasciebus albis stomatiferis praedita; canales resiniferi subepidermales v. in parenchymate siti. Strobili maturi, intense violaceo-purpurei, ovoidei v. ovoideo-oblongi, basin versus latiores, sessiles, apice applanati, saepe depressi 5-9 cm., plerumque 6-7 cm. longi, 3-4 cm. diam., plerumque valdi resinosi; bracteae squamis subaequilongae, leviter $v$. manifeste exsertae, spatulatooblongae v. cuneato-oblongae, basin versus leviter angustatae, apice undulatae, erosae, cuspidatae cuspide 3-5 $\mathrm{mm}$. longo erecto v. recurvo; squamae reniformia, $8-13 \mathrm{~mm}$. longae et $12-20 \mathrm{~mm}$. latae, apice rotundatae incrassatae margine erecta, basi auriculatae v. truncatae v. subito contractae, manifeste stipitatae; semina alis squamam vix aequantibus nitidis brunneis $\mathrm{v}$. atro-purpurascentibus apice truncatis.

Western Szech'uan: north-east of Sungpan Ting, forests, alt. 2600-3800 m., abundant, August and October 1910 (No. 406o, type); west and near Wên-ch'uan Hsien, forests, alt. 3000-3600 m., July 1908 and October 1910 (Nos. 2092, 4052); west of Kuan Hsien, Panlan-shan, forests, alt. 3000-3600 m., abundant, October 1910 (Nos. $4070,4069,4052^{2}$.).

This species is characterized by the short, broadly ovoid scales of its very resinous winter-buds, its ferruginous, villose shoots, rather short, flat leaves, and by its violet-purple, rather oblong, often densely resinous cones of medium size with spatulate or cuneate-oblong bracts more or less exserted, the long acumen often recurved. In transverse section the leaves are rounded at the margins and have a single layer of hypoderm cells beneath the epidermis. In the type the resinducts are nearly median, but they vary somewhat and in Nos. 2092 and $4052^{\mathrm{a}}$ they are lateral and sub-epidermal. In the type specimen the cone is excessively resinous and the exserted part of the bract is usually erect and of the same color as the cone-seales. In No. 4070 the cone is only slightly resinous and the exserted part of the bract is more or less recurved and pale brownish in colour. The various specimens before us show intermediate conditions and there can be little doubt that all belong to one species.

This new Silver Fir is elosely related to Abies Delavayi Franchet, which has glabrous shoots, much larger, more barrel-shaped cones, and longer leaves revolute at the margins; in eross-section these leaves are acute at the margins and have lateral sub-epidermal resin-ducts. 
Abies Faxoniana is the common species in north-western Szech'uan where it forms extensive forests. The wood is soft and of little value.

Pictures of this tree and the cones will be found under Nos. 0287, 0304, 0313 of the collection of Wilson's photographs.

It is named for Mr. Charles E. Faxon, the distinguished botanical artist of the Arnold Arboretum.

Abies recurvata Masters in Jour. Linn. Soc. XXXVII. 423 (1906). Patschke in Bot. Jahrb. XLVIII, 642, fig. 3, 3 (1913).

Western Szech'uan: valley of Min river, south of Sungpan Ting, forests, alt. 2300-3000 m., August and October 1910 (No. 4057; tree 15-40 m. tall, girth 1-5 m.); same locality, September 1903 (Veitch Exped. No. 3021, type); Kwa-tsze-ling, west of the Min River valley, forests, alt. 2800-3300 m., abundant, October 1910 (No. 4057; tree $20-40 \mathrm{~m}$. tall, girth 1-5 m.); west and near Wênch'uan Hsien, forests, alt. 3000-3600 m., October 1910 (No. 405I; tree 20-30 m. tall, girth 2-4 m.).

This remarkably distinct Silver Fir is abundant on the mountains near the Min River between Mao-chou and Sungpan Ting, forming extensive forests. The trees range from 20 to $40 \mathrm{~m}$. or more in height, with a trunk girth of from 2 to $5 \mathrm{~m}$. The habit is pyramidal, becoming flat-headed in old trees and in those exposed to strong winds. The bark on the trunk is rather rough and varies from dark grey to reddish brown; the shoots are glabrous, shining and pale yellow-grey. The winter-buds are ovoid, usually somewhat pointed, and very resinous. The leaves are strongly recurved, either shining green on both surfaces or very glaucous on the upper (ventral) side. On young trees and on adventitious shoots the leaves are twice the normal length and very pungent. The cones which are produced in clusters on the topmost branehes are short-stalked, oblong-ovoid, from 5 to $9 \mathrm{~cm}$. long, and from 3 to $4 \mathrm{~cm}$. wide; they abruptly taper to the peduncle, and are flattened or somewhat pointed at the apex, smooth, with bracts completely hidden, and are slightly resinous and intense violet-purple in eolor when growing, but change after they are ripe and dry to grey-brown. The wood, for a Silver Fir, is of good quality, being fairly close-grained and durable and is valued for general building purposes. In all respects this species is one of the most desirable of the family, and it was well worth a long journey to introduce it into cultivation.

For the original description fragments of some old cones only were available and we have given here further details to supplement Master's description.

Pictures of this tree and the cones will be found under Nos. 0322, 0324, 0325, 0326 of the collection of Wilson's photographs.

Abies chensiensis Van Tieghem in Bull. Soc. Bot. France, XXXVIII. 413 (1891), descriptione valde incompleta. - Franchet in Jour. de Bot. XIII. 256 (1899).

Abies sp. Franchet in Nouv. Arch. Mus. Paris. sér. 2, VII. 100 (Pl. David. I. 290) (1884).

Abies firma Masters in Jour. Linn. Soc. XXVI. 557 (non Siebold \& Zuecarini) (1902), quoad specimen e Shensi. 
Arbor 15-40-metralis, trunco $0.3-2 \mathrm{~m}$. diam.; rami primarii validi, patentes; ramuli juniores glabri, lucidi, luteo-cinerei, cicatricibus suborbicularibus, pulvinis oblongo-rhombicis satis distinctis, ramuli vetustiores obscure cinerei; gemmae flavido-brunneae, ovoideae, acutiusculae, leviter resinosae, perulis persistentibus. Folia inaequalia, horizontaliter patentia, subdisticha, lineari-ligulata, margine leviter recurva, apice plerumque emarginata v. rotundata, rarius acutiuscula et integra, basi in petiolum perbrevem sed satis distinctum contracta, $1.5-4 \mathrm{~cm}$. longa et 3-4 mm. lata, supra nitentia, atroviridia, canalieulata, subtus cinereo-viridia, costa media elevata; canales resiniferi 2 , laterales, sub epidermide, sed in foliis ramulorum fructiferorum in parenchymate positi; hypodermis in facie ventrali contigua epidermidem crassitie aequans, in facie dorsali tantum sub costa media et secus marginem evoluta. Strobili subsessiles, initio virides, sub maturitate cinnamomei, leviter resinosi, ovoideo-cylindrici, perfecte symmetrici, apice applanati, basi rotundati, 8-10 $\mathrm{cm}$. longi et $4.5-5 \mathrm{~cm}$. lati; squamae late obovato-cuneatae, apice in utroque latere in alam brevem margine tenui leviter laciniosam productae, basi subito unguiculatae, $2.5-3 \mathrm{~cm}$. longae, apice $3.5-4 \mathrm{~cm}$., medio $1.8-2.2 \mathrm{~cm}$. latae, apice extus tomentosulae; bracteae flavo-brunneae, suborbiculares emarginatae et apiculatae, eroso-denticulatae, tertiam partem squamae aequantes, circiter $8 \mathrm{~mm}$. latae, in unguiculum latum contractae; semina obovoidea, circiter $1 \mathrm{~cm}$. longa et $5 \mathrm{~mm}$. lata, alis pallide brunneis $2.5-3 \mathrm{~m}$. longis et $1-1.2 \mathrm{~cm}$. latis apice truncatis $\mathrm{v}$. rotundatis minute erosis.

Western Hupeh: Fang Hsien, forests, alt. 2300-3500 m., May and October 1907 (No. 647). Shensi: Tsinling mountains 1872, A. David (type).

Through the courtesy of the Director of the Herbarium of the Muséum d'Histoire Naturelle at Paris we have seen a fragment of the type of this obscure species and are able to identify it. The anatomical character mentioned by Van Tieghem when giving a name to David's specimen has no specific value since it applies equally well to several Chinese species of Abies, and in his key, moreover, he places it with the species which have always sub-epidermal resin-ducts, because he had examined leaves from sterile branches only. The remarks of Franchet (Jour. de Bot. XIII. 256) also are of little service in identifying this species. We have, therefore, drawn up a full description from our No. 647 with which the leaves of a shoot of David's original specimen agree exactly in morphological and anatomical characters.

Abies chensiensis Van Tieghem, is an exceedingly well-marked species and superficially in the character of the branchlets, the colour and size of the leaves and in the shape of the winter-buds strongly resembles Keteleeria Davidiana Beissner, and this explains Franchet's remark in Pl. David. The channelled upper sur- 
face of the leaves, however, at once shows that it is not a Keteleeria. The species is characterized by its relatively long, shining green leaves, glabrous yellow-grey branchlets, ovoid, acute, slightly resinous winter-buds and by its symmetrical ovoidcylindric, pale brown cones with small orbicular bracts and very large cone-scales and seeds. It is most closely related to A. firma Siebold \& Zuccarini, which usually has four resin-ducts (two median and two lateral) in the leaf and sclerotic cells in the parenchyma, dark grey, sometimes reddish, two-year old shoots, more slender cones with narrowly cuneate bracts as long or nearly as long as the cone-scale each furnished with a long, lanceolate, pungent cuspis which is prominently exserted. The affinity of $A$. chensiensis Van Tieghem with $A$. Beissneriana Rehder \& Wilson, is pointed out under the latter species.

Abies chensiensis is a comparatively rare tree in north-western Hupeh. It grows to a very large size but the timber is soft and of little value.

\section{Abies Beissneriana Rehder \& Wilson, n. sp.}

Abies firma Masters in Jour. Linn. Soc. XXXVII. 422 (non Siebold \& Zuccarini) (1906), quoad specimen Wilsonianum, No. 3020 .

Arbor excelsa, ad $60 \mathrm{~m}$. alta, trunco ad $6 \mathrm{~m}$. diam.; cortex obscure griseus, subtus brunnescens, fissus; ramuli hormotini nitiduli, glabri, rarissime primo juventute puberuli, flavidi, annotini albido-cinerei; pulvini prominentes, rhombici v. fere lineares; cicatrices orbiculares, impressi, cinerei; gemmae ovatae, valde resinosae, inter folia absconditae, perulis brunneis ovatis acutiusculis $\mathrm{v}$. obtuse acuminatis persistentibus bases ramulorum cingentibus. Folia spiraliter disposita, adscendentia v. erecto-patentia v. patentia, lineari-ligulata, acuta et pungentia v. obtusa, rarius obsolete emarginata, supra basin leviter constricta, 1-3 cm., plerumque $2 \mathrm{~cm}$. longa et 1.5-2 mm. lata, supra fere plana, rarius medio leviter impressa, subtus carinata, supra atroviridia, subtus pallidiora v. glaucescentia, saepe utrinque stomatifera; canales resiniferi duo laterales sub epidermate positi; hypodermis in facie ventrali contigua crassa, in facie dorsali tantum sub costa et secus marginem evoluta. Strobili pedunculati, cylindrici, rarius ovoideo-cylindrici, apice truncati, saepe leviter angustati, basi rotundati, 5-8 cm. longi et $3-3.5 \mathrm{~cm}$. diam., juventate violaceo-purpurei, deinde griseo-virides, sub maturitate griseo-brunnei; bracteae squamis dimidio breviores, obovatae, cuneatae, apice truncatae, emarginatae, breviter cuspidatae, denticulatae; squamae cuneato-obovatae, apice rotundatae, saepe leviter erosae, nec incrassatae, basin versus subito angustatae, interdum auriculatae et unguiculatae; pedunculi dense bracteati, resinosi, circiter $1 \mathrm{~cm}$. longi. Semina alis squamam fere aequantibus rotundatis nitidis pallide brunneis.

Western Szech'uan: north-east of Tachien-lu Ta-p'ao-shan, forests, alt. 2600-3800 m., abundant, July 1908 (Nos. 2090, type, 
209I); Ching-chi Hsien, summit of Fei-yüeh-ling, alt. 3000 m., October 1908 (No. 2095); same locality, August and October 1904 (Veitch Exped. No. 3020, seed No. 1570); Mupin, forests, alt. 3300 m., October 1908 (No. 2094).

This is the tallest of all the Chinese species of Abies. It is characterized by its shining yellowish and later pale grey branchlets, its pedunculate cones which are grey-brown when ripe and have very small obovate-cuneate bracts, and relatively thin and large cone-scales, and by its ascending-spreading, usually pungent, flat leaves with midribs very rarely impressed above, commonly stomatiferous on both surfaces and either pale green or glaucous on the underside. In transverse section the resin-ducts are lateral and usually sub-epidermal; the epidermis is very thickwalled and on the ventral side is subtended by a hypodermal layer and this by a few scattered sclerotic cells. On the dorsal side the hypodermal layer is not continuous, occurring beneath the midrib and at the margins only. The endodermis is unusually well defined and is composed of large roundish-oval cells.

This new species is closely related to $A$. chensiensis Van Tieghem, which has longer leaves twisted to form one plane, very unequal in length on the same shoot, always green on both surfaces and rarely if ever pungent, and subsessile cones with much larger, nearly orbicular bracts.

Masters refers our No. 3020 to A. firma Siebold \& Zuccarini ${ }^{1}$ which is easily distinguished by its winter-buds, which are prominent, acutish and scarcely if at all resinous, by its dark grey, sometimes reddish, two- or three-year old shoots, its very much longer cones with narrowly cuneate bracts furnished with a long lanceolate cuspis which is exserted, and by its broader cone-scales and much larger seeds. There are slight differences in the leaves and A. firma usually has four resin-ducts, two median and two lateral, and sclerotic cells scattered in the parenchyma. This herbarium specimens show; other differences doubtless would appear, could living trees of the two species be examined growing side by side.

In open country A. Beissneriana develops moderately wide-spreading branches and forms a rather round or flat-headed tree of medium height. In the forests the branches are short, slender and the tree has a very spire-like appearance towering high above every other tree in the forest.

This Silver Fir is the P'ao-sha of the Chinese and the wood is soft and of very little value. The vernacular name signifies "worthless Fir" and has reference to the inferior quality of the wood. Occasionally it is spoken of as Lien-sha, a name more properly applied to $A$. Delavayi Franchet, but these common names are in some districts interchangeable and are often indiscriminately used.

Pictures of this tree will be found under Nos. 181, 182, 189, 267 of the collection of Wilson's photographs and also in his Vegetation of Western China, Nos. 91-93.

We take pleasure in associating with this stately Silver Fir the name of Mr. L. Beissner, author of the Handbuch der Nadelholzkunde, and one of the first authorities on cultivated Conifers.

${ }^{1}$ It is highly improbable that this Japanese species occurs in China proper. The specimens from Yunnan referred to this speeies by Kanitz (in Noven. Gyujit. Szèchenyi, II. 848 (Pl. Enum. 64) [1891]) probably belong to A. Delavayi Franchet. Our No. 1895 referred to A. firma by Masters (in Jour. Bot. XLI. 270 [1903]) belongs to A. Fargesii Franchet. In the Jour. Linn. Soc. XXVI. 557 (1902), Masters reduces $A$. chensiensis Van Tieghem to A. firma. 
Abies Fargesii Franchet in Jour. de Bot. XIII. 256 (1899). Pritzel in Bot. Jahrb. XXIX. 218 (1900). - Masters in Jour. Linn. Soc. XXVI. 557 (1902). - Beissner, Handb. Nadelholzk. ed. 2, 194 (1909). - Patschke in Bot. Jahrb. XLVIII. 642 (1913).

Western Hupeh: Fang Hsien, alt. 2300-3300 m., forming forests, May 1907 (No. 2088; tree 10-40 m. tall, girth 1-5 m.); same locality, June and October 1910 (No. 445I); same locality, June 1901 (Veitch Exped. No. 1895); A. Henry (No. 6881). Eastern Szech'uan: Chengkou Ting, P. Farges (type).

This is the common Silver Fir of north-western Hupeh where remnants of old forests of it still occur. The species is characterized by its glabrous red-brown or purplish branchlets, its slender short-stalked, searcely resinous cones with exserted spreading and recurved obovate-cuneate bracts, and by its horizontally spreading, rather long leaves emarginate or bifid at the apex. The hypoderm consists of a single, fairly uniform layer; the resin-ducts are lateral, either surrounded by parenchymatous cells or sub-epidermal, the latter position being common in young plants. The trunk is of nearly uniform thickness for half its height, the branching is relatively sparse and the branches though short are very massive. The wood though soft and easily worked is fairly durable and is used for coffin-making, indoor finishing and other purposes.

The No. 1895 has been referred by Masters (in Jour. Bot. XLI. 270 [1903]) to the very different $A$. firma Siebold \& Zuccarini, a Japanese species not authentieally known from China proper. The specimens identified and figured by Masters in Gard. Chron. ser. 3, XXXIX. 213 (1906) as A. Fargesii belong to A. Delavayi Franchet.

Pictures of this tree will be found under Nos. 698, 0103, 0104, 0111, 0112 of the collection of Wilson's photographs and in his Vegetation of Western China, No. 17.

Abies squamata Masters in Gard. Chron, ser. 3, XXXIX. 299, fig. 121 (1906); in Jour. Linn. Soc. XXXVII. 423 (1906). - Patschke in Bot. Jahrb. XLVIII. 643, fig. 3, 6 (1913).

Western Szech'uan: north and west of Tachien-lu, forests, alt. 3600-4600 m., October 1910 (No. 4079; tree 20-40 m. tall, girth 25 m.); same locality, June 1904 (Veitch Exped. No. 3019, type).

This remarkable Silver Fir is the most alpine of the species occurring in the neighbourhood of Tachien-lu where it forms pure forests. The violet-coloured cones are resinous and are slightly more elongate than shown in Masters's figure. The shaggy purplish brown bark exfoliates in thin layers exactly in the same way as that of the River Birch (Betula nigra L.). The leaves are short, relatively broad, abruptly acute or obtuse, and vary considerably in degree of glaucescence. The winter-buds are sub-globose, often flattened at the summit, reddish-brown and very resinous.

Here may be added notes on two other Chinese Silver Firs not represented in Wilson's collections.

Abies sutchuenensis Rehder \& Wilson, n. sp.

Abies Fargesii, var. sutchuensis Franchet in Jour. de Bot. XIII. 256 (1899). 
Arbor; ramuli glabri, fusco-rubri v. brunnei, vetustiores cinereo-fusci; pulvini lineares, cicatricibus impressis cincereo-albidis late ovalibus v, orbicularibus; gemmae ovoideae, resinosae, inter folia absconditae, perulis fuscis ovatis obtusis carinatis erosis. Folia spiraliter disposita, curvata, assurgentia, lineari-ligulata, acuta v. obtusa, rarius obsolete emarginata, basi in petiolum distinctum flavescentem contracta, $10-20 \mathrm{~mm}$. longa et 2-2.5 $\mathrm{mm}$. lata, supra canaliculata, nitida, atroviridia, subtus carinata duobus fasciebus albis stomatiferis notata; canales resiniferi 2 laterales, in medio parenchymatis positi. Strobili violacei-purpurei, oblongo-ovoidei, apice rotundati, basi applanati, sessiles, $55-7 \mathrm{~cm}$. longi et $3.2-$ 3.5 diam., sparse resinosi; bracteae squamis paullo breviores, cuneato-obovatae, erosae, breviter cuspidatae; squamae late reniformes, 8-10 mm. longae et 15-18 $\mathrm{mm}$. latae, margine incrassatae et sursum deflexae, basi auriculatae, manifeste unguiculatae; semina alis quam squamae paullo brevioribus truncatis nitidis pallide griseis leviter purpurascentibus.

Western Kansu: "Lotani," 1911, W. Purdom (No. 805); banks of Tow River, 1911, W. Purdom (No. 823). Shensi: Tai-pei-shan, alt. 3000 m., 1910, W. Purdom (No. 405). Eastern Szech'uan: Chengkou Ting, P. Farges (type).

This Silver Fir appears to us quite distinct from A. Fargesii Franchet and in raising it to a species we have drawn up a complete description based on Purdom's No. 805, which as far as we can determine from a fragment and photograph of the type received from Paris is identical with Franchet's variety. Unfortunately we are without any precise information about this tree, which is characterized by its shining red or purplish brown glabrous branchlets mediumsized symmetrical, scarcely resinous, violet-black cones with shortly cuspidate, obovate-cuneate bracts; and by its ascending, stout, relatively short and broad leaves with a distinct petiole which is yellowish in color. It is most elosely allied to A. Faxoniana Rehder \& Wilson which is distinguished by its villose branchlets longer and thinner leaves, its exserted long-cuspidate spatulate or cuneate-oblong bracts, and by its usually very resinous cones. In transverse section the leaves are seen to be very broad, with median resin-ducts, and a single layer of hypoderm cells on the ventral side but none on the dorsal side except immediately beneath the midrib. The margins are rounded with several layers of sclerotic tissue.

Purdom's No. 405 possibly does not belong here. The specimens are without leaves and the cones are immature with exserted bracts, and were probably gathered from a dead branch. Young seedling plants bearing this number and raised from seed collected by Purdom can scarcely be distinguished from A. Fargesii Franchet. For geographical reasons we refer this No. 405 tentatively to $A$. sutchuenensis Rehder \& Wilson rather than to A. Fargesii Franchet, though it may belong to the latter species.

The specimens referred by Beissner (in Bull. Soc. Bot. Ital. 1901, 358) to A. Mariesii and those referred in his Handb. Nadelholzk. ed. 2, 192 (1906) to A. Veitchii, which are doubtless the same as mentioned by Masters (in Jour. Linn. Soc. XXVI. 557 [1902]), probably belong either to A. sutchuenensis or possibly to A. Fargesii Franchet but without seeing the specimens it is impossible to decide. It is now believed that the Chinese species of Pinaceae are confined to China and it is highly improbable that either A. Mariesii Masters, or A. Veitchii Lindley or any other Japanese Fir or Spruce occurs in China proper.

Abies sibirica Ledebour, var. nephrolepis Trautvetter in Maximowicz in Mém. Sav. Étr. Acad. Sci. St. Pétersbourg, IX. 260 (Prim. Fl. Amur.) (1859). - Patschke in Bot. Jahrb. XLVIII. 643, fig. 3, 12 (1913).

Abies nephrolepis Maximowicz in Bull. Acad. Sci. St. Pétersbourg, sér. 3, X. 486 (1866); in Mél. Biol. VI. 22 (1866). - Komarov in Act. Horl. 
Petrop. XX. 200 (Fl. Mansh.) (1901). - Beissner, Handb. Nadelholzk. ed. 2, 186 (1909).

Abies Veitchii Masters in Jour. Linn. Soc. XVIII. 516 (non Lindley) (1881), -

Herder in Act. Hort. Petrop. XII. 118 (1890).

Abies sibirica Korshinsky in Act. Hort. Petrop. XII. 424 (non Ledebour) (1890).

Pinus nephrolepis Voss in Mitt. Deutsch. Dendr. Ges. XVI. 94 (1907).

Shansi: Wutai-shan, 1909, W. Purdom (No. 143). Manchuria : mountains, 12 hours east of Harbin by railway, rare, August 31, 1903, C. S. Sargent. A mur region: May 27, 1891, S. Korshinsky.

Our specimens of thisinteresting addition to the known flora of China agree exactly with Trautvetter's original description, and we believe that it can only be regarded as a variety of $A$. sibirica Ledebour. It is in fact the eastern Asiatic form of that species and its region of distribution is similar to that of Larix dahurica Turczaninow. The slightly different shaped cone with larger bracts and rather different shaped cone-scales and the more hairy branchlets serve to distinguish the variety from the type species. Maximowicz in raising it to a distinct species compared it with $A$. Veitchii Lindley to which species however it is only remotely related, although superficially they do resemble one another somewhat. In $A$. sibirica, var. nephrolepis Trautvetter, the resin-ducts are median as in A. sibirica Ledebour, not lateral as in A. Veitchii Lindley; in the leaves and characters of the branchlets it is also well removed from the latter species.

Wutai-shan, where Purdom collected his specimens, is a particularly interesting region from the point of view of geographical botany. It is the southernmost locality in China for a number of Siberian and Manchurian trees and shrubs and is the most western point reached by many Korean and Manchurian species.

\section{Subfam. TAXODIEAE Parl.}

\section{CUNNINGHAMIA R. Br.}

\section{Cunninghamia lanceolata Hooker in Bot. Mag. LIV. t. 2743 (1827).}

Pinus Abies Loureiro, Fl. Cochin. 579 (non Linnaeus) (1790), synonymis excludendis.

Pinus lanceolata Lambert, Descr. Pinus, 52, t. 34 (1803).

Abies lanceolata Poiret in Lamarck, Encycl. Méth. VI. 523 (1804).

Belis jaculifolia Salisbury in Trans. Linn. Soc. VIII. 315 (1807).

Cunninghamia sinensis Brown apud Richard, Conif. 80, t. 18, fig. 3 (1826). Link in Linnaea, XV. 540 (1841). - Siebold \& Zuccarini, Fl. Jap. II. 7, t. 103, 104 (1844); in Abh. Akad. Münch. IV. pt. III. 235 (Fl. Jap. Fam. Nat. II. 111) (1846).-Bentham, Fl. Hongk, 337 (1861). - Miquel in Ann. Mus. Ludg.-Bat. III. 167 (1867); Prol. Fl. Jap. 331 (1867).- Parlatore in De Candolle, Prodr. XVI. pt. II. 432 (1868), - Debeaux in Act. Soc. Linn. Bordeaux, XXX. 109 (Fl. Shangh. 57) (1875).- Masters in Jour. Linn. Soc. XVIII. 502 (1881); XXVI. 548 (1902); XXXVII. 415 (1906). Franchet in Nouv. Arch. Mus. Paris, sér. 2, VII. 101 (Pl. David. I. 291) (1884); in Jour. de Bot. XIII. 262 (1899).-Beissner in Nuov. Giorn. Bot. Ital. n. ser. IV. 185 (1897). - Pritzel in Bot. Jahrb. XXIX. 218 (1900). - Shirasawa, Icon. Ess. For. Jap. I, 23, t. 9, fig. 1-24 (1900). - 
Matsumura in Bot. Mag. Tokyo, XV. 139 (1901). - Matsumura \& Hayata in Jour. Coll. Sci. Tokyo, XXII. 399 (Enum. Pl. Formos.) (1906).Pampanini in Nuov. Giorn. Bot. Ital. n. ser. XVII. 231 (1910); XVIII. 105 (1911), - Dunn \& Tuteher in Kew Bull. Misc. Inform. add. ser. X. 256 (Fl. Kwangtung \& Hongkong) (1912), - Patschke in Bot. Jahrb. XLVIII. 672 (1913).

Belis lanceolata Sweet, Hort. Brit. 475 (1830).

Raxopitys Cunninghamii Nelson, Pinaceae, 97 (1866).

Araucaria lanceolata Hort. ex Parlatore in De Candolle, Prodr. XVI. pt. II. 433

(quasi synon. Cunninghamiae sinensis) (1868).

Kiangsi : near Kiukiang, foothills of the Lushan range, alt. $300 \mathrm{~m}$., common, August 1, 1907 (No. I740; trees all small). Western Hupeh: north and south of Ichang, forming woods, alt. 30-1300 m., abundant, April and November 1907 (No. 794; tree 6-25 m. tall, 13 m. girth); "Monte Triora," alt. 1950 m., September 1907, C. Silvestri (No. 104). Western Szech'uan: south-east of Tachien-lu, alt. $1600 \mathrm{~m}$., October 1908 (No. $794^{\mathrm{a}}$; tree $40 \mathrm{~m}$. tall, girth $6 \mathrm{~m}$.); Kiating Fu, alt. 350-1000 m., abundant, November 1908 (No. $794^{\text {b }}$; tree 6$20 \mathrm{~m}$. tall); west and near Kuan Hsien, alt. 1000 m., October 1910 (No. 4076; tree 13-20 m. tall, 1-1.5 girth); Shih-ch'uan Hsien, alt. 600-1600 m., August 1910 (No. 4651 ; tree 13-25 m. tall, 1-4 m. girth). Yunnan: Mengtze, mountains, alt. $1600 \mathrm{~m}$., A. Henry (No. 9148 ${ }^{\mathrm{a}}$ ). Central Fokien: without locality; Dunn's Exped., April-June 1905 (Herb. Bot. Gard. Hongkong, No. 3511). Formosa: Tamsui, A. Henry.

This handsome tree is found all over the temperate parts of China from sealevel up to $2000 \mathrm{~m}$. alt. according to latitude, but does not occur where the winters are severe. It is abundant in Fokien, Hunan and Hupeh and more especially so in western Szech'uan where it is partial to red-sandstone and forms pure forests. The trunk is mast-like; the branches numerous, slender, short and horizontally spreading, giving a lax pyramidal appearance to the tree. The leaves, usually dark green above, are frequently more or less glaucescent. After felling sprouts spring from the old stumps and develop into new trees. This peculiarity explains why this tree is still common in regions near densely populated areas.

Cunninghamia is the "Sha-shu" of the Chinese and is esteemed the most useful of all their timber trees. The wood is fragrant, soft and easily worked and is extensively employed in all branches of earpentry; in general construction work for pillars and planking, and as masts for native boats. It is also the principal coffin wood of central and western China, the fragrant properties being considered to act as a preservative. In parts of western Szech'uan, notably in the Chiench'ang valley, and in the valley of the Tung river a few days' journey west of Fulin, whole forests of this tree were engulfed by an earthquake two or three centuries ago. The wood of these trees is to-day mined and furnishes the most valuable of all coffin material. From these logs, known as "Hsiang-mu" (fragrant wood) or "Yin-chên-mu" (long-buried-wood), planks of huge size can be cut and a coffin made of them sells for a thousand to fifteen hundred ounces of 
silver. This buried wood is pale brown, close in texture, but easily worked, and pleasantly fragrant. Trees of this conifer, equalling in size these buried giants, cannot be found in China to-day except as rare and isolated specimens associated with temples or shrines.

A good figure of a branch and a cone of this tree, collected by James Cunningham, is found in Plukenet, Opera IV.t. 351, fig. 1 (Amalt. 1. fig. 1) (1705) under the name of Abies major sinepsis, etc.

Pictures of this tree will be found under Nos. 76, 209, 210, 211, 212, 311, 312, $337,340,373,549,0183$ of the collection of Wilson's photographs and also in his Vegetation of Western China, Nos. 177-185.

\section{CRYPTOMERIA D. Don.}

Cryptomeria japonica D. Don in Trans. Linn. Soc. XVIII. 166, t. 13, fig. 1 (1841). - Hooker, Icon. VII. t. 668 (1844). - Siebold \& Zuccarini in Abh. Akad. Münch. IV. pt. III. 234 (Fl. Jap. Fam. Nat. II. 110) (1846). - Miquel in Ann. Mus. Ludg.-Bat. III. 168 (1867); Prol. Fl. Jap. 332 (1867); in Siebold \& Zuccarini, Fl. Jap. II. 43, t. 124, $124^{\text {b }}$ (1870). - Parlatore in De Candolle, Prodr. XVI. pt. II. 438 (1868), - Debeaux in Act. Soc. Linn. Bordeaux, XXX. 109 (Fl. Shangh. 57) (1875). - Franchet \& Savatier, Enum. Pl. Jap. I. 469 (1875). - Masters in Jour. Linn. Soc. XVIII. 497 (1881); XXVI. 544 (1902); XXXVII. 413 (1906). - Franchet in Nouv. Arch. Mus. Paris, sér. 2, VII. 101 (Pl. David. I. 291) (1884). - Sargent in Garden \& Forest, VI. 443, fig. 66 (1893); For. Fl. Jap. 74, t. 24 (1894). Pritzel in Bot. Jahrb. XXIX. 218 (1900). - Shirasawa, Icon. Ess. For. Jap. I. 24, t. 9, fig. 25-42 (1900). - Pampanini in Nuov. Giorn. Bot. Ital. n. ser. XVII. 231 (1910); XVIII. 105 (1911). - Patschke in Bot. Jahrb. XLVIII. 672 (1913).

Cupressus japonica Linnaeus f., Suppl. 421 (1781). - Thunberg, Fl. Jap. 265 (1784).

Taxodium japonicum Brongniart in Ann. Sci. Nat. XXX. 183 (1833) excludenda var. heterophylla.

Cryptomeria Fortunei Otto \& Dietrich in Allg. Gartenz. 1853, 234.

Kiangsi: Kuling, temple of Wang-lung-shih, alt. 1300 m., July 28, 1907 (No. I746; two trees 35-40 m. tall, 5-5.5 m. girth, said to have been planted a thousand years ago). Hupeh: "Ou-tan-scian" alt. 2050 m., August and September 1907, C. Silvestri (Nos. 105, 106). Western Szech'uan: Kuan Hsien, eultivated in temple grounds, alt. $900 \mathrm{~m}$., October 1910 (No. 4077; tree 10-13 m. tall, 1-1.5 m. girth); same locality, 1904 (Veitch Exped. No. 3008). Yunnan: Mengtze, alt. 2000 m., A. Henry (Nos. 9667, 9667). 
All the trees of Cryptomeria we have seen in China were planted, yet it occurs in such remote places in the far west of Szech'uan that one strongly suspects that it is native of this region. For example: on the lower slopes of the Chiu-tingshan, two days' journey west of Mienchu Hsien, a town on the north-west corner of the Chengtu Plain, Cryptomeria occurs in some quantity; it is also found on the mountains to the west of Kuan Hsien. It would appear highly improbable that these trees or their parents had been introduced to these remote, sparsely populated regions from Japan or eastern China.

This tree was first discovered by James Cunningham in the Chusan Islands, and a specimen collected by him is figured in Plukenet, Opera IV.t. 386, fig. 3 (Amalt.69) (1705) under the name of Cupressus cheusanensis, juniperinis arcuatis foliis, etc.

It is the "Kung-ch'io Sung" (Peacock Pine) of the Chinese.

A picture of this tree will be found under No. 690 of the collection of Wilson's photographs and also in his Vegetation of Western China, No. 174.

\section{Subfam. CUPRESSEAE Lindl.}

\section{THUJA L.}

Thuja orientalis Linnaeus, Spec. 1002 (1753). - Thunberg, Fl. Jap. 226 (1784). - Abel, Narr. Jour. China, 145 (1818).-Wallich, Cat. No. 6047 (1828). - Bunge in Mém. Sav. Étr. Acad. Sci. St. Pétersbourg, II. 137 (Enum. Pl. Chin. Bor. 63) (1833). - Siebold \& Zuccarini, Fl. Jap. II. 31, t. 118 (1844); in Abh. Akad. Münch. IV. pt. III. 234 (Fl. Jap. Fam. Nat. II. 110) (1846), - Ledebour, Fl. Ross. III. pt. II. 680 (1849-1851). - Masters in Jour. Linn. Soc. XVIII. 488 (1881); XXVI. 540 (1902); XXXVII. 412 (1906). Hooker f., Fl. Brit. Ind. V. 644 (1890). - Franchet in Jour. de Bot. XIII. 106 (1899). - Pritzel in Bot. Jahrb. XXIX. 219 (1900).Matsumura in Tokyo Bot. Mag. XV. 137 (1901). - Matsumura \& Hayata in Jour. Coll. Sci. Tokyo, XXII. 401 (Enum. Pl. Formos.) (1906). - Diels in Wiss. Ergeb. Exped. Filchner China Tibet, X. 247 (1908). - Pampanini in Nuov. Giorn. Bot. Ital. n. ser. XVII. 232 (1910); XVIII. 106 (1911). - Patschke in Bot. Jahrb. XLVIII. 675 , t. 8 , fig. 5 (1913).

Thuja acuta Moench, Meth. 692 (1794).

Cupressus Thuia Targioni-Tozzetti, in Ann. Mus. Firenze, I. pt. II. 52 (Obs. Bot. dec. II. 52) (1808).

Platycladus stricta Spach, Hist. Vég. XI. 335 (1842).

Biota orientalis Endlicher, Syn. Conif. 47 (1847). - Miquel in Ann. Mus. Ludg.-Bat. III. 167 (1867); Prol. Fl. Jap. 329 (1867). - Parlatore in De Candolle, Prodr. XVI. pt. II. 461 (1868). - Franehet \& Savatier, Enum. Pl. Jap. I. 470 (1875), - Debeaux in Act. Soc. Linn. Bordeaux, XXX. 110 (Fl. Shangh. 58) (1875), - Franchet in Bull. Soc. Bot. France, XXIX. 
12 (1882). - Kanitz in Noven. Gyüjït. Szèchenyi, II. 847 (Pl. Enum. 63) (1891); Wiss. Ergeb. Reise Szèchenyi, II. 737 (1908). - Beissner in Nuov. Giorn. Bot. Ital. n. ser. IV. 185 (1897). - Palibin in Act. Hort. Petrop. XIX, 137 (Consp. Fl. Koreae) (1901).

Western Hupeh: near Shasi, planted, alt. 30 m., February 10, 1908 (No. 2102; tree 8-12 m. tall, girth 1-1.5 m., branches pendulous); "Monte Triora," alt. 1950 m., 1907, C. Silvestri (No. 107). Western Szech'uan: Mupin, roadside, near a house, alt. 1100 m., November 1908 (No. I272; tree 8 m. tall); Mt. Omei, temple grounds, October 1903 (Veitch Exped. No. 3011). Yunnan: Yuanchiang, planted by temple, alt. 2000 m., A. Henry (No. 13353). Shensi: Yenan Fu, 1910, W. Purdom (No. 355). Chili: Peking, temple of Confucius, September 15, 1903, C. S. Sargent; Peking, Temple of Heaven, January 1907, F. N. Meyer (No. 393); north of Peking, Ming Tombs, October 6, 1905, J. G. Jack.

This tree is very rarely planted in central and western China and we never met with a spontaneous specimen in our travels. It is probably a native of northeastern China, Manchuria and Korea.

\section{CUPRESSUS L.}

Cupressus torulosa D. Don, Prodr. Fl. Nepal. 55 (1825). - Wallich Cat. No. 6046 (1830). - Griffith, Icon. Pl. Asiat. IV. t. 372 (1854). Dalzell \& Gibson, Bombay $\mathrm{Fl}$. suppl. 83 (1861). - Murray in Ravenscroft, Pinet. Brit. II. 201, t. 35 (1867). - Parlatore in De Candolle, Prodr. XVI. pt. II. 469 (1868). - Brandis, For. Fl. Brit. Ind. 534 (1874); Indian Trees, 694 (1906). - Gamble, Man. Ind. Timbers, 410 (1881); new ed. 696 (1902). - Hooker f., Fl. Brit. Ind. 645 (1888). - Masters in Jour. Linn. Soc. XXXI. 335 (1896). Collett, Fl. Siml. 483 (1902). - Cooke, Fl. Bombay, II. 666 (1908). Patschke in Bot. Jahrb. XLVIII. 675, t. 8, fig. 17 (1913).

Juniperus nepalensis Loudon, Encycl. Trees and Shrubs, 1118 (1842).

Cupressus Corneyana Knight \& Perry, Syn. Conif. 20 (nomen nudum) (1850?.) - Carrière, Traité Conif. 128 (1855).

Cupressus majestica Knight \& Perry, Syn. Conif. 20 (nomen nudum) (1850?).

Cupressus Tournefortii Tenore, Ind. Sem. Hort. Neapol. 2 (non Audibert)

(1853); in Ann. Sci. Nat. sér. 3, XIX. 355 (1853).

Cupressus torulosa majestica Carrière, Traité Conif. 118 (1855).

Sabina Corneyana Antoine, Cupress. 54, t. 74, 78, fig. a-f, (1857).

Cupressus Tournefortiana Tenore, Ind. Sem. Hort. Neapol. 4 (1858).

Juniperus chinensis Corneyana Gordon, Pinetum, 117 (1858).

Cupressus torulosa Corneyana Carrière, Traité Conif. 151 (1867).

Cupressus torulosa Tournefortii Carrière, Traité Conif. 152 (1867). 
Western Szech'uan: Min valley, near Mao-chou, arid regions, alt. 1800 m., rare, May 25, 1908 (No. 2105; tree 20 m. tall, girth 3 m.); west and near Wên-ch'uan Hsien, lat. 1600 m., November 1908 (No. $79^{\mathrm{a}}$; tree $13 \mathrm{~m}$. tall, girth $2 \mathrm{~m}$.); valley of Tung river, dry regions, alt. 1300-2600 m., common, June, July and August 1908 (No. 2 Io6; tree 8-33 m. tall, girth $0.6-4 \mathrm{~m}$.); same locality, alt. $1300 \mathrm{~m}$., July 1904 (Veitch Exped. No. 3012).

This tree is common throughout the arid upper reaches of the Tung River between 1300 and $2500 \mathrm{~m}$. altitude and at one time evidently formed extensive forests in this region. In the valley of the Min River it is rare and we have no knowledge of this tree east of this district.

The bark is reddish brown and the trunk usually mast-like. The branches are very numerous, usually short, horizontally spreading and of no great thickness, the outline of the tree then being symmetrical. Sometimes the branches are erect-spreading and the habit is then close and fastigiate. Often the habit is irregular with numerous large branches disposed in a manner to form a widespreading, flat-topped head. Occasionally the branches are somewhat pendulous and the branchlets are more frequently so. Usually the foliage is dark green but sometimes it is pale and slightly glaucous.

The Chinese name "K'an-peh-sha" signifies that it is the Cypress that grows in dry regions. The timber is very highly valued and this probably accounts for the absence of large trees except near houses, temples and lamaseries.

It is highly probable that the C. sempervirens Franchet (in Jour. de Bot. XIII. 263 [1899]) belongs here, for it is not probable that Linnaeus' plant occurs in China or, in the wild state, east of Afghanistan.

Pictures of this tree will be found under Nos. 84, 158, 256, 257, 259 of the collection of Wilson's photographs and also in his Vegetation of Western China, Nos. 192-197.

Cupressus funebris Endlicher, Syn. Conif. 58 (1847). - Parlatore in De Candolle, Prodr. XVI. pt. II. 471 (1868), - Debeaux in Act. Soc. Linn. Bordeaux, XXX. 110 (Fl. Shangh. 58) (1875). - Masters in Jour. Linn. Soc. XVIII. 496 (1881); XXVI. 540 (1902); XXXVII. 412 (1906); in Jour. Bot. XLI. 268 (1903). - Kanitz in Noven. Gyüjit. Szèchenyi, II. 847 (Pl. Enum. 63) (1891); Wiss. Ergeb. Reise Szèchenyi, II. 738 (1898). - Franchet in Jour. de Bot. XIII. 263 (1899). - Pritzel in Bot. Jahrb. XXIX. 219 (1900). - Pavolini in Nuov. Giorn. Bot. Ital. n. ser. XV. 439 (1908). - Patschke in Bot. Jahrb. XLVIII. 675 , t. 8. fig. 6 (1913).

Cupressus pendula Abel in Staunton, Embassy to China, II. 255 (nomen nudum; non Thunberg, nec L'Héritier) (1797). - Lambert, Descr. Pinus, I. 97, t. 43 (1803).

Cupressus funebris gracilis Carrière, Traité Conif. 162 (1867).

Western Hupeh: north and south of Ichang, forming woods, alt. 30-1100 m., abundant, July and November 1907 (No. 798, in 
part; tree 10-30 m. tall, girth 0.5-6 m.); Changyang Hsien, mountain slopes and ravines, alt. 1100 m., November 1907 (No. 798 in part; tree $20 \mathrm{~m}$. tall, girth $2.5 \mathrm{~m}$.).

This beautiful Cypress is widely distributed in the Yangtze Valley from the sea coast to the extreme west of the country. It is particularly abundant in steep, limestone districts throughout western Hupeh and Szech'uan up to $1100 \mathrm{~m}$. altitude, but is much less common where red sandstone prevails. Often it is associated with tombs and wayside shrines, and is commonly planted round temples. As usually seen forming pure woods it is a slender tree with short, thin, more or less pendulous branches. Old and isolated specimens develop a loose, wide-spreading head made up of massive branches. The Chinese call it the "Peh-mu shu" (whitewood tree) and esteem it one of the most useful of all their trees. The timber is white, elose-grained, heavy and exceedingly tough. It is largely employed in the hulls and decks of native boats, for pillars in general construction work and for all purposes where toughness and durability are the qualities desired.

Pictures of this tree will be found under Nos. 55, 98, 309, 382, 461, 486, 533, 534, $08,0226,0228$, of the collection of Wilson's photographs and also in his Vegetation of Western China, Nos. 186-191.

\section{JUNIPERUS L.}

\section{Sect. OXYcedrus Spach.}

Juniperus formosana Hayata in Jour. Coll. Sci. Tokyo, XXV. art. XIX. 209, t. 38 (Fl. Mont. Formosae) (1908).

Juniperus taxifolia Parlatore in De Candolle Prodr. XVI. pt. II. 481 (non Hooker \& Arnott) (1868), quoad specimen Fortuneanum, No. 47, Pritzel in Bot. Jahrb. XXIX. 219 (1900). - Beissner in Bull. Soc. Bot. Ital. 1901, 360. - Masters in Jour. Linn. Soc. XXVI. 543 (1902); XXXVII. 413 (1906); in Jour. Bot. XLI. 268 (1903). - Matsumura \& Hayata in Jour. Coll. Sci. Tokyo, XXII. 403 (Enum. Pl. Formos.) (1906). - Patschke in Bot. Jahrb. XLVIII. 678 (pro parte) (1913).

Juniperus rigida Beissner in Nuov. Giorn. Bot. Ital. n. ser. IV. 186 (non Siebold \& Zuccarini) (1897). - Franchet in Jour. de Bot. XIII. 264 (1899). Masters in Jour. Bot. XLI. 268 (1903); in Jour. Linn. Soc. XXXVII. 413 (1906). - Patschke in Bot. Jahrb. XLVIII. 678 (pro parte) (1913).

Juniperus communis Franchet in Jour. de Bot. XIII. 264 (non Linnaeus) (1899),

Western Hupeh: north and south of Ichang woodlands, alt. 600-1300 m., November 1907 (No. 696, in part; a thin tree 8-13 m. tall, fruit orange-red); Changyang, mountain-sides, alt. 600-1600 m., May 1907 (No. 696, in part; tree 6-13 m., branchlets pendulous); without locality, May 1900 (Veitch Exped. No. 370); Patung Hsien, without precise locality, $A$. Henry (No. 2876); without locality, $A$. Henry (No. 5). Eastern Szech'uan: Wushan Hsien, thickets on 
mountain side, May 1900 (Veitch Exped. No. 428); same locality, A. Henry (No. 5653). Western Szech'uan: west and near Wênch'uan Hsien, alt. 1300-2300 m., May and July 1908 (No. 696 ${ }^{\mathrm{a}}$; thin tree 6-10 m. tall); Tachien-lu, J. A. Soulié (No. 564). Shensi: Tai-pei-shan, 1910, W. Purdom. Fokien: without locality, Dunn's Exped., April - June 1905 (Herb. Bot. Gard. Hongkong, Nos. 3808, 3809). Formosa: Mt. Morrison, alt. 4300 m., T. Kawa Rami and U. Mori, No. 2262 (fragment seen).

As Hayata points out, the J.taxifolia of Hooker \& Arnott is an insular species so far reported only from the Liu-kiu and Bonin archipelagos, and readily distinguished by its obtuse leaves and longer male flowers. Our specimens agree perfectly with Hayata's description of his $J$. formosana and we, therefore, take up this name for the Juniper so long cultivated in gardens as J. taxifolia.

In western Hupeh and eastern Szech'uan J. formosana is not uncommon in the margins of moist woods and thickets between 500 and $1600 \mathrm{~m}$, altitude. In western Szech'uan it ascends to $2300 \mathrm{~m}$. altitude but is rare. This Juniper forms a slender tree from 8 to $15 \mathrm{~m}$. tall, and the trunk usually divides a few feet above the ground into three or more erect stems. The principal branches are erect and spreading or ascending and spreading and the branchlets are pendulous. The bark is greybrown, fibrous, longitudinally fissured and peels off in thin, narrow strips. The leaves are all very pungent and vary considerably in length, some before us being $3 \mathrm{~cm}$. long. The 3-seeded fruit is sub-globose or broadly ovoid, orange or redbrown and from 6 to $8 \mathrm{~mm}$. long and broad.

Juniperus rigida Siebold \& Zuccarini, which some authors have confused with the species under notice, has blue-black fruit and rather differently shaped, narrower leaves and does not occur in China except in the extreme north-east part, although in Japan, Korea and Manchuria it is eommon.

Kent (Veitch's Man. Conif. 191 [1900]) states that $J$. taxifolia (J. formosana Hayata) is cultivated in many gardens under the name of $J$, oblonga pendula Hort., but the Juniper grown in North America under this name is a variety of $J$. communis Linnaeus with pendulous branches. There is, however, in the Arnold Arboretum a plant received from M. L. de Vilmorin as Juniperus spec. from China, which is doubtless $J$. formosana; it has proved hardy so far and is growing well.

A colloquial name of $J$. formosana in Hupeh is "Tz'u-peh-shu." A picture of this tree will be found under No. 542 of the collection of Wilson's photographs and in his Vegetation of Western China, No. 266.

\section{Sect. SABINA Spach.}

Juniperus squamata Lambert, Descr. Gen. Pinus, II. 17 (1824). D. Don, Prodr. Nepal. 55 (1825). - Spach in Ann. Sci. Nat. sér. 2, XVI. 293 (1841). - Endlicher, Syn. Conif. 18 (1847). - Brandis, For. Fl. Brit. Ind. 537 (1874).

Juniperus religiosa Royle, Ill. I. 351 (nomen nudum) (1839).

Juniperus Lambertiana Wallich mss, ex Endlicher, Syn. Conif. 19 (1847), quasi synon. $J$. squamatae. 
Juniperus rigida Wallich mss. ex Endlicher, Syn. Conif. 19 (1847), quasi synon. J. squamatae.

Sabina squamata Antoine, Cupress. 66, t. 90 (pro parte) (1857).

Juniperus recurva, $\beta$. squamata Parlatore in De Candolle, Prodr. XVI. pt. II. 482 (1869). - Hooker f., Fl. Brit. Ind. V. 647 (1888). - Masters in Jour. Linn. Soc. XXVI. 543 (1902); XXVII. 413 (1906); in Jour. Bot. XLI. 268 (1903). - Patschke in Bot. Jahrb. XLVIII. 678 (1913).

Juniperis recurva Franchet in Nouv. Arch. Mus. Paris, sér. 2, VII. 102 (Pl. David. I. 292) (non Hamilton) (1884); in Jour. de Bot. XIII. 263 (1899). Beissner in Nuov. Giorn. Bot. Ital. n. ser. IV. 186 (1907). - Pritzel in Bot. Jahrb. XXIX. 219 (1900). - Patschke in Bot. Jahrb. XLVIII. 678 (pro parte) (1913).

Juniperus recurva, var. densa Hort. Kew, 1880 (vix Carrière) (in Herb. Árnold Arb.).

Western Hupeh: Fang Hsien; Ta-pa-shan, moorlands and open, rocky country, alt. 3000-3600 m., May 16, 1907 (No. 985, in part; gregarious shrub, 0.3-1.5 m. tall); same locality, alt. $2600 \mathrm{~m} ., A$. Henry (Nos. 6896, 6935). Western Szech'uan: west and near Wên-ch'uan Hsien, moorlands, alt. 3000-4300 m., September 1908 (No. 985; shrub 0.3-2.5 m. tall); neighbourhood of Tachien-lu, alpine regions, alt. 3000-5000 m., July and September 1908 (No. 985, in part; shrub $25 \mathrm{~cm} .-1.5 \mathrm{~m}$. tall, branches spreading, ascending at apices); same locality, J. A. Soulié (No. 293); west of Kuan Hsien, Pan-lan-shan, alpine moorlands, alt. 4000-4600 m., October 1910 (No. 4085; scrub 15 cm. -1.5 m.). Shensi: Tai-pei-shan, 1910, W. Purdom. India: east Himalaya, Griffith (No. 4986); Kishtwar, alt. 4000 m., T. Thomson; Chumbi, 1877, Neempen.

This Juniper is common on the tops of the higher mountains in western Hupeh and eastern Szech'uan and in the alpine regions of the Chino-Thibetan borderland it covers immense areas and ascends to a higher altitude than any other woody plant except Ephedra Gerardiana, var. sikkimensis Stapf. Between 3000 and $4000 \mathrm{~m}$. altitude it grows gregariously in association with a species of prickly shrubby oak but above that altitude, and more especially where boulders of granitic gneiss and sandstone occur, this Juniper forms a dense scrub, from 6 inches to 5 feet high. The stems are gnarled and twisted in all directions and it is almost impossible to get through these thickets. In the more sheltered gullies round Tachien-lu and in the forests to the north-east of that town this Juniper is frequently met with in the form of a small or, much more rarely, a large tree (see variety); In the vernacular of Tachien-lu this tree is spoken of as the "Hsiang-ching" (fragrant green) or "Hsiang-sha" (Fragrant Fir) and the branches are used for incense in the lamaseries and houses of Thibetans and related tribes.

Juniperus squamata elosely resembles some of the dwarf forms of $J$. communis Linnaeus but its one-seeded fruit readily distinguishes it. We cannot agree with Parlatore and others in regarding this Juniper as a variety of $J$. recurva Hamilton and to say the least it would be very anomalous for the alpine form to have larger leaves than the arborescent type. The discovery in western Szech'uan of a tree form of $J$. squamata with larger leaves and longer internodes but other- 
wise identical is fairly good proof that this plant is an alpine form of the Chinese tree. Juniperus recurva Hamilton differs in its subulate, closely appressed leaves, recurved branches which singularly resemble those of Lycopodium, and in its much larger (1 cm. long) fruit. That a dwarf form of Hamilton's plant also occurs is shown by several specimens before us of which we may cite one collected by G. A. Gammie in the Luchung valley, alt. $4000 \mathrm{~m}$. August 1892, and described as a small shrub. This specimen like the others we have seen is typical $J$. recurva Hamilton, except that the branches are shorter, the leaves much reduced in size and the internodes much shorter - differences naturally to be expected in an alpine form. Probably this shrub is common at high altitudes in Sikkim and elsewhere, and may somewhere grow in association with $J$. squamata Lambert. This would account for the confusion which has existed in the identity of the two species. Sikkim marks the western limit of distribution of several Chinese plants, and the neighbourhood of Tachien-lu the eastern limit of certain Himalayan plants.

Juniperus densa Gordon, is usually quoted as a synonym of $J$. squamata Lambert, but Gordon (Pinetum, Suppl. 32, [1862]) describes his plant as having a 3seeded fruit and therefore it must be referred to some other species, probably to $J$ communis Linnaeus. There is however in gardens a Juniper known as $J$. recurva, var. densa, which is the true $J$. squamata Lambert and, further, a specimen before us from Gordon's herbarium and labelled $J$, densa, is unquestionably a form of $J$. recurva Hamilton. Apparently two or three Junipers are in cultivation under Gordon's name $J$. densa.

From the description we strongly suspect that $J$. morrisonicola Hayata (in Gard. Chron. ser. 3, XLIII. 194 [1908]) is really J. squamata Lambert. Specimens from Mt. Omei collected by Faber (Masters in Jour. Linn. Soc. XXVI. 543 note [1902]) in all probability belong here also, as we have seen the plant growing abundantly on the summit of that mountain.

Pietures of this shrub will be found under Nos. 226, 228 of the collection of Wilson's photographs and in his Vegetation of Western China, Nos. 264, 265.

\section{Juniperus squamata, var. Fargesii Rehder \& Wilson, n. var.}

\section{Juniperus Fargesii Komarov in Herb. Paris.}

Arbor 5-25-metralis, plerumque 5-12 m. alta, ramis erecto-patentibus, ramulis pendentibus. Folia plerumque angustiora et longiora, saepe plus minusve patula et minus congesta quam in typo, lanceolata, 4-12 mm., plerumque 7-9 $\mathrm{mm}$. longa, circiter $1 \mathrm{~mm}$. lata, acuminata, spinulosa, pallide v. coeruleo-viridia, supra saepe glauca. Fructus ovoideus, apice obtusus, $5-6 \mathrm{~mm}$. longus, obscure nigro-coeruleus.

Western Szech'uan: west and near Wên-ch'uan Hsien, woodlands, alt. 2000-2500 m., October 1908 (No. I02I); west of Kuan Hsien, woodlands, alt. 2000 m., June 21, 1908 (No. IO2I ${ }^{\mathrm{a}}$ ); Wa-shan, alt. 1600-2500 m., June 1908 (No. 2ror). Eastern Szech'uan: Chengkou Ting, P. Farges (No. 153, type of J. Fargesii Komarov).

This is the arborescent form of the type and is not uncommon in woodlands throughout the Chino-Thibetan borderland. Usually it is a small tree from 5 to $12 \mathrm{~m}$. tall, but occasionally larger trees are met with. We saw and photographed one magnificent specimen $28 \mathrm{~m}$. tall, with a trunk girth of $7 \mathrm{~m}$., but we never met 
with another tree approaching this one in size. The trunk in large trees usually divides at about $3 \mathrm{~m}$. above the ground into several erect stems; the bark is brown or grey-brown, fairly smooth and peels off in thin, longitudinal strips. The lateral branches are ascending and spreading, and the slender branchlets are pendulous. The blue-black fruit is smaller and less lustrous in appearance than that of the type.

A picture of this tree will be found under No. 115 of the collection of Wilson's photographs and also in his Vegetation of Western China, No. 263.

Juniperus chinensis Linnaeus, Mant. 127 (1767), - Roxburgh, $\mathrm{Fl}$. Ind. ed. 2, III. 838 (1832). - Bunge in Mém. Sav. Êtr. Acad. Sci. St. Pétersbourg, II. 137 (Enum. Pl. Chin. Bor. 63) (1833). - Siebold \& Zuccarini in Abh. Akad. Münch. IV. pt. III. 233 (Fl. Jap. Fam. Nat. II. 109) (1846). - Miquel in Ann. Mus. Lugd.-Bat. III. 167 (1867); Prol. Fl. Jap. 331 (1867); in Siebold \& Zuccarini, Fl. Jap. II. 58, t. 126, 127, fig. 1, 2, 4 (1870). - Parlatore in De Candolle, Prodr. XVI. pt. II. 487 (1868), excludendis speciminibus indicis. Franchet \& Savatier, Enum. Pl. Jap. I. 472 (1875). - Masters in Jour. Linn. Soc. XVIII. 497 (1881); XXVI. 541 (1902); XXXVII. 412 (1906); in Jour. Bot. XLI. 268 (1903). - Franchet in Nouv. Arch. Mus. Paris, sér. 2, VII. 101 (Pl. David. I. 291) (1884). - Sargent in Garden \& Forest, VI. 493 (1893); For. Fl. Jap. 78 (1894). Beissner in Nuov. Giorn. Bot. Ital. n. ser. IV. 186 (1897). - Pritzel in Bot. Jahrb. XXIX. 220 (1900). - Shirasawa, Icon. Ess. For. Jap. I. 29, t. 12, fig. 14-27 (1900). - Palibin in Act. Hort. Petrop. XIX. 137 (Consp. Fl. Koreae) (1901). - Matsumura in Bot. Mag. Tokyo, XV. 138 (1901). - Matsumura \& Hayata in Jour. Coll. Sci. Tokyo, XXII. 402 (Enum. Pl. Formos.) (1906). - Pavolini in Nuov. Giorn. Bot. Ital. n. ser. XV. 439 (1908). - Pampanini in Nuov. Giorn. Bot. Ital. n. ser. XVII. 232 (1910); XVIII. 105 (1911). - Patschke in Bot. Jahrb. XLVIII. 678 (1913).

Juniperus barbadensis Thunberg, Fl. Jap. 264 (non Linnaeus) (1784).

Juniperus virginica Thunberg, Fl. Jap. 264 (non Linnaeus) (1784).

Juniperus cernua Roxburgh, Fl. Ind. ed. 2, III. 839 (1832).

Juniperus dimorpha Roxburgh, Fl. Ind. ed. 2, III. 839 (1832).

Juniperus Thunbergii Hooker \& Arnott, Bot. Voy. Beechey, 271 (1838?).

Juniperus foetida, a. sabina Spach, Hist. Vég. XI. 315 (1842) quoad synon. $J$. chinensis Hort.

Juniperus flagelliformis Hort, apud Loudon, Encycl. Trees and Shrubs, 1090 (1842),

Juniperus nepalensis Hort. ex Endlicher, Syn. Conif. 21 (quasi synon.) (1847). Cupressus nepalensis Hort. ex. Endlicher, Syn. Conif. 21 (quasi synon.) (1847). Juniperus Reevesiana Hort. ex Endlicher, Syn. Conif. 31 (quasi synon. J. cernuae) (1847).

Juniperus struthiacea Knight \& Perry, Syn. Conif. 13 (nomen nudum) (1850?). 
Juniperus sphaerica Lindley \& Paxton in Paxton's Fl. Gard. I. 58, fig. 35 (1850-1851). - Pampanini in Nuov. Giorn. Bot. Ital. n. ser. XVII. 214 (1910).

Juniperus Cabiancae Visiani in Mem. Istit. Venet. Sci. VI. 246, t. 1 ** $^{\text {** }}$ (1856). - Gard. Chron. 1857, 548.

Sabina sphaerica Antoine, Cupress. 52, t. 72 (pro parte) (1857).

Sabina chinensis Antoine, Cupress. 54, t. 75, 76, fig. a, t. 78, fig. l, u (1857).

Sabina struthiacea Antoine, Cupress. 69 (1857).

Sabina dimorpha Antoine, Cupress. 70 (1857).

Juniperus Fortunii Van Houtte ex. Gordon, Pinetum, 119 (quasi synon.) (1858). Juniperus chinensis, var. pendula Franchet in Nouv. Arch. Mus. Paris, sér. 2, VII. 101 (Pl. David. I. 291) (1884).

Western Hupeh: Fang Hsien, alt. 1000-1300 m., May 24, 1907 (No. 2104, in part; tree 6-10 m. tall, branches horizontally spreading and ascending, stiff); Changyang Hsien, alt. 600-1500 m., cultivated, April 1907 (No. 2ro4, in part; tree 6-10 m. tall, dense, pyramidal in habit); Hsing-shan Hsien, roadside, alt. 300-1000 m., July and Noember 1907 (No. 2103, in part; tree $10 \mathrm{~m}$. tall, with a trunk $1 \mathrm{~m}$. in girth); without locality, A. Henry (No. 6576). Eastern Szech'uan: Wan Hsien, planted among tombs, alt. 100-300 m., April 1908, January 1909 (No. 2103, in part; tree 5-10 m. tall, densely branched and pyramidal in habit). Shensi: base of the Tai-peishan, 1910, W. Purdom; Tsinling mountains, January 1873, A. David (type of $J$. chinensis, var. pendula Franchet).

This tree is a native of the north-eastern parts of China and is very rare in western Hupeh and in Szech'uan where it is occasionally met with planted round tombs and temples. In both fruit and foliage some of the specimens before us agree exactly with the figure of $J$. sphaerica Lindley \& Paxton and we cannot consider this plant as a distinct species or even as a variety. Its identity with $J$. chinensis Linnaeus was first suggested by Masters (in Jour. Linn. Soc. XXVI. 543 [1902]). A colloquial name in Hupeh for this Juniper is "Ai-peh-shu." Pictures will be found under Nos. 26, 462 of the collection of Wilson's photographs, also in his Vegetation of Western China, Nos. $485,486$.

Here may be added deseriptions of two new Junipers of western China not collected during the Arnold Arboretum expeditions.

Juniperus saltuaria Rehder \& Wilson, n. sp.

Arbor 3-15-metralis, trunco $0.3-1 \mathrm{~m}$, circuitu, habitu pyramidali, ramis strictis erecto-patentibus $\mathrm{v}$, ascendenti-patentibus in arboribus vetustis, cortice levi cinnamomeo v. griseo-brunneo, in lamellas tenues soluto; ramuli tetragoni breves, saepius leviter recurvi. Folia laete viridia, tertio anno marcescentia, diu persistentia, heterotaxica, in ramulis lateralibus quadrifaria, squamiformia, arete adpressa, apice leviter incurva, triangulari-ovata, acuta $\mathrm{v}$. obtusiuscula, dorso rotundata, inconspicue glandulifera, 1-2 mm. longa, ea ramulorum terminalium terna, angustius triangulari-ovata, acuta v. acuminata, $2-4 \mathrm{~mm}$. longa. Flores monoeci; masculi terminales in ramulis lateralibus brevibus, subglobosi, circiter $2 \mathrm{~mm}$. longi, staminibus 8-10 decussatis. Galbulus erectus v. patens, monospermus, ovoideus v. subglobosus, $5-6 \mathrm{~mm}$. longus, apice rotundatus, apicibus squamu- 
larum liberis plerumque rotundis vix prominulis notatus, ater, epruinosus, nitidulus; semen ovoideum, apicem versus compressum, obtusum, 4-5 mm. longum.

Kansu: Peling-shan, alt. 3300-3600 m., 1911, W. Purdom. North-western Szech'uan: mountains to north of Sungpan Ting, alt. 3600-4000 m., September 1904 (Veitch Exped. No. 3013).

This new tree Juniper is very distinct in appearance and is easily recognized by its clear, deep green, scale-like leaves and the very small, erect, shining black oneseeded fruit. It is most closely related to $J$. pseudo-sabina Fischer \& Meyer, which is a shrub and is distinguished by its more pronounced dimorphic leaves, and by its much larger, ovoid to oblong, recurved, smooth fruit. Juniperus Wallichiana Hooker f. \& Thomson apud Brandis, which is usually regarded to be the same as J. pseudo-sabina Fischer \& Meyer, agrees with our new species in habit and in having the fruit erect, but is at once distinguished by the very large size of the fruit which is from 2 to 3 times as large as that of $J$. saltuaria and quite smooth. The leaves also differ, resembling more closely the typical plant of Fischer \& Meyer than the species here described. Possibly these three Junipers represent geographical varieties or forms of one polymorphic species, but until our knowledge concerning them is more complete, it appears to us best to keep them as distinct.

Round Sungpan Ting $J$. saltuaria forms extensive woods and the wood, though of no great size, is highly valued for construction purposes, and most of the houses in the city of Sungpan are built of it. The habit of the tree is very shapely and pyramidal and the branching is very dense, although in very old trees the habit becomes more loose and irregular. There is no information with Purdom's specimens, but from the abundance of material sent it is probably a common tree on the Peling-shan. The Juniper collected on the mountains of the Kukunor region and near the upper sources of the Hoang-Ho, by Przewalski, and referred (Bretschneider, Hist. Europ. Bot. Discoveries in China, 987) to J. pseudo-sabina, very probably belongs to our new species. Our No. 3013 has been referred by Masters (Jour. Linn. Soc. XXXVII. 412 [1906]) to the very different J. chinensis Linnaeus.

Juniperus convallium Rehder \& Wilson, n. sp.

Arbor 5-10-metralis, ramis erecto-patentibus v. patentibus, cortice cinereo levi in lamellas tenues irregulares soluto. Folia pallide viridia v. glaucescentia, tertio anno mareescentia et brunnescentia, diu persistentia, squamiformia, quadrifaria, arcte adpressa et imbricato, ovata, acutiuscula v. obtusa, margine scariosa, circiter $1 \mathrm{~mm}$. longa, dorso rotundata, glandula depressa notata, ea ramulorum terminalium triangulari-ovata, acuta v. subacuminata, circiter $2 \mathrm{~mm}$. longa. Galbulus monospermus, recurvus, subglobosus v. ovoideus, $6-8 \mathrm{~mm}$. longus, apicibus squamularum minutis acutiusculis liberis basalibus plerumque majoribus notatus, fuscus, epruinosus, nitidulus; semen globoso-ovoideum, utrinque apiculatus, 5-7 mm. longum.

Western Szech'uan: without precise locality, arid places, alt. $2500 \mathrm{~m}$., August 1904 (Veitch Exped. No. 3010).

A well-marked species not closely related to any Asiatic Juniper, and readily distinguished by its shining, chestnut-brown, decurved one-seeded fruit. In habit and appearance it somewhat resembles $J$. excelsa. Bieberstein, but this has much larger, glaucous-black, 2-5-seeded, erect fruit. It may also be compared with $J$. saltuaria Rehder \& Wilson which has more or less 4-sided branchlets, slightly keeled leaves with inconspicuous dorsal gland and small, erect, jet-black fruit. Juniperus convallium is apparently a rare tree and, as far as our knowledge goes, is confined to the warm and more arid parts of the principal river valleys of the Chino-Thibetan borderland. The tree is very Cypress-like in appearance and is frequently very glaucous. Dr. Masters (in Jour. Linn. Soc. XXXVII. 412 [1906]) referred this number to the entirely different $J$. chinensis Linnaeus. 


\title{
GRAMINEAE.
}

\section{Tribus Bambuseae.}

\author{
Determined by A. B. Rendue.
}

\section{ARUNDINARIA Michx.}

\section{Arundinaria dumetosa Rendle, n. sp.}

Frutex 0.6-2 m. altus; culmi valderamosi, teretes, glabri, in specimine ad $4 \mathrm{~mm}$. crassi; ramuli juveniles fasciculati; vaginae culmi internodia subaequantes, chartaceae, glabrae, ramis floriferis arcte circumvolutae; ligula brevis truncata. Foliorum vaginae arcte convolutae, glabrae; ligula brevis truncata, glabra, ad $1.5 \mathrm{~mm}$. longa; lamina in foliis juvenilibus lineari-oblonga, superne angustata, acuminata, 10-13 cm. longa, $1.5-2 \mathrm{~cm}$. lata, basi subito in petiolum ad $5 \mathrm{~mm}$. longum angustata, in foliis adultis oblonga, interdum deorsum angustata, apice late acuminata, ad $22 \mathrm{~cm}$. longa, $6.5 \mathrm{~cm}$. lata, in petiolum circiter $1 \mathrm{~cm}$. longum subito angustata, glabra, margine scabridula; venae secundariae utrinque 10-11, interspatiis minute tesselatis. Inflorescentia paniculata; paniculae in ramis floriferis terminales et axillares, erectae, ad $14 \mathrm{~cm}$. longae et $10 \mathrm{~cm}$. latae; rami ramulique rigidule patentes v. ascendenti-patentes; pedicelli et rhachis dense cinereo-pubescentes; spiculae sex-florae, $2.2 \mathrm{~cm}$. longae; glumae steriles $2-3$, inaequales, breviter aristatae, margine ciliolatae, dorso puberulae; inferior ovata, 3-4 mm. longa, 3-nervis, nervo mediano superne in aristam brevem producto; superior ovato-oblonga, 4.5-5 $\mathrm{mm}$. longa, apice acuminata in aristam 2-2.5 $\mathrm{mm}$. longam producta, dorso carinata, 5-7-nervis; interdum tertia huic similis sed major, 7-8 $\mathrm{mm}$. longa; glumae florentes membranaceae, approximatae (rhachillae articuli pilosuli), ovatooblongae, apice acuminata breviter aristatae, basi rhachillam amplectantes et pilis brevibus e nodo ortis cinctae, super basin leviter carinatae, 7-nerves, sub apice et arista pilosulae, infima $8 \mathrm{~mm}$. longa; palea gluma brevior, $6 \mathrm{~mm}$. longa, bicarinata, obtusa, 4-nervis, sub apice sparse pilosulae; lodiculae 3 , spathulatae, ciliolatae; stamina non visa. Caryopsis oblonga, brunnea, glabra, 6-7 mm. longa.

Western Hupeh: Wên-tsao-shan, Hsing-shan-Hsien, forming impenetrable thickets, alt. 1600-2500 m., June 1907 (No. 3o).

A very distinet species perhaps nearest A. Fargesii Camus, but distinguished by the differently branched inflorescence, the fewer-flowered spikelets, etc. 


\section{Arundinaria szechuanensis Rendle, n. sp.}

Frutex $2.5-3 \mathrm{~m}$. altus; culmi teretes, glabri, in specimine florente $0.5 \mathrm{~cm}$. crassi; ramuli florentes nodis nudis unilateraliter dense fasciculati, saepe iterum similiter ramulosi; ramuli ultimi breves, basi vaginis glumaceis circumdati; ramuli quidam superne bifoliati, folia linearioblonga, apice graciliter acuminata, $8-11.5 \mathrm{~cm}$. longa, 1-1.5 cm. lata, basi in petiolum perbrevem $(2-3 \mathrm{~mm}$.) angustata, sicut vagina arete convoluta internodium celans, glabra, margine scabridula, in facie inferiore minute tesselata. Spiculae e nodis ramulorum florentium orientes, $2 \mathrm{~cm}$. longae, 4-florae, floribus 2 superioribus imperfectis, glabrae, basi bracteis 4-6 quam glumae steriles minoribus vaginatae; glumae steriles 2 , inaequales, rhachi convolutae, glabrae, ovatae, inferior 5-6 mm. longa, apice obsolete mucronata, inconspicue 7-nervis, superior internodio brevi (circiter $1 \mathrm{~mm}$.) ab inferiore sejuncta, circiter $8 \mathrm{~mm}$. longa, acuta, 7-nervis; glumae florentes membranaceae, articulis 3.5-2 mm. longis; rhachillae glabrae, sejunctae, ovatae, acutae, 7-nerves, gluma infima $9 \mathrm{~mm}$. longa, palea paullo brevior, bicarinata; lodiculae 3 , lanceolatae, superne ciliolatae, $3 \mathrm{~mm}$. longae; stamina 3 , antherae $7 \mathrm{~mm}$. longae, stylus paene ad basin bifidus. Caryopsis ellipsoidea, brunnea, glabra, 8-9 $\mathrm{mm}$. longa, pericarpio $1 \mathrm{~mm}$. crasso, stigmatibus geminis marcidis coronata.

Western Szech'uan: Wa-shan, forming thickets, alt. 17003000 m., June 1908 (No. 3408).

A very distinct species characterized by the densely clustered short flowerbranchlets springing laterally from the nodes from which the leaves have already fallen.

The general appearance of the inflorescence suggests Phyllostachys rather than Arundinaria but the culm is terete not with the one flattened side characteristic of Phyllostachys. A remarkable character is the thick pericarp which, as Mr. J. S. Gamble, who kindly confirms my determination, suggests, recalls the fruit of Dendrocalameae rather than of Arundinarieae.

\section{Arundinaria sp.}

Western Hupeh: Fang Hsien, uplands, alt. 2000-3000 m., April 17, 1907 (No. $1462 ; 2-4 \mathrm{~m}$. tall, stems golden).

Without flowers.

This plant is in cultivation. It forms on the mountains of north-western Hupeh dense thickets and with its clear golden slender stems is one of the most beautiful of Chinese Bamboos. A picture will be found under No. 0111 of the collection of my photographs. 


\section{PHYLLOSTACHYS Sieb. \& Zucc.}

Phyllostachys puberula Munro in Gard. Chron. n. ser. VI. 774 (1876). - Houzeau de Lehaie in Act. Congr. Intern. Bot. Bruxelles, II. 220, t. 52-54 (1910). - Camus, Bambusées, 57.

Phyllostachys Henonis Mitford, Bamboo Gard. 149 (1896). - Stapf in Hooker's Icon. XXVII. t. 2614 (1899).

Bambusa puberula Miquel in Ann. Mus. Lugd.-Bat. II. 285 (1866).

Phyllostachys nigra, var. Henonis Rendle in Jour. Linn. Soc. XXXVI. 443 (1904).

Western Hupeh: Chang-yang Hsien, alt. 900 m., June 1907 (No. 3409; 3-5 m. tall, culms black).

Phyllostachys nidularia Munro in Gard. Chron. n. ser. VI. 773, 774 (1876). - Rendle in Jour. Linn. Soc. XXXVI. 442 (1904).

Phyllostachys nigra Pilger in Bot. Jahrb. XXIX. 227 (non Monro) (1900).

Western Hupeh: Hsing-shan Hsien, ravines, alt. 1-900 m., May 9, 1907 (No. 3406); Chang-yang Hsien, alt. 1-900 m., April 19, 1907 (No. $3407 ; 3-10 \mathrm{~m}$. tall, culms thin, used for paper-making; native name "Twei-chu").

Abundant by the sides of streams up to $1000 \mathrm{~m}$. altitude in western Hupeh. A picture will be found under No. 490 of the collection of my photographs and in my Vegetation of Western China, No. 337.

E. H. W.

\section{BAMBUSA Schreb.}

Bambusa Beecheyana Munro in Trans. Linn. Soc. XXVI. 108 (1868). - Rendle in Jour. Linn. Soc. XXXVI. 445 (1904).

Bambusa verticillata Hooker \& Arnott, Bot. Voy. Beechey, 254 (non Willdenow) (1836-1840).

Western Szech'uan: Kiating Fu, alt. 450 m., April 11, 1908 (No. 3410).

Common bamboo 5-8 m. tall at low altitude in western Szech'uan. Pietures of this Bamboo will be found under Nos. 52,447 of the collection of my photographs and also in my Vegetation of Western China, Nos. 128, 336.

E. H. W.

\section{Bambusa sp.}

Western Hupeh: Patung Hsien, roadsides, alt. 450-1050 m., April 1907 (No. 3405; 1-2 m. tall).

Represented only by a few leaves. 


\section{LAURACEAE.}

\section{Determined by J. S. Gamble. 1}

From river-level up to an altitude of 1000 metres plants of this family are among the most important constituents of the arborescent flora of western China, and the evergreen species are a dominant feature. Especially is this true of the vegetation of the western limits of the Red Basin of Szech'uan, of the Chengtu Plain and of the regions round the base of Wa-shan and Omei-shan. In these regions, up to an altitude of 1000 metres, fully fifty per cent of the broad-leaved trees belong to the Lauraceae. In the glens and gorges of western Hupeh and eastern Szech'uan shrubby members of this family abound. Above an altitude of 1000 metres plants of this family quickly become a relatively unimportant part of the forests, although, in western Hupeh, the Chinese Sassafras is a very common tree between altitudes of 1200 and 2000 metres.

E. H. W.

\section{CINNAMOMUM Blume.}

\section{Cinnamomum Wilsonii Gamble, n. sp.}

Arbor 6-16 m. alta, 0.3-1 m. diam. trunci; ramuli teretes, siccitate purpureo-fusci. Folia coriacea, alterna $v$. subopposita; ovata v. ovato-oblonga, apice acuminata acumine obtuso, basi attenuata in petiolum decurrentia, aliquando subrotunda; supra nitida, laevia, glabra, subtus glauca, juventute conspicue albo-sericea, tandem glabra, margine cartilagineo reflexo, 8-18 cm. longa, 3-5 cm. lata; costae prominentes, 3 ex ima basi ortae, ad 5-20 mm. conjunctae et ibi non semper eodem loco divergentes, additis aliquando 2 gracilibus juxta margines, media in acumen ipsum extensa, 2 laterales curvatae etiam in acumen extensae sed infra acumen plus minus arcuatae et cum paucis (2-3) costae mediae nervis junctae; nervi costarum lateralium extrorsum aliquando nulli, aliquando 3-10 curvati et cum costulis marginalibus juncti; nervuli transversi multi, arcuati, tenues, infra plus minus conspicui; petiolus $10-15 \mathrm{~mm}$. longus, supra canaliculatus. Flores albi, in umbellis 2-5-floris $\mathrm{v}$. in racemis paucifloris longe pedunculatis solis v. interdum fasciculatis in axillis foliorum seu ex internodiis foliorum; pedunculus gracilis, subfiliformis, 1-6 $\mathrm{cm}$. longus, glaber v. parce puberulus; pedicelli filiformes clavati, $6-20 \mathrm{~mm}$. longi, minutissime puberuli; alabastra globosa; perianthii tubus brevis; lobi 
6 , ovati, 4-5 mm. longi, extus et intus parce sericeo-puberuli; stamina filamentis sericeis, ordinis I. et II. 2-3 mm. longa antheris obtusis, ordinis III. $3 \mathrm{~mm}$. longa, glandulis binis reniformibus prope medium filamentorum munita, staminodia ordinis IV. cordata, acuta; ovarium ovoideum, stylo incrassato, stigmate capitato. Drupa non visa; cupula truncata, margine brevissime lobata.

Western Hupeh: without locality, June 1901 (Veitch Exped. Nos. 2003, 2098); Hsing-shan Hsien, open country, alt. 300-1000 m., May 30, 1907 (No. 2227). Western Szech'uan: Mt. Omei, May 1904 (Veitch Exped. No. 5183).

I consider that Ford's Nos. 153, 154 from Kwangtung Province identified by Hemsley as Cinnamomum pedunculatum C. G. Nees and A. Henry's No. 5497 from Wushan Hsien, eastern Szech'uan, identified as Cinnamomum tamala Fr. Nees by that same author belong to this species.

This new species is fairly common in open country up to an altitude of 1000 metres in western Hupeh and Szech'uan. It is a tree of medium size with a rounded, dense, much branched head. Colloquially it is known as the "Kuei-p'i shu" and is considered of much economic value. The twigs and bark are very fragrant and pungent and are used medicinally as a condiment, tonic and stimulant, and as a substitute for and adulterant of the true "Cassia-lignea" (C. Cassia Blume).

E. H. W.

\section{Cinnamomum Wilsonii, var. multiflorum Gamble, n. var.}

Arbuscula 2-3 m. alta. Folia magis coriacea; costae e basi laminae circa $5 \mathrm{~mm}$. divergentes; costulae marginales magis evolutae e margine forsan $4 \mathrm{~mm}$. distantes. Flores flavescentes, in umbellis, racemis v. paniculis paucifloris dense confertis ex axillis foliorum ultimorum et perulis conspicuis ovatis suffultis; filamenta subglabra.

Western Hupeh: neighborhood of Ichang, glens and rocky places generally, alt. 30-300 m., abundant, April 1907 (No. 3712).

The twigs and bark of this common shrub are used in the same manner as those of the typical form.

E. H. W.

\section{Cinnamomum argenteum Gamble, n. sp.}

Arbor 6-16 m. alta, 0.3-0.8 m. diam. trunci; ramuli teretes, siccitate purpureo-fusci, ultimi plus minus angulati; gemmae ovatae, albosericeae. Folia coriacea, alterna v. subopposita, lanceolata, apice acuminata acumine obtuso, basi attenuata; supra nitida, glabra, subtus adpresse sericeo-velutina, juniora argenteo-sericea, 7-11 $\mathrm{cm}$. longa, 3-4 cm. lata; costae 3 supra vix prominentes, ex ima basi ortae ad circa $5 \mathrm{~mm}$. conjunctae et ibi non semper eodem loco divergentes, additis aliquando costulis 2 e basi gracilibus juxta margines, media 
in acumen ipsum porrecta, laterales 2 curvatae et sub acuminis basi evanescentes; nervi e costa media vix 1-2 in acumen curvati, e costis lateralibus extrorsum pauci perobscuri, ad costulas curvati; nervuli transversi multi, areuati, obscuri; petiolus 10-12 $\mathrm{mm}$. longus, supra canaliculatus. Flores in paniculis paucifloris (circa 8-12) ex internodiis foliorum juniorum, 6-9 cm. longis; pedunculus gracilis, subfiliformis, minute puberulus, 2-4 cm. longus; pedicelli filiformes perianthium aequantes vix clavati puberuli; perianthii tubus brevis; lobi 6 obovati, 4-5 mm. longi, intus praecipue albo-sericei; stamina filamentis subglabris, ordinis I. et II. $2 \mathrm{~mm}$. longa antheris obtusis, ordinis III. $2.5 \mathrm{~mm}$. longa, glandulis 2 reniformibus filamenti apicem versus; staminodia ordinis IV. $1.5 \mathrm{~mm}$. longa, cordata; ovarium ovoideum, stylo incrassato, stigmate magno eapitato. Drupa ellipsoidea, $13 \mathrm{~mm}$. longa, 7-8 mm. diam., glabra, pedicello vix incrassato gracili et perianthii tubo hemispherico $4-5 \mathrm{~mm}$. lato insidens.

Western Szech'uan: near Wa-shan, woodlands, alt. $1300 \mathrm{~m}$., June and October 1908 (No. 3708).

This is a handsome tree with a relatively slender trunk, and is abundant in the woods round the base of Mount Wa. From the twigs and bark an inferior form of "Cassia-lignea," is obtained. The tree is colloquially known as the "Kuei-p'i shu."

E. H. W.

Cinnamomum Camphora Fr. Nees von Esenbeck \& Ebermaier, Handb. Med. Pharm. Bot. II. 430 (1831). - Bentley \& Trimen, Med. Pl. III. t. 222 (1888). - Hemsley in Jour. Linn. Soc. XXVI. 371 (1891).

Laurus Camphora, Linnaeus, Spec. 369 (1753).

Persea Camfora Sprengel, Syst. Veg. II. 268 (1825).

Camphora officinarum C. G. Nees von Esenbeck in Wallich, Pl. As. Rar. II. 72 (1831); Syst. Laur. 88 (1836).

Camphora officinalis Steudel, Nomencl. Bot. ed. 2, I. 271 (1840).

Kiangsi: Kiukiang, on plain, alt. 90 m., July 1907 (No. I540). Eastern Szech'uan: banks of the Yangtsze River, alt. $300 \mathrm{~m}$., April 1908 (No. 37II ; tree $20 \mathrm{~m}$. tall, girth $2.5 \mathrm{~m}$., flowers yellowish).

This is the true "Chang shu" (Camphor tree) of Chinese books and is a very rare tree in western Hupeh and Szech'uan where no camphor is prepared. In eastern Hupeh, I have been credibly informed, a small amount of camphor is obtained but whether from this species or from C. hupehanum Gamble, I am unable to say.

E. H. W.

Cinnamomum inunctum Meissner in De Candolle, Prodr. XV. pt. I. 25 (1864). 
Camphora inuncta C. G. Nees von Esenbeck in Wallich, Pl. As. Rar. III. 32 (1832); Syst. Laur. 89 (1836).

Western Szech'uan: Mt. Omei, June 1904 (Veitch Exped. No. 5178).

Cinnamomum inunctum, var. longepaniculatum Gamble, n. var.

Arbor 6-20 m. alta, 0.3-1 m. trunci diam. Folia lanceolata, apice longe acuminata, basi cuneata saepe inaequaliter, glabra; nervorum par infimum oppositum v. suboppositum; glandulae conspicuae; petiolus ad $3 \mathrm{~cm}$. longus. Paniculae $10-20 \mathrm{~cm}$. longae, ramosae; pedunculus $10 \mathrm{~cm}$. longus, ut rami et pedicelli capillaris; rami ultimi triflori, glabri.

Western Szech'uan: Yachou Fu, 600-1000 m. alt., June 1908 (No. 3710).

This is a common tree throughout the Red Basin of Szech'uan up to $1000 \mathrm{~m}$. altitude. A picture of it will be found under No. 451 of the collection of my photographs and also in my Vegetation of Western China, No. 164 . E. H. W.

Cinnamomum inunctum var. albosericeum Gamble, n. var.

Arbor 16-25 m. alta, 0.6-1.5 m. trunci diam.; ramuli subcrassi, angulati, ut gemmae albo-sericei. Folia subcoriacea, elliptica v. elliptico-oblanceolata, apice breve-acuminata, basi cuneata; supra parce puberula, infra praecipue ad nervos conspicue albo-sericea, tandem glabrescentia, $10-15 \mathrm{~cm}$. longa, 5-7 cm. lata; glandulae inconspicuae; petioli $2-3 \mathrm{~cm}$. longi. Panicula sericea, axillaris, ad $15 \mathrm{~cm}$. longa, ramis divaricatis multifloris; pedunculus ad $6 \mathrm{~cm}$. longus; pedicelli vix 1-2 mm. longi; perianthii lobi glandulosi.

Western Szech'uan: near the city of Mien-chu Hsien, $600 \mathrm{~m}$. alt., May 19, 1908 (No. 3713).

Like the preceding variety this is a common tree throughout the Red Basin of "Szech'uan up to an altitude of 1000 metres, where both are colloquially styled "Chang shu" (Camphor tree), and the fragrant wood is made into high class furniture. The thick main roots furnish a beautifully marked wood known as "Ying mu" which is highly valued in eabinet work.

This variety grows to a larger size than the variety longepaniculatum, or any other Camphor tree known in western China. It is a strikingly handsome evergreen tree with a thick trunk, smooth gray bark, and a more or less oval head composed of massive wide-spreading branches. A pieture of this tree will be found in the collection of my photographs under No. 0229.

E. H. W.

\section{Cinnamomum hupehanum Gamble, n. sp.}

Arbor 15-16 m. alta, 2-2.5 m. trunci diam.; ramuli teretes purpureo-fusci, glabri, ultimi angulati; gemmae ovatae, perulis sparse albo-sericeis. Folia alterna, chartacea, ovata v. elliptico-ovata, apice breviter acuminata, basi rotundata, juniora acuta, supra juventute 
minute puberula, tandem glabra lucida, subtus glauca puberula, juniora appresse caesio-sericea, $8-17 \mathrm{~cm}$. longa, $3-10 \mathrm{~cm}$. lata; nervi utrinque 4-6, alterni v. paribus 1-2 infimis suboppositis, irregulariter ascendentes, supra vix prominentes; nervuli transversi obscuri sicut reticulatio; glandulae in axillis nervorum parvae supra haud bulbosae; petiolus $2-3 \mathrm{~cm}$. longus. Paniculae axillares v. laterales e ramulis junioribus, inflorescentiam conspicuam terminalem saepe simulantes, foliis parvis admixtis, $10-15 \mathrm{~cm}$. longae, ramosae, ramis di-trichotomis; pedunculus teres, glaber, 4-6 $\mathrm{cm}$. longus; rami angulati; pedicelli breves, filiformes, $2-4 \mathrm{~mm}$. longi; perianthii tubus infundibularis, glaber; lobi ovati, 1-2 mm. longi, intus albo-sericei, reflexi et cito decidui; stamina minuta, ordinis I. et II. circa $1 \mathrm{~mm}$. longa, antheris subrotundis et filamentis subglabris, ordinis III. paullo longiora, magis puberula, glandulis 2 magnis reniformibus prope basim filamentorum, ordinis IV. staminodia cordata, subsessilia, circa $0.5 \mathrm{~mm}$. longa, sericea; ovarium subglobosum, stylo erecto, stigmate capitato. Drupa globosa, 7-8 mm. diam., glabra, pedicello incrassato et perianthii tubo reflexo insidens.

Western Hupeh: north and south of Ichang, woods and open country, alt. 300-1000 m., common, June and August 1907 (No. 2226); Patung Hsien, woodlands, alt. 300-1000 m., August 1907 (No. 3709); without locality (Veitch Exped. Nos. 464, 836, 1944).

I also place with this $A$. Henry's No. 3936 collected at Nanto and on mountains to northward, identified by Hemsley as C. parthenoxylon Meissner.

This is the common Camphor tree of western Hupeh where it is always spoken of as the "Chang shu," though I never heard of any camphor being prepared from its wood. It grows to a medium height and has a thick trunk elothed with smooth grey bark, and an oval or flattened wide head. The wood is very fragrant, greenishwhite and brown and is largely used in making furniture. A picture of this tree will be found under No. 494 of the collection of my photographs and also in my Vegetation of Western China, No. 165.

E. H. W.

Here may be added a note on a Cinnamomum not collected during the Arnold Arboretum Expeditions.

Cinnamomum pedunculatum C. G. Nees, var. angustifolium Hemsley in Jour. Linn. Soc. XXVI. 373 (1891).

Western Hupeh: without locality, April 1900 (Veitch Exped. No. 85).

\section{ALSEODAPHNE Nees.}

Alseodaphne omeiensis Gamble, n, sp.

Arbor ad $12 \mathrm{~m}$. alta, ramulis teretibus pallidis conspicue lenticellatis. Folia alterna, coriacea, oblanceolata, apice abrupte acuminata, basi longe attenuata; supra opaca, olivacea, subtus glaucescentia, 
marginibus recurvis, $10-18 \mathrm{~cm}$. longa, $3-5 \mathrm{~cm}$. lata; costa conspicua crassa; nervi laterales utrinque 10-12, prominentes, nervulis irregularibus sparsis inter se juncti; petiolus gracilis, 1-2 cm. longus. Flores in paniculis gracilibus paucifloris axillaribus v. lateralibus ad $8 \mathrm{~cm}$. longis; pedunculus fere filiformis; ramuli 2-3-flori, bracteis parvis linearibus; perianthii tubus brevis glaber; lobi ovati, exteriores paullo breviores; stamina 9 minima, $1 \mathrm{~mm}$. longa, ordinis I. et II. antheris orbicularibus obtusis, ordinis III. antheris oblongis, ad basim filamentorum glandulis 2 parvis reniformibus munita, ordinis IV. staminodia cordata, breviter stipitata; ovarium globosum, stylo gracili, stigmate parvo capitato. Bacca globosa, glabra, $1 \mathrm{~cm}$. diam., supra perianthii tubum incrassatum lobis persistentibus insidens; pedicellus fructifer incrassatus, $6 \mathrm{~mm}$. longus.

Western Szech'uan: near Wa-wa-shan, Hung-ya Hsien, alt. 1000-1200 m., September 6, 1908 (No. 3702; bush 2-3 m. high); Mt. Omei, June 1904 (Veitch Exped., No. 5185, type).

I have been much in doubt about the genus of this plant. It has the appearance of a Phoebe near $P$. lanceolata Nees, but with distinctly oblanceolate leaves; the very small flowers and the comparatively large fruit with enlarged pedicel, however, point to Alseodaphne.

\section{PHOEBE Nees.}

\section{Phoebe macrophylla Gamble, n. comb.}

\section{Machilus macrophylla Hemsley in Jour. Linn. Soc. XXVI. 375 (1891).}

Western Szech'uan: Chengtu Plain, round temples and houses, alt. 500-700 m., May 11, 1908 (No. 3705; tree 16 m. tall, girth 2 m.). Western Hupeh: Patung Hsien, April 1900 (Veitch Exped. No. 366); without locality, May 1901 (Veitch Exped. No. 99a).

In western Hupeh and Szech'uan the name "Nanmu shu" is applied to this and the other species of Phoebe and to the genera Machilus and Actinodaphne. These trees are the source of "Nanmu" one of the most valuable of all Chinese timbers. All the species are evergreen and singularly handsome trees. In Szech'uan they are abundant up to an altitude of 1000 metres, often forming extensive woods. They are largely planted round homesteads and temples and are a prominent feature of the scenery of parts of the Chengtu Plain and of the region round the base of Mount Omei. These trees grow to a great size and have clean, straight trunks and wide, umbrageous heads. The wood is close-grained, fragrant, greenish-white and brown in color, easily worked and very durable. It is highly esteemed in furniture-making, and for pillars and beams in the temples and in the houses of the wealthy. In the form of planks it is used for the bottoms of boats, Phoebe macrophylla Gamble, is one of the commonest and most widely spread species of "Nanmu" trees. A picture of it will be found under No. 67 of the collection of my photographs and in my Vegetation of Western China, No. 301. 
Phoebe neurantha Gamble, n. comb.

Machilus neurantha Hemsley in Jour. Linn. Soc. XXVI. 376 (1891).

Kiangsi : Kuling, thickets, alt. 1000 m., August 1907 (No. 16r8; bush 1.2-1.8 m. high). Western Hupeh: Patung Hsien, thickets, alt. 600-1000 m., October 1907 (No. 462; tree 10-13 m. tall, girth 1-2 m., fruit black); without locality, June 1901 (Veitch Exped. Nos. 2006, 2121). Western Szech'uan: Hungyah Hsien, around base of Wa-wu-shan, alt. $1200 \mathrm{~m}$., abundant, September 13, 1908 (No. 3703 ; tree $10 \mathrm{~m}$. tall, fruit globose, black).

This very common and widely distributed species of Nanmu is usually a relatively small and slender tree but occasionally very tall specimens are met with. A picture of an unusually fine tree of this species will be found under No. 320 of the collection of my photographs and also in my Vegetation of Western China, No. 304.

E. H. W.

\section{Phoebe nanmu Gamble, n. comb.}

Persea Nanmu Oliver in Hooker's Icon. XIV. 10, t. 1316 (1880).

Machilus Nanmu Hemsley in Jour. Linn. Soc. XXVI. 376 (1891).

Western Szech'uan: Yachou Fu, woodlands, alt. 600-1000 m., October 1910 (No. 459I; tree 20-26 m. tall, girth 1.60-3 m.); Kuan Hsien, open country, alt. 800-1000 m., October 1910 (No. 459o; tree $26 \mathrm{~m}$. tall, girth $3 \mathrm{~m}$.).

This is a common tree in western Szech'uan where specimens of large size are often met with. A picture of a magnificent example of this species of "Nanmu" will be found under No. 281 of the collection of my photographs and also in my Vegetation of Western China, No. 302.

E. H. W.

Phoebe Sheareri Gamble, n. comb.

Machilus Sheareri Hemsley in Jour. Linn. Soc. XXVI. 377 (1891).

Western Hupeh: Changlo Hsien, thickets and woodlands, alt. 600-1200 m., common, May 1907 (No. 3696; tree 6-15 m. tall, girth 0.6-1.3 m., flowers white); Hsing-shan Hsien, woodlands, alt. 3001000 m., abundant, June 1907 (No. 3697; tree 6-15 m. tall, girth 12 m., flowers white); Kui Chou, June 1901 (Veitch Exped. No. 2007); without locality, June 1901 (Veitch Exped. No. 1163).

To this species I am also inclined to refer the following specimens which have much less pubescence and narrower leaves more acuminate both at apex and base, but which seem to differ little otherwise: Western Hupeh: Patung Hsien, side of streams, alt. 300-1000 m., abundant, June and September 1907 (No. 3698, tree 6-15 m. tall, 
girth 1-2 m., wood rather soft, yellowish); Chienshi Hsien, July 1900 (Veitch Exped. No. 1329). Western Szech'uan: Mt. Omei, June 1904 (Veitch Exped. No. 5184a).

\section{MACHILUS Nees.}

Machilus Bournei Hemsley in Jour. Linn. Soc. XXVI. 373 (1891).

Western Hupeh: Patung Hsien, thickets in rocky places, alt. 300-1000 m., July 1907 (Nos. 3699, 3704; tree 6-15 m. tall, girth 1$1.5 \mathrm{~m}$., flowers white); without locality, June 1901 (Veitch Exped. No. 2006). Western Szech'uan: Chengtu Plain, round houses and temples, alt. 300-600 m., abundant, May 11, 1908 (No. 370r; tree 12-33 m. tall, girth 2-4 m., flowers yellowish); Kiating Fu, alt. 3001300 m., May 1904 (Veitch Exped. No. 4426); Mt. Omei, 1904 (Veitch Exped. No. 5184).

This is the most common species of "Nanmu" in western Szech'uan and is particularly abundant on the Chengtu Plain. It is a tall, stately, densely leafy tree with ascending main branches and relatively short and thin, spreading secondary and tertiary branches. The leaves are comparatively small and narrow and bright shining green on the upper surface. It is a tree of slow growth, but on account of its beauty and its valuable timber it has been largely planted in the temple grounds everywhere in western Szech'uan up to an altitude of 1000 metres. Pietures of this tree will be found under Nos. 101, 290,300, 0238, of the collection of my photographs and also in my Vegetation of Western China, Nos. 36, 303. E. H. W.

Machilus Thunbergii Siebold \& Zuccarini in Abh. Akad. Münch. IV. pt. III. 202 (Fl. Jap. Fam. Nat. II. 78) (1846).

Laurus indica Thunberg, Fl. Jap. 173 (non Linnaeus) (1784).

Machilus japonica Siebold \& Zucearini in Abh. Akad. Münch. IV. pt. III. 202 (Fl. Jap. Fam. Nat. II. 78) (1846).

Western Hupeh: Changyang Hsien, thickets and woodlands, alt. 300-1000 m., common, May 1907 (Nos. 3695, 3700; tree 6-15 m. tall, girth 1-1.5 m., flowers whitish); Nanto, April 1900 (Veitch Exped. No. 99); without locality, April and June 1901 (Veitch Exped. Nos. 119, 366). Western Szech'uan: Mt. Omei, June 1904 (Veitch Exped. No. 5184 ${ }^{\text {a). }}$

This is a tree of medium size very common in western Hupeh where it is colloquially known as the "Hsao Nanmu" (Little Nanmu).

E. H. W.

To this species also belongs, in my opinion, the following specimen from western Hupeh, although the leaves are longer and more narrowly oblanceolate: Patung Hsien, May 1901 (Veitch Exped, No. 1933).

Here may be added a note on another Chinese species not eollected during the Arnold Arboretum Expedition. 
Machilus microcarpa Hemsley in Jour. Linn. Soc. XXVI. 376 (1891).

Western Hupeh: without locality, July and October 1901 (Veitch Exped. Nos. 1826, 2783).

\section{SASSAFRAS L.}

Sassafras tzumu Hemsley in Kew Bull. Misc. Inform. 1907, 55; in Hooker's Icon. XXIX. t. 2833 (1907).

Lindera Tzumu Hemsley in Jour. Linn. Soc. XXVI. 392 (1891).

Litsea laxiflora Hemsley, 1. c. 383, t. 8 (1891).

Kiangsi: Kuling, thickets, alt. 1300 m., not common, July 30, 1907 (No. I7I4; small tree 5-8 m. tall). Western Hupeh: north and south of Ichang, woods, alt. 1000-1850 m., abundant, May, June 1907 (No. 7ro, in part; tree 6-26 m. tall, girth 0.3-3 m.); Changyang Hsien, woods, alt. 1000-1800 m., common, April, May, September 1907 (No. 710, in part; tree 15-25 m. tall, girth 1-3 m., flowers yellow, fruit blue-black, cupule orange-red); Hsing-shan Hsien, woods, alt. 1000-1600 m., common, September 1907 (No. 710, in part; tree 1530 m. tall, girth 1-4 m.); Kui Chou, July 1901 (Veitch Exped. No. 64, in part); without locality, April 1901 (Veitch Exped. No. 64, in part). Chekiang: vicinity of Ningpo, 1908, D. Macgregor.

The Chinese Sassafras is abundant in moist, rich woods on the mountains of western Hupeh, but it has not yet been reported from western Szech'uan. It is a handsome tree occasionally 35 metres tall, with a straight trunk 5 metres or more in girth near the base; the branches are horizontally spreading and give a characteristic appearance to the tree. On young trees the bark is smooth and yellowgreen; on old trees it is dark gray, longitudinally fissured and rugged. The yellow flowers are produced in great quantity in early April before the leaves unfold and when in flower the trees are very conspicuous. The flowers though apparently hermaphrodite are functionally unisexual and my observations lead me to believe that they are polygamo-dioecious. The fruit is black with a glaucous bloom and the cupule is orange-red. In the late autumn the leaves assume beautiful tints of orange and red. The wood is not valued, and its chief use is for fuel though it is also employed for making packing cases. Pictures of this tree will be found under Nos. 559, 681, 706, 066 of the collection of my photographs and also in my Vegetation of Western China, Nos. 470, 471, 472. In Hupeh this tree is colloquially known as the "Tzumu shu."

E. H. W.

\section{ACTINODAPHNE Nees.}

Actinodaphne confertifolia Gamble, n. comb.

Litsea confertifolia Hemsley in Jour. Linn. Soc. XXVI. 379, t. 7 (1891).

Western Hupeh: Hsing-shan Hsien, thickets, alt. $1000 \mathrm{~m}$., September 1907 (No. 358, bush 2 m., fruit black); without locality, 
October 1901 (Veitch Exped. No. 421ª). Western Szech'uan: Mt. Omei, thickets, alt. $1100 \mathrm{~m}$., October 1908 (No. III7; tree $6 \mathrm{~m}$. tall, fruit black); same locality, November 1904 (Veitch Exped. No. 4425).

This is a tree of medium size common in western Hupeh and Szech'uan. With other species of the genus it is colloquially known as "Nanmu shu." E. H. W.

Here may be added notes on two other Chinese species not collected during the Arnold Arboretum Expeditions.

Actinodaphne cupularis Gamble, n. comb.

Litsea cupularis Hemsley in Jour. Linn. Soc. XXVI. 380 (1891).

Western Hupeh: without locality, September and November 1901 (Veitch Exped. Nos. 2637, 421 ). Western Szech'uan: Mt. Omei, September 1904 (Veitch Exped. No. 5179); without locality, A. E. Pratt (No. 799).

Actinodaphne reticulata Meissner in De Candolle, Prodr. XV. pt. I. 212 (1864).

Western Szech'uan: Mt. Omei, October 1903, 1904 (Veitch Exped. Nos. $4424,5177)$.

\section{LITSEA Lam.}

\section{Litsea citrata Blume, Bijdr. 565 (1825).}

Tetranthera citrata C. G. Nees von Esenbeck, Syst. Laur. 560 (1836).

Tetranthera polyantha Wallich, Cat. No. 2538 (nomen nudum) (1829).-C. G.

Nees von Esenbeck in Wallich, Pl. As. Rar. II. 67 (1831).

Kiangsi: Kuling, thickets, alt. 1300 m., abundant, July 1907 (No. r625; bush 2-3 m.). Western Hupeh: neighborhood of Ichang, ravines, alt. 300-600 m., March 20, July 1907 (No. 3689; bush 2-5 m., flowers yellow, fruit black); same locality, April and September 1901 (Veitch Exped. Nos. 1795, 2637). Western Szech'uan: west and near Wên-ch'uan Hsien, thickets, alt. 1300 m., September 1908 (No. $82 \mathrm{I}$; bush $2.5 \mathrm{~m}$., fruit black).

\section{Litsea sericea Hooker f., Fl. Brit. Ind. V. 156 (1886).}

Tetranthera sericea Wallich apud C. G. Nees von Esenbeck in Wallich, Pl. As. Rar. II. 67 (1831). - C. G. Nees von Esenbeck, Syst. Laur. 565 (1836).

Western Hupeh: Changyang Hsien, ravines and woodlands, alt. 300-1000 m., April 1907 (Nos. 3688, 3687, in part; bush or slender tree 2-6 m. tall, flowers yellow); same locality, alt. 1350 m., April 1900 (Veitch Exped. No. 424); near Ichang, thickets, alt. 300-500 m., common, April 1907 (No. 3687, in part; bush 2-3 m., flowers yellow). Eastern Szech'uan: Wushan Hsien, May 1900 (Veitch Exped. No. 623). Western Szech'uan: Tung River valley, near Wa-shan, thickets, alt. 1000-1300 m., June 1908 (No. 3674; bush 4-6 m., flowers yellow); Mt. Omei, June 1904 (Veitch Exped. No. 5176). 
Litsea pungens Hemsley in Jour. Linn. Soc. XXVI. 384 (1891).

Western Hupeh: Hsing-shan Hsien, woodlands, alt. 1000-1300 m., May 10, August 1907 (No. 295; bush 3-6 m., flowers greenishyellow, fruit black); same locality, April 1901 (Veitch Exped. No. 1873); Changyang Hsien, ravines and woods, alt. 1000-1300 m., April, May 23, 1907 (No. 3683; bush 2-4 m., sparingly branched, flowers yellow); near Ichang, ravines, alt. 300-600 m., March 1907 (No. 3682; bush 3 m., flowers yellow); Patung Hsien, April 1901 (Veitch Exped. No. 1770). Western Szech'uan: Malie, near Washan, thickets, alt. 1000-1500 m., September 16, 1908 (No. 867; bush 4-6 m., fruit black); near Monkong Ting, valley of Hsao-chin Ho, alt. 2300-2600 m., June 29, 1908 (No. 3676; bush 2-4 m., fruit blue-black). Eastern Szech'uan: Wushan Hsien, May 1900 (Veitch Exped. No. 594).

It is quite possible that investigation in the field will show that two species are included here, but at present it is not possible to distinguish them.

This common and widely distributed shrub is colloquially known as "Muchiangtzu " or "Shan-hu-chiao." The fruit which is very pungent is used as a condiment.

E. H. W.

\section{Litsea Veitchiana Gamble, n. sp.}

Frutex, circa $3 \mathrm{~m}$. altus; ramuli subcrassi, cortice cinnamomeo rugoso nitido; gemmae lanceolatae, perulis acuminatis parce pilosis. Folia membranacea, obovata, apice acuta, basi attenuata, supra glabra, siccitate olivacea, subtus praecipue in juventute et secus costam pilis longis aureo-sericeis munita; $4-8 \mathrm{~cm}$. longa, $2.5-4 \mathrm{~cm}$. lata; nervi utrinque 7-9, irregulares, arcuati, saepe ramosi; nervuli transversi conspicui, subparalleli; reticulatio conspicue areolata; petiolus circa $1 \mathrm{~cm}$. longus, parce pilosus. Umbellulae $\delta$ ignotae; ? axillares v. solitarii ex internodiis foliorum; pedunculus crassus, 3-4 $\mathrm{mm}$. longus, fructifer ad $1 \mathrm{~cm}$. longus, lignosus; involucri bracteae ovatae, acutae, ciliatae; flores in umbellulis ad 10; perianthii $\$$ tubus brevis, villosus; lobi ovati v. suborbiculares, glandulosi, trinervii, glabri, $1.5 \mathrm{~mm}$. longi; staminodia 9 v. 12 , aliquando $2-3$ exteriora petaloidea, ordinum I. et II. clavata obtusa, ordinis III. subulata glandulis 2 magnis obtusis ad basim munita; ovarium ovoideum, stylo brevi, stigmate capitato. Bacea globosa, nigra, $4 \mathrm{~mm}$. diam. supra perianthii tubum paullo incrassatum insidens; pedicelli fructiferi sursum incrassati, parce pilosi, $2 \mathrm{~cm}$. longi; semen baccae conforme.

Western Szech'uan: without locality, alt. 2500 m., July 1903 
(Veitch Exped. No. 4426); Mupin, thickets, alt. 1000-1600 m., June 1908 (No. 3672).

Litsea ichangensis Gamble, n. sp.

Frutex erectus, 1-4 m. altus; ramuli graciles, teretes, nigro-brunnei; gemmae lanceolatae, glabrae, perulis acuminatis. Folia chartacea, obovata v. fere orbicularia, apice acuta, basi cuneata; supra glabra, siccitate olivacea, subtus pallida, juniora praecipue in nervorum axillis sericeo-hirsuta, tandem glabra; 2-5 cm. longa, 2-3 cm. lata; nervi utrinsecus 4-6, tenues, pallidi; reticulatio areolata; petiolus gracilis, 5-15 mm. longus, glaber. Florum umbellulae singulae v. binae e basi innovationum; pedunculus subcrassus, ad $5 \mathrm{~mm}$. longus; bracteae involucrales citissimo deciduae, $\delta$ orbiculares, $q$ ovatoacuminatae, 5-7-nervae, glanduloso-punctatae; flores in umbellulis saepissime 9 ; pedicelli filiformes, albo-sericei, cirea $5 \mathrm{~mm}$. longi; perianthii tubus vix ullus; lobi in $\delta$ obovati v. fere orbiculares, glandulosopunctati, 2-3 mm. diam., fere glabri; in 9 similes, sed multo minores vix $1 \mathrm{~mm}$. diam.; stamina in $\delta 9$; ordinum I. et II. $1.5-2 \mathrm{~mm}$. longa, antheris subquadratis, filamentis glabris; ordinis III. similia, basi glandulis 2 magnis vix stipitatis munita, omnia glanduloso-punctata; staminodia in $\$ 9$ : ordinum I. et II. clavata, ordinis III. subulata et glandulis ut in 8 munita; omnia glanduloso-punctata; ovarium ovoideum, stylo brevi, stigmate capitato. Bacca nigra, $5 \mathrm{~mm}$. diam., supra perianthii tubum paullo inerassatum et obconicum insidens; pedicelli graciles, 1-1.5 $\mathrm{cm}$. longi; semen baccae conforme; testa crustacea; cotyledones hemisphericae.

Western Hupeh : north and south of Ichang, woodlands, alt. 3001500 m., abundant, May, July, August and September 1907 (Nos. 297, 298); same locality, 1900 (Veitch Exped. No. 34).

The flowers and fruit when boiled give out a pleasant seent of lemon.

Litsea populifolia Gamble, n. comb.

Lindera populifolia Hemsley in Jour. Linn. Soc. XXVI. 390 (1891).

Western Szech'uan: around base of Wa-shan, thickets, alt. 1300-1600 m., June and July 1908 (No. 3693; bush 2.5-4 m. tall, fruit black); Mt. Omei, May 1904 (Veitch Exped. No. 5182); without precise locality, A. E. Pratt (No. 806).

Litsea fruticosa Gamble, n. comb.

Lindera fruticosa Hemsley in Jour. Linn. Soc. XXVI. 388 (1891). 
Kiangsi: Kuling, thickets, alt. 1300 m., common, July 1907 (Nos. I636, I659; bush 2-3 m.). Western Hupeh: Hsing-shan Hsien, thickets, alt. 1000 m., rare, May 22, 1907 (No. 367o; bush $1 \mathrm{~m}$.); without locality, May 1901 (Veitch Exped. No. 1946). Eastern Szech'uan: Taning Hsien, thickets, alt. 600-1000 m., June 1910 (No. $45^{8} 7$; bush $4 \mathrm{~m}$.).

\section{Litsea Wilsonii Gamble, n. sp.}

Arbor ad $10 \mathrm{~m}$. alta; ramuli subcrassi, brunnei, ultimi ferrugineovelutini. Folia chartacea, alterna obovata, apice abrupte breviter acuminata, basi attenuata v. cuneata; supra glabra, olivacea, subtus ferrugineo-velutina, 9-14 cm. longa, 4-6 cm. lata; costa conspicua, subtus conspicue elevata; nervi utrinque 6-10 curvati et prope marginem arcuatim juncti, secundarii pauci breves; nervuli transversi paralleli, omnes subtus conspicui; petiolus 1-3.5 $\mathrm{cm}$. longus, ferrugineovelutinus. Flores in umbellulis pedunculatis in racemis axillaribus fulvo-velutinis brevibus (vix $1 \mathrm{~cm}$. longis) 3-4-floris; pedunculi $1 \mathrm{~cm}$. longi; bracteae ovatae, deciduae; bracteae involucrales 4-6, orbiculares, reflexae, $5 \mathrm{~mm}$. longae; flores in umbellulis $\delta 6$, pedicellis brevibus sericeo-villosis; perianthii $\delta$ tubus brevis; lobi obovati, $3 \mathrm{~mm}$. longi, glanduloso-punctati, extus villosi, intus glabri; $\$$ ignoti; stamina normaliter 9, exserta (aliquando, praecipue in flore medio, plura); ordinis I. et II. $6 \mathrm{~mm}$. longa, antheris obovatis et filamentis gracilibus parce hirsutis; ordinis III. breviora, 4-5 $\mathrm{mm}$. longa, antheris oblongis et filamentis ad basim glandulis 2 stipitatis munitis; ovarium in flore $\delta$ rudimentarium nullum, in flore $\&$ ignotum. Drupa ellipsoidea glabra, $1 \mathrm{~cm}$. longa et $7 \mathrm{~mm}$. diam., basi perianthii tubo incrassato irregulariter fisso $3 \mathrm{~mm}$. longo suffulta; pedicellus fructifer incrassatus, ad $5 \mathrm{~mm}$. longus.

Western Szech'uan: without precise locality, ravines, alt. 1200 m., July and October 1903 (Veitch Exped. Nos. 4422, 4422 ${ }^{\mathrm{a}}$ ); Kiating Fu, hill-side thickets, alt. 300-500 m., September 1908 (No. 3694).

This species is near $L$. elongata Hooker f., and $L$. Faberi Hemsley, but the leaves are less prominently nerved and are distinctly obovate in shape.

Here may be added notes on two Chinese species not collected during the Arnold Arboretum Expeditions.

Litsea elongata Hooker f., Fl. Brit. Ind. V. 165 (1886).

Daphnidium elongatum C. G. Nees von Esenbeck in Wallich, Pl. As. Rar. II. 63 (1831); Syst. Laur. 620 (1836).

Western Hupeh: without locality, April and September 1901 (Veitch Exped. Nos. 1784, 2591). 
Litsea Faberi Hemsley in Jour. Linn. Soc. XXVI. 381 (1891).

Western Szech'uan: Mt. Omei, July 1904 (Veitch Exped. No. 5175).

\section{NEOLITSEA Merr.}

Neolitsea lanuginosa Gamble, n. comb.

Tetradenia lanuginosa C. G. Nees von Esenbeck in Wallich, Pl. As. Rar. II. 64, t. 576 (sphalmate Tetranthera) (1831).

Litsea lanuginosa C. G. Nees von Esenbeck, Syst. Laur. 634 (1836).

\section{Neolitsea lanuginosa, var. chinensis Gamble, n. var.}

Folia glabriora, oblanceolata, subtus magis glauca et costis nervis et nervulis transversis magis prominentibus. Drupa globosa nigra.

Western Szech'uan: Mupin, woodlands, alt. 900-1200 m., October 1908 (No. 3707; small tree 9 m. tall). Western Hupeh: Patung Hsien, July 1901 (Veitch Exped. No. 2266).

Here may be added a note on another Chinese species not collected during the Arnold Arboretum Expeditions.

Neolitsea umbrosa Gamble, n. comb.

Tetradenia umbrosa C. G. Nees von Esenbeck in Wallich, Pl. As. Rar. II. 64 (1831), excludenda var. $\beta$.

Tetradenia consimilis C. G. Nees von Esenbeck, l. c. (1831).

Litsea umbrosa C. G. Nees von Esenbeck, Syst. Laur. 623 (1836).

Litsea consimilis C. G. Nees von Esenbeck, 1. c. 628 (1836), excludendo synonymo Laurus involucrata Roxburgh.

Western Szech'uan: Mt. Omei, September 1904 (Veitch Exped. No. 5180).

\section{IINDERA Thumb.}

Lindera communis Hemsley in Jour. Linn. Soc. XXVI. 387 (1891).

Western Hupeh: north and south of Ichang, ravines, alt. 3001000 m., common, May and September 1907 (No. 296, in part; bush 2-5 m., flowers yellow, fruit dark red); Hsing-shan Hsien, ravines, alt. 600 m., May 10, 1907 (No. 296, in part; bush 5 m., flowers yellow); Changlo Hsien, cliffs, alt. 300-800 m., May 1907 (No. 296, in part; bush 3-4 m., flowers yellow); without locality, April and May 1900 (Veitch Exped. Nos. 246, 600). Western Szech'uan: Kiating Fu, thickets, alt. 300-600 m., May 1908 (No. 3726; bush 3 m.).

This and other evergreen shrubby species of Lindera abound on the cliffs of the glens and gorges of western Hupeh and Szech'uan. These shrubs are cut down and tied into bundles and thoroughly dried in the sun. The branches and leaves are then pounded into powder in a stamping mill driven by water power: the powder is treated with glutinous rice-water to make it adhesive and is 
made into incense sticks. These sticks, by foreigners termed "joss-sticks" are used by the Chinese in enormous quantities at all religious ceremonies. When burning they emit a pleasant fragrance.

E. H. W.

Lindera glauca Blume, Mus. Bot. Lugd.-Bat. I. 325 (1850).

Benzoin glaucum Siebold \& Zuccarini in Abh. Akad. Münch. IV. pt. III. 205 (Fl. Jap. Fam. Nat. II. 81) (1846).

Kiangsi : Kuling, thickets, alt. 1200 m., July 1907 (No. 1620; bush $2.3 \mathrm{~m}$.). Western Hupeh: north and south of Ichang, thickets, alt. 300-1300 m., abundant, April and October 1907 (No. 563; bush 2-4 m. tall, flowers yellow, fruit black); Changyang Hsien, April 1900 (Veitch Exped. No. 49); without locality, June 1900 (Veitch Exped. No. 1788). Eastern Szech'uan: banks of Yangtsze River, alt. 300 m., April 1908 (No. 3677; bush 2 m.).

This is an exceedingly common deciduous shrub in western Hupeh and the leaves assume very fine colors in the autumn. In late summer the plants are cut down and converted into incense in the same way and by the same process as that of the evergreen species.

E. H. W.

Lindera megaphylla Hemsley in Jour. Linn. Soc. XXVI. 389 (1891).

Western Hupeh: north and south of Ichang, woods and open country, alt. 300-1000 m., common, October 1902 (No. 302, in part; tree 8-20 m. tall, girth 1-3 m., fruit shining black); in a ravine 50 kilometres south of Ichang, alt. 300 m., March 15, 1907 (No. 302, \&, in part; tree $16 \mathrm{~m}$. tall, girth $2 \mathrm{~m}$., flowers yellow); 30 kilometres south of Ichang, alt. $300 \mathrm{~m}$., March 20, 1907 (No. 302, ठ , in part; tree $10 \mathrm{~m}$. tall, girth $1.5 \mathrm{~m}$., flowers yellow); Changlo Hsien, open country, alt. 300-1000 m., April, May 1907 (No. 302, in part, $\$$; tree 6-15 m. tall, girth 1-2 m., flowers yellow); Changyang Hsien, roadsides, alt. 600 m., July and November 1907 (No. 302, in part; tree 12-16 m. tall, girth 1.5-2 m.); Hsing-shan Hsien, roadside, alt. $800 \mathrm{~m}$., October 1907 (No. 302, in part; tree $10 \mathrm{~m}$. tall, girth $1 \mathrm{~m}$.); without precise locality, alt. 300-750 m., April and October 1900 (Veitch Exped. No. 59). Western Szech'uan: Mt. Omei, alt. 300-1300 m., common, June 1908 (No. 3706, in part; tree 13-20 m. tall, girth 1.5-3 m.); Wênch'uan Hsien, valley of Min River, alt. 600-1300 m., October 1908, (No. 3706, in part; tree 12-20 m. tall, girth $1.5-3 \mathrm{~m}$., fruit black).

This handsome umbrageous tree is one of the most common evergreens in western Hupeh and Szech'uan up to an altitude of 1200 metres. The branches are thick, erect-spreading and form a more or less broadly oval crown. The trunk is massive and the bark is gray and rather rough. This species is dioecious, and the stalked clusters of flower-buds are formed and are prominent in late autumn but 
do not commence to open until early spring. The ovoid plum-like fruit is shining black and is produced in enormous quantity. Colloquially this tree is known as "Nanmu shu" and the wood is valued for furniture making and in general carpentry.

Pictures of this tree will be found under Nos. 73, 347, 493 of the collection of my photographs and also in my Vegetation of Western China, Nos. 290, 291, 292.

E. H. W.

\section{Lindera umbellata Thunberg, Fl. Jap. 145, t. 21 (1784).}

Benzoin Thunbergii Siebold \& Zuccarini in Abh. Akad. Münch. IV. pt. III. 204 (Fl. Jap. Fam. Nat. II. 80) (1846).

Kiangsi: Kuling, thickets, alt. 1200 m., July 1907 (No. I634; bush 1.5-2 m., tall). Western Hupeh: Changyang Hsien, thickets, alt. 600-1300 m., July 1907 (No. 3684; bush 2.5-3 m. tall, fruit black); Patung Hsien, thickets, alt. 1300-2000 m., August 1907 (No. 368o; bush 3-4 m., fruit black); without locality, April 1900 (Veitch Exped. No. 34, in part). Western Szech'uan: west and near Wên-ch'uan Hsien, thickets, alt. 1000-1300 m., September 1908 (No. 3673; bush $3 \mathrm{~m}$. tall, fruit black); northeast of Tachien-lu, thickets, alt. 26003000 m., July 4, 1908 (No. 3675; bush 5-6 m. tall); without precise locality, alt. 3000 m., July 1903 (Veitch Exped. No. 4427).

No. 3675 seems a little doubtful.

Here may be added the description of a new variety not collected during the Arnold Arboretum Expeditions.

Lindera umbellata, var. latifolia Gamble, n. var.

Folia ovata, acuminata, ad $11 \mathrm{~cm}$. longa, $6 \mathrm{~cm}$. lata. Pedicelli fructiferi crassiores.

Western Hupeh: without locality, June 1901 (Veitch Exped. No. 610 ${ }^{\mathrm{a}}$ ).

I consider that Shearer's specimen from Kiukiang and Faber's No. 42 from Ningpo Mts. in Herb. Kew, also belong to this variety.

Lindera membranacea Maximowicz in Bull. Acad. Sci. St. Pétersbourg, XII. 72 (1867); in Mél. Biol. VI. 175 (1867).

Benzoin membranaceum Kuntze, Rev. Gen. Pl. I. 569 (1891).

Western Hupeh: Patung Hsien, ravines, alt. 600-1000 m., September 1907 (No. 367I; bush 2-4 m.); near Ichang, thickets, alt. 300-1000 m., May 1907 (No. 368r ; bush 3 m., flowers yellow); Hsingshan Hsien, thickets, alt. 300-1300 m., common, May and July 1907 (No. 3678, in part; bush 2-4 m., flowers yellow, fruit black); Changyang Hsien, woodlands, alt. 600-1100 m., common, April 1907 (No. 3678, in part; bush 2-6 m. tall, flowers yellow); Kui Chou, July 1901 (Veitch Exped. No. 2784); without locality, September 1901 (Veitch Exped. No. 1795). 
In Hupeh this shrub is commonly known as "Mu-chiangtzu" and the pungent fruit is used as a spice.

E. H. W.

Lindera reflexa Hemsley in Jour. Linn. Soc. XXVI. 391 (1891).

Kiangsi: Kuling, thickets, alt. 1200 m., common, July and August 1907 (Nos. I62I, I632, I639; bush $3 \mathrm{~m}$. tall).

I make this identification with some doubt because Ford's specimen from which Hemsley described the species is rather poor.

\section{Lindera setchuenensis Gamble, n. sp.}

Arbor ad $18 \mathrm{~m}$. alta, ramulis brunneis conspicue lenticellatis gracilibus. Folia chartacea, lineari-oblonga, apice et basi acuminata, supra glabra olivacea, subtus grisea, praesertim ad nervos et nervulos minute pubescentia, $15-17 \mathrm{~cm}$. longa, 2-3 cm. lata; costa supra gracilis, subimpressa, subtus conspicue elevata; nervi laterales utrinque circa 17, secundariis brevibus alternantibus multis; nervulis transversi conspicui, ramosi; reticulatio areolata; petiolus gracilis $7 \mathrm{~mm}$. longus. Umbellulae $\delta$ nondum visae, $\$$ solitariae v. binae ex axillis foliorum; pedunculus brevis; bracteae involucrales orbiculares, fere glabrae, 3 $\mathrm{mm}$. longae; flores in umbellulis 5; perianthii lobi oblongi, tenues, vix $1 \mathrm{~mm}$. longi; staminodia 9 , ordinum I. et II. clavata, $0.75 \mathrm{~mm}$. longa, basi villosa, ordinis III. paullo breviora, obtusa, glandulis 2 magnis capitatis stipitatis ad basim; ovarium ovoideum, stylo curvato, stigmate capitato. Bacca ovoidea, $1 \mathrm{~cm}$. longa, perianthii tubo incrassato cupuliformi staminodiis persistentibus suffulta; pedicellus fructifer incrassatus, $5 \mathrm{~mm}$. longus.

Western Szech'uan: Yachou Fu, open country, alt. 900 m., October 1910 (No. 4586).

Lindera strychnifolia Villar in Blanco, Fl. Filip. ed. 3, Nov. App. 182 (1880).

Benzoin strychnifolium Kuntze, Rev. Gen. Pl. I. 569 (1891).

Daphnidium strychnifolium Siebold \& Zuccarini in Abh. Akad. Münch. IV. pt. III. 207 (Fl. Jap. Fam. Nat. II. 83) (1846).

Kiangsi: Kuling, thickets, alt. 1200 m., July 1907 (No. I635; a dense bush 1-2 m. tall). Western Szech'uan: Wên-ch'uan Hsien, thickets, alt. 1200-1500 m., October 1910 (No. 4593; bush 3 m. tall, fruit black).

Lindera strychnifolia, var. Hemsleyana Diels in Bot. Jahrb. XXIX. 352 (1900).

Lindera strychnifolia, var.? Hemsley in Jour. Linn. Soc. XXVI. 392 (1891). 
Western Hupeh: north and south of Ichang, ravines, alt. 300600 m., March and June 1907 (No. 372r; bush $3 \mathrm{~m}$. tall); Patung Hsien, ravines, alt. 300-1000 m., April 1907 (No. 3722; bush 2-3 m. tall, flowers yellow); Hsing-shan Hsien, cliffs, alt. 600-1000 m., May 1907 (No. 3725; bush 4-6 m.tall, flowers yellow); without locality, April 1900 (Veitch Exped. No. 1787). Western Szech'uan: base of Washan, thickets, alt. 1000-1300 m., October 1908 (No. 3716; bush 3-6 m. tall, fruit black); same locality, alt. 1800 m., October 1903 (Veitch Exped. No. 4439); Yachou Fu, thickets, alt. 1000-1300 m., August 1908 (No. 3717; bush 3-6 m. tall, fruit black); west and near Wênch'uan Hsien, thickets, alt. 1000-1600 m., common, July and September 1908 (Nos. 3719a , 3718; bush 2-4 m. tall, fruit black); near Mao-chou, Chiu-ting-shan, thickets, alt. 1300 m., May 22, 1908 (No. 3719; bush 2.5-3 m. tall); Mt. Omei, May 1904 (Veitch Exped. No. 5181).

To this variety which has lanceolate or ovate-lanceolate, pubescent or glabrescent leaves belong all the specimens collected by Henry and Faber enumerated by Hemsley under his var?.

Lindera fragrans Oliver in Hooker's Icon. XVIII. t. 1788 (1888).Hemsley in Jour. Linn. Soc. XXVI. 388 (1891). ${ }^{1}$

Western Hupeh: neighborhood of Ichang, cliffs of glens and gorges, alt. 30-300 m., abundant, March 23, July 1907 (Nos. 3723, 3724; bush 1-2 m. tall, flowers yellow, fruit black); Hsing-shan Hsien, rocky places, alt. 300-1000 m., July 1907 (No. 3720; bush 2-3 m. tall, fruit black); Kui Chou, April 1901 (Veitch Exped. No. 1807); without locality, April 1900 (Veitch Exped. Nos. 41, 289).

\section{Lindera Prattii Gamble, n. sp.}

Arbor ad $10 \mathrm{~m}$. alta; ramuli erassi teretes, brunnei, molliter puberuli, innovationes dense ferrugineo-velutinae; gemmae ovatae, velutinae, perulis imbricatis obtusis. Folia coriacea, alterna, elliptico-ovata v. interdum elliptico-obovata, apice abrupte cuspidato-acuminata, basi rotundata v. subcordata; supra glabra olivacea, infra glauca et praecipue ad nervos puberula, $10-20 \mathrm{~cm}$. longa, $5-10 \mathrm{~cm}$. lata; costae $3 \mathrm{ex}$ imo basi oriendae additis interdum 2 tenuibus secus margines, mediana

${ }^{1}$ We refer as a synonym to this species L.9 Rosthornii Diels (in Bot. Jahrb. XXIX. 350 [1900]) of which we have seen fragments and a photograph of the type. We are unable to find any marked difference between the two species, though the specimens of typical $L$. fragrans have the leaves generally more distinctly 3-nerved and more glaucous on their under surface, but these characters are not quite constant.

A. R. and E. H. W. 
in acumen porrecta, laterales curvatae et cum nervis arcuatim junctae; nervi e costa mediana utrinque circa 2-4 marginem versus curvati; e lateralibus versus marginem circa $7-10$ breves; nervuli transversi multi conspicui arcuati; omnes, costae nervi et nervuli infra prominentes; petiolus crassus, $2-3 \mathrm{~cm}$. longus rugosus. Flores e glomerulis axillaribus v. lateralibus multifloris; umbellulae sessiles, bracteis involucrantibus ovatis obtusis ferrugineo-villosis suffultae; pedicelli villosi $5 \mathrm{~mm}$. longi; perianthii tubus brevis; lobi 6 ovati, integri v. ad apicem paullo dentati, $3 \mathrm{~mm}$. longi, in 9 angustiores quam in $\delta$, extus sericeo-villosi, intus glabri; stamina in flore $\delta 9$, antherarum thecis 2 oblongis, ordinis I. et II. filamentis gracilibus glabris et connectivo umbonato, ordinis III. similes, glandulis 2 magnis prope basim filamentorum munitae, omnia conspicue pellucido-punctata; staminodia in flore 99 , ordinis I. et II. clavata, 2-2.5 mm. longa, ordinis III. subulata, glandulis 2 permagnis ad basim. Ovarium in 8 rudimentarium, stylo gracili et stigmate peltato; in $\$$ ovoideum, stylo brevi curvato et stigmate peltato. Fructus niger, ovoideus, circa 8-10 mm. longus, pericarpio lucido et cotyledonibus hemisphaericis; pedicellus fructifer pubescens, $8-10 \mathrm{~mm}$. longus.

Western Szech'uan: without precise locality, 1890, A. E. Pratt (No. 809); Yachou Fu, thickets, alt. 600-1000 m., June and August 1908 (No. 37 I4); Wa-shan, thickets, alt. 1300 m., June and September 1908 (No. 37I5); without precise locality, alt. 1200-1800 m., June 1903 (Veitch Exped. No. 4428).

To this also belongs, I think, the specimen collected by F. S. A. Bourne at Chungking and referred to $L$. strychnifolia, Vill. var.? by Hemsley. The tree is undoubtedly near $L$. strychnifolia but has much larger leaves and is I think specifically distinet.

\section{Lindera rubronervia Gamble, n. sp.}

Frutex 2-3 m. altus; ramuli patentes, teretes, nigrescentes. Folia membranacea, ovato-lanceolata, apice acuminata mucronata, basi cuneata, supra siccitate olivacea, subtus glauca, glabra, 5-9 cm. longa, 2.5-3.5 $\mathrm{cm}$. lata; costae 3, circa 3-4 $\mathrm{mm}$. supra basim ortae, subtus prominentes et rufescentes, media in mucronem producta, laterales paullo supra folii dimidium nervis arcuatim conjunctae; nervi e costa media utrinque 3-4, rufescentes, curvati et prope marginem arcuatim juncti; reticulatio areolata, supra conspicua; petiolus rufescens, gracilis, 3-4 mm. longus. Umbellulae solitariae, e basi ramulorum novorum, fructiferae solum notae; pedunculus subcrassus, 3-4 $\mathrm{mm}$. longus. Bacea globosa, siccitate nigra, 3-5 mm. diam., supra perianthii tubum 
paullo incrassatum insidens; pedicellus sursum incrassatus, $1 \mathrm{~cm}$. longus.

Kiangsi: Kuling, thickets, alt. 1200 m., common, July 1907 (No. I624, I637).

Lindera cercidifolia Hemsley in Jour. Linn. Soc. XXVI. 387 (1891).

Kiangsi: Kuling, thickets, alt. 1300 m., July 1907 (No. r642; bush 2.5-4 m. tall). Western Hupeh: Changyang Hsien, woods, alt. 1300-2000 m., common, May and September 1907 (No. 299; bush 3-8 m. tall, flowers yellow, fruit dark red); Patung Hsien, woods, alt. 1300 m., common, May 1907 (No. 3669; bush 5 m. tall). Eastern Szech'uan: Wushan Hsien, mountains, May 1900 (Veitch Exped. No. 610). Western Szech'uan: south-east of Tachien-lu, woods, alt. 1600-2600 m., common, June and September 1908 (No. 987; bush 3-6 m. tall, fruit dark red).

Lindera obtusiloba Blume, Mus. Bot. Lugd.-Bat. I. 325 (1850).

Lindera mollis Oliver in Jour. Linn. Soc. IX. 168 (1867).

Benzoin obtusilobum Kuntze, Rev. Gen. Pl. I. 569 (1891).

Western Hupeh: Hsing-shan Hsien, woods, alt. 1300-2000 m., common, May and August (Nos. 3690, in part; 300; large bush or thin tree 6-10 m. tall, fruit red, young leaves bronzy-red); same locality, August 1907 (No. 30I; thin tree 8-10 m. tall, fruit black); Fang Hsien, woods, alt. 1300-2000 m., common, May 14, August 1907 (No. 369o, in part; 369r; large bush or thin tree 6-10 m. tall, flowers yellow, fruit dark red); without locality, May 1901 (Veitch Exped. No. 1856). Western Szech'uan: west and near Wênch'uan Hsien, woods, alt. 1600-2300 m., September 1908 (No. 3692; thin tree $6 \mathrm{~m}$. tall, fruit black).

The specimens seem to be more or less intermediate between $L$. obtusiloba Blume and $L$. triloba Blume, but to approach more nearly to the former.

This handsome shrub or small tree is very common in the woods of western Hupeh and in spring is very conspicuous on account of the brilliant color of the young leaves. As here interpreted the distinction between this species and Lindera cercidifolia Hemsley, is obscure.

A note on a species closely related to $L$. setchuenensis Gamble, not collected during the Arnold Arboretum Expedition may be added here:

Lindera pulcherrima Bentham in Bentham \& Hooker, Gen. III. 163 (1880).

Daphnidium pulcherrimum C. G. Nees von Esenbeck in Wallich, Pl. As. Rar. II. 63 (1831); Syst. Laur. 610 (1836).

Benzoin pulcherrimum Kuntze, Rev. Gen. Pl. I. 569 (1891).

Western Hupeh: Patung Hsien, cliffs, alt. 1700 m., April 1900 (Veitch Exped. No. 478 ; bush 2 m. tall). 
On the Himalayas this is a large tree, but it is quite possible that on cliffs in China it may flower as a shrub.

In addition to the species mentioned, the following numbers probably represent two species, but there are no leaves except very young ones, and I think it best not to attempt to describe them.

Lindera sp.

Western Hupeh: Hsing-shan Hsien, woodlands, alt. 1000-1600 m., May 1907 (No. 3685; bush 3-4 m., male flowers yellow).

\section{Lindera sp.}

Western Hupeh: Changyang Hsien, woodlands, alt. 1000-2000 m., April 1907 (Nos. 3679, 3686; bush 2-6 m. tall, male flowers yellow). Hsing-shan Hsien, woods, alt. 1600 m., April 1907 (No. 3678; bush 2-6 m., male flowers yellow); without locality, April 1901 (Veitch Exped. No. $\left.424^{\mathrm{s}},{ }^{\circledR}\right)$. 


\title{
LEGUMINOSAE.
}

\author{
Determined by W. G. CratB. ${ }^{1}$
}

\section{ALBIZZIA Durazz.}

Albizzia julibrissin Durazzini in Mag. Tosc. III. pt. IV. 11 (1792).

Western Hupeh: Hsing-shan Hsien, alt. 1000 m., July 1907 (No. 2032; tree 7-16 m. tall, girth 0.3-1.20 m., flowers white, stamens pink). ${ }^{2}$

In western Hupeh and eastern Szech'uan this tree grows in moist woods up to $1300 \mathrm{~m}$. altitude, but is rare. Occasionally it is planted in temple grounds. The bark is smooth, pale grey and the trunk relatively slender. The branches are moderately stout, short and spreading. The flowers are small, white with pink stamens and are fragrant; they close at night and in consequence the tree is colloquially known as the "Yeh-ho shu."

E. H. W.

\section{CERCIS L.}

Cercis chinensis Bunge in Mém. Sav. Êtr. Acad. Sci. St. Pétersbourg, II. 95 (Enum. Pl. Chin. Bor. 21) (1833).

Western Hupeh: north and south of Ichang, clearings, etc. October 1907 (No. 50r, in part; tree 7-13 m. tall, girth 0.6-1.5 m.); Changlo Hsien, woodlands, alt. 600-1000 m., May 1907 (No. 5or, in part; tree 10-13 m. tall, girth 1.2-1.5 m., flowers rosy pink); Changyang Hsien, woodlands, alt. 1000-1200 m., July 1907 (No. 501, in part; tree 7-13 m. tall, girth 1-1.5 m.); same locality, December 1907 (No. 76r); Hsing-shan Hsien, woodlands, alt. 600-1000 m., May 1907 (No. 5or, in part; tree 10-13 m. tall, girth 1.2-1.5 m.); Patung Hsien, alt. 1000 m., July 1907 (No. 5or, in part; tree 7-10 m. tall, girth 1-1.20 m.); Nanto, mountain sides, April 1900 (Veitch Exped. No. 411; tree 3-8 m. tall, flowers peach color).

${ }^{1}$ Cladrastis and Maackia by H. Takeda, Milletia and Wisteria by S. T. Dunn, Lespedeza and Campylotropis by A. K. Schindler. Occasional notes by Alfred Rehder and E. H. Wilson.

2 To the same species we refer specimens from Patung Hsien, woods, alt. 1000$1500 \mathrm{~m}$., July and October 1907 (No. 792; tree 10-14 m. tall, girth $1.2-1.5 \mathrm{~m}$.) and Veiteh Exped. No. 1315.

A. R, and E, H. W. 
In western Hupeh and eastern Szech'uan this beautiful flowering tree is very common but we never met with it wild west of the Red Basin of Szech'uan. It occurs in open country, and in thickets and the margins of woods up to $1200 \mathrm{~m}$. altitude. Conspicuous when in flower, it is much more so when laden with its immature reddish crimson fruits. This tree grows from 6 to $15 \mathrm{~m}$. tall and has a moderately thick trunk clean of branches for half its height and a flattened round head. The bark is dark grey and smooth but becomes rough and broken into small plates with age. The flowers vary from pale pink to red pink and are produced in great numbers on all parts of the tree including the old branches and main trunk. The wood is close grained, heavy and very durable. Its colloquial name "Lo-chiang shu" signifies that the flowers resemble an open basket. To western minds the significance is not obvious for the flowers more closely resemble a cradle or an open boat with a hooded stem.

It is doubtful if Cercis glabra Pampanini (in Nuov. Giorn. Bot. Ital. n. ser. XV, is anything more than a mere form of this tree.

E. H. W.

\section{Cercis racemosa Oliver in Hooker's Icon. XIX. t. 1894 (1889).}

Western Hupeh: Fang Hsien, woods, side of streams, alt. 13001800 m., May 15, August and September 1907 (No. 314; tree 5-10 m. tall, girth $0.3-1.2 \mathrm{~m}$., flowers rosy pink); without precise locality, May 1900 (Veitch Exped. No. 607).

This remarkable tree is fairly common in the moist woods of central Fang Hsien between $1200-1800 \mathrm{~m}$. alt., but is extremely rare elsewhere in western Hupeh and has not been reported from any other province. It is a low-growing tree, seldom, if ever, more than $12 \mathrm{~m}$. tall, with a single trunk from 1 to $2 \mathrm{~m}$. in girth near the ground, and a wide-spreading head from 4 to $10 \mathrm{~m}$. through of relatively thin branches. The bark is green and smooth but with age becomes pale gray and splits into thin, irregularly oblong flakes which are partially exfoliated in old trees. The silvery-rose colored flowers are produced in great profusion in pendulous racemes $4 \mathrm{~cm}$. to $10 \mathrm{~cm}$. long. When not in flower the species is easily recognized by its habit and by the leaves which are hairy on the underside. Apparently it rarely fruits and its introduction to cultivation was only accomplished on our third expedition. It is essentially a cool temperate tree and in western Hupeh always at higher altitudes than C. chinensis Bunge.

E. H. W.

\section{BAUHINIA.}

The species of Bauhinia here enumerated are common in the warm, arid valleys of western Szech'uan where they form an important part of the vegetation. In western Hupeh they are much less common and are found only at low altitudes growing on the cliffs and in glens and ravines.

E. H. W.

Bauhinia densiflora Franchet, $P l$. Delavay. 191 (1890).

Western Szech'uan: Tung Valley, arid places, alt. 1000-1300 m., June 1908 (No. 3377, in part, flowers only; scandent bush, 2-3 m.).

Bauhinia Faberi Oliver in Hooker's Icon. XVIII. t. 1790 (1888).

Western Szech'uan: Tung Valley, arid places, alt. 1000-1300 m., September 1908 (No. 3377, in part, fruits only; scandent bush, 
2-3 m.). Western Hupeh: Kui chou, August 1901 (Veitch Exped. No. 2000); without precise locality, July 1901 (Veitch Exped. No. 2618).

Bauhinia Faberi var. microphylla Oliver in herb.

A typo foliis manifeste minoribus facile distinguenda.

Western Hupeh: without precise locality, A. Henry (No. 7179). Western Szech'uan: Min Valley, around Mao-chou, arid regions, alt. 1200-2000 m., May 25 and September 1908 (No. 3374; bush 0.3$2 \mathrm{~m}$. tall, flowers white).

This variety is easily distinguished by its very small leaves, only 6-12 $\mathrm{mm}$. long and by its smaller flowers.

Bauhinia yunnanensis Franchet, Pl. Delavay. 190 (1890).

Western Szech'uan: near Mt. Wa, thickets, alt. 1200-2000 m., July 1908 (No. 3378; scandent bush, 2-4 m., flowers pink); without precise locality, alt. 1000 m., June 1903 (Veitch Exped. No. 3378; climber, flowers rosy pink).

\section{Bauhinia hupehana Craib, n. sp.}

Frutex scandens, ad 7-metralis; ramuli primo rufo-puberuli, mox glabri, fusco-corticati. Folia ad $6 \mathrm{~cm}$. longa et $7.2 \mathrm{~cm}$. lata, apice ad partem quartam biloba, lobis apice rotundatis basi ad $3.5 \mathrm{~cm}$. latis, basi alte v. late haud altius cordata, chartacea, e basi 7-nervia, nervis supra conspicuis subtus prominentibus, pagina superiore arcte reticulata, supra pilis pallidis adpressis inconspicuis hic illic instructa, subtus breviter parce adpresse rufo-pubescentia, petiolo ad $4 \mathrm{~cm}$. longo gracili suffulta. Racemi ad $7 \mathrm{~cm}$. longi; bracteae deciduae; pedicelli ad $2 \mathrm{~cm}$. longi, ut rhachis rufo-puberuli; bracteolae binae, alternae, pedicelli medium circiter positae, filiformes, ad $5 \mathrm{~mm}$. longae; calycis tubus $1.3-1.6 \mathrm{~cm}$. longus, sulcatus, rufo-puberulus; lobi $7 \mathrm{~mm}$. longi, $1.75 \mathrm{~mm}$. lati; petala 5 , rosea, obovata v. fere elliptica, ad 12 $\mathrm{mm}$. longa et $8.5 \mathrm{~mm}$. lata, basi in unguem $2-3 \mathrm{~mm}$. longum attenuata; stamina perfecta 4, filamentis glabris $1.8 \mathrm{~cm}$. longis; ovarium glabrum, stipite $5 \mathrm{~mm}$. longo suffiultum.

Affinis $B$. tenuiflorae Watt a qua calycis tubo breviore recedit.

Western Hupeh: Changlo Hsien, ravines, alt. 300-600 m., May 1907 (No. 3373, type; scandent bush, $7 \mathrm{~m}$. tall; flowers pink); Chanyang Hsien, ravines, alt. 300-600 m., June 6 and September 1907 (No. ${ }_{107}$, in part; large climber, $7 \mathrm{~m}$. or more, flowers rose pink; north and south of Ichang, ravines, alt. 30-600 m., June and July 
1907 (No. I07, in part; large climber, 7 m., flowers rose-pink); same locality, A. Henry (Nos. 3551, 3551ㄹ, 2938, 2938 ); Patung Hsien, A. Henry (No. 706); Nanto, May 1900 (Veitch Exped. No. 834). Western Szech'uan: Mt. Omei, June 1904 (Veitch Exped. No. 4828); without precise locality, alt. 800 m., June 1903 (Veitch Exped. No. 3400 ; climber, flowers white, fragrant).

Bauhinia tenuiflora Watt, B. glauca Wallich, and the species above described are very closely related. Of the three B. tenviffora which is found in Upper Assam, Upper Burma and Yunnan has by far the longest ealyx tube $(2.5-3 \mathrm{~cm}$.), that of $B$. glauca being 1-1.2 cm. and of the present species 1.3-1.6 cm. long. In $B$. glauca whose distribution so far as I am aware is in Amherst, Mergui, Perak and Java the calyx-tube is glabrous except at the apex, the buds are glabrous or nearly so and the leaves are lobed to the middle.

Bauhinia hupehana, var. grandis Craib, n. var.

A typo foliis basi plerumque latius minus altius cordatis, floribus paulo majoribus recedit.

Western Szech'uan: Tung Valley, near Mt. Wa, alt. 500-1000 m., June and October 1908 (No. 3372; climber 3-5 m. tall, flowers pink).

This rambling shrub is common at low altitudes growing on limestone eliffs and in the glens and ravines of western Hupeh. The flowers are fragrant, usually rose-pink or more rarely white in color.

E. H. W.

\section{CASSIA L.}

Cassia Leschenaultiana De Candolle in Mém. Soc. Phys. Genève, II. 132 (1824).

Western Hupeh : Ichang, alt. 30-300 m., June and August 1907 (No. 2197; roadside weed, flowers yellow).

\section{GLEDITSIA L.}

Gleditsia macracantha Desfontaines, Hist. Arb. II. 147 (1809).

Western Hupeh : common around Ichang, alt. 30-600 m., April 24, May 3, and October 1907 (No. 799; tree 10-30 m., girth 2-4 m., flowers greenish); Changyang Hsien, alt. 30-600 m., June 1907 (No. 2444; tree 12-20 m., girth 1.6-3 m.); 20 miles southwest of Ichang, road-side, alt. 300 m., November 1907 (No. 2445; tree 7 m., very spiny); without precise locality, April 1900 (Veitch Exped. No. 232).

At low altitudes this is one of the most common trees in western Hupeh and Szech'uan where it is partial to the sides of streams and open country generally. It is also commonly found in close vicinity to houses and in temple grounds. It 
grows to a very large size and has buttressed roots, a massive bole clean of branches for from 3 to $10 \mathrm{~m}$. from the ground, and a wide-spreading head of thick branches. The bark is quite smooth and pale grey in color. In degree of spinescence the trees vary very considerably and some are quite thornless. The flowers are polygamodioecious and the trees have a marked tendency toward dioecism and some individuals appear to be always sterile. The wood is nearly white and of little value but the bloomy-black, flattened pods are rich in saponin and are valued as a substitute for soap and are also used in the process of tanning hides.

This is one of the most important of the Chinese "soap trees" and its colloquial name is "Tsao-k'o shu." Pictures of this tree will be found under Nos, 6, $7,9,467,593,597,629,631,714,717,718,0241,0251$, in the collection of my photographs and also in my Vegetation of Western China, Nos. 233-243.

E. H. W.

Gleditsia officinalis Hemsley in Kew Bull. Misc. Inform. 1892, 82.

Western Szech'uan: Yachou Fu, alt. 1000 m., October 1910 (No. 46r5; tree $16-20 \mathrm{~m}$., girth 2-2.30 m.); without precise locality (No. 2446, pods of unknown origin, purchased in town of Mupin).

This rather rare tree in habit and general appearance resembles $G$. macracantha Desfontaines. The small, flattened and curved, black or brownish-black pods, known as "Ya-tsao" are used for medicinal purposes only. These pods are sliced and boiled with other drugs and the infusion is considered a cure for colds and coughs. This tree is also found very sparingly in western Hupeh and is said to occur in the province of Shensi. The fully ripe pods of No. 2446 are dark chestnut-brown and lustrous, linear oblong, 11-12 $\mathrm{cm}$. long, $1.5-1.6 \mathrm{~cm}$. broad and about 6 or 7 mm. thick.

E. H. W.

Gleditsia sinensis Lamarck, Encycl. Méth. II. 465 (1786).

Western Szech'uan: Mao-chou, dry valleys, alt. 1000-1600 m., May 24 and October 1908 (No. I2I4; tree 10-20 m. tall, girth 1.3$3 \mathrm{~m}$.); Min Valley, near Wên-chuan Hsien, alt. 1000-1300 m., November 1908 (No. I363 $_{3}$ tree 10-20 m., girth 1.3-2.6 m.).

This tree in size, habit and general appearance does not differ from G. macracantha Desfontaines. The vernacular name is the same and the pods have similar uses.

Pictures will be found under Nos. 0240,0248 , in the collection of my photographs.

E. H. W.

\section{GYMNOCLADUS Lam.}

Gymnocladus chinensis Baillon in Compt. Rend. Assoc. Franc. Avanc. Sci. III. 418, t. 4 (1875).

Kiangsi : foothills around Kiukiang, common, alt. 300 m., August 2, 1907 (No. I598; tree 10-16 m. tall, girth 0.6-1.6 m., bark smooth, grey). Western Hupeh: Patung Hsien, alt. 1200 m., May, July, September and December 1907 (No. 76o, in part; tree 10-20 m. tall, girth 0.6-1.6 m., bark smooth, light gray, flowers lilac-purple); Hsing- 
shan Hsien, alt. 1000-1200 m., May 6 and December 1907 (No. 76o, in part; tree 13-16 m. tall, girth 0.6-1.6 m., flowers lilac-purple, young foliage silvery).

On the Kiukiang plain this is a common tree but it is rare in western Hupeh and has not been reported from Szech'uan. In the neighborhood of Kiukiang it is a large but not a tall tree with a wide-spreading oval or flattened head but in Hupeh the trees are smaller with rather short, spreading branches. The bark is quite smooth and light grey in color. The lilac-purple flowers are greyish pubescent on the outside and appear before the leaves. The leaves are silvery when quite young and when fully grown they are pea green and often $60 \mathrm{~cm}$. across. The flattened pods are brown from 7 to $10 \mathrm{~cm}$. long and from 3.5 to $4 \mathrm{~cm}$. wide and are highly esteemed for their saponaceous qualities. An account of the uses of these pods is found in my A Naturalist in Western China, II. 72 (1913).

The colloquial name for this tree is "Yu-tsao-chio," and pictures will be found under Nos. $510,513,687,688,052$ in the collection of my photographs and in my Vegetation of Western China, Nos. 246-249.

E. H. W.

\section{PTEROLOBIUM R. Br.}

Pterolobium punctatum Hemsley in Jour. Linn. Soc. XXIII. 207 (1887).

Western Hupeh: Patung Hsien, ravines, alt. $600 \mathrm{~m}$., July and October 1907 (No. 3225; scandent bush, 7 m., flowers yellowishwhite); without precise locality, July 1901 (Veitch Exped. No. 2435).

This thorny, rambling shrub is common at low altitudes on the limestone cliffs of the glens, gorges and ravines throughout western Hupeh. It grows to a large size and is colloquially known as "Chio-pu-t'a."

E. H. W.

\section{CAESALPINIA.}

Caesalpinia sepiaria Roxburgh, Fl. Ind. II. 360 (1824).

Western Hupeh: Ichang, alt. 30-300 m., April and July 1907 (No. 106; semiscandent bush 1-7 m., flowers yellow, abundant); Kuichou, April 1900 (Veitch Exped. No. 19). Western Szech'uan: Mt. Omei, May 1904 (Veitch Exped. No. 4831).

At low altitudes this subscandent, thorny shrub is abundant everywhere in western Hupeh and Szech'uan. In spring it bears a profusion of erect, thyrsoid racemes of bright yellow, fragrant flowers and is most conspicuous and beautiful. Colloquially known as the "Yeh-tsao-chio," it is the "Shui tsao-chio " of Chinese literature.

E. H. W.

\section{Caesalpinia szechuenensis Craib, n. sp.}

Frutex scandens, 3-metralis; ramuli primo puberuli, mox glabri. Folia bipinnata, ad $18 \mathrm{~cm}$. longa, petiolo $3.8-5 \mathrm{~cm}$. longo ut rhachis puberulo et infra spinis recurvis hic illic instructo suffulta; stipulae 
deciduae; pinnae 4-jugae, ad $7 \mathrm{~cm}$. longae, petiolulo ad $15 \mathrm{~mm}$. longo suffultae, petiolulo rhachillaque interdum infra spinis minoribus sparse instructis; foliola opposita, 4-5-juga, ex oblonga ad ovato-lanceolata v. terminalia oblanceolata, apice rotundata v, obtusa, basi cuneata v. latere altero cuneata, altero rotundata, 2-2.8 cm. longa, 9-11 $\mathrm{mm}$. lata, supra nitida, glabra, subtus pallidiora, sparse puberula, rigida, nervis lateralibus utrinque $7-8$ intra marginem anastomosantibus, pagina utraque cum nervulis pulchre reticulatis prominulis; petioluli $2 \mathrm{~mm}$. longi, puberuli. Panicula terminalis, e racemis alternis ad 9 $\mathrm{cm}$. longis racemosim dispositis constituta, ad $15 \mathrm{~cm}$. longa; pedicelli graciles, $7 \mathrm{~mm}$. longi; calycis tubus $2 \mathrm{~mm}$. longus; segmenta oblonga, 5.5-7 mm. longa; petala oblonga, $5.5 \mathrm{~mm}$. longa, aurea, ungui 0.5 $\mathrm{mm}$. longo; filamenta inferne piloso-barbata; ovarium $1.75 \mathrm{~mm}$. altum, breviter stipitatum, parce pilosum, stylo glabro. Legumen ambitu subrotundatum, $2 \mathrm{~cm}$. longum, eirciter $1 \mathrm{~cm}$. crassum, valvis reticulatis brunneis.

Western Szech'uan: Kiating Fu, thickets, alt. 300-500 m., May 1908 (No. 3255).

The nearest 'ally of this plant is, in my opinion, undoubtedly Mezoneuron sinense, Hemsley, to which, in habit, it has a striking similarity. Mezoneuron sinense, although the fruit has a slight wing, is not a typical Mezoneuron and yet the only tangible difference between the two genera is apparently the winged and unwinged fruits.

\section{MEZONEURUM Desf.}

Mezoneurum sinense Hemsley in Jour. Linn. Soc. XXIII. 204 (1887). - Oliver in Hooker's Icon. XX. t. 1960 (1891).

Western Hupeh: Ichang, glens, alt. 30-300 m., May 9, 1907 (No. 3256; scandent bush, 1.5-2 m. tall, flowers golden); Nanto, glens, May 1900 (Veitch Exped. No. 248; climber). Szech'uan: Yangtsze River cliffs, April 1904 (Veitch Exped. No. 3450; subscandent shrub, flowers bright yellow).

The colloquial name for this rather rare shrub is "Ch'ien-hsüch-fei."

E. H. W.

\section{ORMOSIA Jack.}

Ormosia Henryi Prain in Jour. As. Soc. Beng. LXIX, 180 (1900). - Hemsley \& Wilson in Kew Bull. Misc. Inform. 1906, 156.

Western Hupeh: Changlo Hsien, thickets, alt. 600 m., June, July and September 1907 (No. 2373; small tree 5-8 m. tall, flowers yellowish white); Patung (Veitch Exped. No. 2587). 
This small and very ornamental tree is rare in western Hupeh and has not been reported from Szech'uan. The undescribed flowers are yellowish white and are borne in axillary or terminal panicles or rarely in axillary racemes; rhachis, pedicels and the calyx outside and inside densely fulvous tomentose; calyx turbinate, about $1 \mathrm{~cm}$. long and divided to the middle into triangular-ovate acutish lobes, petals about $2 \mathrm{~cm}$. long, standard suborbicular unguiculate, wings and the petals of the keel obliquely obovate; ovary pilose along the sutures, with an involute style.

R. A. and E. H. W.

Ormosia Hosiei Hemsley \& Wilson in Kew Bull. Misc. Inform. 1906, 156.

Western Szech'uan: Chengtu Plain, temple compound, alt. $650 \mathrm{~m}$., May 18, 1908 (No. 2372, in part; tree $20 \mathrm{~m}$. tall, girth $3 \mathrm{~m}$.); Chengtu, September 1903 (Veitch Exped. No. 3407, type); near Sui Fu, alt. 200-300 m., April 1908 (No. 2372, in part; tree 16-26 m. tall, flowers pink). Western Hupeh: Nanto, May 1900 (Veitch Exped. No. 808; tree 13 m., flowers white); Changyang (Veitch Exped. No. 1994).

This is one of the most beautiful of all Chinese trees and its red-colored wood, which is heavier than water, is esteemed above all other Chinese woods for high-grade cabinet work. Formerly the tree was common in Szech'uan but it is now rare except in the more remote north-central parts of the province. It grows to a large size and has a massive bole, spreading branches and smooth green bark which becomes grey and fissured on old trees. The inflorescence is paniculate, and the undescribed flowers are fragrant, and vary from nearly white to rose-pink; calyx turbinate, $0.8-1 \mathrm{~cm}$. long with short triangular-ovate lobes densely tomentose inside and outside; petals about $2 \mathrm{~cm}$. long; standard broadly obovate, unguiculate; wings and the petals of the keel oblong-obovate, unguiculate; ovary glabrous, with an involute style.

Pictures of this tree will be found under Nos. $61,289,385,386$ of the collection of Wilson's photographs and in his Vegetation of Western China, Nos. 320-322. Colloquially it is known as the "Hung-tou shu" (Red-bean tree).

A. R. and E. H. W.

\section{SOPHORA L.}

\section{Sophora Wilsonii Craib, n. sp.}

Frutex 1-2-metralis; ramuli primo densius adpresse pubescentes, mox glabri, cortice reticulato-striato obtecti. Folia imparipinnata $6.5-15 \mathrm{~cm}$. longa, breviter petiolata, petiolo rhachideque supra canaliculatis ut ramuli pubescentibus; stipulae vix $3 \mathrm{~mm}$. longae, deciduae; foliola alterna, 8-10-juga, lanceolata, ovato-lanceolata, oblongolanceolata v. terminalia oblanceolata, parum inaequilatera, apice obtusa, basi cuneata ad rotundata, $0.5-4.8 \mathrm{~cm}$. longa, $0.5-1.9 \mathrm{~cm}$. lata, chartacea, supra costa excepta demum glabra, subtus adpresse ferrugineo-pubescentia, nervis lateralibus utrinque circiter 8 intra 
marginem anastomosantibus pagina utraque prominulis, margine recurvo, petiolulis $1 \mathrm{~mm}$. longis suffulta. Racemi ad $7 \mathrm{~cm}$. longi, pedunculo communi circiter $2 \mathrm{~cm}$. longo ut rhachis ramulique pubescente; bracteae $5 \mathrm{~mm}$. longae, deciduae; pedicelli sub anthesin $5 \mathrm{~mm}$., mox $8 \mathrm{~mm}$. longi; calyx ad $8.5 \mathrm{~mm}$. longus, ore oblique truncatus; vexillum $1.6 \mathrm{~cm}$. longum, fere $6 \mathrm{~mm}$. latum, cuneatum, apice emarginatum, inferne puberulum, dorso carinatum; alae $6 \mathrm{~mm}$. longae, $3.5 \mathrm{~mm}$. latae, stipite $6.5 \mathrm{~mm}$. longo; carina alis subaequilonga; filamenta inferne pilosa; ovarium adpresse pilosum. Legumen 2-3 cm. longum, stipite $1 \mathrm{~cm}$. longo dense adpresse pubescente suffultum, valvis reticulatis parce adpresse pubescentibus; semina brunnea v. fusco-maculata, $1.1-1.2 \mathrm{~cm}$. longa.

Affinis S. Franchetianae Dunn et $S$. Wightii Baker, ab illa calyce multo longiore, ab hac foliolis minoribus haud longe acuminatis, seminibus majoribus haud rubris distinguenda.

Western Szech'uan: Kuan Hsien, thickets, river valleys, alt. 300-1000 m., October 1908 (No. Io67, in part); near Wa-shan, thickets, alt. 1000 m., June 2, 1908 (No. I067, in part); without precise locality, cliffs, alt. 600 m., May 1904 (Veitch Exped. No. 3390; shrub 1-2 m., flowers pale yellow).

This sparsely branched shrub is not uncommon in moist thickets in the rivervalleys of western Szech'uan.

E. H. W.

Sophora viciifolia Hance in Jour. Bot. XIX. 209 (non Salisbury) (1881). - Hooker f. in Bot. Mag. CXXIX. t. 7883 (1903).

Sophora Moorcroftiana Bentham, var. Davidii Franchet in Nouv. Arch. Mus. Paris, sér. 2, V. 253, t. 14 (Pl. David. 101) (1883).

Sophora Moorcroftiana Kanitz in Math. Naturwiss. Ber. Ungarn, III. 7 (non Bentham) (1885).

Sophora Davidii Komarov apud Pavolini in Nuov. Giorn. Bot. Ital. n. ser. XV. 412 (1908).

Western Hupeh : Ichang, stony places, side of streams, alt. 300600 m., April and June 1907 (No. 256o; bush 30-2 m. tall, flowers bluish white); without precise locality, April 1900 (Veitch Exped. No. 81). Western Szech'uan: valley of the Min River, Mao-chou, arid regions, alt. 1300-1600 m., May 25 and August 1908 (No. 84I ${ }^{3}$; shrub 30-2 m. tall, flowers violet); near Tachien-lu, dry rocky regions, alt. 1300-2000 m., May and August 1908 (No. 84I ; shrub 30-1.60 m. tall; flowers dark violet-blue); between Batang and Tachien-lu, 1911, John R. Muir; without precise locality, dry arid places, June 1904 (Veitch Exped. No. 3388). 
This is a common shrub in western Hupeh up to $1000 \mathrm{~m}$. altitude, especially in rocky places, but it is even more abundant in the arid river-valleys of western Szech'uan where it is found up to $2500 \mathrm{~m}$. altitude. The western form, which is dwarfer and excessively spiny, has smaller leaves and a dark violet-blue colored calyx. Colloquially this shrub is known as the "Tieh-ma-hu-tsao." E. H. W.

\section{Sophora flavescens Aiton, Hort. Kew. II. 43 (1789).}

Western Hupeh: Hsing-shan Hsien, side of streams, etc., alt. 300-1000 m., June and October 1907 (No. 256r; shrub 2 m., flowers white). Eastern Szech'uan: Wushan Hsien, July 1900 (Veitch Exped. No. 1371; bush 2 m., flowers white).

Very common in sandy places and colloquially known as " K' $u$-shen." The seeds and roots are used as medicine in veterinary practice.

E. H. W.

\section{Sophora japonica Linnaeus, Mant. I. 68 (1767).}

Western Hupeh: north and south of Ichang, common, alt. 301000 m., July, August and November 1907 (No. 651, in part; tree 7$14 \mathrm{~m}$. tall, girth 0.6-1.6 m., flowers white); Patung Hsien, roadsides, alt. 30-1000 m., July, August and October 1907 (No. 65I, in part; tree 7-10 m. tall, flowers white); same locality, July 1901 (Veitch Exped. No. 2485; tree 16 m. tall); Changlo Hsien, alt. 600-1000 m., June 1907 (No. 65I, in part; tree $10 \mathrm{~m}$. tall); Fang Hsien, roadsides, alt. 1200 m., August 1907 (No. 2558; tree 8 m. tall, girth 1 m., flowers white); Hsing-shan Hsien, open country, alt. 300-1000 m., October 1907 (No. 651, in part; tree 7-20 m. tall, girth 0.6-1.6 m.); without precise locality, June 1901 (Veitch Exped. No. 2312). Western Szech'uan: Chengtu Plain, alt. 300-600 m., July 1908 (No. 2557; tree 10-20 m. tall, girth 1.6-3 m., flowers white); same locality, August 1903 (Veitch Exped. No. 3393); Yachou Fu, roadside, alt. 300-1000 m., August 1908 (No. 2559; tree 8-16 m. tall, girth 1-2 m., flowers white); without precise locality, August 1904 (Veitch Exped. No. $\left.3393^{\mathrm{a}}\right)$.

This tree, which is native of China and cultivated only in Japan, is common in western Hupeh and Szech'uan and is an important feature of the vegetation in the arid valleys of western Szech'uan. In the park which surrounds the Temple of Heaven at Peking there is a fine avenue of this tree and very large individuals are scattered through the city. In western China it grows to a large size and the degree of pubescence on the leaves varies considerably. The wood is white or nearly so, tough, light and strong and is used in general carpentry. The flowers are employed as a yellow dye for cotton cloth and silk fabrics. The colloquial name for this tree is "Huai shu." Pictures will be found under Nos. 68, 642, $0169,0237,0239$ in the collection of my photographs and also in my Vegetation of Western China, Nos. 474, 475.

E. H. W. 


\title{
CLADRASTIS Raf.
}

\author{
Determined by $H$. TAKEDA.
}

\section{Sect. EUCLADRASTIS Takeda. ${ }^{1}$}

Cladrastis sinensis Hemsley in Jour. Linn. Soc. XXIX. 304 (1892). Western Szech'uan: Wa-shan, woods and clearings, alt. 1300$2500 \mathrm{~m}$., June, July and October 1908 (No. Iro2 ${ }^{\text {a }}$; tree 5-20 m. tall, girth 0.6-3 m., flowers white); same locality, October 1901 (No. 4388; tree 10-25 m. tall, girth 0.6-4 m., flowers white and pink); Mt. Omei, July 1904 (Veitch Exped. No. 4832); without precise locality, alt. 1800 m., July 1903 (Veitch Exped. No. 3392a), alt. 2300 m., July 1904 (Veitch Exped. No. 3392; flowers blush). Western Hupeh: without precise locality, June 1901 (Veitch Exped. No. 2398). Yunnan: Mengtze, A. Henry (No. 10784).

This handsome flowering tree is common in the moist woods of western Szech'uan between 1300 and $2500 \mathrm{~m}$. altitude. Usually it is a tree of medium size but specimens of large size are not infrequent. The bark is quite smooth and greenish-grey, and the branches are wide-spreading and form an oval or rounded head. The much branched panicles are erect and are often $30 \mathrm{~cm}$. high and 20 $\mathrm{cm}$. wide or occasionally $40 \mathrm{~cm}$. high, and stand well above the foliage. The flowers are very freely produced and vary in eolor from white to rosy-pink.

Pictures of this tree will be found under Nos. 269, 360, in the collection of my photographs and also in my Vegetation of Western China, No. 168 . E. H. W.

\section{Cladrastis Wilsonii Takeda, n. sp.}

Arbor 4-16-metralis, trunco 0.3-1.3 circuitu, cortice cinereo v. flavo-cinereo levi lenticellato. Folia breviter petiolata, petiolo basi gemmam albo-sericeam includente, 9-11-foliolata, rhachi petiolulisque primo albo-lanatis mox glabris, foliolis basalibus minoribus ovatis, apicalibus sensim majoribus ovato-ellipticis v. ellipticis subcuspidatis obtusis papyraceis in siceo opacis subtus subglaucis, juvenilibus secus costam mediam pubescentibus, mox glabris. Panicula laxa, multiflora, pedunculis pedicellisque brunneo-pubescentibus; flores ad $25 \mathrm{~mm}$. longi, albi; calyx cylindrico-campanulatus, basi stipitiformiter attenuatus, pedicello paulo longior, 5-lobatus lobis triangularibus obtusis; petala subaequilonga; vexillum rotundatum, unguiculatum, cum ungui $18 \mathrm{~mm}$. longum, $12 \mathrm{~mm}$. latum, vix emarginatum; alae oblique hastatae; carinae petala semisagittata; stamina libera, antheris atropurpureis; ovarium lineare, utrinque attenuatum,

${ }^{1}$ See Takeda in Not. Bot. Gard. Edinburgh, XXXVII. (ined.). 
breviter stipitatum, dense pubescens, stylo longo incurvo, stigmate punctiformi. Legumen maturum compressum, brevissime stipitatum, hirsutum, $4.5 \mathrm{~cm}$. longum, $12 \mathrm{~mm}$. latum.

Western Hupeh: Patung Hsien, woodlands, alt. 1500-1600 m., July and September 1907 (No. I102, in part); Changyang Hsien, woods, alt. 1600-2000 m., July 1907 (No. IIO2, in part); Fang Hsien, woodlands, alt. 2000 m., May 19, 1907 (No. Iro2, in part); Changlo Hsien, woods, alt. 1600-2000 m., July 1907 (No. II02, in part). Kiangsi ; Kuling, not common, thickets, alt. 1200 m., August 1, 1907 (No. I535; bush 3-5 m. tall). Eastern Szech'uan: Wushan Hsien, woods, alt. 1600-2000 m., October 1907 (No. Iro2, in part).

Cladrastis Wilsonii is closely related to C. shikokiana Makino, from which it differs in the very shortly stalked, broader and hirsute pod. The leaves of the two species are similar; the indumentum, however, of the young leaves of C. Wilsonii is white or very pale yellow, and that of C. shikokiana is brown.

This tree is fairly common in the moist woods of western Hupeh but rare in Kiangsi and not reported west of the eastern limits of the Red Basin of Szech'uan, where it is replaced by $C$. sinensis Hemsley. This is easily distinguished from C. Wilsonii by the glabrous ovary and narrower, more numerous leaflets generally oblong and rounded or nearly rounded at the base and more or less villose along the midrib; the flowers, too, are somewhat smaller and the panicles larger, occasionally attaining 30 or $40 \mathrm{~cm}$. in length.

A. R. and E. H. W.

\section{MAACKIA Rupr. \& Maxim. ${ }^{1}$}

Determined by H. TAKeDA.

\section{Maackia hupehensis Takeda, $\mathrm{n}$. sp.}

Arbor 5-23-metralis trunco 0.6-2.5 m. circuitu. Folia imparipinnata, $5-6$-juga, foliolis inferioribus $2-3 \mathrm{~cm}$. longis $12-15 \mathrm{~mm}$. latis ovatis, mediis ovato-ellipticis, superioribus $4-6 \mathrm{~cm}$. longis $15-20 \mathrm{~mm}$. latis, ellipticis obtusis chartaceis in sicco opacis subtus pallidioribus, juvenilibus dense velutinis, adultis subtus dense et adpresse hirsutis, petiolo pubescenti. Racemi basi ramosi, densiflori, rhachi pedicellisque tomentellis. Flores pro genere magni, albi, ad $10 \mathrm{~mm}$. Iongi, bracteati, bracteis subulatis $2-3 \mathrm{~mm}$. longis; calyx campanulatus, $4 \mathrm{~mm}$. longus, tomentellus, inaequaliter 4-lobatus; petala subaequilonga: vexillum orbiculatum, emarginatum, unguiculatum; alae oblique hastatae; carinae petala semisagittata, dorso arete imbricata; stamina basi brevissime connata; ovarium dense hirsutum, subsessile, 6-ovulatum, stylo inflexo, stigmate punctiformi. Legumen desideratur.

${ }^{1}$ For a detailed account of this genus see Takeda in Not. Bot. Gard. Edinburgh, XXXVII. (ined.). 
Western Hupeh: north of Ichang, open country, fairly common, alt. 1000-1300 m., May and August 1907 (No. 709, in part); Hsingshan Hsien, thickets, alt. 1600-2300 m., August 1907 (No. 709, in part); Fang Hsien, woodlands, alt. 1600-2300 m., June and August 1907 (No. 709, in part); Nanto, July 1900 (Veitch Exped. No. 1516). Kiangsi : Kuling, thickets, common, alt. 1300 m., July 29, 1907 (No. I7r6; tree 3-5 m.). Eastern Szech'uan: Wushan Hsien, August 1900 (Veitch Exped. No. 1582).

Maackia hupehensis is to be placed between M. amurensis Ruprecht et Maximowicz and $M$. Fauriei Takeda, and is more intimately related to the latter, from which it differs, however, in its slightly larger flowers, longer bracts and densely hirsute leaves. The fruit which might affords a good distinguishing character is unfortunately unknown.

In moist, rich, open country small trees of this new species are common in western Hupeh, but large specimens are rare, and the tree has not been reported from farther west. The bark is pale greenish-gray and the spreading branches form a flattish crown. In spring the bud-scales are bluish with yellow margins and the young, unfolding leaves are silvery gray and in this stage the tree is particularly striking. The flowers are dirty white and very freely produced but are not attractive. A picture of this new tree will be found under No. 081 of the collection of my photographs.

E. H. W.

\section{PIPTANTHUS D. Don.}

Piptanthus nepalensis D. Don in Sweet, Brit. Flow. Gard. III. t. 264 (1827-29).

Western Szech'uan : Mupin, thickets, alt. $3000-3300$ m., August 1908 (No. 885, in part; bush 1-1.6 m. tall); Tachien-lu, thickets, alt. 2300-3500 m., July and September 1900 (No. 885, in part; bush 1-1.6 m. tall); without precise locality, alt. 3600 m., June 1904 (Veitch Exped. No. 3403).

\section{INDIGOFERA L.}

Indigofera amblyantha Craib in Not. Bot. Gard. Edinburgh, XXXVI. 47 (1913).

Western Hupeh: Hsing-shan Hsien, alt. 1300-1600 m., June 1907 (No. 3077, type; bush $2 \mathrm{~m}$. tall, flowers pink); same locality, thickets, alt. 1000-1200 m., May 25, 1907 (No. 3078, 3078 ; bush 1-2 m. tall, flowers carmine-red); Fang Hsien, thickets, alt. $1800 \mathrm{~m}$., July 1907 (No. 3079; bush 1.2-1.6 m. tall, flowers pink); Ichang, alt. 300-1000 m., December 1907 (No. 786, fruiting specimen); without precise locality, 1901 (Veitch Exped. No. 2017). 
The erect, racemose inflorescence of this pleasing shrub continues to grow and bear flowers from mid-July until late autumn. The flowers vary from pale rose to red-pink and are very freely produced. The shrub is common in western Hupeh but has not been recorded from Szech'uan.

E. H. W.

Indigofera dichroa Craib, 1. c. 50 (1913).

Western Szech'uan: Wa-shan, thickets, alt. 2000 m., June 1908 (No. 3084; bush $1.6 \mathrm{~m}$. tall, flowers pale pink).

Indigofera ichangensis Craib, 1. c. 55 (1913).

Western Hupeh: Fang Hsien, 1901 (Veitch Exped. No. 2034); without precise locality, April 1908 (Veitch Exped. No. 466).

Indigofera ichangensis, f. calvescens Craib, 1. c. 75 (1913).

Western Hupeh: Hsing-shan roadsides, alt. 1000-1300 m., May 5, 1907 (No. 3082; bush 0.6-2 m. tall, flowers blush-pink).

Indigofera ichangensis, f. leptantha Craib, 1. c. 75 (1913).

Western Hupeh: Changlo Hsien, side of streams, alt. $1300 \mathrm{~m}$., May 1907 (No. 308I; bush 1.3-1.6 m. tall, flowers purple).

Indigofera ichangensis, f. rigida Craib, 1. c. 75 (1913).

Western Hupeh: Patung Hsien, thickets, alt. 600-800 m., May and June 1907 (No. 3083; bush 0.6-2 m. tall, flowers pink).

Indigofera Monbeigii, Craib, 1. c. 57 (1913).

Western Szech'uan: near Mao-chou, roadsides, alt. 1000-1600 m., May 23, 1908 (No. 3075; bush 1 m. tall, flowers red); Monkong Ting, dry places, alt. 1600-2300 m., June 1908 (No. 308o; bush 0.6$1 \mathrm{~m}$. tall, flowers crimson).

Indigofera pseudotinctoria Matsumura in Bot. Mag. Tokyo, XVI. 62 (1902). - Craib in Not. Bot. Gard. Edinburgh, XXXVI. 69 (1913).

Western Hupeh: Ichang, ravines, alt. 300-1000 m., May 1907 (No. 786, flowering specimens only; bush 1-2 m. tall, flowers red); Patung Hsien, side of streams, alt. 1000-1300 m., May 1907 (No. 3076; bush 1.3-1.6 m. tall, flowers white); Fang Hsien, thickets, alt. 1000-1300 m., August 197 (No. 3489; bush 2-2.6 m. tall, flowers rosypink); same locality, alt. 2000 m., July 1907 (No. 349o; bush $1.3 \mathrm{~m}$. tall, flowers pink); without precise locality, 1900 (Veitch Exped. Nos. 408, 2711).

A colloquial name for this very common shrub is "Yeh-lan-chih-tzu."

E. H. W. 
Indigofera szechuensis Craib in Not. Bot. Gard. Edinburgh, XXXVI. 62 (1913).

Western Szech'uan: Mao-chou, Min Valley, alt. 1600 m., May 1908 (No. 3075 ; bush $1 \mathrm{~m}$. tall, flowers red).

Indigofera Wilsonii Craib, l. c. 63 (1913).

Western Szech'uan: Min Valley, alt. 1300-16 m., May 26, 1908 (No. 3074; prostrate shrub, flowers crimson).

Indigofera is a feature of the vegetation of the warm arid river-valleys of western Szech'uan.

E. H. W.

Here may be added some species not collected during the Arnold Arboretum Expeditions.

Indigofera chalara Craib in Not. Bot. Gard. Edinburgh, XXXVI. 49 (1913).

Western Hupeh: Hsing-shan, cliffs, May 1901 (Veitch Exped. No. 1230, in part); without precise locality, June 1900 (Veitch Exped. No. 1230, in part).

Indigofera lenticellata Craib, 1. c. 56 (1913).

Western Szech'uan: Min Valley, alt. 1500 m., July 1903 (Veitch Exped. No. 3386 ; bush $0.3-0.6 \mathrm{~m}$. tall, flowers red).

Indigofera myosurus Craib, 1. c. 58 (1913).

Western Szech'uan: without precise locality, alt. 1000 m., May 1904 (Veiteh Exped. No. 3382; $0.6 \mathrm{~m}$. tall, flowers light pink).

Indigofera scabrida Dunn in Jour. Linn. Soc. XXXV. 487 (1903). - Craib in Not. Bot. Gard. Edinburgh, XXXVI. 64 (1913).

Western Hupeh: without precise locality (Veitch Exped, No. 3385).

\section{MILLETTIA Wight \& Arn.}

Determined by S. T. DUnN.

Millettia Dielsiana Harms in Bot. Jahrb. XXIX. 412 (1900).

Western Hupeh: Hsing-shan Hsien, thickets, alt. 300-600 m., July 1907 (No. 3278; climber, 3 m., flowers dark red); Changlo Hsien, eliffs, alt. 500 m., June 1907 (No. 3279; climber, 3 m., flowers dark red); north and south of Ichang, rocky places, common, alt. 3001000 m., June 1907 (Nos. 328o, 328I; climber, 2-4 m., flowers dark red); Patung Hsien, ravines, roadside thickets, alt. 600-1000 m., July and October 1907 (No. 506; climber, 3-5 m., flowers dark red); Nanto, May 1900 (Veitch Exped. No. 824); without precise locality, June 1900 (Veitch Exped. No. 1089). North-central Szech'uan: Pa-chou, thickets, alt. 600-1000 m., July 1910 (No. 4603; climber, 2-3 m., flowers reddish). Western Szech'uan: Mt. Omei, June and July 1904 (Veitch Exped. Nos. 4834, 4835); without precise locality, June and September 1903 (Veitch Exped. Nos. 3412, 3412a).

A colloquial name for this common climber is "Yeh-wan-ton." E. H. W. 
Millettia pachycarpa Bentham in Miquel, Pl. Jungh. I. 250 (1852).Hemsley in Hooker's Icon. XXVIII. t. 2738 (1902).

Western Szech'uan: Ya-chou Fu, thickets, alt. 600 m., November 1910 (No. 4608; large climber, $7 \mathrm{~m}$. or more).

Millettia reticulata Bentham in Miquel, Pl. Jungh. I. 249 (1852).

Kiangsi : Kiukiang, plains, alt. 100 m., July 27, 1907 (No. r648; climber 3-5 m., flowers dark red). Western Hupeh: grassy hills around Ichang, alt. 30-300 m., July 1907 (No. 3282; climber 2-3 m., flowers red); without precise locality, June 1900 (Veitch Exped. No. 1017).

A colloquial name for this common climbing shrub is "Ch'ai-chiao-t'êng."

E. H. W.

\section{WISTERIA Nutt.}

Wisteria chinensis De Candolle, Prodr. II. 390 (1825).

Western Hupeh: fairly common on cliffs and trees around Ichang, alt. 300-500 m., April 1907 (No. 2360; climber, flowers pale purple).

Everywhere common from river-level to $1000 \mathrm{~m}$. altitude in western Hupeh and Szech'uan where it is known by the colloquial name of "Chiao-t'êng." A pieture of a large specimen will be found under No. 62 of the collection of my photographs and also in my Vegetation of Western China, No. 497.

E. H. W.

\section{CARAGANA Lam.}

Caragana bicolor Komarov in Act. Hort. Petrop. XXIX. 299, t. $9^{\mathrm{a}}$ (Gen. Carag. Monog.) (1909).

Western Szech'uan: Valley of Hsao-chin Ho, near Monkong Ting, alt. 3000-3600 m., June and October 1908 (No. 2200; bush 1$2 \mathrm{~m}$. tall, flowers yellow and bronze).

Caragana Boisii Schneider, Ill. Handb, Laubholzk. II. 96. (1907). Komarov in Act. Hort. Petrop. XXIX. 341, t. 15, fig. B (Gen. Carag. Monog.) (1909).

Western Szech'uan: heaths around Tachien-lu, alt. 2600-3300 m., September 1908 (No. 2199; bush 1-2 m. tall, flowers bronzy).

Caragana chamlagu Lamarck, Encycl. Méth. I. 616 (1783).Komarov in Act. Hort. Petrop. XXIX. 200, t. 5, fig. B (Gen. Carag. Monog.) (1909). 
Western Hupeh: north and south of Ichang, cultivated, alt. 600-1300 m., May, 1907 (No. 2203; 1-1.6 m. tall, flowers yellow); Patung Hsien, April 1901 (Veitch Exped. No. 1).

This shrub is frequently cultivated and the flowers, cooked with eggs, are eaten. E. H. W.

Caragana jubata Poiret, Encycl. Méth. Suppl. II. 89 (1811).Komarov in Act. Hort. Petrop, XXIX. 287, fig. 1 (Gen. Carag. Monog.) (1909).

Western Szech'uan: Pan-lan-shan, west of Kuan Hsien, heaths, alt. 3600-4600 m., June 1908 and October 1910 (Nos. 220I, 4374; bush $0.6-1.6 \mathrm{~m}$. tall, flowers primrose-yellow); west of Tachien-lu, heath, alt. 3600-4600 m., June and September 1908, October 1910 (Nos. 2202, 4376; bush 0.3-2 m., flowers rosy-pink); without precise locality, alt. 3600-4600 m., June 1904 (Veitch Exped. No. 3396).

Caragana Maximowicziana Komarov in Act. Hort. Petrop. XXIX. 269, t. 11, fig. B (Gen. Carag. Monog.) (1909).

Western Szech'uan: heaths around Tachien-lu, alt. 3000-4300 m., June and September 1908, October 1910 (Nos. I28o, 4176; bush 0.6-2 m. tall, flowers bronzy-yellow); without precise locality, September 1903, June 1904 (Veiteh Exped. Nos. 3395, 3398).

\section{DESMODIUM Deso.}

Desmodium floribundum G. Don, Gen. Syst. II. 97 (1832).

Western Hupeh: Changyang Hsien, thickets, alt. 600-800 m., June and Oetober 1907 (No. 401; bush 0.6-1.3 m. tall, flowers purple); Changlo Hsien, grassy mountains, alt. 1300-1600 m., June and September 1907 (No. Io79 ; bush $1.6 \mathrm{~m}$. tall, flowers rosy-purple).

A vernacular name for this shrub is "Yeh-huang-tou."

E. H. W.

Desmodium laburnifolium De Candolle, Prodr. II. 337 (1825).

Western Szech'uan: Hungyah Hsien, roadside thickets, alt. 300-800 m., September 4, 1908 (No. 2939; 0.4-0.6 m. tall, flowers white).

Desmodium laxiflorum De Candolle in Ann. Sci. Nat. IV. 100 (1825); Prodr. II. 335 (1825).

Western Szech'uan: Hungyah Hsien, side of ditches etc., alt. 300-800 m., September 5, 1908 (No. 2929; 0.3-0.6 m. tall, flowers purple). 
Desmodium podocarpum De Candolle, var. szechuenense Craib, n. var.

A typo recedit foliolis multo angustioribus.

Western Szech'uan: Ya-chou Fu, grassy places, alt. 300-1000 m., September 1908 (No. 2933; bush 0.6-1 m. tall, flowers purple); without precise locality, 1904 (Veitch Exped. No. 4830); Mt. Omei, A. Henry (No. 167).

Desmodium serriferum Wallich, Cat. No. 5708 (nomen nudum) (1831).

Desmodium oxyphyllum De Candolle, var. serriferum Baker in Hooker f., Fl. Brit. Ind. II. 167 (1879).

Western Szech'uan: Mupin, thickets, alt. 1000-1300 m., November 1908 (No. I236; bush 1-1.3 m. tall, flowers red-purple); near Tachien-lu, roadside thickets, alt. 2300-2500 m., October 1908 (No. I236 ${ }^{\mathrm{a}}$; bush 1-1.6 m. tall); Kiating $\mathrm{Fu}$, thickets, alt. 300-600 m., September 1908 (No. 2927; bush 0.6-1 m. tall, flowers rose-purple); same locality, alt. 300-1000 m., September 1908 (No. 2928; bush 0.6-1 m. tall, flowers violet-purple).

Desmodium sinuatum Blume apud Baker in Hooker f., Fl. Brit. Ind. II. 166 (1879).

Desmodium strangulatum, var. sinuatum Miquel, Fl. Ind. Bat. I. 255 (1855).

Western Szech'uan: Tung Valley, thickets, alt. 600-1200 m., 1908 (No. 294I ; shrub 1-1.2 m. tall, flowers purple).

Desmodium tiliaefolium G. Don, Gen. Syst. II. 297 (1832).

Western Szech'uan: south-east of Tachien-lu, thickets, alt. 1300-1600 m., June 1908 (No. 2936; bush 1.3-2 m. tall, flowers crimson); Mongkong Ting, descent Hsao-chin Ho, alt. 2300-2600 m., June 1908 (No. 2937; bush 0.6-2 m. tall, flowers deep yellow); Mupin, thickets, alt. 1000-1600 m., June 1908 (No. 2940; bush 1-1.2 m. tall, flowers purple).

\section{URARIA Desv.}

Uraria hamosa Wallich, var. sinensis Hemsley in Jour. Linn. Soc. XXIII. 177 (1887).

Western Szech'uan: Wa-shan, thickets, alt. 1300-1600 m., September 1908 (No. 2935; bush 1-1.3 m. tall, flowers violet-purple). 


\section{LESPEDEZA Michx.}

\section{Determined by A. K. Schindler.}

Lespedeza floribunda Bunge, Plant. Mongh.-Chin. 13 (1835).Maximowicz in Mém. Sav. Êtr. Acad. Sci. St. Pétersbourg, IX. 470 (Prim. Fl. Amur.) (1859); in Act. Hort. Petrop. II. 360 (1873).Hance in Jour. Linn. Soc. XIII. 78 (1871). - Franchet in Nouv. Arch. Mus. Paris, sér. 2, V. 248 (Pl. David. I. 96) (1883). - Hemsley in Jour. Linn. Soc. XXIII. 181 (1887). - Diels in Bot. Jahrb. XXIX. 415 (1900), excluso specimine citato Giraldi No. 1593.

Lespedeza medicaginoides Hemsley in Jour. Linn. Soc. XXIII. 182 (pro parte, non Bunge) (1887).

Lespedeza floribunda, var. alopecuroides Franchet, Pl. Delavay., 169 (1889).

Lespedeza fasciculiflora Franchet, 1. c. (1889).

Lespedeza bicolor Prain in Jour. As. Soc. Bengal. LXVI. 377 (non Turezaninow) (1897).

Western Hupeh: grassy places around Ichang, alt. 30-600 m., July 1907 (No. 349I; shrub, 0.30-1 m. high, flowers purple). Chihli: Hills near Nankow, October 5, 1905, J. G. Jack.

Lespedeza floribunda, var. alopecuroides Franchet is identical with the type of Bunge showing only a denser foliage and shorter racemes. Lespedeza fasciculiflora Franchet, based on No. 1976 of Delavay, is a small prostrate plant with leaflets a little shorter and broader, and with narrower bracteoles, but in calyx and corolla and in the nerves of the leaflets identical with $L$. floribunda. There being no fruit it seems impossible on such unimportant differences to separate as a species or even as a variety, these specimens from $L$. floribunda. Lespedeza fasciculiflora seems to me only a depauperate prostrate form of $L$. floribunda.

Lespedeza sericea Miquel in Ann. Mus. Lugd.-Bat. III. 49 (1867); Prol. Fl. Jap. 237 (1867). - Baker in Hooker f., Fl. Brit. Ind. II. 142 (1879). - Prain in Jour. As. Soc. Bengal. LXVI. 374 (1897).

Hedysarum sericeum Thunberg, Fl. Jap. 287 (err. typ. 289) (1784).

Anthyllis cuneata Dumont de Courset, Bot. Cult. ed. 2, VI. 100 (1811).

Aspalathus cuneata D. Don, Prodr. Fl. Nepal. 246 (1824).

Lespedeza juncea De Candolle, Prodr. II. 348 (pro parte) (1825). - Turezaninow, Fl. Baical.-Dahur. I. 340 (1842-45). - Miquel, Fl. Ind. Bat. I. 230 (non Persoon) (1855).

Lespedeza eriocarpa Wallich, Cat. No. 5743 C?, D?, E (nomen nudum) (1831). G. Don, Gen. Syst. II. 307 (non De Candolle) (1832).

Lespedeza cuneata G. Don, Gen. Syst. II. 307 (1832). - Bentham in Hooker, Jour. Bot. \& Kew. Gard. Misc. IV. 47 (1852); Fl. Hongk. 85 (1861); Fl. Austral. II. 240 (1864).

Hedysarum junceum Roxburgh, Fl. Ind. ed. 2, III. 362 (non Linnaeus f.) (1832). 
Indigofera chinensis Vogel in Nov. Act. Acad. Leop.-Carol. XIX. Suppl. 14 (1843). - Walpers, Rep. I. 669 (1842). - Hemsley in Jour. Linn. Soc. XXIII. 156 (1887).

Lespedeza argyrea Siebold \& Zuccarini in Abh. Akad. Muench. IV. pt. II. 120 (Fl. Jap. Fam. Nat. I. 12) (1845).

Lespedezia juncea Miquel in Jour. Bot. Néerl. I. 123 (1861).

Lespedeza juncea, var. sericea Maximowicz in Act. Hort. Petrop. II. 371 (1873). - Hemsley in Jour. Linn. Soc. XXIII. 181 (1887). - Collett \& Hemsley in Jour. Linn. Soc. XXVIII. 45 (1890). - Diels in Bot. Jahrb. XXIX. 415 (1900), excluso specimine citato, Giraldi No. 1595.

Lespedeza juncea Persoon, var. kanaoriensis Maximowiez in Act. Hort. Petrop. II. 371 (pro parte) (1873).

Lespedeza juncea var. a. juncea Hemsley in Jour. Linn. Soc. XXIII. 181 (pro parte, non Maximowicz) (1887).

Lespedeza juncea Persoon, vars. a. glabrescens, $\beta$. sericea, $\gamma$. hispida Franchet, Pl. Delavay. 169, 170 (1889).

Western Szech'uan: Kiating-Fu, grassy places, alt. 300-500 m., September 1908 (No. 293 I shrub, 0.30-1 m. high, flowers white). Western Hupeh: September 1900 (Veitch Exped. No. 1716). Kiangsu: Chinkiang, September 1890, W. R. Carles (No. 470). Chekiang: Vicinity of Ningpo, 1908, D. Macgregor. Formosa: "in collibus Pachiran," June 1903, U. Faurie (No. 150). Corea: "in herbidis Quelpaert," October 1906, U. Faurie (No. 413); same locality, September 1907, Taquet (No. 79).

Lespedeza Buergeri Miquel in Ann. Mus. Lugd.-Bat. III. 47 (1867); Prol. Fl. Jap. 235 (1867). - Maximowicz in Act. Hort. Petrop. II. 353 (1873), excluso specimine citato Wilford. - Hemsley in Jour. Linn. Soc. XXIII. 179 (1887). - Diels in Bot. Jahrb. XXIX. 415 (1900). - Pampanini in Nuov. Gior. Bot. Ital. n. ser. XVII. 398 (1910), XVIII. 123 (1911).

Lespedeza Sieboldii Miquel in Ann. Mus. Lugd.-Bat. III. 47 (1867), quoad specimen citatum: Oldham No. 333, ceteris exclusis; Prol. Fl. Jap. 235 (1867).

Lespedeza Oldhami Miquel l. c. 48; 236 (1867).

Lespedeza cyrtobotrya Miquel, 1. c. 48, 236 (1867), quoad specimen citatum Oldham s. nom. $L$. virgatae?, ceteris exclusis.

Lespedeza Buergeri Miquel, var. Oldhami Maximowicz in Act. Hort. Petrop. II. 354 (1873)

Lespedeza bicolor Turczaninow, $\beta$. intermedia Maximowicz, 1. c. 356 (1873), quoad specimen citatum Oldham No. 335 , ceteris exclusis.

Lespedeza Buergeri Miquel, forma angustifolia Makino in Tokyo Bot. Mag. XX. 41 (1906).

Szech'uan: A.v. Rosthorn(No. 1652). Western Hupeh : Hsingshan Hsien, thickets, alt. 1300 m., July 1907 (No. 3494; bush 2.5 m., 
high, flowers pale purple); same locality, alt. 1300-1600 m., June and November 1907 (No. 644; bush, $2 \mathrm{~m}$. high, flowers greenish white, spotted purple); Fang Hsien, July 1901 (Veitch Exped. No. 2145); Pao-kang (Veitch Exped. No. 1222). Kiangsi: Kuling, side of streams, alt. 1200 m., July 28, 1907 (No. I631; shrub, 1-2 m. high, flowers yellow to purple).

On the sheets of the type specimens of Miquel's Lespedeza Sieboldii and Lespedeza cyrtobotrya and of Maximowicz's Lespedeza bicolor var. intermedia are also specimens of Miquel's Lespedeza Buergeri.

Lespedeza Davidii Franchet in Nouv. Arch. Mus. Paris, sér. 2. V. 246, t. 13 (Pl. David. I. 94, t. 13) (1883). - Hemsley in Jour. Linn. Soc. XXIII. 180 (1887).

Kiangsi : a common constituent of the jungle round Kuling, alt. 1200-1600 m., July 31, 1907 (No. 1616; bush, 1.5-2 m. high, flowers reddish-purple).

I have not seen this species in this locality at a higher altitude than $1400 \mathrm{~m}$.

Lespedeza formosa Koehne, Deutsche Dendrol. 343 (1893).

Desmodium formosum Vogel in Nov. Act. Acad. Leop.-Carol. XIX. Suppl. 29 (1842). - Walpers, Rep. I. 740 (1843). - Hemsley in Jour. Linn. Soc. XXIII. 172 (1887).

Desmodium racemosum Siebold \& Zuccarini in Abh. Akad. Münch. IV. pt. II. 121 (Fl. Jap. Fam. Nat. I. 13) (pro parte, non De Candolle) (1845).

Lespedeza viatorum Champion in Hooker, Jour. Bot. \& Kew. Gard. Misc. IV. 47 (1852). - Seemann, Bot. Voy. Herald, 374 (1852-57). - Bentham, Fl. Hongk. 86 (1861). - Maximowicz in Act. Hort. Petrop. II. 355 (err. typ. viatrum) (1873). - Hemsley in Jour. Linn. Soc. XXIII. 183 (1887).

Lespedeza racemosa Siebold in herb. ex Miquel in Ann. Mus. Lugd.-Bat. III. 47 (quasi synon., pro parte) (1867); Prol. Fl. Jap. 235 (1867). - Dippel, Handb. Laubholzk. III. 720 (1893).

Lespedeza Sieboldi Miquel in Ann. Mus. Lugd.-Bat. III. 47 (1867), excluso specimine citato Oldham No. 333); Prol. Fl. Jap. 235 (1867).

Lespedeza bicolor Turczaninow, forma microphylla Miquel, 1. c. 47 (pro parte) (1867).

Lespedeza cyrtobotrya Miquel in Ann. Mus. Lugd.-Bat. III. 48 (pro parte) (1867); Prol. Fl. Jap. 236 (1887).

Lespedeza elliptica Bentham in Cat. Griffith distr. a Kero, No. 1745 (nomen nudum). - Maximowicz in Act. Hort. Petrop. II. 351 (1873). - Baker in Hooker f., Fl. Brit. Ind. II. 143 (1879). - Hemsley in Jour. Linn. Soc. XXIII. 180 (1887). - Franchet, Pl. Delavay. 168 (1889). - Diels in Bot. Jahrb. XXIX, 415 (1900).

Lespedeza bicolor Maximowicz in Act. Hort. Petrop. II. 356 (1873), quoad var. a. typica (pro parte) et var. $\gamma$. Sieboldii, ceteris exclusis, non Turczaninow). - Hemsley in Jour. Linn. Soc. XXIII. 179 (pro parte) (1887). Diels in Bot. Jahrb. XXIX. 415 (pro parte) (1900).

Desmodium penduliflorum Oudemans in Neerl. Plantentuin, II. t. 2 (1886). 
Kiangsi : Kuling, roadside, alt. 750 m., August 1, 1907 (No. r643), thickets, alt. 1200 m., July 30, 1907 (No. I6r7; shrub 2 m. high, flowers purple). Western Hupeh: north and south of Ichang, thickets, alt. 300-1000 m., June 1907 (No. 2924; shrub, 1 m. high, flowers rosy-purple); Fang Hsien, uplands, alt. 1300-2000 m., July and November 1907 (No. 575; bush 1-1.60 m. high, flowers redpurple); Patung Hsien, thickets, alt. 1000-1600 m., July and December 1907 (No. 774; bush, 1-2 m. high, flowers red-purple); Chang-lo Hsien, thickets, alt. 1300 m., August 1907 (No. 3493; bush, 1.5 m. high, flowers purple); Changyang Hsien, thickets, alt. 1000-1500 m., August 1907 (No. 438; bush, 1-2 m. high); same locality, thickets, alt. 13001600 m., July and December 1907 (No. 787; bush, 2 m. high, flowers rosy-purple); Hsing-shan Hsien, thickets, alt. 1000-1600 m., August and November 1907 (No.643; bush, 1.5-2 m. high, flowers red-purple); Hsing-shan Hsien, July 1900 (Veitch Exped. No. 1238); without precise locality, (Veitch Exped. Nos. 1304, 1581); August 1900 (Veitch Exped. No. 1630); August 1901 (Veitch Exped. No. 1573). Eastern Szech'uan: Wushan, July 1900 (Veitch Exped. No. 1391). Western Szech'uan: west and near Wên-chuan Hsien, thickets, alt. 1000-1600 m., July 1908 (No. 2925; bush, 2 m. high, flowers purplish). Hongkong: October 11, 1893, Ch. Ford; November 5, 1903, C. S. Sargent. Shantung: Tsingtau, 1901, Zimmermann (Nos. 243, 276). Korea: Ping-Yang, September 18, 1905, J. G. Jack; " in herbidis Quelpaert," October 1906, U. Faurie (No. 416); same locality, September 1907, Taquet (No. 82); "Quelpaert in sepibus Hongno," September 30, 1908, Taquet (No. 693).

Here may be added notes and descriptions based on material in the Herbarium of the Arnold Arboretum, but referring to species not collected during the Arnold Arboretum Expeditions.

Lespedeza inschanica Schindler, n. comb.

Lespedeza juncea Persoon, var. inschanica Maximowicz in Act. Hort. Petrop. II. 371, in nota (1873). - Hemsley in Jour. Linn. Soc. XXIII. 181 (1887). Lespedeza medicaginoides Hemsley, 1. c. 182 (1889), cum dubio (pro parte, quoad specimina citata Skatschkoff et Webster, ceteris exclusis).

Lespedeza floribunda Diels in Bot. Jahrb. XXIX. 415 (non Bunge) (1900), quoad specimina citata Giraldi No. 1593, ceteris exclusis.

Lespedeza juncea Persoon, var. $\gamma$. sericea Diels in Bot.Jahrb. XXIX. 415 (non Maximowicz) (1900), quoad specimina eitata Giraldi, No. 1595, eeteris exclusis.

- Lespedeza juncea Maximowicz in Act. Hort. Petrop. II. 370 (1873) (pro parte, quoad specimina citata Bunge, ceteris exelusis.

Lespedeza juncea, var. a. juncea Hemsley in Jour. Linn. Soc. XXIII. 181 (non Maximowicz) (1887), quoad specimina citata Tatarinow et Debeaux, ceteris exclusis. 
? Lespedeza juncea Persoon, var. latifolia Maximowicz in Act. Hort. Petrop. II. 369, 371 (1873). - Hemsley in Jour. Linn. Soc. XXIII. 181 (1887).

? Lespedeza juncea Persoon, var. subsessilis Miquel in Ann. Mus. Lugd.-Bat. III. 49 (1867); Prol. Fl. Jap. 237 (1867).

? Lespedeza Caraganae Maximowicz in Act. Hort. Petrop. II. 372 (pro parte, non Bunge) (1873), quoad specimen citatum Kirilow, ceteris exclusis.

Korea: "in herbidis Chinnampo," August 1906, U. Faurie (No. 414).

Lespedeza juncea Persoon, Syn. II. 318 (1807). - De Candolle, Prodr. II. 348 (1825), exclusis synonymis eitatis: Dumont de Courset et Thunberg. - G. Don, Gen. Syst. II. 307 (1832), - Bunge, Pl. Mongh.-Chin. 10 (1835), - Ledebour, Fl. Ross. I. 714 (1842). - Turezaninow, Fl. Baic.-Dahur. I. 340 (1842-45) excluso synonymo citato Thunberg. - Maximowicz in Mém. Sav. Etr. Acad. Sci. St. Pétersbourg, IX. 86, 471 (Prim. Fl. Amur.) (1859); in Act. Hort. Petrop. II. 370, 371 (1873), quoad var. a. partim, specimina citata: "Peking, Bunge, Shantung, Debeaux." - Franchet in Nouv. Arch. Mus. Paris, sér. 2, V. 248 (Pl. David. I. 96) (1883).

Hedysarum junceum Linnaeus f., Dec. I. 7, t. 4 (1762). - Linnaeus, Spec. ed. II, 1053 (1763). - Hill, Veg. Syst. XXI. 38 f. 2 (1772). - Willdenow, Spec. ed. III. 1194 (pro maxima parte) (1803). - Poiret, Encycl. Mêth. Suppl. III. 3 (1804).

Trifolium hedysaroides Pallas, Reise Russ. Reich. III. Anh. 751, t. Dd, fig. 3 (1772-73). - De Candolle, Prodr. II. 204 (1825).

Trifolium cytisoides Pallas, Reise Russ. Reich. III. 266 (Anh. 124, t. Dd. fig. 2), error pro Trifolium hedysaroides.

Hallia juncea Poiret, Encycl. Méth. Suppl. III. 3 (1813).

Lespedezia juncea Hornemann, Hort. Reg. Bot. II. 699 (1815). - Sprengel, Syst. Veg. ed. 16, III. 202 (1826).

Lespedeza juncea Baker in Hooker f., Fl. Brit. Ind. II. 142 (non Persoon) (1876), quoad synonyma citata: Linnaeus, Persoon, De Candolle.

Lespedeza juncea Persoon, var. a. juncea Hemsley in Jour. Linn. Soc. XXIII. 181 (non Maximowiez) (1887), quoad specimina citata Staunton et David No. 2137, partim, et loc. Siberia et Mandshuria. ${ }^{1}$

Manchuria: province of Mukden on the bank of the Yalu River, September 1896, V. Komarov (No. 963). Siberia : “Amur med.”, July 1891, S. Korshinsky.

Lespedeza trichocarpa Persoon, Syn. II. 318 (1807). - De Candolle, Prodr. II. 349 (1825). - G. Don, Gen. Syst. II. 307 (1832). - Bunge, Pl. Mongh.-Chin. 10 (1835). - Turczaninow in Bull. Soc. Nat. Mosc. X. pt. VII. 151 (Enum. Pl. Chin. Bor. No. 59) (1837); Fl. Baic.-Dahur. I. 341 (1842-45), - Ledebour, Fl. Ross. I. 714 (1842). - Maximowicz in Mém. Sav. Etr. Acad. Sci. St. Pétersbourg, IX. 471, 481 (Prim. Fl. Amur.) (1859); in Act. Hort. Petrop. II. 375 (1873). Debeaux in Act. Soc. Linn. Bordeaux, XXXI. 142 (Fl. Tché-Fou, 47) (1876). -

1 To this species belong also the following Prelinnean names:

Cytisus saxatilis, Meliloti folio ad caulem adpresso, floribus in foliorum alis, pluribus confertim, exiguis albidis. Messerschmidt, Hodeg. 1724 (ex Amman).

Hedysarum triphyllum flosculis albis, polyanthos, silicula laevi. Amman, Stirp. Rar. Ruth. 116 (1749).

Hedysarum foliis ternatis, oblongis acuminatis, floribus sparsis. J. G. Gmelin, Fl. Sibir. IV. 31 (1769). 
Franchet in Nouv. Arch. Mus. Paris, sér. 2, V. 249 (Pl. David. I. 97) (1883); in Mém. Soc. Sci. Nat. Cherbourg, XXIV. 211 (1884). - Hemsley in Jour. Linn. Soc. XXIII. 183 (1887). — Diels in Bot. Jahrb. XXIX. 415 (1900).

Trifolium dauricum Laxmann in Nov. Comm. Acad. Petrop. XV. 560, t. 30, fig. 5 (1771), - Pallas, Reise Russ. Reich. III. 321 (1772-73).

Hedysarum trichocarpum Stephen in Willdenow, Spec. III. 1194 (1803).

Hedysarum hirtum Poiret, Encycl. Méth. VI. 409 (pro parte, non Linnaeus) (1804), synonymis excludendis.

Hallia trichocarpa Poiret, Encycl. Méth. Suppl. III. 3 (1813).

Hallia hirta Poiret, 1. c. (pro parte) (1813).

Lespedeza Pallasii G. Don, Gen. Syst. II. 307 (verisimiliter) (1832).

Lespedeza medicaginoides Bunge in Mém. Sav. Etr. Acad. Sci. St. Pétersbourg, II. 93 (Enum. Pl. Chin. bor. 19) (1833). - Maximowicz in Act. Hort. Petrop. II. 375 (1873). - Franchet in Nouv. Arch. Mus, Paris, sér. 2. V. 248 (Pl. David. I. 96) (1883). - Hemsley in Jour. Linn. Soc. XXIII. 183 (1887), quoad specimina citata: Staunton et Williams.

Lespedeza juncea Persoon, var. inschanica Maximowicz in Act. Hort. Petrop. II. 371 (pro parte, fide herb. Acad. Petrop.) (1873).

Lespedeza juncea Persoon, var. a. juncea Hemsley in Jour. Linn. Soc. XXIII. 181 (pro parte, non Maximowicz) (1887), quoad specimen eitatum Bushell. Lespedeza Gerardiana Franchet, Pl. Delavay. 169 (non Graham) (1890).

Lespedeza Fauriei Léveillé in Fedde, Rep. Nov. Sp. VII. 230 (1909).

Lespedeza Feddeana Schindler in Fedde, Rep. Sp. Nov. X, 405 (1912).

Korea: " in herbidis Chinnampo," August 1906, U. Faurie (No. 415).

Lespedeza virgata De Candolle, Prodr. II. 350 (1825). - G. Don, Gen. Syst. II. 308 (1832). - Miquel in Ann. Mus. Lugd.-Bat. III. 49 (1867), excludendo synonymo citato Siebold \& Zuccarini; Prol. Fl. Jap. 237 (1867). - Maximowicz in Act. Hort. Petrop. II. 362 (1873). - So-mokou-zoussets. XIV. 23 (1874). - Franchet in Mém. Soc. Sci. Nat. Cherbourg, XXIV. 212 (1884). - Hemsley in Jour. Linn. Soc. XXIII. 183 (1887). - Diels in Bot. Jahrb. XXIX. 415 (1900). Pampanini in Nuov. Giorn. Bot. Ital. n. ser. XVIII. 124 (1911).

Hedysarum virgatum Thunberg, Fl. Jap. 288 (err. typ. 290) (1784). — Willdenow, Spec. III. 1201 (1803).

Lespedeza virgata Siebold \& Zuccarini in Abh. Akad. Münch. IV. pt. II. 121 (Fl. Jap. Fam. Nat. I. 13) (pro parte, non De Candolle) (1843), quoad synonyma citata: De Candolle et Thunberg, descriptione et planta excludendis.

Lespedeza Swinhoei Hance in Ann. Sci. Nat. sér. 5, V. 210, t. 5. (1866).

Western Hupeh: July 1900 (Veitch Exped. No. 1417). Kiangsu: Chinkiang, August 1890, W. R. Carles (No. 473). Chekiang: Vicinity of Ningpo, 1908, D. Macgregor.

Lespedeza tomentosa Siebold apud Maximowicz in Act. Hort. Petrop. II. 376 (1873). - Debeaux in Ann. Soc. Linn. Bordeaux, XXXI. 141 (Fl. Tché-Fou, 46) (1876). - Baker in Hooker f., Fl. Brit. Ind. II, 143 (1876). - Franchet in Nouv. Arch. Mus. Paris, sér. 2, V. 249 (Pl. David. I. 97) (1883); in Mém. Soc. Sci. Nat. Cherbourg, XXIV. 212 (1884). - Diels in Bot. Jahrb. XXIX. 415 (1900).

Hedysarum tomentosum Thunberg, Fl. Jap. 286 (1784). - Willdenow, Spec.

III. 1181 (1803).

Hedysarum villosum Willdenow, 1. e. 1195 (1803).

Hedysarum coriaceum Poiret in Encycl. Méth. VI. 418 (1804). 
Lespedeza villosa Persoon, Syn. II. 318 (1807). - De Candolle, Prodr. II. 349 (1825) excludendo synonymo citato Linnaeus et Hornemann. - G. Don, Gen. Syst. II. 308 (pro parte) (1832), - Oliver in Jour. Linn. Soc. IX. 166 (1865). - So-mokou-zoussets, XIV. 20 (1874), - Hemsley in Jour. Linn. Soc. XXIII. 183 (1887).

Lespedezia glomerata Hornemann, Hort. Hafn. Suppl. 87 (1819). - De Candolle, Prodr. II. 350 (1825). - G. Don, Gen. Syst. II. 308 (1832).

Desmodium obtusum De Candolle, Prodr. II. 329 (pro parte) (1825).

Desmodium tomentosum De Candolle, 1. c. 337 (1825).

Lespedeza macrophylla Bunge, Pl. Mongh.-Chin. 10 (1835), - Turczaninow in Bull. Soc. Mosc. X. pt. VII. 151 (Enum. Pl. Chin. Bor.) (1837). Maximowicz in Mém. Sav. Êtr. Acad. Sci. St. Pétersbourg, IX. 470 (Prim. Fl. Amur.) (1859).

Lespedeza hirta Torrey \& Gray, Fl. N. Am. I. 368 (pro parte, non Elliot) (1838).- Miquel in Ann. Mus. Lugd.-Bat. III. 49 (1867); Prol. Fl. Jap. 237 (1867).

Lespedeza hirta, polystachya, villosa, hort. bot. olim.

Western Hupeh: Changyang (Veitch Exped. No. 1694). Yunnan: Mengtze, alt. 1380 m., A. Henry (No. 9815). Chekiang: Vicinity of Ningpo, 1908, D. Macgregor. Korea: "in herbidis Chinnampo," August 30, 1906, $U$. Faurie (No. 419).

Lespedeza Friebeana Schindler in Fedde, Rep. Sp. Nov. IX. 514 (1911).

Lespedeza Buergeri Maximowicz in Act. Hort. Petrop. II. 353 (pro parte, non Miquel) (1873), quoad specimen citatum: "Port Chusan, Wilford."

Lespedeza bicolor Hemsley in Jour. Linn. Soc. XXIII. 179 (pro parte, non Turczaninow) (1887), quoad specimina citata Carles, Wilford, Oldham (No. 339).

Korea : "in collibus Ouen-san," August 1901, U. Faurie (No. 51); same locality, July 1906, U. Faurie (No. 411); Seoul, September 21, 1905, J. G. Jack; Seoul, Nam-san, September 11, 1906, U. Faurie (No. 412).

\section{Lespedeza Dunnii Schindler, n. sp.}

Frutex erectus, ramosus, caule ramisque leviter lineatis, novellis subvillosotomentosis. Folia stipulis obscuris e basi latiore subulatis ad $5 \mathrm{~mm}$. longis et petiolo tomentoso ad $1 \mathrm{~cm}$. longo et rhachide ad $6 \mathrm{~mm}$. longa praedita, foliola elliptica v. ovali-elliptica, basi plerumque bene rotundata, apice obtusa v. retusa v. emarginata, mucronata, supra brevissime molliter subvelutino-sericea, subtus densius longiusque adpresse sericea, nervis secundariis supra impressis, subtus crasse prominentibus, foliolum terminale ad $3.5 \mathrm{~cm}$. longum et ad $1.6 \mathrm{~cm}$. latum, lateralia leviter minora. Racemi axillares, singuli, sublonge pedunculati, tomentosi, elongati, laxiflori, cum pedunculo ad $6 \mathrm{~cm}$. longi, folia superantes; bracteae lanceolatae, circiter $2 \mathrm{~mm}$. longae; pedicelli dense pilosi, eirciter $1.5 \mathrm{~mm}$. longi; bracteae secundariae pedicello saepe paullo adnatae; bracteolae lineares, circiter $2 \mathrm{~mm}$. longae, calycis tubum superantes; calyx profunde ultra dimidium 4-fidus, circiter $6 \mathrm{~mm}$. longus, corollae dimidium excedens, longe denseque adpresse sericeus, tubo 1-1.25 mm. longo, laciniis linearibus $4.5-4.75 \mathrm{~mm}$. longis, postica breviter $(1.5 \mathrm{~mm}$.) bifida; corolla ex sicco purpurea v. violacea, vexillo carinaque aequilongis alas superantibus, vexillo obovato apice retuso $8.5-9 \mathrm{~mm}$. longo et 6-6.5 $\mathrm{mm}$. lato breviter unguiculato et appendiculato, alis anguste ovalibus breviter $(1.5 \mathrm{~mm}$.) unguiculatis circiter $7.5 \mathrm{~mm}$. longis et $2.5 \mathrm{~mm}$. latis, carina obtusa breviter (2 mm.) unguiculata $8.5-9 \mathrm{~mm}$. longa et circiter $3 \mathrm{~mm}$. lata; ovarium apicem versus ciliatum, ceterum glabrum. Legumen ignotum. 
Central Fokien: Dunn's Exped., April to June 1905 (Herb. Bot. Gard. Hongkong, No. 2560).

Lespedeza cyrtobotrya Miquel in Ann. Mus. Lugd.-Bat. III. 47 (1867), excludendis synonymis citatis et planta "Desmodium racemosum var. albiflorum Siebold", partim et specimen citatum Oldhamii sub nom. "L. virgatae?"; Prol. Fl. Jap. 236 (1867). - Maximowicz in Act. Hort. Petrop. II. 357 (1873). Hemsley in Jour. Linn. Soc. XXIII. 180 (err. typ. "cyclobotrya") (1887).

Lespedeza virgata Siebold \& Zuccarini in Abh. Akad. Münch. IV. pt. II. 121 (Fl. Jap. Fam. Nat. I. 13) (pro parte, non De Candolle) (1845), excludendo synonymo citato Thunberg.

Campylotropis virgata Miquel, Fl. Ind. Bat. I. 230 (1855). - Maximowicz in Act. Hort. Petrop. II. 352 (1873).

Lespedeza bicolor Turezaninow, forma microphylla Miquel in Ann. Mus. Lugd.-Bat. III. 47 (pro parte, fide herb.) (1867); Prol. Fl. Jap. 236 (1867).

Lespedeza bicolor Maximowicz in Act. Hort. Petrop. II. 355 (pro parte, non Turczaninow) (1873), quoad synonymum eitatum Siebold partim. - Diels in Bot. Jahrb. XXIX. 415 (pro parte) non Turczaninow) (1900), quoad specimina citata Giraldi (Nos. 1557, 1559).

Lespedeza bicolor, var. a. typica Maximowicz in Act. Hort. Petrop. II. 356 (pro parte, fide herb.) (1873).

Lespedeza bicolor, var. $\beta$. intermedia Maximowicz, 1. c., quoad specimen citatum Tschonoski.

Korea: Seoul, September 21, 1905, J. G. Jack.

Lespedeza bicolor Turezaninow in Bull. Soc. Nat. Mosc. XIII. 69 (1840). Ledebour, Fl. Ross. I. 715 (1842). - Maximowicz in Mém. Sav. Êtr. Acad. Sci. St. Pétersbourg, IX. 86, 470 (Prim. Fl. Amur.) (1859); in Act. Hort. Petrop. I. 355 (1873), quoad var. a. typica, partim, et var. $\beta$. intermedia, partim, nempe specimen citatum Tatarinow. - Regel in Mém. Acad. Sci. St. Pétersbourg, sér. 7, IV. No. IV. 51 (Tent. Fl. Ussur.) (1861), - Miquel in Ann. Mus. Lugd.-Bat. III. 47 (pro parte) (1867); Prol. Fl. Jap. 236 (1867). - Debeaux in Act. Soc. Linn. Bordeaux XXXI. 140 (Fl. Tché-Fou, 45) (1876). - Franchet in Nouv. Arch. Mus. Paris, sér. 2, V. 247 (Pl. David. I. 95) (1883). - Hemsley in Jour. Linn. Soc. XXIII. 179 (1887), quoad specimina citata Skatschkoff, Tatarinow, Bretschneider, Maingay.

Lespedeza bicolor Turezaninow, forma microphylla Miquel in Ann. Mus. Lugd.-Bat. III. 47 (pro parte) (1867); Prol. Fl. Jap. 236 (1867).

Lespedeza bicolori affinis Maximowicz in Mém. Sav. Etr. Acad. Sci. St. Pétersbourg, IX. 470 (Prim. Fl. Amur.) (1859).

Lespedeza cyrtobotrya, So-mokou-zoussets, XIV. 19 (non Miquel) (1874).

Lespedeza japonica Schindler in Bot. Jahrb. XLVI. Beibl. CVI. 54, 55 (nomen) (1912).

Eastern Siberia: Vladiwostok, August 18, 1903, C. S. Sargent. Korea: " in petrosis Hallaisan," August 1907, U. Faurie (No. 1690); " in petrosis Quelpaert," July 1907, U. Faurie (No. 1689); "in herbidis Hallaisan," September 1907, Taquet (No. 77); Quelpaert " in sepibus Letchimeri," July 1908, Taquet (No. 695); Quelpaert " in sepibus Hallaisan," alt. 1500 m., August 13, 1908, Taquet (No. 696). 


\section{CAMPYLOTROPIS Bunge.}

Determined by A. K. SchindLer.

Campylotropis chinensis Bunge, $P l$. Mongh.-Chin. 7 (1835).Walpers, Rep. V. 527 (1845-46). - Schindler in Fedde, Rep. Sp. Nov. XI. 340 (1912). ${ }^{1}$

Lespedeza macrocarpa Bunge in Mém. Acad. Sci. St. Pétersbourg, II. 92 (Enum. Pl. Chin. Bor. 18) (1835).

Lespedeza ciliata Bentham in Hooker, Jour. Bot. \& Kew. Gard. Misc. IV. 48 in nota (1835).

Lespedeza ichangensis Schindler in Fedde, Rep. Sp. Nov. IX. 515 (1911).

Lespedeza Rosthornii Schindler 1. c. 516 (1911).

Lespedeza Muehleana Schindler, 1. c. 517, quoad specimen citatum Wilson, No. 1168.

Western Hupeh: Hsing-shan Hsien, thickets, alt. 1000-1600 m., July and November 1907 (No. 576; bush, 1-2 m. high, flowers pale purple); north and south of Ichang, thickets, alt. 1000-2000 m., July and December 1907 (No. 766; bush, 1-2 m. high, flowers purple); without precise locality, June 1901 (Veitch Exped. No. 1168). Western Szech'uan: Min Valley, roadsides, near Mao-chow, alt. 1500-1800 m., August 1910 (No. 4597; bush 1-2 m. high, flowers rosy-purple); near Wa-shan, grassy places, alt. 600-1300 m., August 1908 (No. 2926; 1-1.2 m. tall, flowers purple); A. v. Rosthorn (No. 1627). Chili : Pagoda Hill near Summer Palace, Peking, September 17, 1903, C. S. Sargent; Hills near Great Wall, Peking-Kalgan road, October 5, 1905, J. G. Jack. Chekiang: Vicinity of Ningpo, 1908, D. Macgregor.

Campylotropis Sargentiana Schindler in Fedde, Rep. Sp. Nov. XI. 341 (1912).

1. Lespedeza macrocarpa was published two years earlier than Campylotropis chinensis, for Bunge's Enumeratio plantarum appeared in 1833, not in 1835 as quoted by Dr. Schindler. This is shown by the fact that Bunge's work was reviewed by De Candolle as early as January 1834 in the Bibliothèque universelle de Genève (p. 107), and that in his Plantarum mongholico-chinensium decas prima Bunge himself quotes Lespedeza macrocarpa as a synonym of his new Campylotropis chinensis. This necessitates therefore the following combination:

Campylotropis macrocarpa Rehder, n. comb.

Lespedeza macrocarpa Bunge in Mém. Acad. Sci. St. Pétersbourg, II. 92 (Enum. Pl. Chin. Bor. 18) (1833).

Campylotropis chinensis Bunge, Pl. Mongh.-Chin. 7 (1835).

A. R. 
Western Szech'uan: north of Tachien-lu, dry arid regions west of Romi-chango, alt. 1800-2400 m., July 2, 1908 (No. 3492).

This species is closely related to $C$. polyantha Schindler, but differs from it in the thicker, more densely sericeous leaflets, in the smaller earlier caducous stipels and the shorter appressed pilose pedicels.

Campylotropis Wilsonii Schindler in Fedde, Rep. Sp. Nov. XI. 343 (1912).

Western Szech'uan: Min Valley, alt. 1500-2100 m., dry arid rock, August and September 1903, E. H. Wilson (Veitch Exped. Nos. $3387,3387^{\mathrm{a}}$ ); Valley above Lungan-Fu, dry places, alt. $1200 \mathrm{~m}$., August 1910 (No. 46I8; bush, 1-1.5 m. high, flowers rosy-red).

Campylotropis trigonoclada Schindler in Fedde, Rep. Sp. Nov. XI. 430 (1912).

Lespedeza trigonoclada Franchet, Pl. Delavay. 167, t. 42 (1889).

Lespedeza trigonoclada Franchet, var. angustifolia Pampanini in Nuov. Gior. Bot. Ital. n, ser. XVII. 24 (1910).

Lespedeza trigonoclada Franchet, f. intermedia Pampanini, 1. c.

Lespedeza angulicaulis (Harms) Schindler in Fedde, Rep. Sp. Nov. IX. 522 (1911).

Western Szech'uan: Tung Valley, grassy places, alt. 800 m., October 1908 (No. 2938; bush, 60-1 m. high, flowers creamy-yellow), (Veitch Exped. No. 3377). Yunnan: Mengtze, alt. 1500 m., A. Henry (Nos. 9135, 9622), Milê district, A. Henry (No. 9135ª).

This species is very variable in the shape of the leaflets, but as all the different forms of leaflets are found on the same plant it is impossible to distinguish varieties.

Here may be added the determination of some specimens of the Arnold Arboretum Herbarium, not collected during the Arnold Arboretum Expeditions. As the names with full synonymy have been published already in Fedde's Reperiorium, the synonyms are not repeated here.

Campylotropis yunnanensis (Franchet) Schindler in Fedde, Rep. Sp. Nov. XI. 338 (1912).

Yunnan: Mengtze, alt. 1380 m., A. Henry (No. 9134); Mengtze, woods, alt. 1400 m., A. Henry (Nos. 9702, 9702 ${ }^{\mathrm{a}}$ ).

Campylotropis Muehleana Schindler in Fedde, Rep. Sp. Nov. XI. 339 (1912).

Western China: (prob. Szech'uan), alt. 900 m., May 1904 (Veitch Exped. No. 3383 ).

Campylotropis polyantha (Franchet) Schindler in Fedde, Rep. Sp. Nov. XI. 340 (1912).

Western Szech'uan: without precise locality, May 1904 (Veitch Exped. No. 3378). Yunnan: Mengtze, grass mountains, alt. 1350-1500 m., A. Henry (Nos. $9626^{\mathrm{a}}, 9626^{\mathrm{b}}$ ). 
Campylotropis Prainii (Collett \& Hemsley) Schindler in Fedde, Rep. Sp. Nov. XI. 341 (1912).

Yunnan: Mengtze, woods, alt. 1500 m., A. Henry (Nos. 9803, 9803 ${ }^{\text {b) }}$.

Campylotropis diversifolia (Hemsley) Schindler in Fedde, Rep. Sp. Nov. XI. 342 (1912).

Yunnan: Mengtze, alt. 1500 m., A. Henry (Nos. $9243^{\mathrm{a}}$, $9243^{\mathrm{b}}$ ).

Campylotropis parviflora (Kurz) Schindler in Fedde, Rep. Sp. Nov. XI. 342 (1912) (sphalmate C. parvifolia).

Yunnan: Szemao, forests, alt. 1500 m., A. Henry (No. 12712).

Campyloytropis hirtella (Franchet) Schindler in Fedde, Rep. Sp. Nov. XI. $428(1912)$.

Yunnan: Mengtze, alt. 1500 m., A. Henry (No. 9689). (1912).

Campylotropis latifolia (Dunn) Schindler in Fedde, Rep. Sp. Nov. XI. 428

Yunnan: Milê district, A. Henry (No. 9889).

\section{DALBERGIA L. f.}

Dalbergia Dyeriana Prain in Jour. As. Soc. Beng. LXX. 44 (1901).

Western Hupeh: Ichang, thickets, alt. 300-600 m., June and October 1907 (No. 2903; climber 7 m. tall); same locality, May 1907 (No. 2909; large semi-scandent shrub, $7 \mathrm{~m}$. or more, flowers pale yellow); Nanto, May 1900 (Veitch Exped. No. 782; tree, 5 m. tall, flowers dirty white). Western Szech'uan : near Wa-shan, thickets, alt. 300-800 m., June and October 1908 (No. 2908; climber, 7 m. or more, flowers pale yellow); Mt. Omei, May 1904 (Veitch Exped. No. 4833).

A large growing climber, common at low altitudes in western Hupeh and Szech'uan.

E. H. W.

Dalbergia hupeana Hance in Jour. Bot. XX. 5 (1882).

Kingsi : Kiukiang, foot-hills, alt. 300 m., August 2, 1907 (No. I567; tree, 7-14 m. tall). Western Hupeh: Ichang, alt. 300-1000 m., June and October 1907 (No. 494; tree 7-20 m. tall, girth 0.3-1.3 m., flowers buff-yellow); same locality, June 1907 (No. 2094; tree, 7$10 \mathrm{~m}$. tall, flowers whitish); Hsing-shan Hsien, alt. $600 \mathrm{~m}$., July and October 1907 (Nos. 494 ${ }^{\mathrm{z}}, 2906$; tree, 7-14 m., girth 0.3-0.6 m., flowers. yellowish; valuable timber). Changyang Hsien, alt. 1000 m., July and December 1907 (No. 768; tree, 7-12 m. tall, girth 0.3-0.6 m., flowers yellowish); Patung Hsien, alt. 600-1000 m., August 1907 (No. 2907; tree, 7-10 m. tall, flowers buff-yellow); without precise locality, June 1900 (Veitch Exped. No. 864). 
This species, which is one of the most valuable of the Chinese timber trees, is everywhere common up to $1000 \mathrm{~m}$. altitude. It is a medium-sized tree with a relatively slender trunk and gray, roughish bark which exfoliates in thin, irregularly oblong sheets. The branches are small and ascending and form a narrow head. The wood is white or nearly so, heavy and very tough. It is largely used in turning and for making pulley-blocks, tool handles and for any and every purpose where strength is needed. Colloquially this tree is known as the "Tian shu," and the wood as "Tian mu." Pietures of this tree will be found under Nos. 63, $473,626,719,0247$ of the collection of my photographs and also in my Vegetation of Western China, Nos. 198-200.

E. H. W.

Dalbergia stenophylla Prain in Jour. As. Soc. Beng. LXX. 56 (1901).

Western Hupeh: Ichang, cliffs, alt. 300-600 m., June 8 and October 1907 (No. 632, in part; scandent bush, 3-7 m., flowers creamy white); without precise locality, July 1900 (Veitch Exped. No. 1350). Western Szech'uan: west and near Wên-chuan Hsien, alt. 1000 m., July 1908 (No. 632 in part; scandent bush, 3-7 m. tall).

Dalbergia spec.

Western Szech'uan: Chen-tu plain, alt. 300-600 m., October 1908 (No. 2905; tree, 8-13 m. tall).

\section{DUMASIA DC.}

\section{Dumasia hirsuta Craib, sp. n.}

Caules volubiles, pilis brunneis rigidiusculis satis longis divaricatis tecti, straminei. Folia trifoliolata, petiolo ad $12 \mathrm{~cm}$. longo pilis is caulium similibus sed parcius instructo stramineo suleato suffulta; stipulae lanceolatae v. lineari-lanceolatae, acutae, $7 \mathrm{~mm}$. longae, nervosae, pauci-ciliatae; foliola subovata, apice obtusissima, parum retusa, mucronulata, basi terminalia latissime cuneata, lateralia truncata, 3.5-9 $\mathrm{cm}$. longa, 3-7.1 cm. lata, membranacea, supra glabra v. ut infra pilis brunneis rigidis adpressis sparsissime instructa, nervis lateralibus utrinque 4-6 pagina utraque conspicuis, petiolulis 2-4 $\mathrm{mm}$. longis pilis ut caulibus instructis suffulta, foliolo terminali a lateralibus $2-4.7 \mathrm{~cm}$. distante; stipellae filiformes, ad $6 \mathrm{~mm}$. longae. Calyx ad $7.5 \mathrm{~mm}$. longus, ore oblique truncatus. Vexillum $11 \mathrm{~mm}$. longum, $9 \mathrm{~mm}$. latum, ungui $6 \mathrm{~mm}$. longo; alae $5.5 \mathrm{~mm}$. longae, basi truncatae, ungui $11 \mathrm{~mm}$. longo; carina basi truncata, $5.5 \mathrm{~mm}$. longa, $3.5 \mathrm{~mm}$. lata, ungui vix $11 \mathrm{~mm}$. longo suffulta.

A Dumasia leiocarpa Bentham, cui affinis, caulibus pilis longiuseulis brunneis divaricatis instructis, petiolis longioribus, foliolis majoribus, lateralibus basi fere truncatis distinguenda. 
Western Hupeh: Patung Hsien, thickets, alt. 1000-1300 m., July 1907 (No. 3483; climber, 2 m., flowers yellowish); same locality, A. Henry (No. 6115); Chiensi, 1900 (Veitch Exped. No. 1330).

\section{ERYTHRINA L.}

Erythrina arborescens Roxburgh, Hort. Beng. 53 (nomen nudum) (1814); Fl. Ind. ed. 2, III. 256 (1832).

Western Szech'uan: near Luting-chiao, alt. 1300 m., October 1910 (No. 4565; tree, $7 \mathrm{~m}$. tall, girth $0.45-0.6 \mathrm{~m}$.).

The specimen is in fruit only and its determination rests doubtful.

This tree is found round dwellings in the warm arid river-valleys of western Szech'uan but is rare.

E. H. W.

\section{APIOS Moench.}

Apios Fortunei Maximowicz in Bull. Acad. Sci. St. Pétersbourg, XVIII. 396 (1873); in Mél. Biol. IX. 67 (1873).

Western Hupeh: Changlo Hsien, thickets, alt. 600-1000 m., June and September 1907 (No. 3488; climber, 1-3 m., flowers yellow). Kiangsi: Kuling, thickets, not common, alt. 1300 m., July 30, 1907 (No. 164I; elimber, 3 m., flowers pale yellow).

\section{MUCUNA Adans.}

Mucuna sempervirens Hemsley in Jour. Linn. Soc. XXIII. 190 (1887).

Western Hupeh: Ichang, glens, alt. 30-300 m., April 24, 1907 (No. 327I; huge climber; flowers maroon-purple, foetid). Szech'uan: Yangtze cliffs, April 1904 (Veitch Exped. No. 3411).

This climber grows to a huge size and is very common on the cliffs of glens and gorges and elsewhere at low altitudes in western Hupeh and in Szech'uan. It is very floriferous and its large, waxy, evil-smelling flowers are very rich in honey and attract a large variety of insects. The flowers are produced mainly on the old wood and are hidden from view by an overhanging mantle of dark green leaves. The flat, broad bean-like pods are a yard or more long and are densely covered on the outside with tawny, appressed barbed hairs. In the neighborhood of Iehang this climber is known as the "Mien-ma-t'êng " or "Niu-ma-t'êng."

E. H. W.

\section{STIZOLOBIUM Pers.}

Stizolobium hassjoo Piper \& Tracy in Bull. U. S. Bur. Pl. Indust. CLXXIX. 17 (1910). 
Western Hupeh: Changyang Hsien, cliffs in ravines, alt. 300600 m., October 1907 (No. 3758; climber, 3 m.). Western Szech'uan: Tung-ch'uan Fu, cultivated, alt. 300-600 m., July 1910 (No. 3767; climber, 2-3 m., seeds white).

This plant is frequently cultivated on the Chengtu Plain and elsewhere in Szech'uan for its white seeds which are an article of food. It is known as the "Mao-huang-tou" (Hairy Soy-bean).

E. H. W.

\section{PUERARIA DC.}

Pueraria hirsuta Schneider, Ill. Handb. Laubholzk. II. 114, fig. 72 (1907).

Dolichos hirsuta Thunberg in Trans. Linn. Soc. II. 339 (1794).

Pachyrhizus Thunbergianus Siebold \& Zuccarini in Abh. Akad. Münch. IV. pt. III. 237 (Fl. Jap. Fam. Nat. II. 113) (1846).

Pueraria Thunbergiana Bentham in Jour. Linn. Soc. IX. 122 (1867).

Kiangsi: Kuling, thickets, abundant, alt. 1300 m., August 1, 1907 (No. I66I; climber, $7 \mathrm{~m}$. or more, flowers dark red). Western Hupeh: north and south of Ichang, abundant, alt. 300-1200 m., August and September 1907 (No. 3226, in part; huge climber, 7-10 m., flowers dark red); without precise locality, July 1900 (Veitch Exped. No. 1406). Western Szech'uan: Wên-ch'uan Hsien, alt. 300-1300 m., July 1908 (No. 3226, in part; large climber, 5-8 m., flowers dark red).

Abundant at low altitudes everywhere in Hupeh and Szech'uan where it is known as the "ko t'êng." The fibre from the shoots is made into a coarse cord and is employed as a slow-burning fuse to explode the native gingals and matchlocks. This fibre is also more elaborately perpared and made into a textile cloth known as "ko-pu." From the thickened rootstock starch is prepared as a food. This starch (ko-fêu) is, however, but little valued and is only used in times of searcity and by the poorer peasants.

E. H. W.

\section{RHYNCHOSIA Lour.}

Rhynchosia Dielsii Harms in Bot. Jahrb. XXIX. 418 (1900).

Western Hupeh: north and south of Ichang, thickets, alt. 30600 m., June 1907 (No. 3485; climber, 2 m., flowers yellow); Hsingshan Hsien, thickets, alt. 60-1000 m., June 6, 1907 (No. 3484; climber $2 \mathrm{~m}$., flowers yellow).

\section{Rhynchosia Craibiana Rehder, n. sp.}

Rhynchosia himalensis Franchet, Pl. Delavay. 185 (non Bentham) (1890). Rhynchosia striata Franchet in herb. (non G. Don). 
Suffrutex scandens, 1-2-metralis; ramuli teretes, tomento patenti villoso flavescente glandulis stipitatis intermixtis vestiti, ut petioli et petioluli pedunculique; stipulae lanceolatae, circiter $4 \mathrm{~mm}$. longae, reflexae. Folia longe petiolata petiolo $3-5 \mathrm{~cm}$. longo; foliola membranacea, laete viridia, subtus paullo pallidiora, utrinque breviter molliter villosa, estipellata, terminale orbiculari-ovatum, basi truncatum v. rotundatum, subito breviter acuminatum, $2.5-4.5 \mathrm{~cm}$. longum et latum, petiolulo $1.5-2 \mathrm{~cm}$. longo suffultum, lateralia similia, sed obliqua, paullo minora et paullo longiora quam lata, petiolulo 2-3 mm. longo. Racemi pedunculati, laxi, 3-5-flori, 6-9 cm. longi; pedicelli $3-5 \mathrm{~mm}$. longi, basi bractea ovata acuta $3-4 \mathrm{~mm}$. longa suffulti; calyx dense pubescens et parce glandulosus, circiter ad medium fissus, dentibus triangulari ovato-lanceolatis acuminatis, infimo e basi lanceolata in acumen longum subulatum producto quam ceteri duplo longiore, cum dente infimo $8-10 \mathrm{~mm}$. longus; corolla lutea, circiter $1.5 \mathrm{~cm}$. longa; vexillum glabrum, conspicue venosum, suborbiculare, circiter $13 \mathrm{~mm}$. diam., basi callosum, manifeste auriculatum; alae oblongae, auriculatae, quam carina paullo breviores. Legumen immaturum, dense pubescens, 2-spermum, acutum.

Western Szech'uan: Monkong Ting, descent of Hsao-chin Ho, alt. 2300-2600 m., June 30, 1908 (No. 2934; 1-2 m., flowers yellow).

This species seems elosely related to $R$. himalensis Bentham which is easily distinguished, however, by the larger leaflets longer than broad, the much longer, many-flowered racemes and by the lowest calyx-tooth breing as long as the corolla. It was determined by $\mathrm{Mr}$. Craib as $R$. striata Franchet, but as this is an unpublished name, and is, moreover, preoccupied by the South African R. striata G. Don, it is necessary to give this plant a new name.

A. $R$.

Rhynchosia volubilis Loureiro, Fl. Cochin. 460 (1790).

Western Hupeh: thickets around Ichang, alt. 300-600 m., August 1907 (No. 3487; twining sub-shrub).

\section{FLEMINGIA Roxb.}

Flemingia fluminalis Clarke apud Prain in Jour. As. Soc. Beng. LXVI. pt. II. 438 (1897).

Szech'uan: Wan Hsien, banks of Yangtze River, alt. 300 m., April 1908 (No. 2930; 0.6 m. tall, flowers white).

Flemingia congesta Roxburgh, var. viridis Prain in Jour. As. Soc. Beng. LXVI. pt. II. 440 (1897).

Western Szech'uan: Mupin, alt. 600-1000 m., October 1908 (No. 2932 ; shrub 0.6-1.3 m. tall, flowers purple). 


\section{ZYGOPHYLLACEAE.}

Determined by Alfred Rehder and E. H. Wilson.

\section{NITRARIA L.}

Nitraria Schoberi Linnaeus, Spec. ed. 2, 638 (1762). - Pallas, Fl. Ross. I. pt. I. 79, t. 50 (1784). - Gaertner, Fruct. I. t. 58 (1788). De Candolle, Prodr. III. 456 (1828). - Hance in Jour. Bot. XXI. 296 (1883). - Hemsley in Jour. Linn. Soc. XXIII. 97 (1886). Franchet in Nouv. Arch. Mus. Paris, sér. 2, V. 214 (Pl. David I. 62) (1883). - Komarov in Act. Hort. Petrop. XXIX. 154 (1908).

Western Szech'uan: near Monkong Ting, valley of Hsao-chin Ho, alt. 2300 m., rare, June 27, 1908 (No. 2459; bush 1-2 m., flowers white, branches dense, decumbent).

This is a rare plant in western Szech'uan and only known to us from the above locality where, however, it is plentiful. It had also been collected in western Szech'uan by Potanin in two localities according to Komarov, and in Kansu by Przewalski. 


\section{RUTACEAE.}

Determined by Alfred ReHder and E. H. Wilson. 1

\section{ZANTHOXYLUM L.}

Sect. 1. EuZanthoxruum Endl.

Zanthoxylum Bungei Planchon in Ann. Sci. Nat. sér. 3, XIX. 82 (1853). - Hance in Jour. Bot. XIII. 131 (1875); XX. 3 (1882), Franchet in Nouv. Arch. Mus. Paris, sér. 2, V. 218 (Pl. David. I. 66) (1883); VIII. 210 (Pl. David. II. 28) (1886). - Hemsley in Jour. Linn. Soc. XXIII. 105 (1886). - Maximowicz in Act. Hort. Petrop. XI. pt. 1, 93 (1890). — Pritzel in Bot. Jahrb. XXIX. 421 (1900). Pampanini in Nuov. Giorn. Bot. Ital. n. ser. XVII. 407 (1910).

Zanthoxylum nitidum Bunge in Mem. Sav. Etr. Acad. Sci. St. Pétersbourg, II. 87 (Enum. Pl. Chin. Bor. 13) (non De Candolle) (1833).

Zanthoxylum simulans Hance in Ann. Sci. Nat. sér. 5, V. 208 (1866).

Zanthoxylum Bungeanum Maximowicz in Bull. Acad. Sci. St. Pétersbourg, sér. 3, XVI. 212 (1871); in Mél. Biol. VIII. 2 (1871).

Zanthoxylum fraxinoides Hemsley in Ann. Bot. IX. 148 (1895).

Western Hupeh: Ichang, wild and cultivated, alt. 30-1000 m., July 1907 (Nos. 2692, 2694; bush 1-2 m. tall); Fang Hsien, alt. 1300 m., August 1907 (No. 2695; bush 1-2 m. tall); without locality, $A$. Henry (Nos. 3956, 6653, 6903, type of Zanthoxylum fraxinoides Hemsley). Eastern Szech'uan: Wushan Hsien, cultivated, A. Henry (No. 5781). Western Szech'uan: Wa-shan, thickets by roadside, alt. 1000-1500 m., September 1908 (No. 96r; bush 2-4 m. tall); southeast of Tachien-lu, wayside thickets and cultivated, alt. 1600-2300 m., June and September 1908, October 1910 (Nos. Ir89, 4622; bush 2-3 m. tall); valley of Min River, Mao-chou to Sungpan Ting, commonly cultivated, August 1910 (Nos. 4621, 4623; bush 1.5-3 m. tall); without precise locality, ravines, alt. $3100 \mathrm{~m}$., June 1904 (Veitch Exped. No. 3308). Shensi: "Lao-y-san," September 1897, G.

${ }^{1}$ Phellodendron determined by C. S. Sargent and Citrus and Poneirus by Walter T. Swingle. 
Giraldi. Chili: near Peking, in hedges, September 16, 1903, C. S. Sargent; same locality, Skatchkov.

This shrub, the "Hwa-chiao" (Chinese pepper or spice bush), is commonly cultivated through central and western China, especially in the dry, hot rivervalleys. It also occurs on the cliffs and by the waysides and is probably indigenous. In degree of armature, and size and shape of the leaves there is considerable variation. Commonly the plant is everywhere glabrous but the larger leaflets have usually beneath a tuft of villose hairs on each side of the base of the midrib; occasionally the pedicels and very rarely the young shoots are sparsely pubescent. Zanthoxylum fraxinoides Hemsley, is founded on a broad-leaved, sparsely spinose form, but specimens before us show every gradation and we are quite unable to separate them even as a variety.

This species is the only one we have seen cultivated by the Chinese and its fruits are their most prized condiment. A picture of this shrub will be found under No. 0145 of the collection of Wilson photographs.

Here may be added a new variety not collected during the Arnold Arboretum Expeditions.

Zanthoxylum Bungei, var. Zimmermannii Rehder \& Wilson, n. var.

A typo recedit foliis majoribus cum petiolo ad $28 \mathrm{~cm}$. longis, foliolis ovatoellipticis v. ovato-oblongis acuminatis $4-9 \mathrm{~cm}$. longis, inflorescentia laxiore et longiore 6-10 $\mathrm{cm}$. longa et 9-13 cm. lata.

Shantung: Tsingtau, Zimmermann, 1901 (No. 460, type). Korea: Quelpaert, U. Faurie, Oetober 1906 and July 1907 (Nos. 463, 1628); Taquet, May 20, 1908 and May 1909 (Nos. 621, 2709).

This variety is chiefly distinguished by its much larger and looser inflorescence, from the type, the inflorescence of which usually measures only $3-4 \mathrm{~cm}$. in diam. and is rather compact; the leaflets of the type are obtusish or acutish and very rarely exceed 4 or $5 \mathrm{~cm}$. in length. In the specimens from Shantung the leaflets measure 5.5-9 cm., while in the specimens from Quelpaert they are smaller and sometimes not more than $3 \mathrm{~cm}$. long, but the infloressence is the same as that of the Shantung specimen.

\section{Zanthoxylum Piasezkii Maximowicz in Act. Hort. Petrop. XI. 93} (1889).

Zanthoxylum piperitum Maximowicz apud Hemsley in Jour. Linn. Soc. XXIII. 107 (non De Candolle) (1886), quoad plantam Piasezkii.

Western Szech'uan: Mao-chou, arid regions throughout Min valley, alt. 1000-2000 m., May and August 1908 (No. II74; bush 12 m., fruit red); Wên-ch'uan Hsien, arid places, alt. 1300-2000 m., October 1910 (No. 4390; bush 1.5-3 m.); same locality, alt. 1600 m., July 1903 (Veitch Exped. No. 3309); without locality, May 1904 (Veitch Exped. No. 3310).

This shrub is common in the dry hot river valleys of western Szech'uan and has smaller leaves than any other Chinese species known to us. Our specimens agree with Maximowicz's description except that the sepals are rather larger and none of the leaflets are quite as small as the lowest measurements given by Maximowicz. 


\section{Zanthoxylum pilosulum Rehder \& Wilson, n. sp.}

Frutex 1-2-metralis ramis divaricatis; ramuli hornotini puberuli v. breviter dense pilosuli, purpureo-rufescentes, aculeis stipularibus compressis et basi valde dilatatis muniti, annotini fusco-grisei, glabrescentes. Folia decidua, 3-5-, plerumque 4-juga cum petiolo 5-8 $\mathrm{mm}$. longo $4.5-8 \mathrm{~cm}$. longa; foliola brevissime petiolulata $\mathrm{v}$. fere sessilia, ovato-elliptica v. oblongo-lanceolata, breviter acuminata v. acutiuscula, apice plerumque emarginata, basi late cuneata, margine irregulariter et remote crenulata, sinubus glanduliferis, 1-3 cm. longa et $0.6-1 \mathrm{~cm}$. lata, glabra, supra obscure luteo-viridia, subtus pallidiora, et saepe in costa media aculeis 1-2 gracilibus instructa; petioli et rhaches glabra, supra canaliculata et angustissime alata, aculeis paucis gracilibus rectis instructa. Inflorescentia terminalis corymbosa, sessilis, pilosula, $3.5-4 \mathrm{~cm}$. longa et 4-5 $\mathrm{cm}$. lata; pedicelli graciles, 7-12 mm. longi; carpella fertilia plerumque 2, immatura. Flores ignoti.

Western Szech'uan: Monkong Ting, descent of Hsaochin Ho, alt. 2300-3000 m., June 1908 (No. 2687).

This new species is apparently most closely related to $F$. setosum Hemsley, which differs chiefly in the pubescent leaves and in the paniculate inflorescence with short pedicels; it is also related to $F$. Bungei Planchon and $F$. Piasezkii Maximowicz, which both are easily distinguished by their glabrous branchlets and glabrous inflorescence, the shorter pedicels and the less dilated prickles.

\section{Zanthoxylum pteracanthum Rehder \& Wilson, n. sp.}

Frutex 2-3-metralis ramis divaricatis; ramuli glabri, dense aculeis setaceis fuscis per plures annos persistentibus obtecti et aculeis stipularibus valde compressis longe decurrentibus et alas formantibus instructi, ala quavis plerumque per duo internodia decurrente et aculeas duas conjungente, ideoque ramuli fere undique 3 -alati; ramuli vetustiores cinerei. Folia cum petiolo $1.5-2.5 \mathrm{~cm}$. longo $10-15 \mathrm{~cm}$. longa, 3-6-juga; foliola breviter petiolulata opposita v. subopposita, oblonga v. ovato-lanceolata, acuminata, apice obtusa v. emarginata, basi obliqua late cuneata $v$. fere rotundata, minute crenulata sinubus glanduliferis, 2-3.5 cm. longa et $0.8-1.5 \mathrm{~cm}$. lata, glabra, supra saturate viridia, subtus pallidiora; petioli rhachesque glabra canaliculata, marginata, aculeis paucis compressis rectis instructa. Inflorescentia terminalis, corymbosa, 5-6 cm. diam., sessilis, minutissime pilosula et ad basin sparse breviter setosa; pedicelli $5-8 \mathrm{~mm}$. longi, graciles; flores non visi. Carpella matura 1-3, pubescentia, circiter 5 
$\mathrm{mm}$. longa, leviter rugulosa; semina ovalia, solitaria, 3-3.5 mm. longa, nigra, nitentia.

Western Hupeh: Hsing-shan Hsien, thickets, alt. 1100 m., June and October 1907 (No. 386).

This is a very remarkable plant with a dense covering of bristles on the stems and with wing-like prickles extending the full length of the internodes similar to those of Rosa sericea, var. pteracantha. We have seen specimens with ripe and immature fruit only and the flowers are unknown to us. From lack of material we cannot be sure to which section of the genus it belongs, but suspect it to belong to Euzanthoxylum, as it seems nearly related to $Z$. Bungei Planchon; it is, however, apparently still closer to our new $Z$. pilosulum of which the flowers are also unknown and may possibly turn out to be a variety of that species with the stipular prickles strongly developed and the hairs of the branchlets changed into prickles.

Zanthoxylum setosum Hemsley in Jour. Linn. Soc. XXIII. 107 (1886).

Fagara setosa Engler in Engler \& Prantl. Nat. Pfanzenfam. III. Abt. IV. 118 (1896).

Kiangsi : Kiukiang plain, thickets and hedgerows, alt. 100-200 m., July 27, 1907 (No. I566; bush 1.5 m.). Western Hupeh: Ichang, thickets and rocky places, alt. 30-1500 m., April 1907 (Nos. 2688, 269r; bush 1-2.5 m. tall); without locality, A. Henry (No. 1504, 1571). Western Szech'uan: west of Kuan Hsien, cliffs, alt. 2300-2600 m., June 1908 (No. 269o; bush $2.5 \mathrm{~m}$., flowers yellow). Chekiang: vicinity of Ningpo, 1908, D. Macgregor.

This shrub is common on the cliffs and in thickets throughout Hupeh and Szech'uan where it is colloquially known as Yeh-hua-chiao (wild Pepper). The specimens before us vary considerably in amount of hairiness especially on the leaves and some of them resemble Zanthoxylum Bungei Planchon, which is most closely related to this species. By Engler this species had been referred to the genus Fagara, but our material shows that it is a true Zanthoxylum with a perianth consisting of one whorl only.

Zanthoxylum undulatifolium Hemsley in Ann. Bot. IX. 148 (1895). - Pritzel in Bot. Jahrb. XXIX. 421 (1900).

Western Hupeh: Hsing-shan Hsien, cliffs, side of streams, alt. 600-1000 m., May 1907 (No. 2689; bush 2.5 m., flowers reddish); without locality, A. Henry (No. 3938, type). Eastern Szech'uan: Wushan Hsien, A. Henry (No. 5646). Shensi: "Kin-san," 1897, G. Giraldi.

This species is comparatively rare and is well characterized by its pubescence and by the undulate margins of the leaves. The young shoots are often slightly pruinose and the degree of pubescence on the leaves varies considerably. The 
affinity of this species is with $Z$. Bungei Planchon, and Z. setosum Hemsley, from both of which it is easily distinguished by its undulate leaves.

Zanthoxylum alatum Roxburgh, Fl. Ind. III. 768 (1832), - Hooker f., Fl. Brit. Ind. I. 493 (1875).

Yunnan: Mengtze, rocky places, alt. 1500-1600 m., A. Henry (Nos. 9366, $\left.9366^{\circ}, 9366^{\alpha}, 11413\right)$; Szemao, alt. 1500-1600 m., A. Henry (Nos. 11908; 12249).-0 Henry's No. 12249 has leaves 1- to 3-jugate on the same shoot.

Zanthoxylum alatum, var. planispinum Rehder \& Wilson, n. var.

Zanthoxylum planispinum Siebold \& Zuccarini in Abh. Akad. Münch., IV. pt. II. 138 (Fl. Jap. Fam. Nat. I. 30) (1846). - Franchet in Nouv. Arch. Mus. Paris, sér. 2, V. 219 (Pl. David. I. 67) (1883). - Maximowicz in Bull. Acad. Sci.St. Pétersbourg, XXXI. 21 (1886); in Mél. Biol. XII. 428 (1886); in Act. Hort. Petrop. XI. 95 (1889). - Pritzel in Bot. Jahrb. XXIX. 421 (1900).

Zanthoxylum Bungei Hance in Ann. Sci. Nat. sér. 5, V. 209 (non Planchon) (1866).

Zanthoxylum alatum Hemsley in Jour. Linn. Soc. XXIII, 105 (non Roxburgh) (1886). - Pritzel in Bot. Jahrb. XXIX. 421 (1900). - Pampanini in Nuov. Giorn. Bot. Ital. n. ser. XVI. 407 (1910).

Western Hupeh: Hsing-shan Hsien, ravines, alt. 300-1000 m., May 7 and September 1907 (No. 138; bush 2-2.5 m. tall); Ichang, side of stream, alt. 30-600 m., May 1907 (No. 2693, in part; bush $2.3 \mathrm{~m}$. tall); Changlo Hsien, thickets, sides of streams, alt. 300-1300 m., April 1907 (No. 2693, in part; bush 2-3 m. tall); without locality, A. Henry (No. 7687). Shensi: "Hu-kia-scien," Hugh Scallan. Yunnan: Mengtze, woods, alt. 1800 m., A. Henry (Nos. 9366a, $\left.9366^{\ominus}, 9366^{\mathrm{T}}\right)$. Chekiang: vicinity of Ningpo, 1908, D. Macgregor. Kiangsu: without locality, hills, E. Faber. Formosa: without precise locality, thickets, May 1903, U. Faurie (No. 22). Korea: Fusan, May 1906, U. Faurie (No. 465); Quelpaert, thickets, June 1907, U. Faurie (No. 1627); same locality, June 1908, September 1909, Taquet (No. 620, 2707, 2708).

In extreme forms this variety looks very distinct from the type, yet in the spines, in the shape of the leaflets and in the width of the wings on the petioles we cannot find any constant character by which to distinguish it specifically from the Indian plant. The only difference appears to be in the number of the leaflets which is from 3 to 5 in the variety and 5 and more in the type. In the specimen from Yunnan, however, this character too is not constant.

This shrub is abundant throughout the warmer parts of central and western China, more especially in rocky places and by the side of streams. A colloquial name for it is "Kou-hua-chiao."

Zanthoxylum alatum, var. planispinum, f. ferrugineum, Rehder \& Wilson, n. forma. 
A typo varietatis recedit ramulis junioribus, petiolis, rhachibus inflorescentiae ferrugineo-pubescentibus.

Western Szech'uan: west and near Wên-ch'uan Hsien, thickets, alt. 1300 m., July 1908 (No. 2693, type; bush 2.5 m. tall); Mt. Omei, May 1904 (Veitch Exped. No. 4769).

This form is easily distinguished by the short, ferruginous pubescence covering the shoots, petioles and the rhachis of the inflorescence.

Zanthoxylum dimorphophyllum Hemsley in Ann. Bot. IX. 150 (1895).

Fagara dimorphophylla Engler in Engler \& Prantl, Nat. Pflanzenfam. III. Abt. IV. 118 (1896). - Pritzel in Bot. Jahrb. XXIX. 422 (1900).

Western Hupeh: Ichang, thickets, alt. 30-600 m., common, May and July 1907 (No. II 3 ; bush $2.5 \mathrm{~m}$. tall, flowers yellow); Changlo Hsien, thickets, alt. 1000-1300 m., September 1907 (No. I49; bush 3 m. tall); without locality, May and July 1900 (Veiteh Exped. No. 601); without locality, A. Henry (Nos. 5512, 7003). Western Szech'uan: Lungan Fu, valleys, alt. 1600-2300 m., August 1910 (No. 4624; bush 2-4 m. tall); Mt. Omei, June 1904 (Veitch Exped. No. $4770^{2}$ ); without locality, May 1904 (Veitch Exped. No. 3311).

This is a very common shrub, abundant in the wayside thickets and on the eliffs. This plant was originally described as very spiny, but this is an error, since it is remarkably free of prickles for a species of Zanthoxylum. It had been referred by Engler to the genus Fagara, though it is stated in Hemsley's original description that it has a simple perianth, which is correet aceording to the material before us.

Zanthoxylum dimorphophyllum, var. spinifolium Rehder \& Wilson, n. var.

A typo recedit ramulis et saepe petiolis aculeatis, foliis $3-\mathrm{v}$. interdum 5 -foliolatis, foliolis margine in sinubus crenarum aculeis gracilibus et interdum supra rarissime infra aculeis rectis instructis.

Western Szech'uan: Chiu-ting-shan, thickets, alt. 1300 m., May 22, 1908 (No. 2696, type). Eastern Szech'uan: without locality, A. Henry (No. 5494).

Easily distinguished from the type by the long setose spines on the margins of the leaflets; the petioles and branches are also very spiny and the leaves are 3or oceasionally 5 -foliolate. 
RUTACEAE. - ZANTHOXYLUM

Sect. 2. Fagara G. Don.

Zanthoxylum stenophyllum Hemsley in Ann. Bot. IX. 147 (1895).

Fagara stenophylla Engler in Engler \& Prantl, Nat. Pflanzenfam. III. Abt. IV. 118 (1896). - Pritzel in Bot. Jahrb. XXIX, 422 (1900).

Western Szech'uan: Wa-shan, thickets, alt. 1300 m., September 1908 (No. 964; bush 2-3 m. tall); south-east of Tachien-lu, thickets, alt. 1600-2000 m., October 1908, 1910 (Nos. I245, 4I48); Mupin, dry rocky places, alt. 1300-1600 m., October 1910 (No. 42I3); Chiuting-shan, thickets, alt. 1000-1200 m., May 21, 1908 (No. 2685, 2686); without locality, alt. 1300 m., May 1904 (Veitch Exped. No. 3415); Mt. Omei, October 1903 (Veitch Exped. No. 3312). Eastern Szech'uan: Wushan Hsien, A. Henry (No. 5560). Western Hupeh: Hsing-shan Hsien, A. Henry (Nos. 6555, 6466, type).

This is a very common subscandent shrub at low altitudes through western China, especially in rocky places. The numerous specimens before us exhibit considerable variation in size of the leaflets but all agree in having a terminal inflorescence, shortly beaked fruit, and shoots slightly pruinose the first year. The specimen from Mount Omei is the most extreme and may possibly constitute a well-marked variety. Henry's No. 9874 from Yunnan possibly belongs here but the inflorescence is very compact and the pedicels are stout and more or less 4sided.

Zanthoxylum stenophyllum Hemsley, is closely related to $Z$. oxyphyllum Edgeworth, which has larger leaves and flowers and axillary and terminal corymbs.

Zanthoxylum micranthum Hemsley in Ann. Bot, IX. 147 (1895).

Fagara micrantha Engler in Engler \& Prantl, Nat. Pflanzenfam. III. Abt. IV. 118 (1896). - Pritzel in Bot. Jahrb. XXIX. 422 (1900).

Fagara Biondii Pampanini in Nuov. Giorn. Bot. Ital. n. ser. XVII. 406 (1910).

Western Hupeh: Changyang Hsien, thickets and margins of woods, alt. 600-1300 m., June and September 1907 (No. 3578; tree 10-12 m. tall, girth 0.6-1 m.); Patung Hsien, woodlands, alt. 600$800 \mathrm{~m}$., common, July and August 1907 (Nos. 2697, 2698; tree 6-13 m. tall, girth 0.3-1 m.); Changlo Hsien, woodlands, alt. 600-1000 m., July 1907 (No. 2697 ${ }^{\text {a }}$; tree 10-13 m. tall, girth $1 \mathrm{~m}$.); without locality, July 1901 (Veitch Exped. No. 2211); Ichang and immediate neighbourhood, A. Henry (No. 4127); without locality, A. Henry (No. $4127^{\mathrm{a}}, 2690,2095$, type).

This species is common in the thickets and margins of woods through western Hupeh and eastern Szech'uan. The trunk is slender and covered with smooth, dark grey bark which is sparsely studded with short stout prickles much thick- 
ened and dilated at their base. All parts of the tree emit a very pungent odour when bruised. The branchlets are much less spiny and more slender but much more woody than those of the allied Zanthoxylum ailanthoides Siebold \& Zuccarini. In that Japanese species the inflorescence differs in its much longer peduncle. The characters by which Pampanini distinguishes his Fagara Biondii do not hold good in the material before us and we are unable to separate it from the typical form of Zanthoxylum micranthum Hemsley. The inflorescence on our specimens varies in diameter from 10 to $30 \mathrm{~cm}$. and although the leaves exhibit slight variations the species is extremely well-marked. Colloquially it is known as the Tz'u-chin-shu. It is the only species of Zanthoxylum in central and western China known to us which becomes a tree.

Zanthoxylum echinocarpum Hemsley in Ann. Bot. IX. 149 (1895).

Fagara echinocarpa Engler in Engler \& Prantl, Nat. Pflanzenfam. III. Abt. IV. 118 (1896). - Pritzel in Bot. Jahrb. XXIX. 422 (1900).

North-central Szech'uan: $\mathrm{Pa}$ Chou, cliffs in sandstone ravines, alt. 600-1000 m., July 1910 (No. 4620; scandent bush 1-2 m. tall). Western Szech'uan: Mt. Omei, October 1904 (Veitch Exped. No. 4773). Yunnan: Mengtze, mountains, south-west, alt. 1600 m., A. Henry (No. 10932). Western Hupeh: Ichang and immediate neighbourhood, A. Henry (No. $3416^{\text {b }}$, type).

This is a remarkable species with a terminal and axillary racemose inflorescence and one-seeded carpels densely clothed with long flattened, sparsely hairy spines. It is not common and is confined to the warm temperate regions.

Zanthoxylum dissitum Hemsley in Jour. Linn. Soc. XXIII. 106 (1886).

Fagara dissita Engler in Engler \& Prantl, Nat. Pfanzenfam. III. Abt. IV. 118 (1896). - Pritzel in Bot. Jahrb. XXIX. 422 (1900). - Pampanini in Nuov. Giorn. Bot. Ital. n. ser. XVIII. 125 (1911).

Western Hupeh: Ichang, glens, alt. 30-300 m., common, March and September 1907 (Nos. 32I, 2684; scandent shrub 2-4 m.); same locality, June 1900 (Veitch Exped. No. 148); same locality, A. Henry (Nos. 3121, 3325, 3713). Eastern Szech'uan: Wushan Hisien, A. Henry (No. 7137). Yunnan: Mengtze, mountains to the southeast, alt. 1600-2000 m., A. Henry (Nos. 10429, 11437); Yuan-chiang, alt. 1300 m., A. Henry (Nos. 13326, 13326ª

This handsome species is common at low altitudes through western Hupeh and eastern Szech'uan, especially in glens and gorges. It forms a large subscandent bush and has persistent shining-green leaves. The number of leaflets is usually from 2 to 4 pairs but varies from 1 to 5 pairs; the leaf-rhachis is usually armed with hooked prickles. The seeds are very large and jet black. In the Yunnan specimens the panicles are rather longer than in the northern form. A colloquial name in Hupeh for this shrub is "San-peh-pang." 
Here may be added a note on a Chinese species not collected during the Arnold Arboretum Expeditions.

Zanthoxylum multijugum Franchet, Pl. Delavay. 124 (1889).

Zanthoxylum multifoliolatum Hemsley in Hooker's Icon. XXVI. t. 2595 (1899).

Yunnan: Mengtze, woods and cliffs, alt. 1500-1600 m., A. Henry (Nos. 9998,$9998^{\mathrm{a}}, 9998^{\mathrm{b}}, 9998^{\mathrm{c}}$; large climber).

In describing this plant as a new species Hemsley apparently overlooked Franchet's earlier description. With its long, narrow multifoliolate leaves this is a most distinct species.

\section{EVODIA Forst.}

\section{Sect. 1. Tetradium Engl.}

Evodia glauca Miquel in Ann. Mus. Lugd.-Bat. III. 23 (1867); Prol. Fl. Jap. 211 (1867). — Dode in Bull. Soc. Bot. France, LV. 703 (1908).

Evodia meliifolia Pritzel in Bot. Jahrb. XXIX. 423 (non Bentham) (1900).

Evodia meliaefolia Shirasawa, Icon. Ess. For. Jap. II. t. 34, fig. 1-9 (non Bentham) (1908). - Pampanini in Nuov. Giorn. Bot. Ital. n. ser. XVII. 405 (1910). - Matsumura, Ind. Fl. Jap. II. 290 (1912).

Evodia Fargesii Dode in Bull. Soc. Bot. France, LV. 704 (1908).

Kiangsi : Kiukiang, foot-hills, alt. 300 m., August 1, 1907 (Nos.

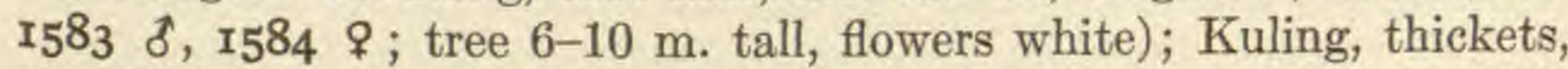
alt. 1300 m., common, July 29, 1907 (No. 1585; bush 2.5-4 m. tall). Western Hupeh: Changyang Hsien, woodlands, alt. 1000-1600 m., common, July and September 1907 (Nos. 253, 3579 \&, fruit; tree 6-16 m. tall, girth $0.6-2 \mathrm{~m}$.); Patung Hsien, woods, alt. 1000-1300 m., August and September 1907 (Nos. 247, fruit, 3579 ${ }^{\mathrm{a}}$ \%); Hsingshan Hsien, woodlands, alt. 1000-1300 m., October 1907 (No. 38r, fruit; tree 5-12 m. tall); without precise locality, July and September 1901 (Veitch Exped. Nos. 1930 \& , 1930 \&, 2210 \& , 2210ª f fruit); without locality, A. Henry (No. 4577); "Ou-tan-scian," alt. 2090 m., August 1907, C. Silvestri (No. 1218, fruit).

This is one of the commonest trees in the moist woodlands of western Hupeh. It is of medium size with smooth bark, moderately thick spreading branches and brittle wood. The much-branched corymbose inflorescence is somewhat rounded; the main branches are usually subtended by leafy bracts. The species is very closely allied to Evodia meliaefolia Bentham, which is a subtropical tree with leaves less glaucous on the underside, smaller flowers and glabrous pistillodes. Dode states that his E. Fargesii difiers from E. glauca Miquel, and E. meliaefolia Bentham, in its glabrous pistillodes, but we do not find this to be the case. We have several of the specimens cited by Dode and in all the pistillodes are pilose as they are in the typical $E$. glauca Miquel from Japan. 
A colloquial name for E. glauca in Hupeh is "Ch'ou-la-shu" (stinking Ash tree). It is hardy in England and promises to succeed in the Arnold Arboretum.

From the deseription we strongly suspect that $E$. sutchuenensis Dode also belongs here.

Evodia officinalis Dode in Bull. Soc. Bot. France, LV. 703 (1908).

Evodia rutaecarpa Pampanini in Nuov. Giorn. Bot. Ital. n. ser. XVIII. 169 (non Jussieu) (1911).

Western Hupeh: north and south of Ichang, thickets and margins of woods, alt. 600-1100 m., July and October 1907 (No. 366; bush 2-4 m. tall, flowers greenish-yellow); Changyang Hsien, thickets, alt. 600-1100 m., July 1907 (No. 366 ; bush 2-4 m. tall); Patung Hsien, thickets, alt. 600-1000 m., September 1907 (No. 25I; bush 3-5 m. tall); Changlo Hsien, woodlands, alt. 1000 m., July 1905 (No. 3577; small bushy tree, $5 \mathrm{~m}$., flowers greenish-white); without locality, June and October 1900 (Veitch Exped. No. 1309); Ichang and immediate neighbourhood, A. Henry (No. 1676); without locality, A. Henry (Nos. 6199, 6569, 6136ª 6199ª 2077); "Monti di Fan-sien," alt. 300 m., August 1906, C. Silvestri (No. 3339). Western Szech'uan: Mt. Omei, E. Faber (No. 26).

In western Hupeh and eastern Szech'uan this is a very common shrub in thickets and along the margins of woods. The long narrow leaves with numerous remote pairs of leaflets and the much more slender branches distinguish this species from E. rutaecarpa Bentham.

Dode quotes from Père Farges the name "houâng pei chou" for this shrub. This name signifies "yellow bark tree" and is very generally applied in central and western China to Phellodendron chinense Schneider, and P. sachalinense Sargent, the bark of which is greatly valued in Chinese medicine. We never heard in China of the bark of Evodia officinalis Dode, having any officinal value, but the fruit is used as a drug and the shrub is known as the Chu-yü, Wu-chu-yü and La-tzu-shu.

Evodia Bodinieri Dode in Bull. Soc. Bot. France, sér. 4, LV. 703 (1908).

Western Hupeh: Hsing-shan Hsien, side of stream, alt. 6001000 m., December 1907 (No. 79r, fruit; bush 2.5). Western Szech'uan: Kiating Fu, roadside thickets, alt. 300-1000 m., September and November 1908, November 1910 (Nos. 3572, , fruit, 3573 , o , 4568, fruit; bush 1-3 m. tall, flowers white, fragrant, fruit reddish); Hungyah Hsien, thickets, alt. 300-1000 m., September 5, 1908 (No. 3573, \&, bush 1-2 m. tall, flowers white).

In western Szech'uan this is a very common low-level shrub but in Hupeh it is comparatively rare. Our specimens agree very well with Dode's short description which is based on a specimen from Kueichou province. 
Evodia Baberi Rehder \& Wilson, n. sp.

Arbor 5-16-metralis, trunco 0.3-0.6 m. diam., cortice laevi fuscocinereo lenticellis parvis oblongis horizontalibus notato; ramuli annotini glabri, purpureo-fusci, vetustiores fusci; gemmae nudae rufopubescentes. Folia 1-4-juga, cum petiolo $15-35 \mathrm{~cm}$. longa; foliola breviter petiolulata petiolulo $2-5 \mathrm{~mm}$. longo, eo folii terminalis 1-3 $\mathrm{cm}$. longo, membranacea, oblongo-ovata v. oblongo-lanceolata, rarius ovata v. elliptica, acuminata v. subito acuminata, basi rotundata obliqua v. vix obliqua, terminale late cuneatum, integra v. minute crenulata, 7-16 $\mathrm{cm}$. longa et $3.5-7 \mathrm{~cm}$. lata, supra glabra costa media villosula excepta, saturate viridia, subtus pallide viridia, in planta mascula glabra nervis sparsissime pilosis saepe fere glabris exceptis, in planta feminea ad costam et nervos laterales pilosis et in facie crebre punctata, nervis utrinsecus 10-15; petioli et rhaches sparse breviter pilosa, purpurascentia, 3-8 cm. longa. Flores masculi albi, pentameri, in paniculis pyramidalibus 9-12 $\mathrm{cm}$. longis et 10-20 $\mathrm{cm}$. latis dispositi; rhachis et pedicelli breviter et satis dense fulvo-pilosula; sepala patentia, ovata, acutiuscula, vix $1 \mathrm{~mm}$. longa, ciliata; petala erecta, oblonga, subacuta, leviter inflexa, 3-4 mm. longa, extus glabra, intus villosa; stamina petalis fere duplo longiora, filamentis subulatis infra medium pilosis, antheris ovalibus, circiter $1 \mathrm{~mm}$. longis; ovarium abortivum apice dense villosum; flores feminei non visi. Fructus rubescens, stellatus, $5 \mathrm{~mm}$. altus et $10 \mathrm{~mm}$. diam., tuberculatus; carpellis fertilibus plerumque $3-5$ rarius 1-2 monospermis apice obtusis; semina ovalia, 3-5 mm. longa, ventre applanata, nigra, nitentia, hilo albido.

Western Szech'uan: Wa-shan, woodlands, alt. 1300-2000 m., July and October 1908 (Nos. I164, \& and fruit, type, 3570); Monkong Ting, roadside thickets, alt. 2000-2600 m., June 19, 1908 (No. 3569, §); Mt. Omei, September 1904 (Veitch Exped. No. 4772, fruit).

This is a very distinct species characterized by its large leaflets, pyramidal inflorescence, pentamerous flowers, reddish, tuberculate, non-beaked fruit and 1seeded carpels. It is apparently most closely allied to $E$. sutchuenensis Dode, which according to his description differs in the leaflets which are pale glaucous on the underside with tufts of villose hairs in the axils of the prineipal veins, and in the inflorescence which is furnished with small leafy bracts.

This new species is named for the late E. Colborne Baber, of the British Consular Service in China, the first foreigner to make the ascent of Mount Wa and Mount Omei, to whom science and literature are both indebted for a most graphic and accurate description of these mountains and the adjacent regions.

Here may be added a note on three other Chinese species of this section, not collected during the Arnold Arboretum Expeditions. 
Evodia rutaecarpa Bentham, $\mathrm{Fl}$. Hongk. 59 (1861).- Miquel in Ann. Mus. Lugd.-Bat. III. 22 (1867); Prol. Fl. Jap. 210 (1867). - Hemsley in Jour. Linn. Soc. XXIII. 104 (1886). - Sargent in Garden \& Forest, VI. 111 (1893). - Dode in Bull. Soc. Bot. France, LV. 702 (1908). - Matsumura, Ind. Fl. Jap. II. 290 (1912).

Boymia rutaecarpa A. L. de Jussieu in Mém. Hist. Nat. Paris, XII. 507, t. 25, fig. 39 (Mém. Rut. 124) (1825). - Siebold \& Zuccarini, Fl. Jap. I. 50, t. 21 (1839).

Western Hupeh: without locality, June 1901 (Veitch Exped. No. 1972); without locality, A. Henry (No. 1676).

As far as we know this is a very rare shrub in central China. We have omitted all references to the Indian plant which has been referred to this plant, as we are doubtful if it is really the same as $E$. rutaecarpa Bentham.

Evodia trichotoma Pierre, Fl. For. Cochin. IV. t. 287 (1891).

Tetradium trichotomum Loureiro, Fl. Cochin. 91 (1790).

Ampacus trichotoma Kuntze, Rev. Gen. I. 98 (1891).

Evodia viridans Drake in Jour. de Bot. VI. 273 (1892). - Dode in Bull. Soc. Bot. France, sér. 4, LV. 706 (1908). - Guillaumin in Lecomte, Fl. Gén. Indo-Chine, I. 634 (1911).

Yunnan: Mengtze, mountains south-west, alt. 1300 m., A. Henry (No. 10951); Szemao and vicinity, alt. 1300-1600 m., A. Henry (Nos. 12137, 12137 ${ }^{\mathrm{a}}, 12237$, $\left.12237^{\mathrm{a}}, 12237^{\mathrm{b}}\right)$.

Henry describes this plant as a bush or small tree from 2 to $6 \mathrm{~m}$. tall, with yellow flowers and reddish fruit. The leaves on all the specimens are densely punctate on the under side.

Evodia rugosa Rehder \& Wilson, n. sp.

Arbor 6-metralis (ex Henry); ramuli hornotini purpurascentes, dense breviter ferrugineo-villosi, vetustiores fusci, glabri, lenticellati; gemmae nudae, dense ferrugineo-pubescentes. Folia 2-3-juga, cum petiolo $13-17 \mathrm{~cm}$. longa; foliola brevissime petiolulata, chartacea, ovato-oblonga v. oblongo-lanceolata, acuminata, basi late cuneata v. rotundata, obliqua, margine integra, leviter revoluta, 4-9 $\mathrm{cm}$. longa et $2-3 \mathrm{~cm}$. lata, supra saturate viridia, subnitentia, sparse pilis adpressis obsita, leviter rugulosa et interdum leviter bullata, subtus pallidiora, ad costam conspicue villosa et ad nervos laterales sparse villosula, ceterum glabra, obscure punctulata, nervis utrinsecus $10-15$ supra saepe impressis subtus elevatis; petioli ut rhachis supra plani et dense villosuli, subtus glabrescentes. Flores non visi. Fructus ruber, stellatus, $5-6 \mathrm{~mm}$. altus et $8-10 \mathrm{~mm}$. diam. in corymbis $2.5 \mathrm{~cm}$. altis et $4.5 \mathrm{~cm}$. latis; rhachis et pedicelli dense breviter pilosula; carpella glabra, 3-5, verruculosa et rugosa, apice rotundata, monosperma; semina ovalia, 4-5 mm. longa, ventre applanata, atra, hilo albido notata.

Yunnan: Mengtze, forests to the north, alt. 2600 m., A. Henry (No. 10245).

A very distinct species not closely related to any species known to us but perhaps nearest to $E$. Baberi Rehder \& Wilson. It is well distinguished by its relatively small leaves, with narrow, more or less rugose subcoriaceous leaflets, its small, crowded corymbs, and by its woody, non-beaked, glabrous fruit which is strongly keeled near the base. Our material is somewhat meagre and in vigorous specimens the dimensions of the leaves and inflorescence may very possibly exceed those given here. 
Sect. 2. Oxyactis Rehder \& Wilson.

Zanthoxylum, sect. Oxyactis Bennett in Ann. Nat. Hist. ser. 3, X. 201 (1862). Evodia, sect. Evodioceras Dode in Bull. Soc. Bot. France, LV. 706 (1908).

\section{Evodia hupehensis Dode in Bull. Soc. Bot. France, LV. 707 (1908).}

Evodia Daniellii Pritzel in Bot. Jahrb. XXIX. 423 (pro parte, non Hemsley) (1900), - Pampanini in Nuov. Giorn. Bot. Ital. n. ser. XVIII. 125 (1911).

Western Hupeh: Hsing-shan Hsien, woodlands, alt. 1000-1500 m., July, August and September 1907 (No. $387^{\mathrm{a}}$, 8 and fruit, 3574, 8 ; tree 6-12 m. tall, girth 0.3-1 m., flowers white); Changlo Hsien, woods, alt. 1000-1500 m., June and July 1907 (Nos. $387^{\text {b }}, 8$, 3576, in part, 8 ; tree 6-13 m. tall); Patung Hsien, moist woods, alt. 1000-1300 m., July 1907 (No. 3576, in part, $\AA$; tree 6-13 m. tall); Fang Hsien, woods, alt. 1000-1600 m., July 1907 (No. 3576, in part, \& ; tree 6-12 m. tall, flowers white); Changyang Hsien, margins of woods, alt. $1300 \mathrm{~m}$., June 1907 (No. 3575; tree 20 m. tall, girth 2 m., bark smooth, gray); same locality, July 1901 (Veitch Exped. No. 2693, §); Paokang Hsien, woodlands, October 1901 (No. 2693 ${ }^{2}$, fruit); without locality, June 1901 (Veitch Exped. No. 2415, ठ); without locality, A. Henry (No. 4482, fruit). Szech'uan: Nan-ch'uan, A. von Rosthorn (No. 1884). Shensi : without locality, 1897, G. Giraldi; "Kusan," Hugh Scallan (No. 75). "Mt. Miao-uan-san," 1899, Hugh Scallan.

This is a very common tree in the woodlands of western Hupeh where it grows to a larger size than any other species. Like its allies it has smooth gray bark, spreading branches and brittle wood, and is known colloquially as the Ch'ou-lashu (Stinking Ash tree). It is also called P'ao-la-tau, a name signifying that its fruit is worthless as a drug in contradistinction to that of $E$. officinalis Dode.

Dode describes the leaves as "subtus albido-glauca," but on our specimens they are merely pale green or pallid on the under surface. Otherwise our material agrees fairly with the short description. The Ieaflets are sometimes narrowed at the base and have usually spreading hairs on the underside of the midrib and secondary veins. The large flat or slightly rounded corymbs, the smaller flowers and the axillary tufts of hair between the veins on the underside of the leaflets readily distinguish this species from the closely allied $E$. Henryi Dode.

A picture of this tree will be found under No. 583 of the collection of Wilson's photographs and also in his Vegetation of Western China, No. 216.

Evodia Henryi Dode in Bull. Soc. Bot. France, LV. 706 (1908).

Evodia Daniellii Pritzel in Bot. Jahrb. XXIX. 423 (pro parte, non Hemsley) (1900).

Western Hupeh: Fang Hsien, woods, alt. 1300-2000 m., June and September 1907 (No. 324, $\%$, fruit; small tree 5-6 m. tall, flowers 
nearly white); same locality, June 1910 (No. 4628 \&); without locality,

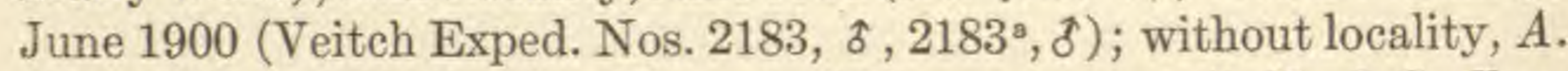
Henry (No. 6712, fruit). Shensi : "Houan-ton-san," Hugh Scallan; Tai-pei-shan, 1910, W. Purdom.

This species is fairly common in north-western Hupeh as a small tree in moist woods and thickets. It is easily recognized by its relatively small pyramidal inflorescence, rather large male flowers, and by the aristate beak to the fruit.

Evodia Henryi, var. villicarpa Rehder \& Wilson, n. var.

A typo recedit foliolis subtus punctulatis, inflorescentia ampliore, fructifera ad $9 \mathrm{~cm}$. longa et ad $12 \mathrm{~cm}$. lata, fructibus villosis.

Western Szech'uan: west of Romi-chango, woods, alt. 23003100 m., July 3, 1908 (No. 357 ; tree 10-20 m. tall, girth 1-3 m.).

This variety may be distinguished from the type by its densely punctulate leaflets, larger inflorescence and more villose earpels. Possibly it is a distinct species but our material which consists of branches with unripe fruit is too incomplete. This variety is a tall and handsome tree and is quite common in the region where it was found.

\section{Evodia velutina Rehder \& Wilson, n. sp.}

Arbor 12-15-metralis, cortice laevi purpureo-fusco; ramuli hornotini dense fulvo-velutini, annotini glabrescentes, fusci, lenticellis parvis sparsis notati; gemmae nudae, dense fulvo-villosae. Folia 35-juga, cum petiolo $16-26 \mathrm{~cm}$. longa; foliola breviter petiolulata petiolulo $2-3 \mathrm{~mm}$. longo, oblongo-lanceolata, infima saepius minora, ovato-oblonga, acuminata apice obtuse, basi plerumque rotundata obliqua, terminale plerumque late cuneatum, minute crenulata, 6-10 cm. longa et $2.5-4 \mathrm{~cm}$. lata, supra obscure luteo-viridia, subtus pallidiora, supra sparsius, subtus in tota facie dense molliter villosa, supra saepe demum fere glabra, nervis utrinque 9-12; petioli 4-7 cm. longi ut rhachis dense velutini. Flores non visi. Inflorescentia fructifera late paniculata, pedunculata, cum pedunculo circiter $2 \mathrm{~cm}$. longo 9$13 \mathrm{~cm}$. longa et $9-18 \mathrm{~cm}$. lata, undique dense velutina; fructus purpureo-brunneus, villosus, $5 \mathrm{~mm}$. altus et $6 \mathrm{~mm}$. diam., carpellis $3-5$, erecto-patentibus oblique obovatis, apice truncatis et intus breviter apiculata acumine circiter $0.5 \mathrm{~mm}$. longo, leviter reticulatis minute punctulatis villosis; semina in quovis loculo duo, inaequalia, superposita, ovalia, 2-2.5 $\mathrm{mm}$. longa, atra, nitentia, hilo albo notata.

Western Szech'uan: west and near Wên-chuan Hsien, woods, alt. 1600 m., October 1908 (No. 994).

This is a very distinct species remarkable for the soft velvety pubescence on the leaves and young branches and for the minute beak to the ripe capsule. It is 
perhaps most closely related to $E$. Henryi Dode, and more especially to the variety villicarpa Rehder \& Wilson. This variety has turbinate fruit but the beak is long and rostrate, the leaflets are glabrous above and nearly glabrous below; the branches are also nearly glabrous; the inflorescence is pyramidate.

Evodia velutina is apparently very local and is only known to us from one district. It is in cultivation.

Here may be added notes on another species of this section and on a species of the section Lepta, not collected during the Arnold Arboretum Expeditions.

Evodia Daniellii Hemsley in Jour. Linn. Soc. XXII. 104 (1886), - Dode in Bull. Soc. Bot. France, LV. 706 (1908).

Zanthoxylum Daniellii Bennett in Ann. Nat. Hist. ser. 3, X. 201, fig. 5 (1862).

Zanthoxylum Bretschneideri Maximowicz in Bull. Acad. Sci. St. Pétersbourg, sér. 3, XXIX. 73 (1884); in Mél. Biol. XI. 655 (1884). - Hemsley in Jour. Linn. Soc. XXIII. 105 (1886).

Shantung: Lau-shan, August 1907, F. N. Meyer (No. 278); without locality, September 1907, F. N. Meyer (No. 262). Chili: mountains, Peking, E. Bretschneider. Korea : Ping-yang, September 18, 1905, J.G.Jack; Seoul, September 24, 1905, J. G. Jack; Seoul, cultivated in Mission grounds, September 1906, U. Faurie (No. 468).

The specimens before us agree very well with Bennett's description and figure, particularly the specimens from Seoul; the specimen from Ping-yang has somewhat broader and shorter leaflets sparingly hairy on both surfaces; that from Shantung has only 5 rather large leaflets, while all the others have from 5 to 9 leaflets.

There can be no doubt that $Z$. Bretschneideri Maximowicz belongs here; we have before us a specimen collected by Bretschneider on the mountains near Peking, consisting of two branches. One of the branches has all the leaves 5foliolate and agrees in every respect even in the dull seeds which are immature with Maximowicz's description; the other branch has 3-7-foliolate leaves and thus approaches the typical $E$. Daniellii. The carpels contain one fully grown and one abortive seed. Sometimes, however, in E. Daniellii both ovules develop into seeds and this explains the differences emphasized by Maximowicz in his original description. In 1890 (in Act. Hort. Petrop. XI.pt. I. 93) Maximowicz points out again the differences between the two species, but makes no mention of the difference in the number of seeds; the specimen from Kansu he refers there to Z. Daniellii, which belongs probably to either Evodia hupehensis Dode or E. Henryi Dode, both of which occur in Shensi.

Sect. 3. Lepta Engl.

Evodia simplicifolia Ridley in Jour. Linn. Soc. XXXVIII. 306 (1908). Guillaumin in Lecomte, Fl. Gén. Indo-Chine, I. 633, t. 24, fig. a. (1911).

Yunnan: Szemao, woods, alt. 1500 m., A. Henry (No. 12092 $)$.

\section{ORIXA Thunb.}

Orixa japonica Thunberg, Fl. Jap. 61 (1784). - Pritzel in Bot. Jahrb. XXIX. 423 (1900). - Shirasawa, Icon. Ess. For. Jap. II. t. 34, fig. 18-25 (1908). - Pampanini in Nuov. Giorn. Bot. Ital. n. ser. XVIII. 170 (1911). 
Othera orixa Lamarck, Tab. Encycl. Méth. I. 310 (1791).

Ilex Orixa Sprengel, Syst. Veg. I. 496 (1825).

Celastrus Orixa Siebold \& Zuccarini in Abh. Akad. Münch. IV. pt. II. 150 (Fl. Jap. Fam. Nat. I. 42) (1846).

Euodia ramiflora Gray in Mem. Am. Acad. n. ser. VI. 383 (1858-1859).

Celastrus japonica K. Koch, Dendr. I. 625 (1869).

Western Hupeh: Hsing-shan Hsien, cliffs, alt. 1000-1300 m., May 25 and November 1907 (No. 64I; spreading bush $2.3 \mathrm{~m}$. tall, flowers yellow); without locality, April 1900 (Veitch Exped. No. 102); without locality, A. Henry (Nos. 7773, 1985, 5247, 6475, 3887). Korea: Quelpaert, thickets, 1908, 1909, Taquet (Nos. 618, 3112, 4149, 4616); same locality, October 1906, U. Faurie (No. 459).

This shrub is not uncommon on cliffs, in thickets, and on the margins of thin woods in western Hupeh.

\section{PHELLODENDRON Rupr.}

\section{Determined by C. S. SARgent.}

Phellodendron sachalinense Sargent, Trees and Shrubs, I. 199, t. 94 (1905).

Phellodendron amurense, var. sachalinense Fr. Schmidt in Mém. Acad. Sci. St. Pétersbourg, sér. 7, XII. 120 (Fl. Saghalin.) (1868). - Palibin in Act. Hort. Petrop. XVII. 51 (Conspect. Fl. Koreae) (1899).

? Phellodendron amurense Franchet \& Savatier, Enum. Pl. Jap. I. 73 (1875).

Western Szech'uan: Mupin, alt. 1200 m., October 9 and 10, 1908 (No. 1286; tree 7-10 m. tall, 0.5-1 m. in diam.); same locality, in open country, alt. 2000 m., October 1910 (No. 42I7; small tree, 7-10 m. tall, 0.5-1 m. diam.).

Except in their slightly thicker leaflets and rather stouter branches of the panicles of fruit, I am unable to distinguish these specimens from those of $P$. sachalinense from central Hokkaido. The discovery of this tree in western China is interesting, for previously it has been known only from Saghalin and northern Japan.

Phellodendron chinense Schneider, Ill. Handb. Laubholzk. II. 126, fig. $79 \mathrm{c}-\mathrm{d}(1907)$.

? Phellodendron japonicum Pritzel in Bot. Jahrb. XXIX. 424 (non Maximowicz) (1901).

Western Hupeh: Changyang Hsien, alt. 1300-1700 m., October 1, 1907 (No. r6r; tree 7 m. tall, 1 m. diam.). 
This species resembles $P$. japonicum Maximowicz in the pale pubescence which covers the lower surface of the leaflets, but is distinguishable from it by its larger fruit on shorter and much stouter pedicels in narrow very compact panicles. The type is Wilson's No. 1972 of the Veitch Expedition which I have not seen.

Phellodendron chinense, var. glabriusculum Schneider, Ill. Handb. Laubholzk. II. 126 (1907).

Phellodendron sinense Dode in Bull. Soc. Bot. France, LV. 649 (1908).

Western Hupeh: Hsing-shan Hsien, woodlands, alt. 1000-1700 m., July 1897 (No. 3227 \&ै, tree 3-10 m. tall, 3 dm.-1 m. diam.); Changyang Hsien, woodlands, alt. 1300-1700 m., July 1907 (Nos. 3566,35678 ; tree $10 \mathrm{~m}$. tall, $1.3 \mathrm{~m}$. diam.); without precise locality, A. Henry (No. 4603 \%, in Herb. Gray). Western Szech'uan: Wa-shan, alt. $1700 \mathrm{~m}$. (No. 3228, ठ ; tree $8 \mathrm{~m}$. tall, $6 \mathrm{dm}$. diam.).

This variety of which Wilson collected only specimens of the staminate tree, is distinguished by the less pubescent under surface of the leaflets which are often nearly glabrous except along the midribs and veins.

The bark of $P$. chinense is used by the Chinese in medicine under the name of huang-peh. A picture of a tree of the variety glabriusculum (No. 3228) will be found under No. 350 of Wilson's collection of photographs and also in his Vegetation of Western China, No. 333.

A Phellodendron raised in Veitch's Nursery as Evodia sp. from seeds collected by Wilson (No. 876, Veitch Exped.) at Changyang Hsien in western Hupeh, at altitudes between 1500 and 2300 metres, and now growing in the Arnold Arboretum, is probably an undescribed species, although the cultivated tree has not yet flowered. I have not seen a Chinese specimen. The young branches are light orange-brown and lustrous; the leaves are 9-11-foliolate, without hairs on the margins, and are villose below along the midribs and veins with rather long white hairs, the unusually slender veins being largely within the parenchyma.

\section{TODDALIA Juss.}

\section{Toddalia asiatica Lamarck, Tab. Encycl. Méth. II. 116 (1793).}

Paullinia asiatica Linnaeus, Spec. 365 (1753), - Osbeck, Dagbok Ostind. Resa 248 (1757); Reise Ostind. 323 (1765); Voy. China East Ind. II. 9 (1771).

Toddalia nitida Lamarek, Tab. Encycl. Méth. II. 116, t. 139, fig. 1 (1793).

Toddalia aculeata Persoon, Syn. Pl. I. 249 (1805), - Bentham, Fl. Hongk. 59 (1861). - Hemsley in Jour. Linn. Soc. XXIII. 108 (1886). - Franchet, Pl. Delavay. 125 (1889), - Pritzel in Bot. Jahrb. XXIX. 424 (1900). Dunn \& Tutcher in Kew Bull. Misc. Inform. add, ser. X. 56 (Fl. Kwangtung \& Hongkong) (1912).

Zanthoxylum nitidum Wallich, Cat. No. 1207 e China (nomen nudum) (non De Candolle) (1828).

Toddalia floribunda Wallich, Pl. As. Rar. III. 17 (1832).

Xanthoxylon floribundum Wallich, Pl. As. Rar. III. t. 232 (1832). 
Limonia oligandra Dalzell in Hooker's Kew. Jour. Bot. II. 258 (1850).

Crantzia asiatica Kuntze, Rev. Gen. I. 99 (1891).

Crantzia nitida Kuntze, Rev. Gen. I. 99 (1891).

Western Hupeh: Ichang, glens, alt. 30-300 m., common, April and July 1907 (No. 2683; semiscandent shrub, 2-6 m. tall); without locality, A. Henry (Nos. 3496, 1306). Szech'uan: "Shan-tzuping," A. von Rosthorn (No. 278). Yunnan: Mi-lê district, A. Henry (No. 9928); Szemao, alt. 1600 m., A. Henry (No. 9928 ${ }^{\mathrm{d}}$ ); Mengtze, alt. 1600 m., A. Henry (No. 13650). Formosa: South Cape, $A$. Henry. Hainan: without locality, C. Ford. Fokien: "Sin-kaikau," alt. 500 m., Dunn's Exped., April to June 1905 (Herb. Bot. Gard. Hongkong, No. 2433).

This thorny semiscandent shrub is common in the glens and gorges near Ichang and also at low altitudes through Szech'uan. A colloquial name is "Pa-tawang."

\section{SKIMMIA Thunb.}

\section{Skimmia melanocarpa Rehder \& Wilson, n. sp.}

Limonia laureola Griffith, Posth. Pap. II. (Itin. Notes) 156, No. 783 (non De Candolle) (1848).

Skimmia laureola Franchet in Nouv. Arch. Mus. Paris, sér. 2, VIII. 211 (Pl. David. II. 29) (non Siebold \& Zuecarini) (1886).

Skimmia japonica Pritzel in Bot. Jahrb. XXIX. 424 (non Thunberg) (1900), quoad specimen Mupinense.

Skimmia Fortunei Pritzel in Bot. Jahrb. XXIX. 424 (non Masters) (1900).

Frutex $0.3-1 \mathrm{~m}$. altus, ramosus (planta yunnanensis interdum ad $5 \mathrm{~m}$. altus secundum cl. Henry); ramuli glabri, crassi, juniores pallide flavo-virentes, vetustiores cinerei. Folia persistentia coriacea, subverticillata, in apicibus ramulorum congesta, oblanceolata v. oblanceolato-oblonga v. lanceolata, rarius anguste elliptica, acuminata $\mathrm{v}$. rarius acuta, basi cuneata, margine leviter recurva, $3.5-9 \mathrm{~cm}$. longa et 1.5-3 cm. lata, interdum ad $15 \mathrm{~cm}$. longa et $4 \mathrm{~cm}$. lata, glabra costa media supra interdum minute villosula excepta, supra saturate luteo-viridia, nitentia, subtus pallidiora, costa media supra leviter subtus magis elevata, nervis obsoletis; petioli crassi, supra plani, anguste alati, 5-7 mm. longi. Flores albidi, dioeci; panicula terminalis sessilis, $2.5-3.5 \mathrm{~cm}$. longa, minute puberula, ramulis inferiorioribus paucifloris, superioribus unifloris, bracteis bracteolisque ovatis acutiusculis minute ciliolatis eirciter $1 \mathrm{~mm}$. longis instructa; pedicelli crassiusculi, $3-8 \mathrm{~mm}$. longi; sepala semiorbicularia v. late ovata, obtusa, ciliolata; petala florum masculorum patentia, oblanceo- 
lato-oblonga, $5 \mathrm{~mm}$. longa et circiter $2 \mathrm{~mm}$. lata, ea florum femineorum angustiora, magis erecta; stamina plerumque petalis subaequilonga, filamentis subulatis glabris, antheris ovoideis, in floribus femineis sterilia, multo minora, ovarium subaequantia; ovarium globosum, $1.5-2 \mathrm{~mm}$. longum; stylus glaber, circiter $1 \mathrm{~mm}$. longus, stigmate capitato; in floribus masculis pistillum abortivum, claviforme v. subulatum, $2 \mathrm{~mm}$. longum. Fructus purpureo-niger, globosus, cireiter $10 \mathrm{~mm}$. diam.; semina albida, subtrigona, $7 \mathrm{~mm}$. longa.

Western Szech'uan: Wa-shan, woods, alt. 1600-2600 m., June and October 1908 (No. Io54, type); Mupin, woods, alt. 2300-2600 m., June 1908 (No. 2597); south-east of Tachien-lu, forests, alt. 26003000 m., September 1910 (No. 4I29); west and near Wên-ch'uan Hsien, woods, alt. 1600-2300 m., June and October (No. 2595); without locality, woods, May 1904 (Veitch Exped. No. 4064). Eastern Szech'uan: Wushan Hsien, A. Henry (No. 5608). Western Hupeh: Fang Hsien, on rocks beneath Silver Fir, alt. 2000-3000 m., May 18, 1907 (No. 2596); without locality, A. Henry (No. 6888). Yunnan: Yuanch'ang, alt. 1600 m., A. Henry (No. 13328); Mengtze, mountains south and east, forests, alt. 1600-2000 m., A. Henry (Nos. 10469,"11069); Feng-chen-lin, forests, alt. 2300 m., A. Henry (No. 11200). India: Sikkim, alt. 2300-3300 m., J. D. Hooker (in Herb. Gray).

This species is a very common undershrub in the forests of western China, more especially in rocky places where it thrives in dense shade. The black fruit distinguishes it from all other species. As known to us this Skimmia is everywhere a small shrub, rarely one metre tall, but Henry describes it in Yunnan as a bush or small tree up to five metres tall. This statement agrees with that respecting the Sikkim plant. The leaves of the Yunnan plant are larger than those of the Szech'uan plant. In Nos. 4064, 2595, the leaves are narrow, long acuminate and much narrowed to the base, and in No. 2595 the flowers are unusually large.

The existence in Sikkim of a Skimmia with black fruit has been known since Griffith's time and that region would appear to constitute the western limit of the range of this species.

Here may be added a note on another Chinese species not collected during the Arnold Arboretum Expeditions.

Skimmia Fortunei Masters in Gard. Chron. ser. 3, V. 520, fig. 9 (1889).

Skimmia japonica Lindley in Lindley \& Paxton, Fl. Gard. II. 56, fig. 163 (non Thunberg) (1851-1852); in Gard. Chron. 1852, 183. - Fortune in Gard. Chron. 1852, 739, 789. - Hooker in Bot. Mag. LXXIX. t. 719 (1853), excludendis synonymis. - Engler in Engler \& Prantl, Nat. Pflanzenfam. III. Abt. 4, 181 (pro parte) (1897). - Pritzel in Bot. Jahrb. XXIX. 424 (1900).

Western Szech'uan: Mount Omei, June and October 1904 (Veitch Exped. No. 4956); same locality, Hugh Scallan. 
Although this plant is fairly common on Mt. Omei, we have not observed it elsewhere in western China, but Rosthorn collected it near Nan-ch'uan. The one flowering specimen before us has polygamo-dioecious flowers but in its general appearance, pentamerous flowers and red fruit it agrees with the S. Fortunei Masters, and we are disposed to doubt that the hermaphrodite character as described for the type is constant in the species.

\section{CLAUSENA Burm.}

Clausena suffruticosa Wight \& Arnott,Prodr.Fl. Ind. I. 96 (1834). Wallich, Cat. No. 8514 (1847). - Oliver in Jour. Linn. Soc. V. Suppl. II. 33 (1861). - Hooker f., Fl. Brit. Ind. I. 506 (1875). Pritzel in Bot. Jahrb. XXIX. 424 (1900).

Amyris suffruticosa Roxburgh, Fl. Ind. II. 250 (1832).

Western Hupeh: Patung Hsien, thickets, alt. 300-1000 m., June and December 1907 (No. 755; bush 2-3 m., flowers greenish-yellow, fruit black); Ichang and immediate neighbourhood, A. Henry (Nos. $3127,4122)$.

This is a rather rare shrub found in glens and ravines at low altitudes. The fruit is orange-yellow before fully ripe and is edible.

Here may be added a note on another Chinese species not collected during the Arnold Arboretum Expeditions.

Clausena punctata Rehder \& Wilson, n. comb.

Cookia punctata Sonnerat, Voy. Ind. Or. II. 231, t. 130 (1782); ed. 2, III. 258, t. 130 (1806). - Poiret in Lamarck, Encycl. Méth. VIII. (1808).De Candolle, Prodr. I. 537 (1824). - Regel in Gartenfl. IX. t. 290 (1860).

Quinaria lansium Loureiro, Fl. Cochin. 272 (1790).

Cookia Wampi Blanco, Fl. Filip. 358 (1837).

Clausena Wampi Oliver in Jour. Linn. Soc. V. Suppl. II. 34 (1861). - Bentham, Fl. Hongk. 50 (1861). - Hooker f., Fl. Brit. Ind. I. 565 (1875). Hemsley in Jour. Linn. Soc. XXIII. 110 (1886). - Dunn \& Tutcher in Kew Bull. Misc. Inform. add. ser. X. 56 (Fl. Kwangtung \& Hongkong). Guillaumin in Lecomte, $F l$. Indo-chin. I. 664, fig. 70 (1912).

Western Szech'uan: Lu Chou, cultivated near the Yangtsze River, May 1903 (Veitch Exped. No. 3374; small tree $4 \mathrm{~m}$. tall). Formosa: Bankinsing, $A$. Henry (No. 42). Kwangtung: Hainan, C. Ford.

This plant is sparingly cultivated as a fruit tree in the neighbourhood of the Yangtsze River in the department of Lu Chou. 


\section{CITRUS L.}

Determined by WALter T. Swingle.

Citrus Medica Linnaeus, Spec. 782 (1753). - Risso in Nouv. Duhamel, VII. 67, t. 22 (1816). - Risso \& Poiteau, Hist. Nat. Orang. t. $96-100$ (1818-1822). ${ }^{1}$

Citrus Tuberosa Miller, Gard. Dict. ed. 8 (1768).

C. Odorata Roussel, Fl. Calvados, 194 (1796).

C. Fragrans Salisbury, Prodr. 378 (1796).

C. cedra Link, Handb. Erkenn. Nutzb. Gew. II. 346 (1831).

C. Cedratum Herquet in Verh. Ver. Beförd. Gartenb. VIII. 36 (1831).

C. cedratus Rafinesque, Sylva Tell. 141 (1838).

C. crassa Hasskarl, Cat. Hort. Bogor. 217 (1844).

Szech'uan: Sui Fu (Süchow Fu), cultivated, December 1908 (No. 474I, fruit in spirits with rough furrowed peel); same locality, December 1908 (No. 4742, large, nearly spherical, smooth fruit in spirits); Lu Chou, sparingly cultivated, December 1908 (No. 4738, fruit in spirits).

Citrus Medica Linnaeus is the type of the genus Citrus and is the only species that was known to the classical Greek and Latin writers. There can be no possible doubt that the citron is the Citrus Medica of Linnaeus.

The Chinese citrons are of several rather diverse sorts. All three of the numbers collected by Wilson are sparingly cultivated in western China. The dried peel is used in Chinese medicine. The fruits of No. 4738 are elongate-obovate, with an apical papilla, 9-10 $\times 4-4.5 \mathrm{~cm}$., slightly furrowed near the base. In the absence of leaves it is difficult to be sure whether this specimen should be placed under this species or not. It is just possible that this is the ancestral form from which the following variety originated.

\section{Citrus Medica, var. sarcodactylis Swingle, n. comb.}

Citrus sarcodactylis Nooten, Fleurs Fruits Feuill. Java, No. 1, t. 3 (1863).

Citrus medica, subsp. genuina, var. Chhangura Bonavia apud Engler in Engler \& Prantl, Nat. Pflanzenfam. III. Abt. IV. 200 (1895). ${ }^{2}$

1 The following Prelinnean names are referable to this species:

Malum citreum vulgare Ferrari, Hesperides, t. 59, 61, 63 (1646).

Cedro Volkamer, Nürnb. Hesperid. t. 114, $116^{\mathrm{a}}, 120^{\mathrm{s}}, 120^{\mathrm{b}}$ (1708); Continuation der Nürnb. Hesperid. t. 50, 57 (1714).

Citria malus Blackwell, Herb. emend. III. t. 361 (1760).

2 The following vernacular names belong to this variety: "Kou yüan," (Giles, Chin. Dict. ed. 2, No. 6140) "Hsiang yüan" (Giles, 1. c., No. 4256) or "Fo shou kan" (Giles, l. c., No. 3589). - Wu Ch'i-chün, Chih wu ming shih t'u k'ao, Bk. 31 , fol. 24, 2 pl., also supplement Chang pien, Bk, 16, fol. 26-28 (1848). - Li Shihchên, Pên ts'ao kang mu, 1596 (see Bretsehneider, Bot. Sin. I. 54), Bk. 30, fol. 13, 
Szech'uan: Sui Fu (Süchow Fu), cultivated, December 1908 (No. 4739, "closed Buddha's hand"); same locality, December 1908 (No. 4740, "open Buddha's hand"). Yunnan: Mengtze, Pan-ya-huan, March 21, A. Henry (No. 10445 ; shrub 1 m. tall, flowers dark pink on outside; photograph and fragments of a specimen from the National Herbarium, Washington, D. C.).

The varietal names cheirocarpa and digitata are often credited to Loureiro ( $F l$. Cochin. I. 465) but he used them merely incidentally in translating a native name and not as specific or varietal names; they consequently have no standing in nomenclature.

The fingered citron, or Buddha's hand is, according to Mr. Wilson's notes, cultivated on a small scale in Szech'uan. The fruits are valued because of their delicious odor and are also used in medicine. They are well known all over China and Japan. Two forms, the one open the other closed, very similar if not identical with those collected by Mr. Wilson are figured by Bonavia under the name Chhàngurà (six fingers). Possibly this variety originated in India and was carried to China by the Buddhist monks. At any rate it seems to have been unknown to the ancient Chinese, as Bretschneider states (Study and value of Chinese botanical works, in Chinese Recorder, III. 178 [1870]) that it is not mentioned in Ki Han, Nan-fang-t'sao-mu-chuang (or Flora of the Southern Regions), the earliest Chinese work of a purely botanical character published about $300 \mathrm{~A}$. D., although the Hsiang yüan or common citron is described.

Henry's specimen (No. 10445 ) shows that the ovary even before the flower opens is broken up into fingers much as is the mature fruit.

Citrus nobilis Loureiro, Fl. Cochin. I. 266 (1790). - Hume in Bull. Florida Agric. Exp. Sta. LXVI. 582, t. 1 (1903); Taylor in Yearb. U. S. Dept. Agric. 1907, 311-313, t. 34 (1908).

Western Szech'uan: Lu Chou, December 1908 (No. 4734, fruit in spirits).

This orange, which is depressed globose in shape and has a rough skin, is cultivated in the same regions as the Mandarin orange but not to the same extent. The rind (Chien-pi) and pithy fibre (Chu-lo) surrounding the carpels are used in Chinese medicine according to Mr. Wilson's notes.

A careful study of Loureiro's descriptions of the species of Citrus found by him during nearly half a century of residence in south-eastern Asia convinces me that his Citrus nobilis must be the orange known in Florida and California as the "King," which was imported into this country from Saigon, Cochinchina, in 1880 . No other known form of the so-called Mandarin group of oranges agrees even remotely with Loureiro's description. Even Loureiro's statement that the peel is edible, "cortice crasso, succoso, dulci, eduli, tubereuloso-inaequali," so impossi-

figure in Atlas under leafy trees (Kuan mu), cited from 1655 ed. - T' $u$ shu tsi ch'eng, 1728 (see Bretschneider, 1. c., 71), Sect. 4. Science, Div. 20, Botany (Ts'ao $\mathrm{mu}$ ), Bk. 286, 1 pl., 10 pp., cited from large reprint.- Sasaki in Jour. Soc. Hort. Jap. No. 151, December, p. 1-15, fig. 1-10 (1 plate) (1904).

"Chhàngurà " or "Chángurá," Bonavia, Cult. Orang. Lemons India, 66-71 Atlas, t. 139, 140 (1888). 
ble to reconcile with the ordinary Mandarin oranges, is supported by Mr. Taylor's statement, "rind ... possessing a distinctive aroma and flavor, agreeable to most persons." Loureiro reported this orange as occurring abundantly in Cochinchina and also in China, though he did not see it in Canton. Mr. Wilson's excellent alcoholic specimens are so like the King orange as to be indistinguishable from this variety. This material is of great interest as it extends the range of this littleknown species well into western Szech'uan.

Citrus nobilis, var. deliciosa Swingle, n. comb. ${ }^{1}$

Citrus nobilis Andrews in Bot. Repos. IX. t. 608 (non Loureiro) (1809).

Citrus nobilis, a. major Ker in Bot. Reg. III. t. 211 (1817).

Citrus reticulata Blanco, Fl. Filip. 610 (1837).

Citrus deliciosa Tenore in Ind. Sem. Hort. Bot. Neapol. [9] (1840).

Citrus madurensis Du Breuil in Risso \& Poiteau, Hist. Cult. Orang. ed. 2, 49, t. 29 bis (non Loureiro) (1872).

Citrus nobilis, subsp. genuina Tanaka in Bot. Mag. Tokyo, XXVI. (204) (1912). ${ }^{2}$

Western Hupeh: Ichang, cultivated alt. 40-300 m., May 1909 (No. 2228; tree 3-8 m., flowers white, fragrant); Western Szech'uan: Kiang-tsin Hsien, between Chungking and Lu Chou, December 1908 (No. 4732; fruit in spirits). Korea : Quelpaert Island, November 1906, U. Faurie (Nos. 479, 481, 482); February 15, 1911, Taquet (No. 4531).

The so-called Mandarin orange said to have been introduced from China into England in 1805 by Mr. Barrow and now grown in all the warmer parts of the globe is undoubtedly a native Chinese species though probably improved by selection through centuries of cultivation. Andrews mistakenly identified this plant as the typical Citrus nobilis of Loureiro in spite of the fact that the plants introduced by Mr. Barrow came from Canton where Loureiro did not find the C. nobilis already familiar to him in Cochinchina. Tenore noting the wide divergence of this plant from Loureiro's description considered it to be a distinct species and named it C. deliciosa. It is probable that Blanco's C. reticulata is the same thing but the application of this name is uncertain since Blanco's type specimen is lost.

It is still a matter of doubt whether the mandarin orange is merely a variety of Citrus nobilis Lour. or a distinct species, as there are a number of other rather diverse varieties such as the "tachibana," a wild, sour form from the Liukiu Islands, and the Tangerine, a red-fruited, large-leaved form probably of Chinese origin, now widely grown in warm climates. For the present it seems best to consider all

1 The following prelinnean name belongs here:

Aurantium sinense Rumphius, Herb. Amb. II. 113, t. 34 (1741).

"Vernacular name: "Kan" (Giles, Chin. Dict. ed. 2, No. 5833), -Wu Ch'i-chün Chih wu ming shih t'u k'ao, Bk. 31, fol. 7 (1848). - T'u shi tsi ch'eng, 1728 (see Bretschneider, Bot. Sin. I. 71) Sect. 4, Science, Div. 20, Botany (Ts'ao $\mathrm{mu}$ ), Bk. 226, 50 pp. with 1 plate, cited from large reprint. - Li Shih-chên, Pên ts'ao kang mu, 1596 (see Bretschneider, I. c., 54), Bk. 30, fol. 11-12, figure in Atlas under leafy trees (Kuan mu), cited from 1655 ed. 
of these as well as some at least of the Suntara, Keonla and Jambhiri oranges of India (Bonavia, Cult. Orang. Lemons India, 44-62, Atlas, t. 114-138) as constituting subspecies or varieties of one very variable species. Better knowledge of this complex group may resolve it into several closely allied species connected by hybrid forms that have appeared in cultivation. Many, in fact most botanists have considered this plant to be the typical Citrus nobilis Loureiro, but an attentive reading of Loureiro's deseription will show that he had a quite different plant in mind, doubtless some orange of the King type.

A picture of this tree will be found under Nos. 456 and 457 in the collection of Wilson's photographs and also in his Vegetation of Western China, No. 167.

\section{Citrus grandis Osbeck, Dagbok Ostind. Resa, 98 (1757). ${ }^{1}$}

Citrus Aurantium, $\gamma$. grandis Linnaeus, Spec. 783 (1753).

Citrus Aurantium, $\gamma$. decumana Linnaeus, Spec. ed. 2, 1101 (1763).

Citrus decumanus Linnaeus, Syst. Nat. ed. 12, II. 508 (1767).

Aurantium decumana Miller, Gard. Dict. ed. 8 (1768).

Citrus decumana Linnaeus, Syst. Veg. ed. 14, 697 (1784). - Poiteau, Pomol. Franc. II. t. 344 (1846). - Nooten, Fleurs Fruits Feuill. Java, No. 4, t. 3 (1863), - Risso in Nouv. Duhamel, VII. 107, t. 38, 42 (1816).

Citrus Pamplemos Risso, Hist. Nat. Prod. Eur. Mérid. I. 412 (1826). - Risso \& Poiteau, Hist. Nat. Orang. t. 62, 63 (1818-1822).2

Western Hupeh: Ichang, cultivated, alt. 40-300 m., May 1907 (No. 2229; tree 3-7 m. tall, fruit very bitter and dry); same locality, December 1908 (No. 4743, fruit). Formosa: without locality, cultivated, A. Henry (No. 318; glaucous form analogous to grapefruit of West Indies and America).

The oldest name for this species seems to be that published by Osbeck in 1757 . There are several well-marked varieties that may upon study be found to merit subspecific rank. Osbeck based his species on a round-fruited form with a spongy skin a finger thick from Java. He found both a round form (lo yao) and a long form (hon yao) at Canton, both of which he referred to Citrus grandis.

Citrus ichangensis Swingle in Jour. Agric. Research, I. 1, fig. 1-7, t. 1 (1913).

1 Prelinnean names of this species are:

Malus arantia, fructu rotundo maximo pallescente humanum caput excedente Sloane, Voy. Jam., 41, t. 12, fig. 2, 3, 4 (1707).

Pompelmus Volkamer, Nürnb. Hesperid. t. $190^{a}$ (1708).

Limo decumanus sive Pompelmoes Rumphius, Herb. Amb. II. 96, t. 24, fig. 2 (1741).

"Vernacular name: "Yu," (Giles, Chin. Dict. ed. 2, No. 13408), Li Shih-chên, Pên ts'ao kang mu, 1596: (see Bretsehneider, Bot. Sin. I. 54), Bk. 30, fol. 12-13, figure in Atlas under leafy trees (Kuan mu) (crude, leaves without petioles), cited from 1655 ed. - Wu Ch'i-chün, Chih wu ming shih t'u k'ao, Bk. 32, fol. 6-7, with 1 plate, also supplement Chang pien, Bk. 15, fol. 28-29 (1848). - T' $u$ shu tsi ch'eng, 1728) (see Bretschneider, Bot. Sin. I. 71), Sect. 4, Science, Div. 20, Botany (Ts'ao mu), Bk. 230, 1 pl., 3 pp., cited from large reprint. 
Frutex v. arbor 1-10-metralis, plerumque 1-5-metralis; rami juniores angulati, saepe spinosissimi, 2-4 $\mathrm{mm}$. diam. Folia angusta, $6-13.5 \mathrm{~cm}$. longa et $1.5-3.3 \mathrm{~cm}$. lata, plerumque $8-11.5 \mathrm{~cm}$. longa et 1-3 cm. lata; petioli late alati, laminam saepe aequantes $\mathrm{v}$. superantes, obovato-elliptici v. oblongo-spathulati, ad basin abrupte attenuati, apice regulariter rotundati $\mathrm{v}$. truncati v. subcordati; laminae ovatoacuminatae, plus minusve caudatae, apice leviter emarginatae, ad basin regulariter rotundatae v. obtuso-cuneatae. Flores grandes, 20$35 \mathrm{~mm}$. diam., 5-meri, solitarii, axillares; pedicelli $3-5 \mathrm{~mm}$. longi; sepala crassa, subtriangularia, $3 \mathrm{~mm}$. longa et lata, margine minute ciliata; petala oblonga, $1.5-2 \mathrm{~cm}$. longa et $0.5-0.8 \mathrm{~cm}$. lata; stamina 20 , polyadelphia, initio usque ad apicem cohaerentia, deinde in fasciculos 3-5 discedentia, $0.8-1 \mathrm{~cm}$. longa; stylus $3-4 \mathrm{~mm}$. longus et $1.5 \mathrm{~mm}$. crassus, stigmate $2-2.5 \mathrm{~mm}$. longo et $3 \mathrm{~mm}$. crasso; ovarium $3 \mathrm{~mm}$. longum ac crassum. Fructus grandis, ovalis, 7-10 $\mathrm{cm}$. longus et 9-10 $\mathrm{cm}$. diam., ad basin tuberculato-sulcatus, apice papilla magna vix prominente sulco circulari plus minusve $25 \mathrm{~mm}$. diam. circumdata coronatus; cortex crassus, 7-9 mm. diam.; segmenta 8-11; pulpa vesicularis, acida; semina 40-70 in quoquefructu, pro genere grandia, 15-20 mm. longa et 10-14 lata et 7-11 crassa, ovato-acuta, polyembryonica.

Western Hupeh: Pingshan-pa, in Ichang gorge, 10 kilometers north-west of Ichang, eultivated, November 1907 (No. 4736, 4737, fruit; Nanto, April 25, 1900 (Veitch Exped. No. 202, flowers); San-yu-tung glen, $10 \mathrm{li}$ from entrance, cultivated, July 1907 (No. $2230^{\mathrm{b}}$, fruit; bushy tree $5 \mathrm{~m}$. tall, Liang-shan-kou, about 17 kilometers south-east of eity of Hsing-shan, alt. 500-700 m., ravine, May 7, 1907 (No. 2230, twig with flowers, type; bush 1-2 m. tall, flowers white); Li-er-kou, 14 kilometers north-north-west of city of Hsing-shan, alt. 1400 m., escaped from cultivation, roadside, May 15, 1907 (No. 2230 ; bush or tree 1-5 m. tall, flowers white). Eastern Szech'uan: Kweichou Fu, Feng-hsiang gorge, spontaneous, May 1903 (Veiteh Exped. No. 3307; $1 \mathrm{~m}$. tall, flowers). Photographs of 18 additional paratypic specimens in other herbaria are filed in the herbarium of the Arnold Arboretum. These represent 9 collections from 8 localities, 2 in Hupeh, 5 in Szech'uan and 1 in Kweichou province. $^{1}$

${ }^{1}$ They are listed in detail in the original description of the species, except the following: eastern Szech'uan, Kweichou Fu, before December, 1887, Ernst Faber (No. 316) in Herb. Kew. 
This very remarkable new species of which Mr. Wilson secured excellent material is not closely related to any other member of the genus Citrus and is undoubtedly native in central and south-west China in the provinces of Hupeh, Szech'uan, Kweichou and probably also in Yunnan. It grows farther north and at higher altitudes than any other known species of Citrus. ${ }^{1}$

It is cultivated on a small scale around Ichang and yields a fruit which looks somewhat like a large coarse lemon, with a thick skin and many large seeds, but has an acid juice of good flavor. It is known to European residents of China as the Ichang lemon and is shipped as far as Hankow, as Mr. Wilson informs me. The type locality of this species is shown in Wilson's collection of photographs, Nos. 025 and 032.

A variety of the species, Citrus ichangensis latipes Swingle (in Jour. Agric. Research. I. 12 [1913]), occurs wild in the Khasi hills in Assam.

There may be added some notes on Chinese Citrus chiefly from eastern China, not collected by Wilson.

\section{Citrus Limonia Osbeck, Reise Ostind. China 250 (1765). ${ }^{2}$}

Citrus Medica, $\beta$. Limon Linnaeus, Spec. 782 (1753).

Limon vulgaris Miller, Gard. Dict. ed. 8 (1768).

Citrus Limon Burmann, Fl. Ind. 173 (1768).

Citrus medica Plenck, Icon. 54, t. 579 (non Linnaeus) (1794). - Hayne, Getr. Darst. Arzneik. Gew. XI. 27, t. (1830). - Guimpel \& Schlechtendal, Abbild. Beschreib. Pharm. Boruss. Gew. I, t. 70 (1830).

Citrus Lima Aitchison, Encycl. Perthensis II. (before 1806); New and Comp. Amer. Encycl. From the Encycl. Perthensis with improvements, New York II. 578 (1806).

Citrus limonum Risso in Ann. Mus. Paris, XX. 201 (1813). - Berg \& Schmidt, Darst. Beschreib. Off. Gew. III. 31, t. (1861). - Bentley and Trimen, Med. Pl. I. 54, t. (1880).

Citrus limon Lunan, Hort. Jam. I. 451 (1814).

Citrus Limonium Risso in Nouv. Duhamel, VII. 77, t. 28 (1816).

Citrus Limonum sylvaticum Risso \& Poiteau, Hist. Nat. Orang. 148, t. 70 (1819).

Citrus fusiformis Rafinesque, Sylva Tell. 142 (1838).

Citrus granulata Rafinesque, Sylva Tell, 142 (1838).

Citrus communis Poiteau, Pomol. Franç. II. t. 274 (1846).

Citrus medica, var. Limonum Hooker f., Fl. Brit. Ind. I. 515 (1875) ${ }^{3}$

Yunnan: Mengtze, mountains, alt. $1445 \mathrm{~m}$. [March 21], A. Henry, (No. 10445 ; 'shrub 1 m., cult.?)

The lemon, though closely related to the citron, differs from it in having the blade of the leaf articulated with the linear margined or narrowly winged petiole and a thin-rinded papillate fruit with a dehiscent style. The leaves of the lemon

1 Except Citrus trifoliata Linnaeus which is here considered to belong to a distinct genus, Poncirus.

2 The following Prelinnean names belong here:

Limon vulgaris Ferrari, Hesperides, 189, 193, t. (1646).

Limon vulgare, Volkamer, Nürnb. Hesperid. 154, t. (1708).

"Vernacular name: "? Fo t'ao" (Giles, Chin. Dict. ed. 2, Nos. 3589, 10807, Buddha's peach). - Wu Ch'i-chün, Chi wu ming shih $t^{\prime} u$ k'ao, Bk. 31, fol. $55, \mathrm{t}$ (1848). 
are more pointed and less serrate than those of the citron, the twigs are more slender, the flowers are smaller and in a number of other characters small but clearly marked differences are found between the two plants.

The oldest available name for the lemon seems to be Citrus limonia Osbeck, dating from 1765 . The original Swedish edition of Osbeck's travels, published in 1757 did not give this plant a Latin name (Dagbok ofwer en Ostindisk Resa, 192). This Osbeck added to the German translation published 8 years later. The application of the name is rendered obscure by faulty translation of the description in the German, and still more in the English edition of 1774, but the Latin diagnostic phrase published in the original Swedish edition applies very well to the lemon. The Cantonese name given as "na-mång " in Swedish is incorrectly given as "Na-mang" in German, which has a very different sound. Dr. Hing Kwei Fung, a Cantonese graduate of the Agricultural School of Cornell University, recognized the name given in Swedish as being the colloquial pronunciation of the words "ning mong" in Cantonese meaning a lemon, which is still commonly grown and sold in pots as in Osbeek's day. Osbeck evidently intended to include in this species the common lemons such as he saw growing in Spain, though he did not find them in China. According to Bretschneider (in Chinese Recorder, III. 179 [1870]) the book name of the lemon is "Hsiang t'ao," fragrant peach, the name " ning mêng" (Giles, Chin. Dict. ed. 2, Nos. 8332 and 7767, the same as "ning mong" in Cantonese) not being found in the books.

\section{Citrus Aurantium Linnaeus, Spec. 782 (1753). ${ }^{1}$}

Aurantium acre Miller, Gard. Dict. ed. 8, errata, (1768).

Citrus fusca Loureiro, Fl. Cochin. II. 467 (1790).

Citrus Medica Roussel, Fl. Calvados, 174 (non Linnaeus) (1796).

Citrus Florida Salisbury, Prodr. 378 (1796).

Citrus vulgaris Risso in Ann. Mus. Paris, XX. 190 (1813). - Berg \& Schmidt, Darst. Beschreib. Off. Gew. III. 31, t. (1861). - Bentley \& Trimen, Med. $\mathrm{Pl}$. I. 50, t. (1880).

Citrus Bigarradia Risso in Nouv. Duhamel, VII. 99 (1816).

Citrus Bigaradia Risso \& Poiteau, Hist. Nat. Orang. 72, t. 30 (1818-22).

Citrus daidai Siebold in Verh. Batav. Genootsch. XII. 59 (Syn. PI. Oec. Jap.) (nomen nudum) (1830).

Citrus amara Link, Handb. Erkenn. Nutzb. Gew. II. 346 (1831).

Citrus Aurantium, var. amara Kosteletzsky, Allgem. Med.-Pharm. Fl. 2000 (1836).

Citrus Karna Rafinesque, Sylva Tell. 142 (1838).

Citrus communis Le Mout \& Decaisne, Traité Gén. Bot. 318 (1868).

Citrus Aurantium, var. Bigaradia Hooker f., Fl. Brit. Ind. I. 515 (1875). ${ }^{2}$

\section{The following Prelinnean names are referable to this species:}

Aurantium olysiponense Ferrari, Hesperid. t. 427, (1646).

Aranzo Silvestre Volkamer, Nürnb. Hesperid. t. 188 (1708).

Aurantium Acidum Rumphius, Herb. Amb. II. 111, t. 33 (1741).

2 Vernacular names: "Ch'êng" (Giles Chin. Dict. ed. 2, No. 774), Wu Chi-chün, Chih wu ming shih $t^{\prime} u k^{\prime} a o$, Bk. 31, fol, 8, with 1 plate, also Chang pien, Bk. 17, fol. 45 (1848). - Li Shih-chên, Pên ts'ao kang mu, 1596 (see Bretschneider, Bot. Sin. I. 54), Bk. 30, fol. 12, figure in Atlas under leafy trees (Kuan mu), eited from 1655 ed. - T' $u$ shu tsi ch'eng, 1728 (see Bretschneider, 1. c., 71), Sect. 4, Science, Div. 20, Botany (Ts'ao mu), Bk. 230,15 fol., with 1 plate, cited from large reprint. 
Yunnan: Szemao Mts., alt. 1400 m., A. Henry (No. 11605; shrub 10 ft., white, cult.?). Korea: Quelpaert Island, November 1910, Taquet (No. 4459; "fruit aplati, écorce rugeuse, mangeable, fruit très acide").

The sour or Seville orange has a very close superficial resemblance to the sweet or common orange, Citrus sinensis Osbeck, but is in reality a very distinet species as noted in the discussion under the latter species.

Linnaeus named the sour orange Citrus Aurantium and distinguished the sweet orange as Citrus Aurantium, $\beta$. sinensis. Much confusion was brought about by Loureiro, Risso and other botanists who followed them by calling the sweet orange Citrus Aurantium and giving some other name to the sour orange. Hooker even called the sour orange a variety of the sweet, thus exactly reversing the usage of Linnaeus. Loureiro is apparently the first writer to misapply Citrus Aurantium to the sweet orange. His Citrus fusca seems to have been intended for the sour orange, though very few botanists have been able to grasp his meaning, to judge from the variety of unrelated species that they have classed under this name.

There is much confusion as to the application of the three principal Chinese names of oranges - Ch'êng, Chü and Kan. Fortunately, we have the direct and competent testimony of Osbeck (Dagbok Ostind. Resa, 192) that the sour orange is called Chang (Tjang in Swedish) in Canton, although he says the common tightskinned sweet orange is sometimes called by the same name. This name is without any doubt the Ch'êng of Mandarin Chinese. Kan refers to the loose-skinned or mandarin type of oranges, so by a process of exclusion the name Chü should apply to the tight-skinned sweet orange. This would give three Chinese names, each written as a single ancient character, for the three species of oranges cultivated in China.

Citrus sinensis Osbeck, Dagbok Ostind. Resa, 41 (nomen nudum) (1775); Reise Ostind. China, 250 (1765). ${ }^{1}$

Citrus Aurantium, $\beta$. sinensis Linnaeus, Spec. 782 (1753).

Aurantium sinense Miller, Gard. Dict. ed. 8 (1768).

Citrus Aurantium Loureiro, Fl. Cochin. II. 466 (non Linnaeus) (1790).

Citrus A urantium vulgare Risso \& Poiteau, Hist. Nat. Orang. 33, t. 3 (1818-22).

Citrus Aurantium dulce Hayne, Getr. Darst. Beschreib. Arzneyk. Gew. XI. t. $28(1830) .^{2}$

Formosa: Bankinsing, A. Henry (No. 150; truly wild in the mountains). Korea: Quelpaert Island, November 1906, U. Faurie (No. 480); October 1910, Taquet (No. 4458; " fruit gros, allongé, écorce épaisse, très rugeuse, pulpe acide ").

The common sweet orange, often confounded with the sour or Seville orange, is in fact quite distinct from the latter. The fruits of the sweet orange have a solid core, never becoming hollow like that of the sour orange; the petioles are

1 To this species belongs the following Prelinnean name:

Aranzo dolce Volkamer, Nürnb. Hesperid, t.188 b (1708).

2 Vernacular names: "Chü" (Giles, Chin. Dict. ed. 2, No. 3026). - Wu Ch'ichün, Chih wu ming shih t'u k'ao, Bk. 32, fol. 5 , with 1 plate; also Chang p'ien, Bk. 15, fol. 18-21 (1848). - Li Shih-chên, Pên ts'ao kang mu, 1596 (see Bretschneider, Bot. Sin. I. 54), Bk. 30, fol. 9-11, figure in Atlas under leafy trees (Kuan mu) eited from 1655 ed. - T' $u$ shu tsi ch'eng, 1728 (see Bretschneider, 1. e., 71), Sect. 4, Science, Div. 20, Botany (Ts'ao mu), Bk. 228,3 pp, with 1 plate cited from large reprint.

? "Ch'êng," see entries under Citrus Aurantium. 
narrowly winged in the sweet and broadly winged in the sour orange; the leaves and flowers of the two species have a very distinct odor. The two species show decided differences in their soil requirements and in their susceptibility to the attacks of fungous diseases. Many other minute but constant divergences are shown between these two oranges in all their organs. These two plants, then, superficially so similar are in reality very unlike and should by no means be united as varieties of one species.

The earliest available name for the sweet orange as a species distinct from the sour orange is Citrus sinensis Osbeck. Osbeck in the German edition of his Voyage applies the name to both the mandarin orange and the tight-skinned or common orange, but expressly excludes the sour orange. He had previously in the Swedish edition of his work called the sweet orange seen in Spain Citrus sinensis and the sour orange Citrus Aurantium, but in an incidental way, probably not establishing the name though referring to it elearly enough to make it plain that of the two forms included in Citrus sinensis in 1765 the type must be held to be the common orange grown in Spain and China both, and not the mandarin orange. There is no warrant for using Citrus A urantium Linnaeus for the sweet orange, as Loureiro, Risso, Hooker and many other authors have done.

All of the commonly cultivated species of Citrus, with the exception of the lime (Citrus aurantifolia (Christman) Swingle, see Jour. Washington Acad. Sci. III. 463-465 [1913]), seem to be native in China and many are found nowhere else. In addition to the species listed above, there are a number of puzzling forms collected by Wilson and others which do not seem to fit into any of the species of Citrus known as yet. Some of the specimens may represent hybrids but until more complete material is at hand it will be impossible to place them with any degree of certainty.

\section{PONCIRUS Raf.}

\section{Determined by Wauter T. Swingle.}

\section{Poncirus trifoliata Rafinesque, Sylva Tell. 143 (1838). ${ }^{1}$}

Citrus trifoliata Linnaeus, Spec. ed. 2, 1101 (1763).-Hooker f. in Bot. Mag. CVI. t. 6513 (1880). - Engler in Engler \& Prantl, Nat. Pflanzenfam. III. Abt. IV. 196, fig. 114 (1896).

Citrus trifolia Thunberg, Fl. Jap. 294 (1784).

Aegle (?) sepiaria De Candolle, Prodr. I. 538 (1824). - Penzig in Ann. di Agricoltura (2), No. 116, p. 132-149, t. 11, 13, 14 (Studii Bot. Agrumi) (1887). - Nicholson in Gard. Chron. ser. 3, XXVII. 269 (1900); in Flora \& Sylva, III. 65 (1905).

Pseudaegle sepiaria Miquel in Ann. Mus. Lugd.-Bat. II. 83 (1845).

Citrus triptera Carrière in Rev. Hort. 1869, 15, fig. 2 (non Desfontaines). - Du

Breuil in Risso \& Poiteau, Hist. Nat. Orang. ed. 2, 145, t. 195 bis (1872).

Limonia trichocarpa Hance in Jour. Bot. XV. 258 (1882). ${ }^{2}$

1 The following Prelinnean name belongs here:

Ssi, vulgo Karatats banna, aliis Gees, Kaempfer, Amoen. 801, t. (1712).

2 Vernacular name: "Kou chü" (Giles, Chin. Dict. ed. 2, No. 6140), Li Shihchên, Pên ts'ao kang mu, 1596 (see Bretschneider, Bot. Sin. I. 54), Bk. 36, fol. $5-7$, figure in Atlas under leafy trees (Kuan mu), very crude, cited from 1655 ed. - Wang Ch'i, San ts'ao t'u hui, 1607 (see Bretschneider, 1. c., 183), Bk. 84, fol. 4, 
Western Hupeh: Ichang, hedgerows, alt. 1-300 m., May 1907 (No. 223r ; tree, $6 \mathrm{~m}$. tall). Shensi: Tai-pei-shan, 1910, W. Purdom. Korea: Quelpaert Island, October 1906, U. Faurie (No. 483); April 16, 1908, Taquet (No. 4617); April 1909, Taquet (No. 2715).

This tree is undoubtedly indigenous in northern China and occurs wild or cultivated over a large part of the Empire. The fruits are used in medicine, and the tree as a stock upon which to graft forms of Citrus. It is called Kou chü.

In Japan the Chinese character pronounced Chih (Giles, Chin. Dict. ed. 2, No. $1864)$, in China is applied to this species and pronounced "Karatachi." This character, rarely used alone in Chinese, is usually in combination, as Chih shih (Chih fruit) and Chih K'o (Chih peel), two common drugs. It is, however, by no means certain that these drugs are yielded by Poncirus trifoliata. Further study will be needed to determine the application of these names in China. It is possible that the Chih fruit and Chih peel are produced by two or more different species of citrous fruits, among them perhaps Poncirus trifoliata. ${ }^{1}$ This species was introduced into Japan many centuries ago but is not native there.

This tree which is commonly called Citrus trifoliata (less often Aegle sepiaria) differs from Citrus in so many and such important characters that it seems preferable to consider it as belonging to a distinct genus. The deciduous leaves are trifoliate, the flower buds form in early summer and being protected by bud scales pass the winter in a dormant condition. The flowers open in early spring, being almost sessile and borne on old wood. The corolla opens nearly flat and the petals are narrowed to a claw at the base; the stamens are entirely free; the ovary is $6-8$ (usually 7) celled; the fruits are densely and finely pubescent; the pulp vesicles have hairlike appendages with expanded tips bearing enlarged pitted thick-walled cells, which secrete a viscous fluid. The pith has transverse plates of thick-walled cells. The stomata of the green twigs are located at the bottom of deep narrow pits. The seedlings have a number of small, linear spirally arranged cataphylls which gradually merge into normal leaves. ${ }^{2}$

fig. (erude), cited from Japanese ed. Osaka, 1713. - T' $u$ shu tsi ch'eng, 1728 (see Bretschneider, 1. c., 71) Sect. 4, Science, Div. 20, Botany (Ts'ao mu), Bk. 302, $3 \mathrm{pp}$. with 1 plate, cited from large reprint. - Wu Ch'i-chün, Chih wu ming shih t'u k'ao (see Bretschneider, 1. c., 72), Bk. 35, fol. 61, plate, good fig., also supplements, Ch'ang Pien, Bk. 22, fol. 57 (1848).

1 There is a sterile specimen from which the blades of all the leaves have fallen leaving the rather widely winged petioles attached, that is labeled, apparently in Henry's handwriting:

"Weucheo (Chi-K'o). Fruit used by Chinese medicinally (only)."

This specimen though too defective to determine is certainly not Poncirus trifoliata but a true Citrus. Wilson's No.4733, small, thick, rough-skinned fruits in spirits collected at Hokiang Hsien in Szech'uan still have a few leaves attached which show elongate obovate petioles $17 \times 8.5 \mathrm{~mm}$., and may possibly belong here. It is impossible to decide without better material.

${ }^{2}$ These differences were noted by Penzig in his Studii botanici sugli Agrumi, but as he erroneously considered the tree to belong to Aegle he did not deem it necessary to justify its separation from Citrus. See also Swingle, The Limitation of the Satsuma Orange to Trifoliate-Orange Stock (in Circular Bur. Pl. Indust. U.S. Dept. Agric. XLVI. 10, fig. 1-6, t. 1 [1909]), and Variation in First Generation Hybrids, etc., in Comptes rendus et rapports, 4 conférence international de Génétique d̀ Paris, 1911, p. 382 (1913). 
In view of these numerous and, from a taxonomic point of view, important points of difference, there ean be no doubt but that the trifoliate orange must be removed from the genus Citrus. The oldest name for it seems to be the Poncirus of Rafinesque.

A picture of this tree will be found under No. 0360 of the collection of Wilson's photographs. 


\section{SIMARUBACEAE.}

Determined by Alfrem ReHder and E. H. Wilson.

\section{PICRASMA Blume.}

Picrasma quassioides Bennett, Pl. Jav. Rar. 198 (1844). - Planchon in Lond. Jour. Bot. V. 573 (1846).-Wallich, Cat. No. 8506 (1847). - Bentham, Fl. Hongk. 61 (1861). - A. W. Bennett in Hooker f., Fl. Brit. Ind. I. 520 (1875), - Hemsley in Jour. Linn. Soc. XXIII. 112 (1886). - Franchet, Pl. Delavay. 125 (1889). - Sargent in Garden \& Forest, VI. 112 (1893). - Pampanini in Nuov. Giorn. Bot. Ital. n. ser. XVII. 407 (1910). - Dunn \& Tutcher in Kew Bull. Misc. Inform. add. ser. X. 57 (Fl. Kwangtung \& Hongkong) (1912).

Simaba quassioides D. Don, Prodr. Fl. Nepal. 248 (1825).

Nima quassioides Hamilton ex D. Don, Prodr. Fl. Nepal. 248 (quasi synon.) (1825).

Rhus ailanthoides Bunge in Mém. Sav. Êtr. Acad. Sci. St. Pétersbourg, II. 89 (Enum. Pl. Chin. Bor. 15) (1833).

Picrasma ailanthoides Planchon in Lond. Jour. Bot. V. 573 (1846). - Shirasawa, Icon. Ess. For. Jap. I. 90, t. 53 (1900). - Pritzel in Bot. Jahrb. XXIX. 425 (1900). - Schneider, Ill. Handb. Laubholzk. II. 129, fig. 82 f-m., $83 \mathrm{a}(1907)$.

Picrasma japonica Gray in Mem. Am. Acad. n. ser. VI. 383 (1858-59).Hance in Ann. Sci. Nat. sér. 5, V. 210 (1866).

Picrasma quassioides, var. glabrescens Pampanini in Nuov. Giorn. Bot. Ital. n. ser. XVIII. 171 (1911).

Kiangsi : Kuling, thickets, alt. 1300 m., July 30, 1907 (No. I67I ; bush 2-2.5 m.). Western Hupeh: north and south of Ichang, thickets and margins of woods, alt. 300-1000 m., May and July 1907 (No. 3223; slender tree 3-6 m. tall); Patung Hsien, woodlands, June 1901 (Veitch Exped. No. 903); without locality, April 1901, May 1900 (Veitch Exped. Nos. 1823, 1965); without locality, A. Henry (Nos. 7570, 7570 b); "Monte Triora," July 1907, C. Silvestri (No. 1239). Eastern Szech'uan: Wushan Hsien, June 1900 (Veitch Exped. No. 1062); same locality, A. Henry (Nos. 5534, 5534a ${ }^{\text {, }}$ 5649). Western Szech'uan: Wa-shan, thickets, alt. $1300 \mathrm{~m}$., May and September 1908 (No. 3223; tree $10 \mathrm{~m}$. tall, girth $1 \mathrm{~m}$., flowers yellow, 
fruit black); without precise locality, in a ravine, alt. 1000 m., May 1904 (Veitch Exped. No. 3361); "Chin-li-wan," A. von Rosthorn (No. 454). Shensi: "Kin-qua-san" and "Lao-y-san," July and September 1897, G. Giraldi; northwest of Han-chang Hsien, Moutan-shan, 1910, W. Purdom (No. 362); Tai-pei-shan, 1910, W. Purdom. North central China: "Fou-sian-fu," Hugh Scallan. Shantung: Lau-shan, August 1907, F. N. Meyer (No. 312); Tsingtau, 1901, Zimmerman (No. 361). Korea: Quelpaert, thickets, August 1910, Taquet (No. 4090); same locality, June 1907, U. Faurie (No. 1608).

This small tree is common all through central and western China up to an altitude of $1300 \mathrm{~m}$. It is colloquially known as the "Ku-lien-shu" and the bark is highly esteemed as a drug. This tree has a very extensive geographical range, and although it varies slightly in degree of pubescence it is otherwise remarkably constant in its characters.

\section{AILANTHUS, Desf.}

Ailanthus cacodendron, Schinz \& Thellung apud Thellung in Mém. Soc. Sci. Nat. Cherbourg, XXXVIII. 637, 679 (Fl. Adv. Montpellier) (1912).

Rhus cacodendron Ehrhart in Hannov. Mag. 1783, 227; in Beitr. Naturk. II. $111 ;^{1}$ III. 20 (1788).

Ailanthus glandulosa Desfontaines in Mém. Acad. Sci. Paris, 1786, 265, t. 8. -

L'Heritier, Stirp. Nov. 179, t. 84 (1791). - Bunge in Mém. Sav. Etr. Acad.

Sci. St. Pétersbourg, II. 89 (Enum. Pl. Chin. Bor. 15) (1833). - Debeaux

in Act. Soc. Linn. Bordeaux, XXXIII. 38 (Fl. Tien-tsin, 15) (1879).-

Baker \& Moore in Jour. Linn. Soc. XVII. 380 (1880). - Franchet in Nouv. Arch. Mus. Paris, sér. 2, V. 220 (Pl. David. I. 68) (1883). - Hemsley in Jour. Linn. Soc. XXXIII. 112 (1886).

Ailanthus procera Salisbury, Prodr. 171 (1796).

Pongelion glandulosum Pierre, Fl. For. Cochin. IV. in textu ad t. 294 (1891).

Chekiang: vicinity of Ningpo, 1908, D. Macgregor. Fokien: without precise locality, Dunn's Exped., April to June, 1905 (Herb. Bot. Gard. Hongkong, No. 2460). Shantung: Tsingtau, 1901, Zimmerman (No. 374).

The type which has relatively small fruit is apparently confined to northern and eastern China where it is often planted.

Ailanthus cacodendron, var. sutchuenensis Rehder \& Wilson, n. comb.

${ }^{1}$ This is an exact reprint of the original publication in Hannov. Mag. 
Ailanthus glandulosa Pritzel in Bot. Jahrb. XXIX. 425 (non Desfontaines) (1900).

Ailanthus sutchuenensis Dode in Bull. Soc. Dendr. France, 1907, 192, fig. a; in Fedde, Rep. Sp. Nov. VI. 8 (1909).

Ailanthus glandulosa, var. sutchuenensis Rehder in Mitt. Deutsch. Dendr. Ges. XXI. 187 (1912).

Western Hupeh: Ichang, common up to $800 \mathrm{~m}$. alt., June and September 1907 (No. 2034; tree 13-25 m. tall, girth 1-3 m.); same locality, May and October 1900 (Veitch Exped. No. 663); without locality, A. Henry (No. 3886).

The more shining and glabrous shoots and larger fruit distinguish this variety from the type; the leaves, too, are less ciliate on the margins, but this character varies. This tree is common in the neighborhood of Ichang where it is known as the "Ch'ao ch'un shu" (stinking Cedrela tree).

Ailanthus Vilmoriniana Dode in Rev. Hort. 1904, 444, fig. 184; in Bull. Soc. Dendr. France, 1907, 190, fig. c.

Ailanthus glandulosa, var. spinosa Vilmorin \& Bois, Frut. Vilmorin. 31, fig. (1904)

Western Hupeh: Fang Hsien, roadsides, alt. 1000-1100 m., May, July and September 1907 (No. 388; tree 6-16 m. tall).

This tree is common in the dry, warm river-valleys of Szech'uan and less so in western Hupeh. Usually it is a tree of moderate size, but specimens forty metres tall occur occasionally. The spiny shoots and petioles is a juvenile character and disappears when the trees attain maturity. The pubescent leaves and larger fruit distinguish this species from $A$. cacodendron, Schinz \& Thellung. In Fang Hsien this tree is sometimes planted and the leaves employed for feeding the Hawk-moth (Attacus cynthia) which produces a kind of silk.

Pictures of this tree will be found under Nos. 048 and 0128 of the collection of Wilson's photographs. 


\section{BURSERACEAE.}

Determined by Alfred ReHder and E. H. Wilson.

CANARIUM, L.

Canarium album Raeuschel, Nom. Bot. ed. 3, 287 (1797). - De Candolle, Prodr. II. 80 (1825). - Hance in Jour. Bot. IX. 39 (1871). - Bretschneider, Early Res. 95 (1881). - Engler in De Candolle, Monog. Phaner. IV. 149 (1883), - Hemsley in Jour. Linn. Soc. XXIII. 113 (1886). - Dunn \& Tutcher in Kew Bull. Misc. Inform. add. ser. X. 57 (Fl. Kwangtung \& Hongkong) (1912).

Pimela alba Loureiro, Fl. Cochin. 408 (1790).

Western Szech'uan: Kiating Fu, cultivated, alt. 350 m., June 1908 (No. 3816; tree $16 \mathrm{~m}$. tall, girth $2 \mathrm{~m}$., cultivated, but not common); near Lu Chou, banks of Yangtsze River, cultivated in orchards, June 1903 (Veitch Exped. No. 3375). Fokien: Ku-shan, cultivated, Dunn's Exped., April to June 1905 (Herb. Bot. Gard. Hongkong, No. 2461).

This Chinese fruit tree is sparingly cultivated in the warmer parts of western Szech'uan. The largest orchards we have seen are in the department of Lu Chou.

The smooth, oval fruit of this tree singularly resembles a large olive, hence the name "Chinese olive" applied to it by foreigners. The fruit is gathered when full grown but still green and is kept in shallow vessels of salted or fresh water until required. It is esteemed as a relish before meals and as an aid to digestion afterwards. It is also employed medicinally. The fruit is also dried and salted or candied, and is also preserved in syrup and used as a sweetmeat.

A picture of this tree will be found under No. 437 of the collection of Wilson's photographs and also in his Vegetation of Western China, No. 144. 


\section{MELIACEAE.}

Determined by Alfred ReHder and E. H. WrLson.

\section{CEDRELA L.}

Cedrela sinensis A. L. de Jussieu in Mém. Mus. Nat. Hist. Paris, XIX. 255, 294 (1830).-Hemsley in Jour. Linn. Soc. XXIII. 114 (1886).-André in Rev. Hort. 1891, 573, fig. 150, 151, 152.Shirasawa, Icon. Ess. For. Jap. II. t. 35, fig. 1-13 (1908). - Dunn \& Tutcher in Kew Bull. Misc. Inform. add. ser. X. 58 (Fl. Kwangtung and Hongkong) (1912).

Toona sinensis Roemer, Fam. Nat. Syn. I. 139 (1846), - Diels in Bot. Jahrb. XXIX. 425 (1900). - Schneider, Ill. Handb. Laubholzk. II. 131 fig. 83 b, 84 l-q (1907).

Ailanthus flavescens Carrière in Rev. Hort. 1865, 366.

Cedrela chinensis Franchet in Nouv. Arch. Mus. Paris, sér. 2, V. 220 (Pl. David. I. 68) (1883).

Toona sinensis, var. grandis Pampanini in Nouv. Giorn. Bot. Ital. n. ser. XVII. 171 (1911).

Kiangsi: Kiukiang Plain, often cultivated, alt. 100 m., August 2, 1907 (No. I543; tree $13 \mathrm{~m}$. tall, bark grey, fissured; young shoots eaten). Western Hupeh: north and south of Ichang, wild and cultivated, alt. 30-1500 m., June and September 1907 (No. 585; tree 6-20 m. tall, girth 0.6-1.5 m., flowers white; shoots eaten); without locality, June 1900 (Veitch Exped. 2708); without locality, A. Henry (No. 3657). Western Szech'uan: near Monkong Ting, roadside, alt. 2300 m., June 29, 1908 (No. $5^{8} 5^{\mathrm{a}}$; tree $15 \mathrm{~m}$. tall, girth $1.5 \mathrm{~m}$., flowers white in long pendulous panicles). Yunnan: Mengtze, alt. $1800 \mathrm{~m}$., A. Henry (No. 11131). Hongkong: without precise locality, C. Ford. Korea: around Chinnampo, September 1, 1906, $U$. Faurie (No. 469).

This is a very common tree in central and western China, especially in western Hupeh, up to $1500 \mathrm{~m}$. alt. It is often cultivated and the young shoots are esteemed as a vegetable. To facilitate the gathering of the shoots the trees are kept dwarf and stunted. In the woods it is a tree from 20 to $25 \mathrm{~m}$. tall, with a straight trunk clean of branches for two-thirds its height, and with relatively 
slender branches forming a narrow head. The bark is grey and fissured into thin, narrow and irregular, longitudinal plates. The leaves and inflorescence are sometimes nearly a metre long but the size varies greatly as does also that of the leaflets and the degree of pubescence on the shoots, branches of the inflorescence, and on the pedicels. The characters on which Pampanini (1. c.) founded his variety grandis are inconstant as specimens before us show.

This Cedrela is one of the most valuable timber trees in China. The wood is beautifully marked with rich red bands on a yellowish brown ground; it is easily worked and very durable and takes a good polish. It is used for window frames, door joists, furniture making and in high grade carpentry generally. By foreigners resident in China it is called "Chinese Mahogany," on account of its color and durability. Colloquially the tree is known as the "Ch'uen-tien shu."

Pictures of this tree will be found under Nos. 536, 628, 679, 689, 013 and 076 of the collection of Wilson's photographs and also in his Vegetation of Western China, Nos. 152-155.

Cedrela microcarpa A. De Candolle, Monog. Phaner. I. 745 (1878). Brandis, Ind. Trees, 146 (1906).

Western Hupeh: southwest of Ichang, in a ravine, alt. $300 \mathrm{~m}$., rare, June and November 1907 (No. 626, in part; tree 6-10 m. tall, girth 1-2 m.) · Changlo Hsien, thickets, alt. 600 m., June 1907 (No. 626 , in part; tree $13 \mathrm{~m}$. tall, girth $1.5 \mathrm{~m}$.).

This interesting addition to the Chinese flora is a very rare tree, as far as our knowledge goes, occurring in sheltered ravines up to $800 \mathrm{~m}$. alt. It does not grow very tall and has thick wide-spreading branches; the bark is dark grey, fissured and very firm. The largest leaflets on our specimens are $21 \mathrm{~cm}$. long and $10 \mathrm{~cm}$. wide; the capsule is from 2.5 to $3.5 \mathrm{~cm}$. long and covered with large lenticels. When young the shoots, rhachis of the inflorescence and the leaf-rhachis are clothed with a very short velvety pubescence.

The young shoots of this tree are not eaten by the Chinese and it is too rare to be of value as a timber tree.

A picture of this tree will be found under Nos. 489 and 0119 of the collection of Wilson's photographs and also in his Vegetation of Western China, No. 151.

\section{MELIA L.}

Melia Azedarach Linnaeus, Spec. I. 384 (1753). - Thunberg, Fl. Jap. 180 (1784). - Loureiro, Fl. Cochin. I. 269 (1790). - Sims in Bot. Mag. XXVII. t. 1066 (1808). - Hiern in Hooker f., Fl. Brit. Ind. I. 544 (1875). - Debeaux in Act. Soc. Linn. Bordeaux, XXX. 74 (Fl. Shangh. 22) (1875). - Franchet in Nouv. Arch. Mus. Paris, sér. 2, V. 220 (Pl. David. I. 68) (1883). - Hemsley in Jour. Linn. Soc. XXIII. 113 (1886). - Diels in Bot. Jahrb. XXIX. 426 (1900). - Pampanini in Nuov. Giorn. Bot. Ital. n. ser. XVII. 125 (1911). - Dunn \& Tutcher in Kew Bull. Misc. Inform. add. ser. X. 58 (Fl. Kwangtung \& Hongkong) (1912). 
Melia Azedarach, B. sempervirens Linnaeus, Spec. I. 385 (1783).

Melia sempervirens Swartz, Nov. Gen. Sp. Prodr. 67 (1788), - Ker in Bot. Reg. VIII. 643 (1822).

Melia florida Salisbury, Prodr. 317 (1796).

Melia sambucina Blume, Bijdr. 162 (1825).

Melia australis Sweet, Hort. Brit. ed. 2, 85 (1830).

Melia japonica G. Don, Gen. Syst. I. 680 (1831). - Maximowicz in Act. Hort. Petrop. XI. 96 (1890), - Shirasawa, Icon. Ess. For. Jap. II. t. 35, fig. 1426 (1908).

Melia bukayun Royle, Ill. Bot. Himal. 144 (1839).

Melia Commelinii Medicus ex Steudel, Nomencl. Bot. II. 118 (quasi synon.) (1841).

Melia cochinchinensis Roemer, Fam. Nat. Syn. 95 (1846).

Melia orientalis Roemer, Fam. Nat. Syn. 95 (1846).

Melia Toosendan Siebold \& Zuccarini in Abh. Akad. Münch. IV. pt. III. 159 (Fl. Jap. Fam. Nat. II. 51) (1846).

Melia composita Bentham, Fl. Austral. I. 380 (non De Candolle) (1863).

Melia chinensis Siebold ex Miquel in Ann. Mus. Lugd.-Bat. III. 23 (quasi synon.) (1867); Prol. Fl. Jap. 211 (1867).

Melia Azedarach, var. subtripinnata Miquel in Ann. Mus. Lugd.-Bat. III. 24 (1867); Prol. Fl. Jap. 212 (1867).

Azedarach sempervirens Kuntze, Rev. Gen. I. 109 (1891).

Melia japonica, var. semperflorens Makino in Tokyo Bot. Mag. XVIII. 67 (1904).

Western Hupeh: Ichang and neighborhood, alt. 30-300 m., April, May and October 1907 (No. 3267; tree 3-12 m. tall, girth 0.6$2 \mathrm{~m}$., bark grey, fissured, flowers lilac, fruit white); without precise locality, A. Henry (Nos. 3882, 7620). Szech'uan: without precise locality, E. Faber (No. 572). Yunnan: Chu-yuan, A. Henry (No. 10864); Szemao, forests, alt. 1500 m., A. Henry (No. 12,889). Shensi: Han-chung Hsien, 1910, W. Purdom (No. 321). Northcentral China: "Lao-y-san," Hugh Scallan. Formosa: South Cape, A. Henry (Nos. 690, 1281); without locality, G. M. Playfair (No. 297). Korea: Quelpaert, June 1907, U. Faurie (No. 1607); same locality, May 1908, October 1909, Taquet (Nos. 598, 2700).

This tree, now so widely spread in the warm-temperate and sub-tropical parts of the world is without doubt indigenous to central and western China where it is very common up to $800 \mathrm{~m}$. altitude. A colloquial name for it in Hupeh and Szech'uan is "Lien shu" or "Ch'uan-lien shu," and the fruit is occasionally employed as a drug.

The different specimens before us exhibit the characters on which various authors have founded species but we find every intermediate condition and are quite unable to distinguish even a marked variety. The dentation of the leaves, and the size of the inflorescence and fruit varies exceedingly. Melia Toosendan Siebold \& Zuccarini represents a form with very large nearly globose fruit, but some specimens before us completely connect this with forms having small fruit. Material from trees cultivated and naturalized in America exhibit a wider range of variation than do all the Old World specimens we have seen. 
Pictures of this tree will be found under Nos. 394, 395, 632 and 0220 of the collection of Wilson's photographs and also in his Vegetation of Western China, Nos. 309 and 310.

Here may be added a note on a new variety of Cipadessa.

\section{CIPADESSA Blume.}

Cipadessa baccifera Miquel in Ann. Mus. Ludg.-Bat. IV. 6 (1868).

Ekebergia indica Roxburgh, Hort. Cat. Beng. 33 (nomen nudum) (1814); Fl • Ind. II. 392 (1832). - Wallich Cat. No. 1256 (nomen nudum) (1828).

Melia baccifera Roth, Nov. Pl. Ind. Or. 215 (1821). - De Candolle, Prodr. I. 622 (1824).

Cipadessa fruticosa Blume, Bijdr. 162 (1825). - Hiern in Hooker f., Fl. Brit. Ind. I. 545 (1875). - Pellegrin in Le Comte, Fl. Gén. Ind.-Chine, I. 782, fig. 85 (1911).

Ekebergia ? integerrima Wallich, Cat. No. 1257 (nomen nudum) (1828).

Mallea Rothii A. L. de Jussieu in Mém. Mus. Nat. Hist. Paris, XIX. 222, t. 13, fig. 6 (1830).

Mallea integerrima Wallich apud Voigt, Hort. Sub. Calcutt. 134 (1845).

Mallea subscandens Teysmann \& Binnendijk in Nat. Tijdschr. Ned. Ind. XXV. 422 (1863).

Cipadessa? subscandens Miquel in Ann. Mus. Ludg.-Bat. IV. 7 (1868).

The Chinese plant differs considerably from that of India and Malaya and is best considered a variety.

Cipadessa baccifera, var. sinensis Rehder \& Wilson, n. var.

A typo recedit ramulis, petiolis foliis utrinque dense molliter pubescentibus, foliolis plerumque majoribus $5-10 \mathrm{~cm}$. longis.

Western Szech'uan: near Sui Fu, banks of Yangtsze River, June 1903 (Veitch Exped. No. 3366, type); same locality, October 1903 (Veitch Exped. No. $3366^{\text {a }}$; Mt. Omei, July 1904 (Veitch Exped. No. 4774); without locality, $E$. Faber (No. 669). Yunnan: Mengtze, A. Henry (No. 9461, in part); south of Red River from Manmei, A. Henry (No. 9461, in part); Manpan, Red River, $A$. Henry $\left(\right.$ No. $9461^{\mathrm{b}}$ ); Szemao, mountains west, alt. 1500 m., A. Henry $\left(\right.$ No. $9461^{\mathrm{c}}$ ).

The dense velvety pubescence everywhere on the leaves, leaf-rhachis, inflorescence and young shoots and the usually larger leaves readily distinguish this variety from the type. In the warmer part of western Szech'uan this plant is not uncommon in thickets. The specimen from Mt. Omei is labelled "Tree $50 \mathrm{ft}$."; this is a mistake it should read " bush $5 \mathrm{ft}$." Henry describes his specimen as a bush or small tree from 6 to 20 feet tall. 


\section{POLYGALACEAE.}

Determined by Alfred REHDER and E. H. Wilson.

\section{POLYGALA L.}

Polygala arillata Hamilton apud D. Don, Prodr. Fl. Nepal. 199 (1824). - Wallich, Pl. As. Rar. I. t. 100 (1830). - Wight, Icon. III. t. 946 (1843-50). - Bennett in Hooker f., Fl. Brit. Ind. I. 200 (1872). - Franchet in Nouv. Arch. Mus. Paris, sér. 2, VIII. 203 (Pl. David. II. 21) (1886); Pl. Delavay. 77 (1889). - Chodat in Mém. Soc. Phys. Genève, Suppl. No. VIII. 94, t. 17, fig. 12-14 (Monog. Polygal.) (1891). - Diels in Bot. Jahrb. XXIX. 426 (1900).

Chamaebuxus arillata Hasskarl in Ann. Mus. Lugd.-Bat. I. 153 (1863-64).

Chamaebuxus paniculata Hasskarl in Ann. Mus. Lugd.-Bat. I. 154 (1863-64).

Western Hupeh: Hsing-shan Hsien, cliffs, alt. 1000 m., June and July 1907 (Nos. 3I98, 3200; bush 1-2 m., flowers yellow); Fang Hsien, alt. 1300 m., June 1907 (No. 3199; bush 1-2 m., flowers yellow); Patung Hsien, thickets, alt. 600-1000 m., June 1907 (No. 3I97; bush 1-1.5 m., flowers yellow); without locality, May 1900 (Veitch Exped. No. 1274); without locality, A. Henry (Nos. 5783, $5783^{\mathrm{b}}$ ). Western Szech'uan: Chin-ting-shan, alt. 600-1000 m., May 25, 1908 (No. 3196; bush 1-1.5 m., flowers golden-yellow); Tachien-lu, thickets, alt. 1600-2000 m., June 1908 (No. 320r ; sub-shrub 45-60 cm., flowers golden-yellow); without precise locality, alt. 1300 m., May 1904 (Veitch Exped., Nos. 3236, 3226ª); Mt. Omei, June 1904 (Veitch Exped. No. 4741); neighborhood of Tachien-lu, A. E. Pratt (No. 108). Yunnan: Mengtze, mountains, alt. 1600 m., A. Henry (Nos. 9999, $9999^{\circ}$ ); Szemao, mountains, alt. 1600 m., A. Henry (Nos. 12621, 12621 ${ }^{2}$ ). Hongkong: C. Wright (No. 22).

This is a very common shrub in thickets and on cliffs in western Hupeh and in Szech'uan and very variable in size of leaf, in length of raceme and in the number of flowers on the raceme. In No. 3201 the shoots terminate in from 1 to 3 racemes but in all the other Chinese specimens before us the raceme is solitary. We have not seen Polygala fallax Hemsley (in Jour. Linn. Soc. XXIII. 59 [1886]) nor P. 
aureocauda Dunn (in Kevo Bull. Misc. Inform. 1911, 188), but from the descriptions we strongly suspect that they should be referred to $P$. arillata.

Polygala Wattersii Hance in Jour. Bot. XIX. 209 (1881). - Hemsley in Jour. Linn. Soc. XXIII. 63 (1886), quoad specimen Ichangense.

Polygala Mariesii Hemsley in Jour. Linn. Soc. XXIII. 61, t. 2, fig. b. 7-13 (1886). - Chodat in Mém. Soc. Phys. Genève, Suppl. No. VII. 102, t. 17, f. 15-28 (Monog. Polygal.) (1891). - Franchet, Pl. Delavay. 77 (1889).Diels in Bot. Jahrb. XXIX. 426 (1900). - Pampanini in Nuov. Giorn. Bot. Ital. n. ser. XVII. 408, 1910; XVIII. 125 (1911).

Western Hupeh: Ichang, in gorges and glens on cliffs, alt. 301000 m., abundant, March 24, June 1907 (No. 29; bush 0.6-1 m., flowers yellow); same locality, C. Morris; same locality, T. Watters, April 1880 (type, drawings of the type specimen seen); Wushan Hsien, April 1901 (Veitch Exped. No. 162); A. Henry (Nos. 2912, 1104, 1973); "Ou-pan-shan," alt. 600 m., March 1910, C. Silvestri (No. 3073). Eastern Szech'uan: Wushan Hsien, April 1901 (Veitch Exped. No. 162). Western Szech'uan: Mupin, cliffs, alt. 1000-1300 m., June 1908 (No. 29 ${ }^{\text {a }}$; bush 1 m., flowers yellow); without precise locality, cliffs, alt. 1600 m., May 1904 (Veitch Exped. No. 3237); Mt. Omei, June 1904 (Veitch Exped. No. 4742). Yunnan: Mengtsze, alt. 1800 m., A. Henry (No. 9395).

Here may be added the description of a new species and a note on another species of Polygala which were not collected during the Arnold Arboretum Expeditions.

\section{Polygala caudata Rehder \& Wilson, n. sp.}

Polygala Wattersii Hance in Jour. Bot, XX. 3 (1882), non Hance in Jour. Bot. XIX. 209 (1881). - Hemsley in Jour. Linn. Soc. XXIII. 63 (1886), quoad specimen e Kwangtung. - Chodat in Mém. Soc. Phys. Genève, XXXI. No. II, 103, t. 17, fig. 29-30 (Monog. Polygal.) (non Hance, 1881) (1893).

Frutex 1-2-metralis, ramosus; ramuli juniores pilis crispulis brevibus adpressis flavescentibus vestiti. Folia subcoriacea, plerumque versus apicem ramulorum congesta, oblonga v. oblanceolata, rarius obovato-oblonga, caudatoacuminata et apiculata, basi attenuata, margine leviter revoluta et plerumque undulata, 3-12, plerumque 7-10 $\mathrm{cm}$. longa et $1-3 \mathrm{~cm}$. lata, glabra, supra obscure flavo-viridia, subtus pallidiora, nervis utrinque 8-12 sub angulo fere recto divergentibus leviter elevatis; petioli $5-10 \mathrm{~mm}$. longi. Flores rosei (ex Henry) circiter $5 \mathrm{~mm}$. longi, in racemis terminalibus pluribus fere umbellatim congestis subsessilibus multifloris $2.5-5 \mathrm{~cm}$. longis dispositi; pedicelli $1-1.5 \mathrm{~mm}$. longi, bracteis minutis caducis suffulti; sepala 3 exteriora ovata, apice rotundata, ciliolata, $1.5 \mathrm{~mm}$. longa, interiora 2 petaloidea, obovata, obtusa, basi attenuata, venosa, earina breviora; petala 2 lateralia carinae ultra medium adnata, $3.5-4 \mathrm{~mm}$. longa; carina $5 \mathrm{~mm}$. longa, crista peltata biloba lobis subacutis; ovarium compressum, late obovoideum; stigma bilobum. Capsula oblongo-obovoidea basim 
versus attenuata $8 \mathrm{~mm}$. longa et $4 \mathrm{~mm}$. lata, apice emarginata, angustissime alata; semina ovalia, $2 \mathrm{~mm}$. longa, pilis longis villosis vestitis comam $3-4 \mathrm{~mm}$. longam formantibus.

Yunnan: Mengtze, cliffs, alt. 1600-1800 m., A. Henry (Nos. 10901, type, $10901^{a}, 10901^{b}$ ). Western Hupeh: without locality, A. Henry (No. 7714). Kwang-tung: Lien-chau River, March 1881, B. C. Henry (fragments seen).

This new species in habit and foliage is similar to $P$. Wattersii Hance, which, however, is readily distinguished by its yellow flowers which are from 12 to $20 \mathrm{~mm}$. long and larger in all their parts. It is apparently the same as the plant referred to $P$. Wattersii by Hance in 1882 , though it is obviously distinct from his species described in 1881. The Hupeh specimen which has slightly larger and thinner leaves, slightly less abruptly acuminate than those of the type, was received from Kew under the name P. Wattersii. Hemsley when founding his P. Mariesii (Jour. Linn. Soc. XXIII. 61 [1886]) had not seen Hance's type of $P$. Wattersii, but only the specimen from Kwangtung collected by B. C. Henry, and it is evident that Hance's mistaken identification of this latter plant misled Hemsley. Chodat in his monograph mistook A. Henry's No. 7114 from western Hupeh for B. C. Henry's plant from Lien-chau, Kwangtung, and believing the latter to represent Hance's species, described and figured it as $P$. Wattersii. To add to the confusion, the two specimens referred by Hance to his $P$. Wattersii are mounted on the same sheet of Hance's herbarium, now in the British Museum, and their labels seem to have been transposed, for the detailed information sent us by Dr. A. B. Rendle and supplemented by sketches and fragments show that the large-flowered specimen (the true P. Wattersii) is labelled "Lien-chau, B. C. Henry" while the small flowered (our P. caudata) is labeled " Ichang, T. Watters." According to Hance's description it is perfectly clear that he had the large-flowered specimen before him when he described the plant collected by Watters near Ichang, the only one he had seen in 1880 , when he published his description, for the smallflowered plant was not collected until the following year.

\section{Polygala congesta Rehder \& Wilson, n. nom.}

Polygala floribunda Dunn in Jour. Linn. Soc. XXXV. 485 (1903), non Bentham Pl. Hartweg. 58 (1840), nec Boissier et Huet in Boissier, Diag. sér. 2, V. 50 (1856).

Yunnan: Mengtze, grassy mountains, alt. 1600-2000 m., A. Henry (Nos. 10511, 10511 $\mathrm{a}, 9364,13519,11472,11079,11416)$; Szemao, forests, alt. $1500-2000$ m., A. Henry (Nos. $12272,12272^{\text {b }}, 12272^{\text {d }}$ ). 


\section{BUXACEAE.}

Determined by AuFred ReHDer and E. H. WrLson.

\section{SARCOCOCCA Lindl.}

Sarcococca ruscifolia Stapf in Kew Bull. Misc. Inform. 1910, 394. - Pampanini in Nuov. Giorn. Bot. Ital. n. ser. XVIII. 172 (1911).

Sarcococca pruniformis Hemsley in Jour. Linn. Soc. XXVI, 418 (non Lindley) (1894), quoad plantam sinensem. - Diels in Bot. Jahrb. XXIX. 431 (1900).

Western Hupeh: Ichang, cliffs in glens and ravines, alt. 3001200 m., March 20, December 1907 (Nos. 68I, 2592; bush 1-1.5 m., flowers white, fruit dark scarlet); Patung Hsien, cliffs, alt. $600 \mathrm{~m}$., April 1907 (No. 259I; bush 1-2 m.); Ichang, San-yu-tung glen, March and November 16, 1900 (Veitch Exped. No. 127, seed No. 927); Nanto and mountains to northward, A. Henry (Nos. 2993, 2588, 3287, 3077 ${ }^{\mathrm{a}}$; Ichang and immediate neighborhood, A. Henry (Nos. 2589, 3832, 3077); "Ou-tan-scian," alt. 2000 m., August 1909, C. Silvestri (No. 3348); "Ou-pan-chan," alt. 600 m., March 1910, C. Silvestri (No. 3349). Western Szech'uan: Chin-ting-shan, on rocks by the roadside, alt. 1300 m., May 22, 1908 (No. 2590; bush 0.6-1 m.).

A very common plant in the limestone region of western Hupeh but rather rare in western Szech'uan. The Nos. 2591, $3077^{\mathrm{a}}$ represent a form with narrow leaves.

Sarcococca ruscifolia, var. chinensis Rehder \& Wilson, n. comb.

Sarcococca saligna, var. chinensis Franchet, Pl. Delavay. 135 (1889).

Western Szech'uan: Wa-shan, woodlands, alt. $1300 \mathrm{~m}$., November 1908 (No. 1336; bush 1.5-2 m., fruit reddish). Yunnan: Mengtze, cliffs, alt. $1600 \mathrm{~m}$., A. Henry (No. 9859 b).

This variety seems to differ from the type only in its narrower leaves more attenuate at the base. 
Sarcococca Hookeriana Baillon, Monog. Buxac. 53 (1859).Mueller Arg. in De Candolle, Prodr. XVI. 13 (1869).

Tricera nepalensis Wallich, Cat. No. 7979 a (pro parte; nomen nudum) (1832). Sarcococca pruniformis, var. Hookeriana, Hooker f., Fl. Brit. Ind. V. 266 (1887).

The Chinese specimens we have seen belong to the following varieties:

Sarcococca Hookeriana, var. digyna Franchet, Pl. Delavay. 135 (1889).

Western Szech'uan: near Wa-shan, eliffs, alt. 1000-2000 m., September 18, 1908 (No. Ir3o; bush 1 m., fruit black).

Here may be added the description of a new variety not collected during the Arnold Arboretum expeditions.

Sarcococca Hookeriana, var. humilis Rehder \& Wilson, n. var.

Frutex humilis, 0.3-1.5 m. altus; folia alterna $\mathrm{v}$. apicem ramulorum versus subopposita, lanceolata $\mathrm{v}$. oblongo-lanceolata, acuta $\mathrm{v}$. acuminata et apiculata, basi attenuata, 3-6 $\mathrm{cm}$. longa et 6-15 mm. lata, supra lucida, subtus pallidiora; petioli 5-8 mm. longi. Styli 2-3.

Eastern Szech'uan: Wushan Hsien, A. Henry (No. 7065, type); same locality, November 1900 (Veitch Exped. seed No. 900). Western Hupeh: without locality, A. Henry (No. 7834). Yunnan: Mengtze, mountains to the

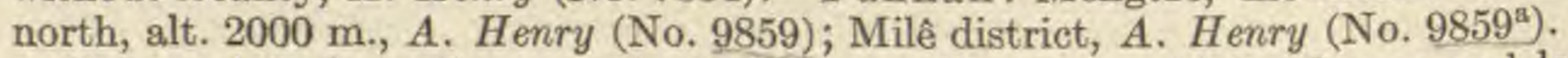

This variety is easily recognized by its small, narrow shining leaves and low habit. It is a rather rare plant and is now in cultivation.

\section{PACHYSANDRA Michx.}

Pachysandra terminalis Siebold \& Zuccarini in Abh. Akad. Münch. IV. pt. II. 142 (Fl. Jap. Fam. Nat. I. 34) (1843), - Baillon, Monog. Buxac. 57 (1859). - Mueller Arg. in De Candolle, Prodr. XVI. 21 (1869). - Hemsley in Jour. Linn. Soc. XXVI. 419 (1894). - Diels in Bot. Jahrb. XXIX. 431, (1900). - Hayata in Jour. Coll. Sci. Tokyo, XX. art. III. 81, t. 6, fig. F (1904).

Western Hupeh: Fang Hsien, woods, alt. 1600-2600 m., common, May and September 1907 (No. 303; subshrub, 15-30 cm. high, flowers white, fruit white).

This is a very common plant growing on rocks in the moist woods of western Hupeh and Szech'uan.

Here may be added a note on another species not collected during the Arnold Arboretum expeditions.

Pachysandra axillaris Franchet Pl. Delavay. 135, t. 26 (1889). - Hemsley in Jour. Linn. Soc. XXVI. 419 (1894). - Diels in Bot. Jahrb. XXIX. 431 (1900).

Yunnan: Lungan, A. Henry (No. 9959²). 


\section{BUXUS L.}

Buxus microphylla Siebold \& Zuccarini in Abh. Akad. Münch. IV. pt. II. 142 (Fl. Jap. Fam. Nat. I. 34) (1843), - Baillon, Monog. Buxac. 64 (1859).

Buxus sempervirens, B. microphylla Blume ex Miquel in Ann. Mus, Lugd.-Bat. III. 128 (quasi synon.) (1867); Prol. Fl. Jap. 292 (1867). - Hayata in Jour. Coll. Sci. Tokyo, XX. art. III. 83, t. 6, fig. C (1904), - Matsumura, Ind. Fl. Jap. II. 311 (1912).

Buxus japonica, $\beta$. microphylla Mueller Arg. apud Miquel in Ann. Mus. Lugd.Bat. III. 128 (1867); Prol. Fl. Jap. 292 (1867). - Mueller Arg. in De Candolle, Prodr. XVI. 20 (1869), - Franchet \& Savatier, Enum. Pl. Jap. I. 428 (1875).

Buxus sempervirens, a. angustifolia Siebold \& Zuccarini ex Hayata in Jour. Coll. Sci. Tokyo, XX. art. III. 84 (quasi synon.) (1904).

The type of the species does not occur in China.

Buxus microphylla, var. sinica Rehder \& Wilson, n. var.

Frutex 1-3-metralis. ramulis et perulis gemmarum inferioribus plus minusve pubescentibus. Folia orbicularia, obovata, ellipticoovata v. elliptico-lanceolata, apice rotundata, plerumque emarginata, 8-35 $\mathrm{mm}$. longa et 5-18 $\mathrm{mm}$. lata, luteo-viridia, supra lucida et in sicco manifeste venulosa, subtus obsolete venulosa; petioli et costa media supra in parte inferiore plerumque pubescentia. Flores ut in typo.

Buxus sempervirens Franchet, Pl. Delavay. 136 (non Linnaeus) (1889). Hemsley in Jour. Linn. Soc. XXVI. 418 (pro parte) (1894). - Diels in Bot. Jahrb. XXIX. 431 (1900). - Pampanini in Nuov. Giorn. Bot. Ital. n. ser. XVIII. 126 (1911).

Western Hupeh: Changyang Hsien, woods, rocky places, alt. 1000-1600 m., common, May and October 1907 (Nos. 3397, type, 3396); Hsing-shan Hsien, woodlands, cliffs, alt. 1300-2400 m., common, May 14, July 1907 (Nos. 3398, 3396²); Hsing-shan Hsien, summit of Wan-tiao-shan, alt. $2600 \mathrm{~m}$., June 5, 1907 (No. 3398 ); without locality, May and July 1900 (Veitch Exped. No. 433a); without locality, A. Henry (Nos. 7159, 6886). Yunnan: Mengtsze, forests, alt. 2800 m., A. Henry (No. 11157). Shensi: Tai-pei-shan, 1910, W. Purdom. Kiangsi: Nanking, E. Faber (No. 902). Shantung: without locality, Zimmerman (No. 529). Hongkong: without locality, C. Wright (No. 422). Formosa: Takow, 
Ape's Hill, A. Henry (No. 1177). Korea: Seoul, cultivated, September 24, J. G. Jack.

This Box is found in many parts of China and is common in rocky places in the woods and thickets of western Hupeh and in Szech'uan. It is also a favorite garden shrub with the Chinese. This variety is really the typical Buxus of eastern continental Asia and the variation in foliage, habit, etc. is similar to what occurs in the European $B$. sempervirens Linnaeus, which is distinguished by the minute gynophore to the rudimentary ovary in the male flower. From B. microphylla Siebold \& Zuccarini, which under the rules of priority must be kept as the type of the species, this Chinese variety is well distinguished by the pubescent branches and larger leaves. It is nearest to B. microphylla, var. japonica Rehder \& Wilson, which is easily recognized by its glabrous shoots. In western Hupeh this plant is colloquially known as "Huang-yang."

We have seen one cultivated specimen from an American nursery labelled $B$. Fortunei, which is undoubtedly the Chinese variety but the true $B$. Fortunei Carrière (in Rev. Hort. 1871, 519) is a very different plant with long and narrow subcuneate leaves and is of doubtful origin and but incompletely described. It is possible that Carrière's plant is a form of the typical B. microphylla Siebold \& Zuccarini, but it is much more probable that it is a variety of the European $B$. sempervirens Linnaeus.

The plant referred to B. sempervirens by Hayata (in Jour. Coll. Sci. Tokyo, XXV. art. XIX. 193 (Fl. Mont. Formosae) [1908] probably belongs to B. microphylla, var. sinica Rehder \& Wilson.

Buxus Harlandii Hance in Jour. Linn. Soc. XIII. 123 (1873). Schneider, Ill. Handb. Laubholzk. II. 139, fig. 89 w, 90 d-e (1907).

Buxus sempervirens Bentham, Fl. Hongk. 315 (non Linnaeus) (1861). Hemsley in Jour. Linn. Soc. XXVI. 418 (pro parte) (1894). - Dunn \& Tutcher in Kew Bull. Misc. Inform. add. ser. X. 233 (Fl. Kwangtung and Hongkong) (1912).

Buxus microphylla Franchet, $P l$. Delavay. 136 (non Siebold \& Zuccarini) (1889), excludendo synonymo $B$. stenophylla.

Western Hupeh: Ichang gorge, on rocks, alt. 30-300 m., March 24, 1908 (No. 3399; fluviatile shrub, 15-30 cm. tall); same locality, $A$. Henry (No. 3313). Fokien : without locality, Dunn's Exped., April to June 1905 (Herb. Bot. Gard. Hongkong, No. 3515). Hongkong: Herb. Hance (No. 322, type).

This curious species is abundant in the gorges and ravines near Ichang growing in rock-crevices and among stones in the bed and banks of streams where during summer floods it is submerged. It is found only at low altitudes where the winters are very mild and would not be hardy in northern temperate regions. The plant we have seen in cultivation as $B$. Harlandii is $B$. microphylla, var. japonica Rehder \& Wilson.

From the habitat given it is very probable that B. cephalantha Léveillé \& Vaniot (in Fedde Rep. sp. Nov. III. 21 (1906)) belongs here.

As the determination of the Chinese material made necessary a study of most of the species of the subgenus Eubuxus, we have improved this opportunity by compiling a short synopsis of all the species of this subgenus. 


\section{CONSPECTUS SPECIERUM SUBGENERIS EUBUXI.}

Flores masculi pedicellati, rudimento ovarii sepalis 4-plo breviore. Folia 2.5-7 cm. longa.

Folia apice rotundata $\mathrm{v}$. emarginata, ovato-oblonga v. oblonga, $3-4 \mathrm{~cm}$. longa et 1.2-2 cm. lata. Styli erecti. . . . . . . . 1. B. balearica. Folia apice acutiuscula $v$. obtusa.

Folia 7-12 mm. lata et $2.5-4 \mathrm{~cm}$. longa, lanceolata v. lineari-elliptica.

2. B. longifolia.

Folia 15-25 mm. lata et 5-7 cm. longa, ovato-lanceolata v. lanceolata; styli patentes, stigmatibus recurvis, ovarium plus quam duplo superantes, exserti; bracteae basales inflorescentiae dorso cinereo-villosuli. Ramuli subteretes. . . . . . . . . . . . 3. B. Henryi.

Flores masculi sessiles (in No. 4 non visi).

Folia subtus papillosa, glaucescentia, anguste lanceolata, $3-6 \mathrm{~cm}$. longa.

Folia epapillosa, viridia v. luteo-viridia.

4. B. papillosa.

Rudimentum ovarii in floribus masculis vix dimidia sepala aequans.

Folia 3-6 $\mathrm{cm}$. longa.

Folia lanceolata v. lineari-lanceolata, $0.6-1.5 \mathrm{~cm}$. lata, margine plana; ramuli pilosuli. . . . . . . . . . 5. B. Wallichiana.

Folia ovato-oblonga, v. fere ovata, $1.5-2.5 \mathrm{~cm}$. lata, margine undulata; ramuli glabrescentes. . . . . . . . 6. B. liukiuensis.

Folia 1-3 cm. longa, rarius paullo longiora. . . . 8. B. sempervirens. Rudimentum ovarii in floribus masculis sepala aequans v. fere aequans; folia plerumque parva, $0.8-3$, rarius ad $5 \mathrm{~cm}$. longa.

Folia suborbicularia v. angusta lanceolata, basi plerumque subito angustata. Styli dimidium ovarium aequantes.

Folia 4-18 mm. lata. Rudimentum ovarii apice valde dilatatum; stamina sepalis duplo longiora.

Ramuli glabri.

Inflorescentiae plerumque omnes terminales. Folia oblongo-obovata v. oblanceolata, 4-8 mm. lata. . . 8. B. microphylla.

Inflorescentiae axillares et terminales.

Folia plerumque obovata v. ovalia, 8-18 mm. lata.

Ramuli plus minusve pubescentes.

var, japonica.

Folia obovata v. ovato-oblonga, apice rotundata v. emarginata, 1-3 cm. longa. Ramuli plus minusve pilosuli. . var. sinica.

Folia oblongo-lanceolata v. oblonga, obtusa v. acutiuscula, $2.5-5$ cm. longa. Ramuli leviter pubescentes v. fere glabri.

var. aemulans.

Folia 3-4 mm. lata, oblongo-lanceolata. Rudimentum ovarii apice vix dilatatum; stamina sepalis circiter dimidio longiora.

9. B, stenophylla.

Folia oblanceolata v. obovato-oblonga, basim versus sensim angustata,

$1.2-2 \mathrm{~cm}$. longa et 4-6 mm. lata. Styli ovarium aequantes.

10. B. Harlandii. 


\section{ENUMERATIO SPECIERUM SUBGENERIS EUBUXI.}

1. Buxus balearica Lamarck, Encycl. Méth. I. 511 (1783). - Willdenow, Spec. IV. 337 (1805). - Loudon, Arb. Brit. III. 1341, fig. 1220, 1221 (1838). - Baillon, Monog. Buxac. 62 (1859). - Mueller Arg. in De Candolle, Prodr. XVI. 18 (1869).

Buxus sempervirens, var. gigantea Nouv. Duhamel, I. 82, t. 23, fig. I. (1801).

Balearic Islands, Spain, Sardinia.

2. Buxus longifolia Boissier, Diagn. Pl. Or. I. 107 (1853); Fl. Or. IV. 1144 (1879). - Baillon, Monog. Buxac. 63 (1859). - Mueller Arg. in De Candolle, Prodr. XVI. 18 (1869).

3. Buxus Henryi Mayr, Fremdl. Wald-u. Parkb. 451 (1906). - Dümmer in Gard. Chron. ser. 3, LII. 423, fig. 182 (1912).

Western Hupeh: Ichang and immediate neighborhood, A. Henry (No. 3387).

4. Buxus papillosa Schneider Ill. Handb. Laubholzk. II. 139, fig. 89 v, $90 \mathrm{k}-1$ (1907).

Northwestern Himalaya.

5. Buxus Wallichiana Baillon, Monog. Buxac. 63 (1859). - Mueller Arg. in De Candolle, Prodr. XVI. 18 (1869). - Schneider, Ill. Handb. Laubholzk. II. 139, fig. $90 \mathrm{~h}-\mathrm{i}$ (1907).

Buxus longifolia Jacquemont ex Baillon, Monog. Buxac. 63 (quasi synon.) (non Boissier) (1869).

Buxus sempervirens Brandis, For. Fl. Brit. Ind. 447 (non Linnaeus) (1874). Hooker f., Fl. Brit. Ind. V. 267 (1887).

Himalayas: Kumaon to Bhotan.

6. Buxus liukiuensis Makino in Tokyo Bot. Mag. XVI. 179 (1902), - Schneider, Ill. Handb. Laubholzk. II. 140 (1907).

Buxus sempervirens, var. liukiuensis Makino in Tokyo Bot. Mag. IX. 279 (1895); XV. 169 (1910).

Buxus Wallichiana Hayata in Jour. Coll. Sci. Tokyo, XX. art. III. 84, t. 6, fig. E (non Baillon) (1904). - Matsumura, Ind. Fl. Jap. II. 311 (1912).

Liu-kiu Islands: C. Wright (No. 284, in Herb. Gray).

7. Buxus sempervirens Linnaeus, Spec. 983 (1753). - Reichenbach, Icon. Fl. German. V. t. 153, fig. 4808 (1841). - Baillon, Monog. Buxac. 59, t. 1, t. 2, fig. 1-12 (1859). - Mueller Arg. in De Candolle, Prodr. XVI. 19 (1869). - Boissier, Fl. Or. IV. 1144 (1879).

Buxus arborescens Miller, Dict. ed. 8, (1768).

Central and southern Europe to the Caucasus.

8. Buxus microphylla Siebold \& Zuccarini. See p. 165.

Buxus microphylla, var. japonica Rehder \& Wilson, n. comb.

Buxus japonica Mueller Arg. apud Miquel in Ann. Mus. Lugd.-Bat. III. 128 (1867); Prol. Fl. Jap. 292 (1867). - Mueller Arg. in De Candolle, Prodr. XVI. 20 (1869). - Franchet \& Savatier, Enum. Pl. Jap. I. 428 (1875).-Schneider, Ill. Handb. Laubholzk. II. 139, fig. $89 \mathrm{v}-\mathrm{x}$. (1907). 
Buxus sempervirens Thunberg, Fl. Jap. 77 (sphalmate virens) (non Linnaeus) (1784). - Matsumura, Ind. Fl. Jap. II. 310 (1912).

Buxus sempervirens, var. japonica Makino in Tokyo Bot. Mag. IX. 281 (1895); XV. 169 (1901). - Hayata in Jour. Coll. Sci. Tokyo, XX. art. III. 82, t. 6, fig. c (1904).

This is a very hardy variety of Box with larger and broader leaves than the type. The leaves are yellowish-green and this same color obtains in the Chinese variety also.

Buxus microphylla, var. sinica Rehder \& Wilson. See p. 165.

Buxus microphylla, var. aemulans Rehder \& Wilson, n. var.

Frutex 1-2-metralis, ramulis patentibus subteretibus sparse pubescentibus. Folia oblongo-lanceolata v. oblonga $\mathrm{v}$. oblongo-obovata, obtusa v. acutiuscula, $2.5-5 \mathrm{~cm}$. longa et 7-15 mm. lata, supra in sicco distincte venulosa, subtus minus venulosa. Florum fasciculi parvi. Ceterum ut in var. sinica.

Western Hupeh: without locality, A. Henry (Nos. 7807, type, $3293^{\mathrm{a}}$ ); Changyang Hsien, woodlands, alt. $1800 \mathrm{~m}$., April 1900 (Veitch Exped. No. 433).

In foliage and general appearance this strongly resembles $B$. Wallichiana Baillon, but the short anthers and the long gynophore to the rudimentary ovary in the male flowers show that it belongs to B. microphylla Siebold \& Zuccarini. This new variety is a distinct looking plant and is not uncommon in the woods of western Hupeh.

9. Buxus stenophylla Hance in Jour. Bot. VI. 331 (1868); in Jour. Linn. Soc. XIII. 124 (1873). - Mueller Arg. in De Candolle, Prodr. XVI. 20 (1869). Schneider, Ill. Handb. Laubholzk. II. 139, fig. $90 \mathrm{v}$ (1907).

Buxus sempervirens Hemsley in Jour. Linn. Soc. XXVI. 418 (non Linnaeus) (1894), quoad synonymum B. stenophyllam.

Fokien: "An-koe," C. de Grijs (No. 6683; fragments seen).

Probably not specifically distinct from $B$. microphylla Siebold \& Zuccarini.

10. Buxus Harlandii Hance. See p. 166. 


\section{CORIARIACEAE.}

Determined by Alfred ReHder and E. H. Wilson.

\section{CORIARIA L.}

Coriaria sinica Maximowicz in Mém. Acad. Sci. St. Pétersbourg, sér. 7, XXIX. No. III. 9, fig. (1881); in Act. Hort. Petrop. XI. 112 (1889). - Schneider, Ill. Handb. Laubholzk. II. 143, fig. 94 i-1 (1907).

Coriaria nepalensis Hemsley in Jour. Linn. Soc. XXIII. 149 (non Wallich) (1886). - Franchet in Bull. Soc. Bot. France, XXXIII. 451 (1886).Diels in Bot. Jahrb. XXIX. 431 (1900). - Pampanini in Nuov. Giorn. Bot. Ital. n. ser. XVII. 415 (1910); XVIII. 126 (1911).

Western Hupeh: Ichang and neighborhood, 30-1000 m., abundant, March 15, May 1907 (No. I2; bush 1-6 m., anthers red, fruit black); same locality, March 1900 (Veitch Exped. No. 150); without locality, A. Henry (No. 1289); "Kao-kien-scian," alt. 800 m., 1907, C. Silvestri (No. 1316). Western Szech'uan: southeast of Tachienlu, roadsides, alt. 1300 m., June 1908 (No. I2 ${ }^{\mathrm{a}}$; bush 1-6 m.).

The relationship of this species with $C$. nepalensis Wallich is very close and ultimately it may prove to be only a variety of the Indian plant but our material of the latter is not sufficient to settle this point. The difference in the length of the filaments does not hold good, but the other differences pointed out by Maximowicz seem to be constant. The style in $C$. sinica is more slender, the rudimentary pistil and petals in the male flowers are much more minute (almost wanting) and the ripe carpels are smaller than in C. nepalensis Wallich.

Coriaria sinica is one of the commonest shrubs on the grassy hills and in the river valleys of western Hupeh up to $1000 \mathrm{~m}$. altitude and in western Szech'uan up to $1500 \mathrm{~m}$. altitude and even higher in the more stony and arid regions. In Hupeh it is colloquially known as the "Ma-sang" and the shoots are said to be poisonous to cattle.

Coriaria terminalis Hemsley in Hooker's Icon. XXIII. t. 2220 (1892); in Gard. Chron. ser. 3, XXIII. 110 (pro parte) (1898).Schneider, Ill. Handb. Laubholzk. II. 144, fig. 94 h (1907).

Western Szech'uan: west and near Wên-ch'uan Hsien, thickets, alt. $2300 \mathrm{~m}$., June and August 1908 (No. 2304, in part; sub-shrub 0.6-1 m. tall, flowers pinkish, fruit black); south-east of Tachien-lu, 
thickets, alt. 2000-2500 m., June and August 1908 (No. 2304, in part; sub-shrub 0.6-1 m. tall, fruit black); same locality, alt. 2800 m., July 1903 (Veitch Exped. No. 3306).

This plant has a woody root-stock and herbaceous annual shoots; the fruit is black. It is eommon in thickets and margins of woods between 2000 and $2600 \mathrm{~m}$. alt. in western Szech'uan.

Hemsley (l. c.) refers certain Indian specimens to this species, but apparently there are two forms, one with black fruit and one found in Sikkim with yellow fruit. A specimen before us, collected by Hooker f. in Sikkim at alt. 5000-7000 ft. apparently has black fruit; another Sikkim specimen (Gammie No. 353) collected at Lachung, at alt. $9000 \mathrm{ft}$. has yellow fruit. This Lachung specimen agrees with the plant figured in the Mitt. Deutsch. Dendr. Ges. VI. 62 (1897) by St. Paul as Coriaria nepalensis. As Hemsley in the Gard. Chron. (1. c.) points out, this plant has nothing to do with $C$. nepalensis Wallich. In the absence of information on the color of the fruit in his Chinese type Hemsley expresses the opinion that the plant figured is the same as his $C$. terminalis. We now know that the Chinese plant has black fruit, and the yellow-fruited Indian plant would appear to constitute at least a well marked variety of $C$. terminalis Hemsley.

Coriaria terminalis, var. xanthocarpa Rehder \& Wilson, n. var.

Coriaria terminalis St. Paul in Mitt. Deutsch. Dendr. Ges. VI. 62, t. (non Hemsley) (1897). - Bean in Gard. Chron. ser. 3, XXXIV. 282, fig. 119 (1903). Mottet in Rev. Hort. 1907, p. 160, t. - Sprague in Bot. Mag. CXXXIX. t. 8525 (1913). 


\section{ANACARDIACEAE.}

Determined by Alfred Rehder and E. H. Wilson.

\section{SPONDIAS L.}

Spondias axillaris Roxburgh, Cat. Hort. Bengal. 34 (nomen nudum) (1814); Fl. Ind. II. 453 (1832), - Hooker f., Fl. Brit. Ind. II. 42 (1876). - King \& Prain in Ann. Bot. Gard. Calcutta, IX. pt. I. 18, t. 25 (1901). - Brandis, Ind. Trees, 201 (1906).

Spondias acuminata Gamble, Trees and Shrubs of Darjeeling, ed. 2, 25 (non Roxburgh) (1896).

Poupartia Fordii Hemsley in Hooker's Icon. XXVI. t. 2557 (1898). - Dunn \& Tutcher in Kew Bull. Misc. Inform. add. ser. X. 69 (Fl. Kwangtung \& Hongkong) (1912).

Poupartia axillaris Prain Mss. apud King \& Prain in Ann. Bot. Gard. Calcutta, IX. pt. I. 18 (1901).

Western Hupeh: Hsing-shan Hsien, margins of woods, alt. 600$1100 \mathrm{~m}$., local, May 1907 (No. 453 ${ }^{\text {b }}$; tree 6-10 m. tall, girth 1-1.5 m.); Changyang Hsien, roadsides, alt. 600 m., November 1907 (No. 480; tree 10-20 m. tall, girth 1-2.5 m., fruit edible); Nanto, woodlands, April 1900 (Veitch Exped. No. 172). Yunnan: Szemao, forests, alt. $1600 \mathrm{~m} .$, A. Henry (No. 11690). Hongkong: Happy Valley, November 5, 1903, C. S. Sargent; same locality, April 17, 1896, C. Ford (ex Herb. Bot. Gard. Hongkong, No. 612); without locality, C. Wright (Nos. 107, 473).

This is a rather common tree at low altitudes in western Hupeh and in Szech'uan and is chiefly confined to the valleys. It grows from 15 to $25 \mathrm{~m}$. tall and the trunk is often a metre in diameter near the base. The branches are massive and form an oval or rounded head; the bark is grey, deeply fissured and persistent; the leaves are deciduous. The flowers are polygamo-dioecious; the male and female flowers are borne in many-flowered panicles which spring from the axils of scales and also from the axils of the lower leaves. The hermaphrodite flowers are much larger than the unisexual flowers and are borne in short racemes which are commonly one-flowered by abortion and never more than 3- or 4-flowered. The leafy shoots bearing panicles of unisexual flowers look very much like branches of Rhus succedanea Linnaeus.

Brandis (1. c.) describes $S$. axillaris Roxburgh as an evergreen tree with brown or reddish bark which peels off in long flakes. We think this must be a mistake, 
otherwise the Chinese tree will have to be referred to another species, although the herbarium material before us from the two countries is identical.

The fruit of $S$. axillaris is yellow, oval, from $2.5-3 \mathrm{~cm}$. long, rounded on the summit; it is eaten by the Chinese. The vernacular name of this tree is "Hsuan Tsao."

Pictures of this tree will be found under Nos. 377 and 441 of the collection of Wilson's photographs and also in his Vegetation of Western China, Nos. 477 and 478.

Spondias axillaris, var. pubinervis Rehder \& Wilson, n. var.

A typo recedit foliolis subtus ad costam nervosque nec non petiolo et rhachi et ramulis junioribus dense breviter villosis.

Eastern Szech'uan: Taning Hsien, roadside, alt. 160-100 m., June 28, 1910 (No. 463I, type; tree 20-25 m. tall, girth $3 \mathrm{~m}$.); Wushan Hsien, A. Henry (No. 5535). Western Szech'uan: Hungya Hsien, roadside, alt. 600 m., September 5, 1908 (No. 480 ${ }^{2}$; tree 6-25 m. tall, fruit yellow, edible); Yachou Fu, ravines, alt. 600-1200 m., May and July 1904 (Veitch Exped. Nos. 3368, 3373, 3363).

This variety is well distinguished by its pubescence; in other particulars it is identical with the type of the species. This tree is common everywhere in Szech'uan up to $1000 \mathrm{~m}$. altitude.

Pictures of this tree will be found under Nos. 94 and 0161 of the collection of Wilson's photographs and also in his Vegetation of Western China, No. 476.

\section{PISTACIA L.}

Pistacia chinensis Bunge in Mém. Sav. Êtr. Acad. Sci. St. Pétersbourg, II. 89 (Enum. Pl. Chin. Bor. 15) (1833). - Hance in Jour. Linn. Soc. XIII. 77 (1873). - Engler in De Candolle, Monog. Phaner. IV. 291 (1883). - Franchet in Nouv. Arch. Mus. Paris, sér. 2, V. 231 ( $P l$. David. I. 79) (1883); Pl. Delavay. 149 (1889). - Hemsley in Jour. Linn. Soc. XXIII. 148 (1886). - Maximowicz in Act. Hort. Petrop. XI. 110 (1889). - Diels in Bot. Jahrb. XXIX. 431 (1900). - Bean in Kew Bull. Misc. Inform. 1910, 393, fig. - Pampanini in Nuov. Giorn. Bot. Ital. n. ser. XVII. 416 (1910); XVIII. 173 (1911).Dunn \& Tutcher in Kew Bull. Misc. Inform. add. ser. X. 69 (Fl. Kwangtung \& Hongkong) (1912). - Rehder in Möller's Deutsch. Gärtn.-Zeit. XXVII. 25, fig. (1912).

Pistacia formosana Matsumura in Tokyo Bot. Mag. XV. 40 (1901). - Matsumura \& Hayata in Jour. Coll. Sci. Tokyo, XXII. 99, t. 9 (Enum. Pl. Formos.) (1906).

Pistacia philippinensis Merrill \& Rolfe in Philipp. Jour. Sci. III. No. 3, 107 (1908). - Merrill \& Merritt in Philipp. Jour. Sci. V. No. 4, 357 (1910). 
Western Hupeh: neighborhood of Ichang, valleys, alt. 30-1000 m., March 26 and September 1907 (No. 38o; tree 15-26 m. tall, girth 1.5-4 m., fruit blue); without locality, April 1900, September 1901 (Veitch Exped. Nos. 407, 1965); Ichang and immediate neighborhood, A. Henry (Nos. 1500, 7702) "Monte Triora," alt. 1950 m., October 1907, C. Silvestri (No. 1318). Western Szech'uan: Kiating Fu, alt. 300-1000 m., common, October 1908 (No. 380 ; tree 15-26 m. tall, girth 2-4 m.); without precise locality, and river valleys, September 1903 (Veitch Exped. No. 3363). Yunnan: Mengtze, woods, alt. $1500 \mathrm{~m}$., A. Henry (Nos. 10254, 10254 a). Shensi : Tai-pei-shan, 1910, W. Purdom. North-central China: "Mt. Lean-san," Hugh Scallan. Chekiang: vicinity of Ningpo, 1908, D. Macgregor; without locality, E. Faber. Kiangsu: hills, E. Faber. Shantung: Lan-shan, August 1907, F. N. Meyer (No. 315). Chili : near Peking, October 1905, F. N. Meyer (No. 181); same locality, 1831, A. Bunge (type). Formosa: Bankinsing, A. Henry (No. 488). Philippine Islands: Luzon, Bagnio, in province of Benguet (distributed by A. D. E. Elmer, No. 8779).

This Pistacia is one of the noblest, most widely distributed and useful of Chinese trees. It is very common in the valleys of western Hupeh and Szech'uan up to $1000 \mathrm{~m}$. alt. and extends up to $1600 \mathrm{~m}$. alt. in favorable localities. The trunk is very thick, buttressed at the base with gray, fissured persistent bark; the branches are massive, wide-spreading and form a rounded or flattened head. The young leafy shoots are often red in color and are eaten as a vegetable in the same manner as those of Cedrela sinensis A. L. de Jussieu. In the autumn the leaves assume wonderful orange and crimson tints. The wood is heavy, close-grained, tough but easily worked and is employed in boat-building, for general construction purposes and in household carpentry. Stout poles of this tree having a natural fork are considered to make the best and most durable rudder-posts for large boats.

Colloquially this tree is known as the "Huang-lien shu" or "Huang-ni-ya shu."

Pietures of this tree will be found under Nos. 14, 25, 262, 443 and 0225 of the collection of Wilson's photographs and also in his Vegetation of Western China, Nos. 384-387.

Hayata's excellent figure shows that Matsumura's $P$. formosana is identical with the Chinese species and we ean find no character by which to distinguish $P$. philippinensis Merrill \& Rolfe. In this eonnection we may observe that Merrill and Merritt suspected the identity of the Philippine species with that of Formosa.

Pistacia integerrima Stewart (in Brandis, For. Fl. Brit. Ind. 122, t. 22 (1874)) is very closely related to $P$. chinensis and perhaps, is not specifically distinct.,

Here may be added a note on a species not collected during the Arnold Arboretum Expeditions.

Pistacia weinmannifolia J. Poisson apud Franchet in Bull. Soc. Bot. France, XXXIII, 467 (1886). - Franchet, $P$. Delavay. 149, t. 36 (1889).

Pistacia coccinea Collett \& Hemsley in Jour. Linn. Soc. XXVIII. 36 (1890). 
Western Szech'uan: Chien-chi Hsien, arid valleys, alt. 1000 m., July 1903 (Veitch Exped. No. 3367). Yunnan: Mengtze, plains, alt. $1500 \mathrm{~m} .$, A. Henry (Nos. 9600, 9600 $)$; Lunan, A. Henry (No. 9000 $)$; Szemao, mountains west, alt. 1600 m., A. Henry (No. 11913).

This is a very rare tree in Szech'uan where it is confined to the arid river-valleys in the southwestern part of the province. In Yunnan it is common and is one of the handsomest trees found there. It grows from $15-20 \mathrm{~m}$. tall, with a straight trunk and medium sized branches which form a shapely oval or flattened head. The leaves are coriaceous, shining and dark green; and the fruit is red and about the size of an ordinary pea. In adult trees the shoots are commonly quite glabrous, and specimens before us agree exactly with Collett \& Hemsley's description of $P$. coccinea and they themselves suspected it might prove identical with $P$. weinmannifolia.

\section{COTINUS Adans.}

Cotinus coggygria Scopoli, Fl. Carn. ed, 2, I. 220 (1772).Engler in De Candolle, Monog. Phaner. IV. 350 (1883). - Diels in Bot. Jahrb. XXIX. 432 (1900). - Schneider, Ill. Handb. Laubholzk. II. 146, fig. $97 \mathrm{a}-\mathrm{g}$ (1907).

Rhus Cotinus Linnaeus, Spec. 267 (1753). - De Candolle, Prodr. II. 67 (1825). - Hooker f., Fl. Brit. Ind. II. 9 (1876). - Franchet in Nouv. Arch. Mus. Paris, sér. 2, V. 230 (Pl. David. I. 78) (1883). - Hemsley in Jour. Linn. Soc. XXII. 146 (1886), - Pavolini in Nuov. Giorn. Bot. Ital. n. ser. XV. 409 (1908).

Rhus simplicifolia Salisbury, Prodr. 170 (1796).

Rhus obovatifolia Stokes, Bot. Mat. Med. II. 159 (1812).

Rhus laevis Wallich apud G. Don, Gen. Syst. II. 69 (1832).

Cotinus Coccygea K. Koch, Dendr. I. 582 (1869).

Cotinus coggygria, a. laevis Engler in De Candolle, Monog. Phaner. IV. 350

(1883). - Pampanini in Nuov. Giorn. Bot. Ital. n. ser. XVII. 416 (1910).

We have seen no Chinese specimens referable to the typical glabrous $C$. $\operatorname{cog}$ gygria Scopoli, and Pampanini's specimen probably belongs to the following form which is fairly common all over the temperate parts of China.

Cotinus coggygria, var. pubescens Engler in Bot. Jahrb. I. 403 (1881); in De Candolle, Monog. Phaner. IV. 351 (1883). - Schneider, Ill. Handb. Laubholzk. II. 146 (1907).

Rhus Cotinus Maximowiez in Act. Hort. Petrop. XI. 110 (non Linnaeus) (1890).

Western Hupeh: Ichang and the neighborhood, alt. 30-1300 m., common, April 1907 (No. 87; bush 1-2 m.); same locality, April 1900 (Veitch Exped. No. 221); without locality, A. Henry (No. 1627). Szech'uan: without locality, E. Faber (No. 114). Shensi: northwest of Hanchung Fu 1910, W. Purdom (No. 364); "Huo-kia-zaez," 
July 16, 1897, G. Giraldi. Chekiang: vicinity of Ningpo, 1908, D. Macgregor.

Our specimens exhibit considerable variation in degree of pubescence; some are very slightly hairy; others as No. 87 are densely so and approach the variety velutina Engler. A colloquial name at Ichang for this shrub is "Lu-mu."

Here may be added a note on another Chinese variety not collected during the Arnold Arboretum Expeditions.

Cotinus coggygria, var. cinerea Engler in Bot. Jahrb. I. 403 (1881); in De Candolle, Monog. Phaner. IV. 351 (1883).

Shantung: Tsingtau, September 1907, F. N. Meyer (No. 255). Chili : near Peking, August 1865, S. W. Williams (Herb. Hance, No. 12008).

\section{RHUS L.}

\section{Sect. I. SUMAC DC.}

Rhus punjabensis Stewart in Brandis, For. Fl. Brit. Ind. 120 (1874). - Hooker f., Fl. Brit. Ind. II. 10 (1876). - Engler in De Candolle, Monog. Phaner. IV. 378 (1883). - Brandis, Ind. Trees, 197 (1907).

The typical form has not yet been found in China.

Rhus punjabensis, var. sinica Rehder \& Wilson, n. var.

Rhus sinica Diels in Bot. Jahrb. XXIX. 432 (1900).

Rhus punjabensis Dunn in Jour. Linn. Soc. XXXIX. 485 (non Stewart) (1911).

Western Hupeh: north and south of Ichang, woodlands, alt. 1000-1600 m., July and September 1907 (No. 275; small tree 5-8 m. tall, flowers whitish, fruit crimson); Changlo Hsien, woods, alt. 1300$2000 \mathrm{~m}$., June and July 1907 (Nos. 275 ${ }^{\mathrm{b}}, 3320$; tree 6-10 m. tall, flowers whitish); Hsing-shan Hsien, woodlands, alt. 1300-2000 m., July and December $1907\left(\right.$ No. $\left.275^{\mathrm{a}}\right)$; tree 6-12 m. tall, girth 0.6-1 m., fruit erimson); without locality, June 1900 (Veitch Exped. No. 1177, flowers only); without locality, A. Henry (Nos. 3157, 5529b). Western Szech'uan: Washan, woods, alt. 1000-1600 m., July 1908 (No. 3317; tree $10 \mathrm{~m}$. tall, girth $0.75 \mathrm{~m}$., flowers white); southeast of Tachien-lu, thickets, alt. 1300-1600 m., June 1908 (No. 3318; bush 2-4 m. tall); Mt. Omei, June 1904 (Veitch Exped. No. 4813); without exact locality, alt. 600 m., May 1904 (Veitch Exped. No. 3369); Nan-ch'uan, A. von Rosthorn (Nos. 1971, 1969).

This variety differs from the type chiefly in the slightly. winged upper part of the rhachis of the leaf, and in the usually fewer and more sessile leaflets. The 
fruits agree exactly with those of $R$. punjabensis. In cultivated plants from four to six years old the wing on the rhachis is very pronounced and continues down its whole length. The differences, however, are not always obvious, but until more is known of the distribution of these plants it is convenient to keep the Chinese as a distinct variety.

This Sumach is abundant in the thickets and margins of woods in western Hupeh and Szech'uan as a small tree with a short, relatively thick trunk covered with dark grey, moderately smooth bark. The numerous branches are spreading and form a flattened round head. In autumn when laden with pendulous panicles of dark red or crimson fruit this tree is very attractive.

Colloquially this tree is known as the "Hung-fu-yang" and the galls which are produced on the leaves and at the ends of the young shoots are sometimes distinguished as "Tu-pei-tzu," but more usually are called "Wu-pei-tzu," though this name strictly speaking belongs to the galls produced on the leaves of Rhus javanica Linnaeus.

A picture of Rhus punjabensis, var. sinica will be found under Nos. 562 and 596 of the collection of Wilson's photographs and also in his Vegetation of Western China, Nos. 447, 449.

Rhus Potaninii Maximowicz in Act. Hort. Petrop. XI. 110 (1889). - Diels in Bot. Jahrb. XXIX. 432 (1900); XXXVI. Beibl. No. LXXXII. 71 (1905). - Pampanini in Nuov. Giorn. Bot. Ital. n. ser. XVII. 416 (1910).

Rhus Henryi Diels in Bot. Jahrb. XXIX. 432 (1900).

Rhus sinica Koehne in Mitteil. Deutsch. Dendr. Ges. XIX. 102, fig. 5 (non Diels) (1910). - Schneider, Ill. Handb. Laubholzk. II. 1022, fig. 603 (1912).

Western Szech'uan: west of Romi-chango, woods, alt. 2500$3000 \mathrm{~m}$., July 4, 1908 (No. 33I9; tree $8 \mathrm{~m}$. tall, flowers whitish); Sintu Hsien, roadsides, alt. 600 m., May 18, 1908 (No. 3318 ; small tree 3-6 m. tall); west and near Wên-ch'uan Hsien, woods, alt. 20002600 m., July 1908 (No. 331 $7^{\mathrm{a}}$; tree $6 \mathrm{~m}$. tall); Tsa-ku-lao, August, A. von Rosthorn (No. 2554). Eastern Szech'uan: Wushan Hsien, A. Henry $\left(\right.$ No. $\left.5529^{a}\right)$. Western Hupeh: without locality, August 1901 (Veitch Exped. No. 1177, fruit only); without locality, A. Henry (Nos. 5529 $9^{\circ}$, 5903). Shensi : Tai-pei-shan, 1910, W. Purdom;" Thuikio-tsuen," September 25, 1897, G. Giraldi; "Monte Qua-in-san," July 16, 1897, G. Giraldi; "Monte kin-qua-san," July 10, 1897, G. Giraldi.

This is a critical species very closely allied to $R$. punjabensis Stewart, from which it is not easy to distinguish it in herbaria. Nevertheless from the behavior of the living trees it is apparent that they are distinct species. In herbaria $R$. Potaninii may be distinguished from $R$. punjabensis by its glabrous shoots, its slightly larger flowers, its fewer and more glabrous leaflets which are distinctly petiolulate and usually oblique at the base and by its unwinged leaf-rhachis.

In the woods of western Hupeh $R$. Potaninii is usually a tree of moderate size, 
but occasionally specimens from $20-25 \mathrm{~m}$. tall are met with. The bark is gray, fissured and rather rough and the tree contains little or no poisonous sap. The branches are moderately thick and form an oval or rounded head. Colloquially this Sumach is known as the "Ching-fu-yang," while the galls which are often produced on the leaf are called "Ch'i-pei-tzu" and are used as a medicine. A picture of this tree will be found under No. 346 of the collection of Wilson's photographs and also in his Vegetation of Western China, No. 448.

The Sumach in cultivation as $R$. sinica is this species. On young plants the leaflets are deeply toothed but on adult trees they are quite entire.

Rhus javanica Linnaeus, Spec. 265 (1753); ed. 2, 380 (1762).Osbeck, Dagbok Ostind. Resa, 232 (1757); Reise Ostind. 302 (1765); Voy. China East Ind. I. 375 (1771). - Thunberg, Fl. Jap. 121 (1784). - Loureiro, Fl. Cochin. 183 (1790).

Rhus chinense Osbeck, Dagbok Ostind. Resa. 232 (1757); Reise Ostind. 302 (1765); Voy. China East Ind. I. 375 (1771). - Miller, Dict. ed. 8 (1768).

Rhus semialata Murray in Comm. Soc. Goetting. VI. 27, t. 3 (1784). - Miquel in Ann. Mus. Lugd.-Bat. II. 84 (1866); Prol. Fl. Jap. 16 (1866). - Hemsley in Jour. Linn. Soc. XXIII. 146 (1886). - Sargent in Garden \& Forest, VI. 163 (1893); For. Fl. Jap. 33 (1894). - Diels in Bot. Jahrb. XXIX. 433 (1900). - Dunn \& Tutcher in Kew Bull. Misc. Inform. add. ser. X. 69 (Fl. Kwangtung \& Hongkong) (1912).

Rhus semialata, $\beta$. Osbeckii De Candolle, Prodr. II. 67 (1825), - Franchet in Nouv. Arch. Mus. Paris, sér. 2, V. 230 (Pl. David. I. 78) (1883). - Engler in De Candolle, Monog. Phaner. IV. 380 (1883). - Shirasawa, Icon. Ess. For. Jap. I. 96, t. 58, fig. 18-34 (1900). - Pampanini in Nuov. Giorn. Bot. Ital. n. ser. XVII. 416 (1910); XVIII. 126 (1911).

Rhus Osbeckii Decaisne ex Steudel, Nomencl. Bot. ed. 2, II. 452 (quasi synon.) (1841). - Schneider, Ill. Handb. Laubholzk. II. 156, fig. 102 d (1907).

Kiangsi: Kuling, thickets, alt. 1300 m., abundant, July 30, 1907 (No. I694; bush 2-4 m.). Western Hupeh: north and south of Ichang, thickets and cliffs, alt. 30-1000 m., abundant, August, September and December 1907 (No. 332I; small tree, 5-8 m. tall, flowers white, fruit reddish-brown); Changyang Hsien, margins of woods, alt. 600-1200 m., August 1907 (No. $332 \mathrm{I}^{\mathrm{a}}$; small tree $5 \mathrm{~m}$. tall, flowers white); without locality, September 1900 (Veitch Exped. No. 1710); Patung Hsien, A. Henry (No. 4890); "Monte Triora," alt. 1990 m., July 1907, C. Silvestri (No. 1321); "Monte Tien-pong-scian," alt. 1990 m., October 1907, C. Silvestri (No. 1323). North-central China: Miao-wang-san, July 1899, Hugh Scallan. Western Szech'uan: Kiating Fu, thickets, alt. 300-1000 m., September 1908 (No. 332 ${ }^{\text {b }}$; small tree 3-8 m. tall, flowers white); Mt. Omei, August 1904 (Veitch Exped. No. 4812). Yunnan: Mengtsze, mountains, alt. 1600 m., A. Henry (No. 11034). Chekiang: vicinity of Ning- 
po, 1908, D. Macgregor. Korea : Fusan, temple grounds, September 6, 1903, C. S. Sargent; Seoul, in gardens, September 1906, U. Faurie (Nos. 486, 487); Quelpaert, September 1908, 1909, Taquet (Nos. $666,2759)$.

This Sumach is abundant up to 1200 metres altitude everwhere in Hupeh and Szech'uan either in the form of a bush from 1-5 m. tall or as a small flattopped tree from 6-8 m. high. The specimens from Mt. Omei and Yunnan have the leaf-rhachis very narrowly winged and very closely approach the Indian variety. Rhus javanica is the "Fu-yang shu" or Chinese Nut-gall tree. The galls which develop on the leaves are a valued article of commerce and colloquially are known as "Wu-pei-tzu."

A picture of these galls will be found under No. 0349 of the collection of Wilson's photographs.

Here may be added a note on the Himalayan form of this species which has been found in Formosa, though not in China proper.

Rhus javanica, var. Roxburghii, Rehder \& Wilson, n. comb.

Rhus Buchi-amelam Roxburgh, Hort. Cat. Beng. 22 (nomen nudum) (1814).

Rhus amela D. Don, Prodr. Fl. Nepal. 248 (1825).

Rhus semialata, $\gamma$. Roxburgii De Candolle, Prodr. II. 67 (1825).

Rhus affinis Wallich, Cat. No. 995 (1828).

Rhus Roxburghii Decaisne ex Steudel, Nomencl. Bot. ed. 2, II. 452 (quasi synon.) (1841).

Rhus semialata Brandis, Forest Fl. Brit. Ind. 119 (1874); Ind. Trees, 197 (1906). - Hooker f., Fl. Brit. Ind. II. 10 (1876).

Rhus semialata, f. exalata Franchet in Bull. Soc. Bot. France, XXXIII. 466 (nomen nudum) (1886); Pl. Delavay. 148 (1889).

Formosa: Tamsui, 1864, R. Oldham (No. 87); Takow, common, A. Henry (No. 348 , in part); Bankinsing, A. Henry (No. 348, in part).

This plant also yields gall-nuts but they are more hairy than those of the species. This variety differs from the type in having the upper part of the rhachis of the leaf only very slightly or not at all winged. Most of the Indian specimens we have seen are best referred to this variety though a few are like those from Yunnan and $\mathrm{Mt}$. Omei and quite intermediate in character. The size of the wing on the rhachis of the leaf seems dependent on climate and latitude; the wings being more strongly developed on trees growing farthest north.

\section{Sect. II. TOXICODENDRON DC.}

Rhus orientalis Schneider, Ill. Handb. Laubholzk. II. 151 (1907).

Rhus Toxicodendron, var. hispida Engler in Bot. Jahrb. XXIX. 433 (1900).

Toxicodendron orientale Greene, Leaft. Bot. Observ. I. 127 (1905).

Rhus intermedia Hayata in Jour. Coll. Sci. Tokyo, XXV. art. XIX. 73 (Fl. Mont. Formosae) (1908).

Western Hupeh: Fang Hsien, rocky places and tree trunks, alt. 1300-2300 m., common, June and September 1907 (No. 284; climber $6 \mathrm{~m}$. and more or when growing on rocks a bush 1-2 m. tall); without 
locality, June 1900 (Veitch Exped. No. 1128); without locality, $A$. Henry (No. 6448). Western Szech'uan: Wa-shan, on rocks, alt. 1600-2000 m., October 1908 (No. 284a ; bush 1-2 m., fruit yellowish); Mupin, rocky places, alt. 1600-2300 m., October 1910 (No. 4647; bush $2 \mathrm{~m}$.).

This plant is very common in rocky places throughout western Hupeh and Szech'uan. The fruit is usually densely setose but this character varies somewhat; the leaves are dull green, not shining like those of the North American $R$. Toxicodendron Linnaeus.

Rhus trichocarpa Miquel in Ann. Mus. Lugd.-Bat. II. 84 (1866); Prol. Fl. Jap. 16 (1866). - Engler in De Candolle, Monog. Phaner. IV. 379 (1883). - Hemsley in Jour. Linn. Soc. XXIII. 148 (1886). Sargent in Garden \& Forest, VI. 163 (1893); X. 384, fig. 49 (1897); For. Fl. Jap. 34 (1894).

Kiangsi : Kuling, thickets, alt. 1300 m., common, July 31, 1907 (No. I69r; bush 2-4 m. tall). Western Hupeh: Changlo Hsien, woods, alt. 1000-1500 m., June 1907 (No. 3316; thin tree, $6 \mathrm{~m}$. tall); without locality, April 1900 (Veitch Exped. No. 194). Fokien: without precise locality, April to June 1905, Dunn's Exped. (Herb. Bot. Gard. Hongkong, No. 2825). Korea: Fusan, May 1906, U. Faurie (No. 484).

This ornamental species is common on the Lushan range in Kiangsi, but is very rare in western Hupeh which is the western limit of its distribution. It occurs in the thickets and margins of woods usually as a large bush and less commonly as a slender tree from 6 to $8 \mathrm{~m}$. tall. The leaves are reddish when young and assume brilliant tints in autumn.

Engler (in Bot. Jahrb. XXIX. 433) states that he regards $R$. trichocarpa Miquel as a hairy-fruited variety of $R$. vernicifera De Candolle. But the dehiscent drupe and the absence of poisonous, varnish yielding sap, as well as other characters, make it abundantly distinct from De Candolle's species.

Rhus sylvestris Siebold \& Zuccarini in Abh. Akad. Münch. IV. pt. III. 140 (Fl. Jap. Fam. Nat. II. 32) (1846). - Miquel in Ann. Mus. Lugd.-Bat. II. 84 (1866); Prol. Fl. 16 (1866). - Engler in De Candolle, Monog. Phaner. IV. 396 (1883). - Hemsley in Jour. Linn. Soc. XXIII. 147 (1886), - Diels in Bot. Jahrb. XXIX. 433 (1900). Shirasawa, Icon. Ess. For. Jap. I. 97, t. 58, fig. 1-17 (1900).

Kiangsi : Kuling, thickets, alt. 1000 m., common, August 1, 1907 (No. r687; bush 1.5-2.5 m.). Western Hupeh: Changyang Hsien, woodlands, alt. 1000-1300 m., May and September 1907 (No. I6o; slender tree 6-10 m. tall, flowers white); Patung Hsien, woodlands, 
alt. $1000 \mathrm{~m}$., May 1907 (No. $\mathrm{I}^{\mathrm{a}} \mathrm{a}^{\mathrm{a}}$; thin tree 6-10 m. tall); without locality, A. Henry (No. 6349). Chekiang: vicinity of Ningpo, 1908, D. Macgregor; "Tang-si," June 1907, F. N. Meyer (No. 443). Fokien: without precise locality, April to June 1905, Dunn's Exped. (Herb. Bot. Gard. Hongkong, Nos. 2525, 2528). Korea : Fusan, temple grounds, September 6, 1903, C. S. Sargent; Quelpaert, October 1906, U. Faurie (No. 485); same locality, May 1908, June 1909, 1910, Taquet (Nos. 667, 3120, 4173); Korean archipelago, 1863, R. Oldham (No. 187); Tsu-sima Island, 1859, C. Wilford.

This Sumach is common on the Lushan mountains in Kiangsi, but is rare in western Hupeh where the western limit of the range of the species is found. Usually it is a large bush but it often forms a slender tree; the number of leaflets which have very prominent veins varies from 3 to 13 . This species does not yield varnish and has no economic value as far as we know.

Rhus verniciflua Stokes, Bot. Mat. Med. II. 164 (1812) .

Rhus Vernix Linnaeus, Spec. 265 (1753), quoad specimina japonica. Thunberg, Fl. Jap. 121 (1784).

Rhus vernicifera De Candolle, Prodr. II. 68 (1825), excludendis speciminibus nepalensibus. - Miquel in Ann. Mus. Lugd,-Bat. II. 84 (1866); Prol. Fl. Jap. 16 (1866). - Hance in Jour. Bot. XX. 259 (1882). - Engler in De Candolle, Monog. Phaner. IV. 398 (1883). - Hemsley in Jour. Linn. Soc. XXIII. 148 (1886), - Maximowicz in Act. Hort. Petrop. XI. 110 (1889). - Sargent in Garden \& Forest, VI. 162 (1893); For. Fl. Jap. 33 (1894). - Shirasawa, Icon. Ess. For. Jap. I. 94, t. 57, fig. 17-30 (1900). Diels in Bot. Jahrb. XXIX. 433 (1900), - De Wildeman, Icon. Hort. Thenens. VI. 1, t. 201 (1906).

Rhus Kaempferi Sweet, Hort. Brit. 97 (1827).

Rhus succedanea, var. himalaica Hooker f., Fl. Brit. Ind. II. 12 (1876).

Rhus vernicifera, var. Silvestrii Pampanini in Nuov. Giorn. Bot. Ital. n. ser.

XVII. 416 (1910); XVIII. 173 (1911).

Western Hupeh: north and south of Ichang, mountain slopes and valleys, wild and cultivated, alt. 1000-2500 m., June and September 1907 (No. 123, in part; tree 8-20 m. tall, girth 0.6-2 m.); Hsingshan Hsien, woodlands, alt. 1000-2500 m., abundant, June 4 and September 1907 (No. 123, in part; tree 6-15 m. tall, girth 1-2 m., flowers greenish-white); Changyang Hsien, woodlands, alt. 10002500 m., abundant, June 1907 (No. I23, in part; tree 10-16 m., girth 1-2 m.); Changlo Hsien, woods, alt. 1300-2500 m., June 1907 (No. I23, in part; tree 10-20 m. tall, girth 1-2 m.); Patung Hsien, wood-

${ }^{1}$ First mentioned by Kaempfer (Amoen. Exot. 791, t. 792 [1712]) as "Sitz" or "Urùs." 
lands, alt. 1300-2500 m., July 1907 (No. 33I4; tree 8 m. tall, girth $1 \mathrm{~m}$.); Fang Hsien; woodlands, alt. 1600-2000 m., May 23, September 1907 (No. 259; tree 10-15 m. tall, girth 1-2 m.); without locality, June and September (Veitch Exped. No. 994); without locality, A.

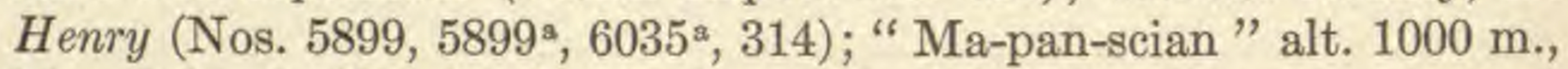
May 1907, C. Silvestri (No. 3353). Western Szech'uan: west of Kuan Hsien, valley of Pan-lan-shan, wild and cultivated, alt. 2300$2600 \mathrm{~m}$., June 19, 1908 (No. 3315, in part; tree 5-10 m. tall, girth 0.6-1.5 m., flowers white); west and near Wên-ch'uan Hsien, alt. 2300-2600 m., July 1908 (No. 33I5, in part; tree 6-15 m., girth 1-2 m.); Nan-ch'uan, A. von Rosthorn (No. 2283). Shensi : Tai-peishan, 1910, W. Purdom.

India : temperate Himalaya, alt. 1000-2000 m., Serahan to Tranda, September 1874, T. Thomson (in Herb. Gray).

This is the Chinese Lacquer-varnish tree and it is one of the most common trees on the mountains of western Hupeh and eastern Szech'uan, being abundant in the woods and thickets; it is also generally planted round the margins of fields. In western Szech'uan it is much less abundant. The trees are from $15-20 \mathrm{~m}$. tall, with a trunk girth of from 1 to $2 \mathrm{~m}$; the bark is pale gray and smooth on young trees, becoming dark gray, rough and irregularly fissured with age. The habit is loosely pyramidal and the branches are more or less whorled. The sap-wood is white and the heart-wood yellow; the wood has no value except for fuel. The leaves vary from $25-75 \mathrm{~cm}$. in length and may be densely pubescent on the under side or virtually glabrous. The rhachis is equally variable in degree of pubescence. The fruit is indehiscent, shining straw-yellow, from 5 to $8 \mathrm{~mm}$. long and broad; it is rich in fatty oil which is expressed and used by the peasants for making candles and for adulterating Tung-oil, the product of the seeds of Aleurites Fordii Hemsley. ${ }^{1}$

The Indian specimens are identical with the Chinese and it is curious that they should have been considered as a variety of $R$. succedanea Linnaeus. The characters on which Pampanini bases his variety are not constant and do not hold good even on one of the specimens he cites.

The vernacular name for this tree is "Che shu," the varnish is "Che" or "Ch'i," and the oil from the fruit "Che-yu."

Pictures of this tree will be found under Nos. 372, 505, 572 and 070 of the collection of Wilson's photographs and also in his Vegetation of Western China, Nos. 450,451 and 452 .

Rhus succedanea Linnaeus, Mant. 221 (1771). ${ }^{2}$ - Thunberg, Fl. Jap. 122 (1784). - De Candolle, Prodr. II. 68 (1825). - Wight, Icon. II. t. 560 (1843). - Bentham, Fl. Hongk. 69 (1861). - Hooker

${ }^{1}$ For an account of the tapping of the trees for varnish see Wilson, A naturalist in Western China, II. 68 (1913).

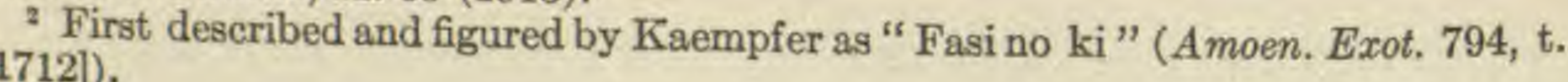


f., Fl. Brit. Ind. II. 12 (1876). - Franchet in Nouv. Arch. Mus. Paris, sér. 2, V. 231 (Pl. David. I. 79) (1883). - Hemsley in Jour. Linn. Soc. XXIII. 147 (1886). - Franchet, Pl. Delavay. 148 (1889). - Sargent in Garden \& Forest, VI. 163 (1893); For. Fl. Jap. 34 (1894). - Diels in Bot. Jahrb. XXIX. 433 (1900). - Shirasawa, Icon. Ess. For. Jap. I. 95, t. 57, fig. 1-16 (1900). - Brandis, Ind. Trees, 199 (1906).

Rhus fraxinifolium Salisbury, Prodr. 169 (1796).

Rhus pubigera Blume, Bijdr, 1165 (1825).

Connarus? juglandifolius Hooker \& Arnott, Bot. Voy. Beechey, 179 (1833).

Rhus succedanea, a. japonica Engler in De Candolle, Monog. Phaner. IV. 399 (1883).

Western Hupeh: Fang Hsien, roadside, alt. 800 m., October 1910 (No. 4425; tree $12 \mathrm{~m}$. tall, girth $1 \mathrm{~m}$.); Hsing-shan Hsien, woodlands, alt. 1000-1200 m., local, October 1907 (No. 453; tree 10 m. tall, girth $1.5 \mathrm{~m}$.); without locality, A. Henry (No. 7578). Western Szech'uan: Mt. Omei, June 1904 (Veitch Exped. No. 4811). Yunnan: Szemao, mountains, alt. 1500-1600 m., A. Henry (Nos. $\left.11690^{a}, 11955,11955^{a}\right)$. Hongkong: Happy Valley woods, November 5, 1903, C. S. Sargent. Formosa: Bankinsing, mountains, A. Henry (No. 62); "Okaseki" mountains, June 1903, U. Faurie (No. 33).

This is a rare tree in western Hupeh and Szech'uan where it grows only at low altitudes. It yields no varnish and in western China the fatty oil is not extracted from the fruit as it is in Japan. The bark is gray, rather thin and irregularly fissured. The tree is shapely in habit and its glossy, rather coriaceous leaves in autumn assume a very fine color.

From the description, native name and distribution it is highly probable that Augia sinensis Loureiro (Fl. Cochin. 337 [1790]) belongs here. Rhus succedanea has been mistaken by some of the older authors for the true Varnish tree, $R$. verniciflua Stokes.

Rhus Delavayi Franchet in Bull. Soc. Bot. France, XXXIII. 466 (1886); Pl. Delavay. 148 (1889); Schneider, Ill. Handb. Laubholzk. II. 153 , fig. $100 \mathrm{c}(1907)$.

Western Szech'uan: Tung-chuan Fu, roadside, alt. $600 \mathrm{~m}$., July 1910 (No. 4648; bush $1 \mathrm{~m}$.). Yunnan: Mengtze, grassy hills, alt. 1600 m., A. Henry (No. 10283).

This is a rather variable species; our specimen agrees very well with Franchet's description except that the inflorescence is rather longer. In Henry's specimen the leaves are larger than Franchet's measurements and the panicle also is much longer. 
Rhus Delavayi, var. quinquejuga, Rehder \& Wilson, n. var.

A typo recedit foliis 2-5-jugis, rarius pluri-jugis cum petiolo 12-18 $\mathrm{cm}$. longis, foliolis basi manifeste obliquis $2-7 \mathrm{~cm}$. longis initio utrinque sparse adpresse pilosulis mox glabris.

Western Szech'uan: south-east of Tachien-lu, woodlands, alt. 1600 m., October 1908 (No. I26o, type; small tree 6 m. tall); valley of Tung river, May 1904 (Veitch Exped. No. 3372).

This variety is rather local and is well distinguished from the type in the characters mentioned above. The relationship between this plant and $R$. succedanea Linnaeus is evidently very close but the latter has rather different flowers, larger panicles and larger, more coriaceous leaves. The rather large petals with prominent dark pinnate veins and the nearly white sepals are characteristic of $R$. Delavayi Franchet, and its variety.

Here may be added a note on a species not collected during the Arnold Arboretum Expeditions.

Rhus paniculata Wallich, Cat. No. 993 (nomen nudum) (1828). - Hooker f., Fl. Brit. Ind. II. 10 (1876). - Engler in De Candolle Monog. Phaner. V. 421 (1883).

Yunnan: Shih Ping, ravine, alt. 1150 m., A. Henry (No. 11578; tree 5 m. tall); Yuan-chiang, alt. $1300 \mathrm{~m}$., A. Henry (No, $11578^{\mathrm{a}}$; bush $2 \mathrm{~m}$.).

In China this plant has been previously recorded only from the extreme southwestern corner of Yunnan. 


\section{STAPHYLEACEAE.}

Determined by AuFred ReHDer and E. H. WILSON.

\section{STAPHYLEA L.}

Staphylea Bumalda De Candolle, Prodr. II. 2 (1825). - Siebold \& Zuccarini, Fl. Jap. I. 180, t. 95 (1835). - Miquel in Ann. Mus. Lugd.-Bat. III. 93 (1867); Prol. Fl. Jap. 257 (1867). - Franchet \& Savatier, Enum. Pl. Jap. I. 90 (1875). - Diels in Bot. Jahrb. XXIX. 447 (1900). - Shirasawa, Icon. Ess. For. Jap. II. 112, t. 40, fig. 14-27 (1908).-Pampanini in Nuov. Giorn. Bot. Ital. n. ser. XVII. 421 (1910).

Bumalda trifoliata Lamarck, Encycl. Méth. Bot. I. 514 (1783).

Bumalda trifolia Thunberg, Fl. Jap. 114 (1784).

Western Hupeh: Hsing-shan Hsien, side of streams, alt. 10001300 m., May 6, September 1907 (No. 29o; bush 1-2.5 m., flowers white, fragrant); Changyang Hsien, May and August 1900 (Veitch Exped. No. 326); without locality, A. Henry (Nos. 1241, 5948, 5948 b); "Ma-pan-scian" alt. 1000 m., May 1907, C. Silvestri (No. 1368). Chekiang: Ningpo, mountains, 1888, E. Faber (No. 92). Korea: "in monte des diamants," June 1906, U. Faurie (No. 478); Quelpaert, woods, July 1908, June 1909, May 1910, Taquet (Nos. 1514, 2934, 4351).

In western Hupeh this shrub is not uncommon in thickets along streams and does not differ from the plant which occurs in Japan.

Staphylea holocarpa Hemsley in Kew Bull. Misc. Inform. 1895, 15. - Diels in Bot. Jahrb. XXIX. 447 (1900). - Schneider, Ill. Handb. Laubholzk. II. 189, fig. 120 c (1907), - Bean in Kew Bull. Misc. Inform. 1910, 175.

Staphylea Emodi Diels in Bot. Jahrb. XXXVI. Beibl. No. LXXXII. 73 (non Wallich) (1905).

Western Hupeh: Patung Hsien, thickets, alt. 1300-1600 m., May and September 1907 (Nos. III, $\mathbf{I 2 2}^{\circ}$; bush 2.5-8 m., flowers 
white); Hsing-shan Hsien, thickets, alt. 1600-2300 m., common, May

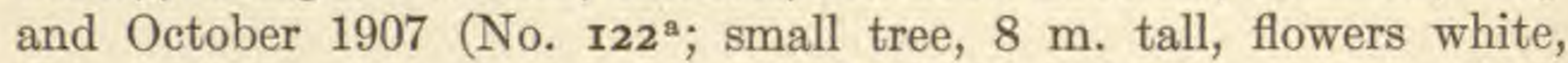
fragrant); same locality, woodlands, alt. 1600-2500 m., common, May 11, 1907 (No. I85 ${ }^{\text {b }}$ bush or small tree, 3-6 m. tall, flowers blushpink); Changyang Hsien, woodlands, alt. 1600-2000 m., May 1907 (No. I22 $^{\mathrm{b}}$; bush or small tree 3-6 m., flowers pale pink); without locality, April and September 1900 (Veitch Exped. No. 14); without locality, A. Henry (Nos. 4536, 5468, $\left.7651^{\mathrm{a}}, 5751^{\mathrm{a}}, 7651\right)$. Eastern Szech'uan: Wushan Hsien, A. Henry (Nos. 5751, 5683). Shensi : north-west of Hanchung Hsien, 1901, W. Purdom (Nos. 3161, 316); north-west of Hanchung Hsien, Moutan-shan, alt. 1500 m., 1910, W. Purdom (No. 365); Tai-pai-shan, 1910, W. Purdom (No. 446); "Lao-y-san," June 4, 1897, G. Giraldi; "Qua-in-san," July 16, 1897, G. Giraldi; " M. Kin-tou-san," July 14, 1897, G. Giraldi.

Very common on the margins of woods and thickets in western Hupeh and eastern Szech'uan and the most beautiful species of the genus. Though usually a large bush it very often forms a shapely tree from 8 to $10 \mathrm{~m}$. tall, with a slender trunk clothed with smooth, grayish bark. The flowers are pure white or pale pink, relatively large and are borne in pendulous cymose clusters from the leaf axils of the naked shoots of the previous season and usually open before the leaves unfold. Occasionally the cymes are subtended by 1 or 2 pairs of leaves and sometimes the leaves unfold almost simultaneously with the opening of the flowers. The inflorescence varies in length from 4-10 cm.; the leaflets also are somewhat variable in size and shape. The capsule is usually pyriform and abruptly acuminate when perfectly ripe, but the shape varies and is dependent upon the degree of coherence of the styles which often differs in the same inflorescence. The upper part of the ovary and the basal part of the style are villose.

This species is elosely related to $S$. Emodi Wallich, which has larger, more membranous leaves, longer petioles, an inflorescence terminal on the leafy shoot of the season, developing with and after the leaves as in S. pinnata Linnaeus, a glabrous pistil, and yellow-brown seeds which are twice the size of the grayishbrown seeds of $S$. holocarpa.

\section{Staphylea holocarpa, var. rosea Rehder \& Wilson, n. var.}

A typo recedit foliolis subtus initio tomento albido villoso obtectis demum secus basin costae tantum albido-villosis, foliis rarissime bijugis, floribus roseis $1-1.5 \mathrm{~cm}$. longis.

Western Hupeh: Fang Hsien, margins of woods, alt. 16002500 m., May 20, September 1907 (No. I85, type; tree 6 m. tall, flowers rosy-pink); Hsing-shan Hsien, thickets, alt. 1600-2500 m., August 1907 (No. $185^{\mathrm{a}}$; bush or small tree $3-6 \mathrm{~m}$.); same locality, alt. 2600 m., May and September 1901 (Veitch Exped. No. 1860); Changyang Hsien, woodlands, alt. 1600-2300 m., September 1907 (No. I22; bush or small tree, 3-8 m. tall). Western Szech'uan: Wa- 
shan, rare, May 1904 (Veitch Exped. No. 3358; tree 10 m. tall). Yunnan: Mengtze forests, alt. 2300 m., A. Henry $\left(\right.$ No. $\left.10220^{\mathrm{a}}\right)$.

This handsome plant is common in western Hupeh and eastern Szech'uan but is rare in western Szech'uan. It is easily distinguished from the type by the characters given above. Occasionally the leaves are pinnately 5 -foliolate. The specimen from Yunnan is less hairy and perhaps should be referred to the type of the species. The Wa-shan form has exceptionally large flowers and seeds.

\section{TURPINIA Vent.}

Turpinia nepalensis Wallich, Cat. No. 4277 (nomen nudum) (1830), excludendo synonymo. - Wight \& Arnott, Prodr. Fl. Ind. 156 (1834). - Wight, Icon. III. t. 972 (1843-50). - Bentham, Fl. Hongk. 48 (1861), - Beddome, Fl. Sylv. S. Ind. I. t. 159 (1869).

Turpinia microcarpa Wight \& Arnott, Prodr. Fl. Ind. 156 (1834).

Turpinia pomifera, $\beta$. (T. nepalensis) Hiern in Hooker f., Fl. Brit. Ind. I. 699 (1875).

Turpinia pomifera Hemsley in Jour. Linn. Soc. XXIII. 143 (non De Candolle) (1886). - Shirasawa, Icon. Ess. For. Jap. II. t. 40, fig. 1-13 (1908).Dunn \& Tutcher in Kew Bull. Misc. Inform. add. ser. X. 67 (Fl. Kwangtung \& Hongkong) (1912).

Western Szech'uan: Hungya Hsien, woodlands, alt. $1000 \mathrm{~m}$., September 8, 1908 (No. 235I; tree $10 \mathrm{~m}$. tall, girth $1.5 \mathrm{~m}$.); Mt. Omei, alt. 800 m., October 1903, June 1904 (Veitch Exped. Nos. 3359, 4803). Yunnan: Szemao, forests, alt. 1300-2000 m., A. Henry (Nos. 11612, $11612^{\mathrm{a}}, 11612^{\mathrm{b}}, 11612^{\mathrm{d}}, 11612^{\mathrm{e}}, 11612^{\mathrm{t}}, 11612^{\mathrm{g}}, 11612^{\mathrm{h}}, 11612^{1}$, $12039,12039^{\mathrm{b}}, 12039^{\mathrm{c}}$ ); Feng-chen-lin, mountains, alt. $2000 \mathrm{~m} ., A$. Henry (No. 10694). Hongkong: April 24, 1893, C. Ford; C. Wright (No. 90); Champion (No. 74). Liu-kiu Islands: C. Wright.

This tree which is of medium size and has tough wood oceurs sparingly on Mt. Omei and in its neighborhood. In Yunnan it is apparently common. It seems to differ from $T$. pomifera De Candolle only in its much smaller fruits and ciliolate petals and is possibly only a variety of that species.

\section{EUSCAPHIS Sieb. \& Zucc.}

Euscaphis japonica Dippel, Handb. Laubholzk. II. 480, fig. 229 (1892). - Diels in Bot. Jahrb. XXIX. 448 (1910). - Pampanini in Nuov. Giorn. Bot. Ital. n. ser. XVII. 421 (1910).

Sambucus japonica Thunberg, Fl. Jap. 125 (1784).

Euscaphis staphyleoides Siebold \& Zuccarini, Fl. Jap. I. 124, t. 67 (1835). Miquel in Ann. Mus. Lugd.-Bat. III. 92 (1867); Prol. Fl. Jap. 256 (1867).-Franchet \& Savatier, Enum. Pl. Jap. I. 91 (1875). - Hance in Jour. 
Bot. XVIII. 260 (1880); XX, 4 (1882). - Franchet in Nouv. Arch. Mus. Paris, sér. 2, V. 230 (Pl. David. I. 78) (1883). - Hemsley in Jour. Linn. Soc. XXIII. 148 (1886). - Shirasawa, Icon. Ess. For. Jap. I. 112, t. 70 (1900), - Schneider, Ill. Handb. Laubholzk. II. 187, fig. 121 c-e, 122 d (1907).

Kiangsi : Kuling, thickets, alt. 1300 m., July 29, 1907 (No. I577; bush 1-2 m., fruit scarlet). Western Hupeh: north and south of Ichang, thickets, alt. 300-1000 m., abundant, June 4, August and September 1907 (No. II4, in part; bush 2-3 m., flowers greenishwhite, fruit reddish, seed black); Patung Hsien, thickets, alt. 1000 m., June 1907 (No. Ir4, in part; bush 2-4 m., flowers greenish-white); same locality, June and August 1901 (Veitch Exped. No. 453); Nanto and mountains to northward, A. Henry (No. 1912); without locality, A. Henry $\left(\right.$ No. $\left.844,5767^{\circ}\right)$. Eastern Szech'uan: Wushan Hsien, A. Henry (No. 5767). Western Szech'uan: Mt. Omei, June 1904 (Veitch Exped. No. 4804); without precise locality, alt. 1300-2300 m., May 1904 (Veitch Exped. No. 3357). Chekiang: vicinity of Ningpo, 1908, D. Macgregor. Fokien: without locality, Dunn's Exped., April and June 1905 (Herb. Bot. Gard. Hongkong, No. 2773). Korea: Fusan, temple grounds, September 6, 1903, C. S. Sargent; Quelpaert, October 1906, June 1907, U. Faurie (Nos. 447, 1604); same locality, May 1908, July 1909, June 1910, Taquet (Nos. 664, 2932, 4172).

A very common shrub in western Hupeh and Szech'uan where it is colloquially known as the "Hung-liang" and where the fruit is used as a drug.

\section{TAPISCIA Oliv.}

Tapiscia sinensis Oliver in Hooker's Icon. XX. t. 1928 (1890). Diels in Bot. Jahrb. XXIX. 448 (1900), - Bean in Kew Bull. Misc. Inform. 1909, 356, fig. - Schneider, Ill. Handb. Laubholzk. II. 1026, fig. 607 (1912).

Western Hupeh: Changyang Hsien, woods, alt. 600-1150 m., July and September 1907 (No. I08, in part; tree 8-13 m. tall, girth 0.6-1.5 m., flowers yellow, fragrant, fruit black); Hsing-shan Hsien, woods, alt. $1000 \mathrm{~m}$., July 1907 (No. I08, in part; tree 6-13 m. tall, flowers yellow); Patung Hsien, woods, alt. 1000 m., August 1907 (No. I08, in part; tree 8-13 m. tall, fruit black); without locality, July 1901 (Veitch Exped. No. 2194). Western Szech'uan: Mupin, woodlands, alt. 1000-1300 m., June and September 1908 (No. I08 ${ }^{\mathrm{a}}$; 
tree 16-30 m. tall, girth 2.5-4 m., flowers yellow). Mt. Omei, alt. 500-1600 m., common, June 1903 (Veitch Exped. No. 3362); without locality, A. Henry (No. 8990). Yunnan: Szemao, alt. 1600 m., A. Henry (No. 13151).

This monotypic genus is rather rare in western Hupeh where it occurs in moist woods and is seldom more than from 12 to $15 \mathrm{~m}$. tall. In western Szech'uan and especially round $\mathrm{Mt}$. Omei, it is common and large trees occur. Under the most favorable conditions it grows from 25 to $30 \mathrm{~m}$. tall with a trunk from $0.6-1 \mathrm{~m}$. in diameter and bare of branches for a considerable height; the branches are stout, spreading and form a flattened head of moderate size; the bark is light gray, slightly fissured and fairly smooth; the wood is white, soft and useless. The flowers are minute, yellow, with a pleasant honey-like fragrance and are borne in fairly large axillary panieles. The ripe fruit is black, subglobose and when young is often attacked by gall-insects. The pinnate leaves turn yellow in the autumn. In herbaria the specimens of this tree suggest a pinnate-leaved species of Ampelopsis.

In Hupeh a colloquial name for this tree is "Yin-ch'iao shu" sometimes abbreviated to "Yin-chi shu." A pieture of this tree will be found under No. 325 of the collection of Wilson's photographs and also in his Vegetation of Western China, No. 482. 


\section{ICACINACEAE.}

Determined by Alfred Rehder and E. H. Wilson.

MAPPIA Jacq.

Mappia pittosporoides Oliver in Hooker's Icon. XVIII. t. 1762 (1888). - Diels in Bot. Jahrb. XXIX. 447 (1900).

Western Hupeh: Hsing-shan Hsien, eliffs, alt. 600-1000 m., May 9, July 1907 (No. 3296, in part; bush 1.5-2 m., flowers yellow, with unpleasant odor); Changlo Hsien, cliffs, alt. 600-1000 m., May and July 1907 (No. 3296, in part; bush 1.5-2 m., flowers yellow, fruit dark red); Ichang and immediate neighborhood, A. Henry (Nos. $3536,4118,3537^{\mathrm{a}}$ ). Western Szech'uan: Wa-shan, thickets, alt. 1500, June 1908 (No. 3295, in part; bush 0.6-2 m., flowers yellowish); Mupin, thickets, alt. 1300 m., June 1908 (No. 3295, in part; bush 1$3 \mathrm{~m}$., flowers yellow); without precise locality, thickets, alt. 5001000 m., June 1903, May and June 1904 (Veitch Exped. Nos. 3234, $4440,4945)$.

A common shrub in western Hupeh and Szech'uan in thickets and rocky places.

HOSIEA Hemsl. \& Wils.

Hosiea sinensis Hemsley \& Wilson in Kew Bull. Misc. Inform. 1906, 154.

Natsiatum sinense Oliver in Hooker's Icon. XIX. t. 1900 (1889). - Diels in Bot. Jahrb. XXIX. 447 (1900).

Western Szech'uan: Wa-shan, on rocks, alt. 1300-2000 m., May and September 1908 (No. 96o; climber 2-3 m., flowers whitish, fruit orange). Eastern Szech'uan: Wushan Hsien, A. Henry (Nos. 5598, 5598 ${ }^{\circ}$ ). Western Hupeh: Fang Hsien, rocks, alt. 6001300 m., May 19, 1907 (No. 960ª); without locality, A. Henry (No. $\left.5598^{\mathrm{b}}\right)$.

This plant is not uncommon in rocky places through western Hupeh and Szech'uan; the flattened and oval, orange-colored fruit is attractive. 


\section{SAPINDACEAE.}

Determined by Alfred ReHder and E. H. WILson.

\section{SAPINDUS L.}

Sapindus mukorossi Gaertner, Fruct. I. 342, t. 70 (1788), - De Candolle, Prodr. I. 609 (1824). - Bretschneider, Early Res. 144 (1881). - Hemsley in Jour. Linn. Soc. XXIII. 139 (1886). - Shirasawa, Icon. Ess. For. Jap. I. 114, t. 71, fig. 1-15 (1900). - Dunn \& Tutcher in Kew Bull. Misc. Inform. add. ser. X. 66 (Fl. Kwangtung \& Hongkong) (1912).

Sapindus abruptus Loureiro, Fl. Cochin. 233 (1790).

Western Hupeh: neighborhood of Ichang, roadsides, alt. 30$1000 \mathrm{~m}$., May, June and December 1907 (No. 759; tree 10-25 m. tall, girth 1-5 m., flowers white, bark gray); same locality, A. Henry (Nos. 1032, 1652, 6367). Formosa: Takow, A. Henry, Bankinsing, A. Henry (No. 552); "Mamyama," June 1903, U. Faurie (No. 32). Hainan: without locality, A. Henry (No. 7958). Korea: Quelpaert, July 1907, U. Faurie (No. 1606); same locality, June 1909, August 1908 and September 1907, Taquet (Nos. 2746, 660, 4).

This is one of the noblest of Chinese trees and is common in the warmer parts of the Yangtsze Valley. It grows to a large size and has a wide-spreading head of massive branches, a smooth, gray bark and bright green leaves. The colloquial name is "Hon-erh-tsao" but in Chinese books it is usually referred to as the "Wu-huan-tzu." The saponaceous fruit is used as soap and the seeds are made into rosaries and beads. The pale yellowish white wood is used for making combs and for other purposes. Pictures of this tree will be found under Nos. 72, 403, 596,0165 and 0232 of the collection of Wilson's photographs and also in his Vegetation of Western China, Nos. 465 and 466.

\section{KOELREUTERIA LaXm.}

Koelreuteria apiculata Rehder \& Wilson, n. sp.

Koelreuteria paniculata Diels \& Pritzel in Bot. Jahrb. XXIX. 450 (non Laxmann) (1900).

Arbor 3-12-metralis, trunco 0.3-1 m. circuitu, coma densa lata applanata, cortice obscure griseo irregulariter fisso scabro; ramuli 
leviter striati, initio puberuli, mox glabrescentes, lenticellis punctiformibus conspersi; gemmae subglobosae, perulis 2 valvatis fuscis extus glabris intus dense tomentosis obtectae. Folia bipinnata, 58-juga, cum petiolo $18-35 \mathrm{~cm}$. longa; pinnae plerumque suboppositae infimis et summis exceptis pinnatae, 1-4-jugae, foliolis ovatis v. ovatooblongis sessilibus v. fere sessilibus, acutis v. breviter acuminatis basi truncatis v. late cuneatis irregulariter duplo inciso-serratis 1.5$3 \mathrm{~cm}$. longis, supra glabris venis pilosulis exceptis, subtus pallidioribus ad venas tantum sparse villosis, foliolis terminalibus pinnarum multo majoribus acuminatis basin versus pinnatisectis, pinnae infimae et summae plerumque indivisae inaequaliter et dupliciter incisoserratae et basin versus plerumque inciso-lobatae, acuminatae, basi saepe subcordatae; petioli $3.5-5 \mathrm{~cm}$. longi, ut rhachis fere cylindrici supra canaliculati et puberuli, basi dilatati. Flores polygamo-dioeci, aurei, in paniculis terminalibus erectis multifloris $15-25 \mathrm{~cm}$. longis v. ultra et $12-20 \mathrm{~cm}$. latis dispositi; rhachis striata et ramuli basi glabrescentia apicem versus villosula; bracteae lanceolatae, acutae, pubescentes, 2-3 $\mathrm{mm}$. longae, deciduae; pedicelli $3-6 \mathrm{~mm}$. longi, villosuli, apice glabrescentes; sepala 5 , paullo inaequalia, concava, orbicularia v. ovalia, 2-2.5 mm. longa, eroso-ciliata v. lacera; petala sursum curvata, anguste oblonga, obtusa, 8-9 mm. longa et 2-3 $\mathrm{mm}$. lata, auriculata, supra unguiculum dense villosum $2 \mathrm{~mm}$. longum; stamina 8 , in floribus masculis 8-9 mm. longa, in femineis 4-5 mm. longa, filamentis curvatis subulatis v. filiformibus, pilosis, antheris ovalibus apice truncatis margine sparse villosis; pistillum circiter 6 $\mathrm{mm}$. longum, sparse pubescens in stylum curvatum attenuatum, stigmate simplice v. obsolete bifido. Capsula ovato-oblonga, basi rotundata v. subcordata, apice obtusa v. rotundata, apiculata, 5-6 cm. longa et 3-3.5 cm. lata; semina globoso-obovoidea, punctulata, nitida, atrobrunnea, circiter $7 \mathrm{~mm}$. longa.

Western Szech'uan: northeast of Tachien-lu, dry valleys near Romi-chango, alt. 2300-2600 m., June 28 and September 1908 (No. 2370, type); without locality, July and September 1904 (Veitch Exped. No. 3364); Wei-kuan, A. von Rosthorn (No. 2523).

This new species is most closely allied to $K$. paniculata Laxmann which is readily distinguished by its often simply pinnate leaves, much broader less coarsely incised leaflets with less acute teeth, by its ovate or oblong-ovate, acute sepals, its smaller petals and chiefly by its sharply pointed fruit with acute or acuminate
valves.

Koelreuteria apiculata Rehder \& Wilson is common in the hot, dry, almost desert-like river valleys of western Szech'uan. It is a rather low tree with wide- 
spreading head and a relatively thick trunk. The flowers are sometimes used as a yellow dye in the same way as those of Sophora japonica Linnaeus. Colloquially both trees are spoken of as the "Huai shu." Pictures of this Koelreuteria will be found under Nos. 151 and 261 of the collection of Wilson's photographs and also in his Vegetation of Western China, Nos. 277 and 278.

Here may be added a note on another Chinese species not collected during the Arnold Arbor etum Expeditions.

Koelreuteria bipinnata Franchet in Bull. Soc. Bot. France, XXXIII. 463 (1886); Pl. Delavay. 143, t. 29, 30 (1889). - Diels \& Pritzel in Bot. Jahrb. XXIX. 450 (1900).

Western Hupeh: without locality, August and November 1900 (Veitch Exped. No. 1609); without locality, A. Henry (No. 7591). Yunnan: Mengtze, mountains, alt. 1800-2300 m., A. Henry (Nos. 9103, 9099).

This tree is rare in Hupeh and Szech'uan where it is confined to low altitudes in the dry river valleys. It is a rather tall tree with a slender trunk and rather thin wide-spreading branches. It is common on the plateaux of Yunnan where it grows to a considerable size.

Here may be added an account of Euphoria longana Lamarck of which a photograph was taken during the Arnold Arboretum Expedition, but no specimens collected.

\section{EUPHORIA Comm.}

Euphoria longana Lamarck, Encycl. Méth. III. 574 (1789). - DeCandolle, Prodr. I. 611 (1824). - Radlkofer in Act. Congr. Intern. Bot. Amsterdam, 75 (Sapind. Holl. Ind. 6) (1878); Sitzber. Math. Phys. Cl. Bayer. Akad. Wiss. 1878, p. 308; in Engler \& Prantl, Nat. Pflanzenfam. III. Abt. V. 329 (1895).

Dimocarpus Longan Loureiro, Fl. Cochin. 233 (1790).

Dimocarpus longus Dietrich ex Steudel, Nomencl. Bot. 328 (quasi synon.) (1821).

Dimocarpus Longan in Trans. Hort. Soc. Lond. II. 400, t. 28 (1822).

Dimocarpus pupilla Moore, Cat. Pl. Ceylon. 31 (nomen nudum) (1824).

Nephelium longana Cambessedes in Mém. Mus. Hist. Paris, XVIII. 30 (1829). Hiern in Hooker f., Fl. Brit. Ind. I. 688 (1875). - Hemsley in Jour. Linn. Soc, XXIII. 139 (1886). - Brandis, Ind. Trees, 192 (1906). - Dunn \& Tutcher in Kew Bull. Misc. Inform. add. ser. X. 66 (Fl. Kwangtung \& Hongkong (1912).

Nephelium Bengalense G. Don, Gen. Syst. I. 670 (1831).

Nephelium longanum G. Don, Gen. Syst. I. 670 (1831).

Scytalia Bengalensis Roxburgh ex G. Don, Gen. Syst. I. 670 (quasi synon.) (1831).

Scytalia Longan Roxburgh, Fl. Ind. ed. 2, II. 270 (1832).

Euphoria Longan Wallich, Cat. No. 8049 (1832). - Lindley in Bot. Reg. XX. t. 1729 (1835).

Euphoria undulata Heyne ex Wallich, Cat. sub. No. 8049 (quasi synon.) (1832).

Sapindus monogyna, Heyne ex Wallich, Cat. sub. No. 8049 (quasi synon.) (1832).

"Cupania canescens?" Wallich Cat., No. 8067³ (nomen nudum) (1832).

Sapindus Benghalensis Roxburgh ex Wight \& Arnott, Prodr. Fl. Ind. 113 (quasi synon.) (1834). 
Dimocarpus undulatus Wight ex Wight \& Arnott, Prodr, Fl. Ind. 113 (quasi synon.) (1834).

Nephelium pupillum Wight, Ill. I. 141 (1840).

Euphoria pupillum Steudel, Nomencl. Bot. ed. 2, II. 192 (1841).

Nephelium longan Hooker in Bot. Mag. LXX. t. 4096 (1844).

Nephelium Mora Gardner ex Thwaites, Enum. Pl. Zeyl. 58 (quasi synon.) (1864).

Nephelium hypoleucum Kurz in Jour. As. Soc. Beng. XL. 50 (1871).

Western Szech'uan: Lu Chou, vicinity of Yangtsze River, cultivated, May 1903 (Veitch Exped. No. 3360; tree 5-8 m. tall). Kwangtung: Hainan, $A$. Henry (No. 7960). Formosa: Takow, common, wild on the eliffs, A. Henry; cultivated, June 30,1903 , U. Faurie (No. 28).

This fruit tree is sparingly cultivated in the warmer parts of Szech'uan west of Chungking Fu. A picture of this tree will be found under Nos. 46 and 661 of the collection of Wilson's photographs and also in his Vegetation of Western China, Nos. 317 and 318. 


\section{SABIACEAE.}

Determined by Alfred Rehder and E. H. Wilson.

\section{SABIA Colebr.}

Sabia Ritchieae Rehder \& Wilson, n. sp.

Frutex scandens, 2-metralis; ramuli annotini glabri v. initio sparse puberuli, hornotini luteo-virides, fuscescentes, vetustiores obscure fusci; gemmae perulis ovatis acuminatis glabris minute ciliolatis. Folia decidua (nondum plane evoluta), elliptico-ovata v. oblongo-elliptica, acuminata, basi late cuneata, margine scariosa initio minute ciliolata, supra initio ad costam sparse puberula, ceterum glabra. Flores subpraecoces, axillares, solitarii, obscure purpurei, penduli; pedicelli $1.2-1.5 \mathrm{~cm}$. longi, puberuli; sepala minuta, vix $1 \mathrm{~mm}$. longa, semiorbicularia, glabra; petala erecta, caduca, obovata, apice rotundata, circiter $7 \mathrm{~mm}$. longa; stamina petalis paullo breviora filamentis complanatis glabris, antheris ovoideis introrsis; discus annularis, glaber; pistillum petala aequans, glabrum, stigmate simplice.

Western Hupeh: Hsing-shan Hsien, mountain-sides and grassclad places, alt. 1000-1200 m., May 1907 (No. 2533).

This new species is closely related to $S$. leptandra Hookerf. \& Thomson which has purplish green flowers with exserted stamens and beautifully reticulated leaves. It must also be closely related to $S$. Cavaleriei Léveillé, which we have not seen but which is described with oblong leaves, tomentulose peduncles and yellow petals.

Henry's No. 6780 from Hupeh probably belongs here. The specimen is in ripe fruit and has sub-coriaceous, elliptic to elliptic-oblong, abruptly acuminate leaves broadly cuneate at the base, glabrous and dark green above, pale below, 5-8 $\mathrm{cm}$. long and $2.3-4 \mathrm{~cm}$. broad, the primary and secondary veins and the veinlets prominent on the under surface.

Sabia Ritchieae is named for the wife of Mr. W. W. Ritchie, Postal commissioner at Chengtu in 1910, in appreciation of kindly services to me during the autumn of that year.

E. H. W.

Sabia latifolia Rehder \& Wilson, n. sp.

Frutex scandens, 2-3-metralis; ramuli hornotini sparse villosi, annotini glabri, luteo-virides, rarius purpurascentes, vetustiores lenti- 
cellati, fusci v. grisei; gemmae parvae, acutae, perulis late triangularibus acutis extus puberulis ciliolatis, persistentibus. Folia membranacea, elliptico-oblonga v. elliptica, rarius elliptico-obovata, breviter acuminata, basi cuneata, rarius rotundata, margine leviter scariosa et interdum minute undulato-erosa, $5-14 \mathrm{~cm}$. longa et 2-7 cm. lata, supra obscure luteo-viridia, glabra, subtus pallide v. cinereo-viridia, reticulata, ad venas sparse pilosa, nervis utrinsecus $5-6$, sub angulo acuto divergentibus; petioli sparse villosi, 6-15 $\mathrm{mm}$. longi. Flores fusco-virides, in cymis axillaribus plerumque 3-floris, rarius 4-5floris; pedunculi $1.5-2 \mathrm{~cm}$. longi, sparsissime villosuli; pedicelli 4-8 $\mathrm{mm}$. longi, apicem versus incrassati, sparse villosuli; bracteae minutae, caducae; sepala semiorbicularia, rarius late ovata et acutiuscula, margine scariosa; petala suberecta, anguste ovalia v. obovata, apice rotundata, rarissime acutiuscula, plerumque minute ciliolata, circiter $6 \mathrm{~mm}$. longa; stamina petalis paullo breviora, filamentis basi dilatatis, antheris ovalibus introrsis; discus leviter tumidus, glaber; pistillum staminibus paullo longius, sparse villosulum, stigmate minuto simplice. Mericarpia coerulea, compressa, subreniformia, reticulatorugosa, $6-8 \mathrm{~mm}$. longa et lata.

Western Szech'uan: Wa-shan, thickets, alt. 1600-2000 m., June and August 1908 (No. 8I8, type); same locality, alt, 1300 m., June 1908 (No. 2530); southeast of Tachien-lu, thickets, alt. 2500 m., June 1908 (No. 253I).

A very distinct plant not closely related to any described species and readily distinguished by the spreading villose hairs on the veins of the under surface of the comparatively broad leaves, on the shoots, peduncles and pedicels, and by its few-flowered cymes on peduncles much shorter than the leaves. It is perhaps nearest to S. purpurea Hooker f. \& Thomson which has glabrous, oblong-lanceolate, acuminate leaves, the shoots glabrous except when very young, glabrous peduncles, and ovate-lanceolate 5-veined petals.

Sabia emarginata Lecomte in Bull. Soc. Bot. France, LIV. 673 (1907).

Western Hupeh: without locality, A. Henry (No. 5314). Kiangsi: Kuling, thickets, alt. 1300 m., common, July 30, 1907 (No. I728; climber 2 m., fruit blue).

The Kuling specimen is in fruit and is somewhat doubtfully referred to this species of which we have only seen material with very young and partly grown leaves.

Sabia Schumanniana Diels in Bot. Jahrb. XXIX. 451 (1900).

Western Szech'uan: Wa-shan, thickets, alt. 1300-2000 m., July 
and September 1908 (No. 86o; climber 2 m., flowers greenish, fruit blue).

Our specimens agree with Diel's description except that the sepals are oval or ovate and obtuse instead of triangular and the leaves are slightly broader. The flowers which were not described by Diels are borne in from 3-6-flowered corymbs, the petals are oval and obtuse, greenish and about $5 \mathrm{~mm}$. long; the stamens about as long as the petals.

Sabia Schumanniana, var. pluriflora Rehder \& Wilson, n. var.

A typo recedit praecipue cymis 6-20-floris. Sepala triangulariovata, acuta; petala interdum acutiuscula; stamina plerumque petalis paullo longiora.

Western Hupeh: Hsing-shan Hsien, thickets, alt. 600-1300 m., May 6 and July 1907 (No. 2534, type; scandent bush, 1-2 m., flowers brownish-chocolate); without locality, A. Henry (Nos. 5421, 6114). Eastern Szech'uan: without locality, A. Henry (No. 5421 b).

This variety resembles in its many-flowered cymes $S$. parviflora Wallich and S. lanceolata Colebrooke, but is easily distinguished from these species by the larger flowers with oval, obtuse or obtusish petals and by the veins of the leaves diverging at acute angles.

Sabia Schumanniana, var. longipes Rehder \& Wilson, n. var.

A typo recedit foliis majoribus ad $14 \mathrm{~cm}$. longis oblongo-lanceolatis basi cuneatis, inflorescentia cum pedunculo 6-9 $\mathrm{cm}$. longo 9-18 $\mathrm{cm}$. longa, floribus purpurascentibus.

Western Szech'uan: Chin-ting-shan, thickets, alt. $1300 \mathrm{~m}$., May 22, 1908 (No. 2529; climber, 3 m., flowers greenish-purple).

This variety differs from the type chiefly in its larger leaves and much elongated peduncles.

\section{Sabia puberula Rehder \& Wilson, n. sp.}

Frutex scandens, 0.5-2 m. altus; ramuli hornotini glabri, annotini pallide olivacei; gemmae ovoideae, acutae, perulis acuminatis ciliolatis. Folia decidua, oblongo-lanceolata v. ovato-oblonga v. ellipticooblonga, acuminata, basi late cuneata v. rotundata, margine scariosa, minute eroso-undulata, 6-9 $\mathrm{cm}$. longa et 2-4 $\mathrm{cm}$. lata, utrinque glabra, supra obscure viridia, subtus pallidiora, reticulata, nervis utrinsecus 5-6 sub angulo acuto divergentibus; petioli initio plerumque puberuli, demum glabri, supra canaliculati, $0.6-1 \mathrm{~cm}$. longi. Flores fusci, in cymis axillaribus 3-8-floris, simul cum foliis bene evolutis; pedunculi graciles, sparse villosuli, $1-2.5 \mathrm{~cm}$. longi; pedicelli $5-8 \mathrm{~mm}$. longi, puberuli; bracteae minutae, caducae; sepala semi-orbicularia, 
rarius late triangularia et acutiuscula, interdum minute ciliolata, circiter $1 \mathrm{~mm}$. longa; petala ovali-elliptica, concava, obtusa, 3-4 mm. longa; stamina petalis paullo longiora, glabra, filamentis basi dilatatis, antheris ovalibus $0.5 \mathrm{~mm}$. longis; discus glaber, tumidus; pistillum stamina aequans minute pubescens. Mericarpia orbiculari-obovoidea, compressa, reticulata, rugosa, $7-8 \mathrm{~mm}$. longa.

Western Hupeh: Hsing-shan Hsien, thickets, alt. 600-1300 m., May and September 1907 (No. 2534a , type); Fang Hsien, thickets, alt. 1100 m., August 1907 (No. 2534 b) ; Patung Hsien, A. Henry (No. 4045); without locality, A. Henry (No.6022). Eastern Szech'uan: without locality, A. Henry (No. 7240).

This new species is distinguished by its small flowers with obtuse petals and exserted stamens and by its pubescent peduncles, pedicels and pistils. It is most closely related to S. Schumanniana Diels which is perfectly glabrous and has longei peduncles.

Sabia gracilis Hemsley in Hooker's Icon. XXIX, t. 2831 (1907). Fedde, Rep. Sp. Nov. V. 339 (1908).

Western Szech'uan: west of Kuan Hsien, roadside thickets, alt. $1000 \mathrm{~m}$., rare, June 17, 1908 (No. 2532; bush $0.6 \mathrm{~m}$. tall, flowers yellow); Mt. Omei, June 1904 (Veitch Exped. No. 4806, type). Dunn.

Here may be added the description of a new Chinese species collected by $\mathrm{Mr}$.

Sabia coriacea Rehder \& Wilson, n. sp.

Frutex ramulis teretibus glahris. Folia coriacea persistentia, oblonga v. oblongo-lanceolata, acuta v. brevissime acuminata, basi late cuneata v. fere rotundata, margine leviter revoluta, $3.5-6.5 \mathrm{~cm}$. longa et 1-2.5 $\mathrm{cm}$. lata, glabra, supra obscure viridia, subtus pallidiora, nervis utrinsecus 5-7 subtus leviter elevatis, venulis obsoletis; petioli glabri, circiter $1 \mathrm{~cm}$. longi. Flores parvi, in cymis axillaribus in parte inferiore ramulorum 6-10-floris glabris; pedunculi $1-1.5 \mathrm{~cm}$. longi; pedicelli $3-4 \mathrm{~mm}$. longi; sepala late ovata, $1 \mathrm{~mm}$. longa, obtusa, sparse ciliolata, persistentia, petala erecto-patentia, oblonga v. ovato-lanceolata, obtusa, recurva, apice inflexa, 5-nervia, $3.5 \mathrm{~mm}$. longa; stamina inaequalia, petalis dimidio breviora, filamentis carnosis complanatis, antheris introrsis apice truncatis et emarginatis; discus annularis, leviter tumidus; pistillum staminibus brevius, glabrum, stigmate simplice. Fructus desideratur.

Fokien: Dunn's Exped., April to June 1905 (Herb. Bot. Gard. Hongkong, No. 2534, type).

A well marked species related to $S$. parvifolia Wallich, which has much thinner leaves with prominent venation and smaller flowers with ovate, acute sepals, acuminate petals strongly inflexed at the apex, a disk with 5 acuminate teeth, smaller anthers and a rather differently shaped pistil. 


\section{MELIOSMA BI.}

\section{Sect. 1. SIMPLICES Warb.}

Meliosma cuneifolia Franchet in Nouv. Arch. Mus. Paris, sér. 2, VIII. 211 ( $P l$. David. II. 29) (1886). - Pampanini in Nuov. Giorn. Bot. Ital. n. ser. XVIII. 127 (1911). - Hutchinson in Bot. Mag. CXXXVII. t. 8357 (1911). - Schneider, Ill. Handb. Laubholzk. II. 1029, fig. 608 (1912).

Meliosma myrianthum Diels in Bot. Jahrb. XXIX. 451 (non Siebold \& Zuccarini) (1900).

Western Hupeh: Hsing-shan Hsien, thickets, alt. $1100 \mathrm{~m}$., September 1907 (No. 326; bush $3 \mathrm{~m}$. tall, fruit black); north and south of Ichang, thickets and margins of woods, alt. 1000-1500 m., common, July 1907 (No. 3034, in part; bush $3 \mathrm{~m}$. tall, flowers white, fragrant); Hsing-shan Hsien, woodlands, alt. $1300 \mathrm{~m}$., July 1907 (No. 3034, in part; bush 2-3 m. tall, flowers white, fragrant); Patung Hsien, thickets, alt. 1000-1300 m., July 1907 (No. 3035, in part; bush or small tree 3-6 m. tall, flowers white, fragrant); Hsing-shan Hsien, thickets, alt. 1000-1300 m., July 1907 (No. 3035, in part; bush or small tree, 3-6 m. tall, flowers white, fragrant); Fang Hsien, woodlands, alt. 1300 m., July 1907 (No. 3035, in part); Changyang Hsien, woodlands, July 1900 (Veitch Exped. No. 1458); without locality, June and July 1900 (Veitch Exped. Nos. 959, 1458 ${ }^{\mathrm{a}}, 1458^{\mathrm{b}}$ ); without locality, A. Henry (Nos. 5849, 5849 a). Western Szech'uan: near Wa-shan, thickets, alt. 600-1300 m., July 1908 (No. 3032 ; thin tree $6 \mathrm{~m}$. tall, flowers white); south-east of Tachien-lu, thickets, alt. 1300-1600 m., June 1908 (No. 3033, in part; bush 2.5$5 \mathrm{~m}$. tall, flowers white); same locality, June 1908 (No. 3033, in part; thin tree $6 \mathrm{~m}$. tall, flowers white, fragrant); Mt. Omei, August 1904 (Veitch Exped. No. 4814; tree 6 m.); same locality, E. Faber. Hunan: without locality, A. Henry (No. 7550). Shensi: Hu-shien, Cho-toe-miao, Hugh Scallan.

This species both as a small tree or as a large shrub is exceedingly common through western Hupeh and Szech'uan, occuring in thickets and in the margins of woods between $1000-1500 \mathrm{~m}$. alt. The fruit is black, globose, and about the size of a small garden pea. The tufts of hairs in the axils of the primary and secondary veins on the underside of the leaf afford an easy means of distinguishing this species from the closely related $M$. myriantha Siebold \& Zuccarini. That species has red fruit and leaves which are usually large and much less narrowly cuneate at the base than those of $M$. cuneifolia Franchet. 


\section{Meliosma pendens Rehder \& Wilson, n. sp.}

Frutex 3-5-metralis, ramis gracilibus; ramuli hornotini initio laxe villosi, mox glabrescentes; annotini purpureo-fusci, lenticellis parvis sparsis notati, vetustiores griseo-brunnei; gemmae nudae, parvae, ferrugineo-strigoso-tomentosae. Folia membranacea, obovato-elliptica v. obovato-oblonga, subito acuminata, basi in petiolum gracilem attenuata, fere ad basin serrata dentibus plerumque ad mucronem erecto-patentem reductis, 6-12 $\mathrm{cm}$. longa et 3-5.5 $\mathrm{cm}$. lata, supra obscure viridia, sparse, ad costam mediam densius breviter strigosopilosa, subtus pallide viridia, ad costam venasque patenti-pilosa, rarius ad costam subaccumbenti-pilosa, saepius etiam ad venulas et in facie sparse pilosa, ebarbata, nervis utrinsecus $12-18$ rectis in dentes excurrentibus subtus elevatis, venulis vix elevatis; petioli $1-1.5 \mathrm{~cm}$. longi, graciles, breviter villosi v. glabrescentes. Panicula terminalis, elongato-pyramidalis, pendens, cum pedunculo $2-3 \mathrm{~cm}$. longo $12-$ $18 \mathrm{~cm}$. longa et $9-15 \mathrm{~cm}$. diam., ramulis patentibus et plus minusve refractis, breviter villosa, pedunculo plerumque glabrescente; bracteae minutae, caducae; pedicelli $1.5-3 \mathrm{~mm}$. longi, villosuli, interdum minute bracteolati; flores albi, 4-5 $\mathrm{mm}$. diam.; sepala 5 , inaequalia, rotundato-ovata, minute ciliolata; petala exteriora suborbicularia 2.5-3 mm. longa et paulo latiora, rarius angustiora quam longa, concava, interiora vix dimidium filamentum aequantia, biloba, lobis patentibus acutiusculis, ciliolata; filamenta sterilia irregulariter bicucullata, incurva, fertilia $2 \mathrm{~mm}$. longa, filamentis compressis apice cupularibus antheras subglobosas amplectentibus; discus membranaceus dimidium ovarium amplectens, breviter et irregulariter 5-dentatus; pistillum glabrum, petalis brevius, ovario subgloboso subito in stylum brevem vix $1 \mathrm{~mm}$. longum contracto. Fructus desideratur.

Western Hupeh: Changlo Hsien, woodlands, alt. 1000 m., July 1907 (No. 326a , in part, type); north and south of Ichang, woodlands, alt. 600-1300 m., July 1907 (No. 326a, in part); without locality, A. Henry (Nos. $5849^{\mathrm{d}}$, 6000). Kiangsi : Kuling, thickets, alt. 1300 m., July 29, 1907 (No. I647).

This species is rather common in western Hupeh and seems most closely related to $M$. cuneifolia Franchet, which is easily distinguished, however, by the loosely appressed pubescence which covers the lower surface of the leaves and by their conspicuous axillary tufts of hairs; the panicles are upright and broader with spreading or ascending, not reflexed branchlets. In its inflorescence it resembles M. flexuosa Pampanini, but that species has, according to the deseription, glabrous branchlets and glabrous leaves which are entire toward the base. 


\section{Meliosma subverticillaris Rehder \& Wilson, n. sp.}

Arbor 6-metralis, trunco tenui, ramis erecto-patentibus; ramuli hornotini dense tomento initio ferrugineo demum cinerascente et per secundum annum persistente vestiti; gemmae tomentosae. Folia persistentia, subcoriacea, 3 v. 4 subverticillata, rarius alterna, oblongooblanceolata $\mathrm{v}$. oblanceolata, subito longe acuminata, basi sensim attenuata, basi excepta remote et breviter spinuloso-serrata, 12-20 $\mathrm{cm}$. longa et 4-5 $\mathrm{cm}$. lata, supra initio dense sericeo-strigosa, demum glabra, levia, subtus tomento fulvo-cinereo dense obtecta et reticulata, nervis utrinsecus $15-20$ subtus elevatis curvatis infimis exceptis in dentes excurrentibus; petioli graciles, tomentosi, $1.5-2 \mathrm{~cm}$. longi. Paniculae (nondum florentes) terminales et axillares, pyramidales, 10-15 cm. longae, totae bracteis alabastrisque inclusis dense tomento brevi strigoso-villoso obtectae; florum alabastra subsessilia; sepala 5 , ovato-lanceolata, acutiuscula, pubescentia. Flores evoluti et fructus desiderantur.

Eastern Szech'uan: Taning Hsien, thickets, alt. 1000 m., June 29, 1910 (No. 4600).

The subverticillate leaves readily distinguish this species which is perhaps most closely related to $M$. rigida Siebold \& Zuccarini. That species has alternate, less coriaceous leaves which are glabrous above even when very young and much larger terminal panicles. $M$. pilosa Lecomte has leaves pilose on the under side as in our new species, but differs from it in the membranous, deciduous leaves, terminal panicles and pedicellate flowers, and is obviously more closely related to $M$. cuneifolia Franchet than to $M$. subverticillaris.

Meliosma parviflora Lecomte in Bull. Soc. Bot. France, LIV. 676 (1907).

Western Szech'uan: Kiating Fu, thickets, alt. 300-600 m., August 1908 (No. 3036; small tree, 5-8 m. tall, flowers white); same locality, July and Oetober 1903 (Veitch Exped. No. 3314, type; thin tree $8 \mathrm{~m}$., flowers white, fruit red).

This small tree is rather common in thickets and by the sides of streams in the neighborhood of Kiating Fu and throughout the Chengtu plain up to an altitude of $800 \mathrm{~m}$. The slender trunk is covered with smooth, firm, dark gray bark, which peels off in large roundish, rather thick flakes which leave brown scars on the trunk. The wood is very hard and heavy. The large lax panicles of small white flowers and the bright red fruits make this tree very conspicuous in late July and September.

Here may be added the description of four new Chinese species of the section Simplices, not collected during the Arnold Arboretum Expeditions.

Meliosma platypoda Rehder \& Wilson, n. sp.

Frutex v. arbor parva, 3-6-metralis; ramuli annotini initio strigoso-pilosi, 
demum glabrescentes, annotini griseo-brunnei, glabri, lenticellati; gemmae dense fulvo-pilosae, post anthesin subglobosae, basi petioli dilatati involutae, apice tantum exsertae. Folia decidua, chartacea, obovata, apice rotundata et breviter cuspidata, basi cuneata, ima basi excepta serrata dentibus praesertim apicem versus late triangularibus mucronatis, $10-18 \mathrm{~cm}$. longa et $5.5-9.5 \mathrm{~cm}$. lata, supra glabra et leviter rugulosa, obseure luteo-viridia, subtus pallide viridia, ad costam mediam et ad nervos laterales pilis longis fulvis laxe adpressis vestita, ceterum glabra, nervis utrinsecus $10-15$ rectis omnibus excurrentibus, supra ut costa media impressis, subtus elevatis et trabeculis leviter elevatis conjunctis; petioli $6-8 \mathrm{~mm}$. longi, pilosi, supra sulcati, basi dilatati et leviter auriculati, gemmam axillarem amplectentes. Panicula terminalis, late pyramidalis, 18 $-24 \mathrm{~cm}$. longa et 12-14 cm. diam., ramis erecto-patentibus, puberula; flores albi, pedicellati pedicellis $1.5-3 \mathrm{~mm}$. longis puberulis; sepala 4 , persistentia, ovata, coneava, $1.5-2 \mathrm{~mm}$. longa, obtusa v. obtusiuscula, sparse ciliolata; petala exteriora orbieulari-reniformia, concava, apice rotundata et leviter inflexa, $2.5-3 \mathrm{~mm}$. Ionga et 3-4 $\mathrm{mm}$. lata, duo interiora bifida dentibus acutis; stamina duo fertilia petalis exterioribus subaequilonga, petalis interioribus adnata, filamentis complanatis incurvis, connectivo peltato ciliolato, antheris ovoideis rimis parvis apicalibus dehiscentibus, stamina sterilia irregularia, incurva, petalis exterioribus adnata et earum trientem aequantia; discus cupularis, membranaceus, dimidium ovarium aequans, trilobatus lobis plerumque bifidis; ovarium subglobosum, glabrum; stylus filiformis, petalis exterioribus subaequilongus, stigmate simplice. Fructus desideratur.

Western Hupeh: Patung Hsien, thickets, alt. 1000 m., June 1900 (Veitch Exped. No. 1126).

A well-marked species distinguished at a glance by the petioles flattened at the base and enclosing the bud. It is most closely related to $M$. cuneifolia Franchet which differs in its membranous, gradually acuminate leaves with axillary tufts of hairs on the lower surface in the slender petioles which do not enclose the buds and in the shorter bifid style.

\section{Meliosma velutina Rehder \& Wilson, n. sp.}

Arbor 6-metralis; ramuli hornotini dense breviter strigoso-villosi, fulvi, annotini glabrescentes lenticellati, griseo-fusci. Folia membranacea, oblanceolata, acuta $v$. breviter acuminata, basi sensim attenuata, integra, 9-15 $\mathrm{cm}$. longa et $2.5-4 \mathrm{~cm}$. lata, supra obscure viridia, in sicco leviter reticulata, ad costam et venas densius in facie sparse breviter pubescentia, subtus pallidiora, velutino-pubescentia, reticulata, nervis utrinsecus $10-15$ ante marginem sursum curvatis supra leviter impressis subtus elevatis; petioli $1.5 \mathrm{~cm}$. longi dense villosi. Panicula terminalis ampla, basi foliosa, $20-25 \mathrm{~cm}$. longa et $15-20 \mathrm{~cm}$. diam., dense breviter fulvo-strigoso-villosa, ramulis gracilibus erecto-patentibus; bracteae subulatae, 2-3 mm. longae, pubescentes; flores albi, parvi, breviter pedicellati, in axibus secundi ad quarti ordinis racemose dispositi; sepala 5, ovata, acuta, circiter $1 \mathrm{~mm}$. longa, extus pubescentia, ciliolata; petala exteriora orbicularia, concava, $1.5-2 \mathrm{~mm}$. diam., interiora duo minuta, biloba, acuta; stamina fertilia filamentis brevissimis, connectivo cupulari, antheris globosis rima apicali dehiscentibus, sterilia valde inflexa petalis exterioribus adnata et eorum trientem aequantia; discus minutus, cupularis, acute dentatus; pistillum petalis exterioribus multo brevius, glabrum, ovario ovoideo compresso, stylo subulato, stigmate simplice. Fructus desideratur.

Yunnan: Szemao, mountains southwards, alt. $1500 \mathrm{~m}$., A. Henry (No. 12114).

A well marked species recognized by its pubescence, entire leaves, laxly branched panicles, and small pedicillate flowers. It is most closely related to $M$. simplicifolia Roxburgh which is easily distinguished by its nearly glabrous leaves and branchlets and by its sessile flowers. 
Meliosma Fischeriana Rehder \& Wilson, n. sp.

Arbor 10-metralis; ramuli annotini graciles, flavo-cinerei, glabrescentes, lenticellati; gemmae nudae, parvae, villosae. Folia coriacea, persistentia, oblongolanceolata $v$. lanceolata, acuminata, basi sensim attenuata, apicem versus utrinque dentibus 3-1 spinulosis parvis instructa v. integra, 7-12 cm. longa et 1.5-3.5 $\mathrm{cm}$. lata, maturitate utrinque glabra costa media supra villosula excepta, supra saturate viridia, nitentia, subtus pallide viridia, nervis utrinsecus 5-8 eurvatis, plurimis ante marginem anastomosantibus, paucis superioribus tantum in dentes excurrentibus; petioli 1-2 cm. longi, pubescentes, demum glabrescentes. Paniculae omnes axillares, basi aphyllae, cum pedunculo 1-3 $\mathrm{cm}$. longo $10-15 \mathrm{~cm}$. longae, laxe villosulae, basi $3-7 \mathrm{~cm}$. diam., ramulis sub angulo fere recto divergentibus; flores albi, subsessiles v. breviter pedicellati, in axibus secundi et tertii ordinis; pedicelli villosuli; bracteae ovato-oblongae, acutiusculae, extus pubescentes, 1.5$2 \mathrm{~mm}$. longae; sepala 4-5, imbricata, ovata, minute eiliolata, petalis dimidio breviora; petala exteriora orbicularia $\mathrm{v}$. orbiculari-ovata, concava, carnosa, apice incurva, 2-2.5 mm. longa, interiora duo minuta, profunde biloba, lobis acutis; stamina incurva, fertilia duo petalis interioribus adnata, filamentis minutis, connectivo peltato, antheris globosis rima apicali transversali dehiscentibus, sterilia petalis exterioribus adnata; discus brevis, membranaceus, cupuliformis, minute 5-dentatus; pistillum petalis paullo brevius, glabrum, ovario ovoideo, stylo subulato, stigmate simplice. Fructus desideratur.

Western Szech'uan: Mt. Omei, woodlands, alt. 1000-1300 m., September 1904 (Veitch Exped. No. 4817).

A rare tree most closely related to $M$. pungens Wallich which is distinguished by its pubescent branches, stouter petioles, terminal and axillary much larger panicles, more numerous flowers and membranous petals. It is less closely related to $M$. Henryi Diels, which is distinguished by its red-purple, prominently lenticellate branchlets, less coriaceous, more oblong, leaves and smaller flowers on much longer pedicels.

Meliosma Fischeriana is named for Herr Fischer, in 1910, German Acting Consul General in Chengtu, as a mark of appreciation of his kind services to me.

E. H. W.

Meliosma glomerulata Rehder \& Wilson, n. sp.

Arbor 8-metralis; ramuli dense tomento strigoso-villoso initio fulvo v. griseofulvo ad tertium annum persistente obtecti; gemmae nudae, dense fulvo-villosae. Folia decidua (v. chartacea et persistentia), oblongo-lanceolata, longe acuminata, basi sensim attenuata, basi excepta remote serrata dentibus parvis saepe fere ad mucronem reductis, $15-25 \mathrm{~cm}$. longa et circiter $4 \mathrm{~cm}$. lata, supra obscure viridia, glabra costa media villosula excepta, subtus densius ad venas, sparsius in facie laxe villosa et spatiose reticulata, nervis utrinsecus 10-12 sub angulo acuto divergentibus, mediis fere rectis et in dentes excurrentibus, infimis et summis anastomosantibus; petioli graciles, dense villosi, $2-4 \mathrm{~cm}$. longi. Panicula terminalis, late pyramidalis, ad $30 \mathrm{~cm}$. longa et ad $18 \mathrm{~cm}$. diam., dense fulvo-villosa; flores albi, subsessiles, in glomerulis parvis sessilibus in parte inferiore panicula et ramulorum secus axes tertii ordinis, in parte superiore secus axes secundi et primi ordinis dispositis aggregati; sepala 5 , inaequalia, ovata v. ovato-oblonga, acuta $v$. obtusa, concava, $1.5-2 \mathrm{~mm}$. longa, exteriora villosa, interiora glabra, ciliolata; petala exteriora carnosa, erecto-patentia, orbieularia, $2.5-3 \mathrm{~mm}$. diam., 3-5-nervia, interiora minuta, biloba, acuta; stamina fertilia duo, filamentis brevibus compressis incurvis, connectivo cupulari et peltato, antheris globosis rimis apicalibus minutis dehiscentibus; stamina sterilia petalis exterioribus adnata et earum trientem aequantia, inflexa; pistillum glabrum, petalis exterioribus 
brevius, ovario ovoideo compresso, stylo filiformi, stigmate simplice. Fructus desideratur.

Yunnan: Szemao, forests, alt. $1600 \mathrm{~m} .$, A. Henry (No. 11737, type); same locality, A. Henry (Nos. $\left.11737^{\mathrm{a}}, 11737^{\mathrm{b}}\right)$.

This species is apparently most closely related to $M$. lancifolia Hooker $\mathrm{f}$., which we have not seen, but according to the description that species differs in its larger, broader, entire leaves, longer, more dense pubescence and in its coriaceous inner sepals. This new species is also related to $M$. rigida Siebold \& Zuccarini, which has ehartaceous, oblanceolate to obovate-cuneate abruptly acuminate leaves, more ferruginous tomentum and thyrsoid panicles. Nos. $11737^{\mathrm{a}}, 11737^{\mathrm{b}}$, differ from the type in their smaller and more densely villose paricles with shorter lateral branches and in their chartaceous persistent leaves, while the type specimen has only young membranous leaves.

\section{Sect. 2. Pinnatae Warb.}

Meliosma Veitchiorum Hemsley in Kew Bull. Misc. Inform. XIX. 155 (1906). - Bean in Kew Bull. Misc. Inform. 1910, 173, t.

Meliosma longicalyx Lecomte in Bull. Soc. Bot. France, sér. 4, VII. 675 (1907).

Western Hupeh: Hsing-shan Hsien, woods, alt. 1300-2000 m., May 20, June 3 and September 1907 (No. 322, in part; tree 5-15 m. tall, $0.3-2 \mathrm{~m}$. girth, flowers yellow, fragrant, in large drooping panicles; fruit black); Fang Hsien, woodlands, alt. 1600-1800 m., not common, June and September 1907 (No. 322, in part; tree 5-16 m. tall, girth 0.3-2 m., flowers yellow, fragrant, fruit black); same locality, alt. 1600-2300 m., October 1910 (No. 4457; tree 10-16 m. tall, 1.5-2.5 m. girth, fruit black); Changyang Hsien, woods, alt. $1500 \mathrm{~m}$., very rare, June 1907 (No. 322, in part; tree 5-13 m. tall, flowers greenish yellow). Eastern Szech'uan: Wushan Hsien, woodlands, 15002000 m., June 1901 (Veitch Exped. No. 1046, type).

This remarkable tree is abundant in moist woods throughout Hsing-shan Hsien and Fang Hsien between 1300-2300 m. altitude, but is rare in other parts of Hupeh and is not recorded from western Szech'uan. It is a tree of medium height with a relatively thick trunk and ascending and very slightly spreading branches forming a loose pyramidal head. The bark is gray, slightly fissured and with age exfoliates in small irregularly-shaped flakes. The large leaves are deciduous, crowded together at the ends of the branches and in falling leave very prominent scars. The honey-scented flowers are greenish yellow, with incurved ferruginous stamens. The loose panicles, produced at the same time as the leaves, are pendulous, much branched, often $60 \mathrm{~cm}$. or more long and wide, with the basal lateral branches exceeding in length the main rhachis. The corky lenticels on the inflorescence are most conspicuous. The undescribed fruit is black, globose, and from 10 to $12 \mathrm{~mm}$.
long and wide.

Pietures of this tree will be found under Nos. 581 and 053 of the collection of Wilson's photographs and also in his Vegetation of Western China, No. 313. 


\section{Meliosma Beaniana Rehder \& Wilson, n. sp.}

Arbor 12-25-metralis, valde ramosa ramis crassis erecto-patentibus v. in arboribus vetustioribus patentibus; truncus $0.2-2 \mathrm{~m}$. circuitu, cortice cinereo, satis levi demum leviter rimoso, et in arboribus vetustioribus magis rimoso fuscescente; ramuli hornotini tenuiter ferrugineotomentosi, annotini glabri v. glabrescentes, lenticellati, cicatricibus foliorum ovalibus magnis instructi, flavido-cinerei; gemmae nudae, ferrugineo-tomentosae. Folia decidua, imparipinnata, 2-6-juga, cum petiolo 4-7 cm. longo 15-35 $\mathrm{cm}$. longa; foliola subopposita v. opposita, breviter petiolulata, ovata v. elliptico-lanceolata, acuminata, basi late cuneata, saepe obliqua, rarius rotundata, remote serrulata dentibus minutis appressis mucronulatis, rarius subintegra, apicem versus accrescentia, par infimum $3-6 \mathrm{~cm}$. longum et $1.5-3 \mathrm{~cm}$. latum, par summum $7.5-15 \mathrm{~cm}$. longum et $3-5 \mathrm{~cm}$. latum, foliolum terminale 10-15 $\mathrm{cm}$. longum, interdum obovatum v. obovato-oblongum, supra obscure viridia, initio pilis sparsis minutis subaccumbentibus conspersa praesertim ad venas, demum glabra v. fere glabra, subtus pallidiora, sparse pilis minutis subaccumbentibus conspersa, in axillis nervorum fulvo-barbata, nervis utrinsecus 8-10 sub angulo $35-40^{\circ}$ divergentibus curvatis anastomosantibus subtus elevatis, reticulo venularum leviter elevato; petioli glabrescentes, basi incrassati. Flores praecoces, albi, in paniculis axillaribus in apice ramorum et ramulorum lateralium brevium; paniculae patentes v. pendentes, dense ferrugineo-villosae, cum pedunculo basi nudo $2-5 \mathrm{~cm}$. longo 12-20 cm. longae et 6-12 cm. diam.; bracteae eaducae; flores in axibus secundi et tertii, interdum quarti ordinis racemosi, pedicellati pedicellis 2-4 $\mathrm{mm}$. longis laxe villosulis; sepala 4, erecto-patentia, ovata, acuta v. obtusa, $1.5-2 \mathrm{~mm}$. longa, saepe leviter irregulariter dentata, minute ciliolata; petala exteriora late reniformia, emarginata, concava, circiter $2 \mathrm{~mm}$. longa et ad $4 \mathrm{~mm}$. lata, interiora minuta, bifida lobis acutis ciliolatis; stamina sterilia irregulariter dentata, apice incurva, petalis exterioribus adnata, fertilia filamentis compressis $2 \mathrm{~mm}$. longis leviter incurvis, connectivo peltato, antheris ovoideis transverse dehiscentibus; discus cupularis, membranaceus, ovarium subaequans, 3-dentatus dentibus duobus bifidis; pistillum petala paullo superans, glabrum, ovario subgloboso, stylo subulato, stigmate simplice. Fructus globosus, niger, 6-7 mm. diam.; semen irregulariter depresso-subglobosum, imo latere leviter et obtuse costatum, basi applanatum, hilo fere triangulari albido notatum, griseobrunneum, leve. 
Western Hupeh: north and south of Ichang, open country, alt. 1000-1300 m., May and September 1907 (No. 258, in part, type); Hsing-shan Hsien, mountain-sides, alt. $1300 \mathrm{~m}$., rare, May 21 and September 1907 (No. 258, in part); Patung Hsien, woodlands, alt. 1300 m., June and September 1907 (No. 154); Hsing-shan Hsien, open country, June 15, 1910 (No. 258 $8^{\mathrm{a}}$. Eastern Szech'uan: Wushan, without locality, April 1901 (Veitch Exped. No. 627). Western Szech'uan: Shih-ch'uan Hsien, near Pien-kou, open country, August 14, 1910 (No. 46o6); village near Lungan Fu, in temple grounds, alt. 1400 m., August 19, 1910 (No. 4607).

A remarkable and well-marked species distinguishable at once from all other members of the genus by its precocious flowers borne in axillary panicles, while in all other pinnate-leaved species the inflorescence is terminal. This new species may be compared with $M$. Oldhamii Miquel which has a similar branching habit but which differs in its large, terminal, erect, much-branched panicles produced after the leaves are nearly fully grown. M. Beaniana is one of the handsomest and most striking of Chinese trees. It is nowhere common but occurs scattered throughout western Hupeh and Szech'uan at altitudes of between $1000 \mathrm{~m}$. and $1500 \mathrm{~m}$., and very commonly it is associated with temples and wayside shrines. The creamy white flowers are relatively large for the genus. The spreading and pendulous panicles are smaller than in other pinnate-leaved species, but they are so numerous and so elustered together that the tree in May, when it is covered with a mass of creamy-white flowers, is a strikingly conspicuous object in the landscape. In Hupeh this tree is colloquially known as the " Ku-ku-lan-shu." It is now in cultivation.

Pictures of this tree will be found under Nos. 079,0258 and 0268 of the collection of Wilson's photographs.

Meliosma Beaniana is named for my friend William J. Bean, Assistant-Curator of the Royal Gardens, Kew, in appreciation of the interest he has always taken in Chinese plants and of his untiring efforts to secure them for cultivation.

E. H. W.

Meliosma O1dhamii Miquel in Ann. Mus. Lugd.-Bat. III. 94 (1867); Prol. Fl. Jap. 258 (1867). - Maximowicz in Bull. Acad. Sci. St. Pétersbourg, sér. 3, XII. 63 (1868); in Mél. Biol. VI. 263 (1868).Hemsley in Jour. Linn. Soc. XXIII. 145 (1886). - Diels in Bot. Jahrb. XXIX. 452 (1900). - Pampanini in Nuov. Giorn. Bot. Ital. n. ser. XVIII. 173 (1911).

Meliosma Wallichii Hemsley in Jour. Linn. Soc. XXIII. 146 (non Planchon) (1886).

Kiangsi : Kuling, thickets, alt. 1300 m., common, July 30, 1907 (No. I650; small tree 2-3 m. tall). Western Hupeh: Patung Hsien, woods, alt. 1200 m., June 1907 (No. 3038, in part; tree 10-12 m. tall, 2 m. girth, flowers white); Changlo Hsien, woods, alt. 1000- 
$1500 \mathrm{~m}$., June 1907 (No. 3038, in part; tree 6-13 m. tall, 0.6-2 m. girth, flowers white); Changyang Hsien, woods, alt. 1000-1500 m., June 1907 (No. 3038 in part; tree 6-13 m. tall, flowers white); Fang Hsien, open country, alt. 1300 m., June 21, 1910 (No. 46o2; tree 20 m. tall, $2.5 \mathrm{~m}$. girth, flowers white); without locality, May and September 1900 (Veitch Exped. No. 463); without locality, A. Henry (No. 5863); "Ma pan-scian," alt. 1000 m., May 1907, C. Silvestri (No. 3355). Korea: Quelpaert, June 1910, Taquet (Nos. 4344, 4345); same locality, August 1907, U. Faurie (No. 1867); Port Chusan, 1859, C. Wilford; Korean Archipelago, 1863, R. Oldham (No. 183).

This fine tree occurs in moist woods and thickets in western Hupeh between altitudes of 1000 and 1500 metres, but is not really common. On young trees the branches are erect and spreading but in old specimens the branches are widespreading and form a symmetrical head. The pure white flowers are borne in terminal, erect, much-branched pyramidal panicles from 15 to $30 \mathrm{~cm}$. long and broad, and are produced after the leaves are nearly full grown. Hooker f. (Fl. Brit. Ind. II. 6 [1876]) states that Wilford's specimen from Korea seems identical with $M$. Wallichii Planchon, and Hemsley has referred the specimen to this species. With both Indian and Korean material before us the species appear obviously distinct. In $M$. Oldhamii Miquel the leaves are nearly glabrous below, and the primary and lateral branches of the panicle are quite glabrous; the flowers are relatively large and the pedicels relatively long. In $M$. Wallichii Planchon the under surface of the leaves and the branches of the panicles are densely clothed with a short, ferruginous pubescence; the small flowers are shortly pedicellate. There are other important differences but these amply distinguish the two species.

Pietures of this tree will be found under Nos. 508 and 0115 of the eollection of Wilson's photographs and also in his Vegetation of Western China, No. 311.

\section{Meliosma Kirkii Hemsley \& Wilson in Kew Bull. Misc. Inform. XIX. 154 (1906).}

Western Szech'uan: Omei Hsien, woodlands, alt. 600-1200 m., July 1908 (No. 3037; tree $10 \mathrm{~m}$. tall, $1 \mathrm{~m}$. girth, flowers white); same locality, alt. 900 m., June 1903 (Veitch Exped. No. 2371, type); Hung-ya Hsien, open country, base of Wa-wu-shan, alt. $1200 \mathrm{~m}$., September 12, 1908 (No. 3037 ${ }^{\mathrm{a}}$, tree $20 \mathrm{~m}$. tall; $2.5 \mathrm{~m}$. girth).

The under surface of the leaves in this species is often quite glaucous; the bark on old trees is gray, fairly smooth and persistent; the branches are ascending and spreading and form a narrow head.

A picture of this tree will be found under No. 339 of the collection of Wilson's photographs and also in his Vegetation of Western China, No. 312.

Here may be added a note on a species from Yunnan collected by A. Henry and remarks on $M$. rhoifolia and $M$. pinnata.

Meliosma Wallichii Planchon in Hooker f., Fl. Brit. Ind. II. 6 (1876).

Yunnan: Mengtze, woods, alt. 1800 m., A. Henry (Nos. 10835, 13692); Szemao mountains, eastern forests, A. Henry (Nos. 12016, 12016 $12016^{\mathrm{b}}$ ). 
In working up our material of Meliosma we have had an opportunity of examining in the Gray Herbarium Oldham's Nos. 85, 86, on which Maximowicz founded his $M$. rhoifolia and which Hooker f., in Fl. Brit. Ind. II. 6 (1876) suggests is the same as $M$. pinnata Maximowicz (Millingtonia pinnata Roxburgh). This examination has satisfied us that these species are without doubt quite distinet. In M. rhoifolia Maximowicz the leaflets are shining green above, the medium sized panicles are nearly as broad as long $(25 \mathrm{~cm}$. long, $20 \mathrm{~cm}$. broad) with dark colored compressed, somewhat angular, glabrous primary branches; the ovary is villose. In $M$. pinnata Maximowicz the leaves are dull green above; the panicles are very large, much longer than broad (from 35 to $45 \mathrm{~cm}$. long and from 25 to $30 \mathrm{~cm}$. broad), the primary branches of the panicle are nearly round, gray, woody and sparsely pubescent; the ovary is glabrous.

The specimens look very different and we consider $M$. rhoifolia Maximowicz to be much more closely related to $M$. Oldhamii Miquel than it is to $M$. pinnata Maximowicz. 


\title{
RHAMNACEAE.
}

\author{
Determined by Camilo Schnemer. ${ }^{1}$
}

\section{PALIURUS Mill.}

Paliurus orientalis Hemsley in Kew Bull. Misc. Inform. 1894, 387 (pro parte maxima). - Pritzel in Bot. Jahrb. XXIX. 457 (1900). Schneider, Ill. Handb. Laubholzk. II. 260, fig. 182 c (1909). - Pampanini in Nuov. Giorn. Bot. Ital. n. ser. XVII. 425 (1910).

? Paliurus lucidus Carrière in Rev. Hort. 1866, 380 (nomen nudum).

? Paliurus australis, var. orientalis Franchet, Pl. Delavay. 132 (1889).

Western Hupeh: north and south of Ichang, open country, alt. 600-1100 m., common, June and September 1907 (No. I05; slender tree 3-6 m. tall); Fang Hsien, June 1901 (Veitch Exped. without number, in Herb. Hofmuseum, Vienna); without locality, May 1901 (Veitch Exped. No. 2103); without locality, A. Henry (No. 6379). Eastern Szech'uan: Taning Hsien, roadsides, alt. 160-600 m., common June 1910 (No. 4630; slender tree 6-12 m. tall, girth 0.30.6 m., immature fruit white); Wushan Hsien, mountains, June 1900 (Veitch Exped. No. 634); same locality, A. Henry (No. 7205); Chengkou Ting, P. Farges. Shensi: "Tciuz Sien," 1893, G. Giraldi.

The type of Franchet's var. orientalis is Delavay's No. 239 from Yunnan in woods near Tali, which I have not yet seen. Hemsley says: Folia cum petiolo usque ad 5 poll. longa et 3 poll. lata, sed in speciminibus Delavayanis minora. He eites Henry's No. 7205 from Szech'uan, Wushan Hsien, and Ford's No. 325 from Kwangtung. Unfortunately I could not compare Wilson's specimens with Franchet's type, but they agree exactly with Hemsley's description. I think, therefore, that Franchet's var. orientalis may belong to $P$. sinicus Schneider, as all the specimens I have seen from Yunnan have short petioles.

Wilson's No. 634 is a poor specimen with very young leaves, which like the

1 Owing to Mr. Schneider's departure for south-western China he has been unable to settle some questions in regard to a few doubtful specimens, and has left their determination to us. We have added a few notes to his manuscript.

2 The specimen collected in southern Shensi by David, and by Franchet referred (Nouv. Arch. Mus. Paris, sér. 2, V. 223 (Pl. David. I. 71) [1883]) to P. australis doubtless belongs here. 
young branchlets are somewhat pubescent and resemble those of $P$. sinicus, but this specimen bears some old fruits, which in no way differ from those of $P$. orientalis, as represented by No. 2103, and as, moreover, the petioles are from 5 to 6 $\mathrm{mm}$. long, I think No. 634 certainly belongs to this species.

This species is fairly common in open country up to $1000 \mathrm{~m}$. altitude through western Hupeh and eastern Szech'uan. It is a tree from 10 to $15 \mathrm{~m}$. tall, with a slender trunk covered with smooth gray bark and usually armed with numerous stout spines; the branches are spiny, short, slender and spreading. The fruit is pure white, changing to brown at maturity, and the trees when laden with immature fruit are very conspicuous from a distance. The wood is hard and tough. A picture of this tree will be found under No. 0160 of the collection of my photographs.

E. H. W.

Paliurus ramosissimus Poiret in Lamarck, Encycl. Méth. Suppl. IV. 262 (1816).- Hemsley in Jour. Linn. Soc. XXIII. 126 (1886). Pritzel in Bot. Jahrb. XXIX. 457 (1900). - Matsumura \& Hayata in Jour. Coll. Sci. Tokyo, xxii. 86 (Enum. Pl. Formos.). - Pitard in Lecomte, Fl. Gén. Indo-Chine, I. 915 (1912). — Schneider, Ill. Handb. Laubholzk. II. 1030 (1912).

Aubletia ramosissima Loureiro, $F l$. Cochin. 283 (1790).

Paliurus Aubletia Schultes in Roemer and Schultes, Syst. Veg. V. 343 (1819).

Paliurus Aubletii Bentham, Fl. Hongk. 66 (1861).

Western Szech'uan: Kiating Fu, roadsides, alt. 300-1000 m., July 1908 (No. 3224; thorny shrub 3-5 m. tall, used as a hedge plant); banks of Yangtsze River, common, June 1903 (Veitch Exped. No. 3340); Mt. Omei, June 1904 (Veitch Exped. No. 4778). Formosa: Tamsui, A. Henry (No. 1382). Korea: Quelpaert, rare, July 1909, Taquet (No. 3116).

This thorny shrub is abundant at low levels through Szech'uan, but it is less common in Hupeh. It is commonly used as a hedge-plant near Kiating Fu and elsewhere and is colloquially known as the "Teh-li-pê Kuotzu." E. H. W.

\section{CLAVIS SPECIERUM.}

Folia apice distincte breviter acuminata, acumine producto foliorum bene evolutorum plus quam $6 \mathrm{~mm}$. longo.

Folia permagna, mediocra 6-12 $\mathrm{cm}$. longa; petioli 8-15 mm. longi.

Planta glabra v. subglabra .

1. P. orientalis.

Planta ramulis, foliis inflorescentiisque pubescentibus (confer etiam No. 5).

Folia minora v. petioli tantum $5 \mathrm{~mm}$. longi

2. P. hirsutus.

Folia apice obtusa v. fere rotundata v. tantum breviter acuta.

Fruetus ala distincta circulari cinctus, glaber.

Folia plerumque haud plus quam $5 \mathrm{~cm}$. longa, apice saepissime obtusa; alae fructuum satis tenues, $6-10 \mathrm{~mm}$, latae 4. P. Spina-Christi. 
Folia plerumque $5-10 \mathrm{~cm}$. longa, apice subito in acumen $3-5 \mathrm{~mm}$. longum producta; alae fructuum ut videtur satis crassae, vix $5 \mathrm{~mm}$. latae.

5. P. tonkinensis.

Fructus ala angusta plerumque trilobata cinctus, tomentosus.

6. P. ramosissimus.

\section{ENUMERATIO SPECIERUM.}

1. Paliurus orientalis Hemsley. See p. 209.

2. Paliurus hirsutus Hemsley in Kew Bull. Misc. Inform. 1894, 388.

Kwangtung: C. Ford (No. 280, type).

According to the descriptions of Hemsley and Pitard this species may be closely related to $P$. tonkinensis, but without having seen ripe fruits of $P$. hirsutus I cannot decide if the two species are the same.

3. Paliurus sinicus Schneider, n. sp.

Arbor spinosa, ad 5-metralis; ramuli hornotini pubescentes, deinde nigricantes, glabri v. tantum supra gemmas puberuli; spinae in speciminibus visis rarae, parvae, vix $5 \mathrm{~mm}$. longae. Folia membranacea, ovata, interdum ovato-oblonga, basi obtusa v. rotunda, sed semper subito brevissime in petiolum producta, obliqua, apice in acumen 5-12 mm. longum attenuata, margine crenato-dentata, supra viridia, glabra v. tantum initio ad nervos primarios tres parce pilosa, subtus paullo pallidiora, tota facie puberula v. fere glabra, nervis primariis et secundariis satis prominentibus, $2.5-7 \mathrm{~cm}$. longa, $1.5-4 \mathrm{~cm}$. lata; petioli breves, tantum 2-4 $\mathrm{mm}$. longi, pubescentes. Inflorescentia axillaris, cymoso-paniculata, vix ad $1 \mathrm{~cm}$. longa, pilosa; flores flavescentes, eirciter $5 \mathrm{~mm}$. diam.; pedicelli fructiferi 10-12 mm. longi; sepala triangularia, acuta, petalis pro genere normalibus subaequilonga. Fructus maturus rubro-brunneus, glaber, supra planus, ala $6-8 \mathrm{~mm}$. lata inclusa $1.5-2.3 \mathrm{~cm}$. latus, sine ala ad $5 \mathrm{~mm}$. altus et $9 \mathrm{~mm}$. latus; semina levia, olivaceo-brunnea, fere orbicularia, $2-2.5 \mathrm{~mm}$. lata, ventre applanata, dorso leviter convexa.

Yunnan: Mengtze, alt. 1800 m., woods, A. Henry (No. 9427, type; shrub 1.25 or tree $4.75 \mathrm{~m}$. tall, yellow flowers; No. $9427^{\mathrm{b}}$; trees $2.5-5 \mathrm{~m}$. tall, greenish-yellow flowers).

Possibly this species is the true $P$. australis, var. orientalis Franchet (see $P$. orientalis). It is well distinguished from the allied species by its very short petioles. The fruits are smaller than those of $P$. orientalis Hemsley or of P.Spina-Christi Miller.

4. Paliurus Spina-Christi Miller, Gard. Dict. ed. 8 (1768).-Hemsley, Kero Bull. Misc. Inform. 1894, 388, in textu. - Schneider, Ill. Handb. Laubholzk. II. 260, fig. $181 \mathrm{a}-\mathrm{f}, 182 \mathrm{a}-\mathrm{b}(1909)$.

Rhamnus Paliurus Linnaeus, Spec. 194 (1753).

Paliurus australis Gaertner, Fruct. I. 203 (1788).

Paliurus aculeatus Lamarck, Encycl. Meth. IV. 697 (1796). - Brongniart in Ann. Sci. Nat. X. 354, t. 12, 1. (Mém. Fam. Rhamn.) (1826).

Paliurus virgatus D. Don in Bot.Mag.LII. t. 2535 (1825); Prodr. Fl. Nep. 189 (1825).

Western Asia, southern Europe.

Franchet, Pl. David. 71 (1884), cites a specimen collected by David in southern Schensi under this name. I have not yet seen it, but I do not believe that the true $P$. Spina-Christi occurs in China.

5. Paliurus tonkinensis Pitard in Lecomte, Fl. Gén. Indo-Chine, I. 916, fig. 115 (5-9) (1912). 
As already indicated this species may be closely related to $P$. hirsutus Hemsley. The figure given by the author shows a fruit which is only $14 \mathrm{~mm}$. broad, but according to the description the fruit with the wing is $25 \mathrm{~mm}$. broad. The fruit is described as black and the leaves as: "attenuées au sommet en une pointe mousse et longue de 3-5 mm."

6. Paliurus ramosissimus Poiret. See p. 210.

ZIZYPHUS Jussieu.

Zizyphus sativa Gaertner, Fruct. I. 202 (1788). - Schneider, Ill. Handb. Laubholzk. II. 261, fig. $181 \mathrm{~g}-\mathrm{k}, 182 \mathrm{~d}-\mathrm{f}$ (1909).

Rhamnus Zizyphus Linnaeus, Spec. 94 (1753).

Zizyphus vulgaris Lamarek, Encycl. Méth. III. 316 (1789). - Brongniart in Ann. Sci. Nat. X. t. 12, II. (Mém. Fam. Rhamn.) (1826). - Maximowicz in Mém. Acad. Sci. St. Pétersbourg, sér. 7, IV. No. XI. 3 (Rhamn. Or.-As.) (1866). - Hemsley in Jour. Linn. Soc. XXIII. 126 (1886).

Zizyphus sinensis Lamarck, Encycl. Méth. III. 316 (1789).

Zizyphus sativa, var. inermis Schneider, Ill. Handb. Laubholzk. II. 261 (1909).

Zizyphus vulgaris, var. inermis Bunge in Mém. Sav. Êtr. Acad. Sci. St. Pétersbourg, II. 88 (Enum. Pl. Chin. Bor. 14) (1833).

Western Hupeh: north and south of Ichang, wild and sparingly cultivated, alt. 30-1000 m., May and September 1907 (No. 2700; tree 3-8 m. tall); same locality, May 1900 (Veitch Exped. No. 848); same locality, A. Henry (No. 2021). Korea : Ping-yang, in thickets, July 1906, U. Faurie (No. 508); "Ouen-san," cultivated, July 1906, U. Faurie (No. 509).

This is a very common bush or small tree especially in the dry river-valleys of western Szech'uan. It is not much cultivated and the oval fruit is relatively small and of poor quality. As elsewhere in China it is known in the western part of the country as the "Tsao-tzu shu."

E. H. W.

Here may be added the description of a new species from Yunnan, collected by A. Henry.

Zizyphus yunnanensis Schneider, n. sp.

Arbor $3.75-5 \mathrm{~m}$. alta, spinosa; spinae visae breves, curvatae; ramuli initio breviter hirti, annotini glabrescentes, nigrescentes, lenticellis multis parvis oblongis albescentibus obtecti. Folia alterna, crasse membranacea, obliqua, ovata, basi rotunda sed in petiolum subito breviter producta, 3- v. fere 5-nervia, apice breviter acuminata, $5.5-10 \mathrm{~cm}$. longa, $3-4.8 \mathrm{~cm}$. lata, margine calloso-crenata, supra ad nervos vix impressos pilosa, intense viridia, satis obscura, subtus pallide viridia, ad nervos prominentes $\mathrm{v}$. initio etiam tota facie sparse pilosa; petioli 5$10 \mathrm{~cm}$. longi, breviter hirti. Inflorescentia cymosa, axillaris, ut rami hirta, pedunculo nudo $1-1.8 \mathrm{~cm}$. longo suffulta, eirciter 30 -flora; flores pro genere normales, flavo-virides(?), 4-5 mm. diam.; sepala deltoidea, acuta, extus hirta, petalis cucul- 
latis staminibusque subaequilonga; ovaria bilocularia, apice hirta, stylis 2 coronata. Fructus globoso-ellipticus, circiter $12 \mathrm{~mm}$. longus et $9 \mathrm{~mm}$. latus, glaber, rubrobrunneus(?); semina 2, nigro-olivacea, laevia, nitida; pedicelli fructiferi 5-9 $\mathrm{mm}$. longi.

Yunnan: Szemao, W. Mts., alt. 1800 m., A. Henry (No. $12086^{\mathrm{a}}$, type; thorny tree, $3.75 \mathrm{~m}$. tall), forests, alt. $1600 \mathrm{~m}$. (No. $12086^{\mathrm{b}}$; tree $5 \mathrm{~m}$. tall).

I cannot identify these specimens with any species hitherto described, but the Asiatic species of this genus need a thorough revision.

\section{Zizyphus spec.}

Yunnan: Szemao, alt. 1800 m., forest, A. Henry (No. 11726; large climbing shrub, white flowers).

Although rather resembling $Z$, yunnanensis this specimen may represent another new species, differing from the last in its thorny branchlets which bear a rather thick rufous pubescence as do the petioles and the inflorescence. In shape and pubescence the young and thin leaves hardly differ from those of $Z$. yunnanensis, but their margin is more serrulate. The inflorescence shows no marked difference, but I have not seen the petals.

\section{BERCHEMIA Neck.}

Berchemia floribunda Brongniart in Ann. Sci. Nat. X. 357, t. 13, I. (Mém. Fam. Rhamn. 50) (1826). - Lawson in Hooker f., Fl. Brit. Ind. I. 637 (1875).

Zizyphus floribunda Wallich in Roxburgh, Fl. Ind. II. 368 (1824).

\section{Nepal to Khasia.}

Berchemia floribunda, var. megalophylla, Schneider, n. var.

A typo praecipue differt foliis majoribus $8-13 \mathrm{~cm}$. longis $5-7.5 \mathrm{~cm}$. latis apice in acumen paullo brevius productis, pedicellis florum expansorum paullo brevioribus.

Kiangsi : near Kuling, alt. 1120 m., thickets, August 1909 (No. I514; semiscandent shrub, 1.5-5 m. tall, flowers white). Yunnan: Szemao, alt. 1800 m., A. Henry (No. $11747^{\circ}$; large climber on trees, flowers white).

At first sight the large leaves seem to distinguish the Chinese forms from those of the Himalaya and Khasia, but after having examined ample material of $B$. floribunda I cannot find other differences sufficient to make it possible to consider var. megalophylla a species.

Berchemia Giraldiana Schneider, Ill. Handb. Laubholzk. II. 263, fig. $182 \mathrm{~m}-\mathrm{n}, 183 \mathrm{k}$ (1909).

Western Hupeh : Hsing-shan Hsien, among rocks, alt. 300-1000 m., May 1907 (No. 3387; spreading shrub 1-3 m.); north and south of Ichang, thickets, alt. 600-1300 m., common, July and August 1907 
(No. 339o; in part; scandent shrub 2-6 m. tall, flowers white, fruit red and black); Changyang Hsien, alt. 600-1300 m., July 1907 (No. 339o, in part; scandent shrub $4 \mathrm{~m}$. tall, flowers white). Yunnan: Mengtze, in woods, alt. 2200 m., A. Henry, No. 10803). Shensi : G. Giraldi (No. 944-949, type, 1796, 4924-26, 4928).

This species which seems to be widely distributed may be at once distinguished by its papillose leaves and obtuse flower-buds. The cylindric obtuse fruits of Henry's 10803 are up to $11 \mathrm{~mm}$. long and about 4-5 mm. thick, while Wilson's numbers bear rather smaller fruits. It needs further observation to decide if these are two distinct but closely related species. Wilson's No. 2230, June 1901 (Veitch Exped.), a rather meagre flowering branch, agrees in the flowers with $B$. Giraldiana, but the rather large leaves $(10.5 \mathrm{~cm}$.) have only 8 pairs of nerves and no distinct papillae. In Henry's number some leaves are very broadly ovate and measure up to $8.6 \mathrm{~cm}$. and with its larger fruits it may possibly represent a distinct variety. The inflorescence of this species is not always quite glabrous.

\section{Berchemia hypochrysa Schneider, n. sp.}

Frutex scandens ad $7.5 \mathrm{~m}$. altus; ramuli glaberrimi, hornotini rotundi, flavescentes v. brunnescentes, interdum leviter pruinosi, annotini ut videtur fuscescentes; gemmae normales, 3-5 $\mathrm{mm}$. longae. Folia papyracea, ovata v. elliptica, basi rotunda v. subcordata, apice satis obtusa brevissime apiculata, supra viridia, glabra, subtus in sicco flava, nervis utrinque 12-14 distinctissimis, glabra, sub lente papillosa, 6-11 $\mathrm{cm}$. longa, $3.5-5.2 \mathrm{~cm}$. lata; petioli glabri, $1.3-2 \mathrm{~cm}$. longi. Inflorescentia in apice ramulorum lateralium 3-14 cm. longorum foliosorum anguste paniculata, $6-10 \mathrm{~cm}$. longa, glaberrima, axibus inferioribus vix ad $3 \mathrm{~cm}$. longis; flores viridi-flavescentes (sec. cl. Wilson), circiter $1.5 \mathrm{~mm}$. longi, pedicelli $1.5-2.5 \mathrm{~mm}$. longi; sepala obtusiuscula; petala sepalis paullo breviora, intensius colorata, late obovata, staminibus aequilonga; antherae albescentes; ovaria parva, stigmatibus fere sessilibus instructa, disco aequilongo circumcincta. Fructus ignotus.

Western Szech'uan: Mupin, thickets, alt. 1600-2000 m., June 1908 (No. 3383, type); near Tachien-lu, thickets, alt. 2000-2500 m., July 1908 (No. 3383 ); Mt. Omei, June 1904 (Veitch Exped. No. 4776); without precise locality, July 1904 (Veitch Exped. No. 3338). Western Hupeh: Hsing-shan Hsien, thickets, alt. 1000-1300 m., June 1907 (No. 3382); without locality, June 1901 (Veitch Exped. No. 2041).

The dried leaves of this species are golden on the under surface. It seems most nearly related to $B$. Giraldiana Schneider, but differs in its longer leaves and mueh smaller inflorescence. 


\section{Berchemia sinica Schneider, n. sp.}

Frutex scandens, 4-6-metralis; ramuli rotundi, glabri, flavescentes v. leviter brunnescentes; gemmae stipulaeque normales. Folia papyracea, ovata v. minora ovato-rotunda, basi rotundata v. subcordata, apice plerumque obtusa, interdum subrotunda, raro subacuta, nervisutrinque 8-10, supra viridia, an opaca?, subtus satis pallida, nervis in sicco flavescentibus, pruinosa v. indistincte papillosa, minora $1.6-2.5 \mathrm{~cm}$. longa et 1.3-2.2 cm. lata, majora $3-5 \mathrm{~cm}$. longa et 2-3 cm. lata; petioli 0.9$2 \mathrm{~cm}$. longi, glabri. Inflorescentia terminalis, anguste paniculata $\mathrm{v}$. racemoso-paniculata, glabra, 8-12 $\mathrm{cm}$. longa; flores ad 3-8 fasciculati, flavescentes, fragrantes, circiter $2-2.5 \mathrm{~cm}$. longi; alabastra globosa obtusa, pedicellis sublongiora; sepala oblongo-ovata, apice obtusa; petala sepalis breviora, obovata, basi breviter unguiculata, staminibus aequilonga; ovaria discum paullo superantia. Fructus cylindricus, niger, $5-6 \mathrm{~mm}$. longus, $2.5 \mathrm{~mm}$. crassus.

Western Hupeh: Hsing-shan Hsien, thickets, alt. 300-1200 m., June 1907 (No. 3386, type). Western Szech'uan: west and near Wên-ch'uan Hsien, woodlands, alt. 1600-2000 m., June and July 1908 (No. 3380); without locality, alt. 3150 m., June 1904 (Veitch Exped. No. 3337). Eastern Kansu: 1885, G. N. Potanin (a rather meagre fruiting specimen in Herb. Bot. Gard. St. Petersbourg, determined as $B$. lineata).

I am not quite convinced that Potanin's specimen really belongs to $B$. sinica. According to the shape of the non-papillose leaves, their long petioles and the rather obtuse flower-buds Wilson's No. $700^{1}$ from western Hupeh, July 1900 (specimen in Herb. Hofmuseum, Vienna) might be referred to this species, although the inflorescence much resembles that of B. yunnanensis Schneider.

\section{Berchemia pycnantha Schneider, n. sp.}

Frutex diffusus v. scandens $2.5-5 \mathrm{~m}$. altus; ramuli hornotini glabri, rotundi, viridi-olivacei, vetustiores flavido-brunnescentes; gemmae stipulaeque ut videtur normales. Folia papyracea, ovato-elliptica v. oblongo-elliptica v. ovata, basi obtusa v. rotunda, apice distincte acuta, mucronulata, supra obscure viridia, glabra, subtus pallide viridia v. pallida, satis distincte papillosa, nervis utrinsecus plerumque 10-13, minora circiter 3-4 $\mathrm{cm}$. longa et $1.6-2.5 \mathrm{~cm}$. lata, majora 3$6.5 \mathrm{~cm}$. longa et $1.5-2.7 \mathrm{~cm}$. lata; petioli 1-1.5 cm. longi, glabri. Inflorescentia racemoso-paniculata, densiflora, terminalis, in apice

1 The specimen of this number from Patung Hsien in the Herbarium of the Arnold Arboretum certainly belongs to $B$. sinica.

A. R. and E. H. W. 
ramorum lateralium brevium 1-5 $\mathrm{cm}$. longorum, glaberrima, an nutans?; flores flavescentes, $3-8$ conferti; alabastra apiculata; pedicelli floribus sublongiores; sepala patula, apice breviter acuminata, petalis obovalibus longiora; ovaria discum duplo superantia. Fructus cylindricus, 8-9 mm. longus, 4-4.5 $\mathrm{mm}$. crassus, basi disco $1 \mathrm{~mm}$. longo circumdatus, apice stylo $1 \mathrm{~mm}$. longo coronatus, pedicello 2$2.5 \mathrm{~mm}$. longo.

Western Szech'uan: west of Kuan Hsien, Nin-tou-shan, alt. 2300-2600 m., June 1908 (No. 338r, type); north of Tachien-lu, thickets, alt. 1300-2000 m., June 1908 (No. 3379).

The dense-flowered rather short inflorescence, terminating very short branchlets which commonly bear only 2 or 3 leaves, distinguish this species at once. It seems most nearly related to $B$. kulingensis Schneider, which differs in its searcely papillose leaves, its more acute flower-buds and in its minute ciliate sepals. A specimen collected by E. Maire, Yunnan, alt. $400 \mathrm{~m}$., June 1910, with rather young flowers of which the sepals are more obtuse, much resembles this number. The leaves, however, are more ovate, otherwise I can detect no difference.

\section{Berchemia kulingensis Sehneider, n. sp.}

Frutex scandens, ad $3 \mathrm{~m}$. altus; ramuli hornotini flavescentes, glabri, rotundi, deinde brunnescentes; gemmae stipulaeque normales. Folia papyracea, ovata v. ad basim inflorescentiae late lanceolata, apice acuta, mucronulata, basi rotunda v. subcordata, $2.5-5 \mathrm{~cm}$. longa, et $1.2-2.5 \mathrm{~cm}$. lata, supra viridia, glabra, subtus pallida, glabra, vix papillosa, nervis utrinque 8-9; petioli $0.6-0.9 \mathrm{~cm}$. longi, glabri. Inflorescentia satis anguste paniculata, in apice ramulorum lateralium 3-18 cm. longorum terminalis, infra foliata, glabra, 3 ad $8 \mathrm{~cm}$. longa; flores viridescentes, 2-3 conferti; alabastri globosi, sed distincte subito acuminati, petiolo floribus sub-breviore; sepala acuminata, minutissime ciliata, petalis obovalibus longiora; ovaria discum duplo superantia. Fructus ignotus.

Kiangsi : Kuling, thickets, alt. 1600 m., abundant, July 28, 1907 (No. I5I3).

Aecording to the leaves and flowers a specimen collected by C. Ford at Hongkong may belong to this species, but the inflorescence of the Hongkong plant looks rather different, terminating shorter branches or being sometimes quite axillary. The petioles measure up to $11 \mathrm{~mm}$.

Berchemia yunnanensis Franchet in Bull. Soc. Bot. France, sér. 2, VIII. (XXXIII.) 456 (1886).

Descriptio emendanda: Frutex scandens, $3-5 \mathrm{~m}$. altus; ramuli ab initio glabri, rotundi, olivacei v. fuscescentes; gemmae stipulaeque 
normales. Folia papyracea, plerumque elliptica v. ovata v. interdum ovato-rotunda, basi rotunda v. subcordata, apice plerumque obtusa v. rotunda, distincte mucronulata, supra viridia, glabra, subtus pallida, distincte papillosa, nervis utrinque (6-)8-10 instructa, minora et latiora $2-2.5 \mathrm{~cm}$. longa et $1.3-2 \mathrm{~cm}$. lata, cetera $2-4.5 \mathrm{~cm}$. longa et 1-2.7 $\mathrm{cm}$. lata; petioli 2-5 mm. longi, supra pilosi. Inflorescentia pseudo-racemosa, in apice ramulorum lateralium 1-18 $\mathrm{cm}$. longorum terminalis, glabra; flores $2-5$ conferti, flavescentes, glabri; alabastra triangularia, acuta; pedicelli floribus aequilongi v. paullo longiores; sepala late lanceolata, sensim acuminata, petalis obovato-oblongis paullo longiora; ovaria stylo satis longo coronata. Fructus ignotus.

Western Hupeh: Patung Hsien, thickets, alt. 300-1150 m., July 1907 (No. 3384; scandent bush 3-4 m., flowers yellowish); Changlo Hsien, thickets, alt. 300-1000 m., Jüne 1907 (No. 3385; scandent shrub, 2-5 m., flowers greenish-white); Nanto, glens, June 1900 (Veitch Exped. No. 1179). Eastern Szech'uan: Wushan Hsien, A. Henry (No. 5283). Yunnan: Szemao, alt. 2000 m., A. Henry (No. $\left.10376^{\mathrm{a}}\right)$.

The numbers quoted above seem to agree very well with each other, but I am not quite convinced that they truly represent Franchet's species, which I know only from the rather imperfect description and without having seen the type specimen my interpretation remains somewhat doubtful. The type was found by Delavay in Yunnan " in silvis ad Hee-chan-men supra Lankong; Fl. 25 maj. 1888" and Franchet says: "Espèce assez bien characterisée par sa grappe courte et cylindrique."

Here may be added the description of a new variety not collected during the Arnold Arboretum Expeditions.

Berchemia yunnanensis, var. trichoclada Rehder \& Wilson, n. var.

A typo recedit ramulis rhachibusque inflorescentiae et petiolis supra breviter dense villosis.

Western Szech'uan: Mt. Omei, July 1904 (Veitch Exped. No. 4777; shrub 2 m. tall).

This variety is well characterized by the pubescent branchlets, otherwise it agrees with the specimens referred to $B$. yunnanensis by Schneider, who did not see this number. The leaves of this new variety are rather small, $1.5-2.5 \mathrm{~cm}$. long; the flowering branchlets are short and straight usually $4-6$, occasionally to $9 \mathrm{~cm}$. long including the inflorescence the leafless part of which is rather denseflowered and from 2 to $4 \mathrm{~cm}$. long. In its pubescent branchlets this variety agrees with $B$. lineata De Candolle, but that species has much smaller, very short-petioled leaves, and the flowers are in axillary few-flowered cymes at the end of the branches, not in elongated spikes.

A. R. and E. H. W.

It seems rather difficult to limit the different species of this genus without having seen both flowering and fruiting branches of the same shrub. I have, however, made an attempt to make a key to the species. 


\section{CLAVIS SPECIERUM ASIATICARUM. ${ }^{1}$}

Inflorescentia maxima, late paniculata axibus inferioribus lateralibus saepissime ramosis et plerumque plus quam $5 \mathrm{~cm}$. longis (inflorescentia anguste paniculata in No. 5 , sed foliis valde discoloribus).

Alabastra ovato-globosa, sed apice subito et distincte acuminata; folia subtus pruinosa v. subpapillosa, sed papillis globosis confertis sub lente non distinctis.

Folia maxima ramulorum floriferorum vix plus quam $7 \mathrm{~cm}$. longa, apice subobtusa in acumen brevissimum subito producta, nervis utrinque 6-8-10; fructus versus apicem leviter incrassatus . . . . . . 1. B. racemosa.

Folia maxima ramulorum floriferorum fere semper distincte longiora, versus apicem subito attenuata, breviter acuminata, nervis utrinque $10-16$.

2. B. floribunda.

Alabastra ovato-globosa, sed apice obtusa v. vix acuta; folia subtus sub lente distincte papillosa.

Inflorescentia late paniculata ad $20 \mathrm{~cm}$. longa, ramis inferioribus lateralibus ad $9 \mathrm{~cm}$. longis; folia maxima vix plus quam $8 \mathrm{~cm}$. longa, subtus in sicco pallida. . . . . . . . . . . 3. B. Giraldiana.

Inflorescentia anguste paniculata, vix $12 \mathrm{~cm}$. longa, ramis inferioribus lateralibus vix ad $3 \mathrm{~cm}$. longis; folia maxima ad $11 \mathrm{~cm}$. longa, subtus in sicco distincte flava . . . . . . . . . 4. B. hypochrysa. Inflorescentia semper anguste paniculata $\mathrm{v}$. plerumque racemoso-paniculata, interdum subracemosa; ${ }^{2}$ folia maxima ramulorum floriferorum vix plus quam 6 $\mathrm{cm}$. longa plerumque minora $\mathrm{v}$. interdum parvula.

Petioli foliorum ramulorum floriferorum satis elongati, saepissime plus quam 6 v. $10 \mathrm{~mm}$. longi; alabastra plerumque ovato-globosa, vix longiora quam crassa.

Folia majora plus quam $6 \mathrm{em}$. longa nervis utrinque 12-17 instructa; inflorescentia racemoso-paniculata, satis brevis, $3-6 \mathrm{~cm}$. longa.

5. B. flavescens.

Folia etiam maxima minora, haud plus quam $5.5-6 \mathrm{~cm}$. longa, nervis utrinque tantum 6-12 instructa; inflorescentia variabilis.

Alabastra distincte obtusa; sepala obtusa; folia fere omnia apice obtusa, subrotunda v. rotunda, minutissime mueronulata . . . . 6. B. sinica.

Alabastra distincte apiculata; sepala acuta v. acuminata; folia apice acuta v. subito in acumen breve produeta.

Folia late ovata, 4-6.5 cm. longa et $2-4 \mathrm{~cm}$. lata . . 7. B. cinerascens. Folia anguste ovata v. elliptica v. minora. . . . 8. B. annamensis.

${ }^{1}$ Species sequentes: B. affinis Hasskarl, Cat. Hort. Bogor. 117 (nomen nudum) (1844); Koorders, Excursionsfl. Java, II. 553 (1912); B. Edgeworthii Lawson in Hooker f., Flor. Brit. Ind. I. 638 (1875); B. pubiflora Miquel, Fl. Ind. Bat. I. pt. 1, 645 (1855); B. sessiliflora Bentham, Fl. Hongl. 68 (1861) mihi tantum ex descriptione eognitae ad Berchemiam versimiliter non pertinent. B. trichantha Miquel, Fl. Ind. Bat. Suppl. I. 331 (1860) cujus specimen originale in Herbario Mus. Palat. Vindob. vidi, est Smythea trichantha Schneider, n. comb. Berchemia alnifolia Léveillé, in Fedde, Rep. Sp. Nov. X. 433 (1912) ad genus Corylopsin pertinet. Vide C. alnifolia Schneider in Fedde, Rep. Sp. Nov. XII. 379 (1913).

${ }^{2}$ Hic verisimiliter B. pauciflora Maximowicz in Bull. Acad. Sci. St. Pétersbourg, XXXII. 484 (1888) e Japonia inserenda est, sed mihi incognita. 
Folia utrinque nervis 8-12 instructa; sepala apice satis acuminata. Inflorescentia densiflora, pseudo-racemosa; sepala glaberrima.

9. B. pycnantha.

Inflorescentia satis laxiflora, elongata, anguste paniculata; sepala minutissime ciliata ........ 10. B. kulingensis.

Folia utrinque tantum nervis 6-8 instructa; sepala apice subito sed distincte breviter acuta ......... 11. B. formosana. Petioli foliorum ramulorum floriferorum breves, vix plus quam $5 \mathrm{~mm}$. longi; alabastra triangulari-ovata, acuta $\mathrm{v}$. elongata.

Ramuli glabri; folia nervis utrinque 6-10 instructa.

Folia subtus distinete papillosa ........ 12. B. yunnanensis. Folia subtus epapillosa . . . . . . . . . . . 13. B. Elmeri. Ramuli puberuli v. tomentosi. (Confer etiam B. yunnanensis, var. trichoclada). Folia subtus glabra.

Petala lanceolata

14. B. lineata.

Petala orbicularia . . . . . . . 15. B. polyphylla. Folia" subtus ochraceo-cinerea puberula" . . . 16. B. philippinensis.

\section{ENUMERATIO SPECIERUM ASIATICARUM.}

1. Berchemia racemosa Siebold \& Zuccarini in Abh. Akad. Münch. IV. pt. II. 147 (Fl. Jap. Fam. Nat. I. 39) (1845). - Maximowicz in Mém. Acad. Sci. St. Pétersbourg, sér. 7, IV. No. XI. 3 (Rhamn. Or.-As.) (1866). — Schneider, Ill. Handb. Laubholzk. II. 262, fig. 182 h, 183 f-g (1909).

Japan: Kiushiu, Hondo.

2. Berchemia floribunda Brongniart. See p.213.

3. Berchemia Giraldiana Schneider. See p. 213.

4. Berchemia hypochrysa Schneider. See p, 214.

5. Berchemia flavescens Brongniart in Ann. Sci. Nat. X. 357 (Mém. Fam. Rhamn. 50) (1826), - Lawson in Hooker f., Fl. Brit. Ind. I. 637 (1875).

Zizyphus flavescens Wallich in Roxburgh, Fl. Ind. II. 367 (1824).

Himalaya: Nepal, Sikkim.

To this species may possibly belong Faber's No. 199 from Szech'uan, Mt. Omei. Wallich's description agrees very well with Faber's plant, but I have seen only a rather scanty flowering specimen of the type. Hooker says: "Young branches with black spreading deciduous hairs," what I think is an error, the "hairs" upon the twigs of the plant before me being the product of a fungus. Our Chinese form needs further study.

6. Berchemia sinica Schneider. See p. 215.

7. Berchemia cinerascens Blume in Miquel Fl. Ind. Bat. I. 1, 644 (1855). Koorders, Excursionsfl. Java, II. 553 (1912).

Rhamnus? cinerascens Blume, Bijdr. 1141 (1826).

Western Java.

Of this species I have seen one specimen with a few very young flowers. Koorders reproduces only the very short description of Blume. This species is probably correctly referred to Berchemia and may be closely related to the following species. 
8. Berchemia annamensis Pitard in Lecomte, Fl. Gén. Indo-Chine, I. 925 (1912).

Annam.

Judging from the description this species may bear some relations to $B$, cinerascens Blume. Both species have rather broad leaves. The flowers of $B$, annamensis are unknown; the fruit has been described as obovate, " haut de 10-12 mm. large au sommet de 4-5 $\mathrm{mm}$. ̀̀ sa base de $2 \mathrm{~mm}$."

9. Berchemia pycnantha Schneider. See p. 215.

10. Berchemia kulingensis Schneider. See p. 216.

11. Berchemia formosana Schneider, n. sp.

Frutex scandens; ramuli ab initio glabri, violacei v. fuscescentes, rotundi; gemmae stipulaeque normales. Folia papyracea, ovata v. late ovata, glabra, basi rotunda, apice plus minusve acuta, 2-3.5 cm. longa et 1-2 cm. lata, supra in sicco nigrescentia, subtus albescentia pruinosa, nervis utrinque $6-8$; petioli $7-9 \mathrm{~mm}$. longi, glabri. Inflorescentia pseudo-racemosa, in apice ramulorum lateralium 4$8 \mathrm{~cm}$. longorum terminalis, 2-4 cm. longa; flores 2-3 conferti, glabri; alabastra globosa, breviter apiculata; pedicelli floribus subbreviores; sepala satis juvenilia ovata, apice subito in acumen breve contracta; petala obovalia, sepalis breviora; ovaria discum distincte superantia. Fructus nondum maturus, circiter $7 \mathrm{~mm}$. longus, $2.5 \mathrm{~mm}$. crassus, versus apicem attenuatus, basi disco brevissimo cinctus, pedicellis $2 \mathrm{~mm}$. longis.

Formosa: Tamsui, R. Oldham (No. 70).

I cannot unite this form with any other species; it may be distinguished by the characters given in the key.

12. Berchemia yunnanensis Franchet. See p. 216.

13. Berchemia Elmeri Schneider, n. sp.

Frutex; ramuli glabri, rotundi, in sicco omnino nigricantes; gemmae stipulaeque ut videtur normales. Folia elliptica v. ovato-elliptica, utrinque rotunda v. apice obtusa, mucronulata, nervis utrinque 8-10, supra viridia, subtus pallida, pruinosa v. vix papillosa, $1.5-3 \mathrm{~cm}$. longa, $0.7-1.8 \mathrm{~cm}$. lata; petioli $6 \mathrm{~mm}$. longi, glabri. Inflorescentia in apice ramulorum lateralium terminalis, pseudo-racemosa $v$. anguste paniculata, valde juvenilis tantum visa floribus nondum satis evolutis.

Philippine Islands: Island of Mindanao, Todaya (Mt. Apo), district of Davao, August 1909, A. D. E. Elmer (No. 11317), sub nomine B. philippinensis Vidal distributa.

The specimen is rather imperfect, but Vidal's description of B. philippinensis differs in: " ramis tomentosis . . . . , foliis . . . . subtus puberulis." Vidal does not describe the flowers. The very young flower-buds of $B$. Elmeri are globose and rather obtuse; in the small, short petioled leaves it resembles $B$. lineata De Candolle.

14. Berchemia lineata De Candolle, Prodr. II. 23 (1825). - Hooker \& Arnott, Bot. Voy. Beechey, 177, t. 37 (1833). - Maximowicz in Mém. Acad. Sci. St. Pétersbourg, sér. 7, IV. No. XI. 6 (Rhamn. Or.-As.) (1866). - Pitard in Lecomte, Fl. Gén. Indo-Chine, I. 923, fig. 116 (4-6) (1912).

Rhamnus lineatus Linnaeus, Cent. Pl. II. 11 (1756); Amoen. IV. 308 (1759)Osbeck, Dagbok Ostind. Resa, 219, t. 7 (1757); Reise Ostind. 286, t. 7 (1765).

Southern China, Tonkin, Formosa, Liu-kiu Archipel.

The pubescence of the branchlets, petioles and inflorescence and also the shape and size of the leaves of this species seem to vary greatly. Probably such specimen as Oldham's No. 69 from Formosa (anno 1864) represent a very small leaved 
variety. The species is well distinguished by its few-flowered inflorescence, its narrow flower-buds and by its narrow sepals and petals.

15. Berchemia polyphylla Wallich apud Lawson in Hooker f., Fl. Brit. Ind. I. 638 (1872).

Birma.

I know this species only from Lawson's very short description. He says: closely related to B. flavescens Brongniart. But according to Lawson's description it must be rather different. The leaves are described as from 2.5 to $3.75 \mathrm{~cm}$. long with petioles only $6 \mathrm{~mm}$. long. Possibly it may be related to those forms which I have referred to $B$. yunnanensis.

16. Berchemia philippinensis Vidal, Rev. Pl. Vasc. Filip. 91 (1886).

Philippine Islands: La Trinidad.

According to the deseription this species seems to be most nearly related to $B$. lineata DeCandolle, but the leaves have 10 pairs of nerves and are puberulous beneath. The flowers have not yet been described.

\section{CHAYDAIA Pitard.}

Chaydaia Wilsonii Schneider, n. sp.

Frutex scandens, 3-6 metralis; ramuli glabri; rotundi, novelli, olivacei, fuscescentes, lenticellis satis numerosis et distinctis, deinde ut videtur brunnei, leviter rimosi, vetustiores cinerei; gemmae nondum satis evolutae; stipulae breves (an apice deciduae ut in Berchemia ?), triangulares, dorso connatae, gemmam obtegentes. Folia alterna, decidua, papyracea, elliptica, basi asymmetrica, rotunda, apice obtusa sed in acumen breve subito producta, mucronulata, 7-10 $\mathrm{cm}$. longa et 3-5 cm. lata, supra viridia, ut videtur opaca, glabra, subtus pallida, epapillosa, tantum axillis nervorum lateralium utrinque 8-9 minute barbulata; petioli breves, 4-5 $\mathrm{mm}$. longi, glabri, supra canaliculati. Inflorescentia terminalis, pseudo-racemosa, glabra, parte efoliata 3.5 $\mathrm{cm}$. longa; flores virescentes, ad 5 -fasciculati, fasciculis infimis in axillis foliorum inter se satis distantibus; alabastra globosa, $1.5 \mathrm{~mm}$. crassa; pedicelli floribus breviores; structura florum fere ut in Berchemia, sed sepalis intus in medio rostellatis; petala late obovata, apice satis emarginata, basi breviter unguiculata, sepalis triangulariovatis vix acutis subaequilonga; ovaria stylo brevi bifido coronata, basi (tamen in floribus juvenilibus) disco satis distincto circumcincta. Fructus ignotus.

Western Hupeh: Hsing-shan Hsien, thickets, alt. 1300 m., July 1907 (No. 3388).

This species seems to be most closely related to C. tonkinensis Pitard in Lecomte Fl. Gén. Indo-Chine, I. 925, fig. 117 (1-3) (1912), of which I have not seen a specimen: Pitard describes the leaves as shining above and quite glabrous. He also says; 
" disque peu épais," and his figure shows a disk like that of Rhamnus, but in our specimen I find the disk well developed and not very different from that of Berchemia.

Chaydaia is certainly closely related both to Berchemia and to Rhamnella. They may be distinguished as follows:

Folia integerrima, nervi utrinsecus $6-15$, paralleli, a costa ad marginem distincte percurrentes et in margine ipso evanescentes; inflorescentia racemosov. paniculato-cymosa.

Petioli in comparatione laminae satis longi; folia symmetrica; sepala tantum apice intus incrassata; petala oblonga v. lanceolata, apice integra; fructus bilocularis.

Berchemia.

Petioli satis breves, folia paullo asymmetrica; sepala intus apice incrassata et etiam medio rostellata; petala obovalia, apice saepe undulata v. lobulata; fruetus unilocularis.

Chaydaia.

Folia fere semper distincte anguste serrulata, nervi utrinsecus 5-10, paralleli

v. subparalleli, a costa versus marginem currentes sed paullo ante marginem inflectentes diluentes; petioli satis breves v. brevissimi; inflorescentia fasciculato-cymosa, axillaris; sepala ut in Chaydaia; petala obovalia, basi breviter unguiculata, apice integra v. distincte emarginata; fructus uni- v. bilocularis.

Rhamnella.

\section{RHAMNELLA Miq.}

\section{Microrhamnus Maximowicz, non A. Gray.}

This genus, which has hitherto been considered monotypic, shows a rather rich development in central China. A short description of the genus with regard to the allied genera is given above. The sepals of all the new species and also of $R$. franguloides Weberbauer are distinctly beaked in the middle, as in Chaydaia. The ovaries seem to be always distinctly bilocular, but the fruits are often, but not always, unilocular.

\section{Rhamnella Wilsonii Schneider, n. sp.}

Frutex 2-6 m. altus; ramuli hornotini tenuissimi, viridescentes, glabri v. ex parte minutissime pilosi, vetustiores brunnescentes; gemmae parvae, obtusae; stipulae colore ramulorum, parte decidua $4 \mathrm{~mm}$. longa subulata. Folia papyracea, pro genere perparva, ovata v. anguste ovata, basi rotunda v. obtusa, apice acuta v. breviter acuminata, margine infra medium plerumque integra, versus apicem indistincte crenato-serrulata, dentibus satis distantibus, ea ramulorum floriferorum 1-3.5 cm. longa et $0.6-1.6 \mathrm{~cm}$. lata, a basi ramulorum ad apicem accrescentia, ea ramulorum fructiferorum ad 4.2 $\mathrm{cm}$. longa et $2.8 \mathrm{~cm}$. lata, supra obscure viridia, glabra, subtus paullo pallidiora, glabra v. ad costam paucissime pilosa, nervis utrinque plerumque 5; petioli $2-4 \mathrm{~mm}$. longi, parce pilosi. Inflorescentia axillaris, pseudo-umbellata, sessilis v. pedunculo nudo brevissimo suffulta, 2-3-flora, glabra; flores viridi-flavescentes, glabri, normales, sepalis quam stamina petalaque longioribus ovatis acutis. Fructus 
ad 7: $3.5 \mathrm{~mm}$. magnus, bilocularis, flavo-brunneus (an maturus?), pedicellis $3-4 \mathrm{~mm}$. longis.

Western Szech'uan: near Monkong Ting, valley of Hsao-chin Ho, alt. 2300-3000 m., June 29, 1908 (No. 3337).

This is a very distinet species, distinguished from all others by its very small, sparingly dentate leaves.

\section{Rhamnella Julianae Schneider, n. sp.}

Frutex $3-5 \mathrm{~m}$. altus, saepe subscandens; ramuli hornotini tomentelli, flavo-virides, vetustiores glabrescentes, nigrescentes, lenticellis paucis vix visibilibus obtecti; gemmae nondum visae; stipulae ut videtur brevissimae, basi nigrescente. Folia decidua, papyracea, ovato-oblonga $\mathrm{v}$. fere elliptica, basi rotunda v. subcordata, apice satis subito breviter v. longiuscule acuminata, margine crenatoserrulata dentibus accumbentibus calloso-mucronulatis, versus basim ramulorum minora, 4-6.5 cm. longa et 2-3.5 cm. lata v. ad 10:4 cm. magna, supra intense viridia, plerumque tantum ad costam incisam pilosa, subtus grisea, tomentella, nervis utrinque 5-7 distincte elevatis; petioli breves, tomentelli, $3-5 \mathrm{~mm}$. longi. Inflorescentia axillaris, pedunculis nudis ad $5 \mathrm{~mm}$. longis, subumbellata, 2-4-flora, tomentella; flores virides; sepala glabrescentia v. glabra, sed ciliata, late ovata, acuta, petalis late obovatis apice emarginatis staminibus vix longiores. Fructus immaturus, $6: 3 \mathrm{~mm}$. v. maturius ad $7: 4$ $\mathrm{mm}$. magnus, aurantiacus, ut videtur 2-locularis.

Western Szech'uan: west and near Wên-ch'uan Hsien, alt. 1000-1600 m., July and September 1908 (No. 3338, type); same locality, alt. 1600 m., November 1910 (No. 4I92).

This seems to be a distinct species although closely related to $R$. franguloides Weberbauer, from which it differs in the characters indicated in the key. No. 4192 has a rather shorter or thinner pubescence and the leaves are somewhat more ovate-lanceolate.

This species is named in compliment to my wife.

\section{Rhamnella obovalis Schneider, $\mathrm{n}$. sp.}

Frutex scandens, 4-6 m. altus; ramuli juniores puberuli, grisei, deinde fere glabrescentes, lenticellis numerosis obtecti; gemmae parvae, puberulae; stipulae is $R$. franguloidis simillimae, albescentes. Folia decidua, papyracea, obovata v. obovato-oblonga, basi rotunda, fere subcordata, obtusa v. fere subacuta, apice rotunda, sed in acumen breve $5-8 \mathrm{~mm}$. longum subito contracta, margine angustissime tenuiter calloso-serrata dentibus accumbentibus, versus basim ramu- 
lorum minora, 2.5-6 cm. longa et 6-3.2 $\mathrm{cm}$. lata, v. ad 7.3 longa et ad $3.5 \mathrm{~cm}$. lata, supra viridia, fere glaberrima, subtus vix pallidiora, breviter hirtella praesertim ad costam et nervos prominentes, nervis utrinque 7-9 satis arcuatis; petioli tantum 1-2 mm. longi, puberuli. Inflorescentia axillaris, pauciflora, puberula, pedunculo nudo brevissimo suffulta; flores nondum visi. Fructus ad 9:4 mm. magnus, rubronigrescens, unilocularis.

Western Hupeh: Fang Hsien, thickets, alt. 1000-1600 m., July 1907 (No. 3389, type). Kiangsi: Kiukiang, $50 \mathrm{~m}$., abundant on plain, July 27,1907 (No. I515; bush $1.5-5 \mathrm{~m}$. tall, fruit orange).

The Kiukiang specimen differs in its obovate-oblong leaves, which measure up to 9:3.4 cm. The older branchlets are brownish. The fruits contain only one seed. Certainly this species is very closely related to $R$. franguloides Weberbauer, but differs in the size and shape of the leaves. I have only seen fruiting specimens, and further investigation is needed to determine the real value of this species. It has the same light colored bases of the stipules as $R$. franguloides. The type of that species seems to be entirely absent from China, while it is abundant in southern Korea. A specimen before me collected by Jelinek during the Novara expedition near Shanghai probably belongs to $R$. obovalis.

\section{CLAVIS SPECIERUM OMNIUM.}

Folia parva, ovata, vix ultra $4.5 \mathrm{~cm}$. longa, tantum versus apicem satis indistincte dentata, nervis utrinsecus 4-5-(6), glaberrima ..... 1. R. Wilsonii.

Folia majora, eireumcirca distincte serrulata.

Ramuli novelli floresque glaberrimi; folia ovato-v. oblongo-lanceolata v. ovata v. elliptica, apice sensim acuminata v. acuta.

Folia ovato- v. oblongo-lanceolata, a medio ad apicem sensim in acumen distinctum satis longum attenuata; inflorescentia 2-5-flora.

2. R. Martinii. florescentia 5 -15-flora ............. 3. R. Mairei. Ramuli novelli floresque tomentelli v. plus minusve pilosi, v, subglabri et folia obovata v. obovato-oblonga, apice subito caudato-acuminata.

Ramuli tomentelli; folia etiam matura subtus tota facie plus minusve pubescentia, ovata v. ovato-oblonga, versus apicem sensim acuminata.

4. R. Julianae.

Ramuli sparse pubescentes v. subglabri; folia fere semper subtus tantum ad nervos pubescentia $\nabla$. obovalia, apice subito caudato-acuminata.

Folia elliptica v. elliptico-oblonga, basi rotunda v. obtusa, subtus glabra v. parce ad nervos pubescentia; inflorescentia 5-10-flora; fructus niger.

5. $R$. franguloides.

Folia obovalia v. obovato-oblonga, basi rotunda v. acuta, subtus ad nervos distincte pubescentia et saepe etiam inter nervos sparse pilosa; inflorescentia pauciflora; fructus aurantiacus (an deinde nigrescens?).

6. R. obovalis. 


\section{ENUMERATIO SPECIERUM.}

1. Rhamnella Wilsonii Schneider. See p. 222.

2. Rhamnella Martinii Schneider, n. comb.

Rhamnus Martini Léveillé in Fedde, Rep. Sp. Nov. X. 473 (1912).

Frutex 1-1.5 m. altus; ramuli tenues, hornotini flavo-virides v. fuscescentes (an tantum in sicco?), vetustiores nigrescentes, ex parte lenticellis flavis obtecti, gemmae nondum visae; stipulae basi persistente nigrescente et apice subulato deciduo $3 \mathrm{~mm}$. longo instructae. Folia alterna, decidua, membranacea, oblongoelliptica, basi rotundata v. obtusa, apice sensim acuminata, acutissima, circumcirca crenato-serrulata, dentibus accumbentibus calloso mucronulatis, 4-11 cm. longa, $1.5-3.9 \mathrm{~cm}$. lata, supra viridia, glabra, nervis vix v. satis ineisis, subtus vix pallidiora, tantum ad costam nervosque parce pilosa, nervis utrinque 6-8 prominentibus, angulo satis acuto a costa versus marginem decurrentibus; petioli breves, supra suleati, pilosi, 3-4 mm. longi. Inflorescentia axillaris, paniculato-cymosa, sessilis $\mathrm{v}$, pedunculo nudo $1-5 \mathrm{~mm}$. longo suffulta, $2-5$-flora, glabra; flores minutissimi, flavo-virides, iis $R$. franguloidis simillimi sepalis paullo acutioribus petalis basi obovatis apice emarginatis exceptis. Fructus oblongus, ad $8 \mathrm{~mm}$. longus et 3-3.5 mm. diam., rubro-nigrescens, pedicellis ad $4 \mathrm{~mm}$. longis.

Western Hupeh : April 1901 (Veitch Exped. No. 1990). Kweichou: " Environs de Gan-pin, rochers au dessus de Ta-tong," May 23, 1898, L. Martin (Herb. Bodinier, No. 2299, type). Yunnan: Mengtze, mountains, alt. 2800 m., A. Henry (No. 10929).

This species seems most closely related to $R$. franguloides Weberbauer, but differs from it in the more gradually acuminate leaves with more ascending and somewhat closer nerves, in the black persistent bases of the stipules and in the glabrous few-flowered inflorescence.

Wilson's No. 1990 which consists of flowering and fruiting branches agrees as well with the type as Henry's No. 10929.

3. Rhamnella Mairei Schneider, sp. nov.

Frutex omnino glaberrimus; ramuli hornotini olivacei, vetustiores rubrobrunnei, lenticellis sparsis obtecti; stipulae brunneae, apice setaceo deciduo. Folia papyracea, ovata v. elliptica, basi rotunda v. obtusa, apice sensim acuta v. breviter acuminata, supra viridia, nervis vix impressis utrinsecus $5-7$, sub angulo satis acuto divergentibus subtus prominentibus, margine satis angustae breviter serrulata, $3.8-8 \mathrm{~cm}$. longa, $1.7-3.5 \mathrm{~cm}$. lata; petioli supra suleati, $4-8 \mathrm{~mm}$. longi. Inflorescentia 5-15-flora, brevissime pedunculata, fasciculato-cymosa; flores ut in $R$. Martinii, flavi. Fructus nondum visus.

Yunnan: "rochers de Ma-hong, juin 1910," alt. 3000 m., E. E. Maire.

This species is certainly closely related to $R$. Martinii Schneider, but can be easily distinguished by the characters indicated in the key.

4. Rhamnella Julianae Sehneider. See p. 223.

5. Rhamnella franguloides Weberbauer in Engler \& Prantl, Nat. Pflanzenfam. III. Abt. V. 406 (1895). - Schneider, Ill. Handb. Laubholzk. II. 263, fig. 183 h-i, $186 \mathrm{~h}$ (1909).

Microrhamnus franguloides Maximowicz in Mém. Acad. Sci. St. Pétersbourg, sér. 7, IV. No. XI. 4, t. fig. 15-23 (Rhamn. Or.-As.) (1866).

Rhamnella japonica Miquel in Ann. Mus. Lugd.-Bat. III. 30 (1867); Prol. Fl. Jap. 218 (1867). 
Southern Japan, southern Korea.

To this species belong the following specimens from Korea, collected by $U$. Faurie, Quelpaert: " in montibus," October 1906 (No. 504; tree 8-10 m. tall), " circa Hongno," August 1907 (No. 1623), " in Hongno," August 22, 1908 (No. 640), June 28, 1908 (No. 639), and also Taquet, " in sylvis Hongno," August 1909 (No. 3214).

6. Rhamnella obovalis Schneider. See p. 223.

\section{SAGERETIA Brongn.}

\section{Sageretia perpusilla Schneider, n. sp.}

Frutex spinosus $0.75 \mathrm{~m}$. altus; ramuli oppositi, juveniles vetustioresque tenuiter cano-tomentelli, rotundi, cinerascentes. Folia perparva, opposita v. subopposita ovata v. ovato-elliptica, basi inaequalia, rotunda v. fere subcordata, apice rotunda v. obtusa, 5-8 $\mathrm{mm}$. longa, 3-4.5 mm. lata, glabra, tantum initio utrinque sparse pilosa, utraque facie tenuiter reticulata, nervis lateralibus $3-4$ vix distinctis prominentibus, subtus vix pallidiora, margine crenatoserrulata dentibus utrinque circiter 8-12 apice callosis; petioli 1-2 $\mathrm{mm}$. longi, pilosiusculi, stipulis setaceis sublongioribus basi ornati. Inflorescentia ut videtur apice ramulorum pseudospicam infra saepe paniculatam terminalem formans, tomentella, ad $4 \mathrm{~cm}$. longa; flores verisimiliter pro genere normales, sessiles, subglabri. Fructus circiter $4 \mathrm{~mm}$. diam., nigro-ruber(?); semina flavida.

Western Szech'uan: Min valley, Mao-chou, alt. 1600-2400 m., May 24, 1908 (No. 3340; bush $0.75 \mathrm{~m}$. tall).

This is a rather scanty specimen with a few old flowers and fruits. The leaves are apparently young, but they are much smaller than even those of the following species, to which $S$. perpusilla may be most closely related, if it does not represent a mere form of it.

\section{Sageretia pycnophylla Schneider, n. sp.}

Frutex spinosus, scandens, $2 \mathrm{~m}$. altus; ramuli oppositi, juveniles vetustioresque tomentelli, cinerascentes v. nigrescentes. Folia parva, opposita v. subopposita, subcoriacea, glabra, elliptica v. obovatoelliptica, utrinque rotunda $\mathrm{v}$. obtusa, 9-18 mm. longa, 5-9 $\mathrm{mm}$. lata v. minima subrotunda, tantum $5 \mathrm{~mm}$. longa et $4 \mathrm{~mm}$. lata, supra viridia, satis laevia, subtus in sicco flavo-viridia, distinctius reticulata, nervis primariis 3-4 paullo prominentibus, margine crenulatoserrata, dentibus utrinque 10-15 apice callosis; petioli 1-2 mm. longi, pilosi, stipulis setaceis deciduis subaequilongi. Inflorescentiae pseudospicatae, graciles, in apice ramulorum terminales et axillares, 1-3.5 
$\mathrm{cm}$. longae, glabrae v. minutissime puberulae; flores sessiles, albi, minimi, glabri, normales; sepala receptaculo longiora, ovato-acuta; petala sepalis breviora, alba, glabra, spathulata, emarginata, convoluta, staminibus sublongiora; antherae albae. Fructus ignotus.

Western Szech'uan: west and near Wên-ch'uan Hsien, arid places, alt. 1000-1600 m., July 1908 (No. 3339).

This species seems very nearly related to S. theezans Brongniart, of which some forms much resemble $S$. pycnophylla. But these forms of $S$. theezans have distinctly larger leaves and pubescent flowers or the leaves are of a rather different shape. See note to $S$, theezans below.

\section{Sageretia rugosa Hance in Jour. Bot. XVI. 9 (1878).}

Sageretia ferruginea Oliver in Hooker's Icon. VIII. pl. 1710 (1887).

Western Hupeh: Patung Hsien, thickets, alt. 600-1000 m., August 1907 (No. 2588, scandent bush 4 m.).

This number agrees very well with the drawing and description given by Oliver of Henry's No. 2701 from Ichang, which I have not seen. Oliver seems to have overlooked S. rugosa Hance, the type of which came from the province of Kwangtung. Hance's description of S. rugosa agrees with that of Oliver. The plate shows that the petals are pubescent on the outside, but neither Oliver nor Hance say anything about this important character in their descriptions. Unfortunately the flowers of Wilson's specimen are far too young to show this character. The permanent pubescence of the underside of the leaves affords the best character to distinguish this and $S$. omeiensis from other species of the genus.

Sageretia theezans Brongniart in Ann. Sci. Nat. X. 360 (Mém. Fam. Rhamn. 53) (1826). - Maximowicz in Mém. Acad. Sci. St. Pétersbourg, sér. 7, IV. No. XI. 20 (Rhamn. Or.-As.) (1866). - Lawson in Hooker f., Fl. Brit. Ind. I. 641 (1875), - Hemsley in Jour. Linn. Soc. XXIII. 131 (1886).

Rhamnus Thea Osbeck, Dagbok Ostind. Resa, 232 (nomen nudum) (1157); Reise Ostind. China, 302 (nomen nudum) (1765). - Linnaeus, Mant. Alt. 207 (quasi synon.) (1771).

Rhamnus theezans Linnaeus, Mant. Alt. 207 (1771).

Western Hupeh: Patung Hsien, cliffs of Yangtsze River, alt. 30-300 m., March 1908 (No. 334I ; spreading bush 1-2 m.). Chekiang: vicinity of Ningpo, D. Macgregor, 1908.

Wilson's specimen differs somewhat from the type, as understood by me, in its rather round leaves. Very similar forms occur in Formosa (A. Henry, No. 227) and also in Korea (Taquet, Quelpaert, October 29, 1908, No. 641; R. Oldham, Korean Arch., 1863, No. 1661). It is, however, difficult to decide, if they represent a distinet variety without having made further investigations. The type is somewhat uncertain, but Linnaeus describes the leaves as ovate, and I have seen some 
specimens from the neighbourhood of Canton, where Osbeck collected the type, which might represent it.

Here may be added the description of a new variety from Korea:

Sageretia theezans, var. tomentosa Schneider, $n$. var.

A typo recedit foliis subtus distinctius tomentosis tomento ut videtur tarde deciduo.

Korea: Quelpaert, " in sepibus, raro," October 28, 1908, Taquet (No. 643).

Another very glabrous variety or even a distinet species may be represented in Sageretia Chanetii Schneider, comb. nov. (Berchemia Chaneti Léveillé in Fedde, Rep. Sp. Nov. X. 433 (1912) from Chihli " montagnes de Ping-Chan, 15 juin 1908," $L$. Chanet (No. 232). I have seen a small piece of the type specimen with oblongelliptic leaves, which measure $2.5-4.5 \mathrm{~cm}$. in length and $1-2.2 \mathrm{~cm}$. in width.

\section{Sageretia subcaudata Schneider, n. sp.}

Frutex ad $1.5 \mathrm{~m}$. altus; ramuli annotini plus minusve puberuli, olivaceo-brunnescentes, vetustiores cinerascentes, vix v. valde glabrescentes; folia tenuiter coriacea, opposita v. subopposita, ovata v. ovato-elliptica, basi leviter cordata, apice subito in acumen $1 \mathrm{~cm}$. longum producta, 5-9 $\mathrm{cm}$. longa, $2.5-4.5 \mathrm{~cm}$. lata v. minora ellipticorotunda, $2-3.5 \mathrm{~cm}$. longa et $2-2.5 \mathrm{~cm}$. lata, supra viridia, sublucida, glabra, nervis incisis, subtus vix pallidiora, nitidula, distincte reticulata, tantum ad nervos utrinsecus 6-9 prominentes parce pilosa (an juvenilia distincte pubescentia?), margine calloso-crenulata; petioli 3-7 mm. longi, supra sulcati, distincte puberuli; stipulae filiformes, puberulae, ad $6 \mathrm{~mm}$. longae. Inflorescentia tantum deflorata visa, ad $7 \mathrm{~cm}$. longa, subspinosa, tomentella, parce ramosa; flores?. Fructus niger; semina late obovata, plana, flava, normalia.

Western Hupeh: Changyang Hsien, ravines, alt. 200-400 m., rare, April 3, 1907 (No. 3343, type); without precise locality, banks of Yangtsze River; March 1900 (Veitch Exped. No. 42).

\section{Sageretia Cavaleriei Schneider, n. comb.}

Berchemia Cavaleriei Léveillé in Fedde Rep. Sp. Nov. X. 433 (1912).

Frutex ad $2.5 \mathrm{~m}$. altus v. scandens, vix spinosus; ramuli annotini glabri, striati, cinerascentes, deinde nigrescentes. Folia subopposita, tenuiter coriacea, lanceolata v. late lanceolata, basi acuta v. obtusa, apice longe acuminata, tantum ea in basi ramulorum ovalia et utrinque obtusiora, supra intense viridia, sublucida, glabra, tantum costa distincte incisa, subtus pallide viridia, glabra, costa nervisque utrinque 5-8 elevatis, utraque facie tenuissime reticulata, margine breviter crenato-serrata dentibus callosis incumbentibus, longiora (lanceolata et acuminata) 8-12 cm. longa, 2-3 cm. lata, minora 5-9 cm. longa, 
1.5-3.6 $\mathrm{cm}$. lata; petioli 4-10 $\mathrm{mm}$. longi, glabri v. in sulco minute puberuli. Inflorescentiae graciles, axillares terminalesque, glabrae, folia paullo superantes v. iis breviores; flores pedicellati pedicellis $0.5-3$ $\mathrm{mm}$. longis, glabri, pro genere normales, albescentes, aperti; sepala obtusa v. subsessilia, petalis spathulatis emarginatis longiora; antherae obtusissimae. Fructus ut videtur subglobosus, ruber.

Western Hupeh: Hsing-shan Hsien, cliffs, alt. 600-1000 m., August 1907 (No. 2589; scandent bush 2-4 m., flowers white). Western Szech'uan: near Wa-shan, valley of Tung River, alt. 600-1300 m., October 1908 (No. 3342; bush 5 m., flowers white); same locality, September 1903 (Veitch Exped. No. 3336); without locality, August 1904 (Veitch Exped. No. 4807); A. Henry (No. 7118). Yunnan: Mengtze, wooded cliffs, alt. 2200 m., A. Henry (No. 11240). Kweichou: "Keou-Tehoang, Kouy-Tin," November 23, 1902, J. Cavalerie (No. 725, type).

After I had finished these studies I received the type of Léveille's species, which agrees exactly with Wilson's Nos. 4807, 3336, 2589). No. 3342 and Henry's Nos. 7118,11240 differ in the branchlets and petioles being minutely pubescent.

\section{CLAVIS SPECIERUM ASIATICARUM.}

Flores sessiles v. subsessiles.

Folia parva, vix ad $2 \mathrm{~cm}$. longa.

Folia minima tantum $0.5-0.8 \mathrm{~mm}$. longa ...... 1. S. perpusilla.

Folia majora, maxima ad $2 \mathrm{~cm}$. longa.

Inflorescentia fere glabra; flores glaberrimi . . . 2. S. pycnophylla.

Infloreseentia distincte pilosa $\mathrm{v}$. villosa. (Confer etiam No, 7).

Folia mediocra v. magna, saepissime plus quam $2.5 \mathrm{~cm}$. longa.

3. S. Brandrethiana.

Folia matura subtus tomento permanente haud facile detergibili obtecta, distincte reticulata.

Folia plerumque $4.5-7 \mathrm{~cm}$. longa, petiolis $2-6 \mathrm{~mm}$. longis. Petala extus pilosa . . . . . . . . . . 4. S. rugosa.

Folia 7.5-11 cm. longa; petioli 8-15 mm. Iongi. Petala glaberrima.

5. S. omeiensis.

Folia initio subtus tomento mox deciduo et facile detergibili obtecta, glabra v. subglabra, matura semper valde glabrescentia v. glabra.

Nervi primarii laterales a costa ad marginem percurrentes $5-10$, subtus distincte elevati, supra fere semper incisi; folia apice saepissime acuminata.

Folia permagna, 10-15 $\mathrm{cm}$. longa, v. glabra, tantum subtus in axillis leviter barbulata, nervis utrinque $8-10$; petioli glabri v. supra pilis paucis sparsis instrueti . . . . . . . . 6. S. hamosa.

Folia minora; petioli supra v. tota facie pilosi.

Folia supra opaca, membranacea, subtus plerumque tarde glabrescentia, subito acuminata, nervis utrinque 6-9; inflorescentia tomentosa.

7. S. subcaudata. 
Folia supra nitentia, chartacea, mox glabra, sensim acuminata, nervis utrinque 5-7.

Petioli tota facie ut ramuli inflorescentiaque villosi v. tomentelli; antherae apice obtusissimae . . . . . . 8. S. filiformis.

Petioli tantum supra ut ramuli inflorescentiaeque pilosi. Antherae apice brevissime apiculatae ....... 9. S. apiculata.

Nervi primarii laterales a costa ad marginem percurrentes tantum 2-5, subtus satis paullo prominentes, supra vix $\mathrm{v}$. haud incisi; folia apice rotunda, obtusa $\mathrm{v}$. acuta, sed non acuminata.

Nervi primarii utrinque tantum 2-3, perobliqui . . 10. S. paucicostata. Nervi primarii fere semper $4-5$, normales . . . . . 11. S. theezans. Flores plus minusve distincte pedicellati ....... 12. S. Cavaleriei.

\section{CONSPECTUS SPECIERUM ASIATICARUM.}

1. Sageretia perpusilla Schneider. See p. 226.

2. Sageretia pycnophylla Schneider. See p. 226.

3. Sageretia Brandrethiana Aitchison in Jour. Linn. Soc. VIII. 62 (1865). Boissier, Fl. Orient. II. 22 (1872). - Lawson in Hooker f., Fl. Brit. Ind. I. 642 (1875).

Northwestern India: Afghanistan, according to Lawson westward to Persia and Arabia.

Of the type specimens I have only seen Griffith's No. 2020 from Afghanistan which fully agrees with Aitchison's description, the leaves having a dense woolly whitish covering on their under surface.

Sageretia Brandrethiana, var. Bornmuelleri Schneider, var. nov.

A typo recedit foliis subtus valde glabrescentibus subintegerrimis.

Southeastern Persia: Prov. of Kerman, Rahbur, "in reg. calida, raro," alt. 2700 m., July 29, 1892, F. Bornmüller (No. 3430).

4. Sageretia rugosa Hance. See p. 227.

5. Sageretia omeiensis Schneider, n. sp.

Frutex subscandens; ramuli ut petioli inflorescentiaque cano-tomentulosi, rotundi, striati. Folia crasse membranacea, ovato-oblonga, basi rotunda, leviter inaequalia, apice acuminata, $7.5-10 \mathrm{~cm}$. longa, $3.5-4.5 \mathrm{~cm}$. lata, supra viridia, glabra v. subglabra, subtus albescentia v. leviter brunnescentia, tomentosa, nervis utrinque $7-9$, supra incisis, subtus valde prominentibus glabrescentibus, margine calloso-serrulata, petioli $8-15 \mathrm{~mm}$. longi, sulcati. Inflorescentia terminalis, paniculata, infra foliacea, ad $16 \mathrm{~cm}$. longa; flores sessiles, pro genere normales, extus basi v. tota facie pubescentes; petala sepalis breviora, glabra. Fructus desideratur.

Szech'uan: Mt. Omei, September 1904 (Veitch Exped. No. 4816).

This species is very closely related to S. rugosa Hance, but it may be at once distinguished from that species by its longer leaves with longer petioles. The petals are quite glabrous.

6. Sageretia hamosa Brongniart in Ann. Sci. Nat. X. 360 (Mém. Fam. Rhamn. 53) (1826). - Lawson in Hooker f., Fl. Brit. Ind. I. 641 (1875).

Zizyphus hamosa Wallich in Roxburgh, Fl. Ind. II. 369 (1824).

? Rhamnus affinis Blume, Bijdr. 1140 (1826).

Rhamnus costata Miquel, Fl. Ind. Bot. I. pt. 1, 645 (1855). - Trimen, Handb. Fl. Ceylon, I. 284 (1893).

Nepal, Peninsular India, Ceylon, Java, ? Formosa. 
Of this species I have only seen a specimen from Ceylon collected by Thwaites, No. 2477. Trimen, 1. e., cites this number under $S$. costata, but he says: "This may perhaps not be distinct from $S$. hamosa." In fact Wallich's description agrees with that of Miquel and our specimen agrees with it. Wallich's statement "leaves .... from four to sixteen inches long" is certainly a misprint. Trimen and Lawson say 3 (or 2 ) -5 in., but the leaves of No. 2477 exactly measure up to 6 in. (15.5 cm.).

7. Sageretia subcaudata, Schneider. See p. 228.

8. Sageretia filiformis G. Don, Gen. Syst. II. 29 (1832).

? Rhamnus filiformis Roth in Roemer \& Schultes, Syst. Veg. V. 293 (1819); Nov. Pl. Spec. 153 (1821).

Rhamnus parviflora Klein in Roemer \& Schultes, Syst. Veg. V. 295 (1819).

Zizyphus oppositifolia Wallich in Roxburgh, Fl. Ind. II. 370 (1824),

Rhamnus trigynus D. Don, Prodr. Fl. Nepal. 190 (1825).

Sageretia oppositifolia Brongniart in Ann. Sci. Nat. X. 360, t. 13, п. (Mém. Fam. Rhamn. 53) (1826). - Lawson in Hooker f., Fl. Brit. Ind. I, 641 (1875).

? Sageretia parviflora G. Don, Gen. Syst. II. 29 (1832).

Northwestern and subtropical Himalaya, western Peninsula, ? Java.

Wallich himself says (1. c. p. 371) that Heyne's specimen, which represents the type of Roth's filiformis, "comes very near to my plant and may perhaps be one and the same species."

9. Sageretia apiculata Schneider, n. sp.

Frutex alte scandens, spinosus; ramuli juniores breviter villosi, striati, vetustiores rotundi, cinerascentes. Folia opposita, crasse membranacea, ovata v. ovato-oblonga, basi leviter inaequalia rotunda, apice acuminata v. minora tantum acuta (v. minima obtusa), majora $5-7.5 \mathrm{~cm}$. longa et $2.5-3 \mathrm{~cm}$. lata, versus basim ramulorum paullo minora et fere latiora, in inflorescentiis minima, obtusiora, margine satis anguste calloso-serrulata, vix crenata, supra viridia, sublucida, subtus pallidiora, utraque facie mox glaberrima, nervis utrinque 4-7, supra incisis, subtus elevatis; petioli $3-6 \mathrm{~mm}$. longi, supra sulcati et puberuli. Inflorescentia apice ramulorum terminalis, paniculata, infra foliata, plus quam $20 \mathrm{~cm}$. longa, minute pilosa; flores albescentes, sessiles, glabri, aperti, pro genere normales; sepala receptaculo longiora, acuta; petala sepalis breviora; antherae apice brevissime apiculatae. Fruetus ruber, globoso-obovalis, eirciter 5-6 mm. longus et $4.5-5$ $\mathrm{mm}$. crassus; semina flavescentia, lenticularia.

Yunnan: Mengtze, alt. 1800 m., A. Henry (No. 10144, type); alt. 2200 m., woods, A. Henry (No. 10144 ${ }^{\mathrm{a}}$ ). This seems to be a good species, which is most nearly related to $S$. filiformis. I have never seen apiculated anthers in any other species of this genus.

10. Sageretia paucicostata Maximowiez in Act. Hort. Petrop. XI. 101 (1890).

Kansu: "valle fl. Peishui infra Kang-tin," June 21, 1885, Potanin.

Aceording to the description this species seems very closely related to the next. The author says: "S. parviflorae Don affinior quam aliis, sed foliorum forma, reticulo utrinque prominulo et pube differt." Without having seen the type specimen I cannot judge the value of this species.

11. Sageretia theezans Brongniart. See p. 227 .

12. Sageretia Cavaleriei Schneider. See p, 228. 


\section{RHAMNUS L.}

Rhamnus crenatus Siebold \& Zuccarini in Abh. Akad Münch. IV, pt. II. 146 (Fl. Jap. Fam. Nat. I. 38) (1845). - Maximowicz in Mém. Acad. Sci. St. Pétersbourg, sér. 7, IV. No. XI. 18 (Rhamn. Or.-As.) (1866). - Schneider, Ill. Handb. Laubholzk. II. 269, fig. 186 p-q, $185 \mathrm{f}-\mathrm{g}^{1}$ (1909).

Kiangsi : alt. 1600 m., abundant, July 28, 1907 (No. r684; bush 0.25-1.25 m., flowers white). Western Hupeh: Changyang Hsien, thickets, alt. 1000-1300 m., July and September 1907 (No. 137; bush 1.5-2.5 m., flowers whitish, fruit black); Changlo Hsien, thickets, alt. 600-1300 m., June and July 1907 (Nos. 3327, 3329 ; bush 3-5 m., flowers greenish, fruit black); Patung Hsien, thickets, alt. 600-1300 m., June and July 1907 (No. 3329; bush 3 m., flowers greenish-white, fruit black); Hsing-shan Hsien, thickets, alt. 1000-1300 m., June and July 1907 (No. 3330; bush 1.5-3 m., flowers greenish, fruit black); Changyang Hsien, June and July 1900 (Veitch Exped. Nos. 1135, $1135^{\mathrm{a}}$ ); without locality, A. Henry (No. 6058). Eastern Szech'uan: Wushan Hsien, side of streams, alt. 1000-1300 m., June and September 1907 (No. 3328; bush 1-2 m., flowers greenish, fruit black). Chekiang: vicinity of Ningpo, 1908, D. Macgregor. Fokien: without precise locality, Dunn's Exped., April to June 1905 (Herb. Bot. Gard. Hongkong, Nos. 2488, 2495).

$R$. crenatus, the type of which is Japanese, seems to be a widely spread and rather variable species and I cannot find any real differences between the Japanese specimens and those from central China. The shape of the leaves and the amount of pubescence are very variable and it would require a special study to decide whether all these forms belong to one species or not.

Rhamnus heterophyllus Oliver in Hooker's Icon. XVIII. t. 1759 (1888). - Pritzel in Bot. Jahrb. XXIX. 459 (1900).

Rhamnus Cavaleriei Léveillé in Fedde, Rep. Sp. Nov. IX. 326 (1910).

Western Szech'uan: thickets in rocky places, alt. 1000-1300 m., July, Oetober and November 1908 (Nos. Ior3, I242; bush 1-1.5 m., branches usually decumbent, fruit black); Kuan Hsien, thickets, alt. 1300-1600 m., October 1910 (No. 4I86; bush 1.5-2 m., fruit black). Kweichou: near Pin-ne, August 1, 1905, J. Cavalerie (No. 2477, type of $R$. Cavaleriei; shrub $1.9 \mathrm{~m}$. tall).

I cannot find any marked difference between any of the numbers cited above. Unfortunately neither Oliver nor Léveillé lay stress upon the persistent, subspinose stipules, which, I think, are a rather important character. $R$. heterophyllus 
Oliver and $R$. procumbens Edgeworth, may represent a peculiar group of the genus, if not a subgenus.

Rhamnus Esquirolii Léveillé in Fedde Rep. Sp. Nov. X. 473 (1912).

Descriptio nova emendata: Frutex $1.5-3 \mathrm{~m}$. altus, espinosus; ramuli initio puberuli, olivacei, deinde brunnescentes, lenticellis parvis obtecti, glabrescentes v. glabri; gemmae satis evolutae nondum visae, ut videtur subnudae. Folia alterna, decidua, papyracea, majora elliptico-lanceolata $\mathrm{v}$. late lanceolata, basi rotunda $\mathrm{v}$. obtusa, apice sensim v. satis subito acuminata, $7-14.5 \mathrm{~cm}$. longa, $1.5-5 \mathrm{~cm}$. lata, minora saepissime ovata v. ovato-elliptica, $2-7 \mathrm{~cm}$. longa, $1.2-3 \mathrm{~cm}$. lata, apice obtusiora, supra satis viridia, opaca?, glabra v. costa impressa pilis paucis conspersa, subtus vix pallidiora, ut videtur nitida, tenue pilosa v. glabra, nervis a costa versus marginem currentibus utrinque 5-8 satis curvatis campylotropis, rete nervorum satis conspicuo, margine denticulata, dentibus brevibus distantibus callosis; petioli pilosi, $5-10 \mathrm{~cm}$. longi; stipulae ut bracteae setaceae, breves, persistentes, flavo-brunnescentes, pungentes. Inflorescentia axillaris, plerumque elongata, racemoso-fasciculata, ad $2.5 \mathrm{~cm}$. longa, v. fasciculum sessilem formans, pilosa; flores pentameri, pilosi, an dioeci?, fere sessiles v. pedicellis ad $3 \mathrm{~mm}$. longis pilosis; sepala triangularia, acuta, receptaculo subaequilonga; petala sepalis paullo breviora, obovata, basi breve unguiculata, in sicco nigrescentia, staminibus subaequilonga; antherae flavo-albae (haud nigrescentes ut a cl. Léveillé descriptae); ovaria satis parva, stylis $2-3$ contiguis instructa. Fructus ignotus.

Western Szech'uan: Yachou Fu, thickets, alt. 1300 m., June 1908 (No. 3334; bush 1.5-2.3 m., flowers greenish); Mt. Omei, June 1904 (Veitch Exped. No. 4800; shrub 2.5 m. tall). Kweichou: "Pin Fa," woods, June 15, 1906; J. Esquirol (No. 392, type).

Wilson's specimens differ from Léveillés type only in the more glabrous leaves and branchlets. In the persistent rather pungent stipules, which Léveillé does not mention, this species resembles $R$. heterophyllus Oliver from which it is otherwise totally different. It may be related to the following group of species, especially to $R$. nipalensis Wallich, but none of these species with an elongated inflorescence bears persistent and prickly stipules.

\section{Rhamnus paniculiflorus Schneider, n. sp.}

Frutex $1.5-3 \mathrm{~m}$. altus saepe scandens, inermis; ramuli initio et annotini puberuli, olivaceo-brunnei, lenticellis numerosissimis brunneis verrucosi. Folia alterna, decidua (an semper?), subcoriacea, ovato-elliptica, elliptica v. elliptico-oblonga, basi rotunda v. obtusa, 
apice satis subito acuminata acumine 1-1.5 $\mathrm{cm}$. longo, satis indistincte breviter dentata, basim versus integra, toto circuitu angustissime cartilagineo-marginata, supra viridia, sublucida, glabra, subtus vix pallidiora, etiam sublucida, juvenilia ad nervos sparse pilosa, matura tantum in axillis nervorum utrinsecus 4-7 campylotroporum leviter barbulata, 6-13 cm. longa et 4-5 cm. lata $\mathrm{v}$. in inflorescentiis angustiora, lanceolata; petioli glabri, supra anguste sulcati, 10-18 $\mathrm{mm}$. longi. Inflorescentia axillaris, fere semper distincte late cymosopaniculata axi centrali ad $11 \mathrm{~cm}$. longa, ramis infimis ad $4 \mathrm{~cm}$. longis, puberula; flores virides(?), glabri v. sparse puberuli, pentameri, dioeci, feminei nondum visi, 2-8 fasciculati; pedicelli fructiferi 2-4 $\mathrm{mm}$. longi, glabri v. tenuissime pilosi; sepala Iate-lanceolata, sensim acuminata, receptaculo subduplo longiora; petala sepalis 1.5 breviora, obovato-oblonga, apice obtusa, basi breve unguiculata, in sicco nigrescentia, staminibus sublongiora; antherae albo-flavidae, apice levissime apiculatae; ovaria perparva, stylis 3 contiguis coronata. Fructus saturate ruber, obovato-globosus, circiter 6-7 mm. crassus; semina immatura 2-3, obovato-oblonga, dorso distincte sulcata.

Western Hupeh: Patung Hsien, cliffs, alt. 300-600 m., July and October (No. 422, type); Changyang Hsien, side of streams, alt. 300600 m., June 1907 (No. 3270); without locality, August 1900 (Veitch Exped. No. 1614). Yunnan: Szemao, mountains to west and east, forests, alt. 1800-2000 m., A. Henry (Nos. 12040, 12040²).

Dr. Henry's specimens differ only in their somewhat more distinctly crenately serrate leaves and smaller fruits. This is a very remarkable new species with its large paniculate inflorescence and its extremely verrucose branches. By these characters it is easily distinguished from the related $R$. nipalensis Wallich and $R$. tonkinensis Pitard.

Rhamnus Hemsleyanus Schneider in Notizbl. Bot. Gart. Berlin, 1908, 78; Ill. Handb. Laubholzk. II. 270, figs. 197 o-p, 199 m-n (1909).

Ad descriptionem addenda: gemmae perparvae, obtusissimae. Fructus maturus ut videtur niger, obovato-rotundus, ad $5 \mathrm{~mm}$. longus, $4 \mathrm{~mm}$. crassus; semina 3, purpurascentia, obovata, dorso impressa, tantum ima basi sulco brevi vix aperto instructa, ventre carinata.

Western Szech'uan: Mupin, woodlands, alt. 2000-3000 m., June 1908 (No. 3324; bush 2-6 m., flowers greenish); Mt. Omei, June 1904 (Veitch Exped. No. 4780); without precise locality, alt. 1800 m., May 1904 (Veitch Exped. No. 3342). Eastern Szech'uan: Wushan Hsien, A. Henry (No. 5677, type). Western Hupeh: without locality, A. Henry (No. 7462). 
At the first glance this species looks very much like $R$. Bodinieri Léveille, f. silvicola Schneider, but $R$. Hemsleyanus may be distinguished at once by its acuminate leaves, short petioles and tetramerous flowers.

\section{Rhamnus Sargentianus Schneider, n. sp.}

Frutex 2-6 m. altus, inermis; ramuli alterni, ab initio glabri v. parcissime pilosi, annotini purpurascentes, leviter nitentes, vetustiores cinerascentes; gemmae parvae, obovatae, circiter $4 \mathrm{~mm}$. longae, squamis paucis ciliatis obtectae; stipulae lineares, mox caducae, circiter $10 \mathrm{~mm}$. longae. Folia alterna, decidua, matura crasse membranacea, oblongo-elliptica $\mathrm{v}$. fere late lanceolata, basi cuneata, apice subito acuta v. plerumque breviter acuminata, toto margine tenuiter sed distincte crenato-serrata dentibus callosis, minora circiter $4.3 \mathrm{~cm}$. longa et $2 \mathrm{~cm}$. lata, majora circiter $12 \mathrm{~cm}$. longa et 4.3 lata v. $15 \mathrm{~cm}$. longa et $12 \mathrm{~cm}$. lata, supra viridia, tantum juniora ad nervos pilosa v. etiam matura tota pagina sparse pilosa, subtus paullo pallidiora, tantum ad nervos $\mathrm{v}$. tota pagina sparse pilosa, nervis utrinque 12-18 parallelis; petioli brevissimi, 2-5 mm. longi, supra pilosi. Pseudoumbella axillaris, 4-5-flora; flores masculi perparvi, virides, tetrameri, apetali; pedicelli floriferi $2-3 \mathrm{~mm}$. longi, minute pilosi, fructiferi ad $5 \mathrm{~mm}$. longi; sepala late ovata, apice subito breviter acuminata, 1-1.5 mm. longa, plerumque glabra; stamina sepalis triplo breviora. Fructus ut videtur purpureo-niger, obovato-rotundus, ad $5 \mathrm{~mm}$. longus; semina 3 , brunnescentia, obovata, basim versus angustata, $3-3.5 \mathrm{~mm}$. longa, dorso impressa, tantum ima basi sulco brevi aperto instructa, ventre carinata.

Western Szech'uan: Wa-shan and vicinity, woodlands, alt. 2300-3000 m., common, June and September 15, 1908 (No. 862, type); Mupin, thickets, alt. 2300-2800 m., June 1908 (No. 862 ${ }^{\mathrm{a}}$; Wa-shan, June 1903 (Veitch Exped. No. 3339a); without precise locality, alt. 2800 m., May 1904 (Veitch Exped. No. 3339).

At the first glance this species recalls $R$. costatus Maximowicz by its multicostate leaves, but the Japanese species may be readily distinguished by the different shape of its broader leaves, the long winter-buds and by the very long pedicels of its larger flowers and fruits. Nevertheless these two species are closely related and may represent a subdivision of the special group formed by all the species with similar multicostate leaves, namely $R$. alpinus Linnaeus, $R$. fallax Boissier, $R$. imeretinus Booth, $R$. purpureus Edgeworth and others. The arrangement of the different groups of the genus, especially of the subgenus Eurhamnus, as adopted by Weberbauer and other authors must probably be changed, but a really natural classification of the species ean only be reached by a careful examination of all the species now known. 


\section{Rhamnus hupehensis Schneider, sp. $\mathrm{n}$.}

Frutex 1.5-2 m. altus, an inermis?; ramuli hornotini glabri, flavobrunnei, in sicco striati, vetustiores cinerascentes; gemmae elongatae, acutae, leviter curvatae, 4-6 mm. longae, squamis paucis laxis acutis apice flavescentibus basi nigrescentibus eiliatis obtectae. Folia distincte alterna, decidua, crasse membranacea, ovata v. obovata, raro lanceolata, basi acuta, apice subito breviter acuminata, supra viridia, glabra, subtus pallidiora, nervis utrinsecus $5-8$ satis parallelis, sparse hirtella, margine praesertim versus apicem crasse crenatodentata, 5.5-10 cm. longa, 2.8-5 cm. lata; petioli glabri, supra sulcati, 10-12 mm. longi. Flores non visi. Fructus 1-2, axillares, ut videtur globosi, nigri, circiter $7 \mathrm{~mm}$. crassi; pedicelli $7 \mathrm{~mm}$. longi, glabri; pyrenae 2 dehiscentes; semina oblonga, laevia, olivacea, circiter $7 \mathrm{~mm}$. longa, dorso plus minusve distincte sulcata, sulco aperto $2-5 \mathrm{~mm}$. longo.

Western Hupeh: Fang Hsien, thickets, alt. 2000-2300 m., November 1907 (No. 6r2).

I am not quite convinced, that this species really belongs in the same group with the foregoing species, and that it is not more nearly related to $R$. Wilsonii Schneider, and to its related species. The nervation is somewhat intermediate between these two groups and I cannot decide if the branchlets become distinctly thorny.

Rhamnus Rosthornii Pritzel in Bot. Jahrb. XXIX. 459 (1900). Schneider, Ill. Handb. Laubholzk. II. 283, fig. 195 g-g², 196 i (1909).

Western Szech'uan: near Mao-chou, arid places, alt. 13002000 m., May 24 and July 1908 (Nos. 872, in part, 3323, in part; bush 1-1.50 m. tall, flowers greenish-yellow); Mupin, thickets, alt. 1300$2000 \mathrm{~m}$., May and August 1908 (No. 872, in part; bush 1-1.50 m. tall); Mt. Wa, thickets, alt. 1300-1700 m., September 1908 (No. $872^{\mathrm{s}}$; bush 1-1.5 m. tall); near Mongkong Ting, desert of Hsao-chin Ho, alt. 2300-3700 m., June 1908 (No. 3322; bush 1-3 m. tall); west and near Wên-ch'uan Hsien, alt. 1600 m., September 1908 (No. 3323, in part; bush 1-1.5 m. tall); Manch'uan, Hung-chia-p'ing, A. von Rosthorn (No. 512, type; small tree).

\section{Rhamnus leptacanthus Schneider, n. sp.}

Frutex valde spinosus, prostratus v. fere prostratus, ramis 1-2 m. longis; ramuli hornotini tenuissimi, minutissime pilosi, olivacei, spinosi, vetustiores glabrescentes v. deinde glabri, cortice laevi colore cerasi obtecti, etiam spinosisimi, rectangulares, suboppositi. Folia decidua, alterna v. subopposita, plerumque in apice ramulorum abbreviatorum conferta, membranacea, pro genere minima, oblanceolata 
v. obovato-lanceolata, basim versus in petiolum gracillimum 1-2.5 $\mathrm{mm}$. longum decurrentia, apice obtusa $\mathrm{v}$. emarginata, margine a medio ad apicem crenato-dentata, minima 6-10 $\mathrm{mm}$. longa et 2-3 $\mathrm{mm}$. lata, maxima ad $15 \mathrm{~mm}$. longa et ad $6 \mathrm{~mm}$. lata, supra cinereo-viridia, subtus pallidiora, nervis utrinsecus $2-3$ vix visibilibus, utrinque versus basim et ad petiolum minute pilosa; stipulae setaceae, petiolis plerumque duplo breviores. Flores masculi axillares, 2-5 conferti, viridi-flavescentes, glabri $2.5 \mathrm{~mm}$. longi; sepala ovato-lanceolata, acuminata, staminibus et petalis angustissimis fere duplo longiora; pedicelli 2.5-4 mm. longi, glabri. Flores femineos fructusque nondum vidi.

Western Hupeh: Fang Hsien, cliffs, alt. 1000-1300 m., May 24, 1907 (No. 739).

This neat species is closely related to $R$. Rosthornii Pritzel, of which I have seen the rather imperfect type specimen with fruits. These two species seem very near to $R$. Leveilleanus Fedde and $R$. dumetorum Schneider.

\section{Rhamnus Leveilleanus Fedde, Rep. Sp. Nov. X. 272 (1911).}

Rhamnus Cavaleriei Léveillé in Fedde, Rep. Sp. Nov. X. 148 (1911), nec Léveillé, l. c. IX. 326 (1910).

Western Hupeh: Fang Hsien, side of streams, alt. 1000-2600 m., May 19, 1907 (No. 738; bush 1.5-2 m. tall, flowers greenish-yellow). Kweichou: "Lo Fou” April 1907, J. Cavalerie (No. 3348, type).

Through the kindness of M. Léveillé I have had an opportunity to examine the type specimen of this species, and find that the original description needs a few corrections. The leaves are not quite glabrous, but distinetly pilose on the nerves beneath, and the petals are always present.

Rhamnus Leveilleanus seems to be most closely related to R. Rosthornii Pritzel, which differs chiefly in the generally smaller and narrower leaves which are quite glabrous with the exception of the minute tufts of hairs in the axils of the veins beneath. It is also closely related to $R$. dumetorum Schneider which differs in the under surface of the leaves being pubescent all over and in the puberulous branchlets.

\section{Rhamnus dumetorum Schneider, $\mathrm{n}$. sp.}

Frutex $0.75-2 \mathrm{~m}$. altus, spinosus; ramuli oppositi v. suboppositi, initio olivacei, tenuissime pilosi, annotini biennesque purpurascentes, aequo modo pilosi v. glabri, vetustiores cinereo-brunnei; gemmae parvae, ovatae. Folia plerumque opposita, chartacea, versus apicem ramulorum elongatorum obovato-lanceolata v. rhomboideo-lanceolata, utrinque acuta, 2-3.5 cm. longa, 1-1.4 cm. lata, basi ramulorum minora, elliptica, ovata, obovata v. obovato-rotunda, $0.7-2 \mathrm{~cm}$. longa et $0.4-1.1 \mathrm{~cm}$. lata, in apice ramulorum brevissimorum formis omnibus 
promiscue apparentia, supra viridia, tota facie plus minusve pilosa, subtus pallidiora, saepe tantum ad nervos utrinque 3-4 pilosa et barbellata, margine crenato-denticulata, basi ex parte integra; petioli 3-6 mm. longi, pilosi; stipulae setaceae, quam petioli plerumque breviores. Flores axillares, 2-12 conferti, virides, dioeci, foeminei 2-2.5 mm. longi, sparse pilosi; sepala anguste triangulari-lanceolata, acuta, quam receptacula paullo longiora; petala nulla; staminodia minima filiformia; styli satis bifidi; pedicelli 4-6 $\mathrm{mm}$. pilosi, masculi ignoti. Fructus obovato-globosus, inaequalis, $6 \mathrm{~mm}$. crassus, niger; semina nigrescentia, nitidula, obovalia, ventre plana v. leviter concava, $5.5 \mathrm{~mm}$. longa et $3 \mathrm{~mm}$. erassa, sulco basi tantum aperto instructa.

Western Szech'uan: Tachien-lu, thickets, alt. 2400-3200 m., October 1910 (Nos. 4II3, type).

Rhamnus dumetorum appears to be closely related to $R$. Leveilleanus Schneider and $R$. globosus Bunge and the difference between these species is not very obvious. From $R$. Leveilleanus our new species differs in the minute pubescence of the branchlets, of which the bark, like that of $R$. leptacanthus Schneider, resembles that of a eherry-tree, in the more dentate, not distinctly crenate leaves, with somewhat longer petioles and shorter stipules, in the pubescent flowers and the differently colored seed with a very short furrow. From $R$. globosus it may be distinguished by the finer and shorter pubescence of branchlets and leaves, the latter being of a different shape, but with the same serration.1

Rhamnus rugulosus Hemsley in Jour. Linn. Soc. XXIII. 129 (1886). - Schneider, Ill. Handb. Laubholzk. II. 276, fig. $196 \mathrm{k}-1$, 198 a-d (1909).

Western Hupeh: Hsing-shan Hsien, thickets and woodlands, alt. 300-1300 m., common, May 4, June 5, 1907 (No. 3326; bush 1-2 m., flowers yellow); Ichang and the immediate neighbourhood, April

1 To this species we refer as a variety No. 4096 which Mr. Schneider considered a possible new species closely related to $R$. hypochrysus Schneider and $R$. leptophyllus Schneider.

Rhamnus dumetorum, var. crenoserratus Rehder \& Wilson, n. var.

A typo recedit foliis $4-7 \mathrm{~cm}$. longis et $2.5-3.5 \mathrm{~cm}$. latis manifestius crenatoserratis plerumque 5 -nerviis, ramulis minutius pilosulis.

Western Szech'uan: Tachien-lu, thickets, alt. 2700-3300 m., October 1910 (No. 4096; bush 1.5-3 m. tall, fruit black).

This variety agrees with the type specimen in all its characters except in the size of the leaves and in its somewhat slighter pubescence. Young plants raised at the Arnold Arboretum from seeds of the two numbers are still more alike, the difference in the size of the leaves being less marked, as the leaves of the variety do not exceed $4 \mathrm{~cm}$. in length, while the leaves of the typical form are up to $2.5 \mathrm{~cm}$. in length. In size and shape of the leaves the variety resembles $R$. leptophyllus Schneider, but this species is easily distinguished by its glabrous leaves.

A. R. and E. H. W. 
1900 (Veitch Exped. Nos. 497, 497ª); same locality, A. Henry (Nos. $\left.1689,3611,3611^{a}, 3609,4560,3593^{a}\right)$. Szech'uan: Nan-ch'uan, $A$. von Rosthorn (Nos. 2293, 2300).

The type was sent by A. Henry from Hupeh, but unfortunately Hemsley cites no number. The branchlets and leaves are alternate on all the specimens I have seen. This species is apparently related to $R$. hypochrysus Schneider, from which it can be at once distinguished by its longer petioles and the different serration of the leaves.

Rhamnus leptophyllus Schneider in Notizbl. Bot. Gart. Berlin, 1908, 77; Ill. Handb. Laubholzk. II. 285, fig. $196 \mathrm{v}-\mathrm{w}, 198 \mathrm{e}-\mathrm{h}$ (1909).

Western Hupeh: north and south of Ichang, thickets, alt. 3001300 m., abundant, May 6, October 1907 (No. 42I, bush 0.6-2 m. tall; flowers yellowish, fruit black); same locality, April and September 1900 (Veitch Exped. No. 356); Hsing-shan Hsien, thickets, alt. 13002000 m., common, May 5, October 1907 (Nos. 4Io, 433; bush 2-2.5 m., flowers yellow, fruit black); Changyang Hsien, thickets, alt. 13002000 m., May and November 1907 (No. 475, in part; bush 1-2.5 m., flowers yellowish, fruit black); Changlo Hsien, thickets, alt. 13002000 m., November 1907 (No. 475, in part; bush 1-2.5 m., fruit black); Fang Hsien, thickets, alt. 2000-2300 m., November 1907 (No. 6r8; bush $2 \mathrm{~m}$., fruit black); Ichang and neighbourhood, A. Henry (Nos. $3407^{\text {a }}, 3407,1493$, type). Western Szech'uan: Mt. Omei, June 1904 (Veitch Exped. No. 4779).

Wilson's specimens differ a little from the type in their glabrous female flowers, but otherwise the differences between them are not very obvious. The species is certainly rather nearly related to $R$. parvifolius Bunge. The type was collected in Hupeh by Dr. Henry (No. 1493). The female flowers have narrow and acute sepals, no petals and only very reduced staminodes. The seeds which are flatter or even concave on the inner surface are broader than the seeds $I$ have seen of $R$. parvifolius Bunge, which are obovate-oblong.

Rhamnus iteinophyllus Schneider in Notizbl. Bot. Gart. Berlin, 1908, 76; Ill. Handb. Laubholzk. II. 281, fig. 198 i-k, 196 n (1909).

Ad descriptionem addenda: folia ramulorum sterilium lanceolata, apice in acumen longum extensa, ad $8 \mathrm{~cm}$. longa et ad $2 \mathrm{~cm}$. lata, ramulorum abbreviatorum vetustiorum variabilia, minora ovatoelliptica v. obovato-elliptica, $3.5-5 \mathrm{~cm}$. longa et $2-2.5 \mathrm{~cm}$. lata, majora oblanceolata, basi acuta v. acuminata, apice acuta, ad $8 \mathrm{~cm}$. longa et ad $2.5 \mathrm{~cm}$. lata, utraque facie distinctius quam in typo pubescentia; petioli foliorum ramulorum abbreviatorum longiores, ad $17 \mathrm{~mm}$. longi. Fructus maturus nigro-violaceus; semina obovato-oblonga, $6 \mathrm{~mm}$. longa, olivacea, dorso sulco angusto aperto instrueta. 
Western Hupeh: Hsing-shan Hsien, thickets, alt. $1600 \mathrm{~m}$., June 1907 and October 1907 (No. 3325; bush 1.5 m., fruit black); without locality, A. Henry (No. $5915^{\mathrm{c}}$, type).

The branch with very young fruits of Wilson's number differs from the type only in its more pilose leaves. The branch with ripe fruits shows the differences described above. The species may be most nearly related to $R$. virgatus Roxburgh.

Rhamnus utilis Decaisne in Compt. Rend. Acad. Sci. Paris, XLIV. 1141 (1857). - Rondot, Vert de Chine, 141, t. 1 (1857). - Koehne, Deutsche Dendr. 394 (1893). - Schneider, Ill. Handb. Laubholzk. II. 289, fig. $197 \mathrm{t}-\mathrm{w}, 199 \mathrm{l}$ (1909).

Western Hupeh : north and south of Ichang, roadsides, alt. 301300 m., abundant, April and October 1907 (No. 3333 ${ }^{\mathrm{s}}$; bush 0.6-2 m. tall, fruit black, leaves used in making a green dye); Fang Hsien, ravines, alt. 1000-1600 m., May 24, June and September 1907 (Nos. 623, in part, 333I; bush 1-2.5 m. tall, fruit black); Changyang Hsien, thickets, alt. 1000-1600 m., May 1907 (No. 3332; bush 1-2.5 m., flowers greenish-yellow); Hsing-shan Hsien, thickets, alt. 300-1300 m., abundant, May, November 1907 (Nos. 3333, 623, in part; bush 0.6-1.5 m. tall, flowers greenish, fruit black); same locality, October 1907 (No. 432; folia ad 15:6 cm. magna); Nanto, April 28, 1900 (Veitch Exped. No. 394); Ichang and neighbourhood, A. Henry (No. 3606, 6018; without precise locality, April 1900 (Veitch Exped. No. $217^{2}$ ). Chekiang: vicinity of Ningpo, 1908, D. Macgregor.

The original description of Decaisne is too short to make it possible to recognize the species meant by the author, and I have not yet seen the plate given in Rondot's book, but after all I think that the interpretation given by Koehne, Deutsche Dendr. 394 (1893), and by me, l. c., may be correct. ${ }^{1}$ Hemsley unites the species with $R$. davuricus Pallas to which it is certainly nearly related, but the large leaves with short petioles, which become yellow-green in drying, distinguish it at once from $R$. davuricus Pallas, $R$. catharticus Linnaeus and $R$. japonicus Maximowicz. The rather large yellow flowers and the fruits are very numerous and densely crowded at the base of the short branchlets. I have not yet seen a fully ripe seed, but they seem to have a distinct but closed furrow.

There are some forms, which I cannot yet determine with sufficient certainty, viz. Wilson's Veitch Exped. No. 649 from Eastern Szech'uan, Wushan Hsien, May 1900 , shrub $1 \mathrm{~m}$. tall. Some of the young leaves resemble those of $R$. Wilsonii Schneider, but I think the No, 649 may belong to $R$. utilis.

Rhamnus Wilsonii Schneider, n. sp.

Frutex ad $1.5 \mathrm{~m}$. altus, ut videtur paullo spinosus; ramuli alterni,

${ }^{1}$ We have compared Rondot's plate with the specimens referred by Schneider to $R$. utilis and believe that his determination is correct.

A. R. and E. H. W. 
annotini glabri, claro-brunnei, in sicco striati, vetustiores cinereobrunnei v. deinde cinerascentes, leviter rimosi; gemmae breviter ovatae, petiolis aequilongae, squamis paucis basi nigrescentibus apice brunneis margine ciliatis obtectae. Folia opposita v. subopposita, chartacea, ovato-lanceolata, basi acuta, apice distincte acuminata, supra viridia, glabra, costa basim versus incisa, subtus flavo-viridia, glabra v. ad nervos utrinsecus 4-5 elevatos ascendentes inter se haud parallelos sparse pilosa, margine distincte serrato-dentata dentibus satis distinctis apice leviter incumbentibus callosis, majora 6-11 cm. longa, 2-4 $\mathrm{cm}$. lata, versus basim ramulorum minora, $2-4 \mathrm{~cm}$. longa et 1-2 cm. lata, lanceolata, acuta; petioli tantum 2-4 mm. longi, supra late sulcati, vix pilosi. Flores ignoti. Fructus fasciculati, basi ramulorum conferti, obovato-globosi, circiter ad $9 \mathrm{~mm}$. longi et 6-7 $\mathrm{mm}$. crassi; pedicelli glabri, 5-6 mm. longi; pyrenae 2-3, dehiscentes?; semina obovato-oblonga, nigro-olivacea, circiter $6.5 \mathrm{~mm}$. longa et 3 $\mathrm{mm}$. crassa, dorso convexa, sulcata suleo a basi ad medium aperto cartilagineo-marginato, ventre leviter concava.

Kiangsi: Kuling, near a temple, alt. 1600 m., July 29, 1907 (No. I680).

This is in every respect a well marked species, which may be related to $R$. utilis Decaisne or possibly to R. hupehensis Schneider.

There is a flowering specimen from Szech'uan, collected by Dr. A. Henry in 1885-88, No. 5601, the leaves of which resemble those of $R$. Wilsonii. They have the same shape and serration and the same short petioles. The male flowers, however, have longer pedicels (up to $12 \mathrm{~mm}$.) and closely resemble those of $R$. utilis. Wilson's Nos. 217 and 649 have the same leaf characters and pistillate flowers with shorter pedicels $(5-7 \mathrm{~mm}$.).

\section{CLAVIS SPECIERUM ORIENTALI-ASIATICARUM HIMALAYENSIUMQUE.}

Flores hermaphroditi, pentameri, styli indivisi; semina dorso haud suleata. Folia semper alterna. (Subgenus Frangula.)

Folia adulta subtus tota facie tomento cano obtecta, margine fere integra, nervis utrinque $8-12 \ldots . . . . .1 .2$. Henryi.

Folia nunquam subtus tota facie tomentella sed sparse pubescentia et plerumque tantum ad nervos puberula, fere toto margine distincte crenata, nervis utrinque 5-9 ..... 2. R. crenatus.

Flores (an semper?) dioeci, pentameri v. plerumque tetrameri; styli 2-3-fidi; semina dorso sulcata (sulco interdum clauso v. tantum ima basi aperto). Folia alterna subopposita v. opposita. (Subgenus Eurhamnus, sensu latissimo.)

Flores pentameri. (Confer etiam No. 16, foliis magnis, membranaceis, nervis numerosis inter se parallelis distinctum).

Stipulae gracillimae, sed plus minusve persistentes et pungentes.

Folia parva v. perparva, diversiformia, vix ad $4 \mathrm{~cm}$. longa. Flores in axillis ad 1-2

3. $R$. heterophyllus. 
Folia satis magna, majora 7-14 $\mathrm{cm}$. longa. Inflorescentia cymosa, ad 2.5 cm. longa . . . . . . . . . . . . 4. R. Esquirolii. Stipulae nunquam pungentes, saepissime mox deciduae.

Inflorescentia elongata, eymoso-paniculata, pseudo-racemosa, saepe foliis quam cetera folia distincte minoribus instructa; flores petaliferi.

Inflorescentia distincte late cymoso-paniculata. Ramuli lenticellis multis prominentibus obtecti, eximie verruculosi. 5. $R$. paniculiflorus.

6. R. tonkinensis.

Inflorescentia haud late paniculata (v. ramuli laeves, non verrucosi), sed plus minus cymoso-racemosa.

Folia etiam juvenilia subtus tantum ad nervos puberula v. glabra.

Flores in inflorescentia satis gracili, cymoso-racemosa v. subpaniculata . . . . . . . . . 7. R. nipalensis.

Flores fasciculati in axillis foliorum secundum ramos laterales plus minus elongatos ex axillis foliorum magnorum nascentes, pseudoracemos foliatos formantes . . . . . . . 8. R. Wightii.

9. R. formosanus.

Folia semper subtus tota facie tomentella. Inflorescentia ut in specie praecedente. . . . . . . . . . . 10. R. triqueter.

Inflorescentia nunquam elongata sed flores tantum in axillis foliorum normalium magnorum fasciculati; flores (an semper?) apetali. Folia apice satis obtusa . . . . . . . . . 11. R. Bodinieri. Flores saepissime tetrameri.

Folia coriacea, sempervirentia.

Folia, majora 8-16 cm. longa; petioli breves, vix plus quam $7 \mathrm{~mm}$. longi.

Folia majora 4.5-7.5 cm. longa; petioli 4-10 mm. longi.

12. $R$. Hemsleyanus.

13. R. Arnottianus.

Folia chartacea v. membranacea, ut videtur semper decidua.

Folia brevissime petiolata (petioli 2-5 mm. longi), utrinque nervis ultra 10 (saepissime 12-20) distincte parallelis instructa.

Folia oblongo-elliptica v. fere late lanceolata, nervis utrinque 12-18. Gemmae parvae, obovatae. Pedicelli tantum ad $5 \mathrm{~mm}$. longi.

14. R. Sargentianus.

Folia late elliptica, nervis utrinque circiter 20 v. ultra. Gemmae fusiformes. Pedicelli ad $3.5 \mathrm{~cm}$. longi ...... 15. R. costatus. Folia longius petiolata v. nervis utrinque paucioribus haud semper inter se distincte parallelis instructa.

Folia ramulique distincte alterna, nervis lateralibus inter se satis parallelis utrinque 5-11. Frutices (an semper?) inermes.

Folia ovato-elliptica, nervis utrinque 8-11 instructa, 7-13 $\mathrm{cm}$. longa. Flores pentameri, apetali. . . . . . . . . 16. R. purpureus. Folia ovata v. obovata, nervis utrinque $5-8$ instructa, 6-10 $\mathrm{cm}$. longa.

17. $R$. hupehensis.

Folia ramulique plerumque opposita v. subopposita, raro distincte alterna, nervis primariis vix inter se distincte paralleli sed saepissime versus apicem semper approximati, fere campylotropi. Frutices plerumque spinosi.

Folia perparva v. parva, plerumque inter 1-3 cm., etiam maxima vix ultra $4 \mathrm{~cm}$. longa, nervis utrinque $2-5$ (confer etiam sub " folia majora "), v. folia lineari-lanceolata, longiora.

Folia lineari-lanceolata ........ 18. R. erythroxylon. Folia nunquam lineari-lanceolata. 
Folia spathulata v. oblanceolata v. obovato-lanceolata, apice obtusa, tantum basim versum et petioli tenuissime pilosa. Ramuli vetustiores cortice colore cerasi obtecti.

19. R. Rosthornii. 20. R. leptacanthus.

Folia obovata, rotunda, obovato-rhomboidea v. obovato-oblonga, apice saepissime acuta v. distinctius pilosa.

Folia saepissime rotundata, vix duplo longiora quam lata, superne v. utrinque tota facie pilosa. Semina subglobosa, paullo longiora quam crassa, tantum basim versus sulco aperto brevi instructa ...... 21. R. globosus.

22. R. Taquetii. 23. R. Meyeri.

Folia fere semper obovato-oblonga v. oblongo-rhomboidea, 2-3-plo longiora quam lata. Semina oblonga, sulco dorsali elongato aperto instructa . . . 24. R. Leveilleanus.

25. $R$. dumetorum.

Folia (certe magna) majora, nervis utrinque saepe $5 \mathrm{v}$. ultra.

Folia etiam matura utrinque pilosa v. pubescentia, ovata, obovata v. ovato-rotunda. Flores pedicellique fruetiferi pilosi. Stipulae petiolis satis longis plus quam duplo breviores. (Confer etiam $R$. hypochrysus et $R$. leptophyllus, var. milensis).

Folia plerumque ovato-rotunda, fere toto margine satis distincte crenata v. crenato-serrata . . . . 26. R. koraiensis.

Folia plerumque ovata v. obovata, saepissime tantum supra medium versus apicem satis breve denticulata.

27. R. rugulosus.

Folia matura glabra v. forma diversa v. flores glabri v. petioli stipulis vix v. paullo longiores.

Folia fere toto margine argute et angustissime serrata dentibus. acuminatis. . . . . . . . . . 28. R. argutus.

Folia nunquam hoe modo serrata.

Petioli foliorum ramulorum elongatorum et brevium satis elongati, saepissime 1/4-3/5 laminae aequantes.

Ramuli vetustiores cortice colore cerasi obtecti, laeves. Folia ovato-rhomboidea, supra breviter pilosa. Flores glabri; pedicelli $1 \mathrm{~cm}$. longi . . . . . . . 29. R. Schneideri.

Ramuli vetustiores fere semper einerascentes, vix laeves, v. planta ceteris signis diversa.

Folia ramulorum elongatorum (haud semper etiam brevium) satis late obovata, obovato-elliptica v. oblongo-obovata, v. rhomboidea et rhomboideo-oblonga, vix 2-21/2-plo longiora quam lata . . . . . 30. R. parvifolius.

31. R. leptophyllus.

Folia ramulorum elongatorum oblonga, oblongo-elliptica, elliptica v. obovato-lanceolata, 2.5-4-plo longiora quam lata.

Ramuli initio pubescentes $\vee$. puberuli. Semina dorso suleo elongato distincte aperto instructa.

32. R. virgatus.

33. R. hirsutus.

Ramuli ab initio glabri v. glaberrimi. Semina dorso sulco (an semper?) clauso instructa. 
Folia semper basim versus sensim in petiolum attenuata.

34. $R$. japonicus.

Folia longiora plerumque basi obtusa $v$. subcordata, tantum leviter in petiolum subito producta.

35. R. davuricus.

Petioli foliorum ramulorum elongatorum satis breves, tantum 1/6-1/10 laminae aequantes.

Folia lanceolata, saliciformia $\nabla$. persiciformia, 4.5-11 cm. longa et $1-2.8 \mathrm{~cm}$. lata . . . . . 36. R. iteinophyllus.

37. R. hamatidens.

Folia haud distincte lanceolata, latiora.

Folia subtus glabra $\mathbf{v}$. tantum ad nervos sparse pilosa et barbulata. Ramuli ab initio glabri.

Folia ovata v. obovata, 2-21/4-plo longiora quam lata.

38. $R$. lamprophyllus.

Folia ovato-lanceolata v. elliptico-oblonga, 2.5-4-plo longiora quam lata.

Folia elliptico-oblonga, apice acuta, petioli 5-12 $\mathrm{mm}$. longi . . . . . . . 39. R. utilis.

Folia ovato-lanceolata, apice acuminata, petioli 2-4 mm. longi . . . . . . . 40. R. Wilsonii.

Folia subtus v. utrinque distincte pubescentia, ramuli puberuli v. pubescentes .... 41. R. hypochrysus.

\section{ENUMERATIO SPECIERUM ORIENTALI-ASIATICARUM HIMALAYENSIUMQUE.}

\section{Rhamnus Henryi, Schneider, n. sp.}

Arbor ad $3.75 \mathrm{~m}$. alta; ramuli initio sparse v. vix pilosi, in sicco fusci, deinde glabri, ut videtur nigrescentes; gemmae nudae, hirsutae. Folia alterna, chartacea (v. subcoriacea?), ovata v. ovato-oblonga, basi obtusa v. acuta, apice sensim acuminata, margine indistincte crenato-dentata, dentibus brevibus distantibus callosis, supra viridia, ad nervos puberula, costa incisa, subtus tota facie tomentulosa, nervis utrinque 8-12 prominulis, costa elevata paullo glabrescenti, majora 11$13.5 \mathrm{~cm}$. longa, 4-5 cm. lata, minora (ramulorum floriferorum) $5.5-8.5 \mathrm{~cm}$. longa, 1.7-3 cm. lata; petioli pilosi, superne sulcati, 9-18 $\mathrm{mm}$. longi. Flores non vidi. Fructus fasciculati in axillis foliorum minorum secundum ramos laterales plus minusve elongatos qui ex axillis foliorum magnorum nascunt, pseudo-racemos foliatos formantes v. in apice pedunculi nudi cymosi, rubri, obovales, circ. ad $7 \mathrm{~mm}$. crassi; pedicelli pilosi, circiter 5-6 mm. longi; semina 2-3, obovalia, laevia, olivacea, basi paullo excisa, dorso leviter convexa, ventre fere plana, circiter $5 \mathrm{~mm}$. longa.

Yunnan: Mengtze, S. E. Mts., alt. 2800 m., A. Henry (No. 9185; tree 3.75 m. tall; red fruit).

Judging by the naked buds and by the seeds this species belongs to the subgenus Frangula. As the material is rather seanty it is difficult to describe the inflorescence accurately but it certainly represents a very well marked species.

2. Rhamnus crenatus Siebold et Zuccarini. See also page 232 .

There are three species, which may be very closely related to $R$. crenatus or represent only varieties of it, namely $R$. oreigenes Hance in Jour. Bot. VII. 114 (1869); VIII. 312 (1870); R. pseudofrangula Léveillé in Fedde, Rep. Sp. Nov. X. 473 (1912) and $R$. cambodianus Pierre apud Pitard in Lecomte, Fl. Gén. IndoChine, I. 926 (1912). Of the last I have not yet seen a specimen, but from the 
description I can find no sufficient difference. Of the two other species I have had the type specimens before me. The leaves of Hance's specimen (Herb. Hance, No. 14113), which unfortunately is not a very good one, have a rather truncate apex with a short suddenly produced acumen. The same shape I find in Faurie's No. 513 (July 1906) from Korea, which in every respect resembles the type of $R$. oreigenes. But some of the leaves of No. 513 with a more prominent acumen are much like the leaves of $R$. pseudofrangula Léveille, the type of which was collected in Kweichou (" environs de Kong-Yang, mont du collège, le long de l'aqueduc; Ye Mou, Yang-tse, 10 juin 1897 ") by Em. Bodinier (No. 1620). These flowering branches with rather young leaves seem to me insufficient to make it possible to decide, if Léveillé's species may be identical with $R$. oreigenes or represent a variety of it or even a good species. Without having seen better and more copious material of both species and without having been able to compare all these forms with those of $R$. crenatus in every detail I cannot form an opinion of this group of forms. Because Léveillé has given a very short and bad description, comparing it only with $R$. Frangula Linnaeus, which widely differs, a new description of the type specimen of $R$. pseudofrangula may be added here:

Frutex magnus; ramuli initio ferrugineo-hirsuti, annotini paullo glabreseentes, in sicco fuscescentes, vetustiores cinerascentes, subglabri, lenticellis numerosis sed paullo visibilibus obtecti; gemmae nudae, hirsutae. Folia alterna, juvenilia crasse membranacea, obovato-elliptica, basi obtusa v. subrotunda, apice obtusa sed subito in acumen distinctum $2-5 \mathrm{~mm}$. longum producta, margine crenulatoserrata dentibus satis angustis callosis, supra ad nervos pilosa, subtus praesertim nervis utrinque 7-9 prominentibus, distinetius pubescentia v. hirsuta, 3-5 $\mathrm{cm}$. longa, $1.5-2.5 \mathrm{~cm}$. lata; petioli ad $6 \mathrm{~mm}$. longi, hirsuti. Inflorescentia axillaris, in apice pedunculi nudi hirsuti $1-10 \mathrm{~mm}$. longi cymosa, fasciculis 6-10-floris; pedicelli $2-3 \mathrm{~mm}$. longi, pilosi; flores 5 -meri, hermaphroditi, ab illis $R$. crenatae vix diversi, extus pilosi; sepala late-triangularia, receptaculis vix v. paullo longiora; petala sepalis fere duplo breviora, late obovalia, apice satis emarginata, basi breve unguiculata, staminibus sublongiora; fructus non visus.

3. Rhamnus heterophyllus Oliver. See also p. 232.

This species may be most closely related to $R$. procumbens Edgeworth in Trans. Linn. Soc. XX. 43 (1846). - Lawson in Hooker, Fl. Brit. Ind. I. 640 (1875), of which I have failed to see a specimen. The author clearly says: stipulae persistentes . . ., and the whole description agrees with the specimens of $R$. heterophyllus which I have had before me. $R$. procumbens inhabits the northwestern Himalaya.

4. Rhamnus Esquirolii Léveillé. See p. 233.

5. Rhamnus paniculiflorus Schneider. See p. 233.

6. Rhamnus tonkinensis Pitard in Lecomte, Fl. Gén. Indo-Chine, 928, fig. 117 (4) (1912).

Tonkin.

According to the description this species may be closely related to $R$. paniculiflorus by its inflorescence, of which the author says: "fleurs groupées par fascicules de 2-8, sur des axes feuillés très allongés et ramifiés, atteignant 10-25 cm." It seems to differ from our new species by its not distinctly verrucose branchlets, its more obtuse leaves and its not apiculated anthers.

7. Rhamnus nipalensis Wallich apud Lawson in Hooker f., Fl. Brit. Ind. I. 640 (1875).

Ceanothus napalensis Wallich in Roxburgh, Fl. Ind. II. 375 (1824). 
Nepal to Khasia (and eastern Bengal).

Unfortunately I have not yet been able to see a type specimen of this species, which seems often misunderstood by different authors. Wallich's description of the inflorescences is as follows: "Flowers small, green, pubescent, fascicled, shortpeduncled, disposed in slender, terminal racemes on the naked branches, interspersed with a number of small, lanceolate floral leaflets, the whole forming a branchy panicle, which as the fruits enlarge changes to numerous axillary racemes." The branches are described as "round, dotted and scabrous." The two specimens before me, which were determined and distributed by J. D. Hooker and J. Thomson in 1859 as $R$. nipalensis came from Sikkim and Khasia. The Sikkim specimen bears female flowers and fruits, both arranged in axillary pseudo-racemes; the branchlets are smooth. The second specimen from Khasia bears young fruits in subpaniculate racemes and the branchlet is provided with many small lentjcels, which are not distinctly elevated.

Other specimens from east Bengal (Herb. Griffith, No. 2032), Assam (Dr. Prain's Collector No. 508, 1896) and Upper Burma (Sheik Mokim, in 1897) bear young fruits in a distinct paniculate inflorescence, but the branchlets are almost smooth. These three specimens might possibly better belong to $R$. tonkinensis Pitard than to $R$. nipalensis, unless these two species really represent only varieties of one. It is possible, that $R$. javanicus Miquel (Fl. Ind. Bot. I. pt. 1, 646 [1855]) from Java also belongs to $R$. nipalensis, as indicated by Koorders (Excursionsfl. Java, II. 554 (1912), but of this species I have not yet seen sufficient material.

8. Rhamnus Wightii Wight \& Arnott, Prodr. Fl. Ind. I. 164 (1834). - Lawson in Hooker f., Fl. Brit. Ind. I. 639 (1875). - Trimen, Handb. Fl. Ceylon, I. 283 (1893),

East India: western peninsula, Ceylon.

In this species the fascicles of flowers are borne in the axils of smaller leaves along rather short branchlets which appear in the axils of the normal large leaves. These early flowering branchlets are different from the inflorescence in the foregoing three species.

9. Rhamnus formosanus Matsumura in Tokyo Bot. Mag. XII. 23 (1898).Matsumura \& Hayata in Jour. Coll. Sci. Tokyo, XXII. 88, t. 8 (Enum. Pl. Formos.) (1906).

Formosa.

This species seems to me closely related to $R$. Wightii, but I have not yet seen any specimens.

10. Rhamnus triqueter Wallich apud Lawson in Hooker f., Fl. Brit. Ind. I. 639 (1875).

\section{Ceanothus triquetra Wallich in Roxburgh, Fl. Ind. 376 (1824).}

Western Himalaya.

The description of Wallich is short and insufficient. I have had before me one of his specimens numbered $4265^{\mathrm{b}}$ from Shringapur, with which fully agree other specimens from the northwestern Himalaya, namely Thomson, in 1859, 2-5000 ft.; G. King, in 1869, near Mussoorie. The dried leaves are rather yellow. The petals of the female flowers are broadly obovate and emarginate, as Hooker describes them, and the seeds have the same broad dorsal furrow as those of the allied species Nos. 4-9, which, I think, form a special group within the genus.

11. Rhamnus Bodinieri Léveillé in Fedde, Rep. Sp. Nov. X. 473 (1912).

Descriptio emendata: Frutex $0.75-1.5 \mathrm{~m}$. altus; ramuli juniores hirsutotomentosi, striato-angulati, vetustiores nigrescentes, vix glabrescentes, rotundi, 
rugulosi; stipulae $3-4 \mathrm{~mm}$. longae, hirsutae, deciduae. Folia alterna, sempervirentia, coriacea, oblonga, elliptica v. elliptico-lanceolata, basi obtusa v. acuta, apice acuta, brevissime mucronulata, margine (in sicco ex parte revoluto) circumcirca dentata, dentibus brevissimis calloso-mueronulatis distantibus, minima 1-3.5 cm. longa, $0.7-1.5 \mathrm{~cm}$. lata, maxima $5-10 \mathrm{~cm}$. longa et $1.2-4.5 \mathrm{~cm}$. lata, supra intense viridia, tantum ad costam valde impressam pilosa, subtus (in sicco) pallidiora, flavescentia, glabra $\mathrm{v}$. in axillis nervorum ad costam paullo barbata, nervis primariis utrinque $5-6$, plus minusve elevatis; petioli $3-10 \mathrm{~mm}$. longi, pilosi. Pseudo-umbella axillaris, sessilis, 3-7-flora; flores virides, parvi, $2-3 \mathrm{~mm}$. longi; pedicelli satis graciles, pilosi, $2-5 \mathrm{~mm}$. longi; sepala triangulari-lanceolata, satis acuta, basi pilosa, margine ciliata; petala ut videtur deficientia; stamina ovariaque sepalis dimidio breviora; ovaria apice stigmatibus distinctis elongatis coronata, basi disco distincto eircumeineta. Fructus maturus niger, vix $5 \mathrm{~mm}$. crassus; semina oblonga, dorso sulco distincto aperto instructa.

Yunnan: Mengtze, rocky mountains, alt. $2600-2800 \mathrm{~m}$, A. Henry (No. 10814 ; spreading shrub $0.75 \mathrm{~m}$. tall, flowers green; No. $10814^{\mathrm{a}}$; shrub $1 \mathrm{~m}$. tall, fruits black when ripe);. Kweichou: "Environs du Tsin Gay, rochers au bord de la rivière à Ché-Tiou-Tchay," June 27, 1899, Émile Bodinier (No. 2697, type; small shrub). ? East Himalaya: Herb. Griffith No. 2029).

After having described the above numbers of Henry's collection as a new species, I have recieved through the kindness of the author the type specimens of R. Bodinieri. At the first glance I saw that this species resembled Henry's numbers 10814 and $10814^{\mathrm{a}}$ and a detailed comparison convinced me, that there are only very slight differences between them in the pubescence of the branchlets and in the size of the leaves. But the leaves are larger as indicated by Léveillé and measure up to $4 \mathrm{~cm}$. in length and $1.5 \mathrm{~cm}$. in width.

Rhamnus Bodinieri Léveillé, f. silvicola Schneider, n. forma.

A typo recedit foliis majoribus, planioribus, ad $10 \mathrm{~cm}$. longis et $4.5 \mathrm{~cm}$. latis pedicellis longioribus, ad $10 \mathrm{~mm}$. longis.

Yunnan: Mengtze, woods, alt. $2200 \mathrm{~m}$. (No. $10464^{\mathrm{a}}$; shrub $1.25 \mathrm{~m}$. tall, fruits black); No. $10464^{\mathrm{a}}$; shrub $1 \mathrm{~m}$. tall, flowers green).

At first sight Henry's numbers 10464 and $10464^{\mathrm{a}}$ look very different from the type, but they seem to represent only a form of shadier places with larger and flatter leaves.

This species and No. 13 and 14 seem to form another separate group within the genus characterized by its leathery leaves, sessile flower-fascicules and apetalous flowers.

12. Rhamnus Hemsleyanus Schneider. See p. 234.

13. Rhamnus Arnottianus Gardener in Thwaites, Enum. Pl. Zeylan. 74 (1858). - Lawson in Hooker f., Fl. Brit. Ind., I. 638 (1875).

Ceylon.

In the leaves this species resembles a good deal $R$. Wightii, but it is well distinguished by the character given in the key.

\section{Rhamnus Sargentianus Schneider. See p. 235.}

15. Rhamnus costatus Maximowiez in Mém. Acad. Sci. St. Pétersbourg, sér. 7, IV. No. XI. 17, t. fig. 1-14 (Rhamn. Or.-As.) (1866). - Schneider, Ill. Handb. Laubholzk. II. 276, fig. $191 \mathrm{~m}$ (1909).

Japan.

See the note under R. Sargentianus, p. 235. 
16. Rhamnus purpureus Edgeworth in Trans. Linn. Soc. XX. 44 (1846). Walpers, Ann. I. 193 (1848). - Lawson in Hooker f., Fl. Brit. Ind. I. 639 (1875). - Schneider, Ill. Handb. Laubholzk. III. 271 (1909).

Western Himalaya.

This species does not belong to the Subgenus Frangula as indicated by the author. It represents a member of the group suggested by me under $R$. Sargentianus from which it differs in the shape of the leaves and in the pentamerous flowers.

17. Rhamnus hupehensis Schneider. See p. 236.

18. Rhamnus erythroxylon Pallas, Reise Russ. Reich. III. App. 722 (1776). - Maximowicz in Mém. Acad. Sci. St. Pétersbourg, sér. 7, IV. No. XI. 7 (Rhamn. Or.-As.) (1866). - Schneider, Ill. Handb. Laubholzk. II. 278 (1909).

Eastern Sibiria, northern Mongolia.

I have not yet seen any Chinese specimens of this species.

19. Rhamnus Rosthornii Pritzel, See p. 236.

20. Rhamnus leptacanthus Schneider. See p. 236.

21. Rhamnus globosus Bunge in Mém. Sav. Êtr. Acad. Sci. St. Pétersbourg, II. 88 (Enum. Pl. Chin. Bor. 14) (1833). - Schneider, Ill. Handb. Laubholzk. II. 284, fig. $195 \mathrm{f}-\mathrm{f}^{3}, 196 \mathrm{q}-\mathrm{r}(1909)$.

Rhamnus virgatus, var. apricus Maximowicz in Mém. Acad. Sci. St. Pétersbourg, sér. 7, IV. No. XI. 13 (Rhamn. Or.-As.) (ex parte) (1866).

Rhamnus tinctorius Hemsley in Jour. Linn. Soc. XXIII. 129 (ex parte, haud Waldstein \& Kitaibel) (1886).

Chili, Shensi, Chekiang.

In my Handbook I have attempted to interpret this speeies correctly, but this is difficult as I have not seen the type specimen of Bunge. I cannot agree, however, with Maximowicz, who unites Bunge's species with $R$. virgatus Roxburgh, and also with $R$. polymorphus Turczaninow. According to Bunge's description I refer to $R$. globosus the distinctly pubescent forms, as does Hemsley under the name of $R$. tinctorius, which is certainly a different species. See also the note under R. parvifolius, p. 250. Whether R. chlorophorus Decaisne (in Compt. Rend. Acad. Sci. Paris, XLIV. 1140 [1857]) also belongs to R. globosus, as indicated by Hemsley, I cannot decide, as the deseription of Decaisne is incomplete and I have not yet seen the figure of this species in Rondot, Vert de Chine. t. 2.1

22. Rhamnus Taquetii Léveillé, Mss. in Herb. Mus. Palat. Vindob.

Prunus Taqueti Léveillé in Fedde, Rep. Sp. Nov. VII. 197 (1909)²

Frutex spinosus, valde ramosus, ad 1-metralis; ramuli initio tenuiter pilosi, deinde glabri, vetustiores crassi, cortice laevi olivaceo v. fere colore corticis cerasi obtecti; gemmae parvae, ovatae. Folia decidua, membranacea, plus minusve alterna, plerumque apice ramulorum brevissimorum conferta, perparva, ovata, obovata, obovato-oblonga $\mathrm{v}$. fere rotundata, basi plerumque acuta, sed interdum distincte rotunda, apice rotunda v. obtusa v. saepe subito in acumen breve producta, superne plus minusve distincte pilosa, subtus saepissime glabra, tantum in axillis nervorum utrinsecus 1-4 satis adscendentium barbata, margine distincte et anguste crenato-

1 After comparing the specimens of $R$. globosus in the Herbarium of the Arnold Arboretum with the plate in Rondot's work, we believe that $R$. chlorophorus must be referred to $R$. globosus as a synonym.

${ }^{2}$ See also Koehne in Sargent, Pl. Wilson. I. 276 (1912). A. R. and E. H. W. 
serrata dentibus incumbentibus callosis, $1-2.2 \mathrm{~cm}$. longa, $0.6-1.5 \mathrm{~cm}$. lata; petioli graciles, superne sulcati, pilosi, $3-6 \mathrm{~mm}$. longi; stipulae pilosae, petiolis subaequilongae v. paullo breviores, plus minusve persistentes. Flores axillares, singuli v. bini, tetrameri, glabri, dioeci, tantum masculos vidi; sepala lanceolata, triangularia, sensim acuminata, receptaculo fere duplo longiora; petala lanceolata, sepalis fere duplo breviora, staminibus sublongiora; ovaria perparva, reducta. Fructus obovato-globosus, circiter $5 \mathrm{~mm}$. crassus; pedicelli glabri, 4-7 mm. longi; semina 2, obovata, laevia, dorso sulco tantum basi aperto instructa.

Korea: Hallaisan, alt. 1800 m., July 1907, U. Faurie (No. 1890, type; bush $1 \mathrm{~m}$. tall); Quelpaert, " in sylvis Yeng sil" (?). alt. 1000 m., August 17, 1908, Taquet (No. 1210); “ in sylvis Hallaisan," June 1909, Taquet (No. 3081).

This seems to be a dwarf, very branched, alpine species, which may be closely related to $R$. globosus Bunge as interpreted above.

23. Rhamnus Meyeri Schneider, n. sp.

Frutex, ut videtur valde ramosus, spinosus; ramuli suboppositi, hornotini graciles, tenuiter puberuli, flavo-cinerei v. leviter brunnescentes, vetustiores cinerascentes; gemmae parvae, ovato-globosae, squamis paucis rotundatis ciliatis obtectae. Folia opposita, crasse papyracea, decidua, ovata v. ovato-rotunda v. orbicularia, raro ovato-oblonga, basi rotunda v. fere subcordata v. obtusa, rare acuta, apice acuta v. subito breviter-acuminata, supra viridia, opaca, tenuissime sparse pilosa, subtus paullo pallidiora, praesertim ad nervos utrinsecus 2-3 paullo prominulos pilosa et barbata, margine satis distincte crenato-dentata, latiora $1.5-3 \mathrm{~cm}$. longa, $1-2.5 \mathrm{~cm}$. lata, angustiora ad $3 \mathrm{~cm}$. longa et $1.3 \mathrm{~cm}$. lata; petioli graciles, 3-8 mm. longi, supra sulcati, pilosi. Flores non vidi. Fructus solitarius, globosus, circiter 6:5 mm. crassus, ? niger; semen obovato-oblongum, olivaceum, dorso sulco lato elongato distincte aperto instructum.

Shantung: near Lung-Tung, September 28, 1907, F. N. Meyer (No. 249).

To this species may possibly belong a specimen of the same collector from Shansi, Tsin-tse,May 5, 1907,(No. 406) with the same thin minutely pubescent spiny branchlets, very young puberulous leaves and male flowers, which may be described as follows: flores masculi, tetrameri, axillares, 1-4-fasciculati, tenuissime puberuli; pedicelli vix ad $3 \mathrm{~mm}$. longi; sepala late ovata, acuta, receptaculo vix longiora; petala lanceolata, acuta, sepalis duplo breviora, staminibus aequilonga; ovaria valde reducta. Folia valde juvenilia ut videtur lanceolata.

It seems somewhat doubtful, however, if these two specimens really belong to the same species, certainly No. 249 represents a good species, which may be nearly related to $R$. globosus Bunge, though the seeds with their broad furrows are rather different.

\section{Rhamnus Leveilleanus Fedde. See p. 237.}

25. Rhamnus dumetorum Schneider. See p. 237.

26. Rhamnus koraiensis Schneider in Notizbl. Bot. Gart. Berlin, 1908, 77; Ill. Handb. Laubholzk. II. 284, fig. 198 n-o (1909).

Korea: "Syon ouen," 1901, U. Faurie (No. 233, type), "Ouen to" (No. 235), "Ouen san," 1901 (No. 236), 1906 (No. 502); without precise locality, "in dumosis," June 1906, U. Faurie (No. 512); Pingyang, September 18, 1908, J. G. Jack (bush $0.25-0.5 \mathrm{~m}$. tall).

This species seems to be closely related to $R$. globosus Bunge, see above, and also to $R$. parvifolius Bunge, see p. 250.

The leaves are alternate or subopposite.

27. Rhamnus rugulosus Hemsley. See p. 238. 
28. Rhamnus argutus Maximowicz in Mém. Acad. Sci. St. Pétersbourg, sér. 7, IV. No. XI. 6 (Rhamn. Or-As.) (1866); Schneider, Ill. Handb. Laubholzk. II. 289, fig. $1971-n, 199 \mathrm{~h}-\mathrm{h}^{1}$ (1909).

Northern China: Weichang, 1910, W. Purdom (No. 32; bush 1-1.25 m. tall),

This differs from all other known Chinese species in the very small and slender teeth of its orbicular-ovate leaves.

29. Rhamnus Schneideri Léveillé et Vaniot in Fedde, Rep. Sp. Nov. VI. 265 (1908).

Korea: Nai-Piang, July 1901, U. Faurie (No. 234).

In my Ill. Handb. Laudholzk. II. 286 (1909) I mentioned this number of Faurie as probably a new species. To this species may belong also No. 501 of the same collector from the "Mont des diamants," June 22, 1906, but the leaves are somewhat pubescent. From $R$. koraiensis it may be distinguished by the more elongate leaves with a different serration and the longer and glabrous pedicels.

30. Rhamnus parvifolius Bunge in Mém. Sav. Êtr. Acad. Sci. St. Pétersbourg, II. 88 (Enum. Pl. Chin. Bot. 14) (1833). - Hemsley in Jour. Linn. Soc. XXIII. 129 (1886). - Schneider, Ill. Handb. Laubholzk. II. 285, fig. 192 i-l, $196 \mathrm{x}-\mathrm{y}^{1}$ (1909).

Rhamnus polymorphus Turczaninow in Bull. Soc. Nat. Mosc. XV. 713 (1842).

Rhamnus virgatus, var. sylvestris Maximowicz in Mém. Acad. Sci. St. Pétersbourg, sér. 7, IV. No. XI. 13 (Rhamn. Or.-As.) (1866).

Chili: Weichang, 1910, Wm. Purdom (Nos. 298, 299).

The young flowering branches collected by Purdom probably belong to this species, which I have interpreted differently from Komarov (in Act. Hort. Petrop. XXV. 11 (Fl. Mansh. III.) [1907]). According to a specimen from northern Korea (May 18, 1897) collected and distributed by Komarov under the name of $R$. globosus, this author takes the glabrous forms for that species. But otherwise Komarov unites $R$. polymorphus Turczaninow with $R$. parvifolius. Unfortunately I cannot read his remarks in Russian on these two species and so I cannot understand his true meaning.

These two and the allied species need further investigation, because it is very difficult to decide whether the characters on which they are based are constant. The shape of the leaves may often be an unreliable character, but I do not know if characters taken from the flowers, seeds and branchlets are more stable.

31. Rhamnus leptophyllus Schneider. See p. 239.

Rhamnus leptophyllus, var. milensis Schneider, n. var.

Arbor ad $3.5 \mathrm{~m}$. alta, spinosus; ramuli hornotini olivacei v. brunnescentes, puberuli v. fere glaberrimi, satis elongati nondum visi, vetustiores cortice laevi colore corticis cerasi obtecti $\mathrm{v}$. cinerascentes, glabri: ramuli abbreviati laterales distincti. Folia ramulorum abbreviatorum obovato-oblonga, basim versus sensim in petiolum 10-20 mm. longum attenuata, apice plus minus subito breviter-acuminata, supra viridia, etiam matura sparse pilosa, subtus pallidiora, pilis sparsis praesertim ad nervos utrinsecus 2-3 elevatos arcuatos obtecta v. glabra et tantum barbulata, margine plus minus distincte crenato-serrata, versus basim integra, majora 4-8 $\mathrm{cm}$. longa, $2-3.5 \mathrm{~cm}$. lata; petioli supra sulcati, pilosi. Flores masculi apice ramulorum fascieulati, virides, glabri, tetrameri, eirciter $5 \mathrm{~mm}$. longi; pedicelli $5-8$ $\mathrm{mm}$. longi, glabri; sepala lanceolata, satis acuminata, receptaculo distincte longiora; petala ovato-lanceolata, sepalis duplo breviora, staminibus aequilonga, in sieco brunnescentia; ovaria perparva, valde reducta. Fructus niger, subglobosus, 
circiter $6 \mathrm{~mm}$. crassus; pyrenae 2, an dehiscentes?; semina 5-6 mm. longa, olivacea, laevia, nitida, obovato-oblonga, dorso convexa, lateraliter sulco angusto fere ad apicem extenso aperto $\mathrm{v}$. clauso, cartilagineo-marginato instructa.

Yunnan: Mi-lê, mountain forest, A. Henry (No. 10021, type); Mengtze, mountain forests, alt. 2200 m., A. Henry (No. 10021ª).

This variety may represent a good species. But I have not yet seen shoots with fully developed leaves, which may have a different shape. The type has rather broadly ovate leaves on such shoots, and its seeds show a broader furrow. No. $10021^{\mathrm{a}}$ is much more glabrous than the type of the variety but agrees otherwise exactly with it.

There is another specimen collected by Henry near Szemao, W. mountains, $2000 \mathrm{~m}$. (No. 11890; shrub $2.5 \mathrm{~m}$., yellow flowers). It bears young leaves and pistillate flowers, which have rather narrow and acute sepals, small lanceolate petals and reduced stamens. The ovaries show a deeply two-cleft style.

Another of Wilson's specimens from western Hupeh, May and October 1907 (No, 410) resembles var. milensis. It consists of flowering and fruiting branches. The male flowers agree well with those of Henry's No. 10021, but the fruits have a shorter furrow, opened only at the very base. All these forms need further study.

32. Rhamnus virgatus Roxburgh, Fl. Ind. II. 351 (1824). - D. Don, Prodr. Fl. Nepal. 190 (1825). - Schneider, Ill. Handb. Laubholzk. II. 285, fig. f-h (1909).

Rhamnus dahuricus, Lawson in Hooker f., Fl. Brit. Ind. I. 639 (1875), excludendis synonym et varietate.

British India: western Himalaya and the western peninsula.

This seems to me a good species, which may be nearer related to $R$. iteinophyllus Schneider than to any other Chinese species.

33. Rhamnus hirsutus Wight \& Arnott, Prodr. Fl. Ind. I. 165 (1834).

Rhamnus dahuricus, var. hirsutus Lawson in Hooker f., Fl. Brit. Ind. I. 639 (1875).

British India: western peninsula.

This species is certainly most closely allied to $R$. virgatus Roxburgh, and may possibly represent only a variety of it. It differs in its more hirsute pubescence, but the name is somewhat misleading, because the pubescence seems to be slight and soon disappears. I have not seen a type specimen.

34. Rhamnus japonicus Maximowiez in Mém. Acad. Sci. St. Pétersbourg, sér. 7, IV. No. XI. 11, fig. 52-64 (Rhamn. Or.-As.) (1866). - Schneider, Ill. Handb. Laubholzk. II. 285, fig. 196, t-u $\mathrm{u}^{1}, 197 \mathrm{e}-\mathrm{k}$ (1909).

Rhamnus Yoshinoi Makino in Tokyo Bot. Mag. XVIII. 97 (1904).

Japan: Hondo, "basi Ontake, in fruticetis," July 1905, U. Faurie (No. 6873).

Of $R$. Yoshinoi I have not yet seen a specimen, but according to the description it may be the same as $R$. japonicus, which Makino does not mention. The seeds have a closed groove. This is not the case in $R$. Buergeri Miquel (in Ann. Mus. Lugd.-Bat. III, 31 [1867]) which I only know from the description.

35. Rhamnus davuricus Pallas, Reise Russ. Reich. III, append. 721 (1776). Schneider, Ill. Handb. Laubholzk. II. 287, fig. 192 m-p (1909).

Rhamnus catharticus, $\gamma$. davuricus Maximowicz in Mém. Acad. Sci. St. Pétersbourg, sér. 7, IV. No. XI. 9 (Rhamn. Or,-As.) (1866). 
Chili: Weichang, 1910, W. Purdom (No. 29; bush 1.5-2.5 m. tall). Korea: " in monte des diamants," June 22, 1906, U. Faurie (No. 500); " in dumosis," Seoul, June 1906, U. Faurie (No. 503).

This species is most nearly related to the European $R$. catharticus Linnaeus, but there are some forms from eastern Siberia which are difficult to determine. They may represent varieties of both these species.

Whether $R$. dahuricus, var. nipponicus Makino in Tokyo Bot. Mag. XVIII. 98 (1904) from middle and northern Japan, where it is said to be common, represents a good variety or even a different species, I cannot decide.

36. Rhamnus iteinophyllus Schneider. See p. 239.

37. Rhamnus hamatidens Léveillé in Fedde, Rep. Sp. Nov. X. 473 (1912).

Kweichou: Pin Fa, April 15, 1903, J. Cavalerie (No. 992).

The type specimen, which I have seen, consists only of young shoots with female flowers. The leaves very much resemble those of a peach or a willow. They are very smooth and only a little pilose on the midrib above and on the short 3-4 mm. long petioles. They measure up to $11 \mathrm{~cm}$. in length and $2.7 \mathrm{~cm}$. in width and have a somewhat irregular serration with appressed rather distant teeth. The base is acute and the apex runs into a long and slender acumen. The glabrous shoots are round and quite smooth. The stamens of the pistillate flowers are very much reduced to filiform staminodes; the petals are wanting. It may be a very distinct species, the relationship of which eannot be indicated before the mature leaves and fruits are known.

38. Rhamnus lamprophyllus Schneider in Notizbl. Bot. Gart. Berlin, 1908, 78; Ill. Handb. Laubholzk. II. 289, fig. 198 l-m, 199 g (1909).

Hupeh: A. Henry (No. 6504).

I have not yet seen any other specimen which I could surely refer to this species.

39. Rhamnus utilis Decaisne. See p, 240.

40. Rhamnus Wilsonii Schneider. See p. 240.

41. Rhamnus hypochrysus Schneider in Notizbl. Bot. Gart. Berlin, 1908, 76; Ill. Handb. Laubholzk. II. 290, fig. 198 p-q, 199 o-q (1909).

Szech'uan: A. von Rosthorn (No. 1585). Northern Shensi: G. Giraldi (Nos. 931, 932, 940).

\section{HOVENIA Thunb.}

Hovenia dulcis Thunberg, Fl. Jap. 101 (1784). - Hemsley in Jour. Linn. Soc. XXIII. 131 (1886), excludendo synonymo. - Schneider, Ill. Handb. Laubholzk. II. 291, fig. 200, 201 ${ }^{\text {a }}$ (1909). - Pampanini in Nuov. Giorn. Bot. Ital. n. ser. XVII. 425 (1910).

Western Hupeh: neighbourhood of Ichang, alt. 300-1000 m., common, June 1907 (No. 2429; tree 10-20 m. tall, girth 1-2.5 m., flowers white); Patung Hsien, June 1900 (Veitch Exped. No. 1191, in part). Eastern Szech'uan: Wushan Hsien, July 1901 (Veitch Exped. No. 1191, in part). Western Szech'uan: Monkong Ting, alt. $1600 \mathrm{~m}$., June 30, 1908 (No. 2429a ; tree 8-20 m. tall, girth 1-2.5 m.); without locality, A. von Rosthorn (No. 1898). 
Yunnan: south of Red River from Manmei, A. Henry (No. 9465); Szemao, mountains, east, alt. 1600-2000 m., A. Henry (Nos. 12034,

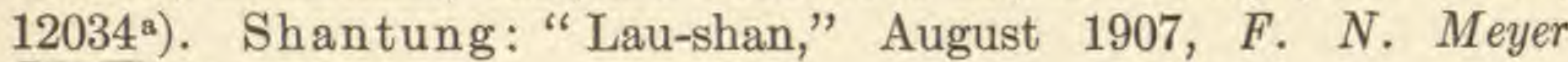
(No. 280).

This is a common tree in western Hupeh and in Szech'uan up to $1000 \mathrm{~m}$. altitude. It is usually from 20 to $25 \mathrm{~m}$. tall, but occasional specimens occur from 30 to 35 $\mathrm{m}$. tall. The trunk is free of branches for from 5 to $10 \mathrm{~m}$. and has a girth of from 2 to $4 \mathrm{~m}$.; the bark is grey, longitudinally fissured and persistent. The branches are stout, spreading and ascending-spreading. In the length of the petiole, the degree of dentation of the leaves and of the pubescence on the leaves and branches, this tree shows considerable variation.

A colloquial name for this tree is "Kuai-tsao" and the thickened pedicels of the fruits are used medicinally by the Chinese to offset the effects of over-indulgence in wine.

Pictures of this tree will be found under Nos. 100, 498, 078, 0194 of my collection of photographs and in my Vegetation of Western China, Nos. 551, 552.

E. H. W.

Here may be added some notes on two Chinese genera of Rhamnaceae not collected during the Arnold Arboretum Expeditions.

\section{VENTILAGO Gaertn.}

Ventilago calyculata Tulasne in Ann. Sci. Nat. sér. 4, VIII. 124 (1857). Lawson in Hooker f., Fl. Brit. Ind. I. 631 (1875).

Yunnan: Manhan, red River bank, A. Henry (No. 10889; large elimber, brownish flowers).

This specimen agrees very well with Wallich's No. 4268 cited by Tulasne. Ventilago calyculata of Pitard (in Lecomte, Fl. Gén. Indo-Chine, I. 912, fig. 115 (1-4) (1912)) and also of Pierre (Fl. For. Cochin. pl. 313 C [1894]) may represent V. sulphurea Tulasne, 1. c. 125 , as indicated on Pierre's plate. This species is at once distinguished by its obtuse not apiculate anthers.

\section{GOUANIA L.}

Gouania javanica Miquel, Fl. Ind. Bat. I. pt. 1, 649 (1855).-Pitard in Lecomte, Fl. Gén. Indo-Chine, I. 932 (1912).

Yunnan: Feng Chen Lin, mountain, alt. 2800 m., A. Henry (No. 11188; tree $2.5 \mathrm{~m}$. tall, yellowish flowers).

G. javanica appears to be distributed from Java through the Malayan Archipel. to Cochinchina. But there is some doubt, if the Yunnan form belongs to that species or to G. napalensis Wallich (in Roxburgh, Fl. Ind.II.417 [1824]), or represents a new species. All the Asiatic species of Gouania need further study. 


\section{NYSSACEAE.}

Determined by E. H. Wruson.

NYSSA L.

Nyssa sinensis Oliver in Hooker's Icon. XX. t. 1964 (1891).

Kiangsi : Kuling, thickets, side of water-courses, alt. 1300 m., common, July 31, 1907 (No. I557; wide spreading bush 2.5-6 m. tall, fruit blue); same locality, July 29, 1907 (No. $\mathbf{I 5 5 7}^{\mathrm{a}}$; small tree, 5-6 m. tall).

This is a very common bush or small tree along watercourses on the Lushan mountain in Kiangsi; it is rare in Hupeh and has not been recorded from western Szech'uan. The undescribed fruit is indigo-blue, oval, from 12 to $15 \mathrm{~mm}$. long, about $7 \mathrm{~mm}$. wide, obtuse at the ends, and produced 2 or 3 together on short pedicels at the end of a peduncle from 2 to $5 \mathrm{~cm}$. or more long. The young leaves and shoots are clothed with pale gray silky hairs which soon fall away. In autumn the leaves turn to a brilliant reddish color.

\section{CAMPTOTHECA Decne.}

Camptotheca acuminata Decaisne in Bull. Soc. Bot. France, XX. 157 (1873). - Baillon, Hist. Pl. VI. 282 (1877). - Franchet in Nouv. Arch. Mus. Paris, sér. 2, VIII. 241, t. 9 (Pl. David. II. 59) (1886). Hemsley in Jour. Linn. Soc. XXIII. 346 (1888), - Diels in Bot. Jahrb. XXIX. 504 (1900). - Dode in Bull. Soc. Bot. France, LV.650, fig. b (1908).

Camptotheca yunnanensis Dode in Bull. Soc. Bot. France, LV. 651, fig. c (1908).

Kiangsi : near Kiuking, around base of foot hills, alt. $160 \mathrm{~m}$,

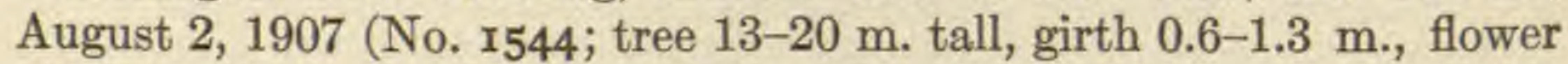
white, bark grey). Western Hupeh : without locality, August 1900 (Veitch Exped. No. 1681); without locality, A. Henry (No. 7606). Western Szech'uan: Mt. Omei, October 1910 (No. 4405, seeds only); same locality, June 1904 (Veitch Exped. No. 4949); without precise locality, alt. 300-600 m., October 1903 (Veitch Exped. No. 3700). Yunnan: Szemao, alt. 1600-2000 m., A. Henry (Nos. $13091,13433)$. 
This is a handsome quick growing tree widely distributed through the warmer parts of central, western and southwestern China and particularly abundant by the streams in the northern parts of the Chengtu Plain, where it ascends to an altitude of 750 metres. It is also common round the base of Mt. Omei but is rare in Hupeh and Kiangsi. It grows from 20 to $25 \mathrm{~m}$. tall, with a girth of $2 \mathrm{~m}$. and the trunk is usually without branches for $10 \mathrm{~m}$. above the ground, the bark is smooth and pale gray; the branches are only moderately thick and spreading. The wood is white, soft and of little value except as fuel. The capitate heads of flowers, with long exserted white stamens, are freely produced in July and early August and may be terminal or axillary, solitary or in racemes of from 3 to 6 or more. The ripe samaras are shining brown, from 2 to $3 \mathrm{~cm}$. long.

The characters on which C. yunnanensis Dode is founded are too slight to be of even varietal value and were probably taken from immature fruiting material. Our No. 1681 from Hupeh, has fruit exactly the size $(1.5 \mathrm{~cm}$.) of that of Dode's species, but it is not fully grown.

Pictures of this tree will be found under Nos. 66, 0245, 0252 in the collection of my photographs and in my Vegetation of Western China, No. 143.

\section{DAVIDIA Baill.}

Davidia involucrata Baillon in Adansonia, X. 115 (1871). - Franchet in Nouv. Arch. Mus. Paris, sér. 2, VIII. 242, t. 10 (Pl. David. II. 60) (1886). - Diels in Bot. Jahrb. XXIX. 505 (pro parte) (1900). Wangerin in Bot. Jahrb. XXXVIII. Beibl. LXXXVI. 75 (1906). Dode in Rev. Hort. 1908, 405. - Hemsley in Gard. Chron. ser. 3, XLV. 321 (1909). - Horne in Trans. Linn. Soc. ser. 2, VII. 303, t. 31, 32, 33 (1909).

Davidia tibetana David in Nouv. Arch. Mus. Paris, sér. 2, XV. 161 (nomen nudum) (1882).

Western Szech'uan: Mupin, woods, alt. 1600-2500 m., June and October (No. 5ro, in part; tree 8-20 m. tall, girth 0.6-1.5 m., bracts pure white, fruit russet-brown); same locality, October 1910 (No. 4393; tree 10-16 m. tall, girth 1-2 m.); Wa-shan, woodlands, alt. 1800-2300 m., Sept. 1908 (No. 5Io, in part); Tu-ti-hang mountains, Lungan Fu, woodlands, alt. 2300-2600 m., common, August 1910 (No. 4393 ${ }^{\mathrm{a}}$; ; west of Tien-ch'uan chou, woods, alt. 2000 m., July and October 1903 (Veiteh Exped. No. 3702). Hupeh: Changyang Hsien, woods, alt. 1300-2000 m., rare, June and Oetober 1907 (No. 510 , in part; tree $10-15 \mathrm{~m}$. tall).

This remarkable tree is fairly common in moist woods throughout western Szech'uan between altitudes of 1600 and $2500 \mathrm{~m}$. In western Hupeh it oceurs in the districts of Changyang and Patung but is very rare. The tree grows to the height of $20 \mathrm{~m}$. with a girth of trunk of $2 \mathrm{~m}$.; the branches are ascending-spreading and the tree is of a loose pyramidal habit similar to that of the common wild Pear. On old trees the lower branches are wide-spreading. The bark is 
dark gray, rough, with corky lenticels and exfoliates in thin, small flat irregularly oblong flakes. The wood is white, tough and heavy. The flowers are pendulous, produced on short, lateral, spur-like branches; the bracts are always flimsy in texture, boat-shaped, coarsely toothed or entire, small and rather greenish at first, attaining full size and snowy whiteness when the anthers are mature; afterwards they turn first creamy-white, then brownish, and fall away. When in full flower the tree is more conspicuous on dull days and in the early morning and evening than when the sun is shining. André (in Rev. Hort. 1902, 378) states, on the authority of Père Farges, that the fruit is edible when bletted. This is an error. The mesocarp is very thin and "gritty;" the endocarp is very sclerotic and remains so even after exposure to the weather or after having been buried for two or three years. A sharp axe or saw is necessary to cut through the endocarp, and the seeds are too small to be of any edible value.

The tree was discovered in Mupin, western Szech'uan, by Abbé David in 1869, and was first introduced to cultivation through seeds which I collected and sent to Messrs. Veiteh in November 1903 and again in 1904. Several hundreds of seedlings were raised in the nursery of Coombe Wood and every one had glabrous leaves and continued to produce such for the first three or four years. The shoots were dark red and this character alone distinguished them from seedlings of the variety Vilmoriniana. The 5-year old plants had leaves very sparsely pubescent below; a specimen before me, taken from one of these plants in June 1911, has the underside of the leaves clothed with a short gray pubescence and the veins with long, appressed hairs. In fact, the densely silkily hairy undersurface of the leaves is a character belonging to the adult tree and is not developed on seedling trees until they are several years old. The red color of the shoots is a juvenile character only; on adult trees the color is grayish the first year, dull purple afterwards and, curiously enough, this is the color of the shoots in juvenile as well as adult plants of the variety Vilmoriniana.

Davidia involucrata, var. Vilmoriniana Hemsley in Bot. Mag. CXXXVIII. t. 8432 (1912).

Davidia involucrata Oliver in Hooker's Icon. XX. t. 1961 (non Baillon) (1891). - Diels in Bot. Jahrb. XXIX. 505 (1900), speciminibus Fargesianis et Henryanis excludendis. - André in Rev. Hort. 1902, 377, fig. 158. Masters in Gard. Chron. ser. 3, XXXIII. 236, fig. 98 (1903); XXXIX. 346, fig. 138 (1906). - Hemsley in Jour. Linn. Soc. IXXXV. 556, t. 19 (1903); in Kew Bull. Misc. Inform. (1907), 301. - Veitch in Jour. Roy. Hort. Soc. XXVIII. 57, fig. 11, 12 (1903), - Vilmorin \& Bois, Frut. Vilmorin. 145, fig. (1904). - Mottet in Rev. Hort. 1906, 297, fig. 124, 125, 126; 1907, 321. fig. 105. - M. de Vilmorin in Rev. Hort. Belge, XXXIV. 230, fig. (1908).

Davidia Vilmoriniana Dode in Rev. Hort. 1908, 406. - M. de Vilmorin in Bull. Soc. Bot. France, LV. 640 (1908).

Davidia laeta Dode in Rev. Hort. 1908, 407.

Western Hupeh: north and south of Ichang, woodlands, alt. 1500-2500 m., June 1907 (No. 2920; tree 10-20 m. tall, girth 1-1.5 m.); Hsing-shan Hsien, moist woods, alt. 2000-2500 m., common, May 29, 1907 (No. 2920, in part; tree 12-20 m. tall, girth 1-2 m.); same locality, alt. 1800 m., June 3, 1907 (No. 2920, in part; tree 16 m. tall, 
girth $1.5 \mathrm{~m}$.); same locality, alt. 1600-2300 m., June 1907 (No. 29r9; tree 10-16 m. tall, girth 1-1.5 m.); Patung Hsien, woods, alt. 16002000 m., June 1907 (No. 2920, in part; tree 10-16 m. tall, girth 1-2 m.); Fang Hsien, woods, alt. 1600-2300 m., common, July and September 1907 (No. 2920, in part); south of Ichang, woods, alt. 1500$2000 \mathrm{~m}$., May and November 1900 (Veitch Exped. No. 642). Eastern Szech'uan: Wushan Hsien, base of cliff, alt. 1950 m., one tree only, May 17, 1888, A. Henry (Nos. 5577, 5577 b); "District de Tchen-kéou-Tin" (Chengkou Ting), P. Farges.

This tree is common in moist woods through north-western Hupeh between altitudes of 1600 and $2300 \mathrm{~m}$. It is less common in the south-west of this province and in eastern Szech'uan. In western Szech'uan it occurs sparingly on Mt. Omei and in the wild region to the south-southwest of this mountain and elsewhere, but is everywhere rare. Formerly I was inclined to believe that this tree might represent a second species but subsequent observation has convinced me that it is nothing more than a glabrous leaved variety of the type. In the adult trees there is no other difference between the type and the variety; in the juvenile stage even this disappears and the only distinguishing character is the color of the young shoots which is dull gray or slightly purplish in the variety and dark red in the type. Specimens agreeing in every detail with $D$. laeta Dode may be obtained from the branches growing in dense shade on any tree of the var. Vilmoriniana. On the juvenile plants, more especially if they grow closely together or in dense shade, the leaves are thin in texture and pale green below. Leaves having teeth with both long and short setae may be found on any one branch and commonly this difference may be detected on the same leaf.

D. involucrata, var. Vilmoriniana Hemsley was first discovered in Wushan Hsien, eastern Szech'uan, by A. Henry in 1888, one tree only being met with during a journey of six months' duration. It was subsequently discovered in northeastern Szech'uan by Père Farges who sent seeds to Monsieur Maurice de Vilmorin who received them in 1897. From these seeds one plant was raised (André in Rev. Hort. 1902, 378). From this plant cuttings have been raised and one of them is now growing at the Arnold Arboretum. To secure this Davidia was the principal object of my first expedition to China for Messrs. Veitch (1899-1901).

I succeeded in introducing a quantity of fruit which produced some thirteen thousand plants. All the seedling Davidia trees of the variety Vilmoriniana in cultivation except the solitary example raised by M. Maurice L. de Vilmorin, resulted from this expedition.

The Davidia has several colloquial names, each very local in application. In north-western Hupeh it is known as the "Shan-peh-k'o" tree, in south-eastern Szech'uan it is the "Kung-t'ung" tree.

Pictures of this tree will be found under Nos. 557 and 687 of the collection of my photographs and also in my Vegetation of Western China, No. 201, 202. 


\section{OLEACEAE.}

\section{FRAXINUS L.}

Determined by Alexander Lingelsheim.

\section{Sect. ORNUS DC.}

Subsect. Euornus Koehne \& Lingelsh.

Fraxinus Griffithii Clarke in Hooker f., Fl. Brit. Ind. III. 605 (1882).- Lingelsheim in Bot. Jahrb. XL. 212 (1907). - Koorders, Excursionsfl. Java, III. 48 (1912).

Fraxinus floribunda, var. integerrima Wenzig in Bot. Jahrb. IV. 173 (1883).

Fraxinus bracteata Hemsley in Jour. Linn. Soc. XXVI. 84 (1889). - Diels in Bot. Jahrb. XXIX. 530 (1900), - Schneider, Ill. Handb. Laubholzk. II. 818 (1912).

Fraxinus Eedenii Boerlage \& Koorders in Natuurk. Tijdschr. Ned. Ind. LVI. 185, t. 1, 2 (1896). - Koorders \& Valeton in Mededel. Lands Plantent. LIX. 229 (Bijdr. Boomsort. Java, VIII.) (1902). - Koorders in Natuurk. Tijdschr. Ned. Ind. LXII. 224 (1902).

Fraxinus philippinensis Merrill in Bureau Gov. Labor. Philipp. Isl. No. XXXV. 57 (1905).

Western Hupeh: without precise locality, June and October 1901 (Veitch Exped. Nos. 1926, 2143); Fang-Hsien, woodlands, 1200 m., July 1907 (No. 2774; tree 5-8 m. tall, girth $1 \mathrm{~m}$., flowers white); north and south Ichang, thickets, alt. 300-1200 m., June and October 1907 (No. 2775; tree $8 \mathrm{~m}$. tall, girth $1 \mathrm{~m}$., flowers white).

A sterile branch of No. 2775 with toothed leaves perhaps belongs to another species.

Fraxinus retusa Champion in Hooker's Jour. Bot. V. 330 (1852).Lingelsheim in Bot. Jahrb. XL. 213 (1907).

The type does not seem to occur in central and western China.

Fraxinus retusa, var. Henryana Oliver in Hooker's Icon. X. t. 1930 (1890). - Lingelsheim in Bot. Jahrb. XL. 213 (1907). - Schneider, Ill. Handb. Laubholzk. II. 818 (1912).

Fraxinus retusa Diels in Bot. Jahrb. XXIX, 530 (non Champion) (1901). 
Western Hupeh: north of Ichang, roadside, rare, alt. $300 \mathrm{~m}$., May 3, 1907 (No. 2783; tree $10 \mathrm{~m}$. tall, girth $0.6 \mathrm{~m}$., flowers pure white), same locality, thickets, not common, alt. 600-1000 m., May 7, 1907 (No. 2784; bush or small tree 2-7 m. tall); same locality, rare, alt. 500-800 m., May 4, 1907 (No. 2788; small tree $5 \mathrm{~m}$. tall, flowers white); Hsing-shan Hsien, side of streams, alt. 600-1000 m., May 1907 (No. 2785; slender tree $8 \mathrm{~m}$. tall, flowers white); Fang Hsien, thickets, alt. 1600 m., July 1907 (No. 2786; bush $8 \mathrm{ft}$.); same locality, ravine, rare, alt. 1200 m., May 26, 1907; No. 2787; tree $10 \mathrm{~m}$. tall, girth $1.3 \mathrm{~m}$., flowers white); Changlo Hsien, woods, alt. 1000-1600 m., May 1907 (No. 2789, in part; tree $8 \mathrm{~m}$. tall, girth 1 m., flowers white); Patung Hsien, alt. 1500 m., May 1907 (No. 2789, in part; tree 8-11 m. tall, flowers white); without precise locality, May 1901 (Veitch Exped. No. 1824). Western Szech'uan: Niu-tou-shan, west of Kuan Hsien, alt. 2600 m., June 21, 1908 (No. 278I; small tree, $8 \mathrm{~m}$. tall).

Here may be added a reference to another variety not collected during the Arnold Arboretum Expeditions.

Fraxinus retusa, var. integra Lingelsheim in Bot. Jahrb. XL. 213 (1907). Schneider, Ill: Handb. Laubholzk. II. 818 (1912).

Western Hupeh: without precise locality, May, June and August 1901 (Veitch Exped. No. 1950).

Fraxinus Paxiana Lingelsheim in Bot. Jahrb. XL. 213 (1907). Schneider, Ill. Handb. Laubholzk. II. 818 (1911).

Fraxinus densiflora Lingelsheim in Bot. Jahrb. XL. 215 (1907). - Schneider, Ill. Handb. Laubholzk. II. 816 (1911).

Western Hupeh: without precise locality, April 1900 and May and October 1901 (Veitch Exped. Nos. 77, 2126, 2126 ${ }^{\mathrm{a}}$ ); Fang Hsien, woods, alt. 2000-2500 m., May and November 1907 (No. 708; tree $14 \mathrm{~m}$. tall, girth $1 \mathrm{~m}$.); same locality, woodlands, alt. 1800-2300 m., June and October 1910 (No. 4423; tree $22 \mathrm{~m}$. tall, girth $2.6 \mathrm{~m}$.); same locality, woods, Sheng Têng Chia, alt. 2600 m., June 1910 (No. 46ro; tree $10 \mathrm{~m}$. tall, flowers white). Western Szech'uan: Panlan-shan, west of Kuan Hsien, alt. 2300-2600 m., June 1908 (No. 2778; tree 5-14 m. tall); foot of Wa-shan, alt. $2600 \mathrm{~m}$., September 1908 (No. 278o; tree $12 \mathrm{~m}$. tall, girth $2.3 \mathrm{~m}$.); without precise locality, July 1903 (Veitch Exped. No. 4085). 
With the rich material of the Wilson collection before me, I have no doubt that the imperfectly known Fraxinus densiflora Lingelsheim is the same as Fraxinus Paxiana. This tree is cultivated in the Arnold Arboretum. The cultivated as well as the wild plants show great variability in form and consistence of the leaves. In some cases the basis of the rhachis is dilatated as is that of Fraxinus Spaethiana Lingelsheim known from cultivated plants only, or of Fraxinus platypoda Oliver from Hupeh, which resembles this species in the shape of the leaves, but differs in having a papillose epidermis.

Pictures of this tree will be found under Nos. 358 and 083 of the collection of Wilson's photographs and in his Vegetation of Western China, No. 228.

Fraxinus Mariesii Hooker f. in Bot. Mag. XXXIV.t. 6678 (1883).Hemsley in Jour. Linn. Soc. XXVI. 86 (1889). - Dippel, Handb. Laubholzk. I. 67 (1889). - Koehne, Deutsche Dendr. 508 (1893). Schneider, Ill. Handb. Laubholzk. II. 818 (1912).

Kiangsi: Kuling, thickets, side of streams, rare, alt. $1300 \mathrm{~m}$., July 1907 (Nos. I590, I59I; bush 2-3 m. tall); same locality, thickets, rare, alt. 1200 m., August 1907 (No. I592; bush 2 m. tall, with wild white wax).

$\mathrm{Mr}$. Wilson has discovered the interesting fact that white wax is also produced on Fraxinus Mariesii as well as on Fraxinus chinensis Roxburgh, the genuine white wax tree, "pe-la-shu" of the Chinese.

\section{Subsect. OrNaster Koehne \& Lingelsh.}

Fraxinus chinensis Roxburgh, Fl. Ind. I. 150 (1820). - G. Don, Gen. Syst. IV. 55 (1838). - Loudon, Arb. Brit. II. 1240 (1838). - De Candolle, Prodr. VIII. 277 (1844). - Hemsley in Jour. Linn. Soc. XXVI. 85 (1889). - Wesmael in Bull. Soc. Bot. Belg. XXXI. 104 (1892). - Lingelsheim in Bot. Jahrb. XV. 216 (1907).

Fraxinus chinensis, var. typica Lingelsheim in Bot. Jahrb. XL. 216 (1907).

Western Hupeh: Ichang, margins of cultivated areas, alt. 300$1000 \mathrm{~m}$., May, June 1907 (No. 1337 in part; tree 8-10 m. tall); Ichang, planted, but no white wax raised, alt. 300-1000 m., October 1907 (No. I337, in part); Ichang Fu, alt. 300-1000 m., June 10, 1907 (No. 1337, in part); without precise locality, April 1900 (Veitch Exped. No. 77). Western Szech'uan: Kiating Fu, cultivated for white wax, alt. 300-500 m., September 4, 1908 (No. I337, in part; tree 3-7 m. tall); without precise locality, cultivated for white wax, July 1903 (Veitch Exped. No. 4085). 
Fraxinus chinensis, var. rhynchophylla Hemsley in Jour. Linn. Soc. XXVI. 86 (1889).

Fraxinus rhynchophylla Hance in Jour. Bot. 164 (1869). - Sargent in Gard. and Forest, VI. 484, fig. 70 (1893). - Schneider, Ill. Handb. Laubholzk. II. 820 (1912).

Fraxinus obovata Schneider, Ill. Handb. Laubholzk. II. 813 (1911).

Fraxinus xanthoxyloides Wenzig in Bot. Jahrb. IV. 187 (ex parte) (1883).

Kiangsi: Kuling, thickets, rare, alt. 1300 m., July 1907 (Nos. I594, I595, I595', bush 2-3 m.). Western Hupeh: Hsin-shan Hsien, woodlands, alt. 1000-1300 m., May 1907 (No. 2790; bush 2-3 m. tall). Western Szech'uan: Lungan-Tu, Tu-ti-liang Mt., alt. 2300-3000 m., August 1910 (No. 4609; tree 10-14 m. tall); without precise locality, alt. 2200-2300 m., July 1903 (Veitch Exped. No. 4082; tree 5-12 m. tall).

Fraxinus chinensis is one of the most polymorphous species of the genus. In Bot. Jahrb. XL. 216 (1902) I have enumerated five varieties, to which I add now var. rhynchophylla Hemsley after having studied the abundant material of the Herbarium of the Arnold Arboretum.

Fraxinus obovata Blume in Mus.-Ludg. Bot. I. 311 (1849-51) with scabrid pubescence on both sides of the leaflets is said to have been introduced from China to Japan. The flowers of this species are unknown and the original plant is not found in any collection and has never been seen since Blume described it.

Pictures of F. chinensis will be found under Nos. 306 and 310 of the collection of Wilson's photographs and also in his Vegetation of Western China, Nos. $226,227$.

Here may be added a reference to another variety not collected during the Arnold Arboretum Expeditions.

Fraxinus chinensis, var. acuminata Lingelsheim in Bot. Jahrb. XL. 216 (1907).

Western China: Yalung Valley, alt. 3000-3300 m., June 1904 (Veitch Exped. No. 4088; tree 7-14 m. tall).

\section{Fraxinus Sargentiana Lingelsheim, n. sp.}

Arbor circiter 8-metralis; gemmae griseo-brunneae, puberulae; ramuli juveniles flavido-grisei, pubescentes. Folia circiter $20 \mathrm{~cm}$. longa, mediocriter petiolata, saepissime 4-juga, rhachide dense velutino-pubescente instructa; foliola subcoriacea, ambitu oblonga, e basi lata, saepius quasi rotundata apicem versus sensim caudatoattenuata, insigniter asymmetrica, 5-12 cm. longa, 2-3.5 cm. lata, supra glaberrima, subtus dense velutino-pubescentia, margine, basi excepta, regulariter adpresse subcrenato-serrata, distincte petiolulata, petiolulo pubescente $0.5-0.8 \mathrm{~cm}$. longo suffulta. Panicula plus minusve laxa, densa, pedunculis et samaris exceptis pubescens; calyx permagnus, cupuliformis, irregulariter dentatus; flores ignoti. 
Fructus e basi latiore subspathulato-lanceolatus, apice acutus v. raro obtusus, $2-3.5 \mathrm{~cm}$. longus, $0.3-0.4 \mathrm{~cm}$. latus.

Western Szech'uan: Mupin, side of streams, alt. 1600 m., August 1908 (No. 2777; tree $8 \mathrm{~m}$. tall).

This new species, certainly a member of the Ornaster group, is related to Fraxinus chinensis, var. acuminata, but differs from that tree in the number of the leaflets and in the velvety pubescence of the vegetative parts.

\section{Sect. FRAXINASTER DC.}

\section{Subsect. Melioides Endl.}

Fraxinus platypoda Oliver in Hooker's Icon. XX. t. 1929 (1890). Diels in Bot. Jahrb. XXIX. 531 (1900). - Schneider, Ill. Handb. Laubholzk. II. 822 (1912).

Western Hupeh: Fang Hsien, rare, alt. 2300 m., May 1907 (No. 2776; tree $20 \mathrm{~m}$., girth $2 \mathrm{~m}$.).

This Ash resembles in the form of the leaves Fraxinus Paxiana Lingelsheim, especially in the dilatated base of the rhachis, but can easily be distinguished by the papillose epidermis of the leaves.

Fraxinus inopinata Lingelsheim, n. sp.

Arbor circiter 20-metralis; gemmae griseo-tomentosae; ramuli cinerei, velutino-pubescentes. Folia satis petiolata, $15-30 \mathrm{~cm}$. longa, 3-4-juga, rhachide dense pubescente instructa; foliola sessilia, subcoriacea, ambitu oblongo-elliptica, apicem versus sensim acuminata, 7-12 cm. longa, 2-3 cm. lata, supra glaberrima simulque impressoreticulata, laete viridia, subtus secus nervos primarios et ad basin pubescentia, papillis densissime obsitis albicantia, margine crenatoserrata. Panicula lateralis circiter $15 \mathrm{~cm}$. longa, velutino-pubescens; flores ignoti. Fructus "periptera" (ala ad basin decurrente) ellipticus, planus, 4-5 cm. longus, $1 \mathrm{~cm}$. latus, apice obtusus v. emarginatus, stigma persistente saepius coronatus, calyce pubescente irregulariter fisso praeditus.

Western Szech'uan: north-east of Tachien-lu, Ta-p'ao-shan, forests, alt. 2500-3200 m., June 1908 (No. 2779; tree 10-20 m. tall, girth 1-3 m., bark gray).

The discovery of a second Ash of the Melioides group in China furnishes another proof of the close relationship of the eastern North American and the Chinese floras. The sterile plant might be confounded from a superficial examination with some forms of Fraxinus pennsylvanica Marshall, but the papillose structure of the epidermis of the leaflets resembles more closely that of Fraxinus americana Linnaeus. The leaves of this new Ash are similar to those of Fraxinus platypoda Oliver, but differ from them in the absence of the dilatation of the rhachis. 


\section{ROSACEAE.}

\section{Subfam. POMOIDEAE.}

Determined by Alfred ReHDer.

\section{PYRUS L.}

\section{Pyrus serotina Rehder in Proc. Am. Acad. L. 231 (1915).}

Western Hupeh: Hsing-shan Hsien, woodlands, alt. 1300-2000 m., May and December 1907 (No. 479 ${ }^{\mathrm{a}}$, type); same locality, May and October 1907 (No. 2977); Patung Hsien, thickets, alt. 1000-1600 m., May 1907 (No. 556 $6^{\mathrm{b}}$ ); north and south of Ichang, thickets, alt. 600-1300 m., April 1907 (No. 479 b); same locality, October 1907 (No. 4I5); Changlo Hsien, thickets, May 1907 (No. 556 ${ }^{\circ}$ ); without precise locality, A. Henry (No. 5299). Eastern Szech'uan: without precise locality, A. Henry (No. 5875). Western Szech'uan: Tachien-lu, alt. 2000-2600 m., October 1908 (No. I293).

This is one of the Chinese Pears formerly referred to $P$, sinensis Lindley (not Poiret). It differs from that species for which $I$ have proposed the name $P$. Lindleyi (in Proc. Amer. Acad. L. 230) chiefly on account of its brown fruit with deciduous calyx and of its sharply and setosely serrate, not denticulate or dentate leaves. In the form which I consider the type of $P$. serotina the leaves are generally oblongovate, rounded at the base, and the brown fruit is subglobose and measures about $3 \mathrm{~cm}$. in diameter.

Wilson's No. 2977, of which the fruit is not known, differs from the type in its broader ovate or broadly ovate leaves with more appressed teeth and may represent a distinct variety or even another species. Henry's No. 5875 has the fruit pyriform and may belong to $P$. serotina, var. Stapfiana Rehder. Henry's No. 5299 is in flower only and agrees with this species in its glabrous styles; both of Henry's specimens may be from cultivated plants.

Pyrus serotina is common in Szech'uan and Hupeh and is cultivated in several improved forms as it is in Japan. The plant known in horticultural literature as $P$. sinensis belongs mostly to this species. Also $P$. sinensis Diels (in Bot. $J a h r b, \mathrm{XX} \perp X, 387$ ) is probably referable to $P$. serotina, if it does not belong to the following species.

A picture of this tree will be found under No. 0148 of the collection of Wilson's photographs.

Pyrus serrulata Rehder in Proc. Am. Acad. L. 234 (1915).

Western Hupeh: Hsing-shan Hsien, thickets, alt. 1300-1600 m., May and December 1907 (No. 779, type); north and south of Ichang, alt. 600-1300 m., October 1907 (No. 479). 
This species seems to be most closely related to $P$. serotina Rehder, but differs chiefly in its serrulate, not setosely serrate, generally broader leaves and in the smaller flowers with usually 3 or 4 styles and shorter sepals and in the smaller fruit.

Pyrus Calleryana Decaisne, Jard. Fruit. I. in textu ad t. 8 (1872). Maximowicz in Bull. Acad. Sci. St. Pétersbourg, XIX. 172 (1873); in Mél. Biol. IX. 169 (1873); in Bull. Soc. Nat. Mosc. LIV.pt. 1, 18 (1879). - Hance in Jour. Bot. XXI. 298 (1883). - Franchet in Nouv. Arch. Mus. Paris, sér. 2, V. 272 (1883).- Schneider, Ill. Handb. Laubholzk. I. 666, fig. 363 p (1906). - Koidzumi in Jour. Coll. Sci. Tokyo, XXXIV. art. 2, 55 (1913). - Rehder in Proc. Am. Acad. L. 237 (1915).

Western Hupeh: Hsing-shan Hsien, thickets, not common, alt. 1000-1300 m., May 14, 1907 (No. 2775); Changlo Hsien, thickets, alt. 1000-1500 m., December 1907 (No. 556); Patung Hsien, alt. 10001700 m., December 1907 (No. 556 ); around Ichang, common, alt. 1000-1300, March and July 1907 (No. 2976); mountains north and south of Ichang, alt. 600-1500 m., April 1907 (No. 4I 5 ${ }^{\mathrm{a}}$ ). Kiangsi : Kuling, side of streams, common, alt. 1300 m., July 29, 1907 (No. r662). Chekiang: Ningpo, 1908, D. Macgregor. Kwangtung: without precise locality, C. Ford (No. 68); Botanic Garden, Hongkong, Nov. 4, 1903, C. S. Sargent.

Pyrus Calleryana is a widely distributed species, and according to Wilson it is common in western Hupeh from river-level up to $1500 \mathrm{~m}$. alt. It is easily recognizable by its comparatively small crenate leaves glabrous or nearly glabrous like the inflorescence and by its small flowers with 2 , rarely 3 styles. When unfolding most specimens show a loose and thin tomentum on the underside of the leaves which usually soon disappears, but in No, 1662 from Kuling even the fully grown leaves are loosely rusty tomentose on the midrib beneath. In No. $415^{\mathrm{a}}$ the leaves are longer, generally ovate-oblong, the pedicels are very long and slender, about $3-4 \mathrm{~cm}$. long, and the sepals are mostly long-acuminate. The fruits of No. $556^{\mathrm{a}}$ are rather large, about 1-1.4 cm. in diameter, but a fruit examined proved to be 2-celled.

A picture of this tree will be found under No. 669 in the collection of Wilson's photographs and also in his Vegetation of Western China, No. 424.

Pyrus pashia Hamilton apud D. Don, Prodr.Fl. Nepal. 236 (1825).G. Don, Gen. Syst. II. 622 (1832). - Decaisne, Jard. Fruit. I. 328, t. 7 (1872). - Wenzig in Linnaea, XXXVIII. 48 (1874). - Brandis, Forest Fl. Brit. Ind. 204 (1874); Ind. Trees, 291 (1906). - Kurz, Forest Fl. Brit. Burma, I. 441 (1877). - Hooker f., Fl. Brit. Ind. II. 374 (1879). - Collett, Fl. Siml. 169, fig. 47 (1902). - Schneider, Ill. Handb. Laubholzk. I. 664, fig. 363 h, 364 e-g (1906). - Diels in Not. Bot. Gard. Edinburgh, VII. 24 (1912). - Rehder in Proc. Am. Acad. L. 238 (1915), 
Pyrus variolosa Wallich, Cat. No. 680 (nomen nudum) (1828).- G. Don, Gen. Syst. II. 622 (1832).

Pyrus verruculosa Bertoloni in Mem. Accad. Sci. Bologna, ser. 2, IV. 312 (Piante As. II.) (1864).

Pyrus heterophylla Hort. ex Decaisne, Jard. Fruit. I. 328, sub. t. 7 (pro synon.) (1872).

Pyrus nepalensis Herb. Hamilt. et Hort. ex Hooker f., Fl. Brit. Ind. II, 374 (pro synon.) (1879).

Western Szech'uan: Ching-chi Hsien, alt. 1500 m., October 1908 (No. I335); same locality, open country, alt. 2600 m., October 1910 (No. 4I32). Yunnan: Mengtsze, alt. 1400-1500 m., A. Henry (Nos. $10035,10035^{\circ}$ ). Himalaya: Kashmir to Bhutan. Assam: Khasia mountains, Ava (ex Hooker f.).

This species is not mentioned by Hemsley in his Index Florae Sinensis, though Hooker f. in 1879 includes Yunnan in the range of the species. Wilson's No. 1335 which is in ripe fruit agrees well with typical P. pashia and the young plants raised at the Arnold Arboretum from seeds of that number show exactly the kind of finely and sharply serrate mostly deeply lobed leaves, figured by Decaisne as the form occurring on suckers. No. 4132 differs in its much shorter and tomentose pedicels, only about $1.5 \mathrm{~cm}$. long, and in the generally broader leaves mostly subcordate at the base; some of the fruits show a persistent calyx. Whether this is a variety of this species or a distinct species may be decided when the plants in cultivation flower and fruit.

Here may be added a note on a variety of this species collected by A. Henry in Yunnan.

Pyrus pashia, var. kumaoni Stapf in Bot. Mag. CXXXV. t. 8256 (1909). Rehder in Proc. Am. Acad. L. 239 (1915).

Pyrus Kumaoni Decaisne, Jard. Fruit. I. 328, sub. t. 7 (1872). - Hooker f., Fl. Brit. Ind. 11.374 (1879). - Schneider, Ill. Handb. Laubholzk. I. 665 (1906).

Pyrus Wilhelmii Schneider, Ill. Handb. Laubholzk. I. 665, fig. 363 n (1906); in Fedde, Rep. Spec. Nov. III. 120 (1907).

Yunnan: Mengtsze, mountain woods, alt. $1600 \mathrm{~m} .$, A. Henry (No. 10035a, type of P. Wilhelmii); same locality, alt. $1400 \mathrm{~m}$., A. Henry (No. 10035 $5^{\text {b). }}$ Himalaya: Kashmir to Kumaon (ex Hooker f.).

This variety differs from the type in its glabrous or nearly glabrous infloreseence and leaves and in the ovate, broader and often obtuse ealyx-lobes. I am unable to separate $P$. Wilhelmii specifically from this variety. Broadly ovate leaves occur also in $P$. pashia, and the statement that $P$. Wilhelmii has only 3 styles is not borne out by the specimen in the herbarium of the Arnold Arboretum, which represents Henry's No. $10035^{\mathrm{a}}$, on which $P$. Wilhelmii is based, as the number of styles varies in that specimen from 3 to 5 .

Pampanini describes (in Nuov. Giorn. Bot. Ital. n. ser. XVII. 291 [1910]) P. hupehensis as a new species allied to $P$. pashia and very similar in general appearance to $P$. communis, but as he states that the three styles are connate at the base and villose-tomentose, this plant cannot belong to the genus Pyrus, if his statement is correct.

For an enumeration of all the Chinese species of Pyrus and a key see my Synopsis of the Chinese Species of Pyrus in Proc. Am. Acad. L. 225-240 (1915). 
This includes besides those enumerated above the following species: $P$. ussurisnsis Maximowiez, P. ovoidea Rehder, P. Lindleyi Rehder, P. Bretschneideri Rehder, $P$. phaeocarpa Rehder, $P$. betulifolia Bunge, $P$. kolupana Schneider and $P$. Koehnei Schneider.

\section{SORBUS L. ${ }^{1}$}

\section{Sorbus pallescens Rehder, n. sp.}

Arbor tenuis 7-metralis; ramuli fusco-purpurei, sparse lenticellati, initio ut videtur lanuginosi, autumno glabri; gemmae pauci-perulatae, oblongo-ovatae, acuminatae, apice villosulo excepto glabrae. Folia decidua, elliptico-ovata v. elliptica, rarius elliptico-obovata, basi rotundata v. late cuneata, acuta v. breviter acuminata, 4-10 $\mathrm{cm}$. longa et 2-5 cm. lata, irregulariter v. dupliciter denticulato-serrata, denticulis saepe ad glandulam reductis, maturitate supra glabra, subtus tomento lanuginoso adpresso albido-cinereo nervis flavescentibus leviter tantum villosis exceptis dense obtecta, nervis utrinsecus $10-12$ fere rectis in dentes exeuntibus subtus colore flavescente conspicuis; petioli 0.5-1.2 cm. longi, flavescentes, maturitate sparse lanuginosi v. fere glabri. Inflorescentia fructifera parva, tota fructibus inclusis circiter $1.5 \mathrm{~cm}$. alta, sessilis, sparse lanuginosa v. fere glabra, fructibus 1-4; pedicelli breves, $2-3 \mathrm{~mm}$. longi; fructus subglobosus, circiter $6 \mathrm{~mm}$. diam., albidus partim rubro suffusus, basi et apice sparse lanuginosus, calyce persistente sepalis recurvis triangularibus acutiusculis intus glabris extus pubescentibus coronatus, bilocularis; styli duo, basi lanuginosi, infra saltem connati (pars inferior persistens tantum visa); semina orbiculari-obovoidea, compressa, circiter $4 \mathrm{~mm}$. longa, castanea.

Western Szech'uan: west of Tachien-lu, thickets, alt. 3000 m., October 1908 (No. I255).

This species is most closely related to S. cuspidata Hedlund, which is easily distinguished by the larger leaves white-tomentose beneath, by the larger inflorescence and by the larger lenticellate $3-5$-celled fruit. It may also be compared with Sorbus Aria Crantz, which differs in the broader distinctly lobulate leaves more densely white-tomentose beneath including the veins and petioles, in the much larger many-flowered inflorescence, longer sepals, and in the larger fruit with the persistent sepals incurved.

Sorbus megalocarpa Rehder, n. spec.

Frutex robustus 5-8-metralis, interdum epiphyticus in variis arboribus veteribus; ramuli crassi, initio, ut videtur, sparse lanuginosi, demum fusco-purpurei, glabri, nitiduli, lenticellis albidis plerumque oblon-

1 For subgen. Aucuparia, see vol. I. 457-483. 
gis notati, vetustiores purpureo-fusci v. atrofusci; gemmae ovatae, floriferae 1-2 cm. longae, crassae, perulis exterioribus 7-12, orbiculariovatis v. late ovatis mucronulatis glabris superioribus plus minusve viscidis olivaceis deciduis. Folia decidua, chartacea, elliptico-obovata, v. obovato-oblonga, acuminata, interdum subito acuminata v. tantum acuta, basi cuneata v. rarius e basi attenuata subito contracta et rotundata, dense erenulato-serrulata, in foliis majoribus interdum fere sublobulata, 11-16, interdum ad $25 \mathrm{~cm}$. longa et $5-8$, interdum ad $13 \mathrm{~cm}$. lata, utrinque glabra v. subtus in axillis nervorum lanuginosobarbata supra intense luteo-viridia, subtus paullo pallidiora, nervis utrinsecus 14-20 fere rectis in dentes exeuntibus, supra ut costa impressis, subtus elevatis flavescentibus, venulis leviter elevatis v. interdum fere obsoletis eis secundi ordinis exceptis; petioli validi, 1-1.5 cm. longi, interdum ob laminam decurrentem breviores. Inflorescentia fructifera corymbosa, $6-8 \mathrm{~cm}$. alta et $10-15 \mathrm{~cm}$. diam., in apice innovationum brevissimorum v. brevium sessilis, foliis pluribus congestis sustenta; rhachis tomentosa v. saepius glabra lenticellata; pedicellia,0.5-1 $\mathrm{cm}$. longi, glabri v. sparse lanuginosi; sepali late triangularia, acutiuscula, circiter $2 \mathrm{~mm}$. longa et paullo latiore, intus glabra, extus lanuginosa, in fructu persistentia et plerumque recurva; petala non visa; stamina circiter 20, glabra, ad $3.5 \mathrm{~mm}$. longa; discus euplaris, sulcatus, glaber; styli plerumque 3 v. 4 , ad medium connati, glabri, circiter 4 $\mathrm{mm}$. longi, in fructu basi incrassati et cupula circiter $3 \mathrm{~mm}$. alta a disco et calycis tubo formata circumdati; carpella tota infera; pomum ovoideum, basi et apice rotundatum v. leviter attenuatum $2-3.5 \mathrm{~cm}$. longum, rarius minus, brunneum et verruculosum, basi tantum interdum purpureo-fuscum, carnosum carne glomicellis mollibus rubris farcta, endocarpio crustaceo fragili; semina obovoidea, compressa, 4-6 mm. longa castanea.

Western Szech'uan: Mupin, woodlands, alt. 2200-2600 m., October 1910 (No. 956, in part); Hung-ya Hsien, epiphytic on various trees, alt. 1200 m., September 12, 1908 (No. 956, in part); near Monkong Ting, cliffs, alt. 2000 m., June 19, 1908 (No. 956, in part).

This species does not seem to be closely related to any other Sorbus. In the inferior ovary and in the 3-4 styles connate below the middle, it agrees with $S$. Hedlundii Schneider, but differs from it in the much larger russet-colored fruit and the glabrous leaves which resemble certain species of the section Micromeles, as $S$, aronioides Rehder and $S$, meliosmifolia Rehder.

Sorbus megalocarpa, var. cuneata Rehder, n. var.

A typo recedit foliis in petiolum vix $1 \mathrm{~cm}$. longum v. breviorem sen- 
sim decurrentibus 11-14 $\mathrm{cm}$. longis, et praecipue fructibus minoribus ovoideis circiter $1.5 \mathrm{~cm}$. longis et $1 \mathrm{~cm}$. diam. brunneo-viridibus mollioribus et magis succulentis.

Western Szech'uan: Mupin, woodlands, alt. 2400-2700 m., October 1910 (No. 42I5; tree 5-8 m. tall, fruit russet-green).

This variety differs from the type chiefly in its smaller softer fruit and in the more cuneate short-stalked leaves; in all other characters it agrees with the type, particularly in the peculiar conical thickening of the base of the connate styles, as it appears on the fruit.

\section{Sorbus aronioides Rehder, n. sp.}

Frutex v. arbor, 4-12-metralis; ramuli ab initio fere glabri, annotini fusco-grisei v. purpureo-fusci, sparse lenticellis parvis instructi; gemmae ovatae, acutiusculae, glabrae, pauci-perulatae. Folia decidua, matura chartacea, breviter petiolata, elliptica v. elliptico-obovata v. elliptico-oblonga, acuminata, basi sensim attenuata v. interdum satis late cuneata, inaequaliter minute serrata, 6-12 cm. longa et $2.5-5 \mathrm{~cm}$. lata, supra glabra, ad costam plerumque glandulis sparsis obsita, luteoviridia, subtus paullo pallidiora, initio ad costam nervosque densius, in facie sparsissime araneoso-lanuginosa, mox glabra, nervis utrinsecus 7-10 leviter curvatis ante marginem in venulas dissolutis; petioli $0.5-1$ $\mathrm{cm}$. longi, lamina decurrente plus minusve marginati, glabri. Corymbi multiflori, satis densi, $3.5-5 \mathrm{~cm}$. diam., glabri; pedicelli $2-5 \mathrm{~mm}$. longi ut calyx extus glaberrimi; sepala orbiculari-ovata, rotundata, margine villoso-ciliata, ceterum glabra; petala irregulariter ovalia, circiter 4 $\mathrm{mm}$. longa, breviter unguiculata, alba; stamina circiter 20 , inaequalia, longiora petalis subaequilonga, antheris late ovalibus fuscis; discus cupuliformis: ovarium totum inferum, carpellis undique connatis; styli $2-3$, rarius 4 , ad medium usque connati, glabri, staminibus manifeste breviores, eirciter $3.5 \mathrm{~mm}$. longi. Fructus ovoideus, $9-11 \mathrm{~mm}$. longus, $8-9 \mathrm{~mm}$. diam., apice cicatrice calycis decidui medio umbilicata notatus, in sicco ruber, laevis; semina immatura obovoidea, compressa, castanea.

Western Szech'uan: Wa-shan, thickets, alt. 2300-3000 m., June 1908 (No. 2993, type); southeast of Sungpan, thickets, alt. 2300-2600 m., August 1910 (No. 4632); Mt. Omei, June 1904 (Veitch Exped. No. 4867).

This species is most closely related to $S$. Keissleri Rehder, which differs chiefly in the villose inflorescence, the subglobose fruits, the stouter and shorter petioles, and in the broader, more obovate and more coarsely crenate-serrate leaves. 


\section{Sorbus Keissleri Rehder, n. comb.}

Micromeles Decaisneana Schneider in Bull. Herb. Boissier, sér. 2, VI. (1906); Ill. Handb. Laubholzk. I. 701, fig. $385 \mathrm{~g}-\mathrm{g}^{1}, 386 \mathrm{i}-\mathrm{k}$ (1906).

Micromeles Keissleri Schneider, Ill. Handb. Laubholzk. I. 701, fig. 388 c, 389 d (1906).

Micromeles Decaisneana, var. Keissleri Schneider in Fedde, Rep. Spec. Nov. III. 151 (1906).

Pirus Keissleri Léveillé, Fl. Kony-Tchéou, 351 (1915).

Western Hupeh: Patung Hsien, woods, alt. 1300-2000 m., June 1907 (No. 470 ; tree 7-13 m. tall, 0.6-1 m. girth, flowers white);

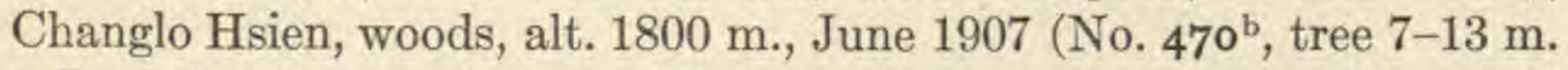
tall, girth 0.6-1 m., flowers white); without precise locality, May 1900 (Veitch Exped. No. 593, type of $M$. Decaisneana), A. Henry (Nos. $\left.5715,5715^{a}\right)$. Eastern Szech'uan: without precise locality, probably Wushan Hsien, A. Henry (No. 7166, type of $M$. Keissleri).

According to Schneider his Micromeles Decaisneana, var. Keissleri differs from the type in the flowers having only 2 styles, but flowers with 2 styles and with 3 styles occur in the same inflorescence. Wilson's No. $470^{\mathrm{b}}$ differs from the type in the dense floccose tomentum of the young inflorescence and the young branchlets and of the under surface of the unfolding leaves at least on the midrib; this tomentum, however, soon disappears.

The specific name "Decaisneana" cannot be used in the genus Sorbus for this species, as there is an older S. Decaisneana Zabel in Beissner, Schelle \& Zabel, Handb. Laubholz-Ben. 199 (1903).

Sorbus caloneura Rehder, n. comb.

Micromeles caloneura Stapf in Kew Bull. Misc. Inform. 1910, 192; in Bot. Mag. CXXXVI, t. 8335 (1910).

Pyrus caloneura Bean, Trees \& Shrubs Brit. Isl. II. 279 (1914).

Western Szech'uan: woods southeast of Tachien-lu, alt. 18002400 m., May and September 1908 (No. 997; bush or thin tree, 3-7 m. tall); Mt. Omei, June 1904 (Veitch Exped. No. 4864); without precise locality, alt. 2500 m., May 1904 (Veitch Exped. No. 3496). Eastern Szech'uan: Wushan Hsien, A. Henry (No. 7027). Western Hupeh: Hsing-shan Hsien, woods, alt. 1300-1500 m., May 1907 (No. 348 ; tree $7 \mathrm{~m}$. tall, girth $0.6 \mathrm{~m}$., flowers white, fruits greenish russet); Patung Hsien, alt. 1300-1800 m., November 1907 (No. 470; tree 7-12 $\mathrm{m}$. tall, girth 0.6-1 m., fruits russet green); north and south of Ichang, alt. 1200-1800 m., September 1907 (No. 2992; thin tree, 8-10 m. tall); without precise locality, May 1900 (Veitch Exped. No. 301).

This seems to be a rather variable species. Wilson's Nos. 470 and 348 have much larger more obovate leaves up to $13 \mathrm{~cm}$. long and to $8 \mathrm{~cm}$. broad. In the specimens from western Szech'uan the leaves when unfolding are covered beneath 
with a caducous cobwebby tomentum, while in No. 348 from Hsing-shan Hsien the leaves are glabrous when they unfold except a few hairs in the axils of the veins. No. 2992 has very small fruits measuring only about $6 \mathrm{~mm}$. in diameter. The number of styles varies from 3 to 5 .

\section{Sorbus meliosmifolia Rehder, n. sp.}

Arbor parva, 4-10-metralis; ramuli juniores purpureo-fusci, lenticellis parvis instructi, glabri; gemmae ovatae, pauci-perulatae, glabrae, fuscae v. fusco-olivaceae. Folia decidua, breviter petiolata, ovata v. elliptico-ovata v. elliptico-oblonga, acuminata, basi late cuneata, dupliciter v. lobulato-serrata dentibus latissime triangularibus serrulatis, 12-16 $\mathrm{cm}$. longa et 5-8 cm. lata, supra laete viridia, glabra, subtus pallide viridia, sub maturitate in facie tenuissime et sparse araneosolanuginosa v. glabrescentia, in costa nervisque glabra, nervis utrinsecus 18-24 rectis in dentes exeuntibus supra impressis subtus elevatis; petioli glabri, supra canaliculati, 4-7 mm. longi, crassiusculi. Corymbus fructifer glaber, 5-9 cm. diam.; pedicelli graciles, circiter $1 \mathrm{~cm}$. longi; fructus subglobosus v. plus minusve turbinatus, $1-1.2 \mathrm{~cm}$. longus, fuscus, lenticellis parvis satis dense notatus et apice cicatrice calycis decidui instructus, 3-locularis; semina late ovalia v. obovata, valde compressa, basi apiculata, apice saepe rotundata, 4-4.5 $\mathrm{mm}$. longa et 3.5 lata, brunnea.

Western Szech'uan: Mupin, woodland, alt. 2600 m., October 1910 (No. 422I).

This species seems to be most closely related to $S$. Schwerinii Rehder and $S$. caloneura Rehder. The former differs chiefly in the more pubescent leaves with only 13-16 pairs of veins, in the longer petioles and in the much smaller fruit, while the latter is easily distinguished by its narrower more oblong leaves mostly broadest about or above the middle and gradually narrowed at the base, with fewer veins and longer petioles.

Sorbus alnifolia K. Koch in Ann. Mus. Lugd.-Bat. I. 249 (1864). Maximowicz in Bull. Acad. Sci. St. Pétersbourg, XIX. 175 (1873); in Mél. Biol. IX. 173 (1873). - Wenzig in Linnaea, XXXVIII. 58 (1874); in Jahrb. Bot. Gart. Mus. Berlin, II. 294 (1883).

Crataegus alnifolia Siebold \& Zuccarini in Abh. Akad. Münch. IV. pt. II. 130 (Fl. Jap. Fam. Nat. I. 22) (1845). - Miquel in Ann. Mus. Lugd.-Bat. III. 40 (1867); Prol. Fl. Jap. 228 (1867). - Franchet \& Savatier, Enum. Pl. Jap. I. 141 (1875). ${ }^{1}$

Aria alnifolia Decaisne in Nouv. Arch. Mus. Paris, X. 166 (Mém. Fam. Pom.) (1874).

Aria tiliaefolia Decaisne, 1. c. 167 (1874).

${ }^{1}$ Crataegus alnifolia Regel in Act. Hort. Petrop. I. 125 (1871) does not belong here, but is a synonym of Malus Sieboldii Rehder. 
Pyrus alnifolia Franchet \& Savatier, Enum. Pl. Jap. II. 350 (non Lindley) (1879). - Diels in Bot. Jahrb. XXIX. 387 (1900), - Hooker f. in Bot. Mag. CXXVII, t. 7773 (1901).

Micromeles alnifolia Koehne, Gatt. Pom. 21 (1890); in Gartenfl. XLI. 282, fig. 61-62 (1892); Deutsche Dendr. 252 (1893), - Dippel, Handb. Laubholzk. III. 381 (1893), - Palibin in Act. Hort. Petrop. XVII. 75 (Consp. Fl. Kor.) (1899). - Komarov in Act. Hort. Petrop. XXII. 479 (Fl. Mansh.) (1904). Schneider, Ill. Handb. Laubholzk. I. 703, fig. 386 d-e, 387 i-k (1906). Nakai in Jour. Coll. Sci. Tokyo, XXVI. art. I. 183 (Fl. Kor.) (1909). Koidzumi in Jour. Coll. Sci. Tokyo, XXXIV.art. II. 68 (Consp. Rosac. Jap.) (1913).

Micromeles tiliaefolia Koehne, Gatt. Pomac. 21 (1890).

Pyrus Miyabei Sargent in Garden \& Forest, VI. 214 (1893); VII. 84, fig. 19 (1894). - Shirasawa, Icon. Ess. For. Jap. I. 84, t. 49, fig. 14-26 (1900).

Sorbus Myabei [sic] Mayr, Fremdl. Wald. u. Parkbäume, 491 (1906).

Micromeles alnifolia, var. tiliaefolia Schneider, Ill. Handb. Laubholzk. I. 703, fig. 386 e, 3871 (1906); in Fedde, Rep. Spec. Nov. III. 152 (1906).

Micromeles alnifolia, a serrata Koidz. $\beta$ tiliaefolia Koidzumi in Jour. Coll. Sci. Tokyo, XXXIV. art. 2, 69 (Consp. Rosac. Jap.) (1913).

Western Hupeh: north and south of Ichang, woods, alt. 12001800 m., June 5, 1907 (No. 2992 ${ }^{a}$; thin tree 8-10 m. tall); Changyang Hsien, alt. 1200-1800 m., November 1907 (No. 553); without precise locality, A. Henry (No.6791). Also in Mandshuria, Korea and Japan.

It does not seem possible to separate Decaisne's Aria tiliaefolia from the type of this species, not even as a variety, though there is apparently a slight difference in the shape of the leaves of the specimens from Hokkaido and of those from Hondo. Of the Chinese specimens Wilson's No. $2992^{n}$ agrees with those from Hondo, while Henry's No. 6791 agrees with those from Hokkaido. Wilson's No. 553 is without leaves, but in its other characters seems to agree perfectly with S. alnifolia K. Koch.

\section{Sorbus Folgneri Rehder, n. comb.}

Micromeles Folgneri Schneider in Bull. Herb. Boissier, sér. 2, VI. 318 (1906); Ill. Handb. Laubholzk. I. 704, fig. 386 q, $387 \mathrm{n}-\mathrm{n}^{1}$ (1906); in Fedde, Rep. Spec. Nov. III. 152 (1906), - Bean in Kew Bull. Misc. Inform. 1910, 175. Rehder in Möller's Deutsch. Gärtn.-Zeit. XXVII. 136, fig. (1912).

Pyrus Folgneri Léveillé apud Bean, Trees \& Shrubs Brit. Isl. II. 283 (1914). - Léveillé, Fl. Kouy-T'chéou, 349 (1915).

Kiangsi: Kuling, thickets, common, alt. 1200 m., July 29, 1907 (No. I677; small tree, $5 \mathrm{~m}$. tall). Western Hupeh: Changyang Hsien, woods, alt. 1200-1800 m., May 1907 (No. 2997; thin tree, 5-8 m. tall, flowers white); without precise locality, May, June and October 1900 (Veitch Exped. Nos. 352 and 951); without precise locality, A. Henry (Nos. 5273 and 5804). Eastern Szech'uan: Wushan Hsien, A. Henry (No. 7075).

A picture of this handsome tree will be found under No. 0150 of the collection of Wilson's photographs. 


\section{CONSPECTUS SPECIERUM ASIAE ORIENTALIS. ${ }^{1}$}

Fructus calyce persistente.

Folia subtus tomentosa v. demum fere glabra, dupliciter serrata.

Fructus subglobosus. Folia subtus tomento persistente obtecta.

Corymbus pauciflorus, vix $2 \mathrm{~cm}$. altus.

Fructus punctulatus, ruber; styli 3 , fere ad basin liberi. Folia 8-12 $\mathrm{cm}$. longa ................ 1. Santhoneura. Fructus levis, pallidus: styli 2 infra coaliti. Folia $4-8 \mathrm{~cm}$, longa.

2. S. pallescens.

Corymbus multiflorus, 4-5 cm. altus: styli 2, ad apicem coaliti. Folia 5-9 cm. longa, basi cuneata . . . . . . . . . 3. S. Dunnii.

Fructus oblongo-ovoideus. Folia subtus tomento floccoso demum fere evanescente instructa . . . . . . . . . 4. S. Zahlbruckneri. Folia subtus glabra, crenato-serrata. Styli 3-4, ad medium coaliti. Fructus ad

$3.5 \mathrm{~cm}$. longus . . . . . . . . . . . 5. S. megalocarpa.

Fructus calyce deciduo, apice cicatrice circulari notatus.

Folia nervis utrinsecus 7-10, leviter curvatis ante marginem subaequaliter serratum in venulas dissolutis. Fructus subglobosus.

Petioli graciles, 1.5-2 $\mathrm{cm}$. longi; folia oblonga, longe acuminata.

Fructus lenticellatus, eirciter $1 \mathrm{~cm}$. diam. . . . . 6. S. granulosa.

Fructus levis, circiter $0.5 \mathrm{~cm}$. diam. . . . . . 7. $\quad$. S. polycarpa.

Petioli breves, $0.5-1 \mathrm{~cm}$. Iongi. Fructus levis.

Inflorescentia glabra. Petioli plerumque $1 \mathrm{~cm}$. longi; folia plerumque obovato-oblonga $\mathrm{v}$. anguste elliptica . . . . . . 8. S. aronioides.

Inflorescentia villosa. Petioli plerumque $0.5 \mathrm{~cm}$. longa; folia plerumque obovata . . . . . . . . . . . . Keissleri.

Folia nervis utrinsecus $10-20$ rectis in dentes majores marginis dupliciter v. lobulato-serrati exeuntes.

Folia matura subtus viridia, glabra v. plus minusve pubescentia.

Fruetus subglobosus, lenticellatus. Petioli $0.5-1 \mathrm{~cm}$., rarius ad $1.5 \mathrm{~cm}$. longi. Folia subtus fere glabri, nervis utrinsecus 10-18 . . 10. S. caloneura. Folia subtus plus minusve lanuginosa.

Folianervisutrinsecus 16-24. Fructus $1 \mathrm{~cm}$. diam. 11. S. meliosmifolia.

Folia nervis utrinsecus 13-16. Fructus $0.5 \mathrm{~cm}$, diam. 12. S. Henryi.

Fructus ovoideus v. ellipsoideus, levis v. sparse lenticellatus. Petioli graciles, 1-2 cm. longi. Folia orbiculari-ovata v. elliptica. .. 13. S. alnifolia.

Folia matura subtus albo- v. cinereo-tomentosa.

Folia serrato-lobulata, elliptica v. ovata. Fructus ovoideus.

Folia vix v. non lobulata, ovato-oblonga v, elliptico-oblonga.

14. S. japonica.

Fructus subglobosus, lenticellatus. Folia nervis utrinsecus 12-14 demum glabris . . . . . . . . . . . . . 15. S. Hemsleyi. Fructus ovoideus, levis. Folia nervis utrinsecus 8-10 tomentosis.

1. Sorbus xanthoneura Rehder, n. sp.

16. S. Folgneri.

Arbor, verisimiliter; ramuli juniores purpureo-fusci, glabri, sparse lenticellati, vetustiores fusco-cinerei v. cinerei, fructiferi cicatricibus perularum et foliorum approximatis conspicue notati; gemmae pauciperulatae ovatae, acuminatae, viridi-

1 For a key to the Chinese species of the subgen. Aucuparia see vol. I. 476-480. 
flavescentes v. rubescentes, omnino glabrae. Folia decidua, oblonga v. obovatooblonga, acuminata, basi rotundata v. late cuneata, margine dupliciter denticulatoserrata dentibus parvis glanduliferis margine revolutis, $8-13 \mathrm{~cm}$. longa et $3.5-5.5$, rarius ad $6 \mathrm{~cm}$. lata, supra luteo-viridia, glabra, subtus dense tomento albido arcte adpresso lanuginoso costa et nervis flavidis glabris exceptis obtecta, nervis utrinsecus rectis in dentes exeuntibus 12-14; petioli glabri, flavidi, 8-15 mm. longi. Inflorescentia fructifera parva, fructibus inclusis circiter $2 \mathrm{~cm}$. alta, sparse lanuginosa v. fere glabra, fructibus 1-3; pedicelli breves, 2-4 mm. longi; fructus subglobosus, circiter $8 \mathrm{~mm}$. diam., ut videtur ruber, sparse lenticellis pallidis notatus, calyce persistente sepalis recurvis anguste triangularibus acutis intus basi excepta lanuginosis partim deciduis coronatus, basi et apice sparsissime lanuginosus, trilocularis, loculis in fructibus dissectis sterilibus; styli 3 , fere ad basin divisi, basi ut videtur, lanuginosi.

Hupeh: without precise locality, A. Henry (No. 6830).

This species is very closely related to $S$. pallescens Rehder, but is easily distinguished by its larger lenticellate fruit and by the glabrous petioles and the glabrous underside of the midrib and lateral veins. It is apparently still closer related to S. cuspidata Schneider, on account of its larger lenticellate 3-celled fruit.

\section{Sorbus pallescens Rehder. See p. 266.}

3. Sorbus Dunnii Rehder, n. sp.

Arbor, verisimiliter; ramuli hornotini initio fulvo-lanuginosi, mox glabri, demum fusco-purpurei, vetustiores fusci v. fusco-cinerei; gemmae non visae. Folia decidua, elliptico-oblonga v. oblonga, acuta v. breviter acuminata, basi late cuneata, inaequaliter serrulata dentibus minutis glanduliferis margine revolutis, $6-8 \mathrm{~cm}$. longa et $2.5-4 \mathrm{~cm}$. lata, supra glabra, subtus dense tomento lanuginoso albido in costa venisque fulvescente et detergibili vestita, nervis utrinsecus circiter 10 angulo valde acuto divergentibus rectis in dentes excurrentibus; petioli $1-1.5 \mathrm{~cm}$. longi, tomento fulvo detergibili obtecti. Inflorescentia multiflora, circiter $5 \mathrm{~cm}$. diam. et 4-5 cm. alta, tomento fulvescente lanuginoso obtecta, rachi glabrescente lenticellata; pedicelli $2-5 \mathrm{~mm}$. longi ut receptaculum turbinatum dense tomentosi; sepala triangulari-ovata, acutiuscula, $1.5 \mathrm{~mm}$. longa, extus tomentosa, intus glabra; petala late ovalia, $4 \mathrm{~mm}$. longa, basi truncata, brevissime unguiculata, alba, glabra; stamina 20 , longiora circiter $4 \mathrm{~mm}$. longa, stylos superantia; discus cupularis, glaber; styli duo, fere ad apicem connati, glabri; carpella duo tota connata, infera. Fructus desideratur.

Fokien: without precise locality, Dunn's Exped., April to June 1905 (Herb. Bot. Gard. Hongkong, No. 2597).

This species seems to be most closely allied to Sorbus Hedlundii Schneider and $S$. Aria Crantz; the former is easily distinguished by the larger leaves with 12-17 pairs of veins, by the 3-5 styles connate only for half their length and woolly at the base and by the lanceolate sepals pubescent on both sides. S. Aria differs chiefly in the more lobulate leaves more or less rounded at the apex and white-pubescent on the midrib and the petiole, in the partly superior ovary, in the pubescence at the base of the style and in the longer and narrower sepals.

The plant described by Pampanini (in Nuov. Giorn. Bot. Ital. n. ser. XVII. 72 [1910]) as Pyrus Aria, var. Silvestrii of which I have seen no specimen may represent a distinct new species; it seems near $S$. Dunnii, but differs in the styles which are densely tomentose at the base and connate to above the middle.

The plant described by Léveillé (in Fedde, Rep. Spec. Nov. XIII. 341 [1914]) as Sorbus Aria, var. Mairei with subsessile leaves green below is certainly no $S$. Aria. 
4. Sorbus Zahlbruckneri Schneider in Bull. Herb. Boissier, sér. 2, VI. 318 (1906); Ill. Handb. Laubholzk. I. 685, fig. 3790 (1906).

Eastern Szech'uan: without precise locality, A. Henry (No. 7021). Western Hupeh: Changyang Hsien, August 1901 Veitch Exped. No. 1980, Seed No. 628).

5. Sorbus megalocarpa Rehder. See p. 266.

6. Sorbus granulosa Rehder, n. comb.

Pyrus granulosa Bertoloni in Mem. Accad. Sci. Bologna, ser. 2, IV. 312, t. 3 (Piant. Nov. As. II.) (1864). - Kurz, Forest Fl. Brit. Burma, I. 442 (1877). - Hooker f., Fl. Brit. Ind. II. 378 (1879). - Prain in Jour. As. Soc. Bengal, LXXIII. 204 (1904). - Brandis, Ind. Trees, 292 (1906).

Pyrus Karensium, Kurz in Jour. As. Soc. Bengal, II. 306 (1872), III. 232 (1873).

Sorbus sikkimensis Wenzig in Linnaea, XXXVIII. 58 (1874), quoad specimina citata "Griffith No. 2077 " et "Pyrus (c) e Khasia."

Micromeles castaneaefolia Decaisne in Nouv. Arch. Mus. Paris, X. 169 (Mém. Fam. Pom.) (1874).

Micromeles khasiana Decaisne, 1. c. (1874), excludendo specimine "Griffith No. 2078."

Micromeles granulosa Schneider, Ill. Handb. Laubholzk. I. 700 (1906); in Fedde, Rep. Spec. Nov. III. 151 (1906).

Yunnan: Mengtsze, southeastern mts., A. Henry (No. 10136; tree $5 \mathrm{~m}$. tall). Khasia: "alt. 4-6000 ped.," J. D. Hooker \& T. Thomson (Pyrus (c), type of Pyrus granulosa).

This species which is elosely related to $S$. polycarpa Rehder and S. sikkimensis Wenzig is easily distinguished from these species by its larger spotted fruit.

The original description of this species is somewhat confusing, as the quotations of the specimens under Pyrus verruculosa and $P$. granulosa are interchanged; "Pyrus (e)" quoted under $P$. verruculosa belongs to $P$. granulosa, and " $P$. variolosa Trell. [sic] var." quoted under P. granulosa belongs to $P$. verruculosa, as a comparison of the description and the plates with the specimens quoted shows.

7. Sorbus polycarpa Rehder, n. comb.

Pyrus polycarpa Hooker f., Fl. Brit. Ind. II. 378 (1879). - Schneider, Ill. Handb. Laubholzk. I. 700 (1906). - Dunn in Jour. Linn. Soc. XXXIX. 483 (1911).

Yunnan: A. Henry (No. 11296, ex Dunn).

8. Sorbus aronioides Rehder. See p. 268.

9. Sorbus Keissleri Rehder. See p. 269.

10. Sorbus caloneura Rehder. See p. 269.

11. Sorbus meliosmifolia Rehder. See p. 270.

12. Sorbus Henryi Rehder, n. nom.

Micromeles Schwerinïi Schneider, Ill. Handb. Laubholzk. I. 702, fig. 388 b,

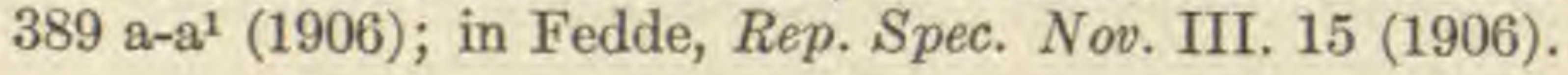

Western Szech'uan: A. Henry (No. 8957, ex Schneider). Shensi: G. Giraldi (No. 986, ex Schneider).

As there is already a Sorbus Schwerinï Schneider (in Bull. Herb. Boissier, sér. 2, VI. 315), the original specific name cannot be retained and the plant may be named after A. Henry, whose specimens served as the type of this species. 
13. Sorbus alnifolia K. Koch. See p. 270.

Sorbus alnifolia, var. lobulata Rehder, n. comb.

Micromeles alnifolia, $\beta$ lobulata Koidzumi in Jour. Coll. Sci. Tokyo, XXXIV. art. 2, 69 (Consp. Rosac. Jap.) (1913).

Korea: Chinnampo, September 17, 1905, J. G. Jack; same locality, June 1901 and August 1906, U. Faurie (Nos. 82 and 305); Seoul, September 1906, U. Faurie (No. 306). Korean Archipelago: Quelpaert, U. Faurie (Nos. 1552, 1554) Taquet (Nos. 748, 758, 2824, 2825).

Though the most extreme form of this variety as represented by Jack's specimens which have orbicular-ovate leaves up to $9.5 \mathrm{~cm}$. long and to $9 \mathrm{~cm}$. broad looks very distinet, the specimens from Quelpaert and from Seoul are intermediate between the variety and the typical form. I suspect that these intermediate forms represent, at least partly, Koidzumi's var. tiliaefolia.

Sorbus alnifolia, var. submollis Rehder, n. var.

A typo recedit foliis subtus tota facie villosa indumento plus minusve persistente et corymbis receptaculis sepalis extus laxe lanuginosis. Folia ovata, basi plerumque rotundata, 4-5 $\mathrm{cm}$. longa et $2.5-3.5 \mathrm{~cm}$. lata.

Hondo: north of Yumoto, oak woods, alt. $1500 \mathrm{~m}$., June 22-24, 1914, E. H. Wilson (No. 6874, type; tree 10-14 m. tall, 0.60-1.25 m. girth, flowers white); Mt. Mitsumine, October 1898, H. Shirasawa. Hokkaido: prov. Tokachi, August 17, 1907, without indication of collector.

This variety, which has comparatively small leaves and differs from the type chiefly in the rather dense villose pubescence of their underside, seems to have been sometimes confused with S. japonica Hedlund, which is easily distinguished by the floccose white or whitish tomentum, the lobed, usually more or less rhombic leaves and by the larger fruit.

14. Sorbus japonica Hedlund in Kongl. Svensk. Akad. Handl. XXXV. No. I. 90 (July 1901). ${ }^{1}$

Sorbus japonica Siebold in Verh. Bat. Genoot. XII. pt. 1, 67 (Syn. Pl. Oec. Jap.) (nomen nudum) (1830).

Pyrus lanata Miquel in Ann. Mus. Lugd.-Bat. III. 40 (non D. Don) (1867); Prol. Fl. Jap. 228 (1867), - Sargent in Garden \& Forest, VI. 213 (1893); For. Fl. Jap. 39 (1893).

Sorbus Aria, var. kumaonensis Maximowiez in Bull. Acad. Sci. St. Pélersbourg, XIX. 175 (1873); in Mél. Biol. IX. 173 (1873), - Shirasawa, Icon. Ess. For. Jap. I. 83 , t. 48 (1900).

Aria japonica Decaisne in Nouv. Arch. Mus. Paris, X. 164 (Mém. Fam. Pomac.) (1874).

Micromeles japonica Koehne, Gatt. Pomac. 21 (1890); Deutsche Dendr. 252 (1893). - Schneider, Ill. Handb. Laubholzk. I. 703, fig. $386 \mathrm{~g}-\mathrm{h}, 387 \mathrm{~m}-\mathrm{m}^{\prime}$ (1906). - Koidzumi in Jour. Coll. Sci. Tokyo, XXXIV. art. II. 69 (Consp. Rosac. Jap.) (1913).

1 In the same year the combination Sorbus japonica based on S. Aucuparia, var. japonica Maximowicz was published by Koehne, but S. japonica Hedlund has the priority by nearly one month, since his publication left the printing press on July 6,1901 , as I was kindly informed by Dr. J. A. Bergstedt, librarian of the Swedish Academy, while the number of Gartenflora in which Koehne's S. japonica was published did not appear until August 1, 1901. This also gives priority to Hedlund's $S$. commixia over $S$. japonica Koehne, which both refer to the same species. 
Sorbus Koehnei Zabel in Beissner, Schelle \& Zabel, Handb. Laubholz-Ben. 200 (1903).

Central and southern Japan.

Sorbus japonica, var. calocarpa Rehder, n. var.

A typo recedit praecipue fructu aurantiaco- v. aureo-luteo levi pyriformi v. ovoideo $1.5 \mathrm{~cm}$. longo et foliis subtus dense tomento niveo adpresso persistenti vestitis ad $10 \mathrm{~cm}$. longis et ad $8 \mathrm{~cm}$. latis.

Hondo: around Lake Yumoto, common in woods, Oct. 15-19, 1914, E. H. Wilson (No. 7643, type; tree 12-20 m. tall, 1.75-3.25 girth, fruit golden-yellow); same locality, June 22-24, 1914, E. H. Wilson (No. 6842); same locality, in Hemlock forest, September 6, 1892, C. S. Sargent.

This is a very striking and handsome variety with its large bright yellow fruits and the large leaves silvery white on their under surface; in the type the fruits are red and marked with white dots wanting in the variety, and the leaves have a looser more floccose tomentum which sometimes partly wears off towards autumn.

15. Sorbus Hemsleyi Rehder, n. comb.

Micromeles Hemsleyi Schneider, Ill. Handb. Laubholzk. I. 704, fig. 388a, $389^{\circ}$ (1906); in Fedde, Rep. Spec. Nov. III. 152 (1906).

Western Hupeh: A. Henry (No. 6830" type, 6269, ex Schneider).

\section{Sorbus Folgneri Rehder. See p. 271.}

In the preceding account of the Chinese species of Sorbus (excl. sect. Aucuparia) I have followed Hedlund and Schneider in the limitation of the genus except that I include Micromeles, which is considered a distinct genus by these authors. Decaisne, who founded the genus Micromeles, distinguishes it from his Aria chiefly by the smaller flowers, the epigynous disk and the deciduous calyx. The difference in the size of the flowers is not very marked and has hardly any significance as a generic character. In typical Aria as represented by Sorbus Aria which Decaisne figures, the disk is certainly perigynous, but in such species as $S$. cuspidata Hedlund (Aria lanata Decaisne), S. Hedlundii Schneider (Aria crenata Decaisne), $S$. japonica Hedlund and S. alnifolia $\mathrm{K}$. Koch enumerated by Decaisne under Aria, the disk is as distinctly epigynous as in the species referred by him to Micromeles. The deciduous calyx is not a distinguishing generic character with Decaisne, as he includes S. japonica and S. alnifolia, which both have a deciduous calyx, in Aria. This leaves no clear distinction between the two genera. Koehne tried to correct this inconsistent characterization of Micromeles and made the deciduous calyx the chief generic character, referring the species with deciduous calyx, as $S$. japonica and S. alnifolia which Decaisne had placed under Aria, to Micromeles. Considering, however, the fact that in allied genera like Pyrus and Malus species with a deciduous and with a persistent calyx exist, and that if these species are generically separated by this character alone very artificial genera would be created, it is hardly possible that in Sorbus the behavior of the calyx should be a sufficient character for generic distinction. That the generic affinity of all the species with deciduous calyx is not very obvious, may be inferred from the fact that Decaisne included only one part of these species in his Micromeles and left the other in Aria. These two groups of species show indeed in all other characters, aside from the behavior of the calyx, a less close relation to each other than each of them has to certain species of Sorbus. We have here the same case in Malus where the classification according to leaf-characters gives an entirely different and apparently more natural arrangement than that based on the behavior of the calyx. In Micromeles Koehne we have two distinct groups: one which has simply, more or less crenately serrate leaves with fewer and eurving veins, and subglobose usually lenticellate 
fruit with firm granulate flesh; here belong $S$. granulosa, S. verrucosa, S. aronioides and most other species. To the second group which has doubly serrate leaves with usually numerous straight veins and ovoid smooth fruits with soft flesh, belong S. japonica, S. alnifolia, S. Hemsleyi and $S$. Folgneri. An intermediate group is formed by $S$. meliosmifolia and $S$. caloneura which have the leaves of the second and the fruit of the first group. The species of the first group are very unlike the true Arias in the venation of their leaves which resemble more those of $S$. megalocarpa and those of the section Aronia, while the leaves of the second group are much like those of $S$. Aria with which they were placed by Decaisne. In Sorbus as distinguished from Micromeles two other species have been placed, which show that the behavior of the calyx is of minor taxonomic value; one of them is $S$. Zahlbruckneri, which is in every respeet like a form of S. Hemsleyi or of S. Folgneri with glabrescent leaves, but with a persistent calyx, though the fruit is in all other characters like that of S. Folgneri; the other species is S. subfusca Boissier, which is in foliage and in fruit very much like $S$. A ria and approaches it even in the structure of the flowers which have, according to Schneider's figure, a slightly perigynous disk, but its fruit has a deciduous calyx. All this shows that the species of Sorbus with deciduous calyx do not form a natural group and that the behavior of the calyx is apparently a phylogenetically recent character and therefore of secondary importance.

Besides the species enumerated above the following Himalayan species now enumerated either under Micromeles or under Pyrus must be transferred to Sorbus.

Sorbus ferruginea Rehder, n. comb.

Sorbus sikkimensis Wenzig, $\delta$ ferruginea Wenzig in Linnaea, XXXVIII. 60 (1874).

Pyrus ferruginea Hooker f., Fl. Brit. Ind. II. 379 (1879). - Brandis, Ind. Trees, 292 (1906).

Micromeles ferruginea, Koehne, Gatt. Pomac. 21 (sphalmate "ferruginosa ") (1890). - Schneider, Ill. Handb. Laubholzk. I. 700 (1906).

Bhot an: Griffith (No. 2074, ex Wenzig).

Sorbus Thomsonii Rehder, n. comb.

Pyrus Thomsoni King mss. apud Hooker f., Fl. Brit. Ind. II. 379 (1879). Brandis, Ind. Trees, 292 (1906).

Sikkim: T. Thomson (fruits); " 8000 ped.," J. D. Hooker (flowers),

This species seems near $S$. Keissleri Rehder with which it agrees in the venation and in the short petioles. Hooker states that young flowering specimens of this species were distributed as "Photinia arguta Wall. var." and were quoted by Decaisne under his Micromeles verrucosa, but a specimen under that name in the Gray Herbarium collected by Hooker \& Thomson consists of a fruiting branch and of a branch with mature leaves only; these both belong to $S$. verrucosa; and possibly Decaisne had a similar specimen and not the flowering branches of $S$. Thomsonii, referred to by Hooker.

Sorbus Griffithii Rehder, n. comb.

Sorbus sikkimensis, y microcarpa Wenzig in Linnaea, XXXVIII. 59 (1874).

Sorbus (Pirus) crenata Wenzig in Linnaca, XXXVIII. 60 (non D. Don) (1874), quoad specimen "Griffith No. 2076."

Pyrus Griffithii Hooker f., Fl. Brit. Ind. II. 377 (1879). - Prain in Jour. As. Soc. Bengal. LXXIII. 204 (1904). - Brandis, Ind. Trees, 291 (1906).

Sikkim: "East Himalaya" Griffith (No, 2076, type); "alt. 7-9000 ped." J. D. Hooker ("Pyrus," fruiting branch); Senadale, May 1879, J. L. Lister; Tanglo forest, October 1901, Dr. Prain's collector (No. 61, as P. rhamnoides). 
Koehne (Gatt. Pom. 21) refers Wenzig's Sorbus sikkimensis, $\gamma$ microcarpa to $S$. rhamnoides; the specimen quoted by Wenzig consists of 2 branches on the same sheet, a flowering branch which belongs to $S$. rhamnoides and a fruiting branch which belongs to S. Griffithii. As Wenzig describes the fruiting branch, his name belongs as a synonym to $\mathrm{S}$. Griffithii.

Sorbus kohimensis Rehder, n. comb.

Pyrus kohimensis Watt mss, apud Brandis, Ind. Trees, 292 (1906).

Assam: Naga Hills, Kohima (ex Brandis).

This species is described by Brandis as similar to S. Griffithii, but different in tufts of hairs inside the petals and in the ovoid ridged fruit $1 / 3 \mathrm{in}$. long.

Sorbus rhamnoides Rehder, n. comb.

Sorbus sikkimensis, $\beta$ oblongifolia Wenzig in Linnaea, XXXVIII. 59 (1874).

Micromeles rhamnoides Decaisne in Nouv. Arch. Mus. Paris, X. 169 (Mém. Fam. Pom.) (1874), - Schneider, Ill. Handb. Laubholzk. I. 701, fig. 385 e-f, 386 b (1906).

Pyrus rhamnoides Hooker f., Fl. Brit. Ind. II. 377 (1879). - Brandis, Ind. Trees, 292 (1906).

Photinia polyneura King in herb. Calcutta ex Hooker f., 1. e. (pro synon.) (1879).

Sikkim: " alt. 7-9000 ped.," J. D. Hooker ("Pyrus," flowers, type); Singale lah, June 1887, King's collector; above Sureil, June 16, 1902, Prain's collector.

Sorbus khasiana Rehder, n. comb.

Micromeles khasiana Decaisne in Nouv. Arch. Mus. Paris, X. 169 (Mém. Fam. Pom.) (1874), excludendo specimine citato "Pyrus (c)" quod ad $S$. granulosam pertinet.

Pyrus khasiana Hooker f., Fl. Brit. Ind. II. 378 (1879). - Prain in Jour. As. Soc. Bengal, LXXIII. 204 (1904). - Brandis, Ind. Trees, 292 (1906).

Khasia: Nungbree wood, Griffith (No. 2078, ex Decaisne et ex Hooker f.); Konoma, alt. 1660 m., April 1896, King's collector (No. 244).

This species is based on Pyrus khasiana Hooker f., and not on Micromeles khasiana Decaisne, which is partly $S$. granulosa, and this name becomes a synonym of $S$. granulosa, if we consider "Pyrus (c)" upon which Decaisne seems to have based his description as the type of Micromeles khasiana. I have not seen the type of Hooker's Pyrus khasiana, but the specimen from Konoma agrees exactly with Hooker's description and 1 have no doubt that it belongs here.

Sorbus verrucosa Rehder, n, comb.

Pyrus cuspidata Bertoloni in Mém. Accad. Sci. Bologna, ser. 2, 1V. 312, t. 1 (Piante As. II.) (1864). - Hooker f., Fl. Brit. Ind. II. 378 (1879). - Brandis, Ind. Trees, 292 (1906).

Sorbus silkimensis Wenzig in Linnaea, XXXVIII. 59 (1874), quoad specimen citatum " Khasia, 5000' alt., Pyrus (a)."

Micromeles verrucosa Decaisne in Nouv. Arch. Mus. Paris, X. 169 (Mém. Fam. Pom.) (1874).

Khasia: "5000 ped." J. D. Hooker \& T. Thomson, (Pyrus (a), type of Pyrus cuspidata Bertoloni and Micromeles verrucosa Decaisne); "alt. 3-5000 ped.," J. D. Hooker \& T. Thomson (as "Photinia arguta Wall. var.); "environs of Tšerapúndži till near Mairong," October 1855, Schlagintweit (No. 258); Cherrapoonji, alt. $1300 \mathrm{~m}$., January 1897, Dr. King's collector (without No.).

This species is very similar in foliage to $S$. granulosa Rehder, but is easily dis- 
tinguished by its much smaller unspotted fruit and by the lighter colored warty branchlets and the warty inflorescence.

The oldest specific name for this species "cuspidata" cannot be used on account of Sorbus cuspidata Hedlund. Neither can the name S. sikkimensis Wenzig be applied to this species, as that name must be considered, if restricted to the typical form, a synonym of $S$. granulosa; the deseription of the fruit shows clearly that S. sikkimensis belongs to that species, and, moreover, at least two of the four specimens quoted under the typical form belong to $S$. granulosa. The three varieties enumerated by Wenzig under S. sikkimensis all represent distinct species.

\section{MALUS Mill.}

Malus prunifolia Borkhausen, var. rinki Rehder, n. comb.

Pyrus Malus Siebold in Verh. Bataav. Genoot. XII. 1, 66 (Syn. Pl. Oecon. No. 350) (non Linnaeus) (1830), - Bunge in Mém. Sav. Etr. Acad. Sci. St. Pétersbourg, II. 101 (Enum. Pl. Chin. Bor. 27) (1835). - Siebold \& Zuccarini in Abh. Akad. Münch. IV. 2, 131 (Fl. Jap. Fam. Nat. 23) (1845). - Gray in Narr. Exp. Perry, II. 311 (1856); in Mem. Am. Acad. n. ser. VI. 388 (Bot. Jap.) (1859). - Miquel in Ann. Mus. Lugd.-Bat. III. 40 (1867); Prol. Fl. Jap. 228 (1867). - Debeaux in Act. Soc. Linn. Bordeaux, XXXIII. 43 (Fl. Tien-tsin, 20) (1879). - Hemsley in Jour. Linn. Soc. XXIII. 257 (1886).

Malus ringo Siebold, Cat. Rais. 5 (nomen nudum) (1856), - Carrière in Rev. Hort. 1874, 170, pro parte. - Koehne, Deutsch. Dendr. 260 (1893). - Schneider, Ill. Handb. Laubholzk. I. 716 (1906). - Koidzumi in Coll. Sci. Jour. Tokyo, XXXIV. art. 2, 92 (Consp. Rosac. Jap.) (1913).

Pyrus praecox Miquel in Ann. Mus. Lugd.-Bat. III. 40 (non Pallas) (1867); Prol. Fl. Jap. 228 (1867), - Franchet \& Savatier, Enum. Pl. Jap. I. 138 (1875).

Pyrus Malus, $\boldsymbol{\beta}$ tomentosa Maximowicz in Bull. Acad. Sci. St. Pétersbourg, XIX. 170 (non W. D. Koch) (1873); in Mél. Biol. IX. 165 (1873). Franchet \& Savatier, Enum. Pl. Jap. II. 349 (1879). - Franchet in Mém. Soc. Sci. Nat. Cherbourg, XXIV. 217 (Cat. Pl. Tche-fou) (1882).

iPyrus Malus, $\zeta$ sinensis Wenzig in Linnaea, XXXVIII. 34 (1874), exclud. synon.

Pyrus Ringo Wenzig in Linnaea, XXXVIII. 37 (1874). - Bailey, Cycl. Am. Hort. III. 1473, fig. 2027, 2028 (1901). - Stapf in Bot. Mag. CXXXV. t. 8265 (1909). - Bean, Trees \& Shrubs Brit. Isl. 11.292 (1914).

१Pyrus prunifolia Debeaux in Act. Soc. Linn. Bordeaux, XXXI. 155 (Fl. Tchéfon 60) (non Willdenow) (1876).

Malus microcarpa Ringo Carrière, Étude Pomm. Microcarp. 98 (pro parte) (1883).

Pyrus spec. Tanaka, Useful Pl. Jap. 156, t. fig. 635 (1895).

Malus Matsumurae Koidzumi in Tokyo Bot. Mag. XXIII. 172 (1909); in Jour. Coll. Sci. Tokyo, XXXIV. art. 2, 87 (Consp. Rosac. Jap.) (1913).

Malus prunifolia Koidzumi in Tokyo Bot. Mag. XXIII. 173 (pro parte) (1909); in Jour. Coll. Sci. Tokyo, XXXIV. art. 2, 91 (Consp. Rosac.Jap.) (pro parte, non Borkhausen) (1909). - Matsumura, Ind. Pl. Jap. II. 2, 205 (1912).

Malus communis Lamk. var. typica Matsumura, Ind. Pl. Jap II. 2, 204 (non Beck) (1912).

Malus pumila, var. Rinki Koidzumi in Jour. Coll. Sci. Tokyo, XXXIV. art. 2, 87 (Consp. Rosac. Jap.) (1913).

Malus yezoensis Koidzumi, 1. c. 89 (1913). 
Western Hupeh: Hsing-shan Hsien, woodlands, alt. 1300-1600 m., May 1907 (No. 2978, tree $8 \mathrm{~m}$. tall, flowers blush); Patung Hsien, April 1901 (Veitch Exped. No. 418, tree $5 \mathrm{~m}$. tall); around Ichang, cultivated, July 1907 (No. 6o, seeds only; tree 3-5 m. tall, fruit small, greenish); same locality, 1901 (Veitch Exped. Seed No. 357). Western Szech'uan: Tachien-lu, cultivated, alt. 2300-2600 m., August 1908 (No. 975; tree $5 \mathrm{~m}$. tall, fruit red). Japan: Hondo, Lake Towada, alt. $300 \mathrm{~m}$., cultivated under the name of "Rinki," October 5, 1914, E. H. Wilson (No. 7619; tree 4-5 m., fruit shining red); Hachinohe, prov. Mutsu, T. Makino.

There is apparently no character to distinguish $M$. prunifolia and $M$. ringo except the lesser or greater amount of pubescence and a slight difference in the color of the flowers, and these can hardly be considered specific characters. Willdenow described $M$. prunifolia in his Berlinische Baumzucht as having the leaves sparingly pubescent on the veins below and the calyx-tube pubescent outside, while De Candolle and many later authors described the leaves and the calyx-tube as glabrous, which made the two plants appear more distinct than they really are. In the specimens and living plants I have seen of $M$. prunifolia, the veins on the under surface of the leaves have been always at least slightly pubescent, the calyx-tube more or less tomentose, rarely glabrous, and the petals either white or slightly pinkish outside.

Before $M$. prunifolia, var. rinki was discovered by Wilson in central China in a wild state, it was known only from plants cultivated in Japan and by most botanists was considered a very doubtful plant. Except by recent Japanese botanists it was either ignored or believed to be of hybrid origin, and $M$. spectabilis and $M$. pumila have been suggested as possible parents. It is, however, difficult to see how this could be its parentage, as $M$. spectabilis is scarcely known in Japan and $M$. pumila has not been cultivated there until recently, the first European Apple trees having been introduced about 1870 . The plant taken by most authors for $M$. pumila is nothing but $M$, prunifolia, var. rinki which is eultivated in different forms in Japan, some of which have been recently separated as distinct species by Koidzumi. The vernacular name also shows that this Apple is of Chinese origin. According to notes kindly sent by Professor Matsumura the name "ringo" is derived from the Chinese " linkun" which changes to "linko," "linko" changes to " rinko " and finally becomes "ringo." There is an older name for this Apple, "riugo," which is also derived from the Chinese. The name "toringo" means "Chinese Apple."

Malus prunifolia, var. rinki varies in the shape of the leaves and in the amount of pubescence and considerably in the size, shape and in the color of the fruit which ranges from greenish yellow or pure yellow to shining red. Malus prunifolia, var. rinki forms a wide-spreading tree usually not exceeding $5 \mathrm{~m}$. in height; its fruit ripens in the neighborhood of Ichang and elsewhere in the warm river valleys in early July, while at greater altitudes it does not ripen until August or September; in Japan it ripens in September.

Some of the synonyms quoted above are somewhat doubtful, particularly those not accompanied by descriptions or notes. It is, however, fairly safe to assume that the Apples of China and Japan considered identical with the common European Apple are either the typical $M$. prunifolia or its variety rinki and usually the latter, since $M$. prunifolia is not known with certainty from China proper and from Japan. 
Malus prunifolia, var. rinki is elosely related to $M$. pumila, but ean be distinguished by its more sharply serrate and usually less tomentose leaves, the longer pedicels and chiefly by the smaller fruit not impressed at the apex, but with a raised calyx thickened and fleshy at the base.

AR.

This Apple grows spontaneously on the margins of woods and on the banks of mountain torrents in Hsing-shan Hsien and in the contiguous district of Patung Hsien at an altitude of from 1300 to $1600 \mathrm{~m}$., but it is rare. The region is very mountainous and sparsely inhabited, and the chance of these trees being escapes from cultivation is very slight. In size, habit and general appearance the trees much resemble those of the common European Apple. The flowers look the same, but the fruitstalk is much longer and more slender in the Chinese Apple. On the wild tree the fruit is greenish yellow and sometimes slightly tinged with red on one side.

In western Hupeh and eastern Szech'uan the Apple, colloquially known as Lin-chien, is sparingly cultivated from river-level to altitudes of $1500 \mathrm{~m}$., but in the warm valleys of western Szech'uan its cultivation extends up to $3300 \mathrm{~m}$. altitude. The fruit is small, seldom more than $11 / 4$ inches in diameter and slightly longer than broad, of a pleasant bitter-sweet flavor and varies in color from greenish to greenish yellow and is rosy on one side; occasionally it is nearly all red. The apples grown in the cold regions near Tachien-lu and Sungpan Ting are better than those grown in the warmer regions contiguous to the Yangtsze River in Hupeh and Szech'uan.

Formerly this Chinese Apple was cultivated in Japan for its fruit, but since the introduction of varieties of the European Apple its cultivation as a fruit tree has been discontinued. It has, however, been largely used as a stock on which to graft the imported varieties of the European Apple.

E. H. W.

Malus Prattii Schneider, Ill. Handb. Laubholzk. I. 719, fig. 397 p- $\mathrm{p}^{1}$, 398 k-m (1906); in Fedde, Rep. Spec. Nov. III. 178 (1906).

Pyrus Prattii Hemsley in Kew Bull. Misc. Inform. 1895, 16.

Western Szech'uan: southeast of Tachien-lu, woodlands, alt. 2600-3200 m., June and October 1908 (No. I252; tree 5-10 m. tall, 0.30-1 m. girth, fruit yellow); Tachien-lu, woodlands, alt. 2600-3000 m., October 1910 (No. 4II2; tree 5-8 m. tall); same locality, A. E. Pratt (No. 93 and 824); Wa-shan, woodlands, alt. 2600 m., June and October 1908 (No. Iro7; tree 7 m. tall, flowers white, fruit yellow); Mupin, woodlands, alt. 2300-2800 m., June and October 1908 (No. IIO $7^{\mathrm{a}}$; tree $5-7 \mathrm{~m}$. tall, flowers white, fruit red); without precise locality, July 1904 (Veitch Exped. No. 3498).

This is a very distinet species and is apparently related to $M$. sikkimensis Koehne with which it shares the peculiarity of having the fruits marked by white dots. It is, however, easily distinguished from the Himalayan species by the persistent calyx and the glabrous or nearly glabrous leaves of a peculiar light yellowish green color.

Malus baccata Desfontaines, var. mandshurica Schneider, Ill. Handb. Laubholzk. I. 721, fig. 397 n (1906). - Matsumura, Ind. Pl. 
Jap. II. 2, 203 (1912). — Koidzumi in Jour. Coll. Sci. Tokyo, XXXIV. art. 2, 83 (Consp. Rosac. Jap.) (1913).

Malus cerasifera Spach, Hist. Vég. II. 152, t. 10, fig. O-T (1834).

Pyrus baccata, $\boldsymbol{\beta}$ mandshurica Maximowicz in Bull. Acad. Sci. St. Pétersbourg, XIX. 170 (1873); in Mél. Biol. IX. 166 (1873). - Franchet in Nouv. Arch. Mus. Paris, sér. 2, V. 272 (Pl. David. I. 120) (1883). - Komarov in Act. Hort. Petrop. XXII. 494 (Fl. Mansh. II.) (1904).

Pyrus spectabilis A. Gray in Mem. Am. Acad. n. ser. VI. 388 (Bot. Jap.) (non Aiton) (1857).

Pyrus prunifolia Maximowicz in Mém. Sav. Étr. Acad. Sci. St. Pétersbourg, IX. 471 (Prim. Fl. Amur.) (non Willdenow) (1859).

Pyrus baccata Watson, Dendr. Brit. II. t. 51 (non Linnaeus) (1825). - Fr. Schmidt in Mém. Acad. Sci. St. Pétersbourg, sér. 7, XII. 2, 129 (Fl. Sacchalin.) (1868). - Hooker f. in Bot. Mag. C. t. 6112 (1874), quoad plantam depictam.

Malus baccata, var. mandshurica, f. latifolia Matsumura, Ind. Pl. Jap. II. pt. 2, 202 (1912).

Western Hupeh: Fang Hsien, woodlands, alt. 1500-2200 m., May 20 and September 1907 (Nos. 26r, 2979; bushy tree, 4-8 m. tall, flowers white, fragrant). Eastern Siberia: Amur, L. Schrenk, Maximowicz; "ad fl. Li-Fudin," 1860, and "Bay Guérin sinus Victoriae," Maximowicz; Vladivostock, cultivated, August 20, 1903, C. S. Sargent. Saghalien: "in dumosis," October 1907, U. Faurie (No. 14); Korsakof, July 1908, U. Faurie (No. 555); Sakaihama, sea-shore, 1914, E. H. Wilson (No. 7369; bush 1-2 m.). Korea: "in horto missionis Seoul," May 1909, Taquet (No. 2525). Hokkaido: Kushiro, sea-level, open country, August 1, 1914, E. H. Wilson (No. 7375; tree 7-12 m. tall, 0.6-1.6 m. girth, much-branched); Sapporo, June 1880, June 12 and 15, 1885 (Herb. Coll. Agric. Sapporo); Shiraoi, August 24, 1905, J. G. Jack. Hondo: foot of Hayachine-san, alt. 600-900 m., September 29, 1914, E. H. Wilson (No. 7596; tree 14-20 m. tall, girth 1.6-2.3 m., fruit red); Mt. Yatsugadake, thickets, common, alt. 1200-1500 m., September 17, 1914, E. H. Wilson (No. 7534; bush 2-4 m., fruit subglobose).

The range of this variety of $M$. baccata extends from the Amur region to central China and through Korea to central Japan where it is fairly common in Hondo from the Shinano province northward; in Hokkaido it is abundant and it is frequent in southern Saghalien. The western limits of this range appear to be northwest Hupeh where it is rare and occurs on the edge of woods. In Hondo it also grows on the margin of woods and by the side of streams, but in Hokkaido it is usually found in open fields and in thin woods of Alder, more especially near the seashore. In woodlands the trees are tall and have wide-spreading and somewhat sparse branches, but in open country the trees are low growing and very densely branched. The white flowers are very fragrant. Pictures of this tree will be found under No. x 417 of the collection of my Japanese photographs.

E. H. W. 
Malus theifera Rehder, n. sp.

Malus baccata Hemsley in Jour. Linn. Soc. XXIII. 255 (non Desfontaines) (1886), quoad plantam e Chekiang. - ? Diels in Bot. Jahrb. XXIX. 387 (1900).

Pyrus spectabilis Hemsley in Jour. Linn. Soc. XXIII. 258 (non Aiton) (1886), quoad plantam e Kiangsi et Hupeh. - ? Diels in Bot. Jahrb. XXIX. 387 (1900).

Malus baccata, var. himalaica Schneider, Ill. Handb. Laubholzk. I. 722, fig. 397 s (1906), quoad plantam chinensem et descriptionem. ${ }^{1}$

Frutex v. arbor 1-8-metralis; ramuli juniores initio plus minusve pubescentes, demum glabri $\mathrm{v}$. fere glabri, fuscescentes, annotini fusci v. fusco-cinerei; gemmae conico-ovoideae, circiter $5 \mathrm{~mm}$. longae, fuscae, pauci-perulatae perulis margine tenuiter ciliatis ceterum glabris. Folia decidua, chartacea, vernatione convoluta, ovata v. ovatooblonga v. elliptico-ovata, acuminata, basi rotundata v. late cuneata, dense et argute serrulata dentibus glanduloso-acuminulatis 4-10, plerumque $6-8 \mathrm{~cm}$. longa et $2.5-6 \mathrm{~cm}$. lata, erumpentia purpurascentia, demum intense viridia, supra initio laxe et longe villosa, mox glabrescentia, demum glaberrima, nitidula, subtus paullo pallidiora, ad costam nervosque pubescentia v. demum glabra, nervis utrinsecus 4-6 curvatis supra leviter impressis, subtus elevatis, venulis subtus leviter v. vix elevatis, costa supra impressa subtus elevata; petioli supra canaliculati, 1-3 cm. longi, pubescentes v. demum glabri. Flores albi v. erubescentes, fragrantes, $3.5-4 \mathrm{~cm}$. diam., graciliter pedicellati pedicello glabro v.interdum laxe lanuginoso $2-3 \mathrm{~cm}$. longo, in fasciculis 3-7-floris; calycis lobi triangulari-ovati, acuti v. acuminulati, circiter $4 \mathrm{~mm}$. longi et basi $3 \mathrm{~mm}$. lati, tubum subaequantes $\mathrm{v}$. paullo breviores, intus villosi extus ut tubus glabri et purpurascentes v. interdum laxe lanuginosi; petala ovalia, obtusa, breviter unguiculata, $15-18 \mathrm{~mm}$. longa et 13-15 $\mathrm{mm}$. lata, intus sparse lanuginosa; stamina circiter 20, petalis triente breviora; styli 3 , raro 4 , stamina aequantes, infra medium connati et ima basi excepta lanuginosi. Fructus globosus, basi rotundatus, apice leviter impressus, cicatrice calycis decidui notatus, 8-12 mm. diam., pallide flavo-viridis v. ruber, plerumque 3 -locularis; semina triangulariobovoidea, circiter $5 \mathrm{~mm}$. longa et $3 \mathrm{~mm}$. lata, pallide flavo-brunnea, nitentia.

1 Pyrus baccata, $\gamma$ himalaica Maximowicz in Bull. Acad. Sci. St. Pétersbourg, XIX. 171 (1873) is based on specimens from Gurhwal, which are near typical $M$. baccata. They are different from the plants of the Khasia Hills, which belong to $M$. theifera; to the same species probably belong the specimens from Sikkim and other parts of the eastern Himalaya. 
Chekiang: without precise locality, E. Faber (No.1714). Kiangsi: Kuling, thickets, not common, alt. 1300 m., July 28, 1907 (No. I668; bush 2-3 m. tall). Western Hupeh: north and south of Ichang, alt. 1000-1600 m., May 27 and November 1907 (No. 45I, type; bush 1-4 m. tall, flowers white, tinged pink); Hsing-shan Hsien, thickets, alt. 1300-2000 m., May 1907 (No. 2982; bush $3 \mathrm{~m}$. tall, flowers white); Fang Hsien, woodlands, alt. 1300-2000 m., May 11, 1907 (No. 2983; bush, not much branched, 2-3 m. tall, flowers like Apple blossoms); Changyang Hsien, thickets, alt. 1300-1600 m., May 1907 (No. 298I, bush $3 \mathrm{~m}$. tall, flowers white); Patung Hsien, October 1900 (Veitch Exped. Seed Nos. 766 a, 839 ); without precise locality, May and September 1900 (Veitch Exped. Nos. 749, 749²); without precise locality, A. Henry (No. 6509). Western Szech'uan: Washan, woodlands, alt. 1600-2000 m., October 1908 (No. II29; bush $7 \mathrm{~m}$. tall, fruit red). Shensi: Yenan Fu, 1910, W. Purdom (No. 329); "Po-uo-li," July 25-30, 1897, G. Giraldi. Assam: Khasia, alt. 6000 ft., Hooker f. \& Thomson; Khasia Hills, April 4, 1894, G. A. Gammie (Herb. Hort. Bot. Calcutt. No. 312).

This handsome species is closely related to $M$. baccata Desfontaines which differs chiefly in the thinner less closely and less sharply serrate leaves, green when unfolding, in the pure white flowers with 5 styles and lanceolate acuminate calyx-lobes exceeding the tube. It is apparently still nearer to $M$. Halliana Koehne which is distinguished by smaller and narrower more coriaceous crenately serrulate leaves on shorter petioles, by the slenderer pedicels, often obtusish calyx-lobes, flowers with usually 4 styles and by the smaller fruits about $6-8 \mathrm{~mm}$. in diameter and abruptly contracted at the base into the thickened pedicel. In drying the leaves and particularly the younger leaves assume a rather dark color like those of $M$. Halliana, while those of $M$. baccata usually keep their bright green color.

Malus theifera is very widely distributed in the mountainous regions of China at elevations of from 1000-2000 m. It ranges from Chekiang through Kiangsi and Hupeh, where it is abundant, into Shensi and western Szech'uan and through Yunnan south to the Khasia Hills, Assam. It varies considerably in the shape and size of the leaves, in the pubescence of the calyx which is either glabrous or more or less woolly as in Wilson's No. 2981 and in the Veitch Exped. No. 749, but in their essential eharacters the specimens all agree.

In the Arnold Arboretum this species has proved quite hardy; it forms a small tree with stiff spreading branches, and is very beautiful in spring when covered with light pink flowers, and resembles at this time a flowering Cherry rather than an Apple tree; the effect of the flowers is heightened by the purple calyx and the purplish tints of the unfolding leaves. The fruits of the cultivated tree are light greenish yellow partly with a slightly reddish cheek and do not ripen until the end of October shortly before those of $M$. Halliana.

Malus theifera, f. rosea Rehder, n. f.

A typo floribus roseis recedit. 
Western Hupeh: Fang Hsien, thickets, alt. 1300-2000 m., May 14 and November 1907 (No. 298o, type; bush 2-5 m. tall, flowers rosy pink, very beautiful); Patung Hsien, October 1900 (Veitch Exped. Seed No. 766).

This is a very beautiful form resembling in the color of its flowers $M$. Halliana, but with a greater profusion of flowers.

In the mountains of western Hupeh this form and the type are exceedingly common in open country, in wayside thickets and on the margin of woods; they are also occasionally cultivated. The leaves of both are collected and dried and are used locally in preparing a beverage which is drunk as a substitute for Tea.

E. H. W.

Malus Halliana Koehne, Gatt. Pomac. 27 (1890); Deutsche Dendr. 261 (1893). - Dippel, Handb. Laubholzk. III. 406 (1893). - Rehder in Sargent, Trees \& Shrubs, I. 35, t. 18 (1902). - Schneider, Ill. Handb. Laubholzk. I. 719, fig. 397 o, 398 e-f (1906). — Koidzumi in Jour. Coll. Sci. Tokyo, XXXIV. art. 2, 85 (Consp. Rosac. Jap.) (1913).

Malus Halliana in Gard. XXII. 162 (nomen nudum) (1882).

Pyrus Malus Parkmanii Temple in Gardn. Monthly, XXIX. 35 (1887).

Pyrus Parkmani Hort. ex Sargent in Garden \& Forest I. 152 (pro synon.) (1888).

Pyrus Halliana Hort. ex Sargent, 1. c. (pro synon.) (1888).

Pyrus Halliana Voss, Vilmorin's Blumengärt. I. 277 (1896). - Ascherson \& Graebner, Syn. Mitteleur, Fl. VI, abt. 2, 71 (1906), - Bean, Trees \& Shrubs Brit. Isl. II. 284 (1914).

Pyrus spectabilis Tanaka, Useful Pl. Jap. 156, t. fig. 634 (non Aiton) (1895). Makino in Toky? Bot. Mag. XX. 80 (1906), excludendis synon. omnibus.

Pyrus floribunda Koidzumi in Tokyo Bot. Mag. XXV. 75 (non Siebold) (1911), excludendis synon. omnibus "P. spectabilis Makino" excepto; in Jour. Coll. Sci. Tokyo, XXXIV. art. 2, 82 (Consp. Rosac. Jap.) (1913), excludendis synon. et var. Scheideckeri et var. pendula. - Matsumura, Ind. Pl. Jap. II. pt. 2, 204 (1912), quoad nomen Jap. "Kaido" et synon. "P. spectabilis Makino."

Malus floribunda, var. Parkmanni Koidzumi in Tokyo Bot. Mag. XXV. 76 (1911); in Jour. Coll. Sci. Tokyo, XXXIV. 2, 83 (Consp. Rosac. Jap.) (pro forma) (1913).

Western Szech'uan: Tachien-lu, thickets, alt. 2000-2500 m., October 1910 (No. 4I 72; bush 3-6 m. tall, fruit globose, red); same locality, 1904 (Veitch Exped. Seed No. 1720). Japan (cultivated): Tokyo, April 1, 1914, E. H. Wilson (No. 6360, cultivated and known as Kaido); same locality, April 19, 1882, K. Miyabe (as Pyrus spectabilis); Subashira, in garden, alt. $600 \mathrm{~m}$., May 8, 1914, E. H. Wilson (No. 6664); "Hirosaki, in hortis," May 1914, U. Faurie (No. 6051, as Pyrus spectabilis); Tokyo, Sakurai's garden, April 21, 1905, K. Sakurai (as M. floribunda). 
The discovery of Malus Halliana in western China adds another plant to the number of those first known to the west from Japanese gardens and long supposed to be Japanese, but later found to be of Chinese origin. Schneider (1. c.) has already stated that Fortune's No. 9 from China referred by Hemsley to $M$. spectabilis is probably $M$. Halliana. This is the "Kaido" of the Japanese and by Japanese botanists it has been confused with $M$. spectabilis Aiton and $M$. floribunda Siebold. A plant raised from seed sent by Wilson from Szech'uan is growing in the Arnold Arboretum and agrees perfectly with the Japanese plant.

The double-flowered form which is the form generally cultivated in this country and in Europe may be distinguished as M. Halliana, f. Parkmanii Rehder, n. comb. (Pyrus Malue Parkmanii Temple). Temple's description, though not technical, is the first good description of the double-flowered form of this tree and of this species in general.

\section{Malus transitoria Schneider, var. toringoides Rehder, n. var.}

A typo recedit foliis majoribus ad $5.5 \mathrm{~cm}$. longis minus profunde lobatis, interdum indivisis elliptico-oblongis crenato-serratis v. lobulatis, fructu majore 8-12 $\mathrm{mm}$. longo.

Western Szech'uan: west of Tachien-lu, alt. 3300-3600 m., October 1908 (No. I285, type; tree 5-8 m. tall, fruit scarlet and yellow); near Tongolo, west of Tachien-lu, alt. 3000-3600 m., June and October, 1904 (Veitch Exped. No. 3494 and Seed No. 1730).

This plant looks quite distinet from typical $M$. transitoria with its larger, partly entire leaves and larger fruit, and may turn out to be a distinet species, but as long as we do not know the mature fruits of the type and the flowers of this variety, we must rely on the difference in the leaves which are not sufficient for specific separation, as intergradations seem to exist, for No. 3494 shows in its smaller and more deeply divided leaves a transition toward the type. The fruits, too, seem to be somewhat smaller than those of No. 1285 .

Malus kansuensis Schneider in Fedde, Rep. Spec. Nov. III. 178 (1906).

Pyrus kansuensis Batalin in Act. Hort. Petrop. XIII. 94 (1893).

Eriolobus kansuensis Schneider, Ill. Handb. Laubholzk. 1. 726, fig. 403 d-d', 404 d-e (1906).

Western Hupeh: Fang Hsien, woods, alt. 2300 m., May and September 1907 (No. 264; bush or thin tree, 3-8 m. tall, flowers white, fruit red); without precise locality, A. Henry (No. 6754). Western Szech'uan: Tachien-lu, woodlands, alt. 2600-3300 m., June 1908 (No. 2996; bush 3-5 m. tall, flowers white); same locality, thickets, alt. 3000-3600 m., October 1910 (No. 4II5, in part; bush 7 m. tall, fruit searlet, ovoid); Pan-lan-shan, west of Kuan Hsien, alt. 3300 m., October 10 (No. 4II5, in part; bush $5 \mathrm{~m}$. tall, fruit scarlet); same locality, alt. 2300-2600 m., June 1908 (No. 2995; bush 6 m. tall, flowers white); without precise locality, alt. 3000 m., May 1904 
(Veitch Exped. No. 3495). Western Kansu: Tibetan country, south of Tow River, 1910, W. Purdom.

This is a very distinet species, and is easily distinguished from all others by its usually broadly ovate, 3- or sometimes 5-lobed and sharply serrate, glabrous or glabrescent leaves 3 -nerved at the base, and by the red ovoid fruit with a deciduous calyx.

Malus yunnanensis Schneider in Fedde, Rep. Spec. Nov. III. 179 (1906). - Rehder in Mitt. Deutsch. Dendr. Ges. XXIII. 258 (1914).

Pyrus yunnanensis Franchet, Pl. Delavay. 228 (1889). - Bean in Bot. Mag. CXLI. t. 8629 (1915).

Eriolobus yunnanensis Schneider, Ill. Handb. Laubholzk. I. 727, fig. 403 e-g, 404 b-c (1906).

Cormus yunnanensis Koidzumi in Jour. Coll. Sci. Tokyo, XXXIV. art. 2, 75 (Consp. Rosac. Jap.) (1913).

Pyrus Veitchii Hort. in Gard. Chron. ser. 3, LII. 288 (nomen) (1912). - Veitch, Cat. New Hardy Pl. China, Autumn 1913, 12.

Western Hupeh: Fang Hsien, woods, alt. 1600-2300 m., May 19, 1907 (No. 2994; thin tree, 3-7 m. tall, flowers white); without precise locality, September 1901 (Veitch Exped. No. 670). Eastern Szech'uan: Wushan Hsien, A. Henry (No. 5638). Western Szech'uan: Ching-chi Hsien, mountain sides, alt. 2300 m., August and September 1908 (No. I00o; tree 8-13 m. tall, girth 0.3-1 m., fruit reddish); Mao-chou, thickets, alt. 2000 m., October 1908 (No. I00o ; bushy tree, $7 \mathrm{~m}$. tall, fruit red); without precise locality, alt. $2000 \mathrm{~m}$., July 1904 (Veitch Exped. No. 3491). Yunnan: Lichiang valley, alt. 25002700 m., May 1906, G. Forrest (No. 2111).

This species much resembles in its leaves $M$. Tschonoskii Schneider, but is easily distinguished by its smaller flowers in many-flowered corymbs, by the much smaller red fruits with reflexed calyx-lobes and by the more distinctly lobed, sharply and closely serrulate leaves.

\section{CLAVIS SPECIERUM ASIAE ORIENTALIS.}

Discus cupuliformis.

Folia semper indivisa, vernatione convoluta. Calyx persistens.

Styli basi villosi; fructus laevis. Folia simpliciter serrata v. crenato-serrata. Calycis lobi tubo longiores, acuminati. Folia membranacea, supra opaca. Pomum basi impressum . . . . . . . . . 1. M. prunifolia. Calycis lobi tubo breviores v. aequilongi, acuti. Folia chartacea, supra nitida.

Pomum basi in pedicellum apice manifeste incrassatum contractum. Folia basi late cuneata v. fere rotundata; petioli $1.5-2.5 \mathrm{~cm}$. logi.

2. M. spectabilis.

Pomum basi impressum, calyce interdum deciduo. Folia basi sensim attenuata; petioli graciles, $2-3.5 \mathrm{~cm}$. longi . . 3. M. micromalus. 
Styli glabri: fructus punctatus. Folia argute et plerumque duplieiter serrata.

Calyx deciduus.

4. M. Prattii.

Calycis lobi tubo longiores, anguste lanceolati; flores albi, stylis 5 , rarius 4 .

Calycis lobi tubo breviores $\mathrm{v}$. aequilongi, triangulari-ovati.

5. M. baccata.

Styli 3, rarius 4; calycis lobi acuti v. acuminulati; flores albi v. rosei.

6. M. theifera.

Styli 5 v. 4; calycis lobi obtusiusculi: flores rosei .

7. M. Halliana.

Folia, ea ramorum luxuriantium saltem, saepe lobata, vernatione conduplicata.

Calyx deciduus.

Fructus subglobosus; styli basi villosi.

Petala basi cuneata, obovata v. oblonga, saepe rubescentes.

Folia nunquam lobata, serrata v. inciso-serrata. Styli plerumque 4, rarius 3 , rarissime 5 , ad medium connati: alabastra intense purpurea.

8. M. floribunda.

Folia rarissime lobata. Styli 4-5, rarissime 3, basi connata; sepala tubo longiora, anguste lanceolata . . . . . . 9. M. zumi.

Folia saepe lobata. Styli 3-4, basi connata; sepala triangulari-ovata v. lanceolata, tubum subaequantia . . . . . 10. M. Sieboldii.

Petala basi subito in unguem contracta, suborbicularia, alba. Folia saepe lobata. Frutex humilis .......... 11. M. Sargentii. Fructus ovoideus.

Styli basiglabri. Folia plerumque profundelobata lobis acutis obtusiuscule serratis .............. 12. M, transitoria.

Styli basi villosi. Folia 3-5-lobata lobis latis acuminatis argute serratis, basi 3-nervia, plerumque glabra . . . . . 13. M. kansuensis.

Calyx persistens.

Pomum parvum, 1-1.5 $\mathrm{em}$. diam, ealyce reflexo. Inflorescentia multiflora. 14. M. yunnanensis.

Pomum 2.5-3 cm. diam. calyce erecto v. suberecto. Inflorescentia 2-5-flora.

15. M. Tschonoskii.

Discus tubularis, basin stylorum arcte circumcingens. Folia oblonga, serrata. Pomum subglobosum, calyce coronatum

16. M. formosana.

1. Malus prunifolia Borkhausen, Handb. Forstbot. II. 1278 (1803). - Spach, Hist. Vég. II. 151, t. $9 \mathrm{~s}-\mathrm{x}$ (1834). - Decaisne in Nouv. Arch. Mus. Paris, X. 155 (Mém. Fam. Pom.) (1874). - Koehne, Deutsch. Dendr. 260 (1893). Schneider, Ill. Handb. Laubholzk. I. 717, fig. 397 i-k, 398 b (1906). - Koidzumi in Tokyo Bot. Mag. XXIII. 173 (pro parte) (1899); in Jour. Coll. Sci. Tokyo, XXXIV. art. 2, 91 (pro parte) (Consp. Rosac. Jap.) (1913).

Pyrus Malus, $\beta$ Aiton, Hort. Kew. II. 175 (1789).

Pyrus prunifolia Willdenow, Phytogr. 8 (1794); Berl. Baumz. 164 (1796); Spec. II. 2, 1018 (1799). - Aiton, Hort. Kew. ed. 2, III. 208 (1811). De Candolle, Prodr. II. 635 (1825). - Ledebour, Fl. Ross. II. 97 (1844). Regel in Gartenfl. XI. 203, t. 364, fig. 7-11 (1862). - K. Koch, Dendr. I. 207 (1869). - Wenzig in Linnaea, XXXVIII. 47 (1874). - Hooker f. in Bot. Mag. CI. t. 6158 (1875). - Bailey, Cycl. Am. Hort. III. 1472 (1901). Ascherson \& Graebner, Syn. Mitteleur. Fl. VI. abt. 2, 80 (1906).

Malus hybrida Loiseleur in Nouv. Duhamel, VI. 140, t. 42, fig. 1 (non Desfontaines) (1815).

Siberia (ex Willdenow), Dahuria and Baikal region (ex Regel), northern China (ex K. Koch). 
Of this tree I have seen only cultivated plants and specimens from cultivated plants from various gardens in this country and in Europe. They show some variation in the degree of pubescence; most of them have the pedicels and calyx more or less tomentose as described by Willdenow, while in the plant growing in the Arnold Arboretum they are glabrous, as described by De Candolle. The leaves resemble those of $M$. baccata Desfontaines; they are slightly pubescent on the veins below and glabrous at maturity; the flowers are white and the fruits vary from yellow to red and from globose to ovoid in shape.

Malus prunifolia has been supposed, like its variety rinki, to be of hybrid origin, but the discovery of the native habitat of var. rinki shows that this theory cannot be accepted; there are, moreover, no two species of Malus in eastern Asia which could produce by hybridizing a plant with the characters of $M$. prunifolia or its variety. The native country of $M$. prunifolia will probably be discovered some time in the near future and it is very likely that it will turn out to be Siberia whence the plant is supposed to have been introduced. There is little doubt that $M$. prunifolia and $M$. ringo are forms of one species, the first being the northern glabrescent, the second the southern pubescent form, a parallel case to that of $M$. baccata and its variety mandshurica. Besides in the greater amount of pubescence the variety rinki differs only in the usually somewhat shorter petioles and the more or less pink or pinkish flowers.

Malus prunifolia, var. rinki Rehder. See p. 279.

2. Malus spectabilis Borkhausen, Handb. Forstbot. II. 1279 (1803), - Desfontaines, Hist. Arb. II. 141 (1809). - Spach, Hist. Vég. II. 134 (1834). Deeaisne in Nouv. Arch. Mus. Paris, X. 155 (Mém. Fam. Pom.) (1874). - Schneider, Ill. Handb. Laubholzk. I. 719, fig. $397 \mathrm{~g}^{-\mathrm{g}^{1}}, 398 \mathrm{c}-\mathrm{d}$ (1906). - Koidzumi in Jour. Coll. Sci. Tolyo, XXXIV. art. 2, 88 (Consp. Rosac. Jap.) (1913), exclud, synon. "P. spectabilis var. Kaido" et "P. Ringo var. Kaido."

Pyrus spectabilis Aiton, Hort. Kew. II. 175 (1789). - Schneevoogt, Icon. Pl. Rar. t. 15 (1793). - Curtis in Bot. Mag. VIII. t. 267 (1794). - Willdenow, Berl. Baumz. 263 (1796); Spec. II. 2, 1018 (1799), - Watson, Dendr. Brit. I. t. 50 (1825). - De Candolle, Prodr. II. 635 (1825). - Bunge in Mém. Sav. Étr. Acad. Sci. St. Pétersbourg, Il. 101 (Enum. Pl. Chin. Bor. 27) (1835). - Siebold \& Zuecarini in Abh. Akad. Münch. IV. 2, 131 (Fl. Jap. Fam. Nat.I. 23) (1846). - Miquel, in Ann. Mus. Lugd.-Bat. III. 40 (1867); Prol. Fl. Jap. 228 (1867). - K. Koch, Dendr. I. 209 (1869). - Maximowicz in Bull. Acad. Sci. St. Pétersbourg, XIX. 170 (1873); in Mél. Biol. IX. 166 (1873), exclud. synonymo "Malus floribunda." - Wenzig in Linnaea XXXVIII. 42 (1874). - Franchet \& Savatier, Enum. Pl. Jap. I. 138 (1875); II. 349 (1879). - Franchet in Mém. Soc. Sci. Nat. Cherbourg, XXIV. 217 (Cat. Pl. Tchéfou) (1882); in Nouv. Arch. Mus. Paris, sér. 2, V. 271 (Pl. David. I. 119) (1883), - Hemsley in Jour. Linn. Soc. XXIII. 258 (1887), exclud. synon. "Malus floribunda," "Pyrus floribunda," "Malus microcarpa " et plantas e Kiangsi et Hupeh. - Palibin in Act. Hort. Petrop. XVII. 75 (Consp. Fl. Kor. I) (1898). - Bailey, Cycl. Am. Hort. III. 1473, fig. 2026 (1901). - Komarov in Act. Hort. Petrop. XXII, 478 (Fl. Mansh. Il.) (1904). - Nakai in Jour. Coll. Sci. Tokyo, XXVI. art. 1, 180 (Fl. Kor.) (1909). Malus sinensis Dumont de Courset, Bot. Cult. ed. 2, V. 429 (1811).

Pyrus spectabilis, var. Riversii Booth apud Kirchner in Petzold \& Kirchner, Arb. Musc. 326 (1865), - Bailey, Cycl. Am. Hort. IIl. 1473 (1901).

Malus microcarpa spectabilis Carrière, Étude Pomm. Microcarp, 114 (1883).

Pyrus sinensis Dumont de Courset ex Jackson, Ind. Kew. II. 669 (pro synon.) (1895). 
Chili : Imperial gardens, Peking, September 17, 1903, C. S. Sargent.

The specimen cited above is the only one I have seen from eastern Asia. The species has not yet been collected in a wild state; it is apparently unknown even as a cultivated plant in Japan and very imperfectly understood by Japanese botanists. The plant ealled $M$. spectabilis in Japan is either $M$. Halliana or M. micromalus.

In Europe it is well known in gardens. It was first cultivated by John Fothergill about 1780 in its double-flowered form, which was figured by Schneevoogt in 1793 and by Curtis in the following year; the single-flowered form with fruits was figured in 1825 by Watson.

3. Malus micromalus Makino in Tokyo Bot. Mag. XXII. 69 (1908), - Koidzumi in Jour. Coll. Sci. Tokyo, XXXIV. art. 2, 89 (Consp. Rosac. Jap.) (1913).

Malus spectabilis, var. Kaido Siebold, Cat. Rais. 5 (nomen nudum) (1856). Carrière in Rev. Hort. 1872, 210, t. fig. 8 (sine descriptione).

Pyrus spectabilis, 3 Kaido Kirchner in Petzold \& Kirchner, Arb. Musc. 326 (nomen nudum) (1865). - Nicholson, Dict. Gard. III. 261 (1887). - Voss, Vilmorin's Blumengärt. 276 (pro forma) (1894).

Malus microcarpa Kaido Carrière, Étude Pomm. Microcarp. 70 (1883).

Pyrus Kaido Mouillefert, Trait. Arb. I. 524 (1893), - Bailey, Cycl. Am. Hort. IIl. 1473, fig. 2029, 2030 (non Malus Kaido Dippel) (1902).

Malus Kaido Pardé, Arb. Nat. Barres, 189 (non Dippel) (1906).

Malus spectabilis, var. micromalus Koidzumi in sched. ex Koidzumi in Jour. Coll. Sci. Tokyo, XXXIV. art. 2, 89 (pro synon.) (Consp. Rosac. Jap.) (1913).

Japan: Hondo, prov. Shinano, Kurosawa, cultivated, alt. 750 m., October 31, 1914, E. H. Wilson (No. 7738; tree $8 \mathrm{~m}$. tall, 0.6 girth, branches ascendingspreading).

This plant is known only in a cultivated state and is apparently a hybrid of $M$. spectabilis Borkhausen probably with $M$. baccata Desfontaines or $M$. floribunda Siebold. It is chiefly distinguished from $M$. spectabilis by the narrower leaves gradually narrowed at the base into a slender petiole, by the tomentose pedicels and calyx and by the subglobose fruit impressed at the base and at the apex with the calyx persistent or deciduous on the same plant; the latter character shows the influence of a species with deciduous calyx. Both Makino and Koidzumi describe the calyx as persistent, but on specimens collected by Wilson from trees which Koidzumi considered typical, the calyx is sometimes deciduous and sometimes persistent. These specimens agree very well with the plants cultivated in the Arnold Arboretum and with the descriptions cited above. An entirely different plant, however, is Malus Kaido Dippel, ${ }^{1}$ which as described has oval to broadly oblong leaves tomentose below, and on vigorous branches often subcordate; it is supposed to be a hybrid between $M$. spectabilis and $M$. Ringo.

Aceording to Makino $M$. micromalus was introduced from China into Japan where according to Makino it was formerly called Kaido, a name now generally applied to $M$. Halliana and probably also to $M$. floribunda.

4. Malus Prattii Schneider. See p. 281.

1 Malus Kaido Dippel, Handb. Laubholzk. III. 400 (1893). - Schneider, IIl. Handb. Laubholzk. I. 717 (1906).

Pyrus Ringo, $\beta$ Kaido Wenzig in Linnaea, XXXVIII. 37 (1874).

Pyrus spectabilis $\times$ Ringo Wenzig in Monatsschr. Ver, Beförd. Gartenb. XVII. 534 (1874).

Malus Ringo $\times$ spectabitis Koehne, Deutsch. Dendr. 259 (1893). 
5. Malus baccata Borkhausen, Handb. Forstbot. II. 1280 (1803). - Desfontaines, Hist. Arb. II. 141 (1809). - Spach, Hist. Vég. II. 153 (1834). - Decaisne in Nouv. Arch. Mus. Paris, X. 155 (Mém. Fam. Pom.) (1874), - Schneider, Ill. Handb. Laubholzk. I. 720, fig. 397 1-m, $398 \mathrm{~g}-\mathrm{i}$ (1906).

Pyrus baccata Linnaeus, Mant. 75 (1767). - Pallas, Fl. Ross. I. 23, t. 10 (1784). - Willdenow, Spec. II. 1018 (1799). - Aiton, Hort. Kew. ed. 2, III. 209 (1811). — De Candolle, Prodr. II. 635 (1825). - Maximowicz in Mém. Sav. Etr. Acad. Sci. St. Pétersbourg, IX. 102 (Prim. Fl. Amur.) (1859). Regel in Gartenfl. XI. 202, t. 364, fig. 1-5 (1862). - Maximowicz in Bull. Acad. Sci. St. Pétersbourg, XIX. 170 (1873); in Mél. Biol. 1X. 166 (1873). Hooker f. in Bot. Mag. C. t. 6112 (1874). - Hance in Jour. Bot. XIII. 132 (1875), - Baker \& Moore in Jour. Linn. Soc. XVII. 382 (1879). Hemsley in Jour. Linn. Soc. XXIII. 255 (1887).

Pyrus baccata, var. leiostyla Ruprècht \& Maximowicz in Bull. Acad. Sci. St. Pétersbourg, XV. 132 (1857).

Pyrus baccata, a sibirica Maximowiez in Bull. Acad. Sci. St. Pétersbourg, XIX. 170 (1873); in Mél. Biol. IX. 166 (1873). - Franchet in Nouv. Arch. Mus. Paris, sér. 2, V. 272 (Pl. David. 1. 120) (1883).

Malus microcarpa baccata Carrière, Etude Pomm. Microcarp. 68 (1883).

Malus baccata, a sibirica Schneider, Ill. Handb. Laubholzk. I. 720 (1906).

Eastern Siberia: Amur, 1859, Maximowicz; "Amur medius," 1891 and "Amur super." 1891, S. Korshinsky; Blagoviestchensk, May and August 1905, Karo; Srychensk, August 13, 1903, Harbin, August 16, 1903, and Khabarovsk, August 23, 1903, C. S. Sargent; Mukden, May 29, 1906, F. N. Meyer (Nos. 81, 104). Chili: near Shi-feng-ko, June 3, 1913, F. N. Meyer (No. 998); Hsaio Wu-tai-shan, August 21, 1913, F. N. Meyer (No. 17). Mongolia: Jehol, A. David (No. 1728). Shensi: Yenan Fu, 1910, W. Purdom (No. 329).

The typical form of $M$. baccata seems to be a more northern form than the var. mandshurica; it ranges from Mandshuria and Chili through Mongolia and Siberia to Shensi; farther south it is replaced by var. mandshurica and in the western Himalaya by var. himalaica Schneider of which I have seen Falconer's No. 393 from Gurhwal, which differs from the type in its more coarsely serrate leaves.

Malus baccata, f. Jackii Rehder, n. f.

A typo recedit foliis majoribus ellipticis ad $12 \mathrm{~cm}$. Iongis et ad 6.5 latis, floribus majoribus circiter $3.5 \mathrm{~cm}$. diam., fructibus intense rubris circiter $1 \mathrm{~cm}$. diam.

Korea: Seoul, September 22, 1905, J.G. Jack. Cultivated at the Arnold Arboretum.

This is a very handsome form with large pure white flowers, large dark green leaves and large dark red fruits. The leaves are quite glabrous on their underside, but on their upper surface they are coated, when unfolding, with a thin floccose tomentum which quickly disappears; at maturity they are of firm texture and glaucescent below. In general appearance this form resembles var. mandshurica, but it is quite glabrous.

Malus baccata, var. mandshurica Schneider. See p. 281.

6. Malus theifera Rehder. See p. 283.

7. Malus Halliana Koehne. See p. 285.

8. Malus floribunda Siebold, Cat. Rais. 5 (nomen nudum) (1856). - Van Houtte in $F l$. des Serr. XV. 161, t. 1585-89 (sine descriptione) (1864). - Neubert in Deutsch. Mag. Gart. Blum. 1865, 193, t. - Desportes in Rev. Hort. 1866, 312, t. Carrière in Rev. Hort. 1870-71, 591, t. - Koehne, Deutsche Dendr. 261 (1893). - 
Schneider, Ill. Handb. Laubholzk. I. 721 (1906), - Koidzumi in Jour. Coll. Sci. Tokyo, XXXIV. art. 2, 82 (pro parte) (Consp. Rosac. Jap.) (1913), exclud. descriptione, syn. "Malus Kaido," varietatibus.

Malus Toringo De Vriese in Tuinbouw-Fl. Nederl. III. 368, t. (sine descriptione; pro parte) (1856), quoad flores.

Pyrus floribunda Kirchner in Petzold \& Kirchner, Arb. Musc. 319 (non Lindley) (1864); in Gartenfl. XV. 50 (1866). - Nicholson, Dict. Gard. III. 259, fig. 335 (1887). - Voss, Vilmorin's Blumengärt. ed. 3, I. 277 (1894). Bailey, Cycl. Am. Hort. III. 472 (1901).

(P. spectabilis Ait. $\times$ Ringo v. Sieb.) $\times$ P. baccata L. Wenzig in Monatsschr. Ver. Beförd. Gartenb. Preuss. XVII. 535 (1874).

Pyrus Ringo, $\gamma$ floribunda Wenzig in Iinnaea, XXXVIII. 38 (1874),

Malus microcarpa floribunda Carrière, Étude Pomm. Microcarp.64, fig. 12 (1883).

Pirus pulcherrima Ascherson \& Graebner, Syn. Mitteleur. Fl. VI. abt. 2, 71 (1906).

I have seen no Japanese specimens of $M$. floribunda, nor has Mr. Wilson collected it or seen it in Japan. The Japanese botanists apparently do not know it; the plant they enumerate under the name $M$. floribunda is $M$. Halliana, as part of their synonymy, their descriptions and specimens named by Japanese botanists show. All we know of this plant is the fact that it was introduced by Siebold from Japan. It may possibly be a hybrid of $M$. baccata and $M$. Sieboldii, as Zabel suggests; according to Wenzig it represents $P$. kaido $\times$ baccata and Schneider mentions as possible parentage $M$. prunifolia $\times M$. toringo.

9. Malus zumi Rehder in Sargent, Trees \& Shrubs, I. 191, t. 91 (1905). Schneider, Ill. Handb. Laubholzk. I. 721 (1906). - Koidzumi in Jour. Coll. Sci. Tokyo, XXXIV. art. 2, 92 (Consp. Rosac. Jap.) (1913).

2Pyrus Toringo, $\gamma$ integrifolia Franchet \& Savatier, Enum. Pl. Jap. I. 139 (1875); II. 350 (1879).

9Malus Toringo, a integrifolia Zabel apud Dippel, Handb. Laubholzk. III. 406 (1893). - Matsumura, Ind. Pl. Jap. II. 2, 205 (1912). - Koidzumi in Jour. Coll. Sci. Tokyo, XXXIV. art. 2, 82 (Consp. Rosac. Jap.) (1913).

Pirus (Malus) Zumi Matsumura in Tokyo Bot. Mag. XIII. 1 (1899).

Malus baccata, var, mandshurica, f. Zumi Matsumura, Ind. Pl. Jap. II. pt. 2, 204 (1912).

Hondo: Gotemba, roadside thickets, alt. 600-300 m., May 7, 1914, E. H. Wilson (No. 6660; bush 1.3-2 m., branches spreading, flowers white); same locality, alt. 600-1000 m., May 7, 1914, E. H. Wilson (No. 6659; tree $8 \mathrm{~m}$. tall, branches erect, flowers white); Lake Chuzenji, margin of woods, alt. 1200-1500 m., June 3, 1914, E. H. Wilson (No. 6797; tree 3-12 m. tall, 0.3-0.6 m. girth, branches erectspreading, flowers white); same locality, August 10, 1905, J. G. Jack; Nikko, prov. Shimotsuke, 1879 and May 1889 (ex Herb. Tokyo, co-type), same locality, June 1899, H. Shirasawa, September 1903, T. Makino.

The specimens from Lake Chuzenji and Wilson's No. 6659 from Gotemba and Shirasawa's and Makino's specimens from Nikko differ from the type specimen in their broader sharply serrate leaves, but apparently they cannot be referred to any other species but $M$. zumi. They resemble in general appearance $M$. baccata, var. mandshurica, but differ in the conduplicate vernation of the leaves and in the number of styles which is usually 4 , but sometimes 5 and less often 3 - among 15 flowers of No. 6797 I found 8 with four styles, 4 with five styles and 3 with 3 styles - while in $M$. baccata, var. mandshurica the number of styles is 5 . From $M$. Sieboldii to which $M$. zumi is also closely related, it is distinguished by the 
larger white flowers with sometimes $\mathbf{5}$ styles and with longer narrowly lanceolate sepals and by the slightly lobed leaves appearing only occasionally and sparingly at the end of vigorous shoots.

This is a common plant on the lower slopes of Fuji-san and in the Nikko region more especially round Lake Chuzenji. It has not yet been authentically reported from other parts of Japan and is very probably peculiar to a limited area in central Hondo. It is usually a low much branched tree 4 to $6 \mathrm{~m}$. tall, with a rounded and oval crown, twiggy branchlets and fragrant white flowers; more rarely it is a tree from 10 to $12 \mathrm{~m}$. tall with ascending-spreading branches. A picture of this tree will be found under No. x 309 of the collection of my Japanese photographs.

10. Malus Sieboldii Rehder, n. comb.

E. H. W.

Malus Toringo Siebold, Cat. Rais. 4 (nomen nudum) (1856). - De Vriese in Tuinbouw-fl. III. 368, t. 17 (sine descriptione) (1857), quoad ramum fructiferum depictum. - Koehne, Deutsch. Dendr. 261 (1893). - Schneider, Ill.

Handb. Laubholzk. I. 723, fig. 399 e, $400 \mathrm{~g}-\mathrm{h}^{1}$ (1906). - Koidzumi in Jour. Coll. Sci. Tokyo, XXXIV. art. 2, 80 (Consp. Rosac. Jap.) (1913).

Pyrus ? rivularis Gray in Mem. Am. Acad. n. ser. Vl. 388 (non Nutt.) (1857).1 Pyrus Sieboldii Regel in Ind. Sem. Hort. Petrop. 1858, 51; in Gartenfl. VIII. 82 (1859). - Kirchner in Petzold \& Kirchner, Arb. Musc. 325 (1864).

Sorbus Toringo K. Koch in Ann. Mus. Lugd.-Bat. I. 249 (1864).

Pyrus Toringo Siebold apud Miquel in Ann. Mus. Lugd.-Bat. III. 41 (1867); Prol. Fl. Jap. 229 (1867). - K. Koch, Dendr. I. 212 (1869). - Franchet \& Savatier, Enum. Pl. Jap. I. 139 (1875); II. 350 (1879).

Pyrus Mengo Siebold ex K. Koch, Dendr. I. 213 (pro synon.) (1869).

Malus Torringo Carrière in Rev. Hort. 1870-71, 451, fig. 63, t.

Pyrus rivularis, $\beta$ Toringo Wenzig in Linnaea, XXXVIII. 39 (1874). - Voss, Vilmorin's Blumengärt. ed. 3, I. 277 (1894).

Pyrus Toringo, $\beta$ incisa Franchet \& Savatier, Enum. Pl. Jap. I. 139 (1875); II. 350 (1879).

Malus microcarpa Torringo Carrière, Étude Pomm. Microcarp. 61, fig. 11 (1883). Malus baccata, subsp. Toringo Koidzumi in Tokyo Bot. Mag. XXV. 76 (1911).

Hondo: Mt. Yatsuga-dake, moorland thickets, common, alt. 1200-1500 m., September 17, 1914, E. H. Wilson (No. 7540; bush 1.5-4 m., fruit globose); Mt. Tsubakura-dake, thickets, alt. 900-1200 m., Sept. 15, 1914, E. H. Wilson (No. 7463; bush 2-3.3 m. tall); "Jizogatake," July 1903, U. Faurie.

The specimens quoted above agree very well with the cultivated form originally introduced by Siebold into European gardens; they have the same deeply lobed, pubescent leaves, small apparently yellow fruits and shrubby habit. This is the nomenclatorial type of the species, though phylogenetically the following much more widely distributed variety is probably to be considered the typical form of which the shrubby plant with deeply divided foliage is probably only a seminal variation.

The Japanese name for this species is "Zumi," a name applied also to the other small fruited indigenous crabs, as $M$. baccata, var. mandshurica and $M$. zumi. The name "Toringo," so long employed as a specifie name for this plant, signifies "Chinese Apple" and in Japan is applied solely to Malus prunifolia, var. rinki

1 In the Gray Herbarium there are mounted on one sheet and labeled Pyrus spectabilis two different specimens collected by Wright near Hakodate. One is M.baccata, var. mandshurica Schneider and the other is $M$. Sieboldii; the first is apparently the plant called by Gray $P$. spectabilis, while the second he doubtfully referred to $P$. rivularis Nuttall. 
Rehder. Its application to $M$. Sieboldii Rehder was a mistake which probably originated with Siebold when he first received the plant from Japan.

Malus Sieboldii, var. arborescens Rehder, n. var.

? Pyrus baccata Thunberg, Fl. Jap. 207 (1784), - Siebold in Verh. Bataav. Genoot. XII. 1, 66 (Syn. Pl. Oec. Jap.) (1830).

Crataegus alnifolia Regel, in Act. Hort. Petrop. I. 125 (Rev. Crat.) (1871).

Pyrus Toringo, $\gamma$ typica Franchet \& Savatier, Enum. Pl. Jap. II. 350 (1879).

Malus Toringo, f. typica Matsumura, Ind. Pl. Jap. II. 2, 205 (1912). - Koidzumi in Jour. Coll. Sci. Tokyo, XXXIV. art. 2, 81 (Consp. Rosac. Jap.) (1913).

Hokkaido: Nopporo, open country, alt. 300 m., August 10, 1914, E. H. Wilson (No. 7411; bush 2-3 m. tall); Hakodate, June 6, 1855, C. Wright (Gray Herb.); "Junsainuma," August 21, 1903, U. Faurie (No. 5380). Hondo: slopes of Fujisan, common, alt. 500-900 m., May 8, 1914, E. H. Wilson (No. 6658; bush 1.5$3 \mathrm{~m}$. tall, flowers white, pinkish in bud); Lake Chuzenji, woods, alt. 1200-1600 m., June 3, 1914, E. H. Wilson (No. 6799; tree 6-8 m. tall, 0.3-0.5 m. girth, branches spreading, flowers white); same locality, alt. 1200-1500 m., June 1, 1914 (No. 6774; tree 5-10 m. tall, $0.3-7.5 \mathrm{~m}$. girth, branches erect-spreading, flowers white, tinged rose); same locality, alt. 1500 m., June 3, 1914, E. H. Wilson (No. 6800; bush or small tree 3-6 m. tall, branches spreading, flowers rosy in bud); near Yumoto, thickets and woods, common, alt. 1500-2100 m., October 18, 1914, E. H. Wilson (No. 7655; tree 7-10 m. tall, 0.5-1 m. girth, head very bushy, fruit red); Karuizawa, thickets, alt. 900-1300 m., August 31, 1914, E. H. Wilson (No. 7428; bush or small tree 2-8 m. tall); Miyanoshito, Hakone Mts., August 25, 1892, C.S. Sargent; woods near Nikko, September 6, 1892, C. S. Sargent; Mt. Mitsumine, October 1898, H. Shirasawa; Mt. Yerdono, prov. Uzen, July 15, 1909, K. Sakurai; Mt. Asama, July 14, 1904, U. Faurie (No. 6044). Korea: Quelpaert, Hallaisan, June 1907, U. Faurie (No. 1555); same locality, alt. 900 m., October 1909, Taquet (No. 2828); Quelpaert, alt. 800-1000 m., May and August 1910, Taquet (Nos. $4219,4220)$.

This variety is widely distributed in Japan and differs from the type in its more arborescent habit, less pubescent, somewhat larger and usually less deeply divided leaves, often lobed only at the end of vigorous shoots and usually nearly glabrous at maturity; the flowers are often nearly white and the fruits yellow or red on different plants. A picture of this tree will be found under No. $\mathrm{x} 528$ of the collection of Wilson's Japanese photographs.

Malus Sieboldii, var. calocarpa Rehder, n. var.

A typo recedit habitu arborescente, foliis minus profunde lobatis crenatoserrulatis, floribus majoribus, fructu majore, 1-1.2 cm. diam. intense rubro.

Cultivated at the Arnold Arboretum, where it was raised from seed introduced in 1890 by Dr. William Sturgis Bigelow from Japan.

This form differs from the preceding variety in its large handsome bright red fruit; the flowers are rather large about $3 \mathrm{~cm}$. across; the leaves of the fruiting branches are generally ovate-oblong, crenate-serrulate and 5-7 cm. long, those of the vigorous shoots are mostly 3 -lobed with short and broad lateral lobes. It has some resemblance to $M$. zumi Rehder, but is easily distinguished by the 3-4 styles of its flowers and by the mostly lobed leaves of the shoots.

11. Malus Sargentii Rehder in Sargent, Trees \& Shrubs, I. 71, t. 37 (1903). Schneider, Ill. Handb. Laubholzk. I. 722 (1906).

Pyrus Sargentii Bean, Trees \& Shrubs Brit. Isl. II. 293 (1914). 
Hokkaido: brackish marsh near Mororan, September 25, 1892, C. S. Sargent.

This species is closely related to $M$. Sieboldii, but differs in its stiff spreading habit, the nearly orbicular pure white petals and the dark red fruit covered by a slight bloom. In the living state, as growing at the Arnold Arboretum, it is very distinct, though in the herbarium it might be confused with $M$. Sieboldii, particularly if only fruiting specimens are seen. The distribution of this plant appears to be very local.

12. Malus transitoria Schneider, Ill. Handb. Laubholzk. I. 726 (1906); in Fedde, Rep. Spec. Nov. III. 178 (1906).

Pyrus transitoria Batalin in Act. Hort. Petrop. XIII. 95 (1893).

Western Kansu: Tibetan country southwest of Choni, 1911, W. Purdom; from south of the Peling Mountains, "brought in by Tibetans," W. Purdom.

Purdom's specimens agree very well with Batalin's description. This species seems to be most closely related to $M$. fusca Schneider (M. rivularis Roemer) with which it agrees in the glabrous styles and in the ellipsoid shape of its fruit. Plants raised from seed sent by Purdom are growing in the Arnold Arboretum.

Malus transitoria, var. toringoides Rehder. See p. 286.

13. Malus kansuensis Schneider. See p. 286.

14. Malus yunnanensis Schneider. See p. 287.

15. Malus Tschonoskii Schneider in Fedde, Rep. Spec. Nov. III. 179 (1906).

Pyrus Tschonoskii Maximowicz in Bull. Acad. Sci. St. Pétersbourg, XIX. 169 (1873); in Mél. Biol. IX. 165 (1873). - Franchet \& Savatier, Enum. Pl. Jap. II. 349 (1879). - Sargent in Garden \& Forest, VII. 45, fig, 9 (1894); Forest Fl. Jap. 40, t. 14 (1894). - Bean in Bot. Mag. CXXXIV. t. 8179 (1908); Trees \& Shrubs Brit. Isl. II. 298 (1914).

Pyrus T'schonoskii, var. Hoggii Franchet \& Savatier, Enum. Pl. Jap. II. 349 (1879).

Eriolobrus Tschonoskii Rehder in Sargent, Trees \& Shrubs, I. 73, t. 37 (1903). Schneider, Ill. Handb. Laubholzk. I. 727, fig. 403 h-i, 404 f (1906).

Cormus Tschonoskii Koidzumi in Tokyo Bot. Mag. XXIII. 171 (1909); in Jour. Coll. Sci. Tolyo, XXXIV. art. 2, 74 (Consp. Rosac. Jap.) (1913). Matsumura, Ind. Pl. Jap. II. 2, 198 (1912).

Hondo: Temple Hill near Nagatsugawa on the Nagasendo, October 22, 1892, C. S. Sargent (red scaly bark); woods near Nikko, September 3, 1892, C. S. Sargent (tree 10-12 m. tall, bark white); Tokose, prov. Musashi, May 11, 1909, K. Sakurai; Fuji-san, May 1900, H. Shirasawa; Mt. Hakone near Tonosawa, May 1901, Y. Yabe; foot of Mt. Ontake, alt. $600 \mathrm{~m}$, October 31, 1914, E. H. Wilson (No. 7753; tree $16 \mathrm{~m}$. tall, $2 \mathrm{~m}$. girth; branches spreading, fruit green).

16. Malus formosana Kawakami in Tokyo Bot. Mag. XXV. 145, t. 4 (1911).

Pirus formosana Kawakami \& Koidzumi in Jour. Coll. Sci. Tokyo, XXX. art. 1, 100 (Mat. Fl. Formosa) (1911).

Formosa (ex Kawakami).

This is a very distinct species, differing from all other Malus by the tubular constricted disk enclosing the connate base of the five styles. The large globose fruit with its impressed persistent calyx and short stalk resembles that of the common Apple. 


\section{DOCYNIA Decne.}

Docynia Delavayi Schneider in Fedde, Rep. Spec. Nov. III. 180 (1906).

Pyrus Delavayi Franchet, Pl. Delavay. 227, t. 46 (1889).

Eriolobus Delavayi Schneider, Ill. Handb. Laubholzk. I. 727 (1906).

Western Szech'uan: Ching-chi Hsien, mountain sides, rare, alt. 1300 m., August 1908 (No. 2998; tree $8 \mathrm{~m}$. tall, girth 2-3 m.); without precise locality, alt. 1800 m., July 1903 (Veitch Exped. No. 3493; fruit edible). Yunnan: Mengtsze, mountains west, alt. 1800-2000 m., A. Henry (Nos. 10036, 10036a); Szemao, mountains east, forests, alt. 1600 m., A. Henry (No. 11603).

A picture of this tree will be found under No. 271 in the collection of Wilson's photographs and also in his Vegetation of Western China, No. 208.

\section{CHAENOMELES Lindl.}

Chaenomeles lagenaria Koidzumi in Tokyo Bot. Mag. XXIII. 173 (1909); in Jour. Coll. Sci. Tokyo, XXXIV. art. 2, 94 (Consp. Rosac. Jap.) (1913).

Pyrus japonica Sims in Bot. Mag. XVIII. t. 692 (non Thunberg) (1803). Jacquin, Fragm. Bot. 85, t. 136 (1809), - Kurz in Jour. Bot. XI. 193 (1873). - Hemsley in Jour. Linn. Soc. XXIII. 257 (1887).

Malus japonica Andrews, Bot. Repos. VII. t. 462 (1806).

Cydonia lagenaria Loiseleur in Nouv. Duhamel, VI. 255, t. 76 (1813?).

Cydonia japonica Loiseleur, Herb. Amat. II. t. 73 (non Persoon) (1817). De Candolle, Prodr. II. 638 (pro parte) (1825). - Siebold \& Zuccarini in Abh. Akad. Münch. IV. pt. II. 131 (Fam. Nat. Fl. Jap. I. 23) (1845). Wenzig in Linnaea, XXXVIII. 10 (1874). - Palibin in Act. Hort. Petrop. XVII. 74 (Consp. Fl. Kor.) (1898).

Cydonia speciosa, Guimpel, Otto \& Hayne, Abb. Fremd. Holzgew, 88, t. 70 (1825).

Chaenomeles japonica Spach, Hist. Vég. II. 159 (pro parte) (1834), exclud. synon. Lindley, Thunberg, Persoon. - Bunge in Mém. Sav. Étr. Acad. Sci. St. Pétersbourg, II. 101 (Enum. Pl. Chin. Bor. 27) (1835). - Decaisne in Nouv. Arch. Mus. Paris, X. 129 (Mém. Fam. Pom.) (pro parte) (1874). Koehne, Gatt. Pomac. 28 (1890). - Diels in Bot. Jahrb. XXIX. 388 (1900). Schneider, Ill. Handb. Laubholzk. I. 730, fig. 405 h-o 1,406 b (1906).

Chaenomeles japonica, a genuina Maximowicz in Bull. Acad. Sci. St. Pétersbourg, XIX. 168 (1873); in Mél. Biol. IX. 163 (1873). - Franchet in Nouv. Arch. Mus. Paris, sér. 2, V. 271 (Pl. David. I. 119) (1883).

Cydonia japonica, var. genuina Ito in Tokyo Bot. Mag. XIV. 117 (Pl. Sin. Yoshi, I. 20) (1900).

Cydonia japonica, var. lagenaria Makino in Tokyo Bot. Mag. XXII. 64 (1908). 
Western Hupeh: cultivated around Ichang, alt. 600-1200 m., April 1907 (No. 2990; bush 1-2 m. tall, flowers red); without precise locality, cultivated, April 1900 (Veitch Exped. No. 129); without precise locality, A. Henry (No. 5249). Hondo: Tokyo, Botanic Gardens, cultivated, April 5, 1914, E. H. Wilson (No. 6365, bush 0.6-1 m. tall, flowers white, tinged pink without; No. 6366, flowers scarlet; No. 6367, bush, flowers white, suffused pink); Tokyo, cultivated, March 29, 1914, E. H. Wilson (No. 6340, bush 1-2 m. tall, flowers salmon; No. 6341, bush 1-2 tall, flowers white); Lake Chuzenji, Lakeside Hotel, cultivated, alt. 15 m., June 3, 1914, E. H. Wilson (No. 6803 , bush $1 \mathrm{~m}$. tall, flowers bright red). Kyushu: Island of Yakushima, cultivated, February 26, 1914, E. H. Wilson (No. 6099, bush 1-2 m., flowers white, suffused pink); Island of Tanegashima, February 27, 1914, E. H. Wilson (No. 6136, bush 1-2 m., flowers soft red).

Of the typical form of $C$. lagenaria I have seen only specimens from cultivated plants, though it probably occurs in central China in a wild state; it is much cultivated all over China and in Japan and was introduced into England probably from China by C. F. Greville about 1800 . It has always been confused with C. japonica, first described by Thunberg as Pyrus japonica, which differs in its smaller crenate and obtuse quite glabrous leaves and in the smaller brick red flowers with glabrous styles. In C. lagenaria, which is a taller plant, the styles are either glabrous or pubescent and the color of the flower varies from white to deep scarlet, the leaves are sharply serrate and are either quite glabrous or brownish pubescent on the midrib below while young.

Chaenomeles angustifolia Koidzumi in Jour. Coll. Sci. Tokyo, XXXIV. art. 2, 97 (1913) is probably only a form of this species with narrow leaves and white flowers. Also C, eugenioides Koidzumi in Tokyo Bot. Mag. XXIX. 160 (1915) with pink flowers and globose fruits is probably only a garden form of $C$. lagenaria.

\section{Chaenomeles lagenaria, var. cathayensis Rehder, n. var.}

Pyrus cathayensis Hemsley in Jour. Linn. Soc. XXIII. 256 (1887), quoad plantam hupehensem.

Cydonia cathayensis Hemsley in Hooker's Icon. XXVII. t. 2657-58 (1900). Bean, Trees \& Shrubs Brit. Isl. I. (1914).

Chaenomeles cathayensis Schneider, Ill. Handb. Laubholzk. I. 730, fig. 405 $\mathrm{p}-\mathrm{p}^{1}, 406 \mathrm{e}-\mathrm{f}(1906)$.

Western Hupeh: north and south of Ichang, wild and cultivated, alt. 300-1200 m., March 20, 1907 (No. 299r, bush 1-3 m. tall, flowers bluish-pink); Changyang Hsien, commonly cultivated as a hedgeplant, alt. 300-1200 m., September 1907 (No. 377, fruits only; bush 1-2 m. tall, fruit yellow); Nanto, April 1900 (Veitch Exped. No. 410).

This variety differs from the type in its narrower more closely and sharply serrulate leaves more or less brownish pubescent on their underside, at least on the midrib. The style seems to be always villous at the base. This is the common 
wild form in central China and is probably the phylogenetic type of this species. The Chinese call it mu-kua and value the fruits for their fragrance and keep them as an ornament in their houses.

\section{Chaenomeles lagenaria, var. Wilsonii Rehder, n. var.}

Cydonia Mallardii in Gard. Chron. ser. 3, LVIII. 158 (nomen nudum) (1915), non Chaenomeles japonica Mallardi Carrière.

A typo recedit foliis subtus tomento lanuginoso fulvo denso sed detergibili obtectis.

Western Szech'uan: Mo-hsi-mien, village southeast of Tachienlu, alt. 1800 m., October 1910 (No. 4I20, type; bush 4-6 m. tall, fruit golden and red); same locality, cultivated, November 1908 (No. 1362, fruits only; bush 2-3 m. tall).

At the first glance this Quince looks very distinct from C. lagenaria, var. cathayensis on account of the dense fulvous tomentum of the underside of its leaves, but as the young seedlings raised from seed of the type plant are quite glabrous, the constancy of this character seems doubtful. A plant very close to this variety seems to have been introduced before, as the leaves of a specimen collected in October 1881 at Kew, where it was cultivated at that time as Cydonia sinensis, show a similar, though much slighter tomentum.

Chaenomeles japonica Lindley ${ }^{1}$ apud Spach, Hist. Vég. II. 159 (pro parte) (1834), quoad synon. "Pyrus japonica Thunberg." - Makino in Tokyo Bot. Mag. XXII. 63 (1908), - Koidzumi in Jour. Coll. Sci. Tokyo, XXXIV. art. 2, 95 (Consp. Rosac. Jap.) (1913).

Pyrus japonica Thunberg, Fl. Jap. 207 (1784). - Willdenow, Spec. II. 1020 (1803). - K. Koch in Ann. Mus. Lugd.-Bat. I. 248 (1864), - Miquel in Ann. Mus. Lugd.-Bat. III. 40 (1867); Prol.Fl. Jap. 228 (1867). - Franchet \& Savatier, Enum. Pl. Jap. I. 138 (1875).

Cydonia japonica Persoon, Syn. II. 40 (1807). - De Candolle, Prodr. II. 638 (pro parte) (1825).

Chaenomeles japonica, $\beta$ alpina Maximowicz in Bull. Acad. Sci. St. Pétersbourg, XIX. 168 (1873); in Mél. Biol. IX. 163 (1873).

Chaenomeles japonica, y pygmaea Maximowicz in Bull. Acad. Sci. St. Pétersbourg, XIX. (1873); in Mél. Biol. IX. 163 (1873).

Pyrus Maulei Masters in Gard. Chron. n. ser. 1. 756, fig. 159 (1874); II. 740, fig. 144 (1874). - Hooker f. in Bot. Mag. CX. t. 6780 (1884).

Pyrus japonica, $\boldsymbol{\beta}$ alpina Franchet \& Savatier, Enum. Pl. Jap. I. 139 (1875). Cydonia Maulei Moore in Flor. \& Pomol. 1875, 49, t.; Nicholson, Dict. Gard. I. 419 (1884).

Chaenomeles japonica, var. Maulei Lavallé, Arb. Segrez, 110 (1877).

Chaenomeles alpina Koehne, Gatt. Pomac. 28, t. 2, fig. 23 a-c (1890). - Dippel, Handb. Laubholzk. III. 408 (1893).

1 Usually Lindley in Trans. Linn. Soc. XIII. 97 (1822) is quoted for this combination, but in this place Lindley gives a generic description of Chaenomeles and quotes Pyrus japonica Thunberg as the type of his new genus without proposing a specific name. 
Cydonia Sargenti Lemoine, Cat. 144, 25 (1900).

Cydonia Maulei, var. alpina Rehder in Bailey, Cycl. Am. Hort. I. 427 (1900).

Chaenomeles Maulei Schneider, Ill. Handb. Laubholzk. I. 731, fig. 405 g-8, $406 \mathrm{c}-\mathrm{d}$ (1906).

Chaenomeles Maulei, var. alpina Schneider, 1. c.

Hondo: slopes of Fuji-san, pastures, alt. 500-900 m., May 8, 1914, E. H. Wilson (No. 6656; 0.15-0.60 m., flowers scarlet); Kamakura, grassy places, May 2, 1914, E. H. Wilson (No. 6616; 0.15-0.30 m., flowers rich red); Tamagawa, Koganei, grassy places, abundant, April 9, 1914, E. H. Wilson (No. 6387; 0.15-0.30 m., flowers salmon red); near Kusakabe village, Kai prov., side of torrent, March 28, 1914, E. H. Wilson (No. 6332; 0.45-0.60 m.); Mt. Yatsuga-dake, Kai prov., woodlands, abundant, alt. 900-1500 m., September 17, 1914, E. H. Wilson (No. 7527; shrub 0.30-0.60 m., fruit yellow, globose); Nikko, September 2, 1892, C. S. Sargent; near Tokyo, April 17, 1910, K. Sakurai.

This species, which occurs only in central Japan, varies somewhat in its habit and in the size of the leaves and their serration, but it can always be easily distinguished from the preceding species by its lower habit, rarely exceeding $0.5 \mathrm{~m}$. in height, by the young branchlets being seabrous the first year, becoming verruculose the second, by the smaller obovate, obtuse and more or less crenately serrate leaves, by the smaller brick- or salmon-red flowers with the styles always glabrous and by the small and usually globose fruit.

Chaenomeles sinensis Koehne, Gatt. Pomac. (sphalmate " chinensis") (1896). Schneider, Ill. Handb. Laubholzk. I. 730, fig. 405 a-g, 406 a (1906).

Cydonia sinensis Thouin in Ann. Mus. Paris, XIX. 145, t. 8, 9 (1812).Loiseleur, Herb. Amat. II. t. 99 (1817). - De Candolle, Prodr. I1. 638 (1825). - Lindley in Bot. Reg. XI, t. 905 (1825). - Siebold \& Zucearini in Abh. Akad. Münch. IV. pt. II. 131 (Fam. Nat. Fl. Jap. I. 23) (1845).Maximowicz in Bull. Acad. Sci. St. Pétersbourg, XIX. (1873); in Mél. Biol. IX. 164 (1873). - Pampanini in Nuov. Giorn. Bot. Ital. n. ser. XVII. 289 (1910). - André, in Rev. Hort. 1889, 228, t.

Pyrus sinensis Poiret, Encycl. Méth. Suppl. IV. 452 (1816). - K. Koch in Ann. Mus. Lugd.-Bat. I. 248 (1864).- Miquel in Ann. Mus. Lugd.-Bat. III. 40 (1867); Prol. Fl. Jap. 228 (1867).

Pyrus chinensis Bunge in Mém. Sav. Êtr. Acad. Sci. St. Pétersbourg, II. 27 (Enum. Pl. Chin. Bor. 101) (1835).

Pyrus cathayensis Hemsley in Jour. Linn. Soc. XXIII. 256 (pro parte) (1887), exclud. specimine Henryano.

Pseudocydonia sinensis Schneider in Fedde, Rep. Spec. Nov. III. 181 (1906).

Cydonia vulgaris Pavolini in Nuov. Giorn. Bot. Ital. n. ser. XV. 415 (non Persoon) (1908).

Northern Hupeh: “Ma-pan-scian,” alt. 1000 m., May 1907, C. Silvestri (No. 908). Chekiang: vicinity of Ningpo, 1908, D. Macgregor. Hondo: Temple grounds, Nara, cultivated, April 22, 1914, E. H. Wilson (No. 6572; tree 10-12 m. tall, $0.6-1 \mathrm{~m}$. girth, bark peeling off in flakes, flowers rose-pink).

This is a very distinct species and even without flowers it is easily distinguished from C. lagenaria Koidzumi by the stipitate-glandular stipules and petioles and by the broader ciliately serrulate leaves. 


\section{SPECIES VARIETATESQUE POMOIDEARUM IMPERFECTE NOTAE ASIAE ORIENTALIS.}

Of the following recently described species and varieties of Pyrus and Sorbus, I have seen no specimens, and as their descriptions are not sufficient for definite determination they could not be referred to their proper position.

Pyrus Aria, var. Silvestrii Pampanini in Nuov. Giorn. Bot. Ital. n. ser. XVII. 290 (1910).

Pyrus Bodinieri Léveillé, Fl. Kouy-Tchéou, 350 (1915).

Pyrus brunnea Léveillé in Fedde, Rep. Spec. Nov. X. 377 (1912).

Pyrus Cavaleriei Léveillé, 1. c. XI. 67 (1912).

Pyrus Esquirolii Léveillé, l. c. XII. 189 (1913).

Pyrus Feddei Léveillé, 1. c. XII. 189 (1913).

Pyrus ferruginea Koidzumi in Tokyo Bot. Mag. XXIX. 158 (not Hooker f.) (1915).

This is probably only a cultivated form or possibly hybrid of $P$. serotina Rehder escaped and naturalized, though Koidzumi compares it with $P$. ovoidea Rehder. Neither the flowers nor the mature fruits were known to the author.

Pyrus hupehensis Pampanini in Nuov. Giorn. Bot. Ital. n. ser. XVII. 291 (1910).

According to the description this species would seem near to or identical with $P$. serrulata Rehder, but Pampanini describes the styles as connate and villosetomentose at the base, which removes the species from the genus Pyrus altogether.

Pyrus Koehnei Léveillé in Fedde, Rep. Spec. Nov. X. 378 (non Schneider) (1912).

Pyrus Mairei Léveillé, l. c. XII. 189 (1913).

Pyrus mokpoensis Léveillé, 1. c. VII. 200 (1909).

Pyrus sinensis, var. Maximowicziana Léveillé, 1. c. X. 377 (1912).

Pyrus spectabilis, var. albescens Léveillé, 1. c. X. 377 (1912).

Pyrus Taquetii Léveillé, l, c. VII. 199 (1909).

Pyrus Vaniotii Léveillé, 1. c. V11. 200 (1909).

Sorbus Aria, var. Mairei Léveillé, 1. c. XIII. 341 (1914).

Subfam. ROSOIDEAE.

Determined by Alfred ReHder and E. H. Wilson.

RHODOTYPUS Sieb. \& Zucc.

Rhodotypus kerrioides Siebold \& Zuccarini, Fl. Jap. I. 185, t. 99, fig. I (1841). - Regel in Gartenfl. XV. 130, t. 505 (1866). - Hooker f. in Bot. Mag. XCV. t. 5805 (1869), - Hance in Jour. Bot. XVI. 10 (1878). - Maximowicz in Act. Hort. Petrop. VI. 244 (1879). Lavallée, Icon. Arb. Segrez. 45, t. 14 (1881).- Hemsley in Jour. Linn. Soc. XXIII. 229 (1887).

Keria tetrapetala Siebold in Verh. Bataav. Genoot. XII. 69 (Syn. Pl. Oec. Jap.) (nomen nudum) (1830).

Rhodotypus tetrapetala Makino in Tokyo Bot. Mag. XVII. 13 (1903). Schneider, Ill. Handb. Laubholzk. I. 501, fig. 304 (1905). 
Western Hupeh: Hsing-shan Hsien, open country, not common, alt. 600-1200 m., May 7, June 8 and October 1907 (No. 3345; bush 1-1.25 m. tall, flowers white, fruits black).

\section{KERRIA DC.}

Kerria japonica De Candolle in Trans. Linn. Soc. XII. 157 (1817); Prodr. II. 541 (1825). - Lindley in Bot. Reg. XXII. t. 1873 (1836). Siebold \& Zuccarini, Fl. Jap. I. 183, t. 98, 99, fig. II, III (1841). - Maximowicz in Act. Hort. Petrop. VI. 242 (1879). - Hemsley in Jour. Linn. Soc. XXIII. 229 (1887). - Diels in Bot. Jahrb. XXIX. 390 (1900). - Schneider, Ill. Handb. Laubholzk. I. 501, fig. 305 (1905). Pavolini in Nuov. Giorn. Bot. Ital. n. ser. XV. 413 (1908). - Pampanini in Nuov. Giorn. Bot. Ital. n. ser. XVII. 290 (1910).

Rubus japonicus Linnaeus, Mant. I. 145 (1767).

Corchorus japonicus Thunberg, Fl. Jap. 227 (1784). - Andrews, Bot. Rep. IX. t. 587 (1809). — Sims, Bot. Mag. XXXII. t. 1296 (1810).

Spiraea japonica Desvaux in Mém. Soc. Linn. Paris, I. 25 (non Linnaeus f.) (1822). - Cambassedes in Ann. Sci. Nat. I, 389 (1824).

Western Hupeh: Ichang, common, alt. 300-1000 m., April and July 1907 (No. II2, in part; shrub 1-1.25 m., the double form cultivated). "Kao-kien-scian," alt. 800 m., May-June 1907, C. Silvestri (No. 928). Western Szech'uan: Ching-chi Hsien, alt. 900-1200 m., May 1908 (No. II2, in part; bush 1-1.5 m., flowers golden). Northern Shensi: "Lao-y-san, presso Zu-lu," May 4 and September 6, 1897, G. Giraldi.

\section{POTENTILLA L.}

Potentilla fruticosa Linnaeus, Spec. 495 (1753), - Nestler, Monog. Potent. 30 (1816). - Lehmann, Monog. Potent. 31 (1820). - Bretschneider, Early Eur. Research. Fl. Chin. 149 (1881). - Franchet in Nouv. Arch. Mus. Paris, sér. 2, V. 262 (Pl. David. I. 110) (1883); Pl. Delavay. 210 (1890), - Hemsley in Jour. Linn. Soc. XXIII. 243 (1887). - Pritzel in Bot. Jahrb. XXIX. 402 (1900). - Wolf in Bibl. Bot. XVI. 54 (Monog. Potent.) (1908), - Törnblom in Svensk. Bot. Tidskr. V. 91, figs. 1-8 (1911). - Diels in Not. Bot. Gard. Edinburgh, VII. 120 (Pl. Chin. Forrest.) (1912).

Potentilla davurica Hance in Jour. Linn. Soc. XIII. 79 (non Nestler) (1873).

Dasiphora fruticosa Rydberg in Mem. Bot. Columb. Univ. II. 188 (1898). 
Western Szech'uan: Mupin, thickets and rocky places, alt. 2600-4000 m., June, July and October 1908, October 1910 (Nos. I2 I3, 3I75, 4629; shrub 1-1.5 m., flowers yellow); Tachien-lu, upland thickets, alt. 3300-4000 m., July and November 1908 (No. I2I3 ${ }^{\mathrm{a}}$; shrub 1 m. tall, flowers yellow); northeast of Tachien-lu, Tap'ao-shan, moorlands, alt. 4000-4600 m., July 7, 1908 (No. 3I74; shrub 0.6-1 m. tall, flowers golden); Wa-shan, cliffs, alt. 3500 m., July 1903 (Veitch Exped. No. 3466; bush $0.6-1 \mathrm{~m}$. tall, flowers yellow); without precise locality, A. Henry (No. 8955). Chili: Weichang, 1909, W. Purdom (No. 127). Yunnan: Lichiang range, alt. 3300-3600 m., August 1906, G. Forrest (No. 2723).

This is a common shrub on exposed rocky mountain slopes, above $2500 \mathrm{~m}$. altitude, in western Szech'uan; in Hupeh it is rather rare. In size of leaves and flowers and in degrees of hairiness this plant is extremely variable. The Chinese specimens quoted above differ from the typical form in the broader usually elliptic and mucronate outer sepals shorter than the inner sepals, approaching in this respect var. davurica Lehmann.

Potentilla fruticosa, var. albicans Rehder \& Wilson, n. var.

A typo recedit foliis supra laxe adpresse villosis subtus sericeotomentosis albicantibus, sepalis exterioribus ellipticis quam interiores subaequilongis mucronatis.

Western Szech'uan: Tachien-lu, alt. 3300-4000 m., November 1908 (No. I2I3 ${ }^{\text {a }}$, in part; seeds only). Cultivated at Highland Park, Rochester, N. Y.: Highland Park, September 14, 1915. E. H. Costich (raised from seed of Wilson's No. 1213 ${ }^{\mathrm{a}}$ ), type.

This variety is apparently near $P$. fruticosa, var. vulgaris Willdenow, from which it differs chiefly in the white-tomentose under surface of the leaflets. The leaves are 5-foliolate with generally elliptic-oblong leaflets, rounded and mucronate at the apex, pubescent and dull grayish green above, white-tomentose beneath; the flowers are bright yellow and about $2 \mathrm{~cm}$. wide with elliptic outer sepals about as long as the inner ones. In foliage it much resembles $P$. fruticosa, var. Vilmoriniana Bean, but that variety has creamy white flowers.

The plants in cultivation were raised from seed collected under No. $1213^{\mathrm{a}}$, but all the herbarium specimens of that number have glabrescent leaves.

Potentilla fruticosa, var. rigida Wolf in Bibl. Bot. XVI. 57 (Monog. Potent.) (1908).

Potentilla rigida Wallich, Cat. No. 1009 (nomen nudum) (1828). - Lehmann, Nov. Stirp. Pugil. III. 3 (1831); in Nov. Act. Acad. Leop.-Carol. XXIII. Suppl. 19, t. 1 (Revis. Potent.) (1856).

Western Szech'uan: near Monkong Ting, alt. 2300-3000 m., June 1908 (No. 3I73; shrub 0.6 m., flowers yellow). 
Not common. Our plant differs from the type of this variety in being sparsely hairy on the underside of the leaves; it also differs slightly in general aspect.

Potentilla fruticosa, var. tangutica Wolf in Bibl. Bot. XVI. 57 (Monog. Potent.) (1908).

Western Szech'uan: Mupin, alt. 2700-3300 m., October 1910 (No. 4629; shrub 1-1.25 m. tall, flowers yellow?).

Our specimen differs from the original description of var. tangutica in the rather large outer sepals which are nearly as long as the inner sepals. The specimen is similar to King's No. 4178 from Patang-lu, Sikkim, which has still larger outer sepals.

Potentilla fruticosa, var. mandshurica Maximowicz in Bull. Acad. Sci. St. Pétersbourg, sér. 3, XIX. 164 (1874).

Potentilla davurica, var. mandshurica Wolf in Bibl. Bot. XVI. 61 (Monog. Potent.) (1908).

Potentilla fruticosa, var. leucantha Makino in Tokyo Bot. Mag. XXIV. 32 (1910).

Western Szech'uan: Monkong Ting, valley of Hsao-chin Ho, alt. 2300-3000 m., June 1908 (No. 3172; shrub 0.6 m., flowers white). Western Hupeh: without precise locality, A. Henry (No. 6967).

This variety is not uncommon in the semi-arid valleys of western Szech'uan.

Potentilla fruticosa, var. Veitchii Bean, Trees \& Shrubs Brit. Isl. II. 223, fig. (1914).

Potentilla Veitchii Wilson in Gard. Chron. ser. 3, L. 102 (1911).

Potentilla davurica, var. Veitchii Jesson in Bot. Mag. CXLI. t. 8637 (1915),

Western Hupeh: Fang Hsien, rocky places, 2500-3000 m., July and October 1901 (Veitch Exped. No. 2187, Seed No. 1087, type of $P$. Veitchii Wilson, shrub 1-1.5 m., flowers white). Western Szech'uan: west and near Wên-ch'uan Hsien, rocky places, alt. 23003600 m., July 1908 (No. 3176; bush 0.6-1 m. tall, flowers white); near Sungpan Ting, uplands, alt. 3000-4000 m., August 1910 (No. 4627; shrub $1 \mathrm{~m}$. tall, flowers white); Tachien-lu, on rocks, alt. $4100 \mathrm{~m}$, July 1903 (Veitch Exped. No. 3468; shrub 0.6-1 m. tall, flowers white). Shensi: Tai-pai-shan, mountain slopes up to alt. $3300 \mathrm{~m}$., July 1, 1910, W. Purdom (Nos. 396, 396ª $396^{\mathrm{xxx}}$, shrub 0.6-1 m. tall, flowers white). Kansu: valley of Tow River, alt. 3000-3300 m., 1911, W. Purdom (No. 819). Chili: Hsiao Wu-tai-shan, alt. 3000 m., August 1913, F. N. Meyer (Nos. 108, 1176, shrubby, flowers white).

This variety is a prominent feature in the scrub which covers large areas above the treeline on the mountains of western Szech'uan. In Hupeh it is rare. It 
shows as much variation in size of leaves and degree of pubescence as the typical $P$. fruticosa L., but is readily distinguished by its pure white flowers. From the other white-flowered variety, var. dahurica Lehmann, it differs in the more or less pubescent leaves and in the absence of the conspicuous tuft of hairs at the apex of the stipules, while in the shape of the sepals there is little or no difference.

Here may be added a note on a variety not collected during the Arnold Arboretum expeditions,

Potentilla fruticosa, var. parvifolia Wolf in Bibl. Bot. XVI. 58 (Monog. Potent.) (1908).

Potentilla parvifolia Fischer apud Lehmann, Nov. Stirp. Pugil. III. 6 (1831); in Nov. Act. Acad. Leop.-Carol. XXIII. Suppl. 20, t. 3, fig. 1 (Revis. Potent.) (1856).

Potentilla fruticosa, var. ochreata Hooker f., Fl. Brit. Ind. II. 347 (non Lehmann) (1878).

Western Szech'uan: Sungpan Ting, grasslands, alt. 3300 m., August 1903 (Veitch Exped. No. 3467; shrub $0.6 \mathrm{~m}$. tall, flowers white or yellow), west of Tachien-lu, moorlands, alt. 4000 m., June 1904 (Veitch Exped. No. 3468 ; shrub $0.6 \mathrm{~m}$. tall, flowers yellow). Kansu: Min-chou and Choni, alt. 3000-3300 m., 1911, W. Purdom (Nos. 821, $821^{\mathrm{xxx}}$, flowers yellow).

Common on the scrub-clad uplands in northwest Szech'uan. The flowers vary much in color. The specimens differ from typical var. parvifolia in their generally 5 -foliolate leaves, but the leaflets are narrow and do not exceed $1 \mathrm{~cm}$. in length; only No. $3468^{\mathrm{a}}$ has broader elliptic leaflets, but they are very small, measuring only $0.3-0.5 \mathrm{~cm}$. in length.

\section{ROSA L.}

Rosa multiflora Thunberg, Fl. Jap. 214 (1784). - Lindley, Ros. Monog. 119 (1820). - Seringe in De Candolle, Prodr. II. 598 (1825). Crépin in Bull. Soc. Bot. Belg. XIII. 250 (Prim. Monog. Ros. 257) (1874); XVIII. 277 (Prim. Monog. Ros. 523) (1879). - Franchet \& Savatier, Enum. Pl. Jap. I. 134 (1874); II. 343 (1876). - Hooker f. in Bot. Mag. CXVI. t. 7119 (1890). - Sargent in Garden \& Forest, III. 405, fig. 51 (1890). - Willmott, Gen. Rosa, I. 23, t. (1910).

The type of this species which has not yet been recorded from China proper occurs in Japan and Korea.

Rosa multiflora, var. cathayensis Rehder \& Wilson, n. var.

A typo recedit inflorescentia magis corymbosa, pauci- v. pluriflora et floribus roseis majoribus.

Rosa multiflora Hemsley in Jour. Linn. Soc. XXIII. 253 (non Thunberg) (1887) quoad specimina chinensia. - Franchet, Pl. Delavay. 218 (1890). Crépin in Bull. Soc. Bot. Ital. 1897, 230. - Vilmorin \& Bois, Frut. Vilmorin. 83, fig. (1904). - Pampanini in Nuov. Giorn. Bot. Ital. n, ser. XVII. 295 (1910). - Dunn \& Tuteher in Kew Bull. Misc. Inform. add. ser. X. 96 (Fl. Kwanglung \& Hongk.) (1912). 
Rosa multiflora, var. adenophora Focke in Bot. Jahrb. XXIX. 405 (non Franchet \& Savatier) (1900). - Léveillé, Fl. Kouy-Tchéou, 354 (1915).

Rosa damascena, f. floribus simplicibus Focke in Not. Bot. Gard. Edinburgh, V. 66 (1911).

Western Hupeh: Hsing-shan Hsien, rocky places, alt. 300-1000 m., May 5, June and December 1907 (Nos. 6r6, type, 3608; bush 0.3-2.5 m. tall, often prostrate, flowers rosy-pink, fruit dull red); Patung Hsien, side of streams, alt. 600-1300 m., June 1907 (No. 36o9; bush $0.6-1.5 \mathrm{~m}$. tall, flowers pink); Fang Hsien, side of streams, alt. 1000-1600 m., May 24, 1907 (No. 36o6; bush 0.6-2 m. tall, flowers pink); north and south of Ichang, side of streams, alt. 300-1300 m. (No. 3607; bush 0.6-1.3 m. tall, flowers pink); Nanto, banks of Yangtsze River, April 1900 (Veitch Exped. No. 178); Chienshi Hsien, alt. 1000 m., July 1900 (Veitch Exped. No. 1298; bush 2 m. tall, flowers pink); without locality, A. Henry (Nos. 5289, 5786, 7183, 3129, 7639). Western Szech'uan : Kiating Fu, banks of Min River, April 1904 (No. 354I; bush 1 m. tall, flowers pink); Mt. Omei, May 1904 (Veitch Exped. No. 4881); without locality, alt. 1000 m., May 1904 (Veitch Exped. No. 3542; bush $2 \mathrm{~m}$. tall, flowers pink). Kansu: without precise locality, 1911, W. Purdom (No. 536). Fokien: without locality, Dunn's Exped. 1905 (Herb. Bot. Gard. Hongkong, No. 2643).

This is a very common Rose growing in sandy and rocky places beside streams everywhere in western Hupeh, and in Szech'uan from river-level to $1300 \mathrm{~m}$. altitude. The flowers are always pink and larger than those of the type, and like the type it is a very variable plant. The stems may be prostrate or erect; the leaves vary extremely in size, and the leaflets vary from narrow-lanceolate to suborbicular and are nearly glabrous or very pubescent; the stipules vary in size and in degree of lacination, and the pedicels are smooth or densely stipitate-glandular. These characters are all inconstant and in this plant have no taxonomic significance.

The typical $R$. multiflora Thunberg is a native of Japan and has pure white smaller and usually more numerous flowers in the clusters. Rosa multiflora, var. cathayensis is the wild parent of the double pink forms enumerated below and introduced into England from China in 1804 and in 1816, while the Japanese $R$. multiflora was not introduced until sometime about 1860 . The first mention of this variety is found in Plukenet (Amalth. 185 [1705]) under the name "Rosa sylvestris cheusanica, foliis subtus incanis, floribus purpureis parvis."

A picture of this Rose will be found under Nos. 014, 019 of the collection of Wilson's photographs.

Rosa multiflora, var. carnea Thory in Redouté, Roses, II. 67, t. (1821).

Rosa multiflora Sims in Bot. Mag. XXVI. t. 1059 (non Thunberg) (1807). Aiton, Hort. Kew. ed. 2. III. 265 (1811). - Lindley in Bot. Reg. V. t. 425 (1819); Ros. Monog. 119 (1820). - Andrews, Roses, II, t. 83 (1828). 
Rosa diffusa Roxburgh, Hort. Beng. 92 (nomen nudum) (1814); Fl. Ind. ed. 2, II. 515 (1832).

Rosa florida Poiret, Encycl. Méth. Suppl. IV. 715 (1816).

Rosa Grevillii Sweet, Hort. Brit. 138 (1827).

Rosa Roxburghii Sweet, Hort. Brit. 138 (non Trattinnick) (1827).

Rosa rubeoides Andrews, Roses, II. t. 84 (1828).

Rosa multiflora, $\beta$ plena Regel, Tent. Ros. Monog. 84 (1877); in Act. Hort. Petrop. V. 368 (1878).

Rosa centifolia Focke in Not. Bot. Gard. Edinburgh, V. 66 (non Linnaeus) (1911).

Western Hupeh: north and south of Ichang, commonly cultivated, alt. 300-1300 m., May 1907 (No. 360 $7^{\mathrm{a}}$; rambling bush 1-2.5 m. tall, flowers rose-pink). Western Szech'uan: Mt. Omei, cultivated, May 1904 (Veitch Exped. Nos. 4881ª $4881^{\mathrm{b}}$ ); side of Yangtsze River, probably an escape, April 1904 (Veitch Exped. No. 3530; bush $2 \mathrm{~m}$. tall). Yunnan: near the city of Tali, alt. $2000 \mathrm{~m}$., June-July 1906, G. Forrest (No. 4449, in part).

Commonly cultivated and variable in size of flowers and leaves. A picture of this Rose will be found under No. 0121 of the collection of Wilson's photographs.

Rosa multiflora, var. carnea, f. platyphylla Rehder \& Wilson, n. comb.

Rosa multiflora, var. platyphylla Thory in Redouté, Roses, II. 69, t. (1821). Lindley in Bot. Reg. XVI. t. 1372 (1830). - Willmott, Gen. Rosa, I. 29 (1910).

Rosa Thoryi Trattinnick, Ros. Monog. 1.85 (1823).

Western Szech'uan: west and near Wên-ch'uan Hsien, cultivated, alt. 1800 m., July 1908 (No. 36ro; bush 3 m. tall, flowers rosepink).

Rosa diffusa Roxburgh, R. Grevillii Sweet, R. Roxburghii Sweet, and R. rubeoides Andrews are probably synonyms of this Rose, but the evidence is rather obscure and vague.

This is the Rose long cultivated in western gardens under the name of Seven Sisters Rose and sent from China to England about 1816. The well-known Rose Crimson Rambler seems to us to be obviously a form of the "Seven Sisters" with intense red and more numerous flowers. Miss Willmott (Gen. Rosa, I. 31 [1910]), considers $R$. multiflora $\times R$. chinensis as the parentage of the "Crimson Rambler," but we eannot discover the slightest influence of $R$. chinensis in this Rose any more than we can in the "Seven Sisters." Both these Roses have long been cultivated in China, and Wilson has often seen them both in gardens in Hupeh and Szech'uan. Like many other ornamental garden plants the Rose Crimson Rambler was doubtless introduced from China to Japan.

Rosa Brunonii Lindley, Ros. Monog. 120, t. 14 (1820). - Hooker in Bot. Mag. LXIX. t. 4030 (1843). 
Rosa Brownii Trattinnick, Ros. Monog. II. 96 (1823).

Rosa moschata, var. nepalensis Lindley in Bot. Reg. X. t. 829 (1824). - Willmott, Gen. Rosa, I. 37, t. (1910).

Rosa Brunonis Wallich, Cat. No. 689 (1828).

Rosa pubescens Roxburgh, Fl. Ind. ed. 2, II. 514 (1832).

Rosa moschata Brandis, Forest Fl. Brit. Ind. 201 (non Miller) (1874). - Hooker f., Fl. Brit. Ind. II. 367 (1879). - Crépin in Bull. Soc. Bot. Belg. XVIII. 287 (1879).

Western Szech'uan: Wa-shan, thickets, alt. 1300-2000 m., June and October 1908 (No. Ir25); vicinity of Tachien-lu, A. E. Pratt (No. 278).

Rosa Brunonii is fairly common in the valley of the Tung River, where it forms tangled masses $6 \mathrm{~m}$. and more high and as much in diameter. The Chinese plant differs slightly from the type of the species as described and figured by Lindley in its glabrous shoots and in the glabrous or nearly glabrous upper surfaces of the leaflets, but most of the Indian specimens before us also show glabrous shoots, so that it does not seem possible to separate the Chinese and the Himalayan plants.

We have restored this Rose to specific rank only after careful consideration. The discovery of several species of Musk Roses in China has caused us to consider Rosa moschata Miller as the centre of a group of these plants. For these species introduced into gardens in Europe and North America have come true from seed, maintained their distinguishing characters, and are so distinct that no horticulturist confuses them with the Musk Roses previously in cultivation. To us there appears to be a number of geographical segregates which agree with the Musk Rose beloved of our ancestors, in having white flowers with a musk-like fragrance, a protruded club-shaped pistil, reflexed calyx-lobes and adnate stipules, but differing from each other in so many other particulars that they are easily recognized as distinct species and varieties.

The original Rosa moschata Miller (Gard. Dict. ed. 8, 1I. 950 [1768]) is an obscure plant in spite of the fact that it had been in cultivation in England fully a century and a half before Miller described it as "Rose with prickly climbing stem, leaves with 7 smooth lobes, glabrous when old and flowers in umbels," a deseription which does not help us much. Miller cites Rosa Moschata major J. Bauhin. In Bauhin's Hist. Pl.II.45, fig. (1650) there are figures of three forms of R. moschata. Bauhin states he found the $R$. moschata major in Burgundy and transferred it to his garden at Montbeliard, where it was not very hardy. Similar figures to those of Bauhin's appear in Lobel's Pl. Stirp. Icon. II. 207 (1581). The R. moschata Miller has been known in European gardens since early times. The first mention we ean find is by C. Gesner as Rosa muscata in his Horti Germaniae (in V. Cordus, Annot. 276 [1561]); it is also mentioned by Turner in his Herbal, II. 116 (1568), and in a rather vague way by Mattioli in his Commentarii, where in later editions it is identified with the "Nesrim" of the Liber Serapionis. Parkinson (Paradisus, 419, fig. 6 [1629]) figures it under the name of Rosa moschata hispanica simplex.

Modern writers agree that the Musk Rose of our ancestors was native somewhere in the Mediterranean region. A specimen before us from M. Gandoger's Herbarium (No. 550), named Rosa ruscinonensis Grenier, and collected at Perpignan in the Pyrenees, agrees remarkably well with Bauhin's and Lobel's figures of $R$. moschata major, and Miller's description fits it more closely than it does any other Musk Rose we have seen. A specimen in the Gray Herbarium collected by G. Schweinfurth (No. 1741) on March 10, 1889, along the upper Wadi Nahemi above 
Attara at $1800 \mathrm{~m}$. altitude, and named Rosa abyssinica R. Brown, f. glandulosa, ${ }^{1}$ differs from $R$. ruscinonensis Grenier only in being more prickly and more glandular, and in the leaflets being less membranous and pale on the underside. These two specimens we regard as representing the two extreme geographical forms of the Musk Rose of our ancestors, the $R$. moschata Miller.

The Musk Roses of China and India and that of the high mountains of Persia, R. moschata, var. nasturana Christ ( $R$. Pissarti Carrière), distinguished at a glance by their larger leaves, much more numerous flowers in large rounded or paniculate corymbs, were unknown to botanists and to western gardens in Miller's time. In the latter half of the 19th century Crépin and other botanists believed that the range of Miller's $R$. moschata extended through Persia and northern India to the extreme east coast of China. Most of them admitted that the new forms discovered differed, however, from their conception of the original Musk Rose, and gave them varietal names. Our study, however, of this perplexing subject has convinced us of two things: - (1) That the Musk Rose of Miller is little if at all different from Rosa ruscinonensis Grenier and Déséglise apud Déséglise (in Billotia, I. 33 [1864]), and from Rosa abyssinica R. Brown, and their intermediate forms: (2) that the Musk Roses of India and China are distinct from those known to Miller and his predecessors and that they are best considered geographical segregates under separate names since they display constant characters sufficient to distinguish them as species.

The Chinese Musk Roses referred by various botanists to $R$. moschata belong to several of the undermentioned species, but without seeing the specimens it is impossible to place them where they actually belong.

The Rose figured by Miss Willmott (Gen. Rosa, I. 33, t. [1910]) as R. moschata Miller is a form of $R$. Brunonii Lindley. Since this last named Rose is superior as a garden plant to the old Musk Rose, it has very generally supplanted it and it is doubtful if $R$. moschata Miller is now in general cultivation.

Rosa Rubus Léveillé \& Vaniot in Bull. Soc. Bot. France, LV. 55 (1908). - Willmott, Gen. Rosa, II. 507, t. (1914). - Léveillé, Fl. Kouy-Tchéou, 354 (1915).

Rosa moschata, var. hupehensis Pampanini in Nuov. 'Giorn. Bot. Ital. n. ser. XVII. 295 (1910).

Western Hupeh: Patung Hsien, thickets, alt. 600-1300 m., November 1907 (No. 43 $\mathrm{I}^{\mathrm{c}}$; scandent bush 2.5-4 m. tall, fruit dull red); Hsing-shan Hsien, woodlands, alt. 1300 m., December 1907 (No. 666ª bush 3-5 m. tall, fruit dark scarlet); without locality, A. Henry (Nos. 5550, 7007). Western Szech'uan: Chien-chi Hsien, roadside, alt. 1800 m., October 1910 (No. 4I74; scandent bush 3-6 m. tall, fruit red); Mt. Omei, June 1904 (Veitch Exped. No. 4880; bush 6 m. tall); without precise locality, banks of Yangtsze River, May 1903 (Veitch Exped. No. 3536 ; large bush, flowers fragrant). Kweichau : "route de Pinyang, May 12, 1899, L. Martin (No. 2603, type).

1 This is apparently a manuscript name, as this specimen is enumerated by Schweinfurth in Bull. Herb. Boissier, IV. app. 2, 205 (1896) under R. abyssinica without any varietal designation. 
This is a common species everywhere in western Hupeh and eastern Szech'uan from river-level to $1300 \mathrm{~m}$. The densely hairy shoots and leaves readily distinguish it from its near relatives. The leaflets are often large and coarsely toothed and the leaves though variable in shape resemble those of certain species of Rubus. The fruit is globose, and the pedicels are relatively long and stout.

Henry's No. 7007 agrees exactly with Pampanini's description of his var. hupehensis except that the teeth are occasionally obscurely biserrate.

A picture of this plant will be found under No. 038 of the collection of Wilson's photographs.

Rosa glomerata Rehder \& Wilson, n. sp.

Frutex sarmentosus, 3-6-metralis v. ultra; rami glabri, rubrobrunnei v. flavo-cinerei, aculeis sparsis brevibus reflexo-falcatis basi dilatatis flavo-brunneis muniti. Folia papyracea, 3-9-, plerumque 5-7-foliolata, petiolo incluso $12-20 \mathrm{~cm}$. longa; foliola breviter petiolulata, basin versus decipientia, par infimum quam supremum circiter dimidio minus, oblonga v. oblongo-ovata, breviter acuminata, basi rotundata v. subcordata et plerumque leviter obliqua, serrulata dentibus parvis glandula terminatis, interdum remote v. obsolete serrulata, saepe leviter revoluta, $3-10 \mathrm{~cm}$. longa et $1.5-4.5 \mathrm{~cm}$. lata, supra obscure luteo-viridia, glabra costa media sparse villosa excepta, rugosa, subtus sparse, in costa et nervis densius villosa, reticulata, utrinsecus nervis 6-10 ut costa supra impressis subtus elevatis, reticulo venularum supra impresso subtus elevato; petioli $2.5-5 \mathrm{~cm}$. longi ut rhachis supra canaliculati, subtus tomentulosi et aciculis curvatis sparsis muniti, sed petioli pars inferioris glabra et purpurascens; petioluli 1-3 mm. longi, dense villosi; stipulae adnatae, angustae, 2-3 cm. longae, purpurascentes, glabrae, auriculis triangularibus acutis plerumque sparse villosis sparse glandulosis. Flores fragrantes, albi, $2-3 \mathrm{~cm}$. diam., numerosi in corymbo terminali congesto circiter $4-6 \mathrm{~cm}$. alto et $7-10 \mathrm{~cm}$. diam.; rhachis sparse villosa v. glabrescens; axes secundi ordinis 1-2 cm. longi et pedicelli subaequilongi dense cinereo-villosa; bracteae bracteolaeque parvae, membranaceae, fugaces; receptaculum ovoideum, villosum, sparse glandulosum; alabastrum ovoideum; sepala ovato-lanceolata, acuminata, $1.2-1.5 \mathrm{~cm}$. longa, extus villosa et glandulosa, intus villosa; petala obovata, $1.2-1.5 \mathrm{~cm}$. longa, rotundata v. emarginata v. truncata, extus sericeo-villosa; styli coaliti, exserti, villosi. Fructus subglobosus, interdum ovoideus, rubro-aurantiacus, $0.8-1.2 \mathrm{~cm}$. longus et $0.7-1 \mathrm{~cm}$. diam., sepalis deciduis, stylis saepe persistentibus.

Western Szech'uan: southeast of Tachien-lu, thickets, alt. 1800$2300 \mathrm{~m}$., June and October 1908 (No. I306, type); same locality, 
valley of Tung River, alt. 1300-2000 m., October 1910 (No. 4I75); Wa-shan, thickets, alt. 1600 m., November 1908 (No. 1334a).

This is a very distinct species readily distinguished by its large leaflets with strong reticulate venation and villose pubescence on the underside, by its large membranous stipules, by its short-peduncled dense corymbs, by the villose tomentum on the pedicels and calyx and by its orange-colored fruit. It is related to Rosa longicuspis Bertoloni, which is nearly glabrous everywhere and has shining green leaves with much less prominent venation, flowers on longer pedicels, and a very much larger red or scarlet fruit. This new species has a rather local distribution but is fairly common in the regions mentioned.

\section{Rosa Helenae Rehder \& Wilson, n. sp.}

Rosa floribunda Rolfe in Gard. Chron. ser. 3, LVIII. 210 (pro parte, non Steven, nec Baker) (1915), quoad descriptionem.

Frutex diffusus sarmentosus; rami crassi, glabri, annotini purpureobrunnei, aculeis plerumque numerosis conformibus, validis falcatis basi dilatatis flavo-griseis muniti. Folia decidua, 3-9-, plerumque 7-9-foliolata, petiolo incluso 5-12, plerumque 10-12 cm. longa; foliola brevissime petiolulata, oblongo-ovata v. ovato-lanceolata, rarius elliptica, interdum elliptico-obovata, $2-4.5 \mathrm{~cm}$. longa et $1-2.5 \mathrm{~cm}$. lata, plerumque breviter acuminata, basi rotundata v. rarius late cuneata, argute serrulata, supra glabra et intense viridia, subtus cinerei et costa nervisque pilosis exceptis glabra v. fere glabra, utrinsecus nervis 4-7 supra impressis subtus elevatis; petioli $2-3.5 \mathrm{~cm}$. longi, ut rhachis supra canaliculati dense pubescentes et subtus aculeis parvis faleatis sparse muniti; petioluli 1-2 mm. longi; stipulae adnatae, 1.5-2.5 longae, satis angustae, auriculis suberectis $4-8 \mathrm{~mm}$. longis anguste semi-ovatis $\mathrm{v}$. triangularibus glanduloso-denticulatis, glabrescentes, margine interdum sparse stipitato-glandulosae. Flores albi, fragrantes, 3-4 cm. diam., in corymbis terminalibus multifloris 6-15 cm. diam.; bracteae membranaceae, anguste lanceolatae, caducae; pedicelli graciles, 2-2.5 $\mathrm{cm}$. longi, dense stipitato-glandulosi; receptaculum obovoideum v. ellipsoideum, stipitato-glandulosum; sepala lanceolata, acuminata, reflexa, 8-12 mm. longa et 3-4 $\mathrm{mm}$. lata, sparse lobata, extus stipitatoglandulosa et sparse villosa, intus dense villosa; petala obovoidea, circiter $1.5 \mathrm{~cm}$. longa, plerumque emarginata, glabra; styli in columnam coaliti, exserti, dense pilosi. Fructus ovoideus v. ellipsoideo-obovoideus, intense aurantiaco-ruber v. scarlatinus, 1-1.5 cm. longus et 8-10 mm. diam., stylis et sepalis caducis.

Western Hupeh: Patung Hsien, thickets, alt. 600-1300 m., June 1907 (No. 43I, type, $43 \mathrm{I}^{\mathrm{b}}$, seeds only); Ichang, glens, June 1900 
(Veitch Exped. No. 945); without locality, A. Henry (No. 5973). Eastern Szech'uan: Wushan Hsien, woodlands, alt. 1000-1500 m., December 1907 (No. 666); same locality, A. Henry (No. 7100).

This species is well distinguished from all its allies by its large ovoid to obovoid ellipsoid fruit, in No. 666 sometimes even exceeding $1.5 \mathrm{~cm}$. in length. It is perhaps most elosely allied to $R$. Brunonii Lindley, which has a paniculate corymb and smaller globose fruit. R. Gentiliana Léveillé \& Vaniot differs in its glabrous, 5 -foliolate leaves, which are glaucescent below and have larger more coarsely toothed leaflets, and in its gray stems and globose fruit.

Rosa Helenae is very abundant in rocky places from river-level to $1500 \mathrm{~m}$. everywhere in western Hupeh and eastern Szech'uan, but has not yet been reported from farther west. It forms in wayside thickets and by the banks of streams tangled masses often $6 \mathrm{~m}$. tall and as much through, and in the margins of woods it rambles over small trees. When covered with masses of its white fragrant flowers this Rose is very beautiful. It has proved quite hardy and flowered profusely at the Arnold Arboretum. Under the original Seed No. 431 seeds of $R$. Helenae and of $R$. Rubus have been distributed; the plant cultivated at Kew under No. 431 belongs to $R$. Rubus according to specimens received from there.

This new species is named for my Wife. (E. H. W.)

\section{Rosa filipes Rehder \& Wilson, n. sp.}

Frutex sarmentosus, 3-6-metralis; rami glabri, pallidi, aculeis conformibus sparsis reflexo-falcatis basi dilatatis fuscis muniti. Folia papyracea 3-9-, plerumque 5-7-foliolata, petiolo incluso $10-20 \mathrm{~cm}$. longa; foliola brevissime petiolulata, oblongo-ovata v. lanceolata, acuminata, basi rotundata $\mathrm{v}$. late cuneata, plerumque obliqua, serrata v. interdum minute biserrata dentibus glandulis terminatis, $4-7.5 \mathrm{~cm}$. longa et 1.5-3.5 cm. lata, supra intense viridia, glabra, subtus pallida, glabra v. fere glabra, glandulis stipitatis minutis fuscis conspersa, utrinsecus nervis $6-10$ subtus elevatis; petioli $3-4.5 \mathrm{~cm}$. longi, ut rhachis supra canaliculati, sparse pubescentes, subtus glabri, glandulis stipitatis minutis sparsis et aculeis falcatis parvis paucis muniti; petioluli 1-1.5 mm. longi, sparse glandulosi; stipulae adnatae, 1.5-1.8 $\mathrm{cm}$. longae, angustae, margine glandulis stipitatis paucis instructae, auriculis patentibus anguste lanceolatis. Flores albi, fragrantes, 2-2.5 $\mathrm{cm}$. diam., numerosi in corymbis terminalibus laxis paniculiformibus $15-25 \mathrm{~cm}$. longis et fere aeque lata, axibus primariis bracteis foliaceis suffultis, rhachi pedunculisque glabris inermibusque v. rhachi tantum aculeis paucis instructa; pedicelli filiformes $2.5-4 \mathrm{~cm}$. longi breviter stipitato-glandulosi, bracteolis fugacibus; receptaculum ovoideum, basin versus sparse glandulosum, ceterum glabrum; alabastrum ovatum, subito contractum; sepala ovata v. oblongo-ovata in acumen longum foliaceum contracta, petalis longiora, lobis paucis instructa, extus sparse pubescentia et glandulosa, intus villosa, reflexa; petala 
obovata, circiter $12 \mathrm{~mm}$. longa, 10-12 $\mathrm{mm}$. lata, apice rotundata, emarginata; styli coaliti, 4-5 mm. exserti, pilosi. Fructus globosus, 8-12 mm. diam., intense scarlatinus, sepalis deciduis, stylis saepe partim persistentibus.

Western Szech'uan: west and near Wên-ch'uan Hsien, thickets, alt. 1300-2300 m., July and November 1908 (No. I228, type); same locality, alt. 1600-2000 m., November 1910 (No. 4200).

This species is very distinct from the other members of this group and is well characterized by its glabrous shoots and leaflets which are gland-dotted on the underside, by its very large paniculate inflorescence of moderately large flowers on filiform pedicels and by its small globose fruit covered with bloom. It may be compared with $R$. Brunonii Lindley, which, however, is a pubescent plant, with narrower leaflets, larger flowers in much smaller and shorter paniculate corymbs. Rosa filipes has a rather local distribution, but it is not uncommon in the rather dry regions mentioned.

Rosa Gentiliana Léveillé \& Vaniot in Bull. Soc. Bot. France, LV. 55 (1908). - Willmott, Gen. Rosa, II. 513, t. (1914).

Rosa adenoclada Léveillé, in Fedde, Rep. Spec. Nov. X. 431 (1912); Fl. KouyTchéou, 353 (1915), - Willmott, Gen. Rosa, II. 517, t. (1914).

Rosa floribunda Baker in Willmott, Gen. Rosa, II. 513 (non Steven) (1914). Rolfe in Gard. Chron. ser. 3, LVIII. 210, fig. 70 (1915), descript. excludenda.

Rosa cerasocarpa Rolfe in Kew Bull. Misc. Inform. 1915, 89, specimine Henryano No. 7007 excepto quod ad $R$. Rubum pertinet.

Rosa moschata maculata Hort. ex Rolfe in Gard. Chron. ser. 3, LVIII. 210 (pro synon.) (1915).

Western Hupeh: north and south of Ichang, alt. 600-1300 m., May, November and December 1907 (Nos. 3599, 36or, spreading scandent bush 2-6 m. tall; Ichang, April 1900 (Veitch Exped. No. 2722 ${ }^{\mathrm{a}}$ ); same locality, A. Henry; Patung Hsien, margin of woods, alt. 10001400 m., May 1907 (No. 3598; scandent bush 3-5 m. tall, flowers white, fragrant); Hsing-shan Hsien, ravines and beside streams, alt. 600-1300 m., May 8, 1907 (No. 36oo; wide scandent bush 1-3 m. tall, flowers sulphur-yellow passing to white, fragrant); same locality, alt. 10001300 m., June and November 1907 (No. 609 ; scandent bush 2-4 m. tall, flowers white, fragrant, fruit dull red); Fang Hsien, woodlands, alt. 1000-1600 m., November 1907 (No. 609; bush 3-5 m. tall, fruit dark red). Eastern Szech'uan: Wushan Hsien, A. Henry (No. 5773). Fokien: Dunn's Exped., April to June 1905 (Herb. Bot. Gard. Hongkong, No. 2647). Kiangsu : without locality, D'Argy (type). Kweichou: "Grotte de Gai-ko," alt. 1200 m., May 3, 1910, J. Esquirol (No. 2100, type of R. adenoclada Léveillé). 
This species is well distinguished by its glabrous shoots which become pale gray with age, by its glabrous $3-5$-foliolate leaves which are shining green above, glaucescent and very pallid on the underside, with relatively broad, coarsely serrate long acuminate leaflets occasionally abruptly rounded with a short acumen. The flowers are very numerous in flattened or rounded corymbs; the fruit is small and globose.

Rosa Gentiliana is abundant in the mountainous region of western Hupeh and eastern Szech'uan which would appear to mark its western limits of distribution. It is partial to rocky places from river-level to $1400 \mathrm{~m}$. altitude, forming tangled masses $6 \mathrm{~m}$. and more tall. The flowers are large, very fragrant, and their beauty is increased by the golden-yellow anthers. Léveillé describes the styles as "free" in his Rosa adenoclada, but this is incorrect. Miss Willmott states that $R$. adenoclada Léveillé is near $R$. lucidissima Léveillé, but we consider the last named to be only a state of the very different $R$. chinensis, f. spontanea Rehder \& Wilson. It is probable that Rosa moschata, var. densa M. de Vilmorin (in Jour. Hort. Soc. Lond. XXVII. 482, fig. 134 [1902]) should be referred to R. Gentiliana Léveillé, although it is not stated whether the shoots and leaves are glabrous or pubescent.

A picture of this plant will be found under No. 060 of the collection of Wilson's photographs.

Rosa longicuspis A. Bertoloni in Mem. Accad. Sci. Bologna, XI. 201, t. 13 (1861); Misc. Bot. XXI. 15, t. 3 (1861). - Crépin in Bull. Soc. Bot. Belg.XIII. 255 (Prim.Ros. Monog. 262) (1874); XVIII. 295 (Prim. Ros. Monog. 541) (1879). - Hooker f., Fl. Brit. Ind. II. 367 (1878). Brandis, Ind. Trees, 288 (1906).

Rosa sempervirens J. D. Hooker \& T. Thomson, Herb. Ind. Orient. ex Hooker f., Fl. Brit. Ind. II. 367 (pro synon.) (non Linnaeus) (1879).

Rosa moschata, var. yunnanensis Crépin in Bull. Soc. Bot. Belg. XXV. pt. 2, 8 (1886). - Franchet, $\mathrm{Pl}$. Delavay. 218 (1890).

Rosa Sinowilsoni Hemsley in Kew Bull. Misc. Inform. XIX. 158 (1906). Willmott, Gen. Rosa, I. 73 (1910).

Rosa Willmottiana Léveillé in Fedde, Rep. Spec. Nov. XI. 299 (1912). - Willmott, Gen. Rosa, II. 521 (1914).

Rosa Soulieana Focke in Not. Bot. Gard. Edinburgh, V. 70 (non Crépin) (1911). Rosa lucens Paul \& Sons, Rose-Cat. 1915-16, 15 (1915).

Western Szech'uan: Mt. Omei, thickets, alt. 1000-1600 m., June and October 1908 (No. Iog8; scandent bush 3-6 m. tall, flowers white, fruit dark scarlet); Wa-shan, alt. 2000 m., November 1908 (No. ro98 $8^{\mathrm{a}}$; scandent bush $3 \mathrm{~m}$. tall, fruit dark scarlet); southeast of Tachien-lu, alt. 1600-2100 m., October 1908 (No. I334; scandent bush $6 \mathrm{~m}$. and more tall, fruit dark scarlet); Yachou Fu, thickets, alt. 1000 m., November 1910 (No. 4r27; bush $6 \mathrm{~m}$. tall, fruit orange-red); valley of Tung River, alt. 800 m., May 1904 (Veitch Exped. No. 3537); Mt. Omei, June 1904 (Veitch Exped. No. 4876; bush $4 \mathrm{~m}$. tall, flowers white). Yunnan: Mengtsze, rocky places, alt. 1600 m., A. Henry $\left(\right.$ No. ${\underline{9236^{\mathrm{s}}}}^{\text {}}$; Tali valley, alt. 2000 m., July-August 1906, G. Forrest 
(No. 4454); "Brousses et haies à Long-ky, 700 m., Juin 1911," E. E. Maire (type of R. Willmottiana Léveillé). India : east Bengal, Griffith (No. 2140); Khasia, alt. 600-1600 m., J. D. Hooker \& T. Thomson; Khasia, "environs of Tserapúndži till near Máirong," alt. 900-1500 m., October 1855, Schlagintweit (No. 209).

This species, heretofore known only from a few specimens, has been variously considered a good species or a geographical form of the European $R$. sempervirens Linnaeus. It is really a very distinct species related to Rosa Brunonii Lindley, but readily distinguished from that species by its glabrous reddish brown shoots, more coriaceous, shining green leaves and especially by its much larger fruit and by the hairy back of its petals.

This Rose is common in thickets round the base of Mt. Omei and in other warm parts of southwest Szech'uan and apparently also in Yunnan extending westward to Khasia and possibly beyond. It is a large rambling shrub and is very beautiful when in flower or in fruit. The leaves persist late into the winter and in the most favorable locations it may be evergreen. No. 4876 from Mt. Omei has leaves and leaf-rhachis rather more pubescent than is usual; otherwise the specimens are remarkably uniform in character. Forrest's No. 4454 determined by Focke as $R$. Soulieana doubtless belongs to this species, though at the first glance it looks rather different with its small elliptic, not acuminate leaflets, but the pubescent petals at once remove it from $R$. Soulieana Crépin.

Rosa Soulieana Crépin in Bull. Soc. Bot. Belg.XXXV. Compt.-Rend. 21 (1896). - Vilmorin \& Bois, Frut. Vilmorin. 85, fig. (1904). - Hemsley in Bot. Mag. CXXXIII. t. 8158 (1907), - Willmott, Gen. Rosa, I. 57, t. (1910).

Rosa moschata, var. yunnanensis Focke in Not. Bot. Gard. Edinburgh, V. 69 (non Crépin) (1911).

Western Szech'uan: near Monkong Ting, valley of Hsao-chin Ho, alt. 2300-3300 m., June 1908 (No. 36I3; bush 2-6 m. tall, flowers sulphur-yellow changing to white); between Mao-chou and Sungpan Ting, valley of Min River, alt. 2000-2600 m., August 1910 (No. 4I64; bush 2-4 m. tall); west of Tachien-lu, valley of Yalung River, alt. 2800 m., June 1904 (Veitch Exped. No. 3532; bush 2 m., flowers yellowish). Yunnan: Machi-chiang valley, alt. $3000 \mathrm{~m}$., June 1906, G. Forrest (2370).

Wilson's specimens from western Szech'uan have perfectly glabrous receptacles and leaves, while in Forrest's specimen the receptacles and pedicels are covered with a short glandular pubescence and the leaves are pubescent on the midrib beneath.

Common in the warm dry river-valleys of the Chino-Thibetan borderland up to $3000 \mathrm{~m}$. altitude. A picture of this Rose will be found under No. 145 in the collection of Wilson's photographs and also in his Vegetation of Western China, No. 454.

Rosa microcarpa Lindley, Ros. Monog. 130, t. 18 (1820). - Walpers, Rep. II. 12 (1843), - Crépin in Bull. Soc. Bot. Belg. XIII. 244 (Prim. 
Ros. Monog. 251) (1874). - Franchet, Pl. Delavay. 218 (1890). Hemsley in Jour. Linn. Soc. XXIII. 251 (1887). - Willmott, Gen. Rosa, I. 113 (1911). - Dunn \& Tutcher in Kew Bull. Misc. Inform. add. ser. X. 96 ( $F l$. Kwangtung \& Hongk.) (1914).

Rosa indica Linnaeus, Spec. I. 492 (1753), quoad synon. Petiveri.

Rosa cymosa Trattinnick, Ros. Monog. I. 87 (1823).

Rosa fragariaeflora Seringe in De Candolle, Prodr. II. 601 (1825).

Rosa amoyensis Hance in Jour. Bot. VI. 297 (1868).

Rosa Banksiae, $\boldsymbol{\beta}$ microcarpa Regel, Tent. Ros. Monog. 92 (1877); in Act. Hort. Petrop. V. 376 (1878).

Rosa sorbiflora Focke in Gard. Chron. ser. 3, XXXVII. 227, fig. 96 (1905), Léveillé, Fl. Kouy-Tchéou, 354 (1915).

Rosa sorbifolia in Rev. Hort. 1905, 234.

Rosa Chaffanjoni Léveillé \& Vaniot in Bull. Soc. Bot. France, LV. 56 (1908).

Rosa Bodinieri Léveillé \& Vaniot in Bull. Soc. Bot. France, LV. 56 (1908). Willmott, Gen. Rosa, II. 485, t. (1914). - Léveille, Fl. Kouy-Tchéou, 353 (1915).

Rosa Esquirolii Léveillé \& Vaniot in Bull. Soc. Bot. France, LV. 56 (1908). Willmott, Gen. Rosa, II. 485, t. (1914). - Léveillé, $F l$. Kouy-Tchéou, 353 (1915).

Rosa Cavaleriei Léveillé in Fedde, Rep. Spec. Nov. VIII. 61 (1910).

Kiangsi: Kiukiang, thickets up to $300 \mathrm{~m}$. alt., August 1, 1907 (No. I678; scandent bush $5 \mathrm{~m}$. tall, common). Western Hupeh : neighborhood of Ichang, alt. 30-800 m., April and December 1907 (No. 3603; scandent bush 1.5-2 m. tall, flowers white, fruit dull red); Nanto, banks of Yangtsze River, May and October 1900 (Veitch Exped. No. 828; bush 2 m., cotype of $R$. sorbiflora Focke); Ichang and immediate neighborhood, A. Henry (Nos. 3106, 3597, 7589). Western Szech'uan: Yachou Fu, thickets, alt. 500-1300 m., October 1908 (No. 3604; seandent bush 2-4 m. tall, fruit dull red); Mt. Omei, May and November 1904 (Veitch Exped. Nos. 4877, 3539ª); banks of Yangtsze River, May 1903 (Veitch Exped. No. 3539). Kweichau: Kweiyang "mont du collège, haies, près les villages," June 2, 1898, J.Chaffanjon (No. 2292; type of R. Chaffanjoni Léveillé \& Vaniot); " monts de Lau-tsong-koan, cc. dans la montagne," May 31, 1897, Emile Bodinier (No. 1604; type of $R$. Bodinieri Léveillé \& Vaniot); "murs de T-chen-lin," June 1904, J. Cavalerie (No. 117; type of $R$. Esquirolii Léveillé \& Vaniot); "Montagnes Hoang-TsaoPa," June 1909, J. Esquirol (No. 1517; type of R. Cavaleriei Léveillé). Chekiang: vicinity of Ningpo, 1908, D. Macgregor. Fokien: "Yuen Fu valley, bamboo plantations," Dunn's Exped., April to June (Herb. Bot. Gard. Hongkong, Nos. 435, 2637); Amoy, A. Henry. 
This is the most widely distributed of all Chinese Roses, being found in all the warmer parts of China from the sea-coast to the extreme western part of Szech'uan. It is particularly abundant in the neighborhood of Ichang in grassy and stony places fully exposed to the sun. It varies considerably, often on the same branch, in degree of hairiness and in the size of leaves and corymbs. Several specimens from Hupeh have very villose young shoots and leaf-rhachis, while those from Chekiang and western Szech'uan are often quite glabrous; the number and form of the spinuliform appendages to the calyx-lobes is also variable. Nevertheless it is an exceptionally well-marked species agreeing with $R$. Banksiae Aiton, in its free, linear, and rarely deciduous stipules, but differing from that species in its cymose-corymbose inflorescence and exserted styles which, however, are not connate into a column, as in the Synstylae, where Crépin places this species. This Rose is first mentioned by Petiver in his Gazophylacium Naturae et Artis, 56, t. 35, fig. 11 (1704), under the name of "Rosa Chusan. glabra, Juniperi fructu," and his figure of a fruiting branch is excellent. Linnaeus (Spec. I. 492 [1753]) cites Petiver's plant under his R. indica, but certainly the greater part at any rate of the description belongs to another plant. The Rose figured by Ker (Icon. Pict. Indo-As. Pl. Dom. Cattley [1818]; Icon. Pl. Chin. e bibl. Braamiana [1821]), and considered by Hemsley (in Jour. Linn. Soc. XXIII. 248 [1887]) to be the wild form of $R$. Banksiae Aiton, is the $R$. microcarpa Lindley, as the cymose inflorescence proves, and was so interpreted by Walpers (Rep. II. 12) and others. Hemsley (1. c. 252) considers that Rosa intermedia or R. dubia Carrière (in Rev. Hort. 1868, 270, figs. 29, 30) "is apparently the same as, or closely allied to, $R$. microcarpa Lindley." Miss Willmott (Gen. Rosa, I. 113) cites these names as synonyms of Lindley's plant. The shape of the stipules and the leaves and inflorescence show that the Rose Carrière described as $R$. dubia and figured as $R$. intermedia is $R$. multiflora Thunberg. Léveillé (l. e.) states that his $R$. Chaffanjoni has the styles glabrous; but in the specimens he has sent us they are decidedly villose. We can find no characters by which we can separate the various forms of this Rose which Léveillé has described as species. We suspect, too, that Rosa Collettii Crépin (in Bull. Soc. Bot. Belg. XXVIII. Compt. Rend. 49 [1889]) is only a geographical variant of $R$. microcarpa Lindley, but Collett \& Hemsley's figure (in Jour. Linn. Soc. XXVIII. 56, t. 10 [1891]) represents a form which is rather different in aspect from any we have seen.

Rosa Banksiae Aiton, Hort. Kew. ed. 2, III. 258 (1811). - Sims in Bot. Mag. XLV. t. 1954 (1818). - Lindley, Ros. Monog. 131 (1820). Thory in Redouté, Roses, II. 43, t. (1821).

Rosa Banksiae, var. albo-plena Rehder in Bailey, Cycl. Am. Hort. IV. 1552 (1902).

Rosa Banksiae, f. subinermis, fl. pleno v. semipleno albo Focke in Not. Bot. Gard. Edinburgh, V. 65 (1911).

The original Rosa Banksiae Aiton is known only as a cultivated plant; it has double-white flowers and was first sent to England in 1807 by William Kerr from gardens in or near Canton. To this typical form belong Henry's No. 10508, described on his label as a large climber with white flowers from mountains north of Mengtsze, Yunnan, and Forrest's No. 2048 from western Yunnan. This form and the double-yellow flowered $R$. Banksiae lutea Lindley, are commonly cultivated in gardens of central and southern Japan, having, according to Professor M. Shirai (A Chronological Table of Natural History in Japan [1908]), been introduced from China in 1733 . 
Rosa Banksiae, var. normalis Regel, Tent. Ros. Monog. 91 (1877); in Act. Hort. Petrop. V. 376 (1878).

Rosa Banksiae Crépin in Bull. Soc. Bot. Belg. XIV. 162 (non Aiton) (1875). Franchet in Nouv. Arch. Mus. Paris, sér. 2, V. 267 (Pl. David. I. 115) (1883); Pl. Delavay. 219 (1890), - Hemsley in Jour. Linn. Soc. XXIII. 248 (1887), quoad specimina Henryana. - Focke in Bot. Jahrb. XXIX. 405 (1900). - Henry in Gard. Chron. ser. 3, XXXI. 438, figs. 171, 172 (1902). Léveillé, $\mathrm{Fl}$. Kouy-Tchéou, 353 (1915).

Rosa Banksiae, $f$. subinermis $f$. simpl. Focke in Not. Bot. Gard. Edinburgh, V. 65 (nomen nudum) (1911).

Western Hupeh: north and south of Ichang, ravines and rocky places generally, alt. 40-1000 m., April and May 6, and October 1907 (Nos. 6r9, 6rg ; scandent bush $6 \mathrm{~m}$. and more tall and as much in diameter, flowers pure white, fragrant, fruit dull red, abundant); same locality, April and September 1900 (Veitch Exped. No. 183; large climber, flowers white, fragrant, common); Hsing-shan Hsien, side of stream, alt. 1000 m., June 7, 1907 (No. 6r9 ${ }^{\text {d }}$; without locality, $A$. Henry (No. 3198). Eastern Szech'uan: south Wushan Hsien, $A$. Henry (No. 5552). Western Szech'uan: Wên-ch'uan Hsien, valley of Min River, alt. 600-1600 m., November 1908 (No. 6r9 ${ }^{\text {b }}$; scandent bush 3-6 m. tall, fruit dull red); without locality, alt. 300-1600 m., May 1904 (Veitch Exped. No. 3538; large bush, abundant).

This Rose is very abundant in western Hupeh and eastern Szech'uan from river-level to $1000 \mathrm{~m}$. alt. and is fairly common in western Szech'uan in the valleys of the Tung and Min rivers and neighboring regions up to $1500 \mathrm{~m}$. alt. It delights in glens, ravines and rocky places generally, where it forms tangled masses $6 \mathrm{~m}$. and more high and as much in diameter; commonly it rambles over trees, and Wilson has seen trees $15 \mathrm{~m}$. and more tall completely festooned with this Rose. The flowers are always pure white, and we have never observed any tendency towards double flowers in the wild plant; nor did Wilson see it or any of its forms cultivated in gardens in central or western China. The umbellate inflorescence well distinguishes this species from its nearest relation Rosa microcarpa Lindley. The root-bark is used loeally for strengthening and dyeing fishing nets brown.

This variety appears to be confined to central and western China, and we have seen no specimens of the wild plant from regions east of the 112th parallel of longitude. Regel (1. c.) distinctly says that Kirilow's specimens were from plants cultivated in gardens round Peking.

Pictures of this Rose will be found under Nos. 684, 043 and 0205 of the collection of Wilson's photographs.

Rosa Banksiae, f. lutescens Voss, Vilmorin's Blumengärt. I. 49 (1896).

Rosa Banksiae Hooker f, in Bot. Mag. CXVII. t. 7171 (non Aiton) (1891).

Western Hupeh: Hsing-shan Hsien, planted on a tomb, alt. 1150 m., May 5, 1907 (No. 6r9 ; scandent shrub $2.5 \mathrm{~m}$. tall, flowers sulphuryellow). 
In bis travels in China Wilson met with only one bush of this form of $R$. Banksiae, and it had evidently been planted.

Rosa laevigata Michaux, Fl. Bor. Am. I. 295 (1803). - Lindley, Ros. Monog. 125 (1820). - Crépin in Bull. Soc. Bot. Belg. XIV. 155 (Prim. Monog. Ros. 359) (1875), - Hemsley in Jour. Linn. Soc. XXIII. 250 (1887); in Gard. LXII. 167 (1902). - Focke in Bot. Jahrb. XXIX. 406 (1900). - Willmott, Gen. Rosa, I. 117, t. (1911). - Dunn \& Tutcher in Kew Bull. Misc. Inform. add. ser. X. 96 (Fl. Kwangtung \& Hongk.) (1912).

Rosa sinica Aiton, Hort. Kew. II. 203 (non Linnaeus) (1789); ed. 2, III. 261 (1814). - Lindley, Ros. Monog. 126, t. 16 (1820); in Bot. Reg. XXIII. t. 1922 (1837). - Hooker in Bot. Mag. LV. t. 2847 (1828). - Bentham, Fl. Hongk. 106 (1861).

Rosa ternata Poiret, Encycl. Méth. VI. 284 (1804).

Rosa nivea De Candolle, Cat. Hort. Monsp. 137 (1813). - Seringe in De Candolle, Prodr. II. 599 (1825).

Rosa Cherokeensis Donn, Hort. Cant. ed. 8, 170 (1815).

Rosa hystrix Lindley, Ros. Monog. 129, t. 17 (1820). - Hance in Ann. Sci. Nat. sér. 5, V. 211 (1866).

Rosa triphylla Roxburgh apud Lindley, Ros. Monog. 138 (1820). - Roxburgh, Fl. Ind. ed. 2, 1I. 515 (1832).

Rosa cucumerina Trattinnick, Ros. Monog. II. 181 (1823).

Rosa trifoliata Bose ex Jackson, Ind. Kew. IV. 739 (pro synon.) (1895). ${ }^{1}$

Rosa Amygdalifolia Seringe in De Candolle, Prodr. II. 601 (1825).

Rosa sinica, a typica Regel, Tent. Ros. Monog. 43 (1877); in Act. Hort. Petrop. V. 327 (1878).

Rosa Camellia Hort. ex André in Rev. Hort. 1889, 246 (pro synon.).

Rosa camelliaefolia Hort. ex Kew Hand-list Trees \& Shrubs, pt. 1, 171 (pro synon.) (1892).

Rosa levigata, var. kaiscianensis Pampanini in Nuov. Giorn. Bot. Ital. n. ser. XVII. 294 (1910).

Kiangsi: Kiukiang, foothills, alt. 300 m., August 1, 1907 (No. I692). Western Hupeh: north and south of Ichang, alt. 30-1000 m., April and December (No. 36r4; scandent bush 2-4 m. tall, flowers white, fruit orange-red); Nanto, banks of Yangtsze River, April 16, 1900 (Veitch Exped. No. 75); without locality, A. Henry (No. 1143). Fokien: Amoy, A. Henry. Formosa: "Mt. Kushaku," June 6, 1903, U. Faurie (No. 129).

This Rose is very common in rocky places at low altitudes throughout western Hupeh. The leaves are variable in size and shape. On the growing shoots the leaves are lanceolate to oblong-lanceolate, whereas on the flowering branchlets the leaves are elliptic to ovate or even suborbicular as deseribed by Pampanini under his var. kaiscianensis, and we can find no characters by which to separate this va-

1 In the place cited in Index Kewensis the combination $R$. trifoliata does not appear, only " Rosier trifolié." 
riety from the typical wild plant. Rosa laevigata is cultivated in Japan, but is not wild there, although it has been enumerated as a Japanese plant by certain botanists. It was brought to North America early in the 17th century and soon becoming widely naturalized was first described as an American plant.

The first mention of Rosa laevigata Michaux in western literature is to be found in Plukenet, Amalth. 185 (1705) under the name "Rosa alba cheusanensis foliorum marginibus et rhachi medio spinosis"; his specimen is preserved in the British Museum. The Rosa sinica, $\beta$ Braamiana Regel (Tent. Ros. Monog. 43 [1877]), based on Braam's figure which Miss Willmott (Gen. Rosa, I. 118 [1911]) says is "doubtless a hybrid," is Rosa bracteata Wendland, a species which is common in the coast provinces of China south of the Yangtsze River.

Rosa Argyi Léveillé (in Bull. Soc. Bot. France, LV. 56 [1908]) from Kiangsu, of which we have seen no specimens, is considered by the author to be a hybrid between this and the following species. Judging from the description, however, it does not appear to be specifically different from $R$. laevigata.

Rosa Roxburghii Trattinnick, Ros. Monog. II. 233 (1823).

Rosa microphylla Roxburgh apud Lindley, Ros. Monog. 9, 146 (non Desfontaines) (1820), - Lindley in Bot. Reg. XI. t. 919 (1825). - Roxburgh, Fl. Ind. ed. 2, II. 515 (1832). - Hooker in Bot. Mag. XXIII, t. 3490 (1836). Baillon in Adansonia, X. 72 (1871-73). - Crépin in Bull. Soc. Bot. Belg. XIV. 146 (1875). - Hooker f., Fl. Brit. Ind. II. 364 (1878). - Hance in Jour. Bot. XX. 5 (1882), - Hemsley in Jour. Linn. Soc. XXIII. 252 (1887). - Franchet, Pl. Delavay. 220 (1890), - Focke in Bot. Jahrb. XXIX. 406 (1900). - Willmott, Gen. Rosa, I. 135, t. t. (1911). - Dunn \& Tutcher in Kew Bull. Misc. Inform. add. ser. X. 96 (Fl. Kwangtung \& Hongk.) (1912).

Rosa microphylla, a glabra Regel, Tent. Ros. Monog. 38 (1877); in Act. Hort. Petrop. V. 321 (1878).

This species was originally described from plants cultivated in the Botanic Garden at Calcutta and was said to have been introduced from China. It is probable that Rosa centifolia Loureiro (Fl. Cochin. 323 [1790]) belongs here.

Rosa Roxburghii, f. normalis Rehder \& Wilson, n. f.

A typo recedit floribus simplicibus. Foliola glabra, obovata v. elliptica, apice rotundata v. acuta.

Rosa microphylla Pampanini in Nuov. Giorn. Bot. Ital. n. ser. XVII. 295 (non Desfontaines, nec Roxburgh) (1910).

Rosa Forrestii Focke in Not. Bot. Gard. Edinburgh, V. 67, t. 62 (Pl. Chin. Forrest.) (1911).

Western Szech'uan: Kiating Fu, roadsides, alt. 300-1300 m., June and September 1908 (No. 36r2; shrub 0.5-1 m. tall, flowers rosyred, fruit yellowish); Mt. Omei, June 1904 (Veitch Exped. No. 4874; bush $0.5-1.3 \mathrm{~m}$. tall); without locality, alt. 300-1300 m., June 1903 (Veitch Exped. No. 3529; bush 0.5-1 m. tall, flowers pink). H upeh: "Ou-tan-scian," alt. 2090 m., July 1907, C. Silvestri (No. 986). Yunnan: Tali range, alt. 2100-2400 m., June 1906, G. Forrest (No. 4450). 
This bush Rose is abundant by waysides and in semi-arid river-valleys throughout the warmer parts of western Szech'uan. In the neighborhood of Kiating Fu and on the Chengtu Plain it is commonly used as a hedge-plant. Focke's $R$. Forrestii is based on specimens having small leaves; our No. 3529 Veitch Exped. is a similar plant, and this character is inconstant. Its obovate rounded to narrowly ovate, acute or abruptly acuminate leaflets and less sharply acute serratures and the absence of pubescence distinguish it from the Japanese R. Roxburghii, var. hirtula Rehder \& Wilson, n. comb. ( $R$. microphylla, $\beta$ hirtula Regel). It is this Japanese variety with single flowers which is in cultivation and which is figured by Hooker f. as R. microphylla in the Bot. Mag. CVll. t. 6548 (1881). This var. hirtula is spontaneous in central Hondo, and Wilson has collected it at $1000 \mathrm{~m}$. alt. on the northern slopes of Fuji-san, Japan.

Rosa chinensis Jacquin, Obs. Bot. III. 7, t. 55 (1768). - K. Koch, Dendr. I. 272 (1869). - Willmott, Gen. Rosa, I. 79, t. (1911).

Rosa sinica Linnaeus, Syst. Veg. ed. 13, 394 (forma calyce monstroso) (1774). Rosa indica Loureiro, Fl. Cochin. 323 (non Linnaeus) (1790). - Aiton, Hort. Kew. ed, 2, 11I. 266 (1811). - Lindley, Ros. Monog. 106 (1820). - Crépin in Bull. Soc. Bot. Belg. XI. 23 (Prim. Ros. Monog. 139) (1872), XIV. 168 (Prim. Ros. Monog. 372) (1875). - Hooker f., Fl. Brit. Ind. II. 364 (1878). - Hemsley in Jour. Linn. Soc. XXIII. 249 (1887). - Dunn \& Tutcher in Kew Bull. Misc. Inform. add. ser. X. 96 (Fl. Kwangiung \& Hongk.) (1914).

Rosa nankinensis, Loureiro, Fl. Cochin. 323 (1790).

Rosa semperforens, $\boldsymbol{\beta}$ Lawrence, Roses, t. 26 (1799).

Rosa bengalensis, $\boldsymbol{\beta}$ chinensis Persoon, Syn. Pl. II. 50 (1807).

Rosa Indica vulgaris Thory in Redouté, Roses, I. 51, t. (1817). - Lindley, Ros. Monog. 106 (1820). - Regel, Tent. Ros. Monog. 74 (1877); in Act. Hort. Petrop. V. 358 (1878).

Western Hupeh: Changlo Hsien, cultivated, June 1907 (No. $36 \mathrm{Ir}$; rambling bush $2 \mathrm{~m}$. tall, flowers red). Yunnan: Mengtsze, mountains southeast, alt. 1600 m., cultivated, A. Henry (No. 11272).

This Rose is commonly cultivated in the eastern and southeastern provinces of China, but is rarely cultivated in the central and western provinces.

Rosa chinensis, f. spontanea Rehder \& Wilson, n. f.

A typo floribus simplicibus recedit. Est forma spontanea et typum phylogeneticum speciei constituit.

Rosa indica Hemsley in Jour. Linn. Soc. XXIII. 249 (non Linnaeus, nec Loureiro) (1887), quoad specimen Henryi. - Focke in Bot. Jahrb. XXIX. 405 (1900), - Henry in Gard. Chron. ser. 3, XXXI, 438, fig. 170 (1902).

North-central Szech'uan: Pa-chou, sandstone ravines, alt. 1000 m., July 1910 (No. 4649; bush 1-2 m. tall, spontaneous). Northwestern Szech'uan: Shih-ch'uan Hsien, roadside thickets, alt. 800-1000 m., August 1910 (No. 4649 ; bush 1.5-2 m. tall, spontaneous). Western Hupeh: near Ichang, San-yu-tung glen, $A$. Henry (No. 1151). 
This Rose is common in wayside thickets and on the banks of rivers in Shihch'uan Hsien, but is rare elsewhere so far as known.

Our specimens are in fruit only, but they agree exactly with Henry's; and we think that Henry is right in considering this plant to be the wild type of Rosa chinensis Jacquin. The Rosa lucidissima Léveillé (in Fedde, Rep. Spec. Nov. IX. 444 [1911]; Fl. Kouy-Tchéou, 254 [1914]) appears to us to be nothing but a state of this forma spontanea distinguished only by its leaves being pale green on the underside and not glaucescent and by the calyx-tube being densely covered with stipitate glands.

Rosa rugosa Thunberg, Fl. Jap. 213 (1784). - Lindley, Ros. Monog. 5, t. 19 (1820). - C. A. Meyer in Mém. Acad. Sci. St. Pétersbourg, sér. 6 (Sci. Nat.), VI. 32 (Ueber Zimmtros.) (1847). - Franchet in Nouv. Arch. Mus. Paris, sér. 2, V. 268 (Pl. David. I. 116) (1883). - Hemsley in Jour. Linn. Soc. XXIII. 253 (1887). - Pampanini in Nuov. Giorn. Bot. Ital. n. ser. XVII. 295 (1910).

Rosa ferox Aiton, Hort. Kew. ed. 2, III. 262 (1811). - Lindley in Bot. Reg. V. t. 420 (1819).

Rosa kamtchatica Thory in Redouté, Roses, I. 47, t. (non Ventenat) (1817).

Rosa Regeliana Linden \& André, in Ill. Hort. XVIII. 11, t. 47 (1871).

Rosa rugosa, f. amurensis Debeaux in Act. Soc. Linn. Bordeaux, XXXI. 152 (Fl. Tchê-fou, 57) (1876).

The type of this species does not seem to occur in China.

Rosa rugosa, var. Chamissoniana C. A. Meyer in Mém. Acad. Sci. St. Pétersbourg, sér. 6 (Sci. Nat.), VI. 34 (Ueber Zimmtros.) (1847).

Rosa rugosa, $\beta$ kamtschatica Regel, Tent. Ros. Monog. 26 (1877); in Act. Hort. Petrop. V. 310 (1878).

Rosa pubescens Baker in Willmott, Gen. Ros. II. 499 (non Roxburgh, nec Schleicher, nec Léman) (1914).

Western Hupeh: Changyang Hsien, cultivated, alt. $600 \mathrm{~m}$., May 1907 (No. 4728; bush 1-2 m., flowers red); Hsing-shan Hsien, June 1901 (Veitch Exped. No. 1294; bush 1 m., flowers red, an escape).

This Rose is occasionally seen in Chinese gardens, but not very often. Our specimens have rather small red semi-double flowers and agree with Meyer's var. Chamissoniana in the almost entire absence of bristles on the branches and in the smaller and narrower, less rugose leaflets; the form enumerated by Pampanini is probably identical.

Rosa caudata Baker in Willmott, Gen. Rosa, II. 495 (1914).

Western Hupeh: Fang Hsien, thickets, alt. 1800 m., September 1907 (No. 306; bush 1-2 m., fruit coral-red); same locality, alt. 2000 m., October 1910 (No. 44I8; bush 3-4 m. tall, fruit orange-red).

This is a rare and very distinct species with erect shoots sparingly elad with stout, straight prickles dilated at the base, prominent winter-buds, large leaves and stipules and a large slightly convex corymb and handsome fruit. It is only known to us from the high mountains of northwestern Hupeh. 
A specimen collected on "Gua-in-san" in Shensi by G. Giraldi on July 16, 1897 , possibly belongs to this species, but the material is too poor for definite determination. The ealyx is very setose.

Rosa banksiopsis Baker in Willmott, Gen. Rosa, II. 503 (1914).

Western Hupeh: Changlo Hsien, thickets, alt. 1300-2000 m., June 1907 (No. 359r; bush 1-2 m. tall, flowers rose-red); Hsing-shan Hsien, thickets, alt. 1600-2000 m., June, July and September 1907 (Nos. 3592, 287 ; bush 2-3 m. tall, flowers pink to red); Fang Hsien, upland thickets, alt. 1600-2300 m., July and September 1907 (No. 287; bush 1-2 m. tall, flowers pink, fruit coral-red); same locality, June and October 1910 (No. 4418 ${ }^{\mathrm{s}}$; bush $3 \mathrm{~m}$. tall, flowers rose-red); Patung Hsien, thickets, October 1900 (Veitch Exped. Seed No. 512); without locality, A. Henry (No. 6071 $)$. Eastern Szech'uan: Wushan Hsien, thickets, 1300-1600 m., September 1907 (No. 204; bush $3 \mathrm{~m}$. tall, fruit orange-red); same locality, June 1900 (Veitch Exped. No. 1045; bush 1.5 m.); same locality, A. Henry (No. 5746).

This is a very common species in western Hupeh in thickets of low-growing shrubs on mountain slopes. The stems are upright, and the more or less reddish-purple shoots and branches are remarkably free of prickles. A specimen collected on "Mt. Kintou-san " in Shensi on July 14, 1897 by G. Giraldi may belong to this species, but the material is so poor that it is not possible to discuss it intelligently. A specimen collected by W. Purdom near Minchou, western Kansu, probably belongs here, though it differs in its perfectly glabrous leaflets.

Rosa Davidii Crépin in Bull. Soc. Bot. Belg. XIII. 253 (Prim. Ros. Monog. 260) (1874). - Franchet in Nouv. Arch. Mus. Paris, sér. 2, V. 270 (Pl. David. I. 118) (1883).

Western Szech'uan: Wa-shan, thickets, alt. 1600-2600 m., July 1908 (Nos. 3585; bush 1.5-5 m. tall, flowers rose-pink, fruit orangered to scarlet); same locality, July 1903 (Veitch Exped. No. 3545, Seed No. 1440; bush $2.5 \mathrm{~m}$. tall, flowers pink); same locality, A. $E$. Pratt in A. Henry (No. 8944); Mupin, thickets, alt. 2000-2600 m., November 1908 and 1910 (Nos. I238, 4223; bush 1-3 m. tall, fruit orange-red to scarlet); west and near Wên-ch'uan Hsien, thickets, alt. 2000-3000 m., September 1908 (Nos. Io6o, I063; bush 2.5-5 m. tall, fruit orange).

Crépin's description supplemented by a photograph of the original specimen in the herbarium of the Museum at Paris leaves little doubt that the specimens enumerated above can be referred only to Rosa Davidii. It is a common Rose on the mountains of western Szech'uan, in Mupin, where David collected it. It is the species in China nearest to $R$. macrophylla Lindley ${ }^{1}$ of the western Himalaya.

1 The different botanists who have dealt with the Roses of the interior of Chins have referred many specimens to Rosa macrophylla Lindley, but in nearly every case have made them varieties or forms, or have remarked that the specimens differ 
Lindley's plant differs in its more acute leaflets with more acute serratures, which are more hairy on the under side and in its shorter styles. In $R$. Davidii the anther cells are markedly divergent at the base, which is not the case in the Himalayan specimens of $R$. macrophylla we have seen.

Our No. 1060 has a very large much-branched inflorescence, and the venation on the under side of the leaflets is very prominent; in No. 1063 the leaflets are more silkily pubescent on the under side than is usual in the species.

Rosa Davidii, var. elongata Rehder \& Wilson, n. var.

A typo recedit foliis majoribus, ad $7 \mathrm{~cm}$. longis subtus glabris v. pubescentibus, corymbis 3-7-floris, fructu elongato oblongo utrinque plus minusve attenuato $2-2.5 \mathrm{~cm}$. longo et circiter $1 \mathrm{~cm}$. diam.

Western Szech'uan: Mupin, thickets, alt. 2000-2600 m., November 1908 (No. rr26, type; bush 3 m.); Wa-shan thickets, alt. 16003000 m., June and October 1908 (Nos. I099, III4, II78; bush 3-5 m., flowers rose-pink, fruit scarlet to orange-red).

This variety is distinguished from the type by its fewer flowers, its larger more elongated fruit and by its usually larger leaflets, which vary from nearly glabrous to silkily pubescent on the under side. In No. 1114 the leaves are pubescent on both surfaces, but seedling plants raised from this number are normal in their pubescence.

Rosa corymbulosa Rolfe in Bot. Mag. CXL. t. 8566 (1914).

Western Hupeh: Hsing-shan Hsien, thickets, 1300-2000 m. alt., November 1907 (Nos. 630, 630 , seeds only, 625; bush $1.3-2 \mathrm{~m}$. tall, fruit coral-red to scarlet); Patung Hsien, mountains, $1600 \mathrm{~m}$. alt., July 1900 (Veitch Exped. No. 1438; bush 2 m. tall, flowers pink); without precise locality, A. Henry (Nos. 6491, 6714).

This Rose is fairly common in thickets on the mountains of western Hupeh. It is easily recognized by its smooth shoots, and by its very membranous leaflets which are gray and puberulous on the under side and turn a deep vinous-purple in the autumn. The wild plants have usually much smaller corymbs than that figured by Rolfe, indeed the flowers are often solitary.

Rosa setipoda Hemsley \& Wilson in Kew Bull. Misc. Inform. 1906, 158. - Willmott, Gen. Rosa, I. 173, fig. 55 (1911). - Rolfe in Bot. Mag. CXL. t. 8569 (1914).

in aspect from Lindley's type. Whether or not the real $R$. macrophylla Lindley occurs in China is problematical, but certainly its nearest ally is the Rose we refer to $R$. Davidii Crépin. Several of the Chinese Roses considered by botanists to be $R$. macrophylla Lindley are probably distinct species, but without having seen the specimens it is impossible to refer them to their proper species. To us it is obvious that in the mountainous parts of China there is a group of Roses of which the Himalayan $R$. macrophylla Lindley may be said to represent one extreme form. The members of this group possess certain distinctive eharacters by which they may be recognized. In the present imperfect state of our knowledge it appears to us best to regard them as distinct species. 
Rosa macrophylla, var. crasseaculeata M. de Vilmorin in Jour. Hort. Soc. Lond. XXVII. 487, figs. 135, 136 (1902-03).

Western Hupeh: Fang Hsien, upland thickets, alt. 2000-2600 m., July and September 1907 (No. 272; bush 1-3 m. tall, flowers pink, fruit coral-red;) same locality July and Oetober 1901 (Veitch Exped. Nos. $2409^{\mathrm{a}}$, type, 2409 , Seed No. 1047).

This well-marked species with its shoots thickly clad with short, stout, flattened prickles is local in its distribution, and is known to us only from the northwest corner of Hupeh and the adjacent region in Szech'uan. The inflorescence varies considerably in size, being largely dependent upon vigor of growth.

Rosa saturata Baker in Willmott, Gen. Rosa, II. 503 (1914).

Western Hupeh: Fang Hsien, thickets, alt. 1600-2300 m., July and September 1907 (No. 3I6; bush 1-2.5 m. tall, flowers rose-red, fruit coral-red); same locality, June 1901 (Veitch Exped. No. 2086, flowers pink, rare); without locality, A. Henry (No. 6747). Northcentral Szech'uan: Pa-chou, thickets, alt. 1000 m., July 1910 (No. 4646; bush 1-2 m., flowers dark red).

This species is closely related to Rosa banksiopsis Baker, which has smaller leaves and smaller usually clustered flowers. It is rather rare and is apparently restricted to northwestern Hupeh and the more northern parts of the Red Basin of Szech'uan.

Rosa Sweginzowii Koehne in Fedde, Rep. Spec. Nov. VIII. 22 (1910); in Mitt. Deutsch. Dendr. Ges. XIX. 95, fig. 2 (1910); in Fedde, Rep. Spec. Nov. XI. 531, fig. 3 (1913).

Western Szech'uan: Ta-p'ao-shan, northeast of Tachien-lu, thickets, alt. 3000-3300 m., July 4, 1908 (No. 3584; bush 2-4 m. tall, flowers deep rose); west of Kuan Hsien, Pan-lan-shan, thickets, alt. 2300-3600 m., June 1908 (No. 3588; bush 3-5 m., flowers deep rose); neighborhood of Sungpan Ting, alt. 3000 m., August 27, 1910 (No. 4028); same locality, alt. 2500-2600 m., September 1903 (Veitch Exped. Seed No. 1447; bush 1-2 m. tall). Kansu: Min-chou, alt. 3000 m., 1911, W. Purdom.

This Rose is closely related to R. setipoda Hemsley \& Wilson, and is perhaps nothing but a geographical form of that species distinguished by its more hairy leaves, smaller inflorescence, and by its rounder flowers with shorter calyx-lobes. No. 4028, from Sungpan, differs from the type in the absence of bristles on the fruit and pedicels and in the unarmed branches, but the plants raised from seed collected in 1903 in the same locality have setose pedicels and receptacles and the branches are armed with broad prickles. No. 3584 from the Ta-p'ao-shan differs in the slenderer prickles and the small broader, sometimes nearly orbicular leaflets. In all specimens except Purdom's the leaflets are simply or nearly simply serrate, but the young plants raised from seed have doubly serrate leaflets. 
Rosa Moyesii Hemsley \& Wilson in Kew Bull. Misc. Inform. 1906, 159. - Garden, LXXII. 313, fig. (1908). - Hemsley in Bot. Mag. CXXXVI. t. 8338 (1910). - Willmott, Gen. Rosa, I. 229, t. fig. 74 (1911). - Bean, Trees \& Shrubs Brit. Isl. II. 435, fig. (1914).

Rosa macrophylla, f. parce glandulosa Focke in Not. Bot. Gard. Edinburgh, V. 69 (1911).

Rosa macrophylla, f. gracilis Focke, 1. c. (pro parte) (1911), quoad No. 4442.

Western Szech'uan: Tachien-lu, thickets, alt. 2600-3300 m., June and October 1908, October 1910 (Nos. I289, 4III 4098; bush 2-4 m. tall, flowers dark red, fruit orange-scarlet); same locality, July 1903 (Veitch Exped. No. 3543, type); northeast of Tachien-lu, thickets, alt. 2300-3600 m., July 9 and September 1908 (No. 1056; bush 2-6 m., flowers deep rose, fruit orange-scarlet); west of Kuan Hsien, Pan-lan-shan, thickets, alt. 2300-3300 m., October 1910 (Nos. 4III, 4309; bush 2.5-5 m., fruit orange-red); same locality, Niu-tou-shan, alt. 2300 m., June 21, 1908 (No. 3587; bush 1-2.5 m., flowers deep rose). Yunnan: Lichiang range, alt. 3000-3300 m., June 1906, G. Forrest (No. 2402); Tali range, alt. 2000-2400 m., June 1906, G. Forrest (No. 4442).

This is a very common species in the mountain thickets of extreme western Szech'uan between 2000 and $4000 \mathrm{~m}$. altitude. The flowers vary considerably in color, and the pedicels and calyx-tube are smooth or densely stipitate-glandular. The typical form, which has dark red flowers, is abundant in the upland thickets round Tachien-lu and is one of the most beautiful of Roses. This species is closely related to a Rose found in the Sikkim Himalaya at $3300 \mathrm{~m}$. alt. and which we think may be $R$. Hoffmeisteri Klotzseh. However, until the flora of the regions between western Szech'uan and Sikkim is known it appears to us best to consider them distinct species. M. de Vilmorin's Rosa macrophylla, var. rubrostaminea (in Jour. Hort. Soc. Lond. XXVII. 490, fig. 139 [1902-03]) is doubtless referable to one of the numerous color forms of Rosa Moyesii, or to the following variety.

Rosa Moyesii, f. rosea Rehder \& Wilson, n. f.

A typo recedit floribus pallide roseis. Foliola ovato-elliptica, subtus ad costam adpresse pilosa, $2-5 \mathrm{~cm}$. longa.

Western Szech'uan: Mupin, thickets, alt. 2000-3000 m., June, July and October 1908 (Nos. II23, type, II $3^{2}$, 3590; bush 1.5-5 m., flowers pink to rose, fruit scarlet); Wa-shan, woodlands, alt. 2300-3000 m., October 1908 (No. I I04; bush 2.3 m., fruit orange-red); same locality, alt. 3150 m., July 1903 (Veitch Exped. 3544; bush 1-2.5 m., flowers pink); Hung-ya Hsien, Ta-p'ao-shan, thickets, alt. 3000-3300 m., September 15, 1908 (No. 93I; bush 1-1.5 m., fruit scarlet); west of Kuan Hsien, Pan-lan-shan, thickets, alt. 2000-2600 m., June and 
Cetober 1908 (Nos. 3589, 3586; bush 2.5-5 m.; flowers pale rose color, fruit scarlet); west and near Wên-ch'uan Hsien, thickets, alt. 20002600 m., June, July and September 1908, October 1910 (Nos. Io62, 4028X; bush $4 \mathrm{~m}$., flowers pale pink, fruit scarlet).

This handsome Rose is abundant in the thickets and on the margin of woods in the regions east of Tachien-lu, where the type is common. With its large pale pink flowers and large leaves this form looks very distinct from the type.

\section{Rosa Murielae Rehder \& Wilson, n. sp.}

Frutex 1.5-3 m. altus; rami satis graciles, erecti v. patentes, glabri, rubescentes, saepe cinerascentes et dense setosi, aculeis sparsis gracilibus rectis basi leviter dilatatis $3-6 \mathrm{~mm}$. longis muniti v. interdum inermes. Folia 9-15-foliolata, petiolo incluso $4-15 \mathrm{~cm}$., plerumque 8-10 cm. longa; foliola membranacea, breviter petiolulata, elliptica v. elliptico-oblonga, rarius ovata v. ovalia, acuta v. obtusiuscula, plerimque apiculata, basi late cuneata v. rotundata, simpliciter serrata et plerumque margine leviter revoluta, dentibus leviter incurvis v. porrectis manifeste glanduloso-mucronatis v. fere aristatis, 1-4 cm., plerumque $1.5-2 \mathrm{~cm}$. longa et $0.5-1.5$, plerumque $0.8-1 \mathrm{~cm}$. lata, supra glabra, saturate viridia, subtus pallidiora, glabra costa media adpresse pilosa excepta, utrinsecus nervis 4-7 subtus leviter elevatis v. fere obsoletis, venulis obsoletis; petioli $0.8-2 \mathrm{~cm}$., plerumque $1-1.2 \mathrm{~cm}$. longi ut rhachis villosi et sparse aciculati, interdum sparse stipitatoglandulosi; stipulae adnatae, membranaceae, $0.6-1 \mathrm{~cm}$. longae, in foliis inferioribus latae, in superioribus satis angustae, auriculis triangularibus patentibus acutis v. acuminatis, glabrae, margine sparse glanduloso-ciliatae v. fere nudae. Flores albi, $2-3 \mathrm{~cm}$. diam., in corymbis umbelliformibus, 3-7-floris, breviter pedunculatis; bracteae et bracteolae lanceolatae v. ovato-lanceolatae, acuminatae, 8-10 $\mathrm{mm}$. longae, mox deciduae; pedicelli filiformes, $1.5-4.5 \mathrm{~cm}$., plerumque $3 \mathrm{~cm}$. longi, breviter villosuli v. fere glabri, saepe stipitato-glandulosi; receptaculum ellipsoideum, glabrum v. apice villosulum; sepala ovata, circiter $5 \mathrm{~mm}$. longa, subito in acumen foliaceum 6-10 $\mathrm{mm}$. longum contracta, integra, extus dense villosula v. fere glabra; petala orbieulari-obovata, rotundata v. emarginata, circiter $1 \mathrm{~cm}$. longa; stamina numerosa, antheris basi leviter divergentibus; styli 8-10, leviter exserti, staminibus multo breviores, dense villosi. Fructus ellipsoideus, apice in collum constrictus, $1.2-1.8 \mathrm{~cm}$. longus et $0.6-1 \mathrm{~cm}$. diam., aurantiaco-ruber, sepalis erectis persistentibus coronatus.

Western Szech'uan: Mupin, thickets, alt. 2300-2800 m., June 
and October 1908 (No. Ir34, type); west of Kuan Hsien, Pan-lanshan, thickets, alt. 2300-3800 m., June 1908, October 1910 (Nos. 3582, 43r2); west and near Wên-ch'uan Hsien, thickets, alt. 2300-2600 m., July 1908 (No. 358o); Tachien-lu, thickets, alt. 2800 m., July 1903, July and October 1904 (Veitch Exped. Nos. 3535 ${ }^{\mathrm{s}}$, 3535, Seed No. 1841).

This pretty and distinct species is perhaps most closely related to $R$. persetosa Rolfe, which is a much more vigorous plant with very densely setose stems, larger leaves of fewer differently shaped leaflets, much branched, many-flowered corymbs of pink flowers and globose fruit. It may also be compared with $R$. sertata Rolfe, which has pink flowers on shorter pedicels, large bracts and bractlets, leaves composed of fewer, differently shaped leaflets, stems slightly and rarely setose and globose fruit. This new species is not uncommon in the upland thickets of the Chino-Thibetan borderland, and it is the only Rose in this group we have met with which has white flowers. No. 4312 has smaller and more oval leaflets and smaller fruits and may possibly represent a distinct variety. No. 3580 resembles No. 4312 in the shape of the leaflets, and the flowers are described as pink.

It is named for my daughter Muriel. (E. H. W.)

Rosa sertata Rolfe in Bot. Mag. CXXXIX. t. 8473 (1913). - Osborne in Gard. Chron. ser. 3, LIV. 166, fig. 63 (1913). - Willmott, Gen. Rosa, II. 493 (1914). - Bean, Trees \& Shrubs Brit. Isl. II. 443 (1914).

Rosa Webbiana Vilmorin \& Bois, Frut. Vilmorin. 93 (non Wallich) (1904).

Rosa macrophylla, f, gracilis Focke in Not. Bot. Gard. Edinburgh, VII. 69 (1911), No. 4442 excluso.

Western Hupeh: Changlo Hsien, thickets, alt. 1300-2000 m., June 1910 (No. 3593; bush 1-1.5 m. tall, flowers rose-red); Fang Hsien, thickets, alt. 1600-2300 m., June and October 1910 (Nos. 44I7, 4643, 4645; bush 1-2.5 m. tall, flowers pink, fruit orange-red); same locality, July 1901 (Veitch Exped. No. 2325; bush 2 m. tall, flowers pink); without locality, A. Henry (No. 6997). Eastern Szech'uan: Wushan Hsien, A. Henry (No. 5679). Western Szech'uan: without precise locality, alt. 300-1300 m., October 1904 (Veitch Exped. Seed No. 1492; bush 0.6-2 m. tall, flowers pink). Kansu: Min-chou, alt. 2600-3000 m., 1911, W. Purdom. Yunnan: Tali valley, alt. 2000 m., June 1906, G. Forrest (Nos. 4445, 4447); eastern flank of the Tali range, alt. 2100-2400 m., June 1906, G. Forrest (No. 4453).

This pretty Rose with its small flowers is common on the mountain slopes of western Hupeh, but is rare in western Szech'uan. None of our specimens have flowers as large as those figured in the Botanical Magazine. A specimen collected on "Thae-pei-san," in Shensi by G. Giraldi, in September 1897, may belong here. 
Rosa multibracteata Hemsley \& Wilson in Kew Bull. Misc. Inform. 1906, 157. - Willmott, Gen. Rosa, I. 209 (1911).

Rosa reducta Baker in Willmott, Gen. Rosa, II. 489, fig. 158 (1914).

Western Szech'uan: south of Sungpan Ting, valley of Min River, alt. 2300-2600 m., August and September 1910 (Nos. 4642, 4026; bush 1-2 m., flowers pink, fruit orange-red); Wên-ch'uan Hsien, valley of Min River, alt. 1600-2000 m., September 1908 (No. I053, Seed No. 1055; bush $2 \mathrm{~m}$. tall, fruit orange-red); west and near Wên-ch'uan Hsien, alt. 2600-3000 m., October 1910 (No. 4I97; bush 2-3 m. tall, fruit orange-red); without locality, May 1904 (Veitch Exped. No. $3542^{\mathrm{a}}$; bush $2 \mathrm{~m}$. tall, flowers pink).

This Rose is very common in the valley of the Min River from Wên-ch'uan Hsien to Sungpan Ting, but is rare elsewhere. The typical form with its paniculate corymbs and crowded bracts is very distinct, but depauperate forms with the inflorescence reduced to a solitary flower are difficult to distinguish from $R$. Willmottiae Hemsley; the calyx and fruit, however, are always stipitately glandular, the calyx is persistent, and the styles are more or less exserted. Baker founded his $R$. reducta on plants raised from our No. 1053, which is one of these depauperate forms. Solitary to many-flowered inflorescences can be found on the same plant, and their size appears to depend largely upon the vigor of the braneh.

Rosa Giraldii Crépin in Bull. Soc. Bot. Ital. 1897, 232. - Pampanini in Nuov. Giorn. Bot. Ital. n. ser. XVII. 294 (1910).

Shensi: "Monte Kan-y-san ad ouest del Lao-y-san," June 11-12, 1897, G. Giraldi.

Rosa Giraldii, f. glabriuscula Rehder \& Wilson, n. f.

A typo recedit foliis glabris pilis sparsis subtus ad costam exceptis.

Western Hupeh: Fang Hsien, thickets, alt. 1600-2300 m., June 1910 (No. 4644, type); same locality, July 1901 (Veitch Exped. No. $\left.2325^{\mathrm{a}}\right)$.

This is a shrub from $1.5-2 \mathrm{~m}$. tall with small rosy-pink flowers and is distinguished from the type by its leaflets, which are glabrous except for a few straight appressed hairs on the lower surface of the midrib.

Rosa Giraldii, var. venulosa Rehder \& Wilson, n. var.

A typo recedit foliolis subtus manifeste reticulato-venosis supra interdum glabris v. fere glabris.

Western Hupeh: Hsing-shan Hsien, thickets, alt. 1300-1600 m., June and November 1907 (No. 628, type); Paokang Hsien, thickets, June 1901 (Veitch Exped. No. 1953). Western Szech'uan: without precise locality, July 1903 (Veitch Exped. No. 3533). 
This variety is distinguished from the type by its leaflets, which are very markedly reticulate on the under side. In the No. 3533 the leaflets are glabrous or nearly so on the upper surface. This new variety is a bush $1.5-2.5 \mathrm{~m}$. tall, with pink flowers and ovoid, scarlet, subsessile fruit.

Rosa Prattii Hemsley in Jour. Linn. Soc. XXIX. 307, fig. 30 (1892). - Willmott, Gen. Rosa, I. 161 (1911).

Western Szech'uan: Tachien-lu, thickets, alt. 2600-3000 m., June and October 1908, October 1910, Nos. I254, I244, 4093; bush 1.5-2.5 m. tall, flowers pink, fruit orange-red to scarlet; same locality, October 1903 (Veitch Exped. Seed Nos. 1563, 1727; bush 1 m. tall); same locality, A. E. Pratt (No. 116, type); northeast of Tachien-lu, Ta-p'ao-shan, thickets, alt. 2300-3000 m., July 3, 1908 (No. 358r ; bush 2-2.5 m. tall, flowers deep rose-pink); Wa-shan, thickets, alt. 2600-3300 m., July and October 1908 (No. II50; bush 2 m., flowers pink, fruit scarlet).

This pretty little Rose is common in thickets near Tachien-lu. It may be recognized by its umbellate-cymose inflorescence of 3 to several small flowers and by its small leaves of 5-7 pairs of small lanceolate to oval or rarely obovate leaflets. The prickles are straight, aciculate, somewhat dilated at the base, and straw-colored; the shoots are reddish, smooth or strongly setose. The No. 1150 has very small leaves, composed of oval to suborbicular leaflets, and may possibly represent a distinct variety.

Rosa Willmottiae Hemsley in Kew Bull. Misc. Inform. 1907, 317; in Bot. Mag. CXXXIV. t. 8186 (1908). - Willmott, Gen. Rosa, I. 195, t. (1911).

Western Szech'uan: near Monkong Ting, valley of Hsao-chin Ho, alt. 2300-3060 m., June 1908 (No. 3602; bush 2-2.5 m. tall, flowers rose-pink); neighborhood of Sungpan Ting, side of streams, alt. 2600-3150 m., August 28, 1910 (Nos. 4009, 4026 ; bush 1.5-3 m. tall, flowers rose-pink, fruit orange-red); west of Tachien-lu, banks of Yalung River, June 1904 (Veitch Exped. No. 3534; bush 1-2.5 m. tall).

This Rose is fairly common in the more arid river-valleys of western Szech'uan and is very abundant in the neighborhood of the city of Sungpan Ting. The flowers are solitary, or very rarely two together; the fruit is smooth, ovoid, orange-red with a thin pericarp and large achenes; the calyx is deciduous from the ripe fruit. The stems are ascending and spreading and much-branched and glaucescent, and the prickles are reddish when young, occasionally flattened, somewhat decurrent, and straw-colored when mature. Both in flower and fruit this is a very pleasing plant. The closely related $R$. Webbiana Wallich has an elongate, sparsely glandular fruit crowned by a persistent calyx in which the lobes are very long.

A picture of this Rose will be found under No. 0309 in the collection of Wilson's photographs. 
Rosa gracilifiora Rehder \& Wilson, n. sp.

Frutex 2-4-metralis, gracilis; rami graciles, annotini fusco-purpurei v. purpurascentes, aculeis gracilibus sparsis saepe infraaxillaribus ad $1 \mathrm{~cm}$. longis muniti, interdum fere inermes. Folia membranacea, 9-11-, rarius 7-foliolata, 4-10 cm. longa petiolo incluso; foliola breviter petiolulata, ovalia v. elliptica, apice rotundata, lateralia basi rotundata, raro late cuneata, terminale late cuneatum, argute dupliciter v. partim simpliciter serrata dentibus acuminatis apice glandulosis, 0.6-2 $\mathrm{cm}$. longa et $0.4-1.3 \mathrm{~cm}$. lata, supra laete viridia, glabra, subtus pallidiora, ad costam mediam sparse adpresse pilosa ceterum glabra, nervis vix elevatis obsoletis; petioli 1-2 cm. longi, ut rhachis glabri, sparse v. sparsissime stipitato-glandulosi et aciculis paucis rectis gracilibus ad $3 \mathrm{~mm}$. longis muniti; stipulae 1-1.5 cm. longae, latae, margine glanduloso-ciliatae ceterum glabrae, auriculis triangularibus acuminulatis patentibus. Flores rosei v. pallide rosei, $3.5-4 \mathrm{~cm}$. lati, in apice ramulorum lateralium solitarii; pedicelli graciles, $1.5-3 \mathrm{~cm}$. longi, glanduloso-setosi, apicem versus glabrescentes, basi ebracteati; receptaculum ovoideum v. oblongo-ovoideum, glabrum; sepala ovato-lanceolata, integra, sensim in acumen longum apice foliaceum et glanduloso-serrulatum producta, tota $1.5-2.5 \mathrm{~cm}$. longa, post florationem patentia; petala orbiculari-obovata, rotundata v. leviter emarginata, sepalis subaequilonga; stamina numerosa, antheris ochraceis ovalibus; capitulum stigmatum sessile v. fere sessile; styli pilosi. Fructus desideratur.

Western Szech'uan: northeast of Tachien-lu, Ta-p'ao-shan, woodlands, alt. 3300-4500 m., July 4, 7, 1908 (No. 3583, type); west of Tachien-lu, Cheto-shan, alt. 3800 m., July 25, 1908 (No. $35^{8} 3^{\mathrm{a}}$ ); same locality, 1911, John R. Muir.

This Rose has no close relationship with any other Chinese Rose. It somewhat resembles $R$. Sweginzowii Koehne, but differs in the slenderer pedicels, in the entire sepals and ehiefly in the absence of the bracts at the base of the pedicel. By the latter character the species is removed from the group of Cinnamomeae and must be referred to the Pimpinellifoliae. From R. spinosissima Linnaeus it differs chiefly in the doubly serrate leaflets and in the elongated receptacle. The fruit is unknown.

Rosa Hugonis Hemsley in Bot. Mag. CXXXI. t. 8004 (1905).Fedde, Rep. Spec. Nov. III. 186 (1906). - Willmott, Gen. Rosa, II. 279, t. (1911). - Bean, Trees \& Shrubs Brit. Isl. II. 429, fig. (1914).

Rosa xanthina Crépin in Bull. Soc. Bot. Ital. 1897, 233 (non Lindley), exclud. synon. 
Western Szech'uan: near Mao-chou, valley of Min River, alt. 1300-1600 m., May 25, 1908 (No. 3605; bush 1-2.5 m. tall, flowers pale to bright yellow).

This is the only species of Rose with yellow flowers known from western China. Though very local it is abundant in the region mentioned above, where a relatively warm and dry climate prevails. It commences to flower very early in May and by the end of the month the flowers have gone; the fruit ripens in July and August and falls at once. The fruits are dark scarlet, glabrous, strongly depressed-globose, on slightly reddish pedicels $0.5-1.5 \mathrm{~cm}$. long and crowned with the persistent calyx-lobes. The prickles vary remarkably in number; some shoots have no prickles and only a few setae, others have abundant setae and a few prickles only slightly dilated at base; while others are densely covered with connate, decurrent, thin, translucent crimson prickles $1.5-2 \mathrm{~cm}$. long with numerous setae between. All forms can be found on the same bush.

Crépin enumerates specimens collected by Père Hugh Scallan under his $R$. xanthina Lindley, but his remarks leave no doubt that the Rose is $R$. Hugonis which was raised at Kew from seed sent to the British Museum by Father Hugh. It was also raised from seed sent by Purdom under No. 534 either from Shensi or Kansu to the Arnold Arboretum.

Rosa omeiensis Rolfe in Bot. Mag. CXXXVIII. t. 8471 (1912). Bean, Trees \& Shrubs Brit. Isl. II. 438 (1914).

Rosa sericea Crépin in Bull. Soc. Bot. Belg. XIV. 151 (non Lindley) (1875), quoad specimina Przewalskii; XXV. Compt. Rend. 9 (1886); in Bull. Soc. Bot. Ital. 1897, 234. - Diels in Not. Bot. Gard. Edinburgh, VII. 238 (Pl. Chin. Forrest.) (1912).

Rosa sericea, f. glabrescens Franchet, Pl. Delavay. 220 (1890).

Rosa sericea, f. intermedia Franehet, 1. c. (1890).

Rosa sericea, f. denudata Franchet, l. c. (1890).

Rosa sericea, f. inermis eglandulosa Focke in Not. Bot. Gard. Edinburgh, V. 69 (Pl. Chin. Forrest.) (1911).

Rosa sericea, f. aculeata eglandulosa Focke, 1. c. 70 (1911).

Rosa Sorbus Léveillé in Fedde, Rep. Spec. Nov. XIII. 338 (1914).

Western Hupeh: Fang Hsien, upland thickets, alt. 2000-3000 m., May 31, August 1907 (No. I79; bush 2-4 m. tall, flowers white, fruit red); same locality, June 1900 (Veitch Exped. No. 2094; bush $2 \mathrm{~m}$. tall); without locality, A. Henry (No. 6782). Western Szech'uan: west of Kuan Hsien, Niu-tou-shan, woodlands, alt. 26003600 m., June 20, September 1908 (No. 959; bush 3-5 m., flowers white, fruit scarlet); Mupin, thickets, alt. 2300-3300m., June 1908 (No. $959^{\text {a }}$; bush 2-5 m. tall, flowers white); Wa-shan, woodlands, alt. 20003600 m., June, July and September 1908 (Nos. 3596, 959 ${ }^{\text {b }}$; bush 2-5 m. tall, flowers white, fruit red); same locality, A.E. Pratt, ex A. Henry (Nos. 8947, 8961); Tachien-lu, alt. 3000-3600 m., October 1910 (No. 4163; bush 3-6 m. tall); west and near Wên-ch'uan Hsien, alt. 1600- 
2600 m., July 1908 (No. 3595; bush 2-4 m. tall, flowers white); Sungpan Ting, alt. 2600-3300 m., August 27, 1910 (No. 4012; bush 1-1.5 m. tall, fruit scarlet with orange-red fleshy peduncle); Mt. Omei, June 1904 (Veitch Exped. No. 4879); same locality, alt. 3500 m., E. Faber (No. 528); without locality, alt. 1300-4000 m., July and September 1903 (Veitch Exped. No. 3546). Yunnan: Sung-kwei, Hoching-cho and Lichiang Fu valleys, alt. 2100-3000 m., April 1906, G. Forrest (No. 2022); Lichiang range, alt. 2800-3300 m., June 1906, G. Forrest (No. 2256); side valleys on the eastern flank of the Tali valley, alt. 2400-2700 m., June-July 1906, G. Forrest (No. 4448); eastern flank of the Tali range, alt. $2100-2400$ m., G. Forrest (No. 4451). Kansu : Min-chou, alt. 2600-3000 m., 1911, W. Purdom. Shensi: "Kiansan," August 4, 1897, G. Giraldi; “ Kin-tou-san," July 11, 1897, G. Giraldi.

This Rose is abundant in upland thickets, on the margins of woods and in forest glades everywhere on the higher mountain ranges of western Hupeh and Szech'uan. In certain characters it is extremely variable. The shoots are smooth or densely setose; the prickles are fairly numerous or wanting, and are only slightly dilated at the base or are strongly decurrent and extend the full length of the internode. The leaves sometimes have up to eight pairs of leaflets and thus exceed in number of leaflets those of any other Rose; the leaflets are nearly glabrous or silkily pubeseent on the under surface. In a general way it may be said that the more exposed the situation in which the plant is growing the smaller the leaves, the larger the prickles and the more abundant the setae. The flowers are always white and solitary with four or very rarely with five petals, and the foot-stalk of the fruit is always thickened, fleshy and brightly colored. It is this last character together with the greater number of leaflets that at once distinguishes this species from Rosa sericea Lindley, which has not yet been found in China. The specimens from Yunnan have fewer and broader generally only 3 to 5 pairs of leaflets and resemble in this character the Himalayan $R$. sericea, but the stalks of the fruit are apparently fleshy. In Lindley's plant the foot-stalk of the fruit is slender and not thickened or fleshy, and the leaves never have more than five pairs of leaflets. It is a native of the western Himalaya, and the eastern limits of its range are not yet clearly defined. We should not be surprised to learn of Rosa omeiensis Rolfe being found as far west as Sikkim.

Rosa omeiensis, f. pteracantha Rehder \& Wilson, n. comb.

Rosa sericea Crépin in Bull. Soc. Bot. Belg. XXV. Compt. Rend. 9 (non Lindley) (1886), quoad specimen No. 861. - M. de Vilmorin in Jour. Hort. Soc. Lond. XXVII, 490, fig. 140 (1902-03).

Rosa sericea, f. pteracantha Franchet, Pl. Delavay. 220 (1890). - Focke in Not. Bot. Gard. Edinburgh, V. 70 (Pl. Chin. Forrest.) (1911).

Rosa sericea fructu rubro aculeis decurrentibus Vilmorin \& Bois, Frut. Vilmorin. 99, fig. (1904).

Rosa sericea, var. pteracantha in Gard. Chron. ser. 3, XXXVIII. 260, figs. 98, 99 (1905). - Bean in Garden, LXIX. 294, t. (1906); Trees \& Shrubs Brit. Isl. Il. 442 (1914), - Hutehinson in Bot. Mag. CXXXIV. t. 8218 (1908). 
Western Szech'uan: Tachien-lu, woodlands, alt. 3000-3600 m., October 1910 (Nos. 4095, 4I I8; bush 1-2 m. tall, fruit scarlet); Chienchi Hsien, Ta-hsiang-ling, open country, alt. 2000-2800 m., May 1908 (No. 3597; bush $1.5 \mathrm{~m}$. tall, flowers white); west of Romi-chango, thickets, alt. 2300-3300 m., July 3, 1908 (No. 3594; bush 1-3 m. tall, fruit red).

This form is very common on the windswept mountain-sides of western Szech'uan, especially near the village of Nitou in Chien-chi Hsien at the extreme western limit of the Red Basin of Szech'uan. The leaflets have usually a more prominent venation, and the fruit has usually a shorter foot-stalk than in the type, but these characters vary. Decurrent prickles are an inherent character in the species and may occur on any vigorous shoot; moreover, a parent plant may be almost without prickles, and seedlings raised from it may have large decurrent prickles. Such a variable and unstable character, though very striking, has no real taxonomic value.

\section{CONSPECTUS SECTIONUM ET SPECIERUM SINENSIUM.}

\section{Clavis sectionum.}

Styli connati in columnam exsertam plerumque stamina aequantem.

Styli liberi, vix v. interdum breviter exserti.

Sect. 1. SYNSTYLAE.

Stipulae basi tantum $\mathbf{v}$. interdum fere ad medium petiolo adnatae, saepe lacinatae.

Ramuli glabri. Folia 3-5-foliolata; stipulae integrae, deciduae.

Receptaculum nudum; flores umbellati. Stipulae subulatae, integrae; folia 3-5-foliolata Sect. 2. BANKSIANAE.

Receptaculum setosum: flores solitarii. Stipulae denticulatae; folia 3-foliolata

Sect. 3 . LAEVIGATAE.

Ramuli et receptaculum tomentosa. Folia 7-9-foliolata; stipulae pectinatae, interdum ad medium adnatae. Flores solitarii v. pauci.

Sect. 4. BRACTEATAE.

Stipulae totae auriculis liberis exceptis petiolo adnatae, non laciniatae.

Flores corymbosi, si solitarii, pedunculis basi bractea $\mathrm{v}$. bracteis suffultis.

Receptaculum aculeatum, depresso-globosum. Stipulae angustae auriculis subulatis. Sepala exteriora pinnata. . Sect. 5. MICROPHYLLAE.

Receptaculum nudum v. hispidum. Stipulae plerumque latae. Sepala plerumque integra.

Styli exserti, liberi, plerumque dimidia stamina aequantes. Folia 3-7-foliolata, persistentia v. subpersistentia ..... Sect. 6. INDICAE. Styli non v. raro paullo exserti. Folia 5-15-foliolata.

Sect. 7. CINNAMOMEAE.

Flores solitarii, pedicello basi ebracteato.

Petala 5.

Foliola $5-7$ in ramulis floriferis. Rami aculeis plerumque recurvis validis muniti, setis destitutis. Sepala plerumque pinnata; petala lutea.

Sect. 8. LUTEAE.

Foliola plerumque 9 in ramulis floriferis. Rami aculeis rectis gracilibus setis intermixtis muniti. Sepala integra; petala, alba, rosea $\mathrm{v}$. lutea. Sect. 9. PIMPINELLIFOLIAE.

Petala 4, alba; sepala integra; styli leviter exserti. Foliola 5-17. Sect. 10. SERICEAE. 


\section{Sect. 1. SYNSTYLAE DC. \\ Clavis specierum.}

Stipulae pectinatae $\mathrm{v}$. irregulariter dentatae.

Foliola 7-9.

Styli glabri. Foliola acuta v. acuminata, 2-4 cm. longa, rarius minora et obtusa; stipulae pectinatae . . . . . . . 1. R. multiflora.

Styli pilosi. Foliola obtusa, 1-2.5 $\mathrm{cm}$. longa; stipulae irregulariter dentatae.

Foliola plerumque 3, lanceolata; stipulae irregulariter dentatae.

2. R. Wichuraiana.

Stipulae integrae, saepe glanduloso-ciliatae.

3. $R$. anemoniflora.

Folia 5-9-foliolata.

Foliola acuta v. acuminata, 3-10 cm. longa. Frutices saepe sarmentosi.

Foliola subtus saltem pubescentia.

Fructus subglobosus, circiter $1 \mathrm{~cm}$. longus. Folia subtus tota facie pubescentia.

Foliola utrinque fere laevia.

Foliola plerumque 7, supra pubescentia. Ramuli saepe puberuli.

4. R. Brunonii.

Foliola plerumque 5, supra glabra, argute grosse-serrata. Ramuli glabri . . . . . . . . 5. R. Rubus.

Foliola subtus reticulata, supra rugosa, ad $10 \mathrm{~cm}$. longa. Corymbus compactus, multiflorus . . . . . . . 6. R. glomerata.

Fructus ovoideus, circiter $1.5 \mathrm{~cm}$. longus. Foliola subtus praecipue ad costam et venas pubescentia. Corymbus multiflorus . 7. $R$. Helenae. Foliola glabra v. fere glabra.

Foliola subtus glaucescentia v. pallida. Fructus subglobosus, circiter 1 em. longus.

Pedicelli graciles, $2-3 \mathrm{~cm}$. longi. Folia subtus glandulosa 8 . R. filipes. Pedicelli $1.5-2 \mathrm{~cm}$. longi. Folia subtus eglandulosa . 9. R. Gentiliana.

Foliola subtus viridia, subcoriacea, plus minusve reticulata. Fructus ovoideus, $1.5-2 \mathrm{~cm}$. longus . . . . . . . 10. R. longicuspis.

Foliola obtusa v. acutiuscula, 1-2.5 cm. longa, glabra, glaucescentia. Frutex erecto-patens . . . . . . . . 11. R. Soulieana. Folia 3-5-foliolata, glabra, obtusa v. obtusiuscula: inflorescentia umbelliformis.

12. R. irridens.

EnUmeratio specierum.

1. Rosa multiflora Thunberg. See p. 304.

Rosa multifiora, var. cathayensis Rehder \& Wilson. See p. 304.

Rosa multiflora, var. carnea Thory. See p. 305 .

Rosa multiflora, var. carnea, f. platyphylla Rehder \& Wilson. See p. 306.

Rosa multiflora, var. brachyacantha Rehder \& Wilson, n. comb.

Rosa damascena, f. floribus semiplenis Focke in Not. [Bot. Gard. Edinburgh, V. 67 (1911).

Rosa damascena, f. brachyacantha Focke, I. c. (1911).

Yunnan : open situations around the eity of Tali, G. Forrest (No. 4444); shady situations around the city of Tali, alt. $2000 \mathrm{~m}$., June, July 1906, G. Forrest (No. 4449 , in part). 
The specimens quoted above cannot be referred to $R$. damascena Linnaeus; the pectinate stipules and the exserted styles connate into a glabrous column show their close relationship to $R$. multiflora. They are apparently nearest to $R$. multiflora, var. cathayensis, but differ in the underside of the leaflets being covered with a soft villose pubescence, in their more crenate serration and in the color of the flowers being sometimes white.

Rosa multiflora, var. quelpaertensis Rehder \& Wilson, n. var.

Rosa mokanensis Léveillé in Fedde, Rep. Spec. Nov. VII. 340 (1909). - Willmott, Gen. Rosa, 1I. 511, t. (1914).

Rosa quelpaertensis Léveillé in Fedde, Rep. Spec. Nov. X. 378 (1912).

Rosa mokanensis, var. quelpaertensis Willmott, Gen. Rosa, II. 512, t. (1914).

Korea: Fusan, May 17, 1906, U. Faurie (No. 325). Korean Archipelago: Quelpaert, Mokan, June 8, 1908, Taquet (Nos. 770, in part, 778 (ex Léveillé), type of $R$. mokanensis); Quelpaert, Hogno, May and June 1909, Taquet (Nos. 2870, type of $R$. quelpaertensis, 2871).

This variety differs from the type chiefly in its much smaller, usually obovate leaflets rounded at the apex and in its smaller flowers. In its general appearance it resembles the following species, but is easily distinguished by the pectinate stipules, the thinner, lighter green leaflets not lustrous above and by the pubescent styles. Taquet's No. 770 consists partly of $R$. Wichuraiana and partly of this variety, and his No. 772 consists of $R$. Wichuraiana and a form intermediate between var. quelpaertensis and typical $R$. multiflora.

2. Rosa Wichuraiana Crépin in Bull. Soc. Bot. Belg. XXV. 189 (1886). - Sargent in Garden \& Forest, IV. 570, fig. 89 (1891). - Mottet in Rev. Hort. 1898, 104, fig. 45-46. - Schneider, Ill. Handb. Laubholzk. I. 540, fig. 319 h-h', 320 c (1905). Willmott, Gen. Rosa, I. 59, t. (1910).

Rosa sempervirens Siebold \& Zuccarini in Abh. Akad. Münch. IV. pt. 2, 20 (Fl. Jap. Fam. Nat. I. 128) (non Linnaeus) (1845). - Miquel in Ann. Mus. Lugd.-Bat. III. 39 (1867); Prol. Fl. Jap. 227.

Rosa moschata Bentham, Fl. Hongk. 106 (1861), quoad plantam hongkongensem. Rosa Luciae Franchet \& Rochebrune apud Crépin in Bull. Soc. Bot. Belg. X. 323 (pro parte) (1871). - Franchet \& Savatier, Enum. Pl. Jap. I. 135 (pro parte) (1872); II. 344 (pro parte) (1879). - Crépin in Bull. Soc. Bot. Belg. XIII. 251 (Prim. Monog. Ros. 258) (pro parte) (1874); XVIII. 285 (Prim. Monog. Ros. 531) (pro parte) (1879). - Hemsley in Jour. Linn. Soc. XXIII. 251 (1887), - Hooker f., in Bot. Mag. CXXI. t. 7421 (1895). - Nakai in Jour. Coll. Sci. Tokyo, XXVI. art. 1, 208 (Fl. Kor.) (1909).

Rosa Wichuraiana, $\beta$ fimbriata Franchet \& Savatier, Enum. Pl. Jap. II. 344 (1879).

Rosa Wichuraiana, $\gamma$ poteriifolia Franchet \& Savatier, l. c. (1879).

Rosa Wichuraiana, 8 adenophora Franchet \& Savatier, 1. c. 345 (pro parte) (1879).

Rosa Wichuraiana, є crataegicarpa Franchet \& Savatier, 1. c. (1879).

Rosa Wichuraiana, $\zeta$ yokoscensis Franchet \& Savatier, 1. c. (1879).

Shantung: Chifu, H. Wawra (ex Crépin). Kwangtung: H. F. Hance (ex Hemsley). Hongkong: W. A. Harland (ex Hemsley). Kwangsi: G. M. Playfair (ex Hemsley). Formosa: R. Oldham (No. 97). Korean Archipelago: Quelpaert, U. Faurie (Nos. 1566, 1568), Taquet (Nos. 770, in part, 772, in part, $2864,2865,2866,2867)$. 
We have seen no specimens of this Rose from China, but it is safe to assume that the Chinese plant belongs to $R$. Wichuraiana and not to $R$. Luciae Franchet \& Rochebrune which seems to be confined to central Japan, as Crépin identifies the plant from Chifu with $R$. Luciae, var. poteriifolia Franchet \& Savatier, which belongs to $R$. Wichuraiana.

3. Rosa anemoneflora Fortune apud Lindley in Jour. Hort. Soc. Lond. II. 316 (1847). - Herincq in Rev. Hort. ser. 3, III. 281 (1849). - Walpers, Ann. III. 845 (1853). - Crépin in Bull. Soc. Bot. Belg. XXII. pt. 2, 46 (1883). - Hemsley in Jour. Linn. Soc. XXIII. 247 (1887). - Willmott, Gen. Rosa, I. 67, t. (1910).

Rosa sempervirens, $\beta$ anemoniflora Regel, Tent. Ros. Monog. 83 (1877); in Act. Hort. Petrop. V. 2, 367 (1878).

Fokien: Dunn's Exped., April to June 1905 (Hongk. Herb. Nos. 2638, 2639). Dunn's specimens have single flowers, while the form originally described by Lindley has the stamens converted into narrow petals quite distinct from the outer whorl of normal petals.

4. Rosa Brunonii Lindley. See p. 306.

5. Rosa Rubus Léveillé. See p. 308.

6. Rosa glomerata Rehder \& Wilson. See p. 309.

7. Rosa Helenae Rehder \& Wilson. See p. 310.

8. Rosa filipes Rehder \& Wilson. See p. 311.

9. Rosa Gentiliana Léveillé. See p. 312.

\section{Rosa Gentiliana, var. australis Rehder \& Wilson, n. var.}

A typo recedit foliis angustioribus plerumque oblongo-lanceolatis sensim acuminatis plus minusve falcatis, $2.5-6 \mathrm{~cm}$. longis, corymbis pauci- v. plurifloris.

Rosa Brunonis Hance in Jour. Linn. Soc. XIII. 115 (non Wallich) (1873).

Rosa moschata Dunn \& Tutcher in Kew Bull. Misc. Inform. add. ser. X. 96 (Fl. Kwangtung \& Hongk.) (non Miller) (1912).

Fokien: without loeality, Dunn's Exped., April to June 1905 (Herb. Bot. Gard. Hongk. No. 2641).

The narrower and smaller more or less curved leaflets and fewer-flowered corymbs serve to distinguish this variety. Had we more material other differences might be apparent. It is possible that the Rosa alba Loureiro (Fl. Cochin. 323 [1790]) belongs here.

\section{Rosa longicuspis Bertoloni. See p. 313.}

Miss Willmott (Gen. Rosa, 1. 52 [1910]) says that Rosa Leschenaultiana Wight \& Arnott has been found in Yunnan by Henry, and Dunn (Jour. Linn. Soc. XXXIX. 486 [1911]) eites Henry No. 10693 as belonging to that species. In this herbarium this number of Henry's from " Feng-chen-lin, mountain forests, south of Red River, $7000 \mathrm{ft}$., climber, white flowers," in our opinion does not belong to Rosa Leschenaultiana Wight \& Arnott, and is distinguished by its straight prickles, its long threadlike petiolules and by its even serration with glandular-ciliolate teeth. It is probably an undescribed species most closely allied to Rosa longicuspis Bertoloni, but the material is too incomplete to determine this. Some of the flowers have more than five petals and suggest a garden escape, but this, considering the remote region in Yunnan where the specimen was collected, is unlikely. That a species of Rose native of the Nilghiri and Pulney mountains of southern India should occur in any part of China seems highly improbable. 
11. Rosa Soulieana Crépin. See p. 314.

12. Rosa irridens Focke apud Diels in Not. Bot. Gard. Edinburgh, VII. 237 (Pl. Chin. Forrest.) (1912).

f. R. Banksiae verosimile hybrida. R. irridens, form. nov., on $R$. Banksiae $\times$ Soulieana Focke in Not. Bot. Gard. Edinburgh, V. 66 (Pl. Chin. Forrest.) (1911).

Yunnan: Tali range, G. Forrest (No. 4443, pro parte; ex Focke).

We have seen no specimens of this Rose, as Forrest's No. 4443 in the herbarium of the Arnold Arboretum consists of branchlets of $R$. Banksiae, var. normalis only.

To the section Synstylae probably belongs $R$. macrophylla, var. hypoleuca Léveillé, Fl. Kouy-Tchéou, 354 (nomen nudum) (1915), which according to the key has exserted styles connate into a column, few-flowered corymbs and leaves glaucous below.

\section{Sect. 2. BANKSIANAE.}

Clatis specierum.

Inflorescentia corymbosa; sepala exteriora pinnata . . . . 13. R. microcarpa. Inflorescentia umbellata; sepala integra ........ 14. R. Banksiae.

\section{EnUMeratio SPECIERUM.}

13. Rosa microcarpa Lindley. See p. 314.

14. Rosa Banksiae Aiton. See p. 316.

Rosa Banksiae, f. normalis Regel. See p. 317.

Rosa Banksiae, f. lutescens Voss. See p. 317.

Sect. 3. LAEVIGATAE Thory.

15. Rosa laevigata Michaux. See p. 318.

Sect. 4. BRACTEATAE Thory.

16. Rosa bracteata Wendland, Obs. 50 (1798); Hort. Herrenh. IV. 7, t. 23 (1801). - Ventenat, Jard. Cels. t. 28 (1800). - Jacquin, Fragm. 30, t. 34, fig. 2 (1809). - Sims in Bot. Mag. XXXIV. t. 1377 (1811). - Thory in Redouté, Roses, I. 35, t. (1817). - Lindley, Monog. 10 (1820). - Seringe in De Candolle, Prodr. II. 602 (1825). - Crépin in Bull. Soc. Bot. Belg. XIV. 2, 137 (Prim. Monog. Ros. 341) (1875). - Hemsley in Jour. Linn. Soc. XXIII. 249 (1887). - Schneider, Ill. Handb. Laubholzk. I. 586, fig. 330 1, $3310-p^{2}$ (1906). - Willmott, Gen. Rosa, I. 125, t. (1911).

Rosa lucida Lawrence, Roses, t. 84 (non Ehrhart) (1799).

Rosa Macartnea Dumont de Courset, Bot. Cult. V. 460 (1805).

Rosa sinica, $\beta$ Braamiana Regel, Tent. Ros. Monog. 43 (1877); in Act. Hort. Petrop. V. 327 (1878).

Fokien: Dunn's expedition to central Fokien, April to June 1905 (Hongkong Herb. No. 2636). Chekiang: G. Staunton, R. Oldham (ex Hemsley).

Sect. 5. MICROPHYLLAE Crép.

17. Rosa Roxburghii Trattinnick. See p. 319.

Rosa Roxburghii, f. normalis Rehder \& Wilson. See p. 319. 


\section{Sect. 6. INDICAE Thory.}

Clavis specierum.

Flores rubri v. rosei, vix v. leviter fragrantes; sepala plerumque pinnata. Fructus ovoideus $v$. pyriformis. Stipulae glanduloso-ciliatae . . . 18. R. chinensis. Flores albi, v. pallida rosei v. flavescentes, fragrantissimi; sepala integra v. interdum sparse pinnata. Fructus depresso-globosus. Stipulae eglandulosae v. auriculis sparse glanduloso-ciliatis

\section{ENUMERATIO SPECIERUM.}

18. Rosa chinensis Jacquin. See p. 320.

Rosa chinensis, f. spontanea Rehder \& Wilson. See p. 320.

19. Rosa odorata Sweet, Hort. Suburb. Lond. 119 (1818).

Rosa indica odorata Andrews, Roses, II. t. 77 (1810-18?).

Rosa indica fragrans Thory in Redouté, Roses, I. 61, t. 19 (1817).

Rosa indica, $\beta$ odoratissima Lindley, Ros. Monog. 106 (1820); in Bot. Reg. X. t. 804 (1824). - Regel, Tent. Ros. Monog. 94 (1877); in Act. Hort. Petrop. V. 358 (1878).

Rosa odoratissima Sweet ex Lindley, Ros. Monog. 106 (pro synon.) (1820).

Rosa Thea Savi, Fl. Ital. II. t. 47 (1822).

Rosa indica, var. ochroleuca Lindley in Trans. Hort. Soc. Lond. VI. 286 (1826).

Rosa indica sulphurea Andrews, Roses, II. t. 86 (1826-28?).

Rosa fragrans Thory in Redouté, Roses, ed. 3, III. groupe 25, t. [19] (in tab. tantum) (1835). - K. Koch, Dendr. I. 273 (1869).

Rosa chinensis, a indica Koehne, Deutsch. Dendr. 281 (pro parte) (1893).

Rosa chinensis, var. fragrans Rehder in Bailey, Cycl. Am. Hort. 1 V. 1551 (1902).

Rosa gechouitangensis Léveillé in Fedde, Rep. Spec. Nov. XI. 299 (1912).

Rosa oulengensis [sic] Léveillé, 1. c. (1912). - Willmott, Gen. Rosa, II. 523, t. (1914).

Rosa tongtchouanensis Léveillé in Fedde, Rep. Spec. Nov. XI. 300 (1912). Willmott, Gen. Rosa, II. 523, t. (1914).

Yunnan: "Ge-choui-tang, alt. 2450 m., April 1911," E. E. Maire (type of R. gechouitangensis Léveillé); "Ou-long, alt. 2500 m., April 1911," E. E. Maire (type of $R$. oulengensis Léveillé); "Haies de Tong-tchouan et de La-kou, alt. 2400-2500 m., March and April 1911," E. E. Maire (type of R. tongtchouanensis Léveillé); Mengtsze, cultivated?, A. Henry (No. 10828; climber, pink flowers).

This Rose in various forms is commonly cultivated in western Yunnan and doubtless from there has been introduced to other parts of China, notably to the sea-board; from there it was first taken to Europe and to other parts of the world. Forms are semi-double or very double and in color are white, yellow, buff or pale rose-pink or combinations of these colors. The leaves have 5-7 leaflets.

The differences on which Léveillé relies for the establishment of his species here quoted do not hold good in the specimens before us; indeed, so nearly identical are they that they might have been collected from the same bush.

Rosa odorata, var. gigantea Rehder \& Wilson, n. var.

Rosa gigantea Collett apud Crépin in Bull. Soc. Bot. Belg. XXVII. 148 (1888); in XXVIII. Compt. Rend. 11 (1889); in Gard. Chron. ser. 3, VI. 12, fig. 4 (1889). - Collett \& Hemsley in Jour. Linn. Soc. XXVIII. 55, t. 9 (1890). Hemsley in Bot. Mag. CXXX. t. 7972 (1904). - Willmott, Gen. Rosa, I. 99, t. (1911). - Raffill in Gard. Chron. ser. 3, LI. 314, fig. 156 (1912). 
Rosa macrocarpa Watt apud Crépin in Bull. Soc. Bot. Belg. XXVIII. Compt. Rend. 13 (non Mérat, nec Nuttall, nec Boissier) (1888). - Hemsley in Bot. Mag. CXXX. t. 7972 (pro synon.) (1904). - Willmott, Gen. Rosa, I. 100 (pro synon.) (1911).

Rosa xanthocarpa Watt apud Willmott, Gen. Rosa, I. 100 (1911).

Rosa Duclouxii Léveillé in Herb. Arnold Arb. (ex Herb. Acad. Intern. Geog. Bot.).

Yunnan: Lu-tung-po, between Mengtsze and Szemao, alt. 2600 m., October 1899 (Veitch Exped. Seed No. 219); Mengtsze, ravines and grassy hills, alt. 1500-1600 m., A. Henry (No. 9098a ; large climber); Szemao, alt. 1600 m., $A$. Henry (No. 9098; large climber, flowers white, fragrant, yellowish in bud); without precise locality, Fr. Ducloux.

This variety is the wild form of the Tea Rose; it is widely dispersed in southern Yunnan and has been reported from Mengtsze in the east to the frontiers of the Shan States in the extreme southwest. The flowers vary from white to yellow or pale buff or to pale pink and are delightfully fragrant. In tall thickets and margins of woods it is a tall and rampant climber, but on the open plateaus it forms a bush with arching stems and is often not more than $2 \mathrm{~m}$. tall.

Watt states that $R$. xanthocarpa is a distinct species chiefly distinguished by its very large yellow fruit.

Rosa odorata, var. gigantea, f. erubescens Rehder \& Wilson, n. comb.

Rosa gigantea, f. erubescens Focke in Not. Bot. Gard. Edinburgh, VII. 68 (1911).

Yunnan: Lichiang valley, alt. 2500 m., May 1906, G. Forrest (No. 2049); Tali valley, alt. 2000-2400 m., May 1906, G. Forrest (No. 4452).

This form differs from the preceding variety in its pale pink often somewhat smaller flowers.

\section{Sect. 7. CINNAMOMEAE DC.}

Clavis specierum.

Rami tomentosi aculeis tomentosis et aciculis muniti. Foliola rugosa, $2-5 \mathrm{~cm}$. longa. 20. R. rugosa. Rami glabri.

Stipulae, eae turionum saltem, conniventia v. convoluta: aculei curvati.

Stipulae planae.

Foliola $1.5-7 \mathrm{~cm}$. longa, plerumque acuta. Corymbi saepe multiflori. Corymbi multiflori.

Rami aculeis tantum muniti v. fere inermes.

Styli non v. vix exserti.

Flores 3.5-5 cm. diam.; pedicelli setosi. Foliola subtus glabra.

22. $R$. caudata.

Flores 2-3 cm. diam.; pedicelli graciles nudi. Foliola plerumque subtus pubescentia

23. $R$. banksiopsis.

Styli plus minusve exserti, liberi. Foliola subtus pubescentia.

Foliola $7-11$, simpliciter serrata. Inflorescentia corymbosa; pedicelli 1.5-3. $\mathrm{cm}$. longi

24. R. Davidii.

Foliola 5-7, plus minusve dupliciter serrata. Inflorescentia subumbellata; pedicelli graciles, $2-4 \mathrm{~cm}$. longi . . . 25. R. corymbulosa. Rami aculeis aciculis setosis intermixtis muniti.

Folia dupliciter, raro simpliciter serrata. Flores circiter $5 \mathrm{~cm}$. diam.; pedicelli et saepe receptacula glanduloso-setosi . . 26. R. setipoda. 
Folia simpliciter serrata. Flores $2-3 \mathrm{~cm}$. diam.: pedicelli et receptacula nuda . . . . . . . . . . 27. R. persetosa. Corymbi pauciflori v. flores solitarii in apice ramulorum plerumque brevium subaequalium secus ramos annotinos.

Folia subtus glabra. Sepala integra.

Foliola 3-6 cm. longa. Pedicelli solitarii, $1.5-3 \mathrm{~cm}$. longi, saepe glabri. 28. $R$. saturata.

Foliola 1.5-2.5 cm, longa. Pedicelli 1-3, rarius plures, circiter $1 \mathrm{~cm}$. longi, setosi . . . . . . . 29. R. bella.

Folia subtus ad costam saltem pubescentia.

Sepala exteriora pinnata v. setoso-ciliata; flores rosei v. rubri.

Rami aculeis robustis et aciculis setosis muniti. Foliola saepe dupliciter serrata, ovalia. Pedicelli breves et receptacula glandulososetosa . . . . . . . . . . 30. R. Sweginzowii.

Rami aculeis tantum muniti, turiones in parte inferiore tantum setosoaciculati. Foliola simpliciter serrata, ovata v. ovato-oblonga, plerumque acuta. Pedicelli saepe nudi ...... 31. R. Moyesii.

Sepala integra: flores albi, $2.5-3 \mathrm{~cm}$. diam., plerumque 3 , graciliter pedicellati. Foliola $1-4 \mathrm{~cm}$. longa ..... 32. R. Murielae. Foliola $1.5 \mathrm{~cm}$. longa v. breviora, obtusa v. acutiuscula (cf. etiam Nos. 29 et 32). Aculei graciles, recti. Flores solitarii v.pauci (saepe multi in No. 35). Pedicelli graciles, nudi. Folia obtusa, glabra.

Flores rosei. Foliola ovalia v. ovata. Rami aculeis et aciculis muniti.

Flores albi. Foliola orbicularia 33. R. sertata. Pedicelli breves.

Styli valde exserti stamina aequantes: flores plures, interdum in corymbo paniculato. Foliola obtusa . . . . . 35. R. multibracteata. Styli vix v. paullo exserti.

Rami non pruinosi. Flores plerumque plures. Folia saepe acutiuscula. Foliola plerumque 7. Rami aculeis uniformibus muniti.

36. R. Giraldii.

Foliola plerumque 11. Rami aculeis et aciculis setosis muniti. Sepala demum decidua. . . . . . . . . . 37. R. Prattii.

Rami juniores pruinosi. Flores plerumque solitarii: sepala demum decidua. Foliola saepe dupliciter serrata, obtusa . 38. R. Willmottiae.

\section{Endmeratio specierum,}

20. Rosa rugosa Thunberg. See p. 321.

Rosa rugosa, var. Chamissoniana C. A. Meyer. See p. 321.

21. Rosa davurica Pallas, Fl. Ross. I. pt. 2, 61 (1788). - Lindley, Ros. Monog. 32 (1820). - Crépin in Bull. Soc. Bot. Belg. XIV. 33 (Prim. Ros. Monog. 327) (1875). - Baker \& Moore in Jour. Linn. Soc. XVII. 382 (1879). - Franchet in Nouv. Arch. Mus. Paris, sér. 2, V. 268 (Pl. David. I. 116) (1883). - Hemsley in Jour. Linn. Soc. XXIII. 249 (1887). - Schneider, Ill. Handb. Laubholzk. I. 578, fig. $327 \mathrm{c}, 328 \mathrm{~b}-\mathrm{c}^{1}(1905)$.

Rosa Willdenovii Sprengel, Syst. II. 547 (1825).

Rosa cinnamomea, $\zeta$ daurica Meyer in Mém. Acad. Sci. St. Pétersbourg, sér. 6 (Sci. Nat.), VI. 27 (Über Zimmtros.) (1847).

Rosa cinnamomea, dahurica Regel, Tent. Ros. Monog. 41 (1877); in Act. Hort. Petrop. V. 325 (1878). 
Chili : west of Weichang, 1910, W. Purdom (No. 107, Seed No. 49); near "Santun-ying," stony places, May 31, 1913, F. N. Meyer (No. 973); "Hsaio Wu-taishan," August 20,1913, F. N. Meyer (Nos. 105, 1240).

22. Rosa caudata Baker. See p. 321.

23. Rosa banksiopsis Baker. See p. 322 .

24. Rosa Davidii Crépin. See p. 322.

Rosa Davidiana, var. elongata Rehder \& Wilson. See p. 323.

25. Rosa corymbulosa Rolfe. See p. 323.

26. Rosa setipoda Hemsley \& Wilson. See p. 323.

27. Rosa persetosa Rolfe in Kew Bull. Misc. Inform. 1913, 263.

Rosa macrophylla? forma gracilis Vilmorin \& Bois, Frut. Vilmorin. 94 (nomen nudum) (1904).

Rosa macrophylla, var. acicularis M. de Vilmorin in Jour. Hort. Soc. Lond. XXVII. 487, figs. 137, 138 (1902-03).

Of this Rose we have seen no wild specimens, and we know it only from cultivated plants sent to the Arnold Arboretum by M. Maurice de Vilmorin, who raised it from seed received from China.

28. Rosa saturata Baker. See p. 324.

29. Rosa bella Rehder \& Wilson, n. sp.

Frutex erecto-patens, 1-3-metralis; rami satis graciles, saepe purpurascentes, aculeis sparsis et infrastipularibus rectis acicularibus basi leviter tantum dilatatis 4-8 mm. longis muniti, rarius fere inermes, turiones basin versus aciculati. Folia membranacea, 7-9-foliolata, raro 5-foliolata, petiolo incluso 4-9 $\mathrm{cm}$. longa; foliola breviter petiolulata, elliptica v. ovata, acutiuscula, rarius obtusiuscula, basi rotundata, 1-2 cm. longa et $0.6-1.2 \mathrm{~cm}$. lata, simpliciter serrata dentibus mucronulatis porrectis v. leviter incurvis, supra laete viridia, glabra, subtus glaucescentia, glabra v. ad costam sparse minute stipitato-glandulosa, utrinsecus nervis 5-6 curvatis subtus leviter elevatis $\mathrm{v}$. fere obsoletis; petioli 1-2 $\mathrm{cm}$. longi, ut rhachis sparse stipitatoglandulosi et aciculati; stipulae adnatae, $1-1.5 \mathrm{~cm}$. longae, in ramulis floriferis latae, in turionibus satis angustae, glabrae margine dense ciliato-glandulosa excepta, auriculis triangularibus acuminatis v, acuminulatis patentibus. Flores rosei, $4-5 \mathrm{~cm}$. diam., fragrantes, solitarii v. 2-3 in apice ramulorum brevium terminales; pedicelli $0.5-1 \mathrm{~cm}$. longi basi bracteati bracteis ovatis $\mathrm{v}$. ovato-lanceolatis acuminatis 1-1.5 $\mathrm{cm}$. longis glanduloso-ciliatis, ut receptaculum ellipsoideum v. oblongum stipitatoglandulosi; sepala ovato-lanceolata in acumen foliaceum attenuata, integra, circiter $2 \mathrm{~cm}$. longa, petalis breviora, extus stipitato-glandulosa, intus villosa, post florationem reflexa, in fruetu erecta; alabastra anguste ovata sensim attenuata; petala late obovata, emarginata, $2-2.5 \mathrm{~cm}$. longa; stamina numerosa, antheris ovalibus luteis; eapitulum stigmaticum sessile. Fructus elliptico-ovatus, satis sensim in collum attenuatus, basi plus minusve attenuatus, aurantiaco-scarlatinus, calyce persistente coronatus, sine calyce $1.5-2 \mathrm{~cm}$. longus, glanduloso-setosus.

Shansi: mountains in northwest, April 1910,W. Purdom (No. 314, seeds only). Cultivated at the Arnold Arboretum; plants raised from Purdom's No. 314: June 17 and Aug. 26, 1914, June 1915 (type).

This pretty Rose seems most closely related to $R$. Moyesii Hemsley \& Wilson, which is a much more vigorous plant with stout prickles, larger usually more acute leaflets pubescent beneath, at least on the midrib, globose-ovoid flower-buds abruptly contracted at the apex, larger flowers and pinnate sepals. It may also be compared with $R$. Sweginzowii Koehne, which differs chiefly in its stouter much 
flattened prickles, the usually doubly serrate leaflets more or less pubescent beneath, in the globose-ovoid flower-buds and in the pinnate sepals.

Rosa bella, f. pallens Rehder \& Wilson, f. $n$.

A typo recedit floribus pallide roseis.

Shansi: mountains in northwest, April 1910, W. Purdom (No. 314, seeds only, in part). Cultivated at the Arnold Arboretum; plants raised from Purdom's No. 314 , together with those of the type; June 1915, type.

Though this form differs from the type in the pale color of the flowers only, it seems desirable to distinguish it for horticultural purposes, as both forms are in cultivation.

30. Rosa Sweginzowii Koehne. See p. 324.

31. Rosa Moyesii Hemsley \& Wilson. See p. 325.

Rosa Moyesii, f. rosea Rehder \& Wilson. See p. 325.

32. Rosa Murielae Rehder \& Wilson. See p. 326.

33. Rosa sertata Rolfe. See p. 327.

34. Rosa orbicularis Baker in Willmott, Gen. Rosa, II. 493 (1914).

Yunnan: without precise locality, Th. Monbeig (ex Baker).

35. Rosa multibracteata Hemsley \& Wilson. See p. 328 .

36. Rosa Giraldii Crépin. See p. 328.

Rosa Giraldii, f. glabriuscula Rehder \& Wilson. See p. 328.

Rosa Giraldii, var. venulosa Rehder \& Wilson. See p. 328.

37. Rosa Prattii Hemsley. See p. 329.

38. Rosa Willmottiae Hemsley. See p. 329.

\section{Sect. 8. LUTEAE Crép.}

39. Rosa xanthina Lindley, Ros. Monog. 132 (1820).

Shantung: Shushan, F. N. Meyer, August 23, 1907 (No. 21620, seeds only). Cultivated at the Arnold Arboretum, raised from seed of Meyer's No. 21620, with the single-flowered form.

This species was based by Lindley on a Chinese drawing of a double flowered yellow Rose. This double Rose seems to have remained practically unknown until it was sent to Washington from Peking by Frank N. Meyer in 1907. At the Arnold Arboretum it flowered for the first time in 1915.

Rosa xanthina, f. normalis Rehder \& Wilson, n. f.

A typo differt floribus simplicibus.

Rosa pimpinellifolia Bunge in Mém. Sav. Etr. Acad. Sci. St. Pétersbourg, II. 100 (Enum. Pl. Chin. Bor. 26) (non Linnaeus) (1833). - Hemsley in Jour. Linn. Soc. XXIII. 253 (1887).

Rosa xanthina Franchet in Nouv. Arch. Mus. Paris, sér. 2, V. 269, t. 15, fig. 2 (Pl. David. I. 117) (non Lindley) (1883).

Shansi: "near Tsin-tse," May 1907, F. N. Meyer (No. 414).

We think Franchet is right in considering this the wild form of Rosa xanthina Lindley. According to Bunge (1. c.) and Bretschneider (Hist. Europ. Bot. Disc. Chin. 861 [1908]) this Rose is commonly cultivated in Peking gardens. At any rate, 
of the two yellow-flowered Roses found in China this is the one which agrees with Lindley's brief description. On our specimen the leaflets are obtusely and often doubly serrate and reticulate on the upper side, with few shining gland dots on the under side; the prickles are straight, flattened-subulate, $1.5 \mathrm{~cm}$. long, very slightly dilated at base and very woolly. The nature of its prickles, the absence of setae, the large flowers and more prominent stipules distinguish this Rose from $R$. Hugonis Hemsley.

Rosa Ecae Aitchison (in Jour. Linn. Soc. XVIII. 54 [1880]; in XIX. 161, t. 8 [1882]), which is figured as R. xanthina by Hooker f. in Bot. Mag. CXXV. t. 7666 (1899) and by Miss Willmott (Gen. Rosa, 277, t. [1911]), we consider a distinct species. It agrees with our $R$. xanthina, f. normalis in the absence of setae, but has much smaller prickles much more dilated at the base and long-pedunculate flowers. We have seen specimens from the Kew plant which was raised from seed collected by Aitchison and have specimens from Samarkand (mountains near Kulikalan, alt. 3000 m., July 10, 1910 [No. 555], and near Pasronte, alt. 2000 m., July 11, 1910 [No. 556]), colleeted by F. N. Meyer.

From his description we do not think R. platyacantha Schrenk in Bull. Acad. Sci. St. Pétersbourg, X. 254 (1842), collected by him in Songaria, has any relation to $R$. Ecae Aitchison or the wild form of Lindley's $R$. xanthina. In the setae on the shoots it is near $R$. Hugonis Hemsley, but the leaflets differ in shape and serrature; Schrenk does not mention the color of the flowers, and very probably his plant is only a geographical variant of $R$. spinosissima Linnaeus.

\section{Sect. 9. PIMPINELLIFOLIAE DC.}

Clavis specierum.

Flores rosei, graciliter pedicellati. Foliola dupliciter serrata, breviter sed manifeste petiolulata. Aculei graciles . . . . . . . 40. R. graciliflora. Flores lutei, breviter pedicellati. Foliola simpliciter serrata, subsessilia. Aculei basi valde dilatati ............ 41. R. Hugonis.

\section{EnUMeratio sPeciertum.}

40. R. graciliflora Rehder \& Wilson. See p. 330 .

41. R. Hugonis Hemsley. See p. 330.

\section{Sect. 10. SERICEAE Crép.}

Clavis specierum.

Foliola supra glabra, subtus sericea v. glabra, plerumque ovalia v. oblonga, 5-17. Receptaculum glabrum. Fruetus pedicello carnoso aurantiaco. 42. R. omeiensis. Foliola utrinque sericeo-lanuginosa, plerumque obovata, 5-7. Receptaculum sericeum . 43. R. Mairei.

\section{ENUMERATIO SPECIERUM.}

42. Rosa omeiensis Rolfe. See p. 331.

Rosa omeiensis, var. pteracantha Rehder \& Wilson. See p. 332.

43. Rosa Mairei Léveillé in Fedde, Rep. Spec. Nov. XI. 299 (1912)._-Willmott, Gen. Rosa, II. 521 (1914). 
Rosa sericea Hemsley in Jour. Linn. Soc. XXIII. 254 (non Lindley) (1887), quoad specimen Andersonii.

Yunnan: "Collines arides autour de Tong-chouan," alt. 2600 m., April 1911, E. E. Maire (type).

This is probably nothing more than a very hairy and small leaved variety of Rosa omeiensis Rolfe, but in the absence of fruiting specimens and first-hand knowledge we hesitate to reduce it to varietal rank. The specimens collected in Manipur by Watt and referred to in the Gard. Chron. ser. 3, XXXVIII. 261 (1905) and in the Bot. Mag. CXXXIV. sub. t. 8218 (1908) in all probability belong here. In the Gray Herbarium are two specimens from the Herb. Griffith (Nos. 2138, 2139) collected on the eastern Himalaya which apparently belong here also. It is unfortunate that none of the specimens are in fruit.

\section{Subfam. PRUNOIDEAE.}

Determined by ATiFred ReHDER.

The genera Maddenia and Prunus having been dealt with by E. Koehne on pp. 56-75 and 196-282 of volume I, it remains only to add here three Chinese genera not collected during the Arnold Arboretum Expeditions.

\section{PYGEUM Gärtn.}

Pygeum Henryi Dunn in Jour. Linn. Soc. XXXV, 493 (1903). - Koehne in Bot. Jahrb. LI. 185 (1913).

Yunnan: Szemao, alt. 1300-1500 m., A. Henry (Nos. 12313, 12313a $12313^{\mathrm{b}}$, 12708).

Pygeum latifolium Miquel is recorded by Hemsley (in Jour. Linn. Soc. XXIII. 223) from Hongkong and by Léveille ( $F$ l. Kouy-Tchéou, 352) from Kwei-chou, but Koehne in his synopsis of the genus (Bot. Jahrb. LI. 195) cites only Javanese specimens under $P$. latifolium and enumerates $P$. Henryi as the only Chinese species.

\section{DICHOTOMANTHES Kurz.}

Dichotomanthes tristaniaecarpa Kurz in Jour. Bot. XI. 195, t. 133, fig. 2 (1873). - Hemsley in Jour. Linn. Soc. XXIII. 307 (1887); in Hooker's Icon. XXVII. t. 2653 (1900).

Yunnan: Mengtsze, alt. 1500-1700 m., A. Henry (Nos. 9367a , 10255, 10255 $)$.

Dichotomanthes tristaniaecarpa, var. glabrata Rehder, n. var.

A typo recedit foliis initio subtus floccoso-tomentosis mox glabrescentibus, maturitate costa media excepta glabris interdum basi rotundatis apice obtusiusculis mucronulatis.

Yunnan: Szemao, alt. 1300-1500 m., A. Henry (Nos. 11959a, type, tree $7 \mathrm{~m}$. tall, fruit red; 11959, shrub $1 \mathrm{~m}$. tall, white flowers).

Except in the glabrescent leaves and a slight difference in their shape this variety agrees in all its other characters with the type.

\section{PRINSEPIA Royle.}

Sect. 1. EUPRINSEPIA Rehder, n. sect.

Prinsepia Royle, Ill. 206, t. 38, f. 1 (1839).

Flores racemosi; stamina numerosa, pluriserialia. Frutex ramis viridibus spinis validis saepe foliosis munitis. 
1. Prinsepia utilis Royle, Ill. Bot. Himal. 206, t. 38, fig. 1 (1839). - Brandis, Forest Fl. Brit. Ind. 196 (1874); Ind. Trees, 281 (1906). - Hooker f., Fl. Brit. Ind. II. 323 (1879). - Franchet, Pl. Delavay. 198 (1890). - Collett, Fl. Siml. 156 (1902). - Schneider, Ill. Handb. Laubholzk. I. 651 (1906). - Hayata in Jour. Coll. Sci. Tokyo, XXX. art. 1, 105 (Mat. Fl. Formosa) (1911); Icon. Pl. Formos. I. 219 (1911). - Diels in Not. Bot. Gard. Edinburgh, VII. 15, 286 (1912).

Yunnan: Mengtsze, A. Henry (Nos. 9281, 11343); Tali valley, alt. 2000-2400 m., G. Forrest (Nos. 146, 4974). Formosa (ex Hayata). East Himalaya.

The Formosan plant is possibly a distinct variety or species.

Sect. 2. PLAGIOSPERMUM Rehder, n. sect.

Plagiospermum Oliver in Hooker's Icon. XVI. t. 1526 (1886).

Flores fasciculati; stamina 10, bi-serialia. Frutices ramis cinereis spinis vix $1 \mathrm{~cm}$. excedentibus aphyllis munitis.

2. Prinsepia sinensis Oliver ms. apud Bean in Kew Bull. Misc. Inform. 1909, 354. - Bean, Trees \& Shrubs Brit. Isl. I. 223, fig. (1914).

Plagiospermum sinense Oliver in Hooker's Icon. XVI. t. 1526 (1886). - A. Purpus in Mitt. Deutsch. Dendr. Ges. XII. 1, t. (1903), - Komarov in Act. Hort. Petrop. XXII. 554, t. 12 (Fl. Mansh.) (1904). - De Wildeman, Icon. Hort. Then. V. 89, t. 182 (1905).

Mandshuria (ex Oliver et ex Komarov).

I know this species only from cultivated plants. It has been growing at the Arnold Arboretum since 1903 and flowers profusely every year, but fruits very rarely and sparingly. The fruits, which ripen in August, are ovoid, about $1.5 \mathrm{~cm}$. long and deep red when fully ripe.

3. Prinsepia uniflora Batalin in Act. Hort. Petrop. XII. 167 (1892); in Gartenfl. XLII. 331 (1892).

Northern Shensi: Yenan Fu, 1910, W. Purdom (No. 324; bush 1-1.25 m.).

As the flowers of this species have not yet been described, their description from the specimens collected by Purdom and from living plants cultivated at the Arnold Arboretum may follow here: Flowers white, $1.5 \mathrm{~cm}$. in diam., 1-3 together with fascicled leaves from axillary buds on last year's branches; pedicels glabrous, $3-5$ $\mathrm{mm}$. long, calyx-tube broadly turbinate, sepals semiorbicular, reflexed, ciliate, 1.5 $\mathrm{mm}$. long; petals obovate, broadly cuneate at the base, scarcely clawed, $5-6 \mathrm{~mm}$. long; stamens 10, with very short compressed filaments finally incurved, about $0.75 \mathrm{~mm}$. long, slightly longer than the orbicular-ovate yellow anthers; style lateral, curved, not exceeding the calyx-tube, with a large oblique capitate stigma. On vigorous shoots of young plants the leaves attain $6 \mathrm{~cm}$. in length, but do not exeed 7 or $8 \mathrm{~mm}$. in width; the margins are distinctly serrate, but the upper third of the leaves is usually quite entire; they are of firm, chartaceous texture, and dark green and somewhat lustrous above, and lighter below. Prinsepia uniflora Batalin is closely related to $P$. sinensis Oliver, but is easily distinguished by the much narrower subchartaceous sometimes serrulate leaves and by the short-stalked white flowers.

The plant was raised in the Arnold Arboretum in 1911 from seeds collected by Purdom in Shensi and flowered for the first time in 1914; in 1915 it produced fruits. 


\section{CELASTRACEAE.}

Determined by Alfred Rehder and E. H. Wrison.

\section{CELASTRUS L.}

Celastrus angulata Maximowicz in Bull. Acad. Sci. St. Pétersbourg, sér. 3, XXVII. 455 (1881); in Mél. Biol. XI. 199 (1881). - Loesener in Bot. Jahrb. XXIX. 446 (1900), XXX. 470 (1902). - Pampanini in Nuov. Giorn. Bot. Ital. n. ser. XVII. 106 (1910).

Celastrus latifolius Hemsley in Jour. Linn. Soc. XXIII. 123 (1886). - Oliver in Hooker's Icon. XXIII, t. 2206 (1892).

Western Hupeh: north and south of Ichang, thickets, alt. 6001300 m., June and October 1907 (No. 364; climber 3-6 m.); same locality, April and August 1900 (Veitch Exped. No. 467); Changyang Hsien, thickets, alt. 1300 m., June and November 1907 (No. 753 ; climber $6 \mathrm{~m}$., flowers greenish-white, fruit yellow, seed vermilion); Fang Hsien, thickets, alt. 1300 m., November 1907 (Nos. 364 ${ }^{\mathrm{a}}$, 753; scandent shrub $6 \mathrm{~m}$., fruit yellow); Nanto and mountains to northward, A. Henry (No. 3883); without locality, A. Henry (Nos. 5925 2084 , 3405); “Ma-pan-scian," alt. 1000 m., May 1907, C. Silvestri (No. 1336). Western Szech'uan: west and near Wên-ch'uan Hsien, alt. 600-1300 m., June 1908 (No. $364^{\text {b }}$; scandent shrub 6 m.); Nanch'uan, A. von Rosthorn (No. 790).

This scandent shrub with large and handsome leaves makes a tangled mass $6 \mathrm{~m}$. or more high and as much through; it is very abundant in western Hupeh and Szech'uan.

A pieture of this plant will be found under No. 0139 of the collection of Wilson's photographs.

Celastrus hypoleuca Warburg apud Loesener in Bot. Jahrb. XXIX. 445 (1900). - Loesener in Bot. Jahrb. XXX. 467 (1902).

Erythrospermum hypoleucum Oliver in Hooker's Icon. XIX. t. 1899 (1889).

Celastrus hypoglaucus Hemsley in Ann. Bot. IX. 150 (1895). - Léveillé, Fl. Kouy-Tchéou, 69 (1914).

Celastrus hypoleucus, forma a genuina Loesener in Bot. Jahrb]XXX. 445 (1902).

Celastrus hypoleucus, forma $\beta$ argutior Loesener, 1. c. (1902). 
Western Hupeh: Fang Hsien, thickets, alt. 2000 m., September and November 1907 (No. 362; climber 3-5 m., fruit orange-yellow); north and south of Ichang, mountains, June 1900 (Veitch Exped. No. 1063); without locality, A. Henry (Nos. 2837, 6811). Eastern Szech'uan: Wushan Hsien, A. Henry (No. 5887). Shensi: "Qua-in-san," "Thae-pei-san," "Kin-qua-san," July 1897, G. Giraldi.

This species is common on the mountains of northwest Hupeh, and in the autumn its long terminal pendant cymose racemes of long-stalked orange-yellow fruits are strikingly beautiful. The leaves vary much in the degree of glaucescence of their under surface and in degree of serration, but these characters are inconstant and we do not consider that they have taxonomic value. The leaves are deciduous, not persistent as stated by Loesener. Henry's No. 2837 was distributed from Kew under the manuscript name of " C. latifolius, var. glaucescens."

\section{Celastrus glaucophylla Rehder \& Wilson, n. sp.}

Frutex scandens, 3-6-metralis, glaber; ramuli hornotini glabri, initio pallidebrunnei, mox fusco-purpurei, sparse lenticellati; gemmae parvae, ovoideae, obtusae v. acutiusculae, fusco-brunneae. Folia decidua, subcoriacea, ovato-elliptica v. obovata, rarius elliptica, subito breviter acuminata, basi rotundata $v$. late cuneata, crenato-serrulata, interdum remote et obsolete serrulata dentibus incurvis glanduloso-mucronulatis, 4-13, plerumque 6-10 $\mathrm{cm}$. longa et $2.5-6.5 \mathrm{~cm}$. lata, supra laete viridia v. glaucescentia, subtus glauca, nervis utrinsecus 4-6 curvatis, subtus ut venulae leviter elevatis; petioli supra canaliculati, 8-12 $\mathrm{mm}$. longi. Flores virescentes in cymis paucifloris breviter pedunculatis v. subsessilibus axillaribus $v$. rarius racemos terminales $3-6 \mathrm{~cm}$. longos formantibus; bracteae et bracteolae fuscae, subulatae, 1-2 mm. longae; pedicelli medio articulati, $3-4 \mathrm{~mm}$. longi; sepala ovata, rotundata, glanduloso-ciliolata; petala oblonga, apice rotundata, leviter erosa, $5 \mathrm{~mm}$. longa et 1-1.5 mm. lata; disci glandulae parvae, ovatae, obtusae; stamina petala subaequantia, filamentis subulatis glabris; floris feminei sepala acutiora; stamina sterilia sepalis breviora; stylus crassus, 2.5 $\mathrm{mm}$. longus; stigma leviter lobatum, lobis patentibus. Capsula lutea, ovoidea, 8-11 mm. longa, 6-8 mm. diam., apiculata, 3-locularis, loculis 2-spermis; arillus scarlatinus; pedicelli crassi $6-10 \mathrm{~mm}$. longi, supra articulationem incrassati; semina ellipsoidea, utrinque attenuata, minute punctulata, $4 \mathrm{~mm}$. longa.

Western Szech'uan: Mupin, thickets, alt. 1300-1600 m., June and October 1908 (No. 952, type); Wa-shan, alt. 1600-2500 m., Sep-

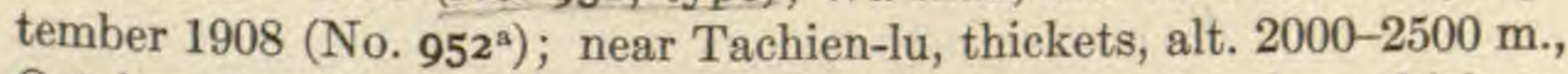
October 1910 (No. 4I22); west of Kuan Hsien, Pan-lan-shan, thickets, 
alt. 2000-2500 m., October 1910 (No. 43I7); Mt. Omei, May 1904 (Veitch Exped. No. 4782).

This species is characterized by its relatively thick and glaucous leaves, by its axillary clustered and short racemose inflorescence and by its short stout pedicels. It is nearly related to C. hypoleuca Warburg, which has thinner and smaller and much less glaucous leaves, a usually terminal racemose inflorescence which in fruit measures 6 to $15 \mathrm{~cm}$., and slightly smaller fruit on slender pedicels $1.5-4 \mathrm{~cm}$. long.

Léveillé (Fl. Kouy-Tchéou, 69) includes C. stylosa Wallich in the Kwei-chou flora and describes it with leaves glaucous on both sides. This may possibly be identical with our C. glaucophylla.

\section{Celastrus spiciformis Rehder \& Wilson, n. sp.}

Frutex scandens, 6-metralis; ramuli hornotini glabri, pallide brunnei, teretes v. leviter compressi, annotini purpureo-fusci, lenticellati; gemmae parvae, globosae. Folia membranacea, elliptica v. ellipticoovata, subito breviter acuminata, basi rotundata $\mathrm{v}$. interdum subito attenuata, crenato-serrulata dentibus incurvis glanduloso-mucronulatis, 6-11.5 cm. longa et 3.5-7.5 lata, supra glabra, intense viridia, subtus paullo pallidiora, costa nervisque puberulis exceptis glabra, nervis utrinsecus 5-6 arcuatis subtus elevatis; petioli supra leviter canaliculati, 1-1.7 cm. longi; glabri. Flores polygamo-dioeci, flavoalbidi, in cymis paucifloris brevissime pedunculatis, partim axillaribus, partim racemum terminalem pendentem 5-12 $\mathrm{cm}$. longum formantibus; bracteae bracteolaeque membranaceae, subulatae, 1-5 mm. longae, deciduae; pedunculi 1-5 $\mathrm{mm}$. longae; pedicelli filiformes, 3-10 mm. longi; flos femineus: sepala ovata, rotundata, glandulosociliolata; petala patentia v. recurva, oblonga v. spathulata, apice rotundata, erosa, $2-2.5 \mathrm{~mm}$. longa et $0.5-1 \mathrm{~mm}$. lata; discus leviter lobatus; stamina calycem aequantia, antheris parvis sterilibus (?); pistillum $3 \mathrm{~mm}$. longum, stylo crasso, stigmatibus leviter lobatis; flos mas differt petalis $3 \mathrm{~mm}$. longis, staminibus petala aequantibus, pistillo abortivo. Fructus non visus.

Western Hupeh: Hsing-shan Hsien, thickets, alt. 2000 m., June 1907 (No. 2312, type); Fang Hsien, margin of wood, alt. 1600-2000 m., June 1901 (Veitch Exped. No. 2215); without locality, A. Henry (No. 5935). Eastern Szech'uan: Wushan Hsien, side of stream, alt. 1300 m., July 1900 (Veitch Exped. No. 1383). Western Szech'uan: west of Kuan Hsien, Pan-lan-shan, thickets, alt. 2300-3000 m., June 1908 (No. 2306).

This is a puzzling plant somewhat intermediate in character between $C$. angulata Maximowiez and C. hypoleuca Warburg. The former differs in its markedly 
angular browner and more uniformly densely lenticellate branches, its much larger quite glabrous leaves and especially in its erect, much branched pyramidal inflorescence. C. hypoleuca differs in its smaller, thicker leaves, glaucous on the under side, longer pedicels, and in its rather longer flowers with more acute calyx-lobes and petals. In general appearance this new species differs conspicuously from C. hypoleusca and more closely resembles $C$. angulata, so much so in fact that Henry's No. 5935 was distributed from Kew as C. latifolia Hemsley which is synonymous with Maximowiez's species. Celastrus spiciformis is not uncommon in thickets and margin of woods throughout northwest Hupeh and Szech'uan.

Specimens collected at "Lao-y-san, pr. Zulu" in northern Shensi by Giraldi may belong here.

\section{Celastrus spiciformis, var. laevis Rehder \& Wilson, n. var.}

A typo recedit foliis subtus glaberrimis leviter glaucescentibus.

Capsula subglobosa stylo coronata, 6-7 mm. longa, luteo-aurantiaca, valvis 3,2 -spermis; semina ovoidea, $3.5 \mathrm{~mm}$. longa, late reticulata et minute punctulata, intense fusco-brunneo, lucidula.

Western Szech'uan: Wa-shan, thickets, alt. 1600-2000 m., June and October 1908 (No. II76, type). Yunnan: Mengtsze, mountains north, alt. 2300 m., A. Henry (No. 11006).

This variety is distinguished from the type by the perfectly glabrous under side of the leaves. On the fruiting branch of No. 1176 the leaves are elliptic-lanceolate and slightly glaucescent on the under side. In this slightly glaucescent character this variety shows a further approach to C. hypoleuca Warburg, but in this species the pedicel of the fruit is two to three times the length of that of our new variety and the fruit of $C$. hypoleuca is also much larger.

\section{Celastrus rugosa Rehder \& Wilson, n. sp.}

Frutex scandens, 3-6-metralis; ramuli glabri, striati v. angulares, lenticellis parvis notati, annotini pallide griseo-brunnei, vetustiores fusci; gemmae parvae, subglobosae v. ovoideae, brunneae, perulis ad basin ramulorum persistentibus. Folia decidua, membranacea, ovatoelliptica v. elliptica v. elliptico-oblonga, rarius obovata, breviter acuminata, basi rotundata v. late cuneata, rarius attenuata, crenatoserrata v. serrato-dentata dentibus incurvis glanduloso-mueronulatis, 5-13 cm. longa et 3-8 cm. lata, supra laete viridia, glabra, plus minusve bullata, subtus paullo pallidiora, glabra v. ad nervos nervulosque puberula, nervis utrinque 5-6 curvatis ut venulae prominentibus, maturitate reticulata; petioli supra canaliculati, glabri, 1-1.5 cm. longi. Flores virescentes solitarii v. in cymis 3 -floris partim axillaribus partim racemum terminalem $3-4.5 \mathrm{~cm}$. longum formantibus; bracteae et bracteolae subulatae, $1.5-4 \mathrm{~cm}$. longae; rhachis racemi apicem versus puberula; pedicelli 3-5 $\mathrm{mm}$. longi; sepala late ovata, $2 \mathrm{~mm}$. longa, rotundata, glanduloso-ciliolata; petala oblonga, $5 \mathrm{~mm}$. longa, $1.5 \mathrm{~mm}$. 
lata, apice rotundata leviter erosa; disci glandulae 5, triangulares acutae, $0.5 \mathrm{~mm}$. longae; stamina $4 \mathrm{~mm}$. longa, filamentis subulatis glabris; flores feminei non visi. Capsulae in cymis axillaribus v. in racemis terminalibus $5-7 \mathrm{~cm}$. longis, luteo-aurantiacae, globosae, 8-10 $\mathrm{mm}$. longae, apiculatae, valvis 3,2 -spermis transverse striatis; pedicelli 5-8 mm. longi, striati, purpurascentes, lenticellati, apice incrassati; semina oblonga, late reticulata, circiter $5 \mathrm{~mm}$. longa, fusco-brunnea, nitidula.

Western Szech'uan: west and near Wên-ch'uan Hsien, thickets, alt. 1600-2000 m., June and October 1908 (No. I Io6, type); Mupin, woodlands, alt. 1600-2100 m., June and October 1908 (Nos. 2310, Ir48); same locality, alt. 2500 m., May 1904 (Veitch Exped. No. 3325); Tachien-lu, alt. 2300-2600 m., October 1910 (No. 4II7); near Sungpan Ting, thickets, alt. 2300-2800 m., October 1910 (No.4I57). Western Hupeh: Fang Hsien, thickets, alt. 2000 m., September 1907 (No. $357)$.

A well-marked species characterized by its bullate, coarsely toothed leaves very prominently veined on the under side and by its axillary eymes and terminal cymose panicles. It is allied to $C$. articulata Thunberg, which has shining smooth leaves in which the principal veins are not raised and the fruits are in axillary cymes.

This handsome species is common in western Szech'uan, but is rare in Hupeh.

Celastrus articulata Thunberg, var. cuneata Rehder \& Wilson, n. var.

A typo recedit petiolis multo brevioribus $2-5 \mathrm{~mm}$. longis, foliis minoribus obovatis v. late obovatis basi manifeste cuneatis apice truncatis v. emarginatis v. brevissime cuspidatis $2-4.5 \mathrm{~cm}$. longis et $1.6-4$ $\mathrm{cm}$. latis, petiolis $2-5 \mathrm{~mm}$. longis.

Western Hupeh: Ichang, roadsides and thickets, alt. 30-600 m., April and November 1907 (No. 2308, type); same locality, April 1900 (Veitch Exped. No. 181).

This variety is well distinguished by its rather small, short-petioled obovate leaves which are rounded and truncate, usually short cuspidate but of ten emarginate at the apex and cuneate at the base. This plant is very abundant at low altitudes round lchang and on the river-banks westward to Szech'uan. The specimen from Kiukiang alluded to in a note by Hemsley (in Jour. Linn. Soc. XXIII. 122) probably belongs here.

\section{Celastrus Loeseneri Rehder \& Wilson, n. sp.}

Celnstrus articulatus Hemsley in Jour. Linn. Soc. XXIII. 122 (pro parte) (non Thunberg) (1886), - Loesener in Bot. Jahrb. XXIX. 446 (pro parte) (1900). Celastrus orbiculata Loesener in Bot. Jahrb. XXX. 468 (pro parte) (non Thunberg) (1902). 
Frutex scandens, 3-6-metralis, glaber; ramuli teretes v. leviter striati, fusco- v. griseo-brunnei, lenticellis parvis notati; gemmae parvae, late ovatae, obtusae v. subacutae. Folia decidua, chartacea, elliptica v. elliptico-lanceolata, rarius ovato-elliptica, acuminata v. subito breviter acuminata, basi rotundata v. late cuneata, crenatoserrata v. serrata dentibus incurvis glanduloso-mucronulatis, 4.5-11 $\mathrm{cm}$. longa et 3-6.5 $\mathrm{cm}$. lata, supra viridia, opaca, subtus vix pallidiora, nervis utrinsecus 4-6 curvatis, supra, in sicco saltem, et subtus leviter elevatis, venulis obsoletis; petioli supra leviter canaliculati, 5-12 $\mathrm{mm}$. longi. Flores albo-virides, in ramis lateralibus paucifoliatis v. rarius aphyllis racemos terminales 3-4 cm. longos et cymas axillares paucifloras subsessiles formantes; bracteae subulatae, membranaceae, 1-2 $\mathrm{mm}$. longae; pedicelli filiformes, $5-7 \mathrm{~mm}$. longi; sepala rotundata, glanduloso-ciliata, tubum calycis subaequentia; petala oblonga v. spathulata, 3.5-4 mm. longa et 1-1.5 mm. lata, leviter concava, erectopatentia, leviter erosa; glandulae disci 5 parvae, latae; stamina petalis paullo breviora, filamentis subulatis glabris; flores pistillati non visi. Capsula 3-valvata et 3-locularis, subglobosa apiculata, lutea, $1 \mathrm{~cm}$. longa et $8 \mathrm{~mm}$. diam., valvis transverse striatis; pedicellus lenticellatus, infra capsulam subito incrassatus; semina in quoque loculo bina, obtuse trigono-oblonga $\mathrm{v}$. fere ellipsoidea, $4.5 \mathrm{~mm}$. longa, dorso late reticulata, atrobrunnea.

Western Hupeh: Hsing-shan Hsien, thickets, alt. 1300-2000 m., May and November 1907 (Nos. 357 $7^{\mathrm{a}}$, type, 2309, 560); Patung Hsien, thickets, alt. 1000-1300 m., October 1907 (No. 503); Changyang Hsien, thickets, alt. 1500 m., November 1907 (No. 688); without precise locality, A. Henry (Nos. 5986, 5986 ${ }^{\mathrm{a}}$ 5909). Eastern Szech'uan: Wushan Hsien, A. Henry (No. 5640, 5734).

This species has been confused with the Japanese C. articulata Thunberg, yet it is really very distinct and when seen growing side by side no one would confuse them. In herbaria the differences are not so obvious, although the leaves and character of the inflorescence differ markedly. The Japanese plant has thinner, more or less orbicular leaves, usually cuneate at the base but occasionally truncate, the upper surface is rather lustrous green and the venation is distinctly reticulate; the flowers are larges and always borne in stalked axillary cymose clusters. Celastrus articulata, var. punctata Makino approaches $C$. Loeseneri in the shape of its leaves, but differs in other particulars, as does the type species.

Celastrus Loeseneri is very common in western Hupeh, and the leaves which are rather fleshy are apt to fall off in drying.

Celastrus Rosthorniana Loesener in Engler, Bot. Jahrb. XXIX. 445 (1900), XXX. 468 (1902). — Léveillé, Fl. Kouy-Tchéou, 69 (1914). 
Western Szech'uan: Chiu-ting-shan, thickets, alt. 1300-1600 m., May 22, 1908 (No. 23II; scandent shrub 4-6 m., flowers greenishwhite); west and near Wên-ch'uan Hsien, thickets, alt. 1600-2300 m., October 1908, 1910 (Nos. II47, seeds only, II75, 4I95; scandent shrub 3-6 m., fruit orange-yellow); southeast of Tachien-lu, thickets, alt. 2000 m., October 1910 (No. 4r87; scandent shrub 4-5 m. tall); Mt. Omei, May 1904 (Veitch Exped. No. 4781). Western Hupeh: without locality, A. Henry (No. 3115).

Fairly common in western Szech'uan and easily recognized by its rather small, thick and shining leaves which are deciduous, not persistent as stated by Loesener. The ripe capsule is orange-yellow. The winter-buds are ovoid, more or less acute, and on the older branches the bark splits and becomes loose and fibrous.

Celastrus gemmata Loesener in Bot. Jahrb. XXX. 468 (1902).

Kiangsi: Kuling, thickets, alt. 1300 m., July 28, 1907 (No. I5I9; climber 5 m.). Western Hupeh: Hsing-shan Hsien, thickets, October 1907 (Nos. 502, 363; climber 3-5 m., fruit golden); Fang Hsien, margin of woods, June and October 1901 (Veitch Exped. Nos. 919, 972, $2215^{\mathrm{a}}$ ); without locality, A. Henry (No. 7614). Western Szech'uan: west and near Wên-ch'uan Hsien, thickets, alt. 2000 m., July 1908 (No. 2305; climber 3-5 m., flowers greenish); near Monkong Ting, thickets, alt. 2000-2300 m., June 19, 1908 (No. 2305 ; climber 3-5 m., flowers greenish); southeast of Tachien-lu, thickets, alt. 1600-2300 m., June and October 1908 (No. I302; climber 3-6 m., flowers greenish, fruit orange-yellow). Yunnan: Mengtsze forests, alt. 1800-2000 m., A. Henry (Nos. 9782 ${ }^{\mathrm{a}}, 10531,11471$ ); south of the Red River from Manmei, alt. 2000 m., A. Henry (No. 9679ª).

This handsome species is common and widely distributed in central and western China and is easily recognized by its large pointed winter-buds. The leaves are very variable in shape, subcoriaceous in texture and with well-marked reticulate venation. Occasionally the principal veins on the under side of the leaf are slightly puberulous or are coated with scaly excrescences. The fruit is very large and goldenyellow, and the shoots are angular when young and densely lenticellate. Henry's No. 7614 was distributed from Kew as C. articulata. Loesener refers Henry's No. $9679^{a}$ to C. stylosa Wallich, but the winter-buds in that species are routhded or very obtuse.

Celastrus Hookeri Prain in Jour. Asiat. Soc. Bengal, LXXII. pt. 2, 197 (1904); Novit. Ind. 418 (1905).

Celastrus stylosa Lawson in Hooker f., Fl. Brit. Ind. I. 618 (pro parte, non Wallich) (1875).

Eastern Szech'uan: Wushan Hsien, without locality, A. Henry (No. 5559). Western Szech'uan: Wa-shan, thickets, alt. 2000 m., 
October 1908 (No. II84; scandent bush 5 m., fruit orange-yellow). Yunnan: Mengtsze, forests, alt. 1600-2000 m., A. Henry (Nos. 10522, 11267). Fokien: Dunn's Exped., April to June 1905 (Hongkong Herb., Nos. 2479, 2479 b 3420). In dia : "Khasia, alt. 4-5000 ped.," Hooker \& Thomson; Sikkim, "Singalala forests, alt. 7000 ft.," January $1900, C$. G. Rogers.

In our specimens the filaments of the stamens are glabrous; the capsules are orange-yellow, and the leaves on the fruiting branches dry green; on the flowering branches they dry brownish. They all agree well with Rogers' Sikkim specimen. The shoots, peduncles and pedicels on the specimens enumerated are more or less rufo-puberulous, a peculiarity unknown to us among other species except $C$. Kusanoi Hayata from Formosa. We suspect the snecimens referred to C. stylosa by Franchet (Pl. Delavay. 131 [1889]) belong here. Loesener (in Bot. Jahrb. XXX. 469 [1902]) refers Henry's No. 11267 to C. articulata. The specimens from Fokien seem to differ somewhat from typical $C$. Hookeri, but the material consisting of immature fruit only is too imperfect for definite determination.

Celastrus Hindsii Bentham, var. Henryi Loesener, in Bot. Jahrb. XXIX. 444 (1900); XXX. 467 (1902).

Western Hupeh: Changlo Hsien, thickets, alt. 1150 m., May 1907 (No. 56 $\mathrm{I}^{\mathrm{s}}$; scandent bush 1-2 m.); Ichang, ravines, alt. 300-1000 m., July and October, 1907 (No. 56r ; scandent bush 1-2 m., fruit orange); Patung Hsien, thickets, 1000 m., October 1901 (Veitch Exped. No. 450); without locality, A. Henry (Nos. 3495, 3495ª 3856). Western Szech'uan: Mt. Omei, alt. 1000 m., September 1908 (No. 2307; scandent bush $3 \mathrm{~m}$.); Kiating $\mathrm{Fu}$, roadside thickets, alt. $600 \mathrm{~m}$., May 1904 (Veitch Exped. Nos. 3324, 3324ª).

This is a common evergreen shrub at low altitudes in western Hupeh and Szech'uan. In addition to the characters given by Loesener it differs from the type species in having subsessile and very shortly peduncled eymes.

\section{CLAVIS SPECIERUM SINENSIUM JAPONICARUMQUE GENERIS CELASTRI.}

Capsula 3-loeularis, 3-6-sperma. Folia decidua.

Inflorescentia semper terminalis, paniculata, pedunculata, gemmis destituta. Ramuli teretes.

Folia plerumque oblonga; petioli $0.5-1 \mathrm{~cm}$. longi . . . . 1. C. dependens. Folia plerumque obovata v. late elliptica; petioli $1 \mathrm{~cm}$. longi v. ultra.

2. C. paniculata.

Ramuli angulares. Folia plerumque late ovala, ad $12 \mathrm{~cm}$. lata; petioli $2 \mathrm{~cm}$. longi v. ultra .................. . angulata.

Inflorescentiae cymosae, axillares et insuper saepe in spicam v. racemum terminalem gemmiferum collectae.

Folia subtus et interdum supra glauca. Flores partim racemos terminales formantes. 
Racemi terminales ad $15 \mathrm{~cm}$. longi, pedicellis gracilibus $2-3 \mathrm{~cm}$. longis. Folia membranacea.

4. C. hypoleuca.

Racemi terminales ad $6 \mathrm{~cm}$. Iongi, pedicellis brevibus vix $1 \mathrm{~cm}$. longis. Folia subcoriacea . . . . . . . . . . 5. C. glaucophylla.

Folia subtus viridia.

Stipulae molles, demum deciduae.

Ramuli glabri.

Flores partim axillares, partim in racemum $\mathrm{v}$. spicam terminalem collecti.

Folia anguste lanceolata, tenuiter denticulata, glabra.

Folia latiora nervis subtus saepe puberulis.

6. C. Franchetiana.

Folia subtus non reticulata nervis secundariis leviter tantum elevatis. Racemi ad $12 \mathrm{~cm}$. longi, pendentes . 7. C. spiciformis.

Folia subtus reticulata. Racemi ad $6 \mathrm{~cm}$. longi. . . 8. C. rugosa.

Flores fere omnes axillares, saepe in parte inferiore aphylla ramulorum

$v$. in ramulis aphyllis, rarius in racemum terminalem brevem collecti (confer etiam No. 8).

Gemmae parvae.

Cymae pedunculatae pedunculis pedicellis subaequilongis. Folia plerumque obovata v. late ovalia. . . . . 9. C. articulata.

Cymae subsessiles v. breviter pedunculatae. Folia plerumque elliptica v. oblonga; petioli $0.5-1.2 \mathrm{~cm}$. longi.

Folia crenato-serrulata, membranacea, supra opaca, subtus leviter reticulata. . . . . . . 10. C. Loeseneri.

Folia minute serrulata, subcoriacea, supra lucida, subtus nervulis obsoletis . . . . . . . . 11. C. Rosthorniana.

Gemmae ovato-conicae, 7-10 mm. longae. Folia plerumque elliptica; petioli 1-1.5 $\mathrm{cm}$. longi . . . . . . 12. C. gemmata.

Ramuli puberuli $\nabla$. fusco-pilosuli.

Folia glabra v. subtus ad nervos tantum pilosula.

Folia elliptica v. elliptico-oblonga, subtus glabra . . 13. C. Hookeri.

Folia suborbicularia, subtus ad nervos pilosula. 14. C. Kusanoi.

Folia brevissime pilosa, ovato-lanceolata. . . . . 15. C. Esquiroliana. Stipulae induratae, spinescentes: folia minute cilioso-serrulata.

16. C. flagellaris.

Capsula 1-locularis, monosperma. Folia persistentia.

Flores in cymis 3 -floris v. solitarii, breviter pedicellati, plerumque axillares. Folia satis dense reticulata. .......... 17. C. Hindsii.

Flores in cymis saepe plurifloris manifeste pedunculatis, saepe paniculam terminalem formantibus.

Folia elliptica v, oblonga, basi plerumque cuneata.

Folia venulis obsoletis, serrulata, 6-12 cm. longa. . . 18. C. monosperma. Folia utrinque reticulata, parce spinuloso-denticulata, 4-6 cm. longa.

19. C. cantoniensis.

Folia ovalia v. late elliptica, ad $7 \mathrm{~cm}$. lata, basi rotundata, non reticulata.

20. C. Benthamii.

\section{ENUMERATIO SPECIERUM.}

Series 1. PANICULATAE Rehder \& Wilson, n. ser.

Flores omnes in paniculis terminalibus plerumque pedunculatis. Folia decidus. Capsula 3-locularis.

To this series belongs also the American $C$. scandens Linnaeus. 
1. Celastrus dependens Wallich in Roxburgh, Fl. Ind. I. 389 (1824); Cat. No. 4302 (1829).

Celastrus multiflorus Roxburgh, Fl. Ind. I. 389 (non Lamarck) (1824); ed. 2, I. 622 (1832). - Prain in Jour. Asiat. Soc. Bengal, LXXIII. pt. 2, 196 (1904); Novit. Ind. 417 (1905).

Celastrus alnifolia D. Don, Prodr. Fl. Nepal. 190 (1825). - De Candolle, Prodr. II. 6 (1825).

Celastrus paniculata Lawson in Hooker f., Fl. Brit. Ind. I. 617 (pro parte, non Willdenow) (1875). - Loesener in Bot. Jahrb. XXX. 470 (1902), quoad specimen Henryanum No. $12122^{\mathrm{a}}$.

Yunnan: Szemao, forests, alt. 1500-1600 m., A. Henry (Nos. 12122, 12122 $12122^{\mathrm{b}}$ ). - Also on the Himalaya and in Assam and upper Burma.

2. Celastrus paniculata Willdenow, Spec. I. 1125 (1797), - Roxburgh, Fl. Ind. II. 388 (1824). - De Candolle, Prodr. II. 6 (1825). - Wallich, Cat. No. 4310 (1829). - Wight, Ill. 176, t. 72 (1840); Icon. I. t. 158 (1840). - Thwaites, Enum. Pl. Zeylan. 72 (1864). - Lawson in Hooker f., Fl. Brit. Ind. I. 617 (pro parte) (1875). - Loesener in Bot. Jahrb. XXX. 470 (1902), exclud. specimine Henryano No. $12122^{a}$. - Prain in Jour. Asiat. Soc. Bengal, LXXIII. pt. 2, 195 (1904); Novit. Ind. 416 (1905). - Pitard in Lecomte, Fl. Indo-Chin. I. 890 (1912).

Celastrus Rothiana Roemer \& Schultes, Syst. Veg. V. 423 (1819).

Ceanothus paniculatus Roth, Nov. Sp. 154 (1821).

Celastrus nutans Roxburgh, Fl. Ind. II. 390 (1824). - Prain in Jour. Asiat. Soc. Bengal, LXXIII. pt. 2, No. 5, 196 (1904); Novit. Ind. 417 (1905).

Scutia? paniculata G. Don, Gen. Syst. II. 34 (1832).

Celastrus Metziana Turczaninow in Bull. Soc. Nat. Mosc. XXXI. 447 (1858).

Yunnan: Szemao, forests, alt. 1500-1600 m., A. Henry (No. 11993, 12572, $12572^{\mathrm{b}}$ ). - Also in India and Burma.

3. Celastrus angulata Maximowicz. See p. 346.

Series 2. AXILLARES, Rehder \& Wilson, n. ser.

Flores axillares, solitarii v. in cymis paucifloris interdum in superiore parte aphylla ramulorum pseudo-paniculam formantes. Folia decidua. Capsula 3-locularis.

Though the flowers are mostly axillary, in some species they are partly crowded at the end of the branchlets into a more or less elongated false panicle leafy at the base, which differs from the true panicle of the preceding section in the absence of a peduncle, in the presence of axillary flowers below the terminal inflorescence, and in the presence of winter-buds in the axils of the flower-bearing bracts at least in the lower part of the inflorescence; these winter-buds are entirely absent in the usually more compound panicle of the preceding section. We consider $C$. articulata Thunberg the type of this series.

4. Celastrus hypoleuca Warburg. See p. 346 .

5. Celastrus glaucophylla Rehder \& Wilson. See p. 347 .

6. Celastrus Franchetiana Loesener in Bot. Jahrb. XXX. 470 (1902).

Celastrus racemulosa Franchet in Bull. Soc. Bot. France, XXXIII. 455 (non Hasskarl) (1886); Pl. Delavay. 132 (1889).

Yunnan: "Mo-so-yn," Delavay (ex Franchet). 
7. Celastrus spiciformis Rehder \& Wilson. See p. 348.

Celastrus spiciformis, var. laevis Rehder \& Wilson. See p. 349.

8. Celastrus rugosa Rehder \& Wilson. See p. 349.

9. Celastrus articulata Thunberg, Fl. Jap. 97 (1784). - De Candolle, Prodr. II. 7 (1825). - Bunge in Mém. Sav. Êtr. Acad. Sci. St. Pétersbourg, II. 88 (Enum. Pl. Chin. Bor. 14) (1835). - Maximowicz in Bull. Acad. Sci. St. Pétersbourg, sér. 3, XXVII. 456 (1881); in Mél. Biol. XI. 200 (1881). - Franchet in Nouv. Arch. Mus. Paris, sér. 2, V. 222 (Pl. David. I. 70) (1883). - Hemsley in Jour. Linn. Soc. XXIII. 122 (pro parte) (1886). - Sargent in Garden \& Forest, III. 551, fig. 73 (1890). Hooker f. in Bot. Mag. CCXXIV. t. 7599 (1898), - Loesener in Bot. Jahrb. XXIX. 446 (pro parte) (1900).

Celastrus orbiculatus Thunberg, $F l$. Jap. p. xlii (nomen nudum) (1784). Poiret, Encycl. Méth. Suppl. II. 144 (1811). - Loesener in Bot. Jahrb. XXX. 468 (pro parte) (1902), - Pampanini in Nuov. Giorn. Bot. Ital. n. ser. XVII. $106(1910)$.

Celastrus Tatarinowii Ruprecht in Bull. Acad. Sci. St. Pétersbourg, sér. 2, XV. 357 (1857).

Celastrus n. sp. Maximowicz, in Mém. Sav. Êtr. Acad. Sci. St. Pétersbourg, IX. 470 (Prim. Fl. Amur.) (nomen nudum) (1859).

Celastrus crispula Regel in Ind. Sem. Hort. Petrop. 51 (1861). - Maximowicz in Bull. Acad. Sci. St. Pétersbourg, sér. 3, XXVII. 457 (1881); in Mél. Biol. XI. 202 (1881). - Hemsley in Jour. Linn. Soc. XXIII. 123 (1886). Loesener in Bot. Jahrb. XXX. 470 (1902).

Chili: Peking-Kalgan road, hills near Great Wall, October 5, 1905, J. G. Jack. Mandshuria: Jehol, A. David (No. 1783, in Herb. Gray). Korea: "Port Chusan," 1859, C. Wilford (in Herb. Gray); Ping-yang, September 18, 1905, J. G. Jack; Quelpaert, May 1908, 1909, Taquet (Nos. 633, 2722).

Celastrus articulata, var. punctata Makino in Tokyo Bot. Mag. XXI. 138 (1907). - Matsumura, Ind. Pl. Jap. II. pt. 2, 319 (1912).

Celastrus punctatus Thunberg, Fl. Jap. 97 (1784).

Celastrus striatus Miquel in Ann. Mus. Lugd.-Bat. II. 210 (non Thunberg) (1865-66); in Prol. Fl. Jap. 142 (1867).

Celastrus kiusianus Franchet \& Savatier, Enum. Pl. Jap. II. 314 (1879).

Celastrus articulatus, var. $\beta$ Maximowiez in Bull. Acad. Sci. St. Pétersbourg, sér. 2, XXVII. 456 (1881); in Mél. Biol. XI. 201 (1881).

Celastrus orbiculatus, var. punctatus Rehder in Bailey, Cycl. Am. Hort. I. 267 (1900).

Celastrus articulatus, var. humilis Matsumura, Ind. Pl. Jap. II. pt. 2, 319 (1912).

Fokien: "Kushan, alt. 200 ft.," Dunn's Exped., April 26, 1905 (No. 2483, Hongkong Herb.). Korea: Port Hamilton, 1859, C. Wilford (in Herb. Gray).

Celastrus articulata, var. cuneata Rehder \& Wilson. See p. 350.

10. Celastrus Loeseneri Rehder \& Wilson. See p. 350.

11. Celastrus Rosthorniana Loesener. See p. 351.

12. Celastrus gemmata Loesener. See p. 352.

13. Celastrus Hookeri Prain. See p. 352.

14. Celastrus Kusanoi Hayata in Jour. Coll. Sci. Tokyo, XXX, art. 1, 60 (1911).

Formosa: Takow, Ape's Hill, A. Henry (No. 1893). 
In this specimen the leaves are 4.5 to $7 \mathrm{~cm}$. long and 5 to $7 \mathrm{~cm}$. broad, and the principal veins on the underside near the base have few or many short, straight spreading hairs, otherwise it agrees with Hayata's description.

15. Celastrus Esquiroliana Léveillé, $F l$. Kouy-Tchéou, 69 (1914).

Kwei-chou: "Tong-chéou," J. Esquirol, No. 3618 (ex Léveillé).

We have not seen a specimen of this species.

16. Celastrus flagellaris Ruprecht in Bull. Acad. Sci. St. Pétersbourg, sér. 2, XV. 357 (1857); Decas Pl. Amur. t. 4 (1859). - Maack, Ilymeu. Aмyp. 72 t. [29] (1859). - Maximowicz in Bull. Acad. Sci. St. Pétersbourg, sér. 3, XXVII. 457 (1881); in Mél. Biol. XI. 302 (1881). - Franchet in Nouv. Arch. Mus. Paris, sér. 3, V. 223 (Pl. David. I. 71) (1883). - Hemsley in Jour. Linn. Soc. XXIII. 123 (1886), - Loesener in Bot. Jahrb. XXX. 470 (1902). - Matsumura, Ind. Fl. Jap. II. pt. 2, 319 (1912).

Celastrus ciliidens Miquel in Ann. Mus. Lugd.-Bat. II. 85 (1865-66).

Celastrus clemacanthus Léveillé in Fedde, Rep. Spec. Nov. VIII. 284 (1910).

This species is confined to northeastern Asia and is common in Korea, but much less so in Mandshuria and Japan.

Series 3. SEMPERVIRENTES Maximowicz in Bull. Acad. Sci. St. Pétersbourg, sér. 3, XXVII. 455 (1881); in Mél. Biol. XI. 198 (1881).

17. Celastrus Hindsii Bentham in Hooker's Jour. Bot. \& Kew Gard. Misc. III. 334 (1851). - Maximowicz in Bull. Acad. Sci. St. Pétersbourg, sér. 3, XXVII. 455 (1881); in Mél. Biol. XI. 199 (1881). - Hemsley in Jour. Linn. Soc. XXIII. 123 (1886). - Loesener in Bot. Jahrb. XXX. 466 (1902), - Dunn \& Tutcher in Kew Bull. Misc. Inform. add. ser. X. 61 (Fl. Kwangtung \& Hongk.) (1912), - Pitard in Lecomte, Fl. Indo-Chin. I. 892 (1912).

Catha monosperma Bentham in Lond. Jour. Bot. I. 483 (1842).

Celastrus monospermus Bentham, Fl. Hongk. 63 (non Roxburgh) (1861).

Yunnan: Mengtsze, mountains, alt. 2300 m., A. Henry (No. 10559).

Celastrus Hindsii, var. Henryi Loesener. See p. 353.

18. Celastrus monosperma Roxburgh, Hort. Beng. 18 (nomen nudum) (1814); Fl. Ind. II. 394 (1824); ed. 2, I. 625 (1832). - Wallich, Cat. Nos. 4311, 7009 (1829-30). - Lawson in Hooker f., Fl. Brit. Ind. I. 618 (1875) excludendis synon. - Loesener in Bot. Jahrb. XXX. 467 (1902). - Léveillé, Fl. Kouy-Tchéou, 69 (1914).

Yunnan: Mengtsze, forests to southeast, alt. 1600 m., A. Henry (Nos. 10446, 11399); Szemao, mountains west, alt. 1500-1600 m., A. Henry (Nos. 11972, $11972^{\mathrm{b}}$; large climber, flowers white, fruit yellow). - Also on the Himalayas and in Assam and Bengal.

The thinner leaves, more or less narrowed to the base, distinguishes this from the elosely related C. Benthamii Rehder \& Wilson, which is apparently confined to Hongkong and the neighborhood.

19. Celastrus cantonensis Hance in Jour. Bot. XXIII. 323 (1885). - Hemsley in Jour. Linn. Soc. XXIII. 122 (1886). - Loesener in Bot. Jahrb. XXX. 467 (1902). - Dunn \& Tutcher in Kew Bull. Mise. Inform. add. ser. X, 62 (Fl. Kwangtung \& Hongk.) (1912).

South China: Kwangtung (ex Hance). 
20. Celastrus Benthamii Rehder \& Wilson, n. comb.

Catha Benthamii Gardner \& Champion in Hooker's Jour. Bot. \& Kew Gard. Misc. I. 310 (1849).

Celastrus Championii Bentham in Hooker's Jour. Bot. \& Kew Gard. Misc. III. 334 (1851); Fl. Hongk. 64 (1861). - Maximowicz in Bull. Acad. Sci. St. Pétersbourg, sér. 3, XXVII. 455 (1881); in Mél. Biol. XI. 198 (1881). Hemsley in Jour. Linn. Soc. XXIII. 122 (1886). - Loesener in Bot. Jahrb. XXX. 467 (1902), - Dunn \& Tutcher in Kew Bull. Misc. Inform. add. ser. X. 61 (Fl. Kwanglung \& Hongk.) (1912).

The specimens we have seen are all from Hongkong, but Dunn \& Tutcher report it from the neighboring island of Lantao and from the mainland opposite Hongkong. It is very elosely related to the Indian $C$. monosperma Roxburgh, but may be distinguished in herbaria by its more coriaceous leaves which are always rounded at the base.

\section{SPECIES EXCLUDENDAE.}

Celastrus alatus Thunberg, Fl. Jap. 98 (1784) = Evonymus alata Regel.

Celastrus Bodinieri Léveillé in Fedde, Rep. Spec. Nov. XIII. 263 (1914) = Ilex purpurea, var. Oldhamii Loesener secundum Loesener in Ber. Deutsch. Bot. Ges. XXXII. 541 (1914).

Celastrus Cavaleriei Léveillé, 1. c. $262(1914)$ = Myrsinacea, verisimiliter Rapanea spec., secundum Loesener, 1. c.

Celastrus diversifolia Hemsley in Jour. Linn. Soc. XXIII. $123(1886)=$ Gymnosporia diversifolia Maximowicz. Lawson.

Celastrus emarginata Roth, Nov. Spec. 155 (1821) = Gymnosporia emarginata

Celastrus Esquirolii Léveillé in Fedde, Rep. Sp. Nov. XIII. 262 (1914) = Sabia parviflora Wallich v. spec. affinis, secundum Loesener, 1. c.

Celastrus euonymoidea Léveillé, Fl.Kouy-Tchéou, 419 (pro syn.) (1915) = Grewia parviflora, var. glabrescens Rehder \& Wilson.

Celastrus Feddei Léveillé, 1. c. $263(1914)=$ Grewia spec., secundum Loesener, 1. c. 543 .

Celastrus Kouytchensis Léveillé,1. c. 263 (1914) = Euphorbiacea ad Phyllanthoideas ducenda, secundum Loesener, 1. c. 543.

Celastrus Lyi Léveillé, 1. c. 264 (1914) = Rhamnacea, verisimiliter Sageretia spec., secundum Loesener, 1 . c.

Celastrus Mairei Léveillé, 1. c. 264 (1914) = Sabia yunnanensis, secundum Loesener, 1. c. 543.

Celastrus salicifolia Léveillé, 1. c. $263(1914)=$ Ilex macrocarpa, var. genuina Loesener, secundum Loesener, 1. c. 543.

Celastrus Seguinii Léveillé, 1. c. $262(1914)$ = Myrsinacea, verisimiliter Rapanea spec., secundum Loesener, 1. c. 541.

Celastrus striatus Thunberg, Fl. Jap. 98 (1784) = Evonymus alata Regel.

Celastrus suaveolens Léveillé in Fedde, Rep. Spec. Nov. XIII. $263(1914)=$ Ilex suaveolens Loesener, secundum Loesener, 1. c. 541.

Celastrus tristis Léveillé, 1. c. $263(1914)$ = Euphorbiacea, verisimiliter Bridelia spec., secundum Loesener, 1. c. 543.

Celastrus variabilis Hemsley in Jour. Linn. Soc. XXIII. 124 (1886) = Gymnosporia variabilis Loesener.

Celastrus Wallichiana Hance in Jour. Bot. XVI. 226 (non Wight \& Arnott) $(1878)=$ Gymnosporia diversifolia Maximowicz. 


\section{GYMNOSPORIA Wight \& Arn.}

Gymnosporia variabilis Loesener in Bot. Jahrb. XXIX. 446 (1900); XXX. 472 (1902).

Celastrus variabilis Hemsley in Jour. Linn. Soc. XXIII. 124 (1886).

Western Hupeh: Ichang, cliffs and river banks, alt. 30-300 m., April and December 1907 (No. 775; thorny shrub 0.3-1 m., flowers white, fruit orange-brown); same locality, A. Henry (Nos. 130, 449a , 3056).

This is a very common shrub at low altitudes in the vicinity of the Yangtsze River throughout western Hupeh and eastern Szech'uan.

Judging from some detached leaves kindly sent by Mgr. Léveillé of Berberis Cavaleriei Léveillé (in Fl. Kouy-Tchéou, 48 [1914]), this supposed Barberry is a Gymnosporia, either a form of $G$. variabilis or an allied species.

\section{PERROTTETIA H. B. K.}

Perrottetia racemosa Loesener in Bot. Jahrb. XXIV. 201 (1893); XXIX. 447 (1900); XXX. 474 (1902).

Ilex racemosa Oliver in Hooker's Icon. XIX. t. 1863 (1889).

Western Hupeh: Changlo Hsien, side of streams, alt. $800 \mathrm{~m}$., June 1907 (No. 939 ; bush 2.5-3 m., flowers white); Ichang, ravines, alt. 300-600 m., May 7, 1907 (No. 3731; bush 2 m., flowers greenish); same locality, A. Henry (Nos. 3527, 7189). Western Szech'uan: Hung-ya Hsien, cliffs, near Wa-wu-shan, September 13, 1908 (No. 939; bush 3 m., fruit red); Mt. Omei, June 1904 (Veitch Exped. Nos. $\left.4802,4802^{\mathrm{a}}\right)$. 


\title{
ELAEOCARPACEAE.
}

\author{
Determined by Alfred ReHDer and E. H. Wilson.
}

\section{ELAEOCARPUS L.}

Elaeocarpus japonicus Siebold \& Zuccarini in Abh. Akad. Münch. IV. pt. 2, 165 (Fl. Jap. Fam. Nat. I. 57) (1845), non Siebold in Verh. Bataav. Genoot. XII. No. 1, 63 (Syn. Pl. Oecon.) (nomen nudum) (1830). - Maximowicz in Bot. Jahrb. VI. 61 (1885). - Hemsley in Jour. Linn. Soc. XXIII. 95 (1886). - Ito \& Matsumura in Jour. Coll. Sci. Tokyo, XII. 349 (Tent. Fl. Lutchu. 82) (1899). - Matsumura \& Hayata in Jour. Coll. Sci. Tokyo, XXII. 66 (Enum. Pl. Formos.) (1906). - Shirasawa, Icon. Ess. For. Jap. II. t. 49, figs. 1-14 (1908).

Western Szech'uan: Ya-chou Fu, thickets, alt. 1000 m., June 1908 (No. 3553; tree $10 \mathrm{~m}$. tall, girth $1.2 \mathrm{~m}$., flowers whitish); Mt. Omei, June 1904 (Veitch Exped. No. 4753; tree 13 m. tall); same locality, E. Faber (No. 57).

This small tree with pale, fairly smooth bark is very rare in western Szech'uan. Our specimens are male and Faber's consist only of leafy shoots, but so far as the material goes we can find no difference between them and specimens from Japan, where the tree is confined to the warm, southern districts.

Here may be added another species not collected during the Arnold Arboretum expeditions.

Elaeocarpus omeiensis Rehder \& Wilson, n. sp.

Arbor 6-metralis; ramuli hornotini initio puberuli, mox glabrescentes, annotini et vetustiores fusco-rubri, sparse lenticellati. Folia membranacea, elliptico-obovata v. oblongo-obovata, obtusa v. breviter obtusa, acuminata, basi cuneata, crenata, triente inferiore plerumque integra, $7-10 \mathrm{~cm}$. longa et $3-4.5 \mathrm{~cm}$. lata, supra glabra v. puberula praesertim basin versus ad costam mediam, luteo-viridia, subtus glabra, in axillis nervorum hine inde glandulis perforatis instructa, nervis utrinsecus 5-7 curvatis et anastomosantibus supra leviter subtus magis elevatis, venulis satis conspicuis; petioli $0.5-1.5$, lamina decurrente anguste alati, supra puberuli. Flores hermaphroditi, albi, in racemis axillaribus $4-6 \mathrm{~cm}$. longis; pedunculus $0.5-1$ $\mathrm{cm}$. longus ut rhachis angulatus et sparse minuteque pubescens; pedicelli graciles, recti v. curvati, $3-5 \mathrm{~mm}$. longi, puberuli; bracteae minutae, caducae; sepala 5 , rubescentia, lanceolata, $4 \mathrm{~mm}$. longa et circiter $1 \mathrm{~mm}$. lata, acuta, leviter incurva, ciliolata, extus puberula, intus sparse pubescentia, leviter carinata; petala, sepalis longiora, fimbriata, usque ad medium incisa, basin versus angustata et inferne ciliolata, intus puberula; discus lobatus, puberulus; stamina 14, filamentis vix $1 \mathrm{~mm}$. longis glabris, antheris oblongis $2 \mathrm{~mm}$. longis minute setulosis; ovarium 
subglobosum, pallide sericeo-pubescens; stylus subulatus, $4 \mathrm{~mm}$. longus, basi excepta glaber, stigmate simplice.

Western Szech'uan: Mt. Omei, July 1904 (Veiteh Exped. No. 5135).

An interesting species apparently most closely related to $E$. serratus Linnaeus, which has rather differently shaped leaves much less attenuate at the base, larger flowers, longer, acuminate, reddish sepals, prominently bearded anthers and a more abundant villose tomentum on the ovary. Elaeacarpus lanceaefolius Roxburgh, which grows in Hongkong, differs in its much more coriaceous, differently shaped, more serrate leaves, and longer racemes.

Henry's No. 7703 from western Hupeh very probably belongs here. Our specimen, which is in ripe fruit, has oblong-lanceolate leaves $15-18 \mathrm{~cm}$. long and an ellipsoid fruit $2 \mathrm{~cm}$. long, with an unusually soft pulpy mesocarp. If we are correct in assuming that this specimen belongs to $E$. omeiensis, then the difference in size of its fruits and those of $E$. serratus and $E$. lanceaefolius constitute another important distinguishing character. Our new species is a rare plant, as far as our knowledge goes, and occurs as a large bush or low tree.

\section{SLOANEA L.}

Sloanea Hemsleyana Rehder \& Wilson, n. comb.

Echinocarpus sinensis Hemsley in Ann. Bot. IX. 147 (non Hance) (1895). Diels in Bot. Jahrb. XXIX. 467 (1900).

Echinocarpus Hemsleyanus Ito in Jour. Sci. Coll. Tokyo, XII, 349 (Tent. Fl. Lutch. 82) (1899).

Sloanea Hanceana Hemsley in Hooker's Icon. XXXV. sub t. 2628 (1900). Gagnepain in Leeomte, Fl. Indo-Chin. I. 563, fig. 59 (1910).

Western Hupeh: Patung Hsien, woods, alt. 800 m., August 1907 (No. $9 \mathrm{I} 7^{\mathrm{a}}$; tree $11 \mathrm{~m}$. tall, girth $1.5 \mathrm{~m}$.); same locality, ravines, November 1901 (Veitch Exped. No. 2687; tree $6 \mathrm{~m}$. tall). Western Szech'uan: Yachou Fu, side of stream, alt. 600-1150 m., August 9 and October 1908 (No. 9r7; tree 13-20 m. tall, 1.5-3 m. girth, flowers white, aril orange-scarlet); Hung-ya Hsien, side of stream, alt. 6001000 m., September 1908 (No. 9I $7^{\text {b }}$; tree 16-20 m. tall, 1-3 m. girth).

This beautiful tree is rare in Hupeh, but is not uncommon in western Szech'uan by the sides of streams in the wooded country southwest of Mt. Omei and in the adjacent district of Yachou Fu. It is a tall tree with stout spreading branches, dense foliage, and corymbose masses of pure white fragrant flowers terminating the shoots. The rather thin leaves are deciduous, shining green and 12 to $25 \mathrm{~cm}$. or even more long. As the fruit nears maturity the long, straight bristles change from yellowish to brownish purple. The ripe fruit opens and displays its shining black seeds each with a large and conspicuous orange-scarlet aril. Both in flower and fruit this tree is strikingly handsome.

The plant named Echinocarpus sinensis by Hance (in Jour. Bot. XXII. 108 [1884]) is possibly not specifically distinct from the Hupeh and Szech'uan species. It differs in the leaves being cuneate at the base and toothed only above the middle. We are indebted to Mr. Edmund Baker of the British Museum for a sketch of a leaf of Hance's type, but unfortunately the evidence is insufficient to settle the question.

A picture of Sloanea Hemsleyana will be found under No. 372 of the collection of Wilson's photographs and also in his Vegetation of Western China, No. 209. 
Here may be added three species collected in Yunnan by A. Henry and to our knowledge not yet recorded from China.

Sloanea assamica Rehder \& Wilson, n. comb.

Echinocarpus assamicus Bentham in Jour. Linn. Soc. V. suppl. 2, 72 (1861). Masters in Hooker f., Fl. Brit. Ind. I. 399 (1874). - Brandis, Ind. Trees, 101 (1906).

Yunnan: south of Red River, A. Henry (No. 13654; tree $16 \mathrm{~m}$. tall, flowers white).

In the absence of fruit the identity of Henry's specimen is somewhat doubtful.

Sloanea sterculiacea Rehder \& Wilson, n. comb.

Elaeocarpea Griffith, Posth. Pap. II. 168 (Itin. Not. 866) (1848).

Echinocarpus sterculiaceus Bentham in Jour. Linn. Soc. V. suppl. 2, 72 (1861). - Masters in Hooker f., Fl. Brit. Ind. I. 400 (1874). - Brandis, Ind. Trees, 101 (1906).

Yunnan: Mengtsze, wooded cliffs, alt. 2000 m., A. Henry (No. 11501; tree $3 \mathrm{~m}$. tall).

Sloanea tomentosa Rehder \& Wilson, n. comb.

Echinocarpus tomentosus Bentham in Jour. Linn. Soc. V. suppl. 2,73 (1861). Masters in Hooker f., Fl. Brit. Ind. I. 400 (1874). - Brandis, Ind. Trees, 102 (1906). - Dunn in Jour. Linn. Soc. XXXIX. 444 (1911).

Yunnan: Szemao, forests to south, alt. 1300-1600 m., A. Henry (Nos. 11745, $\underline{11745^{\mathrm{b}}}, 12110$; tree $6 \mathrm{~m}$. tall, flowers yellow, white). 


\section{TILIACEAE.}

Determined by Alfred ReHder and E. H. Wilson.

\section{TILIA L.}

Tilia paucicostata Maximowicz in Act. Hort. Petrop. XI. 82 (1890). Schneider, Ill. Handb. Laubholzk. II. 371, fig. 250 n-o (1909). V. Engler, Monog. Titia, 87 (1909).

Tilia Miqueliana, var. chinensis Diels in Bot.Jahrb. XXXVI. Beibl. LXXXII. 75 (non Szyszylowicz) (1905).

Tilia paucicostata, var, a firma V. Engler apud Schneider, Ill. Handb. Laubholzk. II. 371 (1909), - V. Engler, Monog. Tilia, 88 (1909).

Tilia paucicostata, var. $\beta$ tenuis V. Engler apud Schneider, Ill. Handb. Laubholzk. II. 371 (1909). - V. Engler, Monog. Tilia, 88 (1909).

Western Hupeh: Hsing-shan Hsien, woods, alt. 1600-2000 m., July and November 1907 (No. 594; tree 8-13 m. tall, 1-2 m. girth); Fang Hsien, mountains, July 1901 (Veitch Exped. No. 2422; tree 10 m. tall); mountains north of Nanto, July 1900 (Veitch Exped. No. 1532 ; tree $13 \mathrm{~m}$. tall).

This is a small and not common tree which grows scattered through the woods and forests of northwestern Hupeh. The branches are slender and glabrous, and the winter-buds are relatively large, ovoid, acutish, glabrous and purple. The leaves are membranous and vary somewhat in shape with a base which is cordate, truncate or abruptly broad-cuneate. On flowering specimens before us the leaves vary in length from 4 to $7 \mathrm{~cm}$. and in width from 3 to $6 \mathrm{~cm}$. on the same branch: the petiole varies in length from $1.5-4 \mathrm{~cm}$. The fruit on one specimen is somewhat malformed.

We have not seen Maximowicz's type, and our material differs slightly from his description, especially No. 594, which has longer petioles, rather narrow leaves of firmer texture, often more or less triangular in outline and somewhat reticulate beneath. Nevertheless, similar small differences occur in many other species of Tilia.

We have specimens of $T$. dictyoneura V. Engler, but in the absence of authentic material of $T$. paucicostata Maximowicz, we cannot say whether Engler's plant represents a distinct species or is merely an extreme state of the one described by Maximowicz.

Tilia nobilis Rehder \& Wilson, n. sp.

Arbor 8-12-metralis, trunco $1-1.5 \mathrm{~cm}$. in circuitu metiente; ramuli glabri, in autumno saepe glaucescentes; gemmae late ovoideae, obtusae, $0.5-1 \mathrm{~cm}$. longae, glabrae v. apice leviter puberulae, saepe 
pruinosae. Folia orbiculari-ovata, subito acuminata, basi oblique cordata v. truncata, argute serrata dentibus porrectis aristato-acuminatis, $15-20 \mathrm{~cm}$. longa et $11-15 \mathrm{~cm}$. lata, supra saturate viridia, glabra, subtus fere glabra v. sparse stellato-pubescentia, in axillis nervorum et nervulorum conspicue barbulata, nervis utrinsecus 7-9, subtus ut trabeculae satis approximatae manifeste elevatis, venulis ceteris minus elevatis; petioli crassiusculi, 4-6 $\mathrm{cm}$. longi, glabri. Cymae 2-5-florae; pedunculi et pedicelli angulares, sparse stellatopilosi; bracteae anguste oblongae, apice rotundatae, basi abrupte contractae, fere sessiles, subtus sparse, supra sparsissime stellato-pilosae, infra medium pedunculo adnatae; sepala anguste triangulari-ovata, acuta, $6 \mathrm{~mm}$. longa et 3-4 $\mathrm{mm}$. lata, extus satis dense breviter stellatopilosa, intus apice et basi villosa; petala concava, ovato-lanceolata, apice truncata v. leviter erosa, basi cuneata, $7-8 \mathrm{~mm}$. longa et circiter $3 \mathrm{~mm}$. lata; staminodia 5 , petaloidea, spathulata, petalis aequilonga; stamina glabra, petalis dimidio breviora; pistillum $7 \mathrm{~mm}$. longum, ovario subgloboso obtuse angulata tomentoso, stylo crasso glabro 3.5 $\mathrm{mm}$. longo, stigmate simplice v. fere simplice. Fructus ovoideus v. leviter obovoideus, 10-12 $\mathrm{mm}$. longus et 7-9 mm. diam., 5-angulatus angulis saepe acutis, apiculatus, dense adpresse tomentosus.

Western Szech'uan: Wa-shan, woods, alt. $2600 \mathrm{~m}$., July and October 1903 (Veitch Exped. No. 3285, type); same locality, alt. 2300-2600 m., October 1908 (No. 2326); Hung-ya Hsien, Wa-wu-shan, woods, alt. 2300 m., September 14, 1908 (No. 2327).

This very distinct species has the largest leaves of any of the Chinese Lindens and is apparently most closely related to $T$. chinensis Maximowicz, which has smaller leaves elothed on the under side with a pale gray felt, very much smaller, densely pubescent bracts, and smaller and more globose fruit. This new species has a very local distribution and is not common.

\section{Tilia chinensis Maximowicz in Act. Hort. Petrop. XI. 83 (1890).}

Tilia Baroniana Diels in Bot, Jahrb. XXIX. 468 (1900); XXXVI. Beibl. LXXXII. 75 (1905). - Schneider, Ill. Handb. Laubholzk. II. 387, fig. 259 h (1909). - V. Engler, Monog. Tilia, 132 (1909).

Western Szech'uan: southeast of Sung-pan, valley of Honton River, alt. 2600-3000 m., August and October 1910 (No. 4295; tree 10-15 m. tall); same locality, alt. 2800 m., August 1904 (Veitch Exped. No. 3286); west of Kuan Hsien, Pan-lan-shan, woods, alt. 2300-3000 m., June 1908 (No. 2323; tree 6-13 m. tall, girth 1-1.5 m.). Western Hupeh: Fang Hsien woods, alt. 2500-3000 m., June and October 1901 (Veitch Exped. No. 2333; tree 10 m. tall, very rare). 
This is a tree of moderate size with numerous spreading branches. It is common in northwest Szech'uan, where the bark is used by the peasants for making sandals; it is rare elsewhere in Szech'uan and in Hupeh. The shoots are glabrous, the winter-buds large, glabrous or with few long and straight hairs, and the 5 -ribbed fruit varies from ovoid to obovoid, and is 9 to $12 \mathrm{~mm}$. long and 6 to $8 \mathrm{~mm}$. wide. In the Hupeh specimen the shoot of the flowering branch is pruinose.

There is no question that Maximowicz's and Diels' species are the same, but to explain the confusion we can only suggest that Diels overlooked Maximowicz's original description and assumed that the very different plant named $T$. Miqueliana, var. chinensis by Szyszylowicz was identical with Maximowicz's species.

\section{Tilia intonsa Wilson in Herb. Kew., n. sp.}

Tilia tonsura Veitch, New Hardy Pl. W. China, 1913, 15 (nomen nudum).

Arbor 6-20-metralis, trunco 1-3 m. in circuitu metiente, cortice fusco-griseo, longitudinaliter leviter fisso lenticellis magnis ovalibus v. rarius oblongis notato; ramuli hornotini dense pilis longis flavidis v. pallidis vestiti, annotini glabri; gemmae ovoideae, obtusae, glabrae v. fere glabrae, purpurascentes. Folia membranacea, late ovata v. orbiculari-ovata, subito breviter acuminata, basi oblique cordata v. truncata, argute serrata dentibus porrectis parvis mucronatis, 7-14, plerumque $9-12 \mathrm{~cm}$. longa et $6-12$, plerumque $7-10 \mathrm{~cm}$. lata, supra laete luteo-viridia, glabra costa venisque sparse stellato-pilosis exceptis, subtus pallidiora, cinereo-viridia, laxe tomento stellato-villoso obtecta et in axillis venarum et venularum plus minusve fulvo-barbulata, rarius fere ebarbulata, nervis utrinsecus 7-9 subtus ut trabeculae elevatis; petioli 4-7 cm. longi, pilosi v. partim glabrescentes. Cymae 1-3-florae; pedunculi et pedicelli crassiusculi, stêllato-pilosuli; bracteae anguste oblongae, obtusae, breviter stipitatae v. fere sessiles, utrinque stellatopilosae, densius in facie dorsali, infra medium pedunculo adnatae; sepala ovato-lanceolata, acutiuscula, $6-8 \mathrm{~mm}$. longa, extus dense breviter stellato-pubescentia, intus villosa; petala, oblongo-lanceolata, obtusa, $8 \mathrm{~mm}$. longa et $2-2.5 \mathrm{~mm}$. lata; staminodia 5 , petaloidea, ligulata, petalis aequilonga; stamina glabra, petalis dimidio breviora; pistillum 9-10 $\mathrm{mm}$. longum, ovario subgloboso 5-angulato stellatotomentoso, stylo crasso glabro, stigmate bifido. Fructus ovoideus v. leviter obovoideus, 5-angulatus, 9-11 mm. longus et 6-7 mm. diam., apiculatus, tomento adpresso flavido $\mathrm{v}$. pallido vestitus.

Western Szech'uan : east of Luting-chiao, Ma-ngan-shan, woods, alt. 2600 m., July and October 1903 (Veitch Exped. No. 3287, type); same locality, October 1903 (Veitch Exped. Seed No. 1569); northeast of Tachien-lu, Ta-p'ao-shan, thickets, alt. 3000-3300 m., July 9, 1908 (No. 2324); Mupin woods, alt. 1600-2600 m., July and October 1908, 
October 1910 (Nos. 2330, 4379); Ching-chi Hsien, Fei-yüeh-ling, woods, alt. 2800 m., August and September 1908 (No. 2329); Wa-shan, woods, alt. 2000-2500 m., July and October 1908 (No. 2328); west of Kuan Hsien, Pan-lan-shan, woodlands, alt. 2300-3000 m., June 1908, October 1910 (Nos. 2325, 433I, 4333).

This species is apparently most closely related to $T$. chinensis Maximowicz, but well distinguished from it and from all other Chinese species of Tilia by its hairy shoots. Occasionally the shoots and more especially the stronger ones are more or less glabrescent, and perhaps it may ultimately turn out to be an extreme variety of Maximowicz's species. This new Linden is a common inhabitant of the woods and forests of western Szech'uan. It was named in 1909 by Wilson in the Kew Herbarium, but no description was published.

Tilia Oliveri Szyszylowicz in Hooker's Icon. XX. sub t. 1927 (1890). - Schneider, Ill. Handb. Laubholzk. II. 387, fig. 259 a-b (1909). - V. Engler, Monog. Tilia, 114 (1909). - Bean in Kew Bull. Misc. Inform. 1914, 53; Trees \& Shrubs Brit. Isl. II. 593 (1914).

Tilia mandshurica Szyszylowicz in Hooker's Icon. XX. sub t. 1927 (non Ruprecht \& Maximowicz) (1890). - Diels in Bot. Jahrb. XXIX. 468 (1900). Tilia pendula V. Engler apud Schneider, Ill. Handb. Laubholzk. II. 387, fig. 259 c (1909). - V. Engler, Monog. Tilia, 113 (1909).

Western Hupeh: Changlo Hsien, woods, alt. 1300-2000 m., July 1907 (No. 2336; tree 6-10 m. tall, 1-1.5 m. girth); Changyang Hsien, woods, alt. 1800 m., Oetober 1900 (Veitch Exped. No. 705); Hsing-shan Hsien, woods, alt. 1000-2000 m., June, July and November 1907 (Nos. 59 I, 7II, plants only, 2333, 2332, 2335; tree 6-25 m. tall, girth 1-4 m.); Fang Hsien, woods, alt. 1600-2300 m., July 1907, October and November 1910 (Nos. 6I5, 634, 2337, 44Io, 44II, 4445; tree 5-25 m. tall, girth 1-3 m.); Paokang Hsien, woods, June 1901 (Veitch Exped. No. 2274); Fang Hsien, A. Henry (No. 7452 b, in Herb. Gray, type No. of $T$. pendula V. Engler). Eastern Szech'uan: Wushan Hsien, A. Henry (No. 7089, in Herb. Gray, type No. of T. Oliveri).

This species is very abundant in the moist woods of northwestern Hupeh, but rare elsewhere in that province and not yet reported from western Szech'uan. As usually seen it is a tree of moderate size with spreading, rather down-sweeping branches, but occasionally large trees are met with. It is easily recognized by its polished young branches, glabrous shoots, prominent winter-buds, by its leaves with white, very dense and close tomentum, by its divaricate many-flowered inflorescence and by its globose to obovoid, very slightly ribbed tuberculate fruit crowned by the short apiculate remains of the style. On the flowering and fruiting specimens before us the leaves vary in length from 3 to $12 \mathrm{~cm}$. and in width from 3 to $10 \mathrm{~cm}$. and the petioles are 2 to $7.5 \mathrm{~cm}$. long. Usually the leaves are very distinctly toothed, but frequently the teeth are reduced almost to a mucro with searcely a trace of a sinus between them. In the color and texture of the tomentum on 
the under surface of its leaves this species resembles the European $T$. tomentosa Moench.

Both Szyszylowicz and V. Engler worked with little material, otherwise they would not have attempted to make two species out of such a homogeneous and clearly defined species as T. Oliveri.

In No. 634 the shoots and winter-buds are slightly pubescent and the fruit is less tuberculate than is usual in the species.

Tilia Oliveri, var. cinerascens Rehder \& Wilson, n. var.

A typo recedit foliis subtus tomento cinereo nec albido minus denso vestitis majoribus ad $14 \mathrm{~cm}$. longis.

Western Hupeh: Fang Hsien, woods, alt. 1600-2300 m., May 19, July and November 1907 (No. 2338, type, 597 ${ }^{\circ}$; tree $6 \mathrm{~m}$. tall).

This variety is distinguished by the gray not white under surface of its leaves and the pubescence is more loosely tomentose; the leaves are distinctly serrate with broad, short teeth. In No. $597^{\circ}$, which consists of a shoot with partly grown leaves, the branchlets are pendulous and the under side of the leaves very sparsely pubescent.

Tilia Henryana Szyszylowicz in Hooker's Icon. XX. t. 1927 (1890).Schneider, Ill. Handb. Laubholzk. II. 388, fig. 259 d-e (1909). V. Engler, Monog. Tilia, 125 (1909). - Pampanini in Nuov. Giorn. Bot. Ital. n. ser. XVII. 431 (1910). - Bean, Trees \& Shrubs Brit. Isl. II. 591 (1914).

Tilia Henryana, var. a fulva V. Engler, Monog. Titia, 125 (1909).

Tilia Henryana, var. $\beta$ subglabra V. Engler, 1. c. 125 (1909).

Tilia Henryana, var. $\beta$ subglabra, f. polyantha V. Engler, 1. c. 125 (1909).

Kiangsi: Kuling, one tree near a temple, alt. 1300 m., July 29, 1907 (No. r56r; tree 10 m. tall). Western Hupeh : Patung Hsien, woods, alt. 1600-2000 m., August 1907 (No. 597 ; tree 15 m. tall, 1.5 m. girth); Hsing-shan Hsien, roadside, alt. 1300 m., May 7, June, October and November (Nos. 4I4, 597; tree 16-26 m. tall, girth 2-9 m.); same locality, May and July 1900 (Veitch Exped. No. 1392); same locality, A. Henry (No. $7452^{\mathrm{a}}$, type No.); Ichang Fu, Nanto, mountains, July 1900 (Veitch Exped. No. 1503); " Monte T'ien-pangscian, a $30 \mathrm{~km}$ a N. E. di Chang-kin," alt. 1990 m., 1907, C. Silvestri (Nos. 1452, 1451).

This very distinct species is not common, but it grows to a greater size than any of the other species from central or western China. In habit it resembles the European T.tomentosa Moench, and the bark is light gray, firm and fissured. As the leaves unfold in the spring they are covered with a nearly white, loose tomentum and the trees in this stage are conspicuous from a distance. As the leaves develop this tomentum more or less completely disappears from both surfaces and what remains becomes darker in color and on dried specimens fulvous-gray. The young shoots in early spring have a similar tomentum to that of the leaves, but in 
the autumn they are often pale and more or less densely puberulous and yellowishbrown and nearly glabrous. The prominent ovoid winter-buds are slightly villous or glabrous.

On our specimens the leaves vary in length from 5-13 cm. and in width from 4-14 $\mathrm{cm}$. and the petioles are from $2.5-5 \mathrm{~cm}$. long. Often the teeth of the leaves are well developed, but usually they are represented almost entirely by the characteristic long aristate point which readily distinguishes this species from all other Chinese Lindens. The ellipsoid to obovoid fruit is from 8-10 $\mathrm{mm}$. long and from 4-6 mm. wide, prominently 5 -angled, slightly verrucose and tipped with the very short remains of the style.

With the material before us it is obvious that the varieties and form founded by V. Engler (1. c.) cannot be maintained.

A picture of this tree will be found under No. 705 of the collection of Wilson's photographs and also in his Vegetation of Western China, No. 487.

Tilia tuan Szyszylowicz in Hooker's Icon. XX. t. 1926 (1890). Diels in Bot. Jahrb. XXIX. 468 (1900). - Schneider, Ill. Handb. Laubholzk. II. 389, fig. $259 \mathrm{f}-\mathrm{g}$ (1909).

Tilia Tuan, var. Cavaleriei, V. Engler and Léveillé in Fedde, Rep. Spec. Nov. VI. 266 (1909). - V. Engler, Monog. Tilia, 124 (1909). - Léveillé, Fl. Kouy-Tchéou, 420 (1915).

Tilia Tuan, var. a Cavaleriei, f. divaricata V. Engler, Monog. Tilia, 124 (1909).

Tilia Tuan, var. $\beta$ pruinosa V. Engler, 1. c. 124 (1909).

Western Hupeh: Hsing-shan Hsien, thickets and woods, alt. 1300-2000 m., July 1907 (No. 2334; slender tree 5-8 m. tall, 0.3-0.6 m. girth); Fang Hsien, woodlands, alt. 1600-2600 m., October 1910 (Nos. 4409, 4449; tree 10-16 m. tall, 1.5-2.3 m. girth); Patung Hsien, woods, June 1901 (Veitch Exped. No. 2316; tree 10 m. tall). Eastern Szech'uan: Wushan Hsien, A. Henry (No. 7452). Southeast Szech'uan: Nan-ch'uan, A. von Rosthorn (No. 842).

In the woods of western Hupeh this is a common tree of medium size with spreading branches, glabrous shoots and glabrescent winter-buds. The bark on the trunk of young trees is quite smooth and pale, but on old trees it is fissured and rough. The leaves may be virtually entire with the teeth reduced to very short muero or they may be decidedly toothed. The bracts are remarkably long, often exceeding the leaves.

In Hupeh the colloquial name of this and all other species of Tilia is " $T$ ' $u a n$," and the bark is used by peasants for making coarse sandals.

In specimens before us we can find no difference between Rosthorn's No. 842 distinguished as var. pruinosa, and Henry's No. 7452, whereas Wilson's No. 1242 , considered by V. Engler the same as Rosthorn's No. 842, has tomentose shoots and villose winter-buds and belongs to our var. chinensis.

A plant in the Arnold Arboretum received from Messrs. Chenault, Orleans, as "Tilia sp. from China" belongs here, although a fruiting specimen of this plant collected in Messrs. Chenault's nursery on August 30, 1911, looks less like typical T. tuan than does our cultivated plant. The fact is that Tilia tuan Szyszylowicz is the most variable of the Chinese species of Tilia. As an extreme form possibly belongs here Rosthorn's No. $335^{a}$ from Nanch'uan with narrow leaves thinly stellate-pubescent below. 
Tilia tuan, var. chinensis Rehder \& Wilson, n. comb.

Tilia Miqueliana, var. chinensis Szyszylowicz in Hooker's Icon. XX. sub t. 1927 (1890).

Tilia chinensis Schneider, Ill. Handb. Laubholzk. II. 384, fig. 257 1-m (non Maximowicz) (1909). - V. Engler, Monog. Tilia, 130 (1909).

Western Hupeh: Changyang Hsien, woods, alt. 1300-2000 m., July and October 1907 (Nos. 486, 233I ; tree 6-16 m. tall, girth 1-2 m.); Ichang Fu, mountains north of Nanto, June and October 1900 (Veitch Exped. No. 1242, tree 16 m. tall); Patung Hsien, woods, October 1900 (Veitch Exped. Seed No. 926); Hsing-shan Hsien, A. Henry (No. 6474 in Herb. Gray).

This variety is as common in western Hupeh as the type from which it is distinguished by its gray tomentose shoots and its densely pubescent winter-buds. The degree of pubescence on the under side of the leaves varies considerably. In No. 2331, which is from a young tree, their under side is nearly glabrous; and in No. 486 it is covered with a rather loose gray felt. Henry's No. 6474 is intermediate between these extremes. On young plants of this variety growing in the Arboretum and also of the type the leaves are practically glabrous. In the flower and fruit there are no differences between the type and the variety, and the dentation of the leaves exhibits the same variability in both.

Tilia sp.

Kiangsi: Kuling, thickets, alt. 1300 m., July 28, 1907 (No. I562; bush or small tree 1-5 m. tall, common).

It is quite possible that this is nothing but a state of the variable $T$. tuan Szyszylowicz, but our material is limited to leafy shoots. The leaves are strongly veined, sharply serrate and nearly glabrous. As a shrubby plant this Linden is common round Kuling, but Wilson failed to discover any flowers.

Here may be added notes on several species not collected during the Arnold Arboretum expeditions.

Tilia mongolica Maximowicz in Bull. Acad. Sci. St. Pétersbourg, XXVI. 433 (1880); in Mél. Biol. X. 585 (1880); Enum. Pl. Mongol. 118 t. 11 (1889). Franchet in Nouv. Arch. Mus. Paris, sér. 2, V. 212 (Pl. David. I. 60) (1883).Hemsley in Jour. Linn. Soc. XXIII. 94 (1886). - Palibin in Act. Hort. Petrop. XIV. 112 (1895), - Rehder in Sargent, Trees \& Shrubs, I. 121, t. 61 (1903). Schneider, Ill. Handb. Laubholzk. II. 369, fig. $249 \mathrm{~g}-\mathrm{h}, 250 \mathrm{c}-\mathrm{d}$ (1909). - V. Engler, Monog. Tilia, 85 (1909).

C hili: Weichang, 1910, W. Purdom (Nos. 86, 864); "Calceenwong," 1910, W. Purdom (No. 67); Hsao Wu-tai-shan, mountain slopes, alt. 1300-2300 m., August 21, 1913, F. N. Meyer (No. 1258).

Barbulae may be present or absent in this species.

Tilia laetevirens Rehder \& Wilson, n. sp.

Arbor; ramuli glabri, satis graciles, hornotini flavescentes, annotini sordide aurantiaci, vetustiores fusco-cinerei; gemmae ovoideae, obtusae, glabrescentes, fulvo-brunneae. Folia membranacea, late ovata v. orbiculari-ovata, interdum leviter lobata, subito leviter acuminata, basi oblique truncata $\mathrm{v}$. subcordata, raro latissime cuneata, serrulata dentibus parvis fere ad mucronem reducta, v. dentato- 
serrata dentibus latissime ovato-triangularibus mucronatis, $5.5-10.5 \mathrm{~cm}$. longa et 4-9 $\mathrm{cm}$. lata, supra laete viridia, glabra, subtus pallidiora, pilis stellatis brevibus albidis laxe conspersa, nervis utrinsecus 6-9, ut trabeculae satis distantes subtus elevatis; petioli graciles, glabri, 4-7 $\mathrm{cm}$. longi. Flores non visi; pedunculi et pedicelli subteretes, laxe breviter stellato-pilosi; bracteae anguste oblongae, obtusae, basi plerumque attenuatae, $5-7 \mathrm{~cm}$. longae et $1-1.5 \mathrm{~cm}$. latae, utrinque stellatopubescentes, subsessiles $\mathrm{v}$. breviter stipitatae, infra medium pedunculo adnatae. Fructus 1-3, ovoideus $\mathrm{v}$. obovoideus, $8-10 \mathrm{~mm}$. longus et $6-7 \mathrm{~mm}$. latus, obscure 5-costatus, styli basi brevissimo coronatus, dense tomento stellato brevissimo cinereo-albido vestitus.

Kansu: Lotani, south of Min-chou on road to Siku, alt. 2600-2800 m., August 13, 1911, W. Purdom, type; Min-chou, alt. 2600 m., 1911, W. Purdom.

We are without any precise information on this interesting Linden which in appearance is markedly different from all other Chinese species. It is apparently most closely related to $T$. chinensis Maximowicz, which is a much more hairy plant with thicker, more strongly veined leaves covered with a thin gray tomentum on the under side and very sharply angled fruit. In a general way it has some resemblance to $T$. paucicostata Maximowicz, but this more glabrous plant with small leaves, relatively large quite glabrous bracts and numerous small flowers and noncostate fruit belongs to an entirely different section of the genus.

Tilia mandshuria Ruprecht \& Maximowicz in Bull. Acad. Sci. St. Pétersbourg, XV. 124 (1856); in Mél. Biol. II. 413 (1857). - Maximowicz in Mém. Sav. Êtr. Acad. Sci. St. Pétersbourg, IX. 62 (Prim. Fl. Amur.) (1859); in Bull. Acad. Sci. St. Pétersbourg, XXVI. 434 (1880); in Mél. Biol. X. 586 (1880). - Bayer in Verh. Zool.-Bot. Ges. Wien, XII. Abh. 48 (Monog. Tilia) (1862). - Baker \& Moore in Jour. Linn. Soc. XVII. 380 (1879). - Franchet in Nouv. Arch. Mus. Paris, sér. 2, V. 212 (Pl. David. I. 60) (1883). - Komarov in Act. Hort. Petrop. XXV. 28 (1907). - Schneider, Ill. Handb. Laubholzk. II. 384, fig. $257 \mathrm{i}-\mathrm{k}$ (1909). - V. Engler, Monog. Tilia, 114 (1909).

Tilia argentea Hort. Paris apud Regel in Bull. Acad. Sci. St. Pétersbourg, XV. 216 (non De Candolle) (1857); in Mél. Biol. II. 482 (1857).

Tilia argentea, $\beta$ mandshuria Regel in Mém. Acad. Sci. St. Pétersbourg, ser. 7, IV. No. 4, 30 (Tent. Fl. Ussur.) (1861).

Tilia pekinensis Ruprecht apud Maximowicz in Mém. Sav. Étr. Acad. Sci. St. Pétersbourg, IX. 469 (Prim. Fl. Amur.) (nomen nudum) (1859). - Bayer in Verh. Zool.-Bot. Ges. Wien, XII. Abh. 49, t. 9, fig. 3 (Monog. Tilia) (1862).

Tilia mandschuria, var. pekinensis V. Engler apud Schneider, IIl. Handb. Laubholzk. II. 384 (1909). - V. Engler, Monog. Tilia, 115 (1909).

Chili: Weichang, 1909, W. Purdom (Nos. 53, 53a); near San-tun-ying, mountain slopes, June 2, 1913, F. N. Meyer (Nos. 129, 991); Hsiao Wu-tai-shan, alt. 1600-2300 m., August 20,1913, F. N. Meyer (Nos. 130, 1245). Mandshuria: Shengking, Tsien-shan mountains, June 9, 1906, F. N. Meyer (No. 123); Mukden, east Tomb, May 29, 1906, F. N. Meyer (No. 100); east of Harbin, mountains, August 31, 1903, C. S. Sargent. Korea: Chinnampo, September 17, 1905, J. G. Jack; Diamond Mountain, June 24, 1906, U. Faurie (No. 490).

On young trees and on very vigorous shoots or adventitious branches the lesves are often more or less three-lobed. 


\section{GREWIA L.}

Grewia parviflora Bunge in Mém. Sav. Êtr. Acad. Sci. St. Pétersbourg, II. 83 (Enum. Pl. Chin. Bor. 9) (1833). - Hance in Jour. Bot. XX. 3 (1882). - Franchet in Nouv. Arch. Mus. Paris, sér. 2, V. 211 (Pl. David. I. 59) (1883). - Hemsley in Jour. Linn. Soc. XXIII. 93 (1886). - Gagnepain in Lecomte, Not. Syst. 124 (1909). - Dunn \& Tutcher in Kew Bull. Misc. Inform. add. ser. X. 51 (Fl. Kwangtung \& Hongk.) (1912).

Kiangsi: Kuling, thickets, alt. 600 m., August 1, 1907 (No. r597; shrub 1-1.5 m., flowers yellowish). Chili: near "Ying-tan Ko," rocky places, September 1913, F. N. Meyer (No. 81); Peking, Pagoda Hill, near Summer Palace, September 17, 1903, C. S. Sargent; Nankow, October 6, 1905, J. G. Jack; near Peking, A. Bunge. Shantung: Tsingtau, 1901, Zimmermann (No. 223); "Pa-shan," September 1907, F. N. Meyer (No. 265).

This northern shrub is rare in the Yangtsze valley, where it is represented by the following variety.

Grewia parviflora, var. glabrescens Rehder \& Wilson, n. comb.

Grewia glabrescens Bentham, Fl. Hongk. 42 (1861). - Hemsley in Jour. Linn. Soc. XXIII. 92 (1886). - Dunn \& Tutcher in Kew Bull. Misc. Inform. add. ser. X. 51 (Fl. Kwangtung \& Hongk.) (1912). — Léveillé, Fl. Kouy-Tchéou, 419 (1915).

Grewia parviflora Diels in Bot. Jahrb. XXIX. 468 (non Bunge) (1900), Pavolini in Nuov. Giorn. Bot. Ital. n. ser. XV. 407 (1908). - Pampanini in Nuov. Giorn. Bot, Ital. n. ser. XVII. 431 (1910).

Grewia Esquirolii Léveillé, Fl. Kouy-Tchéou, 419 (pro synon.) (1915).

Celastrus euonymoidea Léveillé, 1. c. (pro synon.) (1915).

Western Hupeh: Changlo Hsien, open places, alt. 300-1000 m., June and October 1907 (No. 407; shrub $1 \mathrm{~m}$., flowers whitish, fruit orange); Ichang, roadsides, alt. 300-600 m., June 1907 (No. 2437; shrub 0.6-1 m. tall); Hsing-shan Hsien, roadsides, alt. 600-1100 m., June 7, September 1907 (No. Io9; shrub 0.6-2 m., flowers white, fruit orange); Ichang, glens and open country, June 1900, 1901 (Veitch Exped. Nos. 1016, 1265a , 1984); same locality, A. Henry (Nos. 1555, 3629, 7601); Nanto and mountains to northward, A. Henry (Nos. 1929, 2695); "Ou-tan-scian," alt. 2090 m., July 1907, C. Silvestri (No. 1449). Western Szech'uan: Monkong Ting, valley of Hsao-chin Ho, alt. 2000-3000 m., June 29, 1908 (No. I09 ${ }^{\mathrm{a}}$; shrub 0.6-2 m. tall). Northern Shensi: "Thui-kio-tsuen," September 1897, G. Giraldi; 
without precise locality, 1897, G. Giraldi. Formosa: Bankinsing, A. Henry (No. 876). Fokien: Dunn's Exped., April to June 1905 (Hongkong Herb. No. 2419). Hongkong: August 1893, C. Ford.

In rocky places and by the roadside this shrub is abundant in western Hupeh and in Szech'uan. The size and shape of leaves vary very considerably. No. 109a and Giraldi's specimens from northern Shensi before us are intermediate in degree of pubescence between this variety and the type. 


\section{MALVACEAE.}

Determined by Alfred ReHDER and E. H. WILSON.

\section{ABUTILON Gärtn.}

Abutilon sinense Oliver in Hooker's Icon. XVIII. t. 1750 (1888). Diels in Not. Bot. Gard. Edinburgh, VII. 33, 291 (Pl. Chin. Forrest.) (1912). - Léveillé, Fl. Kouy-Tchéou, 272 (1914).

Western Hupeh: Patung Hsien, cliffs of Wushan Gorge, alt. 30-100 m., March 26, 1908 (No. 2023; shrub 1-3 m. tall, flowers golden); same locality, March 1901 (Veitch Exped. No. 1757); near Ichang, A. Henry (No. 3822). Yunnan: Yung-ping Hsien valley, April 1906, G. Forrest. (No. 5026).

This very ornamental species with deep yellow flowers is not common. A picture of this shrub will be found under No. 16 of the collection of Wilson's photographs and also in his Vegetation of Western China, No. 101.

\section{URENA L.}

Urena lobata Linnaeus, Spec. 692 (1753). - Loureiro, Fl. Cochin. 416 (1790). - Hooker in Bot. Mag. LVIII. t. 3043 (1831). - Bentham, Fl. Hongk. 34 (1861). - Masters in Hooker f., Fl. Brit. Ind. I. 329 (1874). - Hemsley in Jour. Linn. Soc. XXIII. 86 (1886). — Gürke \& Diels in Bot. Jahrb. XXIX. 469 (1900). - Dunn \& Tuteher in Kew Bull. Misc. Inform. add. ser. X. 48 (Fl. Kwangtung \& Hongk.) (1912). - Diels in Not. Bot. Gard. Edinburgh, VII. 223 (Pl. Chin. Forrest.) (1912). — Léveillé, Fl. Kouy-Tchéou, 275 (1914).

Urena cana Wallich, Cat. No. 1930 (nomen nudum) (1828).

Urena diversifolia Schumacher \& Thonning, in Afh. Danske Vidensk. Selsk. ser. 4, IV. 29 (Beskr. Guin. Pl. 308) (1829). - Walpers in Nov. Act. Acad. Leop.-Carol. XIX. Supp. 1, 304 (1843); Rep. V. 89 (1845).

Western Szech'uan: valley of Tung River, roadsides, alt. 800 m., August 1908 (No. 2354; subshrub $0.6 \mathrm{~m}$. tall, flowers pink); base of Mt. Omei, sunny places, August 1904 (Veitch Exped. No. 4754); without precise locality, A. Henry (No. $7180^{\mathrm{b}}$ ). 


\section{HIBISCUS L.}

Hibiscus Manihot Linnaeus, Spec. 696 (1753). - Cavanilles, Monadelph. Diss. III. 172, t. 63, fig. 2 (1787). - Sims in Bot. Mag. XLI. t. 1702 (1815). - De Candolle, Prodr. I. 448 (1824). - Hooker in Bot. Mag. LIX. t. 3152 (var. $\beta$ ) (1832). - Masters in Hooker f., Fl. Brit. Ind. I. 341 (1874), - Hochreutiner in Ann. Cons. Jard. Bot. Genève, IV. 153 (1900). - Gürke \& Diels in Bot. Jahrb. XXIX. 469 (1900). - Hooker f. in Bot. Mag. CXXVII. t. 7752 (1901). Dunn in Jour. Linn. Soc. XXXIX. 455 (1911). - Diels in Not. Bot. Gard. Edinburgh, VII. 223 (Pl. Chin. Forrest.) (1912).

Western Hupeh: Ichang, thickets, alt. 30-1000 m., August 1907 (No. 24I6; 1-2 m. tall, flowers yellow); same locality, A. Henry (No. 4183). Western Szech'uan: near Wa-shan, valley of Tung River, alt. 800 m., August 1908 (No. 2417; 1.5-2 m. tall, flowers yellow). Yunnan: Mengtsze, alt. 1600 m., A. Henry (No. 9263).

This is a common plant in the warm parts of Hupeh, Szech'uan and Yunnan. A mucilage obtained from the rootstock is used by Chinese in the manufacture of paper.

We have not considered it necessary to enumerate the numerous synonyms of this variable species; for an enumeration of them we refer to Hochreutiner's Revision du genre Hibiscus, p. 131 (in Ann. Cons. Jard. Bot. Genève, IV. 153), where 36 synonyms are cited.

Hibiscus syriacus Linnaeus, Spec. 695 (1753). - Loureiro, $\mathrm{Fl}$. Cochin. 420 (1790). - De Candolle, Prodr. I. 448 (1824). - Masters in Hooker f., Fl. Brit. Ind. I. 344 (1874). - Hemsley in Jour. Linn. Soc. XXIII. 88 (1886). - Gürke \& Diels in Bot. Jahrb. XXIX. 469 (1900). - Pavolini in Nuov. Giorn. Bot. Ital. n. ser. XV. 407 (1908). - Pampanini in Nuov. Giorn. Bot. Ital. n. ser. XVII. 432 (1910). - Diels in Not. Bot. Gard. Edinburgh, VII. 34, 223 (Pl. Chin. Forrest.) (1912). - Léveillé, Fl. Kouy-Tchéou, 274 (1914).

Althea frutex Hort. ex Miller, Gard. Dict. I. 46, 520 (1768).

Hibiscus rhombifolius Cavanilles, Monadelph. Dissert. I. t. 69, fig. 3 (1790).

Hibiscus syriacus, var. chinensis Lindley in Jour. Hort. Soc. Lond. VIII. 58 (1853).

Western Hupeh: Ichang, cultivated, alt. 30-300 m., July 1907 (No. 2430; bush $2 \mathrm{~m}$.); Nanto, A. Henry (No. 2126a). Szech'uan: Nanch'uan, A. von Rosthorn (No. 2415). Shensi: without locality, 1897, G. Giraldi. Formosa: Takow, Ape's Hill, alt. 3700 m., A. Henry 
(No. 1092). Fokien: Dunn's Exped., April to June 1905 (Hongkong Herb. 2412). Korea: Quelpaert, September 1908, Taquet (No. 595).

Many forms of this Hibiscus are cultivated in gardens in Hupeh and Szech'uan. In the Index Kewensis H. chinensis De Candolle (Prodr. I. 455 [1824]) is given as a synonym of $H$. syriacus Linnaeus. De Candolle cites Braam, Icon. Pl. Chin. t. 24 (1821). In the two editions of this work in the library of the Arnold Arboretum the Hibiseus figured is certainly not $H$. syriacus Linnaeus. 


\section{STERCULIACEAE.}

Determined by Alfred ReHder and E. H. Wilson.

\section{REEVESIA Lindl.}

Reevesia pubescens Masters in Hooker f., Fl. Brit. Ind. I. 364 (1874). - Brandis, Ind. Trees, 92 (1906).

Western Szech'uan: Monkong Ting, descent of Pan-lan-shan, side of stream, alt. 2300 m., October 1910 (No. 4395; tree 20 m. tall, girth $1.5 \mathrm{~m}$., one only seen). Yunnan: Mengtsze, alt. $1800 \mathrm{~m} ., A$. Henry (No. 11510; tree $10 \mathrm{~m}$. tall).

Only one tree is known to us, and this grows in a remote district where it is known as the "Soh-lou" tree. The bark is gray, rough and firm, the branches rather slender and spreading. Our specimens are in ripe fruit and the flowers are unknown to us. The woody fruit is pubescent and verrucose in the upper part, top-shaped or obconical, 4-5 $\mathrm{cm}$. high and about $2.5 \mathrm{~cm}$. wide at the summit, which is flattened and depressed. The leaves are fairly coriaceous, and vary from subcordate and truncate to rounded at the top; the primary and secondary veins are impressed above and prominent on the lower surface. In Henry's specimen, which Dunn (in Jour. Linn. Soc. XXXIX. 484 [1911]) identifies with $R$. Wallichii $\mathrm{R}$. Brown, the leaves are very long, and the base in some of them is inclined to be slightly narrowed.

It is not without some hesitation that we identify our specimens with this species of Masters, but allowing for difference in texture of leaves on flowering and fruiting specimens they agree very well with Griffith No. 548 in Herb. Gray.

The brief description of $R$. Cavaleriei Léveillé \& Vaniot (in Fedde, Rep. Spec. Nov. IV. 330 [1907]) may apply to our plant, but it is too incomplete for definite identification.

\section{STERCULIA L.}

Sterculia lanceaefolia Roxburgh, Hort. Bengal. 50 (nomen nudum) (1814); Fl. Ind. ed. 2, III. 150 (1832).

Sterculia ovalifolia Wallich, Cat. No. 1132 (nomen nudum) (1828).

Sterculia Roxburghii Wallich, Pl. As. Rar. III. t. 262 (1832), - Brown in Bennett, Pl. Jav. Rar. 229 (1844), - Masters in Hooker f., Fl. Brit. Ind. I. 356 (1874). — Léveillé, Fl. Kouy-Tchéou, 406 (1915).

Western Szech'uan: Kiating Fu, cultivated in a garden, alt. 340 m., December 1908 (No. 2458; tree 15 m. tall, girth 2.5 m., seeds shining black). 
Wilson has seen only one cultivated specimen of this tree, the origin of which is unknown to him. The Chinese called it the "Peng-kou" tree. A picture of this tree will be found under No. 440 of the collection of Wilson's photographs and in his Vegetation of Western China, No. 479.

\section{FIRMIANA Marsili.}

Firmiana simplex F. N. Meyer in U. S. Dept. Agric. Bur. Pl. Indust. CCIV. 56 (Agric. Explor. Orchards China) (1911).

Hibiscus simplex Linnaeus, Spec. ed. 2, II. 977 (1763).

Sterculia platanifolia Linnaeus f., Suppl. 423 (1781). - De Candolle, Prodr. I. 483 (1824). - Bentham, Fl. Hongk. 36 (1861). - Kurz in Jour. Bot. XI. 193 (1873), - Debeaux in Act. Soc. Linn. Bordeaux, XXX. 73 (Fl. Shanghai, 21) (1875), XXXIII. 36 (Fl. Tientsin, 13) (1879). Hemsley in Jour. Linn. Soc. XXIII. 90 (1886). - Shirasawa, Icon. Ess. For. Jap. II. t. 51, figs. 10-34 (1908), - Dunn \& Tutcher in Kew Bull. Misc. Inform. add. ser. X. 49 (Fl. Kwangtung \& Hongk.) (1912). Léveillé, Fl. Kouy-Tchéou, 406 (1915).

Sterculia tomentosa Thunberg, Icon. Pl. Jap. IV. t. 8 (1802).

Firmiana chinensis Medicus ex Steudel, Nomencl. 814 (pro synon.) (1821).

Firmiana platanifolia Schott \& Endlicher, Meletem. Bot. 33 (1832). - Diels in Bot. Jahrb. XXIX. 470 (1900).

Sterculia pyriformis Bunge in Mém. Sav. Étr. Acad. Sci. St. Pétersbourg, II. 83 (Enum. Pl. Chin. Bor. 9) (1835).

Western Hupeh: Patung Hsien, roadsides, alt. 800 m., July and December 1907 (No. 667; tree $16 \mathrm{~m}$. tall, $2 \mathrm{~m}$. girth, flowers yellowish, fruit straw-yellow); Ichang, alt. 30-1000 m., June 1907 (No. 2587; tree 5-16 m., girth 0.3-1 m.); same locality, July 1900 (Veitch Exped. No. 1254). Formosa: Tamsui, A. Henry (No. 1387). Shantung: Tsingtau, 1900, Zimmermann (No. 463).

This is a slender tree with smooth gray-green bark and whorled branches and is very common at low altitudes in Hupeh and Szech'uan. The leaves may be glabrous or more or less densely covered with pale tomentum on the under side. Colloquially it is known as Wu-tung, and the fibrous bark is used for making coarse cordage.

Pictures of this tree will be found under Nos. 519 and 0263 of the collection of Wilson's photographs and also in his Vegetation of Western China, No. 480. 


\section{DILLENIACEAE.}

Determined by ALFRED REHDER.

ACTINIDIA Lindl.

Actinidia melanandra Franchet in Jour. de Bot. VIII. 278 (1894). Pritzel in Bot. Jahrb. XXIX. 470 (1900). - Finet \& Gagnepain in Bull. Soc. Bot. France, LII. Mém. IV. 21 (1905); Contrib. Fl. As. Or. II. 21 (1907), - Dunn in Jour. Linn. Soc. XXXIX. 402 (1911).

Actinidia rufa, var. 4 parvifolia Dunn in Jour. Linn. Soc. XXXIX. 403 (1911).

Western Hupeh: Fang Hsien, thickets, alt. 1800 m., October 1910 (No. 4459; climber 5-7 m., fruit smooth, ovoid); without precise locality, June 1900 (Veitch Exped. Nos. 1068, 1068 ); without precise locality, A. Henry (No. 5938 ${ }^{\text {, }}$, type of A. rufa, var. parvifolia Dunn).

This species is easily distinguished from all related species by the glaucous under side of the leaves, which are perfectly glabrous with the exception of tufts of hairs in the axils of the veins. The pistillate flowers are usually solitary, while the staminate are borne in 3-5-flowered cymes. Wilson's No. 1068 differs somewhat in its narrow, oblong to oblong-oblanceolate leaves, broadly cuneate at the base and $8-9 \mathrm{~cm}$. long and $2.5-3 \mathrm{~cm}$. broad; Henry's No. 5838 has the leaves also broadly cuneate at the base, but more elliptic in outline and up to $4 \mathrm{~cm}$. broad. Wilson's No. 3269, referred by Dunn to this species, belongs to the following species.

\section{Actinidia purpurea Rehder, n. sp.}

Frutex alte scandens, 3-7-metralis; ramuli glabri v. initio puberuli, rarius tomentosi, annotini brunneo-grisei, lenticellis destituti, medulla albida lamellosa. Folia decidua, papyracea, elliptica v. elliptico-ovata v. elliptico-oblonga, subito acuminata, basi rotundata, rarius late cuneata, serrata dentibus parvis acuminatis accumbentibus, $8-12 \mathrm{~cm}$. longa et $4.5-6 \mathrm{~cm}$. lata, supra luteo-viridia, opaca, glabra, subtus fere concoloria, axillis barbatis exceptis glabra v. rarius ad costam tomentosa, nervis utrinsecus 5-6, subtus elevatis et trabeculis satis elevatis conjunctis; petioli $3-5 \mathrm{~cm}$. longi, glabri v. rarius tomentulosi. Flores polygami, albi, in cymis axillaribus laxe puberulis, petiolo brevioribus; cymae masculae pluri- v. multiflorae, fertiles plerumque 3 -florae; in 
floribus masculis sepala ovata, obtusa, 4-5 mm. longa, ciliolata, dorso glabra v. rarius laxe puberula; petala ovalia v. oblongo-obovata, 7-7.5 $\mathrm{mm}$. longe et 4-5 mm. lata, margine integra $\mathrm{v}$. eroso-denticulata; stamina dimidia petala aequantia, antheris oblongis $2 \mathrm{~mm}$. longis loculis basi divergentibus nigrescentibus; rudimentum pistilli staminibus plusquam duplo brevius, cylindricum, basi subito in discum dilatatum, apice irregulariter laceratum; in floribus fertilibus sepala ovata, obtusa v. acutiuscula, inaequalia, $5-7 \mathrm{~cm}$. longa, fere glabra; petala late ovata $\mathrm{v}$. ovalia, concava, valde inaequalia, 8-12 $\mathrm{mm}$. longa et $4.5-7 \mathrm{~mm}$. lata; stamina ovario breviora; ovarium conico-cylindricum, apice attenuatum, glabrum, eirciter $6 \mathrm{~mm}$. longum, stylis radiatis circiter 15, stigmate subcapitato. Bacca ovoidea v. oblonga, glabra, apice rostrata, 2-2.5 $\mathrm{cm}$. longa, purpurea, sapore grato; semina late ovoidea, 2-2.5 $\mathrm{mm}$. longa, foveolata, flavo-brunnea.

Western Szech'uan: southeast of Tachien-lu, thickets, alt. 1800-2000 m., June and October 1908 (No. I3I4; staminate flowers and fruits, type); Mupin, thickets, alt. 1500-1800 m., June 1908 (No. I3I $4^{\mathrm{a}}$, fertile flowers); Yung-ching Hsien, Wa-wu-shan, alt. 1800-2250 m., September 14, 1908 (No. 893; fruits); without precise locality, July 1903 (Veitch Exped. No. 3269; staminate flowers). Yunnan: Mengtsze, alt. 2100 m., A. Henry (No. 1108). Western Hupeh: without precise locality, July 1901 (Veitch Exped. No. 1165; staminate flowers); without precise locality, A. Henry (No. 5622). Kiangsi : Kuling, thickets, abundant, July 31, 1907 (No. I5I2).

This species is closely related to $A$. arguta Miquel ${ }^{1}$ which is chiefly distinguished by the broader leaves lustrous above and more strongly serrate with spreading teeth, by the larger flowers and by the greenish yellow subglobose fruit. Actinidia purpurea Rehder is also closely related to $A$. melanandra Franchet which differs in the glaucous under side of the leaves, in the short petioles, in the few-flowered inflorescence and in the globose-ovoid darker fruit.

Wilson's Nos. 893 and 1165 and Henry's No. 5622 differ from the type in having the petioles and the veins or at least the midrib on the under side of the leaves more or less tomentose, and Henry's specimen, moreover, has smaller and brosder leaves partly subcordate at the base while the specimen from Kiangsi which consists only of leafy branches has the petioles and the midrib setose beneath. Henry's

${ }^{1}$ According to the International Rules $A$. arguta Miquel is the correct name of the species, while Dunn follows Komarov and Finet \& Gagnepain in using A. rufa, because Trochostigma rufa precedes $T$. arguta in the original enumeration. The International Rules, however, do not recognize the so-called priority of position, but rule that, if the names of the groups to be united are of the same date, the author chooses and his choice cannot be modified (art. 46). In this case Maximowicz in 1886 was the first to unite the two species, and he took up the name A. arguta for the aggregate and consequently this name must be used for the species. 
11008 from Yunnan belongs apparently to this species and not to $A$, arguta, where Dunn placed it.

Actinidia polygama Maximowicz in Mém. Sav. Etr. Acad. Sci. St. Pétersbourg, IX. 64 (Prim. Fl. Amur.) (1859); in Bull. Acad. Sci. St. Pétersbourg, XXXI. 19 (1886); in Mél. Biol. XII. 425 (1886).-Miquel in Ann. Mus. Lugd.-Bat. III. 15 (1867); Prol. Fl. Jap. 203 (1867). Ito \& Kaku, Fig. Descr. Pl. Koishik. Bot. Gard. II. t. 20 (1883).Rehder in Mitt. Deutsch. Dendr. Ges. XII. 123 (1903). - Gilg \& Loesener in Bot. Jahrb. XXXIV. Beibl. LXXV. 52 (1904). - Komarov in Act. Hort. Petrop. XXV. 39 (Fl. Mansh.) (1905). - Finet \& Gagnepain in Bull. Soc. Bot. France, LII. Mém. IV. 20 (1905); Contr. Fl. As. Or. II. 20 (1907). - Schneider, Ill. Handb. Laubholzk. II. 327, fig. $216 \mathrm{f}-\mathrm{g}, 217 \mathrm{a}-\mathrm{f}(1909)$. - Dunn in Jour. Linn. Soc. XXXIX. 403 (1911).

Trochostigma polygama Siebold \& Zuccarini in Abh. Akad. Münch. III. 727, t. 2, fig. 2 (1843).

Trochostigma volubilis Siebold \& Zuccarini, 1. c. (1843).

Actinidia volubilis Miquel in Ann. Mus. Lugd.-Bat. III. 15 (1867); Prol. Fl. Jap. 203 (1867).

Western Hupeh: Hsing-shan Hsien, thickets, alt. 1200-1800 m., July 1907 (No. 20I3, in part; climber $7 \mathrm{~m}$. tall, flowers white); Fang Hsien, thickets, alt. 1200-1800 m., July 1907 (No. 2013, in part); without precise locality, August 1901 (Veitch Exped. No. 1363 ${ }^{\mathrm{a}}$ ); without precise locality, A. Henry (Nos. 5922, 5922 ${ }^{\mathrm{a}}, 5922^{\mathrm{b}}, 6644,767$ ). Eastern Szech'uan: Wushan Hsien, July 1900 (Veitch Exped. No.1363); same locality, A. Henry (No.5764). Western Szech'uan: Wa-shan, thickets, alt. 1500-1800 m., June, July and September 18, 1908 (Nos. 934, 20ro; climber 5-7 m. tall, flowers white, fruit golden, ovoid $3 / 4$ in. long, of good flavor); Mupin, alt. 2100 m., October 1908 (No. $934^{\mathrm{a}}$; climber $5 \mathrm{~m}$. tall, fruit ovoid, smooth, orange yellow).

Actinidia polygama has been much confused with A. kolomikta Maximowicz, though it is easily distinguished, even without leaves, by the large solid white pith of its branches, while $A$. kolomikta has lamellate brown pith, a character which had passed entirely unnoticed until Professor E. Koehne in a letter dated March 24, 1899 , drew my attention to this remarkable difference in the pith of the two species; this observation I subsequently published in 1903 in Mitt. Deutsch. Dendr. Ges. as quoted above.

Actinidia kolomikta Maximowicz in Mém. Sav. Étr. Acad. Sci. St. Pétersbourg, IX. 63 (Prim. Fl. Amur.) (1859); in Bull. Acad. Sci. St. Pétersbourg, XXXI. 19 (1886); in Mél. Biol. XII. 425 (1886). - Hemsley in Jour. Linn. Soc. XXIII. 78 (1886). - André in Rev. Hort. 1898, 
36 t. - Pritzel in Bot. Jahrb. XXIX. 470 (1900). - Diels in Bot. Jahrb. XXXVI. Beibl. LXXXII. 76 (1905). - Finet \& Gagnepain in Bull. Soc. Bot. France, LII. Mém. IV. 20 (1905); Contrib. Fl. As. Or. II. 20 (1907). — Schneider, Ill. Handb. Laubholzk. II. 327, 216 d-e (1909). - Dunn in Jour. Linn. Soc. XXXIX. 404 (1911).

Prunus ? Kolomikta Maximowicz \& Ruprecht in Bull. Acad. Sci. St. Pétersbourg. XV. 129 (1856).

Kalomikta mandshurica Regel in Bull. Acad. Sci. St. Pétersbourg, XV. 219 (1857).

Trochostigma Kolomikta Ruprecht in Bull. Acad. Sci. St. Pétersbourg, XV. 262 (1857).

Actinidia platyphylla A. Gray apud Miquel in Ann. Mus. Lugd.-Bat. III. 15 (1867); Prol. Fl. Jap. 203 (1867).

Western Szech'uan: Wa-shan, alt. 1800-2400 m., June and September 1908 (No. 854a ; climber 3-7 m., flowers white, fruit smooth, green, ovoid); near and west of Wên-ch'uan Hsien, alt. 1500-2700 m., June and October 1908 (Nos. I058, I058 ${ }^{\mathrm{a}}$; climber 5-7 m., flowers white, fruit solitary, smooth, russet); southeast of Tachien-lu, thickets, alt. 1800-2400 m., June 1908 (No. 2005; climber 7 m. or more, flowers white, fragrant); west of Kuan Hsien, Pan-lan-shan, thickets, alt. 2100-2700 m., June and September 1908 (Nos. 2008, 2009; climber 4-7 m., flowers white); Mt. Omei, June 1904 (Veitch Exped. No. 4761); without precise locality, A. Henry (No. 8806).

The plant of western China does not show any obvious differences from the Japanese plant except that the leaves are generally larger and broader. The color of the fruit of this species is greenish or yellowish, though it is given in all descriptions as bluish black. This error was probably caused by the statement of Maximowicz, that he was told by the natives that the fruit is bluish black and edible, and by the fact that the dried fruit becomes a very dark color.

Actinidia tetramera Maximowicz in Act. Hort. Petrop. XI. 35 (1889). - Finet \& Gagnepain, in Bull. Soc. Bot. France, LII. Mém. IV. 21 (1905); Contrib. Fl. As. Or. 21 (1907). - Schneider, Ill. Handb. Laubholzk. II. 327 (1909). — Dunn in Jour. Linn. Soc. XXXIX. 404 (1911).

Clematoclethra Giraldii Diels in Bot. Jahrb. XXIX. 472 (1900).

Western Szech'uan: northeast of Sungpan, thickets, alt. 21002400 m., August 1910 (No. 4557; 7 m. tall); Mupin, thickets, alt. 1800-2100 m., June 1908 (No. 890 ; climber 5-7 m., flowers white, tinged pink); Pan-lan-shan, west of Kuan Hsien, thickets, alt. 21002700 m., June 1908 (No. 2006; climber 4-7 m., flowers white, fragrant); same locality, alt. 2400 m., October 1910 (No. $4322 ; 7$ m. tall, fruit 
golden, smooth, oval); Mt. Omei, June 1904 (Veitch Exped. No.4764; pistillate plant); without precise locality, alt. $1100 \mathrm{~m}$., May 1904 (Veitch Exped. No. 3271; flowers rosy pink). Western Hupeh: Fang Hsien, thickets, alt. 1500 m., July 1907 (No. 2011 ; 4-5 m., flowers white); same locality, woodlands, alt. 1800-2400 m., June 16 and October 1910 (No. 4322 ; bush 7 m. or more, flowers white, fragrant, fruit oval); Hsing-shan Hsien, June 1907 (Veitch Exped. No. 2096); without precise locality, A. Henry (No. 6821). Northern Shensi: "monte Kan-y-san ad ovest del Lao-y-san," June 11-12, 1897, G. Giraldi (distributed as A. kolomikta).

This species is closely related to $A$. kolomikta Maximowicz, but is readily distinguished by its narrower and smaller leaves, bearded in the axils of the veins beneath but otherwise glabrous or rarely setose on the midrib, and by the tetramerous flowers, though tetramerous flowers oceur also occasionally in $A$. kolomikta. Nos. 3271 and 4764 differ from the other specimens in the longer, long-acuminate leaves which are bearded in the axils beneath and have more spreading teeth, and in the dark purplish brown branches; No. 3271 differs further in its very pink flowers and No. 4764 which is a pistillate plant in its pentamerous flowers. Dunn refers these specimens to his $A$. rubricaulis, but from that species they differ considerably in the lamellate pith, in the thin membranous closely and finely serrulate leaves rounded at the base, and in the very slender-stalked tetramerous staminate flowers.

A picture of this plant will be found under No. 098 of the collection of Wilson's photographs.

Actinidia callosa Lindley, Nat. Syst. Bot. ed. 2, 439 (1836). - Dyer in Hooker f., Fl. Brit. Ind. I. 286 (1874). - Hemsley in Jour. Linn. Soc. XXIII. 78 (1886). - Finet \& Gagnepain in Bull. Soc. Bot. France, LII. Mém. IV. 19 (1905); Contrib. Fl. As. Or. II. 19 (1907). - Schneider, Ill. Handb. Laubholzk. II. 324, fig. 2161 (1909). - Dunn in Jour. Linn. Soc. XXXIX. 19 (1911). - Léveillé, Fl. Kouy-Tchéou, 413 (1915).

Yunnan: Mengtsze, alt. 1600 m., A. Henry (No. 10824, white flowers); south of Red River from Manpan, alt. $2100 \mathrm{~m}$. (No. $10050^{\mathrm{b}}$; yellow flowers).

Actinidia callosa, var. Henryi Maximowicz in Act. Hort. Petrop. XI. 36 (1890). - Finet \& Gagnepain in Bull. Soc. Bot. France, LII. Mém. IV. 19 (1905); Contrib. Fl. As. Or. II. 19 (1907), — Léveillé, Fl. Kouy-Tchéou, 413 (1915).

Actinidia callosa Diels in Bot. Jahrb. XXIX. 470 (non Lindley) (1900).

Actinidia curvidens Dunn in Kew Bull. Misc. Inform. 1906, 1.

Actinidia callosa, forma C. Dunn in Jour. Linn. Soc. XXXIX. 406 (1911).

Western Hupeh: north and south of Ichang, common, alt. 1200$1500 \mathrm{~m}$., May and October 1907 (No. 5I2; climber 5-7 m., flowers 
white, fruit greenish, ovoid to elongate); same locality, April 1900 (Veitch Exped. No. 348); same locality, A. Henry (Nos. 3494, 3564, $3955,4377^{\mathrm{a}}$ ); Fang Hsien, side of streams, alt. 1200-1500 m., May 19, 1907 (No. 2012 ; climber 3-6 m., flowers white, fragrant); without precise locality, A. Henry (Nos. 5797, 6010, 7243). Western Szech'uan: Wa-shan, thickets, alt. 1500-2200 m., June 1908 (No. 2or6; 3-7 m., flowers white); Mt. Omei, May 1904 (Veitch Exped. No. 4762); Nanch'uan, A. von Rosthorn (No. 1824); without precise locality, alt. 1100 m., May 1904 (Veitch Exped. No. 3273).

Actinidia venosa Rehder, n. sp.

Actinidia callosa, forma D. Dunn in Jour. Linn. Soc. XXXIX. 406 (1911).

Frutex scandens, 3-8-metralis; ramuli medulla ampla alba lamellata, juniores puberuli v. tomentosi, mox glabrescentes et fuscescentes, interdum setacei, annotini purpureo-brunnei lenticellis oblongis albidis notati. Folia membranacea, ovata ad ovato-oblonga, ovalia v. elliptica ad elliptico-oblonga, acuminata v. longe acuminata, basi plerumque rotundata, interdum subcordata, rarius late cuneata, denticulatoserrulata v. setaceo-serrulata, $5-15 \mathrm{~cm}$. longa et 3-6, rarius ad $7.5 \mathrm{~cm}$. lata, supra laete viridia, glabra v. initio sparse setosa, subtus vix pallidiora, initio ad nervos et venulas plus minusve tomentosa v. interdum fere glabra, demum glabra $v$. fere glabra, utrinque nervis 7-11 subtus manifeste elevatis ante marginem anastomasantibus et trabeculis numerosis parallelis manifeste elevatis conjunctis; petioli graciles, 1.5-4 cm. longi, initio puberuli v. fere glabri, demum glabri. Flores flavi, 1.5-2 cm. diam., in cymis petiolo brevioribus; masculi in cymis satis densis, 3-7-floris; pedunculi $0.5-1 \mathrm{~cm}$. longi, ut pedicelli subaequilongi fulvo-tomentosi; sepala ovato-oblonga, $5 \mathrm{~mm}$. longa, utrinque fulvo-tomentosa; petala elliptico-oblonga, integra v. rarius eroso-denticulata, eirciter $10 \mathrm{~mm}$. longa et $5-6 \mathrm{~mm}$. lata; stamina petalis triente breviora, antheris $3 \mathrm{~mm}$. longis basi emarginatis; rudimentum pistilli subglobosum, parvum, tomentosum; flores hermaphroditi in cymis 1-5-floris, petiolo brevioribus; sepala ut in floribus masculis; petala ovalia, circiter $8 \mathrm{~mm}$. longa et $5 \mathrm{~mm}$. lata; stamina dimidia petala aequantia; ovarium subglobosum, dense villosum; styli circiter 15, patentes, apice incrassati et leviter curvati. Fructus solitarii v. plures, ovoidei v. subglobosi, circiter $1.5 \mathrm{~cm}$. longi, brunnei, maculis albidis satis dense conspersi, pedunculis $1.5-2 \mathrm{~cm}$. longis; semina ovoidea, vix compressa, minute foveolata, purpureo-brunnea, vix $2 \mathrm{~mm}$. longa. 
Western Szech'uan: west and near Wên-ch'uan Hsien, alt. 1800-2400 m., June and October 1908 (No. 1029, in part, type; flowers buff-yellow, fruit russet); same locality, alt. 1200-2100 m., June 1908 (No. 888, in part; flowers buff-yellow); Wa-shan, thickets, alt. 18002400 m., July 1908 (No. I029, in part); same locality, alt. 1500-1800 m., June 1908 (Nos. 888, in part, 89I, in part); Wa-wu-shan, Yung-ching Hsien, alt. 1200-2100 m., September 14, 1908 (No. 888, in part; fruit glaucescent, ovoid); same locality, September 14, 1908 (No. 89r, in part; fruit ovoid to globose, russet, clustered); southeast of Tachien-lu, alt. 2000 m., July and October 1908 (No. I029 ${ }^{\mathrm{a}}$; flowers buff-yellow, fruit russet); Mt. Omei, July 1904 (Veitch Exped. No. 4765); without precise locality (Veitch Exped. No. 3275).

This species is closely related to A. callosa Lindley, which is easily distinguished, however, by the more elliptic or oblong leaves usually broadly cuneate at the base, with fewer usually 5-7 pairs of lateral veins and with less prominent veinlets on the under surface, by the glabrous sepals and inflorescence, the white flowers and by the smaller brown pith of the branches. The flowering specimens of No. 888 differ somewhat from the other specimens in their narrower and longer, oblong-ovate, long-acuminate and distinctly setosely serrulate leaves. The fruit of No. 888 is described by Wilson as glaucescent, while the fruits of the other specimens are described as russet. Henry's No. 10780 referred by Dunn to his A. callosa f. D. does not seem to belong here according to the specimens in the herbarium of the Arnold Arboretum, and represents probably an undescribed species related to A. chinensis Planchon and A. rudis Dunn.

Here may be added a note on a closely related species not collected during the Arnold Arboretum Expeditions.

Actinidia trichogyna Franchet in Jour. de Bot. VIII. 278 (1894).

Actinidia callosa, var. trichogyna Finet \& Gagnepain in Bull. Soc. Bot. France, LII. 20 (1905); Contrib. Fl. As. Or, II. 20 (1907), - Dunn in Jour. Linn. Soc. XXXIX, 406 (1909).

Western Hupeh: north and south of Ichang, rare, June 1901 (Veitch Exped. No. 2204). Eastern Szech'uan: without precise locality, A. Henry (No. 7135).

Finet \& Gagnepain as well as Dunn consider this a variety of A. callosa Lindley, but it is easily distinguished from that species by the distinctly ovate shape of the leaves rounded or subcordate at the base and glaucous below, and by the shortstalked usually solitary staminate flowers with tomentulose sepals. It has the appearance of a perfectly distinct species. Actinidia sabiaefolia Dunn is very near, but differs in the smaller crenate-serrate leaves acute or obtusish at the apex and in the glabrous sepals.

Actinidia coriacea Dunn in Jour. Linn. Soc. XXXIX. 405 (1911). Actinidia callosa, var. coriacea Finet \& Gagnepain in Bull. Soc. Bot. France, LII. Mém. IV. 20 (1905); Contrib. Fl. As. Or. II. 20 (1907).

Western Szech'uan: Mupin, thickets, alt. 900-1200 m., June 1908 (No. 932, in part; 7 m. tall, flowers reddish); Hung-ya Hsien, 
woodlands, alt. 600-900 m., September 6, 1908 (No. 932, in part; $7 \mathrm{~m}$. tall); Mt. Omei, June 1904 (Veitch Exped. No. 4760); without precise locality, May 1904 (Veitch Exped. Nos. 3272, 3272ª).

This is a very distinct species chiefly characterized by the coriaceous, remotely mucronate-serrulate leaves and red flowers borne on separate leafless branches or along the leafless base of the shoots. Seed of this species has been distributed by the Arnold Arboretum erroneously as A. Henryi.

Actinidia chinensis Planchon in Lond. Jour. Bot. VI. 303 (1847). Hemsley in Jour. Linn. Soc. XXIII. 78 (1886). - Oliver in Hooker's Icon. XVI. t. 1593 (1887).- - Diels in Bot. Jahrb. XXIX. 470 (1900). J. H. Veitch in Jour. Hort. Soc. Lond. XXVIII. 59, t. 15 (1903). Finet \& Gagnepain in Bull. Soc. Bot. France, LII. Mém. IV. 18 (1905); Contrib. Fl. As. Or. II. 18 (1907). - Schneider, Ill. Handb. Laubholzk. II. 323, fig. $216^{\circ}$ (1909). - Woodall in Gard. Chron. ser. 3, XLVI. 79, t. (1909). - Pampanini in Nuov. Giorn. Bot. Ital. n. ser. XVII. 431 (1910). - Dunn in Jour. Linn. Soc. XXXIX. 408 (1911). - Sprague in Bot. Mag. CXL. t. 8538 (1914).

Western Hupeh: north and south of Ichang, thickets, common, alt. 1200-1800 m., June 1907 (No. 347, in part; climber 7-8 m., flowers white changing to buff-yellow); Changyang Hsien, June 1901 (Veitch Exped. No. 993); without precise locality, April 1900 (Veitch Exped. No. 185); without precise locality, A. Henry (Nos. 2076, $\left.5574,5834,5834^{\text {a }}\right)$; "Lan-tau," alt. 900 m., June 3-18, 1906, C. Silvestri (No. 1467). Western Szech'uan: west and near Wênch'uan Hsien, alt. 1500-2400 m., June 1908 (No. 347, in part; climber 5-8 m., flowers white, quickly changing to buff-yellow, fragrant); Nanch'uan, A. von Rosthorn (No. 1997). Chekiang: Ningpo, D. Macgregor, 1908.

Pictures of this plant will be found under Nos. 107, 108, 347, 407, 0129 of the collections of Wilson's photographs and also in his Vegetation of Western China, Nos. 111, 112, 113. An account of the ornamental and economic value of this Actinidia appears in Wilson's A Naturalist in Western China, II. 32 (1913).

Actinidia spec.

Western Szech'uan: Ching-chi Hsien, alt. 1800 m., August 1908 (No. 854; climber 5-6 m., fruit oval, red-purple, $18 \mathrm{~mm}$. long).

This specimen seems to represent a distinct species, but the material is so incomplete that it is impossible to be sure. In its oval-oblong purple fruit it resembles $A$. purpurea Rehder, but the fruit is not rostrate at the apex; the leaves are generally ovate, usually subcordate at the base, sparingly setose above, bright green beneath and glabrous or sparingly villous on the midrib, minutely 
mucronate and serrulate with somewhat spreading teeth. The peduncles of the fruits are solitary and about $2 \mathrm{~cm}$. long.

\section{CLEMATOCLETHRA MaXim.}

Clematoclethra integrifolia Maximowicz in Act. Hort. Petrop. XI. 38 (1890). - Komarov in Act. Hort. Petrop. XXIX. 90 (1908).

Western Szech'uan: northeast of Sungpan, alt. 1800-2200 m., August 1910 (No. 4027; climber 5-7 m., fruit black); northeast of Tachien-lu, Ta-p'ao-shan, alt. 2500-3000 m., July 9, 1908 (No. 2007; climber 4-6 m., flowers white, fragrant). Western Kansu: Minchou district, alt. $2700 \mathrm{~m}$., W. Purdom.

Clematoclethra actinidioides Maximowicz in Act. Hort. Petrop. XI. 38 (1890). - Komarov in Act. Hort. Petrop. XXIX. 91 (1908).

Western Szech'uan: Mupin, thickets, alt. 1800-2100 m., September 1908 (No. 89o; climber 5-7 m., fruit black); Pan-lan-shan, west of Kuan Hsien, alt. 2100-2400 m., October 1910 (No. 429o; climber 6-7 m., leaves variable in size, fruit black); northeast of Sungpan, alt. 1800-2100 m., August 1910 (No. 4027; climber 3-7 m., fruit black).

Clematoclethra lasioclada Maximowiez in Act. Hort. Petrop. XI. 38 (1890). - Pritzel in Bot. Jahrb. XXIX. 471 (1900). - Komarov in Act. Hort. Petrop. XXIX. 95 (1908).

Western Szech'uan: west and near Wên-ch'uan Hsien, thickets, alt. 1500-2700 m., July 1908 (No. 886'; elimber 4-7 m., flowers white, fragrant); same locality, alt. 1800 m., October 1910 (No. 4545; climber 5-7 m., fruit black); Wa-shan, thickets, alt. 18002200 m., July and September 1908 (No. 886 ; climber 4-6 m., flowers white, fruit black); Yung-ching Hsien, Wa-wu-shan, thickets, alt. 2100-2700 m., July and September 15, 1908 (No. 886 ${ }^{\text {b }}$; climber 3-7 m., flowers white, fruit black).

According to Komarov C. lasioclada is glabrous on the under side of the leaves. No. $886^{\circ}$, however, is pubescent on the veins beneath, but does not appear to differ otherwise.

Clematoclethra lasioclada, var. grandis Rehder, n. comb.

Clematoclethra grandis Hemsley in Hooker's Icon. XXIX, in textu ad t. 2808 (1906).

Clematoclethra Prattii Komarov in Act. Hort. Petrop. XXIX. 95 (1908). 
Western Szech'uan: southeast of Tachien-lu, thickets, alt. 21002400 m., October 1910 (No. 4I68; climber 7 m., fruit black); west of Kuan Hsien, alt. 2100-2700 m., June and September 1908 (No. ro3o; climber $7 \mathrm{~m}$., flowers white, fruit black); west and near Wên-ch'uan Hsien, alt. 1800-2400 m., October 1910 (No. 4I93; climber 7 m., fruit black); same locality, alt. 1500-2700 m., July 1908 (No. 886; climber 4-7 m., fruit black).

This variety appears to differ from the type only in its larger leaves; the pubescence on the veins beneath, considered a distinctive character by Komarov, can be found also on specimens of the small-leaved forms.

Clematoclethra Faberi Franchet in Jour. de Bot. VIII. 280 (1894). Komarov in Act. Hort. Petrop. XXIX. 93 (1908).

Clethra ( $\$$ Clematoclethra, Franch.) sp. ? Hemsley in Jour. Linn. Soc. XXVI. 34 (1889).

Clematoclethra Hemsleyi Baillon in Bull. Soc. Linn. Paris, II. 873 (1890), quoad cit. "Hemsley \& Forbes."

Clematoclethra Hemsleyana Baillon ex Komarov in Act. Hort. Petrop. XXIX. 93 (pro synon.) (1908).

Western Szech'uan: Mupin, thickets, alt. 2100 m., October 1910 (No. 4292; climber 5-7 m., fruit black); Mt. Omei, July 1904 (Veitch Exped. No. 4766).

Clematoclethra scandens Maximowicz in Act. Hort. Petrop. XI. 38 (1890). - Diels in Bot. Jahrb. XXIX. 471 (1900). - Komarov in Act. Hort. Petrop. XXIX. 92 (1908).

Clethra scandens Franchet in Nouv. Arch. Mus. Paris, sér. 2, X. 53, t. 10 (Pl. David. II. 91, t. 10) (1887).

Clematoclethra Maximowiczii Baillon in Bull. Soc. Linn. Paris, II. 873 (1890).

Western Szech'uan: Pan-lan-shan, west of Kuan Hsien, alt. 2100-2700 m., June 19, 1908 (No. 895, in part; climber 5-8 m., flowers white); Yung-ching Hsien, Wa-wu-shan, alt. 1500-2100 m., September 17, 1908 (No. 895, in part; fruit scarlet); Wa-shan, thickets, alt. 15002100 m., June 1908 (No. 895, in part; climber 5-8 m., flowers white); Mupin, thickets, alt. 1200-1800 m., September 1908 (No. 895, in part, $895^{\mathrm{a}}$; climber 3-5 m., fruit red); same locality, June 1908 (No. 895 ${ }^{\text {b }}$ climber 3-7 m., flowers white); same locality, alt. 1500-2200 m., October 1910 (No. 4206; climber 3-7 m., fruit red); Mt. Omei, June 1904 (Veitch Exped. No. 4763).

This species varies much in its pubescence and in the shape of its leaves. No. 895 from Mupin differs in its broader leaves from the typical form, which is represented by the specimens from Yung-ching Hsien, Pan-lan-shan and Wa-shan. 
Nos. $895^{\mathrm{a}}, 895^{\mathrm{b}}, 4206$ and 4763 are less strigose; they agree with Maximowicz's description and have been distinguished by Baillon as C. Maximowiczii. No. 4206 is entirely destitute of bristles on the tomentulose branchlets, very sparingly bristly on the petioles and bristly only on the underside of the midrib of the leaves. These are comparatively broad, while in No. $895^{\mathrm{b}}$ they are rather narrow and cuneate at the base and only slightly villose on the under side.

Clematoclethra Franchetii Komarov in Act. Hort. Petrop. XXIX. 94 (1908).

Western Szech'uan: Yung-ching Hsien, Wa-wu-shan, alt. 21002700 m., September 12, 1908 (No. 944, climber 3-7 m., fruit dark red).

\section{Clematoclethra lanosa Rehder, n. sp.}

Frutex scandens, 3-5-metralis; ramuli hornotini initio dense fulvolanuginosi, demum glabrescentes, annotini glabri, griseo-brunnei, lenticellis pallidis plerumque satis dense conspersi; gemmae castaneae, glabrae. Folia ovata v. ovato-oblonga, acuminata, basi rotundata v. subcordata, margine dense ciliato-denticulata, 5-9 $\mathrm{cm}$. longa et 3-6.5 $\mathrm{cm}$. lata, supra obscure viridia, glabra costa et venis rufo-villosulis exceptis, subtus tomento lanuginoso ad costam venasque rufo in facie griseo v. albido vestita, nervis utrinsecus circiter 8 subtus elevatis; petioli 2-3.5 cm. longi, dense fulvo-villosi. Cymae plerumquae triflorae, dimidium petiolum subaequantes v. paullo superantes; pedunculi $1-1.5 \mathrm{~cm}$. longi, ut pedicelli breves $0.3-0.5 \mathrm{~cm}$. longi dense rufolanosi; sepala orbiculari-ovata, extus dense rufo-lanosa, intus puberula; petala alba, ovalia v. oblongo-ovalia, circiter $7 \mathrm{~mm}$. longa, sepala duplo superantia; stamina petalis dimidio breviora; stylus gracilis, petala paullo superantia. Fructus desideratur.

Western Hupeh: Changlo Hsien, thickets, alt. 1200-1800 m., June 1907 (No. 2or4, in part, type); Changyang Hsien, thickets, alt. 1200-1500 m., June 1907 (No. 20r4, in part); Fang Hsien, June 1901 (Veitch Exped. No. 2181).

This species seems most closely related to $C$. cordifolia Franchet, which differs according to the description in its smaller and broader cordate leaves, sparingly setose on the midrib beneath, in its short nearly glabrous petioles and in the glabrous or puberulous sepals. It may also be compared with C. Faberi Franchet and $C$. Franchetii Komarov, but these differ in their less dense and less woolly pubescence and in the glabrous or minutely puberulous sepals. The first of these species differs also in the glaucous under side of the leaves and the second in its much larger leaves. In the pubescence of the leaves and of the inflorescence $C$. lanosa resembles C. Hemsleyi Baillon, which is easily distinguished by the longstalked 'many-flowered inflorescence and by the longer pedicels, and our species might be considered a depauperated form of it, if the color of the fruits proves to be red.

Wilson's No. 2181 I refer only provisorily to this species; it differs in the spar- 
ingly hairy upper surface of the leaves, the hairs being tuberculate at the base, in the presence of long setulose hairs on the midrib beneath and on the petiole, in the dark brown color of the older branchlets and in the less shaggy tomentum of the young branchlets and the petioles. The inflorescence and its tomentum agree with the type.

Clematoclethra Hemsleyi Baillon in Bull. Soc. Linn. Paris, II. 873 (1890), excl. cit. "Forbes \& Hemsley." - Hemsley in Hooker's Icon. XXIX. t. 2808 (1906).

Clematoclethra tomentella Franchet in Jour. de Bot. VIII. 280 (1894). Pritzel in Bot. Jahrb. XXIX. 471 (1900). - Komarov in Act. Hort. Petrop. XXIX. 94 (1908).

Clematoclethra Henryi Franchet ex Komarov in Act. Hort. Petrop. XXIX. 94 (pro synon.) (1908).

Western Hupeh: Fang Hsien, thickets, alt. 1500-1800 m., July 1907 (No. 2015; climber 3-5 m., flowers white); same locality, October 1910 (No. 4455; climber 7 m., fruit red); without precise locality, A. Henry (Nos. 6818, 6885).

Here may be added a species related to C. actinidioides Maximowicz, not collected during the Arnold Arboretum Expeditions.

Clematoclethra tiliacea Komarov in Act. Hort. Petrop. XXIX. 91 (1908).

Western Szech'uan: Tachien-lu, May 1904 (Veitch Exped. No. 3274; flowers white). 


\section{THEACEAE.}

Determined by Alfred Rehder and E. H. Wilson.

\section{THEA L.}

Sect. Euthea Szyszyl.

Thea fraterna O. Kuntze, Rev. Gen. Pl. I. 65 (1891).

Camellia fraterna Hance in Ann. Sci. Nat. sér. 4, XVIII. 218 (1862). Hemsley in Jour. Linn. Soc. XXIII. 81 (1886).

Western Hupeh: Ichang, glens, alt. 30-300 m., March 1907 (No. 2207; bush 1-2 m., flowers white); same locality, March 16, 1900 (Veitch Exped. No. 8); same locality, A. Henry (Nos. 3374, 3374ª). Chekiang: vicinity of Ningpo, 1908, D. Macgregor.

The Ningpo specimen was compared in the Kew herbarium and found to be identical with our specimens. The Hupeh specimens have less hairy sepals. Kochs (in Engler, Bot. Jahrb. XXVII. 586 [1900]) reduces this plant to Thea euryoides Booth, but Lindley's original figure (in Bot. Reg. XII. t. 983 [1826]) shows a plant with a longer peduncle, much smaller bracts and sepals and much smaller flowers. In this herbarium there is a specimen from Formosa collected by A. Henry (No. 90 ) which agrees exactly with Lindley's figure and is obviously distinct from $T$. fraterna.

We suspect that Thea rosaeflora, var. pilosa Kochs (in Bot. Jahrb. XXVII. 585 [1900]) belongs here.

Thea cuspidata Kochs in Bot. Jahrb. XXVII. 586 (1900). - Pampanini in Nuov. Giorn. Bot. Ital. n. ser. XVII. 432 (1910).

Thea rosaeflora, var. glabra Kochs in Bot. Jahrb. XXVII. 585 (1900).Pritzel in Bot. Jahrb. XXIX. 472 (1900).

Camellia cuspidata in Gard.Chron. ser. 3, LI. 262, fig. 123 (1912), - J. H. Veitch in Jour. Hort. Soc, Lond. XXXVIII. LXII, fig. 38 (1912). - Bean, Trees \& Shrubs Brit. Isl. I. 284, fig. (1914).

Western Hupeh: Hsing-shan Hsien, woods, alt. 600-1000 m., May 1907 (No. 2208; bush 2 m., flowers white); Changyang Hsien, October 1900 (Veitch Exped. Seed No. 1099); Nanto and mountains to northward, A. Henry (No. 3024); without locality, A. Henry (Nos. $3216,7864,7917,7442,6323,5165,5151,5360)$. Eastern Szech'uan: Wushan Hsien, May 1900 (Veitch Exped. No. 596); same locality, A. Henry (No. 7026). 
This is a common shrub in thickets and thin woods to the north and south of Ichang. The flowers are white, and no species of Thea with colored flowers has so far been reported from western Hupeh or the neighboring part of Szech'uan. The flowers vary somewhat in size.

Thea sinensis Linnaeus, Spec. 515 (1753). - Kochs in Bot. Jahrb. XXVII. 587 (1900). - Matsumura, Ind. Pl. Jap. II. 2, 363 (1912).

Thea bohea Linnaeus, Spec. ed. 2, 734 (1762), - Hayne, Arzn. Gew. VII. t. 28 (1855).

Thea viridis Linnaeus, Spec. ed. 2, 735 (1762). - Hayne, Arzn. Gew. VII. t. 29 (1855).

Thea cochinchinensis Loureiro, Fl. Cochin. 338 (1790).

Thea cantoniensis Loureiro, 1. c. 339 (1790).

Thea oleosa Loureiro, 1. c. 339 (1790), quoad descriptionem.

Thea chinensis, var. $\beta$ Bohea Sims in Bot. Mag. XXV. t. 998 (1807). - De Candolle, Prodr. I. 530 (1824).

Camellia Thea Link, Enum. Pl. Hort. Bot. Berol. II. 73 (1822). - Hemsley in Jour. Linn. Soc. XXIII. 82 (1886). - Dunn \& Tutcher in Kew Bull. Misc. Inform. add. ser. X. 45 (Fl. Kwangtung \& Hongk.) (1912). - Léveillé, Fl. Kouy-Tchéou, 414 (1915).

Camellia viridis Link, Enum. Pl. Hort. Berol. II. 73 (1822).

Thea chinensis De Candolle, Prodr. I. 530 (1824), - Seemann in Trans. Linn. Soc. XXII. 349, t. 61 (1869).

Thea chinensis, var. viridis De Candolle, Prodr. I. 530 (1824).

Camellia? Scottiana Wallich, Cat. No. 3668 (nomen nudum) (1829). - Dyer in Jour. Linn. Soc. XIII. 328 (pro synon.) (1873).

Theaphyla laxa Rafinesque in Sylva Tellur. 139 (1838).

Theaphyla lanceolata Rafinesque, 1. c. (1838).

Theaphyla viridis Rafinesque, 1. c. (1838).

Theaphyla cantoniensis Rafinesque, 1. c. (1838).

Theaphyla oleifera Rafinesque, 1. c. (1838).

Thea assamica Masters in Jour. Asiat. Soc. Bengal, IV. 48, t. 2 (1844).

Camellia theifera Griffith, Icon. Pl. Asiat. IV. t. 601, fig. 1, 3; et t. 603, fig. 1, 2 (1854). - Dyer in Hooker f., Fl. Brit. Ind. I. 292 (1874). - Franchet in Nouv. Arch. Mus. Paris, sér. 2, V. 210 (Pl. David. I. 58) (1883).

Camellia Bohea Griffith, Icon. Pl. Asiat. IV. t. 602, fig. 1 (1854).

Thea stricta Hayne, Arzn. Gew. VII. t. 27 (1855).

North-central Szech'uan: Pa-chou, red sandstone ravine, alt. 600-1000 m., July 1910 (No. 4723; bush 2.5-5 m. tall, apparently spontaneous). Western Szech'uan: Mt. Omei, cultivated, September 1904 (Veitch Exped. No. 4757). Yunnan: Mengtsze forests, alt. 1600 m., A. Henry (No. 10377; tree 6 m., flowers white); Fang-chenlin Mountain, forests, alt. 2300 m., A. Henry (No. 10377ª shrub 3 m.); south of Red River from Manmei, virgin forests, alt. 2300 m., A. Henry (No. 9722; shrub $2 \mathrm{~m}$.); Ibang, cultivated, A. Henry (No. 13183; shrub $2 \mathrm{~m}$., source of tea known as Puerh Tea). Western Hupeh: Nanto and mountains to northward, cultivated, A. Henry (No. 2214); 
without locality, A. Henry (Nos. 2499, 7822). Chekiang: vicinity of Ningpo, 1908, D. Macgregor.

Although many forms of this long cultivated shrub occur, all are undoubtedly referable to one species. The size of the leaves depends on good cultivation; on neglected plants the leaves are large, coarse and of comparatively little value, and if the soil is fairly good and the plants grow freely the leaves assume the size and shape of those of the so-called Assam Tea plant. Close picking of the young shoots and leaves dwarfs the plants and reduces the size of the leaves. Henry's Nos. 10377, $10377^{\mathrm{a}}$, have large leaves, but his No. 9722 "from a virgin forest" has leaves in size and substance identical with those of several cultivated specimens before us. The specimens are from wild plants (see Henry in Kew Bull. Misc. Inform. 1897, 100), and doubtless the plant occurs wild from various parts of southeastern Yunnan to Assam.

Our No. 4723 has leaves $8-11 \mathrm{~cm}$. long and 4-6.5 $\mathrm{cm}$. wide, and though it is perhaps safer to regard it as from a naturalized plant it might well be considered spontaneous. The region is remote and there were many large bushes growing in a thicket in a sandstone ravine. However this may be, we are of the opinion that the Tea plant is a native of China and that formerly it was common in the rain-forest belt throughout the warm-temperate part of western and southwestern China. To-day these forests have almost entirely disappeared to make way for agriculture.

The Tea plant is but sparingly cultivated in western Hupeh and in eastern Szech'uan where the products of this industry are of local importance only, but in western Szech'uan the industry is a very important one and supplies the whole of Tibet. The methods employed are peculiar, and the product is different from that of other parts of China. A full account of this industry is contained in Wilson's A Naturalist in Western China, II. 89 (1913). A picture of a Tea plantation will be found under No. 0172 of the collection of Wilson's photographs. Kaempfer (Amoen. Exot. 606 [1712]) gives a fine figure of this plant accompanied by a very full description, but he does not make the combination "Thea japonica" attributed to him by Seemann (in Trans. Linn. Soc. XXII. 349, t. 61) and others.

Here may be added the description of a species of the section Euthea not collected during the Arnold Arboretum Expeditions.

Thea elongata Rehder \& Wilson, n. sp.

Frutex 2-6-metralis, ramosus; rami graciles, einerei, glabri; gemmae acutae, leviter pilosae. Folia chartacea, oblongo-lanceolata v. lanceolata v. oblanceolata, caudato-acuminata, mucronulata, basi attenuata, supra medium remote leviter serrulata, $3.5-6 \mathrm{~cm}$. longa et 1-2 cm. lata, supra laete viridia, nitentia, subtus vix pallidiora, utrinque glaberrima, costa media supra impressa subtus elevata, nervis venulisque obsoletis; petioli $2-3 \mathrm{~mm}$. longi, glabri. Flores solitarii v. bini, axillares v. plerumque in ramulis lateralibus pseudo-terminales, albi; pedicelli curvati, 0.4-1 cm. longi, bracteis 5-7 parvis ovatis ciliatis instructi; sepala 5, late ovata v. subrotundata, acutiuscula, $2 \mathrm{~mm}$. longa, margine scariosa, ciliolosa; petala 5 , spathulato-oblonga, $1.5-2.5 \mathrm{~cm}$. longa et $7-9 \mathrm{~mm}$. lata, rotundata; stamina numerosa, petalis paullo breviora; filamenta quarta parte superiore excepta connata, ad partem liberam sparse pilosa; pistillum glabrum, $1.8 \mathrm{~cm}$. longum, stylo filiformi fere ad apicem connato, stigmatibus 3 simplicibus. Fructus desideratur.

Western Szech'uan: Mt. Omei, October 1904 (Veitch Exped. No. 4755, type); same locality, alt. 1300-1600 m., October 1903 (Veitch Exped. No. 3266).

This is a very distinct and graceful species characterized by its narrow elongated leaves and petals and by its very long pedicels and stamens. It is most closely re- 
lated to $T$. cuspidata Kochs, which has stouter branches, large elliptic-lanceolate leaves, broad flowers on very short pedicels, paleaceous much larger sepals, ovate petals and shorter stamens.

This new species is common at low altitudes round the base and on the lower slopes of Mt. Omei.

\section{Sect. Camellia Szyszyl.}

Thea oleifera Rehder \& Wilson, n. comb.

Thea oleosa Loureiro, Fl. Cochin. 339 (1790), quoad nom. chinensia et notam. Camellia oleifera Abel, Narr. Jour. China, 363, t. p. 174 (1818).-Lindley in Bot. Reg. XI. t. 942 (1825), - Loddiges, Bot. Cab. XI. t. 1065 (1825), Booth in Trans. Hort. Soc. Lond. VII. 524 (1830). - Seemann in Bonplandia, VI. 278 (1858); in Trans. Linn. Soc. XXII. 344 (pro synon.) (1859). Léveillé, $F l$. Kouy-Tchéou, 414 (1915).

Camellia sasanqua Staunton, Embas. to China, II. 466 t. (non Thunberg) (1797). - Ker in Bot. Reg. I. t. 12 (1815). - Hance in Jour. Bot. XVII. 9 (1879). - Franchet in Nouv. Arch. Mus. Paris, sér. 2, V. 210 (Pl. David. I. 58) (1883), - Hemsley in Jour. Linn. Soc. XXIII, 82 (1886). - Dunn \& Tutcher in Kew Bull. Misc. Inform. add. ser. X. 46 (Fl. Kwangtung \& Hongk.) (1912).

Sasanqua oleifera Rafinesque, Sylva Tellur. 140 (1838).

Thea sasanqua, var. oleosa Pierre, Fl. For. Cochin. II. t. 116, figs. $\mathrm{b}^{1}, \mathrm{~b}^{2}$ (1887). - Kochs in Bot. Jahrb. XXVII. 594 (1900).

Camellia Sasanqua, var. oleifera Rehder in Bailey, Cycl. Am. Hort. I. 225 (1900).

Camellia Sasanqua, var. oleosa Rehder in Bailey, Stand. Cycl. Hort. II. 641 (1914).

Kiangsi: Kiukiang, foothills, alt. 300 m., August 1, 1907 (No. I532; bush 2-3 m.); Kuling, side of stream, alt. 1300 m., July 31, 1907 (No. I527; bush 2 m.). Western Szech'uan: An Hsien, cultivated, alt. 600 m., August 1910 (No. 4554; bush 2-6 m.); Hung-ya Hsien, Wa-wu-shan, thickets, alt. 800 m., September 1908 (No. 2205; bush 2-2.5 m.); Kiating Fu, banks of Min River, June 1903 (Veitch Exped. No. 3265); Mt. Omei, October 1904 (Veiteh Exped. No. 4756). Fokien: Dunn's Exped., April to June 1905 (Hongkong Herb. Nos. 2457, 2452).

This shrub is abundant on the foothills of the Lushan mountains near Kiukiang and is much cultivated in the warm eastern parts of China for the sake of its seeds, which, when crushed, yield a sweet oil much esteemed in cooking. In parts of western Szech'uan it is not uncommon and is also occasionally cultivated.

In China Wilson paid considerable attention to this plant and when in Japan in 1914 to Thea Sasanqua Noisette, and he cannot agree that these plants are specifically identical. In herbaria they look very similar, it is true, but the Japanese plant may be distinguished by its thinner leaves with more crenate serration and by its buds which are glabrescent or clothed with short, very elose appressed gray pubescence exactly like those of Thea japonica Noisette, whereas in the Chinese $T$. oleifera the buds are covered with pale, loose, shaggy villose hairs. There are differences in the degree of hairiness of the branches and in degree of union of thestamen-filaments, but these are perhaps not constant. The living plants are markedly different in 
general appearance. Thea Sasanqua is exceedingly common throughout the warmer parts of Japan, forming a large wide-spreading bush and in the extreme south a small tree. The branches are very slender and wide-spreading and in the wild plant the flowers are always white. It is a popular garden shrub and under cultivation forms with pink and rose-colored flowers are common. Doubtless the pink-flowered plant Kaempfer (Amoen. Exot. 853 [1712]) was familiar with was cultivated. The Japanese plant is valued chiefly as an ornamental garden shrub, though the seeds do contain an inferior sort of oil formerly and possibly still used by women for dressing their hair. But the oil chiefly used in Japan and most highly valued for this purpose is that expressed from the seeds of Thea japonica. Oil from the seed of the Tea plant (Thea sinensis Linnaeus) is also used for the same purpose. Very probably the oils in the seeds of T. Sasanqua and T. oleifera differ in their chemical composition, as their uses in the two countries are so different.

In regard to Loureiro's Thea oleosa, the native names given belong to $T$. oleifera and the substance of his note applies to this plant, but the description obviously applies to the common Tea plant ( $T$. sinensis Linnaeus). Seemann (1. c.), although he interprets the facts differently, says " what is preserved in the Parisian Museum as the original specimen of Thea oleosa Loureiro is Thea chinensis, var. Bohea." We can appreciate the difficulties under which Loureiro worked, and it is easy to understand the possibility of his describing one plant in the firm belief that it was another of quite different economic value.

A picture of Thea oleifera will be found under No. 0253 of the collection of Wilson's photographs.

Thea Grijsii Kochs in Bot. Jahrb. XXVII. 591 (1900). - Pritzel in Bot. Jahrb. XXIX. 473 (1900).

Camellia Grijsii Hance in Jour. Bot. XVII. 9 (1879). - Hemsley in Jour. Linn. Soc. XXIII. 81 (1886).

Thea Grijsii O. Kuntze, Rev. Gen. Pl. I. 65 (1891). - Szyszylowicz in Engler, Nat. Pflanzenfam. III. Abteil. 6, 183 (1893).

Western Hupeh: Ichang, glens, alt. 30-100 m., January 1909 (No. 2206; bush 2-3 m., flowers white); same locality, A. Henry (No. 3335); without locality, A. Henry (No. 7921). Western Szech'uan: Kiating Fu, thickets, alt. 1100 m., October 1908 (No. 2204; bush 2-2.5 m.).

This shrub is fairly common at low altitudes in Hupeh and Szech'uan, where it flowers at midwinter. The petioles and the lower part of the midrib on both sides and the upper part of the shoots are often more or less hairy.

Though closely related to $T$. oleifera, Grijs's plant may be distinguished in the herbarium by its much more prominently veined and more sharply serrate leaves, by the short, dense, closely appressed pubescence on the winter-buds, by its very deeply cleft petals, more united filaments and by its shorter style. The fruit is also larger and less distinetly globose in shape.

\section{GORDONIA Ell.}

Gordonia axillaris Szyszylowicz in Engler \& Prantl, Nat. Pflanzenfam. III. Abteil. 6, 185 (1893). 
Camellia axillaris Ker in Bot. Reg. IV. t. 349 (1818). - Sims in Bot. Mag. XLVI. t. 2047 (1819).

Gordonia anomala Sprengel, Syst. III. 126 (1826), - Champion in Trans. Linn. Soc. XXI. 114 (1845). - Bentham, Fl. Hongk. 29 (1861). - Hemsley in Jour. Linn. Soc. XXIII. 80 (1886). - Dunn \& Tutcher in Kew Bull. Misc. Inform. add. ser. X. 45 (Fl. Kwangtung \& Hongk.) (1912). - Diels in Not, Bot. Gard. Edinburgh, VII. 77 (1912).

Polyspora axillaris Sweet, Hort. Brit. 61 (1827). - Hooker in Bot. Mag. LXIX. t. 4019 (1843). - Seemann, Bot, Voy. Herald, 367 (1852-57).

Gordonia axillaris, var, acuminata Pritzel in Bot. Jahrb. XXIX. 473 (1900).

Western Szech'uan: Kiating Fu, low hills, alt. 300-600 m., September 1908 (No. 2448; tree 6-8 m. tall, 0.3-0.6 m. girth, flowers white); same locality, November 1903 (Veitch Exped. No. 3264); Mt. Omei, October 1904 (Veitch Exped. No. 4758); Nanch'uan, Ta-ho-kou, A. von Rosthorn (No. 147). Yunnan: Mengtsze, forests, alt. 18002800 m., A. Henry (Nos. 10398, 11162). Hongkong: C. Wright (No. 58 in Herb. Gray); same locality, November 1903, C. S. Sargent. Formosa: South Cape, A. Henry (No. 215); Kelung, May and June 1903, U. Faurie (No. 4).

This is a common small evergreen tree in the neighborhood of Kiating Fu and Mt. Omei and is in flower during the latter part of the summer and the autumn.

A pieture of this tree will be found under Nos. 390, 391 of the collection of Wilson's photographs and also in his Vegetation of Western China, No. 245. The trivial differences on which Pritzel bases his var. acuminata are inconstant.

Gordonia sinensis Hemsley \& Wilson in Kew Bull. Misc. Inform. 1906, 153.

Western Szech'uan: Omei Hsien, woods, alt. 600-1000 m., August and November 1908 (No. 2447; tree $13 \mathrm{~m}$. tall, $2 \mathrm{~m}$. girth, flowers white); Mt. Omei, August 1904, Veitch Exped. (No. 4805).

The bark of this rare tree is gray, firm and moderately smooth with shallow longitudinal fissures.

\section{STEWARTIA L.}

\section{Stewartia sinensis Rehder \& Wilson, n. sp.}

Frutex v. arbor parva, 2-10-metralis, ramis erecto-patentibus; ramuli hornotini glabri v. fere glabri v. patentim pilosi, annotini cinerei, vetustiores cortice fusco-purpureo in laminas tenues solubili vestiti; gemmae acutae, sericeo-pubescentes. Folia membranacea, oblongoelliptica v. obovato-elliptica, acuminata, basi attenuata v. rarius fere rotundata, remote serrata $\mathrm{v}$. crenato-serrulata, dentibus mucronatis porrectis v. leviter incurvis, 6-10 cm. longa et 2-4 cm. lata, supra glabra, luteo-viridia, subtus paullo pallidora v. flavescentia, glabra costa media 
adpresse pilosa excepta $\mathrm{v}$. per totam faciem pilis longis adpressis ad nervos densius conspersa, nervis utrinsecus 7-10 eurvatis subtus ut costa media elevatis, reticulo venularum subtus leviter elevato, costa media supra impressa; petioli $5-8 \mathrm{~mm}$. longi, marginati, glabri v. pilosi. Flores axillares, solitarii, cupulares, albi; pedicelli erecti, 4-8 $\mathrm{mm}$. longi, plus minusve pilosi, apice bracteis 2 foliaceis ovatis $\mathrm{v}$. ovato-oblongis acutis $2-2.5 \mathrm{~cm}$. longis et $1-1.2 \mathrm{~cm}$. latis serrulatis v. integris eiliatis extus fere glabris v. plus minusve pilosis instructi; sepala 5 , basi connata, foliacea, duobus exterioribus longioribus, ovata v. oblongo-ovata, acuta v. obtusiuscula, mucronulata, integra v. sparse leviter serrulata, $1-2.5 \mathrm{~cm}$. longa et $0.5-1 \mathrm{~cm}$. lata, sparse ciliata, extus fere glabra v. basin versus pilosa; petala inaequalia, late obovata, apice rotundata, basi cuneata, $2.5-3 \mathrm{~cm}$. longa et $1.5-2 \mathrm{~cm}$. lata, extus sericeo-pubescentia; stamina in triente inferiore connata, inaequalia, $1.5-1.8 \mathrm{~cm}$. longa, filamentis ad basin partis liberae intus extusque sed intus densius pilosis; ovarium ovoideum, dense pilosum, 6 $\mathrm{mm}$. longum; stylus simplex, glaber, $1 \mathrm{~cm}$. longus, stigmatibus 5 parvis patentibus. Capsula pentagona, subglobosa, apice rostrata, circiter $2 \mathrm{~cm}$. diam., glabrescens v. pilosa, basi sepalis bracteis accrescentibus circumdata; semina oblique ovalia, eirciter $1 \mathrm{~cm}$. longa, compressa, alata, brunnea.

Western Hupeh: Paokang Hsien, July 1901 (Veitch Exped. No. 2148, type); Fang Hsien, woods, October 1901 (Veitch Exped. Seed No. 1285); without locality, A. Henry (No. 6166). Eastern Szeeh'uan: Wushan Hsien, A. Henry (Nos. 7392, 7392). Kiangsi : Kuling, thickets, alt. 1300 m., July 31, 1907 (No. r722).

This interesting addition to the Chinese flora is perhaps most closely related to the little known S. serrata Maximowicz. This Japanese species has similar but smaller leaves with axillary tufts of hairs between the principal veins below, a short pedicel and foliaceous but smaller bracts and sepals. The stamens are free, the ovary is glabrous and the stigmas are more minute. Part of No. 1722 and Henry's No. $7392^{\mathrm{a}}$ differ from the type in the presence of a more copious pubescence on all parts of the plant. Henry's specimens received from Kew are labeled S. monadelpha, var., and this plant is referred to by Bean (Trees \& Shrubs Brit. Isl. II. 553 [1914]) as S. monadelpha Siebold \& Zuccarini. The Chinese plant is certainly closely allied to this Japanese species, as both have monadelphous stamens, a united style and short pedicels, the capsule, however, of S. sinensis is the largest in the genus, while that of $S$. monadelpha is the smallest.

Last year Wilson became well acquainted with $S$. monadelpha, which on the island of Yakushima in particular and in other parts of southern Japan is a very common tree growing from $16-25 \mathrm{~m}$. tall, with a perfectly smooth, pale brown trunk from $1.5-3 \mathrm{~m}$. in girth, spreading branches, pubescent leaves, small ovoid, very slightly and obtusely angled capsules from $8-12 \mathrm{~mm}$. high, 8-9 $\mathrm{mm}$. wide, and elothed with yellowish appressed villous hairs. 
The Chinese Stewartia is very common in bush form on the deforested Lushan range around Kuling. It is a small and rare tree in the forests of western Hupeh and has not been reported from western Szech'uan. Stewartia sinensis is now in cultivation, having been raised from seeds Wilson sent to England in the late autumn of 1901 .

\section{TERNSTROEMIA Mutis.}

Ternstroemia japonica Thunberg in Trans. Linn. Soc. II. 335 (1794). - Siebold \& Zuccarini, Fl. Jap. I. 148, t. 80 (1840-41).Bentham, F'. Hongk. 27 (1861). - Hemsley in Jour. Linn. Soc. XXIII. 75 (1886). - Dunn \& Tutcher in Kew Bull. Misc. Inform. add. ser. X. 43 (Fl. Kwangtung \& Hongk.) (1912).

Cleyera japonica Thunberg, Nov. Gen. Pl. 69 (1783); Fl. Jap. 224 (1784).

Cleyera fragrans Champion in Trans. Linn. Soc. XXI. 115 (1855).

Cleyera dubia Champion in Trans. Linn. Soc. XXI. 115 (1855).

Ternstroemia fragrans Choisy in Mém. Soc. Phys. Genève, XIV. 109 (1855).

Ternstroemia dubia Choisy, 1. c. (1855).

Ternstroemia japonica, f. parvifolia Miquel in Ann. Mus. Lugd.-Bat. III. 14 (1867).

Ternstroemia japonica, var. parvifolia Dyer in Hooker f., Fl. Brit. Ind. I. 281 (1874).

Taonabo japonica Szyszylowicz in Engler \& Prantl. Nat. Pflanzenfam. III.

Abteil. 6, 188 (1895). - Matsumura, Ind. Pl. Jap. II. 2, 360 (1912). -

Diels in Not. Bot. Gard. Edinburgh, VII. 42 (1912).

Kiangsi: Kuling, side of streams, alt. 1300 m., July 28, 1907 (No. I537; bush 2-2.5 m.). Korea: Quelpaert, woods, July 1910, October 1909, Taquet (Nos. 4235, 2931).

This plant is very rare in Kiangsi and apparently does not reach western Hupeh. The leaves on the Kiangsi specimen are acute or even short acuminate and agree closely with others from Hongkong. In size they show some approach to the var. Wightii Dyer.

Ternstroemia japonica, var. Wightii Dyer in Hooker f., Fl. Brit. Ind. I. 281 (1874).

Cleyera gymnanthera Wight \& Arnott, Prodr. 87 (1834). - Wight, Icon. t. 47 (1840). - Thwaites, Enum. Pl. Zeylan. 40 (1864). - Beddome, Fl. Sylv. S. Ind. I. t. 91 (1869).

Cleyera Wightii Choisy in Mém. Soc. Phys. Genève, XIV, 109 (1855).

Ternstroemia aneura Miquel, Fl. Ind. Bat. Suppl. I. 477 (1860).

Western Hupeh: Patung Hsien, eliffs, alt. 1000 m., August 1907 (No. 22I9; bush 3 m., flowers white); without locality, May and Oetober 1901 (Veitch Exped. No. 1921 ); Ichang and immediate neighborhood, A. Henry (Nos. 3301, 5987). Yunnan: Szemao, woods, alt. 1500-1800 m., A. Henry (Nos. 12108 b $12108^{\circ}, 12108^{\mathrm{d}}$, 
$\left.12108^{e}, 12108^{t}\right)$. Kwangtung: "Li-kan-ten," April 22, 1913, W. J. Tutcher (Ex Herb. Hongkong, No. 10218).

This plant with its broad leaves looks very different from the type and it appears best to maintain it as a distinet variety. It is apparently common in Yunnan, but in Hupeh it is rare. The leaves are occasionally slightly serrate.

\section{EURYA Thunb.}

Eurya japonica Thunberg, Fl. Jap. 191, t. 25 (1784). - De Candolle, Prodr. I. 525 (1824). - Bentham, Fl. Hongk. 28 (1861). - Dyer in Hooker f., Fl, Brit. Ind. I. 284 (1874), - Hemsley in Jour. Linn. Soc. XXIII. 77 (1886). - Shirasawa, Icon. Ess. For. Jap. II. t. 53, fig. 1-17 (1908). - Léveillé, Fl. Kouy-Tchéou, 415 (1915).

Eurya microphylla Siebold \& Zuccarini in Abh. Akad. Münch. IV. pt. 2, 163 (Fl. Jap. Fam. Nat. I. 55) (nomen nudum) (1845).

Eurya uniflora Siebold \& Zuccarini, 1. c. (nomen nudum) (1845).

Eurya montana Siebold \& Zuccarini, l. c. (nomen nudum) (1845).

The specimens we have from the mainland of China belong to the following varieties.

Eurya japonica, var. nitida Dyer in Hooker f., Fl. Brit. Ind. I. 284 (1874). - Pierre, Fl, For. Cochinch. II. t. 126 (1887). - Pitard in Lecomte, Fl. Ind.-Chin. I. 338 (1910).

Eurya Roxburghii Wallich, Cat. No. 1465 (pro parte) (1828).

Eurya Wightiana Wallich, 1. c. No. 3662 (nomen nudum) (1829).

Eurya fasciculata Wallich, 1. c. No. 4399 (nomen nudum) (1830).

Eurya nitida Korthals, Verh. Nat. Gesch. Bot. 115, t. 7 (1839-42).

Eurya systyla Miquel ex Dyer in Hooker f., Fl. Brit. Ind. I. 284 (pro synon.) (1874).

Eurya japonica Pritzel in Bot. Jahrb. XXIX. 474 (pro parte) (non Thunberg) (1900). - Pampanini in Nuov. Giorn. Bot. Ital, n. ser. XVII. 121 (1910).

Kiangsi: Kuling, side of streams, alt. 1300 m., July 29, 1907 (Nos. 1579, I572; bush 1-2 m.). Western Hupeh: Ichang, hillsides, alt. 30-600 m., October 1907 (No. 3544; bush 1-3 m., flowers white); same locality, April 1900 (Veitch Exped. No. 1751); same locality, A. Henry (Nos. 1907, 2344, 7946); Nanto and mountains to northward, $A$. Henry (No. 3187). Eastern Szeeh'uan: Wushan Hsien, November 1900 (Veitch Exped. No. 22; fruit only); same locality, A. Henry (No. 7099). Western Szech'uan: Mt. Omei, 1904 (Veitch Exped. Nos. $\left.3280,3280^{\mathrm{a}}\right)$. Yunnan: Mengtsze, woods, alt. 1600-2000 m., A. Henry (Nos. 9039, 9039ª). Chekiang: vicinity of Ningpo, 1908, 
D. Macgregor. Fokien: Dunn's Exped., April to June 1905 (Hongkong Herb. No. 2396).

This is a common low level shrub in the Yangtsze valley and is easily distinguished from the type by its finely serrate leaves. In No. 1572 the shoots are almost terete and puberulous and the styles are deeply divided.

Eurya japonica, var. aurescens Rehder \& Wilson, n. var.

Eurya japonica Pritzel in Engler, Bot. Jahrb. XXIX. 474 (non Thunberg) (1900).

A typo recedit ramulis crassioribus, foliis crassius coriaceis, subito breviter acuminatis, basi subito contractis interdum rotundatis, ellipticis v. elliptico-oblongis $5-9 \mathrm{~cm}$. longis, densius serrulatis, subtus, in sicco saltem, aureis v. flavescentibus, costa media supra valde impressa, stylis distinctis.

Western Hupeh: Changyang Hsien, woods, alt. 600-1300 m., April and September 1907 (No. 3545, type; shrub 2-6 m. tall, flowers white or pink, fruit black); same locality, April 1900 (No. 22; flowers only); Patung Hsien, A. Henry (Nos. 5167, 3673, 5162); without precise locality, A. Henry (Nos. 5170, 7830,6693). Eastern Szech'uan: Wushan Hsien, A. Henry (No. 5616). Szech'uan: Nanch'uan, A. von Rosthorn (No. 2165).

This variety is well distinguished by the characters described above from the type, which has smaller, less coriaceous and much more coarsely toothed leaves usually green on the under side when dry, and united styles. Very possibly it should rank as a distinct species, but the species of this genus are very variable and good distinguishing characters are very few. Most botanists in dealing with this genus have attached importance to the styles being free or united, but it appears to us very doubtful if this character has any real signifieance. We find the degree of union very variable on the same branch, but we have failed to discover them entirely free and also connate in the same flower-cluster or on the same flowering branch. Dyer (in Hooker f., Fl. Brit. Ind. I, 284) includes the Japanese type under var. Thunbergii Thwaites, and says the styles are free. But Thwaites (Enum. Fl. Zeylan. 41 [1864]) describes the branchlets as terete and says nothing about the styles. In the Japanese type the branchlets are angled and the styles connate to well above the middle. The Ceylon plant with which Thwaites was familiar probably belongs to a distinct species.

This new variety is a common shrub in the woods on the mountains of western Hupeh. It grows to a large size and with its shining, dark green leaves is decidedly handsome.

Eurya ochnacea Szyszylowicz in Engler \& Prantl, Nat. Pflanzenfam. III. Abteil. 3, 189 (1893). - Shirasawa, Icon. Ess. For. Jap. II. t. 53, fig. 18-31 (1908). - Matsumura, Ind. Pl. Jap. II. pt. 2, 359 (1912).

Cleyera japonica Siebold \& Zuccarini, Fl. Jap. I. 153, t. 81 (non Thunberg) (1835). 
Cleyera ochnacea De Candolle in Mém. Soc. Phys. Genève, I. 413 (Mém. Fam. Ternstr. 21) (1822); Prodr. I. 525 (1824). - Dyer in Hooker f., Fl. Brit. Ind. I. 283 (1874), - Hemsley in Jour. Linn. Soc. XXIII. 76 (1886).

Ternstroemia Lushia Hamilton apud D. Don, Prodr. Fl. Nepal. 225 (1825).

Cleyera ochnoides Wallich apud G. Don, Gen. Syst. Bot. I. 566 (1831).

Cleyera Wallichiana Siebold \& Zuccarini, Fl. Jap. I. 154 (1841).

Cleyera Mertensiana Siebold \& Zuccarini, 1. c. 154 (1841).

Kiangsi: Kuling, side of stream, alt. 1300 m,, July 28, 1907 (No. r546; bush 1-2 m.). Eastern Szech'uan: Wushan Hsien, October 1900 (Veitch Exped. No. 2688). Korea: Quelpaert, October 1906, U. Faurie (No. 495); same loeality, July 1908, 1909, 1910 and October 1909, Taquet (Nos. 591, 2692, 4136, 2693).

This is a common shrub in the neighborhood of Kuling but rare farther west. In the warmer parts of Japan it forms a small tree and is very abundant.

Here may be added notes on two species not collected during the Arnold Arboretum Expeditions.

Eurya chinensis R. Brown in Abel, Narr. Jour. China, 379, t. (1818). - De Candolle, Prodr. I. 525 (1824). - Champion in Hooker's Jour. Bot. \& Kew Gard. Misc. III. 307 (1851); in Trans, Linn. Soc, XXI. 113 (1855). - Seemann, Bot. Voy. Herald, 366 (1856). - Hemsley in Jour. Linn. Soc. XXIII. 76 (1886). - Pritzel in Bot. Jahrb. XXIX. 474 (1900). - Dunn \& Tutcher in Kew Bull. Misc. Inform. add. ser. X. 44 (Fl. Kwangtung \& Hongk.) (1912).

Western Szech'uan: Kiating Fu, hillsides, June 1903 (Veitch Exped. No. $3280^{b}$ ); Hongkong: Mt. Parker, December 18, 1903, W. J. Tutcher (Ex Herb. Hongkong, No. 987, in part); "Sha-Tin Gap," 1909, M. L. Gibbs (Ex Herb. Hongkong, No. 7447); without exact locality, H.F. Hance (No. 497, in part, Herb. Gray). Kwangtung: Whampoa, December 1865 (Herb. Hance, 497, in part); without locality, J. Potts (in Herb. Gray). Formosa: South Cape, A. Henry (No. 375); "Taitan," May 1903, U. Faurie (No. 49).

This critical species is perhaps only an extreme form of E. japonica Thunberg, yet it is easily recognized by its smaller leaves of thin texture. The pubescence on the shoots varies considerably in degree and in the specimen from western Szech'uan the shoots are puberulous only. But whatever its relationship to $E$. japonica may be it is most certainly distinct from another Japanese species with which it was united by Blume (Mus. Bot. Lugd.-Bat. II. 108 [1862]) and whose conclusions have been accepted by all botanists who have since dealt with this plant. The Japanese species E. emarginata Makino (in Tokyo Bot. Mag. XVIII. 19 [1904]), which was named Tlex emarginata by Thunberg ( $F l . J a p .78$ [1784]), is a littoral shrub with thick, coriaceous, obovate-cuneate, emarginate leaves and relatively thick shoots which are densely elothed with a short rufous-brown, villous tomentum. It is very common on and near the seashore in southern Japan and especially on the island of Yakushima. We have also seen specimens from Quelpaert (U. Faurie, No. 493, and Taquet, Nos. 2691, 2690) off the southern end of Korea, but none from Formosa or China; and probably it does not grow there.

Eurya acuminata De Candolle, in Mém. Soc. Phys. Genève, I. 418 (Mém. Fam. Ternstr. 26) (1822); Prodr. I. 525 (1824). - Wallich, Cat. No. 1464 (1828), Blume, Mus. Bot. Lugd.-Bat. II. 117 (1854). 
Diospyros serrata Hamilton apud D. Don, Prodr. Fl. Nepal. 145 (1825).

Ternstroemia bifaria Buchanan-Hamilton ex D. Don, Prodr. Fl. Nepal. 145 (pro synon.) (1825).

Eurya lucida Wallich, Cat. No. 1462 (nomen nudum) (1828).

Eurya bifaria Wallieh, 1. c. No. 3721 (nomen nudum) (1829).

Eurya membranacea Gardner in Calcutta Jour. Nat. Hist. VII. 444 (1847).

Eurya Wallichiana Blume, Mus. Bot. Lugd.-Bat. II. 118 (non Steudel) (1862).

Eurya japonica, $\beta$ acuminata Thwaites, Enum. Pl. Zeylan. 41 (1864).

Eurya acuminata, var. Wallichiana Dyer in Hooker f., Fl. Brit. Ind. I. 285

(1874). - Pitard in Lecomte, Fl. Indo-Chin. I. 339 (1910).

Western Szech'uan: Kiating Fu mountains, alt. 600-1600 m., October 1903 (Veitch Exped. Nos. 3279, 3279ª); Mt. Omei, June 1904 (Veitch Exped. No. 4767). Yunnan: Mengtsze, forests, alt. 1600-2300 m., A. Henry (Nos. 9039d, 11171, 11414a). Formosa : Bankinsing, A. Henry (Nos. 196, 535).

This plant is common as a shrub from $2-6 \mathrm{~m}$. tall and wide on hills in the neighborhood of the city of Kiating and on the lower slopes of Mt. Omei. The sepals are usually slightly hairy on the outside as described by Don (l. c.). Two specimens in the Herb. Gray collected by Hooker f. and Thomson and by them distributed as Eurya chinensis belong here. Dyer (l. c.) has referred specimens so named to is $E$. acuminata, var. euprista.

Eurya acuminata, var. multiflora Blume, Mus. Bot. Lugd.-Bat. Il. 117 (1854).

Eurya multiflora De Candolle in Mém. Soc. Phys. Genève, I. 417 (Mém. Fam. Ternstr. 25) (1822); Prodr. I. 525 (1824).

Geeria serrata Blume, Bijdr. Fl. Ned. Ind. 124 (1825).

Eurya acuminata Royle, Ill. Bot. Himal. 127, t. 24 (non De Candolle) (1839).

Eurya euprista Korthals, Verh. Nat. Gesch. Bot. 113 (1839-42).

Eurya serrata Blume, Mus. Bot. Lugd.-Bat. II. 115 (1862).

Eurya salicifolia Blume, 1, e. 118 (1862).

Eurya acuminata, var. euprista Dyer in Hooker f., Fl. Brit. Ind. I. 285 (1874). - Pitard in Lecomte, Fl. Indo-Chin. I. 339 (1910).

Eurya angustifolia Wallich ex Dyer in Hooker f., Fl. Brit. Ind. I. 285 (pro synon.) (1874).

Western Szech'uan: hills around Kiating City, October 1903 (Veitch Exped. No. 3278; bush 1-2 m.); Mt. Omei, April 1904 (Veitch Exped. No. 4768; bush 6 m.). Yunnan: Mengtsze, A. Henry (No. 9021); Szemao, mountains, alt. 1600 m., A. Henry (No. 10914 ${ }^{\text {b }}$ ).

In our specimens of this variable plant the bracts and sepals are sparsely hairy without and the styles though virtually free are united at the very base. In one specimen they are entirely free. In Henry's No. $10914^{\mathrm{b}}$ the ovary is sparsely strigose. This plant is very common at the base of $\mathrm{Mt}$. Omei. 


\section{GUTTIFERAE.}

Determined by Alfred ReHder.

\section{HYPERICUM L.}

Hypericum Ascyron Linnaeus, Spec. 783 (1753). - Choisy, Prodr. Monog. Hyperic. 41 (1821); in De Candolle, Prodr. I. 545 (1824).Hance in Jour. Bot. XVIII. 259 (1880). - Maximowicz in Bull. Acad. Sci. St. Pétersbourg, XXVII. 430 (1881); in Mél. Biol. XI. 162 (1881). - Franchet in Nouv. Arch. Mus. Paris, V. 207 (Pl. David. I. 55) (1883). - Hemsley in Jour. Linn. Soc. XXIII. 72 (1886). Diels in Bot. Jahrb. XXIX. 476 (1900). - Keller in Bot. Jahrb. XXXIII. 550 (1904). - Pavolini in Nuov. Giorn. Bot. Ital. n. ser. XV. 406 (1908). - Sprague in Bot. Mag. CXL. t. 8557 (1914).

Hypericum pyramidatum Aiton, Hort. Kew. III. 103 (1789), - Ventenat, Jard. Malmaison, II. t. 118 (1804).

Ascyron sibiricum Lamarck, Enc. Méth. IV. 147, t. 642, fig. 3 (pro synon.) (1797).

Hypericum amplexicaule Lamarck, 1. c. (1797).

Hypericum ascyroides Willdenow, Spec. III. 1443 (1800).

Hypericum macrocarpum Michaux, Fl. Bor. Am. II. 82 (1803).

Roscyna Gmelini Spach, Hist. Vég. V. 430 (1836).

Roscyna americana Spach, l. c. 431 (1836).

Roscyna japonica Blume, Mus. Bot. Lugd.-Bat. II. 21 (1852).

Hypericum Ascyron, var. hupehense Pampanini in Nuov, Giorn. Bot. Ital. n. ser. XVII. 432 (1910), XVIII. 129 (1911).

Western Hupeh: Fang Hsien, uplands, 1907 (No. 582; herb 1 m. tall, flowers yellow).

Hypericum patulum Thunberg, Fl. Jap. 295 (1784); Icon. Pl. Jap. II. t. [7] (1800). - Choisy, Prodr. Monog. Hyperic. 41 (1821); in De Candolle, Prodr. I. 545 (1824). - Hooker f. in Bot. Mag. XCIV. t. 5693 (1868). - Dyer in Hooker f., Fl. Brit. Ind. I. 254 (1875). - Hance in Jour. Bot. XVI. 104 (1878). - Maximowicz in Bull. Acad. Sci. St. Pétersbourg, XXVII. 429 (1881); in Mél. Biol. XI. 161 (1881).Hernsley in Jour. Linn. Soc. XXIII. 73 (1886). - Diels in Bot. Jahrb. XXIX. 476 (1900). - Pavolini in Nuov. Giorn. Bot. Ital. n. ser. XV. 406 (1908).

Norysca patula Blume, Mus. Bot. Lugd.-Bat. II. 23 (1852). 
Western Szech'uan: Yangtsze cliffs, June 1903 (Veitch Exped. Nos. 3261,3263$)$.

Hypericum patulum, var. Henryi Veitch in Gard. Chron. ser. 3, XXXVI. 229 (sine descriptione) (1904). - Bean in Gard. Chron. ser. 3, XXXVIII. 179 (1905); Trees \& Shrubs Brit. Isl. I. 639 (1914). Rehder in Bailey, Standard Cycl. Hort. III. 1631 (1915).

A typo recedit praecipue sepalis ovatis $\mathrm{v}$, ovato-oblongis acutis $\mathrm{v}$. acuminatis, stylis saepe ovario longioribus. Cymae 3-7-florae, interdum ad 15-florae; flores 4-5 cm. diam.

Western Hupeh: Patung Hsien, alt. 1200-1500 m., July 1907 (No. 24I9; shrub 0.75-1 m., flowers yellow); without precise locality, June 1900 (Veitch Exped. No. 2216); without precise locality, $A$. Henry (No. 6099). Western Szech'uan: west and near Wênchuan Hsien, thickets, alt. 1200-1800 m., July 1908 (No. 24I8; bush about $1 \mathrm{~m}$. (No. 24I8); same locality, A. von Rosthorn (No. 3112); Tachien-lu, abundant in thickets, alt. 1500-2400 m., July and November 1908 (No. I355; shrub 0.75-1 m. tall, flowers golden). Yunnan: Mengtsze, alt. 1500 m., A. Henry (No. 9986).

This variety is easily distinguished from the type by its narrower acute sepals, which are broad and rounded in the type. The cymes are several- to many-flowered, the flowers larger and the leaves, too, are usually larger and of thicker texture. At the Arnold Arboretum it has proved of more vigorous growth and hardier than the type. This variety seems to be a parallel ease with $H$. Hookerianum, var. Leschenaultii Dyer, which also differs in its acute sepals from the type.

Hypericum Hookerianum Wight \& Arnott, Prodr. Fl. Ind. 99 (1834). - Dyer in Hooker f., Fl. Brit. Ind. I. 254 (1875). — Schneider, Ill. Handb. Laubholzk. II. 335, fig. 223 e (1909).

Hypericum oblongifolium Hooker f, in Bot. Mag. LXXXII. t. 4949 (non Choisy) (1856).

Hypericum patulum Diels in Not. Bot. Gard. Edinburgh, VII. 129, 224 (non Thunberg) (1912).

Western Szech'uan: Tachien-lu, thickets, alt. 1500-2400 m., July 1908 (No. I355 ; bush $1 \mathrm{~m}$. tall, flowers golden); same locality, alt. 2100-2500 m., Oetober 1910 (No. 4338; bush $1 \mathrm{~m}$. tall); same locality, A. E. Pratt (No. 292). Yunnan: Lichiang valley, alt. 2500 m., June 1906, G. Forrest (No. 2425); Tali range, alt. 2100-3300 m., June-September 1906, G. Forrest (No. 4300). of it.

This species is very near $H$. patulum Thunberg and possibly is only a variety 
Hypericum chinense Linnaeus, Syst. Nat. ed. 10, 1184 (1759). Choisy in Prodr. Monog. Hyperic. 40 (1821); in De Candolle, Prodr. I. 545 (1824). - Bunge in Mém. Sav. Étr. Acad. Sci. St. Pétersbourg, II. 84 (Enum. Pl. Chin. Bor. 10) (1833). - Hance in Jour. Bot. XVII. 8 (1879). - Maximowicz in Bull. Acad. Sci. St. Pétersbourg, XXVII. 428 (1881); in Mél. Biol. XI. 162 (1881). - Hemsley in Jour. Linn. Soc. XXIII. 72 (1886). - Diels in Bot. Jahrb. XXIX. 475 (1900). Keller in Bot. Jahrb. XXXII. 548 (1904). - Schneider, Ill. Handb. Laubholzk. II. 337, fig. 224 (1909).

Hypericum monogynum Linnaeus, Spec. ed. 2, 1107 (1763). - Thunberg, $F l$. Jap. 29 (1784).

Hypericum aureum Loureiro, Fl. Cochin. 472 (1790).

Norysca chinensis Spach, Hist. Vég. V. 427 (1836).

Norysca aurea Blume, Mus. Bot. Lugd.-Bat. II. 23 (1852).

Norysca punctata Blume, 1. c. (1852).

Kiangsi: Kuling, thickets, alt. 1200 m., July 28, 1907 (No. I606; bush $1 \mathrm{~m}$. tall, flowers golden). Western Hupeh: Ichang, cliffs, glens, gorges, alt. 300-500 m., May and July 1907 (No. 2422, 242I; bush about $1 \mathrm{~m}$. tall, flowers yellow); same locality, A. Henry (Nos. 3233, 3234). Szech'uan: cliffs of the Yangtsze, June 1903 (Veitch Exped. No. 3262).

Hypericum Prattii Hemsley in Jour. Linn. Soc. XXIX. 303 (1892). - Diels in Bot. Jahrb. XXIX. 475 (1900).

Kiangsi: Kuling, common, alt. 1200 m., July 27, 1907 (No. 1604; bush $0.75-1 \mathrm{~m}$. tall, flowers golden). Western Hupeh : Ichang, glens, alt. $300 \mathrm{~m}$., May 1907 (No. 2421 ${ }^{\mathrm{s}}$; bush 0.75-1 m. tall, flowers golden yellow). Eastern Szech'uan: Wushan Hsien, alt. 600-1000 m., September 1907 (No. 2420; bush $0.75 \mathrm{~m}$. tall, flowers golden yellow). Western Szech'uan: without precise locality, A. Henry (No. 8808).

This species is perhaps only a variety of the preceding species. Wilson's Nos. 1604 and 2420 are distinetly intermediate, the inflorescence and the upper leaves are those of typical $H$. Prattii, but the lower leaves do not differ from those of $H$. chinense Linnaeus.

Hypericum longistylum Oliver in Hooker's Icon. XVI. t. 1534 (1886). - Diels in Bot. Jahrb. XXIX. 476 (1900). - Pampanini in Nuov. Giorn. Bot. Ital. n. ser. XVII. 670, fig. 15 (1910).

Hypericum Giraldii Keller in Bot. Jahrb. XXXIII. 548 (1904). — Pavolini in Nuov. Giorn. Bot. Ital. n. ser. XV. 406 (1908).

Hypericum longistylum Oliv. var. Giraldii Pampanini in Nuov. Giorn. Bot. Ital. n, ser. XVII. 670, fig. 15 e (1910).

Hypericum longistylum Oliv. var. Silvestrii Pampanini, 1. c. fig. 15 b (1910). 
Western Hupeh: Ichang, cliffs, alt. 300 m., April 1907 (No. 2424; bush about $1 \mathrm{~m}$. tall, flowers yellow); same locality, A. Henry (Nos. $718,1999)$; Hsing-shan Hsien, dry banks and cliffs, alt. 600-1200 m., June 8, 1907 (No. 2423; bush 0.75-1 m. tall, flowers yellow); without precise locality, June 1900 (Veitch Exped. No. 473).

I have not seen the type of $H$. Giraldii, but Pampanini's statements leave little doubt that it is only a variety of $H$. longistylum, elosely connected with the type by the intermediate $H$. longistylum, var. Silvestrii Pampanini. 


\section{TAMARICACEAE.}

Determined by Alfred ReHDer.

\section{TAMARIX L.}

Tamarix chinensis Loureiro, Fl. Cochin. I. 228 (1790). - Willdenow in Abh. Akad. Wiss. Berlin, 1812-13, 79 (1816). - De Candolle, Prodr. III. 96 (1828). - Bunge in Mém. Sav. Étr. Acad. Sci. St. Pétersbourg, II. 102 (Enum. Pl. Chin. Bor. 28) (1833); Tent. Gen. Tamar. 46 (1852). - Hooker \& Arnott, Bot. Voy. Beechey, 186 (1841). - Debeaux in Soc. Linn. Bordeaux, XXXIII. 44 (Fl. Tien-tsin, 21) (1879). Franchet in Mém. Soc. Sci. Nat. Cherbourg, XXIV. 220 (1882). Hemsley in Jour. Linn. Soc. XXIII. 346 (1888). - Niedenzu, Gen. Tamar. 9 (1895). - Schneider, Ill. Handb. Laubholzk. II. 342, fig. 228 e-i (1909).

Tamarix gallica, $\beta$ chinensis Ehrenberg in Linnaea, II. 267 (1827).

Tamarix indica Bunge in Mém. Sav. Êtr. Acad. Sci. St. Pétersbourg, II. 102 (Enum. Pl. Chin. Bor. 28) (non Willdenow) (1833). - Maximowicz in Mém. Sav. Êtr. Acad. Sci. St. Pétersbourg, IX. 471 (Prim. Fl. Amur.) (1859).

Western Hupeh: Hsing-shan Hsien, cultivated, alt. 600-900 m., July 1907 (No. 2350; bush $3 \mathrm{~m}$. tall, flowers blush); same locality, river-side, June 1906 (Veitch Exped. No. 2197; bush $1.25 \mathrm{~m}$. tall). Chili: near Tien-tsin, October 4, 1907, F. N. Meyer (No. 399). Fokien: Amoy, 1845, R. Fortune (No. 103).

In western Hupeh this species seems to be only cultivated or occasionally to have escaped from cultivation; Wilson's No. 2197 collected on the river-side being probably an escape according to Wilson himself.

The two following species not collected during the Arnold Arboretum Expedition are only occasionally cultivated in central and western China.

Tamarix parviflora De Candolle, Prodr. III. 97 (1828). - Bunge, Tent. Gen. Tamar. 28 (1852). - Planchon in Fl. des Serres, IX. 105, t. 898 (1853), - Boissier, Fl. Or. I. 769 (1867). - Niedenzu, Gen. Tamar. 6 (1895), - Halacsy, Consp. Fl. Graec. I. 564 (1901). - Schneider, Ill. Handb. Laubholzk. II. 344, fig. 229 i-m (1909).

Tamarix tetrandra Grisebach, Spicil. Fl. Rumel. I. 299 (non Pallas) (1843). Carrière in Rev. Hort. 1855, 401, t. 
Western Hupeh: Ichang, cultivated, April 1901 (Veitch Exped. No. 1900).

This species is probably only rarely cultivated in China. Wilson found it in the garden of a Mr. Wong, who had introduced plants from European nurseries.

Tamarix juniperina Bunge in Mém. Sav. Êtr. Acad. Sci. St. Pétersbourg, II. 102 (Enum. Pl. Chin. Bor. 28) (1833). - Bunge, Tent. Gen. Tamar. 45 (1852). Schneider, Ill. Handb. Laubholzk. II. 343, fig. 229 e-i (1909).

Tamarix chinensis Siebold \& Zuecarini, Fl. Jap. I. 132, t. 71 (non Loureiro) (1840). - Diels in Not. Bot. Gard. Edinburgh, VII. 91 (1912).

Yunnan: Lichiang valley, cultivated, May 1906, G. Forrest (No. 2039).

\section{MYRICARIA Desv.}

Myricaria bracteata Royle, Ill. Bot. Himal. 214, t. 44 (1839). Boissier, Fl. Or. I. 763 (1867).

Myricaria Hoffmeisteri Klotzsch, Bot. Ergeb. Reise Prinz Waldem. 120, t. 25 (1862).

Myricaria germanica Dyer in Hooker f., Fl. Brit. Ind. I. 250 (non Desvaux) (1875). - Hemsley in Jour. Linn. Soc. XXIII. 347 (1888), synon. "Myricaria alopecuroides" excluso.

Western Szech'uan: beds of streams, common, October 1910, alt. 900-2400 m. (No. 4344; bush 1-3 m. tall, flowers pink); beds of streams, alt. 300-2700 m., September 1903 (Veitch Exped. No. 3191); Min River, sandy and stony places, June 1903 (Veitch Exped. No. 3192). Western Hupeh: Ichang, A. Henry (Nos. 22, 843).

This species is most closely related to $M$. germanica Desvaux, but differs from it chiefly in its shorter acuminate bracts, broader sepals with a broad membranous usually pink margin and petals nearly twice as long as the sepals.

Myricaria dahurica Ehrenberg in Linnaea, II. 278 (1827). - De Candolle, Prodr. III. 98 (1828).

Tamarix dahurica Willdenow in Abh. Akad. Wiss. Berlin, 1812-13, 85 (1816).

Western Szech'uan: Tachien-lu, beds of streams, alt. 1500-4000 m., July 7, 1908 (No. 3268; shrub 3-4 m. tall, flowers pink); without precise locality, alt. 2400 m., May 1904 (Veitch Exped. No. 3193). Western Kansu: Minchow, Tow River, alt. 2100-2700 m., W. Purdom. 


\section{PASSIFLORACEAE.}

Determined by Alfred Rehder and E. H. Wilson.

\section{PASSIFLORA L.}

Passiflora cupiformis Masters in Hooker's Icon. XVIII. t. 1768 (1888).

Passiflora Franchetiana Hemsley in Hooker's Icon. XXVII. sub t. 2623 (1899).

Eastern Szech'uan: Kai Hsien, ravine, alt. 1000 m., July 1910 (No. 4626; climber $5 \mathrm{~m}$. tall, fruit globose). Yunnan: Mengtsze, woods, alt. $1800 \mathrm{~m}$., A. Henry (No. 11192, type of P. Franchetiana Hemsley).

This plant has been seen by Wilson on only one occasion. Hemsley in describing his $P$. Franchetiana must have overlooked Masters's description and figure.

Hemsley (in Hooker, Icon. Pl. XXVII. t. 2622 [1899]) eites Henry No. 10282 as the type of his $P$. Henryi. In the herbarium of the Arnold Arboretum the number is No. 10252 . 


\section{ELAEAGNACEAE.}

Determined by Alfred ReHder.

\section{HIPPOPHAE L.}

Hippophae rhamnoides Linnaeus, Spec. 1023 (1753). - Schlechtendal in De Candolle, Prodr. XIV. 607 (1857). - Hooker f., Fl. Brit. Ind. V. 203 (1890). - Franchet in Nouv. Arch. Mus. Paris, sér. 2, VII. 71 (Pl. David. I. 261) (1884). - Hemsley in Jour. Linn. Soc. XXVI. 405 (1894). - Servettaz in Bot. Centralb. Beih. XXV. 2, 5 (1909). - Schneider, Ill. Handb. Laubholzk. II. 407, fig. 277 a-i, 278 a-d (1909).

Osyris rhamnoides Scopoli, Fl. Carn. ed. 2, II. 261 (1772).

Rhamnoides hippophae Moench, Meth. 343 (1794).

Hippophae littoralis Salisbury, Prodr. 71 (1796).

Hippophae rhamnoides B. H. r. sibirica Hort. Belv. apud Steudel, Nomencl. 410 (nomen nudum) (1821).

Hippophae sibirica Hort. ex Steudel, Nomencl. II. 770 (pro synom.) (1841).

Hippophaës rhamnoideum St. Lager ${ }^{1}$ ex Jackson, Ind. Kew. I. 1164 (pro synon.) (1895).

Western Szech'uan: Mupin, river bottoms, woodlands, alt. 2100 m., August 1908 (No. 928 ). Shensi: Wu-tai-shan, W. Purdom (No. 189). Chili: Hsiao Wu-tai-shan, alt. 1500 m., August 23, 1913, F. W. Meyer (No. 1323).

Hippophae rhamnoides, var. procera Rehder in Bailey, Standard Cycl. Hort. III. 1495 (sine descriptione latina) (1915).

A typo recedit praecipue ramulis junioribus praeter squamas pilis fascieulatis longis vestitis ideoque praesertim apicem versus dense villoso-tomentosis, foliis supra initio pilis stellatis laxe vestitis demum glabris. Frutex v. arbor ad $18 \mathrm{~m}$. alta, trunco ad $4.5 \mathrm{~m}$. in circuitu metiente, ramis spinosis paucis vix rigidis munita $\mathrm{v}$. fere inermis; ramuli juniores praesertim apicem versus villoso-tomentosi. Folia oblongo-lanceolata v. lanceolata, acuta v. acutiuscula, basi plerumque late cuneata, 3-6 $\mathrm{cm}$. longa et $0.7-1.5 \mathrm{~cm}$. lata, supra initio

${ }^{1}$ In the place cited by Jackson (Ann. Soc. Bot. Lyon, VII. 88 [1880]) St. Lager does not make the combination attributed to him, but says merely that Hippophaës is neuter. 
stellato-pilosa, mox glabra, subtus dense argenteo-lepidota, saepe squamis fuscescentibus intermixtis, costa media plerumque fuscescente et basin versus pilis stellatis conspersa; petioli 1-3 mm. longi, saepe fasciculato-pilosi. Fructus subglobosus, 5-6 mm. longus, aurantiacus; putamen $4 \mathrm{~mm}$. longum.

Western Szech'uan: Tachien-lu, woodlands, etc., alt. 2400-3900 m., October 1908 (No. 928, type); same locality, alt. 2800-3300 m., July 1902 (Veitch Exped. No. 4421 a); Mupin, woodlands, riverbottoms, alt. 2100-3800 m., October 1908 (No. 928, in part); Min valley, alt. 1500-3000 m., August 1902 (Veitch Exped. No. 4421; 1-6 m. tall).

This variety differs from the typical $H$. rhamnoides in the villous young branchlets and in the stellate tomentum of the upper surface of the leaves; the villous pubescence being particularly conspicuous on the tips of the growing shoots. In the shape of the leaves and in the stellate pubescence of their upper surface it resembles $H$. salicifolia $\mathrm{D}$. Don, but is easily distinguished from that species by the lepidote, not tomentose under surface of the leaves. Wilson's No. 4421 forms a transition toward typical $H$. rhamnoides; the leaves are scaly and sparingly pilose above while young and become glabrous or nearly so with age. Hippophae rhamnoides, var. procera seems to grow taller than any other form of the genus. Servettaz gives $9 \mathrm{~m}$. as the maximum height of the species.

A picture of this tree will be found under No. 172 of the collection of Wilson's photographs and in his Vegetation of Western China, No. 250.

\section{ELAEAGNUS L.}

Elaeagnus umbellata Thunberg, Fl. Jap. 66, t. 14 (1784). - D. Don, Prodr. Fl. Nepal. 68 (1825). - Schlechtendal in De Candolle, Prodr. XIV. 614 (1857). - Maximowicz in Bull. Acad. Sci. St. Pétersbourg, sér. 3, XV. 378 (1870); in Mél. Biol. VII. 560 (1871). - Hooker f., Fl. Brit. Ind. V. 201 (1870). - S. Moore in Jour. Bot. XVI. 138 (1878). - Hance in Jour. Bot. XX. 38 (1882). - Franchet in Mém. Soc. Sci. Nat. Cherbourg, XXIV. 250 (1882), - Hemsley in Jour. Linn. Soc. XXVI. 404 (1894). - Diels in Bot. Jahrb. XXXVI. Beibl. LXXXII. 79 (1905); in Not. Bot. Gard. Edinburgh, VII. 104, 268, 285 (1912). — Shirasawa, Icon. Ess. For. Jap. II. t. 54 (1908). Servettaz in Bull. Herb. Boissier, sér. 2, VIII. 382 (1908); in Bot. Centralb. Beih. XXV. 2, 49, fig. 9 (1909). - Pampanini in Nuov. Giorn. Bot. Ital. n. ser. XVII. 675 (1910).

Elaeagnus parvifolia Wallich, Cat. No. 4026 (nomen nudum) (1829). Royle, Ill. Bot. Himal. 323, t. 81, fig. 1 (1839). - Lindley in Bot. Reg. XXIX. t. 51 (1843). - Schlechtendal in De Candolle, Prodr. XIV. 612 (1857). 
Elaeagnus umbellata, ssp. parvifolia Servettaz in Bull. Herb. Boissier, sér. 2, VIII. 383 (1908); in Bot. Centralb. Beih. XX, 2, 55 (1909).

Elaeagnus umbellata, var. parvifolia Schneider, Ill. Handb. Laubholzk. II. 411, fig. $280 \mathrm{~d}-\mathrm{e}$ (1909).

Western Hupeh: Fang Hsien, side of streams, abundant, alt. 600-1200 m., May 21, 1907 (No. 356r ; bush 1-3 m., flowers white); "Kao-kien-scian," alt. 800 m., May-June 1907, C. Silvestri (No. 1548). Western Szech'uan: Hung-ya Hsien, Wa-wu-shan, thickets, alt. 1500 m., June and September 12, 1908 (No. 835, in part; bush 2-3 m., flowers white, fruit bright red); Niu-tou-shan, west of Kuan Hsien, alt. 1200-1800 m., June 26, 1908 (No. 835, in part; bush 2-3 m. tall, flowers white, becoming yellow with age); Min valley, around Maochou, alt. 1200-2000 m., May 23-24 and August 1908 (No. 835, in part; bush 1-2 m. tall, flowers creamy-white, fruit scarlet); Wa-shan, thickets, alt. 1500 m., June and August 1908 (No. 835, in part; bush 1.25-2 m. tall, flowers white, fruit scarlet); Tung valley, east of Tachien-lu, side of streams, May 1908 (No. 3556; bush 1-2 m. tall); without precise locality, roadside, alt. 2000 m., July 1903 (Veitch Exped. No. 4419). Western Kansu: Choni district, 1912, Wm. Purdom. Shensi: "Monte Kan-y-san ad O. del Lao-y-san," June 11-12, 1897, G. Giraldi; Yenan Fu, 1910, W. Purdom. Shan-si: Ching-pin, May 1907, F. N. Meyer (No. 413). Shantung: Tsingtau, 1901, Zimmermann (No. 370).

The Szech'uan plant seems to be most closely related to the Himalayan var. parvifolia Schneider, as it has the winter-buds and branchlets covered with silvery scales, the inner surface of the lobes of the perianth stellate-pilose and the anthers, at least partly, apiculate, but the pubescence of the style is scaly, like that of typical $E$. umbellata, not stellate as in var. parvifolia. The specimens, however, from Shensi and Shantung, and Silvestri's specimen from Hupeh, are nearer to the typical Japanese form. This shows that while the Szech'uan plant approaches the Himalayan form, the plant of the northern and northeastern provinces is almost identical with the Japanese plant.

Elaeagnus magna Rehder, n. sp.

Elaeagnus umbellata, ssp. magna Servettaz in Bull. Herb. Boissier, sér. 2, VIII. 383 (1908); in Bot. Centralb. Beih. XXV. 2, 58 (1909).

Frutex 1-3-metralis; rami elongati, inermes v. spinis brevibus nudis v. longioribus foliatis muniti, juniores squamis albidis v. flavido-albidis interdum fulvis intermixtis obtecti, vetustiores cinereo-fusci; gemmae ferrugineae v. fulvae. Folia decidua v. partim per hiemem persistentia, membranacea v. chartacea, ea ramulorum floriferorum plerumque obovata v. elliptica v. obovato-oblonga, basi late cuneata v. rarius 
fere rotundata, apice rotundata $\mathrm{v}$. breviter obtuse acuminata, 2.5-5 $\mathrm{cm}$. longa et $1.5-2.3 \mathrm{~cm}$. lata, rarius majora, ea turionum plerumque oblongo-obovata v. elliptico-oblonga, basi cuneata, apice acuminata v. rarius obtusiuscula, $5-10 \mathrm{~cm}$. longa et $2.5-3.8 \mathrm{~cm}$. lata, omnia subtus dense argenteo-lepidota, nitida, interdum praesertim basalia et minora squamis flavis $\mathrm{v}$. ferrugineis paucis conspersa, supra squamis argenteis laxe v. initio interdum dense conspersa v. fere glabra, luteo-viridia, opaca; petioli canaliculati, squamis albidis ferrugineis v. flavis intermixtis obtecti, 3-6 mm. longi. Flores 1-3, axillares, in ramulis abbreviatis congesti, albidi, extus dense argenteo-lepidoti, cernui, breviter pedicellati pedicello $3-5 \mathrm{~mm}$. longa; perigonii tubus tubuloso-campanulatus, plus minusve quadrangularis, basi subito contractus, $7-8 \mathrm{~mm}$. longus; lobi rotundato-ovati, acuminulati, intus glabri, 5-6 mm. longi, tubum dimidium aequantes v. superantes; antherae subsessiles, nudae, obtusae, $4 \mathrm{~mm}$. longae; stylus glaber, apice leviter incurvatus; ovarium anguste ellipsoideum, argenteo-lepidotum $3 \mathrm{~mm}$. longum. Fructus ellipsoideo-oblongus, $12-15 \mathrm{~mm}$. longus, succulentus, ut videtur ruber, argenteo-lepidotus, styli basi persistente coronatus, nutans, pedicello 4-6 $\mathrm{mm}$. longo; putamen manifeste 8-costatum, anguste ellipsoideum, utrinque attenuatum, eirciter $12 \mathrm{~mm}$. longum et $4.5 \mathrm{~mm}$. diam.

Western Hupeh: north and south of Ichang, rocky places, common, alt. 300-900 m., May 6 and June 1907 (No. 5o; bush 1.25-2.75 m. tall, flowers white, fruit red; same locality, A. Henry (No. 1637, type; quoted by Servettaz as 1437); Changyang Hsien, ravines, alt. 300-750 m., April and June 1907 (No. 50 ; bush 1.25-3.25 m. tall, flowers yellow); same locality, roadsides, alt. 300-750 m., May 1907 (No. 3568; bush 1.75-2.75 m. tall); Fang Hsien, side of streams, alt. 6001200 m., May 21, 1907 (No. 356 $\left.\mathrm{I}^{\mathrm{a}}\right)$; Hsing-shan Hsien, thickets, alt. 600-1200 m., May 1907 (No. 3559; bush 1.75-2 m. tall, flowers yellow); without precise locality, April 1900 (Veitch Exped. No. 106); without precise locality, A. Henry (No. 7775).

Servettaz, who had seen only fruiting specimens, referred this plant as a largefruited subspecies to $E$. umbellata Thunberg, but Wilson's specimens which undoubtedly belong to the same form show that the flowers are tubular-campanulate with a rather short broad tube distinetly constricted at the base, not tubular and gradually narrowed toward the base as in $E$. umbellata. Wilson's Nos. $50^{\mathrm{s}}$ and 3568 agree in fruit and leaf very well with Henry's No. 1637 except that the texture of the leaves is slightly firmer; the other specimens have somewhat smaller, more obtuse and more chartaceous leaves.

Elaeagnus multiflora Thunberg, Fl. Jap. 66 (1784). — Schlechtendal in De Candolle, Prodr. XIV. 614 (1857), - Hooker f. in Bot. 
Mag. CXX. t. 7341 (1894), - Hemsley in Jour. Linn. Soc. XXVI. 404 (1894). - Servettaz in Bull. Herb. Boissier, sér. 2, VIII. 383 (1908); in Bot. Centralb. Beih. XXV. 2, 58 (1909). - Schneider, Ill. Handb. Laubholzk. II. 411, fig. 279 n-w, 280 k-n (1909).

Elaeagnus longipes A. Gray in Mem. Am. Acad. Sci. n. ser. VI. 405 (1859). Maximowicz in Bull. Acad. Sci. St. Pétersbourg, sér. 3, XV. 378 (1870); in Mél. Biol. VII. 560 (1871). - Masters in Gard. Chron. 1873, 1015, fig. 206. — Lavallée, Icon. Arb. Segrez. 9, t. 4 (1880). - Sargent in Garden \& Forest, I. 499, fig. 78 (1888).

Elaeagnus rotundifolia Gagnaire in Rev. Hort. 1870, 540.

Elaeagnus edulis Siebold apud May in Rev. Hort. 1876, 18.

Kiangsi: Kuling, thickets, common, alt. 1200 m., July 28, 1907 (No. 1578; bush 2-3 m.); Kiukiang, E. Faber (No. 999). Western Hupeh: Changlo Hsien, thickets, alt. 600-1000 m., May 1907 (No. 3560 ; bush 1-2 m., flowers yellow).

Wilson's and Faber's specimens agree well with Japanese plants of this species; the upper surface of the young leaves is loosely covered with stellate hairs which soon disappear; the pedicels of the flowers are only $1-1.5 \mathrm{~cm}$. long. The sterile specimen from Kuling approaches in its broadly oval leaves $E$. multiflora, f. rotundifolia Servettaz.

Elaeagnus multiflora, f. angustata Rehder, $n$. forma.

A typo recedit foliis lanceolatis $\mathrm{v}$. oblongo-lanceolatis, acuminatis, $3-9 \mathrm{~cm}$. longis et 1-1.6 cm. v. ad $2 \mathrm{~cm}$. latis, basi rotundatis v. cuneatis.

Western Szech'uan: southeast of Tachien-lu, thickets, alt. 1200$1800 \mathrm{~m}$., September 1908 (No. I076, type; bush $2 \mathrm{~m}$. tall, fruit red); same locality, alt. 1800 m., October 1910 (No. 4I62; bush 2-3 m. tall, fruit red). Western Hupeh: Patung Hsien, thickets, alt. 600-1000 m., May and October 1907 (No. 3558; bush $1.5 \mathrm{~m}$. tall, fruit red); without precise locality, A. Henry (No. 5484'b).

The specimens from Tachien-lu represent the type of this form. They look very distinct on account of their long and narrow leaves rather light yellowish green and glabrous or nearly so at maturity on their upper surface; the pedicels of the fruits are very slender and 2-2.5 cm. long. The specimens from Hupeh differ in their somewhat broader leaves scaly not stellate-pilose above; the pedicels of their fruits are $2.5-4 \mathrm{~cm}$. long.

Elaeagnus lanceolata Warburg in Bot. Jahrb. XXIX. 483 (1900). Servettaz in Bot. Centralb. Beih. XXV. 2, 86, fig. 4, 27 (1909).Schneider, Ill. Handb. Laubholzk. II. 414, fig. $282 \mathrm{e}-\mathrm{f}, 283 \mathrm{e}-\mathrm{h}$ (1909).

Western Hupeh: Hsing-shan Hsien, thickets, common, alt. 9001500 m., July 1907 (No. 3562; bush 1.25-3 m.); same locality, alt. 300-1200 m., May 27, 1907 (No. 3564; bush 2-4 m. tall, fruit salmon- 
red, edible); Patung Hsien, thickets, alt. 900-1500 m., September 1907 (No. 3563; semi-scandent shrub, 1.25-3 m., flowers white); without precise locality, April 1900 (Veitch Exped. No. 2786); without precise locality, A. Henry (Nos. 5483, 6652, 7424). Szech'uan: "Kê t'ou p'ing," October, A. von Rosthorn (No. 1104).

Servettaz divides this species into 3 subspecies; to his subsp. grandifolia belongs Rosthorn's No. 1104 and to his subsp. stricta belong Henry's 6652, and 7424 and Wilson's No. 3564. The difference between the type and this subspecies seems to be very slight; subsp, grandifolia is more distinct.

Elaeagnus Henryi Warburg in Bot. Jahrb. XXIX. 483 (1900). Servettaz in Bot. Centralb. Beih. XXV. 77, fig. 4, 17-20 (1909). Schneider, Ill. Handb. Laubholzk. II. 414, fig. 283 a-b (1909).

Western Hupeh: Hsing-shan Hsien, ravines, alt. 300-750 m., June 1907 (No. 3565; scandent shrub, 3-5 m., fruit salmon-red); without precise locality, May 1900 (Veitch Exped. No. 2785); Ichang, $A$. Henry (Nos. 3307, 3307ª, type). Szech'uan: Nanch'uan, A. von Rosthorn, August (No. 291). Yunnan: Mengtsze, A. Henry (Nos. $10425,11392,11449)$.

The specimens from Yunnan differ from typical $E$. Henryi in their longer pedicels, measuring $0.5-1 \mathrm{~cm}$. in length.

Elaeagnus viridis Servettaz in Bull. Herb. Boissier, sér. 2, VIII. 388 (1908); in Bot. Centralb. Beih. XXV. 2, 88, fig. 28-30 (1909).

Western Hupeh: Yangtsze banks around Ichang, alt. 30-900 m., December 1907 (No. 3557; bush 1.25-2 m.); same locality, A. Henry (Nos. 1105, 2953).

\section{Elaeagnus cuprea Rehder, n. sp.}

Frutex divaricatus v. sarmentosus, 2-3-metralis, inermis; rami sub angulo 50 v. $75^{\circ}$ divergentes, annotini et biennes dense squamis ferrugineis obtecti, vetustiores fusci v. fusco-grisei. Folia persistentia, chartacea, elliptico-oblonga v. elliptico-lanceolata, subito acuminata, basi rotundata v. late cuneata, 6-12 cm. longa et 2-5 cm. lata, supra initio sparse lepidota, mox glabra, subtus fusco-viridia, squamis ferrugineis satis dense conspersa, costa media supra prominula, nervis utrinsecus 7-9 supra vix conspicuis subtus leviter elevatis; petioli supra canaliculati, dense ferrugineo-lepidoti, 1-1.5 cm. longi. Flores vernales, flavescentes, ferrugineo-lepidoti, nutantes, 1-4 in ramulis brevissimis ex axillis foliorum orientes; pedicelli $1-3 \mathrm{~mm}$. longi, ut ovarium ovoideum $2 \mathrm{~mm}$. longum dense ferrugineo-lepidotum; tubus perigonii cylindricus v. cylindrico-campanulatus, basi subito 
constrictus, apicem versus paullo latiore, circiter $5 \mathrm{~mm}$. longus, squamis ferrugineis v. pallidioribus ferrugineis intermixtis obtectus; lobi late triangulari-ovati, apiculati, $2.5 \mathrm{~mm}$. longi, intus stellatopilosi; antherae ellipsoideo-oblongae, $1.75 \mathrm{~mm}$. longae, fuseae, $2 / 3$ loborum aequantes, filamentis dimidios lobos aequantibus; stylus leviter flexuosus, glaber, medios lobos paullulo superans. Fructus oblongus, salmoneo- v. aurantiaco-ruber; putamen ellipsoideo-oblongum, utrinque attenuatum, 8-costatum, $14 \mathrm{~mm}$. longum et $6 \mathrm{~mm}$. diam.

Western Hupeh: Changyang Hsien, ravines, alt. 600 m., April 1907 (No. 3565, type; spreading bush, 1-3 m. tall, flowers yellowish); Hsing-shan Hsien, ravines, alt. 300-750 m., May 10, 1907 (No. 3565 ; scandent shrub, 3-5 m., fruit salmon-red); same locality, June 1907 (No. 59; bush 1.25-4 m., fruit orange-red); without precise locality, A. Henry (Nos. 5154, 5473).

This species seems to be most closely related to $E$. difficilis Servettaz, which differs according to the description and figures in its much narrower leaves slightly undulate on the margins, in the somewhat shorter flowers with subsessile anthers nearly enclosed in the mouth of the perianth and in the style exceeding the anthers. In foliage it resembles $E$. glabra Thunberg to which I refer Henry's No. 3193 from Hupeh, but that species is easily distinguished by the slenderer less ferrugineous flowers gradually narrowed toward the base and not constricted above the ovary. The other allied species, as E. Henryi Warburg, E. lanceolata Warburg, E. viridis Servettaz and $E$. Bockii Diels, differ in the under surface of the leaves being densely covered with silvery white or yellowish scales.

Here may be added notes on several species not collected during the Arnold Arboretum Expeditions.

Elaeagnus stellipila Rehder, n. sp.

Frutex metralis v. ultra, inermis, ramis angulo circiter $60^{\circ}$ divergentibus; ramuli hornotini dense tomento stellato albido-fulvescente obtecti, tertio anno glabrescentes et brunnei, nitiduli; gemmae fulvae, stellato-tomentosae. Folia papyracea, partim per hiemem persistentia, ovalia $\mathrm{v}$. ovata, obtusiuscula $\mathrm{v}$. brevissime et obtuse acuminato, basi subcordata v. rotundata, $1.5-3.5 \mathrm{~cm}$. longa et $0.9-2 \mathrm{~cm}$. lata, supra initio laxa stellato-pilosa, demum glabra, obscure viridia, subtus dense tomento stellato albido $\mathrm{v}$. flavescente obtecta, utrinque nervis 4-5 supra ut costa media impressis, subtus leviter elevatis; petioli eirciter $2 \mathrm{~mm}$. longi, dense stellatotomentosi. Flores 1-3 vere in axillis foliorum novellorum et annotinorum nascentes, fere sessiles, albidi, extus dense stellato-tomentosi tomento perigonii albido, ovarii fulvido, tubo perigonii cylindrico, leviter quadrangulato, eirciter $7 \mathrm{~mm}$. longo, basi subito contracto intus glabro fauce piloso excepto, lobis ovatis acuminatis circiter $4 \mathrm{~mm}$. longis intus stellato-pilosis; antherae filamentis brevibus, obtusae v. apiculatae, $2 \mathrm{~mm}$. longae, fere medium loborum attingentes; stylus glaber, antheras non superans; ovarium ovoideum, $2 \mathrm{~mm}$. longum; discus tenuis, cupularis. Fructus desideratur.

Western Szech'uan: banks of Yangtsze River, May 1903 (Veitch Exped. No. 4418). 
This species seems to be most nearly related to E. Grijsii Hance, which differs according to the description chiefly in its long pedicellate stellate hairs, in the presence of spines, in the ferruginous tomentum of the branchlets and of the flowers, in the campanulate tube of the perigon attenuate toward the base, and in the sparingly lepidote style being shorter than the anthers. To $E$. mollis Diels and E. yunnanensis Servettaz, which also have stellate tomentum, the new species seems to be less closely related.

Elaeagnus Bockii Diels in Bot. Jahrb. XXIX. 482 (1900). - Servettaz in Bot. Centralb. Beih. XXV. pt. 2, 89 (1909).

Western Szech'uan: hills around Kiating, October 1903 (Veitch Exped. No. 4420 ; shrub $2 \mathrm{~m}$. tall); "Ch'ung t'an p'u," A. von Rosthorn (No. 3144, type).

Wilson's specimen is in full flower and agrees very well with Rosthorn's No. 3144 , except that the leaves are somewhat broader and attain a length of $10 \mathrm{~cm}$. and a width of $3.5 \mathrm{~cm}$. and that it shows no spines.

Elaeagnus Loureirii Champion in Jour. Bot. \& Kew Gard. Misc. V. 196 (1853). - Schlechtendal in De Candolle, Prodr. XIV. 613 (1857); in Linnaea XXX. 373 (1860). - Bentham, Fl. Hongk. 298 (1861). - Maximowicz in Bull. Acad. Sci. St. Pétersbourg, sér. 3, XV. 378 (1870); in Mél. Biol. VII. 559 (1871).Hemsley in Jour. Linn. Soc. XXVI. 403 (1894). - Servettaz in Bot. Centralb. Beih. XXV. pt. 2, 68, fig. 3, 12-15 (1909).

Yunnan: Mengtsze, alt. 1500 m., A. Henry (Nos. 9857, 9858, 11457); Talang, alt. 1300 m., A. Henry (No. 11574); Szemao, alt. 1500 m., A. Henry (Nos. 12787, $\left.12787^{\mathrm{a}}, 12787^{\mathrm{b}}\right)$. Kwangtung: Hongkong, Wilford, C. Wright (No. 397) and Mrs. Gibbs, Nov. 1909 (Ex Herb. Hongkong, No. 8170).

This species apparently has not been recorded before from Yunnan. Henry's specimens agree in their somewhat thinner, narrower and long-acuminate leaves very well with Mrs. Gibbs's specimen, while Wilford's and Wright's specimens have the leaves broader, less acuminate and of firmer texture. The Yunnan specimens differ further in the style exceeding the anthers and in No. 11457 even the lobes of the perigon, and in the less uniformly ferruginous color of the flowers of some of the specimens, as Nos. $9857,11457,11574$ and 12787 , on which there is an admixture of paler scales. The Yunnan form might possibly be distinguished as a variety from the typical Hongkong form, but for specific separation the differences seem too slight.

Elaeagnus macrantha Rehder, n. sp.

Frutex $1.25 \mathrm{~m}$. altus, ramis ferrugineis satis rigidis; gemmae ferrugineae. Folia chartacea, persistentia, elliptica v. elliptico-oblonga, apice breviter obtuseque acuminata, basi late cuneata v. fere rotundata, $9-13 \mathrm{~cm}$. longa et $4.2-5 \mathrm{~cm}$. lata, supra maturitate glabra, luteo-viridia, subtus dense albido-lepidota squamis ferrugineis admixtis, costa media et nervis secundariis ferrugineis, nervis utrinsecus 5-7 supra ut costa media impressis, subtus elevatis; petioli canaliculati, 7-10 mm. longi, ferruginei. Flores 1-5 suberecti in ramulis brevissimis aphyllis petiolo brevioribus ex axillis foliorum orientibus; pedicelli $3-7 \mathrm{~mm}$. longi, argenteo-lepidoti, tubus perigonii late campanulatus, in sicco leviter 8-costatus, $8-9 \mathrm{~mm}$. longus, extus ut lobi et ovarium dense argenteo-lepidotus, infra lobos non v. vix constrictus, basi rotundatus et supra ovarium ovoideum $2-3 \mathrm{~mm}$. longum manifeste constrictus, intus glaber, lobi ovati, acuminati, $6-7 \mathrm{~mm}$. longi, intus stellato-pilosi; filamenta $3 \mathrm{~mm}$. longa, antheris oblongis longiora; stylus rectus, apice recurvatus, antheras superans lobis paullo brevior, sparsissime lepidota; discus vix distinctus. Fructus desideratur.

Yunnan: Szemao, east 50 miles, alt. $1500 \mathrm{~m} .$, A. Henry (No. 12818; erect shrub $1.25 \mathrm{~m}$., spiny, flowers white). 
This species is well characterized by its large silvery white flowers and is most closely related to $E$. Loureirii Champion, which is easily distinguished by its ferruginous flowers with the lobes lepidote inside, not stellate-pilose and by the larger leaves.

Elaeagnus conferta Roxburgh, Fl. Ind. I. 460 (1820), - D. Don, Prodr. Fl. Nepal. 67 (1825). - Schlechtendal in De Candolle, Prodr. XIV. 612 (1857); in Linnaea, XXX. 367 (1860). - Servettaz in Bot. Centralb. Beih. XXXV. 2, 89, fig. 5, 1-6, fig. 12 (1909).

Elaeagnus latifolia Hooker f., Fl. Brit. Ind. V. 202 (pro parte) (1890).

Yunnan: Szemao, forests south, alt. 1500 m., A. Henry (No. 12680; climbing shrub).

This species apparently has not been reported from China before.

\section{Elaeagnus sarmentosa Rehder, n. sp.}

Frutex alte scandens, inermis, ramis flexilibus tenuibus, annotinis ferrugineis, vetustioribus flavido-griseis; gemmae ferrugineae. Folia persistentia, chartacea, elliptico-oblonga, breviter acuminata, basi late cuneata v. fere rotundata, 8-13 $\mathrm{cm}$. longa et $3.2-5.5 \mathrm{~cm}$. lata, supra luteo-viridia, maturitate glabra, rete vasculari in sicco prominente, subtus argentea et satis dense squamis ferrugineis conspersa, nitida, costa media densissime ferrugineo-lepidota, nervis utrinsecus 7-8 supra in sicco prominulis subtus elevatis, costa media supra vix impressa basin versus lepidota; petioli late canaliculati canaliculo medio elevato, $12-18 \mathrm{~mm}$. longi, ferruginei. Flores 1-3 in ramulis brevissimis aphyllis petiolo multoties brevioribus axillaribus, graciliter pedicellati, nutantes; ovarium ovoideum, $3 \mathrm{~mm}$. longum, ferrugineo-lepidotum; tubus perigonii cylindricus, basin versus leviter angustatus et supra ovarium distincte constrictus, $8-9 \mathrm{~mm}$. longus, ut lobi squamis ferrugineis paucioribus minoribusque pallidiosibus mixtis obtectus; lobi late ovati basi constricti, breviter, sed manifeste acuminati, $5 \mathrm{~mm}$. longi, intus dense stellato-tomentosi; antherae oblongae, obtusae, $2.25 \mathrm{~mm}$. longae: filamenta antheris plus quam duplo breviora, basi linea incrassata tubum glabrum et lobos stellato-tomentosos distinctissime separante conjuncta; stylus antheras superans, glaber. Fructus desideratur.

Yunnan: Mengtsze, forest, alt. 1500 m., A. Henry (No. 11439; large climber).

This species seems most nearly related to $E$. Henry $i$ Warburg, which is easily distinguished by its thick coriaceous leaves, lustrous and without reticulation above, by the smaller, slenderer and paler flowers gradually narrowed toward the base, the triangular not acuminate lobes and by the shorter style. Henry's Nos. 11309 and 11332 from Mengtsze and No. 12684 from Szemao appear closely related to $E$. sarmentosa, but they differ in the silvery under surface of the leaves destitute of brown dots or in No. 11332 only slightly dotted, in their shorter deeply and narrowly grooved petioles and in the paler and smaller flowers with shorter and less acuminate lobes. From E. Henryi Warburg, these specimens differ in their chartaceous not coriaceous leaves reticulate above, and in their wider flowers scarcely narrowed toward the base and distinctly contracted above the ovary. They may belong to a distinct species, but all three differ slightly from each other. 


\section{LYTHRACEAE.}

Determined by Alfred Rehder and E. H. Wilson.

\section{LAGERSTROEMIA L.}

Lagerstroemia indica Linnaeus, Spec. ed. 2, 734 (1762). - Loureiro, Fl. Cochin. 340 (1790). - Curtis in Bot. Mag. XII. t. 405 (1798).De Candolle, Prodr. III. 93 (1828). - Wight, Ill. Ind. Bot. I. t. 86 (1840). - Bentham, Fl. Hongk. 112 (1861). - Debeaux in Act. Soc. Linn. Bordeaux, XXX. 83 (Fl. Shangh. 31) (1875). - Hance in Jour. Bot. XVII. 11 (1879). - Clarke in Hooker f., Fl. Brit. Ind. II. 575 (1879). - Koehne in Bot. Jahrb. IV. 19 (1883). - Franchet in Nouv. Arch. Mus. Paris, sér. 3, VI. 13 (Pl. David. I. 133) (1883). - Hemsley in Jour. Linn. Soc. XXIII. 306 (1887). - Pritzel in Bot. Jahrb. XXIX. 484 (1900). - Pavolini in Nuov. Giorn. Bot. Ital. n. ser. XV. 416 (1906). - Dunn \& Tutcher in Kew Bull. Misc. Inform. add. ser. X. 109 (1912).

Velaga globosa Gaertner, Fruct. II. 246, t. 133 (1791).

Lagerstroemia elegans Paxton, Mag. Bot. XIV. 269 t. (1848).

Lagerstroemia indica, var. pallida Bentham in Hooker, Jour. Bot. \& Kew Gard. Misc. IV. 81 (1852).

Western Hupeh: north and south of Ichang, alt. 30-600 m., July 1907 (No. 353r; bush 1-3 m. or slender tree 5-6 m. tall, flowers pink to rose-red, wild and cultivated); same locality, A. Henry (No. 2507). Szech'uan: without locality, A. von Rosthorn (No. 152). Northwest Szech'uan: Lungan Fu, cultivated, alt. 800 m., August 18, 1910 (No. 4594; tree $8 \mathrm{~m}$. tall, $0.8 \mathrm{~m}$. girth, flowers carmine-red). Fokien: Dunn's Exped., April to June 1905 (Hongkong Herb. No. 2729). Shantung: Tsintau, 1901, Zimmermann (Nos. 261, 271). Korea: Quelpaert, August 1908, 1909, Taquet (Nos. 823, 2896).

In open grassy places and on cliffs at low altitudes round Ichang and westward into Szech'uan this plant is wild and common. It occurs always in form of a bush with leaves variable in size and shape and flowers of varying shades of red. It is also commonly cultivated in gardens and temple grounds where forms with white and pink to carmine colored flowers are common. In Hupeh its colloquial name is Tzu-ching-shu. A picture will be found under No. 0266 of the collection of Wilson's photographs. 


\section{PUNICACEAE.}

Determined by Alfred ReHDer and E. H. Wrlson.

\section{PUNICA L.}

Punica Granatum Linnaeus, Spec. 472 (1753). - Loureiro, Fl. Cochin. 313 (1790). - Bunge in Mém. Acad. Sav. Etr. St. Pétersbourg, II. 102 (Enum. Pl. Chin. Bor. 28) (1835). - Wight, Ill. Ind. Bot. II. t. 97 (1850). - Bretschneider, Study Chin. Bot. Works, 16 (1870). Debeaux in Act. Soc. Linn. Bordeaux, XXX. 82 (Fl. Shangh. 30) (1875); in XXXIII. 44 ( $F l$. Tientsin, 21) (1879). - Clarke in Hooker f., $F l$. Brit. Ind. II. 581 (1879). - Hemsley in Jour. Linn. Soc. XXIII. 306 (1887). - Pritzel in Bot. Jahrb. XXIX. 484 (1900). - Pavolini in Nuov. Giorn. Bot. Ital. n. ser. XV. 416 (1908).

Punica nana Linnaeus, Spec. ed. 2, 676 (1762). - Sims in Bot. Mag. XVII. t. 634 (1803).

Punica spinosa Lamarck, Fl. Frans., III. 483 (1778).

Punica Florida Salisbury, Prodr. 354 (1796).

Punica grandiflora Hort. ex Steudel, Nomencl. 669 (pro synon.) (1821).

Western Hupeh : Hsing-shan Hsien, cultivated, alt. 1000 m., June 7, 1907 (No. 3218; bush 3 m., flowers brick red); "Lungo il fiume Hang-Kiang," alt. 700 m., June 1907, C. Silvestri (No. 1564). Shensi : without locality, 1897, G. Giraldi; without locality, 1898, Hugh Scallan.

The Pomegranate is a favorite garden shrub and much cultivated by the Chinese, especially in Peking. It is naturalized and cultivated in Yunnan and other warmer parts of China where an inferior fruit is produced. 


\section{MYRTACEAE.}

Determined by Alfred ReHder and E. H. Wrison.

\section{EUGENIA L.}

Eugenia microphylla Abel, Narr. Jour. China, 181, 364 (1818).Forbes in Jour. Bot. XXII. 124 (1884).

Syzygium ? buxifolium Hooker \& Arnott, Bot. Voy. Beechey, 187 (1841).Walpers, Rep. II. 180 (1843). - Bentham, Fl. Hongk. 118 (1861).

Syllysium buxifolium Meyer \& Schauer in Nov. Act. Acad. Leop.-Carol. XIX. suppl. I. 334 (1843).

Eugenia Grijsii Hance in Jour. Bot. IX. 5 (1871), XVII. 10 (1879).

Eugenia pyxophylla Hance in Jour. Bot. IX. 6 (1871).

Eugenia sp. Moore in Jour. Bot. XIII. 227 (1875).

Eugenia sinensis Hemsley in Jour. Linn. Soc. XXIII. 298 (1887). - Dunn \& Tutcher in Kew Bull. Misc. Inform. add. ser. X. 105 (Fl. Kwangtung \& Hongk.) (1912). — Léveillé, Fl. Kouy-Tchéou, 289 (1914).

Kiangsi : near Kuling, cliffs, alt. 300 m., August 1, 1907 (No. I576; bush 1-1.5 m., flowers white). Chekiang: vicinity of Ningpo, 1908, D. Macgregor. Fokien: Dunn's Exped., April to June 1905 (Hongkong Herb. No. 2703). Hongkong: without locality, November 5, 1903, C. S. Sargent.

Our Kiangsi specimen has leaves not exceeding $1.5 \mathrm{~cm}$. in length and agrees perfectly with Abel's description. Though the size of the leaves varies considerably, they are invariably cuneate at the base. 


\section{MELASTOMATACEAE.}

Determined by ALFred ReHDer and E. H. Wrison.

\section{MELASTOMA}

Melastoma normale D. Don, Prodr. Fl. Nepal. 220 (1825).De Candolle, Prodr. III. 145 (1828). - Naudin in Ann. Sci. Nat. sér. 3, XIII. 289 (1849), - C. B. Clarke in Hooker f., Fl. Brit. Ind. II. 524 (1879). - Cogniaux in De Candolle, Monog. Phaner. VII. 352 (1891). - Guillaumin in Le Comte, Not. Syst. II. 319, fig. 7, 6 (1913). - Léveillé, Fl. Kouy-Tchéou, 277 (1914).

Melastoma napalensis Loddiges, Bot. Cab. VIII. t. 707 (1823).

Melastoma Wallichii De Candolle, Prodr. III. 146 (1828).

Melastoma pelagicum Naudin in Ann. Sci. Nat. sér. 3, XIII. 279 (1849).

Melastoma longiflorum Naudin, 1. c. 290 (1849).

Melastoma Cavaleriei Léveillé in Fedde, Rep. Spec. Nov. III. 21 (1906).

Melastoma Esquirolii Léveillé, 1. c. VIII. 61 (1910).

Melastoma malabathricum Dunn in Jour. Linn. Soc. XXXIX. 467 (non Linnaeus, nec Desrousseaux, Sims, Ker, Jack, Blanco) (1911).

Szech'uan: banks of Yangtsze River, May 1903(Veitch Exped. No 3648). Western Szech'uan: Omei Hsien, roadside thickets, alt. 300-800 m., July and October 1908 (No. 3259; bush 1-2 m., flowers rose to rose-purple); Mt. Omei, June 1904 (Veitch Exped. No. 4907); same general locality, A. Henry (No. 8976); E. Faber (No. 495). Yunnan: Mengtsze, alt. 1600 m., A. Henry (No. 10954).

This is a common shrub on the red sandstone hills in the neighborhood of the city of Kiating Fu and in Omei Hsien from river-level up to $800 \mathrm{~m}$. altitude.

\section{OSBECKIA L.}

Osbeckia crinita Clarke in Hooker f., Fl. Brit. Ind. II. 517 (non Naudin) (1879). — Hemsley in Jour. Linn. Soc. XXIII. 299 (1887). Cogniaux in De Candolle, Monog. Phaner. VII. 323 (1891). - Pritzel in Bot. Jahrb. XXIX. 484 (1900), - Dunn \& Tutcher in Kew Bull. Misc. Inform. add. ser. X. 106 (Fl. Kwangtung \& Hongk.) (1912). Guillaumin in Lecomte, Not. Syst. II. 308 (1913). 
Osbeckia stellata, $\beta$ De Candolle, Prodr. III. 142 (1828).

Osbeckia crinita Bentham apud Wallich, Cat. No. 4066 (nomen nudum) (1829).

Osbeckia stellata Naudin in Ann. Sci. Nat. sér. 3, XIV. 72 (non D, Don) (1850), - Hance in Jour. Bot. XVI. 107 (1878).

Osbeckia crinita, $\boldsymbol{\beta}$ yunnanensis Cogniaux in De Candolle, Monog. Phaner. VII. 324 (1891), - Guillemin in Lecomte, Not. Syst. II. 308 (1913), Léveillé, Fl. Kouy-Tchéou, 277 (1914).

Osbeckia yunnanensis Franchet in herb. ex Cogniaux in De Candolle, Monog. Phaner. VII. 324 (pro synon.) (1891).

Melastoma Mairei Léveillé in Fedde, Rep. Spec. Nov. XI. 300 (1912).

Western Hupeh: Hsing-shan Hsien, grassy mountains, alt. 6001000 m., August 1901 (Veitch Exped. No. 2558). Western Szech'uan: Kiating Fu, grassy hills, alt. 300 m., October 1908 (No. 326o; shrub 0.6-1 m. tall, flowers red). Yunnan: Szemao, hills, alt. 1500 m., A. Henry (No. 12458). K wangtung: Lienchou River, August 13, 1887, C. Ford (Hongkong Herb. No. 1782).

A small shrub rare in Hupeh but common in the neighborhood of Kiating Fu and in Yunnan in open grass-clad places. We have followed Hemsley in the determination of this plant.

Wilson's No. 3260 agrees well with specimens from Khasia except that the trabecular veinlets are somewhat more numerous and closer, while No. 2558 differs in the shorter ovate leaves only sparingly setulose beneath and with fewer and less distinct trabecular veinlets. Guillaumin refers all the Chinese plants to $O$. crinita, var. yunnanensis Cogniaux. 


\title{
BETULACEAE.
}

\author{
Determined by Camillo Schneider.
}

\section{OSTRYOPSIS Decne.}

1. Ostryopsis Davidiana Decaisne in Bull. Soc. Bot. France, XX. 155 (1873). - Hance in Jour. Bot. XIII. 137 (1875). - Lavallée, Arb. Segrez. 5, t. 3 (1880), - Maximowicz in Mél. Biol. XI. 316 (1881); in Bull. Acad. Sci. St. Pétersbourg, XXVII. 535 (1882). - Dippel, Handb. Laubholzk. II. 136, fig. 65 (1892), - Palibin in Act. Hort. Petrop. XIV. 140 (1895). - Burkill in Jour. Linn. Soc. XXVI. 502 (1899).Schneider, Ill. Handb. Laubholzk. I. 143, fig. 75 f-n, $76 \mathrm{~s}$ (1904). Winkler in Engler, Pflanzenr. IV.-61, 20, fig. 5 (1904). - Bean, Trees \& Shrubs Brit. Isl. II. 116 (1914).

Corylus Davidiana Baillon, Hist. Pl. VI. 224, fig. 174 (1877). - Franchet in Nouv. Arch. Mus. Paris, sér. 2, VII. 88 (Pl. David. I. 278) (1884).

Western Szech'uan: Mao-chou, cliffs and dry places, Min River valley, alt. 1800-2300 m., August 28, 1910 (No. 4470; bush 1.2-3 m. tall; fruits). Chili: Hsiao Wu-tai-shan, alt. 1600 m., August 8, 1913, F. N. Meyer (No. 1125; fruits); Cal-ceen-wong, 1910, W. Purdom (No. 69 ; fruits); Jehol, A. David (No. 1694; type, ex Decaisne).

Here may be added notes on two Ostryopsis of which I have not seen specimens:

Ostryopsis Davidiana, var. cinerascens Franchet in Bull. Soc. Bot. France, XXXII. 27 (1885). - Burkill in Jour. Linn. Soc. XXVI. 503 (1899).

Yunnan: "in collibus calcareis ad Mosoyn prope Lankong," June 1, 1884, A. Delavay (No. 37, type, ex Franchet; No. 830, ex Burkill).

This variety is said to differ from the type in its broader ovate-rotundate leaves, which are more thickly covered beneath with a shining silky pubescence. The branchlets also are more pilose and glandular. It is said to be a very small bush, $0.6 \mathrm{~m}$. high. Winkler (in Engler, Pflanzenr. IV.-61. 20 [1904]) does not mention this variety, but cites under the type a specimen from Yunnan, A. Delavay (No. 1066), without any special locality.

2. Ostryopsis nobilis Balfour \& Smith in Not. Bot. Gard. Edinburgh, VIII. 194 (1914).

Yunnan: in open thickets on the mountains to the northeast of the Yangtsze Bend, lat. $27^{\circ} 45^{\prime}$ N., alt. $3100-3400$ m., June 1913, G. Forrest (No. 10343, type; shrub $2-4 \mathrm{~m}$; f fruits).

This interesting species according to the authors differs from $O$. Davidiana Decaisne by its much larger leaves (6-12 cm. long, 5-10 cm. broad), which are covered 
underneath with a thick brownish tomentum, and by the more loosely arranged fruits, which do not form dense headlike catkins as in 0 . Davidiana Decaisne.

\section{OSTRYA Scop.}

Ostrya japonica Sargent in Garden \& Forest, VI. 383, fig. 58 (1893); For. Fl. Jap. 66, t. 22 (1894). - Shirasawa in Bull. Agric. Coll. II. 265, t. 13, fig. 15-16 (Jap. Laubh. Wint. t. 9, fig. 15-16) (1895); Icon. Ess. For. Jap. I. 49, t. 25, fig. 1-14 (1900). - Henry in Elwes \& Henry, Trees Gr. Brit. \& Irel. III. 544, t. 201, fig. 10 (1908).-Nakai in Tokyo Bot. Mag. XXIX. 37 (1915).

Ostrya virginica Maximowicz in Mél. Biol. X1. 317 (non Willdenow) (1881); in Bull. Acad. Sci. St. Pétersbourg XXVII. 537 (1882).

Ostrya virginica, var. japonica Maximowicz ex Sargent, Garden \& Forest, VI. 383 (pro synon.) (1893); For. Fl. Jap. 66 (pro synon.) (1894). - Burkill in Jour. Linn. Soc. XXVI. 503 (1899).

Ostrya carpinifolia Franchet in Jour. de Bot. XIII. 204 (non Scopoli) (1899).

Ostrya ostrya, var. japonica Schneider, Ill. Handb. Laubholzk. I. 142, fig. 76 r (1904).

Ostrya italica, subspec. virginiana Winkler in Engler, Pflanzenr. IV.-61, 22 (1904), quoad plantam e Japonia et China.

Ostrya italica, var. virginiana Matsumura, Ind. Pl. Jap. II. pt. 2, 22 (1912).

Western Szech'uan: northeast of Tachien-lu, Ta-p'ao-shan, woods, alt. 2200-2800 m., July 3, 1908 (No. 22 I5; tree 10-17 m. tall, girth 0.9-1.8 m., bark rough and scaly; fruiting branchlets). Western Hupeh: Fang Hsien, woods, not common, alt. 2300-2500 m., September 1907 (No. 2220; tree $8 \mathrm{~m}$. tall; fruiting branchlets); same locality, A. Henry (No. 6581; fruiting branchlets).

NORTHEASTERN ASIA. Korea: Quaelpaert, forests, alt. $1700 \mathrm{~m}$., Taquet (No. 4439; ripe fruits).

JAPAN. Hokkaido: prov. Ishikari, Sapporo, September 1885, and October 1, 1910, K. Miyabe (sterile); same locality, October 1891, Y. Tokubuchi (fruits); same locality, hills, moist soil with Quercus, Aralia, Acanthopanax, September 18, 1892 , C. S. Sargent (tree 13-27 m. tall, girth $5.4 \mathrm{~m}$.; sterile); same locality, August 23, 1905, J. G. Jack (ripe fruits); same locality, July 26, 1904 (ex Herb. Sakurai; fruiting branchlets). Hondo: prov. Musashi, Takao-san, April 25, 1907 (ex Herb. Sakurai; flowers); prov. Shinano, Kisogawa, rare, April? and August 1907 (ex Herb. Sakurai; flowers and fruits); prov. Shimotsuke, Lake Chuzenji, August 24,1904, N. Mochizuki (fruiting branchlet); prov. Kii, Koya-san, ascent of mountain, only one seen, October $2,1914, E$. H. Wilson (No. 7846; small tree, 5 m. tall; sterile).

This species is closely related to the species of eastern Ameriea and of Europe, and it needs further investigation to decide whether these three trees are to be treated as subspecies or as distinct species. So far as I can see without having carefully studied all the specimens from America and Europe, the Asiatic species seems to be somewhat intermediate between them. 


\section{CARPINUS L.}

Carpinus cordata Blume, var. chinensis Franchet in Jour. de Bot. XIII. 202 (1899). — Burkill in Jour. Linn. Soc. XXVI. 501 (1899). Diels in Bot. Jahrb. XXIX. 279 (1900). - Winkler in Engler, Pflanzenr. IV.-61, 27 (1904). - Henry in Elwes \& Henry, Trees Gr. Brit. \& Irel. III. 530 (1908). - Schneider, Ill. Handb. Laubholzk. II. 892, fig. 558 f (1912). - Bean, Trees \& Shrubs Brit. Isl. I. 295 (1914).

Carpinus cordata Winkler in Bot. Jahrb. L. 489 (pro parte) (1914).

Western Hupeh: north and south of Ichang, woods, alt. 13002200 m., July and November 1907 (No. 508; tree 8-17 m. tall, girth 0.3-0.9 m.; fruits); same locality, June 1907 (No. 508 ; young fruits); same locality, May 31, 1907 (No. 508 ${ }^{\text {b }}$; tree 8-17 m. tall, girth 0.3-1.5 m.; young fruits); same locality, September and October 1907 (No. $508^{\circ}$; fruits); same locality, May 31,1907 (No. 508 ; flowers); same locality, May 1900 (Veitch Exped. No. 587; flowers); same locality, May 1900 (Veitch Exped. No. 420; fruits); Fang Hsien, woods, rare, alt. 1900-2400 m., September 1907 (No. 2209; tree 3-12 $\mathrm{m}$. tall, girth $0.3-0.9 \mathrm{~m}$; fruits; branchlets and peduncles more glabrous!); Changyang Hsien, June 1901 (Veitch Exped. No. 527, in part; tree 8-14 m. tall; flowers); Chienshi Hsien, mountains, May 1900 (Veitch Exped. No. 527, in part; tree $7 \mathrm{~m}$. tall; flowers and young fruits). Eastern Szech'uan: Wushan Hsien, A. Henry (Nos. 5886, $5886^{\mathrm{a}}$; fruits); Tchen-keou-tin, alt. 1400 m., P. Farges (No. 14; type of var. chinensis; fruits).

Winkler (1914) unites this variety with the type, but I cannot agree with him in this. The flora of the geographical area where the type is growing in northern China and Mandshuria is rather different from that of central China. If there were not such forms as Wilson's No. 2209 the branchlets and peduneles of which are more glabrous, I should feel inclined to raise this variety to the rank of a species. It represents certainly a form of higher taxonomic value than the other varieties of $C$. cordata or the varieties of C. japonica described by Winkler. It differs distinctly in its densely hirsute-villose pubescence mixed with silky hairs of the branchlets, young petioles and peduncles, which are sparsely hirsute or glabrous in the typical $C$. cordata.

Carpinus laxiflora Blume, var. macrostachya Oliver in Hooker's Icon. Pl. XX. t. 1989 (1891). - Burkill in Jour. Linn. Soc. XXVI 501 (1899). - Diels in Bot. Jahrb. XXIX. 280 (1900). - Winkler in Engler, Pflanzenr. IV.-61, 33 (1904); in Bot. Jahrb. L. 496 (1912). Schneider, Ill. Handb. Laubholzk. II. 894, fig. 559 o-p (1912). Rehder in Bailey, Stand. Cycl. Hort. II. 673 (1914). 
Carpinus Fargesii Franchet in Jour. de Bot. XIII. 202 (1899). - Schneider, Ill. Handb. Laubholzk. II. 894, fig. 558 d, 559 q (1912).

Carpinus laxiflora, var. Fargesii Burkill in Jour. Linn. Soc. XXVI. 501 (1899). - Diels in Bot. Jahrb. XXIX. 280 (1900). - Winkler in Engler, Pflanzenr. IV.-61, 33 (1904); in Bot. Jahrb. L. 496 (1914).

Carpinus laxiflora Henry in Elwes \& Henry, Trees Gr. Brit. \& Irel. III. 530 (1908), quoad plantam chinensem.

Western Hupeh: mountains north and south of Ichang, woods, alt. 1200-1800 m., May 1907 (No. 22I7; tree 7-18 m. tall; flowers); mountains south of Ichang, April 1900 (Veitch Exped. Nos. 40, 295; tree 7-8 m. tall; flowers and young leaves); same locality, June 1900 (Veitch Exped. No. 948, in part; tree 7-13 m. tall; young fruits); same locality, August 1900 (Veitch Exped. No. 948 in part; ripe fruits); Patung Hsien, alt. 1600 m., April 25, 1900 (Veitch Exped. No. 477; tree $12 \mathrm{~m}$. tall; flowers); same locality, A. Henry (No. 7013, type of var. macrostachya; fruiting branchlets); Hsing-shan Hsien, Mahuang-po, alt. 500 m., 1900 (Veitch Exped. Seed Nos. 737, 737 ; tree 8 m. tall). Eastern Szech'uan: near Tehen-keou-tin, P. Farges (No. 699, type of C. Fargesii, ex Franchet). Western Szech'uan: Mt. Omei, 1904 (Veitch Exped. Seed No. 1750; tree 10 m. tall, leaves very small).

This variety doubtless is nearly related to the Japanese type, but the leaves are always distinctly ovate or oblong-ovate with a more gradually tapering apex, while in the typical forms the shape of the leaves is more obovate-oblong, being very often broadest at or above the middle, with a more abruptly pointed apex. The bracts of the male flowers seem to be a little longer, more ovate-oblong, not orbicularovate as in the typical forms. I have not seen the type specimen of var. Fargesii, but the No. 948 of Wilson which I in 1912 partly referred to this variety and partly to var. macrostachya certainly does not belong to two different varieties. I can hardly believe that $C$. Fargesii Franchet even represents a distinct variety.

Carpinus laxiflora, var. Davidii Franchet in Jour. de Bot. XIII. 203 (1899). - Burkill in Jour. Linn. Soc. XXVI. 501 (1899). - Winkler in Engler, Pflanzenr. IV.-61, 33 (1904); in Bot. Jahrb. L. 496 (1914).

Carpinus laxiflora Franchet in Nouv. Arch. Mus. Paris, sér. 2, VII. 89, t. 11, fig. A 1 (Pl. David. I. 279) (non Blume) (1884).

Carpinus Davidii Schneider, Ill. Handb. Laubholzk. II. 893, fig. 558 1, 559 e (1912).

Kiangsi: Kuling, side of streams, alt. 1200 m., July 31, 1907 (No. ${ }_{534}$; bush $7 \mathrm{~m}$. tall; ripe fruits); "montagne de Ly-chan près de Kiukiang," September, A. David (No. 750, type, ex Franchet).

According to Franchet's plate this variety looks so distinct that I formerly considered it a species. But Winkler (1914), who saw the type, says the drawing is very inexact. Certainly Wilson's plant from the same region looks very different from 
Franchet's plate, but agrees with Winkler's statements. The outer (dentate) margin of the bracts is not lobed at the base, but there is a basal lobe at the inner (entire) margin. The differences between the Kiangsi plants and the Hupeh variety are apparently very slight, and more copious material probably will show that both are the same and may represent a good species confined to central China. Then the oldest name would be $C$. Fargesii Franchet.

Carpinus Turczaninovii Hance, var. ovalifolia Winkler in Bot. Jahrb. L. Suppl. 505 (1914).

Carpinus Turczaninowii Franchet in Jour. de Bot. XIII. 203 (pro parte) (1899). - Burkill in Jour. Linn. Soc. XXVI. 502 (pro parte) (1899). Diels in Bot. Jahrb. XXIX. 279 (pro parte) (1900), - Winkler in Engler, Pflanzenr. IV.-61, 38 (1904), exclud. var. polyneura.

Carpinus polyneura Burkill in Jour. Linn. Soc. XXVI. 501 (pro parte, non Franchet) (1899). - Henry in Elwes \& Henry, Trees Gr. Brit. \& Irel. III. 527, t. 201, fig. 5 (1908). - Bean in Kew Bull. Misc. Inform. 1911, 327; Trees \& Shrubs Brit. Isl. I. 297 (1914).

Western Szech'uan: Mao-chou, valley of Min River, alt. 2300 m., September and October 1910 (No. 4I05; tree 7-17 m. tall, girth 1.2-2.4 m.; fruiting branchlets); between Lungan Fu and Sungpan Ting, mountains, alt. 2300 m., August 1903 (Veitch Exped. No. 4489; tree $8 \mathrm{~m}$. tall; almost ripe fruits). Eastern Szech'uan: Wushan Hsien, A. Henry (No. 7020; type of var. ovalifolia; fruiting branches); same locality, A. Henry (No. 7219; co-type, ex Winkler); district of Tchen-keou-tin, Farges (without number, fruiting branchlets; and No. 1273; ex Winkler). Kansu: Lotani road from Min-chou, alt. 2600 m., W. Purdom (No. 787; tree 7 m. tall; fruits).

The specimens which I doubtfully unite under this variety agree with each other in their fruiting bracts of similar shape which differ from those of the typical form in being only toothed and not lobulate on the outer margin. The leaves, too, are somewhat more ovate-oblong and slightly more elongated at the apex than those of the typical C. Turczaninovii Hance. There is no real difference in the pubescence of the upper or lower surfaces of the leaves; this is variable in both the varieties. Certainly var, ovalifolia needs further investigations. From C. polyneura Franchet it differs clearly in the glabrous nutlets, and in the serration of its leaves which is distinetly compound with short teeth. Judging by a specimen cultivated at Kew which is referred by Henry and by Bean to C. polyneura Franchet, the male flowers are different from those of this species. I describe them as follows: Amenta mascula sessilia, usque $3 \mathrm{~cm}$. longa et eirciter $0.7 \mathrm{~cm}$. erassa, densa, rhachi dense sericeovillosa; bracteae late ovatae, acutae, ima apice fere nigrae, ceterum parte superiore rubro-brunneae, parte inferiore olivaceae, intus glabrae, margine satis ciliatae, extus plus minusve adpresse sericeae; stamina circiter 10, toro piloso; thecae separatae, ellipticae, concolores, apice et etiam antica parte superiore pilis longis sericeis instructae, filamentis subbrevioribus tantum apice partitis suffultae.

There is a specimen collected by Wilson, Wushan Hsien, ravine, May 1900 (Veiteh Exped. No. 618; tree $3 \mathrm{~m}$. tall), the male flowers of which are similar, but the bracts are nearly round, more obtuse, and even more eiliate. I am not quite sure whether this specimen belongs to our variety or to another species. 
A picture of C. Turczaninovii, var. ovalifolia will be found under No. 0335 of the collection of Wilson's photographs.

\section{Carpinus Fargesiana Winkler in Bot. Jahrb. L. Suppl. 506, fig. 6 (1914).}

Carpinus yedoensis Franchet in Jour. de Bot. XIII. 203 (non Maximowicz) (1899). - Burkill in Jour. Linn. Soc. XXVI. 502 (1899), - Diels in Bot. Jahrb. XXIX. 279 (1900), - Winkler in Engler, Pflanzenr. IV.-61, 35, fig. 10 G (1904). - Henry in Elwes \& Henry, Trees Gr. Brit, \& Irel. III. 529 (pro parte) (1908). - Bean, Trees \& Shrubs Brit. Isl. I. 297 (pro parte) (1914).

Western Szech'uan: northeast of Tachien-lu, forests, Ta-p'aoshan, alt. 2300-2800 m., July 1908 (No. 22I I tree 8-20 m. tall, girth 0.6-2.4 m.; fruiting branches). Eastern Szechu'an: district of Tchen-keou-tin, P. Farges (without number; type ex Franchet and Winkler).

Winkler also refers to his C. Fargesiana a specimen collected by Wilson numbered $1170^{\circ}$ in Herb. Hofmus. Wien, which $I$ have been unable to compare. Nor did I see the type, but Wilson's No. 2211 may be referred to this species which needs further investigation. ${ }^{1}$ There may be some relationship between it and those forms I have mentioned under $C$. Turczaninovii, var, ovalifolia Winkler. It seems best to give a description of No. 2211 because there is no sufficient description of C. Fargesiana, and there is some doubt whether our specimen is the same as Winkler's type. Arbor 8-20 m. alta; ramuli hornotini versus apicem laxe sericeo-villosi, deinde glabrescentes, brunnei, lenticellis parvis ellipticis flavis numerosis conspersi; gemmae vix satis evolutae, satis parvae, ovatae, obtusae, perulis ciliatis pluribus cinctae. Folia ovato- v. elliptico-oblonga, firma, subrotunda v. paulo angustata, indistincte cordata, apice sensim breviter acuminata, supra intensius viridia, ad costam nervosque et facie inter nervos sericeo-villosula, subtus pallide-viridia, ad costam nervosque plus minusve sericeo-villosula, facie vix pilosa, tenuissime reticulata, in axillis nervorum lateralium distincte prominentium 12-15 inter se 3-5 $\mathrm{mm}$. distantium foveolata et barbata, margine dupliciter $\mathrm{v}$. ad apicem simpliciter dentato-serrata inter dentes apice nervorum haud v. vix elongatos dentibus 1-2 secundariis $\mathrm{v}$. nullis instructa, majora $5-6.5 \mathrm{~cm}$. longa, $2-2.5 \mathrm{~cm}$. lata; petiolis superne sericeis $6-10 \mathrm{~mm}$. longis satis gracilibus instructa. Amenta fruetifera matura pedunculis 1-1.5 cm. longis laxe sericeis suffulta, eirciter $4 \mathrm{~cm}$. longa et $2.5 \mathrm{~cm}$. crassa, subdensa, rhachi sericeo-villosula; bracteae late semiovatae, subobtusae, latere exteriore dentato-serratae v. lobulato-dentatae, latere interiore integrae, rectae, basi haud v. vix involutae, superne sparse pilosae et eiliatae, subtus praesertim ad nervos distinctius pilosae, 13-15 $\mathrm{mm}$. longae, $6-8 \mathrm{~mm}$. latae; nuculae late ovatae, interdum a latere compressae, brunneae, longitudinaliter $8-10$ costato-striatae, apice perigonio distincto coronatae et pilosae sed ceterum facie glabrae, tantum glandulis praesertim versus apicem conspersae, circiter $4 \mathrm{~mm}$. longae et $2.5 \mathrm{~mm}$. crassae.

1 To these central Chinese forms may be closely related C. Kawakamii Hayata, Icon. Pl. Formos. III. 175, fig. 24, t. 33, fig. B (1913), which I know only from the description and the figures. The type was collected by B. Hayata in Formosa on Mt. Morrison, October 1907 (No. 1998). Hayata says: "near C. faginea Lindl.," but according to the plate it seems much nearer to C. Fargesiana Winkler or to C. Henryana Winkler. 
Carpinus Henryana Winkler in Bot. Jahrb. L. Suppl. 507, fig. 7 1914).

Carpinus polyneura Burkill in Jour. Linn. Soc. XIII. 501 (pro parte, non Franchet) (1899).

Carpinus Tschonoskii, var. Henryana Winkler in Engler, Pflanzenr. IV.-61, 36 (1904).

Western Hupeh: Hsing-shan Hsien, woods, alt. 1600-1900 m., November 1907 (No. 645; tree 7-10m. tall, girth $0.6-0.9 \mathrm{~m}$.; old fruiting branchlets); same locality, June 1907 (No.645 ; young fruits). Eastern Szech'uan: Wushan Hsien, A. Henry (No. 7063, type; ripe fruits). Western Szech'uan: Mupin, woods, alt. 1900-2200 m., October 1908 (No. 1226; tree 13-17 m. tall, girth 1.5-1.8 m.; with ripe fruits); northeast of Tachien-lu, Ta-p'ao-shan, forests, 2100-2900 m., July 3, 1908 (No. 2210; tree 12-20 m. tall, girth 1.2-2.1 m.; with young fruits); between Lungan Fu and Sungpan Ting, woods, alt. 1600-2400 m., September 1904 (Veitch Exped. No. 4488; with ripe fruits).

This is an interesting species of which the type differs a little from the other specimens enumerated above. But the serration is quite distinct from that of C. polyneura Franchet to which the type was referred by Burkill. The specimen from Mupin looks rather distinct and may even represent a good variety, but this question needs further investigation because there are too many intermediate characters in all these specimens. Nevertheless I think it best to add a description of Wilson's No. 1226, alluding to its differences from the type which was not sufficiently described by the author; the indications put in parenthesis ( ) refer to the type.

Arbor ad 13-17 m. alta; ramuli novelli sericeo-villosi, deinde plus minusve glabrescentes, purpurascentes, lenticellis albis v. flavidis oblongis conspersi, vetustiores nigrescentes; gemmae foliiferae ovato-oblongae, subtriangulares, sensim acuminatae, rubro-brunneae, perulis pluribus margine ciliatis cinctae, petiolis subduplo breviores floriferae crassiores, ellipticae. Folia satis anguste ovato-lanceolata (ovato-oblonga) basi subobliqua, rotunda v. cuneata (interdum levissime cordata), apicem versus sensim acuminata (saepe subcaudata), saepissime ima basi (pleraque versus medium) latissima, supra intensius viridia, tantum inter nervos sparse (etiam ad costam nervisque et distinctius) sericeo-pilosa, subtus pallide viridia, costa et nervis utrinque 12-16 elevatis inter se ad costam 4-5 mm. (2.5-3.5 mm.) distantibus sericeo-pilosis, facie glabra (saepe laxe pilosa) tenuiter reticulata, margine glabra (ciliata), sublobato-dentata dentibus apice nervorum vix acutis (submucronulatis) basi excepta inter se dente secundario nullo v. uno subobtuso (acuto) instructa, majora $5-8 \mathrm{~cm}$. longa, $2-3 \mathrm{~cm}$. lata (4.5-6 cm. longa); petioli 1.1-1.7 $\mathrm{cm}$. (0.8-1.2 cm.) longi, graciles, glabri v. sparse sericei (saepe subvillosuli); stipulae rarissime (saepe) persistentes, lineares, subsericeae, petiolis fere subaequilongae. Amenta fructifera pedunculis ad $2 \mathrm{~cm}$. longis (brevioribus) villosulis suffulta $6-7 \mathrm{~cm}$. (4-5 cm.) longa, ad 3.5-4 cm. (ad $2.5 \mathrm{~cm}$.) crassa; bracteae semiovatae, acutae, margine exteriore plus minusve lobato-dentato-serratae (dentato-serratae), margine interiore dentatae v. integrae, basi levissime lobulatae v. tantum paulo involutae (integrae, basi saepe distinctius lobatae), intus sparse pilosae, ciliatae, extus intensius pilosae, $1.8-2.4 \mathrm{~cm}$. Iongae, $0.9-1.3 \mathrm{~cm}$. latae $(1.4-1.6 \mathrm{~cm}$. longae, $0.6-0.7 \mathrm{~cm}$. latae); nuculae ovatae, obtusae, tota facie minute puberulae, brunneae, longitudi- 
naliter 6-8-striatae, apice perigonio distincto aperto $\mathrm{v}$. fere clauso instructae, pilosae, eirciter $5 \mathrm{~mm}$. (4 mm.) longae.

Carpinus Seemeniana Diels in Bot. Jahrb. XXIX. 279 (1900). Winkler in Engler, Pfanzenr. IV.-61, 36, fig. 12 E-F (1904).Schneider, Ill. Handb. Laubholzk. II. 895, fig. 558 p (1912).

Carpinus pubescens Schneider, 1. c. fig. 558 g. - Winkler in Bot. Jahrb. L. Suppl. 501 (pro parte, non Burkill) (1914).

I Carpinus pinfaensis Léveillé \& Vaniot in Bull. Soc. Bot. France, LII. 142 (1905), descriptione valde manca.

Western Hupeh: Fang Hsien, woods, alt. 2300 m., October 1907 (No. 646 ; tree $10 \mathrm{~m}$. tall, girth $1.2 \mathrm{~m}$; with ripe fruits); same locality, woods, common, July 1907 (No. 22I3; tree 7-17 m. tall, girth 0.6-1.2 $\mathrm{m}$; ; with ripe fruits); Changlo Hsien, woods, alt. 1200-1600 m., June 1907 (No. 22I2; with young fruits); Patung Hsien, woods, common, alt. 1200-1800 m., July 1907 (No. 22I8; tree 7-13 m. tall, girth 0.9$1.8 \mathrm{~m}$; ; with ripe fruits); southeast of Ichang, mountains, June 1900 (Veitch Exped. No. 1170; tree 7-13 m. tall; fruits not yet ripe). Southeastern Szech'uan: Nanch'uan, Shan-tzi-ping, woods, August 1891, A. v. Rosthorn (No. 294, type).

This species is very nearly related to C. pubescens Burkill, with which it is united by Winkler (1914). I have given the differences in the key, and shall consider it a distinct species until more material from Yunnan shows that it is the same as or only a variety of $C$. pubescens, which, however, inhabits a different geographical region. Neither Winkler nor I have seen any male flowers of these species. Winkler refers also to his $C$. pubescens a specimen from Shensi collected by Giraldi, Lao-y-san mountains, May 2, 1899 (No. 6136), and the type of $C$. pinfaensis Léveille \& Vaniot which was found by $J$. Cavalerie at Pin-fa in Kweichou, March 28, 1903 (No. 1011). All these forms need further investigation.

Carpinus polyneura Franchet in Jour. de Bot. XIII. 202 (1899). Burkill in Jour. Linn. Soc. XXVI. 501 (pro parte) (1899). - Diels in Bot. Jahrb. XXIX. 279 (1900). - Schneider, Ill. Handb. Laubholzk. II. 894, fig. 558e, $559 \mathrm{~m}-\mathrm{n}$ (1912). - Winkler in Bot. Jahrb. L. Suppl. 506 (1914).

? Carpinus faginea Burkill in Jour. Linn. Soc. XXVI. 501 (non Lindley) (1899). - Diels in Bot. Jahrb. XXIX. 280 (1900).

Carpinus Turczaninowii, var. polyneura Winkler in Engler, Pflanzenr. IV.-61, 38, fig. 12 A-B (1904). - Rehder in Bailey, Stand. Cycl. Hort. II. 673 (1914).

Western Hupeh: Hsing-shan Hsien, woods, common, alt. 1600 m., May 1907 (No. 22I4; tree 7-13 m. tall, girth 0.6-1.8 m.; with young fruits); north of Ichang, roadside, alt. $900 \mathrm{~m}$., May 3, 1907 (No. 22 6 ; one large tree, $13 \mathrm{~m}$. tall, girth $1.8 \mathrm{~m}$.; sterile); same locality, mountains, May 1901 (Veitch Exped. No. 1809; tree 7 m. tall; flowers); Patung Hsien, mountains, rare, June 1901 (Veitch Exped. No. 2217; 
tree $8 \mathrm{~m}$. tall; young fruits); Fang Hsien, high mountains, rare, June 1901(Veitch Exped. No. 2102; tree 7 m. tall; young fruits). Eastern Szech'uan: Wushan Hsien, A. Henry (No. 5520; ? also No. 5520 $=$ C. faginea Burkill); same locality, A. Henry (No. $7020^{\mathrm{a}}$; ripe fruits); Tchen-keou-tin, P. Farges (type, ex Franchet).

This is a very distinct species with almost simple setose serration of its small long-pointed leaves. Wilson's No. 1809 with male flowers seems to belong here. These flowers may be described as follows: Amenta mascula nondum satis evoluta ad $2 \mathrm{~cm}$. longa, sessilia, rhachi villosa; bracteae oblongae, subacutae, apice intense brunneae, ceterum flavido-olivaceo-brunnescentes, utrinque glabrae, margine apice excepta ciliatae, $5-6 \mathrm{~mm}$. longae; stamina circiter 8 , toro piloso; thecae separatae ellipticae concolores apice et etiam facie antica pilis longis sericeis instructae, filamentis subaequilongis apice tantum partitis suffultae.

In shape the male bracts resemble those of $C$. cordata, var. chinensis more than those of the other species of central China. The species was misunderstood by Henry and Bean, who apparently referred to it plants belonging to C. Turczaninovii, var. ovalifolia (see p, 427). I have not seen in cultivation a plant which I could refer to C. polyneura.

\section{CONSPECTUS SECTIONUM SPECIERUMQUE ASIAE ORIENTALIS,} NEC NON HIMALAYAE.

Amenta fruetifera bracteis dense imbricatis is Ostryae similia; bracteae cum ligula libera inter axin et nuculam $\mathrm{v}$. basi distincte inflexa nuculam totam occultantes v. nuculae maturae distincte ellipticae, rarius in C. japonica ovato-ellipticae.

Sect. 1. DISTEGOCARPUS.

Folia ovato-lanceolata, fere semper infra medium latissima, basi rotunda v. anguste cordata. Bracteae cum ligula libera inter axin et nuculam.

1. C. japonica.

Folia late ovata, ovato-elliptiea v. interdum subobovata, basi semper distincte late cordata. Bracteae basi distincte inflexae lobo nuculam tegente semper cum bractea plus minusve connato; nuculae distincte ellipticae.

2. C. cordata.

Amenta fructifera laxiores bracteis non dense imbricatis; bracteae basi utrinque $\mathrm{v}$. tantum latere exteriore v. interiore lobatae $\mathrm{v}$. non lobatae, lobo interiore nunquam nuculam totam occultante, sed nueulae fere semper plus minusve v. omnino visibiles; nuculae late ovatae $\mathrm{v}$, interdum subtriangulari-ovatae, apice semper plus minusve contractae . . . . . . . Sect. 2. EUCARPINUS.

Nuculae facie haud pilosae, sed saepissime glandulis minimis praesertim versus apicem conspersae (tantum apice ad perigonii lobos et ad basin styli pilis sericeis fere semper instructae).

Bracteae amentorum fructiferorum maturorum latere interiore basi distincte lobatae, latere exteriore dentatae v. lobulatae et basi saepe etiam lobatae.

Folia majora ramulorum fructiferorum $8-13 \mathrm{~cm}$. longa, ovato- v. ellipticooblonga v. lanceolata, apice longe eaudato-acuminata, basi haud v. tantum leviter cordata (ima basi saepissime in petiolum paulo producta), nervis lateralibus (apice folii excepta) ad costam (5-)6-9 mm. inter se distantibus.

Folia pleraque ovato-oblonga v. -lanceolata et infra medium latissima, nervis lateralibus 2 infimis saepe in petiolum paulo productis; petioli 
foliorum majorum saepissime plusquam $10 \mathrm{~mm}$. longi, glabri v. sparse pilosi

3. C. viminea.

Folia pleraque elliptico-oblonga v. -lanceolata et medio v. supra medium latissima; petioli foliorum majorum vix plusquam $8 \mathrm{~mm}$. longi, tomentosi v. fere glabri

4. C. Londoniana.

Folia majora ramulorum fructiferorum breviora $v$, pro longitudine latiora, e basi rotundata v. cordata, rarius cuneata, ovata v. ovato-oblonga v. apice acuta subobtusave $\mathbf{v}$. nervis lateralibus inter se magis approximatis (confer etiam 7. C. Tanakaeanam, 8. C. Fargesianam et 9. C. Tschonoskii).

Folia apice distincte et saepissime subito acuminata caudatave margine dentibus maximis apice nervorum plus minusve cuspidatis. Bracteae basi saepe utrinque lobatae v. latere interna lobo satis distineto subacuto instructae

5. C. laxiflora.

Folia apice acuta subobtusave, margine dentibus apice nervorum haud cuspidato-elongatis. Bracteae latere interiore lobo tantum parvo obtuso instructae . . . . . . . . 6. C. Turczaninovii.

Bracteae amentorum fructiferorum maturorum latere interiore non distincte lobatae, interdum margineleviter inflexae (confer etiam 7.C.Tanakaeanam). Folia etiam maxima ramulorum fructiferorum vix usque $5.5 \mathrm{~cm}$. longa, apice acuta $\mathrm{v}$. subobtusa, dentibus apice nervorum lateralium haud distincte mucronatis

6. C. Turczaninovii.

Folia majora ramulorum fructiferorum pleraque $6-10 \mathrm{~cm}$. longa v. apice in acumen plus minusve distinctum producta $\mathrm{v}$. dentibus apice nervorum lateralium distinete mucronatis.

Foliorum dentes primarii secundariique haud distincte v. non mucronati.

8. C. Fargesiana.

Foliorum dentes primarii distincte et etiam secundarii plus minusve mucronati ........ 9. C. Tschonoskii.

Nuculae tota facie tenuissime v. distinctius pilosae (interdum etiam glandulosae et apice pilis longioribus sericeis instructae).

Foliorum dentes primarii secundariique nunquam distincte mucronati $\nabla$. setacei.

Folia pleraque ovata v. ovato-elliptica, apice acuta, etiam maxima ramulorum fruetiferorum vix usque $5.5 \mathrm{~cm}$. longa margine semper duplicatoserrata. Nuculae facie saepe satis sparse indistincteve pilosae.

6. C. Turczaninovii var.

Folia pleraque ovato-oblonga $v$. ovato-lanceolata, apice plus minusve acuminata v. margine simpliciter v. sub-simpliciter serrata, majora ramulorum fructiferorum pleraque $(5-) 6 \mathrm{~cm}$. longa $\mathrm{v}$. longiora. Nuculae ut videtur semper distincte dense pilosulae.

Folia pro parte maxima marginis simpliciter v. subsimpliciter serrata, dentibus secundariis haud $\mathrm{v}$, vix evolutis. . . . 10. C. Henryana.

Folia apice excepta dupliciter serrata v. dentata, dentibus secundariis inter primarios 1-4 satis distinetis.

Ramuli hornotini aestate $\mathrm{v}$, autumno glabri v. sparse villosuli v. petioli foliorum maximorum $1 \mathrm{~cm}$. longi $\mathrm{v}$. longiores et tenues. Bracteae majores maturae satis acutae, circiter $2-2.7 \mathrm{~cm}$. longae.

11. C. Seemeniana.

Ramuli hornotini etiam aestate autumnove satis dense villosuli. Petioli etiam foliorum maximorum vix $8 \mathrm{~mm}$. longi, satis crassi, tota facie villosuli v tomentosi. Bracteae etiam maximae maturae vix $1.8 \mathrm{~cm}$. longae, apice obtusae

12. C. pubescens. 
Foliorum dentes primarii distincte setacei, etiam secundarii plus minusve mucronati.

Folia majora 7-9 $\mathrm{cm}$. longa et $2.5-3.5 \mathrm{~cm}$. lata; petioli vix $5 \mathrm{~mm}$. longi, satis crassi, villosi . . . . . . . . . . . 13. C. faginea.

Folia breviora v. angustiora; petioli graciliores, foliorum majorum 6-12 $\mathrm{mm}$. longi v. subglabri.

Folia ovata, 2.5-3.5 cm. lata, breviter acuminata, pro parte maxima marginis dupliciter serrulata. Bracteae maturae majores circiter $2 \mathrm{~cm}$. longae . . . . . . . . . . . 14. C. Fauriei.

Folia ovato-oblonga v. ovato-lanceolata, longe acuminata, plus minusve simpliciter setaceo-serrulata. Bracteae maturae etiam maximae vix $1.5 \mathrm{~cm}$. longae 15. C. polyneura.

\section{ENUMERATIO SECTIONUM SPECIERUMQUE ASIAE ORIENTALIS NEC NON HIMALAYAE.}

Sect. 1. DISTEGOCARPUS Sargent, Silva N. Am. IX. 40 (1896). - Winkler in Engler, Pflanzenr. IV.-61, 24 (1904).

Distegocarpus Siebold \& Zuccarini in Abh. Ak. Münch. IV.pt. 3, 226 (Fl. Jap. Fam. Nat. II. 102) (1846), excludenda C. laxiflora.

Carpinus, subgen. Disterocarpus [sic] Nakai in Tokyo Bot. Mag. XXIX.37 (1915).

The species of this section are well characterized by their dense Ostrya-like fruiting aments and by their elliptical nutlets.

1. Carpinus japonica Blume, Mus. Bot. Lugd.-Bat. I. 308 (1850).-Walpers, Ann. III. 379 (1852-3). - Miquel in Ann. Mus. Lugd.-Bat. I. 121 (1863), III. 194 (1857); Prol. Fl. Jap. 358 (1867). - Franchet \& Savatier, Enum. Pl. Jap. I. 451 (1875). - Maximowicz in Mél. Biol. XI. 311 (1881); in Bull. Acad. Sci. St. Pétersbourg, XXVII. 534 (1882). - Dippel, Handb. Laubholzk. II. 143, fig. 68 (1892). Koehne, Deutsche Dendrol. 117 (1893). - André in Rev. Hort. 1895, 427, fig. 143. Mouillefert, Traité Arb. \& Arbriss. II. 1138 (1897). - Shirasawa in Bull. Agric. Coll. Tokyo, II. 266, t. 13, fig. 10 (Jap. Laubh. Winter. t. 9, fig. 10) (1895); Icon. Ess. For. Jap. I. 47, t. 24, fig. 1-17 (1900). - Rehder in Bailey, Cycl. Am. Hort. I. 253 (1900); in Bailey, Stand. Cycl. Hort. II. 637 (1914). - Winkler in Engler, Pflanzenr. IV.-61, 25, fig. 7 D-F, fig. 8 C (1904); in Bot. Jahrb. L. Suppl. 488 (1914). - Schneider, Ill. Handb. Laubholzk. I. 804 (1906). - Henry in Elwes \& Henry, Trees Gr. Brit. \& Irel. III. 528, t. 201, fig. 1 (1908). - Bean, Trees \& Shrubs Brit. Isl. I. 295, fig. (1914).

Distegocarpus Carpinus Siebold \& Zuccarini in Abh. Akad. Münch. IV. pt. 3, 227, t. 3 C (Fl. Jap. Fam. Nat. II. 103) (1846). - Walpers, Ann. I. 634 (1848-9). - A. De Candolle, Prodr. XVI. pt. 2, 128 (1864).

Distegocarpus carpinoides Siebold \& Zuecarini in Abh. Akad. Münch. IV. pt. 3, 240, in explic. tabulae 3 (Fl. Jap. Fam. Nat. II. 116) (1846).

Carpinus Carpinus Sargent in Garden \& Forest, VI. 364, fig. 56 (1893); For. Fl. Jap. 64, t. 21 (1894); Silva N. Am. IX. 41 (1896), - Schneider, Ill. Handb. Laubholzk. I. 137, fig. 75 b, 76 1, 80 a-i (1904).

Carpinus japonica, var. cordifolia Winkler in Engler, Pflanzenr. IV.-61, 26 (1904).

Carpinus carpinoides Makino in Tokyo Bot. Mag. XXVI. 391 (1912).

Carpinus carpinoides, var. cordifolia, Makino, 1. c. (1912). 
Carpinus Distegocarpus Koidzumi in Tokyo Bot. Mag. XXVII. 144 (1913). Carpinus japonica, var. pleioneura Winkler in Bot. Jahrb. L. Suppl. 488 (1914).

JAPAN. Hondo: prov. Mutsu, Aomori, May 20, 1904, U. Faurie (No. 5780; young fruits); prov. Shimotsuke, around Lake Chuzenji, woods, not common, alt. $1400 \mathrm{~m}$., May 24, 1914, E. H. Wilson (No. 6738 ; tree 13-15 m. tall, girth 0.6-0.9 m., bark gray, fissured; flowers); same locality, common, May 26, 1914, E. H. Wilson (No. 6758; tree 10-13 m. tall, girth 0.9-1.8 m., bark gray; flowers); same locality, side of lake, not common, October 21, 1914, E. H. Wilson (No. 7675; small tree, 8-12 m. tall, girth 0.6-1.5 m.; fruits); same locality, common in forests, October 20, 1914, E. H. Wilson (No. 7692; small tree 7-13 m. tall, girth $0.6-1.5 \mathrm{~m}$.; fruits); same prov., Nikko, July 29, 1882, K. Miyabe (unripe fruits); same locality, N. Mochizuki, August 30, 1904 (fruits); roadside, Nikko to Lake Chuzenji, October 25, 1905, J. G. Jack (fruits); Nikko, Doenitz (type of var. cordifolia ex Winkler); prov. Kozuke, Mt. Asama, July 14, 1904, U. Faurie (No. 5779; fruits); prov. Shinano, Fukushima to Otake, woods, common, June 10, 1914, E. H. Wilson (No. 6994; small tree 7-10 m. tall, girth $0.6-1.2 \mathrm{~m}$.; young fruits); same prov., on Tsubakura-dake, woods, common, alt. 1100-1600 m., September 15, 1914, E. H. Wilson (No. 7454; tree 8-13 m. tall, girth $0.3-0.6 \mathrm{~m}$.; fruits); same locality and date, E. H. Wilson (No. 7483; tree 10-15 m. tall, girth $0.45-0.9 \mathrm{~m}$,, fruits); prov. Musashi, Takao-san, common in woods and thickets, alt. $30-500 \mathrm{~m}$., September 24, 1914, E. H. Wilson (No. 7161; tree 7-12 m. tall, girth 0.6-0.75 m., head very bushy, fruits); same prov., Yokohama, 1862, C. Maximowicz (type of $C$. japonica, var., see below); same place, May and October 1862, C. Maximowicz (co-type of var. pleioneura Winkler); prov. Sagami, Miyanoshita, O. Warburg (No. 7756, type of var. pleioneura ex Winkler); same prov., Miyanoshita, Hakone Mts., August 25, 1892, C. S. Sargent (fruits); same prov., Hakone, 1864, Tschonoski (flowers); prov. Kai, Kofu, (May?) and August 9, 1909 (ex Herb. Sakurai, fruits and flowers); " in sylvis Takayu," June 1904, U. Faurie (No. 5774; young fruits); without exact locality, 1842, P. von Siebold (co-type, ex Herb. Zuccarini; flowers and fruits); without locality and collector (ex Herb. Lugd. Bat.; flowers and leaves).

Siebold \& Zuccarini in the original description deseribe the leaves as "e basi cordata v. rotunda subobliqua," and I cannot see that Winkler's var. cordifolia represents even a good form, and it is the same with var. pleioneura, as nearly every specimen before me has leaves of both these varieties. A picture of this tree will be found under No. x203 of the collection of Wilson's Japanese photographs. I can maintain only the following variety:

Carpinus japonica, var. caudata Winkler in Bot. Jahrb. L. Suppl. 488 (1914).

A typo recedit foliis lanceolato-oblongis longius caudato-acuminatis grossius serratis.

JAPAN. Hondo: prov. Shinano, Mt. Ontake, August 1905, U. Faurie (No. 6641 ; fruits).

This may be only a form and needs further observation.

Maximowicz (in Bull. Acad. Sci. St. Pétersbourg, XXVII. 533 [1882]) mentions a C. japonica, var., "foliis paulo latioribus basi saepe distincte oblique cordatis, ligula non semper a margine bracteae libera, saepius basi cum illa connexa." I have seen the type of this, and all the bracts I have been able to investigate had a free ligula like the those of typical plants. Winkler states the same fact, and we have not seen any form which could be taken for a hybrid between $C$. japonica and the following species. They are both always very distinct and easy to recognize.

2. Carpinus cordata Blume, Mus. Bot. Lugd.-Bat. I. 309 (1850). - Walpers, Ann. III. 379 (1852-3). - Regel in Mém. Acad. Sci. St. Pétersbourg, sér. 7, IV. 
No. 4, 130, 201 (Tent. Fl. Ussur.) (1861). - Miquel in Ann. Mus. Lugd.-Bat. I. 121 (1863). - Franchet \& Savatier, Enum. Pl. Jap. I. 452 (1875). - Maximowicz in Mél. Biol. XI. 312 (1881); in Bull. Acad. Sci. St. Pétersbourg, XXVII. 533 (1882), - Trautvetter in Act. Hort. Petrop. IX. 165 (1884). - Koehne, Deutsche Dendr. 117 (1893). - Sargent in Garden \& Forest, VI. 364 (1893), VIII. 294, fig. 41 (1895); For. Fl. Jap. 65 (1894); Silva N. Am. IX. 41 (1896). - Shirasawa in Bull. Agric. Coll. Tokyo, II. 267, t. 13, fig. 12 (Jap. Laubh. Winter. t. 9, fig. 12) (1895); Icon. Ess. For. Jap. I. 46, t. 24, fig. 18-32 (1900). - Burkill in Jour. Linn. Soc. XXVI. 501 (1899). - Diels in Bot. Jahrb. XXIX. 279 (1900). - Rehder in Bailey, Cycl. Am. Hort. I. 253 (1900); Stand. Cycl. Hort. I. 673 (1914). - Komarov in Act. Hort. Petrop. XXII. 62 (Fl. Mansh.11.) (1903). - Schneider, Ill. Handb. Laubholzk. 1. 137, fig. 75 a, $76 \mathrm{~m}, 80 \mathrm{k}-\mathrm{q}$ (1904). - Winkler in Engler, Pflanzenr. IV.-61, 26, fig. 7 A-C, 8 A-B (1904); in Bot. Jahrb. L. 489 (1914). - Mayr, Fremdl. Wald. \& Parkbäume 453, fig. 173 (1906). - Veitch, Hortus Veitchii, 359 (1906). - Henry in Elwes \& Henry, Trees Gr. Brit. \& Irel. IiI. 589, t. 201, fig. 2 (1908). - Pampanini in Nuov. Giorn. Bot. Ital. n. ser. XVII. 250 (1910), - Nakai in Jour. Coll. Sci. Tokyo, XXXI. 205 (Fl. Kor. 1I.) (1911); in Tokyo Bot. Mag. XXIX. 38 (1915),Bean in Bot. Mag. CXL. t. 8534 (1914); Trees \& Shrubs Brit. Isl. I. 295 (1914).

Carpinus erosa Blume, Mus. Bot. Lugd.-Bat. I. 308 (1850).-Walpers, Ann. III. 379 (1852-3). - Franchet \& Savatier, Enum. Pl. Jap. 1. 452 (1875). Maximowicz in Mél. Biol. XI. 312 (1881); in Bull. Acad. Sci. St. Pétersbourg, XXVII. 534 (1882).

Distegocarpus? erosa A. De Candolle, Prodr. XVI. pt. 2, 128 (1864).

Distegocarpus ? cordata A. De Candolle, l. c. (1864).

Ostrya mandshurica Budischtschew in Зап. Сибпрек. Отд. И. Русск. Геогр. Общ. IX.-X. 461 (1867), ex Trautvetter in Act. Hort. Petrop. IX. 166 (1884), fide Komarov!

2 Carpinus cordata, f. chinensis Nakai in Jour. Coll. Sci. Tokyo, XXXI. 205 (Flor. Kor. II.) (non Franchet) (1911).

CHINA. Northern Hupeh: "Monte T'ien-pong-scian a $30 \mathrm{~km}$. a N. E. di Chang-kin," alt. $1550 \mathrm{~m}$., October 1907, C. Silvestri (No. 319, fruits; form, see below); "Catena di Ou-tan-scian," August-September 1909, C. Silvestri (No. 2925, fruits; see below). Northern Shensi: "Mt. Kin-tou-san," July 14, 1897, $J$. Giraldi (fruits).

NORTHEASTERN ASIA. Mandshuria: prov. Kirin, "inter Omoso et Ninguta, trajectus San-to-alin," July 24, 1896, V. Komarov (sterile). Us su ri : Port Bruce, 1860, C. Maximowicz (fruits); around Vladivostok, in forests, May 17, 1901, Palczewski (fruits); same locality, cultivated, August 20, 1903, C.S. Sargent (sterile). Korea: Hoang-hai-to, mountains, August 1906, U. Faurie (No. 205; fruits); Quelpaert, "in silvis basis Hallaisan," June 1907, U. Faurie (No. 1530; fruits; interesting form, see below); "in vertice Hallaisan," June 1907, U. Faurie (No. 1531; fruits); woods, alt. 1900 m., October 1, 1910, Taquet (No. 4441; fruits); same locality, alt. 1200 m., July 1909, Taquet (No. 3335, 3336; fruits).

JAPAN. Hokkaido: prov. Kitami, around Rubeshibe, not common, August $16,1914, E . H$. Wilson (No. 7383 ; tree $8-13 \mathrm{~m}$. tall, girth $0.3-0.6 \mathrm{~m}$; f fruits); prov. Iburi, Mororan, woods, September 1904, U. Faurie (No. 5775; type of var. robusta; No. 5776; fruits); prov. Shiribeshi, Iwapai, woods, September 1904, U. Faurie (No. 5777; co-type of var. Faurieana and var. pseudojaponica); prov. Ishikari, Sapporo, May (and fall?) 1878, K. Uchida (flowers and fruits); same loeality, July 1 and 20, 1885 (from Agric. Coll. Sapporo; fruits); same locality, May (and summer?) 1889, Y. Tokubuchi (flowers and fruits); Mt. Moiwa, 
September 17, 1892, C. S. Sargent (tree 10-13 m. tall, girth $6 \mathrm{~m}$.; sterile); same place, Oetober 16, 1892, J. H. Veitch (fruits); same locality, October 19, 1903, $S$. Arimoto (fruits); prov. Oshima, Hakodate, 1861, C. Maximowicz (flowers); same place, 1861, M. Albrecht (fruits). Hondo: prov. Mutsu, Fukura, September 12, 1892, J. H. Veitch (sterile, very large leaves); prov. Rikuchu, base of Hayachine-san, near Kadoma, alt. $1200 \mathrm{~m}$., September 28, 1914, E. H. Wilson (No. 7587; tree 12-13 m. tall, head bushy; interesting form, see below); same locality, common, side of streams, alt. 700-1200 m., September 28, 1914, E. H. Wilson (No. 7586; small tree, 8-12 m. tall, girth 0.9-1.2 m.; fruits); prov. Shimotsuke, around Lake Chuzenji, woods, common, alt. 1300-1600 m., May 24, 1914, E. H. Wilson (No. 6740; tree 12-17 m. tall, girth 0.9-1.2 m., bark rough, gray; flowers); same locality, May 26, 1914, E. H. Wilson (No. 6769; tree 8-13 m. tall, girth 0.9-1.5 m.; flowers); same locality, August 30, 1904, N. Mochizuki (fruits); Nikko, October 17, 1892, J. H. Veitch (fruits); prov. Shinano: Hashide to Otake, thickets and woodlands, June 10, 1914, E. H. Wilson (No. 7001; tree 10-13 m. tall, girth 0.9-1.8 m.; unripe fruits); prov. Musashi, Mt. Buko, May 2, 1909 (ex Herb. Sakurai; young fruits); eultivated, Tokyo Bot, Garden, April 12, 1914, E. H. Wilson (No. 6413; small tree, $7 \mathrm{~m}$. tall, bark pale gray, slightly furrowed; flowers); prov. Suruga, Fuji-san, July $29,1891, K$. Watanabe (fruits); same locality, 1864, Tschonoski (flowers); 1862, C. Maximowicz (fruits); without exact locality, alt. 600-2100 m., C. Maries (flowers); May 13, 1886, H. Mayr (young fruits); 1886, H. Mayr (fruits).

This is a very well marked species in the shape of its leaves and in the bristly hairs at the base of the fruiting bracts. These bracts are very variable in shape, especially in the size and shape of the lobe which covers the nutlet. Winkler (1914) has described several varieties. These need further investigation, as 1 have found many even more distinct forms than those described by Winkler. I mention the following without distinguishing them as varieties. The variability of the female bracts seems to be so great that it needs the comparison of copious material to show what variations can be regarded as well fixed and worthy of special systematic treatment.

The most common form ${ }^{1}$ has large ovate or ovate-elliptical acute bracts having several teeth on the outer margin, which usually is slightly folded in at the base, and from 1 to 4 teeth near the top of the inner margin, which otherwise is entire with the exception of the lobe at its base covering the nutlet. This lobe is large and connected with the inner margin of the bract for nearly its entire length; its upper margin is acute with mostly from 2 to 4 teeth. In var. Faurieana Winkler (in Bot. Jahrb. L. Suppl, 489 [1914]), of which one type specimen is mentioned above, the lobe is more rounded at the top and though a little smaller also covers the whole nutlet. In var. robusta Winkler (1. c. fig. 1 a) the lobe is large and toothed, and is connected with the bract for only about half its length, and in var. pseudojaponica Winkler (1. c. 491 , fig. 1 b-d) the connection of the lobe with the bract is even less broad. But this condition of the lobe is even more distinctly developed in No. 1530 of Faurie from Hallai-san. In this specimen the lobe is narrow and connected with the bract only on its base, the shape of the bract being ovate-lanceolate. In Quelpaert on Hallai-san we find always very peculiar forms and often endemic species. No. 1531 of Faurie also deserves a special mention. On this specimen the lobe is very small, entire and semicircular. Another remarkable variation appears in Taquet's No. 4441 from Quelpaert; on this specimen the lobe has about the normal size and shape, but it is fissured for from $\frac{1}{2}$ to

1 I have not seen Blume's type specimen, and Winkler does not mention that he has seen it, therefore I do not know what the type really is, because Blume did not describe the form of the lobes of the fruiting bracts. 
$\frac{2}{3}$ of its length along its line of connection with the bract, and is therefore connected with the bract only at the upper and lower ends. Sometimes the lobe is grown together on its lateral margins with both the margins of the bract forming a real pocket, as I found in several bracts of Silvestri's No. 319. However, the most distinct variation I have found is shown in Wilson's No. 7587, which has ovate-lancelate bracts with entire or nearly entire margins. The lobes are large, connected with the bract for only about $\frac{1}{3}$ of their length near their base, the free part being nearly obovate, acute and more or less toothed on its outer edge. 1 have never found a special form of the bracts and their lobes combined with other distinct characters of the plant. The difference in the shape, size, pubescence and in the nervation and dentation of the leaves is not sufficient to found varieties on.

A picture of this tree will be found under No. x260 of the collection of Wilson's Japanese photographs. There is only the following distinct variety from central China:

\section{Carpinus cordata, var. chinensis Franchet. See p. 425.}

Sect. 2. EUCARPINUS Sargent, Silva N. Am. IX. 40 (1896). - Winkler in Engler, Pflanzenr. IV.-61, 28 (1904). - Schneider, Ill. Handb. Laubholzk. II. 893 (1912).

\section{Carpinus, subgen. Eucarpinus Nakai in Tokyo Bot. Mag. XXIX. 37 (1915).}

This section differs from the first in its looser fruiting catkins, which never look like those of an Ostrya, and in its ovate or ovate-triangular more or less acute nutlets. A natural arrangement of the species of this section according to their relationship is a difficult undertaking. After a careful examination of the ripe fruits of the species from our area I am inclined to consider the pubescence or glabrousness of the nutlets a valuable taxonomic character. They are nearly always more or less provided with silky hairs on the top of the ovary and on the lobes of the perigone, which are more or less distinct; but the pubescence $I$ refer to is a very fine one and is spread over the whole surface, and sometimes is only visible with the aid of a strong lens. The nutlets are nearly always somewhat glandular, but these small yellowish brown glands are different from the minute hairs. Only further investigation can show if the nutlets present some other characters in their size, their ribs, and in the development of the perigone lobes. The shape, dentation, venation, the reticulation and the size of the bracts and their lobes are very variable in the same species, and it would need statistical investigations of hundreds of the bracts of the same plant and of different plants of the same species to fix the limits of this variation in certain species. It is useless to make new sections or groups as Nakai did when dealing only with a few species of a very limited area like Korea. The male flowers may afford good characters too, but I have not seen them of all our species.

3. Carpinus viminea Wallich, ${ }^{1} \mathrm{Pl}$. As. Rar. II. 4, t. 106 (1831), - A. De Candolle, Prodr. XVI. pt. 2, 127 (1864). - Stewart, Punjab Pl. 200 (1869). - Brandis, Forest Fl. Brit. Ind. 492 (1874); Ind. Trees, 623 (1906). - Kurz, For. Fl. Brit. Burma, II. 477 (1877). - Hooker f., Fl. Brit. Ind. V. 626 (1888). - Gamble, Man. Ind. Timb. ed. 2, 684 (1902), - Collett, Fl. Siml. 476 (1902). - Winkler in Engler, Pflanzenr. IV.-61. 32, fig. 12 C-D (1904); in Bot. Jahrb. L. Suppl. 493, fig. 3 (1914). - Schneider, Ill. Handb. Laubholzk. II. 894, fig. 558 b, 559 i-k (1912).

1 According to Wallich's Catalogue the name viminea was given by Wallich in 1824 in his herbarium. At this time Wallich united No. 2801 with it, which in 1831 was named $C$. faginea by Lindley (see p. 442), who gave to Wallich the MSS, of the diagnoses which appeared in the Plantae Asiaticae. 
INDIA. Kumaon: "reg. temp., 6-7000 ped.," T. Thomson (fruits); Nanik, $7000 \mathrm{ft}$., Strachey \& Winterbottom (No. 1; fruits); without locality, R. Blinkworth (No, $2800^{\mathrm{b}}$ Herb. Wallich, second type ex Wallich). United Provinces: Dehra Dun, Kathian, June 17, 1912, R. Manickam (fruits). Nepal: without exact locality, 1821, N. Wallich (No. $2800^{\mathrm{a}}$, type ex Wallich). East Bengal: without locality (No. 4488, Herb. Griffith; fruits). Assam: Konoma, Napa Hills, Dr. King's collector (fruits).

This is a well-marked species with its long pointed leaves; there may be several forms according to their more or less compound serration. 1 have not seen sufficient material to make it possible to say whether or not the western forms are different from those from the eastern parts of the Himalaya. This species certainly is closely related to the following.

4. Carpinus Londoniana Winkler in Engler, Pfanzenr. IV.-61, 32 (1904); in Bot. Jahrb. L. Suppl. 492 (1914). - Schneider, Ill. Handb. Laubholzk. II. 894, fig. $558 \mathrm{~g}, 559 \mathrm{~h}(1912)$.

CHINA. Yunnan: Szemao, forests, alt. 1300 m., A. Henry (No. 11640, type; tree $7 \mathrm{~m}$. tall; immature fruits); same locality, east mountains, alt. 1600 m., $A$. Henry (No. $11640^{\mathrm{a}}$; tree $7 \mathrm{~m}$. tall; immature fruits); same locality, south ravine, A. Henry (No. $11640^{\mathrm{b}}$; tree $2.4 \mathrm{~m}$. tall; young leaves and male flowers):

INDIA. Burma: March 1880, D. Brandis (ex Winkler). Siam: Chiang-mai, forest, January $2,1909, A . F . G$. Kerr (No. 511 ; tree $10 \mathrm{~m}$. tall; ripe fruits and old leaves at the same time with the young leaves and the flowers; ex Winkler).

This species is certainly very closely related to $C$. viminea Wallich, and may perhaps be better treated as a geographical variety. For the main differences see the key, p. 432. I have not seen any male flowers of $C$. viminea. Those of $C$. Londoniana may be described as follows:

Amenta mascula circiter $6 \mathrm{~cm}$. longa; bracteae ovatae v. ovato-lanceolatae, cuspidato-acuminatae, brunneae sed apice purpurascentes, faciebus glabrae, margine plus minusve breviter ciliatae, apicem versus glabriores, cireiter $6-7 \mathrm{~mm}$. longae et 2.5-3.5 mm. latae; stamina circiter 10, toro piloso inserta thecis oblongoellipticis separatis apice rubro-brunneis et hirsutis, filamento communi is fere aequilongo.

5. Carpinus laxiflora Blume, Mus. Bot. Lugd.-Bat. I. 309 (1850). - Walpers, Ann. III. 379 (1852-3). - Miquel in Ann. Mus. Lugd.-Bat. I. 121 (1863). - Franchet \& Savatier, Enum. Pl. Jap. 1. 451 (1875), exclud. Savatier No. 1172. - Maximowicz in Mél. Biol. XI. 315 (1881); in Bull. Acad. Sci. St. Pétersbourg, XXVll. 536 (1882). - Sargent in Garden \& Forest, Vl. 364 (1893); For. Fl. Jap. 64 (1894); Silva N. Am. IX. 41 (1896). - Shirasawa in Bull. Agric. Coll. Tokyo, II. 267, t. 13, fig. 13 (Jap. Laubh. Winter. t. 9, fig. 13) (1895); Icon. Ess. For. Jap. I. 48, t. 25, fig. 15-30 (1900). - Rehder in Bailey, Cycl. Am. Hort. I. $253(1900)$; in Bailey, Stand. Cycl. Hort. II. 673 (1914). - Schneider, Ill. Handb. Laubholzk. 1. 138, fig. 76 i (1904); Il. 894, fig. 558 c, 559 f-g (1912). - Winkler in Engler, Pflanzenr. IV.-61, 33, fig. $10 \mathrm{~K}(1904)$; in Bot. Jahrb. L. Suppl. 494 (1914). - Henry in Elwes \& Henry, Trees Gr. Brit. \& Irel. III. 530, t. 201, fig. 8 (1908), exclud. plantis chinensibus. - Nakai in Jour. Coll. Sci. Tokyo, XXXI. 205 (Fl. Kor. II.) (1911). - Miyabe \& Kudo in Trans. Sapporo Nat. Hist. Soc. V. 145 (1915).

Distegocarpus laxiflora Siebold \& Zuccarini in Abh. Akad. Münch. IV. pt. 3, 228 (Fl. Jap. Fam. Nat. II. 104) (1846). - Walpers, Ann. I. 634 (1848).A. De Candolle, Prodr. XVI. pt. 2, 128 (1864).

9 Carpinus laxiflora, var, chartacea Léveillé in Bull. Soc. Bot. France, LI, 424 (1904), descriptio valde incompleta. 
NORTHEASTERN ASIA. Korea: "in montibus Ouen-san," August 28 1901, U. Faurie (No. 624; fruits not yet fully ripe); Quelpaert, "in silvis Hallaisan," June 1907, U. Faurie (No. 1536; unripe fruits); same locality, May 1907, U. Faurie (No. 1532; flowers); same locality, July 1909, Taquet (No. 3237; unripe fruits); "in sylvis Hioton," April 14, 1908, Taquet (No. 4705; female flowers; may belong to C. Tschonoskii Maximowicz).

JAPAN. Hokkaido: prov. Oshima, near Mori, September 26, 1892, C.S.Sargent (tree 13-17 m. tall, girth 3-5.4 m., smooth white bark; sterile); Hakodate, 1861, C. Maximowicz (fruiting branchlets). Hondo: prov. Shimotsuke, Lake Chuzenji, August 21, 1904, N. Mochizuki (fruits); same locality, roadside, October 26, 1905, J. G. Jack (sterile); Nikko, October 18, 1892, J. H. Veitch (tree 7-10 m. tall; fruiting branchlets); prov. Kozuke, Mt. Asama, July 14, 1904, U. Faurie (No. 5772; fruiting branchlets); prov. Shinano, hills near Fukushima, 1892, C. S. Sargent (tree 7-10 m. tall; fruiting branchlets); Hashide to Otake, common, June 10, 1914, E. H. Wilson (No. 6997; tree 10-15 m. tall, girth $0.6-1.5 \mathrm{~m}$., bark smooth, pale gray; young fruits); Otake-gawa, common, margin of woods, November 2, 1914, E. H. Wilson (Nos. 7745, 7750; bushy tree, 7-12 m. tall, girth 0.5-0.75 m.; fruiting branchlets); Nojiri, September 6, 1905, J. G. Jack (fruiting branchlets); prov. Musashi, Tokyo region, near Sakai station, in grove by farmhouse, April 9, 1914, E. H. Wilson (No. 6389; tree $15 \mathrm{~m}$. tall, girth $1.2 \mathrm{~m}$., bark smooth, pale gray with shallow longitudinal furrows; flowers); same region, June 15, 1908 (ex Herb. Sakurai; young fruits); same prov., Omiya, July 15 and 17, 1911 (ex Herb. Sakurai; folia satis lanceolata, basi plus minusve acuta; amenta fructifera nondum matura longa); same prov., Mejiro, July 18, 1909 (ex Herb. Sakura; young fruits); prov. Sagami, Hakone, 1864, Tschonoski (very young fruits, also flowers named C. Tschonoskii); Miyanoshita, August 25, 1892, C. S. Sargent (tree 7-8 m. tall; fruiting branchlets); prov. Suruga, base of Fuji-san, 1862, C. Maximowicz (very young fruits); prov.?, "in sylvis Ubayu," July 1, 1904, U. Faurie (No. 5773; ripe fruits). Shikoku; prov. Tosa, Nanokawa, September 17, 1887, R. Watanabe (fruiting branchlets). Kyushu: prov. Chikugo, April 1886, H. Mayr (flowers); without precise locality (ex Herb. Lugd.-Bat.; sterile and female flowers).

The male flowers of the typical form of his species have broadly orbicular-ovate very short-pointed or obtuse bracts which are distinctly dark red-brown at the apex and clear yellowish below. The male flowers of Faurie's No. 1532 are hardly different, but the main part of their bracts is brownish without such a strong contrast in color as in the flowers of the Japanese specimens before me. Winkler (1914) in describing the male flowers from Faurie's No. 1532 mentions a white cross line beneath the dark apex which I did not find in the specimen in the herbarium of the Arnold Arboretum. I am not quite sure whether No. 1532 does belong to C. Fauriei with finely puberulous fruits or to the apparently typical $C$. laxiflora represented by the other specimens from Korea. The island of Quelpaert is rich in distinet forms.

As far as I know the typical C. laxiflora Siebold \& Zuccarini does not oceur in Mandshuria or China. There are the following two Chinese varieties:

Carpinus laxiflora, var. macrostachya Burkill. See p. 425.

Carpinus laxiflora, var. Davidii Franchet. See p. 426.

6. Carpinus Turczaninovii Hance in Jour. Linn. Soc. X, 203 (1869). - Maximowicz in Mél. Biol. X1. 315 (1881); in Bull. Acad. Sci. St. Pétersbourg, XXV11. 535 (1882). - Franchet in Nouv. Arch. Mus. Paris, sér. 2, Vil. 88, t. 10 (Pl. Davíd. I. 278) (1884); in Jour. de Bot. XIII. 203 (1899), exclud. specimine Fargesii. - 
Burkill in Jour. Linn. Soc. XXVI. 502 (1899), exclud. specimine Fargesii. Diels in Bot. Jahrb. XXIX. 279 (1900), exelud. specimine Fargesii. - Rehder in Bailey, Cycl. Am. Hort. 1. 253 (1900); in Bailey, Stand. Cycl. Hort. II. 673 (1914). - Schneider, Ill. Handb. Laubholzk. II. 895, fig. 558 h-i, 559 t-u (1904). Winkler in Bot. Jahrb. L. Suppl. 502, fig. 5 (1914).

Carpinus Paxii Winkler in Engler, Pflanzenr. IV.-61, 35, fig. 10 A-C (1914). Nakai in Tokyo Bot. Mag. XXIX. 39 (1915).

Carpinus stipulata Winkler, in Engler, Pflanzenr. IV.-61, 35, fig. 11 (1914).

Carpinus Turczaninowii, var. stipulata Winkler in Bot. Jahrb. L. Suppl. 505 (pro parte) (1914).

CHINA. Chili: near Peking, August 1886, S. W. Williams (No. 12681 Herb. Hance, type; fruits not yet ripe); hills near Peking, August 1876, S. W. Williams (seeds ripen early in July in good seasons; much fruit usually; flowers in May; tree about $10 \mathrm{ft}$. high; not a common tree; it has been destroyed by drought during the last ten years); Tse-tai-ssu, H. Wawra (No. 1067, type of C. Paxii, ex Winkler). Northern Shensi: Tsin-ling-shan, G. Giraldi (No. 7267, type of C. stipulata). Shantung: Po-shan, mountain sides on rocks, September 19, 1907, F. N. Meyer (No. 258; ripe fruits).

NORTHEASTERN ASIA. Korea: Chemulpo, cultivated, September 15, 1905, J. G. Jack (fruiting branchlets); same locality, in horto residentis germanici, September 1906, U. Faurie (No. 202; fruiting branchlets).

In his monograph Winkler described this species under the name of $C$. Paxii. I cannot separate Winkler's $C$. stipulata, of which I have seen a co-type, even as a variety from the typical C. Turczaninovii, which is confined to northern China and, according to Nakai, to southern Korea. The bracts of this species are rather large and sometimes almost obovate. The peculiar development of the beards in the axils of the lateral veins on the under surface of the leaves of this species may be seen more or less clearly in most of the species of the genus, even in C. orientalis Miller where the "wreath" is mostly hidden by overlying straight hairs. Whether the persistence of the stipules is a character of special importance for our species and its varieties or not needs further observation. The form and dentation of the small leaves as indicated in the key are distinct.

Carpinus Turczaninovii, var. ovalifolia Winkler. See p. 427.

Carpinus Turczaninovii, var. firmifolia Winkler in Bot. Jahrb. L. 505 (1914).

CHINA. Kwei-chou: Ma-jo, September 1908, J. Cavalerie (No. 3135, type, ex Winkler).

According to its pubescent nutlets this variety may belong to or represent a different species. Not having seen a specimen I cannot decide this question, but the flora of Kwei-chou contains a large number of endemic species.

7. Carpinus Tanakaeana Makino in Tokyo Bot. Mag. XXVIII. 32 (February 1914).

Carpinus Turczaninowii, var. Makinoi Winkler in Bot. Jahrb. L. Suppl. 505 (March 1914).

JAPAN. Shikoku: prov. Tosa, Mt. Yokogura, T. Makino (type of C. Tanakaeana, ex Makino); same prov., 1889, T. Makino (No. 277; type of var. Makinoi, ex Winkler).

I know this species only from the description and there is nothing in the rich Japanese material before me which I can refer to it. According to Makino the leaves are small, $1.2-4.6 \mathrm{~cm}$. long and $0.8-3 \mathrm{~cm}$. broad, acute or shortly acuminate 
and mucronately doubly serrate. He says that it is closely related to $C$. stipulata Winkler. The bracts of the fruit are described as "obliquely ovate, mucronatoacute at the apex, irregularly mucronato-inciso-serrate, often sub-bilobed, . . . slightly involute and semi-embracing the nut at the base, 9-11 $\mathrm{mm}$. long." The nut is " densely pubescent toward the top," but otherwise seems to be glabrous. The relationship of this species needs further investigation.

8. Carpinus Fargesiana Winkler. See p, 428.

9. Carpinus Tschonoskii Maximowicz in Mél. Biol. XI. 313 (1881); in Bull. Acad. Sci. St. Pétersbourg, XXVII. 534 (1882). - Winkler in Engler, Pflanzenr. IV.-61, 36, fig. 10 M (1904); in Bot. Jahrb. L. Suppl. 499, fig. a-h (1914), exclud. var, subintegra. - Matsumura, Ind. Pl. Jap. II. pt. 2, 21 (1912). - Schneider, Ill. Handb. Laubholzk. II. 894, fig. 559 r-s (1912). - Nakai in Tokyo Bot. Mag. XXIX. 39 (1915).

Carpinus laxiflora Franchet \& Savatier, Enum. Pl. Jap. I. 451 (non Blume) (1875), quoad plantam Savatieri.

Carpinus yedoënsis Maximowicz in Mél. Biol. XI. 314 (1881); in Bull. Acad. Sci. St. Pétersbourg, XXVII. 535 (1882). - Shirasawa in Bull. Agric. Coll. Tokyo, II. 266, t. 13, fig. 11 (Jap. Laubh. Winter. t. 9, fig. 11) (1895); Icon. Ess. For. Jap. Il. t. 11, fig. 1-18 (1908). - Rehder in Bailey, Cycl. Am. Hort. I. 253 (1900); in Bailey, Stand. Cycl. Hort.11.674 (1914). - Schneider, Ill. Handb. Laubholzk. I. 138, in adnot. (1904); II. 895 (1912). - Henry in Elwes \& Henry, Trees Gr. Brit. \& Irel. III. 529 (pro parte) (1908). Bean, Trees \& Shrubs Brit. Isl. I. 297 (pro parte) (1914).

Carpinus yedoensis, var. serratiauriculata Winkler in Bot. Jahrb. L. Suppl. 500, fig, $4 \mathrm{~h}$ (1914).

Carpinus yedoensis, var. Jablonszkyi Winkler, 1. c. fig. 4 g (1914).

CHINA. Chekiang: near Changhua, on rocky slopes, shady, alt. $300 \mathrm{~m}$., July $12,1915, F . N$. Meyer (No. 1542 ; tree $8-13 \mathrm{~m}$. tall; sterile; very similar to the type, but needs further observation).

NORTHEASTERN ASIA. Korea: Quelpaert, June 7, 1910, Taquet (No. 2440 ; fruiting branchlets).

JAPAN. Hondo: prov. Rikuzen, Sendai, temple grounds, August 26, 1905, J. G. Jack (sterile); prov. Kozuke, Banba, very rare, August 29, 1899 (type locality of var. Jablonszkyi; fruiting branches); same prov., Mt. Asama, July 14, 1904, U. Faurie (No. 5778; ripe fruits); prov. Mino, May 13, 1886, H. Mayr (young leaves); prov. Musashi, Tokyo, cultivated, August 30, 1892, C. S. Sargent (with ripe fruits); same locality, November 1892, C. Maximowicz (type of C. yedoensis, ex Maximowiez); same locality, L. Savatier (No. 1172, co-type of C. yedoensis, ex Maximowicz, and of var. serratiauriculata, ex Winkler); same locality, June 26, 1911 (ex Herb. Sakurai; young fruits); district Tokyo, wild! August 12, 1910 (ex Herb. Sakurai; ripe fruits); prov. Suruga, slopes of Fuji-san, temple grounds, June 14, 1914, E. H. Wilson (No. 6915 ; tree $13 \mathrm{~m}$. tall, girth $0.6 \mathrm{~m}$., bark smooth, pale gray, young fruits); same prov., Fuji-san, 1864, Tschonoski (type of C. Tschonoskii; young fruits); without precise locality, April (ex Herb. Sci. Coll. Imp. Univ. Jap.; flowers). Shikoku : prov. Tosa, Nanokawa, August 1888, K. Watanabe (ripe fruits).

I agree with Winkler (1914) that C. yedoensis Maximowicz is identical with this species; I do not understand why Winkler deseribes Savatier's No. 1172 as a new variety, this number having been regarded by C. Maximowicz as one of his type specimens. Besides I cannot see any real difference between Winkler's var. Jablonszkyi and the type. 
The forms of this species from southern Korea are very differently interpreted. The type of Winkler's var. subintegra has pubescent nutlets and is referred to $C$. Fauriei Nakai. Faurie's No. 1533 of June 1907 from Hallai-san has glabrous nutlets, and seems to represent the same form as Taquet's No. 4440, which I take for typical C. Tschonoskii. Faurie's No. 1534 of May 1907 from the same locality is too young to be referred without question to this species, and may belong to $C$. Fauriei, the relationship of which to $C$. Tschonoskii needs further investigation.

Nakai (in Tokyo Bot. Mag. XXIX. 39 [1915]) mentions C. Fargesiana Winkler from the Chiri-san in southern Korea, without further indication. This is probably C. Tschonoskii.

Nakai (1. c. 38) also describes a new species: $C$, eximia, from the same mountain, near the temple Sen-on-ji, alt. $280 \mathrm{~m}$., July 15, 1913, T. Nakai (No. 11, type). As far as I can judge from his description this plant may represent only a robust form of $C$. Tschonoskii. The only difference I can see is "perigonium fructum toto clausum," but this character seems to be variable in this species.

9. Carpinus Henryana Winkler. See p. 428.

10. Carpinus Seemeniana Diels. See p. 430.

11. Carpinus pubescens Burkill in Jour. Linn. Soc. XXVI. 502 (1899). Winkler in Engler, Pflanzenr. IV.-61, 37 (1904); in Bot. Jahrb. L. Suppl. 501 (pro parte) (1914). - Schneider, Ill. Handb. Laubholzk. II. 895 (pro parte) (1914).

CHINA. Yunnan: Milê district, Feng-tien, old woods, November, A. Henry (No. 9929, type; tree 7-10 m. tall; ripe fruits).

$C$. Seemeniana Diels is possibly only a variety of $C$. pubescens. See my remarks under the preceding species. ${ }^{1}$

12. Carpinus faginea Lindley apud Wallich, Pl. As. Rar. II. 5 (1831). - A. De Candolle, Prodr. XVI. pt. 2, 127 (1864). - Brandis, For. Fl. Brit. Ind. 492 , t. 66 (1874); Ind. Trees, 623 (1906). - Kurz, Forest Fl. Brit. Burma, II. 477 (1877). Hooker f., Fl. Brit. Ind. V. 626 (1888). - Winkler in Engler, Pflanzenr. IV.-61, 40 (1904) exclud. citat. Forbes \& Hemsley et Diels. - Schneider, Ill. Handb. Laubholzk. II. 894 , fig. 558 a, 5591 (1912).

INDIA. Kumaon: Naini-tál, alt. 2200 m., Strachey \& Winterbottom (No. 2; sterile); same region, R. Blinckworth (Wallich's No. 2801, ex Wallich). Gurhwal: Kamrup (type, ex Lindley); without locality (No. 4489 Herb. Griffith; young fruits).

I have seen too little material to get sufficiently acquainted with this species, which certainly is very distinct. Henry's specimen (No. $5520^{\mathrm{a}}$ ) referred to it by Burkill may, I believe, belong to C. polyneura Franchet.

13. Carpinus Fauriei Nakai in Tokyo Bot. Mag. XXVI. 325 (1912); 1. c. XXIX. 39 (1915).

Carpinus Tschonoskii, var. subintegra Winkler in Bot. Jahrb. L. Suppl. 501, fig. 4 i (1914).

NORTHEASTERN ASIA. Southern Korea: Quelpaert, Hallai-san, forests, July $1907, U$. Faurie (No. 1535, type of var. subintegra; almost ripe fruits); same locality, 1907, Taquet (No. 587, type, ex Nakai).

Neither Winkler nor Nakai mentions the fine pubescence of the whole surface of the nutlets, which I find in No. 1535 (Herb. Arnold Arboretum), but otherwise

1 To both these species seems closely related C. minutiserrata Hayata (Icon. Pl. Formos. III. 177, t. 33, fig. A [1913]), which I know only from the description and plate. The type was collected in Formosa at Tandaisha, April 1910, by U. Mori. 
Nakai's description of Taquet's number agrees well enough with Faurie's specimen before me. The narrow-oblong or lanceolate fruiting bracts are $1.7-2 \mathrm{~cm}$. long and 6-9 $\mathrm{mm}$. broad. I am not sure about the real relationship of this species, which needs further observation. See also the remarks under C. Tschonoskii Maximowicz.

14. Carpinus polyneura Franchet. See p. 430. (1914).

Carpinus polyneura, var. Wilsoniana Winkler in Bot. Jahrb. L. Suppl. 506

CHINA. Western Szech'uan: Mt. Omei, May 1904 (Veitch Exped. No. 5791 , type; tree $10 \mathrm{~m}$. tall, young fruits).

This variety needs further investigation, as it was collected in a locality where there are so many endemic species. The leaves are longer and even more pointed than in the type. The ripe fruits are not yet known.

\section{CORYLUS L.}

Corylus tibetica Batalin in Act. Hort. Petrop. XIII. 102 (1893). Vilmorin \& Bois, Frut. Vilmorin. 206, fig. (1905). - M. L. de Vilmorin in Rev. Hort. 1910, 203, fig. 82, t. (1910). - Schneider, Ill. Handb. Laubholzk. II. 895 (1912). - Hickel in Bull. Soc. Dendr. France, 1912, 105, fig. 4 f (1912). - Bean, Trees \& Shrubs Brit. Isl. I. 403 (1914).

Corylus ferox, var. thibetica Franchet in Jour. de Bot. XIII. 200 (1899). Burkill in Jour. Linn. Soc. XXVI. 503 (1899). - Diels in Bot. Jahrb. XXIX. 281 (1900). - Winkler in Engler, Pflanzenr. IV.-61, 45 (1904). - Rehder in Bailey, Stand. Cycl. Hort. II. 859 (1914).

Western Hupeh: Fang Hsien, woods, alt. 1800-2400 m., October 1907 (No. 7r2; bush 3-7 m. tall; fruiting branchlets); same locality, 1889, A. Henry (Nos. $6778,6778^{\text {a }}$; old leafy branchlets with catkins); Changyang Hsien, alt. 2100 m., April 8, and fall 1904(Veitch Exped.No. 57 ; shrub $4 \mathrm{~m}$. tall; flowers and ripe fruits). Western Szech'uan: southeast of Tachien-lu, woods, alt. 2200-2800 m., July and October 1908 (No. I30I, in part; bush 3-7 m. tall; with fruits); same locality, October 1908 (No. I30I, in part; bark of thin tree $7 \mathrm{~m}$. tall, girth $0.3 \mathrm{~m}$.); Tachien-lu, common in woods, alt. $1800-2400 \mathrm{~m}$., October 1910 (No. 4283; bush 3-7 m. tall; with fruits); same locality, A. E. Pratt (No. 5; with young fruits); west and near Wên-ch'uan Hsien, woods, alt. 2200-2800 m., July and October 1908 (No. I30I ; bush 3-7 m. tall, old leafy branchlets with catkins). Eastern Kansu: Amdo, valley of Tshagon River, July 10, 1885, G. N. Potanin (fruiting type, ex Batalin).

According to my own observations this species also occurs in southeastern Szech'uan and northern Yunnan, but I have not my specimens at hand. It is distinguished from the Himalayan species by its more copiously spinose fruiting bracts, and by its more distinctly acuminate bracts of the male flowers, the tips of these braets being glabrous and mostly glandular. See also my remarks under the section. 
As a large bush or small bushy tree this species is abundant in the woods and forests of western Hupeh and of Szech'uan.

E. H. W.

Corylus chinensis Franchet in Jour. de Bot. XIII. 197 (1899). Schneider, Ill. Handb. Laubholzk. II. 896, fig. 560 c (1912). - Bean, Trees \& Shrubs Brit. Isl. I. 401 (1914). - Rehder in Bailey, Stand. Cycl. Hort. II. 859 (1914).

Corylus Colurna, var, chinensis Burkill in Jour. Linn. Soc. XXVI. 503 (1899). Diels in Bot. Jahrb. XXIX. 281 (1900), - Winkler in Engler, Pflanzenr. IV.-61, 50, fig. 15 (1904), - Bean in Kew Bull. Misc. Inform. 1911, 327 (1911).

Western Hupeh: Patung Hsien, woodlands, etc., alt. 900-1600 m., January 1909 (No. I453; tree 3-17 m. tall, girth 0.3-2.4 m.; branchlets with old leaves and catkins); Changlo Hsien, woods, alt. 900-1600 m., September 1907 (No. 228I, tree $10 \mathrm{~m}$. tall, girth $0.6 \mathrm{~m}$.; with ripe fruits); Hsing-shan Hsien, oak woods, alt. 1800-2200 m., June 2, 1907 (No. 228 $\mathrm{I}^{a}$; tree $13 \mathrm{~m}$. tall, girth $0.6 \mathrm{~m}$.; sterile); Fang Hsien, alt. 1200 m., June 1910 (No. 4553; huge tree, 40 m. tall, girth $5.4 \mathrm{~m}$.; sterile); Patung Hsien, A. Henry (No. 7533; leafy branchlets with catkins). Eastern Szech'uan: Wushan Hsien, woodlands, alt. 900-1600 m., September 1907 (No. 228o; tree $17 \mathrm{~m}$. tall, girth 2-4 m.; leafy branchlets with catkins); same locality, A. Henry (No. 7111; leafy branchlets with catkins). Western Szech'uan: Hung-ya Hsien, roadside, one tree only, alt. 1100 m., September 8, 1908 (No. 2282; fruiting branchlet). Yunnan: "in silvis montanis faucium ad Santchang kion, in via e Tali ad Ho-king," alt. 2200 m., J. Delavay (Nos. 197 and 212, types, ex Franchet).

In the typical form which $I$ have collected myself in 1914 not far from the type locality, the involucre of the fruits is not distinctly elongated into a tube, but the margin is deeply lobed, and the lobes are more or less furcate, the nutlet being not or less distinctly hidden than in the forms from Szech'uan and Hupeh of which I have seen ripe fruits. The size of the thick-shelled nuts seems to be variable, as well as the size and thickness of the involucres; the nuts are especially thick in Wilson's No. 2282 compared with those from Yunnan or with those of a cultivated specimen in Hort. Vilmorin at Les Barres in France. So far as I can see there is otherwise no real difference between the Yunnan plant and those from Szech'uan and Hupeh, but I have not been able to compare male flowers.

There is another Tree Hazel in eastern Szech'uan, " in silvis ad Heoupin prope Tchen-keou-tin," alt. $1400 \mathrm{~m}$., P. Farges (No. 1307), which was first described as C. rostrata, var. Fargesii by Franchet (in Jour. de Bot. XIII. 199 [1899]), under which name it is kept by Winkler (in Engler, Pflanzenr. IV.-61, 53, fig. 14 F [1904]), while Burkill referred it to C. mandshurica, var. Fargesii in Jour. Linn. Soc. XXVI. 505 [1899]). Diels followed him (in Bot. Jahrb. XXIX. 281 [1900]). Burkill and Winkler saw Franchet's type, but they did not refer any other specimen to this variety, I made it a species, C. Fargesii (Ill. Handb. Laubholzk. II. 896, fig. 561 e 
[1912]), because it was described as a tree by Farges (ex Franchet) and because the involucres are without the setose bristly hairs which are always present in those of $C$. mandshurica Maximowicz and $C$. rostrata Aiton. According to the figure of a fruit published by Winkler, this plant much resembles the specimens collected by Wilson not far from the region where the type had been found. The leaves, however, are described as much narrower, obovate or oblong than those on the specimens before me. Nevertheless, 1 have little doubt that $C$. Fargesii is much more nearly related to $C$. chinensis than to the species with setose involucres, and it may turn out to be a mere variety of the common Tree Hazel of central China, the leaves of which are very unsymmetrical at their base, as they are said to be in C. Fargesii, while in C. Sieboldiana Blume they are usually symmetrical.

Corylus chinensis occurs sparingly on the mountains throughout western Hupeh and Szech'uan, but is very rare in the western part of the last-named province. It forms a magnificent tree, from 25 to $40 \mathrm{~m}$. tall with a trunk from 2 to $5 \mathrm{~m}$. in girth. The main branches spread almost horizontally and the outline of the crown is broadly oval. Pictures of this tree will be found under Nos. 316, 509 and 0122 of the collection of my photographs and also in my Vegetation of Western China, Nos. $172,173$.

E. H. W.

Corylus heterophylla Fischer, var. sutchuenensis Franchet in Jour. de Bot. XIII. 199 (1899). - Burkill in Jour. Linn. Soc. XXVI. 504 (1899). - Diels in Bot. Jahrb. XXIX. 280 (1900). - Winkler in Engler, Pflanzenr. IV.-61, 48 (var. sutchuensis) (1904). - Schneider, Ill. Handb. Laubholzk. II. 896 (1912).

Corylus heterophylla, var. Crista-galli Burkill in Jour, Linn. Soc. XXVI. 504 (1899). - Diels in Bot. Jahrb. XXIX. 280 (1900). - Winkler in Engler, Pflanzenr. IV.-61, 50 (1904). - Schneider, Ill. Handb. Laubholzk. II. 896 (1912).

Corylus heterophylla Pampanini in Nuov. Giorn. Bot. Ital. n. ser. XVII. 250 (non Fischer) (1910).

Western Szech'uan: west and near Wên-ch'uan Hsien, thickets, alt. 1800-2200 m., September 1908 (No. Ir49; bush 1.8-3 m. tall; with ripe fruits, leaves beneath pubescent only on the rib and veins, branchlets and petioles sparsely pubescent; involucres deeply cleft, shorter than the very fine pubescent nutlets); same locality, July 1908 (No. 2276; bush $2.4 \mathrm{~m}$. tall; almost ripe fruits identical with those of typical $C$. heterophylla, anthers yellowish ?); same locality, alt. 2400-2900 m., October 1910 (No. 455I; bush 1.8-4 m. tall; ripe fruits, same form as No. 1149); Tachien-lu, forming scrub, alt. 24003100 m., July and September 1908 (No. 2283; bush 0.9-2.4 m. tall; young and almost ripe fruits like No. 2276, pubescence of leaves and petioles similar to var. yunnanensis, anthers yellowish ?); same locality, thickets, alt. 2400-2700 m.; September 1910 (No. 4552; ripe fruits and pubescence as in No. 2283, or involucres more like those of var. Cristagalli type); Tsaku-lao, Wei-kuan,Tachai-tzu, August, 1891,A.v. Rosthorn 
(No. 2547; ripe fruits, etc., as in No. 1149). Eastern Szechu'an: district of Tchen-keou-tin, alt. 1400 m., P. Farges (No. 809 [or 805 fide Winkler], type of var. sutchuenensis ex Franchet). Western Hupeh: Changlo Hsien, woods, alt. 1200-1800 m., April and July, 1907 (No. 2276; bush $2.4 \mathrm{~m}$. tall; with young fruits like those of var. Crista-galli type); same locality, September 1907 (No. 2279; bush $3 \mathrm{~m}$. tall; fruits as in No. 1149, but branchlets and petioles hirsute and very glandularsetose, kind of pubescence of leaves somewhat intermediate between type and var. yunnanensis); Hsing-shan Hsien, woods, common, alt. 1200-1800 m., June 1907 (No. 2277 ; bush 2.4-4.5 m. tall; fruits as in No. 2276); same locality, October 1907 (No. 2277; ripe fruits, etc. as in No. 1149); Changyang Hsien, woods and sides of streams, alt. 800-1600 m., April and October 1907 (No. 2278; bush 3-7 m. tall; with very young leaves and female flowers; No. $2278^{\mathrm{a}}$; old leaves and catkins, more glabrous than No. 2279); Patung and Tunghu Hsiens, A. Henry (Nos. 1449; male flowers; 2854, 2866, 6413, co-types of var. Crista-galli; old leaves, young and ripe fruits). Northern Hu pe h: "Monte di Fan-sien," July-August 1906, C. Silvestri (No.324; ripe fruits like those of var. Crisia-galli type); "Ou-tan-scian," alt. 2090 m., July 1907, C. Silvestri (No. 328; young fruits similar to those of No. 327); "Monte T'ien-pong-scian, a 30 km. a N.E. di Chang-kin," alt. 1990 m., October 1907, C. Silvestri (No. 329; leaves thin, sparsely pubescent, anthers of young male catkins apparently red). Northern Shensi: Kin-qua-san, July 10, 1897, J. Giraldi (young fruits similar to those of No. 327). Kiangsi: Kuling, thickets, common, alt. 1300 m., July 30, 1907 (No. I538; bush 1.2-3 m. tall; unripe fruits, etc., similar to those of No.2279, leaves and branchlets a little more glabrous). Yunnan: " dans les gorges du Lan ho, au pied du mont Yang in Chan, près Langkong," J. Delavay (No. 128; fide Franchet, similar to the type from Mandshuria, referred by Burkill to var. Crista-galli). Hunan : Shihmen, A. Henry (No. 7942, by Burkill referred to var. Crista-galli).

There is a good deal of variability in the involucres of the nuts and in the pubeseence of the leaves, petioles and branchlets of this speeies. I have not seen Franchet's type specimen, but I do not believe that there is enough difference between var. sutchuenensis and var. crista-galli to keep these varieties distinct. If the anthers of the plants from Hupeh, eastern Szech'uan, and Kiangsi turn out to be always red, this form represents a distinct species most nearly related to var. yunnanensis, while the forms of western and northwestern Szech'uan, if their anthers are really yellow, would represent a variety of the typical $C$. heterophylla Fischer. Both species have differences in the involucres of the fruits and in the pubescence of the leaves, petioles and branchlets. What is needed most are observations in the field. In Yunnan near Lichiang Fu, where the Hazel is very common, I noticed the same 
variability of the involucres of the fruits as occurs in the common Hazelnut of Europe.

\section{CLAVIS ANALYTICUS SECTIONUM SPECIERUMQUE ASIAE ORIENTALIS HIMALAYAEQUE.}

Involucri fructiferi segmenta laciniata in spinas mutata, pungentia. Antherae purpurascentes. Folia dentibus acuminatis inaequaliter duplicato-serrata. Ramuli plus minusve atrofusci; arbores parvae v. frutices altae.

Sect. I. ACANTHOCHLAMYS.

Bracteae florum masculinorum apice acutae v. breviter acuminatae, extus tota facie tomentellae. Folia ovato-oblonga v, obovato-oblonga . 1. C. ferox.

Bracteae florum masculinorum apice distincte acuminatae acumine saepe glandulifero, extus apice glabrae. Folia late ovata v. obovata . 2. C. tibetica. Involucri fructiferi segmenta nunquam spinosa v. pungentia. Antherae flavae, roseae v. purpurascentes. Foliorum dentes haud v. vix, rarius distincte acuminati . . . . . . . . . . . Sect. II. AVELLANA.

Arbores ramulis fragilibus cito rimosis vetustioribus cortice plus minusve suberoso obtectis. Bracteae florum masculinorum distincte acuminatae; antherae flavae et glabrae v. purpurascentes et apice barbatae. Folia magna v. maxima . . . . . . . . Subsect. 1. COLURNAE. Antherae flavae, glabrae. Involucra fructifera apice aperta, segmentis saepissime linearibus multifida v. multipartito-palmatis v. dentatis instructa, facie puberula et pilis longis glanduliferis plus minusve praedita.

3. C. Colurna.

Antherae purpurascentes, apice pilosae. Involuera fructifera segmentis paucioribus saepe latioribus integris dentatisve sed non pilis glanduliferis praeditis instructa, apice aperta v. clausa.

Involuera fructifera supra fructum non constricta, lobis plus minusve dentatis sed vix v. non bifidis, basi saepe glandulifera. Bracteae florum masculinorum pleraeque longiores quam latae $\mathrm{v}$. apice non glanduliferae. Folia saepissime lobulato-dentata ..... . 4. C. Jacquemontii. Involucra fructifera supra fructum constricta, lobis integris, sed apice saepe bifidis, ut videtur glandulis destituta. Bracteae florum masculinorum latae, apice subito argute 'acuminatae et plus minusve glanduliferae. Folia irregulariter dentata, sed in plantis adultis vix lobulata.

5. C. chinensis.

Frutices ramulis tenacibus etiam vetustioribus laevibus. Bracteae florum masculinorum haud v. vix acuminatae; antherae semper apice pilosae. Folia pleraque minora . . . . . . . . Subsect. 2. EUAVELLANAE.

Involucra fructifera velutina v. molliter pilosa, saepe pilis longis glanduliferis vestitata, sed haud v. vix setis pungentibus praedita, apice latereque plus minusve aperta.

Petioli foliorum majorum $1.5 \mathrm{~cm}$. longi v. ultra, v. folia basi distincte cordata, saepe longitudine subaequilata, margine irregulariter serrato-dentata, nervis lateralibus inter se $0.8-1.2 \mathrm{~cm}$. distantibus. 6. C. heterophylla.

Petioli foliorum etiam maximorum vix ad $1.3 \mathrm{~cm}$. longi; folia basi rotunda v. cuneato-rotunda, distincte longiora quam lata, margine anguste irregulariter acuto-serrata, nervis lateralibus $5-7 \mathrm{~mm}$. inter se distantibus.

7. C. hallaisanensis. 
Involucra fructifera velutina et etiam setis pungentibus plus minusve dense vestita (tantum in var. miti setis deficientibus), apice in tubum angustiorem plus minusve longum contracta ....... 8. C. Sieboldiana.

\section{ENUMERATIO SECTIONUM ET SPECIERUM ASIAE ORIENTALIS HIMALAYAEQUE.}

Sect. I. ACANTHOCHLAMYS Spach in Ann. Sci. Nat. sér. 2, XVI. 108 (1841). - A. De Candolle, Prodr. XVI. pt. 2, 129 (1864). - Mouillefert, Trailé Arb. \& Arbriss. II. 1143 (1897).

The main character of this section is found in the spinose segments of the fruiting bracts, the fruits resembling those of a Castanea. In the male flowers the two thecae of the anthers seem to be mostly somewhat united at the middle in C. fero $x$ Wallich, while in C. tibetica Batalin the thecae are free, and only the filaments are more or less united, although they are sometimes divided to the base. The color of the anthers seems to be almost purple, the filaments being whitish. In C. ferox Wallich the anthers are more hairy at their apex than in the other species.

1. Corylus ferox Wallich, Pl. As. Rar, 1. 77, t. 87 (1830), - Loudon, Arb. Brit. III. 2030, fig. 1950 (1838). - A. De Candolle, Prodr. XVI. pt. 2, 129 (1864). Brandis, Forest Fl. Brit. Ind. 494 (1874); Ind. Trees, 624 (1906), exclud. var. thibetica. - Hooker f., Fl. Brit. Ind. V. 625 (1888). - Mouillefert, Traité Arb. \& Arbriss. II. 1143 (1897). - Gamble, Man. Ind. Timb. 684 (1902). - Schneider, Ill. Handb. Laubholzk. I. 144, in adnot. (1904); II. 897, fig. 560 b, 561 e (1912). Winkler in Engler, Pflanzenr. IV.-61, 44, fig. 13 (1904), exclud, var. - Rehder in Bailey, Stand. Cycl. Hort. II. 859 (1904), exclud. var.

INDIA. Nepal: "ad cacumen Shedpore montis," 1821, N. Wallich (No. 2797, type, ex Wallich; tree $7 \mathrm{~m}$. tall). Sikkim: "reg. temp,, alt. 8-10,000 ped.," J. D. Hooker (flowers and young fruits; mixed with a winter branchlet of C. Jacquemontii in Herb. Gray).

This is a well marked species of which I have seen so little material that I cannot point out clearly its differences from the following nearly related species which inhabits a different geographical area, neither of the two species apparently being found in the region from Khasia to southern Yunnan.

\section{Corylus tibetica Batalin. See p. 443.}

Sect. II. AVELlanA Spach in Ann. Sci. Nat. sér. 2, XVI. 101 (1841), includ. sect. Tubo-avellana. - A. De Candolle, Prodr. XVI. pt. 2, 129 (1864).

This section includes all the other species now known. The shape and appearance of the involucres of the fruits of the different species are very variable, but the segments or lobes are never spiny, although there is a group of species the involucres of which are beset with bristly setose hairs. Spach described besides sect. Acanthochlamys two other sections, but his Sect. Tubo-avellana cannot be accepted as of the same taxonomic value as sect. Avellana. A. De Candolle has already united these sections. He made two groups ( $\$ 1$ and $\$ 2$ ) under sect. Avellana, separating the species with setose involucres from the others, but he did not separate C. Colurna and its allies which, I believe, form a distinct subsection, while the other species may be united in another subsection. It needs further investigation to decide if the setose species (C. rostrata Aiton and its allies) form a natural group of equal taxonomic value as $C$. Avellana Linnaeus and its allies or if they are connected with them by intermediate forms. 
Subsect. 1. COLURNAE Schneider, n. subsect. (descriptio in elavi).

The Tree Hazels form, I believe, a natural group on account of their habit of growth and the characters of the bark of the branchlets. They may be divided into two groups by the color of the anthers. It is a rather strange fact that the anthers of C. Colurna Linnaeus are without any hairs, which are always present in all the other species of the genus of which I have seen the male flowers.

3. Corylus Colurna Linnaeus, Spec. 999 (1703), exclud. synon. pro parte. Watson, Dendrol. Brit. II. 99, t. 99 (1825), - Hartig, Vollst. Naturg. Forstl. Culturpfl. 228, t. 17 (1840-51), exclud. var, b. - Spach in Ann. Sci. Nat. sér. 2, XVI. 101 (1841), - Reichenbach, Icon. Fl. Germ. XII. 6, t. 638 (1850), - A. De Candolle, Prodr. XV1. pt. 2, 131 (1864), exclud, var. $\beta$ et $\gamma$. - Hempel \& Wilhelm, Bäume \& Sträucher, II. 29, fig. 135 (1894). - Schneider, Dendrol. Winterst. 171, fig. 164 o-r (1903); Ill. Handb. Laubholzk. I. 144, fig. 82 a-f, h, 83 a, 84 o-r (1904). Winkler in Engler, Pflanzenr. IV.-61, 50, fig. 14 G (1904), exclud. var, $\boldsymbol{\beta}$ et $\boldsymbol{\gamma}$.Elwes \& Henry, Trees Gr. Brit. \& Irel. III. 521 (1908) exclud. var. 2 and 3. Ascherson \& Graebner, Syn. Mitteleur. Fl. IV. 383 (1910), exclud. plantis Himalaica et Chinensi. - Hickel in Bull. Soc. Dendr. France, 1912, 107, fig. e-e $\mathrm{e}^{\prime \prime \prime}$ (1912).

EUROPE: from Bosnia and southern Hungary southward through southeastern Europe.

WESTERN ASIA. Asia Minor to Transcaspia.

This species is often reported from the northwestern Himalaya, but the Tree Hazel of this region is C. Jacquemontii. I mention C. Colurna here to indicate the differences between it and the Himalayan and Chinese species hitherto usually considered varieties of the European and west Asiatic species. See my remarks under the section and in the key. The filaments of the anthers are united mostly at the base and are very short, the thecae being elliptic-oblong; the bracts are distinetly acuminate at the apex, covered with a dense fine pubescence and more or less glandular.

4. Corylus Jacquemontii Decaisne in Jacquemont, Voyage, IV. Bot., 160, t. 160 (1844), - Bean in Kew Bull. Misc. Inform. 1913, 163, t. (1913); Trees \& Shrubs Brit. Isl. I. 452 (1914).

Corylus lacera Wallich, Cat. No. 2798 (nomen nudum) (1829).

Corylus Colurna, var. lacera A. De Candolle, Prodr. XVI. pt. 2, 131 (1864).Stewart, Punjab Pl. 201 (1869). - Henry in Elwes \& Henry, Trees Gr. Brit. \& Irel. III. 521 (1908).

Corylus Colurna, var. Jacquemontii A. De Candolle, Prodr. XVI. pt. 2, 131 (1864).

Corylus Colurna Brandis, For. Fl. Brit. Ind. 494 (pro parte, non Linnaeus) (1874); Ind. Trees, 624 (pro parte) (1906).-Hooker f., Fl. Brit. Ind. V. 625 (pro parte) (1888). - Collett, Fl. Siml. 476 (pro parte) (1902). - Gamble, Man. Ind. Timb. 684 (pro parte) (1902).

INDIA. Northwestern Himalaya: "reg. temp., alt. 7000 ped.," T. Thomson (flowers and young fruits); "a Vernague ad jugum Banhatte," alt. $2952 \mathrm{~m}$., July, V. Jacquemont (type, ex Decaisne); Kumaon, Dwali, alt. 2600 m., Strachey \& Winterbottom (leafy branchlets with flowers); without precise locality, $R$. Blinckworth (Wallich Cat. No. 2798, type of C. lacera). United Provinces: Dehra Dun, Chakrata, alt. 2300 m., May 11, 1912, Sulakhan Sing (with young fruits).

According to the characters given in the key, this species is distinct from both the foregoing and the following species. The thecae of the anthers seem to be more round-elliptical. The length of the petioles and the pubescence of the leaves seem 
variable, and much more material is needed before it is possible to fix the limits of these variations including the shape of the lobes, and the pubescence and glands of the involucres. The geographical area occupied by $C$. Jacquemontii seems to be confined to the western Himalaya, while $C$. ferox Wallich does not occur in Kashmir but extends to Sikkim. In China $C$. tibetica Batalin and $C$. chinensis Franchet occur within almost the same geographical region.

5. Corylus chinensis Franchet. See p. 444.

6. Corylus heterophylla Fischer in Schtschagl. Anz. Entdeck. Phys. Chem. \& Technol. VIII. 3 (1831), fide K. Koch. - Besser in Flora, XVII. Beibl. I. 24 (nomen nudum) (1834). - Turezaninow in Bull. Soc. Nat. Mosc. XI. 101 (nomen nudum) (1838), XXVII. 407 (1854); Fl. Baical.-Dahur. II. 134 (1856). - Trautvetter, Pl. Imag. Descr. 10, t. 4 (1844). - Blume, Mus. Bot. Lugd.-Bat. I. 309 (1850.) - Maack \& Ruprecht in Bull. Acad. Sci. St. Pétersbourg, XV. 372 (1857); in Mél. Biol. II. 553 (1858). - Maximowicz in Mém. Sav. Étr. Acad. Sci. St. Pétersbourg, IX. 241 (Prim. Fl. Amur.) (1859); in Mél. Biol. XI. 317 (1881); in Bull. Acad. Sci. St. Pétersbourg, XXVIl. 537 (1882). — Regel in Mém. Acad. Sci. St. Pétersbourg, sér. 7, IV. 127 (Tent. Fl. Ussur.) (1861). - Miquel in Ann. Mus. Lugd.-Bat. I. 121 (1863-4). - A. De Candolle, Prodr. XVI. pt. 2, 130 (1864), exclud. var. $\gamma$. - K. Koch, Dendr. II. pt. 2, 12 (1873), - Franchet \& Savatier, Enum. Pl. Jap. I. 452 (1875), exclud. var. $\gamma$. - Franchet in Nouv. Arch. Mus. Paris, sér. 2, VII. 88 (Pl. David. I. 278) (1884). - Herder in Act. Hort. Petrop. XI. 362 (1891). Dippel, Handb. Laubholzk. II. 129 (1892), exclud. synon. pro parte. - Korshinsky in Act. Hort. Petrop. XII. 387 (1892), - Koehne, Deutsche Dendr. 117 (1893). Shirasawa in Bull. Agric. Coll. Tokyo, II. t. 12, fig. 12-13 (Jap. Laubh. Winter. t. 8, fig. 12-13) (1895); Icon. Ess. For. Jap. I. 40, t. 20, fig. 1-12 (1900). - Burkill in Jour. Linn. Soc. XXVI. 504 (1899), - Komarov in Act. Hort. Petrop. XXII. 65 (Fl. Mansh. II.) (1903). - Schneider, Ill. Handb. Laubholzk. I. 145, fig. 83 p-q, 85 a-d (1904). - Winkler in Engler, Pflanzenr. IV.-61, 48, fig. 14 B (1904). Nakai in Jour. Coll. Sci. Tokyo, XXXI. 206 (Fl. Kor. II.) (1911); in Tokyo Bot. Mag. XXIX. 35 (1915). - Bean, Trees \& Shrubs Brit. Isl. I. 402 (1914).

Corylus Avellana Thunberg, Fl. Jap. 160 (non Linnaeus) (1784). - Pallas, Fl. Ross. II. 22 (1815), quoad plantam davur., fide Ledebour. - Spach in Ann. Sci. Nat. sér. 2, XV1. 104 (pro parte) (1841).

9 Corylus mongolica Burchardt in Verh. Ver. Bef. Gartenb. Preuss. IX. 108 (1833), descript. incompleta.

Corylus tetraphylla Ledebour in Denkschr. Bot. Ges. Regensb. III. pt. 2, 58 (sphalm.) (1841).

Corylus Hašibami Siebold in Jaarb. Kon. Neederl. Maatsch. Tuinb. 1844, 27 (Kruidk. Naaml.) (nomen nudum) (1844).

Corylus Avellana, var. davurica Ledebour, Fl. Ross. III. pt. II. 588 (1849).

Corylus heterophylla, var. Thunbergii Blume, Mus. Bot. Lugd.-Bat. I. 310 (1850). - Miquel in Ann. Mus. Lugd.-Bat. III. 194 (1867); Prol. Fl. Jap. 358 (1867).

CHINA. Chili : near San-tun-ying, on rocky hillslopes, June 2, 1913, $F$. N. Meyer (No. 989; sterile); Weichang, 1910, W. Purdom (No. 92; sterile); Hsiao Wu-tai-shan, alt. 1600-2200 m., August 19, 1913, F. N. Meyer (with ripe fruits).

NORTHEASTERN ASIA. Mandshuria: "ad ripam dextram fl. Argun contra pagum Oloeza," N. Turczaninow (type, ex Trautvetter et Turezaninow). Amur and Ussuri prov.: Amur River, 1855, R. Maack (with young fruits); same region, C. Maximowicz (with ripe fruits); same region, June 18, July 5, 1891, S. Korshinsky (with flowers and fruits); Ussuri River, 1860, C. Maximowicz 
(flowers); same region, $R$. Maack (with ripe fru its). Korea: Fusan, temple gardens, September 6, 1903, C. S. Sargent (sterile).

JAPAN. Hondo: prov. Kozuke, Mt. Asama, July 1904, U. Faurie (No. 5802; with young fruits); prov. Shinano, Mt. Izuma, March 26, 1905, September 12, 1910 (ex Herb. Sakurai); prov. Suruga, district Tokyo, March 21, 1904 (and fall) (flowers and old leaves, ex Herb. Sakurai). Kyushu: prov. Hizen, Nagasaki, 1862, R. Oldham (No. 746; sterile); without precise locality, P. von Siebold (ex Herb. Zuccarini sub nom. C. retusa; sterile); without locality and collector (ex Herb. Lugd,-Bat. sub nom. var. Thunbergii; with flowers and young fruits).

These specimens represent the typical form, which as far as I can judge from the specimens and from Shirasawa's colored plate has yellow anthers and rather thin leaves which are always slightly pubescent on the rib and nerves of the under surface, and never quite glabrous above. The shape is mostly rectangular-obovate with a more or less cordate base and a truncate and even emarginate apex bearing a narrow acuminate middle lobe. In the Japanese specimens the leaves seem to be a little more rounded at the apex, and further investigations are needed to show if there are any other differences between the Siberian and northern Chinese forms and those from Japan or not. I have not seen a Japanese specimen with such ovate-cordate leaves as appear in Shirasawa's plate.

In central China this species seems to be very variable, and there are probably two varieties of which the one from the west may prove a distinct species on account of its reddish anthers and other characters. As I point out on p. 446, the northwestern forms seem to have yellowish anthers like the typical form. The variety from Yunnan apparently has dark anthers and is most nearly related to the forms from Hupeh. For further remarks, see these varieties.

Corylus heterophylla, var. sutchuenensis Franchet. See p. 445.

Corylus heterophylla, var. yunnanensis Franchet in Jour. de Bot. XIII. 198 (1899). - Burkill in Jour. Linn. Soc. XXVI. 504 (1899). - Winkler in Engler, Pfanzenr. IV.-61, 48 (1904). - Schneider, Ill. Handb. Laubholzk. VI. 896 (1912).

CHINA. Yunnan: "in sylvis prope collum Hee-chan-men, alt. $3000 \mathrm{~m}$. " $J$. Delavay (type, ex Franchet); "in monte Tsang-chan," J. Delavay (No. 555, co-type, ex Franchet); "Mengtsze, on way up to Mt. Benvenu," alt. 2000 m., September 13, A. Henry (No. 9682; shrub 0.6-0.3 m. tall; with ripe fruits); Milê district, alt. $1800 \mathrm{~m}$., November 1, A. Henry (No. 9894; shrub, $1.8 \mathrm{~m}$. tall; old leaves and eatkins).

I have not seen the type, but Henry's specimens agree well with Franchet's description. This variety is distinguished from the others by its leaves being thickly tomentose-hirsute on the whole under surface, by its more tomentose and glandular branchlets and petioles which are short and thick, and by its more distinctly velutinous nuts, but there are more or less intermediate forms apparently connecting this southern variety with that of central China. The color of the anthers seems to be red.

7. Corylus hallaisanensis Nakai in Fedde, Rep. Spec. Nov. XIII. 250 (1914); in Tokyo Bot. Mag. XXIX. 36 (1915).

NORTHEASTERN ASIA. Korea: Quelpaert, Hallai-san, forests, August 1909, Taquet (No. 3239; sterile); same locality, October 1909, Taquet (No. 3238; sterile); same locality, September 1903, Taquet (No. 333, type ex Nakai).

Taquet's specimens of 1909 are from the type locality and agree with Nakai's description, but unfortunately I have not seen the fruits which are described by Nakai (1914) as follows: "Perigonium fructiferum hirsutum compacte clausum ovatum apice mucronatum lobulatum, cum mucrone $3 \mathrm{~mm}$. longo $18 \mathrm{~mm}$. longum 
$10 \mathrm{~mm}$. latum sericeum. Carpella ovata adpressissime ciliata $13 \mathrm{~mm}$. longa $8 \mathrm{~mm}$. lata," while in 1915 the description is as follows: "Bracteae fructiferae ovatae, apice acuminato-paucilobis, pilosae. Nux ovata, cuspidata $1.3 \mathrm{~cm}$. longa." The leaves resemble those of C. Sieboldiana Blume and especially those of var. mitis Maximowicz which $i$ also eredited by Nakai to southern Korea. Further investigations are needed in order to decide if $C$. hallaisanensis is closely related to $C$. heterophylla Fischer or is connected with the $C$. Sieboldiana group, the setose bristles of which are sometimes wanting.

8. Corylus Sieboldiana Blume, Mus. Bot. Lugd.-Bat. I. 310 (sphalm. C. Siboldiana) (1850). - Schneider, Ill. Handb. Laubholzk. I. 150, fig. 83 n (pro parte) (1904), - Bean, Trees \& Shrubs Brit. Isl. I. 403 (1914).

Corylus heterophylla, var. Sieboldiana A. De Candolle, Prodr. XVI. pt. 2, 130 (1864).

Corylus rostrata Maximowicz in Mém. Acad. Sci. St. Pétersbourg, sêr. 7, X. no. 11, 10 in adnot. (Rhamn. As.-Or.) (non Aiton) (1866). - Franchet \& Savatier, Enum. Pl. Jap. I. 452 (1875).

Corylus rostrata, var. Sieboldiana Maximowicz in Mél. Biol. XI. 319 (1881); in Bull. Acad. Sci. St. Pétersbourg, XXVII. 538 (1882), - Herder in Act. Hort. Petrop. XI. 363 (1890). - Winkler in Engler, Pflanzenr. IV.-61, 52, fig. $16 \mathrm{~B}$ (1904).

Corylus heterophylla Dippel, Handb. Laubholzk. II. 129 (non Fischer) (1892), quoad syn. "C. Sieboldiana."

JAPAN. Hokkaido: prov. Ishikari, Mt. Moiwa, thickets and woods, common, July $30,1914, E$. H. Wilson (No. 7311; bush 1.5-3 m. tall; with almost ripe fruits). Hondo: prov. Suruga, Fuji-san, July 31, 1891, K. Watanabe (with unripe fruits); prov. Kai, Mt. Minobu, April 2, 1905 (ex Herb. Sakurai; flowers; the leaves of August 14,1905, of the same specimen belong to C. heterophylla Fischer); prov. Kozuke, around Karuizawa, thickets, common, August 31, 1914, E. H. Wilson (No. 7426; bush 1.2-2.4 m. tall; with ripe fruits); prov. Shinano, on Tsubakura-dake, woodlands, common, alt. 950-1600 m., September 15, 1914, $E$. H. Wilson (No. 7460; bush 0.9-1.8 m. tall; with ripe fruits); Mt. Togakushi, July 10, 1884 (ex Herb. Sei. Coll. Imp. Japan; with unripe fruits); on Jesoga-dake (Jisoga-dake?), July 1903, U. Faurie (No. 6649; with unripe fruits); prov. Shimotsuke, Nikko, April 1, 1904, N. Mochizuki (with male and female fowers); same locality, August $8,1905, J$. G. Jack (with unripe fruits); same locality, P. von Siebold (type ex Blume); Lake Chuzenji, August 12, 1905, J. G. Jack (with ripe fruits); same locality, September 6, 1892, C. S. Sargent (shrub $1.8 \mathrm{~m}$. tall; with ripe fruits); prov. Uzen, Adzuma-yama, common in thickets, alt. 750-1300 m., July $19,1914, E$. H. Wilson (No. 7215 ; bush $6 \mathrm{~m}$. tall, with young fruits); prov. Ugo, Chokai-san, September 14, 1892, J. H. Veitch (with old leaves and catkins); prov. Mutsu, Aomori, forests, May 6, 1905, U. Faurie (No. 6816; flowering branchlets); Iwagisan (? Iwaki Mt.), August 1905, U. Faurie (No. 6648; with ripe fruits).

These specimens represent the typical form which seems to be most frequent in central and northern Hondo, but according to Wilson's No. 7311 occurs also in Hokkaido, at least in a somewhat intermediate form. It is characterized by its obovate, obovate-oblong, elliptic or oval leaves which have a rounded or very slightly cordate base and are mostly more or less gradually pointed at the apex; their serration is rather acute, and they are not or only slightly lobed, while in the var. mandshurica the leaves usually are more orbicular-obovate or almost rectangular-elliptic, being often deeply cordate at the base and more truncate at the 
apex; their serration is coarser and they are mostly distinctly lobed above the middle, the pointed apex being somewhat shorter and broader. The involucre of the fruits of the typical $C$. Sieboldiana is contracted above the nut in a narrower tube which is $11 / 2-2$ times as long as the nut, while in var. mandshurica this tube is less contracted and mostly twice as wide. There is no distinct difference in the setose pubescence of these varieties, but usually the bristles seem to be not so straight and often less numerous in the southern form than in that of northern Japan and Mandshuria. The typical C. Sieboldiana is said by Nakai to occur in southern Korea (Chiri-san). From this region he also mentions the following variety which seems to differ only by its smooth involucres being without bristles or with only a few setose hairs.

Corylus Sieboldiana, var. mitis Nakai in Tokyo Bot. Mag. XXIX. 37 (1915). Corylus rostrata, var. mitis Maximowicz in Mél. Biol. XI, 320 (1881); in Bull. Acad. Sci. St. Pétersbourg, XXVII. 539 (1882). - Herder in Act, Hort. Petrop. XI. 363 (1890). - Winkler in Engler, Pflanzenr. IV.-61, 52 (1904).

JAPAN. Hondo: prov. Suruga, Fuji-san, 1864, Tschonoski (type with ripe fruits and flowers).

The fruits are rather small with a very narrow tube and a yellowish brownish gray soft fine pubescence mixed with a few setose hairs. Otherwise there is scarcely a real difference between this variety and the typical $C$. Sieboldiana. The leaves of var. mitis also much resemble those of $C$. hallaisanensis Nakai (see above), which may turn out to be nearly related to this form, which is said by Nakai to occur also on the Chiri-san in southern Korea. The anthers of var. mitis are reddish as in the typical species and in var. mandshurica, but they are yellowish in the American C. rostrata Aiton and C. californica Rose (C. rostrata, var. californica A. De Candolle).

There are specimens of northern Hondo and Hokkaido which represent another variety which may be described as follows:

Corylus Sieboldiana, var. brevirostris Schneider, n. var.

Frutex 1.5-1.8 m. altus; ramuli novelli ut videtur satis dense hirtello-villosi et glanduloso-hirti, autumno plus minusve glabrescentes, flavo-brunnei, lenticellis albido-flavis conspersi, vetustiores cinereo-brunnescentes, paulo rimosuli, glabri; gemmae ut videtur ovato-ellipticae, obtusae, perulis purpurascentibus dorso fere glabris margine dense villosulis cinctae. Folia crasse papyracea, late obovata v. elliptica, basi cordata, paulo v. vix inaequilateralia, apice obtusa $\mathrm{v}$. fere subrotunda in aeumen brevem satis subito producta, margine inaequaliter dentato-serrata, haud lobulata, supra laevia, intense viridia, tantum costa nervisque impressis paulo puberula, subtus pallide viridia, costa nervisque lateralibus 7-9 elevatis sparse sericea, interdum paulo glandulosa facie glabra, venulis tantum pro parte prominulis, 5-7.5 cm. longa et (3-) $3.5-6 \mathrm{~cm}$. lata; petioli $0.5-1.5 \mathrm{~cm}$. longi, sparse sericei et interdum glanduloso-hirti; stipulae oblongae, obtusae, integrae, extus paulo sericeae, margine villosulae, ad $8 \mathrm{~mm}$. longae. Amenta florifera ignota; fructifera pedunculis hirtello-villosis et plerisque glanduloso-hirtis $1-1.5 \mathrm{~cm}$. longis suffulta. Fructus 2-4 aggregati, $2-3 \mathrm{~cm}$. longi; involucra apice nucis subito valde contracta in tubum nuce subaequilongum apice inciso lobatum producta, ut in var. mandshurica griseo- velutina et praesertim circum nucem albido- $v$. fusco-setosa; nuces (an satis maturae ?) ovato-rotundae, apice acutiusculae, minutissime puberulae circiter $12 \mathrm{~mm}$. longae et fere aequilatae.

JAPAN. Hokkaido: prov. Oshima, Shiribeshi-san, thickets, abundant, up to alt. 700 m., July $27,1914, E$. H. Wilson (No. 7268 , type; fruits apparently not yet fully ripe); Hakodate, 1861, C. Maximowicz (a very similar fruiting 
branchlet). Northern Hondo: prov. Mutsu, Mt. Hakkoda, August 1904, $U$. Faurie (No. 5803; fruits partly ripe).

The leaves of this variety are more cordate at the base than those of the typical C. Sieboldiana, and their serration is not at all lobed as in the type. The tube of the fruiting involueres is shorter than in the other variety, but in Faurie's No. 5803 it is somewhat intermediate between that of our new variety and of the following variety resembling the fruit of C. Sieboldiana figured in my Ill. Handb. Laubholzk. I. 150 , fig. $87 \mathrm{~h}$ (1904).

\section{Corylus Sieboldiana, var. mandshurica Schneider, n. comb.}

Corylus mandshurica Maximowicz \& Ruprecht in Bull. Acad. Sci. St. Pétersbourg, XV. 137 (1856); in Mél. Biol. II. 431 (1857). - Maack \& Ruprecht, in Bull.1. e. 373 (1857); in Mél. Biol. 11.553 (1858), - Maximowicz in Mém. Sav. Etr. Acad. Sci. St. Pétersbourg, IX. 241 (Prim. Fl. Amur.) (1859). Herder in Act. Hort. Petrop. XI. 363 (1890). - Dippel, Handb. Laubholzk. II. 135 (mandschurica) (1892). - Koehne, Deutsche Dendr. 120 (mandschurica) (1893). - Burkill in Jour. Linn. Soc. XXVI. 505 (1899). - Komarov in Act. Hort. Petrop. XXII. 63 (Fl. Mansh. II.) (1903). - Sehneider, Ill. Handb. Laubholzk. I. 150, fig. $831-\mathrm{m}, 87 \mathrm{~d}-\mathrm{f}$ (mandschurica) (1904). - Nakai in Jour. Coll. Sci. Tokyo, XXXI. 206 (Fl. Kor. II) (1911); in Tokyo Bot. Mag. XXIX. 36 (1915), - Bean, Trees \& Shrubs Brit. Isl. I. 402 (1914). Skan in Bot. Mag. CXLI. t. 8628 (1915).

Corylus rostrata, var. mandshurica Regel in Bull. Acad. Sci. St. Pétersbourg, XV. 221 (1857); in Mél. Biol. II. 488 (1857); in Mém. Acad. Sci. St. Pétersbourg, sér. 7, IV. 129 (Tent. Fl. Ussur.) (1861). - A. De Candolle, Prodr. XVI. pt. 2, 133 (1864), - Hance in Jour. Linn. Soc. XIII. 87 (1872); in Jour. Bot. XIII. 137 (1875). - Franchet \& Savatier, Enum. Pl. Jap. I. 452 (1875). - Maximowicz in Mél. Biol. XI. 319 (1881); in Bull. Acad. Sci. St. Pétersbourg, XXVIY. 539 (1882). - Franchet in Nouv. Mém. Mus. Paris, sér. 2, VII. 88 (Pl. David. I. 278) (1884), - Korshinsky in Act. Hort. Petrop. XII. 388 (1892). - Palibin, Act. Hort. Petrop. XIV. 139 (1895). Winkler in Engler, Pflanzenr. IV.-61, 52, fig. 14 E (var. mandschurica) (1904).

Corylus Sieboldiana Schneider, Ill. Handb. Laubholzk. I. 150 (1904), quoad fig. $83 \mathrm{o}$.

CHINA. Northwestern Szech'uan: mountains, alt. 2500 m., August 1904, E. H. Wilson (Veitch Exped. No. 4509; large bush, 4-6.5 m. tall, with ripe comparatively small fruits). Eastern Szech'uan: Tchen-keou-tin, P. Farges (ex Burkill). Chili: Hsiao Wu-tai-shan, alt. 1600-2700 m., August 18, 1913, F. N. Meyer (No. 1227; with ripe fruits).

NORTHEASTERN ASIA. Mandshuria: Shenking, Tsien-shan mountains, June 8, 1906, F. N. Meyer (No. 68; sterile). Amur and Ussuri: " coast of Manchuria Lat. 44-45 N." 1859, C. Wilford (with ripe fruits); Amur River, C. Maximowicz (co-type of C. mandshuria; with ripe fruits and also with flowers); same locality, 1855, R. Maack (with ripe fruits); near Vladivostok, August 18, 1903, C. S. Sargent (with ripe fruits); Khabarovska, August 23, 1903, C. S. Sargent (with ripe fruits). Korea: Hoang-hai-to mountains, August 1906, U. Faurie (No. 207; fruits not yet ripe).

JAPAN. Hokkaido: prov. Ishikari, Sapporo, May (and?) 1878, I. Watase (with flowers and also with unripe fruits); same locality, September $1885, K$. Miyabe (with old leaves and male catkins); same locality, July 1, and September 31, 1903, $S$. Arimoto (with young and ripe fruits).

As I stated above, the typical form seems to be connected in Hokkaido by 
forms like Wilson's No. 7311 with var. mandshurica which otherwise has a different geographical range, and in the extreme forms both varieties look very distinct.

\section{BETULA L.}

Betula luminifera Winkler in Engler, Pfanzenr. IV.-61, 91, fig. 23 a-c (1904). - Schneider, Ill. Handb. Laubholzk. II. 882, fig. 552 d, $553 \mathrm{~g}-\mathrm{h}$ (1912).

Betula acuminata Franchet in Jour. de Bot. XIII, 207 (1899), quoad specim. Fargesii.

Betula acuminata, var. pyrifolia Franchet, 1. c. (1899).

Betula alnoides Burkill in Jour. Linn. Soc. XXVI. 497 (non Hamilton) (1899), quoad specim. Fargesii, - Diels in Bot. Jahrb. XXIX. 281 (1900).

Betula alnoides, var. pyrifolia Burkill in Jour. Linn. Soc. XXVI. 497 (1899), exclud. specim. Delavayi. - Diels in Bot. Jahrb. XXIX. 281 (1900), exclud. specim. Delavayi. - Bean, Trees \& Shrubs Brit. Isl. I. 256 (1914).

Betula cylindrostachys Diels in Bot. Jahrb. XXIX. 281 (1900).

Betula cylindrostachys, var, resinosa Diels, 1. c. 282.

Betula Wilsoniana Schneider, Ill. Handb., Laubholzk. II. 882, fig. 552 a, 553 a-b (1912).

Betula hupehensis Schneider, 1. c. 882 , fig. 552 b, 553 c-d (1912).

Western Hupeh: Hsing-shan Hsien, alt. 700-1700 m., June 12, 1907 (No. I7; tree 8-17 m. tall, girth 0.3-0.9 m., bark dark, smooth; fruits); same locality, alt. 1000-1300 m., woods, May 1907 (No. 85 ; tree 10-17 m. tall, girth $0.3-1.5 \mathrm{~m}$.; flowers; No. 85 ; sterile); same locality, alt. 1000-1700 m., woods, July 1907 (No. 94; tree 7-13 m. tall, girth 0.6-1.5 m., bark dull orange red, fruits); same locality, woodlands, alt. $900 \mathrm{~m}$., May 16, 1907 (No. $337^{\mathrm{I}^{\mathrm{b}}}$; tree $10 \mathrm{~m}$. tall, girth $0.6 \mathrm{~m}$.; flowers and bark); Fang Hsien, alt. 1000-2000 m., woodlands, common, May 26, 1907 (No. 3369; tree 13-20 m. tall, girth 1.5-2.1 m.; fruits); same locality, alt. 700-2300 m., woodlands, abundant, May 15, 1907 (No. 3370; tree 7-17 m. tall, girth 0.6-1.8 m.; flowers; No. $3370^{\mathrm{a}}$; sterile); same locality, April 1901 (Veitch Exped. No. 841 ${ }^{\mathrm{a}}$; flowers); same locality, June 1900 (Veitch Exped. No. 1889 ; flowers; same locality, June 1901 (Veitch Exped. No. 2800, type of B. hupehensis); Patung Hsien, alt. 1000-1700 m., woods and thickets, July 1909 (No. 85; tree 10-17 m. tall, girth 0.3-0.9 m.; fruits); same locality, woods, May 1907 (No. $94^{\mathrm{a}}$; tree 7-13 m. tall, girth 0.6-1.5 $\mathrm{m}$; young fruits); north and south of Ichang, alt. 700-1500 m., woodlands abundant, November 1907 (No. I62; tree 7-20 m. tall, girth 0.6-2.1 m.; fruits); same locality, April 1907 (No. $\mathbf{I 6 2}^{\mathrm{a}}$; small thin tree, 3-13 m. tall, girth 0.3-1.5 m.; flowers); same locality, April 
and July 1900 (Veiteh Exped. No. 48, type of B. Witsomiana; flowers and fruits); same locality, April and July 1900 (Veitch Exped. No. $48^{\mathrm{z}}$; flowers and fruits); north of Iehang, alt. 700-1700 m., woodlands abundant, June 1907 (No. 337I; tree 5-20 m. tall, girth 0.3-1.5 m.; fruits); same Jocality, May 6, 1907 (No. $337 \mathrm{I}^{\mathrm{s}}$; flowers; same loeality, May 1901 (Veiteh Exped. No. 841; flowers); Chienshih, A. Henry (No. 7402; sterile). Eastern Szech'uan: Wushan Hsien, A. Henry (No. 5667; fruits); "Heoupin prope Tchen-keou," alt. 1400 m., P. Farges (No. 1010; type of var. pyrifolia, ex Franchet); same locality, $P$. Farges (without No.; type of $B$. luminifera, ex Winkler). Western Szech'uan: Wa-shan, alt. 1300-2000 m., woods, June 1908 (No. 8I6 and 3368; tree 10-17 m. tall, girth 0.9-1.8 m.; fruit); Mupin, alt. 1700-2000 m., woods, July 1908 (No. 915 and 3367; tree 5-13 m. tall, girth 0.45-1.5 m.; fruits); Yung-king Hsien, ascent of Ta-hsiang-ling, alt. 1000-1300 m.; June 1907 (No. 3364; thin tree, 3-8 m. tall; fruits); east of Mao-chou, alt. $1300-2300 \mathrm{~m}$., thickets, May 23, 1908 (No. 3366; tree 7-13 m. tall, girth $0.6-1.8 \mathrm{~m}$.; young fruits); Mt. Omei, June 1904 (Veitch Exped. No. 5792; tree $8 \mathrm{~m}$. tall; fruits); same locality, 1200 m., E. Faber (No. 212; fruits); Nanch'uan, A. von Rosthorn (No. 1533 ?, No. 1534; type of var. resinosa, ex Diels).

This species is a rather variable one. As long as we compare only the types of the different forms mentioned above they may appear distinct species or well characterized varieties. But with a careful study of all the specimens before me $\mathrm{I}$ find it impossible to limit even good varieties. The shape of the leaves and bracts, the pubescence of the different parts and the length of the fruiting catkins are extremely variable. The type of $B$. luminifera Winkler has broad-ovate and often slightly eordate leaves and does not have the same kind of tomentose pubescence or the very long catkins which I considered the prineipal characters of $B$. Wilsoniana Schneider. On the other hand, B. hupehensis Schneider represents a more glabrous form with short catkins. But the length of the catkins is the same in forms which differ in pubescence and in the shape of the leaves. The glands of the under surface of the leaves do not afford any sufficient character to distinguish forms. Geographically the species seems to be well separated from $B$. alnoides Hamilton, which is a much more subtropical species and may be easily distinguished by the fruiting catkins being more than one and by the shape, texture and serration of the leaves.

This is the low-level Birch of western Hupeh and of Szech'uan. In Hupeh and eastern Szech'uan it grows between 500 and $2000 \mathrm{~m}$. of altitude and in western Szech'uan between 1000 and $2500 \mathrm{~m}$. Though very abundant it does not form pure woods, but is always associated with other trees. It rarely exceeds $20 \mathrm{~m}$. in height, has rather slender branches and a trunk from 1 to $2.5 \mathrm{~m}$. in girth. The bark is firm and smooth and dark-colored on young trees, becoming dull yellowish gray or even dull reddish brown on old trees. It does not exfoliate.

Pictures of this tree will be found under Nos. 163, 517, 556, 565 of the collection of my photographs and also in my Vegetation of Western China, Nos. 135, 136, 137, 138.

E. H. W. 
Betula utilis D. Don, var. Prattii Burkill in Jour. Linn. Soc. XXVI. 499 (1899). - Winkler in Engler, Pflanzenr. IV.-61, 61 (1904). Henry in Elwes \& Henry, Trees Gr. Brit. \& Irel. IV. 981 (1909).

Western Szech'uan: west of Tachien-lu, Cheto-shan, alt. 30004000 m., September 1908 (No. 976; tree 8-20 m. tall, girth 1.5-3 m., bark dull orange; ripe fruits); same locality, alt. 3300 m., July 24, 1908 (No. 976 ; tree $20 \mathrm{~m}$. tall, girth $2.4 \mathrm{~m}$.; unripe fruit and bark); same locality, alt. 3300-4000 m., September 1910 (No. 4089; tree 10-20 m. tall, girth 1.2-2.4 m.; fruits); southeast of Tachien-lu, alt. 3000-3600 m., woodlands, September 1908 (No. 99o; tree 10-17 m. tall, girth 1.8-2.4 m., bark gray; fruits); same locality, alt. 2600$3300 \mathrm{~m}$., forests, October 1910 (No. 4037; tree 7-26 m. tall, girth 0.6-3 m., bark dull orange red; fruits and bark); summit of Wa-shan, alt. 3600 m., September and October 1908 (No. II38; tree 10-13 m. tall, girth 1.5-2.1 m.; fruits and sterile); west of Kuan Hsien, woodlands Pan-lan-shan, alt. 3000-3300 m., September 1910 (No. 4035; tree $10-20 \mathrm{~m}$. tall, girth $1.2-2.7 \mathrm{~m}$.; fruits); without exact locality, forests, alt. 3300-4000 m., June 1904 (Veitch Exped. No. 4492; tree 7 m. tall; flowers); alt. 3300-4000 m., July 1903 (Veitch Exped. No. $4492^{\mathrm{a}}$; tree 5-13 m. tall; fruits); forests, alt. 2300-3200 m., September 1904 (Veitch Exped. No. 4495; tree 7-20 m. tall; fruits); woods, 2000 m., May 1904 (Veitch Exped. No. 4496; tree 8 m. tall; old fruits); forests, 2300-3300 m., May 1904 (Veitch Exped. No. 4530; tree 10-13 m. tall; flowers); near Tachien-lu, 13500 feet, A. E. Pratt (No. 236; co-type of var. Prattii; fruits).

This variety resembles much more the typical $B$, utilis Don than the following species, which was referred to $B$. utilis by Burkill. There are young plants in the Arnold Arboretum raised from seed of Wilson's No. 4035, 4087 and 4089. These plants are very much like those of Wilson's No. 900 and 4106 and Purdom's No. 400 placed under B. albo-sinensis Burkill. We know, however, too little of the behavior of the young plants to draw any conclusions from them.

This species is abundant in mixed forests on the high mountains of extreme western Szech'uan between 2600 and $4000 \mathrm{~m}$. altitude. It grows from 25 to $30 \mathrm{~m}$. tall with a trunk from 2.5 to $3 \mathrm{~m}$. in girth; the bark is rough and rather shaggy and varies in color from orange-brown to orange-gray or even to pale gray on old trees in much exposed situations.

E. H. W.

Betula albo-sinensis Burkill in Jour. Linn. Soc. XXVI. 497 (1899).Diels in Bot. Jahrb. XXIX. 282 (1900).

Betula utilis Burkill in Jour. Linn. Soc. XXVI. 499 (pro parte, non D. Don) (1899). - Diels in Bot. Jahrb. XXIX. 282 (1900). - Winkler in Engler, Pflanzent. IV.-61, 61 (1904), quoad specim. Chinensia.

Betula Bhojpattra, var. sinensis Franchet in Jour. de Bot. XIII. 207 (1899). 
Betula utilis, var. sinensis Winkler in Engler, Pflanzenr. IV.-61, 62 (1904). Henry in Elwes \& Henry, Trees Gr. Brit. \& Irel. IV. 981 (1909).

Western Hupeh: Fang Hsien, alt. 1600-3000 m., woods, May 15, 1907 (No. 3363; tree 5-17 m. tall, girth 0.6-1.8 m., bark orange-red; flowers and bark); same locality, alt. 2300-3300 m., uplands, June 23, 1910 (No. 4438 ; tree $13-23 \mathrm{~m}$. tall, girth $0.9-3 \mathrm{~m}$., bark bright orange; fruits); same locality, mountains, May 1901 (Veitch Exped. No. 1889; flowers; Seed No. 1157); April 1900 (Veitch Exped. No. 1890; flowers); same locality, A. Henry (No. 6798, 6798 ${ }^{\mathrm{a}}$; sterile); Hsing-shan Hsien, June 1901 (Veitch Exped. No. 2123; fruits). Western Szech'uan: west and near Wên-ch'uan Hsien, alt. 26003600 m., October 1910 (No. 4Io6; tree 13-33 m. tall, girth 1.5$3.6 \mathrm{~m}$, bark orange; fruits and bark). Western Kansu: Tibetan country, W. Purdom (fruits). Shensi: Tai-pei-shan, W. Purdom (No. 400; bark).

The typical form of this species with glabrous and glandular branchlets occurs in Hupeh as well as in the area of the following form, but is not yet recorded from the same region as $B$, utilis var. Prattii Burkill.

This beautiful Birch is abundant on the high mountains of northwestern Hupeh and northeastern Szech'uan, but is rare in western Szech'uan and as far as our knowledge goes is confined to the northwest parts of the province. Usually it grows mixed with other deciduous leaved trees, but occasionally it forms almost pure woods. It is a tree from 20 to $26 \mathrm{~m}$. tall with a trunk from 2 to $3.5 \mathrm{~m}$. in girth. The bark is bright orange to orange-red, peeling off in very thin sheets, each successive sheet being covered with white glaucous bloom. Pictures of this tree will be found under Nos. 702 and 0106 of the collection of my photographs and in my Vegetation of Western China, No. 139.

E. H. W.

Betula albo-sinensis, var. septentrionalis Schneider, n. var.

? Betula utilis Winkler apud Diels in Bot. Jahrb. XXXVI. Beibl. LXXXII. 33 (1905).

A typo differt ramulis plus minusve distincte glandulosis, foliis subtus costa nervisque saepe distinctius sericeis et in axillis barbatis.

Western Szech'uan: northeast of Tachien-lu, Ta-p'ao-shan, alt. 3000-3600 m., July 4, 1908 (No. 900, type; tree 13-33 m. tall, girth 1.8-3 m., bark orange; fruits and bark); west of Romi-chango, alt. $2600 \mathrm{~m}$., forests, July 5, 1908 (No. 900a ; tree 20-27 m. tall, girth 2.1-3 m., bark orange; fruits). Western Kansu: Tow River district, W. Purdom (No. 752; fruits). Shensi: "Tai-pa-shan, Miao-wang-shan," G. Giraldi (ex Winkler).

This variety needs further observation. It has very deeply cleft bracts; the middle lobe is long and rather narrow, while the lateral lobes are spreading-erect and variable in shape. The eatkins in both this variety and in the type are somewhat 
more slender than in B. utilis var. Prattii Burkill. The size, shape and the wings of the seeds are so variable in all these forms that it seems impossible to place any dependence upon these characters.

This Birch is common in the mixed forests on the high mountains of extreme western Szech'uan between altitudes of 3000 and $3800 \mathrm{~m}$., where it is a tree often $33 \mathrm{~m}$. tall, with thick branches and a trunk from 4 to $5 \mathrm{~m}$. in girth. The bark is orange-brown or orange to yellowish orange or orange-gray and exfoliates in thin sheets more or less persistent on the trunk and main branches. The bark is singularly beautiful and makes the tree conspicuous in the forest. Pictures of this Birch will be found under Nos. 173,174 of the collection of my photographs and also in my Vegetation of Western China, No. 134.

E. H. W.

Betula insignis Franchet in Jour. de Bot. XIII. 206 (1899). - Burkill in Jour. Linn. Soc. XXVI. 498 (1899), - Diels in Bot. Jahrb. XXIX. 281 (1900). - Winkler in Engler, Pflanzenr. IV.-61, 59, fig. 19 A-C (1904).

Western Hupeh: Changyang Hsien, mountains, June 1901 (Veitch Exped. No. 1130; unripe fruits); same locality, August 1900 (Veitch Exped. No. $1130^{\mathrm{a}}$; ripe fruits). Eastern Szech'uan: Tchenkeou-tin, alt. 1400 m., P. Farges (No. 83, type, ex Franchet; fruits). Western Szech'uan: southeast of Tachien-lu, $3000-3600 \mathrm{~m}$, woodlands, June 1908 (No. I427; tree 10-13 m. tall, girth 1.2-2.4 m.; fruits); west of Kuan Hsien, ascent of Pan-lan-shan, alt. 2300-3700 m., thickets, June 1908 (No. 3365; thin tree 8-9 m. tall; fruits).

1 have not seen the type of this species, but according to Franchet's description and Winkler's figure it differs from Wilson's plants in its longer strobiles up to $6 \mathrm{~cm}$. long and $1.5 \mathrm{~cm}$. thick, the strobiles of the form from Hupeh being about $3 \mathrm{~cm}$. long and 2-2.2 cm. thick. Those of No. 1427 from western Szech'uan are about $4 \mathrm{~cm}$. long and $2.2 \mathrm{~cm}$. thick, while in No. 3365 they are only $2-3 \mathrm{~cm}$. long and 1.5 $\mathrm{cm}$. thick. The last two numbers were collected in June, and bear only the strobiles of the previous year. The lateral lobes of the bracts of No. 3365 are a little more spreading than in the type and in the other numbers, and the serration of the leaves is also a little different. Without more material it is difficult to say whether these numbers represent different varieties or not. The leaves of No. 1427 are up to $13.5 \mathrm{~cm}$. long and $6.5 \mathrm{~cm}$. broad. As a whole $B$. insignis is a most distinet species.

In 1912 I was inclined to refer a specimen of Wilson's (Veitch Exped. No. 2799) from Hupeh to what I called B. chinensis, var. Delavayi. Mr. Wilson tells me this is a tree from 6 to $8 \mathrm{~m}$. tall, and I now think the specimen, which was poor and imperfect, should be referred to $B$. insignis Franchet. Unfortunately the number is not represented in the herbarium of the Arnold Arboretum.

In western Hupeh and in western Szech'uan this species is rare and I saw only a few trees. It is a low tree with a bushy head and smooth, firm dark bark. I suspect that it has an aromatic bark like $B$. lenta Linnaeus, but $I$ omitted to test it in the field, and this character cannot be detected with certainty from dried material. E. H. W.

Betula Potaninii Batalin in Act. Hort. Petrop. XIII. 101 (1893). Burkill in Jour. Linn. Soc. XXVI. 498 (1899). 
Betula Wilsonii Bean in Kew Bull. Misc. Inform. 1914, 30 (1914); Trees \& Shrubs Brit. Isl. I. 264 (1914).

Western Szech'uan: Wa-shan (not Wushan), alt. 2100-2800 m., June and October 1908 (No. Ir40, type of B. Wilsonii; shrub 1.5-3 m. tall, hanging down over cliffs; flowers and old fruits); same place, alt. 2800 m., July 1902 (Veitch Exped. No. 4490; shrub $2.4 \mathrm{~m}$. tall; young fruits); Mupin, alt. 2300 m., October 1910 (No. 4299; prostrate and hanging from cliffs; fruits); southeast of Sungpan Ting, valley of Lungan River, 2800 m., August 1910 (No. 4299 ; prostrate over cliffs; fruits); west of Kuan Hsien, Pan-lan-shan, alt. 20002800 m., October 1910 (No. 4299 ${ }^{\text {b }}$; prostrate and hanging down over cliffs; fruits); "ad flum. Honton, infra pagum San shei," August 13, 1885, G. N. Potanin (type, ex Batalin).

The original description of this species has been overlooked by Bean, and Winkler does not mention it. It is one of the best marked Birches with its very short petioles and its many nerved leaves which, like the branchlets, are covered beneath with a somewhat brownish silky pubescence. It is very nearly related to $B$. Delavayi Franchet, from which it differs in the characters given in the key.

On the moist rocks and cliffs of the forest-covered higher mountains of western Szech'uan this interesting Birch is common. Usually all its slender whiplike branches hang down over clifis and boulders, but often it is a shrub from 1 to $3 \mathrm{~m}$. high with decumbent and prostrate branches.

E. H. W.

Betula Delavayi Franchet in Jour. de Bot. XIII. 205 (1899). Burkill in Jour. Linn. Soc. XXVI. 498 (1899). - Winkler in Engler, Pflanzenr. IV.-61, 67, fig. $19 \mathrm{~m}$ (1904).

Betula chinensis, var. Delavayi Schneider, Ill. Handb. Laubholzk. II. 884 (pro parte) (1912).

Western Szechu'an: Mupin, alt. 2400-2900 m., side of streams, October 1910 (No. 4382; small tree, 8-10 m. tall, girth 0.6-1.2 m.; fruits); Tachien-lu, May 1904 (Veitch Exped. No. 4493; shrub 3 m. tall; flowers and remains of old strobiles); without exact locality, forests, alt. 3600 m., June 1904 (Veitch Exped. No. 4491; shrub, 1.8 m. tall; flowers and old strobiles). Western Kansu: south of Min-chou, Lotani, alt. 1900 m., W. Purdom (No. 812; 1.5-3 m.). Yunnan: "in silvis ad Koutui supra Mo-so-yn," alt. 2800 m., J. Delavay (No. 3725; ex Franchet et Burkill).

I have not seen the type of this species, but 1 have little doubt that the specimens mentioned above belong to $B$. Delavayi Franchet, whicn is an upright shrub or small tree, and seems somewhat intermediate in character between $B$. Potaninii Batalin and B. chinensis Maximowicz, being probably most nearly related to the former. 
Betula japonica Siebold, var. mandshurica Winkler in Engler, Pflanzenr. IV.-61. 78 (var. mandschurica) (1904). - Nakai in Jour. Coll. Sci. Tokyo, XXXI. 202 (Fl. Kor. II.) (1911).

Betula alba, subspec. mandshurica Regel in Rull. Soc. Nat. Mosc. XXXVIII. pt. 2, 399, tab. 7, fig. 15 (1865); in De Candolle. Prodr. XVl. pt. 2, 165 (1868).

Betula alba, var. vulgaris Franchet in Jour. de Bot. XIıI. 206 (1899), - Burkill in Jour. Linn. Soc. XXVI. 497 (1899).

Betula mandshurica Nakai in Tokyo Bot. Mag. XXIX. 42 (pro parte) (1915).

Western Szech'uan: west of Tachien-lu, Cheto-shan, alt. 28003400 m., woodlands, September 1908 (No. 983; tree 10-20 m. tall, girth 1.2-2.4 m., bark white; fruits); same locality, alt. 2800-3700 m., September 1910 (No. 4088; tree 10-25 m. tall, girth 1.5-2.4 m.; bark gray); northeast of Tachien-lu, Ta-p'ao-shan, alt. 2800-3400 m., July 9,1908 (No. $983^{\mathrm{a}}$; tree 10-20 m. tall, girth 1.2-2.4 m., bark white; young fruits); near Monkong Ting, alt. 2800-3400 m., woodlands, June 1908 (No. 983 ${ }^{\text {b }}$; tree 10-20 m. tall, girth 1.2-2.4 m., bark white; unripe fruits); around Sungpan, alt. 2800-3700 m., woods, August 1910 (No. 4636; tree 7-13 m. tall, girth 0.9-1.8 m., bark white; sterile); around Tachien-lu, P. Soulié (No. 566, fide Franchet); without precise locality, forests, altitude 2300 m., August 1903 (Veitch Exped. No. 4494 ; tree $10 \mathrm{~m}$. tall, bark white; fruits).

NORTHEASTERN ASIA. Ussuri: Olga Bay, Fr. Schmidt (type, ex Regel). Korea: "Kyong-san, in monte Chiri-san," summer 1905, Shiki (fide Nakai).

This Chinese White Birch seems geographically well separated from the other forms of B. japonica Siebold, and I am not quite sure whether it is the same as Regel's form. The only real difference I can detect are the very glabrous leaves, which Regel gives as a character for his subspecies.

From the European and western Asiatic Betula pendula Roth (Betula alba Linnaeus pro parte; Betula verrucosa Ehrhart), which also has quite glabrous leaves, the Chinese form differs in the shape and especially in the short and regular dentation of the leaves as well as in the shape of the fruiting bracts, which, however, is variable.

On the extreme west and northwest of Szech'uan at high elevations this is a common tree, but I only saw it scattered through mixed forests in which coniferous trees predominated. However, I was told of vast forests of this Birch to the immediate west and south of Sungpan Ting. The bark is used for lining straw hats and is an article of much value locally; it is used in great quantity in the district of Shuang-liu Hsien on the Chengtu Plain. In general appearance the Chinese White Birch resembles the North American B. papyrifera Marshall, but the bark is more persistent and not so white. Pictures of this tree will be found under No. 178 of the collection of my photographs and also in my Vegetation of Western China, No. 133.

E. H. W. 


\section{CONSPECTUS ANALYTICUS BETULARUM ASIAE ORIENTALIS NEC NON HIMALAYAE.}

Amenta fructifera ad 2-4 racemoso-conferta v. solitaria, pendula, longe et anguste cylindrica; lobi laterales bractearum valde reducti v. in B. Maximowicziana tantum distinctiores; samararum alae latae, bracteas lateraliter superantes $\mathbf{v}$. nuculis fere triplo latiores. Folia multi(9-13)-costata.

Sect. 1. ACUMINATAE.

* Amenta fructifera ad 2-4 racemoso-conferta (rarius interdum abortu solitaria).

Lobi laterales bractearum distincti, medio circiter dimidio breviores; samararum alae nuculo fere triplo latiores. Folia magna, late ovata, basi profunde cordata; petioli $2.5-4 \mathrm{~cm}$. longi . . . . 1. B. Maximovicziana.

Lobi laterales bractearum reducti. Folia ovato-oblonga v. basi haud cordata; petioli $1.2-2(-2.2) \mathrm{cm}$. longi.

Ramuli hornotini petiolique distincte flavo- $\nabla$. griseo-tomentelli et etiam pedunculi et saepissime costa paginae inferioris foliorum eodem tomento obtecta. Folia late ovata v. ovato-oblonga, basi rotunda v. leviter cordata, satis subito acuminata, dentibus plus minusve distantibus.

2. B. cylindrostachya.

Ramuli hornotini petiolique breviter pubescentes v. pleraque tantum pilosi v. subglabri, saepe glanduliferi (pedunculi tantum saepe distinctius tomentelli). Folia ovato-oblonga, sensim acuminata saepe caudata, basi rotundato-truncata v. subacuta, dentibus plus minusve adpressis.

3. B. alnoides.

** Amenta fructifera solitaria; lobi laterales bractearum reducti.

Petioli 0.8-2.5 cm. longi. Amenta fructifera 3.5-11 cm. longa; bractearum lobus medius elongatus lateralibus parvis v. minimis valde longior. Folia pleraque plus quam $6 \mathrm{~cm}$. Ionga . . . . . . 4. B. luminifera.

Petioli 6-8 mm. longi. Amenta fructifera 3-4 cm. longa; bractearum lobus medius satis brevis. Folia tantum 5-6 cm. longa . . . 5. B. Baeumkeri.

Amenta fructifera solitaria (rarissime bina) pendula, patentia v. erecta; lobi laterales bractearum distincti; samararum alae nucula vix latiores, saepe angustissimae; bracteae samaras occultantes.

* Amenta fructifera erecta, pleraque subglobosa, ovata v. anguste elliptica (in

10. B. Schmidtii cylindrica); bractearum Iobi laterales fere semper erectae v. erecto-patentes medio distincte producto plus minusve breviores. Folis nervis lateralibus supra plus minusve impressis (6-)7-14 instructa. (Confer etiam 25. B. davuricam) . . . . . . . . . Sect. 2. COSTATAE.

$\dagger$ Samararum alae satis distinctae, nucula circiter $1 / 2$, rarius ad $2 / 3$ angustiores; amenta fructifera ovato-cylindrica $v$. subcylindrica, 2-3-plo longiora quam lata, pedunculo satis distincto et tenui suffulta ( $v$. folia triangularia versus basim latissima; vide 6. B. Ermanii).

Subsect. a. Ermantanae.

Folia plus minusve triangularia v. ovato-triangularia, versus basim latissima, basi truncata, plus minusve cordata $\mathrm{v}$. rarius subrotunda.

6. B. Ermanii.

Folia ovata, ovato-oblonga v. ovato-rotunda, medio v. versus medium (rarius supra medium) latissima, basi saepissime rotunda v. subacuta, interdum cordata.

Nervi laterales foliorum majorum utrinque 6-9. . 7. B. Jacquemontii. Nervi laterales foliorum (9-)10-14. 
Ramuli floriferi fructiferique plus minusve abunde glanduliferi et villosuli. Folia satis erassa, costa nervisque subtus valde prominentibus satis sericea $\mathrm{v}$. barbato-villosa, saepissime in axillis distinete barbata, saepe etiam facie pilosa; petioli plus minusve sericeo-villosi. Amenta elliptica v. breviter cylindrica. . 8. B. utilis.

Ramuli floriferi fructiferique glabri, haud v. in var. septentrionali distinctius glanduliferi. Folia tenuiora, laeviora, costa nervisque subtus minus prominulis sparse sericea v. subglabra, interdum tantum axillis barbulata; petioli glabri v. sparse sericei. Bracteae sparsius v. vix margine glanduliferi et ciliati; amenta satis cylindrica .

9. B. albo-sinensis.

$\dagger \dagger$ Samararum alae angustissimae, nucula 4-5-plo angustiores v. amenta fructifera crasse ovato-elliptica 11/2-2-plo longiora quam lata, pedunculo brevissimo crasso suffulta $\mathrm{v}$. folia haud triangularia et basim versus latissima.

‡ Folia subtus discoloria, einerascentia, obovata v. obovato-oblonga, grosse aequaliter crenato-serrata. Amenta fructifera crasse cylindrica, ereeta (in speciminibus herbariorum quasi nutantia videntur) bracteae lobis angustis profunde trifidae.

Subsect. c. CoRYlifoliae. 11. B. corylifolia.

$\ddagger \ddagger$ Folia subtus plus minusve viridescentes, haud obovata, margine dentibus minoribus angustioribusque serrata $\mathrm{v}$. dentata.

|| Folia majora 6-14 $\mathrm{cm}$. longa v. ovato-rotunda; petioli fere semper plus quam $1 \mathrm{~cm}$. longi v. strobili crassi subglobosi v. satis anguste cylindrici. Arbores altae.

Amenta fructifera cylindrica, circiter 2-3 cm. longa et $0.8 \mathrm{~cm}$. crassa, pedunculo satis tenui suffulta. Folia brevissime inaequaliter denticulata; petioli 8-10 $\mathrm{cm}$. longi .... Subsect. b. Asperae.

10. B. Schmidtii.

Amenta fructifera crasse ovato-elliptica v. subglobosa, subsessilia v. pedunculo brevi crasso sufiulta. Foliorum dentes distincti, plus minusve acuminati ....... . Subsect. d. Grossae.

Samararum alae pleraeque distinctae, nucula $1 / 2-2 / 3$ angustiores, interdum basim nuculae versus valde reductae; strobili elliptici, 11/2-2-plo longiora quam lata $\mathrm{v}$. lobus medius bractearum lateralibus paulo longior.

Folia satis anguste ovata in apicem longum caudatum producta, nervis lateralibus approximatis ad costam inter se circ, 3-4.5 $\mathrm{mm}$. distantibus, basi pleraque rotunda. Lobus medius bractearum fere semper distincte elongatus; alae samararum saepissime satis evolutae

12. B. costata.

Folia plus minusve ovata $\mathrm{v}$. late ovata, brevius acuminata $\mathrm{v}$. haud caudata, nervis lateralibus ad costam inter se circiter 5-6 mm. distantibus. Bractearum lobi tres inter se subaequilongae v. lobus medius paulo longior; alae samararum versus basim nuculae saepe valde angustatae (confer etiam 14. B. Fargesii)

13. B. grossa.

Samararum alae angustissimae; strobili subglobosi v. valde crassi et magni, bractearum lobus medius valde elongatus.

Folia late ovata v. ovato-rotunda, apice vix acuminata, basi plus minusve late cuneata. Strobili subglobosi, ad $3 \mathrm{~cm}$. longi et $2.5 \mathrm{~cm}$. crassi; bracteae utrinque glabrae, tantum laxe ciliatae 16. B. globispica. 
Folia ovata v. ovato-elliptica, saepissime plus minusve acuminata, basi rotunda. Strobili crassi elliptici; bracteae superne puberulae . . . . . . . . 15. B. insignis.

III Folia etiam maxima vix $6 \mathrm{~cm}$. longa; petioli 4-8 v. rarius $10 \mathrm{~mm}$. longi . . . . . . . . . . Subsect. e. Chinenses. Folia ovato-oblonga v. ovato-elliptica, nervis lateralibus foliorum majorum 10-22, inter se $2-3 \mathrm{~mm}$. ad costam distantibus, argute angusteque inaequaliter serrata; petioli vix plus quam $6 \mathrm{~mm}$. longi (confer etiam 14. B. Fargesii).

Folia nervis lateralibus utrinque (11-)14-22 subtus valde prominentibus albo- et rufo-sericeis instructa facie subtus etiam plus minusve villosa. Bracteae supra sericea et puberula, lobis lateralibus satis obtusis suberectis . . . . 17. B. Potaninii.

Folia nervis lateralibus (9-)10-13 subtus prominentibus et plus minusve laxe albo-sericeis instructa, facie glabra. Bracteae sericeo-ciliatae sed supra facie glabrae; lobis lateralibus acutioribus patentioribusque . . . . . . 18. B. Delavayi.

Folia ovata v. ovato-rotundata, nervis lateralibus foliorum majorum $6-10$, inter se circiter $5 \mathrm{~mm}$. distantibus, subtus paulo prominentibus, satis grosse subacute et subaequaliter dentata v. serrata; petioli $6-12 \mathrm{~mm}$, longi. Bractearum lobus medius satis elongatus, lateralibus angustis 2-3-plo longior . . 19. B. chinensis.

** Amenta fructifera cylindrica et pendula v. folia parva, utrinsecus tantum nervis 2-6 (in 25. B. davurica rarius ad 8) supra haud incisis subtus haud valde prominentibus.

† Amenta fructifera ovata $\mathrm{v}$. elliptica, erecta suberectave (ut videtur tantum in 22. B. Middendorffi subcylindrica et nutantia). Folia saepe parva, rarius plus quam $4.5 \mathrm{~cm}$. longa, paucicostata, nervis utrinque $2-6$, margine subaequaliter serrata, dentata subcrenatave; petioli tantum 1-6(-8) $\mathrm{mm}$. longi. Frutices ...... Sect. 3. HUMILES. Ramuli plus minusve dense pilosi vel tomentosi, haud glanduliferi. Folia saepissime tantum $0.4-1.2 \mathrm{~cm}$. longa, saepe latiora quam longa, nervis 2-4 instructa, subcrenata. Strobili parvi sed satis crassi, erecti; bractearum lobi satis breves, aequilongi, erecti; samararum alae nucula 3-4-plo angustiores . . . . . . . . Subsect. a. NANAE. 20. B. nana.

Ramuli semper plus minusve glanduliferi. Folia saepissime plus quam $14 \mathrm{~mm}$. longa et plus minusve distincte longiora quam lata v. samarae alis satis distinctis instructa ... Subsect. b. FrUTICOSAE. Folia nervis plerisque 5-6 lateralibus utrinque instructa, apice plus minusve acuta, margine breviter serrata. Bracteae fere semper ad medium trilobatae, lobis lateralibus suberectis; samararum alae nucula $1 / 2(-1 / 3)$ angustiores v. aequilatae . . . 24. B. fruticosa. Folia utrinsecus nervis $2-5(-6)$ apice plus minusve obtusa $v$. rotunda, margine breviter dentato-serrata v. grossius dentata $\mathrm{v}$. subserrata. Folia fere semper distincte longiora quam lata, plus minusve ovata, saepe subacuta nervis lateralibus utrinque saepissime $4-5(-6)$. Samararum alae nucula circiter $1 / 2$-plo angustiores; strobili erecti.

23. B. humilis.

Folia saepe haud longiora quam lata, apice valde obtusa v. rotunda, saepe obovata, nervis utrinque pleraque $2-3(-4)$.

Strobili elliptici, erecti; samararum alae nucula circiter 3-plo angustiores. Folia plus minusve erenato-dentata. 
Strobili saepe nutantes et subcylindrici; samararum alae nucula aequilatae v. saepe latiores. Folia ut videtur satis breviter et anguste dentata . . . . . 22. B. Middendorffi.

†† Amenta fructifera pendula v. in 25. B. davurica suberecta, cylindrica v. subelliptica. Folia saepe mediocra, majora plus quam $5 \mathrm{~cm}$. longa (v. petioli $1 \mathrm{~cm}$. longi $\mathrm{v}$. longiores, $\mathrm{v}$. amenta cylindrica et pendula), apice plus minusve acuminata v. subtriangularia, nervis utrinque (4-)5-7 $(-8)$. Arbores

Sect. 4. EXCELSAE.

Folia ovata v. ovato-oblonga, basi cuneata v. cuneato-rotunda. Strobili suberecti, elliptici v. subcylindrici; bractearum lobus medius saepissime distinctus angustusque lateralibus suberectis v. patentibus interdum paulo recurvis longior; samararum alae nucula $1 / 2$ angustiores $\mathrm{v}$. rarius subaequilatae. Cortex trunci junioris griseo-brunneus v. ex parte flavus v. rubescens, lamellis laxis secedens.

Subsect. a. Dahuricae.

25. B. davurica,

Folia triangularia v. ovato- v. rhombico-triangularia. Strobili penduli v. subpenduli; bractearum lobi laterales fere semper margine superiore recurvatis, satis latis, lobus medius brevis, basi dilatatus comparate satis reductus; samararum alae nucula aequilatae v. usque duplo latiores . . . . . . . . . . . . Subsect. b. Alibae.

26. B. japonica.

\section{ENUMERATIO BETULARUM ASIAE ORIENTALIS NEC NON HIMALAYAE.}

Sect. 1. ACUMINATAE Regel in Bull. Soc. Nat. Mosc. XXXVIII. pt. 2, 418 (1865). - Prantl in Engler \& Prantl, Nat. Pflanzenfam. III. Abt. 1, 45 (1887). - Schneider, Ill. Handb. Laubholzk. I. 97 (1904), II. 882 (1912).

Betulaster Spach in Ann. Sci. Nat. sér. 2, XV. 198 (1841).

Betula, subg. Betulaster Endlicher, Gen. Suppl. IV. 20 (1847).

Betula, sect. Betulaster Regel, subsect. Acuminatae Regel in De Candolle, Prodr. XVI. pt. 2, 179 (1864). - Winkler in Engler, Pflanzenr. IV.-61, 88 (1904).

This section is well distinguished by the rather small and narrow bracts of the fruiting catkins and by the broad winged seeds. The bracts of B. Maximowicziana Regel only are somewhat like those of the other sections. The fruiting catkins are racemose or solitary, narrow-cylindric, long and pendulous.

1. Betula Maximowicziana Regel in De Candolle, Prodr.XVI.pt. 2,180 (1868).Franchet \& Savatier, Enum. Pl. Jap. I. 456 (1875). - Shirai in Tokyo Bot. Mag. VIII. 321, t. 6, fig. 36-38 (1894). - Sargent, Silva N. Am. IX. 48 (1896). - Shirasawa, Icon. Ess. For. Jap. I. 45, t. 23, fig. 1-8 (1900). - Mayr, Fremdl. Wald-\& Parkbäume, 449, fig. 108 (1906).

Betula Maximowiczii Regel in Bull. Soc. Nat. Mosc. XXXV1II. pt. 2, 418, t. 6, fig. 1-8 (non Ruprecht) (1865). - Rehder in Bailey, Cycl. Am. Hort. 1. 158 (1900). - Schneider, Ill. Handb. Laubholzk. I. 97, fig. 53 e, 54 c-c ${ }^{2}$ (1904); II. 882 (1912), - Winkler in Engler, Pflanzenr. IV.-61, 89, fig. 22 D-F (1904). - Henry in Elwes \& Henry, Trees Gr. Brit. \& Irel. IV. 976, t. 269, 
fig. 6 (1909), - Skan in Bot. Mag. CXXXVI. t. 8337 (1910), - Bean, Trees \& Shrubs Brit. Isl. 1. 259, fig. (1914).

Betula candelae Koidzumi in Tokyo Bot. Mag. XXVII. 147 (1913).

JAPAN. Hokkaido: prov. Iburi, Nobori-betsu, common in forests, July 3, 1914 (No. 7070, tree 20-30 m. tall, girth 1.5-3.6 m.); " in sylvis Iwanai," September 1904, U. Faurie (No. 5781); " in sylvis Jirafu," June 26, 1905, U. Faurie (Nos. 6599; young fruits; 6632); prov. Ishikari, Mt. Moiwa near Sapporo, September 6, 1892, C. S. Sargent (tree 20-26 m. tall, girth 0.6-0.9 m., pale orange bark; sterile); without locality, C. Maximowicz (type, ex Regel). Hondo: prov. Rikuchu, Mt. Iwate, July 26, 1908 (ex Herb. K. Sakurai; fruits); prov. Iwashiro, Ose, August 10, 1911 (ex Herb. Sakurai); prov. Shimotsuke, Lake Chuzenji, August 12, 1905, J. G. Jack (fruits).

This magnificent Birch is common in southern and central Hokkaido, where it is known as Kaba or Red Birch, and its wood is exported to America and Europe in increasing quantities. On the island of Hondo it occurs sparingly in the Nikko region and elsewhere, and it reaches the southern limits of its range on the Japanese Alps in Shinano province, where I met with it near Nakabusa-onsen on the lower slopes of Tsubakura-dake. It grows from 26 to $33 \mathrm{~m}$. tall and has a trunk clean of branches for more than half its height; the crown is roundisa and mop-like. The bark on old trees is orange-gray to grayish brown and gray, and splits into long and broad thin sheets many of which remain on the tree in the form of shaggy masses. Pictures of this tree will be found under Nos. $\mathrm{x} 327, \mathrm{x} 328, \mathrm{x} 331$, x332, $\mathrm{x} 358$ of the collection of my Japanese photographs.

E. H. W.

2. Betula cylindrostachya Wallich, ${ }^{1}$ Plant. As. Rar. 11 . 7 (1831), - Regel in Bull. Soc. Nat. Mosc. XXXVill. pt. 2, 418 (1865). - K. Koch, Dendr. II. 1, 639 (1872). - Mouillefert, Traité Arb. \& Arbriss. II. 1124 (1897). - Schneider, Ill. Handb. Laubholzk. II. 882, fig. 552 e-f (1904).

Betulaster cylindrostachya Spach in Ann. Sci. Nat. sér. 2, XV. 198 (1841).

Betula acuminata, var. cylindrostachya Regel in Nouv. Mém. Soc. Nat. Mosc. XIII. pt. 2, 129 (Monog. Betulac. 71), t. 6, fig. 32-34 (1861).

Betula cylindrostachys, var. typica Regel in De Candolle, Prodr. XVI. pt. 2, 180 (1868) exclud. synonymis.

Betula alnoides Collett, Fl. Siml. 472 (non Hamilton) (1902).

Betula alnoides, var. cylindrostachya Winkler in Engler, Pflanzenr. IV.-61, 91 (pro parte maxima) (1904).

INDIA. Kumaon: without locality, R. Blinkworth (No. 2794 of Wallich's Cat.; type, ex Wallich); same region, $R$. Colquhoun (co-type, fide Lindley); same region, alt. 2000-2400 m., common, Strachey \& Winterbottom (No. 3; fruits and flowers); same region, "alt. 5-9000 ped." T. Thomson; same region, Naini tal, alt. 2100 m., Strachey \& Winterbottom (No. 4; young flowers). Punjab: Bhali, Bashahr state, Simla district, alt. 2400 m., May 1908 (fruits). United Provinces: Il Chakrata, alt. 2100 m., May 12, 1912, R. Manickam (No. 87, Herb. Imp. For. Coll. Dehra Dun; young fruits).

So far as I can judge from the above material this may be regarded as a distinct species which is very nearly related to $B$. alnoides Hamilton. Most authors have confused it with $B$. alnoides Hamilton (B. acuminata Wallich), which differs

${ }^{1}$ Wallich is the author of the names B. cylindrostachya and B. acuminata, but Lindley is the author of the descriptions in the Pl. As. Rar., as he gave his manuscript to Wallich. 
in the characters mentioned in the key and seems to have a different geographical distribution.

The oldest name for B. cylindrostachya is perhaps B. nitida D. Don (Prodr. Fl. Nepal. 58 [1825]), the type of which was collected by Kamrup in Sirinagur. I have not seen the type, but only a part of Wallich's No.2795, collected by $R$. Blinkworth in Kumaon which apparently represents the type of Lindley's B. nitida in Wallich (Icon. Plant. As. Rar. II. 7 [1831]). This specimen of Blinkworth can hardly be separated from $B$. cylindrostachya. According to Lindley $B$. nitida is "omnino inter B. acuminatam et B. cylindrostachyam media." Spach (in Ann. Sci. Nat., sér. 2, XV. 200 [1841]), describes B. nitida as Betulaster nitida, and he adds, 1. c. 199, another species under the name of Betulaster affinis (Betula affinis Endlicher, Gen. Suppl. IV. 20 [1847]), which according to his description seems to be only B. cylindrostachya Wallich. Regel mentions this form first as $B$. nitida, var, affinis Regel (in Nouv. Mém. Soc. Nat. Mosc. XIII. 130 [Monog. Betulac. 72] [1861]), but later (in De Candolle, Prodr. XV1. pt. 2, 180 [1868]) he placed it under the doubtful species with $B$. nitida D. Don. Winkler made the same disposition of it (in Engler, Pflanzenr. IV.-61, 95 [1904]).

3. Betula alnoides Hamilton apud D. Don, Prodr. Fl. Nepal. 58 (1825).Hooker f., Fl. Brit. Ind. V. 599 (pro parte) (1888), - Burkill in Jour. Linn. Soc. XXVI. 497 (excl. specim. Farges et var.) (1899).-Gamble, ${ }^{1}$ Man. Indian Timb, ed. 2, 669 (1902). - Brandis, Ind. Trees, 622 (pro parte) (1906). - Schneider, Ill. Handb. Laubholzk. II. 882, fig. $552 \mathrm{~g}, 553 \mathrm{e}$ f (1912).

Betula acuminata Wallich, Icon. Pl. As. Rar. 7, 109 (1831). - Regel in Bull. Soc. Nat. Mosc. XXXVIII. pt. 2, 418 (1865); in De Candolle, Prodr. XVI. pt. 2, 178 (1868). - Brandis, Forest Fl. Brit. Ind. 458, t. 46 (descript. tantum pro parte) (1874). - Franchet in Jour. de Bot. XIII. 207 (excl. specim. Fargesii et var.) (1899).

Betulaster acuminata Spach in Ann. Sci. Nat. sér. 2, XV. 199 (1841).

Betula acuminata, var. a glabra, $\beta$ pilosa, $\gamma$ arguta, $\zeta$ lancifolia Regel in Nouv. Mém. Soc. Nat. Mosc. XIII. pt. 2, 129, 130 (Monog. Betulac. 71, 72), t. 6, fig. $29-31$, t. 13 , fig. 29 (1861).

Betula cylindrostachys, var. $\beta$ pilosa et $\gamma$ subglabra Regel in De Candolle, Prodr. XVI. pt. 2, 189 (1868).

Betula alnoides, var. acuminata Winkler in Engler, Pflanzenr. IV.-61, 89, fig. $22 \mathrm{~A}-\mathrm{C}$ (1904).

CHINA. Yunnan: Mengtsze, alt. 1400 m., 1898, A. Henry (No. 11387; tree $10 \mathrm{~m}$. tall; fruits); Mengtsze, forests to southeast, alt. $1500 \mathrm{~m} ., 1898, A$. Henry (No. $10437^{\mathrm{a}}$; tree $13 \mathrm{~m}$. tall; fruits); Mengtsze, mountain forests to southeast, alt. $1800 \mathrm{~m} .$, A. Henry (No. 10437; tree $10 \mathrm{~m}$. tall; sterile); Szemao, mountains to the south, alt. 1500 m., January 9, A. Henry (No. 12869; tree 10 m. tall; flowers; No. $12869^{\mathrm{a}}$; tree $7 \mathrm{~m}$. tall; flowers; No. $12869^{\mathrm{b}}$; fruits).

INDIA. Nepal: "in sylvis ad Narainhetty," F. Hamilton (ex D. Don; type of B. alnoides); without locality, N. Wallich (No. 2793; type of B. acuminata). East Bengal: Mt. Sillet (Silhet), H. Bruce (ex Wallich, No. 2793 var. $\beta$, apparently only in part); without locality (Herb. Griffith, No. 4486).

${ }^{1}$ Gamble, 1. c., mentions a Betula spec. (B. cylindrostachys Gamble, List Trees Darjeel, 79 [non Wallich] [1878]) from Sikkim, Darjeeling Hills from the Terai up to $2000 \mathrm{~m}$., which differs from $B$. alnoides in the color of bark and in the anatomical characters of the wood. As the author says nothing about the leaves, fruits, etc., this Birch needs further investigation. 
The Himalayan and Yunnan forms are very much alike, and this species seems to differ from $B$. cylindrostachya Spach in its more glossy and more or wholly glabrous, longer and narrower leaves which are more distinctly acuminate and also differ somewhat in the character of their serration. It may be possible to distinguish several forms, as Regel did, but I should like to see much more material from India before making such an attempt. The fruiting catkins seem to be always more slender than those of $B$. cylindrostachya Spach.

4. Betula luminifera Winkler. See p. 455 .

5. Betula Baeumkeri Winkler in Engler, Pfanzenr. IV.-61, 91, fig. 22 D-F (1904). - Schneider, Ill. Handb. Laubholzk. 11. 882, fig. 552 c, 553 i-k (1912).

CHINA. Yunnan: without locality, $J$. Delavay (type ex Winkler).

Having seen so many specimens of $B$. luminifera Winkler, showing the variability of this species, I suspect that B. Baeumkeri, of which I have been unable to see any material, may prove to be only a form of that species.

Sect. 2. COSTATAE Regel in Bull. Soc. Nat. Mosc. XXXVIII. pt. 2, 412 (1865). - Prantl in Engler \& Prantl, Nat. Pflanzenfam. III. abt. 1, 45 (1887). Koehne, Deutsche Dendr. 107 (1893). - Schneider, Ill. Handb. Laubholzk. I. 98 (1904).

Betula, sect. Eubetula Regel, subsect. Costatae Regel in De Candolle, Prodr. XVI. pt. 2, 175 (1868). - Dippel, Handb. Laubholzk. II. 183 (1892). Winkler in Engler, Pflanzenr. IV.-61, 57 (1904).

This section is rather an artificial one. It includes very different forms like $B$. Schmidtii Regel and B. corylifolia Regel \& Maximowicz, which may represent distinct groups. The latter species and B. grossa Siebold \& Zuccarini (probably also $B$. insignis. Franchet and B. costata Trautvetter) are characterized in a living state by the same peculiar odor of the inner bark of young branchlets found in that of the American B. lenta Linnaeus and B. lutea Michaux, but it seems to me an unnatural classification to bring together these species in one group on account of this peculiarity which unfortunately cannot be detected in dried specimens with certainty. I distinguish the following subsections to which we have to add subsect. Nigrae, nov. subsect. (including only the American B. nigra Linnaeus) and subsect. Lentae, nov. subsect. (Sect. Lentae Regel in Bull. Soc. Mosc. XXXVIII. pt. 2, 417 [1865]. - Sect. Eubetula, subsect. Lentae Regel, in De Candolle, Prodr. XVI. 2,179 [1868]), including only American species. I cannot accept the different subgenera proposed by Nakai (in Tokyo Bot. Mag. XXIX. 40 [1915]).

Subsect. a. Ermanianae Schneider, n. subsect.

Betula, subg. Ermani Nakai in Tokyo Bot. Mag. XXIX. 41 (pro parte) (1915).

The species united in this group seem to be closely related. They have a smooth whitish or reddish or ereamy bark peeling off in transverse flakes or strips. The following species are well separated geographically, but it is not always easy to distinguish them without sufficient judiciously collected material. What is needed to establish a good classification of a difficult genus like Betula are observations of living plants in the field.

5. Betula Ermanii Chamisso in Linnaea, VI. 537, t. 6, fig. D, a-e (1831).Erman, Reise um die Erde, Naturh. Atlas, 56, t. 17, fig. 2 (1835). - Spach in Ann. Sci. Nat. sér. 2, XV. 190 (1841). - Ledebour, Fl. Ross. III. pt. 2, 653 (1850). Trautvetter in Mém. Sav. Ettr. Acad. St. Pétersbourg, IX. (Maximowicz, Prim. Fl. Amur.) 252 (1859). - Regel in Nouv. Mém. Soc. Nat. Mosc. XIII. pt. 2, 120 (Monog. Betulac. 62), t. 6, fig. 35, 37, 38, t. 12, fig. 13-28 (excl. var. $\gamma$ ) (1861); 
in Bull. Soc. Nat. Mosc. XXXVIII. pt. 2, 414 (1865); in De Candolle, Prodr. XVI. pt. 2, 176 (1868).- - Middendorff, Sibir. Reise, IV.pt. 1, 568 (Gewächse Sibir.) (1864). - Herder in Act. Hort. Pelrop. XII. 69 (1892). - Dippel, Handb. Laubholzk. II. 187, fig. 89 (1892). - Koehne, Deutsch. Dendr. 108 (1893). Shirai in Tokyo Bot. Mag. VIII. 321, t. 6, fig. 7-9 (1894). - Sargent, Silva N. Am. IX. 48 (1896). - Komarov in Act. Hort. Petrop. XXII. 49 (Fl. Mansh. II.) (1903). - Schneider, Ill. Handb. Laubholzk. I. 102, fig. 53, f-g $\mathrm{g}^{2}, 541-\mathrm{1}^{2}$ (1904). - Winkler in Engler, Pflanzenr. IV.-61, 66 (excl, icon.) (1904). - Henry in Elwes \& Henry, Trees Gr. Brit. \& Irel. IV. 977, t. 270, fig. 12 (1909). - Nakai in Jour. Coll. Sci. Tokyo, XXXI. 201 (Fl. Kor. II) (1911); in Tokyo Bot. Mag. XXIX. 43 (1915). - Koidzumi in Tokyo Bot. Mag. XXVII. 147 (1913).

Betula ulmifolia, var. typica Regel in Bull. Soc. Nat. Mosc. XXXVIII. pt. 2, 414 (an tantum pro parte?) (non B. ulmifolia Siebold \& Zuccarini) (1865); in De Candolle, Prodr. XVI, pt. 2, 176 (1868). - Winkler in Engler, Pflanzenr. IV.-61, 64, fig. 18 D-F (1904).

Betula Bhojpattra, var. typica Regel in Bull. Soc. Nat. Mosc. XXVIII. 416 (1865), quoad specim. japon. - Franchet \& Savatier, Enum. Pl. Jap. I. 456 (1875).

Betula ulmifolia Franchet \& Savatier, Enum. Pl. Jap. 456 (non Siebold \& Zuccarini) (1875). - Dippel, Handb. Laubholzk. II. 189, fig. 90 (pro parte) (1892). - Schneider, Ill. Handb. Laubholzk. I. 101 (pro parte) (1904).

Betula alba, var. communis Shirasawa, Icon. Ess. For. Jap. I. t. 21, fig. 1-15 (1900).

Betula ulmifolia, var. $\delta$ glandulosa Winklerin Engler, Pflanzenr. IV.-61, 64 (1904).

This is the most common Birch in Japan and has there a greater latitudinal and altitudinal range than any other species. It also grows to a larger size than any other Birch of eastern Asia with the possible exception of B. grossa Siebold \& Zuccarini, but in the alpine zone of the higher mountains of northern Japan it is reduced to a low, very broad shrub with branches prostrate on the ground. I met with it on the higher mountains northward from those of the Shinano province in central Hondo. It is common in the Nikko region, and most abundant in Hokkaido and Saghalien. In Hokkaido it is known as Gambi (White Birch), and the wood with that of B. japonica Siebold, which is known by the same name, is like that of $B$, Maximowicziana Regel, exported in quantity to America and Europe and used for making furniture. This species growing in such a wide area and under such diverse climatic conditions exhibits naturally much variation. The trees differ in habit, the leaves vary greatly in size and in degree of dentation and considerably in shape also; the bract of the female flowers varies enormously both in size and shape. The bark is grayish and is sometimes suffused with red-brown or it may be nearly white, and exfoliates in thin sheets or the sheets usually remain on the tree in shaggy masses. The fruit is always erect. Usually the trunk divides a few feet from the ground into several massive stems and these branch to form a wide-spreading crown, but when the trees grow crowded together in rich woods the trunk is relatively slender and very tall and the branches are thin and short. During 1914 I paid much attention to this Birch in Japan, but I failed to discover any constant character by which any variety or form of this species could be definitely distinguished in the field. Its variability notwithstanding, B. Ermanii Regel is a well-marked species. Soot obtained by burning the bark of this Birch is used by Ainu women in tattooing themselves. Pictures of this tree will be found under Nos. x237, x238, x252, x257, x258, x259, x268, x299, x310, x366, x370, $\mathrm{x} 377, \mathrm{x} 509, \mathrm{x} 512$ of the collection of my Japanese photographs.

E. H. W. 
This often misunderstood speeies shows a high degree of variability, and it seems difficult to arrange the different forms in a satisfactory way. Not being able to accept the arrangement of Koidzumi, I propose to keep distinct the following varieties and subvarieties which are connected more or less closely by intermediate forms:

Betula Ermanii, var. genuina Regel in Nouv. Mém. Soc. Nat. Mosc. XIII. pt. 2, 122 (Monog. Betulac. 64), t. 2, fig. 13-28 (1861).

Betula Ermani, var. typica Regel in Bull. Soc. Nat. Mosc. XXXVIII. pt. 2, 415 (1865); in De Candolle, Prodr. XVI. pt. 2, 176 (1868).

Betula Ermani, var. acutifolia Winkler in Engler, Pflanzenr. IV.-61, 66 (1904).

Betula Ermani, var. communis Koidzumi in Tokyo Bot. Mag. XXVII. 149 (pro parte) (1913).

? Betula Ermani, var. sachalinensis Koidzumi, 1. c. 148 (1913).

Gemmarum squamae basi strobilorum tantum margine ciliatae facie glabrae v. sparse pilosae; bractearum lobi ciliati, ceterum glabri, laterales plus minusve ereeti; samararum alae interdum satis angustae. Ramuli plus minusve glandulosi, rarius fere eglandulosi, interdum initio sparse pilosi. Folia basi truncata, sabrotunda, leviter cordata $\mathbf{v}$. subacuta, margine satis aequaliter et grosse $\mathbf{v}$. inaequaliter dentato-serrata (haud distincte lobulato-serrata serraturis longe acuminatis), subtus (v. utrinque) ad nervos sericea, interdum barbulata v. plus minusve glabra, glandulis subtus numerosis praedita v. fere eglandulosa, nervis utrinque (6-)7-11).

NORTHEASTERN ASIA. Kamtchatka: "in montibus" A. Erman (type, ex Chamisso); Petropavlovski, C. Wright (distributed as B. fruticosa). Korea: "distr. Musang, vallis Segel-su, fluvium Tumingan," June 18, 1897, V. Komarov (No. 487; fruits); Mamili Mt., August 13, 1906, F. N. Meyer (No. 156; resembling var. subcordata in the serration of the leaves; fruits); Quelpaert (ex Nakai). Saghalien: without locality, Fr. Schmidt (? type of var. acutifolia); "in sylvis Wladimirof," July 22, 1908, U. Faurie (No. 293); same place, June 1908, U. Faurie (No. 291; young fruits); "in plateis Wladimirof," June 1908, U. Faurie (No. 289; flowers); "in silvis basi montium," October 18, 1907, U. Faurie (No. 5; the shape of the leaves agrees well with Erman's plate, the wings of the seeds are very narrow); Soroviyofka (type of var. sachalinensis, ex Koidzumi).

JAPAN. Hokkaido: prov. Shiribeshi, Shiribeshi-san, alt. 300-2200 m., abundant, base to summit, July $27,1914, E$. H. Wilson (No. 7279; tree up to $23 \mathrm{~m}$. tall, girth $4 \mathrm{~m}$., bark pale gray, smoothish; also reduced to shrub with long spreading branches, commonly rising from thick very short base); prov. Ishikari, Teinesan, abundant, July $31,1914, E$. H. Wilson (No. 7304; tree 13-20 m. tall, girth 0.6-2.4 m., bark grayish white; fruits); Sapporo, Mt. Moiwa, September 17, 1892, C. S. Sargent (tree 10-13 m. tall, girth 0.5-0.6 m., white bark; fruits); prov. Oshima, Hakodate, 1861, C. Maximowicz (distributed as B. ulmifolia typica); prov. Iburi, Mororan, August 24, 1905, J. G. Jack (fruits). Hondo : prov. Mutsu, near Aomori, 1200-1500 m., October 3, 1892, C. S. Sargent.

Betula Ermanii, var. genuina, subvar. Saitôana Schneider, n. subvar.

9 Betula Ermani, var. parvifolia Koidzumi in Tokyo Bot. Mag. XXVII. 148 (1913).

Betula Saitôana Nakai in Fedde, Rep. Spec. Nov. XIII. 249 (1914); in Tokyo Bot. Mag. XXIX. 43 (1915).

A typo recedit foliis minoribus, eirciter $3.5-5 \mathrm{~cm}$. longis et $2.5-3.5 \mathrm{~cm}$. latis, nervis lateralibus $6-8$. 
NORTHEASTERN ASIA. Korean Archipelago: Quelpaert: "in cratere Hallai-san," alt. 2000 m., August 13, 1908, Taquet (Nos. 1440, type, et 1439; fruits); same locality, June 1907, U. Faurie (No. 1538; flowers); " in sylvis Hallai-san," alt. 1200 m., June 17, 1907, U. Faurie (No. 1539; fruits); "in vertice Hallai-san," alt. $2000 \mathrm{~m}$., June 17, 1907, U. Faurie (No. 1540; young fruits); "in sylvis secus torrentes," Hallai-san, alt. 1700 m., September 1909, U. Faurie (No. 3234; fruits); "in summo montis Chananbon," alt. 1910 m., July 7, 1913, T. Nakai (No. 678, ex Nakai).

JAPAN. Hokkaido: prov. Ishikari, Teine-san, G. Koidzumi( type of var. parvifolia, ex Koidzumi).

This subvariety represents the most southern form of the species and comes from a locality where we find so many peculiar plants. Koidzumi's variety seems to be only a form of the typical $B$. Ermanii which was collected by Wilson (No. 7304) on the same mountain.

Betula Ermanii, var. genuina, subvar. brevidentata Schneider, n. subvar.

A typo recedit foliis satis parvis $3-5 \mathrm{~cm}$. longis et $2-4 \mathrm{~cm}$. latis late ovatis, basi cordatis margine satis breviter et regulariter dentatis $\mathrm{v}$. serratis, nervis lateralibus 6-7(-8).

JAPAN. Hondo: prov. Rikuchu, Hayachine-san, abundant, alt. 2000 m., September 28, 1914, E. H. Wilson (No. 7577, type; bush; fruits).

I mention this alpine form only on account of the serration of its leaves. The shape of the leaves is more like that of var. subcordata Koidzumi, but their serration resembles that of the typical $B$. Ermanii. It may represent another oecological form like subvar. Saitôana Schneider.

Betula Ermanii, var. subcordata Koidzumi in Tokyo Bot. Mag. XXVII. 148 (1913).

Betula Bhojpaltra, var. subcordata Regel in Bull. Soc. Nat. Mosc. XXXVIII. pt. 2, 416 (1865); in De Candolle, Prodr. XVI. 2, 177 (Bhojpattra) (1868).Franchet \& Savatier, Enum. Pl. Jap. I. 406 (Bhojpattra) (1875).

Betula Ermani, var. nipponica Maximowicz in Bull. Acad. Sci. St. Pétersbourg, XXXII. 622 (1888); in Mél. Biol. XII. 923 (1888). - Shirasawa, Icon. Ess. For. Jap. II. t. 14, fig. 16-23 (1908).

Betula alba, var. communis Shirai in Tokyo Bot. Mag. VIII. 319, t. 6, fig. 3032 (1894).

Betula Bhojpattra, var. japonica Shịrai in Tokyo Bot. Mag. XIX. (165) (1905).

Betula Ermani, var. genuina Winkler in Engler, Pflanzenr. IV.-61, 66 (pro parte) (1904).

Betula Vulcani Léveillé in Bull. Soc. Bot. France, LI. 423 (1904).

Betula Ermani, var. subcordata, f. nipponica Koidzumi in Tokyo Bot. Mag. XXVII. 149 (1913).

Betula Ermani, var. japonica Koidzumi, 1. c. 149 (1913).

Betula Ermani, var. communis Koidzumi, 1. c. 149 (pro parte) (1913).

? Betula Ermani, var. incisa Koidzumi, 1. c. 148 (1913).

Betula nikoensis Koidzumi mss., ex Koidzumi, 1. e. (pro synon.) (1913); in Matsumura, Icon. Pl. Koisikav. II. 17, t. 93 (1914).

Varietati genuinae valde similis ab ea praecipue recedit foliis saepius distinctius cordatis, serraturis angustioribus acutioribus inaequalibus, saepe lobulatis, nervis lateralibus saepissime $10-14$.

NORTHEASTERN ASIA. Saghalien: Toyohara, common, August 3, 1914, E. H. Wilson (No. 7338; tree 14-20 m. tall, girth 1.5-2.4 m., bark grayish white, shaggy; fruit); in montibus Takinosawa, July 24, 1908, U. Faurie (No. 292; fruits); isl. Kaibato (type of var. incisa, ex Koidzumi). 
JAPAN. Hokkaido: "in alpibus To-ka-chi," July 1905, U. Faurie (No. 6636; flowers; No. 6637; fruits); " in sylvis Jirafu," June 26, 1905, U. Faurie (No. 6633 ; fruits). Hondo: prov. Mutsu, Mt. Hakkoda, common, middle and upper slopes, July 5, 1914, E. H. Wilson (No. 7094; tree 8-17 m. tall, girth 0.3-3 m., often mop-headed, bark fine, pale gray; young fruits); same locality, August 1904, U. Faurie (No. 5784; fruits); prov. Ugo, Chokai-san, common near tree limit, October $9,1914, E . H$. Wilson (No. 7172 , bush $5 \mathrm{~m}$. tall; fruits); prov. Rikuchu, Hayachine-san, June 6, 1905, U. Faurie (No. 6639; flowers); prov. Iwashiro, Ose, August 17, 1912 (ex Herb. Sakurai; young fruits); prov. Shimotsuke: round Yumoto, Onsenga-dake, alt. 2200-2300 m., woods, common, June 23, 1914, E. H. Wilson (Nos. 6860, 6864; tree 8-13 m. tall; flowers); same prov., Yumoto, Hemlock forest, common, September 6, 1892, C. S. Sargent (largê tree, spreading orangecolored branches, young trunks pale, old trunks dark with thick bark, bark exfoliating; sterile); same prov., round Chuzenji, alt. 1300-1800 m., May 25, 1914, E. H. Wilson (No. 6751; tree 20-27 m. tall, girth 0.6-3.6 m., bark grayish white, exfoliating in thin sheets, common Birch; flowers); same locality, August 12, 1905, J. G. Jack (fruits); same prov., summit of Nantai-san, alt. 2600 m., May 29, 1914, E. H. Wilson (No. 6789; bush 1.2-3 m. tall); same locality, August 2, 1908 (Herb Sakurai; leaves very cordate with elongated unequal teeth); Nikko, August 8, 1904, and August 12, 1909 (Herb. Sakurai; co-types of var. japonica Koidzumi [B. nikoensis Koidzumi]); same locality, 1904, N. Mochizuki; same prov., Mt. Nasu, August 19, 1908, and July 7, 1911 (Herb. Sakurai); prov. Kozuke, Mt. Asama, 2600 m., August 11, 1909 (Herb. Sakurai); same locality, July 14, 1904, U. Faurie (No. $5783)$; prov. Shinano, on Tsubakura-dake, alt. 2000-2600 m., abundant, September $13,1914, E$. H. Wilson (No. 7511 ; tree up to $20 \mathrm{~m}$. tall, girth $2.4 \mathrm{~m}$., much branched); same prov., Komaga-take, July 1905, U. Faurie (Nos. 6628, 6629); prov.?, Ubaya, July 4, 1904, U. Faurie (No. 5785); without locality, 1892, C.S. Sargent (tree $26 \times 0.9 \mathrm{~m}$., pale bark, orange-colored branches, handsome).

The specimens from Saghalien and Hokkaido referred to this variety differ partly in having fewer veins as in var. genuina, but their serration is mostly like that of the forms of var. subcordata from Hondo. It is as difficult to separate the last variety from var. genuina as it is to distinguish different forms of var. subcordata. These forms which Koidzumi has described as B. nikoensis have rather triangular leaves with a truncate base and 11-14 lateral veins, while what we may call typical var. nipponica has distinctly cordate leaves which are more round-ovate, with 9-12 veins. I have failed to detect any characters sufficient to distinguish these forms in a satisfactory way.

Betula Ermanii, var. lanata Regel, in Nouv. Mém. Soc. Nat. Mosc. XIII. pt. 2, 122 (Monog. Betulac. 64), t. 6, fig. 37-38 (1861); in Bull. Soc. Nat. Mosc. XXXVIII. pt. 2, 415 (1865); in De Candolle, Prodr. XVI. pt. 2, 177 (1868). Betula Ermani Trautvetter \& Meyer in Middendorff, Reise Sibir. I. pt. 2, Bot. abt. 2, 83 (Fl. Ochot.) (1856).

Betula Ermani, var. tomentosa Regel in Bull. Soc. Nat. Mosc. XXXVIII. pt. 2, 415 (1865); in De Candolle, Prodr. XVI. pt. 2, 177 (1868).

Gemmarum squamae basi strobilorum tota facie albo-lanatae. Bractearum lobi valde ciliati et etiam exteriore facie plus minusve puberuli, laterales distincti erecti. Ramuli initio puberuli v. tomentelli. Folia plus minusve triangularia v. triangulari-ovata, breviter acuta, satis grosse subaequaliter dentatoserrata, nervis utrinque 7-9(-10); petioli pilosi.

NORTHEASTERN ASIA. Maritime prov.: "ad fl. Dshukdschandran," July 10-12, 1844, A.T. von Middendorff (type of var. tomentosa, ex Regel); prope 
Ajan, H. Tiling (type of var. lanata); Ochotsk Sea, J. Small (Herb. N. Pacif. Expl. Exped. Wright Coll.).

These northern forms seem to be well distinguished by the characters indicated above.

7. Betula Jacquemontii Spach in Ann. Sci. Nat. sér. 2, XV. 189 (1841).Jacquemont, Voy. VI. t. 158 (1844), - Regel in De Candolle, Prodr. XVI. pt. 2, 178 (1868). - Bean, Trees \& Shrubs Brit. Isl. I. 257 (1913).

Betula Bhojpaltra, var. Jacquemontii Regel in Nouv. Mém. Soc. Nat. Mosc. XIII. pt. 2, 118, t. 6, fig. 19 (Monog. Betulac. 60) (pro parte) (1861); in Bull. Soc. Nat. Mosc. XXXVIII. pt. 2, 416 (1865); in De Candolle, Prodr., XVI. pt. 2, 177 (Bhojpattra) (1868).

? Betula alba, var. glutinosa, lusus latifolia Regel in Nouv. Mém. Soc. Nat. Mosc. XIII. 79 (Monog. Betulac. 21) (1861), quoad specim. Indiae Orient.

i Betula Bhojpaltra, var. glandulifera Regel in Bull. Soc. Nat. Mosc. XXXVIII. pt. 2, 416 (1865); in De Candolle, Prodr. XVI. pt. 2, 177 (Bhojpattra) (1868).

Betula utilis, var. Jacquemontii Henry in Elwes \& Henry, Trees Gr. Brit. \& Irel. IV. 981, t. 270, fig. 15 (1909).

INDIA. Kuma on: "Emodo," V. Jacquemont (type, ex Spach); Chumpua, 3400 m., Strachey \& Winterbottom (No. 1; flowers). United Prov.: Dehra Dun, Deota, alt. 2400 m., June 9, 1912, Sulakhan Singh (No. 98). Kashmir: Zanskar, "14000 ped.," T. Thomson (young leaves); without locality, "9-11000 ped.," T. Thomson; Ahbad, alt. 3300 m., C. B. Clarke (No. 28928; young leaves); Hazara distr., Kagan valley, alt. 2600 m., May 1910; "Tibet, prov. Hasóra, Sangu Sar, on the right side of the Tsúnger glacier," September 12, 1856, Schlagintweit (No. 6568); Rimkim, 3800 m., Strachey \& Winterbottom (No. 2; fruits).

AFGHANISTAN. Kurrum valley, 1879, J.E. T. Aitchison (No. 719).

This species certainly needs further observation. I am not sure whether the plants described by Henry and Bean are really the same as Spach's species, the type of which I have not been able to examine. ${ }^{1}$ Henry and Bean refer to trees in Kew Gardens obtained from Petrograd.

By the kindness of the Keeper of the Kew Herbarium I have been able to compare a dried specimen of the plant cultivated in Kew. It certainly much resembles $B$. Jacquemontii, but the leaves are almost glabrous, a little more ovate in shape and with relatively long petioles. The fruiting bracts show a denser and shorter ciliation, and their lateral lobes are blunter and somewhat shorter compared with the middle one. The pubescence of the branchlets of even the second year is very short and fine and the young branchlets are less glandular. Unfortunately there is no record in Petrograd where the original seeds came from. Young plants in the Arnold Arboretum raised from seeds sent by Mr. R. N. Parker from the northeastern Himalaya look different. The plant in Kew, however, seems more nearly related to $B$. Jacquemontii than to any other Birch I have seen from the Himalayas or eastern Asia. Neither can I refer it to any North American species so far as I know them, nor to any of the numerous hybrids in cultivation. I am

${ }^{1}$ At my request Dr. Gagnepain has kindly looked at the type-specimen in the herbarium of the Muséum d'Histoire Naturelle at Paris. According to his report the type of B. Jacquemontii is certainly different from Wallich's types of $B$. bhojpattra. Jacquemont's plant seems to represent a form without glands on the leaves. In the shape of the fruiting bracts there is apparently no real difference between these two species. 
deeply indebted to Dr. Stapf for much valuable information in this matter and take the liberty to print in a note a part of one of his very interesting letters. ${ }^{1}$

I suppose that typical $B$. Jacquemontii represents the most western form of all these forms which I include under this species and under B. utilis D. Don and $B$. albo-sinensis Burkill. Certainly they are all very similar, but it seems better to keep these species separated according to their geographical distribution until further observations on abundant material can show that the northwestern Himalayan forms are clearly connected by intermediate forms with those of eastern India and central China.

8. Betula utilis D. Don, Fl. Nepal. 58 (1825). - Hooker f., Fl. Brit. Ind. V. 599 (1888). - Dippel, Handb. Laubholzk. II. 187 (pro parte) (1892). - ? Koehne, Deutsche Dendr. 108 (1893). - Gamble, Man. Indian Timb. ed. 2, 668 (pro parte) (1902). - Schneider, Ill. Handb. Laubholzk. I. 102, fig. 53 g (pro parte) (1904). Winkler in Engler, Pflanzenr. IV.-61, 61 (pro parte) (1904).-Brandis, Ind. Trees, 622, fig. 191 (pro parte) (1906). - Henry in Elwes \& Henry, Trees Gr. Brit. \& Irel. IV. 980, t. 269, fig. 7 (excl. var.) (1909). — Bean, Trees \& Shrubs Brit. Ist. I. 263 (1913).

Betula Bhojpattra Wallich, Icon. Pl. As. Rar. II. 7 (1831), - Brandis, For. Fl. Brit. Ind. 457 (pro parte) (1874).

i Betula Bhojpaltra Spach in Ann. Sci. Nat. sér. 2, XV. 189 (1841).

Betula Bhojpaltra, var. genuina Regel in Nouv. Mém. Soc. Nat. Mosc. XIII. pt. 2, 59, t. 13, fig. 7-12 (Monog. Betulac.) (pro parte) (1861).

Betula Bhojpattra, var. typica et var. latifolia Regel in Bull. Soc. Nat. Mcsc.

${ }_{1}$ Dr. Stapf writes: " $B$, utilis D. Don and $B$. bhojpattra, Wall. are absolutely synonymous as they have been based on the same specimens, that is, specimens collected at Gossainthan in Nepal. B. utilis is the earlier name and has, therefore, priority over $B$. bhojpattra. The species extends into Kumaon and I have no doubt that the specimen collected by Blinkworth (Wallich n. 2792 B.) is the same. We further possess specimens collected by Strachey and Winterbottom at Champwa in Kumaon, at 11500 feet. All our other specimens from Kumaon and westwards to Kashmir and Hazara are with one exception evidently B. Jacquemontii. We do not possess Jacquemont's type, but there can be no doubt about it. Spach's "in emodo" simply means that Jaequemont collected it on the Himalayas (very probably in the Sutledj valley), "emodus" being a common Latin term for Himalaya, We have the following specimens of B. Jacquemontii: Kumaon, "in excelsis," Munro (n. 2958); Tihri Garhwal, near the Tibetan frontier, Rimkim, 13500', Strachey \& Winterbottom (n. 2); Upper Ganges valley, above Jangla, Duthie (366); Northwest India (probably Garhwal) (Hb. Royle); Sirmor, Hattu, Thomson; Kunawur (basin of the Sutledj) near the top of the Werang Pass, Thomson; Lahul, Jaeschke (280); Chamba, Ellis; Kishtwar, 10000', Thomson; Zanskar, 14000', Thomson; Kashmir, Gurais Pass, Winterbottom (184) and Clarke (29282); Burzil valley, Winterbottom (1841/2); Zoji La, Thomson, Henderson; Banahal Pass, Thomson; Afghan frontier, Shend Toi Hills, $11000^{\prime}$, Aitchison (719; 10-11000', not common); Aitchison (228)."

"The one exception mentioned above is a sheet containing two specimens collected by Edgeworth at Maduum (n. 247) and Junghury (n. 248). I have not succeeded in tracing these localities, but Junghury may be Janghary in the Upper Sutledj valley, where Edgeworth was. We know he collected there and in Tihri Gharwal and also around Simla. These specimens appear to be intermediate between B. utilis and B. Jacquemontii, but rather nearer to the latter." 
XXXVIII. pt. 2, 416 (Bhojpaltra) (1865); in De Candolle, Prodr. XVI. pt. 2, 177 (1868).

INDIA. Sikkim : Lachung valley, alt. 3800 m., August 22, 1892, G. A. Gammie (common tree); without locality, "10-14000 ped.," J. D. Hooker. Eastern Nepal: Gossainthan, N. Wallich (type, ex D. Don).

I regard this eastern form as the true $B$. utilis $D$. Don, which seems to be more nearly related to the central Chinese forms, especially to var. Prattii Burkill, than to $B$. Jacquemontii Spach. Unfortunately I have seen too little material from the eastern Himalaya to be sure whether the differences in the bracts, mentioned in the key, are important enough to separate the Chinese forms. According to Dr. Stapf (in lit.) the true $B$. utilis seems to be somewhat different from the plants from Sikkim, and only observations in the field can show whether or not different species can be distinguished.

Betula utilis, var. Prattii Burkill. See p. 457.

9. Betula albo-sinensis Burkill. See p. 457.

Betula albo-sinensis, var. septentrionalis Schneider. See p. 458.

Subsect. b. Asperae Schneider, n. subsect. (descriptio in elavi).

Betula, subgen. Asperae Nakai in Tokyo Bot. Mag. XXIX. 41 (1915).

10. Betula Schmidtii Regel in Bull. Soc. Nat. Mosc. XXVIII. pt. 2, 412, t. 6, fig. 14-20 (1865); in De Candolle, Prodr. XVI. pt. 2, 175 (1868). - Herder in Act. Hort. Petrop. XII. 68 (1892), - Komarov in Act. Hort. Petrop. XXII. 52 (Fl. Mansh. II.) (1903). - Nakai in Jour. Coll. Sci. Tokyo, XXXI. 201 (Fl. Kor. II.) (1911); in Tokyo Bot. Mag. XXIX. 44 (1915), - Koidzumi in Tokyo Bot. Mag. XXVII. 146 (1913).

Betula Bhojpattra, var. typica Shirai in Tokyo Bot. Mag. VIII. 319, t. 6, fig. 25-29 (non Regel) (1894). - Shirasawa, Icon. Ess. For. Jap. I. 44, t. 23, fig. 9-22 (1900).

Betula Bhojpattra, var. Jacquemontii Shirai in Tokyo Bot. Mag. VIII. 320, t. 6, fig. 23-24 (non Regel) (1894).

Betula dahurica Shirai in Tokyo Bot. Mag. XIX. 164 (non Pallas) (1905). Matsumura, Ind. Pl. Jap. II. pt. 2, 19 (1912).

Betula punctata Léveillé ex Nakai in Tokyo Bot. Mag. XXIX. 44 (pro synon.) (1915).

NORTHEASTERN ASIA. Ussuri: Port Bruce, 1860; C. Maximowicz (cotype; fruits). Korea (ex Nakai).

JAPAN. Hondo: prov. Shimotsuke, around Lake Chuzenji, alt. 1200-1600 m., May 24, 1914, E. H. Wilson (No. 6741; tree 13-20 m. tall, girth 1.2-2.7 m., bark very dark, peeling off in thick rectangular plates; flowers); same place, October 20, 1914, E. H. Wilson (No. 7687; tree 30-35 m. tall, girth 2.1-3 m., bark in thick dark plates, fruits erect); Sho-buga-hama, August 2, 1908 (ex Herb. Sakurai; unripe fruits); Nikko, July 15, 1911 (ex. Herb. Sakurai; unripe fruits).

This is a well-marked species characterized by the narrow but stiff erect catkins, and by the fine denticulation of the short-petioled leaves. The bracts are rather short with obtusish or acute lobes, the middle one being twice longer than the erect lateral lobes. There is a living plant in the Arnold Arboretum the bark and the twigs of which do not possess the peculiar scent of that of $B$. grossa Siebold \& Zuccarini, $B$. corylifolia Regel \& Maximowicz or of the species of the Lentae group.

This remarkable Birch is rare in Japalx, and I saw it only on the wooded shores of Lake Chuzenji and in the ascent there from Nikko. It is a large tree with thick 
branches and black bark which falls ofi in thick, rather small plates of irregular shape. Pictures of this Birch will be found under Nos. x297 and x304 of the collection of my Japanese photographs.

E. H. W.

Subsect. c. Corylifoliae Schneider, n. subsect. (descriptio in clavi).

11. Betula corylifolia Regel \& Maximowicz in Bull. Soc. Nat. Mosc. XXXVIII. pt. 2, 417, t. 8, fig. 1-3 (1865). - Regel in De Candolle, Prodr. XVI. pt. 2, 178 (1868). - Franchet \& Savatier, Enum. Pl. Jap. I. 456 (1875). — Shirai in Tokyo Bot. Mag. VIII. t. 6, fig. 20-22 (1894). - Schneider, Ill. Handb. Laubholzk. I. 99, fig. $53 \mathrm{p}, 54 \mathrm{i}-\mathrm{i}^{2}$ (1904). - Winkler in Engler, Pflanzenr. IV.-61, 59, fig. 17 (1904). - Shirasawa, Icon. Ess. For. Jap. II. t. 14, fig. 1-7 (1908). - Henry in Elwes \& Henry, Trees Gr. Brit. \& Irel. IV, 975, t. 275, fig. 14 (1909).

JAPAN. Hondo: prov. Shimotsuke, Yumoto, June 23, 1914, E. H. Wilson (No. 6847; tree 10-17 m. tall, girth 0.3-0.9 m., bark silvery gray, shoots with taste of B. lenta; young fruits and bark); same locality, fairly common in forests, October 16, 1914, E. H. Wilson (No. 7651; with old strobiles); Konsei-toge, August 7, 1911 (ex Herb. Sakurai; fruits); prov. Shinano: on Tsubakuradake, fairly common in forests, alt. 2000-2600 m., September $13,1914, E . H$. Wilson (No. 7502; tree up to $17 \mathrm{~m}$. tall, girth $1.2 \mathrm{~m}$.; fruits); same prov., Mt. Ontake, woods, 2800 m., June 11, 1914, E. H. Wilson (No. 7024; thin tree, 8$12 \times 0.3-0.6 \mathrm{~m}$., taste of B. lenta; flowers); same prov., 1862, C. Maximowicz (young fruits); Tokakushi-san, July 12, 1884 (ex Herb. Sci. Coll. Univ. Jap.; young fruits); prov. Uzen, Adzuma-san, alt. 1000-1500 m., woods, not common, July $20,1914, E$. $H$. Wilson (No. 7228 ; tree 8-15 m. tall, girth $0.3-0.9 \mathrm{~m}$., shoots fragrant; fruits); prov. Nambu, 1865, Tschonoski (co-type; fruits).

An extremely well-characterized species which in the whitish-gray color of the somewhat papillose under surface of the leaves resembles the American $B$, nigra Linnaeus, which otherwise is quite different. In the herbarium the fruiting catkins look as if they were nodding, but they are erect, the branches being a little drooping.

This very distinct species occurs sparingly in the Nikko region between altitudes of from 1500 to $2300 \mathrm{~m}$., and southward on the higher mountains to those of the Shinano province, where on Ontake and Tsubakura-dake it is fairly common. I met with it most plentifully however on Adzuma-san in the province of Uzen to the north of Nikko. It also grows on the lower well-forested slopes of Hayachine-san, which is about the northern limit of the range of this species. It is a tree of moderate height with a rather slender trunk, smooth pale gray to white bark and thin spreading and decurved branches and pendent branchlets. The fruit is erect, and the shoots and inner bark have a fragrance similar to that of the American Cherry Birch (B. lenta Linnaeus).

Subsect. d. Grossae Schneider, subsect. nov. (descriptio in clavi).

In some respects the forms of this subsection resemble those of subsect. Ermanianae, and I am not quite sure whether $B$. costata Trautvetter should not be referred to the last subsect. Ermanianae (as Nakai did) or not. If its twigs have the same smell as those of B. grossa Siebold \& Zuccarini, these two species are nearly related. Otherwise B. costata Trautvetter may be placed nearest to B. albo-sinensis Burkill because according to Maximowicz its bark seems to be similar. All the species of this subsection have nearly sessile, erect, short-elliptical or even nearly globose cones, or the cones are very thick and large as in B. insignis Franchet.

12. Betula costata Trautvetter in Mém. Sav. Êtr. Acad. Sci. St. Pétersbourg, IX. 253 (Maximowicz, Prim. Fl. Amur.) (1859). - Komarov in Act. Hort. 
Petrop. XXII. 43 (Fl. Mansh. II.) (1903). - Nakai in Tokyo Bot. Mag. XXIX. 43 (1915).

Betula Ermani, var. costata Regel, in Nouv. Mém. Soc. Nat. Mosc. XIII. pt. 2, 123, t. 13, fig. 1-6 (Monog. Betulac. 65) (1861).

Betula ulmifolia, var. costata Regel in Bull. Soc. Nat. Mosc. XXXVIII. pt. 2, 414 (1865); in De Candolle, Prodr. XV1. pt. 2, 176 (1868). - Herder in Act. Hort. Petrop. XII. 68 (1892). - Winkler in Engler, Pflanzenr. IV.-61. 64 (1904).

Betula ulmifolia Dippel, Handb. Laubholzk. II. 188 (pro parte, non Siebold \& Zuccarini) (1892). - Koehne, Deutsche Dendr. 108 (pro parte) (1893). Schneider, Ill. Handb. Laubholzk. I. 101, fig. $530-\mathrm{o}^{1}, 54 \mathrm{k}-\mathrm{k}^{1}$ (pro parte maxima) (1904).

NORTHEASTERN ASIA. Mandshuria: fluvium Sutar, circa Kanskii, June 13, 1895, V. Komarov (No. 485; sterile); 12 hours east of Harbin, mountains, April 31, 1903, C. S. Sargent (large tree, with pale yellow scaly bark on trunk and large branches; sterile). Amur: without precise locality, 1859, C. Maximowicz (fruits). Korea: "in montibus Chirisan" (ex Nakai).

As far as $I$ can judge from the material before me the most distinct eharacter of this species seems to be the rather narrow ovate-oblong acuminate leaves with numerous nerves and very fine and acuminate double serration. The shoots are glabrous or show a fine villose pubescence like those of forms of $B$. grossa Siebold \& Zuccarini.

13. Betula grossa Siebold \& Zuccarini in Abh. Akad. Münch. IV. pt. 2, 228 ( Fl. Jap. Fam. Nat. 1. 104) (1845). - Regel in Bull. Soc. Nat. Mosc. XXXVIII. pt. 2, 417 (1865); in De Candolle, Prodr. XVI. pt. 2, 178 (1868). - Shirai in Tokyo Bot. Mag. VIII. 320, t. 6, fig. 13-15 (1894). - Shirasawa, Icon. Ess. For. Jap. I. t. 22, fig. 12-25 (1900). - Schneider, Ill. Handb. Laubholzk. 11. 884 (1912). Rehder in Bailey, Stand. Cycl. Hort. I. 499 (1914).

? Betula alba Thunberg, Fl. Jap. 76 (non Linnaeus) (1784).

Betula carpinifolia Siebold \& Zuccarini in Abh. Akad. Münch. 1V. pt. 2, 228

(Fl. Jap. Fam. Nat. I. 104) (1845). - Regel in Bull. Soc. Nat. Mosc. XXXVIII. pt. 2, 417 (1865); in De Candolle, Prodr. XVI. pt. 2, 178 (1868). - Winkler in Engler, Pflanzenr. 1V.-61, 62 (1904).

Betula ulmifolia Siebold \& Zuccarini in Abh. Akad. Münch. IV. pt. 2, 229 (Fl. Jap. Fam. Nat. I. 105) (1845), - Regel in Nouv. Mém. Soc. Nat. Mosc. XIII. pt. 2, 124, t. 6, fig. 20-25 (Monog. Betulac. 66) (1861); in Bull. Soc. Nat. Mosc. XXXVIII, pt, 2, 412 (pro parte) (1865). - Shirai in Tokyo Bot. Mag. VIII. 320, t. 6, fig. 16-19 (1894). - Shirasawa, Icon. Ess. For. Jap. I. t. 22, fig. 1-11 (1900), - Henry in Henry \& Elwes, Trees Gr. Brit. \& Irel. IV. 979 (1909). - Bean, Trees \& Shrubs Brit. Isl. I. 263 (1914).

Betula lenta, var. grossa Regel, in Nouv. Mém. Soc. Nat. Mosc. XIII. pt. 2, 127, t. 6, fig. 27-28 (Monog. Betulac. 69) (1861).

Betula lenta, var. carpinifolia Regel, 1. c. (1861).

Betula ulmifolia, var. sericea Winkler in Engler, Pflanzenr. IV.-61, 64 (1904).

JAPAN. Hondo: prov. Rikuchu, Hayachine-san, June 6, 1905, U. Faurie (No. 6638); prov. Shimotsuke: Nikko, alt. $1200 \mathrm{~m}$., May 18, 1914, E. H. Wilson (No. 6710 ; tree $13 \mathrm{~m}$. tall, girth $1.2 \mathrm{~m}$, bark smooth, dark gray; flowers); round Lake Chuzenji, common, May 23, 1914, E. H. Witson (No. 6735; tree 17-25 m. tall and 1.2-3.6 m., bark dark gray; flowers); same locality, October 21, 1914, E. H. Wilson (No. 7680; tree 20-25 m. tall, girth 2.1-3 m., "Yoguro-minebari," 
fruit erect); descent from Chuzenji to Nikko, October 21, 1914, E. H. Wilson (No. 7701; tree $12 \mathrm{~m}$. tall, girth $0.75 \mathrm{~m}$.; fruits); shores of Lake Yumoto, November 7, 1892, C. S. Sargent (tree 10-13 m., dark bark, the branchlets with the flavor of those of B. lenta; fruits); prov. Shinano, on Tsubakura-dake, alt. 1000-1600 m., September 15, 1914, E. H. Witson (No. 7485; tree 12-17 m. tall, girth 0.6-1.2 m., bark black, Cherry Birch; fruits); same prov., 1864, C. Maximowicz (co-type of $B$. utilis, var. sericea; flowers); Mt. Ontake, July 1905, $U$. Faurie (No. 6627; fruits); prov. Musashi, Takao-san, one tree in wood, alt. 100-1600 m., September 24, 1914, E. H. Wilson (No. 7163 ; tree $18 \mathrm{~m}$. tall, girth 1.8 m., bark gray, rough, a Cherry Birch; sterile); prov. Kozuke, Mt. Akagi, August 19, 1908 (ex Herb. Sakurai; fruits); without locality, Siebold (ex Herb. Mus. Lugd.-Bat., co-type of B. carpinifolia). Shikoku: prov. Tosa, Nanokawa, May 27, 1888, A. Watanabe (fruits).

A carefuI study of copious material has failed to show the possibility of distinguishing varieties of this species by the pubescence of the branchlets and bracts, the shape of the bracts and leaves or by other characters. The Director of the Botanical Museum in Munich has kindly sent photographs and fragments of the type specimens of $B$. carpinifolia and B. ulmifolia ex Herb. Zuccarini. There ean be no doubt that both belong to B. grossa. Betula carpinifolia is identical, but $B$. ulmifolia, as stated by the authors in their original description, differs slightly in having bracts with narrower lobes, the middle one being twice the length of the lateral lobes. I have retained the name $B$. gross $a$ for this species because the name $B$. ulmifolia has been used for so many different plants, espeeially for $B$. Ermanii Chamisso which is easily distinguished by the much more triangular-ovate shape of the leaves and especially by the shape of the strobiles and bracts. $B$. grossa differs from it, too, by the Cherry flavor of the bark of the branchlets and the dark bark.

This Japanese Cherry Birch is very common in mixed woods on the mountains of the Shinano province in central Japan northward to near the limits of the island of Hondo. It has not been reported from Hokkaido and very probably does not grow there. It oceurs on the higher mountains of Shikoku and probably on those of Kyushu also. It grows to a large size, and the trunk in thickness rivals that of $B$. Ermanii Chamisso. The branches are stout and the erown wide-spreading. On trees from thirty to fifty years of age the bark is black or nearly so and perfectly smooth, but on older trees it becomes fissured and rather lighter in color. The speeies, however, is well marked, and in Japan may be readily distinguished in the woods from any other. Pictures of this tree will be found under Nos. $\times 253$ and $\mathrm{x} 254$ of the collection of my Japanese photographs.

E. H. W.

14. Betula Fargesii Franchet in Jour. de Bot. XIII. 205 (1899). - Burkill in Jour. Linn. Soc. XXVI. 498 (1899). - Diels in Bot. Jahrb. XXIX. 282 (1900). Winkler in Engler, Pflanzenr. IV.-61, 66 (1904).

Eastern Szech'uan: Heoupin near Tchen-keou-tin, alt. 2200 m., P. Farges (No. 1012; type, ex Franchet). Western Hupeh: Fang Hsien, A. Henry (No. 6879; sterile).

From Franchet's description it is rather difficult to decide whether Henry's specimen is the same as B. Fargesii, as Burkill says who has seen the type. Winkler gives a somewhat better description of the type, but he did not see Henry's specimen. This sterile specimen resembles B. albo-sinensis Burkill, but differs in having the ends of the branchlets very fine pubescent. According to the descriptions of the cones, bracts and seeds by Franchet and by Winkler, B. Fargesii might represent in China, where it seems to be a very local species, a type similar to $B$. grossa.

15. Betula insignis Franchet. See p. 459. 
16. Betula globispica Shirai in Tokyo Bot. Mag. VIll. 318, t. 6, fig. 1-6 (1894).Shirasawa, Icon. Ess. For. Jap. I. tab. 21, fig. 16-32 (1900). - Schneider, Ill.

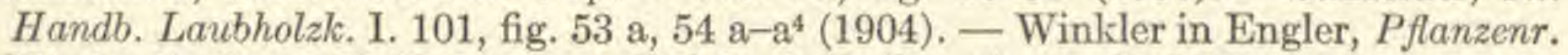
IV.-61. 67, fig. 19 D-F (1904). - Rehder in Bailey, Stand. Cycl. Hort. I. 499 (1914).

Hondo: prov. Musashi, Mt. Mitsumine in Katsuradaira forest, October 17, 1893, M. Shirai (fruiting type, ex Shirai); Mt. Mitsumine, October 1908, M. Koyama (fruits); prov. Shimotsuke, Nikko, near the tea-house in front of the Kegon waterfall, April 3, 1894, M. Shirai (ex Shirai); descent to Kegon fall, around Lake Chuzenji, on cliffs, October 20, 1914, E. H. Wilson (No. 7708; tree $15 \mathrm{~m}$. tall, girth $1.5 \mathrm{~m}$., bark whitish in papery flakes; fruits); Lake Chuzenji, August 30, 1904, N. Mochizuki (fruits); same locality, August 12, 1905, J. G. Jack (fruits); Mt. Akanagi, about 1700 m., July 7, 1910 (ex Herb. Sakurai; fruits).

A species well distinguished by its broad-or orbicular-ovate, rather coarsely but sharply serrated leaves and by its subglobular cones with narrowly lobed bracts. It seems to be a very local species. There are living plants in the Arnold Arboretum.

This species is said to be common on Mt. Mitsumine, but I overlooked it when collecting on that mountain. The only tree I saw grows on the cliffs just past the first waterfall on the way to the foot of the Kegon waterfall near Lake Chuzenji in the Nikko region. This tree is about $15 \mathrm{~m}$. tall with a trunk $1.5 \mathrm{~m}$. in girth, and the bark is nearly white and separates in thin loose sheets.

E. H. W.

Subsect. e. Chinenses Schneider, n. subsect.

Betula, subgenus Chinenses Nakai in Tokyo Bot. Mag. XXIX. 41 (1915).

Frutices v. arbores parvae; ramuli ut videtur semper eglandulosi sed plus minusve villosuli. Folia satis parva et satis breviter petiolata. Strobili erecti, elliptici; samarae anguste alatae v. fere exalatae. Cetera ut in clavi (p. 464) indieata.

17. Betula Potaninii Batalin. See p. 459.

18. Betula Delavayi Franchet. See p. 460.

Betula Delavayi, var. Forrestii W.W. Smith in Not. Bot.Gard. Edinburgh, VIII, 332 (1915).

Yunnan: open situations in pine forests on the eastern flank of the Lichiang range, lat. $27^{\circ} 10^{\prime}$ N., alt. 3100 m., May 1910 , G. Forrest (No. 5546, type; tree 8-13 m. tall; ex Smith).

I have not seen the type of this variety, which is said to differ in its larger, broader, more obtuse leaves (up to $4.5 \mathrm{~cm}$. long and $3 \mathrm{~cm}$. broad and silky on the upper surface, and in its fruiting aments up to $3 \mathrm{~cm}$. long.

Betula Delavayi, var. calcicola W.W. Smith in Not. Bot. Gard. Edinburgh, VIII. 333 (1912).

CHINA. Yunnan: in the crevices of limestone cliffs on the eastern flank of the Lichiang range, lat. $27^{\circ} 20^{\prime}$ N., alt. $3400-3700$ m., June 1910, G. Forrest (No. 5835, type, ex Smith; dwarf shrub, 0.3-0.45 m.).

Not having seen the type of this variety which has densely tomentose young branchlets and roundish or oblong young leaves, I cannot decide whether it is a variety of $B$. Potaninii Batalin or of $B$. Delavayi Franchet.

19. Betula chinensis Maximowicz in Bull. Soc. Nat. Mosc. LIV. pt. 1, 47 (1879). - Burkill in Jour. Linn. Soc. XXVI. 498 (1899), - Komarov in Act. Hort. Petrop. XXV1. 42 (Fl. Mansh. II.) (1903). - Winkler in Engler, Pflanzenr. IV.-61, 67, fig. 19 G-F (1904). - Nakai in Jour. Coll. Sci. Tokyo, XXXI. 202 (Fl. Kor. II.) 
(1911); in Tokyo Bot. Mag. XXIX. 44 (1915). - Schneider, Ill. Handb. Laubholzk. Il. 488, fig. $5531-\mathrm{m}, 554 \mathrm{a}-\mathrm{b}$ (1912).

Betula exalata S. Moore in Jour. Linn. Soc. XVII. 386, t. 16, fig. 8-10 (1879).

Betula chinensis, var. angusticarpa Winkler in Engler, Pflanzenr. IV.-61, 67, fig. $19 \mathrm{~K}-\mathrm{L}$ (1904).

CHINA. Chili: Weichang, 1910, W. Purdom (No. 85; bush 1.8-3 m. tall; flowers and old cones); Pohua-shan, near top of Mt. Conolly, alt. 1600-1800 m., July 1877, E. Bretschneider (type, ex Maximowicz).

NORTHEASTERN ASIA. Mandshuria: Chien-shan, June 4, 1906, $F, N$. Meyer (No. 90; fruits); same locality, alt. 300 m., F. Ross (No. 223, 428, 478, 553; type of B. exalata, ex Moore and Burkill); prov. Mukden (ex Komarov). Korea: "Districtus Mu-sang, Trajectus Czao-rieng, Fluvium Tumingan," May 23, 1897, V. Komarov (flowers); " in montibus Nai-piang, supra $1000 \mathrm{~m}$.," August 1901. U. Faurie (No. 605; fruits); "in montibus Hoang-hai-to," August 1906, U. Faurie (No. 203; fruits); "in monte des diamants," June 24, 1906, U. Faurie (No. 204; young fruits).

Forms of this species sometimes much resemble $B$. davurica Pallas, which, as far as I have seen, has the young branchlets always more or less covered with glands, but otherwise they are glabrous or sparsely pilose, not silky-villose, as in $B$. chinensis. In the specimen distributed by U. Faurie under No. 204 the leaves are very similar to those of $B$. davurica Pallas, but the middle lobe of the fruiting bracts is as long as in typical $B$. chinensis and the pubescence of the young parts is the same. See also under $B$. davurica Pallas.

I do not know Betula collina Nakai (in Tokyo Bot. Mag. XXIX. 44 [1915]) from northern Korea, "in Colle Ungil." According to the description it must be very similar to $B$. chinensis Maximowicz.

Sect. 3. HUMILES W. D. Koch, Syn.Fl.Germ. Helv. ed. 2, 761 (1843). - Prantl in Engler \& Prantl, Nat. Pflanzenfam. III. abt. 1, 45 (1887). - Koehne, Deutsche Dendr. 107 (1893). - Schneider, Ill. Handb. Laubholzk. I. 103 (1904).

Betula, sect. Nanae Regel in Bull. Soc. Nat. Mosc. XXXVIII. pt. 2, 407 (1865).

To this section belong also different American species. Several of the forms referred here need a careful investigation.

Subsect. a. NANAe Schneider, n. comb.

Betula, sect. Eubetula, subsect. Nanae Regel in De Candolle, Prodr. XVI. pt. 2, 162 (pro parte) (1868). - Winkler in Engler, Pflanzenr. IV.-61, 69 (pro parte) (1904).

20. Betula nana Linnaeus, Spec. 983 (1753). - Regel in Bull. Soc. Nat. Mosc. XXXVIII. pt. 2, 407 (1865); De Candolle, Prodr. XVI. pt. 2, 171 (1868). $-\frac{-}{60}$ Dippel, Handb. Laubholzk. II. 181 (1892). - Herder in Act. Hort. Petrop. XII. 60 (1892). - Koehne, Deutsche Dendr. 112 (1893). - Hempel \& Wilhelm, Bäume \& Sträucher, II. 26, fig. 132 E-H (1894). - Schneider, Ill. Handb. Laubholzk. I. 106, fig. $55 \mathrm{f}-\mathrm{i}(1904)$, - Winkler in Engler, Pfanzenr. IV.-61, 69, fig. $20 \mathrm{D}-\mathrm{F}$ (1904). Ascherson \& Graebner, Syn. Mitteleur. Fl. IV. 406 (1911). - Marshall in Moss, Cambridge Brit. Fl. II. 86, t. 88 (1914).

Alnus nana Clairville, Man. d'Herb. 280 (1811).

Chamaebetula nana Opiz in Lotos Jahrb. Nat. V, 259 (1855).

Betula nana, var. genuina Regel, in Nouv. Mém. Soc. Nat. Mosc. XIII. pt. 2, 101, t. 9, fig. 1-8, 13 (Monog. Betulac. 43) (1861). 
For further literature see Herder, 1. c.

NORTHEASTERN ASIA. Kamtchatka; Saghalien? (see Herder, 1. c.).

I have not seen any specimen of this plant from our area, but I do not doubt that it occurs in the Aretic regions of eastern Asia.

Subsect. b. Fruticosae Schneider, n. comb.

Betula, sect. Fruticosae Regel in Bull. Soc. Nat. Mosc. XXV1II, pt. 2, 406 (pro parte) (1865).

Betula, sect. Eubetula, subsect. Fruticosae Regel in De Candolle, Prodr. XV1. 2,162 (1868).

Betula, subgen. Fruticosae, Nakai in Tokyo Bot. Mag. XXIX. 40 (1915).

21. Betula glandulosa Michaux, var. sibirica Schneider, n. comb.

Betula nana Ledebour, Fl. Alt. IV. 246 (excl. syn.) (1833).

Betula rotundifolia Spach in Ann. Sci. Nat. sér. 2, XV. 194 (1841).

Betula nana, var. sibirica Ledebour, Fl. Ross. III. pt. 2, 654 (1850). Regel in Nouv. Mém. Soc. Nat. Mosc. Xill. 101, t. 9, fig. 9-12, 14-18 (Monog. Betulac.) (1861).

Chamaebetula rotundifolia Opiz in Lotos Jahrb. Nat. V. 259 (1855).

Betula glandulosa, var. rotundifolia Regel in Bull. Soc. Nat. Mosc. XXXVIII. pt. 2, 408 (1865); in De Candolle, Prodr. XVI. pt. 2, 172 (1868). Herder in Act. Hort. Petrop. XIl. 64 (1892).

i Betula humilis, var. kamtschatica Regel in Nouv. Mém. Soc. Nat. Mosc. XIII. pt. 2, 107, t. 9, fig. 37-43 (Monog. Betulac. 49) (1861); Bull. Soc. Nat. Mosc. XXXVIII. pt. 2, 410 (1865); in De Candolle, Prodr. XVI. pt. 2, 174 (1868). - Winkler in Engler, Pflanzenr. IV.-61, 74 (1904).

Betula glandulosa Winkler in Engler, Pflanzenr. IV.-61, 73 (non Michaux) (1904), quoad specimina asiat.

NORTHEASTERN ASIA. Kamtchatka; Saghalien? (see Herder, 1. c.).

I have seen only specimens from the Altai and one poor specimen collected by Stewart in Kamtchatka; of this last one branch looks very much like B. humilis Schrank. These forms require a careful investigation of as much and as rich material as possible, for we are far from having sufficiently interpreted all the forms of this group from Asia, Europe and North America.

22. Betula Middendorffii Trautvetter \& Meyer in Middendorff, Reise Sibir. I. pt. 2, Bot. abt. 2, 84, t. 21 (Fl. Ochot.) (1856).- Trautvetter in Mém. Sav. Étr. Acad. Sci. St. Pétersbourg, IX. 255 (Maximowicz, Prim. Fl. Amur.) (1859). - Regel in Nouv. Mém. Soc. Nat. Mosc. XIII. pt. 2, 98, t. 8, fig. 13-27 (Monog. Betulac. 40) (1861); in Bull. Soc. Nat. Mosc. XXXV1II. pt. 2, 406 (1865); in De Candolle, Prodr. XVI. pt. 2, 170 (1868). - Dippel, Handb. Laubholzk. II. 169, fig. 80 (1892). - Herder in Act. Hort. Petrop. XII. 60 (1892). - Koehne, Deutsche Dendr. 111 (1893). - Komarov in Act. Hort. Petrop. XXII. 53 (Fl. Mansh. II.) (1903). - Schneider, Ill. Handb. Laubholzk. I. 105, fig. 59 q-q $\mathrm{q}^{1}, 64 \mathrm{n}-\mathrm{p}$ (1904). Winkler in Engler, Pflanzenr. IV.-61, 87 (1904).

Betula rotundífolia Regel \& Tiling in Nouv. Mém. Soc. Nat. Mosc. XI. 118 (Fl. Ajan.) (non Spach) (1858).

NORTHEASTERN ASIA. Maritime Prov.: "Insula Schantar magna," August 6-7, 1844, A. T. von Middendorff (type, ex Trautvetter \& Meyer); for further specimens see Herder (I. c.). A mu r: without precise locality, C. Maximowicz (fruits).

A doubtful species, of which I have not seen the type. Trautvetter, 1. c., and 
Regel, 1. c., distinguish several varieties, and I believe there are also hybrids, probably of different origin. Such forms, however, can only be correctly interpreted by comparing all the known material.

23. Betula humilis Schrank, Baier. Fl. I. 420 (1789), exel. cit. Gmelinii. ${ }^{1}-$ Spach in Ann. Sci. Nat, sér. 2, XV. 193 (1841). - Ledebour, Fl. Ross. III. pt. 2, 653 (1850). - Dippel, Handb. Laubholzk. II. 180 (1892). - Koehne, Deutsche Dendr. 112 (1893). - Hempel \& Wilhelm, Bäume \& Sträucher, II. 26, fig. 122 A-D (1894). - Schneider, Ill. Handb. Laubholzk. I. 103, fig. 55 b-e, 56 f-i, 57 e (1904). - Ascherson \& Graebner, Syn. Mitteleur. Fl. IV. 404 (1911).

Betula fruticosa Ledebour, Fl. Alt. IV. 246 (1833), excl. syn. Pallasii et Gmelinii.

Betula humilis, var. genuina Regel in Nouv. Mém. Soc. Nat. Mosc. XIII. pt. 2, 106, t. 9, fig. 44-55 (Monog. Betulac. 48) (1861), excl. syn. Pallasii; in De Candolle, Prodr. XVI. pt. 2, 174 (1868). - Herder, in Act. Hort. Petrop. XII. 65 (1912). - Winkler in Engler, Pflanzenr. IV.-61, 74 (1904).

Betula humilis, var. commutata Regel, in Nouv. Mém. Soc. Nat. Mosc. XIII. 108, t. 10, fig. 4-14 (Monog. Betulac. 50) (1861).

For further synonyms and citations see Ascherson \& Graebner, 1. c.

The typical B. humilis Schrank does not occur, I believe, in eastern Asia, and seems to reach the eastern limit of its range in the western Altai. The forms of eastern Siberia, referred to $B$. humilis by different authors, may belong to $B$. fruticosa Pallas and to $B$. glandulosa, var. sibirica Schneider. Probably also to other forms not yet sufficiently understood, as B. Middendorffi Trautvetter \& Meyer.

24. Betula fruticosa Pallas, Reise, III. App. 758, t. Kk, fig. 1-3 (1776); Fl. Ross. I. pt. 1, 62, t. $40 \mathrm{~A}-\mathrm{C}$ (in tab. sub B. fruticans) (1784). - Ledebour, Fl. Alt. IV. 246 (pro parte) (1833); Fl. Ross. III. pt. 2, 653 (1850), - K. Koch, Dendr. II. pt. 1, 658 (1872), exclud. syn. Ledebourii. - Dippel, Handb. Laubholzk. II. 169 (1892). - Herder in Act. Hort. Petrop. XII. 59 (1892). - Koehne, Deutsche Dendr. 111 (1893). - Komarov in Act. Hort. Petrop. XXII. 50 (Fl. Mansh. II.) (1903). - Schneider, Ill. Handb. Laubholzk. I. 103, fig. 56 d-e, 57 b-b ${ }^{1}$ (1904), Winkler in Engler, Pfanzenr. IV.-61, 87 (1904). - Nakai in Jour. Coll. Sci. Tolkyo, XXXI. 203 (Fl. Kor. II.) (1911); in Tokyo Bot. Mag. XXIX. 43 (1915),

Betula, $\gamma$ humilior palustris Gmelin, ${ }^{2}$ Fl. Sibir. I. 167, t. 36, fig. 2 (1747).

Betula Gmelini Bunge in Mém. Acad. Sav. Êtr. St. Pétersbourg, II. 607 in observ. (Verz. Altai-Geb. Pfl. 85) (1835); Verz. Altai-Geb. Pfl. ed. $8^{\circ}, 113$ (1836). - Trautvetter, Pl. Imag. Fl. Ross. 10, t. 5 (1844). - Ledebour, Fl. Ross. III. pt. 2, 652 (1850).

Betula palustris Gmelini Ruprecht in Bull. Acad. Sci. St. Pétersbourg, XV. 376 (1857); in Mél. Biol. II. 6, 558 (1858).

Betula palustris, var. Ruprecht, 1. c. 377 (1857); 1. c. 559 (1858).

Betula ovalifolia Ruprecht, I. c. 378 (1857); 1. c. 560 (1858).

Betula reticulata Ruprecht, 1. c. 378 (1857); 1. c. 561 (1858).
Betula fruticosa, var. Ruprechtiana Trautvetter in Mém. Sav. Etr. Acad. Sci. St. Pétersbourg, IX. 254 (Maximowicz, Prim. Fl. Amur.) (1859). - Winkler in Engler, Pflanzenr. IV.-61, 87 (1904).

1 See under B. fruticosa Pallas.

2 This Birch is cited by Schrank (Baier. Fl. I. 420 [1789]) under his B. humilis. According to the figure it may be a form of B. fruticosa Pallas, who cites Gmelin, and it was named B. Gmelini by Bunge and Betula palustris Gmelini by Ruprecht. 
Betula humilis, var. Ruprechtii Regel in Nouv. Mém. Soc. Nat. Mosc. XIII. pt. 2, 109, t. 8, fig. 40-47 (Monog. Betulac. 51) (1861); in De Candolle, Prodr. XVI. pt. 2, 174 (1868). - Herder in Act. Hort. Petrop. XII. 66 (1892).

CHINA. Chili: Central and west Weichang, 1910, W. Purdom (No. 104). NORTHEASTERN ASIA. Transbaikalia: swamp near Sryetinsk, August 13, 1903, C. S. Sargent (fruits); "Dahuria" (ex Herb. Hort. Petrop.). A mu r and Ussuri : Amur, 1859, C. Maximowicz; " am untern Amur: häufig auf nassen Wiesen in der Niederung bei Kitsi," July 29, 1856, C. Maximowicz (type of var. Ruprechtiana, ex Trautvetter); " am linken Schilka-Ufer gleich unterhalb der Scheltuga-Mündung," May 19, R. Maack (type of B. palustris Gmelini, ex Maack \& Ruprecht); " am mittleren Amur oberhalb der Garin-Mündung," July 25, R. Maack (type of B. ovalifolia, ex Maack \& Ruprecht); same place, $R$. Maack (type of B. reticulata, ex Maack \& Ruprecht); " Amur med.," May 27 and July 5, 1891, S. Korshinsky; "am oberen Amur gleich unterhalb der Onon-Mündung am linken Amur-Ufer," June 7, R. Maack (type of B. palustris, var., ex Maack \& Ruprecht); "Amur superior," September 1, 1891, S. Korshinsky (fruits). Korea : "fluvium Tumingan, districtus Musang, vallis Pakapen," June 8, 1897, V. Komarov (No. 488; young fruits); "in silvis pede montis Pai-ktu-san" (ex Nakai).

$I$ do not know where Pallas' type came from, and I am not sure whether all these forms mentioned in the synonymy above belong to the typical $B$. fruticos $a$ Pallas. It is probable that there are different forms and probably hybrids, too, mixed with that species. Without having seen the type specimens of Pallas, Ruprecht, Trautvetter and Regel it is useless to try to distinguish any varieties.

Sect. 4. EXCELSAE ${ }^{1}$ W. D. Koch, Syn. Fl. Germ. Helv, ed. 2, 760 (1843).

Betula, sect. Albae Regel in Bull. Soc. Nat. Mosc. XXXVIII. pt. 2, 396, incl. Sect. Dahuricae (1865). - Prantl in Engler \& Prantl, Nat. Pflanzenfam. III. abt. 1, 45 (1887). - Koehne, Deutsche Dendr. 107 (1893). - Schneider, Ill. Handb. Laubholzk. I. 109 (1904).

Betula, sect. Eubetula, subsect. Albae Regel in De Candolle, Prodr. XVI. 2, 162 (1868), incl. subsect. Dahuricae. - Winkler in Engler, Pfanzenr. IV.-61, 74 (1904), incl. B. fruticosa. - Ascherson \& Graebner, Syn. Mitteleur. Fl. IV. 390 (1910).

Subsect. a. Dahuricae Schneider, n. comb.

Betula, sect. Dahuricae Regel, in Bull. Soc. Nat. Mosc. XXXV11I. 396 (1865), exel. B. urticifolia.

Betula, sect. Albae, subsect. Dahuricae Regel in De Candolle, Prodr. XVI. pt. 2, 174 (1868), exel. B. urticifolia. - Schneider, Ill. Handb. Laubholzk. I. 109 (1904).

Betula, subgen. Dahuriae [sic] Nakai in Tokyo Bot. Mag. XXIX. 40 (1915).

Possibly there are American forms which might be referred to this subsection. The whole classification of the difficult species and forms of a genus like Betula must be a provisional one as long as we cannot refer to all the forms of the whole genus.

25. Betula davurica Pallas, Reise, III. 422 , not., 321 , 421, t. Kk, fig. 4 a-b (1776), fide Ledebour; Fl. Ross. I. pt. 1, 60, t. 39, tantum fig. A (1784).--Ledebour, Fl. Ross. III. pt. 2, 651 (1850). - Turezaninow in Bull. Soc. Nat. Mosc. XXVII. pt. 1, 401 (1854); Fl. Baical.-Dahur. II. 128 (1856), - Trautvetter in Bull. Soc. Nat. Mosc. XXX. 445, t. 7 (1857), - Maximowicz in Mém. Sav. Êtr.

${ }^{1}$ Koch's name refers to the arborescent species $B$. alba Linnaeus and B. pubescens Ehrhart in contrast to the "Humiles" and does not refer to B. excelsa Aiton. 
Acad. Sci. St. Pétersbourg, IX. 250 (Prim. Fl. Amur.) (1859). - Ruprecht in Bull. Acad. Sci. St. Pétersbourg, XV. 379 (1857); in Mél. Biol. II. 562 (1858).-Regel in Bull. Acad. Sci. St. Pétersbourg, XV. 221 (1857); in Mél. Biol. II. 490 (1857); in Nouv. Mém. Soc. Nat. Mosc. XIII. 113, t. 8, fig. 36-39, t. 10, fig. 14-40 (Monog. Betul. 55) (1861); Bull. Soc. Nat. Mosc. XXXVIII. pt. 2, 411 (1865); in De Candolle, Prodr. XVI. pt. 2,174 (excl. var. $\beta$ ) (1868). - Middendorff, Sibir. Reise, IV. pt. 1, 570 (Gewächse Sżbir.) (1864). - K. Koch, Dendr. II. pt. 1, 647 (1872). Franchet in Nouv. Arch. Mus. Paris, sér. 2, VII. 92 (Plant. David. I. 282) (1884).Dippel, Handb. Laubholzk. II. 178 (pro parte) (1892). - Herder in Act. Hort. Petrop. XII. 67 (1892). - Koehne, Deutsche Dendr. 111 (1893). - Burkill in Jour. Linn. Soc. XXVI. 498 (1899). - Palibin in Act. Hort. Petrop. XVIII. 194 (Consp. Fl. Kor.) (1900). - Komarov in Act. Hort. Petrop. XXII. 45 (Fl. Mansh. II.) (1903). - Schneider, Ill. Handb. Laubholzk. 1. 109, fig. 57 k-k' 60 p (1904).Winkler in Engler, Pflanzenr. IV.-61, 86 (1904). - Henry in Elwes \& Henry, Trees Gr. Brit. \& Irel. IV, 974 (1909). - Nakai in Jour. Coll. Sci. Tokyo, XXXI. 203 (Fl. Kor. II.) (1911); in Tokyo Bot. Mag. XXIX. 42 (1915). - Koidzumi in Tokyo Bot. Mag. XXVII. 146 (1913).

Betula Maximowiczii Ruprecht in Bull. Acad. Sci. St. Pétersbourg, XV. 139 (1856), XV. 379 (1857); in Mél. Biol. II. 435 (1857), II. 563 (1858).

Betula Maackii Ruprecht in Bull. Acad. Sci. St. Pétersbourg, XV. 380 (1857); in Mél. Biol. II. 564 (1858).

Betula dahurica, var. Maximowicziana Trautvetter in Mém. Sav. Étr. Acad. Sci. St. Pétersbourg, IX, 250 (Maximowicz, Prim. Fl. Amur.) (1859).

Betula wutaica Mayr, Fremd. Wald- \& Parkbäume, 450, fig. 169 (1906).

? Betula Rosae Winkler in Engler, Pflanzenr. IV.-61, 135 (1904).

CHINA. Chili: Hsiao Wu-tai-shan, 2500-3100 m., in mountain cañons, August 12, 1913, F. N. Meyer (No. 1207; of shrubby growth, bark dark; fruits); west Weichang, 1910, W. Purdom (No. 109); “Cal-ceen-wong," 1910, W. Purdom (No. 63).

NORTHEASTERN ASIA. Transbaikalia : Nertschinsk and NertschinskoiSawod,Turczaninow (flowers and sterile). Mandshuria: Khingan Mts., alt. 300 m., Yulo Pass, August 15, 1903, C. S. Sargent (sterile). Amur and Ussuri : " ad flumen Amur," "60 Werst unterhalb der Ussuri-Mündung," July 15, 1855, R. Maack (sterile); "am mittleren Amur . . ., am südlichen und am Ussuri," May and August, C. Maximowicz (flowers and fruits of the type of B. Maximowiczii ex Ruprecht; "am mittleren Amur etwa 80 Werst unterhalb der UssuriMündung," July 18, 1855, R. Maack (fruits; type of B. Maackii ex Ruprecht); Amur, near Koeurmi, May 12, 1855; near Daisso, May 26 and July 17, 1855; Ussuri, Nor, August 12, 1855, C. Maximowicz (flowers and fruits; types of var. Maximowicziana ex Trautvetter; co-type in Herb. Gray); Abderi-Mündung, $R$. Maack (fruits); near Khabarovsk, May 10, 1897, V. Komarov; same place, August 20$21,1903, C . S$. Sargent (young tree, bark of trunk dirty white, of upper trunk and branches red and exfoliating like that of $B$. nigra). Nikolsk, Railway star tion, August 22, 1903, C.S. Sargent (young tree, gray bark). Korea: Chinnampo, September 20, 1905, J. G. Jack (bark dark gray, breaking in thin shaggy layers); Kan-ouen-to Mt., alt. 1000 m., U. Faurie (No. 601, type of B. Rosae, ex Winkler).

JAPAN. Hondo: prov. Shinano, Yatsuga-dake, village of Nakashinden, margin of eopse, alt. $1200 \mathrm{~m}$., September 19, 1914, E. H. Wilson (No. 7548; one tree, $15 \mathrm{~m}$. tall, girth $1.2 \mathrm{~m}$; branches wide spreading, bark gray, shaggy like $B$. nigra; fruits, bark); same locality, September 1910 and 1914, M. Koyama (fruits). 
Regarding the variation in the shape of the fruiting bracts and the leaves we might distinguish several forms. But such a thing could be done only after a careful comparison of all the material preserved in the herbarium of the Botanieal Garden at Petrograd. Among the specimens mentioned above there may be some doubtful forms probably of hybrid origin.

Betula Rosae Winkler I know only from the rather incomplete description; according to this, Jack's specimen from Korea may represent this form. The leaves and seeds are like those of $B$. davurica Pallas, and the shape of the bracts is the same as that of other forms of this species; in this it resembles those of B.japonica Siebold, the lateral lobes being very spreading and somewhat recurved. But the middle lobe is always longer and narrower, and the lateral lobes are narrower, too, than in B.japonica Siebold, which has the bracts generally finely pubescent on both surfaces, while those of $B$. davurica Pallas are mostly only ciliate on the margins.

In Japan I saw only one tree of this Birch. It grows near the village of Nakashinden at $1250 \mathrm{~m}$. altitude, on the lower slopes of Yatsuga-dake, situated on the borders of Kai and Shinano provinces. I was, however, told of other trees in the neighborhood. The tree was about $15 \mathrm{~m}$. tall with wide-spreading branches and readily distinguished by its characteristic pale gray bark which splits and exposes the many layers the free ends of which become rolled and form shaggy masses on the tree. In habit and character of bark this species resembles the American River Bireh (B. nigra Linnaeus).

E. H. W.

Subsect. b. Alibae Schneider, n. comb.

Betula, sect. Albae Regel in Bull. Soc. Nat. Mosc. XXXVIII. 396 (1865).

Betula, sect. Eubetula, subsect. Albae Regel in De Candolle, Prodr. XVI. pt. 2, 162 (1868).

Betula, sect. Albae, subsect. Eualbae Schneider, Ill. Handb. Laubholzk. I. 111 (1904).

Betula, sect. Eubetula, subsect. Albae, Gruppe Eualbae, Ascherson \& Graebner, Syn. Mitteleur. Fl. IV. 390 (1910).

Betula, subgen. Albae Nakai in Tokyo Bot. Mag. XXIX. 40 (1915).

26. Betula japonica Siebold apud Winkler in Engler, Pflanzenr. IV.-61, 78 (1904). - Nakai in Tokyo Bot. Mag. XXIX. 42 (1915).

Betula japonica Siebold in Verh. Batav. Genoot. X1I. 25 (Syn. Pl. Oec. Jap.) (nomen nudum) (1830), - Siebold \& Zuccarini in Abh. Akad. Münch. IV. pt. 3, 229 (Fl. Jap. Fam. Nat. I. 105) (nomen nudum) (1846).

Betula alba Turezaninow in Bull. Soc. Nat. Mosc. XXVII. 400 (non Linnaeus) (1854); Fl. Baical. Dahur. II. pt. 1, 927 (1856). - Trautvetter \& Meyer in Middendorff, Sibir. Reise, I. pt. 2, Bot, abt. 283 (Fl. Ochot.) (1856). Ruprecht in Bull. Phys. Math. Acad. Sci. St. Pétersbourg, XV. 381 (1857); in Mél. Biol. II. 565 (1858). - Middendorff, Sibir. Reise, IV. pt. 1, 565 (Gewächse Sibir.) (pro parte) (1864).

Betula alba, var, typica Trautvetter in Mém. Sav. Êtr. Acad. Sci. St. Pétersbourg, IX. 249 (Maximowicz, Prim. Fl. Amur.) (1859).

Betula alba, var. vulgaris Regel in Nouv. Mém. Soc. Nat. Mosc. XIII. 75 (Monog. Betulac. 17), quoad syn. Trautvetteri (1861). - Shirai in Tokyo Bot. Mag. VIII. 319, t. 6, fig. 33-35 (1894).

Betula alba, var. verrucosa Regel in Nouv. Mém. Soc. Nat. Mosc. XIII. 77 (Monog. Betulac. 19) (1861), quoad specim. Kamtchat. - Franchet in Nouv. Arch. Mus. Paris, sér. 2, VIl. 91 (Pl. David. I. 281) (1884). - Burkill in Jour. Linn. Soc. XXVI. 497 (1899). 
Betula alba, subspec. verrucosa, var. resinifera Regel in Bull. Soc. Nat. Mosc. XXXVIII. pt. 2, 398 (1865); in De Candolle, Prodr. XVI. pt. 2, 164 (1868), exclud. specim. Amerieanis. - Herder in Act. Hort. Petrop. XII. 50 (1892).

Betula alba, subspec. latifolia, var. Tauschii Regel in Bull. Soc. Nat. Mosc. XXXV1II. pt. 2, 399, t. 7, fig. 11-14 (1865); in De Candolle, Prodr. XVI. pt. 2, 165 (1868). - Herder in Act. Hort. Petrop. XII. 51 (1892).

Betula alba, var. japonica Miquel in Ann. Mus. Lugd.-Bat. II. 136 (1865); Prol. Fl. Jap. 68 (1866).

Betula alba, subspec. verrucosa, var, sterilis Regel in De Candolle, Prodr. XVI. pt. 2, 164 (1868), quoad specim. Amurensia. - Herder in Act. Hort. Petrop. XII. 50 (1892), quoad specim. Amurensia.

Betula alba, var. mandshurica Franchet in Nouv. Arch. Mus. Paris, sér. 2, VIl. 91 (Pl. David. I. 281) (1884), - Burkill in Jour. Linn. Soc. XXVI. 496 (1899).

Betula alba, subspec. verrucosa, var. vulgaris Herder in Act. Hort. Petrop. XII. 49 (1892).

Betula alba, var. Tauschii Shirai in Tokyo Bot. Mag. VIII. 319 (1894). - Burkill in Jour. Linn. Soc. XXVI. 497 (1899).

Betula pendula, var, japonica Rehder in Bailey, Cycl. Am. Hort. I. 159 (1900). Betula latifolia Komarov in Act. Hort. Petrop. XXII. 38 (Fl. Mansh. II.) (non Tausch $\left.{ }^{1}\right)$ (1903).

Betula pendula, var, japonica, f. microdonta Schneider, Ill. Handb. Laubholzk. I. 113 , fig. $62 \mathrm{q}^{3}$ (1904).

Betula japonica, var. Tauschii Winkler in Engler, Pflanzenr. IV.-61, 78 (1904). - Nakai in Jour. Coll. Sci. Tolyo, XXXI. 202 (Fl. Kor. II.) (1911).

Betula japonica, var. pluricostata Winkler in Engler, Pflanzenr. IV.-61, 79 (1904).

Betula verrucosa, var. japonica Henry in Elwes \& Henry, Trees Gr. Brit. \& Irel. IV. 967 (1909).

Betula pendula, var. Tauschii Rehder in Bailey, Stand. Cycl. Hort. I. 498 (1914). Betula mandshurica Nakai in Tokyo Bot. Mag. XXIX. 42 (pro parte) (1915).

CHINA. Chili: Central and west Weichang, W. Purdom (No. 103; fruits); west Weichang, 1910, W. Purdom (No. 124; fruits); Hsiao Wu-tai-shan, alt. 1600 m., August 8, 1913, F. N. Meyer (No. 1163; fruits).

NORTHEASTERN ASIA. Korea (ex Nakai).

JAPAN. Kurile Islands: Etorofu, Arimoi, July 9, 1884, K. Miyabe (young fruits). Hokkaido: Chemuro, July 7, 1884, K. Miyabe (fruits); prov. Oshima, Hakodate, 1861, C. Maximowicz (type of var. pluricostata ; fruits); prov. Ishikari, Sapporo, Mt. Moiwa, September 18, 1892, C. S. Sargent (tree 20-27 m. tall, white bark; fruits); Sapporo, July 28, 1885 (from Agrie. College; fruits). Hon do: prov. Shinano, on Tsubakura-dake, woods, abundant, alt. 1300-1600 m., September 15, 1914, E. H. Wilson (No. 7456 ; tree $15-17 \mathrm{~m}$. tall, girth $0.3-0.6$ m., bark white; fruits, bark); prov. Shimotsuke, Akanumamoare, July 18, 1906 (ex Herb. Sakurai; fruits); near Lake Yumoto, September 7, 1892, C. S. Sargent (sterile); prov. Kozuke, Mt. Asama, July 14, 1904, U. Faurie (No. 5782; fruits). (1904).

Betula japonica, var. kamtschatica Winkler in Engler, Pflanzenr. IV,-61, 79

${ }^{1}$ As I have stated already in my $I l l$. Handb. Laubholzk. I. 116 (1904), B. latifolia Tausch in Flora 1838,751 , is the same as the American B. papyrifera Marshall. 
Betula alba, subspec. latifolia, var. kamtschatica Regel in Bull. Soc. Nat. Mosc. XXXVIII. pt. 2, 401, t. 7, fig. 16-20 (1865); in De Candolle, Prodr. XVI. pt. 2, 165 (1868).

Betula pendula, var. japonica, f. typica Schneider, Ill. Handb. Laubholzk. I. 113, fig. $62 q^{2}$ (1904).

9 Betula japonica, var. resinifera Winkler in Engler, Pflanzenr. IV.-61, 79 (1904).

Betula alba, var. vulgaris Shirasawa, Icon. Ess. For. Jap. II. t. 11, fig. 19-37 (1858).

A typo praecipue differt foliis saepissime plus minusve tenuioribus, basi truncatis v. late cuneatis, rarius subrotundis, margine inaequaliter acutius serratodentatis, saepe breviter lobulatis, subtus in axillis nervorum paullo barbulatis, rarius etiam ad nervos laxe sericeis, petiolis fere semper glabris.

NORTHEASTERN ASIA. Kamtehatka : without locality, Rieder \& Stewart (type, ex Regel). Saghalien : Odomari, thickets, common, August 6, 1914, E. H. Wilson (No. 7355; bush or small tree, 1.5-5.4 m. tall; probably a distinct form, the lateral lobes of the bracts being very erect; fruits).

JAPAN. Hokkaido: prov. Shiribeshi, Otaru, May 1, 1890, K. Miyabe (flowers); prov. Ishikari, Sapporo, Mt. Moiwa, September 18, 1892, C. S. Sargent (sterile); Kamikawa, July 1905, U. Faurie (No. 6630; fruits, large and thick catkins); in sylvis Jirafu, June 26, 1905, U. Faurie (No. 6634; fruits); "basi vuleani Tarumai," July 1905, U. Faurie (No. 6635; fruits). Hondo: prov. Shimotsuke, round Yumoto, on Senjo-ga-hara, October 19, 1914, E. H. Wilson (No. 7669; slender tree, 8-20 m. tall, girth 0.3-0.9 m., bark pure white, common, fruits pendulous; fruits); round Lake Chuzenji, alt. 1600-1800 m., common, woods, moors, May 26, 1914, E. H. Wilson (No. 6767; slender tree, 6-20 m. tall, girth 0.3-1.2 m., bark white; flowers); Komagatake, July 1905, U. Faurie (No. 6631; fruits); prov. Shinano; above Narai, alt. 1100 m., September 3, 1905, J. G. Jack (fruits); Kawanakazami, July 16, 1884 (ex Herb. Sei. Coll. Univ. Japan; fruits).

It is as difficult to separate the typical B. japonica Siebold from the variety kamtschatica as it is to distinguish both from var. mandshurica Winkler, because there are undoubtedly many intermediate forms. There is great variability in the shape, texture, dentation and pubescence of the leaves as well as of the bracts. The leaves of the type are always more or less pubescent, at least on the under side of the midrib, and are more or less distinctly bearded in the axils of the veins below. In forms like the type of var. pluricostata Winkler the petioles are slightly villose, but other specimens show the same pubescence, texture and dentation, differing only in the size of the leaves and in the less numerous lateral veins which are mostly $6-9$, rarely $9-12$ in number.

$B$. japonica Siebold as a whole seems to be somewhat intermediate between the European and western Asiatic B. alba Linnaeus sensu lato and the North American B. papyrifera Marshall and its nearest allies. The forms of the subsect. Albae from northern Asia and from North America need a thorough investigation.

Betula japonica occurs in fair numbers on the high mountains of Shinano province in central Hondo. It is common as a small tree in the Nikko region and increasingly so to the northward; in Hokkaido and Saghalien it is abundant. It is a tree of moderate size with thin spreading branches and pure white bark.

Pictures of this Birch will be found under Nos. $x 275, x 279, x 301, x 381, x 414$ of the collection of my Japanese photographs.

E. H. W.

Betula japonica, var. mandshurica Winkler. See p. 461. 
Here may be added a very incompletely known species from Kamatchatka, $B$. avatshensis Komarov (in Fedde, Rep. Spec. Nov. XIII. 166 [1914]), which was collected by the author "in valle fl. Kalachtyrka non procul ab oppido Petropavlosk ad medium Octobri mensis 1909." It has pendulous catkins which are about $2 \mathrm{~cm}$. long and $0.8 \mathrm{~cm}$. thick, and very short-petiolate bracts with bbes divided almost to the base. According to the author it may represent a hybrid between B. japonica Siebold and B. Ermanii Chamisso.

\section{ALNUS L.}

Alnus cremastogyne Burkill in Jour. Linn. Soc. XXVI. 409 (1899). Diels in Bot.Jahrb. XXIX. 282 (1900). - Winkler in Engler, Pflanzenr. IV.-61, 127, fig. 28 (1904); in Bot. Jahrb. XXXVI. Beibl. LXXXII. 33 (1905). - Callier apud Schneider, Ill. Handb. Laubholzk. II. 891 (1912). - Bean in Kew Bull. Misc. Inform. XXVI. 164, t. (1913); Trees \& Shrubs Brit. Isl. I. 179 (1914).

Western Szech'uan: without precise locality, abundant, side of streams, etc., up to alt. 1400 m., Oetober-November 1908 (No. I388; tree $10-40 \mathrm{~m}$. tall, girth $0.6-3.6 \mathrm{~m}$.; with ripe fruits and bark); same region, July 1908 (No. $\mathrm{I}_{388^{\mathrm{a}}}$; flowers); same region, Oetober 1908 (No. $13^{88^{d}}$; unripe fruits); southeast of Tachien-lu, alt. $1400 \mathrm{~m}$., October 1908 (No. I3 $^{8}$ b; bark from tree $30 \mathrm{~m}$. tall, girth $4.5 \mathrm{~m}$.); near Wa-shan, alt. 900-1600 m., side of streams, July 1908 (No. 2030; tree $13-20 \mathrm{~m}$. tall, girth $1.5-2.1 \mathrm{~m}$; flowers); without locality, alt. 300-1200 m., abundant, October 1903 (Veiteh Exped. No. 4497; tree 7-13 m. tall; with ripe fruits); without locality, A. Henry (No. 8890, type; young fruits); Tachien-lu, A. E. Pratt (No. 424, ex Burkill); Mt. Omei, H. Scallan (Nos. 2334, 2335 Herb. Giraldi, ex Winkler).

This Alder is very common in the valley of the Min River from near its mouth and northward and westward, but in the valley of the Yangtsze River itself it does not occur east of the city of Sui Fu. In north-central Szech'uan it extends from the prefecture of Paoning westward to the neighborhood of Tachien-lu. In the shingly beds of streams it makes pure growths and up to $1500 \mathrm{~m}$. altitude is everywhere abundant in extreme western Szech'uan. On the Chengtu Plain it is largely planted by the side of rice fields, streams and irrigation canals and is one of the principal sources of fuel. It is a tree from 20 to $30 \mathrm{~m}$. and occasionally more tall, and has a straight trunk from 2 to $3.5 \mathrm{~m}$. in girth clothed with gray rough bark; the branches are rather slender and spreading. The wood is of very little value except as fuel, but is employed for making the small boxes used in western China for transporting silver ingots. Colloquially the tree is known as Ching-shu. Pictures will be found under Nos. 56, 70, 295 and 378 and also in my Vegetation of Western China, Nos. 9, 122, 123, 124 and 125.

E. H. W.

Alnus lanata Duthie apud Bean in Kew Bull. Misc. Inform. 1913, 164. - Bean, Trees \& Shrubs Brit. Isl. I. 180 (1914).

Ad descriptionem valde incompletam addenda v. emendands: 
Arbor 7-26 m. alta; ramuli novelli dense fulvo-tomentosi, annotini glabrescentes, purpureo-brunnei, lenticellis parvis obtecti, dein nigrescentes; gemmae stipitatae, ovato-obtusae v. subglobosae, subglabrae, resinosae, stipite tomentello. Folia obovato-oblonga v. elliptica, basi acuta v. subrotunda, apice obtusa, sed pleraque in acuminem brevem producta, margine (apice distinctius) satis aequaliter distanter brevi-glanduloso-serrata, supra saturate viridia, novella plus minusve pilosa, adulta fere glabra, subtusinitio dense fulvo-tomentosa, dein saepe facie glabrescentia, pallide viridescentia, costa nervisque prominulis fulvo-tomentella v. hirsuta, costa interdum glabriuscula, nervis lateralibus utrinque eirciter $10-13$, axillis barbata, $6-15 \mathrm{~cm}$. longa et $4.5-10$ $\mathrm{cm}$. lata; petioli initio densius tomentelli, dein sulco superno excepto glabrescentes, crassi, $0.8-2 \mathrm{~cm}$. longi. Amenta ut in descriptione subgeneris (p. 490), mascula ad $6 \mathrm{~cm}$. longa; pedunculi utriusque sexus initio fulvo-tomentelli. Strobili maturi singuli, pedunculis $3.8-4.5 \mathrm{~cm}$. longis suffulti, elliptici, utrinque obtusi, 2-2.6 $\mathrm{cm}$. longi, 1-1.6 $\mathrm{cm}$. crassi; bracteae apice truncatae, utrinque indistincte brevi-lobatae et breviter incisae, eirciter $7 \mathrm{~mm}$. longae et $8-9 \mathrm{~mm}$. latae; semina obovato-oblonga, basim versus subacuminata, alis distinctis membranaceis nuculo sublatioribus, apicem versus vix dilatatis cincta, circiter $5 \mathrm{~mm}$. longa.

Western Szech'uan: southeast of Tachien-lu, side of streams, local, alt. 1600-2500 m., October 1908 (No. 1377, type of description; tree 7-26 m. tall, girth 0.9-3 m.; with fruits); same locality, June 1908 (No. $1377^{\mathrm{s}}$; with flowers); same locality, side of streams, alt. 1600 $2000 \mathrm{~m}$., October 1908 (No. $\mathbf{I}_{377^{\circ}}$; tree 10-20 m. tall, girth 1.2-2.4 $\mathrm{m}$; ; with fruits); same locality, woodlands, side of streams, alt. 16002200 m., October 1910 (No. I377 ; tree 26 m. tall, girth $3 \mathrm{~m}$.; with fruits); same locality, alt. 1600-2300 m. (June ?) 1904 (Veitch Exped. No. 4498; tree 7-13 m. tall; with flowers and old fruits).

This species is very closely related to A. cremastogyne Burkill, but it is easily distinguished from it by the character given in the key. There are young plants growing in the Arnold Arboretum. For further remarks see the subgen. Cremastogyne, p. 492.

This tree is local in its distribution and is known to me only from a limited area to the southeast of Tachien-lu, where it is common between 1600 and $2300 \mathrm{~m}$. altitude. In habit it is similar to A. cremastogyne Burkill, but the trunk is usually thicker and the branches stouter.

E. H. W. 


\section{CONSPECTUS ANALYTICUS ALNORUM ASIAE ORIENTALIS}

\section{NEC NON HIMALAYAE.}

Amenta masculina et feminea singula, axillaria, haud ante verem in axillis foliorum ramuli novelli apparentia, masculina basi ramuli, feminea iis supersedentia; flores masculini apetali. Fructus longissime stipitata; semina alis hyalinis latis cincta. Gemmae stipitatae, 2-perulatae, obtusae . . . Subgen. I. CREMASTOGYNE.

Folia subtus citissime glabrescentia, adulta sparse pilosa v. glabra, pleraque tantum axillis ad costam paulo rufo-barbata. Ramuli etiam novelli glabri, tantum sparse glanduliferi. Strobilorum pedunculi ad $8 \mathrm{~cm}$. longi, glabri, graciles . . . . . . . . . . 1. A. cremastogyne.

Folia novella subtus dense rufo-villosa, etiam adulta plus minusve distincte rufopubescentia. Ramuli novelli rufo-tomentelli, etiam annotini sparse villosuli. Strobilorum pedunculi ad $4.5 \mathrm{~cm}$. longi, sparse hirsuti, crassiusculi.

2. A. lanata. Amenta masculina aestate $\nabla$, autumno apparentia et eodem tempore florentia $\nabla$. per hyemem nuda primo vere foliorum evolutione praecociora; flores masculini petalis instructi. Fructus racemosi v. singuli, nunquam longissime stipitati.

Gemmae stipitatae, 2-perulatae, obtusae. Amenta feminea cum masculinis autumno enascentia, axillaria, aphylla, per hyemem nuda, primo vere foliis praecociora . . . . . . . . . . Subgen. II. ALNUS.

Amenta masculina ad 2-9 apice ramulorum floriferorum racemoso-aggregata.

Semina alis angustis rarius latioribus impellucidis coriaceis cineta, saepe tantum quasi marginata ...... Sect. 1. GYMNOTHYRSUS. Amenta masculina per hyemem nuda primo vere foliorum evolutione praecociora.

Folia margine nunquam lobulata, tantum serrata, serrato-denticulata v. crenata, subtus viridescentia, nunquam papillosa.

Amenta fructifera ad 2-6 racemoso-aggregata. Folia basi pleraque cuneata.

Folia utrinque acuta, elliptica, ovata v. lanceolato-ovata, basi angustata v. rarius subrotunda, margine plus minusve calloso-serrata, apice pleraque breviter acuminata ..... 3. A. japonica. Folia obovata $v$, rotundato-obovata, basi cuneata $v$. rarius obtusa, margine (saltem supra medium) minutissime serrato-denticulats $\mathrm{v}$, crenato-dentata, apice obtusa, truncata v. leviter emarginata. Folia minutissime serrato-denticulata .... 6. A. Fauriei. Folia crenato-denticulata . . . . . 7. A. serrulatoides. Amenta fructifera pluria, racemoso-paniculata. Folia basi pleraque rotunda v. subrotunda. (Confer etiam 4. A. paniculatam.)

Folia margine lobulata $\nabla$. subtus cinerascentia papillosa.

Folia apice subacuta v. acuta, rarius breviter acuminata, subtus tota facie $v$. saltem ad nervos costamque hirsuta v. margine distincte lobulata . . . . . . . . . . hirsuta.

Folia apice emarginata, margine vix $\mathbf{v}$. obtuse lobulata, adulta subtus facie nervisque glabra, tantum ad costam sparse sericea et saepe axillis barbulata

9. A. Matsumurae.

Amenta masculina autumno florentia.

Folia remote sed distincte acuteque serrata. Ramuli novelli sparse fulvovillosuli. Bracteae florum masculinorum late ovatae, fere latiores quam longae, apice valde obtusae; thecae antherarum medio plus 
minusve connatae; bracteae fructiferae extus apice lobi mediani clare brunneae, quasi umbonatae ...... 10. A, formosana.

Folia satis remote breviter denticulato-serrata $\mathrm{v}$. repando-serrata v. subintegra. Ramuli novelli griseo-puberuli. Bracteae florum ovatotriangulares, acutae; thecae antherarum separatae; bracteae fructiferae extus apice concoloria, haud punctata . . . . 11. A. nitida. Amenta masculina numerosa, apice ramulorum floriferorum paniculatoracemosa, autumno florentia, longissima et tenuia. Semina alis distinctis hyalinis cincta. . . . . . . . . . Sect. 2. CLETHROPSIS.

12. A. nepalensis.

Gemmae sessiles $v$. subsessiles, acuminatae, perulis exterioribus 3-6 v. interdum tantum 2 inaequalibus obtectae. Amenta feminea racemosa, haud ante verem apice ramuli brevis novelli paucifoliati terminalia; semina alis membranaceis distinctis nuculo saepe aequilatis $\mathrm{v}$. sublatioribus cincta.

Subgen. III. ALNASTER.

Folia late ovata, ovato-elliptica v. ovato-rotunda, apice obtusa v. subito breviter acuminata, pleraque versus medium latissima, margine dentibus patentibus argute serrulata, nervis lateralibus utrinque 5-10(-12). Prophylla dichasiorum masculinorum bracteam margine plus minusve superantia. Frutices. .............. Series a. VIrIdes.

Folia apice sensim breviter acuta v. subobtusa, basi pleraque cuneata v. rotundata. Ramuli annotini purpurascentes $\mathrm{v}$. brunnescentes. Bracteae mediae florum masculinorum dorso distincte umbonatae. ${ }^{1}$

Petala florum masculinorum staminibus longiora; stamina saepissime antheris aequilonga; thecae antherarum toto longitudine connatae.

13. A. fruticosa.

Petala florum maseulinorum staminibus breviora; stamina antheris distincte longiora; thecae antherarum basi apiceque liberae, plus minusve divaricatae ........ 14. A. sinuata, var. kamtschatica. Folia apice saepissime subito breviter acuminata, late ovata v. ovatorotunda, basi late truncata v. cordata. Ramuli annotini grisei v. griseobrunnei. Bracteae mediae florum masculinorum dorso haud umbonatae; thecae antherarum basi apiceque liberae, divaricatae.

15. A. Maximowiczii.

Folia ovato-oblonga $\nabla$. ovato-lanceolata, versus apicem sensim longe acuminata, versus basim latissima, margine argute serrulata dentibus subadpressis, nervis lateralibus 12-27. Prophylla dichasiorum masculinorum parva, basi interiore bracteae occulta. Frutices v. pleraeque arbores parvae.

Series b. Firmae.

Nervi laterales utrinque 12-17; petioli foliorum majorum 1-2 cm. longi. Amenta fructifera crassa, haud pendula; strobili 1-2, majores $1.8-2.5 \mathrm{~cm}$. longi et circiter $1.3-1.5 \mathrm{~cm}$. crassi. . . . . . . . 16. A. firma.

Nervi laterales utrinque plerique 18-27; petioli foliorum etiam maximorum vix $0.8 \mathrm{~cm}$. longi. Amenta fructifera gracilia, nutantia v. subpendentia; strobili $2-5$, etiam maxima vix ad $1.5: 1 \mathrm{~cm}$. magna.

17. A. pendula.

${ }^{1}$ fide Callier; in speciminibus a me visis ex Ajan lg. H. Tiling, umbonem distinetum non vidi. 


\section{ENUMERATIO ALNORUM ASIAE ORIENTALIS NEC NON HIMALAYAE.}

Subgenus I. CREMASTOGYNE Schneider, n. subgen. (descriptio in clavi).

Alnus, sect. Cremastogyne Winkler in Engler, Pflanzenr. IV.-61, 102 (1904).

I raise this group to the rank of a subgenus because it is like subgen. Alnaster, different from all the groups of the subgen. Alnus. Winkler did not know the male flowers and the ripe fruits. Both the male and female inflorescences are single and axillary, but both appear in the spring from the same young branchlets, while in the subgen. Alnus they develop in the autumn. In the subgen. Alnaster only the female flowers appear in the spring after or with the leaves. The male flowers of the subgen. Cremastogyne are much reduced. One dichasium consists of only one bract; the bractlets being apparently wholly united with it or wanting, and 4 (sometimes 5 ?) single stamens without any remains of petals which are present in all the other subgenera. The bracts are ciliate, the thecae of the anthers are separated and a little hairy, and the filaments are very short. The seeds have broad wings as in the subgen. Alnaster.

1. Alnus cremastogyne Burkill. See p. 488.

2. Alnus lanata Duthie. See p. 488.

Subgen. II. ALNUS Endlicher, Gen. Suppl. II. 28 (1842); Suppl. IV. pt. 2, 20 (1847), includ. subgen. Clethropsis.

This subgenus includes all the true Alnus sensu Spach with the male and female inflorescences appearing in the summer or fall on the same branchlet, which does not elongate as in the subgen. Cremastogyne. The male flowers are above the female, and both open in autumn in some of the species, while in most of them the aments remain elosed during the winter and open in spring before the leaves appear. Even in the autumn-flowering species the cones ripen the following year. The sect. Clethropsis, as far as I see, cannot be separated as a different subgenus from Alnus. I can always distinguish 3 flowers in each dichasium, and the petals seem to be partly connate at the base and partly free as in A. maritima Muhlenberg, which also flowers in the autumn. See also my remarks under sect. Clethropsis and sect. Gymnothyrsus.

Sect. 1. GYMNOTHYRSUS Spach in Ann. Sci. Nat. sér. 2, XV. 204 (1841). Endlicher, Gen. Suppl. IV. pt. 2, 21 (1847). - Regel in De Candolle, Prodr. XVI. pt. 2, 184 (1868). - Matsumura in Jour. Coll. Sci. Tokyo XVI. art. 5, 7 (Rev. Alni Spec. Jap.) (1902). - Winkler in Engler, Pflanzenr. IV.-61, 110 (1904).

Alnus, sect. Clethra W. D. Koch, Syn. Fl. Germ. Helv. 663 (sine descriptione) (1837); ed. 2, 762 (1843). - Hayek, Fl. Steierm. I. 108 (1908).

Alnus Spach in Ann. Sci. Nat. sér. 2, XV. 203 (1841). Alnus, subgen. Euclethrus Petermann, Deutschl. Fl. 516 (1849).

Alnus, sect. Eualnus Regel in Nouv. Mém. Soc. Nat. Mosc. XIII. 134 (Monog. Betulac. 76) (1861).

Alnus, sect. Alnaster Regel, l. c. 133 (75) (1861), quoad A. nitidam.

Alnus, subgen. Gymnothyrsus Regel in Bull. Soc. Nat. Mosc. XXXVIII. pt. 2, 425 (1865). - Prantl in Engler \& Prantl, Nat. Pflanzenfam. III. pt. 1, 46 (1887). - Dippel, Handb. Laubholzk. II. 147 (1892). - Koehne, Deutsche Dendr. 112 (1893). - Callier apud Schneider, Ill. Handb. Laubholzk. I. 124 (1904). - Winkler in Engler, Pflanzenr. IV.-61, 102 (1904). - Ascherson \& Graebner, Syn. Mitteleur. Fl. IV. 416 (1911). Alnus, sect. Alnus Sargent, Silva N. Am. IX. 68 (1S96). 
In this section I place all the species of eastern Asia the male catkins of which are solitary, axillary and terminal, forming a racemose terminal main inflorescence. The seeds have thick wings often reduced to a narrow margin. Dealing only with a few species, I cannot propose a proper arrangement of the whole group. There may be several groups of equal taxonomic rank as section Gymnothyrsus proper and sect. Clethropsis, or the first may be divided into different subsections or series. I do not know whether this section also includes section Phyllothyrsus Spach (1841), which is the same as section Pseudalnus Regel (1861), because I have not been able to study the species from Central and South America referred to these sections.

3. Alnus japonica Siebold \& Zuccarini in Abh. Akad. Münch. IV. pt. 3,230 (Fl. Jap. Fam. Nat. II. 106) (1846), - Regel in Nouv. Mém. Soc. Nat. Mosc. XIIl. 143, t. 15, fig. 22-27 (Monog. Betulac. 85) (1861). - Miquel in Ann. Mus. Lugd.-Bat. II. 137 (1865); Prol.Fl. Jap. 69 (1866). - K. Koch, Dendr. II. pt. 1, 632 (1872). - Dippel, Handb. Laubholzk. II. 153, fig. 74 (1892). - Sargent in Garden \& Forest, II. 344, fig. 53 (1893); For. Fl. Jap. 63, t. 20 (1894). - Koehne, Deutsche Dendr. 113 (1893). - Shirasawa, Icon. Ess. For. Jap. I. 47, t. 19, fig. 1834 (1900). - Komarov in Act. Hort. Petrop. XXII. 60 (Fl. Mansh. II.) (1903). Schneider, Ill. Handb. Laubholzk. I. 126, fig. $67 \mathrm{~h}-\mathrm{h}^{1}, 69$, f-g (1904). - Winkler in Engler, Pflanzenr. IV.-61, 114 (1904), exclud. synon. var. formosana. - Henry in Henry \& Elwes, Trees Gr. Brit. \& Irel. IV. 953, t. 268, fig. 12 (1909). - Matsumura, Ind. Pl. Jap. II. pt, 2, 18 (1912). - Ascherson \& Graebner, Syn. Mitteleur. Fl. IV. 428 (1911). - Nakai in Jour. Coll. Sci. Tokyo, XXXI. 204 (Fl. Kor. II.) (1911); in Tokyo Bot. Mag. XXIX. 46 (1915). - Bean, Trees \& Shrubs Brit. Isl. I. 182 (1914).

Alnus maritima, var. japonica Regel in Bull. Soc. Nat. Mosc. XXXVIII. pt. 2, 428 (1865); in De Candolle, Prodr. XVI. pt. 2, 186 (1868), exclud. pl. Formosana. - Franchet \& Savatier, Enum. Pl. Jap. I. 457 (1875). - Matsumura in Jour. Coll. Sci. Tokyo, XVI. art. 5, 7 (Rev. Alni Spec. Jap.) (1902).

Alnus japonica, var. genuina Callier in Fedde, Rep. Spec. Nov. X. 228 (1911); apud Sehneider, Ill. Handb. Laubholzk. II. 890 (1912). - Nakai in Tokyo Bot. Mag. XXIX. 46 (1915).

Alnus japonica, var. latifolia Callier in Fedde, Rep. Spec. Nov. X. 228 (1911); apud Schneider, Ill. Handb. Laubholzk. II. 890, fig. 555 i (1912).

Alnus japonica, var. reginosa (an resinosa?) Nakai in Tokyo Bot. Mag. XXIX. 46 (1915).

NORTHEASTERN ASIA. Ussuri: Vladivostok, low grounds, rare, August 18, 1903, C. S. Sargent (fruits; may represent var, latifolia Callier). Korea : along trail to Pouck Han, Seoul, September 25, 1905, J. G. Jack (fruits).

JAPAN. Hokkaido: prov. Ishikari, Sapporo, common in low grounds, September 18, 1892, C. S. Sargent (tree 17-20 m. tall, girth $0.6-0.9 \mathrm{~m}$.; fruits); same locality, August 23, 1905, J. G. Jack (fruits); same locality, March 28, 1877, S. Tanouchi (flowers); same locality, April 1880 (ex Herb. Sapporo; flowers); prov. Oshima: Hakodate, ad lacum Konuma, 1861, C. Maximowicz (fruits); Hakodate, 1861, M. Albrecht (young leaves). Hondo: prov. Musashi, near Tokyo, by rice fields abundant, September $23,1914, E . H$. Wilson (No. 6155; small tree 5-10 m. tall, girth $0.3-0.75 \mathrm{~m}$.; fruits); same locality, February $12,1914, E . H$. Wilson (No. $6155^{a}$; flowers); same locality, February 2, 1908, September 9, 1905 (ex Herb. Sakurai; flowers and sterile); prov. Shinano: on Tsubakura-dake, moist plains, open country, alt. 600-1100 m., September 15, 1914, E. H. Wilson (No. 7468; slender tree, 7-12 m. tall; fruits); Nagasendo, near Seba, October 28,1892, C. S. 
Sargent (tree 17-20m. tall, girth $0.6 \mathrm{~m}$.; fruits); prov. Ugo, on Chokai-san, common, October 14, 1914, E. H. Wilson (No. 7178; tree 5-8 m. tall, girth 0.3-0.9 m.; fruits).

The specimens enumerated above represent the var, genuina Callier, which has the branchlets always glabrous. The following variety has the young branchlets more or less hairy, and even later in the season they are slightly hairy.

Alnus japonica, var. arguta Callier in Fedde, Rep. Spec. Nov. X. 229 (1911); apud Schneider, Ill. Handb. Laubholzk. II. 890, fig. 5551 (1912).

Alnus maritima, var. arguta Regel in Bull. Soc. Nat. Mosc. XXXV1II. pt. 2, 428 (1865); in De Candolle, Prodr. XVI. pt. 2, 186 (1868). - Franchet \& Savatier, Enum. Pl. Jap. I. 458 (1875). - Herder in Act. Hort. Petrop. XII. 73 (Pl. Radd.) (1892).

Alnus maritima, var. japonica Burkill in Jour. Linn. Soc. XXVI. 500 (non Regel) (1899). - Palibin in Act. Hort. Petrop. XVIII. 194 (Consp. Fl. Kor. II.) (1900).

NORTHEASTERN ASIA. Ussuri : Port Bruce, 1860, C. Maximowicz (? type of var. arguta Regel; fruits). Korea: Port Chusan, 1859, C. Wilford (young inflorescences); Ping-yang, September 18, 1905, J. G. Jack (fruits); Chinnampo, secus aquas, August 1906, U. Faurie (No. 206; fruits).

JAPAN. Hokkaido: prov. Oshima, Onuma-koen, common in swampy places, July 26, 1914, E. H. Wilson (No. 7254; tree 13-18 m. tall, girth 0.6-1.2 m.; bark smooth, branches ascending, spreading, brittle; young fruits); same prov., Hakkodate, in marshes, June 13, 1855, C. Wright (a spreading bush, fruits); prov. Kushiro, forming pure and extensive woods in swampy places, August 12, 1914, E. H. Wilson (No. 7381; tree up to $33 \mathrm{~m}$. tall, girth $3 \mathrm{~m}$., bark gray, rough, trunk straight, free of branches for more than half the height of the tree, spreading, slender; unripe fruits); prov. Ishikari, Sapporo, August 19, 1905, J. G. Jack (sterile); same locality, June 16, 1903, S. Arimoto (young inflorescences). Hondo: prov. Musashi, Yokohama, 1863, $R$. Oldham (No. 721 ; sterile).

According to the material before me this variety seems to be only a form of the type with sparsely pubescent branchlets. Callier keeps distinct $A$. japonica, var. minor Miquel (in Ann. Mus. Lugd.-Bat. II. 137 [1865]; Prol. Fl. Jap. 69 [1866]), of which Miquel mentions no type specimen. To this form may belong Faurie's No. 5786 , Hondo, "in sylvis Ubayu," July 1, 1904, which shows no real difference from var. arguta.

There is another variety:

Alnus japonica, var. koreana Callier in Fedde, Rep. Spec. Nov. X. 229 (1911); apud Schneider, Ill. Handb. Laubholzk. II. 890, fig. $555 \mathrm{~m}$ (1912). - Nakai in Tokyo Bot. Mag. XXIX. 46 (1915).

In this variety the young branchlets and petioles are said to be densely villose and the margins of the leaves more coarsely toothed. Callier does not mention a type specimen, and I have not seen anything which might truly represent this variety which according to Nakai was found in middle and northern Korea. $A$. japonica seems to be planted only in southern Japan, although Matsumura mentions a specimen collected by $K$. Nagano in the prov. Chikuzen, Kyushu.

There is also A. Mayrii Callier apud Schneider, Ill. Handb. Laubholzk. I. 126 (1904), the type of which was collected by H. Mayr in Hokkaido, prov. Kushiro. It is doubtful whether this is a hybrid or only a form of A. japonica.

Alnus japonica is distributed in Japan from the Shinano province in central Hondo and northward in greater numbers; it is also often planted round fields 
as between Yokohama and Tokyo. It reaches its maximum development in open swampy country in northern Hokkaido, where it forms pure and extensive woods. It grows from 25 to $33 \mathrm{~m}$. tall and has a straight trunk from 2 to $3 \mathrm{~m}$. in girth and clear of branches for half the height of the tree. The bark is gray and rough, the branches are slender and rather short and spreading and form a narrow symmetrical crown. This is the tallest of the Japanese Alders and a very handsome tree. Matsumura reports this species from Kyushu, and it may be cultivated there, but I did not see it and doubt if it is indigenous so far south. Pictures of this tree will be found under Nos. $\mathrm{x} 440, \mathrm{x} 441, \mathrm{x} 445$ of the collection of my Japanese photographs.

4. Alnus paniculata Nakai in Tokyo Bot. Mag. XXIX. 45 (1915).

E. H. W.

NORTHEASTERN ASIA. Northern Korea: on the mountains Hoanggui-to (ex Nakai).

I do not know this species, which according to Nakai is "forsan finitima ad $A l$. maritimam quae non vidi et $A l$. japonicae proxima venit, sed a prima inflorescentia foeminea paniculato-decomposita, a secunda inflorescentiae forma et foliis ovatis v. obovatis v. rotundatis bene distinguenda." To judge from the rather insufficient description this species may be a variety of $A$. japonica Siebold \& Zuccarini with more numerous female catkins.

5. Alnus Henryi Schneider, n. sp.

Alnus maritima, var. formosana Burkill in Jour. Linn. Soc. 500, quoad specimen Henryi (No. 1389) (1899).

Arbor ?; ramuli hornotini tantum apice sparse pilosi, subangulati, olivacei, deinde flavo-brunnei v. nigrescentes, lenticellati; gemmae nondum visae. Folia late ovata v. ovato-elliptica, basi rotunda v. rarius subacuta, apice obtusa, sed subito in acumen brevissimum producta, margine breviter subdistanter serrulata, basin versus integra, textura chartacea, supra ut videtur intense viridia, glabra v. nervis costaque sparse pilosa, subtus viridia (an subnitentia?), glabra v. sparse puberula et axillis nervorum lateralium utrinque (6-)7-9 elevatorum paulo barbulata, 4-8 $\mathrm{em}$. longa et $2.5-5.2 \mathrm{~cm}$. lata; petioli tantum sulco superne pilosula, 1-1.6 cm. longa. Amenta masculina femineaque tantum valde juvenilia et incompleta visa; fructifera in ramulis lateralibus racemoso-paniculata, racemis lateralibus strobilos 4 gerentibus pedunculo circiter $1 \mathrm{~cm}$. longo suffultis, inflorescentia tota $11 \mathrm{~cm}$. longa, strobilos circiter 13 gerens. Strobili elliptici, laterales sessiles v. subsessiles, $1.3-1.5 \mathrm{~cm}$. longi, $1-1.3 \mathrm{~cm}$. crassi; bracteae apice truncato-obtusae, indistincte lobulatae, extus levissime excavatae, circiter $4 \mathrm{~mm}$. longae et latae; semina elliptica, utrinque obtusa, crasse marginata.

CHINA. Formosa: Tamsui, September 26, A. Henry (No. 1389, type, in Herb. New York Bot. Gard.).

This species looks very different from A. formosana Makino or A. maritima Mublenberg or A. japonica Siebold \& Zuccarini. The leaves of the only specimen I have seen are rather short and broad, and the fruiting catkins are much more numerous than in the above species. The eones and bracts are different too. It flowers apparently in the spring like A. japonica Siebold \& Zuccarini, and not at the end of the summer or in the fall like the two other species.

5. Alnus Fauriei Léveillé in Bull. Soc. Bot. France, LI. 423 (1904). Alnus glutinosa, var. cylindrostachya Winkler in Engler, Pflanzenr. IV.-61, 118 (1904).

Alnus Schneideri Callier in Fedde, Rep. Spec. Nov. X. 229 (1911); apud

Schneider, Ill. Handb. Laubholzk. II. 890, fig. $556 \mathrm{k}-\mathrm{m}, 557$ e (1912).

Alnus cylindrostachya Makino in Tokyo Bot. Mag. XXVI. 390 (1912). 
JAPAN. Hondo: "in monte Gurvassan," September 28, 1897, U. Faurie (No. 783; type of the two species and the variety mentioned above; ex auctoribus); prov. Shinano, Mt. Togakushi, rare, July 15, 1908 (ex Herb. Sakurai; young fruits).

This species is well distinguished by its obovate leaves, which are emarginate or truncate at the apex. They resemble those of the following species, but their serration is crenate.

7. Alnus serrulatoides Callier in Fedde, Rep. Spec. Nov. X. 229 (1911); apud Schneider, Ill. Handb. Laubholzk. II. 890, fig. 556 g-i, 557 a-b (1912).

Alnus glutinosa Miquel in Ann. Mus. Lugd.-Bat. 11.137 (non Linnaeus) (1865); Prol. Fl. Jap. 69 (1866).

Alnus maritima, var. oblusata Franchet \& Savatier, Enum. Pl. Jap. I. 458 (nomen nudum) (1875); II. 502 (1879).

Alnus glutinosa, var. japonica Matsumura in Jour. Coll. Sci. Tokyo, XVI. pt. 2, art. 5, 9 (1902). - Shirasawa, Icon. Ess. For. Jap. II. t. 13, fig. 13-21 (1908).

Alnus glutinosa, var. obtusata Winkler in Engler, Pflanzenr. IV.-61, 118 (1904). - Matsumura, Ind. Pl. Jap. II. pt. 2, 17 (1912).

Alnus obtusata Makino in Tokyo Bot. Mag. XXVI. 390 (1912).

JAPAN. Hondo: prov. Shinano, Nakatsu-gawa, Nojiri, September 6, 1905, J. G. Jack (fruits); same prov., Adera, September 5, 1905, J. G. Jack (sterile); prov. Mino, on Nakatsu-gawa, July 27,1911 (ex Herb. Sakurai; young fruits); prov. Yamato, July 14 (ex Herb. Coll. Sei. Univ. Jap.; fruits). Shikoku : prov. Tosa, Oti, November 24, 1887, K. Watanabe (young aments). For further specimens see Matsumura, 1. c.

This is a well-marked species with its finely serrate, obovate, obtuse leaves.

There is a flowering specimen collected by Wilson, Higashi-Kirishima, Kyushu, March 8, 1914 (No. 6208; tree 5-15 m. tall, girth 0.3-0.9 m., bark smooth, gray, male flowers reddish brown), representing a form which according to Wilson is " common in forests." The male flowers are very similar to those of A. japonica, but the female aments are mostly without any bractlike scales at their base, which seem always to be present in the other forms of this species. They stand round the base of the flowering female catkins 6 (or more?) in number, somewhat like a loose sheath, or in two distinct more or less opposite groups, and in shape are lanceolate or ovate-lanceolate. Their texture is firm, and the middle bract of each group is mostly the longest. The peduncles are stouter and nearly as thick as the catkins, while in No. 6208 they are somewhat more slender. If there are 2 or 3 scales at the base of the female catkins of No. 6208 , they are of the same shape as the flower bract and ean be easily overlooked. Unfortunately there is neither male nor female flowering material of A. serrulatoides in the collections before me, nor does Shirasawa publish a drawing of them. I suspect that Wilson's specimen may belong to our species, but it is impossible to decide this without having seen leaves and good fruits from the same locality. One of Wilson's specimens has several old fruits which resemble those of $A$. japonica more than those of $A$. serrulatoides.

8. Alnus hirsuta Turezaninow in Bull. Soc. Nat. Mosc. XI. 101 (Cat.Pl. Baical.) (nomen nudum) (1838); fide Ruprecht ${ }^{1}$ in Bull. Acad. Sci. St. Pétersbourg, XV. 376 (1857); in Mél. Biol. II. 558 (1858), - Maack, Ilymeul. Asyp. pt. 2, 87 (1859).

1 There is no description of A. hirsuta, but Ruprecht refers to "Maxim. Amur. No. 42," 1. c. 139 (1856), where Maximowiez eites A. incana, $\beta$ hirsuta in Fl. Ochot. which is the same as A. incana, var. hirsuta of Ledebour and of Spach. 
- Komarov in Act. Hort. Petrop. XXII. 54 (Fl. Mansh. II.) (1903), - Callier apud Schneider, Ill. Handb. Laubholzk. I. 133, fig. 68 a-a 1 , 72 k (1904), - Rehder in Bailey, Stand. Cycl. Hort. I. 253 (1914).

Alnus incana, var. hirsuta Spach in Ann. Sci. Nat. sér. 2, XV. 207 (1841). Ledebour, Fl. Ross. III. pt. 2, 656 (1850). - Turczaninow in Bull. Soc. Nat.Mosc.XXVII. 406 (1854); Flor. Baical.-Dahur. II. 133 (1856). - Trautvetter \& Meyer in Middendorf, Sibir. Reise, I. pt. 2, Bot. abt. 2, 86 (Fl.Ochot.) (1856). - Maximowicz in Bull. Acad. Sci. St. Pétersbourg, XV. 139 (1856); in Mél. Biol. II. 435 (1857). - Trautvetter in Mém. Sav. Êtr. Acad. Sci. St. Pétersbourg, IX. 258 (Maximowicz, Prim. Fl. Amur.) (1859), - Regel in Nouv. Mém. Soc. Nat. Mosc. XIII. pt. 2, 155, t. XVII. fig. 1-2 (Monog. Betulac. 97) (1861); in Mém. Acad. Sci. St. Pétersbourg, sér. 7, IV. 136 (Tent. Fl. Ussur.) (1861); in Bull. Soc. Nat. Mosc. XXXVIII. pt. 2, 433 (1865); in De Candolle, Prodr. XVI. pt, 2, 189 (1868).-Dippel, Handb. Laubholzk. II. 164 (1892), - Herder in Act. Hort. Petrop. XII. 77 (1892). - Matsumura in Jour. Coll. Sci. Tokyo, XVI. art. 5, 12 (1902); Ind. Pl. Jap. II. pt. 2, 17 (1912), - Winkler in Engler, Pflanzenr. IV.-61, 123 (1904). Shirasawa, Icon. Ess. For. Jap. II. t. 13, fig. 1-12 (1908). - Nakai in Jour. Coll. Sci. Tokyo, XXXI. 204 (Fl. Kor. II.) (1911).

Alnus tinctoria Sargent in Garden \& Forest, X. 472, fig. 59 (1897).

Alnus hirsuta, var. vulgaris Callier in Schneider, Ill. Handb. Laubholzk. I. 133 (1904).

Alnus hirsuta, var. Cajanderi Callier, 1. c. 133 (1904).

Alnus hirsuta, var. vulgaris, f. typica Callier in Fedde, Rep. Spec. Nov. X. 233 (1911).

Alnus hirsuta, var. vulgaris, f. macrophylla Callier, 1. c. 233 (1911).

Alnus sibirica, var. hirsuta Koidzumi in Tokyo Bot. Mag. XXVII. 144 (1913). Nakai in Tokyo Bot. Mag. XXIX. 46 (1915).

NORTHEASTERN ASIA. Transbaikalia: "ad fl. Angaram superiorem," 1834, N. Turczaninow (co-type in Herb. Gray; fruits). Am ur: Bureja Mts., 1858, G. Radde (young fruits). Ussuri: coast region, lat. $44-45^{\circ} \mathrm{N} .1859, C$. Wilford (fruits). Saghalien: near Toyohara, abundant in swamps, August 4, 1914, E. H. Wilson (No. 7326 ; bush or tree, $3-15 \mathrm{~m}$. tall, girth $1.5 \mathrm{~m}$; young fruits); "in humidis Korsakof," October 5, 1908, U. Faurie (No. 286; fruits); without locality, Fr. Schmidt (fruits).

JAPAN. Hokkaido: prov. Oshima, Hakodate, 1861, C. Maximowicz (young fruits); same prov., Onuma-koen, moist woods and thickets, common, June 26, 1914, E. H. Wilson (No. 7262; bush or tree, 4-9 m. tall, girth $0.9 \mathrm{~m}$, branches slender, horizontally spreading; young fruits); prov. Kushiro, forming pure woods, August 12, 1914, E. H. Wilson (No. 7377; tree up to $18 \mathrm{~m}$. tall, girth $3 \mathrm{~m}$; ; young fruits); prov. Ishikari, Poronai, September 19, 1892, C. S. Sargent (tree $7-10 \mathrm{~m}$. tall; apparently one of the type specimens of $A$, tinctoria; sterile); same place and date, common, C.S. Sargent (tree 13-17 m. tall; type of A. tinctoria; fruits).

According to Sargent's deseription the typical A. tinctoria is nothing else than A. hirsuta. He says: "the leaves ... are ... clothed below with soft, close, rufous pubescence, which also covers the upper side of the slender midribs and primary veins." The type was gathered in Hokkaido, and the specimens in the Herb. Arn. Arb. cannot be distinguished in the sense of Callier and Komarov as a glabrescent form or species different from $A$. hirsuta, of which I have seen a co-type. Of the typical $A$, hirsuta Callier has distinguished several varieties and forms (apud 
Schneider, Ill. Handb. Laubholzk. I. 133 [1904]; in Fedde, Rep. Spec. Nov. X. 233 [1911]). The value of these forms is doubtful, and they need further investigation. With the rich Japanese material before me I cannot separate as a species from the very villose forms representing $A$. hirsuta Turczaninow the variety sibirica which seems to be connected with the type by intermediate forms of every degree. I refer to this variety all the forms hitherto named $A$. tinctoria and $A$. sibirica or $A$. incana, var. glauca of eastern Asia.

Alnus hirsuta is very abundant in Hokkaido and in southern Saghalien, where in open grassy country it forms nearly pure woods. It is a very bushy tree, not exceeding $20 \mathrm{~m}$. in height and usually much less, with a short, very thick and often gnarled trunk clothed with pale gray bark which is smooth or nearly so. Pictures of this tree will be found under Nos. x354, x360, x363, x366, x376, x418, x419, $\mathrm{x} 420$ of the collection of my Japanese photographs.

E. H. W.

Alnus hirsuta, var. sibirica Schneider, n. comb.

Alnus sibirica Fischer ex Turezaninow in Bull. Soc. Nat. Mosc. XI. 101 (Cat. Pl. Baical.) (nomen nudum) (1838) apud Komarov in Act. Hort. Petrop. XXII. 57 (Fl. Mansh. II.) (1903). - Callier apud Schneider, Ill. Handb. Laubholzk. I. 133 in adnot. (1904); II, 891, fig. $557 \mathrm{f}-\mathrm{h}$ (1912). - Nakai in Tolyo Bot. Mag. XXIX. 47 (1915).

Alnus incana, var. sibirica Spach in Ann. Sci. Nat. sér. 2, XV. 207 (1841). Ledebour, Fl. Ross. III. pt. 2, 656 (1850). - Turczaninow in Bull. Soc. Nat. Mosc. XXVII. 406 (1854); Fl. Baical-Dahur. II. 133 (1856). - Trautvetter \& Meyer in Middendorff, Sibir. Reise, I. pt. 2, Bot. abt. 2, 86 (Fl. Ochot.) (1856). - Regel in Nouv. Mém. Soc. Nat. Mosc. XIII. 156 (Monog. Betulac. 98) (1861); in Bull. Soc. Nat. Mosc. XXXVIII. 434 (1865); in De Candolle, Prodr. XVI. pt. 2, 189 (1868). - Dippel, Handb. Laubholzk. II. 164 (1892). - Herder in Act. Hort. Petrop. XII. 77 (Pl. Radd.) (1892) Matsumura in Jour. Coll. Sci. Tokyo, XVI. art. 5, 12 (1902); Ind. Pl. Jap. II. pt. 2, 18 (1912). - Winkler in Engler, Pflanzenr. IV.-61, 122 (1904). - Nakai in Jour. Coll. Sci. Tokyo, XXXI. 204 (Fl. Kor.) (1911).

Alnus incana, var. glauca Regel in Nouv. Mém. Soc. Nat. Mosc. XIII. pt. 2,

154 (Monog. Betulac. 96) (1861), quoad specim. sibirica; in Bull. Soc. Nat.

Mosc. XXXVIII. 433 (1865), quoad specim. e Mandshuria et Japonia; in

De Candolle, Prodr. XVI. pt. 2, 189 (1868), quoad specim. e Sibiria, Mandshuria et Japonia. - Franchet \& Savatier, Enum. Pl. Jap. I. 458 (1875).Herder in Act. Hort. Petrop. XII. 77 (pro parte) (1892), - Palibin in Act. Hort. Petrop. XVIII. 194 (1900), exclud. syn. Michaux.

Alnus tinctoria Komarov in Act. Hort. Petrop. XXII. 56 (Fl. Mansh. II.) (non Sargent sensu stricto) (1903). - Callier apud Schneider, Ill. Handb. Laubholzk. I. 134, fig. $68 \mathrm{~h}-\mathrm{h}^{2}, 721$ (1904); II. 891, fig. $557 \mathrm{i}(1912)$; in Fedde, Rep. Spec. Nov. X. 233 (1911). - Rehder in Bailey, Stand. Cycl. Hort. I. 253 (1914). - Nakai in Tokyo Bot. Mag. XXIX. 47 (1915). Alnus incana, var. tinctoria Winkler in Engler, Pflanzenr. IV.-61, 123 (1904).Matsumura, Ind. Pl. Jap. II. pt. 2, 17 (1912). Alnus tinctoria, var. typica Callier in Fedde, Rep. Spec. Nov. X. 233 (1911); in Schneider, Ill. Handb. Laubholzk. II. 891 (1912).

Alnus tinctoria, var. obtusiloba Callier, 1. c. 233 (1911); 1. c. 891 , fig. 557 i (1912). Alnus tinctoria, var. mandschurica Callier, 1. c. 233 (1911); 1. c. 891 (1912). Alnus sibirica, var. typica Callier in Schneider, Ill. Handb. Laubholzk. 891, fig. $557 \mathrm{f}(1912)$. Alnus sibirica, var. oxyloba Callier, 1. c. 891 , fig. 557 g (1912). 
Alnus sibirica, var. paucinervia Callier, 1. c. 891, fig. $557 \mathrm{~h}$ (1912).

Alnus sibirica, var. tinctoria Koidzumi in Tokyo Bot. Mag. XXVII. 145 (forma a-e inclusa) (1913).

NORTHEASTERN ASIA. Transbaikalia: “ad fl. Argun," 1833, N. Turczaninow (? type of A. sibirica; co-type in Herb. Gray). Mandshuria: meadow near Sryetinsk, August 13, 1903, C. S. Sargent (sterile; branchlets and petioles finely pubescent or tomentose); mountain streams 12 hours east of Harbin by railway, August 31, 1903, C. S. Sargent (fruits). Amur: " ad fl. Amur," 1855, R. Maack (No. 611; sterile, branchlets and petioles tomentose, leaves rather glabrous); Amur, C. Maximowicz (fruits; pubescence as in No. 611); "Amur superior et medius," August 28, 1891, S. Korshinsky (fruits; less hairy than the foregoing specimen). Ussuri: near Vladivostok, common, August 18, 1903, C. S. Sargent (small tree; sterile).

JAPAN. Hokkaido: prov. Oshima, Hakodate, Oiwagi, 1861, C. Maximowicz (fruits). Hondo: prov. Shimotsuke, around Nikko, common, on way to near Kieifuri waterfall, Oetober 23, 1914, E. H. Wilson (No. 7711 ; tree up to $12 \mathrm{~m}$. tall, girth $0.9 \mathrm{~m}$.; fruits); prov. Rikuchu, Hayachine-san, side of streams, etc., common, September 27, 1914, E. H. Wilson (No. 7553; tree 13-17 m. tall, girth 0.6-1.2 m.; bark smooth, gray, branches long, fairly slender, horizontally spreading; fruits); prov. Shinano, Otake-gawa, mountain slopes, common, October 31, 1914, E. H. Wilson (No. 7751; bushy tree, 7-12 m. tall, girth 0.6-0.75 m., fruits); Ontake, 1905, U. Faurie (No. 6646; fruits); prov. Shimosa, Matsudo, August 11, 1901, February 15, 1905 (ex Herb. Sakurai; sterile and flowers); prov. Musashi, Tokyo, March 11, 1905 (ex Herb. Sakurai; flowers); prov. Suraga, slopes of Fuji-san, abundant, from alt. $600 \mathrm{~m}$. upwards, May 8, 1914, E. H. Wilson (No. 6646; small tree, 4-10 m. tall, bark smooth, gray; female flowers, young leaves); prov. Sagami, Hakone, common, April 17, 1914, E. H. Wilson (No. 6435; tree 7-12 m. tall, girth 0.3-0.9 m., branches ascending-spreading; flowers and old fruits); prov. Kozuke, round Karuizawa, woods, August 31, 1914, E. H. Wilson (No. 7428; slender tree, $7-10 \mathrm{~m}$. tall, girth $0.3-0.45 \mathrm{~m}$; fruits); prov. Mutsu, Lake Towada, common, alt. 300-600 m., October 4, 1914, E. H. Wilson (No. 7608; tree 10-13 m. tall, girth 0.3-0.75 m.; sterile).

I refer to var. sibirica all those forms which have glabrous or nearly glabrous branchlets, peduncles and petioles, and the leaves hairy below only on the midrib and veinlets. But there are several specimens mentioned above which are intermediate between this variety and the typical $A$. hirsuta. In the type the branchlets, peduncles and petioles are more or less hirsute or tomentose, while the leaves are covered beneath with a brownish tomentum or, if glabrescent, are mostly hairy also between the veinlets. I do not see how it is possible to keep the true $A$. sibirica ${ }^{1}$ distinct from $A$. tinctoria of Komarov, Callier and Nakai. The last two authors distinguish several varieties which certainly need further investigation, Leaves from different parts of the same tree sometimes show a good deal of variation in shape, texture and pubescence, so that it is very difficult to describe varieties or forms only from scanty herbarium specimens. There are, I am sure,

1 In the co-type in Herb. Gray the leaves are round-ovate, sometimes somewhat cordate at the base, obtuse at the apex and obtusely lobed at the margin. On the upper surface they are pubescent only on the midrib, while on the under surface also the principal veins and even some veinlets are more or less hirsute, but between the veinlets they are wholly glabrous. The ends of the branchlets, the base of the peduncles and the petioles are more or less finely tomentose. The leaves are up to $8.3 \mathrm{~cm}$. long and $8 \mathrm{~cm}$. broad. The specimen is very imperfect. 
some forms of both varieties which may possibly better be considered subspecies, but it needs more material and more observations in the field in order to get a good idea of the forms which are of taxonomic value. I may mention Wilson's No. 7613 (from near Lake Towada, alt. 600 m., October 6, 1914, slender tree 8-12 m. tall, girth $0.3-0.6 \mathrm{~m}$.), which looks like a distinct form of the typical variety.

There is another specimen of Wilson's (No. 7261, from Hokksido, prov. Oshima, Onuma-koen, local by lake side, July 26,1914 , tree $10 \mathrm{~m}$. tall, girth $0.6 \mathrm{~m}$., branches horizontally spreading). In shape and serration the leaves are more like those of $A$. incana Moench; the pubescence is more like that of the typical A. hirsuta than that of var. sibirica, the cones are not yet ripe. This specimen may belong to A. borealis Koidzumi (in Tokyo Bot. Mag. XXVII. 145 [1913]), the types of which were collected in Hokkaido, prov. Ishikari, near Sapporo, and in northern Hondo, prov. Mutsu, Kawau-chimura. Koidzumi describes the leaves as more orbicular than they are in Wilson's plant. Without having seen a specimen of $A$. borealis it is impossible to say whether it is a distinct species or only a variety of $A$. hirsuta and similar to Wilson's No. 7261 .

Komarov seems to believe that the true $A$. sibirica Fischer is the most western form in Siberia of the group to which also belong $A$. hirsuta Turezaninow, A. tinctoria sensu Komarov and $A$. incana Moench. So far as I know these species I believe that $A$. hirsuta senșu meo represents $A$. incana Moench in eastern Asia. The differences between these eastern Asiatic forms are not greater than they are between the different forms of $A$. incana Moench described by Callier apud Schneider, Ill. Handb. Laubholzk. I. 135 (1904).

Alnus hirsuta var. sibirica is a very common tree in moist woods and on the margins of lakes and by the side of streams in Japan from central Hondo northward, but rare in Hokkaido. It is usually a more slender tree than the typical species.

E. H. W.

Pictures of this Alder will be found under Nos. x191, x251, x252, x508, x540 of the collection of my Japanese photographs.

9. Alnus Matsumurae Callier in Fedde, Rep. Spec. Nov. X. 234 (1911); apud Schneider, Ill. Handb. Laubholzk. II. 891, fig. $556 \mathrm{n}-\mathrm{p}, 557$ k (1912).

Alnus glutinosa Matsumura, List Pl. Nikko, 29 (non Linnaeus) (1894).

Alnus incana, var. emarginata Matsumura in Jour. Coll. Sci. Tokyo, XVI. art. 5, 13, t. IV (1902); Ind. Pl. Jap. II. pt. 2, 17 (1912). - Winkler in Engler, Pflanzenr. IV.-61, 120 (1904).

JAPAN. Hondo: prov. Iwashiro, Ose, July 25, 1909 (ex Herb. Sakurai; young fruits); prov. Shimotsuke, on the Konsei-toge, 1885, J. Matsumura (type; fruits); on Nyoho-san, 1901, Yatabe \& Matsumura (ex Matsumura); Yumoto to Nikko, common in mountain forests, September 6, 1892, C. S. Sargent (tree 13$17 \mathrm{~m}$. tall, girth 3.6-5.4 m., pale bark; fruits); Yumoto, open country and woods, abundant, June 22, 1914, E. H. Wilson (No. 6836; bush or tree, 3-15 m. tall, girth $0.9 \mathrm{~m}$.; young fruits); same place, August 30, 1904, N. Mochizuki (fruits); prov. Shinano, on Tsubakura-dake, side of streams, alt. 1200-1800 m., September 3, 1914, E. H. Wilson (No. 7501; tree 10-13 m. tall, girth 0.9-1.2 m., branches horizontally wide-spreading; fertile); prov. Kai, Fuji-san, July 27, 1908 (ex Herb. Sakurai; young fruits); prov. Shinano, Jizogatake, July 1903, U. Faurie (No. 5362; young fruits).

This is a well-marked species resembling in the shape of its obovate emarginate leaves A. Fauriei Léveillé, but in A. Fauriei the under surface of the leaves is greenish and not grayish and papillose as in A. Matsumurae Callier. 
10. Alnus formosana Makino in Tokyo Bot. Mag. XXVI. 390 (1912).

Alnus maritima, var. japonica Regel in De Candolle, Prodr. XVI. pt. 2, 186 (quoad pl. Formosanam) (1868).

Alnus maritima Henry in Trans. Asiat. Soc. Jap. XXIV. suppl. 90 (List Pl. Formos.) (non Muhlenberg) (1896).

Alnus maritima, var. formosana Burkill in Jour. Linn. Soc. XXVI. 500 (1899). Matsumura in Jour. Coll. Sci. Tokyo, XVI. art. 5, 8 (Rev. Aln. Spec. Jap.) (1902). - Matsumura \& Hayata in Jour. Coll. Sci. Tokyo, XXII. 391 (Enum. Pl. Formos.) (1906).- - Hayata in Jour. Coll. Sci. Tokyo, XXV. 199 (Fl. Mont. Formos.) (1910).

Alnus japonica Winkler in Engler, Pflanzenr. 1V.-61, 114 (1904), quoad pl. Formosanam.

Alnus japonica, var. formosana Callier in Fedde, Rep. Spec. Nov. X. 228 (1911); apud Schneider, Ill. Handb. Laubholzk. II. 890, fig. 555 k (1912). Matsumura, Ind. Pl. Jap. 1I. 2, 18 (1912),

CHINA. Formosa: without locality, 1864, R. Oldham (No. 508, type of var. formosana Burkill; fruits); Tamsui, A. Henry (Nos. 1394 and 1732, Herb. New York Bot. Gard.; flowering, autumn); in montibus Suitenka, June 28, 1903, U. Faurie (No. 516; sterile); see also Matsumura and Hayata, l. c.

This species differs from A. japonica Siebold \& Zuccarini in flowering in the autumn like $A$. maritima Muhlenberg, which otherwise is easily distinguished by the different leaves, by the smaller narrower petals of the male flowers and by other characters. A. formosana is a subtropical species like A. nitida Endlicher.

11. Alnus nitida Endlicher, Gen. Suppl. IV. 2, 20 (1847), - Regel in Nouv. Mém. Soc. Nat. Mosc. XIIl. pt. 2, 140, t. 14, fig. 23-30 (Monog. Betulac.) (1861); in Bull. Soc. Nat. Mosc. XXXVIII. pt. 2, 421 (1865); in De Candolle, Prodr. XVI. pt. 2, 181 (1868). - K. Koch, Dendr. II. pt. 1, 624 (1872). - Brandis, Forest Fl. Brit. Ind. 460, t. 57 (1874); Ind. Trees, 623 (1906). - Hooker f., Fl. Brit. Ind. V. 600 (1888); in Bot. Mag. CXXV. t. 7654 (1899). - Sargent, Silva N. Am. IX. 70, in adnot. (1896). - Collett, Fl. Siml. 473 (1902). - Gamble, Man. Ind. Timb. 670 (1902). - Winkler in Engler, Pflanzenr. IV.-61, 108 (1904). - Henry in Elwes \& Henry, Trees Gr. Brit. \& Irel. IV. 954, t. 268, fig. 3 (1909), - Callier apud Schneider, Ill. Handb. Laubholzk. II. 889, fig. 555 e-f, 556 a-c (1912). Bean, Trees \& Shrubs Brit. Isl. I. 183 (1914).

Clethropsis nitida Spach in Ann. Sci. Nat. sér. 2, XV. 202 (1841). - Cambessèdes in Jacquemont, Voy. IV. Bot. 159, t. 159 (1844).

Alnus sp. Stewart, Punjab Pl. 197 (1869).

INDIA. Western Temperate Himalaya: "Emodo," V. Jacquemont (type, ex Spach); "secus rivulos circa Khoti," alt. 2000-2500 m., V. Jacquemont (ex Cambessèdes); Kunawur, "reg. temp. 5-7000 ped.," T. Thomson; without locality (No. 955, Herb. Falconer).

This species and $A$. nepalensis $D$. Don were referred by Spach to his genus Clethropsis, although they are different except that both flower in the autumn. See my remarks under section 2 .

Sect. 2. CLETHROPSIS Regel in De Candolle, Prodr. XVI. pt. 2, 181 (excl. A. nitida) (1868). - Winkler in Engler, Pflanzenr. IV.-61, 108 (1904), excl. A. nitida.

Clethropsis Spach in Ann. Sci. Nat. sér. 2, XV. 201 (1841), excl. A. nitida. Alnus, subgen. Clethropsis Endlicher, Gen. Suppl. IV. pt. 2, 20 (1847), excl. 
A. nitida. - Regel in Bull. Soc. Nat. Mosc. XXXVIII. pt. 2, 421 (1865), excl. A. nitida. - Prantl in Engler \& Prantl, Nat. Pfanzenfam. III. abt. 1, 45 (1887), excl. A. nitida. - Callier apud Schneider, Ill. Handb. Laubholzk. Il. 889 (1912), excl. A. nitida.

Alnus, sect. Alnaster Regel in Nouv. Mém. Soc. Nat. Mosc. XIII. 133 (Monog. Betulac. 75) (pro parte) (1861), quoad A. napalensem.

I refer to this group only $A$. nepalensis D. Don because it differs from $A$. nitida Endlicher and also from the other species placed under sect. Gymnothyrsus by its numerous handsome paniculate elusters of male catkins and by its seeds, which have the same kind of wings as the species in the subgen. Alnaster and the subgen. Cremastogyne. Besides it differs from A. nitida D. Don in its paniculate female catkins and in the papillose under side of the leaves.

12. Alnus nepalensis D. Don, Prodr. Fl. Nepal. 58 (1825). - Endlicher, Gen. Suppl. IV. pt. 2, 20 (1847). - Regel in Bull. Soc. Nat. Mosc. XXXVIII. pt. 2, 421 (1865); in De Candolle, Prodr. XVI. pt. 2, 181 (1868). - Brandis, Forest Fl. Brit. Ind. 460 (1874); Ind. Trees, 623 (1906).-Kurz, Forest Fl. S. Ind. II. 476 (1877). - Hooker f., Fl. Brit. Ind. V. 600 (1888). - Sargent, Silva N. Am. IX. 70, in adnot. (1896). - Mouillefert, Traité Arb. \& Arbriss. II. 1133 (1897). -Franehet in Jour. de Bot. XIII. 208 (1899). - Burkill in Jour. Linn. Soc. XXV1. 500 (1899). - Collett, Fl. Siml. 473 (1902). - Gamble, Man. Ind. Timb. 670 (1902). Winkler in Engler, Pflanzenr. IV.-61, 108, fig. 25 (1904). - Callier apud Schneider, Ill. Handb. Laubholzk. II. 889, fig. $555 \mathrm{~g}, 556 \mathrm{~d}-\mathrm{f}$ (1912). - Diels in Not. Bot. Gard. Edinburgh, VII. 41 (Pl. Chin. Forrest.) (1912).

Betula Boshia Hamilton ex D. Don, Prodr. Fl. Nepal. 58 (pro synon.) (1825). Betula leptostachya Wallich Herb. 1824 ex Wallich, Cat. No. 2799 (1828).

Alnus napalensis Wallich, Pl. As. Rar. II. 27, t. 131 (1831), - Regel in Nouv. Mém. Soc. Nat. Mosc. XIII. pt. 2, 141, t. 13, fig. 40-43, t. 16, fig. 4-6 (1861). Clethropsis nepalensis Spach in Ann. Sci. Nat. sér. 2, XV. 202 (1841).

CHINA. Yunnan: Mengtsze, south of Red River, alt. 1200-1500 m., forming woods, A. Henry (No. 9223, in part; trees 5-10 m. tall; fruits); same locality, on mountains, forming woods, alt. 1500-1800 m., A. Henry (No. 9223 in part; trees 3-7 m. tall). For further specimens see Burkill, 1. c., and Franchet, l. e.

INDIA. Kumaon : "common at alt. 4-8000 ft.," Strachey \& Winterbottom (flowers and fruits). Gurhwal: Gaurikund via Trijugi Narain and Maser-tál to Bilung, September 24 to Oetober 3,1855 , Schlagintweit (No. 9372; flowers); without special locality, alt. $1000 \mathrm{ft} ., 1886$, H. Mayr (tree; fruits); Nepal: " ad Narainhetty," December, F. Hamilton (sub nom. Betula Boshia; type, ex D. Don); without special locality, "in montibus," 1824, N. Wallich (No. 2799, sub nom. Betula leptostachya). Sikkim: "regio temp. 5-8000 ped.," J. D. Hooker (young flowers and fruits); Darjeeling, Ryang, alt. $1500 \mathrm{ft}$., November 12, 1870, C. B. Clarke (No. 13693; flowers); Yoksun, alt. $3500 \mathrm{ft}$., October 9, 1875, C. B. Clarke (Nos. $25151^{\mathrm{d}}, 25151^{\mathrm{h}}$; flowers); Lingcham, alt. $5000 \mathrm{ft}$., Oetober $22,1875, C$. B. Clarke (No. 25479; sterile); Mongpo, alt. $5000 \mathrm{ft}$., October 10, 1884, C. B. Clarke (No. $36465^{\mathrm{b}}$; flowers); "Sikkim superior," May 1885, Pantling (No. 46331 $1^{\mathrm{b}}$ Herb. Clarke; fruits). Eastern Bengal: without locality (No. 4490 Herb. Griffith; fruits and flowers). Assam: without locality, $1891 \mathrm{Dr}$. King's collector (flowers and fruits).

This species is abundant in southwestern Yunnan in dry woods, often forming pure stands; it also occurs as an undergrowth in Pine woods. 
Subgen. III. ALNASTER Endlicher, Gen. Suppl. II. 28 (1842); IV. pt. 2, 20 (1847). - Regel in Bull. Soc. Nat. Mosc. XXXVIII. pt. 2, 421 (1865). - PrantI in Engler \& Prantl, Nat. Pflanzenfam. III. abt. 1, 45 (1887). - Matsumura in Jour. Coll. Sci. Tokyo, XVI. art. 5, 1 (1902.

Alnus, sect. Alnobetula W. D. Koch, Syn. Fl. Germ. Helv. 663 (sine descriptione) (1837); ed. 2, 762 (1843). - Winkler in Engler, Pflanzenr. IV.-61, 102 (1904). - Ascherson \& Graebner, Syn. Mitteleur. Fl. IV. 413 (1911).

Alnaster Spach in Ann. Sci. Nat. sér. 2, XV. 200 (1841), - Ledebour, Fl. Ross. III. pt. 2, 655 (1850).

Alnus, subgen. Alnibetula Petermann, Deutsche Fl. 516 (1849).

Alnobetula Schur in Verh. Siebenbürg. Ver. Naturw. IV. 68 (1853); Enum. Pl. Transsilv. 614 (1866).

Alnus, sect. Alnaster Regel in Nouv. Mém. Soc. Nat. Mosc. XIII. pt. 2, 133 (Monog. Betulac. 75) (1861), exclud. A. napalensis et A. nitida; in De Candolle, Prodr. XVI. pt. 2, 181 (1868).

Alnus, subgen. Alnobetula K. Koch, Dendr. II. pt. 1, 625 (1872). - Dippel, Handb. Laubholzk. II. 143 (1892), - Koehne, Deutsche Dendr. 112 (1893). Callier apud Schneider, Ill. Handb. Laubholzk. I. 120 (1904).

Wolpert in Flora, C. 37 (Vergleick. Anat. u. Entwoicklungsgeschichte v. A. alnobetula u. Betula) (1910) gives a very interesting account of the differences between the true Alnus and the subgen. Alnaster and of the affinities of the latter with Betula.

Series a. Virides Schneider, n. ser. (descriptio in clavi).

The species placed into this group are very closely related. I doubt whether the characters taken by Callier from the male flowers are constant enough to distinguish Alnus viridis ${ }^{1}$ Lamarek \& De Candolle from A. sinuata Rydberg, etc. The typical $A$. viridis does not oecur within our area so far as I know, but Callier (apud Schneider, III. Handb. Laubholzk. I. 121 (1904) refers specimens collected by Middendorff " ad fl. Boganida" and others to var. typica, f. repens Callier, 1. e. I have not seen these plants, but they are referred to A. fruticosa by Trautvetter.

13. Alnus fruticosa Ruprecht in Beitr. Pflanzenk. Russ. Reich, II. 53 (Fl. Samojed. Cisural.) (1845). - Trautvetter in Middendorff, Sibir. Reise, I. pt. 2, Bot. abt. 1, 152 (Fl. Boganid.) (1857). - Komarov in Act. Hort. Petrop, XXII. 58 (Fl. Mansh. II) (1903). - Callier apud Schneider, Ill. Handb. Laubholzk. I. 121, fig. 66 h (1904); II. 888 (1912); in Fedde, Rep. Spec. Nov. X. 226 (1911). Koidzumi in Tokyo Bot. Mag. XXVII. 144 (1913). - Rehder in Bailey, Stand. Cycl. Hort. I. 253 (1914). - Nakai in Tokyo Bot. Mag. XXIX. 45 (1915).

Alnaster fruticosus Ledebour, Fl. Ross. III. pt. 2, 655 (1850). - Trautvetter \& Meyer in Middendorff, Sibir. Reise, I. pt. 2, Bot. abt. 2, 85 (Fl.

1 There is some confusion about the synonyms of this species, which are given as follows:

Alnus viridis Lamarck \& De Candolle, Fl. Franç. III. 304 (1805).

Betula viridis Chaix apud Villars, Hist. Pl. Dauph. I. 374 (1786).

Betula alnobetula Ehrhart, Beitr. II. 72 (1788).

Betula ovata Sehrank, Baier. Fl. I. 419 (1789).

Alnus ovata Loddiges, Bot. Cab. XII. t. 1141 (1826).

Alnaster viridis Spach in Ann. Sci. Nat. sér. 2, XV. 201 (1841).

Alnus alnobetula Th. Hartig, Naturg. Forstl. Culturpfl. 372 (pro synon.) (1851).-

Schweinfurth apud Ascherson, Fl. Prov. Brandenb. 622 (1864).

Alnobetula viridis Schur in Verh. Siebenbürg. Ver. Naturw. IV. 68 (1853). 
Ochot.) (1856). - Regel \& Tiling in Nouv. Mém. Soc. Nat. Mosc. XI. 119 (Fl. Ajan.) (1858). - Trautvetter in Mém. Sav. Etr. Acad. Sci. St. Pétersbourg, IX. 257 (Maximowicz, Prim. Fl. Amur.) (1859). - Schmidt in Mém. Acad. Sci.St. Pétersbourg, sér. 7, XII. 62, 174 (Reis. Amur-Lande Sachal.) (1868).

Alnaster viridis Turezaninow in Bull. Soc. Nat. Mosc. XXVII. 404 (exclud. synon. plur.) (1854); Fl. Baical.-Dahur.II. 131 (1856) (exclud. synon.plur.) Korshinsky in Act. Hort. Petrop. XII. 389 (1892).

Alnobetula fruticosa Ruprecht in Bull. Acad. Sci. St. Pétersbourg, XV. 139 (1856), 375 (1857); in Mél. Biol. II. 434 (1857), 558 (1858).

Alnus viridis, var, sibirica Regel in Nouv. Mém. Soc. Nat. Mosc. XIII. pt 2, 137 , t. 14, fig. 16-20 (Monog. Betulac. 79) (pro parte) (1861); in Bull. Soc. Nat. Mosc. XXXVIII. pt. 2, 422 (pro parte) (1865); in De Candolle, Prodr. XVI. pt. 2, 182 (pro parte) (1868). - Herder in Act. Hort. Petrop. XII. 70 (pro parte maxima) (1892).

Alnus crispa K. Koch, Dendr. II. pt. 1, 626 (pro parte, non Pursh) (1872). Alnus viridis, var. julacea Franchet in Nouv. Arch. Mus. Paris, sér. 2, VII. 91 (Pl. David. I. 281) (1884). - Burkill in Jour. Linn. Soc. XXVI. 500 (1899).

Alnus fruticosa, var. manshurica Callier ex Komarov in Act. Hort. Petrop. XXII. 59 (Fl. Mansh. II.) (1903).

Alnus fruticosa, var. mandschurica Callier apud Schneider, Ill. Handb. Laubholzk. I. 121 (1904).

Alnus fruticosa, var. typica Callier, 1. c. (1904).

Alnus alnobetula, var, fruticosa Winkler in Engler, Pflanzenr. IV.-61, 160 (pro parte) (1904).

Alnus fruticosa, var. typica, f. vulgaris Callier in Fedde, Rep. Spec. Nov. X. 226 (1911); apud Schneider, Ill. Handb. Laubholzk. II. 888 (1912).

Alnus fruticosa, var. typica, f. macrophylla Callier, 1. o. 226 (1911); 1. c. 888 (1912).

Alnus fruticosa, var. mandschurica, f. normalis Callier in Fedde, Rep. Spec. Nov. X. 227 (1911); apud Schneider, Ill. Handb. Laubholzk. II. 888 (1912). Alnus fruticosa, var. mandschurica, f. grandifolia Callier, 1. c. 227 (1911); 1. c. 888 (1912).

Alnus fruticosa, var. sachalinensis Koidzumi in Tokyo Bot. Mag. XXVII. 144 (1913).

Alnus fruticosa, var. mandshurica, f. normalis Nakai in Tokyo Bot. Mag. XXIX. 45 (1915).

NORTHEASTERN ASIA. Yakutsk: "ad flumen Kolyma," F. M. Augustinowicz (young fruits). Maritime prov.: Ajan river, H. Tiling (flowers). Amur: $C$. Maximowicz (fruits); same region, $F$. M. Augustinowicz (fruits); same region, August 27, 1891, S. Korshinsky (fruits). Korea: "fluvium Jalu superior, infra ostium fluvii Czan-dschingan, August 12, 1897, V. Komarov (No. 492; sterile). For further collections see Herder, 1. c. and Komarov, 1. c.

This species represents in Asia $A$, viridis Lamarck \& De Candolle.

14. Alnus sinuata Rydberg, var. kamtschatica Callier apud Schneider, Ill. Handb. Laubholzk. I. 804 (1906).

Alnus viridis, var. sibirica Regel in Nouv. Mém. Soc. Nat. Mosc. XIII pt. 2, 137 (Monog. Betulac. 79) (pro parte; an includ. lusu kamtschatica 139?) (1861); in Bull. Soc. Nat. Mosc. XXXVIII. pt. 2, 422 (pro parte) (1865); in De Candolle, Prodr. XVI. pt. 2, 182 (pro parte) (1868). 
Alnus sitchensis, var. kamtschatica Callier, apud Schneider, Ill. Handl. Laubholzk. I. 123 (1904).

Alnus alnobetula, var. fruticosa Winkler in Engler, Pflanzenr. IV.-61, 160 (pro parte) (1904).

NORTHEASTERN ASIA. Kamtehatka (ex Callier).

I have not seen a specimen of this variety, which needs further investigation. I suppose that the following species also occurs in Kamtchatka, otherwise the specimen of $\mathrm{C}$. Wright may belong to this variety.

15. Alnus Maximowiczii Callier apud Schneider, Ill. Handb. Laubholzk. I. 122, fig. $66 \mathrm{k}, 67 \mathrm{i}-\mathrm{i}^{1}(1904)$.

Alnus viridis, var. sibirica Regel in Bull. Soc. Nat. Mosc. XXXVIII. pt. 2, 422 (1865), quoad plantam Japon.; in De Candolle, Prodr. XVI. pt. 2, 182 (1868), quoad plantam Japon. - Franchet \& Savatier, Enum. Pl.Jap. I. 456 (1875).Miyabe in Mem. Bost. Soc. Nat. Hist. IV. 259 (Fl. Kuril. Isl.) (1890).Matsumura in Jour. Coll. Sci. Tokyo, XVI. art. 5, 1 (Rev. Alni Spec. Jap.) (1902).

Alnus alnobetula, var. fruticosa Winkler in Engler, Pflanzenr. IV.-61, 106 (pro parte) (1904). - Matsumura, Ind. Pl. Jap. II. pt. 2, 16 (1912).

NORTHEASTERN ASIA. Kamtchatka: Petropavlowski, C. Wright (flowers and old fruits). Saghalien: without locality, Fr. Schmidt (fruits); F.M. Augustinowicz (flowers); " in humidis sylvarum," August 1908, U. Faurie (No. 288; fruits).

JAPAN. Hondo: prov. Shimotsuke, summit of Nantai-san, forming thickets, May 29, 1914, E. H. Wilson (No. 6788; bush 1.2-1.8 m. tall; not yet flowering, old fruits); same prov., Chuzenji, alt. $1400 \mathrm{~m}$., lava bed, not common, May 25, 1914, E. H. Wilson (No. 6752; bush $3 \mathrm{~m}$. tall; flowers); same prov., Onsenga-dake, Yumoto, woods, alt. 2000-2100 m., June 23, 1914, E. H. Wilson (No. 6865; tree $7 \mathrm{~m}$. tall, girth $0.6 \mathrm{~m}$.; flowers); prov. Suraga, Fuji-san, alt. 2400-2600 m., October 9, 1892, P. Codman (fruits); same locality, July 29, 1881 (ex Herb. Sei. Coll. Univ. Jap.; fruits); prov. Shinano, on Tsubakura-dake, side of torrents, not common, alt. 1200-2200 m., September 13, 1914, E. H. Wilson (No. 7505; bush 3-5 m. tall; fruits); same prov., on Komaga-dake, alt. 2400 m., August 25, 1906 (ex Herb. Sakurai); Mt. Ontake, alt. 2700 m., woodlands, thickets, June 12, 1914, E. H. Wilson (No. 7019; tree 4-8 m. tall, girth 0.3-0.9 m.; flowers); prov. Ugo, Chokai-san, July 27, 1887, J. Matsumura (fruits); Chokai-san, common, October 14, 1914, E. H. Wilson (No. 7175; fruits); prov. Rikuchu, Hayachinesan, upper slopes of forest, common, alt. 1200-1600 m., September 27, 1914, E. H. Wilson (No. 7556; bush 3-7 m. tall; fruits); prov. Mutsu, Mt. Hakkoda, near Aomori, alt. $1100 \mathrm{~m}$., common, October 2,1892 , C. S. Sargent (tree $5-7 \mathrm{~m}$. tall or shrubby; fruits); same locality, forming thickets in the upper slopes of mountains, July 5, 1914, E. H. Wilson (No. 7098; large bush, 3-6 m. tall, flowers and young fruits); same locality, "in apice Hakkoda," August 1904, U. Faurie (No. 5787; "arbusta prostrata," $0.5 \mathrm{~m}$. tall; fruits); same locality, August 1904, U. Faurie (No. 7588; fruits). Hokkaido: prov. Shiribeshi, Shiribeshi-san, July 27, 1914, E. H. Wilson (fruits); prov. Oshima, Onuma-koen, common, swamps, July 26, 1914, E. H. Wilson (No. 7260 ; bush $2-4 \mathrm{~m}$. tall, much branched, sometimes small tree; fruits); Hakodate, 1861, C. Maximowicz (fruits); same locality, June 1, 1905, U. Faurie (No. 6645; young fruits); same locality, August ? 1905, U. Faurie (No. 6647 ; young fruits); same place, J. Small (Collectio Wright; fruits); same prov., Komagatake, August 19, 1888, T. Tokubuchi (fruits); prov. Hidaka, August 1892, T. Tokubuchi (fruits); prov. Ishikari, Sapporo, April 1878 (ex Herb. Sapporo; 
flowers); same place, May 1891, T. Tokubuchi (flowers). Kurile Islands: Arimoi, Etorofu, July 29, 1884, K. Miyabe (fruits).

This is the Alpine Alder of Japan and is common on all the higher mountains from the Japanese Alps in Shinano province northward. In Hokkaido and in Saghalien it descends to sea-level. It is always a much branched shrub 1.5 to $5 \mathrm{~m}$. tall and as much in diameter.

E. H. W.

Series b. Firmae Schneider, n. ser. (descriptio in clavi).

16. Alnus firma Siebold \& Zuccarini in Abh. Akad. Münch. IV. pt. 3, 230 (Fl. Jap. Fam. Nat. II. 106) (1846). - Regel in Nouv. Mém. Soc. Nat. Mosc. XIII. pt. 2, 142, t. 15, fig. 1-9 (Monog. Betulac. 84) (1861). - K. Koch, Dendr. II. pt. 1, 627 (1872). - Franchet \& Savatier, Enum. Pl. Jap. I, 457 (pro parte et exclusa var.) (1875). - Dippel, Handb. Laubholzk. II. 146, fig. 69 (1892), - Koehne, Deutsche Dendr. 113 (1893), - Callier apud Schneider, Ill. Handb. Laubholzk. I. 123, fig. $66 \mathrm{~m}, 67 \mathrm{a}^{-\mathrm{a}^{2}}$ (1904). - Shirasawa, Icon. Ess. For. II. t. 12, fig. 1-20 (1908). - Rehder in Bailey, Stand. Cycl. Hort. I. 253 (1914).

Alnus firma, var. typica Regel in Bull. Soc. Nat. Mosc. XXXVIII. pt. 2, 423 (1865); in De Candolle, Prodr. XVI. pt. 2, 183 (pro parte) (1868).

Alnus Sieboldiana Matsumura in Jour. Coll. Sci. Tokyo, XVI. art. 5, 3, t. 1 (Rev. Alni Spec. Jap.) (1902).

Alnus firma, var. Sieboldiana Winkler in Engler, Pflanzenr. IV.-61, 104, fig. 24 D-G (1904). - Henry in Elwes \& Henry, Trees Gr. Brit. \& Irel. IV. 953 (1909). - Matsumura, Ind. Pl. Jap. II. pt. 2, 15 (1912). - Bean, Trees \& Shrubs Brit. Isl. I. 181 (1914).

JAPAN. Kyushu : open place, lower slopes of Mt. Kirishima, March 6, 1914, E. H. Wilson (No. 6185 ; bush or small tree 0.6-3 m. tall; flowers); "haud procul a vulcano Aso," P. von Siebold (? type; ex Franchet \& Savatier); without locality, R. Oldham (fruits); island of Yakushima, side of streams, rare, alt. $180 \mathrm{~m}$., February 19, 1914, E. H. Witson (No. 6029; bush 0.9-1.8 m. tall; undeveloped). Hondo: prov. Mikawa, on the shore, August 29, 1905, March 16, 1913 (ex Herb. Sakurai; fruits and flowers); prov. Idzu (ex Herb. Sci. Coll. Univ. Jap.; flowers); Shimoda, hills, May 17, 1855, C. Wright (a large spreading bush; leaves and old fruits); prov. Suraga, Mt. Kuno, only by seaside, March 15, 1911 (ex Herb. Sakurai; flowers, old fruits).

The typical $A$. firma is a southern plant growing by the seaside, while the following subspecies grows on the mountains and in the more northern parts of Japan. It seems so closely allied to the type that I cannot separate it as a species.

This is a very common shrub or low scrubby tree in Kyushu and particularly so on the open exposed slopes of Higashi-Kirishima. A picture of this Alder will be found under No. x105 of the collection of my Japanese photographs. E. H. W.

Alnus firma, subspec. hirtella Schneider, n. subspec.

? Betula Alnus Thunberg, Fl. Jap. 76 (non Linnaeus) (1784).

Betula harinoki Siebold in Verh. Batav. Genootsch. XII. 25 (Syn. Pl. Oecon. Jap.) (nomen nudum) (1830).

Alnus firma, var. typica Regel in De Candolle, Prodr. XVI. pt. 2, 183 (proparte) (1868).

Alnus firma, $\beta$ hirtella Franchet \& Savatier, Enum. Pl. Jap. I. 457 (nomen nudum) (1875); II. 502 (1879).

Alnus Yasha Matsumura in Jour. Coll. Sci. Tokyo, XVI. art. 5, 4, t. 2 (1902). Callier apud Schneider, Ill. Handb. Laubholzk. I. 123, fig. $66 \mathrm{n}-\mathrm{n}^{1}, 67 \mathrm{~b}-\mathrm{c}^{1}$ (1904). - Rehder in Bailey, Stand. Cycl. Hort. I. 252 (1914). 
Alnus firma, var. Yasha Winkler in Engler, Pflanzenr. IV,-61, 104 (1904). Henry in Elwes \& Henry, Trees Gr, Brit. \& Irel. IV. 953, t. 268, fig. 2 (1909). - Matsumura, Ind. Pl. Jap. II. pt. 2, 17 (1912). - Bean, Trees \& Shrubs Brit. Isl. I. 180 (1914).

Alnus yasha, var. typica Callier in Fedde, Rep. Spec. Nov. X. 227 (1911); apud Schneider, Ill. Handb. Laubholzk. HI. 889 (1912).

Alnus yasha, var. macrocarpa Callier, 1. c. 227 (1911); l. c. 889 (1912).

Alnus yasha, var. microcarpa Callier, 1. c. 227 (1911); 1. e. 889 (1912),

Alnus hirtella Koidzumi in Tokyo Bot. Mag. XXVII. 144 (1913).

JAPAN. Hondo: prov. Suraga, slopes of Fuji-san from alt. $600 \mathrm{~m}$. upwards, thickets, abundant, May 8, 1914, E. H. Wilson (No. 6645; bush or small tree, 0.9-5 m. tall; flowers and old fruits); same locality, July 29, 1891, K. Watanabe (fruits); same locality, L. Savatier (No. 1152; type of var. hirtella ex Franchet \& Savatier); prov. Sagami, Hakone mountains, common, April 17, 1914, E. H. Wilson (No. 6427; tree $8 \mathrm{~m}$. tall, girth $1.5 \mathrm{~m}$.; flowers and old fruits); same prov., Miyanoshita, August 25, 1892, C. S. Sargent (tree 7-10 m. tall, fruits); Shinano prov., on Komaga-dake, August 29, 1880, J. Matsumura (fruits); same prov., Nagasenka, October 24, 1892, C.S. Sargent (small tree; fruits); same prov., on Tsubakura-dake, forming thickets in beds of streams, September 13, 1914, E. H. Wilson (No. 7449; slender tree or bush, 3-10 m. tall; fruits); same locality, September 14, 1914, E. H. Wilson (No. 7452; bush or slender tree, 3-12 m. tall, girth 0.3-0.45 m.; fruits); same prov., Otake-gawa, mountain slopes, common, October 31, 1914, E. H. Wilson (No. 7752; small bushy tree, 5-9 m. tall; fruits); prov. Kozuke, Mt. Asama, July 20, 1880 (ex Herb. Sci. Coll. Univ. Jap.; fruits); same place, July 1904, U. Faurie (Nos. 5791, 5792; fruits); same prov., Mt. Myogi, August 12, 1912 (ex Herb. Sakurai; fruits); prov. Shimotsuke, Nikko region, around Yumoto, common, October 19, 1914, E. H. Wilson (No. 7662; small tree, 5-8 m. tall, girth 0.3-0.75 m.; fruits); same prov., side of Lake Chuzenji, not common, October $21,1914, E$. H. Wilson (No. 7674; small tree, $8 \mathrm{~m}$. tall, girth $0.9 \mathrm{~m}$.; fruits); Nikko to Lake Chuzenji, roadside, October 26, 1905, J. G. Jack (fruits); prov. Mino, Nojiri to Nakatsu-gawa, September 6, 1905, J. G. Jack (fruits). Hokkaido: prov. Oshima, Hakodate, 1861, C. Maximowicz (flowers and fruits; sub nom. var. multinervis).

The pubescence of the branchlets and petioles and the somewhat more abundant pubescence of the leaves seem to be the only characters to separate this subspecies from the type. The bracts of the male flowers are also sometimes ciliate in the type, and the shape of the leaves is about the same in both forms, only the leaves are usually somewhat narrower in subspec. hirtella.

This is a small bushy tree not exceeding $10 \mathrm{~m}$. in height, and very common in woods throughout central Hondo between 500 and $1600 \mathrm{~m}$. altitude. E. H. W.

17. Alnus pendula Matsumura in Jour. Coll. Sci. Tokyo, XVI. art. 5, 6, t. 3 (1902). - Sehneider, Ill. Handb. Laubholzk. I. 804 (1906), - Rehder in Bailey Stand. Cycl. Hort. I. 252 (1914).

Alnus firma, var. multinervis Regel in Bull. Soc. Nat. Mosc. XXXVIII. pt. 2, 423 (1865); in De Candolle, Prodr. XVI. pt. 2, 183 (1868). - Winkler in Engler, Pflanzenr. IV.-61, 104 (1904). - Henry in Elwes \& Henry, Trees Gr. Brit. \& Irel. IV. 952 (1909), - Bean, Trees \& Shrubs Brit. Isl. I. 180 (1915).

Alnus firma, var. multinervia Franchet \& Savatier, Enum. Pl. Jap. I. 457 (1875). - Shirasawa, Icon. Ess. For. Jap. II. t. 12, fig. 21-34 (1908). 
Alnus multinervis Callier apud Schneider, Ill. Handb. Laubholzk. I. 123, fig. 66 o, $67 \mathrm{~d}-\mathrm{d}^{2}$ (1904).

Alnus multinervis, var. typica Callier, 1. c. (1904).

Alnus multinervis, var. nikkoensis Callier, 1. c. (1904).

JAPAN. Hokkaido: near Mohidsi, C. Maximowicz (type of var. multinervis, ex Regel). Hondo: prov. Mutsu, Mt. Hakkoda, woodlands, thickets, lower slopes of mountains, July 6, 1914, E. H. Wilson (No. 7114; bush 1.5-3 m. tall, fruits); same prov., near Aomori, common up to $900 \mathrm{~m}$., October 2, 1892, C.S. Sargent (tree $7 \mathrm{~m}$. tall; fruits); same locality, April 1902, U. Faurie (No. 5068; flowers); prov. Echigo, Deyu, August 1, 1886, J. Matsumura (fruits); prov. Shinano (Senano), 1864, C. Maximowicz (flowers and fruits); same prov., Mt. Tokagushi, August 7, 1907 (ex Herb. Sakurai; fruits); "Nippon media," 1866, Tschonoski (flowers). For further specimens see Matsumura, l. c.

A distinct species, well marked by its many-nerved leaves and by its nodding clusters of small fruits. 


\title{
LEGUMINOSAE. ${ }^{1}$
}

\author{
WISTARIA.
}

Determined by Alfred ReHder and E. H. Wruson.

Wistaria sinensis Sweet, Hort. Brit. 121 (Wisteria) (1827). Dyer in Jour. Linn. Soc. XVII. 329 (1879). - Schneider, Ill. Handb. Laubholzk. II. 78, figs. $46 \mathrm{f}-\mathrm{h}, 47 \mathrm{~b}-\mathrm{c}$ (Wisteria) (1907). - Pavolini in Nuov. Giorn. Bot. Ital. n. ser. XV. 410 (1908).

Glycine sinensis Sims in Bot. Mag. XLVI. t. 2083 (1819). - Edwards in Bot. Reg. VIII, t. 650 (1822). - Loddiges, Bot. Cab. VIII. t. 773 (1823). Fortune, Wanderings in China, 66 (1847).

Wisteria chinensis De Candolle, Prodr. II. 390 (1825), - Sweet, Brit. Fl. Gard. III. t. 211 (1827); Hort. Brit. ed. 2, 157 (1830). - Walpers, Rep. I. 770 (1842). - Fortune, Jour. Tea Count. China, 334-338 (Wistaria) (1852). Hemsley in Jour. Linn. Soc. XXIII. 161 (Wistaria) (pro parte) (1886). Harms in Bot. Jahrb. XXIX. 412 (Wistaria) (1900). - Pampanini in Nuov. Giorn. Bot. Ital. n. ser. XVII. 404 (Wistaria) (1910). - Dunn \& Tuteher in Kew Bull. Misc. Inform. add. ser. X. 77 (Wistaria) (1912), - Dunn in Sargent, Pl. Wilson. II. 102 (1914), - Bean, Trees \& Shrubs Brit. Isl. II. 680 (Wistaria) (1914). - Léveillé, Fl. Kouy-Tchéou, 245 (Wistaria) (1914).

Wistaria Consequana Loudon, Hort. Brit. 315 (1830). - Paxton in Paxton's Mag. Bot. VII. 127, t. (1840).

Millettia chinensis Bentham in Junghuhn, Pl. Junghuhn. 249, in adnot. (18511855).

Wistaria polystachya K. Koch, Dendr. I. 62 (pro parte) (1869). - Dippel, Handb. Laubholzk. III. 695 (pro parte) (1893). - Kleemann in Gartenfl. XLVI. 44, fig. 4 (1897). - Beissner, Schelle \& Zabel, Handb. LaubholzBen. 269 (pro parte) (1903).

Wistaria brachybotrys Maximowicz in Bull. Soc. Nat. Mosc. LIV. 9 (Fl. As. Or. Fragm.) (non Siebold \& Zuccarini) (1879), - Hemsley in Jour. Linn. Soc. XXIII. 161 (1886), quoad plantam Ningpoensem.

Phaseolodes floribundum O. Kuntze, Rev. Gen. I. 201 (pro parte) (1891).

Kraunhia floribunda Taubert in Engler \& Prantl, Nat. Pflanzenfam. III. abt. 3, 271 (pro parte) (1894).

Kraunhia sinensis Makino in Tokyo Bot. Mag. XXIV. 76 and 297 (1910).

Kraunhia floribunda, $\beta$ sinensis Makino in Tokyo Bot. Mag. XXV. 18 (1911).

Western Hupeh: Ichang, fairly common on cliffs and trees, alt. 30-500 m., April 1907 (No. 2360; flowers pale purple). Kiangsu : without locality, E. Faber.

2 See also pp. 87-119. 
JAPAN. Hondo: prov. Musashi, grounds of Yokohama Nursery Co., Kamata, cultivated, April 27, 1914, E. H. Wilson (No. 6579).

This species is endemic in China and is not uncommon at low altitudes in western Hupeh and in eastern Szech'uan, but is very rare in western Szech'uan. It is much cultivated in gardens at Shanghai, Soo-chou, Han-chou, and other centres of wealth and culture in eastern China. Fortune says it is a common wild plant on the island of Chusan and elsewhere in the province of Chekiang, but there is no record of it growing wild in districts north of Shanghai. In Japan, where it was unknown as a cultivated plant until quite recently, it has been introduced and is now cultivated by the Yokohama Nursery Company.

This Chinese Wistaria is closely related to the Japanese $W$. floribunda De Candolle, which has been confused with it. However, the Japanese species is readily distinguished by its more numerous (7-9) pairs of leaflets, which fall earlier in the autumn, and by its much smaller flowers, which open two to three weeks later. The Japanese is also much hardier than the Chinese species. In western Hupeh $W$. sinensis is colloquially known as " Chiao-têng." A picture will be found under No. 62 of the collection of Wilson's photographs and also in his Vegetation of Western China, No. 497.

Wistaria sinensis was first introduced into England by Captain Wellbank in 1816, and presented to Charles Hampden Turner of Rook's-nest, Surrey. Two years later it was sent from Canton by John Reeves to the Chiswiek Garden of the Horticultural Society of London.

The geaus Wistaria is represented in eastern Asia by several other species and garden forms, an account of which follows here.

Wistaria sinensis, f. alba Lindley in Jour. Hort. Soc. Land. IV. 221 (W. sinensis: alba) (1849).

Wistaria sinensis, var. albiflora Lemaire in Ill. Hort. V. t. 166 (1858). Sehneider, Ill. Handb. Laubholzk. II. 78 (1907).

Wisteria chinensis, var. alba Lavallée, Arb. Segrez. 65 (nomen nudum) (1877).Bean, Trees \& Shrubs Brit. Isl. 681 (Wistaria) (1914).

Wistaria ehinensis, var. abbiflora Mifler in Bailey, Cycl. Am. Hort. IV. 1988 (1902).

Wistaria polystachya alba Beissner, Sehelle \& Zabel, Handb. Laubholz-Ben. 269 (1903).

According to Wilson (A Naturalist in Western China, I. 18 [1913]) this albino form occurs wild near Ichang in western Hupeh. Fortune, who introdueed this plant to the Chiswick Garden of the Horticultural Society of London in May, 1846, first mentions it in his Wanderings in China, 260 (1847) as a white Glycine.

Wistaria floribunda De Candolle, Prodr. II. 390 (Wisteria) (1825).

Dolichos polystachios Houttuyn, Pflanzensyst. VIII. 563, t. 64, fig. 2 (non Linnaeus) (1782) exclud. synon. - Thunberg, Fl. Jap. 281 (polystachyos) (1784).

Glycine floribunda Willdenow, Spec. III. 1066 (1800). - Persoon, Syn. 11. 301 (1807).

Dolichos japonicus Sprengel, Syst. Veg. III. 252 (1826).

Dolichos (?) polystachyos Siebold in Verh. Batav. Genoot. XII. no. 1, 56 (Syn. Pl. Oecon. Jap.) (1830).

Wisteria brachybotrys Siebold \& Zucearini, Fl. Jap. I. 92, t. 45 (1839). - Spae in Ann. Soc. Agric. Bot. Gand. III. 49, t. (1847). - Planchon in Fl. des Serres, IX. 61, t. 880 (Wistaria) (1853). - Miquel in Ann. Mus. Lugd.-Bat. III. 44 (Wistaria brachybotrya) (1867); Prol. Fl. Jap. 232 (1867). - Tanaka, Useful 
Pl. Jap. 42, 70, fig. 334 (1891); 91, fig. 334 (1895). - Schneider, Ill. Handb. Laubholzk. II. 79, figs, 47 f., 48 q-s (1907), - Bean, Trees \& Shrubs Brit. Isl. II. 680 (Wistaria) (1913).

Wistaria polystachya K. Koch, Dendr. I. 62 (pro parte) (1869). - Dippel, Handb. Laubholzk. III. 695 (pro parte) (1893). - Beissner, Schelle \& Zabel, Handb. Laubholz-Ben. 269 (pro parte) (1903).

Phaseolodes brachybotrys O. Kuntze, Rev. Gen. I. 201 (1891).

Kraunhia brachybotrys Green, Pittonia, II. 175 (1892).

Kraunhia floribunda Taubert in Engler \& Prantl, Nat. Pflanzenfam. III. abt. 3, 271 (pro parte) (1894). - Shirasawa, Icon. Ess. For. Jap. Il. t. 32, figs, 12-24 (1908). - Hayata, Vegetation Mt. Fuji, 60 (1911).

Wistaria chinensis Matsumura, List Pl. Nikko, 51 (non De Candolle) (1894),Tanaka, Useful Pl. Jap. 152, No. $611^{\mathrm{b}}$ (1895).

Milletia floribunda Matsumura in Tokyo Bot. Mag. XVI. 64 (1902); Ind. Pl. Jap. II. pt. 2, 270 (1912).

Wistaria brachybotrys, var. rubra, Hort. apud Miller in Bailey, Cycl. Am. Hort. IV. 1989 (1902).

Kraunhia sinensis, var. brachybotrys Makino in Tokyo Bot. Mag. XXIV. 76 (1910).

Kraunhia sinensis, var. floribunda Makino, 298, 1. c. (pro parte) (1910).

Kraunhia floribunda, a typica Makino, 1, c. XXV. 17 (pro parte) (1911).

Kraunhia floribunda, $\gamma$ brachybotrys Makino, 1. c. 18 (1911).

JAPAN. Shikoku: prov. Awa, April 1913, Nikai. Hondo: prov. Mino, Nakatsugawa, September 6, 1905, J. G. Jack; prov. Kai, slopes of Yatsuga-dake, September 17, 1914, E. H. Wilson (No. 7532); prov. Sagami, Kamakura, thickets, May 2 and 8, 1914, E. H. Wilson (Nos. 6620, 6620); prov. Musashi, Mt. Mitake, May 27, 1912, K. Sakurai; prov. Shimotsuke, Nikko, thickets, side of streams, May 16, 1914, E. H. Wilson (No. 6677); prov. Rikuchu, Hayachine-san, woods, June 1905, U. Faurie (No. 6923).

This Wistaria is endemic in Japan, and it is common on the margins of woods, in thickets and by the sides of streams and lakes from northern Hondo southward. It is much cultivated in temple grounds, parks, and gardens where several distinct forms have originated. The young leaves are densely clothed with straight appressed hairs which soon disappear, and the adult leaves are quite glabrous. This species is closely related to $W$. sinensis Sweet, which has much larger flowers and fewer (5 to 7 ) pairs of leaflets and which blossoms fully two weeks earlier and is not so hardy a plant.

Willdenow's name is founded on Thunberg's plant, and there is no valid reason why it should not be accepted for the wild Wistaria of Japan. Thunberg says " racemis longissimis," but it must be remembered that he was contrasting it with species of the genus Dolichos, and further on in the description he says the racemes are often a foot long. As a matter of fact, on wild specimens before us the racemes vary in length from 10 to $35 \mathrm{~cm}$. Houttuyn's figure, which is probably based on a specimen of Thunberg's, is very good. Siebold \& Zuecarini's W. brachybotrys has been a source of difficulty to botanists and horticulturists alike, but the plant so named is certainly merely a state of the wild Japanese Wistaria. Such short racemes occur occasionally in the spring, but are much more common in late summer, when some plants often bear a sparse second crop of flowers.

The vernacular name given by Siebold \& Zucearini means Mountain or Wild Wistaria and is still in common use in Japan.

According to Spae this Wistaria was introduced from Japan to the Botanic Gardens at Ghent by Siebold in 1830. It and its variety macrobotrys were intro- 
duced to the United States of Ameriea from Japan in March 1862, by Dr. G. R. Hall to the nursery of Samuel Parsons, Flushing, Long Island, N. Y.

A picture of this plant will be found under No. x222 of the collection of Wilson's Japanese photographs.

Wistaria floribunda, f. alba Rehder \& Wilson, n. comb.

Wistaria multijuga, var. alba, Carrière in Rev. Hort. 1891, 421, fig. 109. Miller in Bailey, Cycl. Am. Hort. IV. 1989 (1902), - Schneider, Ill. Handb. Laubholzk. II. 77 (Wisteria) (1907). - Bean, Trees \& Shrubs Brit. Isl. II. 683 , fig. (1914).

Wistaria polystachya multijuga alba Zabel in Beissner, Schelle \& Zabel, Handb. Laubholz-Ben. 269 (1903).

Kraunhia sinensis, var. albiflora Makino in Tokyo Bot. Mag. XXIV. 299 (1910).

Kraunhia floribunda, a typica, forma albiflora Makino in Tokyo Bot. Mag. XXV. 18 (1911).

JAPAN. Hondo: prov. Musashi, grounds of Yokohama Nursery Co., Kamata, cultivated, April 27, May 21, 1914, E. H. Wilson (Nos. 6581, 6672).

The racemes of this white flowered form are from 30 to $60 \mathrm{~cm}$. long and the flowers are fragrant. It is commonly eultivated in Japan.

A picture of this plant will be found under No. x243 of the collection of Wilson's Japanese photographs.

Wistaria floribunda, f. rosea Rehder \& Wilson, n. comb.

Wistaria polystachya multijuga rosea Hort. apud Beissner, Schelle \& Zabel, Handb. Laubholz-Ben. 269 (1903).

Wistaria multijuga, var. rosea Bean, Trees \& Shrubs Brit. Isl. II. 683 (1914).

JAPAN. Hondo: prov. Musashi, grounds of Yokohama Nursery Co., Kamata, cultivated, April 27, 1914, E. H. Wilson (No. 6578); Hatogaya, cultivated, April 29, 1914, E. H. Wilson (No. 6582).

This pleasing form has pale pink flowers in which the tip of the keel and of the wings is purple. The racemes are from 30 to $45 \mathrm{~cm}$. long. A picture of this plant will be found under No. x219 of the collection of Wilson's Japanese photographs.

Wistaria floribunda, f. variegata Rehder \& Wilson, n. comb.

Wistaria chinensis, var. variegata Nicholson, Dict. Gardening, IV. 214 (1889). Miller in Bailey, Cycl. Am. Hort. IV. 1988 (1902). - Schneider, Ill. Handb. Laubholzk. II. 78 (Wisteria) (1907).

Wistaria chinensis, var. foliis variegatis Nicholson in Kew Hand-List Trees \& Shrubs, ed. 2, 183 (1902). - Bean, Trees \& Shrubs Brit. Isl. II. 681 (1914).

Wistaria polystachya variegata Zabel in Beissner, Schelle \& Zabel, Handb. Laubholz-Ben. 269 (1903).

This plant was introduced from Japan to the nurseries of Samuel Parsons, Flushing, Long Island, N. Y., by Dr. G. R. Hall, in March 1862 (see Horticulturist, XVII. 186 [1862]).

Wistaria floribunda, f. violaceo-plena Rehder \& Wilson, n. comb.

Wistaria sinensis flore pleno Carrière in Rev. Hort. 1878, 260; 1887, 564, t. Goldring in Garden, XVII. 105, fig. (1880). - Moore in Flor. \& Pomol. 1882, 33 , t. 557 .

Wistaria Chinensis, var. flore-pleno Miller in Bailey, Cycl. Am. Hort. IV. 1988 (1902). - Bean, Trees \& Shrubs Brit. Isl. II. 681 (1914).

Wisteria sinensis, var. violaceo-plena Schneider, Ill. Handb. Laubholzk. II. 78 (1907). 
Kraunhia sinensis, var, pleniflora Makino in Tokyo Bot. Mag. XXIV. 299 (1910).

Kraunhia floribunda, a typica, forma pleniflora Makino in Tokyo Bot. Mag. XXV. 18 (1911).

This double-flowered form of the type is occasionally cultivated in Japan. It was first introduced to western gardens by Dr. G. R. Hall, who sent it from Japan to Francis Parkman, Jamaica Plain; Boston, Mass., in 1861 through Mr. F. Gordon Dexter. A year or so later it was also sent from Japan by Mr. Thomas Hogg. The first note on this plant we have found appears in Gard. Chron. 1871, 7, and the first figure is given in Garden, II. 51 (1872), taken from Hearth \& Home.

A form with double white flowers is mentioned by Dippel (Handb. Laubholzk. III. 696 [1893]) under the name $W$. polystachya fl. albo-pleno and by Miller (in Bailey, Cycl. Am. Hort. IV. 1988 [1902]) and by Bean (Trees \& Shrubs Brit. Isl. II. 681 [1914]) as W. chinensis, var, alba plena. As Dippel does not mention the form with violet double flowers, it is possible that he assumed that the doubleflowered form had white flowers, but according to information received from Mr. Bean there is now a Wistaria with double white flowers in cultivation in England introduced from Japan, which, however, cannot be referred to $W$. floribunda.

Wistaria floribunda, f. macrobotrys Rehder \& Wilson, n. comb.

Wisteria sinensis Siebold \& Zuecarini, Fl. Jap. I. 90, t. 44 (non Sweet) (1839).

Wistaria chinensis Miquel in Ann. Mus. Lugd.-Bat. III. 44 (non De Candolle) (1867); Prol. Fl. Jap. 232 (1867). - Franchet \& Savatier, Enum. Pl. Jap. I. 98 (1875). - Tanaka, Useful Pl. Jap. 69, fig. 611, (1891).

Wistaria macrobotrys Siebold apud Neubert in Deutsch. Mag. Gart.-Blumenk. $1870,16, \mathrm{t}$.

Wistaria multijuga Van Houtte in Fl. des Serres, XIX. 127, t. 2002 (1873). Carrière in Rev. Hort. 1891, 175, figs. 44-46. - Schneider, Ill. Handb. Laubholzk. II. 77, figs. 46 i-p 1,47 d-e (Wisteria) (1907). - Bean, Trees \& Shrubs Brit. Isl. II. 682 (1914).

Wisteria chinensis, var. macrobotrys Lavallée, Arb. Segrez. 65 (1877). - Nicholson, Dict. Gardening, IV. 214 (Wistaria) (1889).

Wisteria grandiflora Hort. ex Lavallée, Arb. Segrez. 65 (pro synon.) (1877).

Kraunhia chinensis Green, Pittonia, II. 175 (1892).

Wistaria chinensis "var." Tanaka, Useful Pl. Jap. 152, fig. 611 (1895).

Wistaria chinensis, var. multijuga Hooker f. in Bot. Mag. CXXIII. t. 7522 (pro parte) (1897).

Wistaria polystachya multijuga Hort. Siebold apud Zabel in Beissner, Schelle \& Zabel, Handb. Laubholz.-Ben. 269 (1903).

Kraunhia sinensis, var. floribunda Makino in Tokyo Bot. Mag. XXIV. 298 (pro parte) (1910).

Kraunhia floribunda, a typica Makino in Tokyo Bot. Mag. XXV. 17 (pro parte) (1911).

JAPAN. Hondo: prov. Musashi, grounds of the Yokohama Nursery Co., Kamata, May 21, 1914, E. H. Wilson (No. 6671; racemes 56 inches long); prov. Shimosa, Kasukabe, cultivated, May 15, 1914, E. H. Wilson (No. 6691; racemes $1.6 \mathrm{~m}$. long).

This form differs from the type in its phenomenally long racemes, although under cultivation in the Occident there is no record of the racemes equaling in length those produced in Japan. In Tokyo this Wistaria is commonly cultivated and some fine specimens may be seen. In the garden of Mr. Tokoen at Kasukabe there 
is a magnificent specimen which is said to be a thousand years old and which covers an arbor of latticed bamboo one-sixth of an acre in extent.

Pictures of this plant will be found under Nos. x221, x228, x230, x240, x241 of the collection of Wilson's Japanese photographs.

Wistaria venusta Rehder \& Wilson, n. sp.

?Wisteria chinensis Bunge in Mém. Sav. Êtr. Acad. Sci. St. Pétersbourg, II. 94 (Enum. Pl. Chin. Bor, 20) (non De Candolle) (1833).- - Turezaninow in Bull. Soc. Nat. Mosc. X. No. VII. 151 (1837). - Maximowicz in Mém. Sav. Êtr. Acad. Sci. St. Pétersbourg, IX. 471 (Prim. Fl. Amur. Suppl.) (1859). - Komarov in Act. Hort. Petrop. XXII. 638 (Fl. Mansh. II) (Wistaria) (1904), exclud. synon. pluribus.

Wistaria brachybotrys Hemsley in Jour. Linn. Soc. XXIII. 161 (non Siebold \& Zuccarini) (1886), quoad plantam Pekinensem.

Milletia floribunda, var. brachybotrys Matsumura in Tokyo Bot. Mag. XVI, 64 (1902); Ind. Pl. Jap. Il. pt. 2, 270 (1912).

Wistaria brachybotrys, var, alba Miller in Bailey, Cycl. Am. Hort. 1989 (1902). Kraunhia sinensis, var. brachybotrys, forma albiflora Makino in Tolvyo Bot. Mag. XXIV. 77 (1910).

Kraunhia floribunda, $\gamma$ brachybotrys, forma albiflora Makino in Tokyo Bot. Mag. XXV. 18 (1911).

Frutex volubilis, 2-10 m. altus; ramuli juveniles adpresse flavescenti- v. cinereopubescentia, demum glabri. Folia decidua, 4-6-, plerumque 5-juga, petiolo incluso 18-35 $\mathrm{cm}$. longa et 10-15 $\mathrm{cm}$. lata; foliola oblongo-lanceolata v. elliptico-oblonga, $\mathrm{v}$. ovato-oblonga breviter acuminata, basi rotundata $\mathrm{v}$. subcordata $\mathrm{v}$. truncata, terminale basi saepe late euneatum, integra, 6-10 cm. longa et $2.5-5 \mathrm{~cm}$. lata, utrinque plus minusve, supra sparsius, subtus ad venas densius adpresse villosa, nervis utrinsecus $6-10$ arcuatis subtus ut costa elevatis; petioluli $3-4 \mathrm{~mm}$. longi, dense villosi; petioli subteretes, 4-10 cm. longi ut rhachis dense adpresse villosi. Racemi penduli, pedunculo brevi incluso $10-15 \mathrm{~cm}$. longi; rhachis dense adpresse cinereo-villosa; pedicelli fere sub angulo recto patentes, $1.5-3.5$, plerumque $2.5-3 \mathrm{~cm}$. longi; calyx membranaceous, fere cupuliformis, circiter $4.5 \mathrm{~mm}$. altus et $8-10 \mathrm{~mm}$. diam., leviter bilabiatus, lobo antico dentibus 3 subulatis, dente medio 2-2.5 $\mathrm{mm}$. longo, alteralibus 1-1.5 mm. longis, lobo postico truncato obsolete emarginato; corolla alba, vexillo suborbiculari $2-2.5 \mathrm{~cm}$. diam. apice truncato basi auriculato, unguiculo $5 \mathrm{~mm}$. longo, alis oblongis unguiculo $4-5 \mathrm{~mm}$. longo inclusis $1.7-2 \mathrm{~cm}$. longis et $9-10 \mathrm{~mm}$. latis, rotundatis, basi auriculatis, carina alis breviore petalis oblongis apice fere truncatis; stamina glabra, $2 \mathrm{~cm}$. longa; ovarium compressum breviter velutinum, stylo adscendente glabro. Legumen compressum, dense velutinum.

JAPAN. Hondo: prov. Musashi, cultivated, Iris Garden, Kamata, April 27, 1914, E. H. Wilson (No. 6580, type; flowers); Tokyo, cultivated, H. Sakurai's garden, May 21, 1913 (ex Herb. K. Sakurai); prov. Shimotsuke, Nikko, temple grounds, cultivated, May 7 and May 18, 1914, E. H. Wilson (Nos. 6580 ${ }^{3}, 6714$ ); prov. Yamata, Nara Park, cultivated, December 4, 1914, E. H. Wilson (No. 7852, mature leaves, co-type).

CHINA. Chili: "Ying-tan-ko," September 12, 1913, F. N. Meyer (No. 1299; "among high scrub, apparently genuinely wild").

This new species whose identity has so long been obscured is the most distinct of the four Wistarias of Eastern Asia. It is characterized by the persistent velvety pubescence on both surfaces of the leaves, by its short, very broad racemes, its long, stout, nearly horizontally spreading pedicels, by its very large flowers, and by the subulate anterior teeth of the calyx. We have made the 
Japanese cultivated plant the type, and the only fruit of this we have seen is only $8 \mathrm{~cm}$. long. This we do not think, however, is normal. Meyer's specimens from China are in fruit, and the legumes are 16 to $22 \mathrm{~cm}$. long. The leaflets, though of the same shape, are rather smaller and less pubescent on the upper surface. Nevertheless we feel confident that they belong to our new species, and in all probability the habitat of this plant is northeast China, southern Mandshuria, and possibly Korea.

Bretschneider (Hist. Europ. Bot. Discov. China, 20 [1898]) says that Dominicus Parennin, a Frenchman who went to China in 1698, and who died at Peking in 1741, traveled in southern Mongolia and Mandshuria on the hunting expeditions of the Emperor Kanghi. Parennin in letters gave a slight sketch of the botany of those regions, and in one letter he mentions a "climbing plant," "Teng-lo," with beautiful violet flowers hanging down in large bunches." We strongly suspect that this is the wild type of our $W$. venusta and that Meyer's specimens belong to it.

In Japan it is here and there cultivated in temple grounds under the name of Shira-fudzi (White Wistaria) and in Japanese nurseries as "Wistaria sinensis, var. brachybotrys" and as " $W$. brachybotrys." Under one or other of these names this plant has been introduced to North America and to Europe and is mentioned by Bean (Trees \& Shrubs Brit. Isl. II. 680 [1914]) under W. brachybotrys Siebold, as a doubtful albino form. From the vernacular name given (Siroo-koo Fudsi) it is probable that the plant referred to W. brachybotrys by Franchet \& Savatier (Enum. Pl. Jap. I. 98 [1875]) belongs here.

A pieture of this plant will be found under No. x210 of the collection of Wilson's Japanese photographs.

Wistaria japonica Siebold \& Zuccarini, Fl. Jap. I. 88, t. 43 (Wisteria) (1839). Franchet \& Savatier, Enum. Pl. Jap. I. 98 (1875). - Schneider, Ill. Handb. Laubholzk. II. 75, figs. 46 a-e, 47 a (Wisteria) (1907).

Milletia japonica Gray in Mém. Am. Acad. VI. 386 (Bot. Jap.) (1859). Miquel in Ann. Mus. Lugd.-Bat. IlI. 44 (1867); Prol. Fl. Jap. 232 (1867).Tanaka, Useful Pl. Jap. t. 610 (1891). - Matsumura in Tokyo Bot. Mag. XVI. 64 (1902); Ind. Pl. Jap. II. pt. 2, 271 (1913).

Phaseolodes japonicum O. Kuntze, Rev. Gen. I. 201 (1891).

Kraunhia japonica Taubert in Engler \& Prantl, Pflanzenfam. III. abt. 3, 271 (1894). - Hayata, Vegetation Mt. Fuji, 60 (1911).

JAPAN. Shikoku: prov. Tosa, thickets, alt. 1000 m., November 23, 1914, E. H. Wilson (No. 7796). Hondo: prov. Musashi, Botanic Garden, Tokyo, eultivated August 30,1892, C. S. Sargent.

NORTHEASTERN ASIA. Korea: Fusan, temple grounds, September 6, 1903, C. S. Sargent.

Wisteria dubia Walpers (in Leop.-Carol. Akad. Naturf. Verh. XIX, suppl. 1, 324 [1843]; Rep. V. 536 [1845-46]), described as having solitary, axillary subsessile flowers, is an obscure plant, which certainly does not belong to the genus Wistaria. 


\title{
EUPHORBIACEAE.
}

\author{
Determined by J. Hutchinson.
}

\section{ANDRACHNE L.}

\section{Andrachne capillipes Hutchinson, n. comb.}

Andrachne cordifolia Hemsley in Jour. Linn. Soc. XXVI. 420 (non Müller Arg.) (1894).

Flueggea capillipes Pax in Bot. Jahrb. XXIX. 427 (1900).

Western Hupeh: Ichang, roadsides, alt. 500 m., May 1907 (No. 3205; shrub 0.6-1 m.). Western Szech'uan: Nanch'uan, A. von Rosthorn (Nos. 2250, 2253).

A. capillipes is very similar in general appearance to A. cordifolia, Müll. Arg., from India, but differs markedly in the female calyx which is much smaller in our plant and not enlarged and foliaceous in the fruiting stage; the female pedicels in the Indian plant are usually longer.

Pax places this species in Flueggea which has apetalous flowers, but the examination of the flowers of von Rosthorn's Nos. 2250 and 2253 shows the presence of oblong petals about half as long as the sepals. The latter are in the pistillate flower sometimes, but not always, acute or mucronulate. Von Rosthorn's specimens agree perfectly with those collected by Wilson, and there can be no doubt of their identity.

Andrachne capillipes, var. pubescens Hutchinson, n. var.

A typo recedit foliis subtus crispato-pubescentia.

Western Hupeh: Ichang, ravines, alt. 500 m., May 1907 (No. 3539, in part; bush $1 \mathrm{~m}$. tall, flowers greenish yellow); Hsing-shan Hsien, ravines and roadsides, alt. 300-900 m., May 1907 (No. 3539, in part; bush $0.6 \mathrm{~m}$. tall, flowers greenish).

This variety differs from the type only in its leaves being pubescent beneath. Pax in his description mentions both forms, but from the fact that he enumerates the glabrous specimens first, it may be assumed that he considers the glabrous form the typical one.

Andrachne hirsuta Hutchinson, n. sp.

Frutex gracilis, $0.75-2 \mathrm{~m}$. altus; ramuli patuli, foliosi, leviter flexuosi, graciles, paulum angulares, parce vel subdense pilosi. Folia lanceolata v. ovato-lanceolata, subacute acuminata, basi obtusissima v. rotundata, 2-3.5 $\mathrm{cm}$. longa, $0.7-1.5 \mathrm{~cm}$. lata, chartacea, supra leviter, infra dense adpresse pubescentia; nervi laterales utrinsecus 4-5, supra 
frequenter impressi, infra prominentes et conspicue straminei; petioli 2-5 mm. longi, pilosi; stipulae subulato-lanceolatae, parvae, parce pubescentes. Flores monoici, axillares, solitarii vel plerumque masculi et foeminei geminati. Flores masculi: pedicelli gracillimi, 6-8 mm. longi, glabri v. parce pubescentes; sepala 5, obovata, apice rotundata, $3 \mathrm{~mm}$. longa, $1.5 \mathrm{~mm}$. lata, submembranacea, conspicue nervosa, extra longe pilosa, intra glabra; petala sepalis dimidio breviora, spathulatoobovata, hyalina, glabra; discus profunde 10-lobatus, membranaceus, glaber, lobis oblongis obtusis $1 \mathrm{~mm}$. longis; stamina 5; filamenta libera, petalis paullo longiora, glabra; antherae rotundatae, $0.45 \mathrm{~mm}$. latae; ovarium rudimentarium inconspicuum, profunde trilobum, lobis subfiliformibus glabris. Flores foeminei: pedicelli ut in floribus masculis sed demum longiores, fructiferi usque ad $1.5 \mathrm{~cm}$. longi; sepala 5 , rotundato-obovata, $2.5 \mathrm{~mm}$. longa, $2 \mathrm{~mm}$. lata, extra adpresse pubescentia, viridia; petala minuta, $0.25 \mathrm{~mm}$. longa, glabra; discus glaber, patelliformis, ad medium 10-lobatus, lobis ovato-oblongis subcarnosis glabris; ovarium ovoideo-globosum, obscure trilobum inferne pilosum; styli liberi, erecti, demum patuli, $0.4 \mathrm{~mm}$. longi, profunde bilobi, lobis apice incrassatis rugulosis. Fructum seminaque non visi.

Western Szech'uan: west of Kuan Hsien, Niu-tou-shan, in thickets, alt. 1300 m., June 1908 (No. 3204; 0.7-2 m. high, flowers white); without locality, roadsides, alt. 2200 m., July 1903 (Veitch Exped. No. 4453).

This is a very distinct species, characterized by its lanceolate acutely acuminate, very hairy leaves and long-pilose calyx-segments.

Here is added the deseription of a new species not collected during the Arnold Arboretum Expeditions.

Andrachne montana Hutchinson, n. sp.

Frutex $1.25 \mathrm{~m}$. altus; ramuli elongati, foliosi, glabri. Folia lanceolata v. ellipticolanceolata, utrinque obtusa, $1.5-5 \mathrm{~cm}$. longa, $1-2 \mathrm{~cm}$. lata, tenuiter chartacea v. firme membranacea, utrinque glabra; nervi laterales utrinsecus 4-5, graciles, supra interdum paullo impressi, infra prominuli; petioli $3-4 \mathrm{~mm}$. longi, graciles; stipulae minutae. Flores monoici, axillares, fasciculati v. brevissime racemosi. Flores masculi: pedicelli capillares, $1 \mathrm{~cm}$. longi, glabri; sepala 5 , obovato-elliptica, apice rotundata, $2 \mathrm{~mm}$. longa, venosa, glabra; petala sepalis dimidio breviora, obovatocuneata, obscure dentata, $0.75 \mathrm{~mm}$. lata, glabra; discus profunde 10-lobatus, glaber, lobis oblongis obtusis; stamina 5; filamenta libera, glabra; antherae rotundatae, $0.35 \mathrm{~mm}$. longae; ovarium rudimentarium parvum, trilobatum glabrum. Flores foeminei: pedicelli demum $1 \mathrm{~cm}$. longi, ad apicem incrassati; sepala inaequalia, duobus quam ceteris majoribus, orbicularia, 1.25-2 mm. diametro, glabra; petala minutissima; discus irregulariter lobatus, glaber; ovarium glabrum; styli patuli, ad basin lobati, stigmatibus parvis capitatis. Fruetus maturus non visus.

Western Szech'uan: Mt. Omei, July 1904 (Veitch Exped. No. 5173, type); 1600 m., Dec. 1887, Faber (No. 4). 
This species may be at once recognized by its obtuse leaves and shortly racemose or fasciculate axillary inflorescences.

\section{SAUROPUS Bl.}

Sauropus albicans Blume, Bijdr. 596 (1825). - Baillon, Étude Gén. Euphorb. 635, t. 27, fig. 19, 20 (1858). - Müller Arg. in De Candolle, Prodr. XV. pt. 2, 240 (1866). - Hooker f., Fl. Brit. Ind. V. 332 (1887). - Hemsley in Jour. Linn. Soc. XXVI. 420 (1891).

Western Szech'uan: Hungya Hsien, thickets, alt. $1000 \mathrm{~m}$., September 1908 (No. 2436; shrub 1-1.25 m. high; flowers white); Mt. Omei, July 1904 (Veitch Exped. No. 5772; shrub 3 m. high).

\section{GLOCHIDION Forst.}

Glochidion puberum Hutchinson, n. comb.

Agyneia pubera Linnaeus, Mant. II. 296 (1771).

Agyneia impubes Linnaeus, 1. c.

Bradleia sinica Gaertner, Fruct. II. 127, t. 109, fig. 1 (1791).

Glochidion sinicum Hooker et Arnott, Bot. Voy. Beechey, 210 (1836). - Bentham, Fl. Hongk. 314 (1861).

Phyllanthus puberus Müller Arg. in Flora, XLVIII. 387 (1865); in De Candolle, Prodr. XV. pt. 2, 307 (1866), exel. var. a Fortunei.

Glochidion obscurum Hemsley in Jour. Linn. Soc. XXVI. 425 (non Blume) (1894).

Kiangsi: Kuling, common on roadside, up to 650 m., Aug. 1, 1907 (No. 1599; shrub 0.7-1.5 m. high). Western Hupeh: Ichang, common up to 450 m., June and September 1907 (No. 2434; shrub $1 \mathrm{~m}$. high; flowers whitish, fruit bright scarlet). Western Szech'uan: without precise locality, 600 m., June 1903 (Veitch Exped. No. 4446). Chekiang: vicinity of Ningpo, 1908, D. Macgregor.

Readily distinguished from G. obscurum Blume (Phyllanthus obscurus Willdenow) from India and the Malay Archipelago, with which it has hitherto been associated, by the shortly stalked depressed-globose many-lobed capsules. In Blume's species the capsules are long-stalked and ovoid-ellipsoid in shape and scarcely or not at all lobed.

\section{Glochidion Wilsonii Hutchinson, n. sp.}

Frutex usque ad $3 \mathrm{~m}$. altus; rami angulares v. costati, sicco brunnei, glabri; ramuli erecto-patentes, graciles, glabri. Folia oblique lanceolata, apice acuta v. breviter acuminata, basi obtusa v. cuneato-obtusa, $3-8 \mathrm{~cm}$. longa, $1.5-3 \mathrm{~cm}$. lata, tenuiter chartacea, glabra, infra glaucescentia; costa media utrinque elevata, infra prominens, ad apicem laminae sensim angustata, infra straminea; nervi laterales utrinsecus 
5-6, arcuati, prope marginem elongato-conjuncti, infra prominentes; venae laxe reticulatae, plerumque distinctae; petioli $3-4 \mathrm{~mm}$. longi, minutissime puberuli v. fere glabri; stipulae e basi triangulari lata subulatae, 2-2.5 mm. longae, extra glabrae, intra parce puberulae. Flores virides, monoici, axillares, fasciculati, masculi in ramulorum parte inferiore, foeminei in parte superiore plerumque dispositi. Flores masculi longe pedicellati; pedicelli graciles, usque ad $0.8 \mathrm{~cm}$. longi, glabri; sepala 6 , oblonga v. oblongo-oblanceolata, obtusa, $2.5-3 \mathrm{~mm}$. longa, circiter $1 \mathrm{~mm}$. lata, carnoso-coriacea, margine angustissime hyalina, glabra; stamina 3 ; antherae subsessiles, apiculatae, sepalis dimidio breviores. Flores foeminei breviter pedicellati; sepala 6 , oblonga, obtusa, $2.5 \mathrm{~mm}$. longa, coriacea, glabra; ovarium multiloculare, lobulatum, glabrum; columna stylorum ovario aequilata et similariter lobulata. Capsula depresso-globosa, multilobulata, circiter $1.5 \mathrm{~cm}$. diametro, sicco brunnea, glabra, basi sepalis persistentibus induratis instructa, exocarpio submembranaceo, endocarpio flavescente tenuiter coriaceo. Semina subtriquetra, dorso rotundata, $4.5 \mathrm{~mm}$. longa, nitida, rubra.

Western Hupeh: Changlo Hsien, sides of streams, alt. $650 \mathrm{~m}$., May 1907 (No. 2435, $\delta$ and $\&$ flowers; without precise locality, June 1900 (Veitch Exped. No. 1102; fruit). Kiangsi: Kuling, abundant in thickets, $1300 \mathrm{~m}$., August 1907 (No. 16oo, flowers and fruit; shrub 2-3 m. high, flowers greenish).

This species is very similar to G. lanceolarium Dalzell, but differs from it in having smaller male flowers with only 3 stamens; the styles are also much larger than those of that species, and on this account our plant should be placed near $G$. sphaerogynum Kurz; the large calyx-lobes of the female flowers and the much lobulate column of the style serve to distinguish it from that species.

\section{PHYLLANTHUS L.}

Phyllanthus flexuosus Müller Arg. in De Candolle, Prodr. XV.pt. 2, 324 (1866). - Hemsley in Jour. Linn. Soc. XXVI. 421 (1894).

Cicca flexuosa Siebold \& Zucearini in Abh. Akad. Münch. IV́. pt. II. 143 (Fl. Jap. Fam. Nat. I. 35) (1845).

Hemicicca japonica Baillon, Etude Gén. Euphorb. 646 (1858).

Phyllanthus japonicus Müller Arg. in Linnaea, XXXII. 52 (1863).

Glochidion flexuosum Müller Arg. apud Miquel in Ann. Mus. Lugd.-Bat. III. 128 (1867). - Franchet \& Savatier, Enum. Pl. Jap. I. 426 (1875).

Kiangsi : Kuling, thickets, alt. 1300 m., July 28, 1907 (No. r575; bush 1-2.5 m. tall). Western Hupeh : Ichang, hillsides, up to 950 
m., August 1907 (No. 3208; bush 2-3 m. high, flowers and fruit); glens around Ichang, 90-650 m., May and June 1907 (No. 3540; bush 2-3 m. high; fruits black).

Phyllanthus glaucus Wallieh apud Müller Arg. in Linnaea, XXXII. 14 (1863). - Hooker f., Fl. Brit. Ind. V. 228 (1887), - Hemsley in Jour. Linn. Soc. XXVI. 421 (1894).

Phyllanthus fluggeiformis, Müller Arg. in De Candolle, Prodr. XV. pt. 2, 349 (1866).

Chekiang: Vieinity of Ningpo, 1908, D. Maegregor.

\section{SECURINEGA Juss.}

Securinega fluggeoides Müller Arg. in De Candolle, Prodr. XV.pt. 2, 450 (1866). - Hemsley in Jour. Linn. Soc. XXVI. 426 (1894).

Securinega japonica Miquel in Ann. Mus. Lugd.-Bat. III. 128 (1867). - Franchet \& Savatier, Enum. Pl. Jap. I. 425 (1875).

Western Hupeh: Iehang, glens and rocky places, up to $950 \mathrm{~m}$., June 1907 (No. 3206; bush 2-3 m. high, flowers greenish).

\section{FLUGGEA Willd.}

Flúggea leucopyrus Willdenow, Spec. IV. 757 (1805). - A. de Jussieu, Euphorb. Tent. 106, t. 2, fig. 7A (1824). - Wight, Icon. t. 1875 (1852). - Thwaites, Enum. Pl. Zeylan. 281 (1864). - Hooker f., Fl. Brit. Ind. V. 328 (1887).

Xylophylla Lucena Roth, Nov. Spec. 185 (1821).

Fluggea xerocarpa A. de Jussieu, Euphorb. Tent. t. 2, fig. 7B (1824).

Phyllanthus Leucopyrus Koenig apud Roxburgh, Fl. Ind. ed. 2, III. 658 (1832).

Phyllanthus albicans Wallieh, Cat. 7937 (nomen nudum) (1847).

Fluggea Wallichiana Baillon, Étude Gén. Euphorb. 592 (1858).

Fluggea virosa Dalzell \& Gibson, Bombay Fl. 236 (1861).

Securinega Leucopyrus Müller Arg. in De Candolle, Prodr. XV. pt. 2, 451 (1866). - Brandis, Forest Fl. Brit. Ind. 456, t. 54, partim (1874). - Beddome, $F l$. Sylv. S. Ind. II. For. Man. p. excvii, t. 24, fig. 4 and 1-6 (1874).Gamble, Man. Ind. Timb. 354 (1881).

Securinega virosa Baillon in Adansonia, VI. 334 (1866).

Cicca Leucopyrus Kurz, For. Fl. Brit. Burma, II. 353 (1877).

Phyllanthus Lucena Heyne ex Hooker f., Fl. Brit. Ind. (pro synon.) (1887).

Western Hupeh: Patung Hsien, eliffs, Wushan gorge, March 24, 1908 (No. 3335; 3336; bush 0.6-1.5 m., flowers yellow); same locality, March 1904 (Veitch. Exped. No. 3344; bush 1 m.); without locality, March 1901 (Veitch Exped. No. 412 ${ }^{\mathrm{a}}$ ). 


\section{BISCHOFIA Bl.}

Bischofia javanica Blume, Bijdr. 1168 (1825). - Bentham, Fl. Hongk. 316 (1861). - Müller Arg. in De Candolle, Prodr. XV. pt. 2, 478 (1866). - Hooker f., Fl. Brit. Ind. V. 345 (1887), - Hemsley in Jour. Linn. Soc. XXVI. 428 (1894).

Andrachne trifoliata Roxburgh, Hort. Bengal. 70 (nomen nudum) (1814); Fl. Ind. ed. 2, III. 728 (1832).

Stylodiscus trifoliatus Bennett, Pl. Jav. Rar. 133, t. 29 (1840).

Bischofia oblongifolia Decaisne in Jacquemont, Voy. IV. 152, t. 154 (1844).

Bischofia trifoliata Hooker in Hooker's Icon. IX. t. 844 (1852).

Western Hupeh: Changlo Hsien, roadsides, 30-300 m., April 1907 (No. 3402; tree 13-20 m. tall, girth 1.5-2 m., male and female flowers and young fruits); south of Ichang, alt. $500 \mathrm{~m}$., October 1901 (Veitch Exped. No. 2431; tree 10 m. tall).

This is a rather rare tree in Hupeh and Szech'uan, where it is found only at low altitudes and is colloquially known as the Wu-yang. It grows to a moderately large size and has normally a rounded head; the trunk is straight and is elothed with gray fissured bark; the wood is soft and of no value. The fruit of our specimens is smaller than on specimens from tropical Asia. Pictures of this tree will be found under Nos. 33, 454 of the collection of my photographs and also in my Vegetation of Western China, Nos. 140, 141.

E. H. W.

\section{DAPHNIPHYLIUM Bl.}

\section{Daphniphyllum angustifolium Hutchinson, n. sp.}

Frutex 2-2.5 m. altus; ramuli satis robusti, cortice glabro fusco obtecti; gemmae axillares oblongo-cylindricae, circiter $0.8 \mathrm{~cm}$. longae, squamis late ovatis coriaceis glabris indutae. Folia anguste oblongolanceolata, apice triangulari-acuta, ad basin sensim et breviter angustata, 12-16 cm. longa, 3-4 cm. lata, firme chartacea v. subcoriacea, integra, supra sicco brunneo-viridia, infra leviter glaucescentia, costa utrinque elevata, infra straminea et valde prominens, basi circiter 2.5 $\mathrm{mm}$. lata, ad laminae apicem sensim angustata; nervi laterales utrinsecus 14-16, a costa sub angulo lato divergentes, utrinque aequaliter prominuli, flexuosi, intra marginem circiter $0.5 \mathrm{~cm}$. furcati, conjuncti; venae utrinque vix evidentes; petioli $2-2.5 \mathrm{~cm}$. longi, $2.5 \mathrm{~mm}$. crassi, minutissime verruculosi, ceterum glabri. Flores non visi. Infructescentiae juniores axillares, racemosae, $2.5 \mathrm{~cm}$. longae, 7-8-florae; rhachis robustus, conspicue flexuosus, longitudinaliter verrucosus; pedicelli robusti, 3-4 mm. longi, glabri. Fructus juniores oblique ellipsoidei, 
5-6 mm. longi, conspicue coeruleo-glauci; stylus non visus, mox deciduus.

Western Hupeh: Fang Hsien, abundant in woods, alt. 1800-2400 m., May 19, 1907 (No. 2959, type); Changyang Hsien, woods, alt. 1600-2300 m., June 1907 (No. 3727²).

Only specimens with young fruits of this species have been collected. It is readily distinguished, however, from all the other species of Daphniphyllum by its narrow leaves, short inflorescences and short stout pedicels. The "bloom" on the young dried fruits is very conspicuous.

A much branched shrub with shining green leaves and very abundant as undergrowth in the woods and forests of western Hupeh.

E. H. W.

Daphniphyllum glaucescens Blume, Bijdr. 1153 (1825). - Müller Arg. in De Candolle Prodr. XVI. pt. 1, 3 (1869). - Franchet \& Savatier, Enum. Pl. Jap. I. 427 (1875); II. 488 (1887). - Hance in Jour. Linn. Soc. XIII. 120 (1873). - Hooker f., Fl. Brit. Ind. V. 353 (1887). - Hemsley in Jour. Linn. Soc. XXVI. 429 (1894). - Maximowicz in Bot. Jahrb. VI. 59 (1885).

Daphniphyllum Roxburghii Baillon, Etude Gén. Euphorb. 565 (1858), exel. syn. Roxburghii. - Bentham, $\mathrm{Fl}$. Hongk. 316 (1861).

Goughia neilgherrensis Wight, Icon. Pl. Ind. Orient. 22, t. 1878-9 (1852).Bentham in Hooker's Jour. Bot. \& Kew Gard Misc. VI. 8 (1854).

Western Hupeh : Changyang Hsien, abundant in woods, alt. 9502300 m., May and June 1907 (Nos. 296o, 3727; bush 3 m. high).

Daphniphyllum macropodum Miquel in Ann. Mus. Lugd.-Bat. III. 129 (1867). - Müller Arg. in De Candolle, Prodr. XVI. pt. 1, 5 (1869). - Hemsley in Jour. Linn. Soc. XXVI. 429 (18)94.

Western Hupeh: Changyang Hsien, woods, alt. 1200-1600 m., September 1900 (Veitch Exped. No. 20, fruit). Eastern Szech'uan: Wushan Hsien, woods, 1200-1800 m., July 1900 (Veitch Exped. No. 20, flowers; tree $6 \mathrm{~m}$. tall). Western Szech'uan: Mupin, thickets, alt. 1000 m., November 1908 (No. 3552; tree 8 m. tall, girth 0.3-1 m.); Mt. Omei, October 1904 (Veitch Exped. No. 5174; tree $6 \mathrm{~m}$. tall).

This small tree is common in moist woods of western Hupeh and Szech'uan.

Here are added two genera not collected during the Arnold Arboretum Expeditions.

\section{ANTIDESMA Burm.}

Antidesma delicatulum Hutchinson, n. sp.

Frutex 1-3.5 m. altus; ramuli foliati, leviter flexuosi, prominenter lenticellati, breviter fusco-pubescentes. Folia oblonga v. oblongo-lanceolata, basi obtuso- 
rotundata, apice subsensim acute acuminata acumine mucronato $0.5-1 \mathrm{~cm}$. longo medio 1-2 mm. lato, plerumque $3.5-8 \mathrm{~cm}$. longa et $1.5-3 \mathrm{~cm}$. lata (in fructu interdum 10-13 cm. longa et usque ad $4 \mathrm{~cm}$. lata), tenuiter chartacea, supra costa parce puberula excepta glabra, infra solum in costa et nervis lateralibus breviter setulosopubescentia; costa infra conspicua; nervi laterales utrinsecus 5-8, supra distincti, infra prominentes, intra marginem conjuncti, in axillis lanato-pubescentes; venae plerumque conspicuae et laxae; petioli $0.4-1 \mathrm{~cm}$. longi, hirsuti; stipulae mox deciduae, lineari-subulatae, acutae, 4-5 mm. longae, setuloso-pubescentes. Inflorescentiae of terminales, 3-4-ramosae, ramis pergracilibus $1.5-2 \mathrm{~cm}$. longis: rhachis parce pubescens; bracteae stipulis similes, sed parum breviores; bracteolae minutae, subulato-lanceolatae, glabrae; flores $\delta$ breviter pedicellati, pedicellis patulis demum vix $1 \mathrm{~mm}$. longis glabris; sepala 4, late transverse oblonga, $0.35 \mathrm{~mm}$. longa, $0.75 \mathrm{~mm}$. lata, glabra; stamina 4 ; discus carnosus, glaber. Flores $\$$ non visi. Infructescentiae $\&$ pergraciles, 3-ramosae, $6-8 \mathrm{~cm}$. longae; rhachis angularis, parce puberula $v$. fere glabra; pedicelli fructiferi patuli v. leviter reflexi, 3-4 mm. longi, parce puberuli; sepala triangularia, brevia, glabra; discus crassus, glaber. Fructus juniores oblique ellipsoidei, tetragoni, glabri, stylis brevissimis bilobis coronati.

Western Szech'uan: Kiating, July 1903 (Veitch Exped. No. 4449; shrub $1 \mathrm{~m}$. tall, \& flowers); November 1903 (Veitch Exped. No. 4058; shrub 4 m. tall, young fruits); Mt. Omei, June 1904 (Veiteh Exped. No. 4480; bush 3 m. tall; o flowers).

This species is related to A. japonicum Siebold \& Zuccarini, but differs from it chiefly in its oblong leaves more rounded at the base and hairy on the midrib and lateral nerves below, and in its strictly terminal inflorescence.

\section{CROTON L.}

Croton Tiglium Linnaeus, Spec. 1004 (1753), - Müller Arg. in De Candolle, Prodr. XV. pt. 2, 600 (1866), - Hooker f., Fl. Brit. Ind. V. 393 (1887). - Hemsley in Jour. Linn. Soc. XXVI. 435 (1894). - Léveillé, Fl. Kouy-Tchéou, 160 (1914).

Western China: Fu-chou, Yangtsze banks, cultivated, May 1903 (Veitch Exped. No. 4447; tree $5 \mathrm{~m}$. high).

This small tree is commonly cultivated in Szech'uan in the vicinity of the Yangtsze River. Its leaves are mostly retained through the winter and become highly colored before they fall in the spring. Colloquially it is known as the Pa-tou tree and its seeds are used medicinally.

E. H. W.

\section{ACALYPHA L.}

Acalypha acmophylla Hemsley in Jour. Linn. Soc. XXVI. 436 (1894). Western Hupeh: Ichang gorge, cliffs, April 1907 (No. 1987; shrub about $1 \mathrm{~m}$. high).

Our specimen is an exact match of Henry's Nos. 1188 and 3824 mentioned in a note by Hemsley as probably being the same as his A. acmophylla. I think he is right in this; in his type specimens the inflorescences are solitary in the leaf axils, but they are borne on fully grown lateral shoots, whilst in Henry's specimens and in ours the inflorescence is borne on very young branches just emerging from the 
older shoots and thus appear to be fasciculate; the petioles of the leaves of the latter specimens are shorter than in the type, but I think this is probably due to their young condition.

\section{Acalypha szechuanensis Hutchinson, n. sp.}

Frutex $1.5 \mathrm{~m}$. altus; rami cortice cinereo striato pubescente obtecti; ramuli laterales breves, dense foliati, hirsuto-villosissimi. Folia lanceolata v. ovato-lanceolata, acute caudato-acuminata, basi obtusa v. rotundata, 2-6 cm. longa, 1-3 cm. lata, membranacea, crenato-serrata, utrinque patule pilosa v. subvillosa; nervi laterales $4-5$, ascendentes, graciles; petioli graciles, usque ad $1.5 \mathrm{~cm}$. longi, hirsuto-villosi; stipulae minutae, caducae. Flores monoici; racemi in axillis foliorum dispositi, pergraciles, patuli, plerumque masculi, interdum ad basin flore foemineo unico instructi; axis villosa; flores masculi glomerulati, brevissime pedicellati; gemmae glabrae v. fere glabrae, minutissime mucronatae; flores foeminei solitarii, breviter pedicellati; bractea inaequaliter triloba, foliacea, lobo medio lanceolato acuto usque ad $6 \mathrm{~mm}$. longo et $2 \mathrm{~mm}$. lato piloso; calycis segmenta oblanceolata, viridia, 2 $\mathrm{mm}$. longa, pilosa; ovarium villosum; styli laciniati, graciles, $4.5 \mathrm{~mm}$. longi.

Western Szech'uan: Kiating, sides of streams, alt. $300 \mathrm{~m}$., common, June 1908 (No. I988).

Very closely related to A. acmophylla Hemsl., but different in the very short petioles, narrower leaves and hirsute-villose inflorescence with larger and more foliaceous bracts of the female flower.

\section{ALCHORNEA Swartz.}

Alchornea Davidii Franchet in Nouv. Arch. Mus. Paris, sér. 2, VII. 74, t. 6 (Pl. David. I. 264) (1884), - Hemsley in Jour. Linn. Soc. XXVI. 438 (1894). - Léveillé, Fl. Kouy-Tchéou 157 (1914).

Western Hupeh: Ichang, a weed in glens, common up to $650 \mathrm{~m}$., May 1907 (No. I993; shrub 1-2 m. tall).

Alchornea rufescens Franchet in Nouv. Arch. Mus. Paris, sér. 2, VII. 75, t. 7 (Pl. David. I. 265) (1884). - Hemsley in Jour. Linn. Soc. XXVI. 438 (1894).

Acalypha Giraldii Pax in Bot. Jahrb. XXIX. 429 (1900). - Pampanini in Nuov. Giorn. Bot. Ital. n. ser. XVII. 408, fig. 10 a (1910).

Wetria rufescens Pampanini, 1. c. XVIII. 172, fig. 10 a (1911).

Western Hupeh: Changlo Hsien, roadsides, alt. 650 m., May 1907 (No. I989; bush 1.5-2 m. high). Around Ichang, by side of 
streams, May 1907 (No. I99o; shrub about $1 \mathrm{~m}$. high); roadsides, May 1907 (No. I99I); June 1907 (No. I992); September 1907 (No. 1992).

\section{MALLOTUS Lour.}

Mallotus apelta Müller Arg. in Linnaea, XXXIV. 189 (1865); in De Candolle, Prodr. XV. pt. 2, 963 (1866). - Hance in Jour. Linn. Soc. XIII. 122 (1873). - Hemsley in Jour. Linn. Soc. XXVI. 439 (1894).

Ricinus A pelta Loureiro, $\mathrm{Fl}$. Cochin. 585 (1790).

Croton chinensis Geiseler, Croton Monogr. 24 (1807).

Rottlera cantoniensis Sprengel, Syst. III. 878 (1828). - Hooker \& Arnott, Bot. Voy. Beechey, 212 (1836). - Bentham, Fl. Hongk. 306 (1861).

Mallotus Paxii Pampanini in Nuov. Giorn. Bot. Ital.n. ser. XVII, 414 (1910).

Kiangsi : Kuling, thickets, alt. 1000-1300 m., July 1907 (Nos. I644, I645; bush 1.5-3 m.). Western Hupeh: Changlo Hsien, sides of streams, alt. 300-800 m., May 1907 (No. 3283; bush 3 m.); Fang Hsien, roadsides, alt. 1000 m., June and September 1907 (Nos. 3284, 3287; bush 2-3 m.); Hsing-shan Hsien, thickets, alt, 600-1300 m., June and September 1907 (Nos. 3285, 3286; bush 2-3 m.).

This is a very common shrub particularly in warm rocky valleys and on cliffs. The leaves vary considerably in size and shape and the inflorescence varies much in length. These differences depend largely upon the vigor of the shoots.

E. H.W.

Mallotus tenuifolius Pax in Bot. Jahrb. XXIX. 429 (1900). - Pampanini in Nuov. Giorn. Bot. Ital. n. ser. XVII. 104 (1910); XVIII. 172 (1911).

Mallotus japonicus Hemsley in Jour. Linn. Soc. XXVI. 440 (pro parte, non Müller Arg.) (1894). - Pax in Bot. Jahrb. XXIX. 428 (1900). - Léveillé, Fl. Kouy-T chéou, 165 (1914).

Western Hupeh: Changlo Hsien, roadside thickets, alt. 6001000 m., June and September 1907 (No. 3289; bush 4 m.); Changyang Hsien, thickets, alt. 300-1000 m., May, June and July 1907 (Nos. 329I, 3292, 3292 ${ }^{\mathrm{a}}$; bush, 2-3 m.); Hsing-shan Hsien, thickets, alt. 1000 m., June 1907 (No. 3293; bush 2-3 m.); Fang Hsien, thickets, alt. 1000 m., June 4, 1907 (No. 3290; slender flat-topped tree 5 m. tall); " Ma-panscian," alt. 1000 m., May 1907, C. Silvestri (No. 1302). Eastern Szech'uan: Wushan Hsien south, A. Henry (No. 5742 ${ }^{\text {b }}$. Western Szech'uan: Mt. Omei, June 1904 (Veitch Exped. No. 5169; bush $3 \mathrm{~m}$.$) .$ 
The simple inflorescence well distinguishes this species from the closely related M. japonicus Müller Arg., which has a branched paniculate inflorescence. All the specimens I have seen from Hupeh and Szech'uan belong to Pax's species and very probably the Japanese species does not occur in that region.

This is a very common roadside bush or small tree in western Hupeh and Szech'uan, being particularly abundant in warm rocky valleys.

E. H.W.

Mallotus philippinensis Müller Arg. in Linnaea XXXIV. 196 (1865); in De Candolle, Prodr. XV. pt. 2, 980 (1866). - Hance in Jour. Linn. Soc. XIII. 122 (1873). - Hooker f., Fl. Brit. Ind. V. 442 (1887). Hemsley in Jour. Linn. Soc. XXVI. 440 (1894). - Pax in Bot. Jahrb. XXIX. 428 (1900). - Pampanini in Nuov. Giorn. Bot. Ital. n. ser. XVII. 414 (1910). - Léveillé, Fl. Kouy-Tchéou, 165 (1914).

Croton philippense Lamarck, Encycl. Méth. II. 206 (1786).

Croton coccineus Vahl, Symb. II. 97 (1791).

Croton punctatus Retzius, Obs. Bot. V. 30 (1789).

Rottlera tinctoria Roxburgh, Pl. Corom. II. 36, t. 168 (1798).

Croton montanum Willdenow, Spec. IV. 547 (1805).

Rottlera aurantiaca Hooker \& Arnott, Bot. Voy. Beechey, 270 (1836).

Western Hupeh: Chang-lo Hsien, thickets, alt. 300-1000 m., June 1907 (No. 3294; small tree 5.5 m. high). Western Szech'uan: Chengtu Plain, alt. 350 m., August 1904 (Veitch Exped. No. 4444).

Mallotus repandus Müller Arg. in Linnaea, XXXIV. 197 (1865); in De Candolle, Prodr. XV. pt. 2, 981 (1866). - Hooker f., Fl. Brit. Ind. V. 442 (1887). - Hemsley in Jour. Linn. Soc. XXVI. 441 (1894). Pampanini in Nuov. Giorn. Bot. Ital. n. ser. XVII. 104 (var. scabrifolius Müll. Arg.) (1910). — Léveillé, Fl. Kouy-T chéou, 165 (1914).

Rottlera scabrifolia A. de Jussieu, Tent. Euphorb. III. t. 9, f. 29 (1824).

Rottlera cordifolia Bentham, Fl. Hongk. 307 (1861).

Trewia nudiflora Hance in Jour. Bot. XVI. 14 (non Willdenow) (1878).

Mallotus contubernalis Hance in Jour. Bot. XX. 293 (1882).

Mallotus chrysocarpus Pampanini in Nuov. Giorn. Bot. Ital. n. ser. XVII. 413, fig. 12 (1910).

Western Hupeh: north and south of Ichang, thickets and cliffs, alt. 30-1000 m., May and September 1907 (Nos. 3288, 3542; bush 2-2.5 m.). Eastern Szech'uan: Wan Hsien, banks of Yangtsze River, April 1908 (No. 3288; ; bush 2-3 m., flowers yellow). Western Szech'uan: Mt. Omei, June 1904 (Veitch Exped. No. 5168; bush 1-4 m.).

This is a very common shrub throughout the warmer parts of Hupeh and Szech'uan. The leaves vary much in size and in the amount of their pubescence. E. H.W. 
SAPIUM R. Br.

Sapium discolor Müller Arg. in Linnaea XXXII. 121 (1863). Hooker f., Fl. Brit. Ind. V. 469 (1887). - Hemsley in Jour. Linn. Soc. XXVI. 445 (1894). - Pax in Engler, Pfanzenreich IV.-147, v. 239 (1912).

Stillingia discolor Champion apud Bentham in Hooker Jour. Bot. \& Kew Gard. Misc. VI. 1 (1854). - Bentham, Fl. Hongk. 303 (1861).

Excoecaria discolor Müller Arg. in De Candolle, Prodr. XV. pt. 2, 1210 (1866).

Western Hupeh: Fang Hsien, roadsides, alt. 1000 m., July 1907 (No. 2522; tree $10 \mathrm{~m}$. high, flowers yellow).

Sapium japonicum Pax \& K. Hoffmann in Engler, Pflanzenreich, IV.147, v. 252 (Euphorb.) (1912).

Croton Siraki Siebold \& Zuccarini in Abh. Akad. Münch. IV. pt. 2, 144 (Fl. Japon. Fam. Nat. I. 36) (nomen nudum) (1845).

Stillingia japonica Siebold \& Zuccarini in Abh. Akad. Münch. IV. pt. 2, 145 (Fl. Jap. Fam. Nat. I. 37) (1845).

Triadica japonica Baillon, Elude Gén. Euphorb. 512 (1858).

Excoecaria japonica Müller Arg. in Linnaea, XXXII. 123 (1863); in De Candolle, Prodr. XV. pt. 2, 1217 (1866). - Hance in Jour. Linn. Soc. XIII. 123 (1873). - Hemsley in Jour. Linn. Soc. XXVI. 446 (1894). - Hayata in Jour. Coll. Sci. Tolkyo, XX. 59, t. 4 E (1904). - Shirasawa, Icon. Ess. For. Japon. II. t. 36, f. 1-13 (1908).

Kiangsi: Kuling, thickets, common, alt. 1300 m., July 28, 1907 (No. I574; bush 2-3 m.). Western Hupeh: north and south of Ichang, roadside thickets, abundant, alt. 30-800 m., June 1907 (No. 3543; bush 1-5 m., flowers yellow); same locality, May 1900 (Veitch Exped. No. 760).

Sapium sebiferum Roxburgh, Fl. Ind., ed.2, III. 693 (1832).--Müller Arg. in Linnaea XXXII. 121 (1863). - Hooker f., Fl. Brit. Ind. V. 470 (1888). - Pax in Engler \& Prantl, Nat. Pflanzenfam. III. 5, 97, f. 63 (1890); in Engler, Pflanzenreich, IV.-147, v. 237 (1912). - Hemsley in Jour. Linn. Soc. XXVI. 445 (1894). - Pax in Bot. Jahrb. XXIX. 430 (1900). - Hayata in Jour. Coll. Sci. Tokyo, XX. 61 (1904). Smith in Mededeel. Depart. Landbouw, No. 10, 629 (1910). - Pampanini in Nuov. Giorn. Bot. Ital. n. ser. XVII. 415 (1910). - Dunn \& Tutcher in Kew Bull. Misc. Inform. add. ser. X. 241 (Fl. Kwangtung \& Hongk.) (1912). - Léveillé, Fl. Kouy-Tchéou, 167 (1914).

Croton sebiferum Linnaeus, Spec. 1004 (1753).

Triadica sinensis Loureiro, Fl. Cochin. 610 (1790). - Bretschneider, Early Europ. Research. Fl. China, 173 (1881). 
Stillingia sebifera Michaux, Fl. Bor. Amer. II. 213 (1803). - Hooker \& Arnott, Bot. Voy. Beechey, 213 (1836). - Bentham, Fl. Hongk. 302 (1861). Stillingfleetia sebifera Bojer, Hort. Maurit. 284 (1837).

Excoecaria sebifera Müller Arg. in De Candolle, Prodr. XV. pt. 2, 1210 (1866). Stillingia sinensis Baillon, Êtude Gén. Euphorb. 512, t. 7, figs. 26-30 (1858).

Western Hupeh: north and south of Ichang, much cultivated, 30-800 m., June and November 1907 (No. 252I; tree 6-20 m. tall).

This valuable tree is largely cultivated at low altitudes in western Hupeh and Szech'uan and in the autumn the leaves assume most brilliant tints. In Hupeh it is colloquially known as the Mou-tzu shu and as Ch'uan-tzu shu in Szech'uan. An account of the products of this tree is to be found in my A Naturalist in Western China, II. 67 (1913). Pictures of it will be found under Nos. 389, 442, 483, 0372 of the collection of my photographs and in my Vegetation of Western China, Nos. $467,468,469$.

E. H. W.

\section{EXCOECARIA L.}

Excoecaria acerifolia Didrichsen in Videnskab. Medd. Nat. Foren. Kjöbenh. 1857, 129. - Müller Arg. in De Candolle, Prodr. XV. pt. 2, 1222 (1866). - Hooker f., Fl. Brit. Ind. V. 473 (1888). - Pax in Engler, Pflanzenreich, IV.-147, v. 169 (1912).

Western Szech'uan: west of Romi Chango, forming scrub in dry places, 2000-2500 m., July 1908 (No. 354I; bush 1-2 m. high; flowers yellow); without precise locality, alt. 1400 m., July 1903 (Veitch Exped. No. 4448; shrub $1 \mathrm{~m}$. tall, flowers yellow).

\section{ALEURITES Forst.}

Aleurites Fordii Hemsley in Hooker's Icon. XXIX. tt. 2801, 2802 (1906); in Kew Bull. Misc. Inform. 1906, 120; 1914, 3; in Bull. Imp. Inst. V. 134 (1907). - Pax in Engler, Pflanzenreich, IV.-147, I. 132 (1910). - Dunn \& Tutcher in Kew Bull. Misc. Inform. add. ser. X 237 (Fl. Kwangtung \& Hongk.) (1912). - Fairchild in U. S. Dept. Agric. Circ. No. 108, with figs. (1913). - Wilson in Bull. Imp. Inst. XI. 447 , tt. $9,10,11,12$, 13 fig. 2 (1913).

Elaeococca verrucosa A. de Jussieu, Euphorb. Tent. 38, t. 11, fig. 35 (1824), quoad fruct. et semen.

Dryandra oleifera Wallich, Cat. No. 7958 (nomen nudum) (non Lamarck)

(1832).
Aleurites cordata Hooker f., Fl. Brit. Ind. V. 384 (non R. Brown) (1887) ,Hemsley in Jour. Linn. Soc. XXVI. 433 (1894) exclud. synon. et speciminibus ex Hainan et Hongkong, partim. - Pax in Bot. Jahrb. XXIX. 430 (1900). - Pampanini in Nuov. Giorn. Bot. Ital. n. ser. XVII. 410 (1910), - Lé-

veillé, Fl. Kouy-Tchéou 157 (1914).
Aleurites verniciflua Léveillé, Fl. Kouy-Tchéou, 157 (1914), an etiam Baillon? 
Kiangsi: Kiukiang, base of foothills, alt. 150 m., August 2, 1907 (No. I5Io; tree 3-5 m.); north, south and west of Ichang, largely cultivated, alt. 30-800 m., April, July and October 1907 (No. 203I; tree $3-10 \mathrm{~m}$. tall). Szech'uan: Wan Hsien, banks of Yangtsze River, April $1908\left(\mathrm{No.} \mathrm{203}^{\mathrm{a}}\right)$. Yunnan: Milê District, A. Henry (No. 10,587; tree 3 m.).

This important tree is cultivated in vast numbers in western Hupeh and Szeeh'uan, especially in rocky places, from river level to $1000 \mathrm{~m}$. altitude. An account of this tree and of the methods of expressing the oil from the seeds will be found in my A Naturalist in Western China, II. 65 (1913).

Pictures of this tree are to be found under Nos. $31,37,38,44,45,460,0171$, 0350 of the collection of my photographs and also in my Vegetation of Western China, Nos. 117, 118, 119, 120.

E. H. W. 


\title{
THYMELAEACEAE.
}

\author{
Determined by ALFred REHDER. ${ }^{1}$
}

\section{WIKSTROEMIA Endl.}

Wikstroemia stenophylla Pritzel in Bot. Jahrb. XXIX. 480 (1900).

Western Szech'uan: Valley of Hsao-chin-ho, near Monkong Ting, alt. 2100-2400 m., June 1908 (No. 2366; bush 0.30-0.50 m. tall, flowers yellow); Min River valley, Mao-chou, alt. 1200-1600 m., May 25, 1908 (No. 2365; bush $0.30-0.60 \mathrm{~m}$. tall, flowers yellow); same locality, rocks, alt. 1200 m., August 1903 (Veitch Exped. No. 4435; bush 0.30$0.60 \mathrm{~m}$., flowers yellow); T'ao-kuan, Lung-ch'ih, September, A. von Rosthorn (No. 3113, type).

Wilson's Nos. 2365 and 2366 are of more compact habit and have somewhat larger flowers in simple terminal spikes, while in the type as well as in Wilson's No. 4435 the inflorescence is paniculate and the flowers smaller, but this is probably due to the specimens having been collected at different seasons; in all other characters all the specimens agree.

Wikstroemia micrantha Hemsley in Jour. Linn. Soc. XXVI. 399 (1894). - Diels in Bot. Jahrb. XXIX. 480 (1900).

Western Hupeh: near Ichang, A. Henry (No. 4173, co-type); Hsing-shan Hsien, ravines, uncommon, alt. 300-600 m., May 9, 1907 (No. 2364; bush $0.3-1 \mathrm{~m}$. tall, flowers white). Szech'uan: Yangtsze gorges, May 1903 (Veitch Exped. No. 4432; bush 0.5-1 m. tall, flowers yellow, fragrant).

This species seems most closely related to $W$. angustifolia Hemsley, from which it differs chiefly in the glaucescent under side of the broader, generally oblong or oblanceolate less crowded leaves. Hemsley compares it with $W$. chamaedaphne Bunge, but that species differs considerably in its paniculate inflorescence, densely pubescent flowers, much larger leaves and in its different habit with virgate branches. Wilson's specimens have larger glabrous flowers in 3-7-flowered fascicles and somewhat smaller leaves.

Wikstroemia capitata Rehder, n. sp.

Frutex gracilis, $0.5-1 \mathrm{~m}$. altus; ramuli hornotini teretes, tenues, glabri, plerumque virides, annotini fusco-purpurei. Folia membrana-

1 With a description of a new species of Wikstroemia Léveillé \& Blin and a new variety of Daphne by Léveillé \& Rehder. 
cea, opposita v. subopposita, elliptica v. obovato-elliptica, rarius obovato-oblonga, obtusa v. obtusiuscula, basi attenuata, 1-2 cm. longa et 0.4-0.9 cm. lata, utrinque glabra v. initio parcissime strigosa, supra obscure luteo-viridia, subtus pallidiora, utrinsecus nervis 5-7 angulo valde acuto divergentibus leviter curvatis subtus leviter elevatis; petioli breves v. brevissimi, $0.5-1.5 \mathrm{~mm}$. longi. Flores lutei, sessiles in capitulis 3-7-floris terminalibus graciliter pedunculatis pedunculo filiformi $1-1.8 \mathrm{~cm}$. longo; perianthii tubus circiter $7 \mathrm{~mm}$. longus et $1 \mathrm{~mm}$. diam., extus sericeo-strigosus, lobis 4 ovatis v. ovato-oblongis eirciter $1.5 \mathrm{~mm}$. longis; antherae 8 , ovali-oblongae $0.8-1 \mathrm{~mm}$. longae, filamentis brevissimis, eae seriei superioris faucem vix attingentes, seriei inferioris paullo supra medium affixae; disci squama unica ovario circiter triente brevior, linearis, apice 2- v. 3-dentata; pistillum $3 \mathrm{~mm}$. longum, ovario strigoso-pubescente, stylo $0.5 \mathrm{~mm}$. longo, stigmate capitato purpureo. Fructus ovoideus, utrinque attenuatus, $4.5 \mathrm{~mm}$. longus, aurantiacus, parce strigosus, ante maturitatem perianthio diu persistente obtectus; semen ovoideum, utrinque breviter productum, obscure nigrum, $4 \mathrm{~mm}$. longum.

Western Hupeh: Patung Hsien, thickets, alt. 300-900 m., May and June 1907 (No. 40).

This species is apparently most closely related to W. linoides Hemsley which is an herbaceous plant with narrower, oblong leaves and glabrous flowers. From other related species it is easily distinguished by its few-flowered, slender-stalked heads of flowers.

\section{Wikstroemia ligustrina Rehder, n. sp.}

Frutex 1-1.25 m. altus; ramuli graciles, teretes, dense sericeostrigosi, annotini purpureo-fusci, tarde glabrescentes; gemmae subglobosae, parvae sed tomento albo conspicuae. Folia membranacea, alterna v. rarius subopposita, anguste oblonga v. oblanceolata, rarius oblongo-oblanceolata v. oblonga, acuta v. acutiuscula, basi cuneata, 1-2.5 cm. longa et $0.3-0.6 \mathrm{~cm}$. lata, glabra v. subtus parcissime strigosa, supra obscure viridia, subtus pallidiora; nervis utrinsecus 4-6 curvatis vix distinctis; petioli pubescentes, circiter $1 \mathrm{~mm}$. longi. Flores lutei, sessiles v. breviter pedicellati in capitulis v. spicis brevibus terminalibus solitariis v. ternis pluri- v. multifloris breviter pedunculatis pedunculo 1-5 mm. longo sericeo-strigoso, folia vix superantibus; perianthii tubus sericeo-strigosus, $9 \mathrm{~mm}$. longus, lobis 4 patentibus ovalibus 2.5 $\mathrm{mm}$. longis; antherae 8 , oblongae, $1.25 \mathrm{~mm}$. longae, eae seriei superioris faucem tubi attingentes, filamentis brevissimis, eae seriei inferioris paullo supra medium affixae, filamentis $0.5 \mathrm{~mm}$. longis; 
disci squama unica, fere quadrata, apice irregulariter dentata, circiter $1 \mathrm{~mm}$. longa; pistillum $3.5 \mathrm{~mm}$. longum, ovarium strigoso-pubescente, stylo brevissimo, stigmatae capitato. Fructus ignotus.

Western Szech'uan: Valley of Hsao-chin-ho, near Monkong Ting, alt. 2100-3300 m., June 1908 (No. 2363).

This species seems to be most nearly related to W. chamaedaphne Meisner, which differs in its stouter glabrous more or less angular branchlets, glabrous petioles, larger leaves and in the paniculate inflorescence.

Wikstroemia brevipaniculata Rehder, n. sp.

Frutex gracilis $0.3-1 \mathrm{~m}$. altus, glaber; ramuli teretes, hornotini glaucovirides v. leviter rubescentes, annotini rubro-brunnei. Folia opposita, chartacea, subpersistentia, oblonga v. elliptico-oblonga, v. anguste oblonga, rarius oblanceolato-oblonga, basi attenuata, apice acutiuscula et mucrone spinescente munita, margine leviter revoluta, 1.5-4 cm. longa et 0.4-1.2 $\mathrm{cm}$. lata, supra coeruleo-viridia, opaca, subtus glaucescentia, nervis utrinsecus $6-10$ subtus leviter elevatis margine anastomosantibus venulis levissime prominulis; petioli 1-2 $\mathrm{mm}$. longi. Flores lutescentes, parce strigosis v. fere glabris, circiter $4 \mathrm{~mm}$. longi, in paniculis terminalibus $1-4 \mathrm{~cm}$. longis; lobi ovati v. acutiusculi tubo triplo v. quadruplo breviores; stamina 8 , antheris subsessilibus: ovarium obovoideum, basi attenuatum, apice pilosum, stigmate capitato subsessili; squama disci unica, subquadrata apice erosa (semper?). Fructus ovoideus, purpureo-niger, $4 \mathrm{~mm}$. longus, apice strigosulus.

Eastern Szech'uan: Taning Hsien, roadside, alt. 900-1100 m. July 1910 (No. 46r3).

This species seems to be most nearly related to W. micrantha Hemsley, which differs in its simple spicate or fascicled inflorescence, larger flowers, and in the smaller leaves usually obtusish and searcely mucronulate and in their obsolete venation. It may also be compared with $W$. chamaedaphne Meisner, which is easily distinguished by the densely pubescent flowers in larger and denser panicles, the longer yellowish green obtusish leaves and the striate or slightly angular branchlets.

Flores tetrameri.

\section{CLAVIS SPECIERUM SINENSIUM.}

Flores in racemis $\mathrm{v}$. fasciculis solitariis (interdum paniculatae in No. 7).

Folia opposita, persistentia v. subpersistentia.

Folia ovata v. elliptica ad ovato-oblonga.

Ramuli et folia glabra.

Folia subtus glaucescentia. Flores glabri, spicati, pedunculo gracili nutante suffulti; ovarium glabrum . . . . ... 1. W. nutans.

Folia concoloria v. fere concoloria. Spica erecta.

Folia basi acuta.

2. W. indica.

Folia basi obtusa v. rotundata, brevissime petiolata.

3. W. stenantha. 
Ramuli pubescentes. Folia subtus sparse pilosa v. fere glabra.

Folia apice rotundata v. emarginata, obovata . . . 4. W. retusa. Folia acuta.

Folia elliptica v. elliptico-ovata, nervis utrinsecus 3-5. Inflorescentia longe pedunculata, disci squamae $2 \ldots . .5$. W. monnula. Folia lanceolato-oblonga, membranacea, venis obsoletis. Inflorescentia breviter pedunculata; disci squamae 4 . .6. W. chinensis.

Folia linearia v, anguste oblonga v, oblanceolata, glabra.

Ramuli manifeste 4-angulati angulis subalatis.

Folia linearia, valde revoluta. Flores extus pubescentes: ovarium pubescens . . . . . . . . . . 7. W. stenophylla.

Ramuli subteretes. Folia anguste oblonga v. anguste lanceolata v. oblanceolata.

Folia subtus (in sicco saltem) flavescentia v. fuscescentia plerumque lineari-oblanceolata acuta, ad $2 \mathrm{~cm}$. longa et ad $0.4 \mathrm{~cm}$. lata.

8. W. angustifolia.

Folia subtus albida, plerumque oblanceolata, basi plerumque subito contracta, interdum obovatis intermixtis, ad 1.5, rarius ad $2 \mathrm{~cm}$. longa et ad $0.7 \mathrm{~cm}$. lata . . . . . . . 9. W. micrantha.

Folia alterna, membranacea. Inflorescentia subcapitata $\mathrm{v}$. breviter racemosa.

Ramuli et folia glabra. Inflorescentia graciliter pedunculata.

Flores extus glabri. Planta herbacea . . . . . . 10. W. linoides. Flores extus sericeo-strigosa. Planta fruticosa .... 11. W. capitata. Ramuli pubescentes. Inflorescentia breviter pedunculata.

Folia glabra, plana. Inflorescentia interdum terna in apice ramulorum.

12. W. ligustrina.

Folia utrinque pubescentia, margine revoluta. Ramuli dense strigosovillosi ............. 13. W. salicina.

Flores in spicis paniculatis.

Folia obtusa, plerumque ovalia, mox glabrescentia, opposita.

14. W. gracilis.

Folia acuta.

Ramuli et folia glabra, opposita.

Rhachis inflorescentiae et flores dense pubescentes.

Rhachis inflorescentiae glabra; flores parce strigosi v. glabri.

15. W. chamaedaphne.

16. W. brevipaniculata.

Ramuli et folia pubescentes.

Folia saepe opposita, supra saepe glabrescentia, subtus nervis prominulis.

Spicae pedunculatae, saepe elongatae . . . 17. W. canescens.

Folia semper alterna, utrinque dense pubescentia, nervis obsoletis. Spicae breves subsessiles v. breviter pedunculatae.

Flores 12-13 $\mathrm{mm}$. longi. Folia lanceolata, $3-3.8 \mathrm{~cm}$. longa.

18. W. alternifolia.

Flores 5-6 mm. longi. Folia anguste elliptica, 1-2 cm. longa.

19. W. Pampaninii.

Flores pentameri.

Ramuli et folia pubescentia.

Folia linearia, utrinque dense sericeo-pilosi, 1-1.5 cm. longi.

Folia elliptico-oblonga $v$. oblonga, parce, rarius densius pilosa.

20. W. holosericea.

21. W. dolichantha. 
Ramuli et folia glabra.

Flores strigoso-pubescentes; inflorescentia paniculata, laxa. Folia opposita, oblonga, $2-3 \mathrm{~cm}$. longa . . . . . . . . . . 22. W. effusa.

Flores glabri; inflorescentia solitaria. Folia alterna v. superiora opposita, oblanceolata, $3-6 \mathrm{~cm}$. longa . . . . . . . 23. W. scytophylla.

\section{ENUMERATIO SPECIERUM SINENSIUM.}

1. Wikstroemia nutans Champion in Hooker Kew Jour. Bot. V. 195 (1853).Meisner in De Candolle, Prodr. XIV. 545 (1857). - Bentham, Fl. Hongk. 297 (1861). - Maximowiez in Bull. Acad. Sci. St. Pétersbourg, XXXI. 100 (1886); in Mél. Biol. XII. 541 (1886). - Hemsley in Jour. Linn. Soc. XXVI. 400 (1894). Dunn \& Tutcher in Kew Bull. Misc. Inform. Add. Ser. X. 227 (Fl. Kwangtung \& Hongk.) (1912).

Hongkong: Happy Valley (=Wongnai chung), January 30, 1893, C. Ford.

2. Wikstroemia indica C. A. Meyer in Bull. Acad. Sci. St. Pétersbourg, sér. 2, I. 358 (1843); in Ann. Sci. Nat. sér. 2, XX. 50 (1843). - Bentham in Hooker's Jour, Bot. V. 195 (1853), - Meisner in De Candolle, Prodr. XIV. 543 (1857), Maximowicz in Bull. Acad. Sci. St. Pétersbourg, XXXI. 98 (1886); in Mél. Biol. XII. 539 (1886). - Hemsley in Jour. Linn. Soc. XXVI. 398 (1894). - Henry in Trans. As. Soc. Jap. XXIV. Suppl. 80 (List Pl. Formosa) (1896), excl. No. 1131. - Dunn \& Tutcher in Kew Bull. Misc. Inform. Add. Ser. X. 227 (Fl. Kwangtung \& Hongk.) (1912).

Daphne indica Linnaeus, Spec. 357 (1753), - Hooker \& Arnott, Bot. Voy. Beechey, 68, 209, t. 15 (1832).

Capura purpurata Linnaeus, Mant. II. 225 (1771).

Daphne cannabina Loureiro, Fl. Cochin. 236 (1790).

Daphne viridiflora Wallich, Cat. No. 1049 (nomen nudum) (1828).

Wikstroemica viridiflora Meisner in Denkschr. Regensb. Bot. Ges. III, 286 (1841). - Bentham, Fl. Hongk. 297 (1861). - Maximowicz in Bull. Acad. Sci. St. Pétersbourg, XXXI. 99 (1886); in Mél. Biol. XII. 539 (1886).

Diplomorpha? viridiflora C. A. Meyer in Bull. Acad. Sci. St. Pétersbourg, sér. 2, I. 358 (1843); in Ann. Sci. Nat. sér. 2, XX. 50 (1843).

Wikstroemia alpina, var. Bentham ex Bentham, Fl. Hongk. 297 (pro synon.) (1861).

Wikstroemia indica, var. viridiflora Hooker f., Fl. Brit. Ind. V. 195 (1886).

Kwangtung: Canton, E. Faber. Kwangsi: Lungchow, H. B. Morse (No. 328). Formosa: Takow, A. Henry (Nos. 1197, 1883); Bankinsing, A. Henry (No. $\left.1197^{\mathrm{a}}\right)$.

3. Wikstroemia stenantha, Hemsley in Jour. Linn. Soc. XXVI, 400 (1894). Dunn \& Tuteher in Kew Bull. Misc. Inform. Add. Ser. X. 227 (Fl. Kwangtung \& Hongk.) (1912).

Kwantung: Lofau-shan, C. Ford.

4. Wikstroemia retusa A. Gray in Jour. Bot. III. 303 (1865). - Maximowicz in Bull. Acad. Sci. St. Pétersbourg, XXXI. 98 (1886); in Mél. Biol. XII. 538 (1886).

Wikstroemia indica Henry in Trans. As. Soc. Jap. XXIV. Suppl. 80 (List Pl. Formosa) (pro parte, non C. A. Meyer) (1896), quoad No. 1131.

Formosa: Lambay Island, August 15, 1893 (or 1894), A. Henry (No. 1131). The Formosan plant agrees well with the type specimen except in some slight 
difference in the disk scales. In the type one of the two opposite scales is oblong and bifid, the other broadly oblong to nearly quadrate, bifid at the apex and with a more or less distinct tooth on each side below the middle; in the Formosan plant one of the scales is divided to the base into two linear-oblong lobes, while in the other the linear-oblong lobes are connate below the middle. Maximowicz, who apparently did not know Gray's original description based on specimens collected in the Liukiu Islands by $C$. Wright in 1856, as he quotes "A. Gray in sched.," bases his description partly on other material. The leaves in the type specimen are $2.5-3.5 \mathrm{~cm}$. long and $1.3-1.8 \mathrm{~cm}$. broad, with 8-10 pairs of veins, and the petioles are 1-2 $\mathrm{mm}$. long, while the measurements Maximowiez gives are considerably larger. Hemsley's $W$. obovata, also from the Liukiu Islands, differs according to the description in the glabrous flowers and glabrous ovaries, otherwise it seems very similar.

5. Wikstroemia monnula Hance in Jour. Bot. XVI. 13 (1878), - Maximowicz in Bull. Acad. Sci. St. Pétersbourg, XXXI. 98 (1886); in Mél. Biol. XII. 538 (1886). - Hemsley in Jour. Linn. Soc. XXVI. 399 (1894). - Dunn \& Tutcher in Kew Bull. Misc. Inform. Add. Ser. X. 227 (Fl. Kwangtung \& Hongk.) (1912).

Kwangtung: Canton, E. Faber. Hongkong: C. Ford; Lantao Island, May 8, 1888, May 30, 1904 (ex Herb. Hongkong, No. 1256). Fokien: Dunn's Exped. to Cent. Fokien, April to June 1905 (Herb. Hongkong, No. 2498).

6. Wikstroemia chinensis Meisner in De Candolle, Prodr. XIV. 546 (1857). Debeaux in Act. Soc. Linn. Bordeaux, XXXI. 356 (Fl. Tché-fồ) (1876), - Franchet in Mém. Soc. Nat. Cherbourg, XXIV. 250 (1882); in Nouv. Arch. Mus. Paris, sér. 2, VII. 70 (Pl. David. I. 260) (1884). - Maximowicz in Bull. Acad. Sci. St. Pétersbourg, XXXI. 99 (1886); in Mél. Biol. XII. 400 (1886). - Hemsley in Jour. Linn. Soc. XXVI. 397 (1894).

Shantung: Fauvel (ex Franchet). Kiangsi: A. David (ex Franchet).

7. Wikstroemia stenophylla Pritzel. See p. 530.

8. Wikstroemia angustifolia Hemsley in Jour. Linn. Soc. XXVI. 396 (1891). Pampanini in Nuov. Giorn. Bot. Ital. n. ser. XVII. 675 (1910).

Wikstroemia chamaedaphne Pavolini in Nuov. Giorn. Bot. Ital. n. ser. XV. 437 (non Meisner) (1908).

Western Hupeh: gorges near Ichang, on cliffs, June 1900 (Veitch Exped. No. 1246; shrub $1 \mathrm{~m}$. tall, flowers pink); without precise locality, A. Henry (Nos. 1519, $2270,3313,3594,4184$ ).

9. Wikstroemia micrantha Hemsl. See p. 530 .

10. Wikstroemia linoides Hemsley in Jour. Linn. Soc. XXVI. 398 (1894).

Western Hupeh: Ichang, A. Henry (ex Hemsley).

This seems to be the only herbaceous species in the genus.

11. Wikstroemia capitata Rehder. See p. 530.

12. Wikstroemia ligustrina Rehder. See p. 531.

13. Wikstroemia salicina Léveillé \& Blin, n. sp.

Frutex dumosus, $1.50 \mathrm{~m}$, altus, aspectu salicino; rami grisei, subnodosi, pubescentes, teretes; folia anguste lanceolata, integerrima, confertissima, margine revoluta, subsessilia, petiolo subnullo villoso, acuta $\mathrm{v}$. obtusata, $1.5-2.5 \mathrm{~cm}$. longa et $5.8 \mathrm{~mm}$. lata, supra atro-viridia, nervis parum conspicuis, subtus primum incanosericea, mox tantum villosa, imo glabrata, nervis elevatis. Flores ad apicem ram- 
ulorum dense capitati, 8-20, lutei; pedicelli 1-2 mm. longi; perianthum 10-15 $\mathrm{mm}$. longum, extus tomentoso-sericeum, intus villosum; lobi ovati, obtusi; ovarium ovatum, papillosum.

Yunnan: " pâturages de Ié-ma-tchouan, $3200 \mathrm{~m}$., juillet 1913," E. E. Maire.

This new species, the description of which was sent to me by Mgr. Léveillé together with a specimen, seems most closely related to $W$. ligustrina Rehder, but is readily distinguished by the narrower leaves of firmer texture, pubescent on both sides and revolute at the margin, by the pubescent inside of the perianth and by the linear solitary disk scale at the base of the pubescent ovary. The pubescence chiefly present on the 8 longitudinal veins inside the tube of the perianth is a rather unusual character in the genus; all Chinese species I have examined are perfectly glabrous on the inner surface of the perianth.

14. Wikstroemia gracilis Hemsley in Jour. Linn. Soc. XXVI. 397 (1894).

Western Hupeh: Hsing-shan Hsien, A. Henry (No. 6440).

15. Wikstroemia chamaedaphne Meisner in De Candolle, Prodr. XIV. 547 (1857). - Franchet in Nouv. Arch. Mus. Paris, sér. 2, VII. 70 (Pl. David. I. 260) (1884). - Maximowicz in Bull. Acad. Sci. St. Pétersbourg, XXXI. 99 (1886); in Mél. Biol. XII. 540 (1886), - Hemsley in Jour. Linn. Soc. XXVI. 397 (1894).

Passerina Chamaedaphne Bunge in Mém. Sav. Etr. Acad. Sci. St. Pétersbourg, II. 132 (Enum. Pl. Chin. Bor. 58) (1833). - Maximowicz in Mém. Sav. Etr. Acad. Sci. St. Pétersbourg, IX. 476 (Prim. Fl. Amur.) (1859).

Diplomorpha Chamaedaphne C. A. Meyer in Bull. Acad. Sci. St. Pétersbourg, sér. 2, I. 358 (1843); in Ann. Sci. Nat. sér. 2, XX. 50 (1943).

Chili : Kalgan road, near Peking, October 5, 1905, J. G. Jack; Hwai-lai, July 30, 1913, F. N. Meyer (No. 1050). Kansu: without precise locality, 1910, W. Purdom (No. 772).

16. Wikstroemia brevipaniculata Rehder. See p. 532 .

17. Wikstroemia canescens Meisner in Denkschr. Regensb. Bot. Ges. III. 288 (1841); in De Candolle, Prodr. XIV. 547 (1857). - Maximowiez in Bull. Acad. Sci. St. Pétersbourg, XXXI. 100 (April 1886); in Mél. Biol. XII. 451 (1886). Hooker f., Fl. Brit. Ind. V. 195 (August 1886), excl. synon. W. chamaedaphne.Hemsley in Jour. Linn. Soc. XXVI. 397 (1894).

Daphne sericea D. Don, Prodr. Fl. Nepal. 69 (non Vahl) (1825).

Daphne cana Wallich ex D. Don, 1. c. (pro synon.) (1825).

Daphne oppositifolia Hamilton ex D. Don 1. c. (pro synon.) (1825).

Daphne canescens Wallich, Cat. No. 1046 (nomen nudum) (1828).

Daphne virgata Wallich, Cat. No. 1047 (nomen nudum) (1828).

Wikstroemia virgata Meisner in Denkschr. Regensb. Bot. Ges. III. 289 (1841); in De Candolle, Prodr. XIV. 547 (1857), - Beddome, Fl. Sylv. S. Ind. II. For. Man. p. clxxviii, t. 25, fig. 4 (1874).

Diplomorpha canescens C. A. Meyer in Bull. Acad. Sci. St. Pétersbourg, sér. 2, I. 358 (1843); in Ann. Sci. Nat. sér. 2, XX. 50 (1843).

Diplomorpha virgata C. A. Meyer, 1. c. (1843).

Wikstroemia salicifolia Decaisne in Ann. Sci. Nat. sér. 2, XX. 50 (in nota) (1843); in Jacquemont, Voy. IV. 144, t. 149 (1844). - Walpers, Ann. I. 589 (1848). - Meisner in De Candolle, Prodr. XIV. 546 (1857).

Daphne inamoena Gardner in Calcutta Jour. Nat. Hist. VII. 454 (1846).

Wikstroemia inamoena Meisner in De Candolle, Prodr. XIV. 547 (1857).

Kiangsi : Kiukiang, F. B. Forbes (ex Hemsley). 
18. Wikstroemia alternifolia Batalin in Act. Hort. Petrop. XIII. 99 (1893). Hemsley in Jour. Linn. Soc. XXVI. 397 (1894). - Pritzel in Bot. Jahrb. XXIX. 480 (1900).

Kansu : "vallis fl. Hei-ho supra pagum Hun-nei-ku” July 24, 1885, G. N.Potanin (ex Batalin).

19. Wikstroemia Pampaninii Rehder, n. sp.

Wikstroemia alternifolia Pampanini in Nuov. Giorn. Bot. Ital. n. ser. XVII. 675 (non Batalin) (1910).

Frutex 0.5 v. ultra altus, ramis gracilibus erectis; ramuli teretes, hornotini, praesertim apicem versus, dense pilis albidis subaccumbentibus obtecti, annotini glabrescentes ut vetustiores fusco-purpurei; gemmae subglobosae, conspicue albido-tomentosae. Folia omnia alterna, membranacea, elliptica v. obovatoelliptica v. anguste elliptica, utrinque acuta, margine, in sicco saltem, revoluta, 1-2 cm. longa et 0.4-0.8 lata, utrinque pilis longis accumbentibus ad costam subtus densius vestita, fere concoloria, costa media subtus elevata, nervis paucis inconspicuis; petioli cireiter $1 \mathrm{~mm}$. longi, dense pubescentes. Flores sessiles in spicis dense pilosis terminalibus pluri- v. multifloris et axillaribus saepius paucifloris in apice ramulorum paniculas angustas foliatas foliis apicem versus decrescentibus formantibus; perianthii tubus dense adpresse pilosus, $3.5-4 \mathrm{~mm}$. longus, lobis ovalibus 4 extus pilosis $1.5 \mathrm{~mm}$. longis; antherae 8 , oblongae, $0.8 \mathrm{~mm}$. longae, filamentis vix $0.2 \mathrm{~mm}$. longis, superiores paullo exsertae, inferiores supra medium tubi affixae; pistillum $2.5 \mathrm{~mm}$. longum, ovario pilis adpressis dense obtecta, stylo brevissimo, stigmate capitato pilis longis id subaequantibus fere occultato; squamae disci 2 , eirciter quartam partem ovarii aequantes, una linearis, altera latior, inaequaliter plus minusve 2-3-dentata. Fructus immaturus tantum visus, pubescens.

Northern Hupeh: "monte Triora," alt. 1950 m., July 3, 1907, C. Silvestri (No. 1540, type); "monte Niang-niang," alt. $1950 \mathrm{~m}$., July 1907, C. Silvestri (No. 1541).

This species seems most closely related to $W$. alternifolia Batalin, which differs according to the description in its gray branches, in the narrower leaves, which are about twice as long, in the $12-14 \mathrm{~mm}$. long flowers and in the solitary diskseale about half as long as the ovary. The hairs at the apex of the ovary are in W. Pampaninii remarkably long and nearly hide the stigma, which is slightly ovoid or obovoid in shape.

20. Wikstroemia holosericea Diels in Not. Bot. Gard. Edinburgh, V. 286 (1912).

Yunnan: Descent of the Yangtsze from Chung Tien, alt. 3000 m., September 1904, G. Forrest (No. 13, ex Diels).

According to Diels this species has no disk-scales, which makes it doubtful whether it belongs in the genus Wikstroemia.

21. Wikstroemia dolichantha Diels in Not. Bot. Gard. Edinburgh, V. 286 (1912).

Yunnan: Chien-chuen and Hoching valleys, alt. 2100-2700 m., September 1904, G. Forrest (No. 133 ex Diels); Mengtsze, grass hills, alt. 1400 m., A. Henry (No. 10277; slender shrub 0.6-1 m. tall, flowers yellow).

Henry's specimens differ from the original description in their more copious pubescence, though the different specimens distributed under No. 10277 show great variation in this respect; in one specimen in the herbarium of the Arnold Arboretum the leaves are densely pubescent on both sides, while in the other they are less pubescent and narrowly elliptic; in the one specimen in the herbarium of the New York Botanic Garden the leaves are nearly glabrous below, but thinly pubescent above and also narrowly elliptic. 


\section{Wikstroemia effusa Rehder, n. sp.}

Frutex $0.6 \mathrm{~m}$. altus (ex Wilson), ramis gracilibus erectis, ramulis superioribus floriferis plus minusve, interdum fere angulo recto, patentibus; ramuli hornotini teretes, tenues glabri v. praesertim apicem versus sparse pubescentes, purpurascentes. Folia membranacea, opposita, oblonga v. elliptico-oblonga, utrinque acuta, $1.5-3 \mathrm{~cm}$. longa et $0.5-0.9 \mathrm{~cm}$. lata, supra livido-viridia, subtus pallidiora, utrinque glabra, nervis utrinsecus $5-6$ rarius pluribus subtus elevatis; petioli eirciter $1 \mathrm{~mm}$. longi, glabri, interdum sparse pilosi. Flores lutei sessiles v. fere sessiles, in spicis terminalibus pedunculatis saepe ternis ad $1.5 \mathrm{~cm}$. longis sparse pubescentibus ramos et ramulos terminantibus et paniculam gracilem effusam formantibus; perianthii tubus gracilis $8-9 \mathrm{~mm}$. longus, extus sericeo-pubescens, lobis 5 anguste ovatis fere $2 \mathrm{~mm}$. longis; antherae 10 , oblongae, 1-1.2 $\mathrm{mm}$. longae, superiores faucem vix attingentes, inferiores supra medium affixae, filamentis $0.2 \mathrm{~mm}$. longis: pistillum $4 \mathrm{~mm}$. longum, ovario subclavato apice sparse piloso, stylo distincto $0.2 \mathrm{~mm}$. longo; disci squama unica linearis, apice $2-3$ dentata, eirciter ovarium dimidium aequans, interdum ovario fere aequilonga, rarius squama secunda breviore addita. Fructus desideratur.

Yunnan: Szemao, alt. 1500 m., A. Henry (No. 13367, type). Western Szech'uan: Kiating Fu, eliffs, alt. 500 m., June 1903 (Veitch Exped. No. 4436).

This species seems nearest to $W$. dolichantha Diels, which differs in its densely pubescent branchlets and in the narrower more or less pubescent leaves. Possibly this is only a glabrous form of $W$. dolichantha. Wilson's No. 4436 differs slightly from the type in the sparingly pubescent branchlets which are glabrous in the type, and in the more numerous and closer pairs of veins of the leaves.

23. Wikstroemia scytophylla Diels in Not. Bot. Gard. Edinburgh, V. 286 (1912).

Yunnan: between Tang-tui and Chiao-tou, alt. 2100-2700 m., September 1904, G. Forrest (No. 44, ex Diels).

\section{SPECIES IMPERFECTE NOTAE v. EXCLUDENDAE.}

Wikstroemia Valbrayi Léveillé, $F l$. Kouy-Tchéou, 417 (1915).

K wei-chou: "Roule de Pin, Fa à Tui Fan; Tsin Gai," J.Cavalerie (Nos. 1261, 1865, ex Léveillé).

This species I know only from the very short description and from a fragment sent by the author and consisting of a few detached leaves and fruits. It is apparently a distinct species, but the material is too meagre to make it possible to form an opinion about the affinity of the plant.

Wikstroemia Bodinieri Léveillé, Fl. Kouy-Tchéou, 417 (1915). (Syn.: Daphne Bodinieri Léveillé in Fedde, Rep. Spec. Nov. XIII. 258 ([1914]).

According to a fragment of the type specimen sent by the author this plant belongs to the Apocynaceae.

\section{DAPHINE L.}

Daphne genkwa Siebold \& Zuccarini, Fl. Jap. I. 137, t. 75 (1840). Meisner in De Candolle, Prodr. XIV. 531 (1857). - Maximowicz in Mél. Biol. XI. 310 (1881); in Bull. Acad. Sci. St. Pétersbourg, XXVII. 532 (1882). - Hemsley in Jour. Linn. Soc. XXVI. 395 (1894). - Gilg \& Loesener in Bot. Jahrb. XXXIV. Beibl. LXXV. 53 (1904). - Pampanini in Nuov. Giorn. Bot. Ital. n. ser. XVII. 674 (1910). 
Daphne Fortunei Lindley in Jour. Hort. Soc. Lond. I. 147 (1846); II. 34, t. 1 (1847). - Lemaire in Fl. des Serr. III. t. 208 (1847). - Franchet in Mém. Soc. Nat. Cherbourg, XXIV. 250 (1882).

Daphne Genkwa, var. Fortunei Franchet in Nouv. Arch. Mus. Paris, sér. 2, VII. 69 (Pl. David. I. 259) (1884). - Schneider, Ill. Handb. Laubholzk. II. 403 (1909).

Western Hupeh: Ichang, hillsides, abundant, alt. 300-1000 m., March 20, and June 1907 (No. I9; shrub 0.5-1.2 m. tall, flowers lilac, fruit white); same locality, April 1900 (Veitch Exped. No. 33); "Kao-kien-scian," alt. 800 m., May, June 1907, C. Silvestri (No. 1534); without precise locality, A. Henry (Nos. 1541, 7873). Shantung: Cape Yatan, Tai-ching-gong, April 14, 1902, R. Zimmermann (No. 535). Chekiang: Ningpo, 1910, D. Macgregor.

This species is a native of China; in Japan it is only cultivated.

\section{Daphne acutiloba Rehder, n. sp.}

Frutex $0.6-1.5 \mathrm{~m}$. altus, dichotome v. interdum subverticillatim ramosus; rami hornotini pilis strigosis brevibus flavis nitidulis obtecti, annotini glabrescentes v. fere glabri, ut vetustiores laeves, purpurei v. fusco-rubri. Folia coriacea, oblongo-lanceolata v. oblanceolata v. lanceolata, breviter obtuse acuminato acumine interdum leviter emarginato plerumque mucronulato rarius acutiusculo, basi in petiolum brevissimum marginatum attenuata $\mathrm{v}$. subsessilia, 4-8 cm. longa et $1-2$, rarius ad $2.5 \mathrm{~cm}$. lata, supra nitida, luteo-viridia, in sicco leviter v. vix corrugata, subtus fere concoloria, utrinque glaberrima, nervis utrinsecus 7-10 subtus leviter elevatis, supra plerumque leviter impressis. Flores albi, in eapitulis 5-7-floris in apice innovationis basi perulis oblongo-lanceolatis ciliatis caducis circumdatae plus minusve elongatae et bracteis sparsis ovalibus ciliatis caducis et saepe foliaceis persistentibus glabris instructae, breviter pedicellati pedicellis sericeostrigosis $0.5-1.5 \mathrm{~mm}$. longis $\mathrm{v}$. subsessiles; perianthii tubus cylindricus, $11 \mathrm{~mm}$. longus, glaber, lobis 4 ovato-oblongis acutis dimidium tubum paullo superantibus; antherae 8 , oblongae, obtusae, $1.5 \mathrm{~mm}$. longae, superiores basin loborum vix attingentes, inferiores supra medium tubi affixae, filamentis $0.5 \mathrm{~mm}$. longis basi bulboso-dilatatis; pistillum $4 \mathrm{~mm}$. longum, basi disco annulari $0.5 \mathrm{~mm}$. alto circumdatum, ovario ovoideo glabro, stigmate magno capitato subsessili. Fructus ruber; semen ovoideum, leviter apiculatum, 5-6 $\mathrm{mm}$. longum, nigrescens, vix nitidum.

Western Szech'uan: Mupin, woods, alt. 1800-2100 m., June 1908 (No. 2946, type); Wa-shan woods, alt. 2100 m., June 1908 (No. 
2949); Ta-hsiang-ling, alt. 2500 m., May 1904 (Veitch Exped. No.4438). Western Hupeh: Changlo Hsien, alt. 1200-1500 m., July 1907 (No. 2944). Yunnan: Mengtze, wooded cliffs, alt. 2100 m., A. Henry (No. 11321; flowers white, fragrant).

This species is closely related to $D$. odora Thunberg which differs chiefly in its perfectly glabrous branchlets, broader usually distinctly petioled acute leaves, in the sessile head of many flowers surrounded by persistent bracts and by the comparatively shorter lobes of the perianth. Henry's No. 11321 from Yunnan differs somewhat from the type in the paler branches, in the distinctly petioled leaves, and in the perianth being pubescent toward the base. In this and the following species the inflorescence is borne on a longer or shorter stalk from $0.5-3 \mathrm{~cm}$. long, furnished with a few scattered membranous and ciliate deciduous bracts and passing toward the apex into usually 1-3 leaves or sometimes wanting. From the apex of this stalk at the base of the flowers a new shoot usually appears which continues the branch; this shows that the stalk of the inflorescence is not a peduncle, but a branch. The branching therefore in this and the following species is usually sympodial with most of the older inflorescences apparently lateral on the branches, while in $D$. odora it is dichotomous with the old inflorescences in the forkings of the branches.

\section{Daphne Wilsonii Rehder, n. sp.}

Frutex erectus, $0.5-1.75 \mathrm{~m}$. altus; rami crassi, carnosuli, hornotini dense flavido-strigosi; annotini saltem apicem versus strigosi, glabrescentes, ut vetustiores pallide flavo-grisei v. flavescentes. Folia alterna, persistentia, crasse coriacea, oblonga v. oblanceolato-oblonga, apice acutiuseula v. obtusa, mucronulata, rarius leviter emarginata, basi cuneata in petiolum brevissimum attenuata v. subsessilia, 4-7, rarius ad $10 \mathrm{~cm}$. longa et $1-2$, rarius fere ad $3 \mathrm{~cm}$. lata, utrinque glabra, supra luteo-viridia in sicco manifeste corrugata, subtus paullo pallidiora v. fuscescens, costa media supra impressa subtus elevata, nervis subtus leviter elevatis v. fere obsoletis. Flores albi v. rosei, rarius virescentes, fragrantes, in capitulis 5-12-floris in apice innovationis plus minusve elongatae et bracteis sparsis ovalibus v, oblongo-ovalibus dense ciliolatis caducis v. interdum foliaceis glaberrimis instructae breviter pedicellati v. subsessiles; perianthii tubus cylindricus apice ampliatus, 8-9 $\mathrm{mm}$. longus, extus glaber, lobis 4 , oblongis $\mathrm{v}$. oblongo-lanceolatis acuminatis, rarius ovali-oblongis et obtusiusculis tubum fere aequantibus v. paullo brevioribus; antherae 8 anguste oblongae, mucronulatae, $2 \mathrm{~mm}$. longae, superiores paullo exsertae sed basin loborum vix attingentes, inferiores circa medium tubi insertae, filamentis brevissimis; pistillum $4.5 \mathrm{~mm}$. longum, basi disco annulari leviter crenulato brevissimo vix $0.1 \mathrm{~mm}$. excedente circumdatum, ovario ovoideo glabro, stigmate subsessili capitato sublobato. Fructus baccatus, ovoideus, 
apiculatus, ruber, 6-7 mm. longus; semen globoso-ovoideum, leviter apiculatum, 6-7 mm. altum, fusco-brunneum, nitidum.

Western Hupeh: north and south of Ichang, woodlands, alt. 1200-1800 m., June 1907 (No. 3728, type); same locality, May 1900 (Veitch Exped. No. 637); Hsing-shan Hsien, woods, alt. 1200-1500 m., May 1907 (No. 2942; flowers greenish-white or pink, fragrant); same locality, alt. 600-900 m. (No. 2947; flowers pink); Fang Hsien, woods and forests, alt. 2200-2700 m., June 17 and October 1910 (No. 4454); Changyang Hsien, woods, alt. 1200 m., June 1907 (No. 3728 a); Changlo Hsien, woods, alt. 900-1400 m., May 1907 (No. 2943); without precise locality, A. Henry (No.6838). Western Szech'uan: west of Kuan Hsien, thickets, alt. 2100 m., June and August 1908 (No. 802); west and near Wên-ch'uan Hsien, woods, alt. 1500-1800 m., July 1908 (No. 2948).

This species is closely related to $D$. odora Thunberg, which differs in its brown glabrous or nearly glabrous branches, the less fleshy more coriaceous leaves, and the many-flowered sessile heads surrounded by the persistent bracts, and by the smaller less lustrous blackish seeds. From the preceding species it differs in its yellowish strigose branches, the longer tube and the shorter lobes of its flowers and the larger lustrous dark brown seeds. Two small specimens from Yunnan, without locality and collector, kindly sent by Mgr. Léveillé, apparently belong to this species.

A picture of D. Wilsonii will be found under No. 0353 in the collection of Wilson's photographs.

Daphne retusa Hemsley in Jour. Linn. Soc. XXIX. 318 (1893); XXVI. 401 (1894). - Keissler in Bot. Jahrb. XXIX. 96 (1898). Stapf in Bot. Mag. CXXXVIII. f. 8430 (1912).

Western Szech'uan: Pan-lan-shan, west of Kuan Hsien, upland thickets, alt. 3000-3600 m., June 1908 (No. 2945; shrub 0.3-0.6 m. tall, flowers pink, fragrant); Sungpan Ting, uplands, alt. 3300-3900 m., August 25, 1910 (No. 4019; shrub 0.3-0.6 m. tall, fruit scarlet); near Tachien-lu, woods, alt. 3000-3600 m., July 1903 (Veitch Exped. No. 4439; shrub 0.6-1.2 m. tall, flowers pink).

This is closely related to the preceding species and differs chiefly in the smaller leaves emarginate at the apex and in the lower habit of the plant.

Daphne modesta Rehder, n. sp.

Frutex humilis ramosus, $15-45 \mathrm{~cm}$. altus; ramuli satis robusti interdum valde abbreviati, teretes, pallide griseo-flavidi, vetustiores cinerei, hornotini dense strigosi. Folia alterna, chartacea, lineari-oblonga v. anguste-oblonga, obtusiuscula v. obtusa, basi attenuata, margine revoluta, $1.5-3 \mathrm{~cm}$. longa et $0.3-0.6 \mathrm{~cm}$. lata, supra livido-viridia, glabra, subtus vix pallidiora, fere glabra v. sparsissime, ad costam paullo 
densius strigosa, nervis utrinsecus $10-15$ obsoletis, costa media supra incisa subtus manifeste elevata; petioli circiter $1 \mathrm{~cm}$. longi, glabri v. parce strigosi. Flores lutei, breviter pedicellati, in fasciculis paucifloris terminalibus quam folia brevioribus; pedicelli circiter $1 \mathrm{~mm}$. longi, strigosi; perianthii tubus $8-9 \mathrm{~mm}$. longus, extus sparse strigosus; lobi 5 , ovati, $3.5-4 \mathrm{~mm}$. longi; antherae 10 , oblongae, $2 \mathrm{~mm}$. longae, filamentis $0.5-0.75 \mathrm{~mm}$. longis, eae seriei superioris faucem attingentes, seriei inferioris paullo supra medium affixae; disci squama unica, fere quadrata, $1 \mathrm{~mm}$. longa, apice leviter sinuato-dentata; pistillum $3 \mathrm{~mm}$. longum, ovario basi attenuato apice piloso, stylo brevi, stigmate capitato. Fructus desideratur.

Western Szech'uan: Monkong Ting, valley of Hsao-chin-ho, alt. 2100-2700 m., June 1908 (No. 236r).

This is a very distinct species; it is somewhat similar in general appearance to D. gemmata Pritzel, but that species is easily distinguished by its flowers which have the stamens inserted below the middle and by the broader leaves.

\section{Daphne penicillata Rehder, n. sp.}

Frutex ramosus, $15-25 \mathrm{~cm}$., altus ramis brevibus; ramuli juniores angulati, dense cinereo-strigosi, tertio anno glabrescentes, vetustiores flavo- v. fusco-grisei; gemmae terminales ovatae, 3-5 mm. longae, dense cinereo-pubescentes. Folia alterna, membranacea, ovalia v. obovata v. ovali-oblonga, obtusa v. emarginata, mucronata mucrone praesertim in foliis inferioribus dense longe pilosa appendicem penicilliformem formante, $1.5-3 \mathrm{~cm}$. longa et $0.8-1.5 \mathrm{~cm}$. lata, utrinque glabra v. initio subtus praesertim ad costam mediam sparse adpresse pilosa, supra livido-viridia, subtus paullo pallidiora, nervis utrinsecus 5-7 curvatis subtus leviter elevatis, petioli glabri, vix $1 \mathrm{~mm}$. longi. Flores lutei, sessiles, in fasciculis sessilibus terminalibus $2-3$-floris; perianthii tubus gracilis, glaber, $10 \mathrm{~mm}$. longus; lobi5, oblongi, $4.5 \mathrm{~mm}$. longi; antherae 10 oblongae, $1.5 \mathrm{~mm}$. longae, eae seriei superioris faucem attingentes, inferioris supra medium affixae, filamentis brevissimis; disci squama unica, fere quadrata, $0.5 \mathrm{~mm}$. longa; pistillum $2.5 \mathrm{~mm}$. longum, ovario apice piloso, stylo fere $0.5 \mathrm{~mm}$. longo, stigmate capitato minute pilosulo. Fructus desideratur.

Western. Szech'uan: Min River valley, near Mao-chou, arid places, alt. 1200-1700 m., May 25, 1908 (No. 2367).

This species is not closely related to any other; it is easily recognized by the generally oval glabrous or nearly glabrous leaves, the lower with a peculiar taillike appendage at the apex, by the glabrous 5 -merous flowers with long narrow lobes nearly equalling half the tube, and by the large densely pubescent winter-buds. 
Daphne gemmata Pritzel in Bot. Jahrb. XXIX. 481 (1900), Nitsche, Beitr. Kenntn. Daphne, 29 (1907).

Western Szech'uan: west and near Wên-ch'uan Hsien, dry regions, alt. 1400 m., July 1908 (No. 2368, type; bush $0.30-0.60 \mathrm{~m}$. tall); Mien-chu Hsien, dry sunny banks, alt. 800-900 m., May 21, 1908 (No. 2362; shrub 15-30 cm. high); Shih-ch'uan Hsien, cliffs, alt. 900 m., August 1910 (No. 46I4; flowers yellow); "Tsa-ku-lao, Wei-kuankou," August, A. von Rosthorn (No. 2545, type).

This species belongs to a small group of species with 5-merous flowers recently discovered in western China which differ from all other species of the genus in having the stamens inserted in the lower part of tube of the perianth; five stamens are inserted just above the ovary and five near the middle of the tube. In Pritzel's original description this is correctly stated, but Nitsche says that he found the insertion normal. In von Rosthorn's specimen No.2545, however, in the herbarium of the Arnold Arboretum I find the insertion of the stamens exactly as described by Pritzel. Wilson's specimens referred to this species differ slightly from each other. In the type, with which Wilson's No. 2368 agrees very well except that it has larger flowers about $1.5 \mathrm{~cm}$. long and somewhat curved below the middle, the leaves are generally obovate-oblong to oblong-elliptic, sparingly strigose below, not glabrous as described by Pritzel and the ovary is glabrous or nearly so; No. 2362 has obovate to elliptic leaves nearly glabrous beneath and smaller much curved flowers with the more elongated ovary slightly pilose at the apex; No. 4614 has smaller more coriaceous, obovate to oblong-obovate leaves, $1-3 \mathrm{~cm}$. long and very sparingly strigose below; its flowers are shorter with more oval lobes only $2.5 \mathrm{~mm}$. long; the stamens are all aborted except one stamen in one of the two flowers examined; the ovary is sparingly pilose at the apex.

\section{CONSPECTUS SPECIERUM SINENSIUM GENERIS DAPHNES.}

Inflorescentiae axillares. Folia opposita v. alterna, decidua.

Folia supra glabra. Perianthii lobi $5 \mathrm{~mm}$. longi v. ultra.

Folia utrinque pubescentia. Perianthii lobi circiter $2 \mathrm{~mm}$. longi.

1. D. genkwa.

2. D. Championii.

Inflorescentiae terminales, rarius terminales et praeterea axillares.

Flores 4-meri: discus annularis, minutus v. nullus.

Inflorescentia paniculata, ebracteata. Folia decidua, lineari-lanceolata.

3. D. Roumea.

Inflorescentia capitata v. spicata.

Folia decidua, lanceolata. Inflorescentia ebracteata. . . 4. D. Giraldii.

Folia persistentia. Inflorescentia bracteata.

Folia alterna. Flores albidi v. rosei.

Ramuli glabri, rarius initio leviter puberuli.

Folia angusta, 8-12 mm. lata. Capitula pauciflora.

Bracteae ciliatae; pedicelli hispiduli. Folia emarginato-obtusa.

5. D. tangutica.

Bracteae et pedicelli glabra. Folia acuta . . 6. D. Vaillantii.

Folia latiora, $1-3 \mathrm{~cm}$. lata. Capitula multiflora v. pluriflora.

Bracteae extus glabrae. 
Perianthii lobi ovati; bracteae flores glabros v. sericeos subaequantes . . . . . . . . 7. D. odora. Perianthii lobi lanceolati; bracteae flores sericeos superantes.

8. D. sinensis.

Bracteae extus sericeae; perianthium extus villoso-sericeum.

9. D. papyracea, var. crassiuscula.

Ramuli juniores plus minusve strigoso-sericei (interdum glabrescentes in No. 9, sed pallidi).

Flores extus sericei, interdum glabrescentes.

Lobi perianthii eireiter $6-8 \mathrm{~mm}$. longi; bracteae sericeae. Folia acuminata, $7-12 \mathrm{~cm}$. longa et $1.5-3 \mathrm{~cm}$. lata. 9. D. papyracea.

Lobi perianthii cireiter 3-5 mm. longi . . . . 10. D. Feddei. Flores extus glabri ut bracteae.

Ramuli brunnei v. purpurei.

11. D. acutiloba.

Ramuli flavescentes v. flavido-cinerei.

Folia acuta, $4-7 \mathrm{~cm}$. longa

12. D. Wilsonii.

Folia retusa, $2-3 \mathrm{~cm}$. longa . . . . . . 13. D. retusa.

Folia subopposita, elliptica, acuta $0.8-1.8 \mathrm{~cm}$. longa. Flores terminales et axillares, aurantiaci. . . . . . . 14. D. aurantiaca.

Flores 5-meri; disci squama unica, plerumque quadrata, interdum sinuatolobata, rarius bifida; inflorescentia ebracteata (No. 22 et 23 exceptis).

Stylus brevis v. brevissimus (ad $0.5 \mathrm{~mm}$. longus in Nos. 18, 19, 22).

Stamina supra medium tubi affixa; ovaria apice pilosa; flores ebracteati.

Folia angusta linearia v, anguste-oblonga. Ramuli juniores plus minusve pubescentes.

Flores extus glabri. Folia glaberrima, acuta . . 15. D. angustiloba.

Flores extus sericei. Folia supra fere glabra, subtus ad costam et marginem tantum pilosa, obtusa . . . . . . 16. D. modesta.

Folia obovata v. elliptico-oblonga, glabra v. fere glabra, decidua.

Inflorescentia pedunculata, pluri- $\mathbf{v}$. multiflora. Ramuli et folia glaberrima v. sparse pilosa. Folia $3-6.5 \mathrm{~cm}$. longa. 17. D. leuconeura.

Inflorescentia sessilis, 2-3-flora. Ramuli saltem apicem versus pubescentes.

Folia ovalia v. oblongo-ovalia, $1.5-3 \mathrm{~cm}$. longa . 18. D. penicillata. Folia obovata, circiter $1.5 \mathrm{~cm}$. longa . . . 19. D. myrtilloides. Stamina infra medium tubi affixa; ovaria glabra v. apice pilosa.

Perianthii tubus extus pubescens; flores ebracteati.

Folia subtus ad costam saltem pubescentia. . . . 20. D. gemmata. Folia glabra v. juniora breviter eiliata. . . . . 21. D. gracilis.

Perianthii tubus extus glaber; flores bracteati. Folia persistentia, linearioblonga, revoluta, glabra margine ciliato excepta.

22. D. rosmarinifolia.

Stylus ovarii fere longitudine; flores bracteati. Folia anguste oblonga, mox glabrata (cfr. etiam No. 22) . . . . . . 23. D. tenuiflora.

\section{ENUMERATIO SPECIERUM SINENSIUM.}

1. Daphne genkwa Siebold \& Zucearini. See p. 538.

2. Daphne Championii Bentham, Fl. Hongk. 296 (1861). - Hemsley in Jour. Linn. Soc. XXVI. 395 (1891).

Daphne Fortunei Bentham in Hooker Kew Jour. Bot. V. 196 (non Lindley) (1853). 
Hongkong: C. Ford, February 9, 1894 (ex Herb. Hongkong Bot. Gard. No. 1766).

3. Daphne Roumea Meisner in De Candolle, Prodr. XIV. 538 (1857), - Hemsley in Jour. Linn. Soc. XXVI. 395 (1891).

Roumea chinensis Wallich ex Meisner in De Candolle, Prodr. XIV. 538 (pro synon.) (1857).

A doubtful species described from a plant cultivated in the Calcutta Botanic Garden, to which, according to Wallich, it was sent from China by Reeves.

4. Daphne Giraldii Nitsche, Beitr. Kennt. Daphne, 7 (1907).

Daphne tangutica Pritzel in Bot. Jahrb. XXIX. 481 (non Maximowicz).

Northern Shensi: "monte Kian-san," August 4, 1897, G. Giraldi; Mt. Ugosan (Lao-y-san), September 1899, Hugh Scallan. Western Kansu : west of Tow River, alt. $2700 \mathrm{~m}$., W. Purdom.

Purdom's specimens collected apparently in the same region where $D$. tangutica Maximowicz was found agree exactly with Giraldi's specimens from Shensi.

5. Daphne tangutica, Maximowicz in Bull. Acad. Sci. St. Pétersbourg, XXVII. 531 (1883); in Mél. Biol. XI. 309 (1883). - Hemsley in Jour. Linn. Soc. XXVI. 396 (1891).

Kansu: western alpine regions, N. M. Przewalski (ex Maximowicz).

6. Daphne Vaillantii P. Danguy in Lecomte, Not. Syst. II. 166 (1911).

Shensi: "Col de Low-pan-chan," alt. 2700 m., August 10, 1908, Pelliot \& Vaillant (No. 1054, ex Danguy).

7. Daphne odora Thunberg, Fl. Jap. 159 (1784). - Smith, Exot. Bot. 91, t. 47 (1804). - Sims in Bot. Mag. XXXVIII. t. 1587 (1813). - Meisner in De Candolle, Prodr. XIV. 537 (1857). - Hemsley in Jour. Linn. Soc. XXVI. 395 (pro parte) (1891). - Keissler in Bot. Jahrb. XXV. 89 (1898). - Diels in Not. Bot. Gard. Edinburgh, VII. 16, 17, 251 (1912).

Daphne triflora Loureiro, $\mathrm{Fl}$. Cochin. 236 (1790). - Meisner in De Candolle, Prodr. XIV. 541 (1857), - Hemsley in Jour. Linn. Soc. XXIV. 396 (1891).

Daphne japonica Thunberg in Mus. Acad. Upsal. XIII. 106 (1792). - Paxton in Paxton's Mag. Bot. VIII. 175, t. (1825). - Siebold \& Zuccarini in Abh. Akad. Münch. IV, pt. 3, 199 (Fl. Jap. Fam. Nat. II. 75) (1846). - Miquel in Ann. Mus. Lugd.-Bat. III. 134 (1867); Prol. Fl. Jap. 298 (1867), Keissler in Bot. Jahrb. XXV. 88 (1898).

Daphne Mazeli Carrière in Rev. Hort. 1872, 392, t.

Daphne odora, var. Mazeli Hemsley in Gard. XIV. 442, t. (1878).

Typical D. odora does not seem to occur wild in China. Daphne triflora Loureiro is probably the same as D. Mazeli and D. japonica which represent only an abnormal form with axillary smaller inflorescences below the terminal one, as they occur also occasionally in other species, e. g., in D. papyracea Wallich and D. aurantiaca Diels.

Daphne odora, var. atrocaulis Rehder, n. var.

Daphne odora Hemsley in Jour. Linn. Soc. XXVI. 395 (pro parte) (1891), quoad No. 7119. - ? Léveillé, Fl. Kouy-Tchéou, 416 (1915).

A typo recedit floribus extus sericeis, bracteis caducis, ramulis atropurpureis. Floribus extus sericeis ad var. kiusianam accedit, sed differt bracteis deciduis, ramulis atropurpureis. 
Eastern Szech'uan: Wushan Hsien, A. Henry (Nos. 7119, type, 5502, both in Herb. Gray).

This variety seems to be nearest to $D$. odora, var. kiusiana Keissler (D. kiusiana Miquel) which differs ehiefly in the persistent bracts, the thinner leaves and in the usually paler, often yellowish brown color of the branchlets. The leaves resemble those of the var. kiusiana in their shape and are longer and narrower (about 7-11 $\mathrm{cm}$. long and 2-3.5 $\mathrm{cm}$. broad) than those of the type.

8. Daphne sinensis Lamarck, Encycl. Méth. II. 438 (1791). - Meisner in De Candolle, Prodr. XIV. 537 (1857), - Keissler in Bot. Jahrb. XXV. 91 (1898).

Daphne odora Loureiro, Fl. Cochin. 237 (non Thunberg) (1790). - Jacquin, Hort. Schoenbrunn. III. 54, t. 351 (1798), - Loiseleur, Herb. Amat. II. 105, t. (1817). - Hemsley in Jour. Linn. Soc. XXV1. 395 (pro parte) (1891).

Daphne indica Loiseleur, Herb. Amat. II. t. 105 (pro synon. et in tab., non Linnaeus) (1817).

Daphne chinensis Sprengel, Syst. II. 237 (1825).

China (ex Lamarck) and Cochinchina (ex Loureiro).

1 have seen no specimens of this plant and it seems doubtful whether it is specifically distinct from the preceding species.

9. Daphne papyracea Wallich apud Steudel, Nomencl. ed. 2, I. 483 (1841).Meisner in Denkschr. Regensb. Bot. Ges. III. 282 (1841); in De Candolle, Prodr. XIV. 537 (1857). - Decaisne in Jacquemont, Voy. IV. 143, t. 148 (1844). - Brandis, Forest Fl. Brit. Ind. 386 (1874). - Diels in Not. Bot. Gard. Edinburgh, VII. 258 (1912).

Daphne cannabina Wallich in As. Research. XIII. 315, t. 7, 8 (non Loureiro) (1820). - Hooker f., Fl. Brit. Ind. V. 193 (1890). - Keissler in Bot. Jahrb. XXV. 93 (1898). - Collett, Fl. Siml. 435, fig. 140 (1902). - Brandis, Ind. Trees, 544 (1906).

Daphne papyrifera Hamilton mss. ex D. Don, Prodr. Fl. Nepal. 68 (pro synon.) (1825). - Léveillé, Fl. Kouy-Tchéou, 416 (1915).

Daphne papyracea, f. grandifiora Meisner apud Diels in Not. Bot. Gard. Edinburgh, VII. 290 (1912).

Yunnan: Feng-chen-lin, mountain woods, alt. 2400 m., A. Henry (No. 10118; shrub 1-3 m. tall, flowers white, very fragrant); Mengtsze, mountains to south, alt. $1800 \mathrm{~m} .$, A. Henry (No. $10118^{\mathrm{a}}$; shrub $1 \mathrm{~m}$. tall, flowers white); same locality, eastern forests, alt. $2100 \mathrm{~m}$., A. Henry (No. 11363; shrub $0.6 \mathrm{~m}$. tall, flowers white, fragrant); Yuan-chiang, alt. 1800 m., A. Henry (No. 13293; shrub 2 m., flowers white, fragrant); Mekong Valley, alt. 2100-2400 m., G. Forrest (No. 5024, as D. papyracea f. grandiflora); "sous bois des mont. à Ta-tchai," April 1913, E. E. Maire; without precise locality, J. Cavalerie. Also on the Himalayas from Chamba to Bhotan and on the Khasia Mts.

I am not sure that Maire's specimen, which is very fragmentary, belongs here; the flowers and the bracts are silky pubescent, but the leaves resemble those of D. acutiloba Rehder. Another specimen from Yunnan, without locality, collected by $\mathrm{J}$. Cavalerie, is very similar.

Daphne papyracea, var. crassiuscula Rehder, n. var.

A typo recedit ramis junioribus crassiusculis purpureo-fuscis glabris, folios magis coriaceis et plerumque latioribus, capitulis densifloris, floribus dense villososericeis, tubo latiore et breviore, lobis ovatis acutiusculis v, obtusiusculis. 
Yunnan: Mengtsze, mountains north, alt. 1200 (?) m., A. Henry (No. 10859; shrub 2-3 m., flowers white, fragrant).

This variety differs from the typical form in its stouter glabrous and purplish brown branches, in the more coriaceous shorter and comparatively broader leaves and the shorter villose flowers. In its purple glabrous branches it resembles $D$. odora, var. atrocaulis Rehder, but differs in the densely villose bracts and the dense heads of villose flowers. By the villosity of its flowers it seems related to $D$. cannabina, var. bholua Keissler (D. Bholua Hamilton), which I know only from the description, but as nothing is said about any difference in the leaves and in the branches, I must assume that it is not identical with the new variety proposed above.

10. Daphne Feddei Léveillé in Fedde, Rep. Spec. Nov. IX. 326 (1911); Fl. Kouy-Tchéou, 416 (1915).

Daphne Martini Léveillé 1. c. X. 369 (1912); 1. c. 416 (1915).

Kwei-chou: "Gan-Pin," L. Martin (No. 2076, ex Léveillé); "Kouy-Yang," $J$. Chafjanjon \& E. Bodinier (No. 2076 ex Léveillé); "Yeou-Lang," J. Esquirol (No. 775 ex Léveillé).

Of this species I have seen only a detached flower and a detached leaf sent to me by Mgr. Léveillé. Of $D$. Martini Mgr. Léveillé has sent me a small branch; it does not seem to differ specifically from $D$. Feddei, but the lobes of the perianth are somewhat shorter equaling only about one third of the tube; the inflorescence is 12-flowered and has no bracts left. Daphne Feddei seems nearest to D. papyracea Wallich, but the flowers are smaller and the lobes are nearly glabrous with the exception of a few hairs on the middle, while the narrow tube is densely pubescent up to the base of the lobes.

11. Daphne acutiloba Rehder. See p. 539.

12. Daphne Wilsonii Rehder. See p. 540 .

13. Daphne retusa Hemsley. See p. 541.

14. Daphne aurantiaca Diels in Not. Bot. Gard. Edinburgh, V. 285 (1912).

Yunnan: limestone cliffs on the eastern flank of the Lichiang range, alt. 30003500 m., May 1906, G. Forrest (No. 2115).

This is a very distinct species and differs from all allied species in its opposite or sometimes subopposite leaves. Occasionally on vigorous branches it develops axillary small inflorescences below the terminal one.

\section{Daphne angustiloba Rehder, n. sp.}

Frutex circiter $0.5 \mathrm{~m}$. altus, ramis satis tenuibus divaricatis; ramuli hornotini teretes sparse strigosi, vetustiores einereo-brunnei. Folia alterna, subchartacea, subpersistentia lineari-oblonga, acuta et mucronulata, basi attenuata, margine plus minusve revoluta, $1-2.5 \mathrm{~cm}$. longa et $1.5-4 \mathrm{~mm}$. lata, supra obscure viridia, subtus pallidiora, venis obsoletis, costa media supra incisa, subtus manifeste elevata; petioli glabri 1-2 mm. longi. Flores lutei breviter pedicellati in fasciculis terminalibus 2-5-floris quam folia paullo brevioribus; pedicelli glabri, eirciter $1 \mathrm{~mm}$. longi; perianthii tubus glaber, tenuis, $10-11 \mathrm{~mm}$. longus, lobi 5 , elliptico-oblongi v. oblongi, 4-5 longi; antherae 10, oblongae, $1.25 \mathrm{~mm}$. longae, eae seriei superioris faucem attingentes, inferioris paullo supra medium affixae, filamentis brevissimis; disei squama unica fere quadrata, vix $1 \mathrm{~mm}$. longa; pistillum $3 \mathrm{~mm}$. longum, ovario apice pilosa, stylo brevissimo, stigmate sublobato. Fructus desideratur.

Western Szech'uan: southeast of Tachien-lu, woods, alt. 3500 m., June 1904 (Veitch Exped. No. 4433). 
This is not closely related to any other species, and is well characterized by its narrow, glabrous leaves, the glabrous 5-merous flowers and by their narrow lobes often nearly half as long as the tube.

\section{Daphne modesta Rehder. See p. 541.}

\section{Daphne leuconeura Rehder, n. sp.}

Frutex erectus, $0.5-1.2 \mathrm{~m}$. altus, dichotome ramosus, gemmis pubescentibus exceptis glaberrimus; ramuli hornotini glabri, virides, teretes, apicem versus subangulati, annotini flavo-grisei v. flavo-brunnei, vetustiores pallide fusci; gemmae ovatae, obtusiusculae, strigoso-pubescentes, grisei. Folia membranacea, tenuia, alterna, obovata $\mathrm{v}$. obovato-oblonga, apice rotundata, rarius acutiuscula, basi cuneata, 4-7.5 $\mathrm{em}$. longa et 1.8 $-3.5 \mathrm{~cm}$. lata, supra laete luteo-viridia, subtus paullo pallidiora, utrinque glabra, nervis utrinseeus $6-12$ curvatis subtus ut costa elevatis, supra ut costa plerumque colore albido conspicuis; petioli $2 \mathrm{~mm}$. longi, supra canaliculati. Flores lutei, brevissime pedicellati in spica terminali densa pluri- v. multiflora pedunculata pedunculo $0.5-1.5 \mathrm{~cm}$. longo perianthii tubus $10-15 \mathrm{~mm}$. longus, glaber, lobis 5 ovalibus v. oblongo-ovalibus patentibus 4-6 mm. longis; antherae 10 , anguste oblongae, $2 \mathrm{~mm}$. longae, superiores faucem paullo superantes, filamentis $0.2-0.5 \mathrm{~mm}$. longis, inferiores circa medium insertae, filamentis $0.5-0.75$ longis; disci squama unica fere quadrata, apice truncata v. leviter emarginata, circiter $1 \mathrm{~mm}$. longa; pistillum 4-5 mm. longum, ovario subclavato apice tantum sparse breviter piloso, stylo brevissimo, stigmate capitato magno sublobato. Fructus immaturus tantum visus, perianthio inclusus.

Western Szech'uan: Tung River valley, alt. 700 m., May 1904 (Veitch Exped. No. 4431).

This is a very distinct species well characterized by its thin light green rather large leaves marked with conspicuous white veins and by the peduncled head of yellow flowers. The whole plant is quite glabrous except the winter-buds.

Daphne leuconeura, var. Mairei Léveillé \& Rehder, n. var.

A typo recedit rhachi inflorescentiae et ramulis junioribus et foliis juvenilibus sparse strigoso-villosis.

Yunnan: " monts derrière Mong-kou, alt. 2000 m., mars 1912," E. E. Maire.

The leaves in Maire's specimens are very young and they may present further differences when fully grown.

\section{Daphne penicillata Rehder. See p. 542.}

19. Daphne myrtilloides Nitsche, Beitr. Kenntn. Daphne, 29 (1907).

Northern Shensi: G. Giraldi (No. 5995, ex Nitsche).
According to Nitsche the style in this species is comparatively long, the length being given in the description as $0.5 \mathrm{~mm}$., though in the accompanying note he says that it is often as long as the ovary; the only other species of Daphne with a similar long style is D. tenuiflora, Bureau \& Franchet.

\section{Daphne gemmata Pritzel. See p. 543.}

21. Daphne gracilis Pritzel in Bot. Jahrb. XXIX. 480 (1900). - Nitsche, Beitr. Kenntn. Daphne, 28 (1907).

Western Szech'uan: Nanch'uan, A. von Rosthorn (No. 2006, ex Pritzel).

It is possible that Wilson's No. 4614 enumerated under D. gemmata belongs to this species of which I have seen only a photograph of the type specimen and that D. gracilis and D. gemmata are forms of one species. According to Pritzel's original description this species has 4-merous flowers, but Nitsche states that all the flowers examined by him proved to be 5-merous. I believe Nitsche's statement to be cor- 
rect, particularly as all the other species with the stamens inserted below the middle have 5-merous flowers.

22. Daphne rosmarinifolia Rehder, n. sp.

Frutex $0.5-1.2 \mathrm{~m}$. altus; ramuli hornotini et annotini subangulati, dense strigosopilosi, anno tertio glabrescentes brunnei. Folia persistentia chartacea, alterna, approximata, lineari-oblonga, apice rotundata leviter mucronulata, basi cuneata, margine revoluta, $1-2 \mathrm{~cm}$. longa et $0.2-0.4 \mathrm{~cm}$. lata, supra obscure viridia, subtus pallidiora, utrinque glabra, margine initio pilis longis ciliata, apice villosa, costa media subtus leviter elevata nervis secundariis obsoletis; petioli $1 \mathrm{~mm}$. longi, marginati, glabri. Flores lutei, sessiles, folia paullo v. vix superantes, in spicis paucifloris sessilibus terminalibus bracteis deciduis spathulato-oblongis pubescentibus 4-6 mm. longis suffultis; perianthii tubus supra basin leviter ventricosus, glaber, 10-11 mm. longus, lobis 5 ovatis v. ovato-oblongis patentibus, $3.5-4.5 \mathrm{~mm}$. longis; antherae 10, oblongae, $1.75 \mathrm{~mm}$. longae, fere sessiles, biseriatae, infra medium tubi affixae, filamentis brevissimis; discus fere annularis v. bipartitus irregulariter sinuato-lobatus, vix $1 \mathrm{~mm}$. longus; pistillum $3.5 \mathrm{~mm}$. longum, ovario ovoideo, oblongo basin versus attenuato glabro, style $0.5 \mathrm{~mm}$. longo, stigmate capitato parvo. Fructus desideratur.

Western Szech'uan: Tachien-lu, May 1904 (Veitch Exped. No. 4434).

This is a well marked species easily distinguished from the other species which have the stamens inserted below the middle of the tube by the narrow glabrous leaves and by the glabrous bracteate flowers. Like $D$. penicillata Rehder this has a comparatively long style, though not as long as that of D. myrtilloides Nitsche and that of the following species.

23. Daphne tenuiflora Bureau \& Franchet in Jour. de Bot. V. 151 (1891). Keissler in Bot. Jahrb. XXV. 104 (1898). - Nitsche, Beitr. Kenntn. Daphne, 29 (1907).

Western Szech'uan: Tachien-lu, June 21, 1890, Bonvalot (ex Bureau \&

After having examined most of the Chinese species of Daphne and Wikstroemia which together number at present 46 species, I am inclined to doubt whether these two genera are sufficiently distinct. The only obvious difference between them is in the development and shape of the disk-like excrescences at the base of the ovary, or "receptacular effigurations" (Receptaculareffigurationen) as they are named by Gilg, which I shall call here disk or disk-scales. In Wikstroemia they are represented by 1-4 narrow and entire or sometimes broader and variously toothed or incised scales, while in Daphne they are entirely wanting or represented either by a minute ring-like or eupular disk or by a broad unilateral entire, truncate or rounded scale. These broad unilateral scales seem to occur only in the species with 5merous flowers, and as there is sometimes no great difference between these entire scales and the more or less lobed scales of Wikstroemia, I was almost inclined, even if I kept the other species in Daphne, to refer the 5-merous species to Wikstroemia, if they had not shown an apparently close affinity to the species of the sections Daphnanthes and Daphnanthoides, and if in some cases as in D. rosmarinifolia Rehder and in D. tenuiflora Bureau \& Franchet they had not had floral bracts which are entirely absent in Wikstroemia. Between species of Wikstroemia like W. ligustrina Rehder, W. Pampaninii Rehder and $W$. canescens Meisner with broad often not very deeply dentate seales and those of Daphne like D. gemmata Pritzel, D. modesta Rehder and $D$. rosmarinifolia Rehder with broad sometimes slightly emarginate or minutely dentate scales there is no conspicuous morphological difference in the shape of these scales, particularly if one considers their great variability within 
the same species. Also the fact that in western China 5-merous species occur in both genera, while they are unknown in other regions of their wide geographical range, points toward a close connection of these two genera. Neither are there strong anatomical characters to separate the two genera. The only difference Van Tieghem points out is the presence of pitted tracheids in the vascular bundle of the leaves in Wikstroemia, wanting in Daphne, but as Van Tieghem has examined only a limited number of species, it remains still to be proved if this character holds good for all species. Considering, however, that I had to deal here only with a limited number of species which do not represent all the sections and groups of the two genera, I have hesitated to make any change and have maintained the two genera in their usual limitation, leaving the question open for future investigation.

Here may be added a note on a closely related genus not collected by Wilson.

ERIOSOLENA BI.

Eriosolena involucrata Van Tieghem in Ann. Sci. Nat. sér. 7, XVII. 196 (1893).

Daphne involucrata Wallich in As. Research. XIII. 383, t. 6 (1820). - Meisner in Denkschr. Regensb. Bot. Ges. III. 282 (1841). - Hooker f., Fl. Brit. Ind. V. 193 (1886).

Eriosolena Wallichii Meisner in Pl. Vasc. Gen. II. 243 (1836-43). - Nitsche, Beitr. Gatt. Daphne, 9 (1907).

Scopolia involucrata C. A. Meyer in Bull. Acad. Sci. St. Pétersbourg, sér. 2, I. 357 (1843); in Ann. Sci. Nat. sér. 2, XX. 49 (1843).

Daphne Wallichii Meisner in De Candolle, Prodr. XIV, 540 (1857).

Yunnan : Szemao, alt. 1500-1600 m., A. Henry (Nos. 11564, 11564 $4^{\text {b }}, 11564^{\mathrm{c}}$ ). In considering Eriosolena a distinet genus I am following Van Tieghem and Nitsche. Van Tieghem (in Ann. Sci. Nat. sér. 7, XVII. 194, 225 [1893]) points out important anatomical differences between Daphne and Eriosolena which are confirmed by Nitsche. Eriosolena is also well distinguished morphologically by the axillary peduncled heads of flowers enclosed by an involucre. It is perhaps more closely related to Edgeworthia which also has a lateral peduncled capitate inflorescence and like it has calcium oxalate in the stem and in the leaves, which is absent from Daphne. Eriosolena involucrata has apparently not been recorded before as a Chinese plant.

\section{EDGEWORTHIA Meisn.}

Edgeworthia chrysantha Lindley in Jour. Hort. Soc. Lond. I. 148 (June 1846); in Bot. Reg. XXXIII. 7, 48 (1848), - Pritzel in Bot. Jahrb. XXIX. 480 (1900). - Meisner in De Candolle, Prodr. XIV. 543 (1857). - Hemsley in Jour. Linn. Soc. XXVI. 401 (1894). - Pampanini in Nuov. Giorn. Ital. Bot. n. ser. XVII. 675 (1910).

Magnolia tomentosa Thunberg in Trans. Linn. Soc. II. 336 (1794), synon. "Kobus" excludendo, non M. tomentosa Thunberg, Fl. Jap. Nov. Sp. 8 (1824).

Magnolia sericea Thunberg, Pl. Jap. Nov. Sp. 8 (nomen nudum) (1824) secundum specimen originale in Herb. Thunbergiano. ${ }^{1}$

${ }^{1}$ See foot-note on p. 400 of Vol. I. 
Daphne papyrifera Siebold in Verh. Bot. Genootsch. XII. pt. 1, 22 (nomen nudum) (Syn. Pl. Oecon. Jap. No. 130) (1830).

Edgeworthia papyrifera Siebold \& Zuccarini in Abb. Akad. Münch. IV. pt. III. 199 (Fl. Jap. Fam. Nat. II. 75) (1846). - Miquel in Ann. Mus. Lugd.Bat. III. 135 (1867); Prol. Fl. Jap. 299 (1867), - Schneider, Ill. Handb. Laubholzk. II. 403 (1909), excl. fig.

Edgeworthia Gardneri Hemsley in Jour. Linn. Soc. XXVI. 396 (non Meisner) (1891).

Daphne nudiflora, Hort.

Kiangsi: Kuling, side of streams, spontaneous, alt. 1200 m., July 29, 1907 (No. I582; bush 1-1.6 m. tall). Western Hupeh: commonly cultivated around Ichang, alt. 300-1000 m., April and October 1907 (No. 3555; bush 0.6-1.6 m. tall, flowers yellow); without precise locality, April 1900 (Veitch Exped. No. 56).

I do not think that tomentosa is to be considered the oldest specific name for $E$. papyrifera, as it was not Thunberg's intention to name this plant, when publishing his Magnolia tomentosa, but he intended to give a specific name to the Magnolia previously distinguished by him as $M$. glauca, a flore albo, named later $M$. kobus by De Candolle. That this was his intention is shown by the fact that the plant he figured afterwards (Icon. Pl. Jap. V. t, 8) as $M$. tomentosa is M. kobus De Candolle. Magnolia sericea which is based entirely on our plant is a nomen nudum. Daphne papyrifera also is a nomen nudum, and therefore $E$. chrysantha has the priority, as it was published several months earlier than $E$. papyrifera. In the herbarium of the Arnold Arboretum there is a specimen of this species collected at the Villa Thuret near Antibes, France, by Ch. Naudin in 1889 and labeled "Daphne nudiflora L.", but I have been unable to find this name mentioned anywhere in botanical or horticultural literature.

The Chinese colloquial name of this plant is " Mêng-hwa."

A picture of it will be found under No. 0353 of the collection of Wilson's photographs.

\section{STELLERA Gmel.}

Stellera chamaejasme Linnaeus, Spec. 559 (1753). - Willdenow, Spec. II. pt. 1, 429 (1799). - Meisner in De Candolle, Prodr. XIV. 549 (1857), - Hooker f., Fl. Brit. Ind. V. 196 (1890), - Hemsley in Jour. Linn. Soc. XXVI. 401 (1894).

Passerina Stelleri Wikström in Svensk. Vetensk. Akad. Handl. 1818, 321.

Passerina Chamaejasme Fischer ex Meisner in De Candolle, Prodr. XIV. 549 (pro synon.) (1857).

Western Szech'uan: Tachien-lu, moor-lands, alt. 2700-3600 m., June and September 1908 (No. I0Ix; flowers white and various colors, fragrant). Eastern Tibet: between Derge and Tachien-lu, 1911, John R. Muir. Yunnan: Mengtsze, A. Henry (No. 10126).

According to Mr. Muir the root is used by the Tibetans in making paper. 


\section{ALANGIACEAE.}

Determined by Alfred ReHDEk.

\section{ALANGIUM Laur.}

Alangium Faberi Oliver in Hooker's Icon. XVIII. t. 1774 (1888). Harms in Engler \& Prantl, Nat. Pflanzenfam. III. Abt. 8, 262 (1898); in Bot. Jahrb. XXIX. 505 (1900). - Wangerin in Engler, Pflanzenr. IV. $-220^{\mathrm{b}}, 18$ (1910).

Karangolum Faberi Kuntze, Rev. Gen. I. 273 (1891).

Szech'uan: Taning Hsien, cliffs, alt. 600 m., June 1910 (No. 4505; bush $0.3-1 \mathrm{~m}$. tall, flowers white); Yangtsze banks, May 1903 (Veitch Exped. No. 3699); Mt. Omei, July 1904 (Veitch Exped. No. 4947).

In Wilson's No. 4505 one of the leaves is deeply 3-lobed with lanceolate lobes and is cordate at the base, the other leaves are oblong-lanceolate, very oblique and mostly semicordate at the base.

\section{Alangium chinense Rehder, n. comb.}

Stylidium chinense Loureiro, Fl. Cochin. 220 (1790).

Stylis chinensis Poiret, Encyel. Méth. Suppl. V. 260 (1817).

Marlea begoniifolia Roxburgh, Hort. Beng. 28 (nomen nudum) (1814); Pl. Corom. III. 80, t. 283 (1819); Fl. Ind. ed. 2, II. 261 (1832). - De Candolle, Prodr. IV. 267 (1830). - Lindley in Bot. Reg. XXIV. t. 61 (1838). - Bentham, Fl. Hongk. 138 (1867). - Kurz in Jour. As. Soc. Bengal, XL. 2, 61 (1871); Forest Fl. Brit. Burma, I. 544 (1877). - Brandis, Forest Fl. Brit. Ind. 251 (1874); Ind. Trees, 355 (1906). - Clarke in Hooker f., Fl. Brit. Ind. II. 743 (1879). - Hemsley in Jour. Linn. Soc. XXIII. 344 (1888). Micheli in Rev. Hort. 1898, 501, fig. 175. - Collett, Fl. Siml. 218 (1902). Léveillé, Fl. Kouy-Tchéou, 116 (1914).

Styrax javanicum Blume, Bijdr. 671 (1825). - De Candolle, Prodr. VIII. 268 (1844). - Miquel, Fl. Ind. Bat. I. 2, 464 (1859).

Diacicarpium tomentosum Blume, Bijdr. 657 (1825).

Styrax Rossamala Reinwardt apud Steudel, Nomencl. ed. 2, II. 651 (1841).

Marlea tomentosa Endlicher apud Hasskarl in Flora, XXVII. 605 (1844).Koorders \& Valeton in Mededel. Lands Plantent. XXXIII. 79 (Bijdr. Boomsort. Java, V.) (1900).

Marlea affinis Decaisne in Jacquemont, Voy. IV. 74, t. 83 (1844).

Diacicarpium rotundifolium Hasskarl in Bonplandia, VII. 172 (1859).

Alangium begoniifolium Baillon, Hist. Pl. VI. 270 (1877). - Harms in Engler \& Prantl, Nat. Pflanzenfam. III. 8, 261 (1898); Bot. Jahrb. XXIX. 505 
(1900). - Wangerin in Engler, Pfanzenr. IV. $-220^{\mathrm{b}}, 20$ (1910). - Pampanini in Nuov. Giorn. Bot. Ital. n. ser. XVII. 132 (1910).

Karangolum chinense Kuntze, Rev. Gen. I. 273 (1891).

Alangium platanifolium, var. $\beta$ genuinum, f. triangulare Wangerin in Engl er' Pflanzenr. IV.-229, 24, fig. 6, G (1910).

Kiangsi: Kuling, thickets, common, alt. 900 m., August 1, 1907 (No. I646; shrub $3 \mathrm{~m}$. tall). Western Hupeh: common around Ichang, alt. 30-900 m., June and August 1907 (No. 165, in part; thin tree, 6-10 m. tall, flowers white, fruit black); Changlo Hsien, thickets, alt. 600 m., June 1907 (No. 596́, in part; bush 3 m. tall, flowers white); same locality, alt. 1000 m., June 1907 (No. 3273; small tree or large bush, 3-6 m. tall); Fang Hsien, thickets, alt. 600-900 m., June and October, 1907 (No. 596, in part; bush 2.5-4 m. tall, flowers white, fruit black); same locality, roadsides, alt. 600 m., June 6, 1907 (No. 3274; bush 3-4.5 m. tall, flowers white); Changyang Hsien, thickets, alt. 600-900 m., September 1907 (Nos. 3275, 3276; bush 4 m. tall, fruit black); same locality, July 1901 (Veitch Exped. No. 501); Hsingshan Hsien, thickets, alt. 600-1000 m., June and August 1907 (No. 3277; bush 4.5-4 m. tall, fruit black); "Kiu Ki-kou," alt. 800 m., June to July 1906, C. Silvestri (No. 1671); "Monti di Ku-tcen," alt. 600 m., July to August 1906, C. Silvestri (No. 1672); without precise locality, June 1900 (Veiteh Exped. No. 1134), A. Henry (Nos. 1399, $\left.1503,5855,5855^{\mathrm{a}}, 5855^{\mathrm{b}}, 6416,7666\right)$. Western Szech'uan: Wên-ch'uan Hsien, Min valley, alt. 900 m., July 1908 (No. r65, in part; thin tree 10 m. tall, girth 0.6 m.); Mit. Omei, July 1904 (Veitch Exped. No. 4946); Nanch'uan, A. von Rosthorn (No. 1689). Northern Shensi: Lao-y-san, June 4, 1897, and Po-uo-li, 1897, G. Giraldi; same locality, 1899, Hugh Scallan; Mt. Ngo-san, 1899, Mt. "Ki-san-sien," 1897, and "Mt. Thui-Rio-tsuen," 1898, Hugh Scallan. Yunnan: Mengtsze, alt. 1500 m., A. Henry (Nos. 10142a, 10142 b); Red River valley, near Manpan, alt. 700 m., A. Henry (No. 10647); Szemao, alt. 1500 m., A. Henry (No. 13030). Chekiang: vicinity of Ningpo, 1908, D. Macgregor. Kwangtung: Canton, Hance (No. 663); Hongkong, C. Wright (No. 608); Hainan, A. Henry (No. 7976).

Alangium chinense is exceedingly variable in the shape of its leaves, but it does not seem advisable to distinguish varieties, as entire and lobed leaves often occur on the same branch. The most extreme forms with deeply lobed leaves has been referred by Wangerin to $A$. platanifolium Harms as forma triangulare; of the specimens he quotes under this name I have seen only Henry's No. 6416, which agrees very well with several of Wilson's specimens, particularly with his No. 3277 which has some of the leaves even more deeply divided, but on one of the branches two of the leaves are quite entire and like typical $A$. chinense; the flowers of No. 3277 are those 
of $A$. chinense. Other specimens with at least some of the leaves deeply lobed are Nos. 3275, 1134, Henry's 7666, Hugh Scallan's specimen from Ki-san-scien and from Lao-y-san and Giraldi's specimen from Po-uo-li. Henry's No. 10142 ${ }^{\mathrm{a}}$ differs in its very large broadly ovate leaves sparingly hairy on both sides and with conspicuous axillary tufts below. Wilson's No. 1646 from Kiangsi which is in young fruit seems to be the most distinct form of all and may represent a new species; it differs in its oblong-ovate, quite entire leaves, with 5-7 pairs of veins, in the dense brownish pubescence of the short petioles and young branchlets and in the darker reddish brown color of the mature branches.

Alangium platanifolium Harms in Engler \& Prantl, Nat. Pflanzenfam. III. Abt. 8, 261 (1898); in Bot. Jahrb. XXIX 505 (1900).Wangerin in Engler, Pflanzenr. IV. $-220^{\mathrm{b}}$, 22, fig. 6 a-f (1910), forma triangulari excludenda.

Marlea platanifolia Siebold \& Zuccarini in Abh. Akad. Münch. IV.pt. 2, 134 (Fl. Jap. Fam. Nat. I. 26) (1845). - Miquel in Ann. Mus. Lugd.-Bat. II. 159 (1866); Prol. Fl. Jap. 91 (1866). - Franchet \& Savatier, Enum. Pl. Jap. I. 195 (1875). - Hemsley in Jour. Bot. Linn. Soc. XXIII. 344 (1888). Marlea macrophylla Siebold \& Zuccarini in Abh. Akad. Münch. IV. pt. 2, 135 (Fl. Jap. Fam. Nat. I. 27) (1845).

Karangolum platanifolium Kuntze, Rev. Gen. I. 273 (1891).

Kiangsi: Kiukiang, foothills, not common, alt. 300 m., August 1, 1907 (No. I65I; bush 5 m. tall). Western Hupeh: north and south of Ichang, woodlands, alt. 1200-1800 m., September 1907 (No. I42, in part; bush 2-5 m. tall, fruit black); Hsing-shan Hsien, common, alt. 1600 m., June 3, 1907 (No. 142, in part); same locality, woodlands, alt. 1200-1500 m., June 1907 (No. 3272; bush $2 \mathrm{~m}$. tall); without precise locality, A. Henry (Nos. 1731, 4770, 5813, 5813 ${ }^{a}$ ). Western Szech'uan: Wa-shan, woodlands, alt. 1500-1800 m., September 1908 (No. 937, in part; bush 1.2-2 m. tall, flowers pink, fruit black); Chiuting-shan, near Mao-chou, alt. 1200 m., May 22, 1908 (No. 937, in part; bush $2.5 \mathrm{~m}$. tall); near Monkong Ting, thickets, alt. 1800-2100 m., June 19, 1908 (No. 937, in part; bush 2-3 m. tall, flowers rose-purple); Nanch'uan, A. von Rosthorn (No. 460). 


\section{ARALIACEAE.}

Determined by H. Harms and Alfred ReHder.

SCHEFFLERA Forst.

\section{Schefflera Delavayi Harms in Bot. Jahrb. XXIX. 486 (1900).}

Heptapleurum Delavayi Franchet in Jour. de Bot. X. 307 (1896).

Western Szech'uan: Kuan Hsien, thickets, alt. 300-800 m., October 1910 (No. 4559; bush 3-5 m. tall, flowers white). Yunnan: Mengtsze, A. Henry (No. 9214).

\section{HEDERA L.}

Hedera himalaica Tobler, Gatt. Hedera, 67, fig. 31-38 (1912).

Hedera Helix Roxburgh, Fl. Ind. II. 515 (non Linnaeus) (1824). - D. Don, Prodr. Fl. Nepal. 187 (1825). - C. B. Clarke in Hooker f., Fl. Brit. Ind. II. 739 (1879). - Hance in Jour. Bot. XX. 6 (non Linnaeus) (1882), - Hemsley in Jour. Linn. Soc. XXIII. 343 (1888), quoad plantam chinensem. - Harms in Bot. Jahrb. XXIX. 487 (1900). - Pavolini in Nuov. Giorn. Bot. Ital. n. ser. XV. 418 (1908). - Schneider, Ill. Handb. Laubholzk. II, 423, fig. $287 \mathrm{~m}-\mathrm{p}$ (1909), quoad plantam himal, et fig. citatas, - Pampanini in Nuov. Giorn. Bot. Ital. n. ser. XVII. 678 (1910); XVIII. 130 (1911), - Diels in Not. Bot. Gard. Edinburgh, VII. 258, 288 (1912). - Léveillé, Fl. Kouy-Tchéou, 34. (1914).

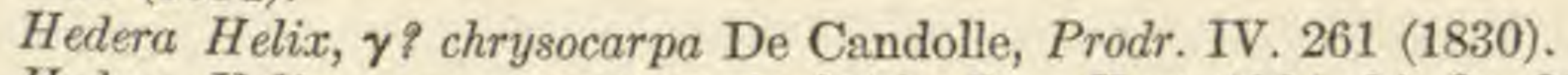

Hedera Helix, var. aurantiaca André in Rev. Hort. 1884, 84, fig. 20, t.

Hedera himalaica, var. sinensis Tobler, Gatt. Hedera, 79, fig. 39-42 (1912).

Western Hupeh: common around Ichang, alt. 300-1200 m., March and May 1907 (No. 2427; fruit orange); "monte Tien-pongscian," October 1907, C. Silvestri (No. 1613); without precise locality, A. Henry (No, 3261). Northern Shensi: "Huo-kio-zaez," July 1897, G. Giraldi; Tai-pei-shan, 1910, W. Purdom. Chekiang: Ningpo, 1908, D. Macgregor. Fokien: Dunn's Exped. to central Fokien, April to June 1905 (Hongkong Herb. No. 2760). Yunnan: Shweli-Salwin divide, alt. 2100 m., March 1906, G. Forrest (No. 4997); Mengtsze, alt. 1500-2100 m., A. Henry (Nos. 9856, 9856 ${ }^{\mathrm{a}}$.

Here may be inserted a note on a genus not collected during the Arnold Arboretum Expeditions. 
BRASSAIOPSIS Dene. \& Planch.

Brassaiopsis fatsioides Harms, n. sp.

Arbuscula, 1-2 m. alta (ex Wilson). Folia ampla, petiolata petiolo subglabro v. apicem versus parce puberulo, profunde palmato-lobata, basi cordata, membranacea v. papyracea, subtus sparse pilosula v. subglabra, parte integra $3-6 \mathrm{~cm}$. alta, lobis 7-9 oblanceolatis v. oblongo-oblanceolatis usque oblongis sinu latiusculo rotundato basi remotis, apice acuminulatis, serrulato-denticulatis, $6-22 \mathrm{~cm}$. longis, 3-8 cm. latis. Panicula elongata, rhachi pilosula v. parce puberula, umbellis multiforis pedunculatis pedunculis pilosulis v. puberulis $2-3 \mathrm{~cm}$. v. ultra longis; pedicelli subglabri v. puberuli, $0.5-1.5 \mathrm{~cm}$. v. serius $2 \mathrm{em}$. longi; calycis margo brevissimus non v. vix denticulatus; petala 5 , acuta, $3.5-4 \mathrm{~mm}$. longa; stamina 5 ; ovarium obconicum, glabrum v. subglabrum, loculis 2, disco crasso hemisphaerico, stylo unico, eum stylo $4-5 \mathrm{~mm}$. longum.

Western Szech'uan: without precise locality, roadsides, alt. 1400 m., 1904 (Veitch Exped. No. 3967).

This species is most elosely related to B. Griffithii Clarke and to B. mitis Clarke, but it differs from the former in its more deeply divided leaves and in the obsolete calyx-teeth and from $B$, mitis chiefly in the much slighter pubescence of the infiorescence. Unfortunately the material I have seen of this species consists only of a large leaf and parts of an inflorescence.

\section{NOTHOPANAX Seem.}

\section{Nothopanax Davidii Harms in Bot. Jahrb. XXIX. 488 (1900).}

Panax Davidii Franchet in Nouv. Arch. Mus. Paris, sér. 2, VIII. 248 (Pl. David. II. 66) (1886); Jour. de Bot. X. 306 (1896).

Acanthopanax diversifolium Hemsley in Jour. Linn. Soc. XXIII. 340 (1888). Nothopanax diversifolius Harms in Engler \& Prantl, Nat. Pflanzenfam. III. Abt. 8, 48 (1894).

Western Hupeh: Fang Hsien, woods, alt. 900-1200 m., July 1907 (No. I952; small tree 5-7 m. tall); same locality, alt. 1200-1400 m., August 1907 (No. I957; bush $3 \mathrm{~m}$. tall); Patung Hsien, thickets, alt. 600-1200 m., July and Oetober 1907 (No. I953; small tree 3.5-7 m. tall, flowers white, fruit black); same locality, alt. 900 m., August 1907 (No. 1958; bush 2-3 m. tall, flowers greenish yellow); Hsing-shan Hsien, thickets, alt. 900-1500 m., August-November 1907 (Nos. 332, 6I4 in part, I956, I957, I959, I960; bush 2-3 m. tall, flowers white, fruit black); Changlo Hsien, thickets, alt. 900-1200 m., September 1907 (No. 6I4 in part; bush 2-3 m. tall, flowers greenish); north and south of Ichang, July 1901 (Veitch Exped. No. 1564; bush or small tree, 5-7 m. tall); without precise locality, A. Henry (No. 2969, type No. of Acanthopanax diversifolium Hemsley, $6608^{\mathrm{b}}$ ). Western Szech'uan: Mupin, thickets, alt. 1200-1800 m., August 1908 (No. 875; bush 1.3-2 m. tall, fruit black; Wa-shan, alt. 1800-2100 m., October 
1908 (No. II36, bush 2-3 m. tall, fruit black); same locality, alt. 12001800 m., August 1908 (No. I955; bush 1.6-3 m. tall, flowers greenish); west and near Wên-ch'uan Hsien, thickets, alt. 1500-1800 m., July 1908 (No. I954; bush or small tree 3-5 m. tall, flowers greenish).

Nothopanax Bockii Harms is possibly only a small-leaved form of this species.

Nothopanax Rosthornii Harms in Bot. Jahrb. XXIX. 487 (1900).

Western Hupeh: Hsing-shan Hsien, thickets, alt. 900-1200 m., August 1907 (No. I96r, in part; bush $5 \mathrm{~m}$. tall, flowers white); without precise locality, August 1901 (Veitch Exped. No. 2497; bush 3 m. tall). Western Szech'uan: Hungya Hsien, woodlands, alt. 900 m., September 8, 1908 (No. I96r, in part; tree $8 \mathrm{~m}$. tall, flowers white); Mt. Omei, September 1904 (Veitch Exped. No. 4938; bush 5 m. tall, flowers white).

A picture of this plant will be found under No. 314 of the collection of Wilson's photographs and also in his Vegetation of Western China, No. 102.

\section{ACANTHOPANAX Miq.}

\section{Sect. I. Eleutherococcus Harms.}

Acanthopanax Henryi Harms in Engler \& Prantl, Nat. Pflanzenfam. III. Abt. 8, 49 (1897); in Bot. Jahrb. XXIX. 488 (1900). - Gard. Chron. ser. 3, XXXVIII. 402, fig. 151 (1905). - Schneider, Ill. Handb. Laubholzk. II. 424, fig. 289h-i, 290 b (1909).-Stapf in Bot.Mag. CXXXVI. t. 8316 (1910). - Pampanini in Nuov. Giorn. Bot. Ital. n. ser. VIII. 130 (1911).

Eleutherococcus Henryi Oliver in Hooker's Icon. XVIII. t. 1711 (1887). Hemsley in Jour. Linn. Soc. XXIII. 341 (1887), - Hesse in Mitt. Deutsch. Dendr. Ges. XXII. 272, fig. (1913).

Western Hupeh: Hsing-shan Hsien, alt. 1200-2100 m., October 1907 (Nos. 379, I977; shrub 1.25-2 m. tall, fruit black); without precise locality, A. Henry (Nos. 4832, 7609).

Acanthopanax leucorrhizus Harms in Engler \& Prantl, Nat. Pflanzenfam. III. Abt. 7, 49 (1897); in Bot. Jahrb. XXXIX. 488 (1900). Bean, Trees \& Shrubs Brit. Isl. I. 130, fig. (1914).

Eleutherococcus leucorrhizus Oliver in Hooker's Icon. XVIII. sub t. 1711 (1887). - Hemsley in Jour, Linn. Soc. XXIII. 342 (1887).

Western Hupeh: Changyang Hsien, thickets, alt. 1200-1800 m., July and August 1907 (Nos. 1965, 1967; bush 1.60-3.10 m.); Patung 
Hsien, thickets, alt. 1200-1500 m., July 1907 (No. I967; bush 2.30$3.30 \mathrm{~m}$.); without preeise locality, July 1901 (Veitch Exped. No. 2229); without precise loeality, A. Henry (No. 7909). Western Szech'uan: Mt. Omei, August 1904 (Veiteh Exped. No. 4936); same locality, July 1904 (Veitch Exped. No. 4937; specimen foliolis valde angustis).

Acanthopanax leucorrhizus, var. fulvescens Harms \& Rehder, n. var.

A typo recedit foliolis subtus praesertim ad costam et nervos fulvovillosis, supra setis brevibus subaccumbentibus seabris, interdum subtus ad eostam tantum villosis et supra sparse et minute setulosis, simpliciter rarius dupliciter serratis, petiolulis densius et petiolis sparse fulvo-villosis interdum glabris v. fere glabris.

Western Szech'uan: west and near Wên-ch'uan Hsien, thickets, alt. 2300 m., July 1900 (No. I975, type; bush about $3 \mathrm{~m}$. tall, flowers white); around Tachien-lu, thickets, alt. $1800 \mathrm{~m}$., August and September 1908 (Nos. roor, r023; bush 1.30-2 m., flowers greenish, fruit black); same locality, woods, August 1904 (Veitch Exped. No. 3693a); northeast of Sungpan Ting, thickets, alt. 2400-2700 m., August 1910 (No. 4558; bush 3-4 m. tall). Western Hupeh: Fang Hsien, thickets, alt. 1100-1500 m., September 1907 (No. 288; bush 1.60-2 m. tall, fruit black).

This variety differs from the type chiefly in the fulvous pubescence of the veins on the under side of the leaflets and in the scabrous pubescence of the upper side; the number of leaflets varies from 3 to 5 . They are mostly elliptic and rather large and broad, in some specimens $6-13 \mathrm{~cm}$. long, $2.5-6 \mathrm{~cm}$. broad, sharply and rather closely serrate and often slightly doubly serrate, rarely distinctly doubly serrate as in No. 288 and particularly in No. 4558 , which thus form a transition to the following variety, altliough they lack the bristles on the veins and petioles.

Acanthopanax leucorrhizus, var. scaberulus Harms \& Rehder, n. var.

A typo recedit foliis semper 5-foliolatis, foliolis plerumque obovatooblongis v. oblanceolatis dupliciter serratis dentibus acuminatis v. setoso-acuminatis, supra scabridis, subtus praesertim ad nervos costamque plus minusve crispulo-villosis et ad costam setosis raro fere inermibus, petiolis setosis, raro fere inermibus.

Western Hupeh: Fang Hsien, thickets, alt. 1200 m., September 1907 (No. 323, type; bush 1-1.6, fruit black); same locality, August and September 1907 (No. $323^{\mathrm{s}}$; bush $1.6 \mathrm{~m}$. tall, flowers greenish white, fruit black); Patung Hsien, thickets, alt. 1500-1800 m., August and September 1907 (No. 323 ${ }^{\mathrm{b}}$; bush $1.3-1.6 \mathrm{~m}$. tall); without precise locality, A. Henry (Nos. $5950^{\circ}, 6503^{\mathrm{b}}$ ). Western Szech'uan: Wa- 
shan, thickets, alt. 1200-1800 m., August 1908 (No. I966; bush 2-3.3 m. tall, flowers green).

This variety resembles the preceding variety in its leaflets being pubescent beneath, but the leaves are always 5 -foliolate, the leaflets smaller and narrower, generally oblong-obovate, distinctly doubly serrate and furnished with spreading or slightly reflexed bristles on the petiole and on the midrib beneath. Wilson's No. $323^{a}$ and Henry's No. $6503^{b}$ differ from the type in the leaves being pubescent only on the midrib, and in Henry's No. $5950^{\circ}$ the bristles are wanting on both the petiole and the midrib; in Wilson's No. 1966 the bristles are nearly wanting. The stem may be prickly or nearly unarmed.

Acanthopanax setchuenensis Harms in Bot. Jahrb. XXIX. 488 (1900); XXXVI. Beibl. LXXXII. 81 (1905).

Western Hupeh: Fang Hsien, thickets, alt. 1800-2100 m., August and September 1907 (No. 620; bush 2-3 m. tall, flowers white, fruit black); Hsing-shan Hsien, thickets, alt. 1500-1800 m., August 1907 (No. I968; bush 2-2.6 m. tall, flowers white); without precise locality, A. Henry (Nos. 5950 b , 6521, 6630). Western Szech'uan: Mupin, thickets, alt. 1500-2300 m., September 1908 (No. 865; bush 1.30-3 m. tall, fruit black); around Tachien-lu, thickets, alt. 1800-2400 m., October 1908 (No. I044; bush 2-4 m. tall); same locality, August 1904 (Veitch Exped. No. 3693); Wa-shan, thickets, alt. 1200-2100 m., August and October 1908 (No. III3; bush 1.3-2.6 m. tall, flowers greenish, fruit black); "Tsaku-lao, K'ou-shan," August 1891, A. von Rosthorn (No. 2573, type No.). Northern Shensi: Tai-pei-shan, 1910, W. Purdom (No. 2); Lao-y-shan, 1897, G. Giraldi.

This species is very closely related to A. leucorrhizus Harms, but is easily distinguished from it by the leaves with almost invariably 3 leaflets (among 18 sheets with approximately 140 leaves we found only three leaves with 5 and one with 4 leaflets), by their glaucous under side, their more coriaceous texture and by their more remote and shallower serration; in the type specimens this is restricted to the upper part of the leaflets, while in almost all other specimens it extends nearly to the base. The inflorescence consists of several usually rather short-peduncled umbels, while in $A$. leucorrhizus there is usually one long-stalked umbel, occasionally with a few short-stalked smaller ones at its base.

Here is added a species not collected during the Arnold Arboretum Expeditions.

Acanthopanax Simonii Sehneider, Ill. Handb. Laubholzk. II. 426, fig. 290 (1909). - Purpus in Möller's Deutsch. Gärtn.-Zeit. XXV. 25, fig. (1910), - Bean, Trees \& Shrubs Brit. Isl. I. 133 (1914).

Eleutherococcus Simoni Decaisne apud Simon-Louis, Cat. 7 (nomen nudum) (no date). - Vilmorin \& Bois, Frut. Vilmorin. 141 (1904). - Hesse in Mitt. Deutsch. Dendr. Ges. XXII. 272, fig. (1913).

Eleutherococcus leucorrhizus in Gard. Chron. ser. 3, XXXVIII. 404, fig. 152 (non Oliver) (1905). 
Western Hupeh: Changyang Hsien, alt. 1200-1800 m. (Veitch Exped. No. 1456 and Seed No. 1196; bush $1 \mathrm{~m}$,, flowers green); without precise locality, A. Henry (No. 6503 $)$.

This species is nearest to A. leucorrhizus Harms, but is well distinguished by the bristly leaves, by the inflorescence which consists of several short-stalked umbels, and by the stout recurved prickles gradually tapering from a broad decurrent base into a pungent point, while in A. leucorrhizus the prickles are slender and thin, transversely compressed, and abruptly enlarged into a rather small and flat suborbicular base.

\section{Sect. II. Euacanthopanax Harms.}

Acanthopanax Giraldii Harms in Bot. Jahrb. XXXVI. Beibl.LXXXII 80 (1905).

Western Szech'uan: Tachien-lu, thickets, alt. 2700-3000 m., September 1908 (No. Ior4; bush 1.3-2 m. tall, fruit black); southeast of Tachien-lu, alt. 2400 m., June 1908 (No. 1969; bush 1-2 m. tall, flowers greenish); northeast of Tachien-lu, ascent of Ta-p'ao-shan, thickets, rare, alt. 3000-3300 m., July 5 and 8, 1908 (Nos. I970, I97I; bush 1-2.6 m. tall, flowers greenish); Sungpan Ting, alt. 2400-2700 m., August 1910 (No. 4018; bush 1-1.6 m. tall, fruit black); Pan-lanshan, west of Kuan Hsien, thickets, alt. 2400-2700 m., August 1910 (No. $4018^{\mathrm{a}}$; bush $0.6-2.6 \mathrm{~m}$. tall). Western $\mathrm{Hupeh}$ : without precise locality, A. Henry (No.6891). Northern Shensi: Tai-pei-shan, 1910, W. Purdom (Nos. 3, 445). Northern Chili: Wei-chang, May 1909, W. Purdom (No. 71).

Acanthopanax Giraldii, var. inermis Harms \& Rehder, n. var.

A typo recedit caule inermi v. subinermi, leviter scabrido, nec setis rigidis armato.

Western Hupeh: Fang Hsien, upland thickets, alt. 2100-2400 m., August and September 1907 (No. 276; bush 1-1.3 m. tall, flowers white, fruit black); Hsing-shan Hsien, alt. 1200 m., September 1907 (No. I976; bush 1-1.3 m., fruit black); without precise locality, 1901 (Veitch Exped. No. 1020).

This unarmed variety seems to occur only in western Hupeh, while the typical form is distributed from western Szech'uan through Shensi and Hupeh to northern Chili.

\section{Acanthopanax Wilsonii Harms, n. sp.}

Frutex 1-2-metralis; ramis satis tenuibus glabris vel minute puberulis, cortice cinereo v. sordide subatro, inermibus vel ad nodos setosoaculeolatis. Folia gracilia, longe v. breviter petiolata, petiolo glabro, $0.5-6 \mathrm{~cm}$. longo; foliola $3-5$, subsessilia, pro rata parva, oblanceolata 
v. lanceolata v. oblongo-oblanceolata (lateralia saepe obliqua et leviter curvata), basin versus angustata et interdum subpetiolulata, apice acuta v. acuminata, margine praeter basin subintegram crenulatoserrulata, glabra, subtus paullo pallidiora, circiter $2-5 \mathrm{~cm}$. longa, $0.5-1.6$ $\mathrm{cm}$. lata. Umbella in ramulo abbreviato v. elongato terminalis solitaria, pedunculata pedunculo glabro $2-4 \mathrm{~cm}$. longo v. interdum brevissimo, pedicellis glabris $5-10 \mathrm{~mm}$. longis; styli $3-5$, basi breviter connati. Fructus subglobosus, in sicco angulatus, 6-7 mm. diam., niger.

Western Szech'uan: ascent of Pan-lan-shan, west of Kuan Hsien, cliffs, alt. 2400-2700 m., June and August 1908 (No. I972, type); northeast of Sungpan Ting, thickets, alt. 2400 m., August 1910 (No. 456I); Tachien-lu, May 1904 (Veitch Exped. No. 3690).

This species is closely related to A pentaphyllus Marchal, but is easily distinguished from it by the terminal inflorescence, by the styles being connate only at the base, by the narrower leaflets and by the bristle-like prickles.

\section{Acanthopanax Rehderianus Harms, n. sp.}

Frutex seandens eirciter 3-metralis; ramis satis tenuibus, junioribus minute puberulis cinereis $\mathrm{v}$. flavido-cinereis; aculeis infrastipularibus solitariis v. geminis v. paucis dissitis longe decurrentibus validiusculis recurvis $\mathrm{v}$, fere rectis minute puberulis $0.3-0.5 \mathrm{~cm}$. longis. Folia longe petiolata petiolis $2-7 \mathrm{~cm}$. longis; foliola 5 , rarius $3-4$, subsessilia, obovata v. obovato-oblonga v. oblanceolata, acuta v. breviter acuminata, basi sensim attenuata, triente $\mathrm{v}$. interdum dimidio inferiore excepto crenato-serrulata dentibus leviter incurvis, $2-6 \mathrm{~cm}$. longa et $0.8-2 \mathrm{~cm}$. lata, glabra, supra lucida, subtus vix pallidiora, nervis inconspicuis costa media tantum leviter elevata. Umbella in ramulis abbreviatis v. elongatis terminalis, solitaria, pedunculata pedunculo glabro $1-2 \mathrm{~cm}$. longo; pedicellis glabris circiter $1 \mathrm{~cm}$. longis gracilibus interdum $1 \mathrm{v}$. pluribus ad basin pedunculi evolutis; styli 4-5 breves connati, apice in stigmata 4-5 brevissima patentia v. recurva divisi. Fructus subglobosus, in sicco angulatus, $5 \mathrm{~mm}$. longus, niger.

Eastern Szech'uan : Wushan Hsien, alt. 1200 m., September 1907 (No. I974, type). Western Hupeh: without precise locality, $A$. Henry (No. 5930); without precise locality, June 1901 (Veitch Exped. No. 1020).

This species is most elosely related to $A$. Wilsonii Harms, but the stouter solitary infrastipular prickles, the broader leaflets with more crenate serration, the shorter peduncles and the connate styles distinguish it at once. From $A$. pentaphyllus Marchal with which it agrees in its prickles and in the connate styles it differs chiefly in its terminal short-stalked inflorescence. 
Acanthopanax spinosus Miquel in Ann. Mus. Lugd.-Bat. I. 10 (pro parte) (1863), quoad synonyma Linnaei et Thunbergii. - Seemann in Jour. Bot. V. 238 (1867); Rev. Hederac. 86 (1868). - Hance in Jour. Bot. XVIII. 261 (1880). - Marchal in Bull. Soc. Bot. Belg. XX. 80 (1881). - Hemsley in Jour. Linn. Soc. XXIII. 341 (1887). Schneider, Ill. Handb. Laubholzk. II. 427, fig. 290 f-g (1909). - Dunn \& Tutcher in Kew Bull. Misc. Inform. add. ser. X. 119 (Fl. Kwangtung \& Hongk.) (1912).

Panax spinosum Linnaeus f., Suppl. 441 (1781).

Aralia pentaphylla Thunberg, Fl. Jap. 128 (non Siebold \& Zuccarini) (1784). -

De Candolle, Prodr. IV. 259 (1830). - Léveillé, Fl. Kouy-Tchéou, 34 (1914).

Acanthopanax ? Hemsley in Jour. Bot. XIV. 207 (1876).

Western Hupeh: Changlo Hsien, alt. 600-900 m., June and October 1907 (No. 1973; scandent bush 2-3 m. tall, flowers greenish, fruit black); near Ichang, A. Henry (Nos. 3406, 3406²); without precise locality, A. Henry (No. 1224). Shensi: Yenan Fu, 1910, W. Purdom (No. 350). Chekiang: Ningpo, 1908, D. Macgregor. Yunnan: Mengtsze, A. Henry (No. 10639).

\section{Acanthopanax villosulus Harms, n. sp.}

Frutex 1-2-metralis; ramulis glabris cortice incano v. sordide brunneo, ad basin ramulorum abbreviatorum pulviniformium aculeo solitario saepe uncinato validiusculo armatis; folia in ramulis lateralibus abbreviatis solitaria v. pauca congesta, longe vel longiuscule petiolata, petiolo $2-9 \mathrm{~cm}$. longo parce pilosulo v. subglabro; foliola 5 sessilia vel subsessilia, oblonga $v$. obovato-oblonga, basi angustata, apice acuta $v$. obtusa, margine sursum fere a medio latiuscule crenatoserrulata, inferiore parte integra v. subintegra, supra glabra v. parcissime setulosa, subtus breviter villosula et ad nervos parce setulosa, 2-6 cm. longa, $1-2.5 \mathrm{~cm}$. lata. Umbellae in ramulis abbreviatis solitariae, breviter v. longe pedunculatae pedunculo glabro $1-5 \mathrm{~cm}$. longo, pedicellis glabris 4-8 $\mathrm{mm}$. longis, floribus virescentibus; ovarium glabrum, stylis $2-3$ fere liberis v. basi connatis, divaricatis.

Acanthopanax spinosus Pavolini in Nuov. Giorn. Bot. Ital. n. ser. XL. 418 (1908) (non Miquel).

i Acanthopanax spinosus, var. pubescens Pampanini in Nuov. Giorn. Bot. Ital. n. ser. XVII. 678 (1910).

Western Hupeh: Patung Hsien, alt. 1200-1800 m., August 1907 (No. 379²); Chienshi Hsien, alt. 1200 m., 1900 (Veitch Exped. No. 
957). Eastern Szech'uan: without precise locality, cultivated, $A$. Henry (No. 5890).

This species is closely related to A. spinosus Miquel, but differs from it in the villose underside of the leaves.

\section{Acanthopanax lasiogyne Harms, n. sp.}

Frutex 2-6-metralis; ramulis glabris cortice subpallido vel pallide cinereo; folia breviter v. longiuscule petiolata petiolo glabro 1.5-6 cm. longo. Foliola 3, subsessilia v. sessilia v. brevissime petiolulata, pro rata latiuscula $\mathrm{v}$. lata, oblonga $\mathrm{v}$. obovato-oblonga $\mathrm{v}$. obovata (lateralia plus minusve obliqua, interdum ovata v. oblongo-ovata), basi acuta $\mathrm{v}$. in petiolulum angustata $\mathrm{v}$. lateralia oblique obtusa, apice latiuscule breviter acuminata $\mathrm{v}$. acuminulata $\mathrm{v}$, acuta $\mathrm{v}$. acumine destructo obtusa, margine integra v. subintegra v. sursum pauciserrata, circiter 4-6 cm. longa et $1.5-4.5 \mathrm{~cm}$. lata. Umbella terminalis densiflora, breviter v. brevissime pedunculata, floribus albidis, pedicellis parce albido-pilosulis, circiter 5-7 $\mathrm{mm}$. longis, ovario albido-villosulo tomento detergibili; styli 2, basi connati. Fructus compressus, margine calycino parce albido-villosulo v. subglabro, stylis 2 basi breviter v. interdum fere ad medium connatis coronatus, 7-8 $\mathrm{mm}$. longus, niger.

Western Szech'uan: Tachien-lu, thickets, alt. 2100-2400 m., August and October 1908 (No. I3 I3, type); same locality, alt. 15001800 m., September 1910 (No. 4r67).

This species resembles A. sessiliflorus Seemann in its woolly flowers, but is easily distinguished from it by the longer pedicels and the nearly free or only partly connate styles.

Acanthopanax evodiaefolius Franchet in Jour. de Bot. X. 306 (1896).

Western Hupeh: mountains north of Ichang, 1900 (Veitch Exped. No. 1142). Western Szech'uan: west and near Wênch'uan Hsien, alt. 2000 m., October 1910 (No. 4204; tree 16 m. tall, girth $1.3 \mathrm{~m}$., bark smooth, pale gray; fruit black).

Acanthopanax trifoliatus Schneider, Ill. Handb. Laubholzk. II. 427 (pro synon.) (1909). - Rehder in Bailey, Standard Cycl. Hort. I. 193 (1914).

Zanthoxylum trifoliatum Linnaeus, Spec. 270 (1753), ed. 2, II. 1455 (1763). Lamarck, Encycl. Méth. II. 40 (1786).

Panax aculeatum Aiton, Hort. Kew, III. 448 (1789). - Jacquin, Coll. IV. 175

(1790); Icon. Pl. Rar. III. 20, t. 634 (1786-93). - Willdenow, Spec. IV. 
1125 (1805). - De Candolle, Prodr. IV. 252 (1830). - Seemann, Bot. Voy. Herald 38 (1852).

Plectronia chinensis Loureiro, Fl. Cochin. 162 (1790).

Panax Loureirianum De Candolle, Prodr. IV. 252 (1830).

Aralia trifoliata Meyen, Reise, II. 332 (nomen nudum) (1835), secundum

Walpers in Nov. Act. Leop,-Carol. XIX. Suppl. I. 348 (1834) et K. Koch

in Wochenschr. Gärtn. Pflanzenk. I. 366 (1859).

Acanthopanax sepium Seemann in Jour. Bot. V. 239 (1867); Rev. Hederac. 86 (1868).

Acanthopanax aculeatum Seemann in Jour. Bot. V. 238 (1867); Rev. Hederac. 86 (1868), - Hance in Jour. Linn. Soc. XIII. 104 (1873). - C. B. Clarke in Hooker f., Fl. Brit. Ind. II. 726 (1879), - Franchet in Nouv. Arch. Mus. Paris, sór. 2, VI. 26 (Pl. David. II. 146) (1883). - Hemsley in Jour. Linn. Soc. XXIII. 339 (1887). - Harms in Bot. Jahrb. XXIX. 489 (1900). -

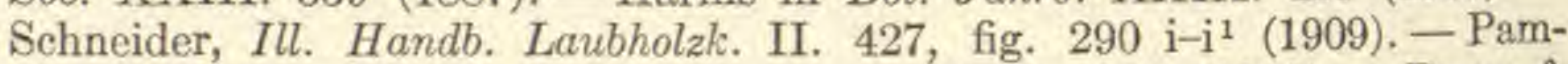
panini in Nuov. Giorn. Bot. Ital. n. ser., XVII. 678 (1910). - Dunn \& Tutcher in Kew Bull. Misc. Inform. add. ser. X. 109 (Fl. Kwangtung \& Hongk.) (1912). - Léveillé, Fl. Kouy-Tchéou, 33 (1914).

Western Hupeh: common around Ichang, alt. 30-300 m., July, October and November 1907 (Nos. 399, 399: ; scandent bush 3-7 m., flowers greenish, fruit black); same locality, A. Henry (Nos. 2253, 2639, 2702). Yunnan: Mengtsze, A. Henry (No. 11158a); Szemao, A. Henry (Nos. 12561, 12770).

Henry's No. $11158^{a}$ differs in its more numerous bristles.

Here may be added a new species not collected during the Arboretum Expeditions.

Acanthopanax stenophyllus Harms, n. sp.

Frutex ramulis tenuibus, subglabris $\mathrm{v}$. glabris, cortice einereo. Folia longe v. longiuscule petiolata petiolo glabro $3-7 \mathrm{~cm}$. longo; foliola $3-5$, angusta, petiolulats v. subsessilia, lanceolata v. oblanceolata v. oblongo-oblanceolata, basi angustata, apice acuminata acumine saepe tenui curvato, margine argute simpliciter v. interdum duplicate serrata, glabra, subtus pallidiora, $2-6.5 \mathrm{~cm}$. longa, 0.4-1.5 cm. lata. Umbella terminalis solitaria, breviter $\mathrm{v}$. interdum longius pedunculata pedunculo glabro in specimine typico $0.5 \mathrm{~cm}$. longo, pedicellis glabris $0.8-1.3 \mathrm{~cm}$. longis; styli $3-5$, basi in columnam brevem v. brevissimam connati.

Shensi: Tai-pei-shan, 1910, W. Purdom (No. 4, type); same locality, G. Giraldi (No. 2231 in Herb. Berol.).

This species is characterized by its comparatively narrow leaflets; in Giraldi's specimen the leaflets are somewhat broader than in the type.

\section{KALOPANAX Miq.}

Kalopanax ricinifolius Miquel in Ann. Mus. Lugd.-Bat. I. 10 (1863). - Harms in Engler \& Prantl, Nat. Pflanzenfam. III. Abt. 8, 51 (1897); in Bot. Jahrb. XXIX. 489 (1900). - Pampanini in Nuov. Giorn. Bot. Ital. n. ser. XVII. 678 (1910).

Panax ricinifolium Siebold \& Zuccarini in Abh. Akad. Münch. IV. 2, 199 (Fl. Jap. Fam. Nat. I. 91) (1845). 
Brassaiopsis ricinifolia Seemann in Jour. Bot. II. 291 (1864).

Acanthopanax ricinifolium Seemann in Jour. Bot. VI. 140 (1868); Rev. Hederac. 86 (1868), - Marchal in Bull. Soc. Bot. Belg. XX. pt. 2, 83 (1881). - Hance in Jour. Bot. XXIII. 323 (1885), - Hemsley in Jour. Linn. Soc. XXIII. 340 (1887). - Sargent in Gard. \& For. VI. 234, fig. 36 (1893). - Shirasawa, Icon. Ess. For. Jap. II. t. 56, fig. 11-24 (1908). - Schneider, Ill. Handb. Laubholzk. II. 429, fig. 289 v-z, 291 b-d (1909). - Koehne in Mitt. Deutsch. Dendr. Ges. XXII. 145, fig. (1913), - Rehder in Bailey, Standard Cycl. Hort. I. 192, fig. 80 (1914).

Acanthopanax ricinifolius, var. magnificus Zabel in Gartenwelt, XI. 535 (1907). Acanthopanax acerifolium Schelle in Mitt. Deutsch. Dendr. Ges. XVII. 297 (1908); XVIII. 289 (1909).

Kiangsi: Kiukiang, 1873, G. Shearer. Western Hupeh: Hsingshan Hsien, woodlands, rare, alt. 1200 m., August and November 1907 (No. 602; tree $18 \mathrm{~m}$. tall, girth $2 \mathrm{~m}$., fruit black); north and south of Ichang, woodlands, alt. 600-1200 m., September and November 1907 (No. I963; tree 7-23 m. tall, girth 1-2 m., flowers white, fruit black); same locality, A. Henry (Nos. 2246a , 3101); "Tien-scian-sien," alt. 700 m., November 1906, C. Silvestri (No. 1601); without precise locality, A. Henry (No. 4573). Western Szech'uan: near Wa-shan, woodlands, alt. 2000 m., September 17, 1908 (No. I962; tree $13 \mathrm{~m}$. tall, girth $2.6 \mathrm{~m}$.).

The Chinese specimens before us differ somewhat from the Japanese type in the leaves being truncate or sometimes even broadly cuneate at the base, in their shorter and broader lobes sometimes reduced to a point, in their wider sinuses forming about a right angle, in their smaller and usually incurved teeth, and as regards the Hupeh specimens in their glaucescent and glabrous or nearly glabrous under surface, while the Szech'uan specimen has the leaves green and slightly pubescent beneath. The Chinese form, too, is a smaller tree with a slenderer trunk measuring rarely more than $2 \mathrm{~m}$. in girth, while the trunk of the Japanese tree often attains $5 \mathrm{~m}$. and occasionally $7 \mathrm{~m}$. in girth.

Pictures of this tree will be found under Nos. 354, 396, 524, 050, 0170 of the collection of Wilson photographs and in his Vegetation of Western China, Nos. 267, 268, 269; also in his collections of Japanese photographs, Nos. x40, x278, x291, $\mathrm{x} 292, \mathrm{x} 406, \mathrm{x} 436, \mathrm{x} 446$.

\section{PENTAPANAX Seem.}

Pentapanax Henryi Harms in Bot. Jahrb. XXIII. 21 (1896); XXIX. 489 (1900).

Western Szech'uan: Mupin, cliffs, alt. 1800-2100 m., August 1908 (No. I3II, in part; bush 1.6-3 m. tall, flowers white); near Fulin, among rocks, alt. 1800-2300 m., September 16, 1908 (No. I3II, in part; bush 1.3-4 m. tall, flowers white); near Tachien-lu, cliffs, alt. 1800-2100 m., September, October and November 1908 (No. I3II, in 
part; flowers white, fruit black); Pan-lan-shan, west of Kuan Hsien, cliffs, alt. 1800-2100 m., October 1910 (No. 4284; bush 2-2.6 m. tall, flowers white, fruit black).

\section{ARALIA L.}

Aralia chinensis Linnaeus, Spec. 273 (1753). - De Candolle, Prodr. IV. 259 (1830). - Bentham, Fl. Hongk. 135 (1861). - Seemann in Jour. Bot. VI. 133 (1868); Rev. Hederac. 90 (1868). - Henriques in Bol. Soc. Broter. III. 149 (1885). - Harms in Bot. Jahrb. XXIX. 490 (1900). - Pavolini in Nuov. Giorn. Bot. Ital. n. ser. XV. 418 (1908). Shirasawa, Icon. Ess. For. Jap. II. t. 55, fig. 13-24 (1908). Schneider, Ill. Handb. Laubholzk. II. 431, fig. 291 h, 292 b-g (1909). Pampanini in Nuov. Giorn. Bot. Ital. n. ser. XVII. 678 (1910); XVIII. 130 (1911).

Leea spinosa Sprengel, Syst. I. 670 (1825).

Aralia mandshurica Maximowicz in Bull. Acad. Sci. St. Pétersbourg, XV. 134 (1857). - Maack \& Ruprecht in Bull. Acad. Sci. St. Pétersbourg, XV. 367 (1857),

Dimorphanthus mandshuricus Ruprecht \& Maximowicz in Mém. Sav. Êtr. Acad. Sci. St. Pétersbourg, IX. 133 (Prim. Fl. Amur.) (1859).

Aralia spinosa Miquel in Ann. Mus. Lugd.-Bat. I. 7 (1863) (non Linnaeus).Franchet \& Savatier, Enum. Pl. Jap. I. 191 (1875). - Hemsley in Jour. Linn. Soc. XXIII. 338 (1881). - Dunn \& Tutcher in Kew Bull. Misc. Inform. add. ser. X. 118 (Fl. Kwangtung \& Hongle.) (1912).

Aralia Decaisneana Hance in Ann. Sci. Nat. sér. 5, V. 215 (1866); in Jour. Bot. IV. 172 (1866).

Aralia Planchoniana Hance in Jour. Bot. IV. 172 (1866).

Aralia mandshurica Seemann in Jour. Bot. VI. 134 (1868).

Aralia japonica Hort. ex K. Koch, Dendr. I. 674 (pro synon.) (1869).

Aralia spinosa, $\beta$ canescens Franchet \& Savatier, Enum. Pl. Jap. I. 192 (1875). Aralia spinosa, var. Chinensis Sargent, Silva N. Am. V. 90 (1895).

Kiangsi: Kuling, thickets, alt. 1200 m., August 1, 1907 (No. I508; unbranched shrub 1.3-2 m. tall, flowers white). Western Hupeh: north and south of Ichang, thickets, alt. 900-1500 m., August and September 1907 (No. 128, in part; shrub 2-4 m. tall, flowers white, fruit black); Changyang Hsien, alt. 900-1500 m., August 1907 (No. I28, in part); Patung Hsien, alt. 900-1500 m., August 1907 (No. 128, in part); Hsing-shan Hsien, alt. 900-1500 m., August 1907 (No. 128, in part). Northern Shensi: Lao-y-san, 1897, G. Giraldi.

The specimens enumerated above are all rather densely pubescent on the under side of the leaves and show scarcely any variation; they represent apparently typical $A$. chinensis, which seems to reach its western limit in western Hupeh, while farther west it is replaced by the following variety. 
A picture of A. chinensis will be found under No. 0110 of the collection of Wilson's photographs.

Aralia chinensis, var. glabrescens Schneider, Ill. Handb. Laubholzk. II. 431 (1909).

Dimorphanthus elatus Miquel, Comm. Phytog. 95, t. 12 (1840).

?Aralia canescens Siebold \& Zuccarini in Abh. Akad. Münch. IV. 2, 202 (Fl. Jap. Fam. Nat. I. 94) (1845).

Aralia elata Seemann in Jour. Bot. VI. 134 (1868); Rev. Hederac. 90 (1868). Aralia spinosa, var. glabrescens Franchet \& Savatier, Enum. Pl. Jap. I. 191 (1875).

Aralia chinensis, var, canescens Koehne, Dendr. 432 (1893).

Aralia spinosa, var. clata Sargent in Garden \& Forest, VI, 233 (1893); Forest Fl. Jap. 44 (1894); Silva N. Am. V. 60 (1895).

Northern Hupeh: "Monte Triora," alt. 1950 m., October 1907, C. Sitvestri (No. 1609). Eastern Szech'uan: Wushan Hsien, alt. 900-1200 m., thickets, September 1907 (No. I28 ; shrub 3 m. tall, fruit black). Western Szech'uan: Pan-lan-shan, west of Kuan Hsien, alt. 2400-2700 m., October 1910 (No. 4386; bush 3 m. tall, fruit black); Mao-chou, Min River valley, thickets, alt. 2400 m., August 1910 (No. 456o; bush 2-2.6 m. tall, flowers white); without precise locality, July 1903 (Veitch Exped. No. 3692; specimen foliolis subtus parce pubescentibus). Northern Shensi: Tai-pei-shan, 1910, $W$. Purdom (No. 1; specimen foliolis angustis).

This variety differs from the type in the glabrous or nearly glabrous glaucescent under side of the leaflets; from the equally glabrous A. chinensis, var. mandshurica Rehder it differs chiefly in the usually smaller, more chartaceous leaflets with smaller appressed teeth. Wilson's No. $128^{\mathrm{a}}$ has somewhat larger leaves with more pubescent veins and forms thus a transition toward the type.

Aralia Wilsonii Harms, n. sp.

Fruticosa, 2-3 m. alta, ramulis subglabris v. minute puberulis. Folia ampla, longe petiolata, duplo-pinnata, petiolo ipso circiter 14-16 $\mathrm{cm}$. longo, rhachi tota cum petiolo circiter $30-40 \mathrm{~cm}$. longa, glabra v. subglabra, pinnis bijugis v. trijugis, rhachi folii ad basin pinnarum infimarum interdum pari foliolorum instructa, foliola in pinnis $3-7$, petiolulata v. superiora sessilia v. subsessilia, oblongo-ovata v. ovata, basi saepe obliqua obtusa v. rotundata v. emarginulata v. obtusiuscula v. rarius leviter cuneato-angustata, apice longiuscule acuminata, margine simpliciter v, duplicate serrulata, glabra v. subglabra, $3-5 \mathrm{~cm}$. longa, 1.5-2.5 $\mathrm{cm}$. lata; inflorescentia terminalis ampla, ramosa, axi ramulisque glabris v. subglabris, umbellis verticillatis v. racemosis, pedunculatis, pedunculis $3-6 \mathrm{~mm}$. longis, pedicellis glabris v. subglabris 
5-10 mm. v. serius $20 \mathrm{~mm}$. longis; styli 5 ; fructus immaturi 5-angulati, maturi nigri, subglobosi, circiter $5 \mathrm{~mm}$. diam.

Western Szech'uan: Ching-chi Hsien, Fei-yueh-ling, thickets, rare, alt. 2100 m., August 1908 (No. 1964, type); without precise locality, alt. 1700 m., July 1903 (Veitch Exped. No. 3717).

Apparently closely related to $A$. chinensis $\mathrm{L}$. but easily distinguished by the glabrous inflorescence and the glabrous leaves bright green on their under side. 


\title{
CORNACEAE.
}

\author{
Determined by Alfred ReHDer.
}

\section{TORRICELLIA DC.}

Torricellia angulata Oliver in Hooker's Icon. XXIX. t. 1893 (1889). Harms in Bot. Jahrb. XXIX. 506 (1900). - Wangerin in Engler, Pflanzenr. IV.-229, 33, fig. 6 (1910).-Léveillé, Fl. Kouy-Tchéou, 117 (1914).

Torricellia intermedia Harms in Bot. Jahrb. XXIX. 507 (1900). - Wangerin in Engler, Pflanzenr. IV.-229, 33 (1910).

Western Hupeh: Hsing-shan Hsien, thickets and roadsides, rare, alt. $1000 \mathrm{~m}$., May 8 and June 7, 1907 (No. 2349; bush 1-2 m. tall, flowers dirty white). Eastern Szech'uan: Taning Hsien, alt. 6001300 m., July 1910 (No. 46r r ; bush 2-7 m. tall, fruit black); Wushan Hsien, A. Henry (No. 5524). Western Szech'uan: Nanch'uan, A. von Rosthorn (No. 1542, type of T. intermedia).

Torricellia intermedia does not seem to be specifically distinct from T. angulata, for Wilson's No. 4611 is clearly intermediate between von Rosthorn's and Henry's specimens; the leaves are sparingly dentate between the lobes, and the veins on the underside are very slightly and sparingly pubescent, while in Henry's specimen they are perfectly glabrous with the exception of small tufts of hairs in the axils of the veins. The staminate flowers of $T$. angulata not previously described are borne in many-flowered and much-branched drooping nearly sessile panicles $6-10 \mathrm{~cm}$. long and developed from leafless axillary and terminal buds; rachis slightly puberulous, the ramifications subtended by small lanceolate or irregularly ovate-lanceolate scarious and glabrous bracts; pedicels with two small bractlets about the middle, $2-3 \mathrm{~mm}$. long; tube of the calyx nearly flat, with very short broadly triangular or obsolete teeth; petals oblong-lanecolate, slightly concave with incurved apex, 3-4 $\mathrm{mm}$. long; stamens with short filaments about $1 \mathrm{~mm}$. long and with broadly oval anthers $1.5 \mathrm{~mm}$. long; the rudimentary pistil consists of a flat disk.

A picture of this plant will be found under No. 0166, of the collection of Wilson's photographs.

Here may be added a reference to a species not collected during the Arnold Arboretum Expeditions.

Torricellia tiliifolia De Candolle, Prodr. IV. 257 (1830). — Seemann in Jour. Bot. III. 361, t. 41 (1865). - Clarke in Hooker f., Fl. Brit. Ind. II. 748 (1879). Wangerin in Engler, Pflanzenr. IV.-229, 31 (1910).

Sambucus tiliaefolia Wallich, Cat. No. 483 (nomen nudum) (1828). 
Yunnan: Szemao, mountains west, alt. 1600 m., A. Henry (No. 11909); Puerh Fu, alt. 1800 m., A. Henry (No. 13297).

This species does not seem to have been reported before from China. The leaves of Henry's No. 11909 show a slight tendency toward lobing, otherwise the specimens agree perfectly with those from Sikkim.

\section{HELWINGIA Willd.}

Helwingia japonica F. G. Dietrich, Nachtr. Vollst. Lex. Gärtn. Bot. III. 660 (1817). - Steudel, Nomencl. 399 (1821). - Morren \& Decaisne in Bull. Acad. Brux. III. 170 (1836). - De Candolle, Prodr. XVI. 1, 680 (1868). - Franchet \& Savatier, Enum. Pl. Jap. I. 195 (1875). Shirasawa, Icon. Ess. For. Jap. II. t. 58, fig. 1-9 (1908). - Schneider, Ill. Handb. Laubholzk. II. 434, fig. 294 c (1909). - Wangerin in Engler, Pflanzenr. IV.-229, 35 (1910).

Osyris japonica Thunberg, Fl. Jap. 31 (1784); Icon. Pl. Jap. Dec. 3, t. 1 (1863). - F. G. Dietrich, Vollst. Lex. Gärtn. Bot. VI. 576 (1806).

Helwingia rusciflora Willdenow, Spec. IV. 716 (1805). - Hagen, Preussens Pflanz. II. t. (1818). - Siebold \& Zuccarini, Fl. Jap. I. 164, t. 86 (1835). Miquel in Ann. Mus. Lugd.-Bat. III. 21 (1867); Prol. Fl. Jap. 209 (1867). Hemsley in Jour. Linn. Soc. XXIII. 341 (1888), - Harms in Bot. Jahrb. XXIX. 505 (1900). - Léveillé, Fl. Kouy-Tchéou, 34 (1914).

Kiangsi: Kuling, common among rocks, alt. 1300 m., July 31, 1907 (No. r607; bush 1-1.5 m. tall). Western Hupeh: north and south of Ichang, abundant, roadside thickets, alt. 600-1300 m., September 1907 (No. 132, in part; bush 1-1.5 m. tall); Hsing-shan Hsien, abundant, thickets, alt. 600-1300 m., May 11 and 27, 1907 (No. 132, in part); without precise locality, A. Henry (Nos. $5282^{\circ}, 5282^{\circ}$ ). Western Szech'uan: southeast of Tachien-lu, thickets, alt. 10001600 m., June 1908 (No. 132, in part); near Tachien-lu, alt. 3000-4500 m., A. E. Pratt (No. 99); Nanch'uan, A. von Rosthorn (No. 1685, fruit). Northern Shensi: "Qua-in-san," July 16, 1897, G. Giraldi. Yunnan: without precise locality, Delavay (No. 3718).

Of Delavay's No. 3718 I have only a few detached leaves with fruits before me which I cannot distinguish from those of $H$. japonica, though all the other specimens from Yunnan I have seen belong to $H$. himalaica Hooker f. \& Thomson.

Helwingia japonica, var. hypoleuca Hemsley in herb.

A typo recedit foliis subtus glaucis, sub lente dense papillosis.

Hupeh: without precise locality, A. Henry (No. 1706, type); Changlo Hsien, roadside thickets, common, alt. 1000 m., September 1907 (No. 13232, in part). Eastern Szech'uan: "Tchen-kéou-tin," Farges (No. 758). 
Wilson's specimens are somewhat less glaucous and less strongly papillose than Henry's and Farges's specimens and form a transition toward the type.

Helwingia himalaica Hooker f. \& Thomson apud Clarke in Hooker f., Fl. Brit. Ind. II. 726 (1879).-Harms in Bot. Jahrb. XXIX. 505 (1900). - Brandis, Ind. Trees, 357 (1906). - Wangerin in Engler, Pflanzenr. IV.-229, 37 (1910).

Western Szech'uan: Hung-ya Hsien, red sandstone cliffs, alt. 800 m., September 6, 1908 (No. 24I5; shrub $45 \mathrm{~cm}$. tall; fruit red); Mt. Omei, June 1904 (Veitch Exped. No. 4942; shrub 3 m. tall). Yunnan: Mengtsze, woods, alt. 1600 m., A. Henry (Nos. 9032, $9032^{\mathrm{a}}, 9032^{\mathrm{b}}, 9032^{\circ}$, red fruit); Szemao, alt. $1300-1600$ m., A. Henry (Nos. 11992, 11992 ${ }^{\text {b }}$ shrub 2 m., fruit red).

Wilson's specimens from Szech'uan differ somewhat from typical H. himalaica in their thicker bluish green leaves and less numerous staminate flowers. The fruits of the Szech'uan and of the Yunnan specimens are red, and this appears to be also the color of the fruits of Himalayan specimens before me, though in none of the descriptions of this species is the color mentioned.

Helwingia chinensis Batalin in Act. Hort. Petrop. XIII. 97 (1893). Harms in Bot. Jahrb. XXIX. 505 (1900). - Wangerin in Fedde, Rep. Spec. Nov. IV. 337 (1907); in Engler, Pflanzenr. IV.-229, 37, fig. 8 (1910).

Helwingia japonica, var. himalaica Franchet in Nouv. Arch. Mus. Paris, sér. 2, VIII. 249 (Pl. David. II. 67) (non H. himalaica Hooker f. \& Thomson) (1885).

Helwingia rusciflora Hemsley in Jour. Linn. Soc. XXIII. 341 (pro parte, non Willdenow) (1888).

Western Szech'uan: Chiu-ting-shan, thickets, alt. $1300 \mathrm{~m}$., May 22, 1908 (No. $172^{\mathrm{b}}$, bush 1-2 m. tall); Niu-tou-shan, west of Kuan Hsien, thickets, alt. 1300-1600 m., June 20, 1908 (No. I72 ${ }^{\mathrm{a}}$ ); Lungan Fu, Tu-ti-liang-shan, thickets, alt, 2000-2300 m., August 1910 (Nos. 447r, 4472; bush 2 m. tall, fruit black); near Sungpan Ting, thickets, alt. 2300-3000 m., August 1910 (No. 4473, bush 1.5 m. tall, fruit black); Nanch'uan, A. von Rosthorn (Nos. 1672, 1684 [var. longipedicellata Wangerin], 1698); without precise locality, August 1903 (Veitch Exped. No. 3696), A. Henry (No. 5282 b).

Helwingia chinensis, var. macrocarpa Pampanini in Nuov. Giorn. Bot. Ital. n. ser. XVII. 681, fig. 16 (1910).

Western Hupeh: Hsing-shan Hsien, thickets, rocky places, alt. $1300 \mathrm{~m}$., June and August 1907 (No. I72, bush 1-2 m. tall); without precise locality, A. Henry (No. 6719). 
The fruits of Henry's No. 6719 agree very well with Pampanini's description and figure; and Wilson's No. $172^{\mathrm{a}}$ seems nearer to this variety than to the type, though the fruits are slightly smaller. The flowering branch of Wilson's specimen has staminate flowers with very slender pedicels almost like those of $H$. chinensis, var. longipedicellata Wangerin.

\section{AUCUBA Thurb.}

Aucuba chinensis Bentham, Fl. Hongk. 138 (1861). - Hemsley in Jour. Linn. Soc. XXIII. 346 (1888). - Henry in Trans. As. Soc. Jap. XXIV. suppl. 48 (List Pl. Formosa) (1896). - Matsumura \& Hayata in Jour. Coll. Sci. Tokyo, XXII. 178 (Enum. Pl. Formos.) (1906). Wangerin in Engler, Pfanzenr. IV.-229, 40, fig. 9 B, c (1910)..Schneider, Ill. Handb. Laubholzk. II. 455, fig. 502 k (1909). - Léveillé, Fl. Kouy-Tchéou, 115 (1914).

Aucuba japonica Harms in Bot. Jahrb. XXIX. 507 (non Thunberg) (1900). Aucuba japonica, var longifolia Nakai in Tokyo Bot. Mag. XXIII. 43 (pro parte) (1909), quoad synon. A. chinensis.

Western Hupeh: north and south of Ichang, thickets, alt. 301000 m., April 10 and June 1907 (No. 2047); bush 1-3 m. tall, fruit red); without precise locality, May 1900 (Veitch Exped. No. 314). Western Szech'uan: Mt. Omei, October 1903 (Veitch Exped. No. 3701); same locality, June 1904 (Veitch Exped. No. 4955; Nanch'uan, A. von Rosthorn (No. 456). Yunnan: Feng-chen-lin Mt., forests, alt. 2300-2500 m., A. Henry (Nos. 10122, 10123); Mengtsze, forests east, A. Henry (No. 10123a). Hongkong: Happy Valley, December 1, 1899, Mou. Formosa: Bankinsing, A. Henry (No. 140).

This species is exceedingly variable. Most of the forms from central and western China differ from the type as represented by the Hongkong plant in their smaller leaves, shorter fruiting panicles and smaller fruits. The Hongkong plant with which Wilson's Nos. 3701 and 4955 from Mt. Omei agree has large generally oblong leaves $12-20 \mathrm{~cm}$. long and $3.5-8 \mathrm{~cm}$. broad, elongated fruiting panicles with the peduncle $8-10 \mathrm{~cm}$. long and distinctly pedicelled oblong fruits about 2 $\mathrm{cm}$. long. All the other specimens from central and western China have smaller leaves varying from obovate to linear-oblong and from coarsely dentate to nearly entire, short glomerulate panicles with the peduncle about $3-4 \mathrm{~cm}$. long and ovoid fruits tapering toward the apex and $1.2-1.5 \mathrm{~cm}$. long; the leaves are quite or nearly glabrous beneath except on Henry's No. 10123 from Yunnan, which has the midrib and the lateral veins covered with short spreading hairs. As stated above the leaves of the western plant vary from obovate to linear-oblong and as the most extreme forms look very distinct, they may be distinguished as follows:

Aucuba chinensis, forma obcordata Rehder, n. f.

A typo recedit foliis obovatis, basin versus sensim angustatis et infra medium integris $\mathrm{v}$. fere integris, apice truncatis et in dentem medium longum acutum desinentibus, dentibus lateralibus minoribus interdum ad mucrones reductis, 8-14 cm. longis et $4.5-8 \mathrm{~cm}$. latis. 
Western Hupeh: Ichang, San-yu-tung glen, April 1901 (Veitch Exped. No. 101, type), A. Henry (Nos. 3353, 3353²).

Aucuba chinensis, forma angustifolia, Rehder n. f.

A typo recedit foliis anguste $v$. lineari-lanceolatis, denticulatis, rarius manifeste dentatis v. interdum fere integris, acumine longo saepe falcato, $7-20 \mathrm{~cm}$. longis et $1.5-3.5 \mathrm{~cm}$. latis.

Yunnan: Yuan-chang, alt. 2300 m., A. Henry (Nos. 10123 ${ }^{\text {b }}$, type, 13300). Western Hupeh: without precise locality, May 1900 (Veitch Exped. No. 703), A. Henry (Nos. 5383, 5383a).

Henry's No. 5383 differs from the type of this form in its smaller rather coarsely dentate leaves distinctly broadest above the middle and gradually narrowed toward the base, while his No. $5383^{\mathrm{a}}$ has the leaves pubescent on the veins beneath, but in shape and dentation much like those of the type. Wilson's No. 703 has smaller and narrower nearly entire leaves with only 4 or 5 minute almost invisible teeth on each side.

\section{CORNUS L.}

Cornus controversa Hemsley in Bot. Mag. CXXXV. in textu ad t. 8261 (1909); in Kew Bull. Misc. Inform. 1909, 331. - Schneider, Ill. Handb. Laubholzk. II. 437, fig. 294 i, 295 c-d (1909). - Wangerin in Engler, Pflanzenr. IV.-229, 49, fig. 14 C-D (1910). - Pampanini in Nuov. Giorn. Bot. Ital. n. ser. XVII. 681 (1910).

Cornus brachypoda K. Koch, Dendr. I. 685 (pro parte, non C. A. Meyer) (1869). - Koehne, Deutsche Dendr. 435 (pro parte) (1893); in Gartenfl. XLV. 285 (1896).

Cornus glauca Blume mser. ex K. Koch, Dendr. I. 685 (pro synon.) (1869). Blume ex Koehne in Gartenfl. XLV. 286 (pro synon.) (1896); XLVI. 96 (pro synon.) (1897).

Cornus macrophylla Clarke in Hooker f., Fl. Brit. Ind. II. 744 (pro parte, non Wallich) (1879). - Hemsley in Jour. Linn. Soc. XXIII, 345 (pro parte) (1886). - Koehne, Deutsche Dendr. 435 (1893); in Gartenfl. XLV. 286, fig. 51, 1 (1896); XLVI. 96 (1897). - Shirasawa, Icon. Ess. For. Jap. I. 121, t. 77, fig. 13-23 (1900). - Harms in Bot. Jahrb. XXIX. 506 (1900).

Kiangsi: Kuling, thickets, common, alt. 1300 m., July 28, 1907 (No. 1536; small tree, 5 m. tall). Western Hupeh: Patung Hsien, woodlands, common, alt. 1000-1300 m., May and August 1907 (No. 83; tree $10 \mathrm{~m}$. tall, girth $1.20 \mathrm{~m}$., fruit black); Changyang Hsien, common, alt. 1300-1600 m., June 3 and September 1907 (No. I29, tree 8-16 m. tall, girth 1-2 m., fruit black); same locality, woodlands, alt. 1300-2000 m., May and September 1907 (No. I33; tree 7-12 m. tall, girth 1-2 m., flowers white, fruit black); Nanto, April 1900 (Veitch Exped. No. 233); "Ma-kin-kcon," alt. 700 m., April 1907, C. Silvestri (No. 1679). Western Szech'uan : Chiu-ting-shan, thickets, alt. 600-1300 m., May 1908 (No. 1848 , in part; tree 8-20 m. tall, 
girth 1-2.5 m.); Wa-shan, woods, alt. 300-1300 m., June 1908 (No. I848, in part); Mt. Omei, June 1904 (Veitch Exped. No. 4951); Nanch'uan, A.von Rasthorn (No. 1125). Yunnan: Red River valley, near Manpan, alt. 600 m., A. Henry (No. 10747 a).

A picture of this tree will be found under No. 371 of the collection of Wilson's photographs and also in his Vegetation of Western China, No. 169.

Cornus Hemsleyi Schneider \& Wangerin in Fedde, Rep. Spec. Nov. VII. 229 (1909). - Schneider, Ill. Handb. Laubholzk. II. 446, fig。 $296 \mathrm{~m}-\mathrm{n}$ (1909). - Wangerin in Engler, Pflanzenr. IV.-229, 67 (1910).

Western Hupeh: Changlo Hsien, woodlands, alt. 1800 m., June 1907 (No. 1847; tree 5-8 m. tall, flowers white). Eastern Szech'uan: western Hsien, July 1900 (Veitch Exped. No. 1385). Western Szech'uan: Niu-tou-shan, west of Kuan Hsien, alt. 2300-2800 m., June 21, 1908 (No. I843; bush 3-4 m. tall, flowers white, anthers blue); Wa-shan, thickets, alt. 2000-2600 m., July 1908 (No. 1845; tree $8 \mathrm{~m}$. tall, girth $1 \mathrm{~m}$., flowers white); Pan-lan-shan, west of Kuan Hsien, alt. 3000 m., August 1910 (No. 40I7, in part; bush $7 \mathrm{~m}$. tall); northeast of Sungpan Ting, woods, alt. 2600-3000 m., August 1910 (No. 4017, in part; bush 3-7 m. tall, stems red, fruit blue-black); Mupin, thickets, alt. 1600-2500 m., June 1908 (No. 1844; bush 2-6 m. tall); Mt. Omei, June 1904 (Veitch Exped. No. 4952). Northern Shensi: "Kiotou-san," July 14, 1897, G. Giraldi (No. 3290); “ Ngo-san," 1899, Hugh Scallan. Western Kansu: Min-chou district, alt. 2600-3000 m., 1910, W. Purdom.

Cornus poliophylla Schneider \& Wangerin in Fedde, Rep. Spec. Nov. VII. 228 (1909). - Schneider, Ill. Handb. Laubholzk. II. 447, fig. 298 a (1909). - Wangerin in Engler, Pflanzenr. IV.-229, 68 (1910).

Western Hupeh: without precise locality, June 1901 (Veitch Exped. No. 2167, flowering branches). Western Szech'uan: west and near Wên-ch'uan Hsien, thickets, alt. $2300 \mathrm{~m}$., June and August 1708 (No. 809; small tree, $7 \mathrm{~m}$. tall, flowers white, fruit black); near Mongkong Ting, alt. 2300 m., June 19, 1908 (No. s846; bush $6 \mathrm{ft}$. tall, flowers white, anthers blue).

Cornus ulotricha Schneider \& Wangerin in Fedde, Rep. Spec. Nov. VII. 228 (1909). - Schneider, Ill. Handb. Laubholzk. II. 445, fig. 298 c (1909). - Wangerin in Engler, Pflanzenr. IV.-229, 65 (1910).

Western Hupeh: without precise locality, July 1901 (Veitch Exped. No. 2341 a). Western Szech'uan: west and near Wên- 
ch'uan Hsien, alt. 2500 m., July 1908 (No. I84I; tree 13 m. tall, girth $1.60 \mathrm{~m}$., flowers white).

A picture of this tree will be found under No. 69 of the collection of Wilson's photographs and also in his Vegetation of Western China, No. 0171.

Cornus macrophylla Wallich in Roxburgh, Fl. Ind. I. 433 (1820). D. Don, Prodr. Fl. Nepal. 141 (1825). - De Candolle, Prodr. IV. 272 (1830). - Wight, Ill. II. t. 122 B (1850).-Brandis, Forest Fl. Brit. Ind. 252, t. 32 (1874); Ind. Trees, 355 (1906). - Clarke in Hooker, Fl. Brit. Ind. II. 744 (pro parte) (1879). - Hemsley in Jour. Linn. Soc. XXIII. 345 (pro parte) (1888); in Bot. Mag. CXXXV. t. 8261 (1909); in Kew Bull. Misc. Inform. 1909, 330. - J. H. Veitch in Jour. Hort. Soc. Lond. XXVII. 861, fig. (1902). - Schneider, Ill. Handb. Laubholzk. II. 444, fig. 296 k, 297 s-v, x (1909.) —Léveillé, Fl. Kouy-T chéou, 116 (1914).

Cornus alba Thunberg, Fl. Jap. 62 (non Linnaeus) (1784). - Siebold \& Zuccarini in Abh. Akad. Münch. IV. 2, 194 (Fl.Jap. Fam. Nat. I. 86) (1845). Miquel in Ann. Mus. Lugd.-Bat. II. 160 (1866); Prol. Fl. Jap. 92 (1866).

Cornus sanguinea, Thunberg, Fl. Jap. 63 (non Linnaeus) (1784). - Siebold \& Zuecarini, 1. c. (1845).

Cornus brachypoda, C. A. Meyer in Ann. Sci. Nat. sér. 3, IV. 74 (1845). Walpers, Ann. II. 725 (1852). - Miquel in Ann. Mus. Lugd.-Bat. II. 160 (1866); Prol. Fl. Jap. 92 (1866), - Koehne in Gartenfl. XLVI. 94 (1897); in Mitt. Deutsch. Dendr. Ges. XII. 44 (1903), - Harms in Bot. Jahrb. XXIX. 506 (1900), - Rehder in Sargent, Trees \& Shrubs, I. 81, t. 41 (1903). - Wangerin in Engler, Pflanzenr. IV.-229, 64 (1910).

Cornus Thelicanis Lebas in Rev. Hort. 1875, 394, fig. 64.

Cornus crispula Hance in Jour. Bot. X. 216 (1881).

Cornus corynostylis Koehne in Gartenfl. XLV. 286, fig. 511, ${ }^{6}$ (1896).

Cornus Theleryana Hort. ex Koehne, 1. c. (pro. synon.).

Cornus ignorata Shirasawa, Icon. Ess. For. Jap. I. 121, t. 77 (non K. Koch) (1900).

Cornus glauca Blume ex Rehder in Sargent, Trees \& Shrubs, I. 81 (pro synon.) (1903).

Cornus Thelycrania Hort. ex Rehder 1. c. (pro synon.).

Cornus Religiana Hort. ex Hemsley in Kew Bull. Misc. Inform. 1909, 330 (pro synon.).

Western Hupeh: north and south of Ichang, woods, common, alt. 1200-1800 m., May and September 1907 (No. I40, in part; tree 6-15 m. tall, girth 1-2.5 m., flowers white, fruit black); Fang Hsien, woodlands, alt. 1800 m., June 1907 (No. I40, in part); Hsing-shan Hsien, woods, alt. 1500 m., August 1907 (No. I40, in part); Patung Hsien, alt. 1500 m., May 1907 (No. I40, in part); without precise locality, June 1900 (Veitch Exped. Nos. 984, 1152), May 1901 (Veitch Exped. 1935), A. Henry (Nos. 5506, 6300). Western Szech'uan: 
Mt. Omei, June 1904 (Veitch Exped. No. 4951). Northern Shensi: "Ta-sce-tsuen," September 18, 1897, G. Giraldi (No. 3287). Yunnan: Mengtsze, alt. 2100 m., A. Henry (No. 10747).

I am unable to follow Koehne and Wangerin in distinguishing C. macrophylla and $C$. brachypoda as species. There seems to be no reliable character by which to separate them, even the shape of the style upon which much stress is laid by these authors is variable; though in the Japanese and Korean specimens the style is apparently always eylindric or very slightly thickened at the apex, it is not uniformly clavate in the Himalayan specimens and varies even in the same inflorescence, while in the Chinese specimens the style is mostly more or less though usually only slightly thickened. The somewhat smaller fruit and the more shrubby habit of the Japanese plant are not sufficient characters for specific separation. The geographical distribution of the species as I understand it is almost exactly that of C. controversa Hemsley.

A picture of this tree will be found under No. 574 of the collection of Wilson's photographs and also in his Vegetation of Western China, No. 0170.

Cornus Walteri Wangerin in Fedde, Rep. Spec. Nov. VI. 99 (1908); in Engler, Pflanzenr. IV.-229, 71 (1910). - Schneider, Ill. Handb. Laubholzk. II. 450 (1909).

Cornus Henryi Hemsley apud Wangerin in Engler, Pfanzenr. IV.-229, 90 (1910).

Western Hupeh: Hsing-shan Hsien, woodlands, alt. $1800 \mathrm{~m}$., June and October 1907 (Nos. 375, in part, 592; tree 12 m. tall, girth 1.2 m., flowers white, fruit blue-black); same locality, alt. $900-1200$ m., June 15, 1910 (No. 4744; tree $8 \mathrm{~m}$. tall, girth $0.6 \mathrm{~m}$.); Changyang Hsien, alt. 1500 m., June and October 1907 (No. 375, in part); Fang Hsien, woodlands, alt. 900-1500 m., June and October 1907 (No. 375, in part; tree 6-12 m. tall, flowers white); Patung Hsien, alt. $1400 \mathrm{~m}$., June 1907 (No. 375, in part); without precise locality, May 1901 (Veitch Exped. No. 764, in part, flowering branch with the flowers partly in bud), A. Henry (Nos. 3891, 6382). Western Szech'uan: west and near Wên-ch'uan Hsien, woods, alt. 1800-2200 m., September 1908 (No. ror7, tree 10-15 m. tall, girth 1.2-1.8 m.); Mupin, thickets, alt. 1800 m., June 1908 (No. 1842; bush 3-3.5 m. tall, flowers white, "Yu-chin shu").

A picture of this tree will be found under No. 017 of the collection of Wilson's photographs.

Cornus paucinervis Hance in Jour. Bot. XIX. 217 (1881). - Hemsley in Jour. Linn. Soc. XXIII. 346 (1888). - Koehne in Gartenfl. XLV. 287 (1896); in Mitteil. Deutsch. Dendr. Ges. XII. 46 (1903). - Harms in Bot. Jahrb. XXIX. 506 (1900). - Schneider, Ill. Handb. Laubholzk. II. 449, fig. 298 n-o (1909). - Wangerin in Engler, Pflanzenr. IV.-229, 
72, fig. 18 a-e (1910). - Pampanini in Nuov. Giorn. Bot. Ital. n. ser. XVII. 681 (1910). — Léveillé, Fl. Kouy-Tchéou, 116 (1914).

Cornus quinquenervis Franchet in Jour. de Bot. X. 307 (1896). - Koehne in Mitteil. Deutsch. Dendr. Ges. XII. 46 (1903).

Western Hupeh: abundant around Ichang, alt. 30-600 m., June and September 1907 (No. 136; shrub 1-3 m. tall, flowers white, fruit black); without precise locality, May 1900 (Veitch Exped. No. 495). Western Szech'uan: Mt. Omei, June 1904 (Veitch Exped. No. 4950); without precise locality, E. Faber (No. 637). Yunnan: Mengtsze, alt. 1600 m., A. Henry (Nos. 10800, 10800). K w a n g tung: West River, C. Ford.

Though Faber's No. 637 differs from all other specimens in its much broader, elliptic to broadly obovate more densely pubescent leaves, I think it must be referred to this species. The flowers which are not yet open agree well with those of typical $C$. paucinervis in their comparatively large lanceolate sepals and distinctly clavate style.

Cornus chinensis Wangerin in Fedde, Rep. Spec. Nov. VI. 100 (1908); in Engler, Pflanzenr. IV.-229, 80 (1910). - Schneider, Ill. Handb. Laubholzk. II. 452, fig. 229 m (1909).

Cornus officinalis Harms in Bot. Jahrb. XXIX. 506 (non Siebold \& Zuccarini) (1900).

Western Hupeh: north and south of Ichang, woods, not common, alt. 1500-1800 m., May 1907 (No. 88, in part; tree 6-12 m. tall, flowers yellow); Hsing-shan Hsien, woods, alt. 1800 m., May and August 1907 (No. 88, in part; tree $14 \mathrm{~m}$. tall, fruit black); without precise locality (Veitch Exped. No. 552), A. Henry (Nos. 5733, 6560, 6707). Western Szech'uan: Wa-shan, woods, alt. 1500-2200 m., September 1908 (No. 825, in part; tree 5-9 m. tall, fruit black); Mupin, woods, alt. 1800 m., August 1908 (No. 825, in part); same locality, alt. 1500-1800 m., September 1910 (No. 42r8; tree 8-12 m. tall, fruit black); Mt. Omei, May 1904 (Veitch Exped. No. 4953).

The most striking character of this very distinct species, the black color of its fruit, by which it differs from all allied species, was apparently not known to Wangerin when he described it as a new species.

Cornus kousa Buerger apud Hance in Jour. Linn. Soc. XIII. 105 (1873). - Franchet \& Savatier, Enum. Pl. Jap. I. 196 (1875). - Gard. Chron. ser. 3, XIX. 782, fig. 135 (1896). - Palibin in Act. Hort. Petrop. XVII. 1, 101 (1899). - Harms in Bot. Jahrb. XXIX. 506 (1900). Yabe in Tokyo Bot. Mag. XVIII. 30 (1904). - Schneider, Ill. Handb. 
Laubholzk. II. 454, fig. $301 \mathrm{n}-\mathrm{q}, 302 \mathrm{~g}$ (1909). - Wangerin in Engler, Pflanzenr. IV.-229, 88 (1910).

Benthamia japonica Siebold \& Zuccarini, Fl. Jap. I. 38, t. 16 (1835). - Miquel in Ann. Mus. Lugd.-Bat. II. 159 (1865); Prol. Fl. Jap. 91 (1865).

Cornus Kousa Buerger ex Miquel in Ann. Mus. Lugd.-Bat. II. 159 (pro synon.) (1865); Prol. Fl. Jap. 91 (pro synon.) (1865).

Cornus japonica Koehne, Deutsche Dendr. 438 (non Thunberg) (1893).

Western Hupeh : north and south of Ichang, abundant, alt. 12002100 m., June and September 1907 (Nos. 223, 223 ${ }^{\mathrm{a}}$; bush or small flattopped tree, $5-10 \mathrm{~m}$. tall, flowers white, fading pink, fruit red, edible); Nanto, May 1900 (Veitch Exped. No. 811); without precise locality, May 1900 (Veitch Exped. No. 681); "monte di Ku-tcen," alt. 700 m., September 1906, C. Silvestri (No. 1684); "Kai-scian," alt. 1100 m., June to July 1906, C. Silvestri; without precise locality, A. Henry (Nos. $\left.4073,5672,5672^{\text {b }}, 5672^{\circ}\right)$. Western Szech'uan: Wa-shan, thickets, alt. 1200-2200 m., June and September 1908 (No. 223 ${ }^{\text {b }}$; bush 3-6 m. tall, flowers white, fruit red, edible). Northern Shensi: "monte Kin-qua-san," July 10, 1897, G. Giraldi; " monte Qua-in-san," July 16, 1897, G. Giraldi. Chekiang: Moukan-shan, 1915, F. N. Meyer.

A picture of this tree will be found under No. 013 of the collection of Wilson's photographs.

Cornus capitata Wallich in Roxburgh, Fl. Ind. I. 434 (1820); Pl. As. Rev. III. 10, t. 214 (1832).-D. Don, Prodr. Fl. Nepal. 141 (1825).-De Candolle, Prodr. IV. 273 (1830), - Hooker f. in Bot. Mag. LXXVIII. t. 4641 (1852). - Brandis, For. Fl. Brit. Ind. 253 (1874); Ind. Trees, 355 (1906). - Clarke in Hooker f., Fl. Brit. Ind. II. 745 (1879). Hemsley in Jour. Linn. Soc. XXIII. 245 (1888), - Harms in Bot. Jahrb. XXIX. 506 (1900). — Collett, Fl. Siml. 220, fig. 67 (1902). Wangerin in Engler, Pflanzenr. IV.-229, 89 (1910). - Léveillé, Fl. Kouy-Tchéou, 115 (1914).

Benthamia fragifera Lindley in Bot. Reg. XIX. t. 1579 (1833). - Wight, Ill. II. t. $122^{\mathrm{a}}(1850)$.

Western Hupeh: Patung Hsien, thickets, sunny places, alt. 1200 m., July 1907 (No. I85I, in part; tree $5 \mathrm{~m}$. tall); Changlo Hsien, margins of woods, rare, alt. 1200 m., June 1907 (No. I85I, in part; small tree, 3-5 m. tall, flowers white); without precise locality, $A$. Henry (No. 5307). Western Szech'uan: Mupin, not common, thickets, alt. 1500-1800 m., June 1908 (No. 1849; tree 6-8 m. tall. flowers white); Mt. Omei, June 1904 (Veitch Exped. No. 4954). 
Yunnan: Mengtsze, A. Henry (Nos. 9176, 9176ª $9176^{\text {b }}$; tree 5-9 m. tall).

Wilson's No. 1851 from Patung Hsien differs from the typical form in the much narrower elliptic-oblong, acute or somewhat acuminate bracts, which are about $3 \mathrm{~cm}$. long and 0.8-1 cm. broad and resemble in shape those of $C$. kousa Buerger.

Cornus capitata, var. mollis Rehder, var. nov.

A typo recedit foliis subtus et petiolis et ramulis junioribus molliter crispulo-villosis, foliis supra initio sparse villosis demum glabrescentibus plerumque ellipticis $4.5-7 \mathrm{~cm}$. longis et 2-3.5 latis.

Western Hupeh: Changyang Hsien, thickets, alt. 1400 m., rare, July 1907 (No. I850, tree 6 m. tall, bark gray, flowers white).

In the section Thelycrania one would be inclined to consider the difference in the pubescence a specific character, but as the proposed variety agrees in all other characters with the typical species it seems better to treat it as a well marked variety.

Here may be added notes on three species not collected during the Arnold Arboretum Expeditions.

Cornus oblonga Wallich in Roxburgh, Fl. Ind. I. $432(1820)$. - D. Don, Prodr. Fl. Nepal. 140 (1825), - De Candolle, Prodr. IV. 272 (1830). - Brandis, Forest Fl. Brit. Ind. 253 (1874); Ind. Trees, 358, fig. 188 (1906). - Kurz, Forest Fl. Brit. Burma, I. 545 (1877). - Clarke in Hooker f., Fl. Brit. Ind. II. 744 (1879). - Collett, Fl. Siml. 220 (1902), - Wangerin in Engler, Pflanzenr. IV.-229, 64 (1910).

Szech'uan: without precise locality, A. Henry (No. 7031, distributed as "Viburnum"). Yunnan: Mi-lê district, A. Henry (No. 9930); Mengtsze, alt. 1800-2800 m., A. Henry (Nos. 11161, 11397).

Henry's No. 7031 has the young branchlets, petioles and the under side of the leaves quite villose; his 9930 from Yunnan is almost as villose, while the other numbers are only slightly pubescent.

Cornus Bretschneideri L. Henry in Jardin, XIII. 309, fig. 154 (1899). - Koehne in Mitt. Deutsch. Dendr. Ges. XII. 45 (1903). - Schneider, Ill. Handb. Laubholzk. II. 446, fig. 298 d-d $d^{1}$ (1909). - Wangerin in Engler, Pflanzenr. IV.-229, 67 (1910).

Cornus aspera Wangerin in Fedde, Rep. Spec. Nov. VI. 97 (1908).

Chili: Hsiao Wu-tai-shan, August 8, 1913, F. N. Meyer (No. 89); same locality, August 23, 1913, F. N. Meyer (No. 90). Western Kansu: on road to Sikou, August 13, 1910, W. Purdom.

Cornus Wilsoniana Wangerin in Fedde, Rep.Spec. Nov. VI. 97 (1908).-Schneider, Ill. Handb. Laubholzk. II. 444, fig. 2961 (1909). - Wangerin in Engler, Pflanzenr. IV.-229, 65 (1910).

Western Hupeh: without precise locality, May 1901 (Veitch. Exped. No. 764 , in part, flowering branch with the corollas mostly dropped and fruiting branch), A. Henry (No. 300).

This species has been confused with $C$. Walteri Wangerin, to which the flowering branches partly in bud of the type number belong. 


\section{MYRSINACEAE.}

Determined by Alfred ReHDer.

\section{MYRSINE.}

> Myrsine semiserrata Wallich in Roxburgh, Fl. Ind. II. 293 (1824); Tent. Fl. Nepal. 34, t. 24 (1824-26). - A. De Candolle, Prodr. VIII. 93 (1844). - Brandis, Forest Fl. Brit. Ind. 285 (1874); Ind. Trees, 416 (1906). - Kurz, Forest Fl. Brit. Burma, II. 105 (1877). - Clarke in Hooker f., Fl. Brit. Ind. III. 511 (1882), - Hemsley in Jour. Linn. Soc. XXVI. 61 (1889). - Diels in Bot. Jahrb. XXIX. 518 (1900). - Mez in Engler, Pflanzenr. IV.-236, 339 (1902). - Diels in Not. Bot. Gard. Edinburgh, VII. 41, 43, 262 (Pl. Chin. Forrest.) (1912). - Léveillé, Fl. Kouy-Tchéou, 287 (1914).

Myrsine sessilis D. Don, Prodr. Fl. Nepal. 146 (1825).

Samara sessilis Hamilton ex D. Don, l. c. (pro synon.) (1825).

Myrsine subspinosa D. Don, l. c. 147 (1825). - A. De Candolle, Prodr. VIII. 94 (1844).

Samara subspinosa Hamilton ex D. Don, 1. c. 147 (pro synon.) (1825).

Myrsine excelsa D. Don, 1. c. 147 (1825). - A. De Candolle, Prodr. VIII. 94 (1844).

Myrsine acuminata Royle, Ill. Bot. Himal. 265 (1839) (nomen nudum).Madden in Jour. As. Soc. Bengal, XVII. 1, 368 (1848).

Myrsine khasyana Kurz in Jour. As. Soc. Bengal, XLVI. pt. 2, 21 (1877).

Western Hupeh: Ichang, glens, alt. 30-600 m., March and June 1907 (No. 3297, in part; bush 1.25-2 m. tall, flowers whitish, fruit purple); same locality, A. Henry (Nos. $\left.3277,3277^{\mathrm{b}}, 3277^{\mathrm{d}}\right)$ : Changlo Hsien, side of streams, alt. 900 m., May 1907 (No. 309I, bush 2-2.25 m. tall); without precise locality, A. Henry (No. 7685). Western Szech'uan: Kiating Fu, cliffs, alt. 300 m., May 1908 (No. 3297, in part; bush 1.25-2 m. tall, flowers whitish); Kuan Hsien, thickets, alt. 900-1200 m., September 1910 (No. 4605; bush 2-3 m. tall, fruit purple). Yunnan: south of Red River from Manmei, alt. 2000 m., A. Henry (No. 9173 b); Mengtze, alt. 1600-1800 m., A. Henry (Nos. 9173 $9173^{\mathrm{d}}, 9173^{\mathrm{e}}$ ); Yuan-chiang, alt. $1500 \mathrm{~m} .$, A. Henry (Nos. 13270, 13311).

Myrsine africana Linnaeus, Spec. 196 (1753). - Lamarck, Tab. Encycl. Méth. II. 49, t. 122 (1793). - A. De Candolle, Prodr. VIII. 93 
(1844). - Brandis, Forest Fl. Brit. Ind. 286 (1874); Ind. Trees, 416 (1906). - Boissier, Fl. Orient. IV. 31 (1879). - Clarke in Hooker f., Fl. Brit. Ind. III. 511 (1882). - Hemsley in Jour. Linn. Soc. XXVI. 60 (1889). - Diels in Bot. Jahrb. XXIX. 518 (1900). Mez in Engler, Pflanzenr. IV.-236, 340 (1902). - Pampanini in Nuov. Giorn. Bot. Ital. n. ser. XVII. 683 (1910), XVIII. 131 (1911). Diels in Not. Bot. Gard. Edinburgh, VII. 32, 215 (1912).

Buxus dioeca Forskal, Fl. Aeg.-Arab. 159 (1775).

Myrsine glabra Gärtner, Fruct. I. 282 (1788).

Myrsine scabra Gärtner, Fruct. I. 282, t. 59, fig. 1 (1788). - J. F. Gmelin, Syst. I. 404 (1791). - Roemer \& Schultes, Syst. IV. 511 (1819).

Myrsine retusa Aiton, Hort. Kew. I. 271 (1789).- Ventenat, Descr. Jard. Cels. t. 86 (1800). - Jacquin, Hort. Schoenbrunn. IV. 12, t. 124 (1804), Loddiges Bot. Cab. V. t. 409 (1820).

Myrica montana Vahl, Symb. II. 99 (1791).

Myrsine rotundifolia Lamarck, Encycl. Méth. IV. 194 (1796). - Roemer \& Schultes, Syst. IV. 507 (1819).

Myrsine acuta Salisbury, Prodr. 141 (1796).

Nageia arabica Willdenow, Spec. IV. 749 (1806).

Myrica arabica Vahl ex Willdenow, 1. c. (pro synon.) (1806).

Myrsine bifaria Wallich in Roxburgh, Fl. Ind. II. 296 (1824). - A. De Candolle, Prodr. VIII. 93 (1844).

Myrica Potama D. Don, Prodr. Fl. Nepal. 146 (1825).

Samara Potama Hamilton ex D. Don, 1. c. (pro synon.) (1825).

Myrsine africana, $\beta$ retusa A. De Candolle in Trans. Linn. Soc. XVII. 105 (1834); Prodr. VIII. 93 (1844).

Myrsine bottensis A. De Candolle, Prodr. VIII. 93 (1844).

Myrsine africana, var. bifaria Franchet in Nouv. Arch. Mus. Paris, sér. 2, VI. 82 (Pl. David. I. 202) (1883).

Myrsine divica Ascherson \& Schweinfurth in Verh. Berlin, Ges. Erdk. XVIII. 549 (1891).

Western Hupeh: north and south of Ichang, arid stony places, alt. 30-600 m., May 9 and December 1907 (No. 3298; bush 0.25-1m.); "monte Triora," alt. 1950 m., September 1907, C. Silvestri (No. 1706); "Ou-pan-chan," alt. 600 m., March 14-23, 1910, C. Silvestri (No. 3133); without precise locality, A. Henry (No. 3808). Szech'uan: Nanch'uan, A. von Rosthorn (No. 2169). Yunnan: Mengtsze, woods, alt. 1500 m., A. Henry (Nos. 9972, 9972 ${ }^{\text {b) }}$.

\section{ARDISIA Sw.}

Ardisia crispa A. De Candolle in Trans. Linn. Soc. XVII. 124 (1837); Prodr. VIII. 134 (1844). - Bentham, Fl. Hongk. 206 (1861). - Mez in Engler, Pflanzenr. IV.-236, 144, fig. 22 (1902). - Diels in Not. Bot. Gard. Edinburgh, VII. 52 (Pl. Chin. Forrest.) (1912). 
Bladhia crispa Thunberg, Fl. Jap. 92 (1784). - Banks, Icon. Kaempfer. t. 7 (1791).

Ardisia elegans Andrews, Bot. Repos. X. t. 623 (1810). - Loddiges, Bot. Cab. III. t. 264 (1818).

Ardisia crenata Roxburgh, Hort. Bengal. 85 (nomen nudum) (1814); Fl. Ind. II. 276 (1824), - Sims in Bot. Mag. XLV. t. 1950 (1818), - Hemsley in Jour. Linn. Soc. XXVI. 63 (1889). - Diels in Bot. Jahrb. XXIX. 518 (1900).

Ardisia crenulata Loddiges, Bot. Cab. I. t. 2 (1817).

Ardisia lentiginosa Ker in Bot. Reg. VIl. t. 533 (1821).

Ardisia nana Colebrooke ex Roxburgh, Fl. Ind. II. 282 (pro synon.) (1824).-

Hamilton ex A. De Candolle in Trans. Linn. Soc. XVII. 118 (pro synon.)

(1834); Prodr. VIII. 135 (pro synon.) (1844).

Ardisia glandulosa Blume, Bijdr. 690 (non Roxburgh) (1826).

Ardisia densa Miquel, Fl. Ind. Bot. Suppl. I. 575 (1860).

Ardisia polysticta Miquet, l. c. 576 (1860).

Ardisia hortorum Maximowiez in Gartenfl. XIV. 363, t. 491 (1865).

Ardisia undulata Clarke in Hooker f., Fl. Brit. Ind. III. 524 (1882).

Tinus crispa Kuntze, Rev. Gen. II. 405 (1891).

Western Hupeh: thickets around Ichang, alt. 30-600 m., December 1907 (No. I98r; 0.60 m., fruit red); same locality, A. Henry (No. 3265). Western Szech'uan: "Uo-mi-san," (Mt. Omei) 1899, Hugh Scallan; without precise locality, June 1903 (Veitch Exped. No. 4056). Yunnan: Mengtsze, alt. 1600 m., A. Henry (Nos. 9791, 9791 ${ }^{\mathrm{a}}$. Kwangtung: Hainan, 1889, A. Henry (No. 847); Hongkong, C. Ford; same locality, November 5, 1903, C. S. Sargent. Chekiang: Ningpo, 1908, D. Macgregor.

Ardisia Henryi Hemsley in Jour. Linn. Soc. XXVI. 65 (1889). Diels in Bot. Jahrb. XXIX. 518 (1900). - Mez in Engler, Pflanzenr. IV.-236, 149 (1902).

Tinus Henryi Kuntze, Rev. Gen. II. 974 (1891).

Western Szech'uan: Mupin, thickets, alt. 900-1200 m., June 1908 (No. r98o; shrub 0.75-1 m. tall, flowers white); Mt. Omei, June 1904 (Veitch Exped. No. 5062). Eastern Szech'uan: Wushan Hsien, thickets, alt. 900 m., October 1907 (No. 458; bush 0.75-1 m. tall, fruit red). Western Hupeh: without precise locality, May 1900 (Veitch Exped. No. 414); without precise locality, A. Henry (Nos. 3455, 3972, 4314, 7747).

Ardisia japonica Blume, Bijdr. 690 (1826). - Morren \& Decaisne, Bull. Acad. Sci. Brux. III. 171 (1836).-A. De Candolle, Prodr. VIII. 135 (1844). - S. Moore in Jour. Bot. XIII. 231 (1875).- Hemsley in Jour. Linn. Soc. XXVI. 65 (1889). - Mez in Engler, Pflanzenr. IV.- 
236, 151 (1902). - Schneider, Ill. Handb. Laubholzk. II. 571, fig. 371 a-c (1911). - Léveillé, Fl. Kouy-T chéou, 283 (1914).

Bladhia japonica Thunberg, Nov. Gen. 7 (1781); Fl. Jap. 1. 96, t. 18 (1784). Lamarck, Tab. Encycl. Méth. II. 102, t. 133, fig. 1 (1793).

Bladhia glabra Thunberg, Fl. Jap. 350 (1784); in Trans. Linn. Soc. Il. 331 (1794).

Ardisia glabra A. De Candolle in Trans. Linn. Soc. XVII. 350 (1834); Prodr. VIII. 135 (1844).

Ardisia odontophylla Lindley in Bot. Reg. XXII. t. 1892 (non Wallich) (1836). Ardisia japonica, $\beta$ montana Miquel in Ann. Mus. Lugd.-Bat. II. 263 (1866). Ardisia montana Siebold ex Miquel, 1. c. (pro synon.) (1866).

Tinus japonica Kuntze, Rev. Gen. II. 405 (1891).

Tinus montana Kuntze, 1. c. 974 (1891).

Western Hupeh : Iehang, common, alt. 30-300 m., December 1907 (No. 670; 15-30 cm., fruit scarlet); without precise locality, A. Henry (Nos. 98, 2275, 7683). Western Szech'uan: Mt. Omei, August 1904 (Veitch Exped. No. 5063). Chekiang: Ningpo, 1908, D. Macgregor.

\section{MAESA Forsk.}

Maesa castaneifolia Mez in Engler, Pflanzenr. IV.-236, 44 (1902).

Central Szech'uan: Chung-chou, banks of Yangtze River, alt. 150 m., April 1908 (No. 3257; rambling bush 1-2 m., flowers white); Yangtze banks, April 1904 (Veitch Exped. No. 4059). Yunnan: Mengtsze, alt. 1500 m., A. Henry (Nos. 9464, 9464a , 10153); Mi-lê, A. Henry (No. $9464^{\text {b }}$ ); Szemao, alt. 1500 m., A. Henry (Nos. 11625, 11625 ).

The inflorescence in Wilson's No. 3257 is longer than in any of the flowering specimens from Yunnan, attaining a length of 6-7 cm. Mez in his key to Maesa places $M$. castaneifolia under the division "Sepala lineata" but in all the specimens before me, even in his type numbers, 1 find the sepals entirely destitute of dark lines. I also find the free part of the filament about as long as the very small anthers, while in the key Mez says "filamenta antheris subduplo vel ultra longiora."

\section{Maesa hupehensis Rehder, n. sp.}

Frutex glaber, 1-2-metralis, ramulis gracilibus glabris. Folia membranacea, oblongo-lanceolata v. lanceolata, sensim longe acuminata, basi late cuneata, margine indistincte remote serrata v. fere integra, $8-14 \mathrm{~cm}$., rarius ad $17 \mathrm{~cm}$. longa et $2-3.5$, rarius ad $6 \mathrm{~cm}$. lata, utrinque glabra, subtus paullo pallidiora, nervis utrinsecus 8-11 curvatis angulo acuto divergentibus subtus ut costa elevatis, supra, in sicco saltem, leviter elevatis ut costa; petioli 5-7 mm. longi, glabri, canaliculati. Flores albi, in racemis axillaribus simplicibus, erecto-patentibus 3-4 $\mathrm{cm}$. longis, pedunculatis pedunculo $0.5-1.5 \mathrm{~cm}$. longo; pedicelli gra- 
ciles, circiter $3 \mathrm{~mm}$. longi, basi bractea subulato-lanceolata dimidium pedicellum aequante suffulti, apice bracteolas duas lanceolatas circiter $1 \mathrm{~mm}$. longus gerentes; sepala ovata, acuta, margine minute denticulata, dorso lineata; petala fere ad medium connata, $2.5 \mathrm{~mm}$. longa, lobis late rotundatis, lineis paucis plerumque duobus interruptis pictis; antherae ovatae, utrinque emarginatae, prope basin dorsifixae, medium loborum attingentes, filamenta subaequantes; ovarium semisuperum, placenta multiovulata, stylo cylindrico sepala aequante, stigmate leviter 4-lobo. Fructus subglobosus, cireiter $5 \mathrm{~mm}$. longus, albus, in racemis 7-9 $\mathrm{cm}$. longis; pedicelli circiter $5 \mathrm{~mm}$. longi.

Western Hupeh: Changlo Hsien, ravines, alt. 300-600 m., May and Oetober 1907 (No. 764; flowers, type, and fruits).

Maesa hupehensis seems most closely related to $M$. castaneifolia Mez which is easily distinguished by its larger paniculate inflorescence, the obtuse sepals destitute of dark markings, and by the larger and broader distinctly serrate leaves. The fruiting specimen differs somewhat from the flowering specimen in its larger and broader leaves and in the longer inflorescence.

Maesa Wilsonii Rehder, n. sp.

Frutex glaber, 2-3-metralis, ramulis gracilibus leviter flexuosis. Folia membranacea, ovato-laneeolata v. lanceolata, sensim longe acuminata, basi late cuneata v. rotundata, margine indistincte et remote denticulata, $8-18 \mathrm{~cm}$. longa et $2.5-4.5 \mathrm{~cm}$. lata, utrinque glabra, supra laete viridia, subtus pallidiora, nervis utrinsecus 8-10 angulo acuto divergentibus, subtus ut costa distincte elevatis, supra in sicco leviter elevatis; petioli satis graciles, $0.6-1 \mathrm{~cm}$. longi, canalieulati. Inflorescentiae paniculatae, sparse ramosae, plerumque basi tantum racemis brevibus solitariis v. 2-3 institutae, rarius apicem ramulorum versus simplices, axi centrali plerumque infra medium floribus destituta, 6-10 cm. longae, graciles, cuneatae v. nutantes; pedicelli graeiles, 3-4 $\mathrm{mm}$. longi, basi bractea subulata $1 \mathrm{~mm}$. longa suffulti, apice bracteolis 2 lanceolatis instituti; sepala ovata, apice rotundata et subito in mucronum producta, margine minute erenulata, dorso lineata; petala fere ad medium connata, 3.5-4 $\mathrm{mm}$. longa, lobis rotundatis crenulatis lineis interruptis pietis; antherae ovatae utrinque emarginatae, medium loborum fere attingentes, prope basin dorsifixae, filamenta subaequantes; ovarium ad $2 / 3$ superum, placenta multi-ovulata, stylo sepala superante, stigmata leviter 4-fido. Fructus subglobosus, circiter $4 \mathrm{~mm}$. diam., albus, sepalis persistentibus et stylo exserto coronatus.

Western Szech'uan: Mt. Omei, June 1904 (Veitch Exped. No. 
4905, type); same locality, October 1903 (Veitch Exped. No. 4057); Ya-chou Fu, thickets, alt. 300-600 m., October 1908 (No. 3258).

Maesa Wilsonii is apparently most closely related to $N$. castaneifolia Mez which is easily distinguished by the smaller flowers, the obtuse not mucronulate sepals destitute of markings, the more branched inflorescence and the distinctly serrate broader leaves. From $M$. hupehensis Rehder it differs in its larger flowers, rounded and mucronate sepals, the paniculate longer inflorescence and in the style which is longer than the sepals. 


\title{
PLUMBAGINACEAE.
}

\author{
Determined by E. H. WiLson.
}

\section{CERATOSTIGMA Bge.}

Ceratostigma minus Stapf apud Prain in Jour. Bot. XLIV. 7 (1906). Ceratostigma Griffithii Pritzel in Engler, Bot. Jahrb. XXIX. 525 (non Clarke) (1900).

Western Szech'uan: near Monkong Ting, valley of Hsiao-chinho, alt. 2300-3600 m., June 30, 1908 (No. 23r5; shrub 0.3-0.8 m. tall, flowers blue); Wên-ch'uan Hsien, A. von Rosthorn (No. 3001).

In the arid valleys of the upper Tung and Yalung rivers and their tributaries this is a very common low-growing shrub. The upper parts of the branches are leafless or nearly so and are crowded with axillary and terminal flower clusters which collectively form a narrow panicle or false raceme. The flowers are small and clear sky-blue.

This species is undoubtedly very close to C. Griffithii Clarke, and may eventually prove to be only a glabrescent variety of that species. The plant called $C$. Polhilli by Bulley (in Gard. Chron. ser 3. XXX. 6 (nomen nudum) [1901]) very probably belongs here.

Ceratostigma Willmottianum Stapf in Bot. Mag. CXL. t. 8591 (1914).

Western Szech'uan: Wên-ch'uan Hsien, valley of Min River, alt. 1300-2000 m., July and November 1908 (No. 1373; shrub 0.6-1 m. tall, flowers cobalt blue); Mao-chou, dry regions, alt. $2000 \mathrm{~m}$., May and October 1908 (No. 2314; shrub 0.3-1 m. tall).

This shrub with beautiful blue flowers in terminal, solitary capitate clusters is abundant in the semi-arid regions of the Min River valley between 1200 and $2500 \mathrm{~m}$. altitude, but I did not meet with it elsewhere in western China.

Here may be added a note on a species collected by A. Henry.

Ceratostigma Griffithii Clarke in Hooker f., Fl. Brit. Ind. III. 481 (1882), Prain in Jour. Bot. XLIV. 7 (1906). - Diels in Not. Bot. Gard. Edinburgh, VII. 45, 194 (Pl. Chin. Forrest.) (1912).

Yunnan: Mengtsze, ravine, alt. 1500 m., A. Henry (No. 9586).

With its obovate-spatulate leaves hairy on both surfaces and the rufous pubescence on the shoots this plant agrees with Clarke's description. The specimen, however, is poor, being in young fruit. 


\section{EBENACEAE.}

Determined by Alfred ReHder and E. H. Wilson.

\section{DIOSPYROS L.}

7 Diospyros Lotus Linnaeus, Spec. 1057 (1753). - Pallas, Fl. Ross. II. 20, t. 58 (exclud. fig. H.), t. 59, fig. a, b, c (1788). - Loiseleur in Nouv. Duhamel, VI. 83, t. 26 (1813?). - Hance in Jour. Linn. Soc. XIII. (1873). - Hiern in Trans. Camb. Phil. Soc. XII. pt. 1, 223 (Monog. Eben.) (1873). - Brandis, Forest Fl. Brit. Ind. 297, t. 36 (1874); Ind. Trees, 432 (1906). - Franchet \& Savatier, Enum. Pl. Jap. I. 306 (1875). - Bretschneider, Early Europ. Research. Fl. China, 128 (1881). - Hemsley in Jour. Linn. Soc. XXVI. 70 (1889). - Diels in Engler, Bot. Jahrb. XXIX. 527 (1900). - Shirasawa, Icon. Ess. For. Jap. I. 123, t. 79 (1900). - Meyer in Bull. U. S. Dept. Agric. Bur. Pl. Indust. CCIV. 15, fig. 5, 6 (Agric. Explor. Orchards China) (1911). - Dunn \& Tutcher in Kew Bull. Misc. Inform. add. ser. X. 161 (Fl. Kwangtung. \& Hongk.) (1912). - Matsumura, Ind. Pl. Jap. II. pt. 2, 484 (1912). - Léveillé, Fl, Kouy-Tchéou, 145 (1914).

Dactylus trapezuntinus Forskal, Fl. Aegypt.-Arab. XXXVI. (1775).

Diospyros Kaki, Thunberg, Fl. Jap. 158 (1784).

Diospyros Kaki, glabra A. De Candolle, Prodr. VIII. 229 (1844).

Diospyros microcarpa Siebold in Ann. Soc. Hort. Pays-Bas, 1844, 28 (non Spanhoge).

Diospyros japonica Siebold \& Zuecarini in Abh. Akad. Münch. IV. pt. 3, 136 (Fl. Jap. Fam. Nat. II. 12) (1846).

Diospyros Umlovok Griffith, Itin. Not. 355, No. 137 (1848).

Diospyros Pseudo-Lotus Naudin in Nouv. Arch. Mus. Paris, sér. 2, III. 220 (1880).

Western Hupeh : north and south of Ichang, woodlands, alt. 6001500 m., May and October 1907 (No. 44I; tree 8-20 m. tall, 0.3-2 m. girth, fruit yellow); Changlo Hsien, woodlands, alt. 1000-1300 m., May and November 1907 (No. 62I ; tree 6-13 m. tall, 0.3-1.5 m. girth); Nanto and mountains to northward, A. Henry (No. 3014); without locality, A. Henry (Nos. 1914, 5820², 6235). Eastern Szech'uan: Wushan Hsien, woodlands, alt. 1000-1300 m., June and Oetober 1907 (No. $429^{\mathrm{a}}$; tree 5-16 m. tall, 0.3-2 m. girth); same locality, A. Henry 
(No. 7044). Western Szech'uan: Mien-chu Hsien, roadsides, alt. 600 m., May 19, 1908 (No. 29I5; tree $13 \mathrm{~m}$. tall, $1.5 \mathrm{~m}$. girth, flowers white); without locality, A. von Rosthorn (No. 2092). Yunnan: Mi-lê district, A. Henry (No. 9898); Mengtsze, A. Henry (Nos. 9898d, 9898 ${ }^{\circ}$. Chili: Peking, courtyard of Imperial Palace, September 18, 1903, C. S. Sargent; same locality, Temple grounds, Pagoda Hill, near Summer Palace, September 17, 1903, C. S. Sargent; " Nankow to Great Wall," October 5, 1905, J. G. Jack; "Ying-tan Ko, along a mountain stream," September 12, 1913, F. N. Meyer (Nos. 46, 1297); " near Changli," October 1905, F. N. Meyer (No. 183). Shensi: "Huo-kiaZaez," July 16, 1897, G. Giraldi; mountains near " Nanto-tchu," January 21, 1914, F. N. Meyer (No. 1391).

This tree is common in thickets and on the margins of woods in western Hupeh, where it is undoubtedly indigenous, and it is plentiful in the valleys of western Szech'uan. It grows to a large size and trees $26 \mathrm{~m}$. tall with trunks $4 \mathrm{~m}$. in girth are occasionally met with. The bark is striking, being very dark and deeply fissured and broken into thick, irregular, more or less square blocks. The yearold shoots are smooth and usually pale gray, but occasionally they are slightly purplish. The winter-buds are prominent, acute and glabrous. The leaves are dark shining green above, pale, even subglaucous beneath and vary considerably in the degree of pubescence. The subsessile globose fruit as it ripens changes to yellow and finally to bloomy purplish black. In central and western China this tree is colloquially known as the Kou-shihtzu and there as elsewhere in China and also in Japan it is used as the stock in grafting D. kaki Linnaeus.

Meyer states that his No. 1391 is D. kaki and is the "original wild persimmon." Our specimen of this number consists of leafless twigs with a number of adherent calyces, but the winter-buds show that it belongs to $D$. Lotus. We have not seen D. Balfouriana Diels in Not. Bot. Gard. Edinburgh, V. 209 (Pl. Chin. Forrest.) (1912), but Henry's No. 9898 D, which Diels says is very similar, is without doubt $D$. Lotus. Matsumura does not admit D. Lotus as indigenous to Japan and Wilson certainly saw no wild tree during his travels in Japan, though it is not uncommon in cultivation. In all probability this species was introduced with or at about the same time as D. kaki. Pictures of this tree will be found under Nos. 270, 570 of the collection of Wilson's photographs and also in his Vegetation of Western China, Nos. 204, 205.

Diospyros kaki Linnaeus f., Suppl. 439 (1781). - Thunberg, Fl. Jap. 157 (1784). - Loureiro, Fl. Cochin. 226 (1790). - Wight, Icon. Pl. Ind. Or. II. 415 t. (1843), - Hiern in Trans. Camb. Phil. Soc. XII. 227, fig. (Monog. Eben.) (1873). - Bretschneider, Early Europ. Research. Fl. China, 5, 23, 29 (1881). - Clarke in Hooker f., Fl. Brit. Ind. III. 555 (1882). - Hemsley in Jour. Linn. Soc. XXVI. 69 (1889); in Bot. Mag. CXXXIII. t. 8127 (1907); in Kew Bull. Misc. Inform. 1911, 235. - Sargent in Garden \& Forest, VI. 273 (1893); For. Fl. Jap. 50 (1894). - Diels in Bot. Jahrb. XXIX. 527 (1900). - F. N. 
Meyer in Bull. U. S. Dept. Agric. Bur. Pl. Indust. CCIV. 10, with plates and figs. (Agric. Explor. Orchards China) (1911). - Dunn \& Tutcher in Kew Bull. Misc. Inform. add. ser. X, 161 (Fl. Kwangtung \& Hongk.) (1912).

Diospyros chinensis Blume, Cat. Hort. Buitenz. 110 (nomen nudum) (1823).

Diospyros Schi-tse Bunge in Mém. Sav. Etr. Acad. Sci. St. Pétersbourg, II. 116 (Enum. Pl. Chin. Bor. 42) (1835).

Embryopteris Kaki G. Don, Gen. Syst. IV. 41 (1838).

Diospyros Kaki, $\beta$ cordata A. De Candolle, Prodr. VIII. 229 (1844).

Diospyros costata Carrière in Rev. Hort. 1870, 131, 410, t.

Diospyros Kaki, var. costata André in Ill. Hort. XVIII. 176, t. 78 (1871).

Diospyros Roxburghii Carrière in Rev. Hort. 1872, 253, fig. 28-29.

Diospyros Mazeli Carrière, 1. c. 1874, 70, t.

Diospyros lycopersicon Carrière, 1. c. 1878, 470, t.

Diospyros Kaempferi Naudin in Nouv. Arch. Mus. Paris, sér. 2, 111. 226, t. 10 (1880).

Diospyros Aurantium André in Rev. Hort. 1887, 349, t.

Diospyros Bertii André, 1. c. 1887, 349 t.

Diospyros elliptica André, 1. c. 1887, 349, t.

Diospyros Sahuti André, 1. c. 1887, 349, t.

Diospyros Kaki, f. grandifolia Diels in Bot. Jahrb. XXIX. 527 (1900).

Diospyros Kaki, $\boldsymbol{\beta}$ domestica Makino in Tokyo Bot. Mag. XXII. 159 (1908).

Western Hupeh: Changyang Hsien, alt. 1300 m., cultivated, May and November 1907 (No. 472; tree 6-20 m. tall, 0.3-2 m., girth, fruit ovoid, golden). Chili: near Peking, Yellow Temple, September 16, 1903, C. S. Sargent. Fokien: Dunn's Exped. April to June, 1905 (Herb. Bot. Gard. Hongkong No. 2912).

This fruit tree is generally cultivated all over China and from there has been introduced to Korea, Japan and other countries. The varieties are as numerous as those of the apple and pear in western lands. The fruits differ in size, shape, season of ripening, and in quantity or absence of seeds and in degree of astringeney. In central and western China the fruit is not considered edible until dead ripe and bletted, but in Japan there are varieties which have flesh firm as in an apple and which eaten in early October are not astringent. In Japan, where this tree has been long cultivated, many different varieties have originated and some are equal to the best of the Chinese varieties, but on the whole the persimmons of Japan are smaller than those of China, which are more or less ovoid and obtuse, fiattened, round and depressed forms being much less common.

In China and also in Japan this tree is usually grafted on Diospyros Lotus and the point of union of scion and stock is elearly indicated by the difference between the barks. In $D$. kaki it is pale gray and scales off, whereas in D. Lotus it is dark in color, deeply ridged and persistent.

In D. kaki individual trees bear purely male or female flowers, and others bear both male and female flowers on the same individual. The flowers vary greatly in size, and the calyx is extremely variable. So different are the male and female flowers in appearance and size that they appear to belong to different spe- 
cies. In many varieties at least fertilization is not necessary for the development of fruit and there are numerous seedless forms.

In northern China this fruit is known as "Schitsze," but the colloquial name varies in different parts of the country, though the written characters may be the same. It is figured by Boym in his Flora Sinensis t. M. (1656). In Japan it is known as "kaki" and it is described and figured by Kaempfer (Amoen. Exot. V. 807, fig. [1712]).

Much has been written to prove that the Japanese and Chinese Persimmons have been evolved from distinct species and different varieties have been given specific rank. From the evidence gleaned during his travels in China and Japan Wilson is of the opinion that all these different forms have originated from one common species and that the wild form of this species is to-day naturalized and spontaneous in western Hupeh and probably elsewhere in China.

A picture of this tree will be found under No. 675 of the collection of Wilson's photographs.

Diospyros kaki, var. silvestris Makino in Tokyo Bot. Mag. XXII. 159 (1908). - Matsumura, Ind. Pl. Jap. II. pt. 2, 484 (1912).

Diospyros Roxburghii Hemsley in Kew Bull. Misc. Inform. 1911, 236 (vix Carrière).

Western Hupeh: north and south of Iehang, thickets, margins of woods, alt. 300-1500 m., May and Oetober 1907 (Nos. 5II, 429, 29I3; tree 6-12 m. tall, girth 0.6-1.5 m., flowers creamy-white, fruit depressed, golden); same locality, A. Henry (Nos. 1502, 3485, 3441); Changlo Hsien, margins of woods, alt. 1000 m., May 1907 (No. 2914; tree $6 \mathrm{~m}$. tall). Szech'uan: banks of Yangtze River, May 1902 (Veitch Exped. No. 4060; bush $1 \mathrm{~m}$. tall, flowers white). Yunnan: Mengtsze, mountains north, alt. 1600 m., A. Henry (No. 9898 ; shrub $3 \mathrm{~m}$.); Szemao, woods and forests, alt. 1500-1600 m., A. Henry (Nos. $\left.9341,11618,11618^{\mathrm{b}}, 11618^{\circ}, 11618^{\mathrm{d}}\right)$. Korea: Quelpaert, in woods, May and June 1909, Taquet (Nos. 2933, 2978, 2980).

This tree, the wild type of the Chinese and Japanese Persimmons, is common as an escape everywhere in Hupeh and Szech'uan, and is spontaneous in thickets and on the margin of woods in western Hupeh. It is a small or moderately large tree with light gray bark which peels off in small irregular flakes or patehes. The year-old shoots are purplish gray and the winter-buds are small, obtuse or rounded and usually more or less pubescent. The leaves vary immensely in size and degree of hairiness. In shape they vary from lanceolate to broadly ovate and from narrowly cuneate to rounded or truncate at the base. These same variations are met with in the type, but as a rule the leaves on the cultivated plant are larger. The flowers show the same variation as in the type, but the female flowers are not so large and the ovary is often densely hairy. The fruit is small $(1.5-5 \mathrm{~cm}$. diam.), golden, ovoid or depressed and yields a valuable varnish-oil (see Wilson, A Naturalist in Western China, II. 73 [1913]), hence the colloquial name Yu-shih-tzu, i. e. "OilPersimmon." In Japan this tree occurs as an escape from cultivation only and it is not indigenous to Japan. This wild variety is often used in western China as a stock for the garden forms of edible Persimmon. 
Diospyros armata Hemsley in Jour. Linn. Soc. XXVI. 69 (1889). Bean in Kew Bull. Misc. Inform. 1913, 165.

Western Hupeh: north of Ichang, alt. 300 m., May 4, 1907 (No. 2912 ; tree $5-10 \mathrm{~m}$. tall, girth $0.5-1.5 \mathrm{~m}$., flowers creamy-white, fragrant); near Ichang, alt. 300 m., May 1907 (No. 3730; tree $13 \mathrm{~m}$. tall, flowers white, fragrant); Nanto and mountains to northward, $A$. Henry (No. 7717, type).

This is a very rare tree which is known to us from only one or two localities in western Hupeh. The male flowers are urn-shaped, creamy-white and delightfully fragrant; the leaves are very lustrous and dark green. On Henry's specimen in the Gray Herbarium the leaves are oblanceolate-oblong to lanceolate-oblong, but on our specimens which have male flowers the leaves vary from obovate to elliptic and elliptic-lanceolate. The winter-buds are very small, obtuse and pubescent. The tree is deciduous or subevergreen.

Diospyros sinensis Hemsley in Jour. Linn. Soc. XXVI. 71 (1889); in Hooker's Icon. XXIX. t. 2804 (1906).

Diospyros armata Diels in Bot. Jahrb. XXIX. 525, fig. 4 (non Hemsley) (1900).

Western Hupeh: cultivated, Temple garden, Ichang, April 1901 (Veitch Exped. No. 1902). Western Szech'uan: Wên-ch'uan Hsien, valley of Min River, alt. 1000 m., June 1, 1908 (No. 29ro; small tree, 3-8 m. tall); same locality, October 1910 (No. 46r 7; tree 3-10m. tall, 1-2.5 m. girth of trunk, fruit orange); same locality, alt. $1100 \mathrm{~m}$., August 1903 (Veitch Exped. No. 4062); Yachou Fu, alt. 600-1000 m., October 1910 (No. 46r6; bush 3 m., evergreen, fruit globose, golden); Kiating Fu: hills around city, June 1903 (Veitch Exped. No. 4061; small tree $5 \mathrm{~m}$. tall); Mt. Omei, alt. $1300 \mathrm{~m}$., E. Faber (No. 207, type).

This is a common small evergreen or subevergreen tree in the dry valleys of western Szech'uan. The short trunk is thick, the branches are very numerous and wide-spreading and the branchlets are spiny.

Diels (l. e.) has mistaken this plant for the rare and very closely allied $D$. armata Hemsley, which has shorter, more coriaceous oblong-oval to obovate leaves and the male flowers have shorter pedicels and are more numerous in the cyme.

Here may be added the description of two new species not collected during the Arnold Arboretum Expeditions.

Diospyros mollifolia Rehder \& Wilson, n. sp.

Arbor 5-6-metralis; rami graciles tomento cinereo v. rufo-cinereo dense obtecti, in secundo v. tertio anno glabrescentes, brunnei v. rubro-brunnei, lenticellati; gemmae parvae, obtusae, villosae. Folia chartacea, decidua v. interdum subpersistentia, elliptica, ovalia v. lanceolata, obtusa v. acuminata, mucronata, basi cuneata $\mathrm{v}$. rotundata, $2-6 \mathrm{~cm}$. longe et $1-2.5 \mathrm{~cm}$. lata, supra pustulata, plus minusve molliter adpresse pubescentia, subtus densius pubescentia, ciliata, nervis subtus elevatis; petioli $3-5 \mathrm{~mm}$. longi, dense villosi. Flores masculi plures in cymis axillaribus brevissime pedunculatis, albi; calyx villosus, $3 \mathrm{~mm}$. longus, 
profunde 5-partitus, lobis erectis, ovato-lanceolatis, acutis, 2-2.5 $\mathrm{mm}$. longis; corolla urceolata, $6-7 \mathrm{~mm}$. longa, costis pubescentibus, lobis 4-5, leviter patentibus et recurvis subacutis sparse eiliatis; stamina 16, acuminata, filamentis sparse pubescentibus; flores feminei desiderantur. Fructus immaturus ovoideus, adpresse pubescens, stylo breviter villoso apice 4-partito stigmatibus lobatis instructo coronatus, calyce 4-partito accrescente suffultus.

Western Szech'uan: valley of Tung River, alt. 700 m., May 1904 (Veitch Exped. No. 4063, type). Yunnan: Yuan-chiang, alt. 1150 m., A. Henry (No. 13303).

This species belongs to the section Danzleria Hiern and is very different from any other recognized species from China. It appears to us most closely related to $D$. cordifolia Roxburgh (D. montana, $\beta$ cordifolia Hiern), which has leaves usually more or less cordate at the base, longer petioles and peduncles, tetramerous flowers, differently shaped calyx-lobes and corolla and a glabrous ovary.

This new species is a rare plant in western Szech'uan and has been seen on only one occasion.

\section{Diospyros yunnanensis Rehder and Wilson, n. sp.}

Arbor 5-10-metralis; rami graciles, juniores pilis ferrugineis adpressis sparse obtecti, annotini glabri, fusco-brunnei, satis dense lenticellati; gemmae parvae, obtusae, pubescentes. Folia chartacea, ovato-lanceolata v. lanceolata, acuminata, mucronata, basi rotundata $\mathrm{v}$. late cuneata, $2.5-6 \mathrm{~cm}$., plerumque $3.5-4.5 \mathrm{~cm}$. longa et 1-2.3 cm. lata, pustulata, initio utrinque sparse adpresse pilosa, demum margine ciliato et costa media subtus sparse pilosa exceptis glabra v. fere glabra, utrinsecus nervis $4-6$ arcuatis subtus ut costa elevatis; petioli $2-3 \mathrm{~mm}$. longi, adpresse pilosi. Flores masculi $1-3$ in cymis brevissime pedunculatis; ealyx $3.5 \mathrm{~mm}$. longus, profunde 4-partitus lobis ovato-lanceolatis acuminatis erectis $3 \mathrm{~mm}$. longis adpresse pubescentibus; corolla urceolata, $5 \mathrm{~mm}$. longa, costis pubescentibus, lobis brevibus rotundatis; stamina 16, antheris oblongis apiculatis, filamentis sparse pilosis; flores feminei solitarii, axillares, subsessiles; calyx 4-partitus, $8 \mathrm{~mm}$. longus, sparse pubescens, lobis lanceolatis acutis, $6-6.5 \mathrm{~mm}$. longis patentibus, margine leviter revolutis; corolla campanulata, costis pubescentibus, $5 \mathrm{~mm}$. longa, 4-loba, lobis rotundatis patentibus $2 \mathrm{~mm}$. longis; staminodia 5, glabra; pistillum $3.5 \mathrm{~mm}$. longum, ovario ovoideo glabro, stylo 4-fido sparse piloso, stigmatibus apice leviter bilobis. Fructus subglobosus, circiter $1.2 \mathrm{~cm}$. diam., glaber.

Yunnan: Szemao, forests, alt. 1300-1600 m., A. Henry (Nos. 12984 ô, 12984 A. o, 13288, fruit, type); Mengtsze, mountains southwest, alt. $1600 \mathrm{~m} .$, A. Henry (No. 10938).

This species belongs to the section Danzleria Hiern, and is apparently distinct and not closely related to any other Chinese species. It is characterized by its thin glabrescent, short, petiolate leaves which dry black, by its very shortpeduncled tetramerous flowers, by the spreading, narrow calyx-lobes in the female flowers and by its small glabrous fruit. It may be compared with D. mollifolis Rehder and Wilson, described above, which is perhaps its nearest ally. 


\title{
SYMPLOCACEAE.
}

\author{
Determined by ALFRed REHDER.
}

\section{SYMPLOCOS Jacq.}

Symplocos paniculata Wallich ex D. Don, Prodr. Fl. Nepal. 145 (pro synon.) (1825). - Wallich, Cat. No. 4429 (nomen nudum) (1830). Miquel in Ann. Mus. Lugd.-Bat. III. 102 (1867); Prol. Fl. Jap. 266 (1867).-Makino in Bot. Mag. Tokyo, XVIII. 112 (1904). - Schneider, Ill. Handb. Laubholzk. II. 576, fig. 375 a-g (1911).

Prunus paniculata Thunberg, Fl. Jap. 200 (1784).

Symplocos crataegoides Hamilton apud D. Don, Prodr. Fl. Nepal. 145 (1825). A. De Candolle, Prodr. VIII. 258 (1844), - Brandis, Forest Fl. Brit. Ind. 299 (1874); Ind. Trees, 440 (1906).-Kurz, Forest Fl. Brit. Burma, II. 143 (1877). - Clarke in Hooker f., Fl. Brit. Ind. III. 573 (1882). - Hemsley in Jour. Linn. Soc. XXVI. 72 (1889). - Gürke in Engler \& Prantl, Nat. Pflanzenfam. IV. Abt. 1, 169 (1890). - Rehder in Möller's Deutsch. Gärtn.Zeit. XVI. 100, 2 fig. (1901), - Brand in Bot. Jahrb. XXIX. 528 (1900); in Engler, Pflanzenr. IV.-242, 33 (1901). - Collett, Fl. Siml. 305, fig. 95 (1902). - Shirasawa, Icon. Ess. For. Jap. II. t. 68, fig. 1-13 (1908). Léveillé, Fl. Kouy-Tchéou, 409 (1915).

Palura odorata Hamilton ex D. Don, Prodr. Fl. Nepal. 145 (pro synon.) (1825).

Lodhra crataegoides, Jacquemont, Voy. IV. 103, t. 110 (1844).

Symplocos pallida Franchet \& Savatier, Enum. Pl. Jap. I. 308 (1875).

Kiangsi: Kuling, abundant, alt. 1300 m., July 28, 1907 (No. I720; bush 1.5-3 m. tall); north and south of Ichang, common, alt. 300-2800 m., April, May, June, September and October 1907 (No. 2536; bush 1-4 m. tall, flowers white, fruit blue); same locality, A. Henry (No. 2301 ${ }^{\mathrm{a}}$ ); Changyang Hsien, alt. 1300-2000 m., June and October 1907 (No. 360; bush 3-5 m. tall); Nanto and mountains to the northward, A. Henry (No. 2998); “Ma-pan-scian," alt. 1000 m., May 1907, " monte Triora," alt. 1950 m., July 3, 1907, " Kao-kien-scian," alt. 800 m., C. Silvestri (Nos. 1762, 1763, 1764); without precise locality, April and June 1900, September 1901 (Veitch Exped. Nos. 76, 956); without precise locality, A. Henry (Nos. 270, 1149, 1762, 2853, 5755 ${ }^{\text {b }}$, $\left.5755^{\mathrm{c}}, 6279,7723\right)$. Szech'uan: without precise locality, A. Henry (Nos. 5492, 5755, 5760). Western Szech'uan: near Tachien-lu, thickets, alt. 1600-2300 m., June and October 1908 (No. r29I; bush 
$2 \mathrm{~m}$. tall, flowers white, fruit blue); southeast of Tachien-lu, thickets, alt. 2000-2300 m., June 1908 (No. 2535; bush $7 \mathrm{~m}$. tall, flowers white); Wa-shan, open country, alt. 1000-1600 m., June 1908 (No. 2536 ; bush 1.5-2 m. tall, flowers white); Mt. Omei, May 1904 (Veitch Exped. Nos. 5069, 5069a); Nanch'uan, A. von Rosthorn (No. 1820). Yunnan: south of Red River from Manmei, alt. 2000 m., A. Henry (No. 9466); Mi-lê district, mountain forest, A. Henry (No. 9948); Mengtsze, alt. 1600-2300 m., A. Henry (Nos. 9466 b ${ }^{\text {, 9948 }}$, 10554); Szemao, alt. 1600 m., A. Henry (No. 11671). Northern Shensi: "Lao-y-san," June 4, 1897, G. Giraldi; " monte Kan-y-san ad ovest del Lao-y-san," June 11-12, 1897, G. Giraldi. Shantung: Lau-shan, August 1907, $F . N$. Meyer (No. 320). Chekiang: vicinity of Ningpo, 1900, D. Macgregor. Fokien: Dunn's Exped., April to June 1905 (Hongkong Herb. No. 2909). Formosa: South Cape, A. Henry (No. 635); Mt. Taitum, May 1903, M. Faurie (No. 314). Mandshuria: Shengking, June 27, 1906, F. N. Meyer. Also in Korea, Japan and the Himalaya.

There can be no doubt that Prunus paniculata Thunberg is the Symplocos crataegoides Hamilton. Professor $\mathrm{O}$. Juel of Upsala kindly compared specimens of Symplocos which I had sent to him with Thunberg's original specimen and pronounced them identical; he also sent me a photograph of Thunberg's type specimen which fully corroborated his statement.

Symplocos paniculata is an exceedingly variable species of wide distribution, ranging from the Himalayas through China to Korea and Japan. There seem to be, however, no marked geographical varieties, and the extremes in the shape and pubescence of the leaves are so closely connected by intermediate forms that it seems to be useless to distinguish varieties or forms.

\section{Symplocos laurina Wallich, Cat. No. 4416 (1830).}

Myrtus laurinus Retzius, Observ. 26 (1786).

Eugenia laurina Willdenow, Spec. II. 967 (1799).

Myrtus serratus Koenig ex Steudel, Nomencl. 321 (pro synon. Eugeniae laurinae) (1821).

Bobua laurina, De Candolle, Prodr. III. 24 (1828). - Miers in Jour. Linn. Soc. XVII. 303 (1880).

Symplocos Loha Hamilton apud D. Don, Prodr. Fl. Nepal. 144 (1825). De Candolle, Prodr. VIII. 255 (1844).

Symplocos subspinosa Hamilton ex D. Don, Prodr. Fl. Nepal. 144 (pro synon. S. Loha) (1825).

Symplocos spicata Roxburgh, Cat. Hort. Beng. 40 (nomen nudum) (1814); Fl. Ind. ed. 2, II. 541 (1832). - A. De Candolle, Prodr. VIII. 254 (pro parte) (1844), var. $\beta$ Zeylanica excludenda. - Wight, Ill. II. t. 150 (1851).Brandis, Forest Fl. Brit. Ind. 300 (1874); Ind. Trees, 441 (1906). - Kurz, Forest Fl. Brit. Burma, II. 146 (1877); in Jour. As. Soc. Beng. XLVI. pt. 2, 239 (1877). - Clarke in Hooker f., Fl. Brit. Ind. III. 573 (1882), var. attenuata excludenda. - Brand in Engler, Pfanzenr. IV.-242, 39 (1901). Léveillé, Fl. Kouy-Tchéou, 410 (1915). 
Dicalix spicatus Blume, Bijdr. 1118 (1826).

Symplocos polycarpa Wallich, Cat. No. 4423 (nomen nudum) (1830).

Symplocos atroviridis Wallich ex A. De Candolle, Prodr. VIII. 254 (pro synon.) (1844).

Symplocos xanthophylla Junghuhn \& De Vriese in De Vriese, Pl. Nov. Ind. Bat. 11 (1845).

Symplocos theophrastaefolia Siebold \& Zuccarini in Abh. Akad. Münch. IV. pt. III. 134 (Fam. Nat. Fl. Jap. II. 10) (1846).

Symplocos spicata Roxburgh, var. gracilis, Zollinger, Syst. Verz. 136 (1854).

Symplocos rufescens Thwaites, Enum. Pl. Zeyl. 184 (1860).

Hopea spicata Dalzell \& Gibson, Bombay Fl. 140 (1861).

Lodhra Lohu Miers, in Jour. Linn. Soc. XVII. 298 (1880).

Lodhra spicata Miers, 1. c. 298 (1880).

Lodhra polycarpa Miers, 1. c. 301 (1880).

Lodhra rufescens Miers, 1. c. 301 (1880).

Lodhra xanthophylla Miers, 1. c. 302 (1880).

Bobua oligostachya Miers, l, c. 304 (1880).

Bobua atroviridis Miers, 1. c. 304 (1880).

Symplocos flavida Miquel ex Clarke in Hooker, Fl. Brit. Ind. III. 573 (pro synon.) (1882).

Western Szech'uan: Kiating Fu, common, alt. 300-600 m., September and November 1908 (Nos. 2537, 2538; thin tree, 7-12 m. tall, girth 0.30-0.45 m., flowers white, fragrant); same locality, June 1903 (Veitch Exped. No. 4070); Mt. Omei, September 1904 (Veitch Exped. No. 5066); same locality ("Mt. Uo-mi-sam "), Hugh Scallan.

Symplocos caudata Wallich, Cat. 4413 (nomen nudum) (1830). A. De Candolle, Prodr. VIII. 256 (1844), - Clarke in Hooker f., Fl. Brit. Ind. III. 577 (1882). - Brand in Bot. Jahrb. XXIX. 528 (1900); in Engler, Pfanzenr. IV.-242, 42 (1901).

Symplocus prunifolia Siebold \& Zuccarini in Abh. Akad. Münch. IV.pt. II. 133 (Fam. Nat. Fl. Jap. I. 9) (1845), - Miquel in Ann. Mus. Lugd.-Bat. III. 101 (1867); Prol. Fl. Jap. 265 (1867). - Shirasawa, Icon. Ess. For. Jap. II. t. 66 , fig. 1-10 (1908).

Symplocos Swinhoeana Hance in Ann. Sci. Nat. sér. 4, XV. 226 (1861).

Western Hupeh: Changyang Hsien, woods, alt. 1000-1300 m., May 1907 (Nos. 2546, 2548; bush $2.5 \mathrm{~m}$. tall, flowers white); without precise locality, April 1900 (Veitch Exped. No. 6); without precise locality, A. Henry (Nos. 5292, 5319). Western Szech'uan: Mt. Omei, alt. 2000 m., October 1903 and June 1904 (Veitch Exped. Nos. 4068, 5067); Kiating Fu, October 1903 (Veitch Exped. No. 4069). Chekiang: vicinity of Ningpo, 1908, D. Macgregor. Also in Quelpaert, Korean Archipelago (U. Faurie, No. 1889; Taquet, Nos. 284, 1107), in Japan and on the Himalaya. 
Symplocos myriantha Rehder, n. sp.

Arbor 10-metralis ramulis gracilibus; ramuli hornotini purpurascentes, sparse fulvo-strigosi, annotini fusco-purpurei, glabri, lenticellis sparsis minutis conspersi. Folia chartacea, persistentia, elliptica v. oblongo-elliptica, subito acuminata, basi late cuneata, juniora denticulata denticulis initio glandula elongato-conica leviter curvata mox decidua munitis, demum indistincte repando-denticulata, 5-8 $\mathrm{cm}$. longa et $2.5-4 \mathrm{~cm}$. lata, luteo-viridia, supra glabra, subtus vix pallidiora, initio praesertim ad nervos sparsissime strigosa, demum glabra, nervis utrinsecus 4-6 supra ut costa impressis subtus elevatis, venulis inconspicuis; petioli canaliculati, circiter $1 \mathrm{~cm}$. longi, initio sparse strigosi, demum glabri. Paniculae axillares, subsessiles, ramosae, patulae, multiflorae, $1.5-2 \mathrm{~cm}$. longae et $1.5-2.5 \mathrm{~cm}$. diam.; rhachis ut pedicelli bracteae, ovaria dense fulvo-strigosa; bracteae et bracteolae minutae lanceolatae, acutae; flores parvi, albi, paullo ultra $5 \mathrm{~mm}$. diam., sessiles v. subsessiles v. inferiores breviter pedicellati; calycis lobi rotundati v. late ovati, ciliolati, glabri v. basin versus sparse strigosi tubo dense strigoso breviores, $1 \mathrm{~mm}$. longi; corolla $3 \mathrm{~mm}$. longa lobis ovalibus apice saepe eroso-denticulatis; stamina pentadelpha, circiter 50, corollae subaequilonga; stylus glaber; ovarium 3-loculare. Fructus desideratur.

Western Szech'uan: Wa-shan, woods, alt. 1300-1600 m., June 1908 (No. 2550).

This species seems to be most closely related to $S$. adenophylla Wallich, which is easily distinguished by the narrower and longer leaves, by the lanceolate acute calyx-lobes, the glabrous ovary and by the 25 stamens. It is very different from any of the Chinese species known to me.

Symplocos botryantha Franchet in Nouv. Arch. Mus. Paris, sér. 2, X. 60 (Pl. David. II. 98) (1888). - Brand in Engler, Pflanzenr. IV. $-242,60$ (1901).

Western Hupeh: Changlo Hsien, woods, alt. 600-1000 m., May 1907 (No. 2549; bush 2-3 m., flowers white); without precise locality, April 1901 (Veitch Exped. No. 1802), A. Henry (No. 5357). Eastern Szech'uan: Wu-shan Hsien, A. Henry (No. 5272 ${ }^{\text {b }}$. Western Szech'uan: Mt. Omei, alt. 1300 m., E. Faber (No. 87). Fokien: Dunn's Exped., April to June, 1905 (Hongkong Herb. No. 2903).

Symplocos anomala Brand in Bot. Jahrb. XXIX. 529 (1900); in Engler, Pflanzenr. IV.-242, 67 (1901).

Western Szech'uan: Omei Hsien, thickets, alt. 1000-1500 m., 
September 1908 (No. 2545; bush 1.2-2 m. tall, flowers white); Nanch'uan, A. von Rosthorn (Nos. 798, 2167). Western Hupeh: Patung Hsien, thickets, alt. 1000 m., September 1907 (No. 2547, in part; bush 2-3 m. tall, flowers white); Changlo Hsien, thickets, alt. $1000 \mathrm{~m}$., September 1907 (No. 2547, in part; bush 2-3 m. tall, flowers white); Nanto, August 1900 (Veitch Exped. No. 1672); without precise locality, September 1901 (Veitch Exped. No. 2580); A. Henry (Nos. 6691, $7440)$.

Symplocos stellaris Brand in Bot. Jahrb. XXIX. 528 (1900); in Engler, Pflanzenr. IV.-242, 68 (1901).

Symplocos Wilsoni Hemsley in Kew Bull. Misc. Inform. 1906, 161.

Kiangsi: Kuling, thickets, rare, alt. 1300 m., July 28, 1907 (No. I7I5; bush $2 \mathrm{~m}$. tall). Western Szechu'uan: Mupin, woods, alt. 1600 m., July 1908 (No. 2543; bush 2-3 m. tall): Wa-shan, woods, alt. 1600 m., June 1908 (No. 2544; large bush, 8 m. tall, flowers white); without precise locality, May 1904 (Veitch Exped. No. 4067, type of S. Wilsoni); Nanch'uan, A. von Rosthorn (No. 135). Fokien: Dunn's Exped., April to June 1905 (Hongkong Herb. No. 2906).

Symplocos javanica Kurz in Jour. As. Soc. Bengal. XI. 2, 64 (1871); Forest Fl. Brit. Burm. II. 145 (1877).

Dicalix javanicus Blume, Bijdr. 1117 (1826).

Dicalix aluminosus Blume, l. c. (pro parte) (1826).

Dicalix salaccensis Blume, 1. c. (1826).

Symplocus polystachya Wallich, Cat. No. 4428 (nomen nudum) (1830).

Symplocos mollis Wallich, 1. c. No. 4433 (nomen nudum) (1830).

Symplocos ferruginea Roxburgh, Hort. Beng. 40 (nomen nudum) (1814); Fl. Ind. ed. 2, II. 542 (1832). - Wallich, Cat. No. 4412 (nomen nudum) (1830). G. Don, Gen. Syst. IV. 2 (1837). - A. De Candolle, Prodr. VIII. 257 (1844). - Clarke in Hooker f., Fl. Brit. Ind. III. 574 (1882). - Koorders \& Valeton in Mededel. Lands. Plantent. XLII. 141 (Bijdr. Boomsort. Java VII.) (1900). - Brand in Engler, Pflanzenr. IV.-242, 40 (1901). - Brandis, Ind. Trees, 441 (1906).

Symplocos Verhuellii Junghuhn \& De Vriese in De Vriese, Pl. Nov. Ind. Bat. 12 (1845).

Symplocos salaccensis Miquel, Fl. Ind. Bat. II. 466 (1856-59).

Symplocos lachnobotrya Miquel, Fl. Ind. Bat. Suppl. 475 (1860).

Symplocos Horsfieldiana Miquel, 1. e. (1860).

Lodhra ferruginea Miers in Jour. Linn. Soc. XVII. 299 (1880).

Lodhra polystachya Miers, l. c. 300 (1880).

Lodhra Verhuelli Miers, 1. c. 302 (1880).

Lodhra javanica Miers, 1. c. 302 (1880).

Dicalyx (?) tinctorius Zollinger ex Koorders \& Valeton, in Mededel. Lands. Plantent. XLII. 141 (Bijdr. Boomsort. Java VII.) (pro synon.) (1900). 
Western Szech'uan: Kiating, common, alt. 300-600 m., September 1908 (No. 2537 ${ }^{\mathrm{a}}$; thin tree, 7-10 m. tall, flowers white); same locality, alt. 300-800 m., September 1908 (No. 2539; small tree, 5-8 m. tall, evergreen, flowers white, fragrant). Kwangtung: Hainan, $A$. Henry (No. 8713).

Here may be added the description of three new species collected by A. Henry in Yunnan.

Symplocos tetramera Rehder, n. sp.

Arbor 12-14-metralis glaberrima; ramuli angulati, glabri, flavido-cinerei. Folia coriacea, persistentia, elliptica, breviter et obtusiuscule acuminata, basi late cuneata, minute et obscure denticulata denticulis fere ad glandulam adustam reductis, 5-7.5 $\mathrm{cm}$. longa et $2.5-3.5 \mathrm{~cm}$. lata, glaberrima, supra luteoviridia, subtus pallidiore, costa media supra manifeste impressa, nervis utrinsecus 6-7 supra leviter v. vix impressis subtus leviter elevatis. Flores in fasciculis axillaribus 1020-floris, polygamo-dioeci ? (masculi tantum visi); pedicelli graciles 1-4 mm. longi; calyx cupularis, 4-lobus, lobis semiorbicularibus minute ciliolati, ceterum glabri, corolla tubo brevissimo, lobis 4 oblongis obtusis patentibus vix $3 \mathrm{~mm}$. longis; stamina 4, petala subaequantia; rudimentum pistilli subglobosum, sepala paullo superans, basi tantum tubo calycis adnatum. Fructus desideratur.

Yunnan: Puerh Fu, alt. 1600 m., A. Henry (No. 13273).

This remarkable species is not closely related to any Asiatic species, but seems nearest to the South American S. tetrandra Martius and S. variabilis Martius which both belong to the section Barberina of the subgenus Epigenia, characterized by polygamous flowers and 4-25 free stamens. The individual flowers look very much like those of S. tetrandra as figured in the Flora Brasiliensis (VII. t. 14, fig. 1) except that the style is wanting, while the shape of the calyx and of the rudimentary ovary resembles closely that of $S$. variabilis figured in the same work (VII. t. 11, fig. 3 and 4) except that there are only 4 stamens in our plant. In foliage our species resembles the Chinese $S$. decora Hance so elosely that without flowers it might be taken for it. The occurrence in Asia of a species belonging to the subgenus Epigenia known before only from South America and the West Indies forms a parallel case to S. tinctoria L'Héritier which is the only American species of the otherwise purely Asiatic subgenus Hopea.

\section{Symplocos pilosa Rehder n. sp.}

Arbor 3-metralis; ramuli hornotini dense flavido-pilosi, secundo anno tarde glabrescentes, vetustiores glabri fusco-purpurei. Folia papyracea, partim subpersistentia, oblonga v. oblongo-lanceolata, basi rotundata, satis longe acuminata, serrulata, $7-15 \mathrm{~cm}$. longa et $2.5-4.5 \mathrm{~cm}$. lata, supra laete viridia, glabra, subtus ad nervos venulasque pilosa, nervis utrinsecus $7-10$, supra ut costa media impressis, subtus elevatis; petioli dense pilosi, circiter $5 \mathrm{~mm}$. longi. Racemi axillares praecipue in basi ramulorum numerosi, plerumque basi ramosi, interdum simplices, 2.5-4 cm. longi, rhachide, pedicellis, bracteis, tubo calycis dense flavido-pilosis; pedicelli 1-2 $\mathrm{mm}$. longi, rarius inferiores longiores; bracteae lanceolatae, circiter 4 $\mathrm{mm}$. longae, intus glabrae; bracteolae lineari-lanceolatae, $2-2.5 \mathrm{~mm}$. longi, circiter dimidios lobos calycis attingentes; calycis lobi ovati, obtusi, $2 \mathrm{~mm}$. longi, tubum paullo superantes, longe eiliati, intus glabri, extus sparse pilosi, patentes; corolla fere ad basin partita, lobis ovali-oblongis, obtusis, $5 \mathrm{~mm}$. longis; stamina circiter 50 , longiora corollam dimidio longiora, basi tantum coalita, indistincte pentadelphia, filamentis filiformibus glabris, antheris subglobosis; ovarium apice glabrum, 3- 
loculare; stylus glaber, $7 \mathrm{~mm}$. longus, stamina longiora subaequans. Fructus desideratur.

Yunnan: Mengtsze, south mountain forests, alt. 2600 m., A. Henry (No. 10698).

This very distinct species is distinguished by its densely pilose branches and pilose inflorescences which are racemose and branched at the base and by the nearly membranous leaves, pilose beneath. It seems to belong near $S$. javanica Kurz and $S$. laurina Wallich, but differs considerably from these species in its dense pilose pubescence and in the thinner leaves rounded at the base. Like in S. myriantha Rehder most of the flowers are borne on the lower part of the branchlets below the foliage leaves.

\section{Symplocos longipetiolata Rehder, n. sp.}

Arbor parva, 5-metralis; ramuli giabri, flavido-cinerei; gemma terminalis aeuta glabra. Folia coriacea persistentia, elliptico- v. oblongo-lanceolata, acuminata, basi cuneata, 8-12 $\mathrm{cm}$. longa et $2.5-4 \mathrm{~cm}$. lata, integra, glaberrima, supra luteoviridia, subtus flavescentia, costa media supra impressa subtus elevata, nervis utrinsecus 9-10 supra leviter v. vix impressis subtus elevatis; petioli glabri, supra canaliculati, $1,5-2 \mathrm{~cm}$. longi. Flores in sicco albidi, in spicis axillaribus densís multifloris, $2.5-3 \mathrm{~cm}$. longis, sessiles $\mathrm{v}$. brevissime pedicellati; rhachis, bracteae bracteolae dence fulvo-sericeo-villosae; bracteae rotundatae concavae, 5-6 mm. diam.; bracteolae dimidio breviores, lanceolatae; calycis tubus turbinatus, glaber, $1.5 \mathrm{~mm}$. longus, lobi ovati v. ovato-oblongi, obtusi, pallidi, inaequales, tubo circiter dimidio $\mathrm{v}$. interdum paullo tantum breviores; corollae lobi ovali-oblongi v, oblongi, circiter $5 \mathrm{~mm}$. longi, $2.5-3 \mathrm{~mm}$. lati; stamina eireiter 50 , indistincte pentadelphia, valde inaequalia, longiora corolla triente longiora; ovarii apex minute pubescens; stylus glaber, corolla paullo brevior. Fructus desíderatur.

Yunnan: Mengtsze, northern mountain forests, alt. 3000 m., A. Henry (No. 10874).

This species seems nearest to $S$. botryantha Franchet and $S$. decora Hance, but is easily distinguished by the quite entire, acutely acuminate leaves and the sessile or nearly sessile flowers, with about 50 stamens. It also resembles in its foliage $S$. Wilsonii Brand (not $S$. Wilsonii Hemsley which is $S$. stellaris Brand). 


\section{OLEACEAE. ${ }^{1}$}

Determined by Alfred ReHder.

\section{LIGUSTRUM L.}

Ligustrum acutissimum Koehne in Festschrift Siebzig. Geburtst. Ascherson, 192, fig. 1 a (1904); in Fedde, Rep. Spec. Nov. I. 8, fig. 1 a (1905). - Schneider, Ill. Handb. Laubholzk. II. 806, fig. 505 m-n ${ }^{2}$ (1911).

Ligustrum Ibota Hemsley in Jour. Linn. Soc. XXVI. 21 (non Siebold) (1889), quoad specimina Hupehensia.-Diels in Bot. Jahrb. XXIX. 532 (1900).

Western Hupeh: north and south of Ichang, thickets, alt. 6001200 m., June, July and September, 1907 (No. 315; bush about $2 \mathrm{~m}$. tall, flowers white, fruit black); Hsing-shan Hsien, thickets, alt. 3001600 m., June and November 1907 (No. 3I $5^{\mathrm{a}}$; bush 2-3 m. tall, flowers white); Fang Hsien, thickets, side of streams, alt. 300-1000 m., May 28, 1907 (No. 3503; bush 1-3 m. tall, flowers white); without precise locality, June 1900 (Veitch Exped. No. 938), A. Henry (Nos. 5881, $6583,7158,7447)$. Kiangsi: Kuling, thickets, common, alt. $1300 \mathrm{~m}$.; July 28, 29, 31, 1907 (Nos. 1633, 1638, 1640; bushes 1-2 m. tall); same locality, alt. 1200 m., August 1, 1907 (No. 1593; bush 2 m. tall, with wild insect white wax (peh-la).

This species seems to be as variable in its pubescence and in the shape of its leaves as $L$. ibota Siebold to which it is closely related; Henry's No. 7158 and the specimens from Kiangsi except No. 1633 have nearly glabrous leaves sometimes, particularly on the flowering branches, obtuse and rather broad. On some fruiting specimens as on Henry's No. 7447 and Wilson's No. 1633 the calyx and pedicels show traces of pubescence. The glabrescent specimens from Kiangsi and No. 7158 from Hupeh which are all in immature fruit may belong to $L$. ibota, but differ from that species in their more pointed leaves and in the generally narrower inflorescence.

Ligustrum expansum Rehder, n. sp.

Frutex circiter 3-metralis (secundum cl. Wilson); ramuli hornotini sparse pilosi v. fere glabri, teretes, annotini pallide flavo-cinerei sparsissime lenticellati. Folia membranacea, elliptico-oblonga v. lanceolato-oblonga, utrinque sensim attenuata, apice saepius longe acuminata,

${ }^{1}$ See also vol. I. 297-302 and vol. II. 258-262. 
v. obovato-oblonga ad obovata, acuminata, basi cuneata, 6-12 $\mathrm{cm}$. longe et 2-3.5 $\mathrm{cm}$. late v. latiora 7-12 $\mathrm{cm}$. longa et $4.5-5.5 \mathrm{~cm}$. lata, supra glabra, subtus tota facie plus minusve villosa, interdum glabrescentia et tantum basin versus et secus nervos villosa, nervis utrinsecus $6-8$ subtus vix v. leviter elevatis; petioli $0.5-1.2 \mathrm{~cm}$. longi, sparse pilosi v. glabri. Inflorescentia paniculata, ampla et laxa, 10-18 $\mathrm{cm}$. longa et $12-16 \mathrm{~cm}$. lata, in parte inferiore saepe bracteis foliaceis instructa, rhachi et ramulis teretibus breviter plerumque biseriatim pilosis; flores in axibus tertii et secundi ordinis solitarii v. basin versus 2-3-fasciculati, breviter pedicellati v. fere sessiles; pedicelli glabri; ealyx truncatus v. indistincte dentatus, glaberrimus; corolla hypocraterimorpha, 8-9 mm. longa, tubo lobis ovatis $3-4 \mathrm{~mm}$. longis demum reflexis plerumque duplo longiore; stamina exserta, filamentis dimidios lobos superantes $\mathrm{v}$. interdum lobos fere aequantes, antheris oblongis exsertis et demum saepe subhorizontalibus. Fructus ignotus.

Western Hupeh: without precise locality, A. Henry (No. 5908, type, 5908'); Hsing-shan Hsien, side of streams, alt. $1300 \mathrm{~m}$., June 1907 (No. 3504).

This is a very distinct species and resembles in general appearance $L$. robustum Hooker f. \& Thomson which, however, is easily distinguished by the glabrous leaves and the smaller corolla with a short tube. It also suggests a species of Syringa, particularly of the section Villosae, but none of the species with elongated corollatube have exserted stamens.

Ligustrum Henryi Hemsley in Jour. Linn. Soc. XXVI. 90 (1889). Koehne in Festschr. Siebzig. Geburtst. Ascherson, 203, fig. 4a (1904). Schneider, Ill. Handb. Laubholzk. II. 808, fig. 509 f-i, 510 a (1911).

Western Hupeh: Hsing-shan Hsien, ravines, alt. 300-1000 m., August and December 1907 (No. 699; bush 2-4 m. tall, flowers white, fruit black); near Ichang, A. Henry (Nos. 3124, 3310, 3575).

Ligustrum Delavayanum Hariot in Jour. de Bot. XIV. 172 (1900). Boucher in Rev. Hort. 1901, 495, fig. 221. - Schneider, Ill. Handb. Laubholzk. II. 799 (1911).

Ligustrum Prattii Koehne in Festschr. Siebzig. Geburtst. Ascherson, 203, fig. $4^{\mathrm{b}}$ (1904); in Fedde, Rep. Spec. Nov. I. 11, fig. 4 (1905). - Schneider, Ill. Handb. Laubholzk. II. 808, fig. 509 k-1, 510 b (1911).

Western Szech'uan: Wa-shan, thickets, alt. $1300 \mathrm{~m}$., June and October 1908 (No. 1075 ; bush 2-3 m. tall, flowers white, fruit blueblack); same locality, October 1908 (No. 3732; bush 2-3 m. tall; fruit blue-black); north of Tachien-lu, side of streams, alt. $2600 \mathrm{~m}$., October 1910 (No. 4592; bush $2 \mathrm{~m}$. tall); Mupin, thickets, alt. 1300 m., October 
1908 (No. I075; bush 2-3 m. tall, fruit blue-black); same locality, side of streams, alt. 1000-1600 m., June and November 1908 (No. I290; bush 1.5-2.5 m. tall, flowers white); without precise locality, July 1904 (Veitch Exped. No. 4083); Nanch'uan, "Chao-chia-ai," September 29, 1891, A. von Rosthorn (No. 1052).

Though in the original description of $L$. Delavayanum the corolla is described as rotate, I find that in a specimen I collected myself in 1901 from a plant under this name in Vilmorin's Fruticetum at Les Barres the corolla is infundibuliform as in $L$. Prattii. Another specimen of $L$. Delavayanum sent to me recently by M. Mottet from Vilmorin's nursery at Verrières is exactly like it. As both specimens agree in all other characters with the original description, I must assume that the description of the corolla as rotate is not quite correct, especially as the tube is described as " tubo calycem circiter duplo superante." The specimens agree well with those collected by Henry and by Wilson and referred to L. Prattii except that the pedicels are slightly hairy toward the base. Ligustrum Delavayanum seems somewhat variable in the size and shape of the leaves. Wilson's No. 4083 has the leaves on vigorous shoots up to $6.5 \mathrm{~cm}$. long and almost oblong-lanceolate in outline, while on the flowering branchlets they are $2-3.5 \mathrm{~cm}$. long and differ little from those of typical $L$. Delavayanum. The panicles, too, are larger and more pyramidal in outline and measure from 6 to $7 \mathrm{~cm}$. in length; the whole specimen resembles closely $L$. ovalifolium Hasskarl except that it has the branchlets and the axes of the inflorescence puberulous and terete and rather longer petioles. In spite of these differences, however, I cannot take No. 4083 for anything else than an extremely vigorous specimen of $L$. Delavayanum. A. von Rosthorn's No. 1052 is somewhat intermediate.

Ligustrum ionandrum Diels from Yunnan seems very near and is possibly only a form of this species with stunted flowering branchlets and short and dense panicles.

\section{Ligustrum gracile Rehder, n. sp.}

Frutex $1.5-3 \mathrm{~m}$. altus, ramis gracilibus patentibus; ramuli tenues, teretes, annotini fere glabri, basin versus tantum minutissime puberuli, lenticellis sparsis notati, annotini et vetustiores cinerei v. flavido-cinerei. Folia decidua, lanceolata v. lineari-lanceolata, rarius oblongolanceolati, utrinque attenuata, inferiora interdum obtusiuscula, 1.53.5 longa et 4-7 mm. lata, rarius ad $5 \mathrm{~cm}$. longa et ad $1.4 \mathrm{~cm}$. lata, glaberrima, supra luteo-viridia, opaca, subtus paullo pallidiora, costa media supra leviter impressa subtus elevata, nervis obsoletis v. fere obsoletis; petioli graciles, 1-4 mm. longi. Inflorescentia paniculata, $5-8 \mathrm{~cm}$. longa et fere ac lata, ramis ad $12 \mathrm{~cm}$. longa, ramulis subteretibus patentibus, bracteis foliaceis suffultis, glabra, floribus plerumque in axibus tertii v. quarti ordinis subsessilia v. brevissime pedicellati; calyx minute denticulatus, glaber; corolla hypocraterimorpha, 4-5 $\mathrm{mm}$. longa, tubo lobos oblongo-ovatos apice acutiusculos cucullatos demum recurvos subaequante v. eis paullo longiore, rarius paullo bre- 
viore; antherae oblongae, flavae, lobis corollae paullo breviores, erectae v. suberectae, basi in tubo inclusae. Fructus desideratur.

Western Szech'uan: descent of Hsao-chin-ho, near Mongkong Ting, alt. 2300-2800 m., June 29, 1908 (No. 3498, type); Tung River valley, July 1904 (Veitch Exped. No. 4084).

This species seems most closely related to L. Massalongianum Visiani which differs in its densely pubescent inflorescence, with suberect ramifications, pubescent and closely lenticellate branchlets; in the longer corolla-tube and shorter exserted anthers. The variability in the length of the corolla-tube is rather unusual in the genus; in Wilson's No. 4084 the tube is as long or somewhat longer than the lobes, while in No. 3498 it is about as long or shorter than the lobes.

Ligustrum lucidum Aiton, Hort. Kew. ed. 2, I. 19 (1810). - Loiseleur-Delongchamps, Herb. Amat. IV. t. 264 (1820). - Sims in Bot. Mag. LII. t. 2565 (1825), - De Candolle, Prodr. VIII. 293 (1844), Hance in Jour. Linn. Soc. XIII. 82 (1873). - Decaisne in Fl. des Serres, XXII. 8 (1877); in Nouv. Arch. Mus. Paris, sér. 2, II. 20 (1879). - Hemsley in Jour. Linn. Soc. XXVI. 92 (1889). - Dippel, Handb. Laubholzk. I. 129, fig. 78 (1889). - Diels in Bot. Jahrb. XXIX. 532 (1900). - Pampanini in Nuov. Giorn. Bot. Ital. n. ser. XVII. 690 (1910); XVIII. 134 (1911). - Schneider, Ill. Handb. Laubholzk. II. 796, fig. 500 1.c. $501 \mathrm{k}-\mathrm{m}$ (1911). - Léveillé, Fl. Kouy-Tchéou, 295 (1914).

Phillyrea paniculata Roxburgh, Fl. Ind. I. 100 (1820); ed. 2, I. 100 (1832). Roemer \& Schultes Syst. Mant. I. 82 (1822), - Sprengel, Syst. I. 33 (1825).

Olea clavata G. Don, Gen. Syst. IV. 49 (1838).

Ligustridium japonicum Spach, Hist. Vég. VIII. 271 (pro parte) (1839).

Visiania paniculata De Candolle, Prodr. VIII. 289 (1844).

Ligustrum Roxburghii Blume, Mus. Bot. Lugd.-Bat. I. 315 (non Clarke) (1850).

Ligustrum japonicum Hort. ex Decaisne in Fl. des Serres, XXII. 8 (pro synon., non Thunberg) (1877).

Ligustrum sinense latifolium robustum T. Moore in Gard. Chron. n. ser. X. 752, fig. 125 (1878).

Esquirolia sinensis Léveillé in Fedde, Rep. Spec. Nov. X. 441 (1912).

Western Hupeh: common around Ichang, alt. 30-600 m., June, July and November 1907 (No. 3507, in part; bush 2-7 or tree 7-16 m. tall, girth 0.6-2 m., flowers white, fruit blue-black); same locality, $A$. Henry (No. 1073); Patung Hsien, roadside, alt. 300-600 m., August 1907 (No. 3507, in part; tree $7 \mathrm{~m}$. tall, girth $1 \mathrm{~m}$., flowers white); Fang Hsien, roadsides, alt. 300-1000 m., July 1907 (No. 3506; tree 5-12 m. tall, flowers white); "monte Triora," alt. 1950 m., October 1907, C. Silvestri (No. 1802); without precise locality, A. Henry (No. 6217). 
Western Szech'uan: Min River valley, near Mao-chou, alt. 3001600 m., July 1908 (No. 3508; tree 13-20 m. tall, girth 1.6-2.5 m., flowers white); " Hung-pê-t'ang," A. von Rosthorn (No. 806); without precise locality, July 1903 (Veitch Exped. No. 4086), E. Faber (No. 202). Fokien: Dunn's Exped., April to June 1905 (Hongkong Herb. No. 2892). Chekiang: Ningpo, 1908, D. Macgregor.

Pictures of this tree will be found under Nos. 83, 307, 633 of the collection of Wilson's photographs and also in his Vegetation of Western China, Nos. 286, 287. An account of this tree in relation to breeding the white-wax insect (Coccus pela Westwood), will be found in Wilson's A Naturalist in Western China, II. 100 (1913).

Ligustrum compactum Hooker f. \& Thomson apud Brandis, For. Fl. Brit. Ind. 310 (1874); Ind. Trees, 447 (1906). - Decaisne in Fl. des Serres, XXII. 10 (1877); in Nouv. Arch. Mus. Paris, sér. 2, II. 23 (1879). - Clarke in Hooker f., Fl. Brit. Ind. III. 616 (1882). - Dippel, Handb. Laubholzk. I. 127, fig. 77 (1889). - Kanjalil, Forest Fl. 230 (1901). - Schneider, Ill. Handb. Laubholzk. II. 797, fig. 500 p. (1911).

Olea compacta Wallich, Cat. No. 2819 (nomen nudum) (1828). - De Candolle, Prodr. VIII. 287 (1844).

Ligustrum oblongifolium Hort. Panorm. ex Decaisne in Fl. des Serres, XXII. 10 (pro synon.) (1877).

Ligustrum longifolium Carrière ex Decaisne, 1. c. (pro synon.) (1877).

Ligustrum lancifolium Carrière ex Decaisne, 1. c. (pro synon.) (1877).

Ligustrum Simonii Carrière ex Decaisne (pro synon.) (1877).

Western Hupeh: Hsing-shan Hsien, roadsides, alt. 300-1000 m., July and October 1907 (No. 3505, in part; small tree, 3-7 m. tall, flowers white, fruit blue-black); same locality; alt. $1300 \mathrm{~m}$., May 7, 1907 (No. 3509, branch with only young leaves; tree $8 \mathrm{~m}$. tall, girth $1.6 \mathrm{~m}$.); Patung Hsien, roadsides, alt. $600 \mathrm{~m}$., October 1907 (No. 3505 , in part; small tree 3-7 m. tall, fruit black); without precise locality, June 1900 (Veitch Exped. No. 1193). Yunnan: Mengtsze, eastern mountains, alt. 2000 m., A. Henry (No. 9968; tree 10 m. tall).

This species closely resembles $L$. lucidum Aiton, but is easily distinguished by its thinner deciduous leaves, usually narrower and more cuneate at the base, dull, not glossy above, with closer more distinct veins, and by its less strongly lenticellate branchlets.

Ligustrum thibeticum Decaisne in Nouv. Arch. Mus. Paris, sér. 2, II. 21 (1879).

Western Szech'uan: Mupin, thickets, alt. 1600 m., June 1908 (No. 3500 , bush $2-3 \mathrm{~m}$. tall, flowers white).

Although Wilson's specimen has the inflorescence and branchlets slightly puberulous and Decaisne places his species among the group "Frutices glaberrimi" it 
agrees in all other respects perfectly with his description. The leaves are lustrous on both surfaces and the dark colored branchlets marked by numerous conspicuous lenticels.

Ligustrum strongylophyllum Hemsley in Jour. Linn. Soc. XXVI. 93 (1889). - Skan in Bot. Mag. CXXXII. t. 8069 (1906). - Schneider, Ill. Handb. Laubholzk. II. 799, fig. 501 a-c, 502 h-i (1911).

Western Hupeh: Ichang, San-yu-tung glen, cliffs, alt. $300 \mathrm{~m}$., June 11, 1907 (No. 35or; bush 1-1.5 m. tall, flowers white); Ichang, A. Henry (Nos. 1559, 3104); Fang Hsien, rocky places, alt. 1000 m., July 1907 (No. 35or, in part; bush $1.5 \mathrm{~m}$. tall, flowers white); Patung Hsien, cliffs, alt. 300 m., August 1907 (No. 35or, in part; bush 1.5-2.5 m. tall, flowers white); without precise locality, June 1900 (Veitch Exped. No. 1504), A. Henry (No. 6299). Western Szech'uan: Shih-ch'uan Hsien, cliffs, alt. 1000 m., August 1910 (No. 4596; bush 1-1.5 m. tall).

Ligustrum sinense Loureiro, Fl. Cochin. 19 (1790). - De Candolle, Prodr. VIII. 295 (1844). - Bentham in Hooker's Jour. Bot. \& Kew Gard. Misc. IV. 331 (1852); Fl. Hongkong. 215 (1861); Gard. Chron. 1858, 621, fig.; n. ser. X. 364, fig. 64 (1878). - Decaisne in Fl. des Serres, XXII. 10 (1877); in Nouv. Arch. Mus. Paris, sér. 2, II. 36 (1879). - Hemsley in Jour. Linn. Soc. XXVI. 92 (1889). - Dippel, Handb. Laubholzk. I. 125, fig. 75 (1889). - Schneider, Ill. Handb. Laubholzk. II. 801, fig. 502 m-n, 504 k-1, 505 a-d (1911). - Léveillé, Fl. Kouy-Tchéou, 295 (1914).

Olea Walpersiana Hance in Walpers, Ann. III. 17 (1852).

Olea consanguinea Hance, 1. c. 18 (1852).

Ligustrum villosum May in Rev. Hort. 1874, 299. - Carrière in Rev. Hort. $1875,460$.

Ligustrum Ibota villosum Hort. ex Decaisne in Fl. des Serres, XXII. 10 (pro synon.) (1877).

Ligustrum sinense, var. villosum Rehder in Bailey, Cycl, Am. Hort. II. 913 (1900).

Western Szech'uan: Wa-shan, thickets, alt. 2000 m., June 1908 (No. 3496; bush 3-5 m. tall, flowers white). Western Hupeh: near Ichang, A. Henry (No. 3619); without precise locality, A. Henry (No. 4171).

This species is exceedingly variable in the shape and pubescence of the leaves and although the most extreme forms look very distinct, they are all connected by intermediate forms. The specimens enumerated above seem to come nearer to the type as it is usually interpreted than any of the other specimens from central and western China. Of the cultivated specimens I have seen, I consider No. 540 of Koehne's Herbarium dendrologicum from the Botanic Garden at Darmstadt 
and specimens from the Botanic Gardens at Buitenzorg in the Arnold Arbozetum herbarium close to the type.

Ligustrum sinense, var. Stauntonii Rehder in Bailey, Cycl. Am. Hort. II. 913 (1900). - Schneider, Ill. Handb. Laub̉holzk. II. 801, fig. 502 o-p, 504 m-n, $505 \mathrm{~g}-1$ (1911).

Ligustrum Stauntoni De Candolle, Prodr. VIII. 294 (1844). - Decaisne in Fl. des Serres, XXII. 10 (1877); in Nouv. Arch. Mus. Paris, sér. 2, II. 37 (1879). - Dippel, Handb. Laubholzk. I. 126, fig. 76 (1889). - Koehne, Deutsche Dendr. 502 (1893).

Ligustrum chinense Carrière in Rev. Hort. 1863, 88.

Ligustrum ehinense nanum Carrière in Rev. Hort. 1876, 20 (forma humilis),

Western Hupeh: Changlo Hsien, side of streams, alt. 1000-1300 m., May and December 1907 (No. 754; bush 2-3 m. tall, flowers white, fruit blue-black); north and south of Ichang, side of streams, alt. 3001300 m., May 1907 (No. 754 ${ }^{\text {b }}$ bush $4 \mathrm{~m}$. tall, flowers white); same locality, A. Henry (No. 3561); Patung Hsien, A. Henry (No. 1763). Western Szech'uan: Kiating Fu, thickets, alt. 300-600 m., May 1908 (No. 3495; bush 2-3 m. tall, flowers white); Mupin, side of streams, alt. 1300 m., July 1908 (No. 3499; bush 2-3 m. tall, flowers white). Fokien: Dunn's Exped., April to June 1905 (Hongkong Herb. No. 2891). Chekiang: near Ningpo, 1908, D. Macgregor.

A picture of this plant will be found under No. 030 of the collection of Wilson's photographs.

Ligustrum sinense, var. nitidum Rehder in Bailey, Standard Cycl. Hort. IV. 1700 (sine descriptione Latina) (1915).

A typo recedit praecipue ramulis puberulis v. brevissime pilosis, foliis supra nitidis utrinque glabris costa media subtus basin versus tantum adpresse pubescente excepta.

Frutex 2-4-metralis. Folia ovato-oblonga v. oblongo-lanceolata, acuta v. acuminata, rarius inferiora et minora obtusiuscula v. obtusa, basi cuneata v. late cuneata, rarius fere rotundata, supra glabra, nitida, costa media incisa, subtus pallide viridia, punctulata, ad costam mediam plerumque basin versus tantum adpresse pubescentia, ceterum glabra, 4-6.5 cm. longa et $1.5-2.5 \mathrm{em}$. lata, rarius latiora; petioli breviter pubescentia, 4-6 mm. longa. Panicula 6-8 longa, breviter pilosula; pedicelli glabri; corollae lobi ovati, filamentis manifeste breviores. Fructus subglobosus v. ovoideus, 5-6 $\mathrm{mm}$. longus atrocoeruleus pruinosus.

Western Hupeh: near Ichang, A. Henry (Nos. 3549, type, 3320); north and south of Ichang, side of streams, common, alt. 300-1300 m., 
May and December 1907 (No. 754ª , in part; bush 3-4 m. tall); Hsingshan Hsien, thickets, side of streams, alt. 1000-1200 m., June and November 1907 (No. 599; bush 3-4 m. tall); Patung Hsien, thickets, not common, alt. $1300 \mathrm{~m}$., May 1907 (No. 3497; bush $3 \mathrm{~m}$. tall); same locality, alt. 1000 m., December 1907 (No. 754 ${ }^{\mathrm{a}}$, in part; bush 3-4 m. tall); Nanto and mountains to northward, A. Henry (Nos. 1922, 2683, 3072, 3190). Western Szech'uan: Mt. Omei, May, June, July 1904 (Veitch Exped. Nos. 5015, 5017, 5017ª).

This variety differs from the type chiefly in its nearly glabrous narrower acute or acuminate leaves lustrous above and in the shorter and slighter pubescence of the branchlets. From L. sinense, var. Stauntonii it is easily distinguished in its typical form by the much longer and comparatively narrower pointed leaves. There are, however, many intermediate forms, as Wilson's Nos. 599, 754 a 3497 and Henry's 3072, which might be taken for large-leaved forms of var. Stauntonii. The specimens nearest to the type are Henry's 1922 and Wilson's No. 5017 and also his Nos. 5015 and 5017.

Ligustrum myrianthum Diels in Bot. Jahrb. XXIX. 533 (1900).

Western Hupeh: Hsing-shan Hsien, side of streams, alt. 10001300 m., May 27 and October 1907 (No. 47I; bush 2-3 m. tall, flowers white, fruit blue-black); without precise locality, May 1900 (Veitch Exped. No. 459). Szech'uan: Nanch'uan, A. von Rosthorn (No. 2099). Hongkong: E. Faber; same locality, C. Ford; same locality, 1853-56, C. Wright (No. 318, fruiting specimen).

This peculiar Privet which differs from all species known to me in the inflorescences which spring directly from the axils of the leaves of the previous year without leaves at their base, or are borne, if the subpersistent leaves have fallen, on perfectly leafless branches, is possibly only an abnormal form of $L$. sinense Loureiro. I can see no difference between von Rosthorn's and Wilson's specimens, except that the flowers of the former are slightly smaller, although scarcely smaller than those of Ford's Hongkong specimen, while in the shape of the inflorescence and in the pubescence they are exactly the same; the leaves which are still partly retained on Wilson's and on the Hongkong specimens agree very well with those of L. sinense. Henry's specimens Nos, 3619 and 4171 enumerated under L. sinense are distinctly intermediate in the character of their inflorescence; most of these panicles have only small bract-like leaves in their lower part, some are entirely leafless, while a few have nearly normal leaves below the inflorescence.

Ligustrum Quihoui Carrière in Rev. Hort. 1869, 377. - Decaisne in Fl. des Serres, XXII. 6 (1877); in Nouv. Arch. Mus. Paris, sér. 2, II. 35 (1879). - Dippel, Handb. Laubholzk. I. 124, fig. 73 (1889).W. D. in Gard. LXVI. 292, fig. (1904). - Schneider, Ill. Handb. Laubholzk. II. 801, fig. 502 k-1 (1911).

Ligustrum brachystachyum Decaisne in Nouv. Arch. Mus. Paris, sér. 2, II. 34 (1879). - Franchet in Nouv. Arch. Mus. Paris, sér. 2, VI. 85 (Pl. David. I. 205) (1883). - Hemsley in Jour. Linn. Soc. XXVI. 89 (1889). - Diels in 
Bot. Jahrb. XXIX. 533 (1900). - Pampinini in Nuov. Giorn. Bot. Ital. n. ser. XVII. 689 (1910).

Western Hupeh: Fang Hsien, side of streams, alt. 1000-13002000 m., July and November 1907 (Nos. 631, 780, bush 1.5-3 m. tall, flowers white, fruit blue-black); Patung Hsien, roadside thickets, alt. 300-1000 m., August and December 1907 (No. 778; bush 1.5-3 m. tall; fruit blue-black); Ichang, side of streams, alt. 30-600 m., June 1907 (No. 3502; bush 1-2 m. tall); same locality, A. Henry (No. 3973); without precise locality, A. Henry (Nos. 6352, 7744); " monti di Nan-tcian, l. d. To-p'in," November 1907, C. Silvestri (No. 1794). Northern Shensi: "Huan-kia-fan," June 1897, G. Giraldi; " Mt. Lao-y-san," Hugh Scallan.

Ligustrum brachystachyum, of which I have seen neither the type nor any specimen agreeing in the shape of the leaves with Decaisne's description, seems not to be specifically different and is apparently only a form of $L$. Quihoui with broader leaves. This view is strengthened by the fact that plants raised from seed collected by Wilson in Hupeh have the leaves generally elliptic and about $2.5 \mathrm{~cm}$. long and $1.3 \mathrm{~cm}$, broad, broader than those of his herbarium specimens.

Here may be added the description of two new species not collected during the Arnold Arboretum expeditions.

Ligustrum formosanum Rehder, n. sp.

Ligustrum sp. Henry in Trans. As. Soc. Jap. XXIV. suppl. 59 (List Pl. Formosa) (1896).

Frutex 1-3-metralis; ramuli hornotini scabro-villosuli, annotini et vetustiores cinerei v. pallide brunneo-cinerei, glabri, sparse lenticellati. Folia persistentia coriacea, lata ovata v. ovalia v. rhombico-ovalia, rarius obovata, plerumque breviter acuminata, rarius obtusiuscula, basi cuneata v. late cuneata, 1.5-3 cm. longa et 1-2 $\mathrm{cm}$. late, glaberrima, supra luteo-viridia, subtus paullo pallidiora; nervis utrinsecus 3-5 supra in sicco ut venulae leviter elevatis subtus tenuioribus leviter elevatis venulis obsoletis; petioli brevissimi, 1-2 mm. longi, crassiusculi, purpurascentes, breviter pilosuli. Inflorescentia terminalis, sine pedunculo $2-3 \mathrm{~cm}$. longa, laxa, paniculata v. interdum racemosa, rhachi et ramulis quadrangularibus, sparse pilosis; pedunculus brevis v. interdum ad $2 \mathrm{~cm}$. longus, sparse lenticellatus et sparse pilosus; pedicelli 1-5 mm. longi, graciles, angulares, glabri v. fere glabri; calyx glaber, plerumque truncatus; corolla hypocraterimorpha, tubo gracili $3-4$ $\mathrm{mm}$. longo lobos reflexos oblongo-ovatos duplo superante; stamina filamentis tubum paullulo superantibus, antheris anguste oblongis $2 \mathrm{~mm}$. longis, lobis paullo brevioribus erectis v. demum subhorizontalibus. Fructus desideratur.

Formosa: Takow, Ape's Hill, A. Henry (No. 331).

This is a very distinct species characterized by very short-petioled, rhombic-ovate leaves, a small and lax, sometimes racemose, slightly pubescent inflorescence and small flowers with a slender elongated tube. It seems nearest to $L$. japonicum Thunberg and L. Henryi Hemsley, the first of which is easily distinguished by its larger, longer-petioled leaves, large, perfectly glabrous panicles and larger flowers with a shorter tube, while the second differs chiefly in its thinner ovate leaves rounded at the base, in the denser inflorescence with sessile or nearly sessile flowers and in the short hairs on the branchlets. 
Ligustrum pedunculare Rehder, n. sp.

Frutex ad 7-metralis, ramis gracilibus patentibus; ramuli tenues teretes, hornotini dense breviter villoso-pilosuli, annotini tarde glabrescentes, flavido-cinerei. Folia persistentia, subcoriacea, firma, oblongo-lanceolata, v. elliptico-lanceolata, rarius fere lanceolata, acuminata $\mathrm{v}$. longe acuminata, basin versus sensim in petiolum attenuata 4-8 $\mathrm{cm}$. longe et 1-2.5 rarius ad $3 \mathrm{~cm}$. lata, glaberrima, supra luteo-viridia costa media manifeste et anguste impressa sicut incisa, subtus paullo pallidiora costa elevata, nervis utrinsecus 4-7 supra obsoletis subtus leviter elevatis anastomosantibus; petioli $2-6 \mathrm{~mm}$. longi, canaliculati, glabri. Inflorescentia paniculata, dense villoso-pilosula, sine pedunculo gracili tereti plerumque $1-2 \mathrm{~cm}$. longo 2-3 cm. longa, satis laxa, axibus secundariis duobus infimis $5-10 \mathrm{~mm}$. longa pedunculatis, 3-7-floris, supra plerumque floribus solitariis $\mathrm{v}$. fascieulatis instituta; axes subteretes, in fructu angulares; pedicelli sparse minute pilosuli v. fere glabri; calyx plerumque minute denticulatus, glaber; corolla circiter $7-8 \mathrm{~mm}$. longa, hypocraterimorpha, tubo lobis ovatis acutiusculis margine involutis apice cucullatis $2 \mathrm{~mm}$. longis plus quam duplo longiore; stamina antheris quam lobi corollae fere triente brevioribus ovato-oblongis acutiusculis $2.5-3 \mathrm{~mm}$. longis et $1.5 \mathrm{~mm}$. latis, filamentis brevibus circiter $1 \mathrm{~mm}$. longis. Fructus (immaturus) ovoideus, circiter $7 \mathrm{~mm}$. longus.

Szech'uan: Mt. Omei, June 1904 (Veitch Exped. No. 5016, type); without precise locality, A. Henry (No. 7117).

This species seems most closely related to $L$. Delavayanum Hariot, which differs chiefly in the usually much smaller and broader leaves with the midrib slightly impressed and more or less covered with short hairs above, in the sessile denser and subcylindric inflorescence and in its lower habit.

\section{OSMANTHUS Lour.}

Osmanthus fragrans Loureiro, Fl. Cochin. 28 (1790). - De Candolle, Prodr. VIII. 291 (1844). - Debeaux in Act. Soc. Linn. Bordeaux, XXX. 94 (Fl. Shanghai, 42) (1875). - Clarke in Hooker f., Fl. Brit. Ind. III. 606 (1882), - Hance in Jour. Bot. XX. 37 (1882); XXI. 323 (1883). - Hemsley in Jour. Linn. Soc. XXVI. 88 (1889). - Diels in Bot. Jahrb. XXIX. 532 (1900). - Brandis, Ind. Trees, 445 (1906). Pavolini in Nuov. Giorn. Bot. Ital. n. ser. XV. 427 (1908). - Schneider, Ill. Handb. Laubholzk. II. 789, fig. $496 \mathrm{c}-\mathrm{f}$ (1911). - Diels in Not. Bot. Gard. Edinburgh, VII. 43, 193, 265 (1912).

Olea fragrans Thunberg, Fl. Jap. 18, t. 2 (1784). - Sims in Bot. Mag. XXXVIII. t. 1552 (inflorescentia anormalis) (1813). - Loddiges, Bot. Cab. XVIII. t. 1786 (1831). - Franchet \& Savatier, Enum. Pl. Jap. I. 312 (1872), - Brandis, For. Fl. Brit. Ind. 309 (1874). - Léveillé, Fl. Kouy-Tchéou, 295 (1914).

Olea acuminata Wallich, Cat. No. 2809 (nomen nudum) (1828). - De Candolle, Prodr. VIII. 285 (1844).

Western Szech'uan: Hungya Hsien, cultivated in temple grounds, etc., alt. 900 m., September 10, 1908 (No. 2374; tree 7-10 m. tall, flowers white); Mt. Omei, September 1904 (Veitch Exped. No. 
5040); Nanch'uan, A. von Rosthorn (Nos. 628, 855). Western Hupeh: Ichang, cultivated, April 1900 (Veitch Exped. No. 38); same locality, A. Henry (Nos. 2288, 2497); without precise locality, A. Henry (No. 7722). Yunnan: Yuan-chiang, alt. 2100 m., A. Henry (No. 13213).

A picture of this tree will be found under No. 326 of the collection of Wilson's photographs and also in his Vegetation of Western China, No. 323.

Osmanthus serrulatus Rehder, n. sp.

Frutex 2-4 m. altus (v. arbor ad $12 \mathrm{~m}$. alta), glaber; rami annotini et vetustiores pallide brunneo-cinerei, lenticellati. Folia tenuiter coriacea, oblonga $\mathrm{v}$. oblongo-lanceolata, interdum anguste oblongoobovata, acuminata, basi cuneata, spinuloso-serrulata dentibus utrinsecus ad 30, v. dentibus paucis tantum instituta v. omnino integra, 6-14 cm. longa et 1.8-4.5 cm. lata, subtus luteo-viridia lucidula, subtus pallidiora opaca, costa media supra manifeste $\mathrm{v}$. vix elevata, nunquam immersa pallida, subtus elevata, nervis utrinsecus 8-12 supra ut venulae plus minusve elevatis et plerumque pallidis, subtus leviter elevatis, reticulo venulorum obsoleto; petioli canaliculati, 0.6-1 cm. longi. Flores vernales, fragrantes, polygami, 4-9 fasciculati, e gemmis axillaribus perulatis perulis minute ciliolatis ceterum glabris; pedicelli graciles 1-2 $\mathrm{cm}$. longi; calycis lobi ovati v. late ovati, apice erosodenticulati v. acuti, rarius acuminati, $1-1.5 \mathrm{~mm}$. longi, membranacei; corolla fere ad basin 4-partita, lobis late oblongis circiter $5 \mathrm{~mm}$. longis; stamina paullo supra basin inserta lobis corollae paullo breviora, antheris oblongis circiter $2.5 \mathrm{~mm}$. longis quam filamenta paullo longioribus stylus brevis tubum corollae superans. Fructus 1-3, graciliter pedicellati, pedicellis $1-2 \mathrm{~cm}$. longis, calyce persistenti suffultus, oblongus, apice stylo v. rudimento styli coronatus, nigro-coeruleus; endocarpium tenue, crustaceum fragile, leviter compressum $1 \mathrm{~cm}$. longum et $5 \mathrm{~mm}$. latum.

Western Szech'uan: Mupin, thickets, alt. 1500-1800 m., October 1910 (No. 42I6, type; bush 2-4 m. tall, fruit blue-black); without precise locality, alt. 2400-2600 m., May 1904 (Veitch Exped. No. 4079; tree 3-12 m. tall, flowers white, fragrant; No. $4079^{\mathrm{a}}$; shrub 2-3 m., flowers white).

This species seems most nearly related to $O$. fragrans Loureiro which differs chiefly in the broad subsessile anthers not longer than the tube of the corolla which is smaller and less deeply divided, and in the usually entire more coriaceous leaves with the midrib deeply impressed above and with slightly impressed lateral nerves and indistinct veinlets. No. 4079 differs from the type which has the leaves closely 
serrulate with from 25 to 30 teeth on each side, in its somewhat larger more coriaceous leaves sometimes entire or nearly entire; No. $4079^{\mathrm{a}}$ differs in its impressed veinlets. I have, however, little doubt that the flowering and the fruiting specimens belong to the same species, particularly as the young plants raised from seed of No. 4216 agree better with a branch of No. 4079 bearing spinosely serrate leaves than with the parent plant.

Osmanthus venosus Pampanini in Nuov. Giorn. Bot. Ital. n. ser. XVIII. 265, fig. 25 (1911).

Western Hupeh: Ichang, cultivated, alt. 300-900 m., September 1907 (No. $2374^{2}$; tree 8-10 m. tall, flowers white, fragrant).

Pampanini places this species in the section Siphosmanthus and his figure shows a corolla with a rather tubular tube, while Wilson's No. 2374 has a distinctly campanulate corolla with the tube $2.5-3 \mathrm{~mm}$. and the lobes about $2 \mathrm{~mm}$. long. This agrees exactly with the measurements given by Pampanini for the flowers of his $O$. venosus. I assume that in the drawing the shape of the corolla is somewhat exaggerated, and as our plant agrees in all other points with Pampanini's description, there is hardly any doubt that it is $O$. venosus. The branchlets, petioles and the scales of the flower-buds are minutely puberulous as in $O$. armatus Diels. A note on the latter species which had not been collected during the Arnold Arboretum Expedition may be appended here.

Osmanthus armatus Diels in Bot. Jahrb. XXIX. 532 (1900). - Wilson in Gard. Chron. ser. 3, L. 113, fig. 54 (1911), - Bean in Kew Bull. Misc. Inform. 1913, 166.

Western Hupeh: Ichang, on rocks in woods, September 1901 (Veitch Exped. No. 2645; bush or small tree, 1-7 m. tall); same locality, A. Henry (No. 6730); Nanch'uan, A. von Rosthorn (No. 2040, in Herb. Christiania).

Like those in other species of this genus the leaves vary from toothed to entire. The entire leafed form may be distinguished from the preceding species to which it is closely related by the short petioles and the rounded base of the leaves.

\section{CHIONANTHUS L.}

Chionanthus retusus Lindley \& Paxton in Paxton's Flow. Gard. III. 85, fig. 273 (1853). - Walpers, Ann. V. 482 (1858). - Maximowicz in Bull. Acad. Sci. St. Pétersbourg, XXII. 259 (1876); in Mél. Biol. IX. 653 (1877). - Gard. Chron. ser. 2, XXIII. 820, fig. 178 (1885). Hemsley in Jour. Linn. Soc. XXVI. 88 (1889). - Shirai in Tokyo Bot. Mag. VIII. 98, t. 3 (1894). - Rehder in Rhodora, VI. 19, fig. 3, 4 (1904). - Schneider, Ill. Handb. Laubholzk. II. 793, fig. 497 t-y, 500 c (1911).

Linociera chinensis Fischer apud Maximowicz in Mém. Sav. Etr. Acad. Sci. St. Pétersbourg, IX. 474 (Prim. Fl. Amur.) (nomen nudum) (1859).

Chionanthus chinensis Maximowicz in Bull. Acad. Sci. St. Pétersbourg, XX. 430 (1875); in Mél. Biol. IX. 393 (1875).

Chionanthus Duclouxii Hickel in Bull. Soc. Dendr. France, 1914, 72, fig. 
Western Hupeh: north and south of Ichang, cliffs, etc., alt. 30600 m., May 1907 (No. I057, in part; bush 2-5 m. tall, flowers white, fragrant); without precise locality, April 1900 (Veitch Exped. No. 89). Western Szech'uan: west and near Wên-ch'uan Hsien, cliffs, alt. 1300-1600 m., September 1908 (No. I057, in part; small tree, $7 \mathrm{~m}$. tall). Yunnan: Mengtsze, woods, alt. 1500 m., A. Henry (Nos. $10532,10532^{\circ}$, tree $10 \mathrm{~m}$. tall, fruit plum-colored); Chuyan, $A$. Henry (No. 10532 $2^{\text {a }}$. Northern Shensi: Lao-y-san, Hugh Scallan. Shantung: Po-shan, September 1907, F. N. Meyer (No. 256, 266); Kiauchau, July 1887 (Ex Herb. Hongkong No. 1112). Korea: Quelpaert, May 1908, August 1909, Taquet (Nos. 1515, 3055).

Young seedling plants of this species have the leaves serrulate or on vigorous shoots even doubly denticulate-serrulate; in plants 10 years old the leaves are still serrulate, but all the flowering and fruiting specimens the wild as well as the cultivated have perfectly entire leaves. Hickel's $C$. Duclouxii is based on such a juvenile plant with serrulate leaves.

\section{JASMINUM L.}

ᄀ Jasminum sinense Hemsley in Jour. Linn. Soc. XXVI. 80 (1889). Diels in Bot. Jahrb. XXIX. 533 (1900). — Léveillé, Fl. Kouy-Tchéou, 294 (1914).

Western Szech'uan: Yachou Fu, thickets, alt. 600-1000 m., August and November 1908 (No. 2808; climber 4 m., flowers white). Western Hupeh: without precise locality, A. Henry (No. 4464). Yunnan: Mengtsze, alt. 2000 m., A. Henry (Nos. 9657, 9657, $9657^{\mathrm{b}}$ ).

To this species probably belongs also Henry's No. 13354 from Szemao, which differs, however, in its glabrous leaves; only the petioles, branchlets and inflorescences are thinly puberulous.

Jasminum lanceolarium Roxburgh, Fl. Ind. I. 97 (1820). - De Candolle, Prodr. VIII. 310 (1844), - Clarke in Hooker f., Fl. Brit. Ind. III. 601 (1882).

Western Szech'uan: Yachou Fu, thickets, alt. 600-1000 m., July 1908 (No. 78r; climber 5 m., flowers white); Mt. Omei, July 1904 (Veitch Exped. No. 5042). Yunnan: Szemao, forest, alt. 1600 m., A. Henry (No. 11713).

Jasmithm lanceolarium, var. puberulum Hemsley in Jour. Linn. Soc. XXVI. 78 (1889).

Western Hupeh: north and south of Ichang, ravines, alt. 3001000 m., July and December 1907 (No. $78 \mathrm{I}^{\mathrm{a}}$; elimber $7 \mathrm{~m}$., flowers 
white, fragrant); same locality, A. Henry (No. 3669); without precise locality, June 1900 (Veitch Exped. No. 1018); A. Henry (Nos. 2729, $3000,4562)$.

Jasminum urophyllum Hemsley in Jour. Linn. Soc. XXVI.81 (1889). Western Szech'uan: near Wa-shan, thickets, alt. 1000 m., October 1908 (No. II22; climber 2 m., flowers white).

Hemsley describes the flowers of this species as yellow, while Wilson states that they are white; his specimen consists only of fruiting branches.

There may be added the description of two new varieties not collected during the Arnold Arboretum Expeditions.

Jasminum urophyllum, var. Wilsonii Rehder, n. var.

A typo recedit foliis ut videtur fere semper 3 -foliolatis, foliolis glabris, terminalibus anguste oblongo-lanceolatis $3-7 \mathrm{~cm}$. longis et $0.8-1.5 \mathrm{~cm}$. latis, lateralibus minoribus ovato-lanceolatis $\mathrm{v}$. oblongo-lanceolatis $1.5-3.5$ longis et $0.5-1 \mathrm{~cm}$. latis, omnibus basi rotundatis et distincte 3 -nerviis, cymis paucifloris, pedicellis gracilibus $1.5-2.5 \mathrm{~cm}$. longis.

Western Szech'uan: without precise locality, eliffs, July 1903 (Veitch Exped. No. 4075).

Though Wilson's No. 4075 looks at the first glance very distinct from J. urophyllum, I am unable to find any other characters to distinguish it from the 3 -foliolate forms of that species except the glabrous, smaller and narrower leaflets, characters which are of rather slight morphological value.

Jasminum urophyllum, var. Henryi Rehder, n. var.

A typo recedit foliis glabris plerumque unifoliolatis longioribus oblongo-lanceolatis basi rotundatis $\mathrm{v}$. truncatis manifeste trinerviis $6-11 \mathrm{~cm}$. longis et $2-3.8 \mathrm{~cm}$. latis, cymis laxis, pedicellis gracilibus $1-1.5 \mathrm{~cm}$. longis.

Western Hupeh: without precise locality, A. Henry (No. 5944, type), July 1900, E. H. Wilson (Veitch Exped. No. 1499).

This variety is easily distinguished from the type by its glabrous oblonglanceolate more distinctly 3 -nerved simple leaves which are in $J$. urophyllum only occasionally unifoliolate toward the end of the branches, generally broader, ovatelanceolate in outline and somewhat less distinctly 3-nerved or sometimes 5-nerved. Henry's specimen of his No. 5944 before me has all the leaves unifoliolate, while Wilson's No. 1499 has partly unifoliolate and partly 3 -foliolate leaves, otherwise the two do not differ.

Though at the first glance the two varieties look very different, one having large simple and the other small 3 -foliolate leaves, I am unable to find characters between them and $J$. urophyllum which would admit of specific separation.

Jasminum officinale Linnaeus, Spec. 7 (1753). - Curtis in Bot. Mag. I. t. 31 (1787). - De Candolle, Prodr. VIII. 313 (1844). - Brandis, Forest Fl. Brit. Ind. 313 (1874); Ind. Trees, 452 (1906). - Boissier, Fl. Orient. IV. 43 (1879). - Clarke in Hooker f., Fl. Brit. Ind. III. 603 (1882). - Dippel, Handb. Laubholzk. I. 150 (1889). - Collett, Fl. Siml. 307 (1902). - Schneider, Ill. Handb. Laubholzk. II. 837, fig. 526 i-m, 527 d-e (1911). 
Jasminum vulgatius Lamarck, Fl. Franc, II. 306 (1778).

Jasminum viminale Salisbury, Prodr. 12 (1796).

Jasminum affine Lindley in Bot. Reg. XXXI. t. 26 (1845).

Western Szech'uan: Monkong Ting, alt. 2300-2600 m., June 1908 (No. 2807; climber 2-3 m., flowers white, fragrant); without precise locality, ravines, alt. 3000 m., June 1904 (Veitch Exped. No. $\left.4074^{a}\right)$.

This species does not seem to have been recorded from China before; Hemsley states that it is cultivated in China, but Wilson's specimens were collected from wild plants. Wilson's No. 2807 differs from the type in the leaves which are mostly 3 -or 5 -foliolate and sometimes simple or incompletely 3 -foliolate, while No. $4074^{\mathrm{a}}$ which has the leaves varying from 7 -foliolate to nearly simple differs in its very small leaflets not exceeding $2 \mathrm{~cm}$. in length.

Jasminum floridum Bunge in Mém. Sav. Êtr. Acad. Sci. St. Pétersbourg, II. 116 (Enum. Pl. Chin. Bor. 42) (1833). - De Candolle, Prodr. VIII. 313 (1844). - Miquel in Ann. Mus. Lugd.-Bat. II. 263 (1866); Prol. Fl. Jap. 151, 359 (1866-67). - Franchet \& Savatier, Enum. Pl. Jap. I. 314 (1875). - Hooker f, in Bot. Mag. CIX. t. 6719 (1883). - Hemsley in Jour. Linn. Soc. XXVI. 78 (1889). - Dippel, Handb. Laubholzk. I. 147, fig. 92 (1889). - Diels in Bot. Jahrb. XXIX. 534 (1900). - Schneider, Ill. Handb. Laubholzk. II. 839, fig. 527 h-i, 528 a (1911).

Jasminum subulatum Lindley in Bot. Reg. XXVIII. misc. notes, 57 (1842). - De Candolle, Prodr. VIII. 312 (1844).

Western Hupeh: north and south of Ichang, alt. 300-700 m., June and December 1907 (No. 789, in part; bush $1 \mathrm{~m}$. tall, flowers yellow); Hsing-shan Hsien, thickets, alt. 600 m., June 1907 (No. 789, in part); without precise locality, April 1900 (Veitch Exped. No. 83), A. Henry (Nos. 2700, 6288). Western Szech'uan: Nanch'uan, Taho-kou, A. von Rosthorn (No. 163).

Jasminum Giraldii Diels in Bot. Jahrb. XXIX. 534 (1900). - Pampanini in Nuov. Giorn. Bot. Ital. n. ser. XVII. 689 (1910).

Western Hupeh: Fang Hsien, rocky places, etc. abundant, alt. 1000 m., May 23 and November 1907 (No. 598; 1-2 m. tall, flowers deep yellow, fruit black). Northern Shensi: Lao-y-san, June 4, 1897, G. Giraldi.

Jasminum humile Linnaeus, Spec. 7 (1753). - Aiton, Hort. Kew. I. 9 (1789). - Ker in Bot. Reg. V. t. 350 (1819). - De Candolle, Prodr. VIII. 313 (1844). - Clarke in Hooker f., Fl. Brit. Ind. III. 602 (1882). 
- Dippel, Handb. Laubholzk. I. 146, fig. 91 (1889). - Brandis, Ind. Trees, 452 (1906). — Schneider, Ill. Handb. Laubholzk. II. 840 (1911).

Jasminum chrysanthemum Roxburgh, Cat. Hort. Beng. 3 (1814); Fl. Ind. I. 98 (1820).

Jasminum revolutum Sims in Bot. Mag. XLII. t. 1731 (1815), - Ker in Bot. Reg. III. t. 178 (1817); VI. notes 2 (1820), - Loddiges in Bot. Cab. X. t. 966 (1824). - D. Don, Prodr. Fl. Nepal. 106 (1825), - De Candolle, Prodr. VIII. 313 (1844). - Wight, Icon. Pl. Ind. Orient. IV. 14, t. 1258 (1850). Brandis, Forest Fl. Brit. Ind. 313 (1874). - Boissier, Fl. Orient. IV. 42 (1879). - Dippel, Handb. Laubholzk. I. 148, fig. 93 (1889). — Schneider, Ill. Handb. Laubholzk. II. 839, fig. 527 m-n, 528 g-i (1911).

Jasminum bignoniaceum Wallich, Cat. No. 2888 (nomen nudum) (1829). G. Don, Gen. Syst. IV. 63 (1838). - De Candolle, Prodr. VIII. 313 (1844). Jasminum Wallichianum Lindley in Bot. Reg. XVII. t. 1409 (1831). — Schneider, Ill. Handb. Laubholzk. II. 839, fig. 527 k-1, 528 d-f (1911).

Jasminum inodorum Jacquemont apud Decaisne in Jacquemont, Voy. IV. 139, t. 143 (1844). - De Candolle, Prodr. VIII. 312 (1844).

Western Szech'uan: Monkong Ting, descent of Hsao-chin-ho valley, alt. 2300-3000 m., June 1908 (No. 2809; bush 1-2 m. tall, flowers yellow); Min River valley, Wên-ch'uan Hsien, alt. 600-1300 m., July and November 1908 (No. 28ro; bush 0.75-1 m. tall; flowers yellow); Maochou, dry arid places, common, alt. 1300-1600 m., May 24, 1908 (No. 28r r ; bush 0.3-2 m. tall, flowers yellow); without precise locality, alt. 3000-3300 m., June 1904 (Veitch Exped. No. 4077), alt. 2300 m., August 1903 (Veitch Exped. No. 4078).

Wilson's specimens differ from all the Himalayan specimens I have seen in the 3-5-foliolate leaves with generally oblong obtusish leaflets and in the usually 3-5flowered inflorescence. In these characters it agrees very well with the description of typical $J$. humile as contrasted with the Himalayan $J$. revolutum. Wilson's Nos. 4078 and 2810 are very much like the figure in the Botanical Register (t. 350 ) except that the leaflets are more obtusish; the other specimens have generally narrower leaflets, particularly Nos. 2809 and 4077, which have the leaflets oblong and about 1-2 cm. long and $0.4-0.6 \mathrm{~cm}$. broad. In Nos. 2810 and 2811 the leaflets and the petioles and in No. 2811 the young branchlets also are slightly pubescent.

Here may be added some notes on species not colleeted during the Arnold Arboretum expeditions.

Jasminum Beesianum Forrest \& Diels in Not. Bot. Gard. Edinburgh, V. 253 (1912). - Léveillé, Fl. Kouy-Tchéou, 293 (1914).

Western Szech'uan: without precise locality, ravines, alt. 1000-2000 m., May 1904 (Veitch Exped. No. 4074; climber, flowers rose to nearly white).

Jasminum nintooides Rehder, n. sp.

Frutex scandens ramis medulla lamellosa fulvescente repletis; ramuli hornotini dense pilis patentibus flavescentibus vestiti, annotini glabrescentes. Folia opposita, chartacea, subpersistentia, breviter petiolata, ovata $\mathrm{v}$. late ovata, acuta $\mathrm{v}$. obtusa et mucronulata, basi rotundata $\mathrm{v}$. truncata, interdum subcordata, margine plus minusve revoluta, $1.5-3.5 \mathrm{~cm}$. longa et $1-2.5 \mathrm{~cm}$. lata, utrinque molliter villosa, 
supra sparsius, subtus dense et longe villosa, nervis utrinsecus 2-4, saepe obscuris, basalibus saepe magis distinctis, inde basi plus minusve manifeste trinervia, rarius 5-nervia; petioli dense villosi, $2-6 \mathrm{~mm}$. longi. Flores solitarii axillares, saepe in apice ramulorum 2-4 aggregati; pedicelli dense villosi, $2-3 \mathrm{~mm}$. longi; calyx dense villosus, tubo campanulato, lobis linearibus $3-4 \mathrm{~mm}$. longis; corolla alba, tubo angusto circiter $2 \mathrm{~cm}$. longo, lobis 5-6 oblongo-lanceolatis acutis v. acutiusculis circiter $1 \mathrm{~cm}$. v. paullo ultra longis et $3-4 \mathrm{~mm}$. latis. Fructus subglobosus, purpureo-niger, nitidus, $6-7 \mathrm{~mm}$. diam.

Yunnan: Mengtsze, alt. $1600 \mathrm{~m}$., trailing and climbing over rocks, A. Henry (Nos. 9433, type, $9433^{\mathrm{s}}, 9433^{\mathrm{b}}$ ).

This is a very distinct looking species particularly in the fruiting state when it much resembles Lonicera ( $\$$ Nintooa) japonica Thunberg in general appearance. Apparently it is most closely related to $J$. pubescens Willdenow which has larger, more acuminate and less villose leaves on longer petioles and the flowers in dense capitate cymes. 


\section{CAPRIFOLIACEAE. ${ }^{1}$}

Determined by AlFred REHDER.

\section{HEPTACODIUM Rehder, n. gen.}

Calycis tubus turbinatus, dense setosus; lobi 5, oblongi, persistentes, accrescentes; corolla tubuloso-infundibuliformis, tubo leviter curvato basi subaequali; limbus leviter bilabiatus, 5-partitus, lobis oblongis, antico patente v. reflexo, posticis erecto-patentibus; stamina 5, filamentis fauci corollae insertis elongatis, antheris oblongis; stylus filiformis; ovarium inferior, 3-locularis; loculi duo ovulis pluribus sterilibus instructi, tertius ovulo solitario fertili. Fructus coriaceus, oblongus, calyce limbo accrescente coronatus, 3-locularis, loculis duobus effoetis compressis, tertio monospermo; semen elongatum basi subcylindrium, supra compressum, testa membranacea, albumine carnoso; embryo brevis cylindricus, in basi seminis. - Frutex erectus, ramulis striatis medullosis, gemmis perulatis. Folia decidua, opposita, petiolata, 3-nervia, integra; stipulae nullae. Flores albi, sessiles, in capitulis axes primi ad tertii ordinis terminantibus et paniculam terminalem erectam formantibus; capitula 7-flora, involucrata, involucro persistente, e bracteolis 10 ovatis dense sericeis in duobus seriebus dispositis, 4 exterioribus et 6 interioribus, composito et basi bracteis 2 majoribus orbiculari-ovatis suffulto, pedunculata pedunculo stricto bracteis parvis 2 v. 4 decussatis instructo.

Genus novum Abeliae et Lonicerae proxima; ab utroque recedit capitulis 7-floris involucratis, a priore insuper distinguitur staminibus 5 fauci corolla insertis, a posteriore ovarii et fructus indole.

Species unica Chinae centralis incola.

This genus is very distinct in its general appearance from any other genus of the Caprifoliaceae. In the structure of its flowers it closely resembles Lonicera, while in the structure of its ovary and in its fruit it is very near Abelia. The inflorescence may be compared with the 6-flowered whorls representing two 3-flowered cymes of the section Periclymenum of Lonicera; if it is assumed that the central axis of these whorls is terminated by a flower, we have the inflorescence of Heptacodium, and if a species with well-developed bractlets like Lonicera Periclymenum Linnaeus

I See also vol. I. 106-144, 306-312. 
is examined, a perfect agreement in the position and in the number of bracts and bractlets is found. In that species the whole whorl is supported by two bracts; these are followed by a series of four narrow bractlets corresponding to the prophylla of the central flowers of the two cymes, and alternate with the ovaries follows a second series of six larger and broader bractlets corresponding to the prophylla of the four lateral flowers of the cymes. The only difference is that in Heptacodium the bractlets of the two series are almost alike in size and shape. In either case the inner series ought to consist really of eight bractlets, but the deviation in the number of bractlets is easily explained by the abortion of one pair or the union of two pairs of bractlets caused by the fact that they alternate with the six ovaries which leaves space for six bractlets only. Abortion or union of bractlets is of very frequent occurrence in Lonicera.

Only a single ripe fruit was available for examination; the seed was $7.5 \mathrm{~mm}$. long and cylindrical in the lower fourth, which contained the embryo; the upper threefourths were flattened and had the appearance of a wing-like appendage to the lower thick part. This appendage, however, did not consist of the testa alone, but contained a narrow layer of albumen, which suggests that the peculiar shape of the seed may be due to the shrinking of the upper part for want of nourishment, the fruit having possibly been gathered before it was fully ripe.

The generic name is derived from $\dot{\varepsilon} \pi \tau \dot{a}$ and $\kappa \dot{\omega} \delta \epsilon \iota a$ in allusion to the sevenflowered heads of the inflorescence.

\section{Heptacodium miconioides Rehder, n. sp.}

Frutex 3-metralis, ramis erectis medulla ampla solida repletis; ramuli hornotini striati, sparse adpresse pilosi, annotini purpurei, glabri; gemmae ovatae acutiusculae, perulis circiter 8 exterioribus margine dense ciliosulo excepto glabris. Folia decidua, chartacea, late ovata, subito acuminata, basi truncata $\mathrm{v}$. rotundata et interdum plus minusve in petiolum decurrentia, margine integra, interdum crispulo-undulata, 5-8.5 cm. longa et 4-5.5 cm. lata, supra glabra intense luteo-viridia, subtus pallidiora, lutescentia, nervis primariis praecipue basin versus dense strigoso-pilosis exceptis glabra, leviter reticulata, manifeste 3 -nervis, nervis lateralibus plerumque in petiolum decurrentibus supra leviter subtus manifeste elevatis; petioli supra canaliculati, $0.7-1 \mathrm{~cm}$. longi, subtus dense piloso-strigosi. Panicula $4.5-8 \mathrm{~cm}$. longa et 4-5 $\mathrm{cm}$. lata, rhachi et ramulis strigoso-pilosis; bracteae inferiores foliaceae, ceterae lanceolatae, eae ramulorum ovatae, acuminatae, $2-3 \mathrm{~mm}$. longae, ciliatae, bracteae ad basin capitulorum late ovate, acuminulatae, $4 \mathrm{~mm}$. longae, ciliatae, basin versus pubescentis; bracteolae capitulorum late ovatae v. ovales obtusiusculae, dense sericeae, circiter $3 \mathrm{~mm}$. longae; flores sessiles; calycis tubus dense pilis setosis erecto-patentibus vestitus, circiter $2 \mathrm{~mm}$. longus, lobi oblongi, subaequilongi, acutiusculi, dense sericei; corolla circiter, $1 \mathrm{~cm}$. longa, extus dense pilis reflexis minutis vestita, tubo leviter curvato intus villosulo, lobis oblongis paullo breviore; limbus leviter bilabiatus, lobis 5 fere 
aequalibus, $6 \mathrm{~mm}$. longis et $2-2.5 \mathrm{~mm}$. latis; stamina 5 , corolla paullo breviora, filamentis glabris, antheris $2 \mathrm{~mm}$. longis versatilibus; stylus $8 \mathrm{~mm}$. longus fere ad apicem pilosus, stigmate capitato parvo. Fructus oblongo-cylindricus, 10-costatus, sparse adpresse setosus, eirciter $1 \mathrm{~cm}$. longus; calycis lobi oblongi v. spathulato-oblongi, obtusiusculi, nervosi, utrinque minute pubescentes $10-12 \mathrm{~mm}$. longi.

Western Hupeh: Hsing-shan Hsien, cliffs, alt. 900 m., very rare, July and October 1907 (No. 2232).

In its habit and general appearance this plant suggests a member of the family of Melastomaceae and on account of the comparatively small flowers in terminal panicles it resembles particularly Miconia. Only elose examination showed that this interesting plant belongs to the Caprifoliaceae. 


\section{CORRECTIONS}

Tsuga chinensis (p. 38). In the herbarium of the Botanic Garden, Tokyo, Wilson saw the type specimen of Tsuga formosana Hayata and considers it typical T. chinensis Pritzel, although the leaves are rather shorter than is usual.

Keteleeria Davidiana (p. 40). In the herbarium of the Botanic Garden, Tokyo, Wilson saw the type specimen of Keteleeria Davidiana, var. formosana Hayata and considers it typical $K$. Davidiana Beissner.

Abies Beissneriana (p. 46). Line 1 of deseription read: "trunco ad $6 \mathrm{~m}$. in circuitu metiente," instead of "trunco ad $6 \mathrm{~m}$. diam."

Juniperus squamata (p. 59). In the herbarium of the Botanic Garden, Tokyo, Wilson saw the type specimen of Juniperus morrisonicola Hayata and considers it typical $J$, squamata Lambert.

Cinnamomum hupehanum (p. 69). Add as a synonym:

Cinnamomum glanduliferum Lecomte in Nouv. Arch. Mus. Paris, sér. 5, V. 74 (pro parte, non Meisner) (1915), saltem quoad specimen Wilsonii No. 836.

Phoebe Sheareri (p. 72). Add to the enumeration of specimens under western Hupeh: Changyang Hsien, alt. 900 m., May 1907 (No. 3695; tree 8-15 m. tall).

Machilus Thunbergii (p. 73). The true $M$. Thunbergii Siebold and Zuccarini does not occur in central or western China. The Chinese specimens referred by Gamble to this species with the exception of No. 3695 and $5184^{2}$ which belong to Phoebe Sheareri Gamble represent the following new species:

MachiLUS ICHANGensis Rehder \& Wilson, n. sp.

Machilus Thunbergii Hemsley in Jour. Linn. Soc. XXIII. 378 (pro parte, non Siebold \& Zuccarini) (1891); Hooker's Icon. XXVI. t. 2538 (1897). - Gamble in Sargent, Pl. Wilson. II. 73 (pro parte) (1914).

Arbor 7-15-metralis; ramuli satis graciles, glabri, fusco-rubri, rarius fuscocinerei, vix lenticellati. Folia alterna, chartacea, oblongo-lanceolata v. lanceolata, longe acuminata, basi sensim attenuata, rarius late cuneata, 10-18 $\mathrm{cm}$. longa et $2-4.5 \mathrm{~cm}$. lata, rarius paullo latiora, supra glabra, nitidula, luteo-viridia, subtus glaucescentia initio costa media glabra excepta minute sericea, demum glabra, in sieco utrinque subtus manifestius dense reticulata, nervis utrinsecus 12-17 arcuatis subtus ut costa media manifeste; supra leviter elevatis, costa media supra leviter impressa; petioli supra canaliculati, graciles, circiter $1.5 \mathrm{~cm}$., rarius ad $2.5 \mathrm{~cm}$. longi. Paniculae ad basin innovationum ex axillis bractearum caducarum orientes, graciliter pedunculatae pedunculo $3.5-5 \mathrm{~cm}$. longo, ramulis inferioribus 2-3-floris superioribus unifloris, glabrae; pedicelli $5-7 \mathrm{~mm}$. longi, sparse minute sericei; flores albidi; perianthium fere ad basin divisum; lobi 5-6 mm. longi, extus minute sericei, intus apice excepta glabri, demum reflexi, exteriores anguste oblongi, obtusiusculi, $2 \mathrm{~mm}$. lati, interiores oblongi, obtusi, $3 \mathrm{~mm}$. lati; stamina 9 , perianthio paullo breviora, subaequilonga, filamentis glabris $2.5 \mathrm{~mm}$. longis, antheris oblongis obtusis $1.5 \mathrm{~mm}$. longis, ea ordinis III. basi sericeo-pilosa et glandulis 2 suborbicularibus stipitatis instrueta; staminodia ordinis IV. triangularia, 
acutiuscula, basi truncata, stipite incluso $1.75 \mathrm{~mm}$. longa: ovarium subglobosum, glabrum; stylus basi incrassatus, $3 \mathrm{~mm}$. longus, stigmate capitato parvo. Drupa subglobosa, minute apiculata, 6-7 $\mathrm{mm}$. diam., glabra, basi perianthio reflexo instructa, pedicello vix incrassato.

Western Hupeh: Ichang gorge, Ping-shan-pa, at river level, April and June 1901 (Veitch Exped. No. 366; type); Nanto, April 28, 1900 (Veitch Exped. No. 99; tree $8 \mathrm{~m}$. tall, flowers white); Changyang Hsien, alt. $300 \mathrm{~m}$., May 1907 (No. 3700; tree 7-10 m. tall, flowers whitish); Hsingshan Hsien, April 1901 (Veitch Exped. No. 119); Patung Hsien, May 1901 (Veiteh Exped. No. 1933); without precise locality, A. Henry (No. 6121).

This species is closely related to $M$. Thunbergii Siebold \& Zuccarini which differs chiefly in its broader, obovate or oblong-obovate, more coriaceous and more lustrous leaves quite glabrous even while young, in the yellow flowers quite glabrous outside and in the larger fruits measuring $1 \mathrm{~cm}$. or more in diameter. Henry's No. 6121 differs from the type of $M$. ichangensis in the slightly silky under surface of the mature leaves, but in all other characters it agrees with the type of the species.

Wilson's Nos. 3695 and $5184^{a}$ referred by Gamble to $M$. Thunbergii Siebold \& Zuecarini belong to Phoebe Sheareri Gamble.

Like most other Chinese Lauraceae $M$. ichangensis is of rather local distribution and is confined to a limited area in western Hupeh. It is very common at low altitudes round Ichang and in other places in western Hupeh and is colloquially known as the Hsiao Nanmu (Little Nanmu). It is a rather small tree, seldom exceeding $15 \mathrm{~m}$. in height, and has short, thin branches which form a neat oval crown. The flowers are white or nearly so and the globose fruit is shining black.

The Japanese $M$. Thunbergii Siebold \& Zuccarini with which this new species has been confused is very different in habit and general appearance. During 1914, Wilson became well acquainted with the Japanese species which grows from Yokohama southward to the island of Yakushima and is especially common near the sea. It is usually a tree of moderate height (from 10-15 m.) with a wide-spreading flattened or flattened-round crown composed of massive branches and a short trunk from 2 to $4 \mathrm{~m}$. in girth; the leaves are relatively broad, dark green and shining and the flowers are yellow. The wood is heavy, very hard and tough and is used for various purposes, among others by peasants and lumbermen it is used for making solid wheels for low earts and trucks. The Japanese call this tree the "Tabu-no-ki." A picture of this tree will be found under No. x220 of the collection of Wilson's Japanese photographs.

Hemsley in a note (Hooker's Icon. sub. t. 2538) states that according to "G. M. H. Playfair Esqr., H. B. M. Consul at Ningpo, shavings of the wood of the Chinese species yield a mucilage, when soaked in water, which is used by Chinese ladies in 'bandolining' their hair." According to Wilson the wood of neither the Ichang tree ( $M$. ichangensis Rehder \& Wilson) nor that of the Japanese tree ( $M$. Thunbergii Siebold \& Zuecarini) is used for any such purpose.

Sassafras tzumu (p. 74). Add as a synonym after Litsea laxiflora: Pseudosassafras Tzumu Lecomte, Not. Syst. II. 269 (1912); in Nowv. Arch. Mus. Paris, sér. 5, V. 108 (1913).

Caragana Maximowicziana (p. 103). To this species belongs the following specimen: Kansu: Min-chou, alt. 2600-3000 m., 1910, W. Purdom (No. 681). All specimens from western Szech'uan cited under this species belong to the following species:

Caragana erinacea Komarov in Act. Hort. Petrop. XXIX. 268, t. 9, fig. B (Gen. Carag. Monog.) (1909). 
Clausena punctata (p. 140). Add as a synonym:

Claucena Lansium Skeels in Bull. U. S. Dept. Agric. Bur. Pl. Indust. CLXVIII. 31 (1909).

Skeels apparently rejected the oldest specific name on account of Clausena punctata Voigt, Hort. Suburb. Calcutt. 140 (1845) ${ }^{1}$ based on Amyris punctata Roxburgh (Fl. Ind. ed. 2, 251 [1832]); this name, however, is universally considered a synonym of C. excavata Burman (Fl. Ind. 87 [1768]), though, as the latter species is based on a Javanese plant, while Amyris punctata is based on an Indian plant, there is the possibility that the two may turn out to be specifically different; in such a case $C$. punctata Voigt would become the name of the Indian plant, and $C$. punctata Rehder \& Wilson would be replaced by $C$. lansium Skeels.

Sageretia Cavaleriei (p. 228). This becomes a synonym of the following name:

Sageretia Henryi Drummond \& Sprague in Kew Bull. Misc. Inform. 1908, $14 ; 1914,175$.

Sageretia apiculata (p. 231). This becomes a synonym of the following name:

Sageretia gracilis Drummond \& Sprague in Kew Bull. Misc. Inform. 1908, $15 ; 1914,175$.

Rhamnus heterophyllus (p. 232). Add to the enumeration of specimens:

Western Hupeh: Fang Hsien, thickets, alt. 1000 m., September 1907 (No. 29I I ; bush 0.4-1 m., flowers yellowish).

Fraxinus Griffithii Clarke (p. 258). In the enumeration of specimens for No. 2775 read: $2775^{\mathrm{a}}$.

Fraxinus Paxiana (p. 259). Add to the enumeration of specimens under Western Szech'uan: Lungan Fu, alt. 2100-2700 m., August 1910 (No. 4609); without precise locality, alt. 2000-2100 m., July 1903 (Veitch Exped. No. 4087; tree 5-8 m. tall).

Remove from the enumeration of specimens Nos. 708, 4423, 2778 and 2780 and transfer to Fraxinus platypoda.

Fraxinus chinensis (p. 260). Add to the enumeration of specimens under western Szech'uan: northeast of Tachien-lu, Ta-pao-shan, side of streams, alt. 2200 m., July 2, 1908 (No. 2782); tree $12 \mathrm{~m}$. tall, girth $1.3 \mathrm{~m}$.); valley of Yalung River, alt. 2700-3000 m., June 1904 (Veitch Exped. No. 4088; tree 7-12 m. tall); without precise locality, ravines, alt. 3000 m., June 1904 (Exped. No. $4088^{\mathrm{a}}$; tree $7 \mathrm{~m}$. tall).

Fraxinus chinensis, var. Thynchophylla (p. 260). Remove from the enumeration of specimens No. 4609 and Veitch Exped. No. 4082 which is a misprint for 4087, and transfer both to $F$. Paxiana.

Fraxinus platypoda (p, 262). Add to the enumeration of specimens: Western Hupeh: Fang Hsien, woods, alt. 1800-2600 m. May 19 and November 1907, June 15 and Oetober 1910 (Nos. 708, 444I plants only, 4423). Western Szech'uan: Wa-shan, alt. $1800 \mathrm{~m}$. September 1908 (No. 2780); west of Kuan Hsien, ascent of Pan-lan-shan, alt. 2300-2600 m. June 1908 (No. 2778).

By Lingelsheim these specimens except No. 4441 are erroneously referred to his F. Paxiana.

1 The combination $C$. punctata is usually credited to Wight \& Arnott (Prodr. Fl. Ind. 95, in adnot. [1834]), but these authors did not make the combination, they merely state that Amyris sumatrana and punctata belong to the genus Clausena. 
Fraxinus platypoda is fairly common in the woods on the higher mountains of northwestern Hupeh and also in western Szech'uan. Pictures will be found under Nos. 358 and 083 of the collection of Wilson's photographs and also in his Vegetation of Western China No. 228.

Rosa microcarpa (p. 316). Line 9 from above last word read " early" instead of "rarely."

Rosa Wichuraiana (p. 335). In the enumeration of synonyms instead of Rosa Wichuraiana, $\beta$ fimbriata, $\gamma$ poteriifolia, $\delta$ adenophora, $\epsilon$ crataegicarpa, $\zeta$ yokoscensis, read:

Rosa Luciae, $\boldsymbol{\beta}$ fimbriata Franchet \& Savatier, Enum. Pl. Jap. II. 344 (1879). Rosa Luciae, $\gamma$ poteriifolia Franchet \& Savatier, 1. c. (1879).

Rosa Luciae, ó adenophora Franchet \& Savatier, 1. c. 345 (pro parte) (1879).

Rosa Luciae, є crataegicarpa Franchet \& Savatier, 1. c. (1879).

Rosa Luciae, לyokoscensis Franchet \& Savatier, 1. c. (1879).

Firmiana simplex (p. 377). Insert before F. N. Meyer: W. F. Wight in Bull. U. S. Dept. Agric, Bur. Pl. Indust. CXLII. 67 (1909). - 
INDEX 


\section{INDEX}

Names of families and subfamilies are in small capitals; names of admitted genera, subgenera, sections, species and varieties are in roman type; synonyms in ilalics.

Abies, 41 .

Abies Beissneriana, 46, 621 .

Abies brachytyla, 33 .

Abies chensiensis, 44 .

Abies chinensis, 37.

Abies Davidiana, 39.

Abies Delavayi, 41.

Abies dumosa, var. chinensis, 36, 37.

Abies Fargesii, 48.

Abies Fargesii, 41.

Abies Fargesii, var. sutchuensis, 48.

Abies Faxoniana, 42.

Abies firma, 47.

Abies firma, 44, 46.

Abies Fortunei, 41.

Abies Fortuni, 40.

Abies Jezoensis, 40.

Abies Kaempferi, 21.

Abies lanceolata, 50.

Abies likiangensis, 31 .

Abies Mariesii, 49.

Abies nephrolepis, 49.

Abies recurvata, 44 .

Abies sacra, 39.

Abies Schrenkiana, 29.

Abies sibirica, 50 .

Abies sibirica, var. nephrolepis, 49 .

Abies Smithiana, 29.

Abies sp., 44.

Abies squamata, 48 .

Abies sutchuenensis, 48 .

Abies thié-sha, 37.

Abies Tsuga, 37.

Abies Veitchii, 49.

Abies Veitchii, 50.

Abies yunnanensis, 36.

Abieteae, 10.

Abietia Fortunei, 41.

Abutilon, 373.

Abutilon sinense, 373 .

Acalypha, 523.

Acalypha acmophylla, 523 .
Acalypha Giraldii, 524.

Acalypha szechuanensis, 524 .

Acanthochlamys, 447, 448.

Acanthopanax, 557.

Acanthopanax?, 562.

Acanthopanax acerifolium, 565 .

Acanthopanax aculeatum, 564 .

Acanthopanax diversifolium, 556.

Acanthopanax evodiaefolius, 563 .

Acanthopanax Giraldii, 560.

Acanthopanax Giraldii, var. inermis, 560 .

Acanthopanax Henryi, 557.

Acanthopanax lasiogyne, 563 .

Acanthopanax leucorrhizus, 557.

Acanthopanax leucorrhizus, var. fulvescens, 558 .

Acanthopanax leucorrhizus, var. scaberulus, 558 .

Acanthopanax Rehderianus, 561.

Acanthopanax ricinifolium, 565 .

Acanthopanax ricinifolius, var. magnificus, 565 .

Acanthopanax sepium, 564 .

Acanthopanax setchuenensis, 559.

Acanthopanax Simonii, 559.

Acanthopanax spinosus, 562 .

Acanthopanax spinosus, 562.

Acanthopanax spinosus, var. pubescens, 562.

Acanthopanax stenophyllus, 564 .

Acanthopanax trifoliatus, 563 .

Acanthopanax villosulus, 562 .

Acanthopanax Wilsonii, 560.

Actinodaphne, 74 .

Actinodaphne confertifolia, 74 .

Actinodaphne cupularis, 75 .

Actinodaphne reticulata, 75 .

Actinidia, 378.

Actinidia arguta, 379.

Actinidia callosa, 382 .

Actinidia callosa, 382 . 
Actinidia callosa, var. coriacea, 384 . Actinidia callosa, forma $C$., 382 . Actinidia callosa, forma D., 383 . Actinidia callosa, var. Henryi, 382 . Actinidia callosa, var, trichogyna, 384 . Actinidia chinensis, 385 . Actinidia coriacea, 384. Actinidia curvidens, 382. Actinidia kolomikta, 380 . Actinidia melanandra, 378 . Actinidia platyphylla, 381 . Actinidia polygama, 380 . Actinidia purpurea, 378. Actinidia rufa, var. 4. parvifolia, 378 . Actinidia sabiaefolia, 384 .

Actinidia spec., 385.

Actinidia tetramera, 381 . Actinidia trichogyna, 384 .

Actinidia venosa, 383 . Actinidia volubilis, 380 . Acuminatae, 462, 465. Acuminatae, 465.

Aegle (?) sepiaria, 149.

Agyneia impubes, 518.

Agyneia pubera, 518.

Ailanthus, 153.

Ailanthus cacodendron, 153.

Ailanthus cacodendron, var. sutchuenensis, 153.

Ailanthus flavescens, 156.

Ailanthus glandulosa, 153, 154.

Ailanthus glandulosa, var. spinosa, 154 .

Ailanthus glandulosa, var. sutchuenensis, 154.

Ailanthus procera, 153.

Ailanthus sutchuenensis, 154.

Ailanthus Vilmoriniana, 154.

Alangiaceae, 552.

Alangium, 552.

Alangium begoniifolium, $\mathbf{5 5 2}$.

Alangium chinense, 552 .

Alangium Faberi, 552.

Alangium platanifolium, 554.

Alangium platanifolium, var. $\boldsymbol{\beta}$ genuinum, f. triangulare, 553 .

Albae, 465, 485.

Albae, 483, 485 .

Albizzia, 87.

Albizzia julibrissin, 87.

Alchornea, 524.

Alchornea Davidii, 524.

Alchornea rufescens, 524 .

Aleurites, 528 .
Aleurites cordala, 528 .

Aleurites Fordii, 528.

Aleurites verniciflua, 528 .

Alnaster, 491, 503.

Alnaster, 492, 502, 503.

Alnaster fruticosus, 503.

Alnaster viridis, 503, 504.

Alnibetula, 503.

Alnobetula, 503.

Alnobetula fruticosa, 504.

Alnobetula viridis, 503 .

Alnus, 488, 490, 492.

Alnus, 492.

Alnus alnobetula, 503.

Alnus alnobetula, var. fruticosa, 504, 505.

Alnus borealis, 500 .

Alnus cremastogyne, 488, 490, 492.

Alnus crispa, 504.

Alnus cylindrostachya, 495.

Alnus Fauriei, 490, 495.

Alnus firma, 491, 505 .

Alnus firma, $\boldsymbol{\beta}$ hirtella, 506.

Alnus firma, subspec. hirtella, 506.

Alnus firma, var. multinervia, 507.

Alnus firma, var. multinervis, 507.

Alnus firma, var. Sieboldiana, 506.

Alnus firma, var. typica, 506.

Alnus firma, var. Yasha, 507.

Alnus formosana, 491, 501 .

Alnus fruticosa, 491, 503 .

Alnus fruticosa, var. mandschurica, 504. Alnus fruticosa, var. mandschurica, f. grandifolia, 504.

Alnus fruticosa, var. mandschurica, $\mathrm{f}$. normalis, 504.

Alnus fruticosa, var, sachalinensis, 504.

Alnus fruticosa, var. typica, 504 .

Alnus fruticosa, var. typica, f. macrophylla, 504.

Alnus fruticosa, var. typica, f. vulgaris, 504.

Alnus glutinosa, 496, 500 .

Alnus glutinosa, var. cylindrostachya, 495.

Alnus glutinosa, var. japonica, 496.

Alnus glutinosa, var. obtusata, 496.

Alnus Henryi, 490, 495.

Alnus hirtella, 507.

Alnus hirsuta, 490, 496.

Alnus hirsuta, var. Cajanderi, 497.

Alnus hirsuta, var. sibirica, 498.

Alnus hirsuta, var. vulgaris, 497. 
Alnus hirsuta, var. vulgaris, f. macrophylla, 497.

Alnus hirsuta, var. vulgaris, f. typica, 497.

Alnus incana, var. emarginata, 500 .

Alnus incana, var. glauca, 498.

Alnus incana, $\beta$ hirsuta, 496.

Alnus incana, var. hirsuta, 497.

Alnus incana, var. sibirica, 498.

Alnus incana, var. tinctoria, 498.

Alnus japonica, 490, 493.

Alnus japonica, 501.

Alnus japonica, var. arguta, 494.

Alnus japonica, var. formosana, 501.

Alnus japonica, var. genuina, 493 .

Alnus japonica, var. koreana, 494 .

Alnus japonica, var. latifolia, 493.

Alnus japonica, var. minor, 494 .

Alnus japonica, var. reginosa (an resinosa ?), 493.

Alnus lanata, 488, 490, 492.

Alnus maritima, 501.

Alnus maritima, var. arguta, 494.

Alnus maritima, var. formosana, 495, 501.

Alnus maritima, var. japonica, 493, 494, 501.

Alnus maritima, var. obtusata, 496.

Alnus Matsumurae, 490, 500.

Alnus Maximowiczii, 491, 505.

Alnus Mayrii, 494.

Alnus multinervis, 508.

Alnus multinervis, var. nikkoensis, 508.

Alnus multinervis, var. typica, 508.

Alnus nana, 480.

Alnus napalensis, 502.

Alnus nepalensis, 491, 502.

Alnus nitida, 491, 501 .

Alnus obtusa, 496.

Alnus ovata, 503.

Alnus paniculata, 495.

Alnus pendula, 491 .

Alnus pendula, 507.

Alnus Schneideri, 495.

Alnus serrulatoides, 490, 496.

Alnus sibirica, 498 .

Alnus sibirica, var. hirsuta, 497.

Alnus sibirica, var. oxyloba, 498.

Alnus sibirica, var. paucinervia, 499.

Alnus sibirica, var. tinctoria, 499.

Alnus sibirica, var. typica, 498.

Alnus Sieboldiana, 506.
Alnus sinuata, var. kamtschatica, 491, 504.

Alnus sitchensis, var. kamtschatica, 505. Alnus sp., 501.

Alnus tinctoria, 497, 498.

Alnus tinctoria, var. mandschurica, 498.

Alnus tinctoria, var. obtusiloba, 498.

Alnus tinctoria, var. typica, 498 .

Alnus viridis, 503 .

Alnus viridis, var, julacea, 504.

Alnus viridis, var. sibirica, 504, 505.

Alnus Yasha, 506.

Alnus yasha, var. macrocarpa, 507.

Alnus yasha, var. typica, 507 .

Alseodaphne, 70.

Alseodaphne omeiensis, 70 .

Althea frutex, 374.

Ampacus trichotoma, 132.

Amyris punctata, 623 .

Amyris, suffruticosa, 140.

ANACARDIACEAE, 172.

Andrachne, 516.

Andrachne capillipes, 516.

Andrachne capillipes, var. pubescens, 516.

Andrachne cordifolia, 516.

Andrachne hirsuta, 516.

Andrachne montana, 517.

Andrachne trifoliata, 521.

Anthyllis cuneata, 105.

Antidesma, 522.

Antidesma delicatulum, 522 .

Apios, 117.

Apios Fortunei, 117.

A pocynaceae, 538.

Aralia, 566.

Aralia canescens, 567.

Aralia chinensis, 566.

Aralia chinensis, var. canescens, 567.

Aralia chinensis, var. glabrescens, 567.

Aralia Decaisneana, 566.

Aralia elata, 567.

Aralia japonica, 566 .

Aralia mandshurica, 566 .

Aralia pentaphylla, 562.

Aralia Planchoniana, 566.

Aralia spinosa, 566 .

Aralia spinosa, $\beta$ canescens, 566.

Aralia spinosa, var. Chinensis, 566.

Aralia spinosa, var. elata, 567.

Aralia spinosa, var. glabrescens, 567 .

Aralia trifoliata, 564.

Aralia Wilsonii, 567. 
Araliaceae, 555.

Araucaria lanceolata, 51.

Ardisia, 581.

Ardisia crenata, 582.

Ardisia crenulata, 582.

Ardisia crispa, 581.

Ardisia densa, 582.

Ardisia elegans, 582.

Ardisia glabra, 583 .

Ardisia glandulosa, 582 .

Ardisia Henryi, 582.

Ardisia hortorum, 582.

Ardisia japonica, 582 .

Ardisia japonica, $\boldsymbol{\beta}$ montana, 583.

Ardisia lentiginosa, 582.

Ardisia montana, 583 .

Ardisia nana, 582.

Ardisia odontophylla, 583.

Ardisia polysticta, 582 .

Ardisia undulata, 582.

Aria alnifolia, 270.

Aria japonica, 275.

Aria tiliaefolia, 270.

Arundinaria, 63.

Arundinaria dumetosa, 63.

Arundinaria sp., 64.

Arundinaria szechuanensis, 64.

Ascyron sibiricum, 402.

Aspalanthus cuneata, 105.

Asperae, 463, 475.

Asperae, 475.

Aubletia ramosissima, 210.

Aucuba, 572.

Aucuba chinensis, 572 .

Aucuba chinensis, f. angustifolia, 573 .

Aucuba chinensis, f. obcordata, 572.

Aucuba japonica, 572 .

A ucuba japonica, var. longifolia, $\mathbf{5 7 2}$.

Augia sinensis, 183.

Aurantium acre, 147.

Aurantium decumana, 144.

A urantium sinense, 148.

Avellana, 447, 448 .

Axillares, 355 .

Azedarach sempervirens, 158.

Bambusa, 65.

Bambusa Beecheyana, 65.

Bambusa puberula, 65.

Bambusa sp., 65.

Bambusa verticillata, 65 .

Bambuseae, 63.

Banksianae, 333, 337.
Bauhinia, 88 .

Bauhinia densiflora, 88 .

Bauhinia Faberi, 88.

Bauhinia Faberi, var. microphylla, 89.

Bauhinia hupehana, 89.

Bauhinia hupehana, var. grandis, 90 .

Bauhinia yunnanensis, 89 .

Belis jaculifolia, 50 .

Belis lanceolata, 51.

Benthamia fragifera, 578 .

Benthamia japonica, 578 .

Benzoin glaucum, 80.

Benzoin membranaceum, 81.

Benzoin obtusilobum, 85 .

Benzoin pulcherrimum, 85.

Benzoin strychnifolium, 82.

Benzoin Thunbergii, 81.

Berchemia, 213, 222.

Berchemia affinis, 218.

Berchemia alnifolia, 218.

Berehemia annamensis, 218, 220.

Berchemia Cavaleriei, 228.

Berchemia Chaneti, 228.

Berchemia cinerascens, 218, 219.

Berchemia Edgeworthii, 218.

Berchemia Elmeri, 219, 220.

Berchemia flavescens, 218, 219.

Berchemia floribunda, 213, 218, 219.

Berchemia floribunda, var. megalophylla, 213.

Berchemia formosana, 219, 220.

Berchemia Giraldiana, 213, 218, 219.

Berchemia hypochrysa, 214, 218, 219.

Berchemia kulingensis, 216, 219, 220.

Berchemia lineata, 219, 220.

Berchemia pauciflora, 218.

Berchemia philippinensis, 219, 221.

Berchemia polyphylla, 219, 221.

Berchemia pubiflora, 218.

Berchemia pycnantha, 215, 219, 220.

Berchemia racemosa, 218, 219.

Berchemia sessiliflora, 218.

Berchemia sinica, 215, 218, 219.

Berchemia trichantha, 218.

Berchemia yunnanensis, 216, 219, 220.

Berchemia yunnanensis, var. trichoclada, 217.

Betula, 455 .

Betula acuminata, 455, 467.

Betula acuminata, $\gamma$ arguta, 467.

Betula acuminata, var. cylindrostachya, 466.

Betula acuminata, a glabra, 467. 
Betula acuminata, §lancifolia, 467.

Betula acuminata, $\boldsymbol{\beta}$ pilosa, 467.

Betula acuminata, var. pyrifolia, 455.

Betula affinis, 467.

Betula alba, 477, 485 .

Betula alba, var. communis, 469, 471.

Betula alba, var. glutinosa, lusus latifolia, 473.

Betula alba, var. japonica, 486.

Betula alba, subspec. latifolia, var. kamtschatica, 487.

Betula alba, subspec. latifolia, var. Tauschii, 486.

Betula alba, subspec. mandshwrica, 461.

Betula alba, var. mandshurica, 486 .

Betula alba, var. Tauschii, 486.

Betula alba, var. typica, 485.

Betula alba, var. verrucosa, 485.

Betula alba, subspec. verrucosa, var. resinifera, 486.

Betula alba, subspec. verrucosa, var. sterilis, 486 .

Betula alba, subspee. verrucosa, var. vulgaris, 486.

Betula alba, var. vilgaris, 461, 485, 487.

Betula albo-sinensis, 457, 463, 475 .

Betula albo-sinensis, var. septentrionalis, 458,475 .

Betula alnobetula, 503.

Betula alnoides, $462,467$.

Betula alnoides, 455, 466.

Betula alnoides, var. acuminata, 467.

Betula alnoides, var. cylindrostachya, 466.

Betula alnoides, var. pyrifolia, 455 .

Betula Alnus, 506.

Betula Baeumkeri, 462, 468.

Betula Bhojpaltra, 474.

Betula Bhojpaltra, var. genuina, 474.

Betula Bhojpaltra, var. glandulifera, 473.

Betula Bhojpaltra, var. Jacquemontii, 473.

Betula Bhojpaltra, var. subcordata, 471.

Betula Bhojpattra, 474.

Betula Bhojpattra, var. glandulifera, 473.

Betula Bhojpattra, var. Jacquemontii, 473, 475.

Betula Bhojpattra, var. japonica, 471 .

Betula Bhojpattra var. latifolia, 474.

Betula Bhojpattra, var. sinensis, 457.
Betula Bhojpattra, var. subcordata, 471.

Betula Bhojpattra, var. typica, 469 , 474,475 .

Betula Boshia, 502.

Betula candelae, 466.

Bebula carpinifolia, 477.

Betula chinensis, 464, 479.

Betula chinensis, var. angusticarpa, 480 .

Betula chinensis, var. Delavayi, 459, 460.

Betula corylifolia, $463,476$.

Betula costata, 463, 476.

Betula eylindrostachya, 462, 466 .

Betula cylindrostachya, 466 .

Betula cylindrostachys, $455,467$.

Betula cylindrostachys, $\boldsymbol{\beta}$ pilosa, 467 .

Betula cylindrostachys, var. resinosa, 455.

Betula cylïndrostachys, y subglabra, 467 .

Betula cylindrostachys, var. typica, 466.

Betula dahurica, 475.

Betula dahurica, var. Maximowicziana, 484.

Betula davurica, 465, 483.

Betula Delavayi, 460, 464, 479.

Betula Delavayi, var. calcicola, 479.

Betula Delavayi, var. Forrestii, 479.

Betula Ermani, 472.

Betula Ermani, var. acutifolia, 470.

Betula Ermani, var. communis, 470, 471.

Betula Ermani, var. costata, 477.

Betula Ermani, var. genuina, 471.

Betula Ermani, var. incisa, 471.

Betula Ermani, var. japonica, 471.

Betula Ermani, var. nipponica, 471.

Betula Ermani, var. parvifolia, 470.

Betula Ermani, var. sachalinensis, 470.

Betula Ermani, var. subcordata, f. nipponica, 471.

Betula Ermani, var. tomentosa, 472.

Betula Ermani, var. typica, 470 .

Betula Ermanii, 462, 468.

Betula Ermanii, var. genuina, 470.

Betula Ermanii, var. genuina, subvar. brevidentata, 471.

Betula Ermanii, var. genuina, subvar. Saitôana, 470 .

Betula Ermanii, var. lanata, 472.

Betula Ermanii, var. subcordata, 471.

Betula exalata, 480.

Betula Fargesii, 478. 
Betula fruticosa, 464, 482.

Betula fruticosa, 482 .

Betula fruticosa, var. Ruprechtiana, 482.

Betula glandulosa, 481.

Betula glandulosa, var. rotundifolia, 481.

Betula glandulosa, var. sibirica, 464, 481.

Betula globispica, 463, 479 .

Betula Gmelini, 482.

Betula grossa, $463 ; 477$.

Betula harinoki, 506.

Betula humilis, 464, 482.

Betula humilis, var. commutata, 482 .

Betula humilis, var. genuina, 482.

Betula humilis, var. kamtschatica, 481 .

Betula y humilior palustris, 482.

Betula humilis, var. Ruprechtii, 483.

Betula hupehensis, 455

Betula insignis, 459, 464, 478.

Betula Jacquemontii, 462, 473.

Betula japonica, 465, 485.

Betula japonica, 485.

Betula japonica, var. kamtschatica, 486.

Betula japonica, var. mandshurica, 461, 488.

Betula japonica, var. pluricostata, 486.

Betula japonica, var. resinifera, 487.

Betula japonica, var. Tauschii, 486.

Betula latifolia, 486.

Betula lenta, var. carpinifolia, 477.

Betula lenta, var. grossa, 477.

Betula leptostachya, 502.

Betula luminifera, $455,462,468$.

Betula Maackii, 484.

Betula mandshurica, 461-486.

Betula Maximowicziana, 462, 465.

Betula Maximowiczii, 465, 484.

Betula Middendorffii, 465, 481.

Betula nana, 464, 480.

Betula nana, 481.

Betula nana, var. genuina, 480 .

Betula nana, var, sibirica, 481.

Betula nitida, 467.

Betula nitida, var. affinis, 467.

Betula ovalifolia, 482.

Betula ovata, 503.

Betula palustris, var. 482.

Betula palustris Gmelini, 482.

Betula pendula, var. japonica, 486.

Betula pendula, var. japonica, f. microdonta, 486.
Betula pendula, var. japonica, f. typica, 487.

Betula pendula, var. Tauschii, 486.

Betula Potaninii, 459, 464, 479.

Betula punctata, 475 .

Betula reticulata, 482.

Betula Rosae, 484.

Betula rotundifolia, 481.

Betula Saitôana, 470.

Betula Schmidtii, 463, 475.

Betula ulmifolia, 469, 477.

Betula ulmifolia, var. costata, 477.

Betula ulmifolia, var. $\delta$ glandulosa, 469.

Betula ulmifolia, var. sericea, 477.

Betula ulmifolia, var. typica, 469.

Betula utilis, 463, 474.

Betula utilis, 457, 458.

Betula utilis, var. Jacquemontii, 473.

Betula utilis, var. Prattii, 457, 475.

Betula utilis, var. sinensis, 458.

Betula verrucosa, var. japonica, 486 .

Betula viridis, 503.

Betula Vulcani, 471.

Betula Wilsoniana, 455.

Betula Wilsonii, 460.

Betula wutaica, 484.

Betulaaceae, 423.

Betulaster, 465.

Betulaster acuminata, 467.

Betulaster affinis, 467.

Betulaster nitida, 467.

Biota orientalis, 53.

Bischofia, 521.

Bischofia javanica, 521.

Bischofia oblongifolia, 521.

Bischofia trifoliata, 521.

Bladhia crispa, 582.

Bladhia glabra, 583.

Bladhia japonica, 583.

Bobua atroviridis, 595.

Bobua laurina, 594.

Bobua oligostachya, 595.

Boymia rutaecarpa, 132.

Bracteatae, 333, 337.

Bradleia sinica, 518.

Brassaiopsis, 556.

Brassaiopsis fatsioides, 556 .

Brassaiopsis ricinifolia, 565.

Bumalda trifolia, 185.

Bumalda trifoliata, 185.

Burseraceae, 155.

BuXaceae, 163.

Buxus, 165. 
Buxus arborescens, 168.

Buxus balearica, 167, 168.

Buxus cephalantha, 166.

Buxus dioeca, 581.

Buxus Harlandii, 166, 167, 169.

Buxus Henryi, 167, 168.

Buxus japonica, 168.

Buxus japonica, $\boldsymbol{\beta}$ microphylla, 165.

Buxus liukiuensis, 167, 168.

Buxus longifolia, 167, 168.

Buxus longifolia, 168.

Buxus microphylla, 165, 167, 168.

Buxus microphylla, 166.

Buxus microphylla, var. aemulans, 167, 169.

Buxus microphylla, var. japonica, 167, 168.

Buxus microphylla, var. sinica, 165, 167, 169.

Buxus papillosa, 167, 168.

Buxus sempervirens, 167, 168.

Buxus sempervirens, 165, 166, 168, 169.

Buxus sempervirens, $a$ angustifolia, 165.

Buxus sempervirens, var. gigantea, 168.

Buxus sempervirens, var. japonica, 169.

Buxus sempervirens, var. liukiuensis, 168.

Buxus sempervirens, $\beta$ microphylla, 165.

Buxus stenophylla, 167, 169.

Buxus Wallichiana, 167, 168.

Caesalpinia, 92.

Caesalpinia sepiaria, 92.

Caesalpinia szechuenensis, 92 .

Camellia, 393.

Camellia axillaris, 395.

Camellia Bohea, 391.

Camellia cuspidata, 390.

Camellia fraterna, 390.

Camellia Grijsii, 394.

Camellia oleifera, 393.

Camellia sasanqua, 393.

Camellia Sasanqua, var. oleifera, 393.

Camellia Sasanqua, var. oleosa, 393.

Camellia? Scottiana, 391.

Camellia Thea, 391.

Camellia theifera, 391.

Camellia viridis, 391 .

Camphora inuncta, 69.

Camphora officinalis, 68.

Camphora officinarum, 68 .
Camptotheca, 254.

Camptotheca acuminata, 254.

Camptotheca yunnanensis, 254.

Campylotropis, 113.

Campylotropis chinensis, 113.

Campylotropis chinensis, 113.

Campylotropis diversifolia, 115.

Campylotropis hirtella, 115.

Campylotropis latifolia, 115.

Campylotropis macrocarpa, 113.

Campylotropis Muehleana, 114.

Campylotropis parviflora, 115 .

Campylotropis polyantha, 114 .

Campylotropis Prainii, 115.

Campylotropis Sargentiana, 113.

Campylotropis trigonoclada, 114.

Campylotropis virgata, 112.

Campylotropis Wilsonii, 114.

Campylotropis yunnanensis, 114.

Canarium, 155.

Canarium album, 155.

Caprifolitaceae, 617.

Capura purpurata, 534.

Caragana, 102.

Caragana bicolor, 102.

Caragana Boisii, 102.

Caragana chamlagu, 102.

Caragana erinacea, 622 .

Caragana jubata, 103.

Caragana Maximowicziana, 103, 622.

Caragana Maximowicziana, 622.

Carpinus, 425.

Carpinus Carpinus, 433.

Carpinus carpinoides, 433.

Carpinus carpinoides, var. cordifolia, 433.

Carpinus cordata, 425, 431, 434.

Carpinus cordata, 425.

Carpinus cordata, var. chinensis, 437.

Carpinus cordata, f. chinensis, 435.

Carpinus Davidii, 426.

Carpinus Distegocarpus, 434.

Carpinus erosa, 435.

Carpinus faginea, 433, 442.

Carpinus faginea, 430 .

Carpinus Fargesiana, 428, 432, 441.

Carpinus Fargesii, 426.

Carpinus Fauriei, 433, 442.

Carpinus Henryana, 429, 432, 442.

Carpinus heterophylla, var. sutchuensis, 445.

Carpinus japonica, 431, 433.

Carpinus japonica, var. caudata, 434 . 
Carpinus japonica, var. cordifolia, 433. Carpinus japonica, var. pleioneura, 434. Carpinus Kawakamii, 429.

Carpinus laxiflora, 432, 438.

Carpinus laxiflora, 426, 441.

Carpinus laxiflora, var. chartacea, 438.

Carpinus laxiflora, var. Davidii, 426, 439.

Carpinus laxiflora, var. Fargesii, 426.

Carpinus laxiflora, var. macrostachya, $425,439$.

Carpinus Londoniana, 432, 438.

Carpinus minutiserrata, 442.

Carpinus Paxii, 440.

Carpinus pinfaensis, 430.

Carpinus polyneura, 430, 433, 443.

Carpinus polyneura, 427, 429 .

Carpinus polyneura, var. Wilsoniana, 443.

Carpinus pubescens, 432, 442.

Carpinus pubescens, 430.

Carpinus Seemeniana, 430, 432, 442.

Carpinus stipulata, 440.

Carpinus Tanakaeana, 432, 440.

Carpinus Tschonoskii, 432, 441.

Carpinus T'schonoskii, var. Henryana, 429.

Carpinus Tschonoskii, var. subintegra, 442.

Carpinus Turczaninovii, 432, 439.

Carpinus Turezaninovii, var. firmifolia, 440 .

Carpinus Turezaninovii, var. ovalifolia, 427,440 .

Carpinus Turezaninovii, var. 432.

Carpinus Turczaninowii, 427.

Carpinus Turczaninowii, var. Makinoi, 440.

Carpinus Turczaninowii, var. polyneura, 430.

Carpinus Turczaninowii, var. stipulata, 440.

Carpinus viminea, $432,437$.

Carpinus yedoensis, 428, 441.

Carpinus yedoensis, var. Jablonszkyi, 441.

Carpinus yedoensis, var. serratiauriculata, 441.

Caryotaxus grandis, 7.

Casicta, 29.

Cassia, 90.

Cassia Leschenaultiana, 90.
Catha Benthamii, 358.

Catha monosperma, 357.

Ceanothus napalensis, 245.

Ceanothus paniculatus, 355 .

Ceanothus triquetra, 246.

Cedrela, 156.

Cedrela chinensis, 156.

Cedrela microcarpa, 157.

Cedrela sinensis, 156 .

Celastraceae, 346.

Celastrus, 346.

Celastrus alatus, 358.

Celastrus alnifolia, 355 .

Celastrus angulata, 346, 353, 355 .

Celastrus articulata, 354,356 .

Celastrus articulata, var. cuneata, 350 356.

Celastrus articulata, var. punctata, 356.

Celastrus articulatus, 350.

Celastrus articulatus, var. $\beta, 356$.

Celastrus articulatus, var. humilis, 356.

Celastrus Benthamii, 358, 554.

Celastrus Bodinieri, 358.

Celastrus cantonensis, 354, 357.

Celastrus Cavaleriei, 358.

Celastrus Championii, 358.

Celastrus ciliidens, 357.

Celastrus clemacanthus, 357 .

Celastrus crispula, 356.

Celastrus dependens, 353,355 .

Celastrus diversifolia, 358.

Celastrus emarginata, 358 .

Celastrus Esquiroliana, 354, 357.

Celastrus Esquirolii, 358.

Celastrus euonymoidea, $358,371$.

Celastrus Feddei, 358.

Celastrus flagellaris, 354, 357.

Celastrus Franchetiana, 354, 355.

Celastrus gemmata, $352,354,356$.

Celastrus glaucophylla, $347,354,355$.

Celastrus Hindsii, 354, 357.

Celastrus Hindsii, var. Henryi, 353, 357.

Celastrus Hookeri, 352, 354, 356.

Celastrus hypoglaucus, 346.

Celastrus hypoleuca, $346,354,355$.

Celastrus hypoleucus, forma $\beta$ argutior, 346.

Celastrus hypoleucus, forma a genuina, 346.

Celastrus japonica, 136.

Celastrus kiusianus, 356. 
Celastrus Kouytchensis, 358.

Celastrus Kusanoi, 354, 356.

Celastrus latifolius, 346.

Celastrus Loeseneri, 350, 354, 356.

Celastrus Lyi, 358.

Celastrus Mairei, 358.

Celastrus Metziana, 355.

Celastrus monosperma, 354, 357.

Celastrus monospermus, 357.

Celastrus multiflorus, 355.

Celastrus n. sp., 356.

Celastrus nutans, 355.

Celastrus orbiculata, 350 .

Celastrus orbiculatus, 356.

Celastrus orbiculatus, var. punctatus, 356.

Celastrus Orixa, 136.

Celastrus paniculata, 353,355 .

Celastrus paniculata, 355 .

Celastrus punctatus, 356.

Celastrus racemulosa, 355 .

Celastrus Rosthorniana, 351, 354, 356.

Celastrus Rothiana, 355.

Celastrus rugosa, 349, 354, 356.

Celastrus salicifolia, 358.

Celastrus Seguinii, 358.

Celastrus spiciformis, 348, 354, 356.

Celastrus spiciformis, var. laevis, 349, 356.

Celastrus striatus, 356, 358.

Celastrus stylosa, 352 .

Celastrus suaveolens, 358.

Celastrus Tatarinowii, 356 .

Celastrus tristis, 358.

Celastrus variabilis, $358,359$.

Celastrus Wallichiana, 358.

Cephalotaxus, 3 .

Cephalotaxus argotaenia, 6.

Cephalotaxus coriacea, 3.

Cephalotaxus drupacea, 3 .

Cephalotaxus drupacea, 5.

Cephalotaxus drupacea, var. sinensis, 3.

Cephalotaxus drupacea, var. sinensis, f. globosa, 4.

Cephalotaxus filiformis, 5 .

Cephalotaxus foemina, 3.

Cephalotaxus Fortunei, 4.

Cephalotaxus Fortunei, var. concolor, 6.

Cephalotaxus Fortunei foemina, 3.

Cephalotaxus Griffithii, 5, 6.

Cephalotaxus Harringtonia, 4.
Cephalotaxus Mannii, 5.

Cephalotaxus Oliveri, 6.

Cephalotaxus pedunculata, var. sphaeralis, 4.

Cephalotaxus umbraculifera, 8.

Ceratostigma, 586 .

Ceratostigma Griffithii, 586.

Ceratostigma Griffithii, 586.

Ceratostigma minus, 586.

Ceratostigma Polhilli, 586.

Ceratostigma Willmottianum, 586.

Cercis, 87.

Cercis chinensis, 87.

Cercis glabra, 88.

Cercis racemosa, 88 .

Chaenomeles, 296.

Chaenomeles alpina, 298.

Chaenomeles angustifolia, 297.

Chaenomeles cathayensis, 297.

Chaenomeles eugenioides, 297.

Chaenomeles japonica, 298.

Chaenomeles japonica, 296.

Chaenomeles japonica, alpina, 298.

Chaenomeles japonica, genuina, 296.

Chaenomeles japonica, var. Maulei, 298.

Chaenomeles japonica, $\gamma$ pygmaea, 298.

Chaenomeles lagenaria, 296.

Chaenomeles lagenaria, var. cathayensis, 297.

Chaenomeles lagenaria, var. Wilsonii, 298.

Chaenomeles Maulei, 299.

Chaenomeles Maulei, var. alpina, 299.

Chaenomeles sinensis, 299.

Chamaebetula nana, 480.

Chamaebetula rotundifolia, 481 .

Chamaebuxus arillata, 160.

Chamaebuxus paniculata, 160.

Chaydaia, 221, 222.

Chaydaia tonkinensis, 221.

Chaydaia Wilsonii, 221.

Chinenses, 464, 479.

Chinenses, 479.

Chionanthus, 611.

Chionanthus chinensis, 611.

Chionanthus Duclouxii, 611.

Chionanthus retusus, 611 .

Cicca flexuosa, 519.

Cicca Leucopyrus, 520.

Cinnamomeae, 333, 339.

Cinnamomum, 66.

Cinnamomum argenteum, 67 . 
Cinnamomum Camphora, 68.

Cinnamomum glanduliferum, 621 .

Cinnamomum hupehanum, 69, 621.

Cinnamomum inunctum, 68.

Cinnamomum inunctum, var. albosericeum, 69 .

Cinnamomum inunctum, var. longepaniculatum, 69.

Cinnamomum pedunculatum, 70 .

Cinnamomum Wilsonii, 66.

Cinnamomum Wilsonii, var. multiflorum, 67.

Cipadessa, 159.

Cipadessa baccifera, 159.

Cipadessa baccifera, var. sinensis, 159.

Cipadessa fruticosa, 159.

Cipadessa? subscandens, 159.

Citrus, 141.

Citrus amara, 147.

Citrus aurantifolia, 149.

Citrus Aurantium, 147.

Citrus Aurantium, 148.

Citrus Aurantium, var. amara, 147.

Citrus Aurantium, var. Bigaradia, 147.

Citrus Aurantium, $\gamma$ decumana, 144.

Citrus A urantium dulce, 148.

Citrus Aurantium, $\gamma$ grandis, 144.

Citrus Aurantium, $\boldsymbol{\beta}$ sinensis, 148.

Citrus Aurantium vulgare, 148.

Citrus Bigaradia, 147.

Citrus Bigarradia, 147.

Citrus cedra, 141.

Citrus Cedratum, 141.

Citrus cedratus, 141.

Citrus communis, 146, 147.

Citrus crassa, 141.

Citrus daidai, 147.

Citrus decumana, 144.

Citrus deliciosa, 143.

Citrus Florida, 147.

Citrus Fragrans, 141.

Citrus fusca, 147.

Citrus fusiformis, 146.

Citrus grandis, 144.

Citrus granulata, 146.

Citrus ichangensis, 144.

Citrus ichangensis latipes, 146.

Citrus Karna, 147.

Citrus Lima, 146.

Citrus Limon, 146.

Citrus limon, 146.

Citrus Limonia, 146.

Citrus Limonium, 146.
Citrus limonum, 146.

Citrus Limonum sylvaticum, 146.

Citrus madurensis, 143.

Citrus Medica, 141.

Citrus Medica, 147.

Citrus medica, 146.

Citrus medica, subsp. genuina, var.

Chhangura, 141.

Citrus Medica, $\beta$ Limon, 146.

Citrus medica, var. Limonum, 146.

Citrus Medica, var. sarcodactylis, 141.

Citrus nobilis, 142.

Citrus nobilis, 143.

Citrus nobilis, var. deliciosa, 143.

Citrus nobilis, subsp. genuina, 143.

Citrus nobilis, a major, 143.

Citrus Odorata, 141.

Citrus Pamplemos, 144.

Citrus reticulata, 143.

Citrus sarcodactylis, 141.

Citrus sinensis, 148.

Citrus trifolia, 149.

Citrus trifoliata, 149.

Citrus triptera, 149.

Citrus Tuberosa, 141.

Citrus vulgaris, 147.

Cladrastis, 97.

Cladrastis sinensis, 97.

Cladrastis Wilsonii, 97.

Claucena Lansium, 623.

Clausena, 140.

Clausena excavata, 623.

Clausena punctata, 140, 623.

Clausena punctata, 623.

Clausena suffruticosa, 140.

Clausena Wampi, 140.

Clematoclethra, 386 .

Clematoclethra actinidioides, 386 .

Clematoclethra Faberi, 387.

Clematoclethra Franchetii, 388.

Clematoclethra Giraldii, 381.

Clematoclethra grandis, 386 .

Clematoclethra Hemsleyana, 387.

Clematoclethra Hemsleyi, 389.

Clematoclethra Hemsleyi, 378.

Clematoclethra Henryi, 389.

Clematoclethra integrifolia, 386 .

Clematoclethra lanosa, 388.

Clematoclethra lasioclada, 386 .

Clematoclethra lasioclada, var. grandis, 386.

Clematoclethra Maximowiczii, 387.

Clematoclethra Prattii, 386. 
Clematoclethra scandens, 387 .

Clematoclethra tiliacea, 389.

Clematoclethra tomentella, 389 .

Clethra, 492.

Clethra ( $\$$ Clematoclethra) sp.?, 387.

Clethra scandens, 387.

Clethropsis, 491, 501.

Clethropsis, 501.

Clethropsis nepalensis, 502.

Clethropsis nitida, 501.

Cleyera dubia, 397.

Cleyera fragrans, 397.

Cleyera gymnanthera, 397.

Cleyera japonica, 397, 399.

Cleyera Mertensiana, 400.

Cleyera ochnacea, 400.

Cleyera ochnoides, 400.

Cleyera Wallichiana, 400.

Cleyera Wightii, 397.

Colurnae, 447, 449.

Connarus? juglandifolius, 183.

Cookia punctata, 140.

Cookia Wampi, 140.

Corchorus japonicus, 301.

Coriaria, 170.

Coriaria nepalensis, 170.

Coriaria sinica, 170.

Coriaria terminalis, 170.

Coriaria terminalis, 171.

Coriaria terminalis, var. xanthocarpa, 171.

Coriariaceae, 170.

Cormus Tschonoskii, 295.

Cormus yunnanensis, 287.

Cornaceae, 569.

Cornus, 573 .

Cornus alba, 575.

Cornus aspera, 579.

Cornus brachypoda, 573, 575 .

Cornus Bretschneideri, 579.

Cornus capitata, 578 .

Cornus capitata, var. mollis, 579.

Cornus chinensis, 577.

Cornus controversa, 573.

Cornus corynostylis, 575 .

Cornus crispula, 575.

Cornus glauca, 573, 575.

Cornus Hemsleyi, 574 .

Cornus Henryi, 576.

Cornus ignorata, 575.

Cornus japonica, 578.

Cornus kousa, 577.

Cornus Kousa, 578.
Cornus macrophylla, 575 .

Cornus macrophylla, 573.

Cornus oblonga, 579.

Cornus officinalis, 577.

Cornus paucinervis, 576 .

Cornus poliophylla, 574 .

Cornus quinquenervis, 577.

Cornus Religiana, 575.

Cornus sanguinea, 575 .

Cornus Theleryana, 575.

Cornus Thelicanis, 575.

Cornus Thelycrania, 575.

Cornus ulotricha, 574 .

Cornus Walteri, 576.

Cornus Wilsoniana, 579.

Corylifoliae, 463, 476.

Corylopsis alnifolia, 218.

Corylus, 443.

Corylus Avellana, 450.

Corylus Avellana, var. davurica, 450.

Corylus chinensis, 444, 447, 450.

Corylus Colurna, 447, 449.

Corylus Colurna, 449.

Corylus Colurna, var. chinensis, 444.

Corylus Colurna, var. Jacquemontii, 449.

Corylus Colurna, var. lacera, 449.

Corylus Davidiana, 423.

Corylus Fargesii, 444.

Corylus ferox, 447, 448.

Corylus ferox, var. thibetica, 443.

Corylus hallaisanensis, 447,451 .

Corylus Hasibami, 450.

Corylus heterophylla, 447, 450 .

Corylus heterophylla, 445, 452.

Corylus heterophylla, var. Crista-galli, 445.

Corylus heterophylla, var. Sieboldiana, 452.

Corylus heterophylla, var. sutchuenensis, $445,451$.

Corylus heterophylla, var. Thunbergii, 450 .

Corylus heterophylla, var. yunnanensis, 451.

Corylus Jacquemontii, 447, 449.

Corylus lacera, 449.

Corylus mandshurica, 454.

Corylus mandshurica, var. Fargesii, 444.

Corylus mongolica, 450.

Corylus rostrata, 452 .

Corylus rostrata, var. Fargesii, 444. 
Corylus rostrata, var. mandshurica, 454.

Corylus rostrata, var. mitis, 453 .

Corylus rostrata, var. Sieboldiana, 452.

Corylus Siboldiana, 452.

Corylus Sieboldiana, 448, 452.

Corylus Sieboidiana, 454.

Corylus Sieboldiana, var. brevirostris, 453.

Corylus Sieboldiana, var. mandshuriea, 454.

Corylus Sieboldiana, var. mitis, 453 .

Corylus tetraphylla, 450.

Corylus tibetica, $443,447,448$.

Costatae, 462, 468.

Costatae, 468.

Cotinus, 175.

Cotinus Coccygea, 175.

Cotinus coggygria, $\mathbf{1 7 5}$.

Cotinus coggygria, var. cinerea, 176.

Cotinus coggygria, a laevis, 17.5.

Cotinus coggygria, var. pubescens, 175.

Crantria asiatica, 138.

Crantzia nitida, 138.

Crataegus alnifolia, 270, 294.

Cremastogyne, 490, 492 .

Cremastogyne, 492.

Croton, 523.

Croton chinensis, 525.

Croton soccineus, 526.

Croton montanum, 526.

Croton punctatus, 526.

Croton phitippense, 526 .

Croton sebiferum, 527.

Croton Siraki, 527.

Croton Tiglium, 523.

Cryptomeria, 52.

Cryptomeria Fortunei, 52.

Cryptomeria japoniea, 52.

Cunninghamia, 50.

Cunninghamia lanceolata, 50 .

Cunninghamia sinensis, 50 .

Cupania canescens?, 193.

Cupresseae, 53.

Cupressus, 54.

Cupressus Corneyana, 54.

Cupressus funebris, 55 .

Cupressus funebris gracilis, 55.

Cupressus japonica, 52.

Cupressus majestica, 54.

Cupressus nepalensis, 60.

Cupressus pendula, 55
Cupressus sempervirens, 55.

Cupressus Thuia, 53.

Cupressus torulosa, 54 .

Cupressus torulosa Corneyana, 54 .

Cupressus torulosa majestica, 54 .

Cupressus torulosa Tournefortii, 54 .

Cupressus Tournefortiana, 54 .

Cupressus Tournefortii, 54 .

Cydonia cathayensis, 297.

Cydonia japonica, 296, 298.

Cydonia japonica, var. genuina, 296.

Cydonia japonica, var. lagenaria, 296.

Cydonia lagenaria, 296.

Cydonia Mallardii, 298.

Cydonża Maulei, 298.

Cydonia Maulei, var. alpina, 299

Cydonĩa Sargenti, 299.

Cydonia sinensis, 299.

Cydonia speciosa, 296.

Cydonia vulgaris, 299.

Dactylus trapezuntinus, 587.

Dahuriae, 483.

Dahuricae, $465,483$.

Dahuricae, 483.

Dalbergia, 115.

Dalbergia Dyeriana, 115.

Dalbergia hupeana, 115.

Dalbergia spec., 116.

Dalbergia stenophylla, 116.

Daphne, 538.

Daphne acutiloba, 539, 544, 547.

Daphne angustiloba, 544, 547.

Daphne aurantiaca, 544, 547 .

Daphne Bodinieri, 538.

Daphre cana, 536.

Daphne canescens, 536.

Daphne cannabina, 534, 546.

Daphne Championii, 543, 544.

Daphne chinensis, 546 .

Daphne Feddei, 544, 547.

Daphne Eortunei, 539, 544.

Daphne gemmata, 543, 544, 548 .

Daphne genkwa, 538, 543, 544.

Daphne Genlwwa, var. Fortunei, 539.

Daphne Giraldii, 543, 545.

Daphne gracilis, 544, 548 .

Daphne inamoena, 536.

Daphne indica, 534, 546.

Daphne involucrata, 550.

Daphne japonica, 545.

Daphne leuconeura, 544, 548.

Daphne leuconeura, var. Mairei, 548 . 
Daphne Martini, 547.

Daphne Mazeli, 545.

Daphne modesta, 541, 544. 548.

Daphne myrtilloides, 544, 548 .

Daphne nudiflora, 551.

Daphne odora, 544, 545.

Daphne odora, $545,546$.

Daphne odora, var. atrocaulis, 545 .

Daphne odora, var. Mazeli, 545.

Daphne oppositifolia, 536.

Daphne papyracea, $544,546$.

Daphne papyracea, var. crassiuscula, $544,546$.

Daphne papyracea, f, grandiflora, 546 .

Daphne papyrifera, 546,551 .

Daphne penicillata, $542,544,548$.

Daphne retusa, $541,544,547$.

Daphne rosmarinifolia, 544, 549 .

Daphne Roumea, 543, 545.

Daphne sericea, 536.

Daphne sinensis, 543, 546 .

Daphne tangutica, 543,545 .

Daphne tangutica, 545 .

Daphne tenuiflora, 544, 549 .

Daphne triflora, 545 .

Daphne Vaillantii, 543, 545.

Daphne virga 536.

Daphne viridific 534.

Daphne Wallichii, 550.

Daphne Wilsonii, 540, 544, 547.

Daphnidium elongatum, 78.

Daphnidium pulcherrimum, 85.

Daphnidium strychnifolium, 82.

Daphniphyllum, 521 .

Daphniphyllum angustifolium, 521 .

Daphniphyllum glaucescens, 522 .

Daphniphyllum macropodum, 522 .

Daphniphyllum Roxburghii, 522.

Dasiphora fruticosa, 301.

Davidia, 255.

Davidia involucrata, 255 .

Davidia involucrata, 256.

Davidia involucrata, var. Vilmoriniana, 256.

Davidia laeta, 256.

Davidia tibetana, 255.

Davidia Vilmoriniana, 256.

Desmodium, 103.

Desmodium floribundum, 103.

Desmodium formosum, 107.

Desmodium laburnifolium, 103.

Desmodium laxiflorum, 103.

Desmodium obtusum, 111.
Desmodium oxyphyllum, var. serriferum, 104.

Desmodium penduliflorum, 107.

Desmodium podocarpum, var. szechuenense, 104.

Desmodium racemosum, 107.

Desmodium serriferum, 104.

Desmodium sinuatum, 104.

Desmodium strangulatum, var. sinuatum, 104.

Desmodium tiliaefolium, 104.

Desmodium tomentosum, 111.

Diacicarpium rotundifolium, 552.

Diacicarpium tomentosum, 552 .

Dicalix aluminosus, 597.

Dicalix javanicus, 597.

Dicalix salaccensis, 597.

Dicalix spicatus, 595.

Dicalyx (?) tinctorius, 597.

Dichotomanthes, 344 .

Dichotomanthes tristaniaecarpa, 344 .

Dichotomanthes tristaniaecarpa, var. glabrata, 344 .

Dilleniaceae, 378.

Dimocarpus Longan, 193.

Dimocarpus longus, 193.

Dimocarpus pupilla, 193.

Dimocarpus undulatus, 194.

Dimorphanthus elatus, 567.

Dimorphanthus mandshuricus, 566 .

Diospyros, 587.

Diospyros armata, 591 .

Diospyros armata, 591 .

Diospyros Aurantium, 589.

Diospyros Balfouriana, 588.

Diospyros Bertii, 589.

Diospyros chinensis, 589 .

Diospyros costata, 589.

Diospyros elliptica, 589.

Diospyros japonica, 587.

Diospyros kaki, 588.

Diospyros Kaki, $\beta 587$.

Diospyros Kaki, $\beta$ cordata, 589.

Diospyros Kaki, var. costata, 589.

Diospyros Kaki, $\boldsymbol{\beta}$ domestica, 589.

Diospyros Kaki, $\gamma$ glabra, 587.

Diospyros Kaki, f. grandifolia, 589.

Diospyros kaki, var. silvestris, 590 .

Diospyros Kaempferi, 589.

Diospyros Lotus, 587.

Diospyros lycopersicon, 589.

Diospyros Mazeli, 589.

Diospyros microcarpa, 587. 
Diospyros mollifolia, 591 .

Diospyros Pseudo-Lotus, 587.

Diospyros Roxburghii, 589, 590.

Diospyros Sahuti, 589.

Diospyros Schi-tse, 589.

Diospyros serrata, 401.

Diospyros sinensis, 591 .

Diospyros Umlovok, 587.

Diospyros yunnanensis, 592 .

Diplomorpha canescens, 536.

Diplomorpha Chamaedaphne, 536.

Diplomorpha virgata, 536.

Diplomorpha ? viridiflora, 534.

Distegocarpus, 431, 433.

Distegocarpus. 433.

Distegocarpus carpinoides, 433.

Distegocarpus Carpinus, 433.

Distegocarpus ? cordata, 435 .

Distegocarpus? erosa, 435 .

Distegocarpus laxiflora, 438.

Disterocarpus, 433.

Docynia, 296.

Docynia Delavayi, 296.

Dolichos hirsuta, 118.

Dolichos japonicus, 510.

Dolichos polystachios, 510 .

Dolichos (?) polystachyos, 510.

Dryandra oleifera, 528 .

Dumasia, 116.

Dumasia hirsuta, 116.

Ebenaceat, 587.

Echinocarpnes assamicus, 362.

Echinocarpus Hemsleyanus, 361.

Echinocarpus sinensis, 361 .

Echinocarpus sinensis, 361.

Echinocarpus sterculiaceus, 362.

Echinocarpus tomentosus, 362.

Edgeworthia, 550.

Edgeworthia chrysantha, 550.

Edgeworthia Gardneri, 551.

Edgeworthia papyrifera, 551.

Ekebergia indica, 159.

Ekebergia ? integerrima, 159.

Elaeagnaceae, 409.

Elaeagnus, 410.

Elaeagnus Bockii, 416.

Elaeagnus conferta, 417.

Elaeagnus cuprea, 414.

Elaeagnus edulis, 413.

Elaeagnus Henryi, 414.

Elaeagnus lanceolata, 413 .

Elaeagnus latifolia, 417.
Elaeagnus longipes, 413.

Elaeagnus Loureirii, 416.

Elaeagnus macrantha, 416.

Elaeagnus magna, 411.

Elaeagnus multiflora, 412.

Elaeagnus multiflora, f. angustata, 413.

Elaeagnus parviflora, 410.

Elaeagnus rotundifolia, 413.

Elaeagnus sarmentosa, 417.

Elaeagnus stellipila, 415 .

Elaeagnus umbellata, 410 .

Elaeagnus umbellata, ssp. magna, 411.

Elaeagnus umbellata, ssp. parvifolia, 411.

Elaeagnus umbellata, var. parvifolia, 411.

Elaeagnus viridis, 414 .

Elaeocarpaceae, 360 .

Eleaocarpea, 362.

Elaeocarpus, 360 .

Elaeocarpus japonicus, 360 .

Elaeocarpus omeiensis, 360 .

Elaeococca verrucosa, 528 .

Eleutherococeus, 557.

Eleutherococcus Henryi, 557.

Eleutherococcus leucorrhizus, 557, 559.

Eleutherococcus Simoni, 559.

Embryopteris Kaki, 589.

Eriolobus Delavayi, 296.

Eriolobus kansuensis, 286.

Eriolobus Tschonoskii, 295.

Eriolobus yunnanensis, 287.

Eriosolena, 550.

Eriosolena involucrata, 550.

Eriosolena Wallichii, 550.

Ermani, 468.

Ermanianae, 462, 468.

Erythrina, 117.

Erythrina arborescens, 117.

Erythrospermum hypoleucum, 346.

Esquirolia sinensis, 603.

Euacanthopanax, 560.

Eualbae, 485.

Eualnus, 492.

Euavellanae, 447.

Eubetula, 468, 480, 481, 483, 485.

Eucarpinus, 431, 437.

Eucarpinus, 437.

Eucladrastis, 97.

Euclethrus, 492.

Eugenia, 420.

Eugenia Grijsii, 420.

Eugenia laurina, 594. 
Eugenia microphylla, 420.

Eugenia pyxophylla, 420.

Eugenia sinensis, 420.

Eugenia, sp., 420.

Euodia ramiflora, 136.

Euornus, 258.

Euphorbiaceae, 516.

Euphoria, 193.

Euphoria Longan, 193.

Euphoria longana, 193.

Euphoria pupillum, 194.

Euphoria undulata, 193.

Eupicea, 22.

Euprinsepia, 344.

Eurya, 398.

Eurya acuminata, 400.

Eurya acuminata, 401.

Eurya acuminata, var. euprista, 401.

Eurya acuminata, var. multiflora, 401.

Eurya acuminata, var. Wallichiana, 401.

Eurya angustifolia, 401.

Eurya bifaria, 401.

Eurya chinensis, 400.

Eurya emarginata, 400.

Eurya euprista, 401.

Eurya fasciculata, 398.

Eurya japonica, 398.

Eurya japonica, 398, 399.

Eurya japonica, $\boldsymbol{\beta}$ acuminata, 401.

Eurya japonica, var. aurescens, 399.

Eurya japonica, var. nitida, 398.

Eurya lucida, 401.

Eurya membranacea, 401.

Eurya microphylla, 398.

Eurya montana, 398.

Eurya multiflora, 401.

Eurya nitida, 398.

Eurya ochnacea, 399.

Eurya Roxburghii, 398.

Eurya salicifolia, 401.

Eurya serrata, 401.

Eurya systyla, 398.

Eurya uniflora, 398.

Eurya Wallichiana, 401.

Eurya Wightiana, 398.

Euscaphis, 187.

Euscaphis japonica, 187.

Euscaphis staphyleoides, 187.

Euthea, 390.

Euzanthoxylum, 121.

Evodia, 129.

Evodia Baberi, 131.
Evodia Bodinieri, 130.

Evodia Daniellii, 135.

Evodia Daniellii, 133.

Evodia Fargesii, 129.

Evodia glauca, 129.

Evodia Henryi, 133.

Evodia Henryi, var. villicarpa, 134.

Evodia hupehensis, 133.

Evodia meliaefolia, 129.

Evodia meliifolia, 129.

Evodia officinalis, 130.

Evodia rugosa, 132.

Evodia rutaecarpa, 132.

Evodia rutaecarpa, 130.

Evodia simplicifolia, 135.

Evodia, sp., 137.

Evodia trichotoma, 132.

Evodia velutina, 134.

Evodia viridans, 132.

Evodioceras, 133.

Evonymus alata, 358 .

Excelsae, 465, 483.

Excoecaria, 528.

Excoecaria acerifolia, 528 .

Excoecaria discolor, 527.

Excoecaria japonica, 527.

Excoecaria sebifera, 528.

Fagara, 127.

Fagara Biondii, 127.

Fagara dimorphophylla, 126.

Fagara dissita, 128.

Fagara echinocarpa, 128.

Fagara micrantha, 127.

Fagara setosa, 124.

Fagara stenophylla, 127.

Firmae, 491, 506.

Firmiana, 377.

Firmiana chinensis, 377.

Firmiana platanifolia, 377.

Firmiana simplex, 377, 624.

Flemingia, 119.

Flemingia congesta, var. virdis, 119.

Flemingia fluminalis, 119.

Flueggea capillipes, 516.

Fluggea, 520.

Fluggea leucopyrus, 520 .

Fluggea virosa, 520 .

Fluggea Wallichiana, 520.

Fluggea xerocarpa, 520.

Fraxinaster, 262.

Fraxinus, 258.

Fraxinus bracteata, 258. 
Fraxinus chinensis, 260, 623.

Fraxinus chinensis, var. acuminata, 261.

Fraxinus chinensis, var. rhynchophylla, $261,5623$.

Fraxinus chinensis, var. typica, 260.

Fraxinus densiflora, 259.

Fraxinus Eedenii, 258.

Fraxinus floribunda, var. integerrima, 258.

Fraxinus Griffithii, 258, 623.

Fraxinus inopinata, 262.

Fraxinus Mariesii, 260.

Fraxinus obovata, 261.

Fraxinus obovata, 261.

Fraxinus Paxiana, 259, 623.

Fraxinus philippinensis, 258.

Fraxinus platypoda, 262, 623 .

Fraxinus retusa, 258.

Fraxinus retusa, 258.

Fraxinus retusa, var. Henryana, 258.

Fraxinus retusa, var. integra, 259.

Fraxinus rhynchophylla, 261.

Fraxinus Sargentiana, 261.

Fraxinus xanthoxyloides, 261.

Fruticosae, 464, 481.

Fruticosae, 481.

Geeria serrata, 401.

Ginkgo, 1.

Ginkgo, 1.

Ginkgoaceae, 1.

Ginkgo biloba, 1.

Gleditsia, 90.

Gleditsia macracantha, 90.

Gleditsia officinalis, 91.

Gleditsia sinensis, 91 .

Glochidion, 518.

Glochidion flexuosum, 519.

Glochidion obscurum, 518.

Glochidion puberum, 518.

Glochidion sinicum, 518.

Glochidion Wilsonii, 518.

Glycine floribunda, 510.

Glycine sinensis, 509.

Gordonia, 394.

Gordonia anomala, 395.

Gordonia axillaris, 394.

Gordonia axillaris, var. acuminata, 395.

Gordonia sinensis, 395.

Gouania, 253.

Gouania javanica, 253.

Goughia neilgherrensis, 522.
Gramineae, 63.

Grewia, 371.

Grewia Esquirolii, 371.

Grewia glabrescens, 371.

Grewia parviflora, 371 .

Grewia parviflora, 371.

Grewia parviflora, var. glabrescens, $358,371$.

Grossae, 463, 476.

GUTTIFERAE, 402.

Gymnocladus, 91.

Gymnocladus chinensis, 91 .

Gymnosporia, 359.

Gymnosporia diversifolia, 358 .

Gymnosporia emarginata, 358 .

Gymnosporia variabilis, 358, 359.

Gymnothyrsus, 490, 492.

Gymnothyrsus, 492.

Hallia hirta, 110.

Hallia juncea, 109.

Hallia trichocarpa, 110.

Hedera, 555.

Hedera Helix, 555.

Hedera Helix, var. aurantiaca, 555.

Hedera Helix, $\gamma$ ? chrysocarpa, 555.

Hedera himalaica, 555.

Hedera himalaica, var. sinensis, 555 .

Hedysarum coriaceum, 110.

Hedysarum hirtum, 110.

Hedysarum junceum, 105, 109.

Hedysarum sericeum, 105.

Hedysarum tomentosum, 110.

Hedysarum trichocarpum, 110.

Hedysarum villosum, 110.

Hedysarum virgatum, 110.

Helwingia, 570.

Helwingia chinensis, 571.

Helwingia chinensis, var. longipedicellata,'572.

Helwingia chinensis, var. macrocarpa, 571.

Helwingia himalaica, 571.

Helwingia japonica, 570 .

Helwingia japonica, var. himalaica, 571.

Helwingia japonica, var. hypoleuca, 570.

Helwingia rusciflora, 570, 571.

Hemicicca japonica, 519.

Heptapleurum Delavayi, 555.

Heptacodium, 617.

Heptacodium miconioides, 618. 
Hibiscus, 374.

Hibiscus Manihot, 374.

Hibiscus rhombifolius, 374.

Hibiscus simplex, 377.

Hibiscus syriacus, 374 .

Hibiscus syriacus, var. chinensis, 374.

Hippophae, 409.

Hippophae littoralis, 409.

Hippophae rhamnoides, 409.

Hippophae rhamnoides, var. procera, 409.

Hippophae rhamnoides r. sibirica, 409.

Hippophae sibirica, 409.

Hippophaës rhamnoideum, 409.

Hopea spicata, 595.

Hosiea, 190.

Hosiea sinensis, 190.

Hovenia, 252.

Hovenia dulcis, 252.

Humiles, 464, 480.

Hypericum, 402.

Hypericum amplexicaule, 402.

Hypericum ascyroides, 402.

Hypericum Ascyron, 402.

Hypericum Ascyron, var. hupehense, 402.

Hypericum aureum, 404.

Hypericum chinense, 404.

Hypericum Giraldii, 404.

Hypericum Hookerianum, 403.

Hypericum longistylum, 404.

Hpyericum longistylum, var. Giraldii, 404.

Hypericum longistylum, var. Silvestrii, 404.

Hypericum macrocarpum, 402.

Hypericum monogynum, 404.

Hypericum oblongifolium, 403.

Hypericum patulum, 402.

Hypericum patulum, 403.

Hypericum patulum, var. Henryi, 403.

Hypericum Prattii, 404.

Hypericum pyramidatum, 402.

ICACINACEAE, 190.

Ilex emarginata, 400 .

Ilex macrocarpa, var. genuina, 358 .

Ilex Orixa, 136.

Ilex purpurea, var. Oldhamii, 358.

Ilex racemosa, 359 .

Ilex suaveolens, 358 .

Indicae, 333, 338.

Indigofera, 99 .
Indigofera amblyantha, 99.

Indigofera chalara, 101.

Indigofera chinensis, 106.

Indigofera dichroa, 100.

Indigofera ichangensis, 100.

Indigofera ichangensis, f. calvescens, 100.

Indigofera ichangensis, f. leptantha, 100.

Indigofera ichangensis, f. rigida, 100.

Indigofera lenticellata, 101.

Indigofera Monbeigii, 100.

Indigofera myosurus, 101.

Indigofera pseudotinctoria, 100.

Indigofera scabrida, 101.

Indigofera szechuensis, 101.

Indigofera Wilsonii, 101.

Jasminum, 612.

Jasminum affine, 614.

Jasminum Beesianum, 615.

Jasminum bignoniaceum, 615 .

Jasminum chrysanthemum, 615 .

Jasminum floridum, 614.

Jasminum Giraldii, 614.

Jasminum humile, 614.

Jasminum inodorum, 615.

Jasminum lanceolarium, 612.

Jasminum lanceolarium, var. puberulum, 612.

Jasminum nintooides, 615 .

Jasminum officinale, 613.

Jasminum revolutum, 615 .

Jasminum sinense, 612 .

Jasminum subulatum, 614.

Jasminum urophyllum, 613.

Jasminum urophyllum, var. Henryi, 613.

Jasminum urophyllum, var. Wilsonii, 613.

Jasminum viminale, 614.

Jasminum vulgatius, 614 .

Jasminum Wallichianum, 615.

Juniperus, 56.

Juniperus barbadensis, 60 .

Juniperus Cabiancae, 61.

Juniperus cernua, 60.

Juniperus chinensis, 60 .

Juniperus chinensis Corneyana, 54.

Juniperus chinensis, var. pendula, 61.

Juniperus communis, 56.

Juniperus convallium, 62.

Juniperus dimorpha, 60. 
Juniperus Fargesii, 59.

Juniperus flagelliformis, 60.

Juniperus foetida, a sabina, 60.

Juniperus formosana, 56 .

Juniperus Fortunii, 61.

Juniperus Lambertiana, 57.

Juniperus morrisonicola, 59.

Juniperus morrisonicola, 621.

Juniperus nepalensis, 54, 60.

Juniperus pseudo-sabina, 62 .

Juniperus recurva, 58.

Juniperus recurva, var, densa, 58.

Juniperus recurva, $\beta$ squamata, 58.

Juniperus Reevesiana, 60.

Juniperus religiosa, 57.

Juniperus rigida, 56,58 .

Juniperus saltuaria, 61.

Juniperus sphaerica, 61.

Juniperus squamata, $57,621$.

Juniperus squamata, var. Fargesii, 59 .

Juniperus struthiacea, 60.

Juniperus taxifolia, 56.

Juniperus Thunbergii, 60.

Juniperus virginica, 60.

Kalomikta mandshurica, 381.

Kalopanax, 564.

Kalopanax ricinifolius, 564 .

Karangolum chinense, 553.

Karangolum Faberi, 552.

Karangolum platanifolium, 554.

Keria tetrapetala, 300.

Kerria, 301.

Kerria japonica, 301.

Keteleeria, 39.

Keteleeria Davidiana, 39, 621.

Keteleeria Davidiana, var, formosana, 40.

Keteleeria Davidiana, var. formosana, 621.

Keteleeria Delavayi, 39.

Keteleeria Esquirolii, 40.

Keteleeria Evelyniana, 40.

Keteleeria Fabri, 41.

Keteleeria formosana, 40.

Keteleeria Fortunei, 40.

Keteleeria sacra, 39.

Keteleeria sp., 41.

Koelreuteria, 191.

Koelreuteria apiculata, 191.

Koelreuteria bipinnata, 193.

Koelreuteria paniculata, 191.

Kraunhia brachybotrys, 511.
Kraunhia chinensis, 513.

Kraunhia floribunda, 509, 511.

Kraunhia floribunda, $\gamma$ brachybotrys, 511.

Kraunhia floribunda, $\boldsymbol{\beta}$ sinensis, 509.

Kraunhia floribunda, a typica, 511, 513.

Kraunhia floribunda, a typica, forma albiflora, 512.

Kraunhia floribunda, a typica, forma pleniflora, 513.

Kraunhia japonica, 515.

Kraunhia sinensis, 509.

Kraunhia sinensis, var. albiflora, 512.

Kraunhia sinensis, var. brachybotrys, 511.

Kraunhia sinensis, var. brachybotrys, forma albiflora, 514 .

Kraunhia sinensis, var. floribunda, 511, 513.

Kraunhia sinensis, var. pleniflora, 513 .

Laevigatae, 333, 337.

Lagerstroemia, 418.

Lagerstroemia elegans, 418.

Lagerstroemia indica, 418.

Lagerstroemia indica, var. pallida, 418.

Laricopsis Kaempferi, 22.

Larix, 18.

Larix amabilis, 21.

Larix Cajanderi, 21.

Larix chinensis, 18.

Larix dahurica, var. Principis Rupprechtii, 21.

Larix Griffithii, 20.

Larix Griffithii, 18.

Larix Kaempferi, 21.

Larix Mastersiana, 19.

Larix Potaninii, 18.

Larix Principis Rupprechtii, 21.

Larix thibetica, 18.

LaURAceae, 66.

Laurus Camphora, 68.

Laurus indica, 73.

Leea spinosa, 566 .

Leguminosae, 87, 509.

Lentae, 468.

Lentae, 468.

Lepta, 135.

Lespedeza, 105.

Lespedeza angulicaulis, 114.

Lespedeza argyrea, 106.

Lespedeza bicolor, 112.

Lespedeza bicolor, 105, 107, 111, 112.

Lespedeza bicolori affinis, 112. 
Lespedeza bicolor, $\beta$ intermedia, 106.

Lespedeza bicolor, var. $\boldsymbol{\beta}$ intermedia, 112.

Lespedeza bicolor, forma microphylla, $107,112$.

Lespedeza bicolor, var. a typica, 112.

Lespedeza Buergeri, 106.

Lespedeza Buergeri, 111.

Lespedeza Buergeri, forma angustifolia, 106.

Lespedeza Buergeri, var. Oldhami, 106.

Lespedeza Caraganae, 109.

Lespedeza ciliata, 113.

Lespedeza cuneata, 105.

Lespedeza eyrtobotrya, 112.

Lespedeza cyrtobotrya, 106, 107, 112.

Lespedeza Davidii, 107.

Lespedeza Dunnii, 111.

Lespedeza elliptica, 107.

Lespedeza eriocarpa, 105.

Lespedeza fasciculiflora, 105.

Lespedeza Fauriei, 110.

Lespedeza Feddeana, 110.

Lespedeza floribunda, 105.

Lespedeza floribunda, 108.

Lespedeza floribunda, var. alopecuroides, 105.

Lespedeza formosa, 107.

Lespedeza Friebeana, 111.

Lespedeza Gerardiana, 110.

Lespedeza hirta, 111.

Lespedeza ichangensis, 113.

Lespedeza inschanica, 108.

Lespedeza japonica, 112.

Lespedeza juncea, 109.

Lespedeza juncea, 105, 106, 108, 109.

Lespedeza juncea, a. glabrescens, 106.

Lespedeza juncea, $\gamma$ hispida, 106.

Lespedeza juncea, var. inschanica, 108, 110.

Lespedeza juncea, var. a juncea, 106, 108, 109, 110.

Lespedeza juncea, var. kanaoriensis, 106.

Lespedeza juncea, var. latifolia, 109.

Lespedeza juncea, $\boldsymbol{\beta}$ sericea, 106.

Lespedeza juncea, var. sericea, 106.

Lespedeza juncea, var. $\gamma$ sericea, 108.

Lespedeza juncea, var. subsessilis, 109.

Lespedeza macrocarpa, 113.

Lespedeza macrophylla, 111.

Lespedeza medicaginoides, 105, 108, 110.
Lespedeza Muehleana, 113.

Lespedeza Oldhami, 106.

Lespedeza Pallasii, 110.

Lespedeza polystachya, 111.

Lespedeza racemosa, 107.

Lespedeza Rosthornii, 113.

Lespedeza sericea, 105.

Lespedeza Sieboldi, 107.

Lespedeza Sieboldii, 106.

Lespedeza Swinhoei, 110.

Lespedeza tomentosa, 110.

Lespedeza trichocarpa, 109.

Lespedeza trigonoclada, 114.

Lespedeza trigonoclada, var. angustifolia, 114.

Lespedeza trigonoclada, f. intermedia, 114.

Lespedeza viatorum, 107.

Lespedeza villosa, 111.

Lespedeza virgata, 110.

Lespedeza virgata, 110, 112.

Lespedezia glomerata, 111.

Lespedezia juncea, 109.

Ligustridium japonicum, 603.

Ligustrum, 600.

Ligustrum acutissimum, 600 .

Ligustrum brachystachyum, 607.

Ligustrum chinense, 606.

Ligustrum chinense nanum, 606.

Ligustrum compactum, 604.

Ligustrum Delavayanum, 601.

Ligustrum expansum, 600 .

Ligustrum formosanum, 608.

Ligustrum gracile, 602.

Ligustrum Henryi, 601.

Ligustrum Ibota, 600.

Ligustrum Ibota villosum, 605.

Ligustrum ionandrum, 602.

Ligustrum japonicum, 603.

Ligustrum lancifolium, 604.

Ligustrum longifolium, 604.

Ligustrum lucidum, 603.

Ligustrum myrianthum, 607.

Ligustrum oblongifolium, 604 .

Ligustrum pedunculare, 609.

Ligustrum Prattii, 601.

Ligustrum Quihoui, 607.

Ligustrum Roxburghii, 603.

Ligustrum Simonii, 604.

Ligustrum sinense, 605.

Ligustrum sinense latifolium robustum, 603.

Ligustrum sinense, var. nitidum, 606. 
Ligustrum sinense, var. Stauntonii, 606.

Ligustrum sinense, var. villosum, 605 .

Ligustrum sp., 608.

Ligustrum Stauntonii, 606.

Ligustrum strongylophyllum, 605.

Ligustrum thibeticum, 604.

Ligustrum villosum, 605 .

Limon vulgaris, 146.

Limonia laureola, 138.

Limonia oligandra, 138.

Limonia trichocarpa, 149.

Lindera, 79.

Lindera cercidifolia, 85 .

Lindera communis, 79 .

Lindera fragrans, 83.

Lindera fruticosa, 77.

Lindera glauea, 80 .

Lindera megaphylla, 80.

Lindera membranacea, 81 .

Lindera mollis, 85.

Lindera obtusiloba, 85 .

Lindera populifolia, 77.

Lindera Prattii, 83.

Lindera pulcherrima, 85 .

Lindera reflexa, 82.

Lindera ? Rosthornii, 83.

Lindera rubronervia, 84.

Lindera setchuenensis, 82 .

Lindera sp., 86.

Lindera strychnifolia, 82.

Lindera strychnifolia, var.?, 82.

Lindera strychnifolia, var. Hemsleyana, 82.

Lindera Tzumu, 74.

Lindera umbellata, 81 .

Lindera umbellata, var. latifolia, 81.

Linociera chinensis, 611.

Litsea, 75 .

Litsea citrata, 75 .

Litsea confertifolia, 74.

Litsea consimilis, 79.

Litsea cupularis, 75 .

Litsea elongata 78.

Litsea Faberi, 79.

Litsea fruticosa, 77.

Litsea ichangensis, 77 .

Litsea lanuginosa, 79.

Litsea laxiflora, 74.

Litsea populifolia, 77.

Litsea pungens, 76 .

Litsea sericea, 75 .

Litsea umbrosa, 79.
Litsea Veitchiana, 76.

Litsea Wilsonii, 78.

Lodhra crataegoides, 593.

Lodhra ferruginea, 597.

Lodhra javanica, 597.

Lodhra Lohu, 595.

Lodhra polycarpa, 595.

Lodhra polystachya, 597.

Lodhra rufescens, 595.

Lodhra spicata, 595.

Lodhra Verhuelli, 597.

Lodhra xanthophylla, 595.

Luteae, 333, 342.

LYTHRACEAE, 418.

Maackia, 98.

Maackia hupehensis, 98.

Machilus, 73.

Machilus Bournei, 73.

Machilus ichangensis, 621 .

Machilus japonica, 73.

Machilus macrophylla, 71 .

Machilus microcarpa, 74 .

Machilus Nanmu, 72.

Machilus neurantha, 72 .

Machilus Sheareri, 72.

Machilus Thunbergii, 73, 621.

Machilus Thunbergii, 621.

Maesa, 583.

Maesa castaneifolia, 583.

Maesa hupehensis, 583.

Maesa Wilsonii, 584.

Magnolia sericea, 550.

Magnolia tomentosa, 550 .

Mallea integerrima, 159.

Mallea Rothii, 159.

Mallea subscandens, 159.

Mallotus, 525.

Mallotus apelta, 525 .

Mallotus chrysocarpus, 526 .

Mallotus contubernalis, 526 .

Mallotus japonicus, 525 .

Mallotus Paxii, 525.

Mallotus philippinensis, 526 .

Mallotus repandus, 526 .

Mallotus tenuifolius, 525 .

Malus, 279.

Malus baccata, 281, 288, 291.

Malus baccata, 283.

Malus baccata, var. himalaica, 283.

Malus baccata, f. Jackii, 291.

Malus baccata, var. mandshurica, 291.

Malus baccata, var. mandshurica, f. latifolia, 282. 
Malus baccata, var. mandshurica, f. Zumi, 292.

Malus baccata, a sibirica, 291.

Malus baccata, subsp. Toringo, 293.

Malus cerasifera, 282.

Malus communis, var, typica, 279.

Malus floribunda, 288, 291.

Malus floribunda, var. Parkmanii, 285.

Malus formosana, 288, 295.

Malus Halliana, 285, 288, 291.

Malus Halliana, 285.

Malus Halliana, f. Parkmanii, 286.

Malus hybrida, 288.

Malus japonica, 296.

Malus Kaido, 290.

Malus kansuensis, 286, 288, 295.

Malus Matsumurae, 279.

Malus microcarpa baccata, 291.

Malus microcarpa floribunda, 292.

Malus microcarpa Kaido, 290.

Malus microcarpa Ringo, 279.

Malus microcarpa spectabilis, 289.

Malus microcarpa Torringo, 293.

Malus micromalus, 287, 290.

Malus Prattii, 281, 288, 290.

Malus prunifolia, 280, 287, 288.

Malus prunifolia, 279.

Malus prunifolia, var. rinki, 279, 289.

Malus prunifolia $\times M$. toringo, 292 .

Malus pumila, 280.

Malus pumila, var. Rinki, 279.

Malus ringo, 279.

Malus Ringo X spectabilis, 290.

Malus Sargentii, 288, 294.

Malus Sieboldii, 288, 293.

Malus Sieboldii, var. aborescens, 294.

Malus Sieboldii, var. calocarpa, 294.

Malus sinensis, 289.

Malus spectabilis, 287, 289.

Malus spectabilis, var. Kaido, 290.

Malus spectabilis, var. micromalus, 290.

Malus theifera, 283, 288, 291.

Malus theifera, f. rosea, 284.

Malus Toringo, 292, 293.

Malus Toringo, a integrifolia, 292.

Malus Toringo, f. typica, 294.

Malus Torringo, 293.

Malus transitoria, 288, 295.

Malus transitoria, var. toringoides, 286, 294.

Malus Tschonoskii, 288, 295.

Malus yezoensis, 279.

Malus yunnanensis, 287, 288, 295.
Malus zumi, 288, 292.

Malvaceae, 373 .

Mappia, 190.

Mappia pittosporoides, 190.

Marlea affinis, 552.

Marlea begoniifolia, 552 .

Marlea macrophylla, 554.

Marlea platanifolia, 554.

Marlea tomentosa, 552 .

Melastoma 421.

Melastoma Cavaleriei, 421.

Melastoma Esquirolii, 421.

Melastoma longiflorum, 421.

Melastoma Mairei, 422.

Melastoma malabathricum, 421.

Melastoma napalensis, 421.

Melastoma normale, 421.

Melastoma pelagicum, 421.

Melastoma Wallichii, 421.

Melastomataceae, 421.

Melia, 157.

Melia australis, 158.

Melia Azedarach, 157.

Melia Azedarach, $\boldsymbol{\beta}$ sempervirens, 158.

Melia Azedarach, var. subtripinnata, 158.

Melia baccifera, 159.

Melia bukayun, 158.

Melia chinensis, 158.

Melia cochinchinensis, 158.

Melia Commelinii, 158.

Melia composita, 158.

Melia florida, 158.

Melia japonica, 158.

Melia japonica, var. semperflorens, 158.

Melia orientalis, 158.

Melia sambucina, 158.

Melia sempervirens, 158 .

Melia Toosendan, 158.

Meliaceae, 156.

Melioides, 262.

Meliosma, 199.

Meliosma Beaniana, 204.

Meliosma cuneifolia, 199.

Meliosma Fischeriana, 203.

Meliosma glomerulata, 203.

Meliosma Kirkii, 207.

Meliosma longicalyx, 204.

Meliosma myrianthum, 199.

Meliosma Oldhamii, 206.

Meliosma parviflora, 201.

Meliosma pendens, 200.

Meliosma pinnata, 208. 
Meliosma platypoda, 201.

Meliosma rhoifolia, 208.

Meliosma subverticillaris, 201.

Meliosma Veitchiorum, 204.

Meliosma velutina, 202.

Meliosma Wallichii, 207.

Meliosma Wallichii, 206.

Mezoneurum, 93.

Mezoneurum sinense, 93.

Micromeles alnifolia, 271.

Micromeles alnifolia, $\boldsymbol{\beta}$ lobulata, 275 .

Micromeles alnifolia, a serrata, 271 .

Micromeles alnifolia, var. tiliaefolia, 271.

Micromeles caloneura, 269.

Micromeles castaneaefolia, 274.

Micromeles Decaisneana, 269.

Micromeles Decaisneana, var. Keissleri, 269.

Micromeles ferruginea, 277.

Micromeles Folgneri, 271.

Micromeles granulosa, 274.

Micromeles Hemsteyi, 276.

Micromeles japonica, 275.

Micromeles Keissleri, 269.

Micromeles khasiana, 274, 278.

Micromeles rhamnoides, 278.

Micromeles Schwerinii, 274.

Micromeles tiliaefolia, 271.

Micromeles verrucosa, 278.

Microphyllae, 333, 337.

Microrhamnus, 222.

Microrhamnus franguloides, 225.

Milletia floribunda, 511.

Milletia floribunda, var. brachybotrys, 514.

Milletia japonica, 515.

Millettia, 101.

Millettia chinensis, 509.

Millettia Dielsiana, 101.

Millettia pachycarpa, 102.

Millettia reticulata, 102.

Millingtonia pinnata, 208.

Mucuna, 117.

Mueuna sempervirens, 117.

Myrica arabica, 581 .

Myrica montana, 581 .

Myrica Potama, 581.

Myricaria, 407.

Myricaria bracteata, 407.

Myricaria dahurica, 407.

Myricaria germanica, 407 .

Myricaria Hoffmeisteri, 407.
Myrsinaceae, 580.

Myrsine, 580.

Myrsine acuminata, 580.

Myrsine acuta, 581 .

Myrsine africana 580.

Myrsine africana, var. bifaria, 581.

Myrsine africana, $\beta$ retusa, 581 .

Myrsine bifaria, 581 .

Myrsine boltensis, 581 .

Myrsine dioica, 581.

Myrsine excelsa, 580.

Myrsine glabra, 581 .

Myrsine khasyana, 580.

Myrsine retusa, 581.

Myrsine rotundifolia, 581 .

Myrsine scabra, 581 .

Myrsine semiserrata, 580 .

Myrsine sessilis, 580 .

Myrsine subspinosa, 580.

Myrtactae, 420.

Myrtus laurinus, 594.

Myrtus serratus, 594 .

Nageia arabica, 581.

Nanae, 464, 480.

Nanae, 480.

Natsiatum sinense, 190.

Neolitsea, 79.

Neolitsea lanuginosa, 79 .

Neolitsea lanuginosa, var. chinensis, 79.

Neolitsea umbrosa, 79 .

Nephelium Bengalense, 193.

Nephelium hypoleucum, 194.

Nephelium longan, 194.

Nephelium longana, 193.

Nephelium longanum, 193.

Nephelium Mora, 194.

Nephelium pupillum, 194.

Nigrae, 468.

Nima quassioides, 152.

Nitraria, 120.

Nitraria Schoberi, 120.

Norysca aurea, 404.

Norysca chinensis, 404.

Norysca patula, 402.

Norysca punctata, 404.

Nothopanax, 556.

Nothopanax Bockii, 557.

Nothopanax Davidii, 556.

Nothopanax diversifolius, 556.

Nothopanax Rosthornii, 557.

Nyssa, 254. 
Nyssa sinensis, 254.

NYSSACEAE, 254.

Olea acuminata, 609.

Olea clavata, 603.

Olea compacta, 604.

Olea consanguinea, 605 .

Olea fragrans, 609.

Olea Walpersiana, 605.

Oleaceae, 258, 600.

Omorica, 33.

Orixa, 135.

Orixa japonica, 135.

Ormosia, 93.

Ormosia Henryi, 93.

Ormosia Hosiej, 94.

Ornaster, 260.

Ornus, 258.

Osbeckia, 421.

Osbeckia crinita, 421.

Osbeckia crinita, 422 .

Osbeckia crinita, $\beta$ yunnanensis, 422.

Osbeckia stellata, 422 .

Osbeckia stellata, $\beta, 422$.

Osbeckia yunnanensis, 422 .

Osmanthus, 609.

Osmanthus armatus, 611.

Osmanthus fragrans, 609.

Osmanthus serrulatus, 610 .

Osmanthus venosus, 611 .

Ostrya, 424.

Ostrya carpinifolia, 424.

Ostrya italica, subspec. virginiana, 424 .

Ostrya italica, var. virginiana, 424 .

Ostrya japonica, 424.

Ostrya mandshurica, 435.

Ostrya ostrya var. japonica, 424.

Ostrya virginica, 424.

Osirya virginica, var. japonica, 424 .

Ostryopsis, 423.

Ostryopsis Davidiana, 423.

Ostryopsis Davidiana, var. cinerascens, 423.

Ostryopsis nobilis, 423.

Osyris japonica, 570.

Osyris rhamnoides, 409.

Othera orixa, 136.

Oxyactis, 133.

Oxycedrus, 56.

Pachyrhizus Thunbergianus, 118.

Pachysandra, 164.

Pachysandra axillaris, 164.
Pachysandra terminalis, 164 .

Paliurus, 209.

Paliurus aculeatus, 211.

Paliurus Aubletia, 210.

Paliurus Aubletii, 210.

Paliurus australis, 209, 211.

Paliurus australis, var. orientalis, 209.

Paliurus hirsutus, 210, 211.

Paliurus lucidus, 209.

Paliurus orientalis, 209, 210, 211.

Paliurus ramosissimus, 210, 211, 212.

Paliurus sinicus, 210, 211.

Paliurus Spina-Christi, 210, 211.

Paliurus tonkinensis, 211.

Paliurus virgatus, 211.

Palura odorata, 593.

Panax aculeatum, 563.

Panax Davidii, 556.

Panax Loureirianum, 564.

Panax ricinifolium, 564.

Panax spinosum, 562.

Paniculatae, 354 .

Passerina Chamaedaphne, 536.

Passerina Chamaejasme, 551.

Passerina Stelleri, 551.

Passiflora 408.

Passiflora cupiformis, 408.

Passiflora Franchetiana, 408.

Passiflora Henryi, 408.

Passifloraceae, 408.

Paullinia asiatica, 137.

Perrottetia, 359.

Perrottetia racemosa, 359.

Persea Camfora, 68.

Persea Nanmu, 72.

Pentapanax, 565.

Pentapanax Henryi, 565.

Phaseolodes brachybotrys, 511.

Phaseolodes floribundum, 509.

Phaseolodes japonicum, 515.

Phellodendron, 136.

Phellodendron amurense, 136.

Phellodendron amurense, var. sachalinense, 136.

Phellodendron chinense, 136.

Phellodendron chinense, var. glabriusculum, 137.

Phellodendron japonicum, 136.

Phellodendron sachalinense, 136.

Phellodendron sinense, 137.

Phillyrea paniculata, 603.

Phoebe, 71. 
Phoebe macrophylla, 71 .

Phoebe nanmu, 72.

Phoebe neurantha, 72.

Phoebe Sheareri, 72, 621.

Photinia arguta, var., 277.

Photinia polyneura, 278.

Phyllanthus, 519.

Phyllanthus albicans, 520.

Phyllanthus flexuosus, 519.

Phyllanthus fluggeiformis, 520 .

Phyllanthus glaucus, 520 .

Phyllanthus japonicus, 519.

Phyllanthus Leucopyrus, 520.

Phyllanthus Lucena, 520.

Phyllanthus puberus, 518.

Phyllostachys, 65.

Phyllostachys Henonis, 65.

Phyllostachys nidularia, 65 .

Phyllostachys nigra, 65.

Phyllostachys nigra, var. Henonis, 65.

Phyllostachys puberula, 65 .

Picea, 22.

Picea ajanensis, 33.

Picea Alcockiana, 31, 33.

Picea ascendens, 34 .

Picea asperata, 22.

Picea asperata, var. notabilis, 23.

Picea asperata, var. ponderosa, 23.

Picea aurantiaca, 26.

Picea Balfouriana, 30 .

Picea brachytyla, 33.

Picea complanata, 35.

Picea gemmata, 24.

Picea heterolepis, 24.

Picea hirtella, 32 .

Picea likiangensis, 31.

Picea likiangensis, var. rubescens, 31 .

Picea Mastersii, 27.

Picea Maximowiczii, 27.

Picea Meyeri, 28.

Picea montigena, 33.

Picea Neoveitchii, 26.

Picea obovata Schrenkiana, 29.

Picea obovata, $\beta$ Schrenkiana, 29.

Picea orientalis, $\beta$ longifolia, 29.

Picea pachyclada, 33.

Picea purpurea, 29.

Picea retroflexa, 25.

Picea Sargentiana, 35.

Picea Sehrenkiana, 29.

Picea tianschanica, 29.

Picea Watsoniana, 27.

Picea Wilsonii, 27.
Picrasma, 152.

Picrasma ailanthoides, 152.

Picrasma japonica, 152.

Picrasma quassioides, 152.

Picrasma quassioides, var. glabrescens, 152.

Pimela alba, 155.

Pimpinellifoliae, 333, 343.

Pinaceae, 10.

Pinnatae, 204.

Pinus, 10.

Pinus Abies, 50.

Pinus abies, f. schrenkiana, 29.

Pinus Argyi, 15.

Pinus Armandi, 12.

Pinus Armandi, var. Mastersiana, 12.

Pinus Bungeana, 13.

Pinus canaliculata, 14.

Pinus Davidiana, 39.

Pinus densata, 17.

Pinus densiflora, 15.

Pinus densiflora, var. tabuliformis, 15.

Pinus excelsa, var. chinensis, 12.

Pinus Fabri, 41.

Pinus Fortunei, 40.

Pinus funebris, 15.

Pinus Henryi, 15.

Pinus jezoensis, 40.

Pinus Kaempferi, 22.

Pinus koraiensis, 12.

Pinus lanceolata, 50.

Pinus leucosperma, 15.

Pinus levis, 12.

Pinus mandschurica, 12.

Pinus Massoniana, 14.

Pinus Mastersiana, 12.

Pinus nephrolepis, 50.

Pinus prominens, 17.

Pinus sacra, 39.

Pinus Schrenkiana, 29.

Pinus scipioniformis, 12.

Pinus sinensis, 15 ,

Pinus sinensis, 14, 18.

Pinus sinensis, var. densata, 17.

Pinus sinensis, var, yunnanensis, 17.

Pinus tabulaeformis, 15.

Pinus Thunbergii, 15.

Pinus yunnanensis, 17.

Pinus Wilsonii, 15.

Piptanthus, 99.

Piptanthus nepalensis, 99.

Pirus formosana, 295.

Pirus Keissleri, 269. 
Pirus pulcherrima, 292.

Pirus Zumi, 292.

Pistacia, 173.

Pistacia chinensis, 173.

Pistacia coccinea, 174.

Pistacia formosana, 173.

Pistacia integerrima, 174.

Pistacia philippinensis, 173.

Pistacia weinmannifolia, 174.

Plagiospermum, 345.

Plagiospermum sinensis, 345 .

Platycladus stricta, 53.

Plectronia chinensis, 564.

Plumbaginaceae, 586.

Podocarpus, 9.

Podocarpus argotaenia, 6.

Podacarpus coriacea, 3.

Podocarpus insignis, 6.

Podocarpus macrophylla, 9.

Podocarpus macrophylla, var. acuminatissima, 9.

Podocarpus neriifolius, 9 .

Podocarpus sutchuenensis, 39.

Polygala, 160.

Polygala arillata, 160.

Polygala aureocauda, 161.

Polygala caudata, 161.

Polygala congesta, 162 .

Polygala fallax, 160 .

Polygala floribunda, 162.

Polygala Mariesii, 161.

Polygala Wattersii, 161.

Polygala Wattersii, 161.

Polygalaceae, 160.

Polyspora axillaris, 395.

Pomoideae, 263.

Poncirus, 149.

Poncirus trifoliata, 149.

Pongelion glandulosum, 153.

Potentilla, 301.

Potentilla davurica, 301.

Potentilla davurica, var. mandshurica, 303.

Potentilla davurica, var. Veitchii, 303.

Potentilla fruticosa, 301.

Potentilla fruticosa, var. albicans, 302.

Potentilla fruticosa, var. leucantha, 303.

Potentilla fruticosa, var. mandshurica, 303.

Potentilla fruticosa, var. ochreata, 304.

Potentilla fruticosa, var. parvifolia, 304.

Potentilla fruticosa, var, rigida, 302 .
Potentilla fruticosa, var. tangutica, 303.

Potentilla fruticosa, var. Veitchii, 303.

Potentilla parvifolia, 304.

Potentilla rigida, 302.

Potentilla Veitchii, 303.

Poupartia axillaris, 172.

Poupartia Fordii, 172.

Prinsepia, 344.

Prinsepia, 344.

Prinsepia sinensis, 345.

Prinsepia uniflora, 345 .

Prinsepia utilis, 345 .

Prunoideae, 344 .

Prunus? Kolomikta, 381.

Prunus paniculata, 593.

Prunus Taqueti, 248.

Pseudaegle sepiaria, 149.

Pseudocydonia sinensis, 299.

Pseudolarix, 21.

Pseudolarix Fortunei, 22.

Pseudolarix Kaempferi, 21.

Pseudosassafras Tzumu, 622.

Pseudotsuga Davidiana, 39.

Pseudotsuga jezoensis, 41.

Pterolobium, 92.

Pterolobium punctatum, 92.

Pterophyllus Salisburiensis, 1.

Pueraria, 118.

Pueraria hirsuta, 118.

Pueraria Thunbergiana, 118.

Punica, 419.

Punica Florida, 419.

Punica Granatum, 419.

Punica grandiflora, 419.

Punica nana, 419.

Punica spinosa, 419.

Punicaceae, 419.

Pygeum, 344.

Pygeum Henryi, 344.

Pygeum latifolium, 344.

Pyrus, 263.

Pyrus alnifolia, 271.

Pyrus Aria, var. Silvestrii, 273, 300.

Pyrus baccata, 282, 291, 294.

Pyrus baccata, $\gamma$ himalaica, 283.

Pyrus baccata, var, leiostyla, 291.

Pyrus baccata, $\beta$ mandshurica, 282.

Pyrus baccata, a sibirica, 291.

Pyrus Bodinieri, 300.

Pyrus brunnea, 300 .

Pyrus Calleryana, 264. 
Pyrus caloneura, 269.

Pyrus cathayensis, 297, 299.

Pyrus Cavaleriei, 300.

Pyrus chinensis, 299.

Pyrus cuspidata, 278.

Pyrus Delavayi, 296.

Pyrus Esquirolii, 300 .

Pyrus Feddei, 300.

Pyrus ferruginea, 300 .

Pyrus ferruginea, 277.

Pyrus floribunda, 285, 292.

Pyrus Folgneri, 271.

Pyrus granulosa, 274.

Pyrus Griffithii, 277.

Pyrus Halliana, 285.

Pyrus heterophylla, 265.

Pyrus hupehensis, 265, 300.

Pyrus japonica, 296, 298.

Pyrus japonica, $\boldsymbol{\beta}$ alpina, 298.

Pyrus Kaido, 290.

Pyrus Kaido X baccata, 292.

Pyrus kansuensis, 286.

Pyrus Karensium, 274.

Pyrus khasiana, 278.

Pyrus Koehnei, 300.

Pyrus kohimensis, 278.

Pyrus Kumaoni, 265.

Pyrus lanata, 275.

Pyrus Lindleyi, 263.

Pyrus Mairei, 300.

Pyrus Malus, 279.

Pyrus Malus, $\beta 288$.

Pyrus Malus Parkmanii, 285, 286.

? Pyrus Malus, $\delta$ sinensis, 279.

Pyrus Malus, $\boldsymbol{\beta}$ tomentosa, 279.

Pyrus Maulei, 298.

Pyrus Mengo, 293.

Pyrus Miyabei, 271.

Pyrus mokpoensis, 300 .

Pyrus nepalensis, 265.

Pyrus Parkmanii, 285.

Pyrus pashia, 264.

Pyrus pashia, var. kumaoni, 265.

Pyrus polycarpa, 274.

Pyrus praecox, 279.

Pyrus Prattii, 281.

Pyrus prunifolia, 279, 282, 288.

Pyrus rhamnoides, 278.

Pyrus ringo, 279.

Pyrus Ringo, $\gamma$ floribunda, 292.

Pyrus ringo, $\beta$ Kaido, 290.

Pyrus ? rivularis, 293.

Pyrus rivularis, $\boldsymbol{\beta}$ Toringo, 293.
Pyrus Sargentii, 294.

Pyrus serotina, 263.

Pyrus serrulata, 263.

Pyrus Sieboldii, 293.

Pyrus sinensis, 263, 289, 299.

Pyrus sinensis, var. Maximowicziana, 300.

Pyrus spec., 279.

Pyrus spectabilis, 282, 283, 285, 289.

Pyrus spectabilis, var. albescens, 300.

Pyrus spectabilis, \Kaido, 290.

Pyrus spectabilis, $\times$ Ringo, 290 .

(Pyrus spectabilis $\times$ Ringo $) \times P$. baccata, 292.

Pyrus spectabilis, var. Riversii, 289.

Pyrus Taquetii, 300 .

Pyrus Thomsonii, 277.

Pyrus Toringo, 293.

Pyrus Toringo, $\boldsymbol{\beta}$ incisa, 293.

Pyrus Toringo, $\gamma$ integrifolia, 292.

Pyrus Toringo, $\gamma$ typica, 294.

Pyrus transitoria, 295.

Pyrus Tschonoskii, 295.

Pyrus Tschonoskii, var. Hoggii, 295.

Pyrus Vaniotii, 300.

Pyrus variolosa, 265.

Pyrus Veitchii, 287.

Pyrus verruculosa, 265.

Pyrus Wilhelmii, 265.

Pyrus yunnanensis, 287.

Quinaria lansium, 14.

Raxopitys Cunninghamii, 51.

Reevesia, 376.

Reevesia Cavaleriei, 376.

Reevesia pubescens, 376 .

Rhamnaceae, 209.

Rhamnella, 222.

Rhamnella franguloides, 222, 224, 225.

Rhamnella japonica, 225.

Rhamnella Julianae, 223, 224, 225.

Rhamnella Mairei, 224, 225.

Rhamnella Martinii, 224, 225.

Rhamnella obovalis, 223, 224, 226.

Rhamnella Wilsonii, 222, 224, 225.

Rhamnoides hippophae, 409.

Rhamnus, 232.

Rhamnus affinis, 230.

Rhamnus argutus, 243, 250.

Rhamnus Arnottianus, 242, 247.

Rhamnus Bodinieri, 242, 246.

Rhamnus Bodinieri, f. silvicola, 247. 
Rhamnus cambodianus, 244.

Rhamnus catharticus, $\gamma$ davuricus, 251.

Rhamnus Cavaleriei, 232, 237.

Rhamnus chlorophorus, 248.

Rhamnus ? cinerascens, 219.

Rhamnus costata, 230.

Rhamnus costatus, 242, 247.

Rhamnus crenatus, 232, 241, 244.

Rhamnus dahuricus, 251.

Rhamnus dahuricus, var. hirsutus, 251.

Rhamnus dahuricus var. nipponicus, 252.

Rhamnus davuricus, 244, 251.

Rhamnus dumetorum, 237. 243, 249.

Rhamnus dumetorum, var. crenoserratus, 238.

Rhamnus erythroxylon, 242, 248.

Rhamnus Esquirolii, 233, 242, 245.

Rhamnus filiformis, 231.

Rhamnus formosanus, 242, 246.

Rhamnus globosus, 243, 248.

Rhamnus hamatidens, 244, 252.

Rhamnus Hemsleyanus, 234, 242, 247.

Rhamnus Henryi, 241, 244.

Rhamnus heterophyllus, 232, 241, 245 , 623.

Rhamnus hirsutus, 243, 251.

Rhamnus hupehensis, 236, 242, 248.

Rhamnus hypochrysus, 244, 252.

Rhamnus iteinophyllus, $239,244,252$.

Rhamnus japonicus, 244, 251.

Rhamnus javanicus, 246.

Rhamnus koraiensis, 243, 249.

Rhamnus lamprophyllus, 244, 252.

Rhamnus leptacanthus, 236, 243, 248.

Rhamnus leptophyllus, $239,243,250$.

Rhamnus leptophyllus, var. milensis, 250.

Rhamnus Leveilleanus, 237, 243, 249.

Rhamnus lineatus, 220.

Rhamnus Martinii, 225.

Rhamnus Meyeri, 243, 249.

Rhamnus nipalensis, 242, 245.

Rhamnus oreigenes, 244 .

Rhamnus Paliurus, 211.

Rhamnus paniculiflorus, 233, 242, 245.

Rhamnus parviflora, 231.

Rhamnus parvifolius, $243,250$.

Rhamnus polymorphus, 250.

Rhamnus procumbens, 245.

Rhamnus pseudofrangula, 244, 245.

Rhamnus purpureus, $242,248$.

Rhamnus Rosthornii, 236, 243, 248.
Rhamnus rugulosus, 238, 243, 249.

Rhamnus Sargentianus, 235, 242, 247.

Rhamnus Schneideri, 243, 250.

Rhamnus Taquetii, 243, 248.

Rhamnus Thea, 227.

Rhamnus theezans, 227.

Rhamnus tinctorius, 248 .

Rhamnus tonkinensis, 242, 245.

Rhamnus trigynus, 231.

Rhamnus triqueter, 242, 246.

Rhamnus utilis, 240, 244, 252.

Rhamnus virgatus, 243, 251.

Rhamnus virgatus, var. apricus, 248.

Rhamnus virgatus, var. sylvestris, 250.

Rhamnus Wightii, 242, 246.

Rhamnus Wilsonii, 240, 244, 252.

Rhamnus Yoshinoi, 251.

Rhamnus Zizyphus, 212.

Rhodotypus, 300.

Rhodotypus kerrioides, 300 .

Rhodotypus tetrapetala, 300 .

Rhus, 176.

Rhus affinis, 179.

Rhus ailanthoides, 152.

Rhus amela, 179.

Rhus Buchi-amelam, 179.

Rhus cacodendron, 153.

Rhus chinense, 178.

Rhus Cotinus, 175.

Rhus cotinus, 175.

Rhus Delavayi, 183.

Rhus Delavayi, var. quinquejuga, 184.

Rhus fraxinifolium, 183.

Rhus Henryi, 177.

Rhus intermedia, 179.

Rhus javanica, 178.

Rhus javanica, var. Roxburghii, 179 .

Rhus Kaempferi, 181.

Rhus laevis, 175.

Rhus obovatifolia, 175.

Rhus orientalis, 179 .

Rhus Osbeckii, 178.

Rhus paniculata, 184.

Rhus Potaninii, 177.

Rhus pubigera, 183.

Rhus punjabensis, 176.

Rhus punjabensis, 176.

Rhus punjabensis, var. sinica, 176.

Rhus Roxburghii, 179.

Rhus semialata, 178, 179.

Rhus semialata, f. exalata, 179.

Rhus semialata, $\boldsymbol{\beta}$ Osbeckii, 178.

Rhus semialata, $\gamma$ Roxburghii, 179. 
Rhus simplicifolia, 175.

Rhus sinica, 176, 177.

Rhus succedanea, 182.

Rhus succedanea, var. himalaica, 181.

Rhus succedanea, a japonica, 183.

Rhus sylvestris, 180.

Rhus Toxicodendron, var. hispida, 179.

Rhus trichocarpa, 180.

Rhus vernicifera, 181.

Rhus vernicifera, var. Silvestrii, 181.

Rhus verniciflua, 181.

Rhus vernix, 181.

Rhynchosia, 118.

Rhynchosia Craibiana, 118.

Rhynchosia Dielsii, 118.

Rhynchosia himalensis, 118.

Rhynchosia striata, 118.

Rhynchosia volubilis, 119.

Ricinus Apelta, 525.

Rosa, 304.

Rosa abyssinica, f. glandulosa, 308.

Rosa adenoclada, 312 .

Rosa amoyensis, 315 .

Rosa Amygdalifolia, 318.

Rosa anemoneflora, 334, 336.

Rosa Argyi, 319.

Rosa Banksiae, 316, 337.

Rosa Banksiae, 317.

Rosa Banksiae, var. albo-plena, 316.

Rosa Banksiae, f. lutescens, 317, 337.

Rosa Banksiae, $\boldsymbol{\beta}$ microcarpa, 315.

Rosa Banksiae, f. normalis, 337.

Rosa Banksiae, var. normalis, 317.

Rosa Banksiae X Soulieana, 337.

Rosa Banksiae, f. subinermis fl. pleno v. semipleno albo, 316.

Rosa Banksiae, f. subinermis fl. simpl., 317.

Rosa Banksiae verosimile hybrida, 337.

Rosa banksiopsis, 322, 339, 341.

Rosa bella, 340, 341 .

Rosa bella, f. pallens, 342 .

Rosa bengalensis, $\beta$ chinensis, 320 .

Rosa Bodinieri, 315.

Rosa bracteata, $319,337$.

Rosa Brownii, 307.

Rosa Brunonii, 306, 334, 336.

Rosa Brunonis, 307, 336.

Rosa Camellia, 318.

Rosa camelliaefolia, 318.

Rosa caudata, 321, 339, 341.

Rosa Cavaleriei, 315.

Rosa centifolia, 306, 319.
Rosa cerasocarpa, 312.

Rosa Chaffanjoni, 315.

Rosa Cherokeensis, 318.

Rosa chinensis, 320 , 338 .

Rosa chinensis, var. fragrans, 338 .

Rosa chinensis, a indica, 338 .

Rosa chinensis, f. spontanea, 320, 338.

Rosa cinnamomea dahurica, 340 .

Rosa cinnamomea $\zeta$ daurica, 340 .

Rosa Collettii, 316.

Rosa corymbulosa, $323,339,341$.

Rosa cucumerina, 318.

Rosa cymosa, 315.

Rosa damascena, f. brachyacantha, 334 .

Rosa damascena, f. floribus semiplenis, 334.

Rosa damascena, f. floribus simplicibus, 305.

Rosa Davidii, 322, 339, 341.

Rosa Davidii, var. elongata, 323, 341.

Rosa davurica, 339, 340.

Rosa diffusa, 306.

Rosa dubia, 316.

Rosa Duclouxii, 339.

Rosa Ecae, 343.

Rosa Esquirolii, 315.

Rosa ferox, 321 .

Rosa filipes, 311, 334, 336.

Rosa floribunda, 310, 312.

Rosa florida, 306.

Rosa Forrestii, 319.

Rosa fragariaeflora, 315 .

Rosa fragrans, 338 .

Rosa gechouitangensis, 338 .

Rosa Gentiliana, 312, 334, 336.

Rosa Gentiliana, var. australis, 336 .

Rosa gigantea, 338 .

Rosa gigantea, f. erubescens, 339.

Rosa Giraldii, 328, 340, 342.

Rosa Giraldii, f. glabriuscula, 328, 342 .

Rosa Giraldii, var. venulosa, $328,342$.

Rosa glomerata, 309, 334, 336.

Rosa graciliflora, 330, 343.

Rosa Grevillii, 306.

Rosa Helenae, 310, 334, 336.

Rosa Hugonis, 330, 343.

Rosa hystrix, 318.

Rosa indica, 315, 320 .

Rosa indica fragrans, 338.

Rosa indica, var. ochroleuca, 338.

Rosa indica odorata, 338.

Rosa indica, $\boldsymbol{\beta}$ odoratissima, 338.

Rosa indica sulphurea, 338 . 
Rosa Indica vulgaris, 320.

Rosa intermedia, 316.

Rosa irridens, 334, 337.

Rosa irridens, form. nov., 337.

Rosa kamtchatica, 321 .

Rosa laevigata, 318, 337.

Rosa Leschenaultiana, 336.

Rosa levigata, var. kaiscianensis, 318.

Rosa longicuspis, $313,334,336$.

Rosa lucens, 313.

Rosa Luciae, 335.

Rosa Luciae, $\delta$ adenophora, 624.

Rosa Luciae, є crataegicarpa, 624.

Rosa Luciae, $\beta$ fimbriata, 624.

Rosa Luciae, $\gamma$ poteriifolia, 624.

Rosa Luciae, $\zeta$ yokoscensis, 624.

Rosa lucida, 337.

Rosa lucidissima, 313, 321.

Rosa Macartnea, 337.

Rosa macrocarpa, 339.

Rosa macrophylla, 322.

Rosa macropyhlla, var. acicularis, 341.

Rosa macrophylla, var. crasseaculeata, 324.

Rosa macrophylla, f. gracilis, 325, 337.

Rosa macrophylla? forma gracilis, 341 .

Rosa macrophylla, var. hypoleuca, 337 .

Rosa macrophylla, f. parce glandulosa, 325.

Rosa macrophylla, var. rubrostaminea, 325.

Rosa Mairei, 343.

Rosa microcarpa, 314, 337, 624.

Rosa microphylla, 319, 320.

Rosa microphylla, a glabra, 319 .

Rosa microphylla, $\boldsymbol{\beta}$ hirtula, 320.

Rosa mokanensis, 335.

Rosa mokanensis, var. quelpaertensis, 335.

Rosa moschata, 307.

Rosa moschata, 307, 308, 335, 336.

Rosa moschata, var. densa, 313.

Rosa moschata hispanica simplex, 307.

Rosa moschata, var. hupehensis, 308.

Rosa moschata maculata, 312.

Rosa Moschata major, 307.

Rosa moschata, var. nasturana, 308 .

Rosa moschata, var. nepalensis, 307.

Rosa moschata, var. yunnanensis, 313, 314.

Rosa Moyesii, 325, 340, 342.

Rosa Moyesii, f. rosea, 325, 342.

Rosa multibracteata, 328, 340, 342.
Rosa multiflora, 304, 334.

Rosa multiflora, 304, 305.

Rosa multiflora, var. adenophora, 305.

Rosa multiflora, var. brachyacantha, 334.

Rosa multiflora, var, carnea, 305, 334.

Rosa multiflora, var. carnea, f. platyphylla, 306, 334 .

Rosa multiflora, var. cathayensis, 304, 334.

Rosa multiflora, var. platyphylla, 306 .

Rosa multiflora, $\boldsymbol{\beta}$ plena, 306.

Rosa multiflora, var. quelpaertensis, 335.

Rosa Murielae, 326, 340, 342.

Rosa muscata, 307.

Rosa nankinensis, 320 .

Rosa nivea, 318.

Rosa odorata, 338 .

Rosa odorata, var. gigantea, 338 .

Rosa odorata, var. gigantea, f. erubescens, 339 .

Rosa odoratissima, 338 .

Rosa omeiensis, 331, 343.

Rosa omeiensis, f. pteracantha, 332, 343.

Rosa orbicularis, 340,342 .

Rosa oulengensis, 338 .

Rosa persetosa, 340,341 .

Rosa pimpinellifolia, 342 .

Rosa Pissarti, 308.

Rosa platyacantha, 343.

Rosa Prattii, 329, 340, 342.

Rosa pubescens, 307, 321.

Rosa quelpaertensis, 335 .

Rosa reducta, 328 .

Rosa Regeliana, 321.

Rosa Roxburghii, 319, 337.

Rosa Roxburghii, 306.

Rosa Roxburghii, var. hirtula, 320 .

Rosa Roxburghii, f. normalis, 319, 337.

Rosa rubeoides, 306.

Rosa Rubus, 308, 334, 336.

Rosa rugosa, $321,339,340$.

Rosa rugosa, f, amurensis, 321 .

Rosa rugosa, var. Chamissoniana, 321, 340.

Rosa rugosa, $\beta$ kamtschatica, 321 .

Rosa ruscinomensis, 307.

Rosa saturata, 324, 340, 341.

Rosa semperflorens, $\beta, 320$.

Rosa sempervirens, 313, 335 . 
Rosa sempervirens, $\boldsymbol{\beta}$ anemoniflora, 336.

Rosa sericea, 332 .

Rosa sericea, 331, 332, 344.

Rosa sericea, f. aculeata eglandulosa, 331.

Rosa sericea, f. denudata, 331.

Rosa sericea fructu rubro aculeis decurrentibus, 332.

Rosa sericea, f. glabrescens, 331 .

Rosa sericea, f. inermis eglandulosa, 331.

Rosa sericea, f. intermedia, 331.

Rosa sericea, f. pteracantha, 332 .

Rosa sericea, var. pteracantha, 332 .

Rosa sertata, $327,340,342$.

Rosa setipoda, 323, 339, 341.

Rosa sinica, 318, 320 .

Rosa sinica, $\beta$ Braamiana, 319, 337.

Rosa sinica, a typica, 318 .

Rosa Sinowilsoni, 313.

Rosa sorbiflora, 315 .

Rosa sorbifolia, 315.

Rosa Sorbus, 331.

Rosa Soulieana, 314, 334, 337.

Rosa Soulieana, 313.

Rosa Sweginzowii, 324, 340, 342.

Rosa ternata, 318.

Rosa Thea, 338.

Rosa Thoryi, 306.

Rosa tongtchouanensis, 338.

Rosa trifoliata, 318.

Rosa triphylla, 318.

Rosa Webbiana, 329.

Rosa Webbiana, 327.

Rosa Wichuraiana, 334, 335, 624.

Rosa Wichuraiana, $\delta$ adenophora, 335, 624.

Rosa Wichuraiana, $\epsilon$ crataegicarpa, 335,624 .

Rosa Wichuraiana, $\boldsymbol{\beta}$ fimbriata, 335, 624 .

Rosa Wichuraiana, $\gamma$ poteriifolia, 335, 624.

Rosa Wichuraiana, $\zeta$ yokoscensis, 335, 624.

Rosa Willdenovii, 340.

Rosa Willmottiae, 329, 340, 342.

Rosa Willmottiana, 313.

Rosa xanthina, 342 .

Rosa xanthina, $330,342$.

Rosa xanthina, f. normalis, 342.

Rosa xanthocarpa, 339.

Rosaceae, 263.
Roscyna americana, 402.

Roscyna Gmelini, 402.

Roscyna japonica, 402.

ROSOIDEAE, 300.

Rottlera aurantiaca, 526 .

Rottlera cantoniensis, 525 .

Rottlera cordifolia, 526.

Rottlera scabrifolia, 526.

Rottlera tinctoria, 526.

Roumea chinensis, 545 .

Rubus japonicus, 301 .

RUtaceae, 121.

Sabia, 195 .

Sabia coriacea, 198.

Sabia emarginata, 196.

Sabia gracilis, 198.

Sabia latifolia, 195.

Sabia parviflora, 358 .

Sabia puberula, 197.

Sabia Ritchieae, 195.

Sabia Schumanniana, 196.

Sabia Schumanniana, var. longipes, 197.

Sabia Schumanniana, var. pluriflora, 197.

Sabia yunnanensis, 358 .

SABIACEAE, 195.

Sabina, 57.

Sabina chinensis, 61.

Sabina Corneyana, 54.

Sabina dimorpha, 61.

Sabiaa sphaerica, 61.

Sabina squamata, 58.

Sabina struthiacea, 61 .

Sageretia, 226.

Sageretia apiculata, 230, 231.

Sageretia apiculata, 623.

Sageretia Brandrethiana, 229, 230.

Sageretia Brandrethiana, var. Bornmuelleri, 230.

Sageretia Cavaleriei, 228, 230, 231.

Sageretia Cavaleriei, 623.

Sageretia Chanetii, 228.

Sageretia ferruginea, 227.

Sageretia filiformis, 230, 231.

Sageretia gracilis, 623 .

Sageretia hamosa, 229, 230.

Sageretia Henryi, 623.

Sageretia omeiensis, 229, 230.

Sageretia oppositifolia, 231.

Sageretia parvifiora, 231.

Sageretia paucicostata, 230, 231.

Sageretia perpusilla, 226, 229, 230. 
Sageretia pycnophylla, 226, 229, 230.

Sageretia rugosa, 227, 229, 230.

Sageretia subcaudata, 228, 229, 231.

Sageretia theezans, 227, 230, 231.

Sageretia theezans, var. tomentosa, 228.

Salisburia adiantifolia, 1.

Samara Potama, 581.

Samara sessilis, 580.

Samara subspinosa, 580.

Sambucus japonica, 187.

Sambucus tiliaefolia, 569.

SAPINDACEAE, 191.

Sapindus, 191.

Sapindus abruptus, 191.

Sapindus Benghalensis, 193.

Sapindus monogyna, 193.

Sapindus mukorossi, 191,

Sapium, 527.

Sapium discolor, 527 .

Sapium japonicum, 527.

Sapium sebiferum, 527.

Sarcococca, 163.

Sarcococea Hookeriana, 164.

Sarcocoeca Hookeriana, var. digyna, 164.

Sareococca Hookeriana, var. humilis, 164.

Sarcococca pruniformis, 163.

Sarcococca pruniformis, var. Hookeriana, 164.

Sarcococea ruscifolia, 163.

Sarcoeocea ruscifolia, var. chinensis, 163.

Sarcococca saligna, var. chinensis, 163.

Sassafras, 74 .

Sassafras tzumu, 74, 622 .

Sasanqua oleifera, 393.

Sauropus, 518.

Sauropus albicans, 518 .

Schefflera, 555.

Schefflera Delavayi, 555 .

Scopolia involucrata, 550 .

Scutia? paniculata, 355.

Scytalia Bengalensis, 193.

Scytalia Longan, 193.

Securinega, 520 .

Securinega fluggeoides, 520.

Securinega japonica, 520.

Securinega Leucopyrus, 520.

Securinega virosa, 520 .

Sempervirentes, 357 .

Sericeae, 333, 343.
Simaba guassioides, 152.

Simardbaceae, 152.

Simplices, 199.

Skimmia, 138.

Skimmia Fortunei, 139.

Skimmia Fortunei, 138.

Skimmia japonica, 138, 139.

Skimmia laureola, 138.

Skimmia melanocarpa, 138.

Sloanea, 361.

Sloanea assamica, 362 .

Sloanea Hanceana, 361.

Sloanea Hemsleyana, 361 .

Sloanea sterculiacea, 362 .

Sloanea tomentosa, 362 .

Smythea trichantha, 218.

Sorbus, 266 .

Sorbus alnifolia, 270, 272, 275 .

Sorbus alnifolia, var. lobulata, 275 .

Sorbus alnifolia, var. submollis, 275 .

Sorbus Aria, var. kumaonensis, 275.

Sorbus Aria, var. Mairei, 273, 300.

Sorbus aronioides, 268, 272, 274.

Sorbus ealoneura, 269, 272, 274.

Sorbus commixta, 275.

Sorbus crenata, 277.

Sorbus Dunnii, 272, 273.

Sorbus ferruginea, 277.

Sorbus Folgneri, 271, 272, 276.

Sorbus granulosa, 272, 274.

Sorbus Griffithii, 277.

Sorbus Hemsleyi, 272, 276.

Sorbus Henryi, 272, 274.

Sorbus japonica, 272,275 .

Sorbus japonica, 275.

Sorbus japonica, var. calocarpa, 276.

Sorbus Keissleri, 269, 272, 274.

Sorbus khasiana, 278.

Sorbus Koehnei, 276.

Sorbus kohimensis, 278.

Sorbus megalocarpa, 266, 272, 274.

Sorbus megalocarpa, var. cuneata, 267.

Sorbus meliosmifolia, 270, 272, 274.

Sorbus Myabei, 271.

Sorbus pallescens, 266, 272, 273.

Sorbus polycarpa, $272,274$.

Sorbus rhamnoides, 278.

Sorbus sikkimensis, 274, 278.

Sorbus sikkimensis, $\delta$ ferruginea, 277.

Sorbus sikkimensis, $\gamma$ microcarpa, 277.

Sorbus sikkimensis, $\boldsymbol{\beta}$ oblongifolia, 278 .

Sorbus Thomsonii, 277. 
Sorbus verrucosa, 278.

Sorbus xanthoneura, 272.

Sorbus Zahlbruckneri, 272, 274.

Sophora, 94.

Sophora Davidii, 95.

Sophora flavescens, 96.

Sophora japonica, 96 .

Sophora Mooreroftiana, 95.

Sophora Moorcroftiana, var. Davidii, 95.

Sophora viciifolia, 95 .

Sophora Wilsonii, 94.

Spiraea japonica, 301.

Spondias, 172.

Spondias acuminata, 172.

Spondias axillaris, 172.

Spondias axillaris, var. pubinervis, 173.

Staphylea, 185.

Staphylea Bumalda, 185.

Staphylea Emodi, 185.

Staphylea holocarpa, 185.

Staphylea holocarpa, var. rosea, 186.

Staphyleaceae, 185.

Stellera, 551.

Stellera chamaejasme, 551.

Sterculia, 376.

Sterculia lanceaefolia, 376.

Sterculia ovalifolia, 376.

Sterculia platanifolia, 377.

Sterculia pyriformis, 377 .

Sterculia Roxburghii, 376.

Sterculia tomentosa, 377.

Sterculiaceae, 376 .

Stewartia, 395.

Stewartia monadelpha, 396.

Stewartia serrata, 396.

Stewartia sinensis, 395 .

Stillingia discolor, 527.

Stillingia japonica, 527.

Stillingia sebifera, 528 .

Stillingia sinensis, 528 .

Stillingfleetia sebifera, 528 .

Stizolobium, 117.

Stizolobium hassjoo, 117.

Stylidium chinense, 552.

Stylis chinensis, 552.

Stylodiscus trifoliatus, 521.

Styrax javanicum, 552.

Styrax Rossamala, 552.

Syllysium buxifolium, 420.

Symplocaceate, 593.

Symplocos, 593 .

Symplocos anomala, 596.
Symplocos atroviridis, 595 .

Symplocos botryantha, 596 .

Symplocos caudata, 595 .

Symplocos crataegoides, 593.

Symplocos ferruginea, 597.

Symplocos flavida, 595.

Symplocos Horsfieldiana, 597.

Symplocos javanica, 597 .

Symplocos lachnobotrya, 597.

Symplocos laurina, 594 .

Symplocos Loha, 594.

Symplocos longipetiola, 599 .

Symplocos mollis, 597.

Symplocos myriantha, 596.

Symplocos pallida, 593.

Symplocos paniculata, 593 .

Symplocos pilosa, 598 .

Symplocos polycarpa, 595.

Symplocos polystachya, 597.

Symplocos prunifolia, 595.

Symplocos rufescens 595.

Symplocos salaccensis, 597.

Symplocos spicata, 594.

Symplocos spicala, var. gracilis, 595.

Symplocos stellaris, 597.

Symplocos subspinosa, 594.

Symplocos Swinhoeana, 595 .

Symplocos tetramera, 598 .

Symplocos theophrastaefolia, 595.

Symplocos Verhuellii, 597.

Symplocos Wilsoni, 597.

Symplocos xanthophylla, 595.

Synstylae, 333, 334.

Syzygium ? buxifolium, 420.

Tamaricaceae, 406.

Tamarix, 406.

Tamarix chinensis, 406.

Tamarix chinensis, 407.

Tamarix dahurica, 407.

Tamarix gallica, $\beta$ chinensis, 406.

Tamarix indica, 406.

Tamarix juniperina, 407.

Tamarix parviflora, 406 .

Tamarix tetrandra, 406.

Taonabo japonica, 397.

Tapiscia, 188.

Tapiscia sinensis, 188.

Taxacean, 3.

TAXodieat, 50 .

Taxodium japonicum, 52.

Taxus, 8.

Taxus baccata, 3,8 . 
Taxus baccata, subsp. 2. cuspidata, 8 .

Taxus baccata, subsp. 2. cuspidata, var. b. chinensis, 8 .

Taxus coriacea, 3 .

Taxus cuspidata, 8 .

Taxus cuspidata, var. chinensis, 8 .

Ternstroemia, 397.

Ternstroemia aneura, 397.

Ternstroemia bifaria, 401.

Ternstroemia dubia, 397.

Ternstroemia fragrans, 397.

Ternstroemia japonica, 397.

Ternstroemia japonica, f. parvifolia, 397.

Ternstroemia japonica, var. Wightii, 397.

Ternstroemia Lushia, 400.

Tetradenia consimilis, 79.

Tetradenia lanuginosa, 79.

Tetradenia umbrosa, 79.

Tetradium, 129.

Tetradium trichotomum, 132.

Tetranthera citrata, 75 .

Tetranthera polyantha, 75 .

Tetranthera sericea, 75 .

Thea, 390 .

Thea assamica, 391.

Thea bohea, 391.

Thea cantoniensis, 391.

Thea chinensis, 391 .

Thea chinensis, var. $\beta$ Bohea, 391 .

Thea chinensis, var. viridis, 391.

Thea cochinchinensis, 391.

Thea cuspidata, 390 .

Thea elongata, 392 .

Thea euryoides, 390 .

Thea fraterna, 390 .

Thea Grijsii, 394.

Thea Grijsii, 394.

Thea japonica, 394.

Thea oleifera, 393.

Thea oleosa, 391, 393.

Thea rosaeflora, var. glabra, 390 .

Thea rosaeflora, var. pilosa, 390 .

Thea Sasanqua, 393.

Thea sasanqua, var. oleosa, 393 .

Thea sinensis, 391.

Thea stricta, 391 .

Thea viridis, 391.

Theaceae, 390 .

Theaphyla cantoniensis, 391.

Theaphyla lanceolata, 391.

Theaphyla laxa, 391.
Theaphyla oleifera, 391 .

Theaphyla viridis, 391 .

Thuja, 53.

Thuja acuta, 53.

Thuja orientalis, 53 .

Thymelaeaceae, 530 .

Tilia, 363.

Tilia argentea, 370 .

Tilia argentea, $\boldsymbol{\beta}$ mandshurica, 370.

Tilia Baroniana, 364.

Tilia chinensis, 364 .

Tilia chinensis, 369 .

Tilia dictyoneura, 363 .

Tilia Henryana, 367.

Tilia Henryana, var. a fulva, 367.

Tilia Henryana, var. $\boldsymbol{\beta}$ subglabra, 367.

Tilia Henryana, var $\boldsymbol{\beta}$ subglabra, f. polyantha, 367 .

Tilia intonsa, 365 .

Tilia laetevirens, 369 .

Tilia mandshurica, 370 .

Tilia mandshurica, 366.

Tilia mandshurica, var. pekinensis, 370.

Tilia Miqueliana, var. chinensis, 363, 369.

Tilia mongolica, 369 .

Tilia nobilis, 363 .

Tilia Oliveri, 366 .

Tilia Oliveri, var. cinerascens, 367 .

Tilia paucicostata, 363 .

Tilia paucicostata, var. a firma, 363 .

Tilia paucicostata, var. $\beta$ tenuis, 363 .

Tilia pekinensis, 370.

Tilia pendula, 366 .

Tilia sp., 369.

Tilia tuan, 368.

Tilia Tuan, var. Cavaleriei, 368.

Tilia Tuan, var. a Cavaleriei, f. divaricata, 368.

Tilia tuan, var. chinensis, 369 .

Tilia Tuan, var. $\boldsymbol{\beta}$ pruinosa, 368.

Tilia tonsura, 365 .

Tiliaceae, 363.

Tinus crispa, 582.

Tinus Henryi, 582.

Tinus japonica, 583 .

Tinus montana, 583.

Toddalia, 137.

Toddalia aculeata, 137.

Toddalia asiatica, 137.

Toddalia floribunda, 137.

Toddalia nitida, 137. 
Toona sinensis, 156.

Toona sinensis, var. grandis, 156 .

Torreya, 7 .

Torreya Fargesii, 7.

Torreya grandis, 7 .

Torreya nucifera, 7 .

Torreya nucifera, var. grandis, 7 .

Torricellia, 569.

Torricellia angulato, 569 .

Torricellia intermedia, 569 .

Torricellia tiliifolia, 569 .

Toxicodendron, 179.

Toxicodendron orientale, 179.

Trewia nudiflora, 526.

Triadica japonica, 527.

Triadica sinensis, 527 .

Tricera nepalensis, 164.

Trifolium cytisoides, 109.

Trifolium dauricum, 110.

Trifolium hedysaroides, 109.

Trochostigma Kolomikta, 381.

Trochostigma polygama, 380 .

Trochostigma rufa, 379.

Trochostigma volubilis, 380 .

Tsuga, 36.

Tsuga chinensis, 37,621 .

Tsuga dumosa, var. chinensis, 37.

Tsuga formosana, 38 .

Tsuga formosana, 621 .

Tsuga Sieboldii, 37.

Tsuga yunnanensis, 36 .

Tsuga yunnanensis, 37 .

Tubo-avellana, 448.

Tumion grande, 7 .

Turpinia, 187.

Turpinia microcarpa, 187.

Turpinia nepalensis, 187.

Turpinia pomifera, 187.

Turpinia pomifera, $\boldsymbol{\beta}$ (T. nepalensis), 187.

Uraria, 104.

Uraria hamosa, var. sinensis, 104.

Urena, 373.

Urena cana, 373.

Urena diversifolia, 373.

Urena lobata, 373.

Velaga globosa, 418.

Ventilago, 253.

Ventilago calyeulata, 253 .

Virides, 491, 503.

Visiania paniculata, 603.
Wetria rufescens, 524.

Wikstroemia, 530 .

Wilstroemia alpina, var., 534 .

Wikstroemia alternifolia, 533, 537 .

Wikstroemia alternifolia, 537 .

Wikstroemia angustifolia, 533, 535.

Wikstroemia Bodinieri, 538.

Wikstroemia brevipaniculata, 532 , $533,536$.

Wikstroemia canescens, $533,536$.

Wikstroemia capitata, $530,533,535$.

Wikstroemia chamaedaphne, 533, 536.

Wikstroemia chamaedaphne, 535.

Wikstroemia chinensis, 533,535 .

Wikstroemia dolichantha, $533,537$.

Wikstroemia effusa, 534, 538 .

Wikstroemia gracilis, 533, 536 .

Wikstroemia holosericea, 533, 537.

Wikstroemia inamoena, 536.

Wikstroemia indica, 532, 534.

Wikstroemia indica, 534 .

Wikstroemia indica, var. viridiflora, 534.

Wikstroemia ligustrina, 531, 533, 535.

Wikstroemia linoides, 533,535 .

Wikstroemia micrantha, $530,533,535$.

Wikstroemia monnula, 533, 535 .

Wikstroemia nutans, 532, 534 .

Wikstroemia Pampaninii, 533, 537.

Wikstroemia retusa, 533, 534 .

Wikstroemia salicifolia, 536 .

Wikstroemia salicina, 533,535 .

Wikstroemia scytophylla, 534, 538 .

Wikstroemia stenantha, 532, 534 .

Wikstroemia stenophylla, 530,533 , 535.

Wikstroemia Valbrayi, 538.

Wikstroemia virgata, 536.

Wikstroemia viridiflora, 534.

Wistaria, 509.

Wistaria brachybotrya, 510 .

Wistaria brachybotrys, 509, 514 .

Wistaria brachybotrys, var. alba, 514.

Wistaria brachybotrys, var. rubra, 511.

Wistaria chinensis, 511, 513.

Wistaria chinensis, var. alba plena, 513.

Wistaria chinensis, var. albiflora, 510 .

Wistaria Chinensis, var. flore-pleno, 512.

Wistaria chinensis, var. foliis variegatis, 512.

Wistaria chinensis, var. multijuga, 513.

Wistaria chinensis, var. variegata, 512 . 
Wistaria Consequana, 509.

Wistaria floribunda, 510 .

Wistaria floribunda, f. alba, 512.

Wistaria floribunda, f.macrobotrys, 513.

Wistaria floribunda, f. rosea, 512 .

Wistaria floribunda, f. variegata, 512 .

Wistaria floribunda, f. violaceo-plena, 512.

Wistaria japonica, 515 .

Wistaria macrobotrys, 513.

Wistaria multijuga, 513.

Wistaria multijuga, var. alba, 512 .

Wistaria multijuga, var. rosea, 512.

Wistaria polystachya, 509, 511.

Wistaria polystachya alba, 510 .

Wistaria polystachya fl. albo-pleno, 513.

Wistaria polystachya multijuga, 513 .

Wistaria polystachya multijuga alba, 512.

Wistaria polystachya multijuga rosea, 512.

Wistaria polystachya variegata, 512 .

Wistaria sinensis, 509 .

Wistaria sinensis, f. alba, 510 .

Wistaria sinensis, var. albiflora, 510 .

Wistaria sinensis flore pleno, 512.

Wistaria venusta, 514 .

Wisteria, 102.

Wisteria brachybotrys, 510 .

Wisteria ehinensis, 102.

Wisteria chinensis, 509, 514.

Wisteria chinensis, var. alba, 510 .

Wisteria chinensis, var. macrobotrys, 513.

Wisteria dubia, 515.

Wisteria grandiflora, 513 .

Wisteria sinensis, 513.

Wisteria sinensis, var. violaceo-plena, 512.

Xanthoxylum floribundum, 137.

X ylophylla Lucena, 520.

Zanthoxylum, 121.

Zanthoxylum alatum, 125.
Zanthoxylum alatum, 125.

Zanthoxylum alatum, var. planispinum, 125.

Zanthoxylum alatum, var. planispinum, f. ferrugineum, 125.

Zanthoxylum Bretschneideri, 135.

Zanthoxylum Bungeanum, 121.

Zanthoxylum Bungei, 121.

Zanthoxylum Bungei, 125.

Zanthoxylum Bungei, var. Zimmermannii, 122.

Zanthoxylum Daniellii, 135.

Zanthoxylum dimorphophyllum, 126.

Zanthoxylum dimorphophyllum, var. spinifolium, 126.

Zanthoxylum dissitum, 128.

Zanthoxylum echinocarpum, 128.

Zanthoxylum fraxinoides, 121.

Zanthoxylum micranthum, 127.

Zanthoxylum multifoliolatum, 129.

Zanthoxylum multijugum, 129.

Zanthoxylum nitidum, 121, 137.

Zanthoxylum Piasezkii, 122.

Zanthoxylum pilosulum, 123.

Zanthoxylum piperitum, 122.

Zanthoxylum planispinum, 125.

Zanthoxylum pteracanthum, 123.

Zanthoxylum setosum, 124.

Zanthoxylum simulans, 121.

Zanthoxylum stenophyllum, 127.

Zanthoxylum trifoliatum, 563.

Zanthoxylum undulatifolium, 124.

Zizyphus, 212.

Zizyphus flavescens, 219.

Zizyphus floribunda, 213.

Zizyphus hamosa, 230.

Zizyphus oppositifolia, 231.

Zizyphus sativa, 212.

Zizyphus sativa, var. inermis, 212.

Zizyphus sinensis, 212.

Zizyphus spec. 213.

Zizyphus vulgaris, 212.

Zizyphus vulgaris, var. inermis, 212.

Zizyphus yunnanensis, 212.

ZYGOPHYLLACEAE, 120 . 